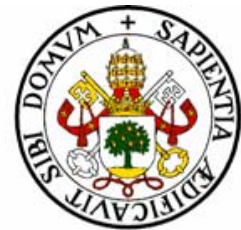

UNIVERSIDAD DE VALLADOLID

\title{
LA ACUSACIÓN POPULAR
}

JULIO PÉREZ GIL

Valladolid, 1997 



\section{UNIVERSIDAD DE VALLADOLID \\ Facultad de Derecho}

Departamento de Derecho Constitucional, Procesal y Eclesiástico del Estado

Área de Derecho Procesal

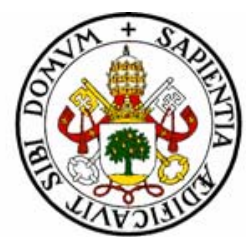

UNIVERSIDAD DE VALLADOLID

\section{LA ACUSACIÓN POPULAR}

Memoria de Tesis para la obtención del grado de Doctor presentada por D. JULIO PÉREZ GIL bajo la dirección del

Prof. Dr. D. ERNESTO PEDRAZ PENALVA,

Catedrático de Derecho Procesal de la

Universidad de Valladolid

Valladolid, 1997 



\section{ABREVIATURAS}

A

Auto

AAVV .varios autores

Act. Pen Actualidad Penal ADPCP

AG. Anuario de Derecho Penal y Ciencias Penales AHDE Attorney General AJA Anuario de Historia del Derecho Español AN. Actualidad Jurídica Aranzadi Audiencia Nacional AP Audiencia Provincial art. (s) ATC artículo (s)

BIMJ Auto del Tribunal Constitucional

$\mathrm{CC}$ $\mathrm{CCC}$ Constitutio Criminalis Carolina

$\mathrm{CE}$ Constitución Española $\mathrm{CEDH}$ CGPJ $\mathrm{CPC}$ $\mathrm{CP}$ CPP franc. Code de Procédure Pénale (francés) CPP ital. Codice di Procedura Penale (italiano) CPP port CPS Codigo de Processo Penal (portugués) Cr. App. R Crown Prosecution Service Crim. L. R. Criminal Appeal Review D Criminal Law Review Decreto

DA

DD. Disposición Adicional

DF Disposición Derogatoria

DPP Disposición Final ed. Director of Public Prosecutions edición EOMF Estatuto Orgánico del Ministerio Fiscal (Ley 50/1981 de 30 de dic.) esp. especialmente FGE Fiscalía General del Estado FJ / FD GA GG GS $\mathrm{JC}$ Convención Europea de Derechos Humanos .Consejo General del Poder Judicial .Cuadernos de Política Criminal Código Penal Boletín Informativo del Ministerio de Justicia Código Civil 


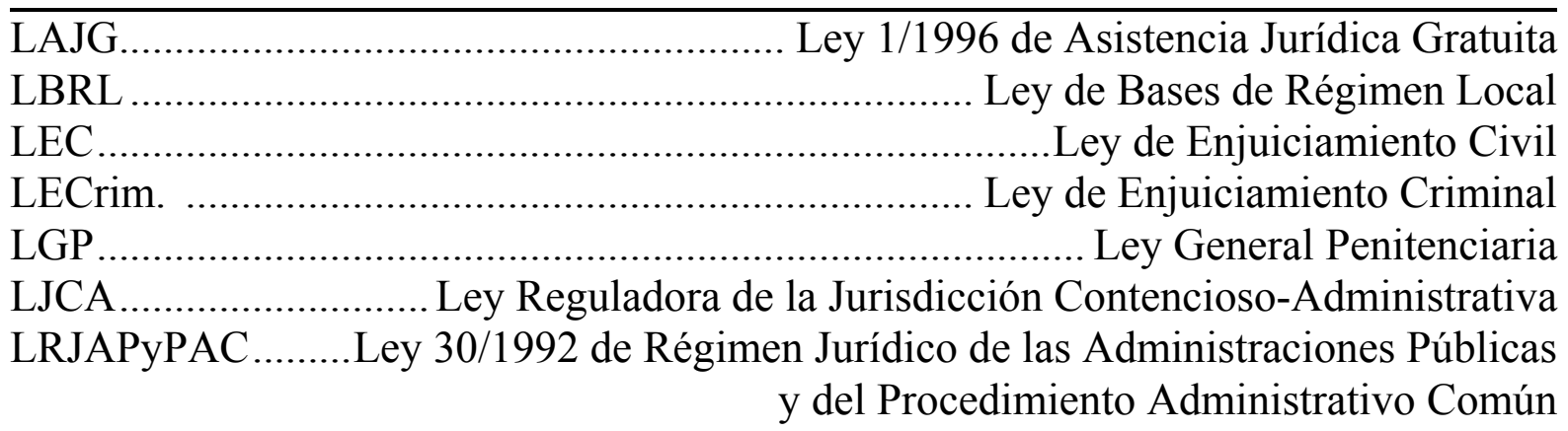

LO Ley Orgánica

LOPJ

Ley Orgánica del Poder Judicial

LOPTP Ley Orgánica 19/1994 de 23 de diciembre de protección de testigos y peritos en causas criminales LORCPJM ................. Ley Orgánica reguladora de la Competencia y el procedimiento de los Juzgados de menores (D. de 11.6.1948 reformado por la LO 4/1992 de junio) LOTJ Ley Orgánica del Tribunal del Jurado LPJDFP ......... Ley 62/1978 de Protección Jurisdiccional de los Derechos Fundamentales de la Persona marginal marg MF Ministerio Fiscal $\mathrm{n}$ nota NJW NStZ Neue Juristische Wochenschrift $\mathrm{n}^{\mathrm{o}}$ Neue Zeitschrift für Strafrecht ÖstPO $\mathrm{p}(\mathrm{p})$ p. ej. par. PJ.

POA PTC QB QC RAJ RAL RAP RD número tPO.................. Österreichische Strafprozeßordnung (Ley Procesal Penal austriaca)

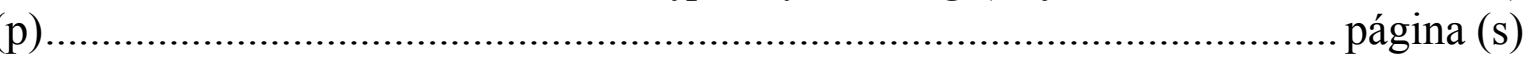
párrafo Revista "Poder Judicial" Prosecution of Offences Act Providencia del Tribunal Constitucional .Queen's Bench, Law Reports ..Questione Criminale Repertorio Aranzadi de Jurisprudencia . Repertorio Aranzadi de Legislación Revista de Administración Pública RDLeg. Real Decreto RDProc. (Ibam.)......................................Revista de Derecho Procesal (Iberoamericana) REDA ………….................................... Revista Española de Derecho Administrativo REDC .................................................... Revista Española de Derecho Constitucional REDEM …..................................................... Revista Española de Derecho Militar RGD Revista General del Derecho RGLJ Revista General de Legislación y Jurisprudencia Riv. ital. dir. proc. pen. RJCat. Rivista italiana di diritto e procedura penale Revista Jurídica de Catalunya 
RUDProc

$\mathrm{SJZ}$

$\mathrm{S}(\mathrm{S})$

SAN

ss.

$\mathrm{S}(\mathrm{S}) \mathrm{TS}$

$\mathrm{S}(\mathrm{S}) \mathrm{TC}$

StPO

$\mathrm{T}$.

$\mathrm{TC}$

TCE

TJCE

TEDH

TS

TSJ

v. gr.

vol.

ZRP

ZStW
Revista Universitaria de Derecho Procesal Schweizerische Juristenzeitung Sentencia(s) Sentencia de la Audiencia Nacional siguientes sentencia(s) del Tribunal Supremo sentencia(s) del Tribunal Constitucional Strafprozeßordnung (Ley Procesal Penal alemana) Tomo

Tribunal Constitucional Tratado Constitutivo de la Comunidad Europea Tribunal de Justicia de las Comunidades Europeas Tribunal Europeo de Derechos Humanos Tribunal Supremo .Tribunal Superior de Justicia verbi gratia volumen Zeitschrift für Rechtspolitik .Zeitschrift für die gesamte Strafrechtwissenschaft 



\section{INTRODUCCIÓN}

El trabajo que presentamos en calidad de memoria de tesis doctoral es un estudio de la acusación popular en el ordenamiento jurídico español, inserto lógicamente en sede procesal penal. Partiendo del imprescindible análisis de su configuración histórica y de su generalizado rechazo en el Derecho comparado, se pretende con él contribuir a desvelar datos esenciales en torno a su naturaleza, su régimen legal y las razones sobre las que en la actualidad se justifica su mantenimiento.

De la acusación popular se predica habitualmente su aptitud para constituir un baluarte garantizador del óptimo desempeño de la función del Ministerio Público, del cual, por razones derivadas de su configuración orgánica y, más concretamente, de su campo de juego potencial y actual, se desconfía. El planteamiento de la acusación por los ciudadanos vendría así a suponer un contrapeso para posibles deficiencias en la protección del interés general, que pudieran seguir a la constitucional adscripción de la fiscalía a la esfera de control del Ejecutivo. El ordenamiento español, a diferencia de los de nuestro entorno, permite de este modo no sólo un control externo de la acusación pública, sino que va más allá al favorecer su propia realización privada. Lo que en otros sistemas es considerado una improductiva vía de introducción en el proceso de presiones y manipulaciones inadmisibles, en el nuestro es visto generalmente como válido cauce para satisfacer el cumplimiento de una prestación estatal. La inquebrantable necesidad de afianzar el principio de legalidad, parámetro delimitador de la necesidad y el contenido de la potestad acusatoria, justificaría la difusión entre la mayoría del cuerpo social de la competencia para su ejercicio.

Para su plena efectividad, y correspondiente satisfacción del interés general, las propias connotaciones del ejercicio de la acusación comportan su atribución a un órgano encuadrado institucionalmente en lo público, dotado de todos los medios materiales y personales precisos y aptos para evitar que intereses particulares puedan obstaculizar la generalidad de la norma. El conflicto al que la acusación popular viniera a dar solución no admite ser entendido como una confrontación procesal entre un ciudadano que, más o menos desinteresadamente, asume desvelos en favor de la res publica frente a un sujeto 
presuntamente delincuente, sino, en el mejor de los casos, como forma de solventar un déficit en el funcionamiento del Estado. Su justificación ha de buscarse en la resolución de hipotéticas manifestaciones de ineficiencia estatal y, por ello, no ha de ser considerada deseable en sí misma, sino que su uso vendrá a demostrar que alguno de los resortes del sistema ha fallado. No debe ser, por tanto, contemplada como una suma, sino como una resta que en algún caso contribuye a la mejor y más eficaz administración de la justicia, no añadiendo algo, sino sustrayendo alguna de las impurezas a ella achacables. Su esencia está dotada así de una finalidad puramente utilitaria, en tanto mecanismo que suple la actividad de los órganos estatales a los que per se compete la acusación.

La presencia de una pluralidad de sujetos acusadores ocupando exactamente la misma posición y defendiendo teóricamente el mismo y único interés no es imprescindible, ni resulta siempre beneficiosa para los fines del proceso. Si la fiscalía, órgano vinculado constitucional y estatutariamente al imperativo de legalidad, pudiere hacerse acreedora de desconfianza, un acusador popular habrá de merecerla con mayor razón, precisamente por la indeterminación y subjetividad de sus móviles y fines. Y la suma de dos arbitrariedades difícilmente conduciría al objetivo de la plena vigencia de la legalidad. Aún más, con la acusación popular cabría facilitar la entrada en el proceso penal de un verdadero caballo de Troya que, mediante la introducción de intereses extravagantes, pudiera contribuir al socavamiento de los principios esenciales de los que históricamente se ha dotado. No ha de ignorarse que, amén de generarse mayores costes en tiempo y dinero, de ella podrían ser derivables desproporcionados perjuicios para el imputado, ni sería posible desdeñar el peligro cierto de su utilización fraudulenta (cauce de extorsión, de lucha política, de venganza personal), frente al que las garantías normativas no pueden considerarse suficientes. Su vigencia es, pues, una cuestión de técnica procesal, prescindible, mudable, contingente y de difícil encaje conceptual en el Estado Social y Democrático de Derecho. Su necesidad podrá ser el resultado histórico de un balance entre sus aportaciones y los costes y disfuncionalidades que acarrea, de una ponderación entre los diversos intereses que hace aparecer en juego y de la posibilidad de contrarrestar sus efectos nocivos, pero más allá de su residual valor, nunca podrá ser considerada inequívoco signo de democracia ni indicativo de un más alto grado de desarrollo de ésta.

Con la acusación popular se corre además el riesgo de sancionar en significativa medida el reconocimiento explícito de la ineficacia o negligencia estatales, y el 
alejamiento del Estado de las necesidades sociales que, por definición, deben ser acogidas y fielmente representadas en el proceso penal. Servirse de la insuficiencia, en algún modo provocada, de las Instituciones Públicas para permitir particulares persecuciones penales en pro del interés general, podría entenderse así contrario a los propios imperativos definidores del Estado de Derecho.

Cabría pensar que estas afirmaciones llevan implícito el deseo de privar a los ciudadanos de un afirmado derecho subjetivo, forzadamente construido con base en el art. 24.1 CE. Aquéllas se realizan, sin embargo, desde la premisa de que no cabe tal mistificación conceptual, y de que la delegación en los particulares de la facultad de acusar carece esencialmente y por definición de razón de ser. Nuestro análisis no elude en este sentido la denuncia del empleo de parámetros equívocos, ideológicamente calificados de democráticos, justificativos en apariencia de la denominada "acción popular" como vía articulada para una supuestamente necesaria participación ciudadana en la Justicia. Lo que en verdad pretendemos defender es, empero, la preexistencia de un derecho de los ciudadanos a la constitucional configuración de los elementos sobre los que se asienta la Justicia criminal, al cual se corresponderá el deber del Estado de dotarse de todos los medios, orgánicos y procesales, necesarios para su correcto cumplimiento. El principal riesgo de la acusación popular sería hacer depósito en ella de una inmerecida confianza que impida acometer las ineludibles reformas que el sistema precisa, convirtiéndola en coartada para encubrir tal necesidad. 



\section{Primera parte:}

\section{Configuración histórica de la acusación popular}





\section{DERECHO ROMANO: ACUSACIÓN Y ACTIONES POPULARES}

\subsection{Antecedentes}

El entendimiento de la criminalidad como fenómeno social y no como mera lucha entre particulares es el fruto de una larga evolución ligada estrechamente a la titularidad de la facultad de acusar. La primitiva vigencia de la venganza de la sangre y de formas privadas de resolución del conflicto, dieron paso con el tiempo a una relación triangular constitutiva del proceso entre dos sujetos enfrentados y un tercero neutral, quien dictaminaría en favor de uno u otro. El proceso, entendido como contienda entre dos oponentes, se convertirá en la única forma de legitimar el castigo por las ofensas criminales, introduciéndose con él importantes limitaciones al ejercicio de la venganza privada. En el tránsito desde las originarias formas de hacer justicia a las formas más evolucionadas a las que hoy estamos acostumbrados, el sistema de acusación ha jugado tradicionalmente un papel determinante no exento en ningún momento de connotaciones políticas de primer orden. El incremento de las facultades públicas de iniciación y sostenimiento del proceso penal ha sido interpretado habitualmente como un avance en la publicitación del mismo y, de esa manera, de los mecanismos de control del monarca sobre sus súbditos. Ha sido, pues, uno de los cauces a través de los que se ha ido trastocando la concepción privada del proceso penal para abrir la puerta a su consideración como público. Afirmar que el proceso penal es algo ligado íntimamente a los intereses del poder no es algo novedoso ${ }^{1}$, y en concreto, tratándose de la facultad de intervención de los particulares en la acusación, esa afirmación puede ser percibida desde diferentes ópticas que hablarán siempre de diversas concepciones sobre la relación entre lo público y lo privado.

Desde los albores de la civilización el juicio acusatorio en su formulación más simple de acusador, acusado y juez, era el único concebible, y la acusación popular (o acusación de cualquiera) tuvo ya acomodo en este sistema desde los primeros Códigos

\footnotetext{
${ }^{1}$ Cabe recordar aquí entre otras muchas las palabras de GOLDSCHMIDT en el sentido de que "los principios de la política procesal de una nación no son otra cosa que segmentos de su política estatal en general". GOLDSCHMIDT, J., Problemas jurídicos y politicos de proceso penal, Barcelona 1935, p. 67.
} 

(art. 108 y ss.) recogía ya el principio de la acusación del ofendido o de cualquier particular para la persecución de delitos que hoy consideraríamos públicos, tales como el homicidio o los fraudes en los pesos y medidas. Para la represión de infracciones de carácter militar (art. 26) o las cometidas por oficial (art. 33 y 34), la legitimación era aún más amplia y se reconocía directamente a todo ciudadano, sin alusión alguna al perjudicado $^{3}$. La prevención frente a falsas acusaciones estaba garantizada con el principio del Talión, previéndose que el que acusara a otro de un delito sin poder aportar prueba debería sufrir la misma pena que el acusado si ésta llegara a demostrarse ${ }^{4}$. La ley del Talión como pena para el acusador falso fue de la misma manera recogida también en el libro bíblico del Deuteronomio ${ }^{5}$.

Los textos de los clásicos griegos nos han dado a conocer igualmente la existencia de acusación popular en el Derecho Ático y en la cultura jurídica helena. La mayoría de los autores que han abordado el tema consideran las reformas legislativas de Solón como el término a partir del cual cabe hablar de "acciones populares", puesto que desde este momento se concede a todos los ciudadanos el derecho de emprender acciones en favor

\footnotetext{
${ }^{2}$ Vid. FILANGIERI, C., Ciencia de la Legislación, traducción de RIBERA, J., T. III, Madrid 1821, pp. 12 y ss. que, con referencias al derecho hebreo, egipcio y griego, afirma común a todos los principios sociales el que no se puede negar a un ciudadano el derecho de acusar a otro. Vid. también el interesante y conciso análisis histórico realizado recientemente entre nuestra doctrina por VERGER GRAU, J., La defensa del imputado y el principio acusatorio, Barcelona 1994, p. 15.

${ }^{3}$ SZLECHTER, É., "La procédure accusatoire en droit suméro-babylonien”, Revue Internationale des droits de l'Antiquité, T. XVI (1969), pp. 99 y ss.

${ }^{4}$ Art. 22 del Código de Lipit-Ishtar y 1 a 4 del Código de Hammurabi. Vid. KOROSEC, V.., "Le Code de Hammurabi et les droits antérieurs", Revue Internationale des droits de l'Antiquité, T. VIII (1961), p. 26. Este principio lo encontramos reiterado también en Egipto. Vid. VALERIOLA, T., Idea general de la policía o tratado de policía, Valencia 1799, (reimpresión 1977), p. 35, para quien esta norma se fundamenta en el derecho natural "que priva hacer á otro lo que uno mismo no quisiera sufrir".

${ }^{5}$ Deuteronomio XIX, 16 y ss. "Si surgiere contra uno un testigo malo acusándole de un delito, los dos interesados en la causa se presentarán ante Yavé, ante los sacerdotes y los jueces en funciones en ese tiempo; quienes si, después de una escrupulosa investigación, averiguasen que el testigo, mintiendo habia dado falso testimonio contra su hermano, le castigarán haciéndole a él lo que él pretendia se hiciese con su hermano; así quitarás el mal de en medio de Israel. Los otros, al saberlo, temerán y no cometerán esa mala acción en medio de ti; no tendrá tu ojo piedad; vida por vida, ojo por ojo, diente por diente, mano por mano, pie por pie". El ejemplo del cumplimiento de tal previsión lo encontramos por ejemplo en la acusación al profeta Daniel por la que se le arroja al foso de los leones. Al constatar su error en la condena, el Rey Darío ordena que se arroje al foso a quienes habían acusado maliciosamente, a sus hijos y a sus mujeres. Vid. Daniel, 6, 24/25.
} 

y defensora del Estado de la acusación popular griega se ha sustentado en PLATÓN, y en especial en uno de sus textos en el que se refiere a la existencia de dos tipos de tribunales permanentes: "uno para cuando un particular acuse a otro de daños contra el interesado (...); el otro, para cuando alguien crea que el Estado se ha visto perjudicado por la acción de algún ciudadano y quiera defender los intereses comunitarios" ${ }^{7}$. En relación con la Constitución de Atenas, ARISTÓTELES se refería también al reconocimiento a los ciudadanos del derecho de actuar en juicio en beneficio de una persona ofendida ${ }^{8}$. Ello suponía a su juicio una reforma en sentido democrático, en cuanto que la defensa de derechos del prójimo frente a un tercero poderoso debilitaría el poder de éste último y podría igualar el poder social ${ }^{9}$. Pero esta concepción de la acusación popular, que considera que su fundamento se encuentra en la defensa por cualquiera del bienestar del Estado, no ha sido compartida por la generalidad de la doctrina, sino que en ella se ha visto sólo un mecanismo para la defensa de intereses de quienes no los pudieran hacer valer por sí mismos ${ }^{10}$.

La ideología griega habría unido así la acción popular, que en origen no sería otra cosa que un mecanismo de defensa jurídica de los incapaces de hacerlo por sí mismos, con la defensa de intereses estatales. Estos motivos han sido los que han llevado a algún autor a la conclusión de que las acciones populares romanas tendrían su origen en la

\footnotetext{
${ }^{6}$ PLUTARCO, Vida de Solón, 18, 6. Para algún autor, sin embargo, Solón no derogó la anterior Ley de Dracón que confería a los parientes un derecho de persecución del delito, dejando a la acción popular un papel meramente subsidiario. En este sentido vid. DARESTE, R. et. al. Recuil des inscriptions juridiques grecques, II-1, 22, n. 1 cit. por WINKEL, L.C., "Quelques remarques sur l'accusation publique en droit grec et romain", Revue internationale des droits de l'Antiquité, T. XXIX (1982), p. 285 que contiene la crítica al anterior. Lo que sí parece claro es que en el derecho ático ya hubo antes que en el romano acusaciones privadas y acusaciones públicas. Entre los otros autores que han abordado el tema de la acción popular en el derecho griego vid. en especial FILANGIERI, C., Ciencia de la Legislación, T. III, pp. 23 y s. y LATTE, K., "Beiträge zum griechischen Strafrecht, I: Die Entstehung der Popularklagen" en la recopilación dirigida por BERNEKER, E., Zur griechischen Rechtsgeschichte, Darmstadt 1968, pp. 263-282.

${ }^{7}$ PLATÓN, Las Leyes, Edición de RAMOS BOLAÑOS, Barcelona 1988, p. 257. El fundamento de la existencia de defensores del interés común ha sido siempre comúnmente cifrado en la carencia de un órgano asimilable al Ministerio Fiscal actual.

${ }^{8}$ ARISTÓTELES, Constitución de Atenas IX, 1.

${ }^{9}$ WINKEL, L.C., “Quelques remarques sur l'accusation publique...”, op. cit, p. 285.

${ }^{10}$ Sobre la discusión vid. WINKEL, L.C., “Quelques remarques sur l'accusation publique...”, op. cit. p. 286.
} 

con la ideología romana el que un simple ciudadano pudiera emprender un procedimiento para la defensa de una causa pública, por lo que la sola explicación de este fenómeno, ajeno a la esencia romana del Estado, dejaría entrever la influencia griega ${ }^{11}$. Aun así no parece que ésta sea más que una mera hipótesis no suficientemente justificada.

La actio popularis romana y el derecho de acusar

Las acciones populares romanas, y el derecho de acusación como una de las especies de éstas, han suscitado históricamente importantes debates doctrinales ya que inciden en un ámbito nada fácil como es el de las zonas tangenciales entre el ius publicum y el ius privatum, ligado a concepciones políticas romanas que, en muchos casos, nos son todavía desconocidas. A ello se han superpuesto en no pocas ocasiones las concepciones políticas del momento en que se ha abordado el tema y las propias de los autores que se han aproximado a él. Parece claro en este sentido que la popularidad en la legitimación activa de las acciones romanas sufrió con el tiempo un proceso de privatización, extendiendo a ámbitos civiles las previsiones referentes a la accusatio publica anteriores en el tiempo ${ }^{12}$. La acusación pública quedó así englobada en un concepto general de popularidad, en el que también se encontrarían otras acciones populares que pese a su naturaleza privada, abarcaban aspectos esenciales de interés público. Aun cuando no fuera acertado unificar totalmente tales figuras en la medida en que con ella se daba respuesta a realidades diferentes ${ }^{13}$, el estudio de las formas populares de acusación en Roma requiere su observación conjunta.

\subsubsection{La accusatio}

\subsubsection{Regla general: acusación quivis ex populo}

Desde el s. III a. c. podemos encontrar ya una acción popular para la defensa de los

\footnotetext{
${ }^{11}$ WINKEL, L.C., "Quelques remarques sur l'accusation publique...", op. cit. pp. 292 y s. A juicio de WINKEL en la historia romana nunca se produjo un verdadero movimiento democrático.

${ }^{12}$ MURGA, J.L., Derecho Romano Clásico, T. II (El Proceso), Zaragoza 1980, p. 239 y “Las acciones populares en la Lex Coloniae Genetivae Iuliae", Seminarios Complutenses de Derecho Romano. I. Cuestiones de Jurisprudencia y Proceso (abril-junio 1989), pp. 103 a 173.

${ }^{13}$ FADDA, C., L'azione popolare, Turín 1894, pp. 286 y ss.
} 

constancia de la presencia de acción popular en el campo del derecho penal público atribuyendo el derecho de acusar a todo ciudadano se debe situar en la Lex Calpurnia (149 a.c.). Si se confronta con la venganza del agraviado o su familia como forma de resolución de conflictos, la atribución quivis ex populo del derecho de acusar supuso una progresión hacia la publicitación. En ese tránsito hacia formas evolucionadas de administración de la justicia penal, la acusación popular sirvió para conservar la forma acusatoria, a la vez que contribuía simultaneamente a la eliminación de la vindicta privada.

La función acusatoria en Roma no venía atribuida específicamente a ningún oficial público $^{14}$, sino que la regla general era que cualquier persona íntegra y con plena capacidad podría acusar en el juicio público ${ }^{15}$. La justificación se cifraba en que la sociedad entera tendría un derecho a la paz pública y todos los ciudadanos, en tanto miembros de la comunidad, sufrirían en su derecho propio con la lesión que produce el delito ${ }^{16}$. De tal daño surgía una "acción” cuyo instrumento formal sería la acusación ${ }^{17}$,

\footnotetext{
${ }^{14}$ GARRAUD señalaba que los romanos no tuvieron jamás la idea de crear un Ministerio Público. La protección de los intereses generales no estaba atribuida a ningún magistrado, sino únicamente a los ciudadanos de buena voluntad. GARRAUD, Traité theorique et pratique d'instruction criminelle et de Procédure Pénale, T. I, p. 170. Ni el advocatus fisci ni el procurator Caesaris pueden ser equiparados al actual Ministerio Fiscal. Mientras que el primero podría considerarse precedente del Abogado del Estado, el segundo sería un oficial con funciones relacionadas con la Hacienda Pública. Vid. FERNÁNDEZ MARTÍN-GRANIZO, M., El Ministerio Fiscal en España (Notas para una futura construcción de dicha figura y estudio de su posición en el Derecho Procesal Español), Madrid 1977, pp. 15 y ss.
}

${ }^{15}$ D. 47, 23, 4; PAULO, III ad. Ed.: "Popularis actio integrae personae permittitur, hoc est, cui per Edictum postulare licet" "El ejercicio de la acción popular se le permite a persona integra, esto es, a aquella a quien por el Edicto le es lícito pedir"). En la época clásica el juicio penal se desenvolvía en un proceso promovido por iniciativa del Magistrado (inquisitio) o por acusación quivis ex populo (accusatio). A él se sometían actos punibles designados como "delitos públicos" (crimina) en oposición a los delitos privados (delicta, maleficia) los cuales, por referirse a casos en los que se había causado un daño a un particular, eran sancionados simplemente con penas pecuniarias que se reclamaban a través de un proceso privado MOMMSEN, T., Römisches Strafrecht, 1899, pp. 366 y ss (existe traducción de DORADO, P., Madrid, s.f., $1^{a}$ parte, pp. 363 y ss.); ÁLVAREZ SUÁREZ, U., Curso de Derecho Romano, T. I., pp. 180 y ss. y GIUFFRE, V. Il diritto penale nell'esperienza romana, 1989, pp. 59 y ss.

\footnotetext{
${ }^{16}$ Entre otros muchos, recoge CARRARA en su Programa de Derecho Criminal, vol. II, p. 299 (traducción de Editorial Temis, Bogotá 1973) el silogismo romano sobre la acusación: "la sociedad tiene derecho a la paz pública. Yo soy ciudadano y por tanto tengo derecho a la paz pública. Como un individuo atacó la paz pública, violó mi derecho y provocó el nacimiento de mi acción para acusar".

${ }^{17} \mathrm{El}$ término accusare, palabra que sustituyó a la de petere, no fue voz característica de ninguna forma determinada de demanda, sino que designaba exclusivamente la acción, acentuando únicamente su aspecto ético. Por esta circunstancia no ha sido posible deducir modalidades de procedimiento fijándose en una denominación que no es precisa ni técnica. MOMMSEN, T., Römisches Strafrecht, op. cit., p. 377.
} 
Aun así, las acusaciones no se realizaban sólo para la mera defensa del interés común, sino que a veces se dirigían a obtener el premio que, procedente del patrimonio del reo, se asignaba a los acusadores victoriosos ${ }^{18}$, o a lograr alcanzar el acusador una notoriedad para la que el dominio de la oratoria forense constituía un medio idóneo ${ }^{19}$. En cualquier caso, la regla general de que el acusador representaba el interés de la comunidad, encontraba asimismo importantes limitaciones en supuestos en que se restringía la intervención de quienes no hubieran sido lesionados por el delito ${ }^{20}$.

En la época imperial desapareció la accusatio generalizada y se permitía únicamente la acusación de quienes ostentaran un interés personal en el castigo del reo, con lo que la inquisitio se convirtió en forma habitual de iniciativa penal ${ }^{21}$. Con ello se pretendió conseguir un incremento de las garantías en la persecución, en tanto se evitaban la impunidad de los delitos y los acuerdos colusorios entre acusadores y acusados, supliéndose a la vez con creces la incapacidad de los ciudadanos comunes para la acusación. La acusación perdió entonces su naturaleza dispersa entre la ciudadanía y se transformó en una suerte de querella de parte, proponible únicamente a instancia del

\footnotetext{
${ }^{18}$ Se ha afirmado por ello que el sistema acusatorio romano, aun cuando garantizara el principio de contradicción, no podría ser considerado un sistema garantista para el acusado. Vid. GIUFFRE, V., Il diritto penale..., op. cit, pp. 59 y ss.

${ }^{19} \mathrm{Ha}$ de advertirse que durante el último siglo de la República la oratoria en el procedimiento penal adquirió un desarrollo desmesurado, alterando la propia naturaleza tanto de la defensa como de la acusación y los discursos adquirían un cariz político en relación con la vida pública de la comunidad. Esta era una de las vías que utilizaban ciudadanos ambiciosos como campo de preparación y exhibición ya que en él podían perfeccionarse en el arte de declamar en público, tomar práctica del derecho y mostrar a los electores su aptitud para el ejercicio de cargos políticos. Con el Principado la elocuencia en el proceso fue perdiendo trascendencia política y recuperando su carácter meramente forense, sin relevancia más allá del propio proceso, por lo que los auxiliares jurídicos (advocati), en lugar de aspirantes a cargos públicos, fueron a partir de estos momentos ante todo procuradores, agentes o gestores. Vid.entre otros muchos MOMMSEN, Römisches Strafrecht, op. cit. p. 372 y MANZINI, Diritto Processuale Penale italiano, I, Turín 1952, p. 4.
}

${ }^{20}$ Por ejemplo, en supuestos considerados aún hoy día, o hasta épocas recientes, delitos privados (injuria, adulterio, etc). Vid. MOMMSEN, Römisches Strafrecht, op. cit. p. 367.

${ }^{21}$ En opinión de BISCARDI, el principio inquisitivo en la cognitio extra ordinem representa históricamente una garantía jurisdiccional en ausencia del Ministerio Fiscal como órgano propulsor de la represión criminal. BISCARDI, A., "Inquisitio ed accusatio nel processo criminale «extra ordinem»" en Seminarios Complutenses de Derecho Romano. I. Cuestiones de Jurisprudencia y proceso, abril-junio 1989, p. 234. En esta época se amplió además el concepto de delitos públicos, entrando dentro de él cualquier hecho que supusiera infracción de una norma jurídica, por lo cual pasaron a la jurisdicción criminal muchos de los actos punibles que antes se reservaban al proceso privado. 


\subsubsection{Exclusiones}

A aquel generalizado reconocimiento de la facultad de acusar de todos los ciudadanos se superponían determinadas exclusiones de las que nos da noticia el siguiente texto de MACER: "Entenderemos quienes pueden acusar, si supiéremos quiénes no pueden. Y así, a unos se les prohibe acusar por razón del sexo o de la edad, como la mujer o el pupilo; a otros por razón de su juramento, como los que militan; a otros por razón de su magistratura o potestad, los cuales permaneciendo en ella no pueden ser llamados a juicio sin infracción de la ley; a otros por razón de su propio delito, como los infames; a otros por razón de torpe ganancia, como los que tienen suscritos dos juicios contra dos reos, o hubieren recibido dinero por acusar o no acusar; a otros por razón de su propia condición, como los libertinos contra los patronos" ${ }^{23}$. Dos características fundamentales pueden ser extraídas de este régimen: en primer lugar, que la posibilidad de acusar los delitos cometidos contra los sujetos excluidos o sus parientes quedaba con carácter general a salvo ${ }^{24}$, y en segundo, que el derecho de acusar no tenía la amplitud subjetiva que podría parecer a simple vista. Debemos por ello referirnos a varias limitaciones en el ejercicio de la acusación ${ }^{25}$ :

1) En primer lugar quedaban excluidos de tal facultad los no ciudadanos, puesto que no podrían representar a la comunidad romana ni asumir una función considerada cuasi magistratural ${ }^{26}$.

2) Los menores sólo podrían hacer uso de la acusación a título de excepción cuando fueren los afectados directamente, es decir, cuando ellos mismos o sus parientes

\footnotetext{
${ }^{22}$ Sobre la época imperial vid. GIUFFRE, Il diritto penale..., op. cit. pp. 93 y ss.

${ }^{23}$ D. 48, 2, 8. MACER, De publicis Iudiciis, L. II. Tomamos la referencia del Cuerpo del Derecho Civil Romano de KRIEGEL, HERMANN y OSENBRÜGGEN traducido al castellano por GARCÍA DEL CORRAL, T. III, Barcelona 1897, p. 725.

${ }^{24}$ D. 48,2 , 11. (MACER): “Mas todos éstos, si persiguen su propia injuria o vindican la muerte de sus parientes, no son excluidos de la acusación". En el mismo sentido también D. 48, 2, 13 (MARCIANO).

${ }^{25} \mathrm{Al}$ respecto vid. especialmente MOMMSEN, T., Römisches Strafrecht, op. cit. p. 370.

${ }^{26}$ MOMMSEN, T., Römisches Strafrecht, op. cit. p. 368.
} 

del tutor. Incluso en estos supuestos se les prefería frente a todos los demás, al reputarse que serían los miembros de la comunidad más dañados ${ }^{27}$.

3) A las mujeres, excluídas habitualmente de funciones públicas, tampoco se les reconocía esta facultad, excepto cuando los delitos se cometieran contra ellas mismas o sus parientes ${ }^{28}$. En estos casos, matiza MOMMSEN, serían consideradas sólo denunciantes, con lo que no estarían sometidas a las estrechas obligaciones que exigía la acusación. No obstante, en las hipótesis de delitos de lesa majestad y de acciones para perseguir el acaparamiento de cereales, sí se les otorgaría de forma ilimitada el derecho de $\operatorname{acusar}^{29}$.

4) El que ejercitara la acción debería gozar de la plenitud jurídica inserta en el status civitatis. Deberían así tomarse en cuenta los siguientes casos:

a) se exigía la posesión de un patrimonio superior a 50 áureos $^{30}$, lo cual hacía que sólo los ciudadanos acaudalados pudieran servirse del derecho de acusar sin ser ofendidos;

b) el hijo de familia sólo podría acusar cuando el paterfamilias otorgara su consentimiento $^{31}$;

c) al siervo se le negaba esta facultad excepto si tenía un hijo o un patrimonio de 30.000 sestercios, siempre que no se dirigiera contra su patrón ${ }^{32}$. Sin embargo sí podría acusar, incluso a su patrón, por el delito de lesa majestad y en general

\footnotetext{
${ }^{27}$ D. $48,2,8$.
}

${ }^{28}$ Sobre la cuestión puede consultarse la reciente monografía de RESINA, P., La legitimación activa de la mujer en el proceso criminal romano, Ediciones clásicas, Madrid 1996.

${ }^{29}$ D. 48, 2, 1 y 2 (POMPONIO, de accusationibus). Vid. también FILANGIERI, C., Ciencia de la Legislación, op. cit. p. 17 y MOMMSEN, Römisches Strafrecht, op. cit. p. 370. Al igual que a las mujeres, la atribución del derecho de acusar en estos supuestos venía reconocida también a otros sujetos excluidos habitualmente de la acusación.

\footnotetext{
${ }^{30}$ D. $48,2,10$ (HERMOGENIANO).

${ }^{31}$ D. 48, 2, 2 (PAPINIANO).

${ }^{32}$ PAPINIANO, Coll. 4, 5, 1.
} 
5) La nota de infamia, que privaba del derecho de representación en los litigios, impedía también el derecho de acusación, salvo por los asuntos propios y los de los parientes, en los de lesa majestad y en los de acaparamiento de cereales.

6) Al magistrado en funciones, por regla general, se le negaba en los tiempos del Principado la facultad de deducir acusación. Ello se hacía porque tampoco podían ser llamados a juicio sin infracción de la ley. Los magistrados y cuantos ejercieran algún cargo no podían ser acusadores sino en los delitos que interesaban a todo el cuerpo de la República u ofendían a su persona o a la de los suyos.

Se excluían también de la acusación los soldados en activo, excepto cuando fueran afectados por el delito, así como en la acción de lesa majestad y en la acusación contra los acaparadores de cereales ${ }^{34}$.

7) Cuando se ejercitaran acciones recíprocas, se sentenciaba y resolvía primeramente la más grave, $\mathrm{y}$, en caso de igual gravedad, la que se hubiese inferido primero, quedando mientras tanto en suspenso el procedimiento de la otra ${ }^{35}$.

8) El que hubiera intentado ya dos acciones no podía ejercitar una tercera a no ser por delito contra él o sus parientes ${ }^{36}$.

9) El que se encontrara acusado no sería admitido como acusador ${ }^{37}$.

10) Se excluían las acusaciones contrarias a las normas de la piedad (hijo contra padre, hermano contra hermano, marido contra mujer, paterfamilias contra los que vivieran en su casa, etc.) ya que se consideraba sospechoso al acusador que no respetaba los vínculos de sangre o las obligaciones de la gratitud ${ }^{38}$.

\footnotetext{
${ }^{33}$ ARCADIO, Cod. 11, 50, 2.

${ }^{34}$ D. $48,2,8$. y 11 pr.; Cod. 9, 1, 8. y 10.

${ }^{35}$ D. 48, 3, 19, 1. Esta regla no regía en tiempos de la república. Vid. MOMMSEN, Römisches Strafrecht, op. cit. p. 371 .

${ }^{36}$ D. 48, 2, 8, y 11 pr.; D. 48, 2, 11, 2 (MACER); D. 48, 2, 12, 2.; Cod. 9, 1, 16.

${ }^{37}$ MOMMSEN, T., Römisches Strafrecht, op. cit. p. 371.

${ }^{38}$ Vid. FILANGIERI, C., Ciencia de la Legislación, op. cit. pp. 19 y s.
} 
La regla general fue por tanto el reconocimiento de un derecho de todos los ciudadanos capaces para acusar, el cual quedaba en determinadas ocasiones excluido bien por razón de los sujetos acusadores o acusados, bien por tratarse de delitos privados. De esta manera se recibió el sistema de acusación en el derecho común y específicamente por lo que a este trabajo respecta, en las Partidas y, finalmente, en la LECrim de 1882.

\subsubsection{Concurrencia de varios acusadores}

Ante la coincidencia de una pluralidad de acusadores, el magistrado tenía la facultad de escoger como actor principal a la persona que juzgara más idónea, es decir, a aquélla que pudiera tener un interés mayor o a quien estuviera revestido de especiales cualidades personales (dignidad, edad, costumbres u otra justa causa). Dentro de la popularidad de la acusación se matizaban así los intereses de los ciudadanos en función de la cercanía al bien jurídico atacado o por motivos de utilidad social y el Juez otorgaba la oportunidad de acusar al que consideraba ser el más perjudicado o a quien mejor pudiera tutelar el bien común o interés público dañado ${ }^{39}$. Fue por tanto norma general otorgar también la legitimación popular al que se preveía iba a litigar mejor, aunque se tratara de mujer o de pupilo, quienes en principio estaban excluídos. La ley buscaba además garantías de igualdad e imparcialidad en la acusación cuando la concurrencia de muchos pudiera hacer temer que llegara a ejercerse presión ilegítima sobre los derechos de la defensa $^{40}$.

Puesto que la acción ejercitada era única (la acusación) y lo único plural eran los sujetos que estaban facultados para hacerla valer, si su ejercicio fuera sucesivo daría lugar a la exceptio rei judicatae a favor del sujeto pasivo, el cual podría oponerla frente a cualquier nuevo actor por la misma causa. No obstante, las acusaciones podían ser deducidas en ocasiones por más de una persona simultáneamente, concurriendo junto a un

\footnotetext{
${ }^{39}$ ULPIANO, D. 48, 2, 16, "si plures existant, qui eum in publicis iudiciis accusare volunt, iudex eligere debet eum qui accuset, cauda scilicet cognita aestimatis accusatorum personis vel de dignitate vel ex eo quod interest vel aetate vel moribus vel alia iusta de causa". " "Si hubiera muchos que quieren acusar a uno mismo en juicios públicos, el juez debe elegir a uno que lo acuse, por supuesto, con conocimiento de causa, habiendo hecho estimación de las personas de los acusadores, o por su dignidad o por lo que les interesa, o por su edad, o por sus costumbres, o por otra justa causa"). SILVELA hacía referencia a este juicio previo o diligencia sumaria para averiguar cual de los varios acusadores que se presentaban para ejercitar la acción popular había de llevar la representación, y lo denomina siguiendo a AULO GELLIO “divinatio". Vid. SILVELA, F., "La acción popular", $R G L J 1888$, p. 459.

${ }^{40}$ SILVELA, F., "La acción popular", op. cit. p. 460.
} 

derecho a suministrar pruebas al acusador que hubiere sido preferido así como a velar sobre su conducta, pero no ostentaban la condición de acusadores ${ }^{41}$.

\subsubsection{Garantías de fiabilidad de la acusación}

El acusador popular en el juicio público debía desempeñar su función personalmente, sin que cupiera representación, de lo que se ha deducido en ocasiones que actuaba procuratorio nomine, esto es, en interés de la res publica aun cuando en su obrar primara en cuantiosas ocasiones un interés principalmente personal ${ }^{42}$. Habitualmente el que ejercitaba las acciones no se valía de asistencia jurídica de otras personas, excepto en la acción de repetundis y en los casos en los que acusaban mujeres o menores, en los que se precisaba de la oportuna representación legal que supliera su incapacidad.

El acusador adquiría mediante juramento la obligación de sostener la acusación durante todo el proceso hasta la sentencia, para lo cual debía afianzar su acusación prestando una caución o presentando fiadores ${ }^{43}$. Mediante tal compromiso se sujetaba a la misma pena que él solicitare para el acusado en caso de no poder probar los hechos que fundamentasen su acusación ${ }^{44}$. La acusación calumniosa llevó aparejada no sólo la pena de Talión, sino incluso también la declaración de infamia a partir de la Ley Remnia, con lo que se pretendió establecer una garantía más frente a quienes acusasen de mala $\mathrm{fe}^{45} . A$ fortiori, como freno a las acusaciones calumniosas, se autorizó legalmente al acusado para

\footnotetext{
${ }^{41}$ Tal y como resalta PAULO, debía ser admitido cualquiera que quisiera defender el interés del Estado ("reipublicae interest quam plurimos ad defendam suam causam admittere"), D. 4, 39, 1. FILANGIERI, C., Ciencia de la Legislación, op. cit. p. 22.

${ }^{42}$ Así CODACI-PISANELLI, Azione Popolare, Nápoles 1887, pp. 79 y ss.

${ }^{43}$ ULPIANO, D. 48, 2, 7, pr. y 1: "Si a alguno le fuera imputado un delito debe preceder a la acusación la suscripción, lo cual se estableció para esto, para que nadie se lance fácilmente a acusar, sabiendo que no habrá de quedar sin castigo para él la acusación"; "presten todos caución por haber imputado un delito, y además, de que perseverarán en la acusación hasta sentencia”.

${ }^{44}$ Vid. FILANGIERI, C., Ciencia de la Legislación, op. cit. p. 14, n. 2, donde se detalla la fórmula en la que este compromiso se realizaba.

${ }^{45}$ Vid. FILANGIERI, C., Ciencia de la Legislación, op. cit. pp. 15 y ss., que relata la previsión de la Ley de marcar con un hierro candente la letra " $\mathrm{K}$ " en la frente del calumniador.
} 
poner un guarda que espiase toda la actividad del acusador encaminada a sostener su acusación, por ejemplo en las conversaciones con testigos, jueces, etc ${ }^{46}$. Como freno a la posible negociación fraudulenta entre acusador y acusado, se impuso el castigo al acusador a la misma pena que correspondía al delincuente ${ }^{47}$.

Ulteriores garantías de fiabilidad en el ejercicio de la acusación eran la limitada vigencia en el tiempo de esta facultad y el que ni pudiera ser transmitida mortis causa ${ }^{48}$, ni ser objeto de compromiso arbitral.

\subsubsection{Las actiones populares romanas}

El interés de realizar un estudio de las acciones populares romanas en el marco de un trabajo procesal penal se cifra en su equiparación con las acusaciones por delito, cuyo paralelismo en orden a la legitimación activa es indudable en todas las fuentes. Los sujetos a quienes venía atribuido el derecho de hacer uso de las acciones populares sin exigirse mayores requisitos de legitimación, eran así los mismos que podían acusar por delito $^{49}$. Por la estrecha cercanía entre lo que para nosotros son procesos de distinta naturaleza y las amplias intersecciones en sus reglas básicas, en el Derecho Romano no era siempre posible una clara distinción en este sentido. De ahí que las acciones denominadas populares, revestidas en la mayoría de los casos de un carácter privado a pesar de su contenido materialmente público, no podrían permanecer ajenas a esta ausencia de delimitación. Con la actio popularis, cuyo origen se encuentra en la accusatio publica $^{50}$, habría aparecido una nueva categoría de vías litigiosas a caballo entre lo público y lo privado que, no obstante estar dentro de los iudicia privata, ofrecían un cierto

\footnotetext{
${ }^{46}$ También es reseñada esta garantía por FILANGIERI, C., Ciencia de la Legislación, op. cit. p. 17.

${ }^{47}$ El Talión se seguía también de la infamia. Vid. FILANGIERI, C., Ciencia de la Legislación, op. cit. p. 22.

${ }^{48}$ D. $48,3,19$ pr: no debían ser obligados los herederos de los acusadores a proseguir las acusaciones criminales.

${ }^{49}$ Lo que la acción popular romana comparte con la acusación pública y a la vez la diferencia de la acción privada era precisamente la amplitud en el reconocimiento a los sujetos activos, pero se separaría de aquélla en el hecho de no ser ejercitada en iudicia publica como las acusaciones y en su apariencia de acción. FADDA destacaba que el prius no estaría en la popularidad ni para el iudicium publicum ni para la actio publica. Popularis y publicus no serían sino formas diversas derivadas de una raíz y el concepto que está en su base es siempre el mismo. FADDA, C., L'azione popolare, Turín 1894, pp. 59 y ss.

${ }^{50}$ MURGA, J.L., “Las acciones populares...”, op. cit. p. 118.
} 

colectividad $^{51}$. Constituían así un instrumento adecuado para velar por el buen funcionamiento de la vida urbana, a la vez que servían también para reprimir actuaciones llevadas a cabo por los munícipes o los propios particulares ${ }^{52}$.

Cualquier ciudadano (quivis ex populo), por su mera condición de miembro de la comunidad podría ejercitar las acciones que fueran populares, obteniendo con ello un beneficio pecuniario que revertiría en su patrimonio o redundaría en favor del erario público $^{53}$. Las definiciones de PAULO no dejan duda de que la titularidad de su ejercicio correspondía a cualquier integrante del populus: "Eam popularem actionem dicimus, quae suum ius populi tuetur" ("Llamamos acción popular a la que ampara el derecho propio del pueblo") ${ }^{54} \mathrm{e}$ "in popularibus actionum, ubi quasi unus ex populo agit defensionem ut procurator praestare cogendus non est" ("En las acciones populares, en las que uno litiga como individuo del pueblo, no debe ser obligado a hacer la defensa como procurador") 55 . GAYO aporta por otra parte una explicación del concepto de populus en los siguientes términos: "populi apellatione universi cives significantur" ("con la denominación Pueblo quedan expresados todos los ciudadanos") ${ }^{56}$, aun cuando ello haya sido motivo con posterioridad de amplio y fructífero debate entre la doctrina romanista ${ }^{57}$.

\footnotetext{
${ }^{51}$ MURGA, J.L., Derecho Romano Clásico, op. cit., p. 239.

${ }^{52}$ MURGA, J.L., “Las acciones populares...”, op. cit. pp. 105 y 143.

${ }^{53} \mathrm{La}$ discusión de los romanistas sobre la naturaleza y los objetivos de las acciones populares tiene su origen precisamente en el intento de dar respuesta a la cuestión sobre a quién correspondería el importe de las multas obtenidas por el ejercicio de una acción popular y en qué concepto. La más antigua teoría, sostenida por PUCHTA, afirmaba que las ganancias iban a parar al actor legitimado. En contraposición a ella publicó BRUNS un artículo que comienza sin ambages con la pregunta "¿Quién recibía en Roma el dinero demandado mediante una acción popular, el actor o el Estado?”. BRUNS, C.G., “Die römische Popularklagen”, Kleinere Schriften, 1, Band, Weimar 1882, pp. 313 y ss. Publicado originalmente en Zeitschrift für Rechtsgeschichte, B. III, (1864), pp. 341-415. MOMMSEN, por el contrario, en concordancia con su idea del actor popular como procurator del Estado (populus), sostenía que el provecho de la acción siempre pertenecería a éste. LUÉ clasifica las acciones populares romanas precisamente en función del destinatario de los ingresos obtenidos con las multas impuestas como pena: a favor del erario público, del actor o de un tercero y por último los interdictos populares. LUÉ, G.B., Voz “Azione popolare”, en Enciclopedia Giuridica Italiana, vol. I, Parte V, Milán 1904, pp. 1403 y ss.

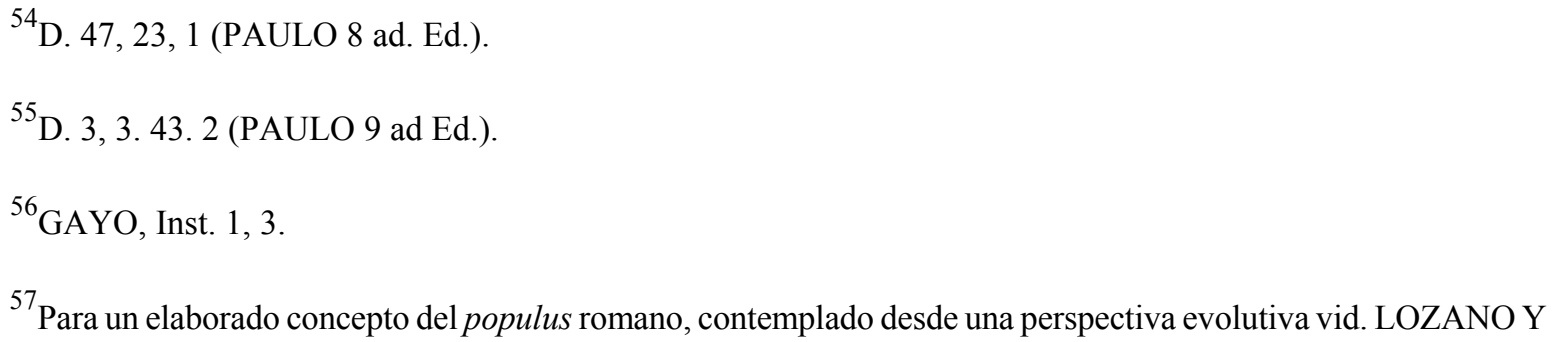


La expresión actio popularis, que probablemente no perteneció al lenguaje legislativo ${ }^{58}$, se encuentra sin embargo en 22 fragmentos de juristas clásicos, contenidos en su práctica totalidad en el Digesto. En 5 de ellos se precisa o constata cuándo una acción es popular, mientras que en los otros se hace relación a las reglas especiales que se aplican en este género de acción ${ }^{59}$. En opinión de LOZANO Y CORBI, todos se refieren a supuestos en los que, aun prevaleciendo el interés público sobre el personal, existe una concordancia entre el interés de la colectividad y el individual ${ }^{60}$. Sería precisamente el interés del ciudadano, considerado como tal cives, el que le legitimaría para actuar. Debemos destacar ya en este momento que incluso los jurisconsultos romanos designaban la acción popular como "acción pública", al objeto de hacer resaltar su antítesis con las meramente privadas, las que sólo podía ejercitar el que tuviera interés directo.

Puesto que el derecho romano no conoció una concepción abstracta de la actio popularis $^{61}$, deberemos hablar de diferentes acciones en las que confluía su carácter

CORBI, E., La legitimación popular en el proceso romano clásico, Barcelona 1982, pp. 9 y ss. El populus en origen debió ser entendido como una auténtica comunidad concreta, como un grupo ligado por vínculos de paridad y de contigüidad, por lo que debió llevar consigo un sentimiento comunitario. Este significado técnico de populus desapareció, permaneciendo en su lugar la idea de una multitud jurídicamente organizada sobre la base de un común consenso para la consecución de un fin colectivo. Desde el punto de vista político, sería una agrupación o colectividad de personas, que se encontraban en unas condiciones históricas tales como para constituir una comunidad regida por un ordenamiento jurídico autónomo y totalmente soberano. Los autores alemanes, primeros que se ocupan de la cuestión de la actio popularis, cuentan sin embargo con una dificultad idiomática básica. En alemán no existe un término exacto en el que se incluya el elemento voluntarista con que frecuentemente se dota al concepto romano de populus, por lo que el término populus ha sido traducido con frecuencia a esta lengua como "Estado" (Staat), y no como Pueblo (Volk). El término Volk indicaría la mera agregación física de individuos con base en elementos naturales tales como la estirpe o la raza, pero no implicaría la expresa voluntad en esa agregación. Vid. LOZANO Y CORBI, op. cit. pp. 25 y ss.

\footnotetext{
${ }^{58}$ PAALZOW, Zur Lehre von der römischen Popularklagen, Berlín 1889, p. 51.
}

${ }^{59}$ Casi todos provienen de los comentarios sobre el edicto, escritos por Paulo y Ulpiano, a excepción de dos que son de Gayo y Marciano. Los textos completos han sido recopilados por LOZANO Y CORBI, E., La legitimación popular en el proceso romano clásico, Barcelona 1982, pp. 64 y ss. No entramos a considerar los "edictos populares"que entendemos nos desvían en exceso del tema objeto de estudio. Éstos serían mecanismos procesales para la protección de cosas, lugares y bienes sagrados y de las rei publicae en general (vías públicas, orillas de ríos, puertos, etc.). Son cercanas así a las acciones populares de nuestro derecho administrativo. Vid. entre otros FADDA, C., L'azione..., op. cit. pp. 50 y ss.

\section{${ }^{60}$ LOZANO Y CORBI, E., La legitimación popular..., op. cit. pp. 64 y ss.}

${ }^{61}$ En palabras de ORESTANO, las lenguas nacionales actuales tienen una ventaja sobre el latín: la utilización de conceptos abstractos construidos con el artículo determinado. Así fue posible construir el concepto de "la acción" procedente de las diversas actiones romanas. Vid. ORESTANO, R., Azione, diritti soggettivi, persone giuridiche, Bolonia 1978, pp. 79 y ss. 
1) Acciones populares pretorias y edilicias: eran en general acciones in personam, en las que el actor sostenía que el demandado, al infringir el edicto, había incurrido en un hecho ilícito con contenido penal que llevaba consigo la obligación de reparar el daño causado. En defecto de personas interesadas, las acciones populares eran otorgadas a cualquier ciudadano aun cuando la idea central fue siempre la de la elección de aquel que tuviera interés más directo en el hecho ilícito ${ }^{62}$. Se podrían incluir en esta categoría las acciones: a) actio de sepulchro violato para reprimir la violación de sepulturas en virtud de la defensa de su carácter santo, que afectaba a todos los integrantes del populus ${ }^{63}$; b) actio de albo corrupto contra todo aquel que dolosamente hubiera destruido, borrado, alterado o hecho desaparecer cualquier notificación pública del Pretor ${ }^{64}$; c) actio contra aquellos que no hubiesen acatado a los magistrados con Jurisdicción ${ }^{65}$; d) actio de effusis et deiectis para garantizar la seguridad viaria en las calles de la ciudad. Se dirigía contra los que derramaran o arrojaran líquidos o sólidos causando daño a las cosas, herida o muerte de un hombre libre, desde los edificios a la vía y siempre durante el día ${ }^{66}$; e) actio de positis et suspensis complementaria de la anterior ${ }^{67}$; f) Actio edilicia de feris con el fin de prohibir la tenencia de animales peligrosos ${ }^{68} ; \mathrm{g}$ ) actio de tabulis apertis contra los que hubiesen abierto el testamento o cualquier acción contra el edicto ${ }^{69}$; h) actio de mortu illato para el caso de depósito de un cadáver en lugar público ${ }^{70}$.

2) Acciones populares nacidas de leyes y de senadoconsultos: éstas nunca

\footnotetext{
${ }^{62}$ Vid. LOZANO Y CORBI, La legitimación..., op. cit. p. 306. D. 47.23.3.1 ULPIANO, 1 ad ed.: In popularis actionibus is cuius interest praefertur.

${ }^{63}$ D. 47.12.3.9., ULPIANO, 25 ad Ed.

${ }^{64}$ D. 2.1.7. pr.; ULPIANO, 3 ad Ed.

${ }^{65}$ D. 2.3.1. pr., ULPIANO, 1 ad Ed.

${ }^{66}$ D. 9.3.1; ULPIANO, 23 ad Ed.

${ }^{67}$ D. 9.3.5 y 6; ULPIANO, 23 ad Ed.

${ }^{68}$ D. 21.1.41; ULPIANO, 2 ad Ed. aedil. curul.

${ }^{69}$ D. 29.5.25.2; GAYO, 17 ad Ed. prov.

${ }^{70}$ D. 11.7.8.2; ULPIANO, $25 \mathrm{ad} E d$.
} 

multas cuya naturaleza civil o penal ha sido debatida por la doctrina romanista, pronunciándose la más reciente en favor de su carácter civil a pesar de que mediante su ejercicio se defendieran intereses de la colectividad. En estos casos el interés público radicaba en la defensa de los derechos e intereses de la colectividad, de todos y cada uno de los ciudadanos, cuyos deberes como tales ciudadanos les obligarían a interponer esta acción con ánimo de garantizar el bien común de la sociedad a la que pertenecían. Es este contenido ético, y no el puramente económico referido al reparto del beneficio obtenido con la interposición de la acción, el que le otorgaría el carácter de popular por ir contra los que mediante la realización de hechos ilícitos perjudicasen el interés general de toda la comunidad y de cada ciudadano en particular ${ }^{71}$. Son encuadrables en esta categoría por ejemplo las acciones contenidas en la Lex Iulia municipalis, la Lex agraria de Cayo César, la Lex Quinctia de aqueductibus, la Lex Bantiae latina, la Lex Municipii Salpensani, la Lex Municipii Malacitani, la Lex Iulia agraria, etc ${ }^{72}$.

\subsubsection{Redescubrimiento de las actiones populares romanas en el siglo XIX: el actor popular como valedor de un derecho propio o como "procurator populi"}

Una vez expuestas las relaciones entre la acusación y las acciones populares romanas, consideramos conveniente hacer una referencia al apasionado debate de la doctrina romanista de mediados del siglo pasado sobre la naturaleza jurídica de éstas últimas, iniciado en Alemania por BRUNS ${ }^{73}$ y enriquecido de manera trascendental por los autores italianos ${ }^{74}$. A través de él se trataba de determinar si lo que se ejercitaba con

\footnotetext{
${ }^{71}$ Vid. LOZANO Y CORBI, La legitimación..., op. cit. p. 325.

${ }^{72}$ Para una relación completa y un estudio pormenorizado vid. LOZANO Y CORBI, La legitimación..., op. cit. pp. 309 y ss.

${ }^{73}$ BRUNS, C.G., "Die römische Popularklagen”, op. cit., pp. 313 y ss.

${ }^{74} \mathrm{El}$ interés por el estudio de la acción popular en Italia coincidió a finales del siglo XIX con la presentación del diputado LUCCHINI de una propuesta para utilizarla ampliamente. Si a ello se le suma la oportuna traducción de SCIALOJA de la obra de BRUNS, completada con un serio estudio, podremos encontrar explicación a la multitud de trabajos sobre la materia en aquel momento. Sobre este debate vid. COSTA, E. "Nota a proposito di alcuni recenti studi sulle azioni popolare romane”, Rivista italiana di scienze giuridiche, 11 (1891), pp. 360 y ss.
} 
cada una de las acciones populares era un derecho privado de los individuos que constituyera parte de su status civitatis o un derecho integrante de la esfera estatal que permitía ser representado por los legitimados. En esta controversia se perciben ya las dos orientaciones que siguieron presentes en el siglo XIX en torno a la instauración de un sistema de acusación popular en los sistemas de derecho continentales, dos visiones que ponen al descubierto una diversa concepción en torno a su naturaleza, bien como manifestación de una facultad propia, bien como satisfacción privada de una función pública.

La doctrina más autorizada en el periodo citado sostenía que el quivis de populo legitimado para ejercitar las acciones que el Digesto agrupaba bajo el título "de popularibus actionibus" no hacía valer un interés propio sino un interés público, del Estado (o del Pueblo) ${ }^{75}$. El actor no sería más que un procurator del populus, y su función podría ser encuadrable dentro del instituto de la representación, ya que litigaría in nomine alieno. El actor popular desempeñaría un servicio público, por lo que la suma monetaria obtenida con su acción representaría más un premio concedido por la actividad desplegada para tutelar derechos de la comunidad que una compensación por los perjuicios causados a un derecho propio ${ }^{76}$.

La posición contraria fue mantenida por BRUNS al defender la dicotomía entre acciones populares de creación pretoria, en las que el actor haría valer un interés propio, y acciones populares previstas en la ley, de carácter procuratorio por cuanto se actuaría en favor de la comunidad ${ }^{77}$. Las verdaderas o propias acciones populares no serían estas últimas en las que se hacía valer un interés del populus, sino las pretorias en las que el ciudadano actúa por un derecho público pero no de pertenencia exclusiva a la comunidad, por lo que el beneficio pecuniario obtenido redundaría únicamente en su favor. Próximas

\footnotetext{
${ }^{75}$ Recuérdense al respecto las dificultades terminológicas a las que ya hemos hecho referencia.

${ }^{76}$ MOMMSEN, T., "Kommentar zu den Stadrechten von Salpensa und Malaca”, Berichte der kgl. sächs. Ak, 3 (1857), pp. 461 y ss; “Die Popularklagen”, Gesammelte Schriften, T. 3, Juristitsche Schriften, T. 3, Berlín 1907, pp. 375 y ss. Este último artículo fue publicado originariamente en Zeitschrift der Savigny-Stiftung für Rechtsgeschichte, Romanistische Abt., XXIV, (1903), pp. 1-12 como crítica a BRUNS. Vid. también SAVIGNY, F.K., Sistema del diritto romano attuale (traducción al Italiano de SCIALOJA), T. II, Turín 1888, p. 139.

${ }^{77}$ BRUNS, C.G., "Die römische Popularklagen", op. cit. El punto clave para la distinción no sería tanto el origen legal o edictal de las acciones de que se trate cuanto la atribución al actor del beneficio obtenido. Vid. FADDA, C., L'azione popolare, op. cit., p. 286. Es significativo señalar que BRUNS era consciente de la actualidad del tema en un momento en el que se empieza a proponer el establecimiento de un sistema de acusación penal con intervención generalizada de los particulares (p. 313).
} 

interponer en favor del erario público o tesoro, las pertenecientes a todo ciudadano en ventaja de terceras personas y las acusaciones populares penales (popularis accusatio) que podían concluir con multa y recompensa pecuniaria ${ }^{78}$.

Con respecto a estas últimas, en las que aquí nos habremos de fijar, BRUNS se mostraba de acuerdo con SAVIGNY en el sentido de que debería verse en ellas una especie de acciones de policía (Polizeiklagen) en las que todo ciudadano representaría la posición de un fiscal ${ }^{79}$ que persigue en interés público una pena pecuniaria ${ }^{80}$. La suma obtenida por el desempeño de esta actividad pública le correspondería como una especie de recompensa por ello. Las acciones populares encontrarían su aplicación solamente en casos de delitos leves que sólo podían ser castigados con multa dineraria a través del proceso civil y serían paralelas, pero no idénticas, al derecho general de acusación ${ }^{81}$. Tratándose de delitos públicos, cuyo castigo iría en interés de la comunidad y por consiguiente también del individuo, entendía BRUNS que, por la propia naturaleza de la materia, el que aquí demanda lo hace en interés de la colectividad y en definitiva del Estado, aunque lo haga directamente en su propio nombre y para su provecho. Representará así a la colectividad aun cuando en estrictos términos procesales no sea su procurator $^{82}$. Esto significaría que el actor popular actuaba en su propio nombre y provecho defendiendo uti civis un derecho que le pertenece a él, constituyendo así un

\footnotetext{
${ }^{78}$ BRUNS, “Die römische Popularklagen”, op. cit. p. 367; FADDA, C., L'azione popolare, op. cit. pp. 62 y 286 ; MURGA, “Las acciones populares...”, op. cit. p. 168.

${ }^{79}$ No olvidemos que la palabra alemana que designa al fiscal (Staatsanwalt) y de la que se sirve BRUNS significa literalmente "Abogado del Estado".

${ }^{80}$ En otros casos se justificó la necesidad de introducir la acción popular en Roma por el insuficiente control sobre las conductas ilícitas, de modo que cualquiera podría perseguir mediante una pena privada aquellos comportamientos lesivos del interés público. KUNTZ, Cursus des römisches Rechts, Leipzig 1879, p. 318.

${ }^{81}$ BRUNS, "Die römische Popularklagen", op. cit., p. 367. Con respecto a la naturaleza de las acciones penales legales otorgadas quivis ex populo, PAALZOW afirmó que, si bien sí eran acciones populares, no lo serían en sentido técnico. Este autor incluía un matiz diferente: la prevalencia de un "elemento democrático" en el último siglo de la República para que pudieran surgir las acciones populares. PAALZOW, Zur Lehre..., op. cit., p. 51. Consideraba PAALZOW que la dominancia por elementos aristocráticos hacía que sólo funcionarios revestidos de autoridad pública pudieran desempeñar la función de perseguir las infracciones a los derechos de la colectividad.

${ }^{82}$ BRUNS, “Die römische Popularklagen”, op. cit. p. 346.
} 
Las tesis de BRUNS tuvieron una importante repercusión en Italia donde encontraron tanto apasionados defensores como acérrimos adversarios. Entre los primeros se encuentra SCIALOJA, quien además de traducir su obra reelaboró sus ideas llegando a la conclusión que la distinción del autor alemán se fundamentaba en la existencia de dos categorías diversas de derechos públicos: los "concentrados" en la comunidad y ejercitables por sus órganos o los ciudadanos privados que, para ese supuesto se transforman en instrumentos del Estado, y los “difusos”, atribuídos a los miembros de la comunidad a cuya tutela se ponen las acciones populares verdaderas y propias, que son las previstas en los Edictos pretorios ${ }^{84}$. El derecho que se hace valer con estas acciones en nombre propio es un derecho público que corresponde al ciudadano como miembro del pueblo, pero es un derecho que le corresponde a él y no al Pueblo, que es un ente diferente. El beneficio que obtuviera el actor popular no sería ya un premio sino una compensación por la lesión de un derecho que es suyo y no de todo el Pueblo ${ }^{85}$.

Entre quienes refutaron las opiniones de BRUNS destaca CODACI-PISANELLI, que combatió la idea de que en el fundamento de la acción popular se encuentre un derecho subjetivo. Esa concepción no sería más que la proyección al mundo romano de una idea moderna, la que ve un "derecho accionable" o un "interés jurídico" como

\footnotetext{
${ }^{83}$ La tesis de BRUNS se sustenta sobre un presupuesto sustancial elaborado anteriormente por IHERING, según el cual la aparente anomalía de la legitimación atribuida a cualquier ciudadano encuentra su explicación en la estructura gentilicia de la antigua comunidad. Si la gens es una entidad ordenada comunalmente en la que Estado y Pueblo son equivalentes y la persona física no desaparecería del todo en la abstracción de una personalidad diversa, aquél que actúa en beneficio de la res publica, realiza un interés que le pertenece, no como individuo sino como miembro de la comunidad. El derecho se considerará cuestión de interés común y no, como en los regímenes despóticos, predominio egoísta de uno solo o de una clase. IHERING, Geist des römischen Rechts auf den verschiedenen Stufen seiner Entwicklung, vol. I , p. 211. El concepto de CELSO de actio como ius persequendi iudicio quod sibi debetur (D. 44, 7,51) se correspondería a juicio de BRUNS con este tipo de acciones, pero no con las que se ejercitaban en nombre del pueblo, para las cuales incluso se utilizaban términos diferentes tales como el de petitio. BRUNS, "Die römische Popularklagen", op. cit. p. 352. Contradicen esta opinión entre otros autores HOLDER, VERING, SERAFINI, KIPP y ASCOLI, quienes estiman que las acciones legales fueron también populares de un mayor grado que las pretorias. Vid. las referencias hechas por LOZANO Y CORBI, La legitimación..., op. cit. p. 233. Hay quien ha considerado esta teoría de BRUNS como una simple "expresión de optimismo liberal". Vid. WINKEL, L.C., "Quelques remarques...", op. cit. p. 291.

${ }^{84}$ SCIALOJA, V., Prefazione a Le azioni popolari romane di Bruns, en Studi Giuridiche, I, 1, Roma 1933, pp. 108 y ss. La obra fue publicada originariamente en el Archivio Giuridico de 1882, y constituyó el pistoletazo de salida en el debate doctrinal sobre la acción popular en Italia, no sólo entre los romanistas, sino también en otros ámbitos del derecho.
}

${ }^{85}$ BRUNO, T., Voz “Azione Popolare”, Il Digesto Italiano, IV, 2, Roma/Nápoles 1893-1899, p. 953. 

éstas tienen de especial puesto que, si se hiciera valer un derecho propio, ello sería una acción ordinaria y el atributo de popular no hubiera tenido razón de existir ${ }^{86}$. Siguiendo a MOMMSEN, afirmaba este autor que el Estado romano absorbió al individuo, con lo que el papel del actor popular se reservaba a ciertas funciones que pertenecían a una esfera ética superior. Se trataría de dejar en manos de la iniciativa ciudadana algunas funciones estatales, por lo que en las acciones populares siempre permanecería el carácter de representación del Estado. Aun cuando el importe de la multa ingresara en el patrimonio del actor, la acción popular sería siempre procuratoria ${ }^{87}$.

Un ulterior y definitivo paso que intenta superar la discusión precedente es el dado por FADDA, quien parte del concepto de soberanía popular en el que Estado y pueblo son una sóla cosa. El ciudadano, investido de la soberanía, haría valer un derecho público subjetivo del que es titular. Con ello se superaría la dualidad entre derechos "concentrados" y "difusos" a la que se había referido SCIALOJA dado que en temas de interés general considera difícil si no imposible, hacer una neta distinción entre derechos de la comunidad y derechos del individuo como miembro de ésta. En los supuestos donde la ley concede al ciudadano la facultad de actuar por un interés, le estará reconociendo simultaneamente un derecho, de manera que quedaría así realizado un enlace entre interés individual e interés público ${ }^{88}$.

Ya a mediados del presente siglo CASAVOLA retomó la polémica distinguiendo dos modalidades de legitimación popular y fijando como punto clave el interés del individuo. Por un lado estaría la legitimación exclusiva del interesado a la que podría seguir en su ausencia, renuncia o fallecimiento una legitimación general subsidiaria y, por otro, la legitimación original o inmediatamente general. Sólo en el primer caso podríamos

\footnotetext{
${ }^{86}$ CODACI-PISANELLI, Azione popolare, Nápoles 1887, pp. 79 y ss.

${ }^{87}$ Para realizar esta afirmación, CODACI-PISANELLI toma como base indicios tales como la ubicación en el Digesto del título "De Popularibus actionibus", justo después de lo referido a los Delicta privata y antes del título De publicis judiciis, el no poderse ejercer mediante procurador, el ser intransmisibles pasivamente y la homogeneidad del fundamento jurídico de todas las acciones calificadas como populares. CODACI-PISANELLI, Azione popolare, op. cit. pp. 9 a 81 passim. En el mismo sentido se habían pronunciado también BRINZ en Lehrbuch der Pandekten, Orlangen 1884, pp. 281 y ss. y MASCHKE, "Zur Theorie und Geschichte der Popularklagen", Zeitschrift der Savigny Stiftung. Rom. Abteilung, 6 (1885), pp. 226-259.

${ }^{88}$ FADDA, C., L'azione popolare, op. cit, pp. 306 y 320.
} 

integrar como interés general del populus o como interés público. Nos separaríamos del ius privatum pero no entraríamos en el ámbito del ius publicum, entendiendo ambos en el sentido romano de las palabras y no en el moderno. Por ello sería también un error de la doctrina el calificar como delitos públicos a los perseguibles mediante acción popular, en tanto éstos serían delitos privados que, por no tener un contenido patrimonial, permanecerían ajenos a la familia. Lo "popular" constituiría una especie de zona intermedia entre lo público y lo familiar-privado, y el litigante no tendría que representar ni al poder público ni tan siquiera al populus, sino que actuaría como homo singularis, si bien lo haría como miembro natural de una comunidad ${ }^{90}$.

Más recientemente DANILOVIC enfoca de forma diversa el problema, tomando como referencia el término popularis y el casuismo predicable del derecho romano. En su visión, el calificativo "popular" designaría la legitimación del actor, y no el interés protegido por la acción. Serían populares por tanto todas aquellas acciones concebidas con legitimación expandida, aun cuando su régimen jurídico presentara variaciones importantes entre unas y otras ${ }^{91}$.

Entre los romanistas españoles que se han ocupado del tema hemos de referirnos a LOZANO Y CORBI, quien sostiene que con las acciones populares se trataría de defender un interés público ligado a un interés particular, del cives como tal. De ahí que el actor popular no fuera nunca un representante del populus, de la comunidad a la que pertenece, porque actuaba siempre defendiendo sus propios intereses como ciudadano. En la mentalidad del ordenamiento jurídico romano estuvo presente la idea de tutelar la comunidad contra los actos atentatorios al bien común, los cuales incidían por ello en un daño a la ciudadanía de los miembros integrados en dicho populus ${ }^{92}$.

\footnotetext{
${ }^{89}$ CASAVOLA, F., Studi sulle azioni popolari romane. Le «actiones populares», Nápoles 1958, esp. pp. 17 y s.

${ }^{90} \mathrm{El} \mathrm{fenómeno} \mathrm{de} \mathrm{la} \mathrm{popularidad} \mathrm{derivaría} \mathrm{de} \mathrm{la} \mathrm{insuficiencia} \mathrm{de} \mathrm{la} \mathrm{familia} \mathrm{para} \mathrm{hacer} \mathrm{frente} \mathrm{a} \mathrm{nuevas} \mathrm{materias,}$ siempre de derecho privado, pero que conciernen no sólo a los tradicionales sujetos de derecho privado, sino a todos los miembros del ordenamiento social. CASAVOLA, Studi sulle azioni popolari romane..., op. cit. p. 20 y MURGA, "Las acciones populares", op. cit. p. 108.

${ }^{91}$ DANILOVIC, J., Observations sur les “actiones populares”, Studi in onore di G. Grosso 6, Turín 1974, p. 15 y ss.

${ }^{92}$ LOZANO Y CORBI, La legitimación..., op. cit. pp. 244 y s.
} 
Lo trascendente en este momento será retener que nos movemos en un ámbito fronterizo entre lo público y lo privado, en el que el carácter popular de las acciones tiene más que ver con la extensión generalizada de la legitimación para su ejercicio que con el interés defendido mediante cada una de ellas. En este marco se produjo la recepción en nuestro derecho de un sistema de acusación en el que se contiene una acción de carácter popular que viene a determinarlo significativamente en su apertura y generalización subjetiva. 


\section{LA ACUSACIÓN POPULAR EN NUESTRO DERECHO HISTÓRICO}

\subsection{La acusación popular hasta el siglo XIX}

\subsubsection{El antiguo derecho castellano}

En la alta Edad Media castellana las diferencias entre proceso penal y civil eran prácticamente inexistentes y el principio "nadie responda sin querelloso" (nullum respondeat sine querelloso) regía la actividad procesal en la mayoría de los Fueros municipales. El proceso era un sustitutivo del combate (duelo) entre ofensor y ofendido y la función del juez no iba más allá de la mera vigilancia de la observancia de las normas, dado que el interés de la comunidad se centraba sólo en la necesidad de un marco institucionalizado que legitimara el castigo ${ }^{93}$. De ordinario, el proceso principiaba por simple citación, querella o demanda presentada por el ofendido o sus parientes, que por lo regular iba acompañada del llamado "juramento de manquadra" para garantizar la buena fe del demandante. Este solemne juramento, cuyo valor se fundamentaba sobre el castigo del perjuro en el más allá, podía actuar en defecto de otra prueba principal tanto en favor del acusador como del reo (juramento purgatorio) ${ }^{94}$. A medida que se puso de manifiesto que determinadas acciones constituían un ataque contra el orden de la comunidad en su conjunto, la dependencia de la actividad de los directamente ofendidos se reveló ineficaz. Con el objeto de arbitrar los medios necesarios para satisfacer la vindicta pública, los jueces fueron asumiendo funciones activas en la investigación de los delitos y en los procesos a través de la institución de la "pesquisa" hasta que posteriormente, con el influjo de la recepción romano-canónica, ésta se convirtió en uno de los medios de

\footnotetext{
${ }^{93}$ Es esclarecedora a este respecto la visión de Eberhard SCHMIDT que, si bien se refiere al primitivo proceso germánico, es plenamente aplicable en varios de sus aspectos al castellano. Vid. SCHMIDT, E., Einführung in die Geschichte der deutschen Strafrechtspflege, $3^{\mathrm{a}}$ edición, Gotinga 1965, pp. 76 y ss.

${ }^{94}$ ALONSO ROMERO, M.P., El proceso penal en Castilla (siglos XIII-XVIII), Salamanca 1982, pp. 4 y ss. El elemento característico de la manquadra era el juramento de que no se hacía la demanda por malquerencia, sino porque se creía culpable a una determinada persona. Vid. GARCÍA GONZÁLEZ, J., "El juramento de Manquadra", AHDE, XXV, pp. 211-255.
} 
iniciación del proceso penal.

El Fuero Juzgo, de base romanista y utilizado por Fernando III y Alfonso X dentro de su política legislativa unificadora, regulaba como norma general un proceso acusatorio que comenzaba a iniciativa del ofendido, complementado con un proceso de oficio previsto para casos especialmente graves. La norma contemplaba ya para supuestos de homicidio una acusación quivis ex populo de ejercicio subsidiario a la que deberían ejercer los parientes más cercanos y únicamente en defecto de ésta preveía la intervención de otros sujetos: "mandamos a los parientes mas propincos del muerto que puedan acusar aquel, quien fizo el omezillio; é si por ventura aquellos no lo quisieren acusar, ó tardaren por lo fazer, dalli adelantre todos los otros parientes lo pueden acusar, é los otros estrannos " 95 . En el Fuero Juzgo aparece en nuestro derecho histórico por primera vez la idea de la inscriptio romana, es decir, el compromiso del acusador de recibir la misma pena por él pretendida para el acusado en el caso de que éste resultara absuelto. Sin embargo, no era suficiente la mera acusación para someterse al riesgo de sufrir el Talión, sino que sólo vendría obligado a ello aquel acusador que exigiera la aplicación de tormento al reo, y ello siempre bajo ciertas garantías ${ }^{96}$.

\subsubsection{El proceso canónico y las Decretales}

Al tiempo de la promulgación de las Decretales, la Iglesia ya había dado entrada en su legislación penal al proceso inquisitivo, permitiendo que el juez pudiera entablar procedimiento contra persona infamada, oír a los testigos y dictar sentencia aun cuando no hubiese acusación. La persecución de oficio, eficaz instrumento de control basado sobre la plenitudo potestatis del Pontífice y el derecho de vigilancia inherente a ella, constituyó posteriormente una fuente fundamental de inspiración para el Espéculo y las

\footnotetext{
${ }^{95}$ Vid. El Rey Don Rescindo. Ley XV, Tít. V, Libro VI. Extraído de la edición publicada por la REAL ACADEMIA ESPAÑOLA, Fuero Juzgo o Libro de los Jueces cotejado con los mas antiguos y preciosos códices, Madrid, 1815. En opinión de CERDÁ, en las leyes visigodas se autorizaba para estos casos incluso la persecución por iniciativa del Juez. Vid. CERDÁ RUIZ DE FUNES, J., "En torno a la pesquisa y procedimiento inquisitivo en el derecho castellano-leonés de la Edad Media", AHDE, T. XXXII, p. 498.

${ }^{96}$ ALONSO ROMERO, M. P., El proceso penal en Castilla..., op. cit. p. 10.
} 
Partidas $^{97}$. En las Decretales se preveían ya las tres formas de iniciación del proceso típicas del proceso romano-canónico: la acusación, que daba paso a un procedimiento acusatorio, la denuncia y la inquisitio, que daban paso a un procedimiento inquisitivo ${ }^{98}$. En el primer caso, dominado por un principio de intervención privada, se establecía como requisito de admisión de la acusación la inscriptio -compromiso de sufrir la misma pena pretendida para el acusado en el caso de que la acusación no se pudiera probar, que se actualizaba con la sentencia absolutoria- ${ }^{99}$. El proceso inquisitivo podía ser iniciado por denuncia de los particulares o de oficio por el juez tras conocer la diffamatio de una persona, el rumor público que atribuyera a una persona la comisión de un delito ${ }^{100}$. La denuncia no llevaba aparejada consigo el compromiso de la inscriptio, ya que se consideraba que la denuncia pretendía la corrección del pecador, mientras que con la acusación se pretendía expresamente la pena ${ }^{101}$.

\footnotetext{
${ }^{97}$ CERDÁ RUIZ DE FUNES, J., “En torno a la pesquisa y procedimiento inquisitivo...”, op. cit. p. 493.

${ }^{98}$ Sobre las formas de iniciación de los procesos inquisitivos vid. la interesante obra de EIMERIC, N. y PEÑA, F., El Manual de los Inquisidores, Traducción editada por Muchnik, Barcelona 1996, pp. 134 y ss.
}

99."Hay proceso de acusación cuando ante el inquisidor alguien acusa a otro de herejía, manifiesta su voluntad de demostrar su acusación y declara aceptar la ley del talión, en virtud de la cual el acusador acepta, si fracasa, sufrir el castigo que sufriría el denunciado si se demostrara su culpabilidad". EIMERIC, N., Manual de los Inquisidores, op. cit. p. 136. EIMERIC no se declara partidario de este sistema y nos dice que "no es el mejor método en la práctica inquisitorial; es peligroso y muy discutible", pero si el acusador insistiera "el inquisidor no "procederá»" por cuenta propia, sino a instancias de una parte con asistencia de un notario público y de dos religiosos o, al menos, dos personas honradas". Aun así, el inquisidor "aconsejará" al acusador que abandone su acción si viera que de la declaración de los testigos no se derivan suficientes cargos contra el acusado y se contente con ser delator. Op. cit. p. 140.

\footnotetext{
100“"No hay ni confesión espontánea, ni acusación, ni delación, sino el rumor que circula en tal ciudad o en tal región de que fulano ha dicho o ha hecho tal o cual cosa contra la fe o en favor de los herejes. En tal caso el inquisidor inquiere, no a instancias de una parte, sino por su propio oficio (...) Es una modalidad muy común de procesar". EIMERIC, N., Manual de los Inquisidores, op. cit. p. 138.

${ }^{101}$ Relataba EIMERIC en su Manual, redactado originariamente en 1376, que "el inquisidor pregunta al delator si quiere ser acusador en el proceso o si quiere limitarse a denunciar. Si el delator quiere ser acusador, el inquisidor le hará saber que se halla sujeto a la ley del talión. Si, una vez informado de esto, mantiene su calidad de acusador y quiere que se proceda por acusación, se hará como desea el acusador y el proceso se desarrollará por acusación. Si después de la información, el delator no quiere asumir el papel de acusador y declara que se contenta con ser delator (es el caso más frecuente) y si, además, no quiere intervenir en el proceso (también es el caso más frecuente), entonces se procederá (...) por denuncia”. Op. cit. pp. 135 y s. Dos siglos después, PEÑA, en sus comentarios realizados por encargo de la Santa Sede reconoce que "Actualmente ha caido en desuso la ley del talión. El motivo más frecuente alegado por los doctores contra su aplicación es evidente: si se aplicara esta ley al acusador fallido, no se encontrarían delatores $y$, en consecuencia, los delitos quedarían impunes, en gran detrimento del Estado (Reipublicae)". Como destaca SALA-MOLINS en sus notas a la obra de EIMERIC y PEÑA,
} 
Dada la previsión de condena por denuncia calumniosa se admitía, sin embargo, que el denunciante interviniera en el proceso suministrando junto a su propio testimonio pruebas y otros datos sobre la culpabilidad del denunciado, dando origen a la denominada inquisitio cum promovente. Aun así, en caso de que el Juez considerase que no existía el ambiguo requisito de la diffamatio, al denunciante sólo le quedaba la posibilidad, si quería continuar con la persecución del delito, de constituirse en acusador, asumiendo directamente la carga de la prueba y el riesgo que implicaba la inscriptio. Por lo que a este trabajo respecta, la trascendencia de la figura del acusador-denunciante se sitúa en el hecho de que se configura por primera vez una especie de acusador no necesariamente ofendido directamente por el delito y libre del requisito de la inscriptio, enmarcado en el contexto de un proceso de corte inquisitivo teóricamente de carácter extraordinario pero que en la práctica era ya el ordinario ${ }^{102}$. Tal y como se verá posteriormente, su aparición en las Decretales será decisiva para realizar el trasvase al campo secular dentro de la posterior evolución del proceso romano-canónico.

\subsubsection{La legislación alfonsina}

Es en las normas del Derecho Común donde encontramos reflejado diáfanamente el sistema romano de acusación, que se ve trasplantado prácticamente en sus mismos términos a la legislación castellana. El proceso penal comienza a ser visto en esta época como uno de los instrumentos de actuación del poder Real para llevar a la práctica su política y acrecentar el control sobre sus súbditos ${ }^{103}$. Conceder legitimación a todo

es indispensable señalar que éste último se refiere a la Respublica y no a Christianitas o Populus christianus. Op. cit. p. 137.

${ }^{102}$ ALONSO ROMERO, M.P., El proceso penal en Castilla..., op. cit. pp. 22 y ss. El carácter extraordinario del proceso inquisitivo se derivaría en su opinión del hecho de que en estos supuestos el Juez podría atenuar la pena que le viniera asignada.

\footnotetext{
${ }^{103}$ Como señala PEDRAZ, a lo largo del Antiguo Régimen, la administración de la justicia como función progresivamente estatal, en coexistencia con otras Justicias de muy variados orígenes (señorial, eclesiástica, etc.) se presenta, junto con la recepción romano-canónica, como "uno de los instrumentos utilizados por el príncipe para ir asentando su poder, crecientemente absolutista frente a los estamentos privilegiados". En este sentido resalta el citado autor que "es precisamente en la aplicación judicial del «ius commune», en el proceso, donde más claridad puede destacarse la influencia del nuevo derecho, tendiéndose a institucionalizar, de un lado, la renuncia a la autodefensa, y de otro, la posibilidad de eludir la «justicia particular» en favor de un órgano público, controlado pues por el poder Real a cuya Administración pertenece". La administración de la justicia constituirá de esta manera uno de los medios utilizados por el Estado, crecientemente absolutista, para atraer a sí, con carácter exclusivo, la
} 
individuo que quisiera luchar contra las infracciones de la ley emanada de la potestad regia, autorizando la lucha contra los enemigos de la nación, no puede concebirse sino como una forma más de acrecentar la autoridad real mediante el establecimiento de una vigilancia dispersa. El ejercicio de la acusación quivis ex populo en el marco de un proceso penal acusatorio tendencialmente privatista, no puede ser entendido en estos momentos si no lo es dentro del propósito de acrecentar el control del Rey sobre su reino, persiguiendo eficazmente todos los delitos. Dado que el delito es ya considerado un hecho que excede el ámbito de lo puramente privado y entra dentro del interés público en la administración de la justicia, la acusación popular es ciertamente un medio de evitar la impunidad en que pudieran permanecer determinadas conductas en las que faltara un acusador. Si a ello añadimos el papel cada vez más relevante del proceso inquisitivo habremos de concluir que de una u otra forma, la orientación que asume el proceso penal desde su iniciación adquiere tintes publicistas que lo hacen alejarse de su entendimiento dentro de estrictos términos privados para considerar la existencia de un verdadero daño social.

Con el objeto de corroborar estas afirmaciones veremos cómo se articula en los textos alfonsinos la facultad acusatoria de los particulares, comprobando que esa facultad se modula, ampliándola o restringiéndola, en función de criterios que persiguen la finalidad de reafirmación del poder de legislar del monarca a través del efectivo cumplimiento de sus mandatos. La máxima represión posible de los hechos criminosos a través del proceso, para la cual se invoca la colaboración de los súbditos del reino, puede ser contemplada como una de las formas de que se sirve el monarca para asentar su potestad. Excluir a algunos sujetos de la acusación y autorizarla cuando sean los ofendidos, ampliar más la legitimación activa cuanto más graves se consideren los delitos o elegir como acusador al extraño sólo en defecto de ofendido por el delito y de entre ellos sólo al primero que concurra, son indicios de que el objetivo no se cifraba en garantizar una libertad individual de acusar sino en asegurar la máxima implantación de la ley penal allí donde políticamente se percibía necesario.

función legislativa. De ahí que deba resaltarse la trascendencia el derecho castellano-leonés de los «casos de Corte». PEDRAZ PENALVA, E., "Sobre el «Poder» Judicial y la Ley Orgánica del Poder Judicial”, en Constitución, Jurisdicción y Proceso, Madrid 1990, pp. 147 y s. 


\subsubsection{Fuero Real}

El primer reconocimiento expreso en el Derecho castellano de la facultad general de acusar en favor de los particulares que no hubieran sido ofendidos por el delito se encuentra en el Fuero Real de Alfonso X en los siguientes términos: "Establecemos que todo ome pueda acusar a otro sobre fecho desaguisado, si non a aquellos que defiende la ley que non puedan acusar" ${ }^{104}$. Cuando se tratare de un acusador no ofendido por el delito se le exigían como garantía de su recta actuación ciertas formalidades, entre las cuales destacaba el que debiera hacerse por escrito ante autoridad competente con el compromiso asegurado por la inscriptio de probar el hecho de que se acusare: "Quien a otro quisiere acusar sobre cosa, que non fue fecha a él, nin a ome por que él aya derecho de demandar, dé la acusacion en escripto antel rey, o ante alcalle ante qui lo acusa, e escriba el fecho sobre que lo acusa, e el anno, e el mes, e el logar, en que lo fizo, e escriva que él provará aquello que dize, e si non que él se pasará aquella pena que levarie aquel otro, si gelo provase, e en otra guisa non lo pueda acusar" ${ }^{105}$. La simple interposición de acusación acarreaba consecuencias muy gravosas para el reo puesto que daba lugar a una culpabilidad aparente como idea que regía el proceso y que el acusado debería destruir. Por ello la garantía de fiabilidad quedaba reafirmada con el establecimiento de la pena de Talión para el caso de que no se probase el hecho de que se acusó sin haber sido dañado por el delito: "Sy el acusador non provare al acusado aquello sobre quel acusó, aya tal pena qual avrie el acusado, si gelo provase" ${ }^{106}$. Por el contrario, las consecuencias de la falta de prueba en las acusaciones para las que no se exigía la inscriptio serían simplemente el pago de las costas y los daños infligidos al acusado.

\footnotetext{
${ }^{104}$ L. 1, T. 20, Lib. IV. Las referencias al Fuero Real han sido tomadas de la edición realizada por la REAL ACADEMIA DE LA HISTORIA: Fuero Real del Rey Don Alonso el Sabio. Copiado del Códice del Escorial y cotejado con varios Códices de diferentes Archivos, Madrid 1836. En el Fuero Real se consideraba pleito criminal aquel que puede desembocar en pena de muerte, corporal, pérdida de todos los bienes o destierro (L.7, T. 10, Lib. Iy L. 3, T. 20, Lib. IV). Los delitos que sólo llevasen aparejada pena pecuniaria debían sustanciarse como si se tratara de una demanda civil. La regla general era el proceso civil y las particularidades del proceso penal se introducían por vía de excepción, como por ejemplo, tratándose del modo de iniciación: mientras el proceso penal comienza por acusación, el civil lo hace por querella. Vid. ALONSO ROMERO, M.P., El proceso penal en Castilla..., op. cit. p. 29.
}

\footnotetext{
${ }^{105}$ L. 5, T. 20, Lib. IV.

${ }^{106}$ L. 7, T. XX, Lib. IV.
} 
No era posible tampoco el nombrar personero en representación del acusador, de forma que la responsabilidad de la acusación no podría ser de ningún modo transmitida. Para evitar componendas, una vez iniciado el procedimiento, las partes no podían desistir o hacer avenencias sin licencia del juez. La validez de la cosa juzgada tratándose de acusaciones realizadas por personas no ofendidas por el delito era más bien escasa, por cuanto se podía acusar de nuevo a una persona ya absuelta por esa misma causa cuando lo hiciese persona afectada por el delito en su persona, sus parientes, vasallos y hombres de su compañía y jurase que no había tenido noticias del otro juicio o probase que el reo había sido absuelto por falsa sentencia o falsas pruebas ${ }^{107}$. Un indicativo del carácter privatista del proceso se puede deducir también de la vinculación personal con la acusación, como demuestra la previsión de dar por quito al reo no sólo por sentencia absolutoria, sino también cuando el acusador moría antes de la sentencia, cometía delito por el que mereciese morir o retirase su acusación con permiso del juez ${ }^{108}$.

La iniciativa oficial en la persecución, complementada con la facultad popular de denuncia, cumplía solamente una función supletoria de la iniciativa privada a través de la accusatio $^{109}$.

\subsubsection{Las Partidas}

Legitimados para acusar

En Las Partidas se encuentra el origen inmediato de la posibilidad de cualquier ciudadano de deducir acusación con las excepciones previstas legalmente, recibiéndose así en su plenitud en nuestro ordenamiento el sistema procedente del derecho romano clásico $^{110}$ : la Ley 2 , Título I de la $7^{a}$ Partida establece que "Acusar puede todo ome que

\footnotetext{
${ }^{107}$ L. 13, T. 20, Lib. IV.

${ }^{108}$ ALONSO ROMERO, M.P., El proceso penal en Castilla..., op. cit. p. 34.

${ }^{109}$ En opinión de ALONSO ROMERO, M.P., El proceso penal en Castilla..., op. cit. p. 35, se admitiría en bloque la denuncia popular ya que no se especifica nada ni se alude a personas imposibilitadas para denunciar.
}

\footnotetext{
${ }^{110}$ La trascendencia de Las Partidas se sitúa en el hecho de que en ellas quedó fijado el esquema del proceso penal romano-canónico que persistirá durante siglos y que se verá en gran medida reflejado en nuestras normas procesales tras el periodo codificador decimonónico. No se conserva del "Espéculo", la otra de las principales obras legislativas alfonsinas, el título correspondiente a las acusaciones a pesar de que muchas de sus leyes se refieran a él. En cualquier caso, sus diferencias con las Partidas no debieron de ser importantes. ALONSO ROMERO, M.P., El proceso penal en Castilla..., op. cit. p. 38.
} 
non es defendido por las leyes deste nuestro libro" "111. Con este reconocimiento accedían al proceso penal finalidades que iban más allá de la venganza del ofendido al hacer presentes dentro de él intereses no estrictamente privados que se entroncan ya con una contemplación del delito como lesión social. Se perseguía de esta manera una función de carácter preventivo, dirigiendo al resto de la comunidad un aviso tendente a evitar la comisión de nuevos delitos: "Propiamente es dicha acusacion, profaçamiento que vn ome faze a otro ante del Judgador, afrontandolo de algun yerro, que dize que fizo el acusado, e pidiendol, que le faga vengança del. E tiene grand pro tal acusacion a todos los omes de la tierra comunalmente. Ca por ella, quando es prouada, se escarmienta derechamente al malfechor, e recibe vengança aquel que recibio el tuerto. E demas, los otros omes que lo oyeren, guardarse han despues de fazer cosas, por que puedan ser acusados"112. El otorgamiento de un "derecho de acusación" a todo aquel que quisiere ejercitarlo iba así dirigido a evitar el que, por falta de quien hiciera poner en marcha la pesada maquinaria de la justicia, pudieran quedar impunes los delitos. La fiabilidad de la norma estaba en juego si no se aplicaba y la garantía dimanante del control recíproco de todos frente a todos podría constituir un cauce certero para la consecución de aquel objetivo. En un momento de relativa debilidad estatal, el súbdito deviene destinatario de una facultad dirigida a hacer cumplir la norma emanada del emergente poder regio y contribuye con su acción procesal al reforzamiento de éste. La competencia para acusar seguía siendo no obstante una facultad de los particulares antes que una obligación de la autoridad pública y su finalidad se cifraba también en la propia satisfacción privada del acusador. La tensión, siempre presente en el proceso, entre el interés del poder público y el del individuo particularmente afectado iba, sin embargo, tendiendo en favor del primero, y el ejercicio generalizado de la acusación se erigía en uno de sus principales puntos de apoyo.

La salvaguardia del derecho a acusar por parte del ofendido junto con el interés por

\footnotetext{
${ }^{111}$ El hecho de que por "pleyto criminal" se entiendiera un concepto mucho más amplio que el contenido en el Fuero Real, abarcando también las infracciones que llevaran aparejada "pena qualquier, por que fuesse mal enfamado", incrementaba de hecho el ámbito en el que era permitida la acusación de cualquiera.

${ }^{112}$ L. 1, T.I, P.VII. Ya entrado el siglo XIX escribía GUTIÉRREZ que la libertad de acusar se confirió con un carácter tan amplio porque "creyeron los sabios legisladores de aquellas naciones que la libertad de acusarse los ciudadanos, siendo unos recíprocos y observadores vigilantes de su conducta, era el mas fuerte freno para contenter á los malhechores, y un sólido apoyo del orden público y de las leyes". GUTIÉRREZ, J.M., Práctica Criminal de España, Madrid 1819, T. I, p. 101.
} 
la represión de todos los delitos, especialmente los sensibles en relación con el afianzamiento y ampliación del poder real, pueden ser contemplados como dos de los rasgos básicos sobre los que se asienta la forma acusatoria de las Partidas. Al tratar cada delito en concreto se especifica quiénes pueden acusar, restringiendo el número de personas en unos casos (v. gr. el adulterio) y aumentándolo en otros, que normalmente coinciden con delitos especialmente graves o que atacan bienes jurídicos de titularidad estatal. La facultad general de acusar se completa así en supuestos en los que, por concurrir un interés que pudiéramos definir como general, se prevé acusación popular específicamente para la persecución de delitos perjudiciales a los intereses del conjunto de la sociedad, el Estado y en definitiva el monarca, tales como los de falsedad o falsificación de moneda ${ }^{113}$. En otros casos se libera al actor de gravámenes formales que dificulten su acusación e incluso se habilita a personas no autorizadas con carácter genérico para acusar en juicio por traición al Rey o al reino o por ofensa recibida por él mismo, sus parientes, libertos o señores ${ }^{114}$.

Partiendo de la habilitación general para deducir acusación en delitos no privados, la ley determina al igual que en el sistema romano las personas y las hipótesis en las que no se reconoce tal facultad ${ }^{115}$. Ello da origen a un régimen totalmente casuístico en el que se precisa en cada supuesto específico la determinación de si era o no posible acusar ${ }^{116}$.

113،Cada vno del pueblo puede acusar a aquel que faze falsedad en alguna de las maneras que son puestas en este titulo (...) Otrosi dezimos que cada vno del Pueblo puede prender a los que fizieren moneda falsa. Pero deuenlos aduzir al Rey o ante el Judgador del lugar, que los judgue, assi como es fuero e derecho". L. 5, P. VII.

${ }^{114}$ Desde otro punto de vista, sin embargo, y atendiendo entre otras razones a una consideración de naturaleza privada del delito de homicidio, la previsión de acción popular en este supuesto es solamente de carácter subsidiario, en defecto de acusación realizada por los familiares de la víctima: “...Pero si los mas cercanos parientes fueran negligentes, que non quisieran acusar al matador, estonce bien lo pueden fazer los otros: e si pariente non ouiere ninguno, que pueda, nin quiera acusar, nin demandar la muerte del ome que ouiesen muerto; estonce bien puede fazer cada vno del Pueblo acusacion, en aquella manera, e ante aquellos Juezes, que diximos en el titulo de las acusaciones". L. 14, Tít. 8, P. VII.. No se olvida el contenido de ataque contra la colectividad en la medida que se habilita a todos a acusar, pero este interés se subordina al de los allegados a la víctima.

${ }^{115}$ L. 2, T. I, P. VII.

${ }^{116}$ Frente a las prohibiciones quedaba siempre a salvo para el ofendido la garantía de solicitar el castigo del delito mediante acusación, y en todas las hipótesis de exclusión sería admisible la querella cuando el delito hubiese sido cometido contra ellos mismos, sus familiares hasta el cuarto grado o sus señores (por tuerto o mal, que ellos mesmos ouiessen rescebido, o sus parientes fasta el quarto grado). Tratándose de delitos de conspiración contra el Estado o de lesa majestad divina y humana (pleyto de traycion, que pertenesciesse al Rey o al Reyno), dado el supremo interés en su represión, no quedaba excluido nadie de aquella facultad. Vid. L. 2, T. I, P. VII y la glosa de GREGORIO LÓPEZ. 
En este sistema estaban excluidas expresamente las mujeres ${ }^{117}$ (la muger), los menores de catorce años (el moço que es menor de catorze años) ${ }^{118}$ y los oficiales encargados de la administración de la justicia (el Alcalde o Merino, o otro Adelantado que tenga oficio de Justicia $)^{119}$. No ostentaban esta capacidad tampoco los infames (dado por de mala fama), los que hubiesen cometido falso testimonio (aquel que le fuesse prouado que dixesse falso testimonio) y los que por dinero acusaren o desistieren de la acusación hecha (que rescibiera dineros por que acusasse a otro o que desamparasse por ellos la acusacion que ouiesse fecha). Tampoco podrían acusar legítimamente los que ya tuviesen ejercitadas dos acusaciones hasta que no se hubiesen resuelto aquellas (aquel que ouiesse fechas dos acusaciones, non puede fazer la tercera fasta que sean acabadas en juyzio las primeras) ni quienes carecieran de medios económicos superiores a la renta de cincuenta maravedíes (ome que es muy pobre, que non ha la valia de cincuenta marauedies) ${ }^{120}$. Asimismo no podían acusar los clérigos ${ }^{121}$ (ni éstos ser acusados por los laicos ${ }^{122}$ ), esclavos ${ }^{123}$ ni el

${ }^{117}$ Para DOU y BASSOLS, ya en el siglo XIX, las razones de tal exclusión estribaban en que no parecía decente por razón de su sexo la intervención en juicios públicos y en que no se las admitía en empleos públicos ni como abogados. A ello se añadía un principio de desconfianza en su capacidad y de temor por la manipulación de que pudieran ser objeto, pues "estaría expuesto a muchas colusiones de empeñarse las mugeres en acusaciones por algunos calumniadores, y a seguridad de quedar impune la maldad de la calumnia con el pretexto y seguridad del sexo". Instituciones de Derecho Público..., op. cit. p. 127. Los mimos motivos están presentes también en la opinión de GUTIÉRREZ: "no puede ejercerla (la acusación) porque no es decoroso que frecuente los Tribunales persiguiendo delitos cuyo castigo no le interesa particularmente y ya porque a causa de su fragilidad e inexperiencia no pueden esperarse de sus acusaciones los mejores efectos". Práctica Criminal de España, op. cit. T. I, p. 103. Sí podía acusar la mujer, sin embargo, la muerte de su marido e incluso podía hacerlo con carácter preferente a otras personas.Vid. GREGORIO LÓPEZ DE TOVAR, glosa 3, L. 2, T. I, P. VII.

${ }^{118}$ El menor de 25 años sí estaba autorizado a acusar, pero precisaba la intervención de curador.

${ }^{119}$ DOU y BASSOLS (p. 126) esgrime tres causas: que en el Derecho Romano los magistrados no podían ser acusados y hubiera sido disonante que tuviesen la facultad de acusar, que debían ocuparse en las funciones de su ministerio "sin distraerse en acusar a otros" y para que "no se oprimiese con la prepotencia del acusador a los inocentes". GUTIÉRREZ (p. 104) afirma que "hubo de temer más la ley el poder e influjo de su cargo que confiar en el honor e integridad con que deben estar condecorados".

${ }^{120}$ En opinión de DOU y BASSOLS, R.L., Instituciones del Derecho Público General de España con noticia particular de Cataluña, Madrid 1803, T. VIII, p. 131, les puede ocurrir lo que de los jueces de Clodio relata Ciceron: que les mueva más el hambre que la fama, jugando con el vocablo latino que identifica hambre con fama: quos fames magis quam fama commoverit. GUTIÉRREZ, (p. 103) indica que "aunque el pobre no es despreciable como tal, y puede ser un hombre honrado, la indigencia es fácil al soborno y la seducción".

${ }^{121}$ Pero sí podían en el fuero eclesiástico cuando fueran ofendidos o perjudicados por el delito o se tratara de delito contra la Iglesia y no se previera pena de sangre: "empero prosiguiendo su propia injuria, ó de los suyos, ó de su Iglesia, bien lo puede hacer, si el delito es tal en que no venga pena de sangre, como esta definido en el derecho canónico". HEVIA BOLAÑOS, J., Curia Philipica, Edición publicada en Madrid, 1797, p. 199. cap. Sacerdotem, quaest. $7^{\mathrm{a}}$. El clérigo que acusara y de ello se derivara pena de sangre, incurría en Irregularidad, impedimento 
procesado criminalmente por delito grave mientras lo estuviera, a no ser que lo hiciera por otro crimen mayor ${ }^{124}$.

Se establecían también limitaciones específicas para la acusación entre sí a los que tuviesen participación conjunta en el delito (los que fueran compañeros en algun yerro, non pueden acusar, el vno al otro, sobre aquel mal que fizieron de consuno), al siervo con respecto a su señor (el que fuere sieruo al señor que lo aforro), los hijos y nietos con respecto a sus ascendientes (el fijo, nin el nieto, al padre, nin al auuelo), los hermanos entre sí (el hermano a su hermano), o los criados y sirvientes a sus señores (el criado o el seruiente e familiar a aquel que lo crio, o en cuya compañia biuio, faziendole seruicio o

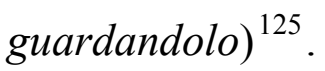

\section{Pluralidad de acusadores}

La acusación por más de una persona a la vez no era admitida, por lo que concurriendo varios acusadores con la misma acusación, el Juez debía escoger a uno sólo de entre ellos. En estos casos sería preferido en primer lugar el acusador "propio", es decir, el que acusa por ofensa cometida contra él o sus parientes y sólo posteriormente el “extraño". Entre éstos se optaría por el primero que hubiera acudido al Juez o bien, a juicio de éste, por "el que entendiere que se mueue con mejor intencion, que faga la acusacion". Solamente al sujeto así determinado debería responder el acusado ${ }^{126}$.

canónico y personal para recibir órdenes o administrar las recibidas. Aun así, parece que esta prohibición decayó con el tiempo. Vid. GUTIÉRREZ, J.M., Práctica..., op. cit. p. 106.

\footnotetext{
${ }^{122}$ Caps. Laico y $2^{\circ}$ quaest. $7^{\mathrm{a}}$; Cum de acusat. y Omnib. quast. $4^{\mathrm{a}}$.

${ }^{123}$ L.3, T. I, P. $7^{\mathrm{a}}$.

${ }^{124}$ L. 4, Tít. X, P. 3 y L. 4, Tít. I, P. 7.

${ }^{125}$ L. 2, T. I, P. VII.

${ }^{126}$ L. 13, T. I, P. VII. La distinción entre acusadores “propios” y “extraños” estaba clara para los prácticos. Vid. VILLADIEGO VASCUÑANA Y MONTOYA, A. de, Instrucción política y práctica judicial conforme al estilo de los Consejos, Audiencias y Tribunales de la Corte, y otros ordinarios del reyno...", Madrid 1729, nº 149 y ss, pp. 72 y ss. "Concurriendo dos o más extraños a acusar a uno, el primero que le acusó, cuya causa fue contestada es preferido y concurriendo juntos, el Juez elige el que le parece que lo haze con mejor intención" ( $\left.\mathrm{n}^{\mathrm{o}} 157\right)$. En el mismo sentido HEVIA BOLAÑOS, Curia Philipica III, §8, 7, p. 200, que advierte que "uno sólo ha de ser el acusador, no dos ni mas haciendose la acusacion sobre la misma cosa". Sólo en defecto de uno de los primeros podrá serlo cualquiera del pueblo. Lo corrobora también GUTIÉRREZ, J.M., Práctica Criminal..., op. cit. p. 104.
} 
Garantías en el ejercicio de la acusación

El hecho de que la consecuencia inmediata de la acusación y del cumplimiento de todos sus trámites fuera el mandamiento de prisión contra el acusado, hacía que tuviera especial trascendencia la garantía de su correcto ejercicio. Es destacable en este sentido la obligación de que la acusación se realizara por escrito "porque la acusacion sea cierta e non la puede negar, ni cambiar el que la fiziere, desde que el pleyto fue començado". Era preciso que se especificara en la "carta de acusación" el nombre del acusador y del acusado, el Juez ante quien se hace y las circunstancias del delito cometido y debía jurarse “que no se mueue maliciosamente a acusar"y que cree que el acusado es culpable del delito que le acusa ${ }^{127}$. Junto a ello se exigía también el requisito de la inscriptio presente en el derecho romano, en las Decretales y en el Fuero Real de forma que la amenaza de sufrir pena de Talión continuaba cerniéndose sobre los que no pudieran probar la acusación realizada: "quando alguno acusa a otro de yerro, que es de tal natura, que si lo non pudiere prouar, que deue auer el acusador la pena que deue auer el acusado, si le fuesse prouado" ${ }^{128}$. La acusación debía hacerse en persona, sin que cupiera representación ("Por si mismo estando delante del Judgador, e non por personero, deue cada vno a otro acusar"), de forma que si fallare la prueba de su acusación no pueda eludir la pena de Talión, consecuencia de la actualización de la inscriptio ${ }^{129}$.

De la obligación de la inscriptio se excluyeron casos en que la acusación era consecuencia de un perjuicio general, tal como ocurría en las falsedades o en la falsificación de moneda ${ }^{130}$. La dualidad de intereses protegidos en el proceso penal,

${ }^{127}$ L. 14, T. I, P. VII. Vid. también GUTIÉRREZ, J.M., Práctica Criminal..., op. cit. p. 107.

${ }^{128}$ L. 1 y 26, T. I, P. VII. Incluso el de acusación falsa era uno de los escasos supuestos en que podía procederse de oficio para la persecución de los delitos. Vid. L. 27, T. I, P. VII. En virtud del plazo establecido como de máxima duración para el proceso, transcurridos dos años sin que se hubiera podido prohibir nada, el acusado debería ser absuelto y al acusador se le impondría la pena, actualizándose la inscriptio. Vid. ALONSO ROMERO, M.P., El proceso penal en Castilla..., op. cit. p. 39.

\footnotetext{
${ }^{129}$ De estos casos se exceptua la representación desempeñada por el tutor en nombre del tutelado ofendido por el delito, supuesto en el que no estará sujeto a pena a no ser que se demostrase que acusó maliciosamente. L. 6, T.I, P. VII. Relata ORTIZ DE ZÚÑIGA en 1870 que en la práctica es permitido a cualquiera que tiene aptitud legal para ello acusar por medio de procurador autorizado con especial poder. ORTIZ DE ZÚÑIGA, M., Práctica General Forense, op. cit., p. 206.

${ }^{130}$ «Acusando vn ome a otro, diziendo que auia falsado moneda del Rey, maguer non lo pudiesse prouar, dezimos que non deue auer pena porende. E esto mandamos porque los omes, por miedo de pena, non dexen de acusar de tal
} 
públicos y privados, se hacía perceptible por la dualidad de regímenes de la inscriptio, liberando de esa pesada carga a quien acusara por daño u ofensa cometido contra él o sus parientes hasta el cuarto grado ${ }^{131}$. La justificación ("porque estos atales se mueuen con derecha razon, e con dolor, a fazer estas acusaciones, e non maliciosamente") ${ }^{132} \mathrm{se}$ fundamentaba sobre una presunción de veracidad de la acusación ejercitada por el ofendido pero no por los demás, cuyo reflejo se extiende hasta nuestros días a través del vigente régimen de fianzas de los acusadores en la LECrim ${ }^{133}$.

Desde muy pronto la imposición del Talión cayó en desuso por costumbre contra legem consentida por el Monarca ${ }^{134}$, y la acusación calumniosa se castigó en el derecho castellano con pena arbitraria más o menos grave según las circunstancias hasta que tal delito encontró reflejo normativo en el Código Penal de 1822 y luego en el de 1848. En ningún momento se justificó la flexibilidad en la aplicación de este requisito con la intención de quitarle trabas al ejercicio de un hipotético derecho de los sujetos para intervenir en el proceso, sino que dada la insuficiencia de la maquinaria oficial de la justicia, la supresión de la intervención de los particulares hubiera conllevado serias consecuencias en la efectividad de la represión del crimen. El razonamiento de todos los autores para aceptar tal vulneración clara de una norma consolidada por la costumbre es unánime: la conveniencia de evitar que por temor de la pena y en ausencia de acusación oficial, los delitos pudieran quedar impunes ${ }^{135}$. El sustitutivo de la pena de Talión era así

yerro como este. Ca es cosa de qeu podria acaescer daño a todos. E porende tenemos por bien, que cada vno del pueblo pueda acusar a tales falsarios, sin miedo de pena, porque non puedan ser encubiertos en ningun lugar» L. 20, T. I, P. VII y L. 5, T. 8, P. VII.

\footnotetext{
${ }^{131}$ En esta distinción basaba HEVIA BOLAÑOS la diferencia entre la calumnia evidente y la calumnia presumpta. La primera se da cuando existe un "acusador extraño que se le prueba que maliciosamente hizo acusacion" y la segunda consiste en "no probar la acusación el acusador propio o el extraño que acusa a alguno de haber hecho moneda falsa, mas no en los demas casos”. Curia Philipica III, § 8, 14, p. 201.
}

\footnotetext{
${ }^{132}$ L.25, T. I, P. VII.
}

${ }^{133}$ Este prejuicio histórico y la conveniencia de su revisión ya fue advertida por GIMENO SENDRA, V., "La fianza del acusador particular: notas sobre legitimación activa y caución juratoria en el proceso penal”, RDProc (Ibam) 1976, p. 56.

\footnotetext{
${ }^{134}$ Aun cuando ya se encuentra ausente de las obras del maestro Jacobo de las Leyes (el "Doctrinal" y las "Flores del Derecho") toda referencia a la inscriptio sólo es constatable su desuso desde al menos los años centrales del siglo XVI. Vid. ALONSO ROMERO, M.P., El proceso penal en Castilla..., op. cit. pp. 78 y 181.

${ }^{135}$ En este sentido vid. HEVIA BOLAÑOS, J., Curia Philippica, op. cit. III, § 8, 13 , p. 201 que basa su opinión en GREGORIO LÓPEZ DE TOVAR (L. 3 Glos. 3 T. 9, P. IV) y ANTONIO GÓMEZ (3 T. var. c.II n. 31 in fine).
} 
la necesaria constitución de fianza por el acusador, por la cual se obligaba a probar los hechos objeto de la acusación ${ }^{136}$, y a tenor de lo que relata GUTIÉRREZ lo más frecuente, aunque no obligatorio, era que el Juez exigiera al acusador el depósito de fianza para dar inicio al proceso ${ }^{137}$. La primera referencia legal a ésta la encontramos en la Novísima Recopilación, en concreto en una pragmática de Felipe III de 28 de junio de 1619 que contiene la obligación de dar junto con los memoriales "fianza primero y ante todas cosas a probar y averiguar lo en ellos contenido, so pena de las costas que de sus averiguaciones se causaren, y de quedar expuesto á la pena que, en falta de verificarlo, se le impusiere, quedando esta á la disposicion y arbitrio del Juez que la causa conociere ${ }^{138}$.

El juez tenía facultades de vigilancia para comprobar y controlar que la actuación del acusador fuera leal, previniendo los riesgos que pudieran derivarse de la colusión entre acusador y acusado con el propósito de conseguir la absolución y acogerse al efecto de cosa juzgada ${ }^{139}$. El acusador podría abandonar la acusación sin pena si lo hacía con permiso del juez, excepto si éste considerase que el acusador se movió maliciosamente, si la acusación versare sobre traición, falsedad, hurto o robo al Estado o a la Iglesia o cuando el acusado "es ya metido en carcel do ha recibido algun tormento, o desonra",

\footnotetext{
"Esta rigurosa pena del Talion, por general costumbre del Reyno, y de otros muchos, en quanto al acusador, ya no esta en uso, porque por temor de la pena no dexen de acusar los delitos y queden impunidos". Lo corroboran también los autores de manuales de práctica forense. Así en opinión de ÁLVAREZ POSADILLA, J., Practica Criminal por principios, ó modo y forma de instruir los procesos criminales, Madrid 1815, pp. 86 y s. "por costumbre general, que tiene fuerza de ley, por no separar las gentes con el miedo de la pena de las acusaciones de los delitos verdaderos, ha cesado la del Talion, quedando al arbitrio del Juez, segun las circunstancias, calidad de personas é injurias, el imponer la que estimare conveniente". GUTIÉRREZ, J.M., Práctica Criminal de España, Madrid 1819 T. I, p. 112 testificaba de su tiempo "lo que muchos intérpretes testificaron del suyo; a saber que (el Talión) se hallaba abolida por costumbre general de España y otros reinos para que por miedo del castigo no dejaran de acusarse ni quedarse impunes los delitos". GIMENO SENDRA, V., "La fianza del acusador particular: Notas sobre la legitimación activa y «caución juratoria» en el proceso penal”; RDProc. 1976, pp. 57 y ss. da cuenta también de estos extremos. En sentido contrario, fiel al texto de las Partidas, reitera la vigencia de la norma GÓMEZ Y NEGRO, L., Elementos de Práctica Forense, Valladolid 1830, p. 189 en nota.

${ }^{136}$ Vid. GIMENO SENDRA, V., “La fianza...” op. y loc. cit.

${ }^{137}$ GUTIÉRREZ, J.M., Práctica Criminal..., op. cit. p. 107.

${ }^{138}$ L. 7, T. 33, Lib. XII, Novísima Recopilación. Vid. también ÁLVAREZ POSADILLA, J., Practica Criminal..., op. cit. p. 77 y ORTIZ DE ZÚÑIGA, M., Práctica General Forense, T. II, Madrid 1870, p. 206.

${ }^{139}$ GUTIÉRREZ, J.M., Práctica Criminal..., op. cit. p. 141.
} 
supuesto en el que necesitaría la aprobación de éste ${ }^{140}$. El carácter acusatorio del proceso venía también determinado entre otros motivos por la posibilidad de disponer de la acusación, en tanto cabía la posibilidad de llegar a acuerdos entre acusador y acusado cuando del proceso pudiese acarrearse pena de muerte o mutilaciones: "que si la auenencia fuere fecha ante que la sentencia sea dada sobre tal yerro como este, que vala, quanto para non rescebir porende pena en el cuerpo el acusado" ${ }^{\text {141 }}$. Pero un dato definitivo en esta dirección era la necesidad de absolución del encausado cuando el acusador no compareciera o desistiera en los supuestos permitidos. Muerto el acusador, se considera fenecido el pleito $\mathrm{y}$, de no quererlo expresamente, no tendrían por qué continuarlo sus parientes o herederos ${ }^{142}$. La reapertura del proceso era posible cuando se demostrara razonablemente la existencia de concierto o, por la preferencia en la acusación del ofendido por el delito, cuando éste probare no haber tenido previamente noticia del proceso.

A diferencia de lo que ocurría con el reo, no existían prohibiciones para el acusador ni para el fiscal cuando hubiera intervenido, que le impidieran apelar las sentencias perjudiciales para sus intereses. De las sentencias condenatorias a penas de sangre podía apelar cualquier persona, incluso las ajenas al proceso. Aun así, tratándose de acusadores extraños, se precisaba el consentimiento del reo, mientras que si los apelantes eran los familiares del reo podrían hacerlo incluso en contra de su decisión expresa $^{143}$.

\subsubsection{Decadencia de las acusaciones particulares}

No debemos olvidar que en las Partidas la acusación no era la única forma de

\footnotetext{
${ }^{140}$ L. 17 y 19, T. I, P. VII. Las limitaciones a la norma vienen determinadas en virtud de la afección al interés público atacado. La transgresión de estos impedimentos para el desistimiento daba lugar no sólo a la obligación de abonar las costas y perjuicios ocasionados, sino también a la actualización de la inscriptio y por tanto, teóricamente, a la imposición al acusador de la pena de Talión. Vid. ALONSO ROMERO, M.P., El proceso penal en Castilla..., op. cit. p. 44.

${ }^{141}$ L. 22, T. I, P. VII.

${ }^{142}$ L. 23, T. I, P. VII. Sin embargo en el Fuero Real no cabía esa posibilidad.

${ }^{143}$ ALONSO ROMERO, M.P., El proceso penal en Castilla..., op. cit. p. 274.
} 
iniciación procesal y, al igual que en las Decretales, el proceso diseñado en ellas podía iniciarse por tres vías: acusación, denuncia y pesquisa, dando lugar a un procedimiento acusatorio en el primer caso o inquisitivo en cualquiera de los otros dos ${ }^{144}$. La competencia de casi todos para el ejercicio de la acusación se reconocía sólo en el proceso acusatorio, pero debemos tener en cuenta también el dato de que la actual regulación de la acusación tiene mucho que ver con el de iniciación oficial.

El proceso inquisitivo de las Partidas podía dar comienzo por denuncia de cualquier persona de buena fama y sin enemigos en el lugar $y$, aun cuando se castigara la denuncia calumniosa, el denunciante no estaba, como el acusador, obligado a someterse al severo requisito de la inscriptio ${ }^{145}$. Probablemente la influencia del proceso canónico hizo que se recogiera también la figura de la inquisitio cum promovente, figura peculiar a medio camino entre denunciante y acusador. Sin la exigencia de obligarle a realizar la inscriptio y sin conferirle la carga de la prueba, su presencia en el proceso supuso una modulación importante de un proceso desarrollado fundamentalmente de oficio. $\mathrm{La}$ oportunidad de su admisión era evidente ya que con ella los supuestos de funcionamiento del proceso inquisitivo aumentarían de modo considerable: de cara al particular personalmente interesado en el castigo de un delincuente ofrecía la posibilidad de colaborar de modo activo en la consecución de su condena eximiéndose al mismo tiempo del riesgo de la inscriptio y de incomodidades e inconvenientes. En lugar de la asunción explícita del carácter de parte, a la larga, los particulares acabarían prefiriendo el método más cómodo, sencillo y exento de riesgo que se les ofrecía: presentar la denuncia y dejar que el proceso siguiera por sí mismo, con el aliciente de poder formar parte del proceso como promovente y proporcionar pruebas de culpabilidad ${ }^{146}$. Lenta pero progresivamente, los sujetos intervinientes en el proceso se limitarán a juez, fiscal y reo, a los que se añade en ocasiones el particular ofendido por el delito, promoviendo su acción

\footnotetext{
${ }^{144}$ TOMÁS y VALIENTE, F., El Derecho Penal de la Monarquía Absoluta (s. XVI, XVII y XVII), Madrid 1969, p. 157; ALONSO ROMERO, M.P., El proceso penal en Castilla..., op. cit. p. 39.

${ }^{145}$ La pesquisa, la tercera de las formas de iniciación del proceso, tenía una finalidad subsidiaria en tanto parecía ser concebida como un remedio de carácter extraordinario para cuando fallare la actividad del particular en la persecución del delito o presentación de pruebas.

${ }^{146} \mathrm{La}$ complicación y abundancia de trámites y requisitos a cumplir en el proceso acusatorio y su carestía frente a la rapidez y sencillez del proceso inquisitivo pudieron operar también en favor de una mayor aplicación del proceso de oficio y de la desviación de la intervención activa de los particulares hacia este cauce procesal.
} 
simultáneamente a la del fiscal ${ }^{147}$. El "derecho de acusación" pierde efectividad por la escasez de su uso, si no por su olvido total, y las acusaciones de personas extrañas al delito prácticamente desaparecen, a la vez que aumentan las simples denuncias o delaciones iniciales ${ }^{148}$.

Nadie pretendía hacer uso de una prerrogativa gravosa y olvidada, pero las causas del abandono no vienen sólo determinadas por las trabas que se le ponían a aquél que quisiera constituirse en acusador, sino también y sobre todo, por la progresiva atribución al procurador fiscal del carácter de acusador por excelencia en todo tipo de delitos. Aun cuando se siguiera considerando que la persecución de los delitos exigía previa acusación, lo cierto es que, a pesar de la dicción de la norma legal, la práctica se orientaba en otra dirección y siempre en pro de la consecución de una mayor eficacia en la represión penal. La aparición del promotor fiscal, originariamente sólo con funciones de representación de los intereses del monarca, llegó a constituir en este sentido un factor capital para la conservación de rasgos acusatorios a la vez que de forma simultánea se operaba un progresivo apartamiento del acusador privado. Si bien hasta una época muy tardía no se consideró al fiscal como pieza clave inserta en todo tipo de procesos en calidad de representante del interés público en la persecución de los delitos, su creciente asunción de esta tarea junto con la de defensa patrimonial del monarca fue consecuencia de la transformación en intereses públicos de los de aquél a quien representaba y a la salvaguardia de cuyos intereses era destinado ${ }^{149}$. La presencia de este oficial público en el proceso, que podía coexistir con la del acusador particular, va dando así prioridad en la administración de la justicia a los intereses de la colectividad frente a los privados. Si al principio su participación se limitaba a aquellos procesos que repercutían en la Hacienda real mediante la recepción de penas pecuniarias o confiscaciones, pronto se le atribuyó un papel subsidiario en suplencia de un acusador privado y con el tiempo y la prevalencia de la supremacía del interés en la vindicta pública, la figura del fiscal se cualificó hasta configurarse como la parte acusadora por excelencia.

El fenómeno de atribución progresiva de la competencia para acusar al fiscal y de

\footnotetext{
${ }^{147}$ ALONSO ROMERO, M.P., El proceso penal en Castilla..., op. cit. pp. 59 y 142.

${ }^{148}$ TOMÁS Y VALIENTE, F., El Derecho Penal..., op. cit. p. 160; ALONSO ROMERO, M.P., El proceso penal en Castilla..., op. cit. p. 142.

${ }^{149}$ Vid. ALONSO ROMERO, M.P., El proceso penal en Castilla..., op. cit. p. 84.
} 
su intervención en cualquier proceso, hubiera o no parte acusadora, es conflictivo y lento, pero constante. Se produjo por la vía de hecho, sin normas expresas, y sólo es constatada por los autores que dieron cuerpo doctrinal a esa realidad sobre la base de la actuación subsidiaria del fiscal en defecto de parte, tal y como venía previsto en una disposición de Juan II recogida en la Nueva Recopilación ${ }^{150}$. Por lo menos ya desde principios del siglo XVII el fiscal actúa siempre al lado del acusador particular al tiempo que es perceptible la decadencia de las acusaciones particulares ${ }^{151}$. El resultado final de esta evolución es la Real Cédula de 8 de noviembre de 1787 en la que se prevé que en aquellas causas criminales en que hubiera acusación pública, debería ser parte siempre el Fiscal, pidiendo y promoviendo la administración de justicia ${ }^{152}$.

Dado que la iniciativa persecutoria se estaba consolidando como actividad oficial en la que únicamente como complemento se precisaba la actividad de los ofendidos por el delito, cuya intervención en el proceso debía ser obligatoriamente requerida, la participación de acusadores "extraños" devino con el tiempo algo más teórico que real. El cauce procesal habilitado dentro de una estructura acusatoria para la intervención de particulares era utilizado ahora para dar forma procesal a las facultades de un acusador oficial que, con el tiempo, se había convertido en representante del interés público en la represión de los delitos. La defensa del interés público y la forma acusatoria encuentran así un punto de unión, y la intervención de los no lesionados por el delito deviene en este sentido irrelevante. La iniciativa de particulares se mantiene únicamente allí donde se excluía la iniciativa del juez (injurias, adulterio, disputas domésticas...). En el caso de los demás hechos delictivos, el interés social en la vindicta pública quedará asegurado por la intervención del juez, el fiscal y la gradual sustitución de los acusadores extraños por meros denunciantes.

La nota definitiva para distinguir un proceso penal no era la pena perseguida, como en las Partidas, sino el hecho de que se iniciase en interés público. Para dar fundamento a este nuevo concepto y poder compaginar los diversos intereses que se entremezclan en el proceso penal se acudió a la distinción entre las diversas acciones que surgirían del delito:

\footnotetext{
${ }^{150}$ NR. II, $13,1$.

${ }^{151}$ Vid. ALONSO ROMERO, M.P., El proceso penal en Castilla..., op. cit. p. 151 y ss.

${ }^{152}$ De ella da cuenta GUTIÉRREZ, J.M., Práctica Criminal..., T. I, pp. 252 y s.
} 
la civil y la criminal. Mientras que la civil compete sólo al ofendido, el ejercicio de la criminal en los delitos públicos cabría por cualquiera salvo por los exceptuados legalmente ${ }^{153}$. Dado que se consideraba que de todo delito nace, junto con la ofensa al lesionado, una lesión al interés de la República, la distinción entre delitos públicos y privados, que variaba según los usos forenses locales ${ }^{154}$, se realizaba por los autores precisamente en función de categorías procesales: se tomaban en consideración los legitimados para acusar y se consideraban públicos los delitos que podrían ser acusados quivis ex populo -salvas las excepciones-, y privados aquellos otros en los que sólo se admitía a los agraviados ${ }^{155}$.

La distinción entre acusación, querella, denuncia y delación no se mantuvo siempre con claridad y se puede afirmar que ya entrado el siglo XIX tal distinción no era fácil. La delación profesional de los soplones o malsines se convirtió en un oficio lucrativo por la participación en las penas pecuniarias impuestas y con ello en un mecanismo eficaz para el descubrimiento y castigo de la criminalidad ${ }^{156}$. El denunciante que se integraba en el proceso era un auténtico acusador que rehuía la consideración de tal, máxime tras la desaparición de la división acusatorio-inquisitivo y la pérdida de un espacio propio de la figura del promovente de la inquisitio ${ }^{157}$. Además, para evitar y reprimir los abusos de las

${ }^{153}$ A tenor de las Partidas (L. 21, T. 9, P. VII) ambas acciones se prejuzgan recíprocamente, de modo que, si se plantea una, ya no se puede intentar la otra y, a excepción de en el delito de hurto, no se pueden ejercer a un tiempo.

${ }^{154}$ TOMÁS Y VALIENTE, F., “El Derecho Penal...”, op. cit. p. 160.

${ }^{155}$ Vid. GREGORIO LÓPEZ, Gl. 1, L. 23, T. I, P. VII; y a raíz de él, todos los prácticos: p. ej. ELIZONDO y ÁlVAREZ, F. A. de, Práctica Universal forense de los Tribunales de España y las Indias, Madrid 1746, T. I, pp. 256 y s. o ÁLVAREZ POSADILLA, J. Practica Criminal por principios, ó modo y forma de instruir los procesos criminales en sumario y plenario, Parte $2^{\mathrm{a}}, 3^{\mathrm{a}}$ edición, Madrid 1815, pp. 77 y ss. que, fiel a su estilo, se sirve de un ejemplo: "si se mandase no correr los coches en poblado, y se dixese que todos pudiesen acusar esta contravencion a la ley, sería un delito público en España el correr los coches en poblado". Pero dada la facultad de iniciación procesal de los jueces, la línea separadora entre ambas acciones sólo era justificable si se atiende a las razones esgrimidas por ANTONIO GÓMEZ: si un extraño ejercitase la acción criminal, incompatible con la civil, perjudicaría el interés de la parte lesionada que se vería imposibilitada para pedir civilmente la reparación del daño. En los delitos públicos, hechos que ocasionan grave daño a la comunidad en su conjunto, en ningún caso podría aceptarse que quedasen sin pena, por lo cual se permitiría pedir por incidencia la acción civil en querellas criminales. Vid. ALONSO ROMERO, M.P., El proceso penal en Castilla..., op. cit. pp. 102 y s. El problema se planteaba sólo con los acusadores extraños. En el caso de los ofendidos, el juez estaba obligado a realizarles un llamamiento cuando hubiera comenzado el proceso de oficio para que se presentaren a acusar si quisieran, bajo nulidad del proceso.

\footnotetext{
${ }^{156}$ TOMÁS Y VALIENTE, F., El Derecho Penal..., op. cit. p.169 y ALONSO ROMERO, M.P., El proceso penal en Castilla..., op. cit. p. 183.
}

${ }^{157}$ A partir del siglo XVI la mezcla de actuaciones y principios procedentes de los esquemas procesales acusatorio 
falsas delaciones se había ido exigiendo con el tiempo que los meros denunciantes probaran su delación ${ }^{158}$, con lo que se añadía un punto más de confusión a la distinción nítida de los perfiles diseñados en la ley sobre ambos solicitantes de la actividad judicial. La cláusula de "acuso y denuncio" podría contemplarse por ello como la perfecta condensación de ese fenómeno: la denuncia, que había aparecido como uno de los métodos de iniciación del proceso inquisitivo se convierte en cauce de representación de intereses particulares, una vez salvaguardada la defensa de los intereses de la República por la ofensa a ella conferida ${ }^{159}$.

Entrado el siglo XIX, la acusación ejercitada por los extraños era algo prácticamente inexistente y aun constatando su pervivencia teórica, no hay autor de la época que dé noticia alguna de su uso. En la Enciclopedia de ARRAZOLA se advierte que en la praxis se encuentran pocos ejemplos de acusaciones de delitos públicos sostenidas por particulares ${ }^{160}$. En 1803 escribe DOU y BASSOLS que la libertad de acusación se funda sobre "la natural libertad que tiene todo particular de hacer cualquier cosa que no le esté expresamente prohibido, y en la razón, de que qualquiera miembro de la sociedad tiene derecho de interesarse por ella, considerándose la facultad de acusar como propia de todo ciudadano". Aun así, para él "no parece conforme a la mansedumbre christiana que acuse para el efecto de aplicar la pena quien no tenga obligación de hacerlo (...) el empeño de acusar no dexaba de tener aun entre los romanos un aspecto odioso: ¿quanto mas le ha de tener quando no se acuse por obligacion del empleo entre los que profesan una religion, que obliga a amar a los enemigos, y sofoca todo espíritu y sentimiento de venganza?(...)". Por ello, en su opinión "aunque haya en estos tiempos acusación formal de particular, el proceso criminal se dice siempre del

e inquisitivo permite aludir a la progresiva configuración en la práctica, sin fundamento normativo claro, de una forma procedimental mixta. Uno de los elementos determinantes de esta confusión fue precisamente la figura de la inquisitio cum promovente de inspiración canónica y la habilitación de otros cauces para la intervención del ofendido en un proceso regido por la oficialidad (denuncia, delación). Vid.ALONSO ROMERO, M.P., El proceso penal en Castilla..., op. cit. p. 96.

\footnotetext{
${ }^{158}$ Vid. p. ej. las pragmáticas de 6 de febrero de 1502 (Nov. Recopilación XII, XXXIII, $3^{\text {a }}$ ) y de 26 y 28 de julio de 1705 (Nov. Recopilación XII, VI, $6^{a}$ ). Ello originó que, en ocasiones, aquellos que quisieran dar cuenta de la existencia de un delito buscaran vías alternativas tales como la denuncia anónima o la utilización del secreto de confesión.

${ }^{159}$ ALONSO ROMERO, M.P., El proceso penal en Castilla..., op. cit. p. 186.

${ }^{160}$ T. I, p. 506. Reseñada también por SILVELA “La acción popular”, RGLJ 1888, p. 475.
} 
fiscal en Cataluña: y lo mismo será generalmente en otras partes (...) tratándose en qualquier acusación de la vindicta pública, aunque tenga algun particular intervención en esto, la propia y principal ha de ser la del fiscal" ${ }^{161}$. SALA relata también en 1803 que "en el día apenas sucede que acusen los particulares, pues solamente suelen acusar los Procuradores y Promotores de la justicia..." 162 . GUTIÉRREZ, acreditado práctico y antiguo redactor del FEBRERO, expresaba en la misma época su temor a que la libertad de acusar pudiera ser entre nosotros funesta y superflua: "funesta, si se hace uso de ella, y superflua, si no está en uso. No vemos que el fuego sagrado del amor de la patria ó del bien público arda con tan vivas llamas en nuestros corazones que sacrifiquemos en sus aras nuestro sosiego, nuesta comodidad, y nuestras facultades. ¿Dónde estan al presente los ciudadanos que comparezcan ante los jueces y tribunales solo por un merecido horror á los delitos y un loable deseo de evitar otros? En vez de perseguir el crimen ¿no perseguirán delincuente supuesto ó verdadero? En vez de la utilidad pública ¿no serán sus miras a la satisfacción de la venganza, de su odio, de su codicia, de su ambición, ó de otra pasión vituperable?". Aun así no propugnaba la modificación de la norma, lo cual parecía lejos de sus pretensiones, sino la adopción frente a ella de toda suerte de recelos y cautelas: "aunque debe quedar salva como establecida en las leyes la libertad de acusar, de que por ventura algunas personas honradas harán el debido uso, deberán los jueces proceder con la mayor cautela y circunspección en las causas suscitadas por acusadores extraños, de los cuales generalmente se ha de recelar". Reconoce incluso haberle dedicado demasiada atención "a la vista del poco uso que se hace de ella en el dia", y aunque reconozca su alejamiento de la realidad práctica, se muestra optimista con respecto a las funciones de la acusación:"basta que se vean algunos acusadores en los Tribunales, con especialidad de los que llamamos propios, para que debiesemos exponer acerca de la acusación lo principal que se encuentra en nuestras leyes, que han practicado naciones sabias y han discurrido sabios escritores, mayormente cuando aun puede ser útil por otros respectos ${ }^{\text {“163. }}$.

En 1848 el ejercicio popular de la acusación era una cuestión ya prácticamente

\footnotetext{
${ }^{161}$ DE DOU y BASSOLS, R.L., Instituciones del Derecho Público General de España con noticia particular de Cataluña, Madrid 1803, T. VIII, pp. 123 y ss.

${ }^{162}$ SALA, Juan, Ilustración del Derecho real de España, Valencia 1803, T. II, Tít. XXX, p. 102, cit. por ALONSO ROMERO, M.P., El proceso penal en Castilla..., op. cit. p. 142.

${ }^{163}$ GUTIÉRREZ, J.M., Práctica Criminal..., op. cit. pp. 107 y 117.
} 
olvidada, y lo habitual en la praxis era que acusaran los Promotores Fiscales en cumplimiento de la función de defensores de las leyes y de la causa pública que tenían encomendada desde el Reglamento Provisional para la Administración de Justicia de 1835 y las RR.OO. de 20 de diciembre de 1838 y de 9 de mayo de $1839^{164}$. Un anónimo fiscal de la época relataba que "si bien todos los que tenían noticia de la perpetración de un delito, participaban en corta dosis de la obligación de acusar a los criminales, por lo tenue, por lo leve de la obligación apenas se ejercitaba por ninguno" ${ }^{165}$.

En el tránsito del sistema acusatorio difuminado de la baja Edad Media al sistema de principios del XIX de acusación oficial por órgano diferente a los Jurisdiccionales, ha de considerarse decisivo el que el propio Estado hubiera asumido de facto en el sistema inquisitivo la potestad acusatoria con carácter de monopolio ${ }^{166}$. En el regreso a un sistema de separación entre acusador y juzgador, el Estado se reserva ambas funciones e instituye el Ministerio Fiscal como órgano específico de acusación, llamado a cumplir lo que se consideraba función eminentemente pública. De esta forma, la acusación quivis ex populo permaneció incrustada en el sistema como un elemento inerte con el papel de eslabón perdido en la evolución de un sistema acusatorio que ya había hecho un recorrido de oficialización, un camino que iba desde el ámbito de lo puramente privado al terreno de lo publicitado, y que contaba ya con un órgano específico para el cumplimiento de aquella tarea $^{167}$. La acusación popular no hacía más que revivir épocas pasadas en un momento en que su función práctica estaba poco menos que olvidada, difuminada en la bruma de la admiración por el derecho romano y en la nostalgia de tiempos pretéritos.

\footnotetext{
${ }^{164}$ Vid. los comentarios a la Séptima Partida, que se añaden a las glosas de GREGORIO LÓPEZ DE TOVAR en Los Códigos españoles concordados y anotados, T. IV, Madrid 1848, pp. 257, 316 y 329. Lo corrobora SANTOS HIDALGO, Manual de Práctica Forense, 2a edición, Madrid 1865, p. 376.

${ }^{165}$ V.H.Ch., De la Organización atribuciones y deberes del Ministerio Fiscal, Madrid 1853, p. 83.

${ }^{166}$ Advertía GOLDSCHMIDT la relación entre la existencia de Tribunales permanentes y los sistemas de acusación: allí donde se advierte la falta de permanencia y movilidad no puede exigirse de los Tribunales populares encargados de administrar la justicia un procedimiento de oficio ni la recogida del material procesal por lo que la natural consecuencia será la forma procesal acusatoria, primero a través de la querella del particular ofendido y sólo posteriormente la acusación popular. Por el contrario, donde el Juzgado criminal es un Tribunal de magistrados profesionales, parecería natural que proceda de oficio y recoja por sí mismo el material que necesita para convencerse de si se comprueban los presupuestos del derecho de penar. GOLDSCHMIDT, J., Problemas jurídicos y políticos del proceso penal, op. cit. p. 68.

${ }^{167}$ Cfr. MUÑOZ ROJAS, T., “En torno al acusador particular en el proceso penal español”, RDProc (Ibam) 1973, p. 141.
} 


\subsection{El momento codificador}

\subsubsection{Periodo anterior a las leyes de Enjuiciamiento Criminal}

La discusión sobre las formas de acusación constituyó un debate en ocasiones velado, en ocasiones abierto, sobre una competencia con una honda raigambre histórica: la de acusar para la represión de los delitos, aun sin haber recibido directamente el agravio. Los sucesivos proyectos y códigos decimonónicos presentan una constante oscilación entre la salvaguardia de un derecho a acusar con el fin de dispersar al máximo el control penal, y su consideración como un peligroso portillo para la introducción de intereses extraños a los propios del proceso penal, máxime una vez que ya existía un funcionario público encargado del cumplimiento de esa función. En el constante vaivén de permisividad y prohibición de la acusación de los particulares hay, sin embargo, un dato inamovible que ya de por sí marca un significativo distanciamiento entre nuestro proceso codificador y el de otros países: la asunción sin apenas reparos de la intervención en el proceso penal del agraviado por el delito. En último término, esta intervención de los ofendidos vendrá a equipararse por la práctica judicial y la opinión doctrinal mayoritaria también a la de los no ofendidos.

GARCÍA GOYENA y AGUIRRE advertían en su FEBRERO que "El derecho de acusar se ha mirado por todos los legisladores como uno de los mas sagrados y trascendentales(...). Cuando los ciudadanos son honrados y virtuosos, cuando la moralidad es el primer elemento de la asociacion, sin la menor duda se considerará al derecho de acusacion como honorifico y saludable, y el que se presente ante los tribunales á acusar al malvado merecia las bendiciones de sus convecinos, porque es incalculable el beneficio que de ello reporta á la sociedad, ya porque se consigue el castigo de los delincuentes, y ya tambien porque cuando los hombres criminales ven en cada uno de los que le rodean un vigilante observador de su conducta, refrenan sus malvados impulsos, ya que no por virtud, á lo menos porque temen ser descubiertos y entregados al brazo de la ley. El principio de la gloriosa fama que ganó el inmortal Ciceron nació sin duda del ejercicio del derecho de acusar, que concedian las leyes romanas". Pero, reconociendo un carácter sagrado al derecho a acusar, advierten también de los serios peligros que éste puede reportar: "es una cuestion dificultosísima de 
resolver, á la par que de inmensa importancia para los intereses sociales la de si será mas conveniente conceder el derecho de acusar ó prohibirle. Lo primero concedido absolutamente, lleva consigo el gravísimo inconveniente de que se fomenta la calumnia, y se dá margen á las persecuciones que sugieren el encono y deseo de venganza, ocasionando males que no siempre pueden repararse, sin que sirva para compensarle el castigo del falso testimonio, porque nada adelantará el desgraciado inocente que sufrió las penalidades de una larga prision, con que al calumniador se le imponga una pena por dura que sea: pero lo segundo, es decir la prohibición general de acusar, tambien perjudica considerablemente á la sociedad, porque tiende á la impunidad funesta para los intereses particulares y generales, y la seguridad de las personas y el honor de las familias" ${ }^{168}$. De esta manera quedaban delimitados en nuestro país, al igual que en los de nuestro entorno y con argumentos muy similares, los términos de la discusión sobre la conveniencia o no de la acusación por particulares.

Siguiendo un orden cronológico, debemos comenzar con la referencia al Decreto de Cortes $n^{\circ}$ LXI de 22 de abril de 1811 de “Abolición de la tortura y de los apremios, y prohibición de otras prácticas aflictivas”. En él se establecía, en relación con la abolición del tormento, que este crimen "podrá perseguirse por acción popular" 169 . Contiene esta norma, por tanto, la primera mención expresa de una "acción popular" para acusar, por lo que puede ser considerada el origen inmediato de este término en nuestra legislación penal.

La Constitución de la Monarquía Española promulgada en Cádiz el 19 de marzo de 1812 reiteraba la previsión de una acción popular en su artículo 255.2, al referirse a la exigencia de responsabilidad penal de Magistrados y Jueces. En él se

${ }^{168}$ FEBRERO O LIBRERIA DE JUECES, ABOGADOS Y ESCRIBANOS, por GARCÍA GOYENA, F. y AGUIRRE, J. T. VIII, $3^{\text {a }}$ ed., Madrid 1845, Marg. 7513 y s. En la $4^{\text {a }}$ ed. (1852), en la que intervino VICENTE Y CARAVANTES, se reiteran los mismos argumentos (T. V, Marg. 50 y s). Un razonamiento parejo se halla en GÓMEZ DE LA SERNA, P.; MONTALBÁN, J.M., Tratado Académico-Forense de los Procedimientos Judiciales, T. III, Madrid 1861, pp. 9 y s.

\footnotetext{
${ }^{169}$ El texto de la prohibición era el siguiente: "Quede abolido para siempre el tormento en todos los dominios de la Monarquía española, y la práctica introducida de afligir y molestar á los reos por los que ilegal y abusivamente llamaban apremios: y prohiben los que se conocían con el nombre de esposas, perrillos, calabozos extraordinarios y otros (...); sin que ningún juez, tribunal ni juzgado, por privilegiado que sea, pueda mandar ni imponer la tortura, ni usar de los insinuados apremios bajo responsabilidad y la pena, por el mismo hecho de mandarlo, de ser sustituidos los jueces de su empleo y dignidad". Vid. Colección de los Decretos y órdenes que han expedido las Córtes Generales y Extraordinarias desde su instalación, T. I, Madrid, Imprenta Nacional, 1820, pp. 133 y 134.
} 
establecía que "El soborno, el cohecho y la prevaricación de los magistrados y jueces producen acción popular contra los que los cometan”. Pero es en su artículo 300 donde se recoge una referencia genérica a la posible presencia de un acusador en el proceso penal, sin especificar quién pudiera ser éste: "Dentro de las veinte y cuatro horas se manifestará al tratado como reo la causa de su prisión, y el nombre de su acusador, si lo hubiere". A pesar de que en esos momentos los fiscales ya tenían la obligación de ser oídos en lo criminal aunque hubiera otro acusador, la acusación no era únicamente competencia suya, sino que seguía todavía en manos de los particulares según el sistema de las Partidas ${ }^{170}$.

Ya desde el primer intento de reforma global de la legislación penal al amparo de la Ilustración que representó el plan de Código Criminal de 1787, había existido la plena conciencia de que tal reforma debería ir necesariamente acompañada de normas procesales. Sin embargo, en él no se contenían previsiones nuevas de alcance en cuanto a la iniciación del proceso, manteniéndose las tres clásicas: acusación, denuncia o auto de oficio $^{171}$. El primer intento de modificar tal sistema procede del Proyecto de Código de Procedimiento Criminal de las Cortes de Riego de $1821^{172}$, el cual ni llegó a estar en vigor, ni sirvió de base para otros proyectos. En su texto, al igual que en el del Proyecto de Ley que para la breve sustanciación de las causas criminales, se preveía, como novedad más significativa a este respecto, la introducción de un Jurado de acusación junto con otro de calificación ${ }^{173}$. La "acción criminal para la imposición de las penas" se atribuía al ofendido en los delitos privados en el art. 4, y el art. 5 mantenía un derecho de acusar en manos de cualquier español: "La misma acción respecto de los delitos públicos corresponde no solo á los funcionarios encargados por la ley, sino tambien á cualquier español'. A continuación se señalaban las excepciones, prácticamente coincidentes con las exclusiones históricas que vetaban su ejercicio: " $1^{\circ}$ ) El que no es ciudadano en el

\footnotetext{
${ }^{170}$ Vid. Reglamento de las Audiencias de 9 de octubre de 1812.

${ }^{171}$ Vid. CASABÓ RUIZ, J.R., "Los orígenes de la codificación penal en España; el plan de Código Criminal de 1787 ", $A D P, \mathrm{n}^{\mathrm{o}} \mathrm{XII}(1969)$, pp. 313 a 342.

${ }^{172}$ Vid. Proyecto de Código de Procedimiento Criminal presentado a las Cortes por la Comisión nombrada al efecto, Imprenta Nacional, Madrid 1821.

${ }^{173}$ Vid. Proyecto de Ley que para la breve sustanciación de las causas criminales presentó á las Córtes en 1821 la Comisión especial nombrada al efecto, Madrid, Imprenta de I. Sancha, 1821. En este Proyecto no se habla explícitamente del acusador popular pero, además de la referencia al Fiscal, sí se hizo mención de la presencia de otros acusadores (vid. arts. 83 y 84 ).
} 
ejercicio de sus derechos; $\left.2^{\circ}\right)$ El que conste judicialmente haber usado de la acción popular, ó separándose por dinero ú otra recompensa; $3^{\circ}$ ) El que hubiese deducido dos acciones de esta clase mientras estuviere pendiente cualquiera de ellas; $4^{\circ}$ ) El menor de 14 años; $5^{\circ}$ ) Las mugeres; $6^{\circ}$ ) Los Jueces; $7^{\circ}$ ) Los eclesiásticos. Pero todas las personas referidas pueden usar de esta accion por delitos en que hayan sido ofendidas ellas mismas, ó sus ascendientes, descendientes, hermanos y cónyuges...". La veracidad de la acusación debería quedar asegurada mediante la "fianza de calumnia" que los querellantes prestarían, y que podría comprender "la de seguridad de la persona, y la de responder á las resultas del juicio" (art. 172 en relación con los arts. 173 a 175 y 176 a 180 respectivamente). En ningún estado de la causa podría separarse el que hubiese deducido la acción criminal por delito público (art. 7). El ejercicio de la acción civil correspondería a los perjudicados por el delito y podría ejercitarse juntamente con la criminal o usando "bien de sola la civil", pero en este caso procedería la penal con suspensión del procedimiento hasta la final determinación de la causa criminal (arts. 8,9 y 12) ${ }^{174}$.

El primer párrafo del art. 134 del Código Penal de $1822{ }^{175}$, reproducía la previsión entonces vigente de la acusación popular en el proceso penal en los siguientes términos: "La ley concede a todo español, no infame, la accion para acusar criminalmente ante los jueces ó tribunales respectivos cualquiera de las culpas ó delitos públicos que se cometan, exceptuándose únicamente las personas á quienes en el Código

\footnotetext{
${ }^{174}$ No obstante la aparente claridad del reconocimiento quivis ex populo de la acusación, el proyecto suscitó dudas con respecto a su imprecisión en la diferente regulación de los procesos por delitos graves y leves, por lo que el Tribunal Supremo hizo ver que no se podía saber claramente si cabía acusación o "acción popular" en los delitos leves, aunque no hubiera agravio particular. La Audiencia de Madrid, por su parte, consideró innecesaria la prohibición a los que se hubieren separado por dinero de la acusación, por cuanto el art. 7 prohibía ya la retirada de ésta, así como juzgó también anacrónico el veto a los que tuvieren pendientes dos denuncias pues se trataba de un reflejo inactual del derecho romano. Las Universidades de Alcalá y Oviedo y la Audiencia de Barcelona se opusieron a la prohibición a los eclesiásticos por carecer de base y amparo en el Código Penal. Vid. SILVELA, F., "La acción popular", op.cit. p. 472 y COMISIÓN GENERAL DE CODIFICACIÓN, con la colaboración de LASSO GAITE, J.F. Crónica de la Codificación Española. Vol. 3: Procedimiento Penal, Madrid 1970, pp. 38 y s.

${ }^{175}$ Código Penal Español, decretado por las Cortes en 8 de junio, sancionado por el rey, y mandado promulgar en 9 de julio de 1822, Imprenta Nacional, Madrid 1822. Esta regulación se encuentra en el Capítulo VII del Título Preliminar : "Del derecho de acusar los delitos, y de los acusados y procesados". Se ha de advertir que sobre la vigencia de este Código, en cualquier caso muy breve, se han suscitado dudas que parecen totalmente superadas por la doctrina actual. Así por ejemplo ÁLVAREZ GARCÍA ha encontrado apoyo con respecto a su aplicación efectiva en la Real Cédula de 5 de febrero de 1824. Vid. ÁLVAREZ GARCÍA, F.J., "Contribución al estudio sobre la aplicación del Código Penal de 1822", CPC 1978, n 5, p.235. Vid. también, entre otros, TOMÁS Y VALIENTE, F., Manual de Historia del Derecho Español, Madrid 1990, p. 497 y CEREZO MIR, J., Curso de Derecho Penal Español. Parte General. T. I. Introducción, $5^{\mathrm{a}}$ ed., Madrid 1996, p.112, n. 21.
} 
de procedimientos se prohiba el ejercicio de este derecho, ya en general ya en casos determinados". En todo caso, la falta de acusación no debía ser óbice para que "las autoridades procedan de oficio á la averiguación, persecucion y castigo de dichos delitos, con arreglo al propio Código de procedimientos". Indicativo de la desconfianza en la iniciación oficial del proceso es que tras enumerar cuales eran los supuestos de delitos públicos ${ }^{176}$, se incluyeran expresamente en el art. 136 como susceptibles de ser perseguidos mediante una acción popular "las injurias públicas y libelos infamatorios contra los funcionarios públicos acerca de su conducta como tales en el ejercicio de sus funciones". Advierte también el texto, distinguiendo entre acusaciones de buena y mala fe, que "el que acuse judicialmente una culpa ó delito de los públicos, hace un servicio á la sociedad y contrae un mérito si procede con verdad y con justicia: de lo contrario será castigado con la pena correspondiente segun este código" (art. 138). En concreto esta condena, que hacía revivir en alguna medida la pena de Talión, sería "a las costas, daños y perjuicios y á tanto tiempo de prisión, como el que haya sufrido en ella el acusado" si es que "no prueba completamente la acusación aunque no resulte en ella malicia" o bien a "la propia pena que se impondria al acusado si fuese cierta la acusacion, y no podrá volver á ejercer el derecho de acusar sino en causa propia" (art. 429). Se obligaba al acusador, si lo pidiere el acusado, a prestar fianza de calumnia, así como "a no desamparar la acusación hasta que recaiga la sentencia que cause ejecutoria" (art. 139) ${ }^{177}$, extendiéndose las penas de los calumniadores a aquellos que abandonaren la acusación o se separasen de ella. Como cautela frente a posibles acuerdos establece el Código que "si interviniere para que el acusador desampare su acusación ó se aparte de ella, algun concierto con el acusado por dinero ó cosa equivalente, uno y otro pagarán de mancomunum una multa igual al tres tanto del precio que haya mediado en el concierto y el acusador no podrá volver a acusar como no sea en causa propia" (art. 430). Siguen vigentes, por tanto, los principios que históricamente regulaban la acusación en nuestro país: la salvaguardia en todo momento de su ejercicio por el ofendido y el recelo hacia los acusadores extraños, a los cuales teóricamente se sometía a un estricto régimen de cautelas.

Las partes procesales de los Proyectos de Código Penal entre 1829 y 1834

\footnotetext{
${ }^{176}$ De entre los cuales quedan excluidos delitos como el homicidio, lesiones, etc. que se consideran privados.

${ }^{177}$ Tratándose de acusaciones contra funcionario público por delito o culpa en el ejercicio de sus funciones no se admitirá la acusación sin que se presente la fianza referida (arts. 139).
} 
abandonan el sistema de las Partidas y, en consonancia con el sistema francés, atribuyen al naciente Ministerio Fiscal la acusación en los delitos públicos, con escaso margen de intervención de los particulares. Así, el Proyecto de Código Criminal de Sáinz de Andino de 7 de mayo de $\mathbf{1 8 3 0}^{178}$ atribuía la competencia para acusar los delitos públicos al Ministerio Fiscal, dando posibilidad de intervención en el juicio exclusivamente a la parte agraviada y con el solo fin de obtener una reparación por los daños y perjuicios (art. 429). Si bien el art. 441 confería la facultad de ejercicio de la acción criminal a la persona ofendida por el delito, el 432, sin distinguir entre las ofensas públicas y privadas, excluía la acusación popular en los siguientes términos: "No ejerciéndose la acusación privada por la parte que haya recibido daño u ofensa en el delito, ninguna otra persona puede deducirla ni aun a pretexto de parentesco ni de afecto, sino el padre por las ofensas hechas al hijo que esté bajo su potestad, el tutor por los derechos de su pupilo, el curador por el incapaz de quien lo sea y el marido por la mujer". El Proyecto de Código penal y de Instrucción Criminal de la Tercera Junta (1833) matizaba la exclusión de la acusación popular manteniendo el mismo texto del art. 432 del Proyecto anterior en su art. 527. En este caso la acusación se refería exclusivamente a delitos privados y no a los públicos, lo cual entendemos constituía una mejora técnica del texto, pero no cabe extraer de ahí el reconocimiento de un ejercicio popular de la acusación en el caso de delitos públicos. Y ello por la atribución exclusiva que en el artículo 524 se hacía para deducir acusación al "ministerio fiscal del tribunal o del juzgado en cuyo territorio se haya cometido el delito". La aclaración quedaba reafirmada posteriormente en el título XI, el relativo al procedimiento en primera instancia, donde se especificaba quiénes eran los que podían denunciar y se excluía el carácter popular de la acción en los delitos públicos, alegando "los gravísimos abusos que traía". Para ello se señalaba "la diferencia que hay entre delatar y acusar o proseguir la causa en lo que verdaderamente consiste lo que se llama acción y lo que puede causar el desorden y perjuicios que se recelaban en dicha observación..." (art. 582) ${ }^{179}$. Sin entrar en su análisis, no podemos dejar de destacar que el art. 526 preveía que, ante la omisión del ejercicio de la acción pública por el MF, el ofendido y solamente él, podría deducir su queja ante el Juez del partido. Se trata en definitiva de una forma de revisión judicial del ejercicio de la acusación, instado por el

\footnotetext{
${ }^{178}$ Se han manejado las ediciones de CASABÓ RUIZ, J.R. Estudio Preliminar y edición del Proyecto de Código Criminal de 1830 y Proyecto de Código Criminal de 1834. Murcia 1978.

${ }^{179}$ SILVELA, F. “La acción popular”, op. cit. p. 472 y CRÓNICA DE LA CODIFICACIÓN, op. cit. p. 69.
} 
ofendido y dirigido en semejante sentido en el que varias décadas después lo hará el Klageerzwingungsverfahren alemán.

El art. 45 del Estatuto Real de 1834 reitera lo previsto en la Constitución de 1812 sobre la popularidad del ejercicio de las acciones contra Jueces y Magistrados afirmando que "todo español tiene derecho y acción para acusar a los jueces por los delitos de soborno, cohecho y prevaricación" ${ }^{180}$.

\section{El Reglamento Provisional para la Administración de Justicia promulgado}

por RD de 26 de septiembre de 1835, que significó oficialmente la derogación del título XXXII del libro XII de la Novísima Recopilación, establecía en su art. 101 la intervención del Fiscal desde la iniciación de la investigación como defensor de la causa pública y de la Real Jurisdicción Ordinaria, encargado de promover la persecución y castigo de los delitos ${ }^{181}$. Aunque no proscribió todo vestigio de iniciativa ciudadana en la persecución del delito público, tampoco reguló ni el ejercicio de la denuncia como deber, ni la acusación como derecho de nadie que no fuera el ofendido y ni siquiera la diferencia entre ambas. No se restableció una acción pública acusatoria tal y como existía desde las Partidas, y se ordenaba únicamente que a todo español que denunciase o acusase cualquier atentado contra su persona, honra o propiedad se le administrase eficazmente la justicia sin exacción de derechos, "siempre que fuera persona conocida y suficientemente abonada, o que diere fianza de estar a las resultas del juicio" ${ }^{182}$. Todos los gastos le

\footnotetext{
${ }^{180}$ Tal reconocimiento no volverá a aparecer en ninguno de los textos constitucionales de nuestro atormentado siglo XIX hasta la Constitución de 1869. Las Constituciones de 1837, 1845 y 1856 no contienen norma alguna respecto a la exigencia de responsabilidad penal de los jueces.
}

\footnotetext{
${ }^{181}$ El texto del art. 101, que consideramos de interés en tanto recoge la opinión que ya había sido reiteradamente expuesta por la doctrina, era el siguiente: "Los fiscales y los promotores fiscales, como defensores que son de la causa pública y de la Real Jurisdicción Ordinaria y encargados de promover la persecucion y castigo de los delitos que perjudican á la sociedad, deberán apurar todos los esfuerzos de su celo para cumplir bien con tan importantes obligaciones; pero no se mexclarán en los negocios civiles que solo interesan á personas particulares, ni tampoco en las causas sobre delitos meramente privados en que la ley no da accion sino á las partes agraviadas». FERNÁNDEZ MARTÍN-GRANIZO llama la atención a este respecto al afirmar que por primera vez aparece el MF con la función de "defensor de los intereses de la sociedad" y no "de los intereses del Estado". Vid. FERNÁNDEZ MARTÍN-GRANIZO, M., El Ministerio Fiscal en España (notas para una construcción de dicha figura y estudio de su posición en el Derecho Procesal español), Madrid 1977, p. 69. La organización y caracteres del Ministerio Fiscal en lo que se refiere al ejercicio de la acción pública quedarían cerrados con el Reglamento Orgánico promulgado por RD de 9 de abril de 1858.
}

${ }^{182}$ Vid. ORTIZ DE ZÚÑIGA, M., Biblioteca Judicial o Tratado original y metódico de la organización y atribuciones de los Juzgados de Primera Instancia, de las Audiencias y del Tribunal Supremo de Justicia, $2^{\mathrm{a}}$ ed., Madrid 1840, p.53. El práctico admite la querella por delito público de otras personas pero sólo cuando fuera el 
serían reembolsados por medio de la condena en costas del reo y sufriría su pérdida en caso contrario $^{183}$.

Ni previsión había de que los no perjudicados por el delito directamente pudieren acusar y, aun cuando esta posibilidad no se excluyera terminantemente, no hay recuerdo o reseña alguna entre la doctrina de su utilización. Es digna de destacarse la afirmación de PACHECO en aquellos mismos años negando el que alguien pudiera tener un natural o especial interés en la persecución del delito público. Ese interés, dirá el que fuera fiscal del TS, "parecerá en algunos delitos que nadie lo tiene; en otros se podrá creer que lo tiene todo el mundo; pero esta misma igualdad, esta misma universalidad, es la prueba de que directamente y en particular nadie lo tiene. Lo que es propio de todos, no pertenece en verdad a persona alguna" "184 . GÓMEZ DE LA SERNA y MONTALBÁN relataban que "pocas personas, á excepcion de aquellas á quienes mas inmediatamente daña un delito, se constituyen en acusadores; aun los mismos que son directamente perjudicados rehusan casi siempre seguir una acusacion, ya escitados por el principio religioso que les aconseja el perdon de sus enemigos, ya para libertarse de las incomodidades y disgustos consiguientes á la prosecucion de una causa criminal, ya por último por el temor de la responsabilidad en que pueden incurrir, si no prueban el hecho de que acusan" ${ }^{185}$. Además, no puede pasar desapercibida una característica de la forma de acusación así esbozada cual es la de que sólo se eximía del abono de derechos por la administración de la justicia a la persona que hubiera sufrido el daño consecuencia del delito. A sensu contrario cabría imaginar que sólo quienes gozaran de medios económicos suficientes para hacer frente a la exacción de esos honorarios podrían plantearse teóricamente el ejercicio de la acusación no habiendo sido perjudicados.

Tras la constitución de la Comisión General de Codificación en 1843, vuelven los

ofendido por el delito (o sus deudos en caso de homicidio) gozarían del beneficio previsto en el Reglamento Provisional.

\footnotetext{
${ }^{183}$ Este precepto, contenido en el art. 3, se aplicaba frecuentemente. Vid. las SSTS de 8 de octubre de 1872 , de 25 de febrero o de 6 de marzo de 1873.

${ }^{184}$ PACHECO, J.F., Estudios de Derecho Penal, $3^{\text {a }}$ ed. Madrid 1868, p.129. La obra recoge el texto de las conferencias pronunciadas por el que fuera Fiscal del TS en el Ateneo de Madrid durante los últimos meses de 1839 y primeros de 1840.

${ }^{185}$ GÓMEZ DE LA SERNA, P.; MONTALBÁN, J.M., Tratado Académico-Forense de los Procedimientos Judiciales, T. III, Madrid 1861, p. 10.
} 
intentos de expulsar la acusación popular de nuestro ordenamiento. La base $10^{\mathrm{a}}$ de las Bases de Enjuiciamiento Criminal aprobadas por la Comisión General de Codificación en 1847 establecía que "la acción para pedir la imposición de las penas será en todo caso del Ministerio público; pero se admitirán tambien a ejercerla a la parte agraviada, salvo los casos en que sólo se permite reclamar al agraviado". El art. 2 del Proyecto de Ley de Enjuiciamiento Penal de 1858 excluía la acusación por particulares, atribuyendo ésta principalmente -salvo en los delitos privados- al Ministerio Público como representante de la sociedad. Por otra parte, en el art. 5 se confería una participación accesoria al ofendido por el delito en los siguientes términos: "Podrán ejercitar la acción penal, pero sólo como coadyuvantes del Ministerio Fiscal, el ofendido, el marido a nombre de la mujer, el padre á nombre del hijo constituido bajo su potestad, y el tutor ó curador en representación de los puestos bajo su guarda" ${ }^{186}$. De esta forma se apartaba de la exclusión absoluta del perjudicado en el ejercicio de la pretensión penal, propia del modelo francés que se había tomado como referencia, pero también de nuestra tradición en la que los particulares, ofendidos o no, contaban con una importante intervención activa.

Esta exclusión quedaba justificada con el argumento de que "la persecución de los delitos es una función pública cuyo desempeño corresponde principalmente al Estado, y que salvas ciertas excepciones, no debe abandonarse al interés privado". En opinión de los integrantes de la Comisión de Codificación, la asignación de la tarea de perseguir los delitos al MF garantizaba suficientemente el cumplimiento de la función de vindicta pública y no sería admisible que se le relegara al papel de mero coadyuvante cuando estuviera presente un acusador privado actuando por el mismo motivo. La acusación popular habría dejado de tener razón de ser en aquel momento, consecuentemente a la evolución de la naturaleza misma de la justicia penal. La desconfianza hacia la intervención de extraños en el proceso cuando ya existía un órgano público especializado se debía al temor de que se produjeran abusos del crédito en ellos depositado, en la medida en que, según sus palabras, la mayoría de las veces que se hacía uso de la

\footnotetext{
${ }^{186}$ MEMORIA HISTORICA DE LOS TRABAJOS DE LA COMISIÓN DE CODIFICACIÓN suprimida por Real Decreto del Regente del Reino de $1^{\circ}$ de Octubre de 1869 , escrita y publicada por acuerdo de la misma siendo ponente D. FRANCISCO DE CARDENAS, vocal de ella. RGLJ, Tomo XXXVIII, Madrid 1871, pp. 19 y ss. El proyecto completo se encuentra en los apéndices, pp. 189 y ss. La Comisión que elaboró el proyecto estaba presidida por Cortina y la redacción del título referido a las acciones se atribuyó a Cárdenas, siendo Ministro de Justicia Fernández Negrete. Vid. COMISIÓN GENERAL DE CODIFICACIÓN, op. cit. p. 136.
} 
acusación popular ello no respondía a motivos de interés público, sino de intereses extraños al proceso. No era descartable, además, el peligro, cierto o supuesto, de que "por cohecho particular o motivos privados, venga á ser más aparente que real la persecución de ciertos delitos". Por ello, y siguiendo con una cita textual que no deja lugar a dudas de su posición, "la acción llamada popular porque podía ser ejercitada por cualquiera del pueblo tuvo mucha razón de ser cuando no había un ministerio público (...) Hoy que existe ¿para qué encomendar la vindicta pública á quien puede abusar de esta confianza, ó á los que las más de las veces ó siempre suelen usar de ella, no por motivos de interés público, sino por satisfacer pasiones ruines ó indignas venganzas?" ${ }^{187}$. Sobre la base de esta desconfianza se facultaba solamente al ofendido, al marido en nombre de la mujer, al padre por los hijos, al tutor por el pupilo, y en defecto de éstos, al cónyuge superviviente, los ascendientes, los herederos testamentarios y los parientes colaterales dentro del tercer grado civil para el "ejercicio de la acción penal como coadyuvantes". Ello nos viene también a revelar una concepción devaluada con respecto a lo que se venía entendiendo por "ejercicio de la acción penal" en la medida en que de tal concepto se excluyen la iniciativa y el poder de dirección sobre la acusación, que quedarían exclusivamente en manos del Ministerio Público. El art. 9, claro precedente de nuestro actual art. 113 LECrim, obligaba a las personas que litigasen por una misma acción penal a que lo hicieran unidas en un sólo proceso y bajo una misma dirección. Por último, parece necesario constatar que, dada la exclusión del ejercicio de la acción por los no ofendidos, la única previsión respecto al depósito de fianza se hacía en relación con la querella por delitos privados interpuesta por los extranjeros.

La Constitución de la nación española de 6 de junio de 1869 recogía en su art. 98.II la acusación popular a título de excepción en las causas contra Jueces y Magistrados en los siguientes términos: “Todo español podrá entablar acción pública contra los jueces o magistrados por los delitos que cometieren en el ejercicio de su cargo". Esta previsión fue reproducida por el art. $245.3^{\circ}$ de la Ley Provisional sobre Organización del Poder Judicial de $1870{ }^{188}$. Reseñamos la excepcionalidad de este supuesto que deja

\footnotetext{
${ }^{187}$ MEMORIA HISTÓRICA DE LOS TRABAJOS DE LA COMISIÓN DE CODIFICACIÓN publicada en la RGLJ, Madrid 1871, p. 21. En opinión de la Comisión, esto suponía una novedad importante "reclamada por la naturaleza misma de la justicia penal, segun el concepto que tiene en la sociedad moderna". La intervención de los particulares no sería conforme con el principio de que la sociedad es la más interesada en el castigo de los delincuentes. Vid. también COMISIÓN GENERAL DE CODIFICACIÓN, op. cit. pp. 139 y s.
}

188“"El juicio de responsabilidad criminal contra Jueces y Magistrados sólo podrá incoarse..... $3^{\circ}$ A instancia de 
traslucir una clara pretensión de control difuso de la actividad de los jueces, por cuanto no existía ningún otro precepto de rango constitucional que sustentase la acción popular en el momento en que ésta se introdujo en nuestro ordenamiento jurídico en los términos en que hoy la conocemos $(1872)^{189}$. En el art. 838.8 LOPJ de 1870 se atribuía al MF la función de ejercitar la acción pública en todas las causas criminales, sin más excepción que la de aquéllas que según las leyes, sólo pueden ser promovidas a instancia de parte agraviada. Ninguna referencia más se consignaba en ella sobre un derecho de los ciudadanos al ejercicio de la acusación, lo cual llevó a SILVELA a afirmar que, hasta que se promulgó la LECrim de 1872, el MF era "el guardador único del antiguo derecho popular romano de acusar a los delincuentes" 190.

Donde sí se establecían supuestos designados como acción popular, pero a menudo no adecuadamente distinguidos y en ocasiones realmente confundidos con un mero derecho de denuncia, era en diversas normativas sectoriales que no siempre tenían un contenido enteramente penal. Con toda certeza constituyeron puntos de referencia en el momento de aprobación de la LECrim y en su reconocimiento de la acusación quivis ex populo. El sector donde encontramos las primeras alusiones a una acción de carácter popular es en la legislación de imprenta y en concreto, la que se realizaba en el art. 32 Decreto de 22 de octubre de $1820^{191}$. El Decreto reformando la legislación de imprenta de 9 de abril de 1844 preveía en el último inciso de su art. 49 una acción popular para la denuncia por particulares de infracciones en materia de imprenta, conjuntamente con la de los Promotores Fiscales ${ }^{192}$. Con posterioridad, el art. 47 del Real Decreto de 2 de abril

persona hábil para comparecer en juicio, en uso del derecho que da el art. 98 de la Constitución”.

${ }^{189} \mathrm{La}$ Constitución de la Restauración de 1876 vuelve a pasar por alto la acción popular contra jueces y magistrados, reproduciendo en materia de responsabilidad criminal de éstos los textos de 1837, 1845 y 1856 . Hasta la Constitución de 1931, no volveremos a encontrar sustento constitucional para la vigencia de la acción popular y sólo para la persecución de los delitos de detención y prisión ilegal.

${ }^{190}$ SILVELA, F., “La acción popular”, op. cit. p. 478.

${ }^{191}$ Vid. ORTIZ DE ZÚÑIGA, M., Biblioteca Judicial..., op. .cit. p. 147; GIMENO SENDRA, V., La Querella, Barcelona 1977, p. 104, n. 243.

${ }^{192}$ Éstos tenían la obligación, bien de oficio, bien excitados por el Gobierno, de denunciar los impresos que juzgaran subversivos o sediciosos Se permitía además la existencia de unos "Fiscales de Imprenta" voluntarios, los cuales, en caso de concurrencia con el Promotor Fiscal ostentarían el carácter de coadyuvantes. Vid. EGUIZÁBAL, J.M., Apuntes para una historia de la legislación española de Imprenta, Madrid 1879, p. 283. De todo ello da noticia SILVELA, "La acción popular", op. cit. p. 478. 
de 1852, reformando las disposiciones vigentes en materia de imprenta establecía también una acción popular en los siguientes términos: "En los delitos cuyo conocimiento corresponde al Jurado ${ }^{193}$, hay acción popular, que pueden ejercitar todos los españoles capaces para ello, según el derecho común”. SILVELA relataba en 1888, sin embargo, que no constaban noticias de utilización por particulares de esta acción penal para los delitos de imprenta ${ }^{194}$.

En materia de Hacienda, el Real Decreto de 20 de junio de 1852 sobre jurisdicción de Hacienda y Represión de los delitos de Contrabando y Defraudación contenía en su art. 64 la posibilidad de iniciar un procedimiento judicial en este ámbito no sólo por aprehensión de géneros de contrabando y defraudación o por iniciativa del promotor fiscal, sino también a instancia de parte agraviada. En opinión de los tratadistas de la época nos encontramos ante una acción popular porque "efectivamente, en los delitos de contrabando ó defraudacion, ningun perjuicio inmediato sienten los particulares, de modo que no hay términos hábiles para que nazca una accion privada criminal que autorice la demanda: tiene que ser la popular o pública"195. Es, pues, un precedente decimonónico de las acciones en defensa de intereses supraindividuales.

En otro ámbito especial de interés público, la de policía de ferrocarriles, se establecerá posteriormente también una acción popular para la denuncia de infracciones. El artículo 28 de la Ley de 23 de noviembre de 1877 de Policía de Ferrocarriles

\footnotetext{
${ }^{193}$ A tenor del art. anterior, el jurado conocía de los delitos contra el orden público, contra la sociedad y contra la Autoridad.

${ }^{194}$ SILVELA, F., "La acción popular”, op. cit. p. 478. Aun así, ya el RD de 7 de marzo de 1867 preveía en su artículo 37 la instrucción de las causas por delito de imprenta sólo a iniciativa del juez de imprenta, de la autoridad civil o por denuncia del Fiscal del ramo.

${ }^{195}$ A.G., Observaciones críticas acerca del Real Decreto de 20 de junio de 1852 sobre jurisdicción de Hacienda y Represión de los delitos de Contrabando y Defraudación, Madrid 1853, p. 179. Con una indiferente utilización de los conceptos de denuncia y acusación, al referirse a si deberá prestarse o no fianza de calumnia, este casi anónimo autor la rechaza por cuanto «no debe olvidarse que se trata de una materia escepcional.... y que la Hacienda pública tiene un gran interés en facilitar el descubrimiento del contrabando y del fraude, y que por consiguiente necesita proteger á los denunciadores. Por esa causa, la práctica constante de los Tribunales especiales de Hacienda reservó siempre el nombre del denunciador cuando este no queria aparecer bajo aquel concepto, lo cual prueba que no se le exigia fianza ni responsabilidad de ninguna especie (....) Esta práctica, no tan solo facilitaba las delaciones sino que dió márgen á abusos inmorales y escandalosos». Es perceptible la utilización una vez más de la legitimación ampliada como forma de control disperso de la represión de delitos considerados gravosos para el Estado. La Jurisdicción de Hacienda desaparece muy pocos años después, concretamente en 1868 con el Decreto estableciendo la unidad de Fueros.
} 
contenía en su regla $1^{\mathrm{a}}$ el derecho "de naturaleza popular" a denunciar, atribuyéndose la competencia para el recibimiento de la denuncia y de su posterior enjuiciamiento a los Jueces Municipales ${ }^{196}$.

Existían también acciones populares reconocidas expresamente en dos materias de relevancia política trascendental: las normas electorales y la legislación municipal. Con respecto a las primeras, donde el interés en juego es normalmente y por definición de carácter supraindividual, el art. 178 de la Ley electoral de 1870 contenía una acción denominada popular para la persecución de los delitos comprendidos en las sanciones penales de la ley electoral ${ }^{197}$. Para valerse de tal posibilidad no bastaba con la simple denuncia en virtud de la cual los Tribunales estuvieran obligados a proceder de oficio a su averiguación, y la ley requería un verdadero ejercicio formal de acusación verificada por medio de querella y acompañada de la oportuna fianza garantizadora de las responsabilidades en que incurría el acusador que no probase lo afirmado. Sin el cumplimiento de estos requisitos, el acusador no llegaba a adquirir verdadero carácter de parte $^{198}$. En repetidas ocasiones, la jurisprudencia declaró equivalente esta acción a la que con posterioridad se introdujo en la LECrim. Incluso de esta equiparación se hizo derivar la facultad del MF para deducir acusación por delitos electorales, en tanto que, de igual manera que ésta correspondía a todos los ciudadanos, no se admitía la exclusión del que

\footnotetext{
${ }^{196}$ Las referencias han sido extraídas de MEDINA Y MARAÑÓN, Leyes Penales de España, Madrid 1942, pp. 43, 147, 182 y 645. Es de señalar la confusión general imperante entre el ejercicio de la acción popular y el llamado derecho "popular" de denuncia que en muchas ocasiones tendría solamente implicaciones administrativas. Vid. en este sentido también la Ley de Caza de 16 de mayo de 1902, art. 44 ("es pública la acción para denunciar las infracciones de esta ley").
}

${ }^{197}$ La denominación “acción popular" se cambió por la de "pública” en la Ley de Sufragio Universal de 1890 y se confirmó posteriormente en la Ley electoral de 8 de agosto de 1907. En concreto, su art. 79 recogía en el segundo párrafo la acción popular en los siguientes términos: "La acción penal que nace de los delitos especialmente electorales es pública y podrá ejercitarse hasta dos meses después del término del mandato conferido por la elección. Para su ejercicio no se exigirán depósitos ni fianza".

\footnotetext{
${ }^{198}$ Vid. en este sentido la STS 172/1873 de 24 de marzo, la primera de las que conocemos en las que el TS hace uso del término "acción popular". En este caso lo hace para referirse a la previsión del art. 178 de la ley electoral entonces vigente, pero todavía no para la contenida en la entonces provisional LECrim. En los mismos términos en cuanto a las exigencias formales, se pronuncian las SSTS 346/1881 de 13 de julio y 379/1881 de 5 de octubre. En el ámbito de los delitos electorales se produjo una copiosa jurisprudencia del TS a finales del siglo pasado, consecuencia de las turbulencias de la vida política y de la actividad de los candidatos que se sentían agraviados por las manipulaciones de los resultados de los comicios. Vid. en este sentido las SSTS 259/1874 de 12 de mayo, 453/1874 de 9 de octubre, 177/1878 de 13 de abril, 200/1881 de 29 de abril, 346/1881 de 13 de julio, 429/1881 de 26 de octubre, $327 / 1881$ de 4 de julio, de 11 y 28 de enero de 1888, 2 de julio del mismo año y 5 de julio de 1889 .
} 
legalmente estaba obligado a ejercitar la "acción pública o popular" 199 .

La Ley Municipal de 1870 contenía en su art. 24 una acción pública en materia municipal para la persecución criminal de los regidores que cometieran hechos punibles en la administración de los intereses de su municipio ${ }^{200}$. Preveía este precepto que "todos los habitantes de un término municipal tienen acción y derecho para reclamar contra los acuerdos de los Ayuntamientos, así como para denunciar y perseguir criminalmente a los alcaldes, regidores y vocales de la Asamblea de asociados en los casos, tiempo y formas que prescriban esta ley y la especial a que se refiere el art. 77 de la Constitución" ${ }^{201}$. La norma se veía completada en el art. 198 al atribuir acción ante los Tribunales de Justicia a cualquier vecino o hacendado del pueblo para denunciar y perseguir criminalmente a alcaldes, concejales y asociados siempre que éstos en el establecimiento, distribución o recaudación de los arbitrios o impuestos, se hubieren hecho culpables de fraude o exacciones ilegales $^{202}$, ámbito este que a juzgar por la jurisprudencia, era el mayor campo de aplicación del ejercicio de la acusación por particulares ${ }^{203}$.

\subsubsection{LECrim provisional de 1872}

\section{El art. 2 de la Ley Provisional de Enjuiciamiento Criminal aprobada por}

\footnotetext{
199 "El art. 178 de la ley Electoral no hace más que reconocer a todos los ciudadanos españoles el mismo derecho que les otorga el 270 LECrim". SSTS de 24 de febrero de 1888 y en el mismo sentido la de 28 de enero (JC nº 169 y 86 , pp. 339 y 174 respectivamente).

${ }^{200}$ En la de 1876, reformadora de la anterior era el art. 25. Junto a ella, se discutía la pervivencia de una acción popular de naturaleza civil en virtud de la cual todos los vecinos tendrían adjudicado el derecho de asumir la defensa de los intereses municipales. La jurisprudencia había rechazado repetidamente tal posibilidad, sosteniendo que sólo al alcalde le correspondía ejercer "tal acción popular". Vid. ALCUBILLA, Diccionario de la Administración Española, T. I, 6 a ed., Madrid 1914. Sobre las acciones populares en la legislación municipal vid. FERNÁNDEZ DE VELASCO, R., La acción popular en el Derecho Administrativo, Madrid 1920, pp. 85 y ss.

${ }^{201}$ El precepto fue reproducido por la nueva Ley Municipal de 2 de octubre de 1877 en su art. 25, aun cuando en esos momentos fuera ya supérfluo por haber sido introducida la acusación pública en el 2 de la LECrim. de 1872.

${ }^{202}$ Se especificaban en la ley a renglón seguido una serie de supuestos concretos encuadrables en esta norma, así como las posibles sanciones a imponer, en su caso, por los Tribunales ALCUBILLA, Diccionario de la Administración Española, 6 ${ }^{a}$ Edición, Tomo II, Madrid 1914, p. 264 y FERNÁNDEZ DE VELASCO, R., La «acción popular» en el Derecho Administrativo, Madrid 1920, pp. 85 y ss.
}

${ }^{203}$ Vid. por ejemplo STS de 8 de mayo de 1889. 
Decreto de 22 de diciembre de 1872 establece el ejercicio popular de la acusación prácticamente en los mismos términos en los que hoy se encuentra en nuestro ordenamiento procesal: "La acción penal es pública. Todos los ciudadanos españoles podrán ejercitarla con arreglo á las prescripciones de esta ley" ${ }^{204}$. Nuestra primera LECrim, considerada obra personal del ministro MONTERO RÍOS ${ }^{205}$, fue aprobada sin debate en Cortes y sin el debido respeto a las formas parlamentarias con la promesa de discutirla en otro periodo legislativo tras contrastarla con la experiencia de su aplicación provisional $^{206}$. El reconocimiento de la facultad de acusar a todos los ciudadanos españoles, rechazado una década antes por los especialistas de la Comisión General de Codificación, se asumió así por una decisión política, pese a la crítica de muchos de aquéllos a quienes se dejó intervenir en el debate. La Audiencia de Madrid, por ejemplo,

${ }^{204}$ Varía con respecto a la LECrim. vigente únicamente en la referencia a “esta Ley”, y no a "la Ley". Por lo que supuso con respecto al control previo y la revisión judicial de las acusaciones, puede ser destacada de aquella nuestra primera LECrim la supresión del Jurado de acusación de origen francés, al atribuirse esta tarea a las Salas de lo Criminal.

${ }^{205}$ Es significativa una nota-curriculum en la que afirma haberse "consagrado a la redacción de los proyectos jurídicos que más tarde, sin auxilio de Comisión ni Cuerpo consultivo alguno, habían de convertirse en leyes". Vid. COMISIÓN GENERAL DE CODIFICACIÓN, op. cit. p. 201, n. 16. La biografía de D. Eugenio Montero Ríos, destacada personalidad del partido liberal que, posteriormente, llegó a presidir el Tribunal Supremo, el Senado y el Consejo de Ministros, ha quedado unida indisolublemente a la historia de la acción popular en nuestro país. Y no sólo por ser el redactor del cuerpo legal que la introdujo en los términos actuales, sino también porque en una de las primeras y más sonadas apariciones del derecho de acusación al amparo de los nuevos códigos procesales, fue ejercitado para evitar las sospechas de que aquel prócer pudiera influenciar el desarrollo del proceso por el "crimen de la calle Fuencarral", muy célebre en su momento y que causó conmoción en la sociedad española de finales del XIX. Su alto cargo (Presidente del Tribunal Supremo en 1888) y su relación personal con el asunto (los rumores apuntaban a que el presunto asesino o inductor del crimen era hijo natural suyo y se encontraba cumpliendo condena en la cárcel modelo, de la que había salido irregularmente con permiso expreso de su director) contribuyeron a difundir maledicencias sobre su actuación. Al respecto vid. TRENZADO RUIZ, M., "Proyección de Don Eugenio Montero Ríos sobre la Administración de Justicia española", RDProc. (Ibam), 1972, n 1, pp. 121-163, COMISIÓN GENERAL DE CODIFICACIÓN, Organización Judicial, Vol. I, p. 189, n. 18, que contiene su biografía, MARTÍNEZ VAL, Montero Ríos y su época, Madrid 1980, p. 165 y s.; y ALCALÁ-ZAMORA Y CASTILLO, N., "Examen de la estructura y contenido de la Ley de Enjuiciamiento Criminal de 1882 en el momento de su promulgación", RDProc (Ibam). $\mathrm{n}^{\mathrm{o}} 2-3,1982$, p. 270 y "Puntualizaciones relativas al concepto de parte", RDProc. (Ibam.) $\mathrm{n}^{\mathrm{o}}$ 1, 1983, p. 117, n. 57, donde se narran los truculentos sucesos.

\footnotetext{
${ }^{206}$ Se da así la paradoja de que las reformas emanadas de la Constitución de 1869 y del espíritu democrático de la "Gloriosa" fueron promulgadas al dictado del Ejecutivo, el cual, por otra parte, desapareció al poco tiempo junto con la forma política que regía nuestro país, dejando paso a uno de los periodos de tiempo más turbulentos en todo el siglo XIX, poblado de cambios políticos vertiginosos. Con su provisionalidad, muchas de las instituciones introducidas en nuestro ordenamiento de forma casi subrepticia se mantuvieron -y aún se mantienen por lo que a la acusación popular se refiere- inalteradas durante más de un siglo, superando vaivenes políticos y sociales que, sin embargo, consiguieron hacer tambalear pilares jurídicos más firmemente asentados en las conciencias de nuestros hombres de leyes. Vid. COMISIÓN GENERAL DE CODIFICACIÓN, op. cit. p. 196.
} 
afirmó en este sentido que "nunca o casi nunca aparece el acusador privado impulsado por un resorte legítimo. La saña, el rencor, la especulación, las malas pasiones, son sus móviles naturales". Para la de Sevilla, que se manifestó tajantemente en favor de la supresión de la acción popular, no debería conferirse el derecho de acusación más que a los perjudicados y al Fiscal, incluso en los procedimientos especiales contra Jueces y Magistrados, por lo que no se justificaría proveer de abogado a acusadores que alegasen pobreza. Se llegaba a criticar incluso el término "querella" en relación con delitos públicos, puesto que no significa otra cosa que "queja”, y no se correspondería con quien no fue ofendido, y los de "querellante" y "querellado" "por referirse a un verbo recíproco sin participio" ${ }^{207}$.

Estos recelos encontraron reflejo práctico ya desde la primera jurisprudencia emanada del Tribunal Supremo, entre la que no es posible encontrar sentencias en las que un ánimo altruista y de defensa exclusiva de la legalidad constituyera el motor que impulsara a acusadores privados. El esfuerzo que exigía la necesidad de prestar fianzas para acusar (y depósitos para interponer recurso de casación) y sobre todo las características de la estructura social española del momento eran barreras insuperables para hipotéticos acusadores desinteresados. Quizá por ello sólo nos conste de aquella época la presencia de acusadores particulares allí donde hubieran sido afectados puros intereses privados, aun en concurrencia con el interés público en la persecución de los delitos $^{208}$.

Otros intervinientes en aquella discusión aceptaban, sin embargo, la presencia de una pluralidad de acusadores y simplemente planteaban dificultades de carácter técnico en temas como los referidos a la recusación de los miembros del jurado por los acusadores o la falta de calificación adecuada por el $\mathrm{MF}^{209}$. Pero la doctrina se pronunció de forma

${ }^{207}$ COMISIÓN GENERAL DE CODIFICACIÓN, op. cit. pp. 203 y s. y p. 209. Por otro lado, en los capítulos referidos a la obligatoriedad de la denuncia, muestran su disconformidad las Audiencias de Madrid, Burgos, Valencia y Sevilla haciendo ver lo poco dado que es el pueblo español a la denuncia, de lo que se podría inferir que menos lo sería a la acusación meramente altruista.

\footnotetext{
${ }^{208}$ Tratándose por ejemplo de delitos electorales, ámbito donde es relativamente frecuente hallar querellas particulares, puede observarse como los querellantes son en la totalidad de los casos los sujetos perjudicados directamente por los frecuentes abusos cometidos con el fin de falsear los resultados electorales y no cualquier otro ciudadano motivado por la limpieza del proceso electoral. Vid. a título de ejemplo las SSTS de 10 de mayo de 1871 , 24 de marzo de 1873, 9 de octubre de 1874, 7 de febrero de 1878 o 29 de abril de 1881.

${ }^{209}$ COMISIÓN GENERAL DE CODIFICACIÓN, op. cit. pp. 223 y ss.
} 
generalizada en favor del principio de acusación popular instaurado por el nuevo código procesal, continuador de nuestra tradición jurídica y reinterpretado al calor de la ideología liberal, en una época de especial turbulencia política. En este sentido entre las opiniones de aquel momento, expresadas en las páginas de la Revista General de Legislación y Jurisprudencia, son destacables especialmente las siguientes:

* VALLADARES, aun censurando la confusión contenida en los ocho primeros artículos de la LECrim de 1872 al afirmar sin más precisión que "la acción penal es pública", se mostró favorable a otorgar un derecho de acusar a todos los ciudadanos porque ello tiene un valor político que se derivaría de nuestro sistema constitucional y democrático $^{210}$.

* SAVALL Y DRONDA, ardiente partidario de una interpretación amplia de la facultad de ejercicio de la acción penal, defendía el que se posibilitara que incluso los declarados rebeldes en otro juicio pudieran hacer uso de ella. En su opinión, la Ley no lo impedía y ni siquiera era exigible la presencia efectiva del querellante puesto que debía estar representado por procurador ${ }^{211}$.

* RODRÍGUEZ MARTÍN, tras advertir que es absolutamente inexacto que la acción penal sea pública puesto que no todas lo son, se pronunciaba en favor de la introducción del término "popular", con el que "se ha significado siempre el derecho que asiste a toda persona para acusar en los delitos públicos". Aplaudía este "gran principio por el que se reconoce la facultad de acusar como propia de todo ciudadano", con lo que no habrá ni un sólo ciudadano que directa e inmediatamente deje de estar interesado en la persecución y pronto castigo del delito. Destacaba además su histórico papel como indirecto medio preventivo de la comisión de ciertos delitos en tanto "hace que cada uno pueda ser un vigía y un fiscal que observe la conducta de los demás, lo cual puede servir de freno a los malhechores y contribuir muy poderosamente al sostenimiento del orden público y de las leyes". Aun así, mostraba su escepticismo por el funcionamiento futuro de este instituto basándose en "la hidalguía y nobleza de corazón que distingue a los españoles, (que) ha de influir en que sean los menos los que quieran voluntariamente

\footnotetext{
${ }^{210}$ VALLADARES, L.P. de, “Ley Provisional de Enjuiciamiento Criminal de 22 de diciembre de 1872 ", RGJL, T. 42 (1873): "no vamos a impugnar el principio a que obedece esta disposición, consecuencia indeclinable de las doctrinas democráticas sobre que descansa nuestra Constitución política".

${ }^{211}$ SAVALL Y DRONDA, P., “Ejercicio de acciones por el declarado rebelde”, RGLJ, T. 43 (1873), pp. 56 y ss.
} 
hacer uso del derecho de acusar. (...) Existiendo, por lo tanto, ese derecho desde muy antiguo, lo natural parece que continúe sucediendo lo que hasta ahora ha sucedido; es decir, que no llegue entre nosotros a desaparecer la repugnancia que tenemos a convertirnos en acusadores, y hagamos muy poco uso del derecho de acusar, al contrario que sucedía en los pueblos antiguos". Para concluir en que, a pesar de ello "el precepto es bueno, y por eso le aplaudimos" 212 .

* SERRANO, al exponer sus opiniones sobre el MF, deja ver un cierto grado de desconfianza en él, que "por cualquier género de contemplaciones indebidas se abstiene de perseguir o persigue tímidamente". Afirmaba por ello que "la acusación popular voluntaria y la acusación oficial necesaria bien combinadas son los elementos necesarios para la debida represión de los delitos y eficaz acción de la justicia (...) No debe privarse al individuo, ni a ninguna clase o corporación de la sociedad, bajo su debida responsabilidad penal, de la facultad de denunciar y acusar por sí mismos a los delincuentes, con todo el calor y decisión de las personas que han sido víctimas de sus iniquidades." Para el adecuado funcionamiento del sistema establecía como necesaria "la energía del espíritu público y de las costumbres varoniles y liberales, que deben existir necesariamente en todos los países, en que se halla bien cimentada la solidaridad del interés público y privado, en beneficio del Estado y de los particulares". Concluía, sin embargo, con clarividentes palabras afirmando la necesidad de una acción pública que supla la inercia, debilidad o malicia del ciudadano "a fin de que el procedimiento criminal no se convierta, y más en medio de la agitación de las anárquicas y ardientes pasiones políticas de nuestros días, en arma y partido y siempre en un medio de opresión y de innoble tiranía, con descrédito y deshonra de la justicia". Sería exigible para evitar desviaciones de su finalidad el establecimiento de severas responsabilidades penales para la acusación particular y aun para la denuncia ${ }^{213}$.

${ }^{212}$ RODRÍGUEZ MARTÍN, C., "Consideraciones sobre el capítulo primero, título preliminar de la Ley provisional de Enjuiciamiento Criminal de 22 de diciembre de 1872”, RGLJ T. 44 (1874), pp. 297 y s.

${ }^{213}$ SERRANO, L.J., “Organización del Ministerio Fiscal y Tribunales”, RGLJ, T. 47 (1875), pp. 322 y ss. La garantía frente acusaciones calumniosas no se derivaba sólo de la LECrim sino del Código Penal de 1870 que las regulaba en su art. 340: "Se comete delito de acusación ó denuncia falsa imputando falsamente á alguna persona hechos, que si fueren ciertos, constutuirian delito de los que dan lugar á procedimiento de oficio, si esta imputacion se hiciere ante funcionario administrativo ó judicial que por razon de su cargo debiera proceder á su averiguacion ó castigo....”. En el 341 se preveía que "El reo de acusacion ó denuncia falsa será castigado con la pena de presidio correccional en sus grados medio y máximo cuando el delito imputado fuera grave, y con la de arresto mayor si la imputación hubiere sido de una falta, imponiéndose además en todo caso una multa de 250 á 2.500 pesetas"Código 
* MONER remarcaba el carácter público de la acusación y de la denuncia, pero lo hacía unificando ambas bajo el término de "acción pública". En su intento de distinguir lo que sean querella, denuncia y acción civil derivada del delito, se sirve de términos gramaticales referidos a los diferentes complementos: "es acción directa o verdadero acusativo la querella; es indirecto o dativo la denuncia, y tambien circunstancial o ablativo la acción civil" ${ }^{214}$.

La vigencia del ejercicio por los ciudadanos de la acusación en el momento de promulgarse la LECrim de 1872 se derivó mucho más del mantenimiento de la tradición histórica que de otras consideraciones ${ }^{215}$. La acusación de los particulares no era algo totalmente novedoso, sino perfectamente asumible por la mayoría de los operadores jurídicos de la época y su permanencia en el sistema no chocaba, salvo excepciones, con el espíritu de los juristas del momento. Muy por el contrario, la acusación popular se mantuvo en tanto expresión del individualismo que había dado aliento al derecho romano, con siglos de historia a sus espaldas y todo ello pasado por el tamiz liberal. Negar una prerrogativa que la tradición había consolidado, aunque hubiera devenido teóricamente innecesaria en tanto las circunstancias habían variado por la presencia de un acusador oficial sujeto al principio de legalidad, pudo ser entendido como una intervención del Estado en la esfera de los particulares o como una dejación de funciones, al permitir que algún delito quedara impune. La acusación popular no puede considerarse sino un producto histórico de la inadecuada separación entre el proceso civil y el penal, al que a pesar de estar basado en las actiones romanas, se superpuso la necesidad social de evitar

Penal reformado con notas y concordancias con el de 1850, Imprenta de la Biblioteca de Instrucción y Recreo, Madrid, 1870. En este Texto Legal se encuentra recogido entre las falsedades del Título IV, en concreto en su Capítulo VI: "De la ocultación fraudulenta de bienes ó de industria, del falso testimonio y de la acusación y denuncia falsas”. El art. 241 del Código Penal de 1848 y el 248 del Código Penal de 1850 ya preveían que “La acusación ó denuncia que hubieren sido declaradas calumniosas por sentencia ejecutoriada, serán castigadas con las penas de prision menor cuando versaren sobre un delito grave; con las de prisión correccional si fuere sobre delitos menos graves, y con las de arresto mayor si se tratare de una falta, imponiéndose ademas en todo caso una multa de 50 á 500 duros". Vid. Código Penal de España, Imprenta Nacional, Madrid 1848 y Código Penal de España. Edición Oficial reformada. Imprenta Nacional, Madrid 1850.

${ }^{214}$ MONER, J.M., "Diferencias y semejanzas entre la accion de querella, la de denuncia y la de los actores civiles establecidas por la Ley de Enjuiciamiento Criminal”, RGLJ, T. 48 (1876), pp. 56 y ss.

${ }^{215}$ Así se pronunciaba también p. ej. PANTOJA en su Introducción a la Jurisprudencia Criminal, Imprenta de la RGLJ, Madrid 1871, p. XXIV. 
la impunidad de los delitos y la desconfianza en un órgano burocrático-estatal. Puede ser contemplado, por tanto, como un residuo que la historia había petrificado y que se fundamentó en el retorno del proceso inquisitivo al acusatorio sobre una concepción liberal de los derechos subjetivos en la que se tomó como espacio preponderante la garantía de un ámbito de libertad que ni el Estado ni ninguno de sus oficiales podrían invadir o coartar.

El intento de dar satisfacción a opiniones distantes hizo que se llegara a un sistema que a la vista de observadores externos puede parecer carente de lógica interna ${ }^{216}$ : la combinación de la obligatoriedad de ejercitar la pretensión penal simultáneamente al mantenimiento de la prerrogativa de los particulares para satisfacer esa función. Cualquier otro sistema (acusación totalmente privada, acusación del ofendido, acusación del MF y privada subsidiaria o monopolio de la acusación por el MF garantizado con la sujeción al principio de legalidad) hubiera sido más coherente, pero sobre él hubiese sido difícil alcanzar un mínimo consenso político. De esta manera se intentó satisfacer intereses contrapuestos que contribuyeron a la creación de un sistema con intrínsecas contradicciones.

\subsubsection{Compilación General de 1879}

\section{La Compilación General de las Disposiciones Vigentes sobre Enjuiciamiento} Criminal de $\mathbf{1 8 7 9}^{217}$ supuso el siguiente paso en el afianzamiento de la acusación popular en nuestro ordenamiento positivo. En tanto en esta materia no hizo más que reproducir las previsiones anteriores, poco más puede destacarse salvo que en su art. 235 se contiene el reconocimiento de la facultad de los ciudadanos para acusar en los exactos términos en que hoy la conocemos en el 101 de la vigente LECrim: "La acción penal es pública. Todos los ciudadanos españoles podrán ejercitarla con arreglo a las

\footnotetext{
${ }^{216}$ Así, desde una óptica contemporánea, vid. por ejemplo TAK, P.J.P., The legal scope of non-prosecution in Europe, HEUNI (Helsinki Institute for Crime Prevention and control. Affiliated with the United Nations) Publication series $n^{\circ}$ 8, Helsinki 1986, p. 73.

${ }^{217}$ La Compilación ha sido amplia y frecuentemente criticada, fue elaborada con precipitación y vocación claramente provisional sin un mínimo debate parlamentario: la Ley de 30 de diciembre de 1878, aprobada tras breve discusión en el Senado y sin debate en el Congreso, autorizó al Ministro a que, previa consulta a la Comisión de Códigos, publicara una compilación general articulada y metódica, en la que se refundieran las disposiciones que regían el procedimiento criminal.
} 
prescripciones de la ley".

\subsubsection{LECrim de 1882}

En plena restauración monárquica y una vez superada la convulsión revolucionaria del 68, los intentos por erradicar la acusación popular de los textos procesales continuaron en las ponencias de los vocales de la "Comisión sobre Reforma del Procedimiento Penal". AURIOLES fue el encargado de la redacción del título preliminar, y con ello el principal promotor de la supresión del art. 2 de la Ley (el actual 101) relativo a la declaración de que "la acción penal es pública", confiriendo su ejercicio por el contrario solamente al Ministerio Fiscal y al perjudicado por el delito o falta ${ }^{218}$. DANVILA, en su Anteproyecto de Código Procesal Penal presentado ante la Comisión en diciembre de 1880, pero redactado probablemente con anterioridad a la Compilación General, propugnaba además la restricción del ejercicio de la acusación cuando el delito debiera ser perseguido de oficio. Reservaba al perjudicado el papel de coadyuvante del Fiscal, para lo que tomaba ejemplo de los Códigos de Alemania, Austria, Italia, Francia y Bélgica ${ }^{219}$. FERNÁNDEZ DE LA HOZ presentó en marzo de 1881 la ponencia referida al título II de la futura LECrim, retomando el texto de la Compilación General ${ }^{220}$, pero proponiendo la limitación del ejercicio de la acción pública, al conferírselo exclusivamente al Ministerio Fiscal y a las personas inmediatamente agraviadas por el delito. Tal tesis fue aprobada por la Sección de la Comisión de Codificación según figura en acta de 4 de abril de $1881^{221}$ pero se varió con posterioridad sin que conste en qué momento, manteniéndose en el artículo 101 vigente la literalidad del 235 de la Compilación General y con ello el sistema

${ }^{218}$ COMISIÓN GENERAL DE CODIFICACIÓN, op. cit. p. 248. A éste se le reconoce también el beneficio de gratuidad.

${ }^{219}$ A este tipo de reformas se oponía el vocal BRAVO ROMERO por considerar que se pretendía hacer "una Ley nueva calcada en disposiciones de Códigos extranjeros". Vid. COMISIÓN GENERAL DE CODIFICACIÓN, op. cit. pp. 249, 250, 254 y 266. En el Anteproyecto se acompañaban tambien importantes reformas orgánicas, entre las que se contaba la necesidad de crear una amplia plantilla fiscal.

\footnotetext{
${ }^{220}$ Según el mandato contenido en la Ley de bases ya aprobada por el Senado que autorizaba al Gobierno a redactar una nueva Ley de Enjuiciamiento Criminal. La aprobación por las Cámaras legislativas de una Ley de Bases conteniendo instrucciones sobre la materia distingue el proceso de creación de nuestra actual Ley de Enjuiciamiento Criminal con respecto a su predecesora de 1872, aun cuando al igual que ella, una vez elaborada no fue sometida nunca a informe de Tribunales ni Corporaciones.
}

${ }^{221}$ COMISIÓN GENERAL DE CODIFICACIÓN, op. cit. p. 266. 
de acción penal popular ${ }^{222}$. Esta rectificación es sólo comprensible desde el espíritu conciliador y de arbitraje de fórmulas de transacción que distinguió en la Comisión de Códigos a ALONSO MARTÍNEZ y que, con toda probabilidad, podría haber contribuido a la búsqueda de soluciones consensuadas ${ }^{223}$. Se realizaba así una declaración política de hondo calado (“Todos los ciudadanos españoles podrán ejercitarla..."(art. 101), “Todos los ciudadanos españoles, hayan sido o no ofendidos, pueden querellarse" (art. 270)), dirigida a consolidar un derecho individual nunca derogado expresamente, extendiendo el carácter de ofendido por el delito a toda la ciudadanía. Con el cambio no se afectó al resto del cuerpo de la ley, por lo que la acusación popular se mantuvo sobre unas estructuras habilitadas para la intervención de los inmediatamente agraviados por el delito, sin que en ningún otro trámite se previera la intervención de diferentes acusadores con diferentes grados de afección por el delito ${ }^{224}$.

La principal defensa de la acción popular penal en su configuración por la nueva LECrim fue la realizada en 1888 por el político conservador, antiguo ministro de Gracia y Justicia del Gabinete liberal-conservador y presidente de la Real Academia de Jurisprudencia y Legislación, D. Francisco SILVELA en un discurso leído ante ésta ${ }^{225}$.

${ }^{222}$ LASSO GAITE nos dice que "no se conservan más actas que indudablemente existieron". COMISIÓN GENERAL DE CODIFICACIÓN, op. cit. p. 269.

${ }^{223}$ Según afirmación de BUGALLAL en el Congreso, lo que más distinguía en la Comisión de Códigos a ALONSO MARTÍNEZ era su espíritu conciliador y arbitrador de fórmulas de transacción. Un ejemplo de esa búsqueda de acuerdo, cercano en lo que a nuestra materia se refiere, lo encontramos en la discusión sobre el actual art. 733. En este caso CALDERÓN COLLANTES hizo ver la preocupación por los efectos perniciosos sobre el proceso penal, por lo que suponía de elemento de arbitrariedad, el que el Ministerio Fiscal estuviera sujeto a dependencia gubernativa. COMISIÓN GENERAL DE CODIFICACIÓN, op. cit. p. 268.

${ }^{224} \mathrm{De}$ ahí, por ejemplo, que no se establezcan en ningún caso prelaciones entre diferentes tipos de acusadores.

${ }^{225}$ Vid. SILVELA, F., “La acción popular”, $R G L J$ T. 73, 1888, pp. 457 a 487. El principal epígono de la acción popular entre la doctrina del siglo XIX elaboró su discurso en un momento especialmente significativo desde el punto de vista político: el entonces presidente del Tribunal Supremo, el liberal D. Eugenio Montero Ríos, a la sazón adversario político suyo, se encontraba en el punto de mira de una acusación popular puesta en marcha por varios directores de periódicos para la persecución del famoso "crimen de la calle Fuencarral" y al que el autor hace referencia en el texto. SILVELA, recogiendo el rumor de la calle lo transformó en querella política y tras denunciar en un discurso pronunciado en Málaga la "inmoralidad que llega hasta la Presidencia del Tribunal Supremo", se dedicó a cantar las excelencias de la institución como freno a la discrecionalidad del Estado. Aquella acusación sobre el presidente del TS nunca llegó a probarse, pero aun así, Montero Ríos no se mostró remiso a abandonar el cargo con el fin de no afectar el buen nombre de la institución que presidía. MARTÍNEZ VAL, Montero Ríos y su época, Madrid 1980, p. 166. Debe destacarse además que en el juicio intervino D. Emilio BRAVO ROMERO, otro de los defensores del entendimiento de la acusación popular en su vieja concepción romana. Vid. COMISIÓN GENERAL DE CODIFICACIÓN, op. cit. p. 255, n. 15. 
Su opinión destila unos planteamientos profundamente liberales de desconfianza máxima hacia todo aquello que, en favor de su atribución al Estado, significase la privación a los individuos de alguna esfera de libertad. SILVELA realizaba una retórica comparación entre la conciencia cívica del ciudadano romano y la de las épocas anteriores a la suya llegando a la conclusión de que, a pesar de la vigencia prolongada de tal derecho en nuestra historia, éste había carecido de virtualidad práctica. La escasez de su uso la achacaba precisamente a la inadecuación al espíritu del momento: “ ¿cómo era posible que la acción popular romana, perdida en el rincón de un Código como planta exótica, viviera en un medio ambiente tan contrario a los principios que le dieron origen, como eran el procedimiento canónico, y la justicia y el poder público, teniendo por ideal del progreso, la centralización en la monarquía, de las facultades y medios destinados a crear y mantener el orden social y la vida interior y extensiva de la nación? En este concepto están escritas las leyes de la Novísima que tratan de las acusaciones, y a nadie ocurrió entonces ni después escribir un precepto que arrancase al ciudadano el derecho de formular y perseguir la acción por delito público, porque ni memoria había de que nadie pretendiese tan extremo privilegio, y de común consentimiento se entendió reducido a denunciar a las justicias, para que ellas procedieran a lo que hubiere lugar" 226 . Con ello pretendía rescatar del olvido una vez más el elemento individualista que regía el sistema romano por encima de la sumisión a que estaban sujetos los ciudadanos en el Antiguo Régimen y hacerlo valer por oposición al oscurantismo anterior como demostración del espíritu liberal que le guiaba. A SILVELA le costaba admitir que tal función, en tanto pública, pudiera pertenecer solamente al Estado sin respetar las facultades del ciudadano sometido a éste ${ }^{227}$. Profundamente desconfiado frente a los

${ }^{226}$ SILVELA, F., “La acción popular”, $R G L J 1888$, p. 477.

${ }^{227}$ A pesar de esos anhelos participativos del ciudadano en la administración de justicia, SILVELA se había manifestado repetidamente contrario al Jurado. Según su opinión, "es un sofisma absurdo suponer que en una profesión tan difícil como el juicio en materia criminal, pueda hacerlo mejor el indocto que el Magistrado" (...) "Lo mismo que la gravedad en el mundo fisico, asi en el intelectual la ciencia y la experiencia son el fundamento de todas las profesiones. El Jurado tuvo su justificación entre nosotros en los siglos medios, cuando la incultura, salvo excepciones, era general". Sobre el Jurado como escuela de ciudadanía, aduce que no merece aprecio pues si el ciudadano aprende condenando sin razón, malo para el criminal y si absuelve sin justicia, peor para la sociedad. Concluye, en fin, que lo que es bueno en otros países, puede no conformarse a nuestro carácter y nuestras costumbres. COMISIÓN GENERAL DE CODIFICACIÓN, op. cit. p. 283 en la que se cita la Gaceta del Senado, núm. 74 de 3 de abril de 1883, p. 1377. Tras leer esto se nos antoja cuando menos chocante que el mismo SILVELA, en su apasionada defensa de la acción popular unos años más tarde desde las páginas de la RGLJ, si bien con cautelas, asumiera el que se tomara como modelo un ordenamiento extranjero totalmente ajeno a nuestra tradición jurídica y de muy difícil traslación a otros sistemas tal y como era el inglés. Vid. SILVELA, F., "La acción popular", op. cit. p. 484. A pesar de que a primera vista pudiera entenderse que durante el final de nuestro siglo XIX, los 
abusos del Poder Ejecutivo y "las innovaciones peligrosas que piden al Estado y a la ley organismos de carácter preceptivo, apoyados y fortalecidos por el presupuesto y cuyo procedimiento y funciones se imponen por mandato de la autoridad pública", propugnaba el establecimiento de cauces para que el ciudadano ejerciera su libertad con sinceridad, convicción desinteresada y amor a la justicia. La aspiración máxima que se deriva de sus palabras es la desaparición del Ministerio Fiscal en tanto ésta, aun sin citarla expresamente, sería una de aquellas "instituciones progresivas y benéficas" que "el pueblo abomina y detesta" por poder convertirse en "instrumento de tiranía o semillero de inmoralidades". La participación en las funciones jurídicas por movimiento de la voluntad como es el caso de la acción popular, y tal y como ocurre en la libertad de pensamiento, enseñanza o asociación, serían en su opinión como "moldes preparados, que no se llenan ni se utilizan sino a medida que las necesidades y los medios sociales lo requieren" 228 .

El motivo de su artículo merece la pena ser destacado someramente, en tanto reflejo de un cambio fundamental en la interpretación de la novedosa LECrim, de tan extraordinario alcance, que la doctrina entonces sentada se mantiene aún hoy. La acusación popular se había configurado en la Ley como un principio incompleto y no claramente desarrollado en cuanto a las funciones y atribuciones del acusador no ofendido por el delito. Ello dio origen a que, de forma solapada y sin designarlo por su nombre, se mantuviera en nuestro país la misma discusión que en los de nuestro entorno: conferir a la facultad acusatoria de los particulares un carácter subsidiario con respecto a la del MF o bien reconocerle el carácter de derecho autónomo inserto en la esfera subjetiva privada con independencia de la actividad de los nacientes órganos estatales encargados de esa función. Las diferencias se suscitaron así entre los que propugnaban que el ejercicio por los ciudadanos consistía en un mero auxilio de las funciones acusatorias de los órganos públicos y los que, como SILVELA, veían en ella un derecho del ciudadano a perseguir la aplicación de la norma con independencia de lo que hiciera el Estado a tal efecto.

liberales apoyaban la institución del Jurado, mientras que los conservadores lo hacían con la acción popular, ésta, al igual que aquél, era instrumento de una clase social en mayor o menor grado representada por los grupos políticos componentes del parlamento. A ella se recurría como arma arrojadiza con fines políticos extraparlamentarios pervirtiendo así su finalidad originaria.

\footnotetext{
${ }^{228}$ Op. cit. pp. 486 y s. Consciente de la dificultad en la extensión de tales principios hace suya para esta materia la frase de TOCQUEVILLE en el sentido de que "la libertad necesita permanecer escrita mucho tiempo en las leyes, antes de que penetre en las costumbres" (p. 485).
} 
Mientras que para los primeros, en consonancia con la primera jurisprudencia sobre la ley, la llamada acción popular no sería más que una manera de poner en ejercicio la acción pública y no llevaría consigo un procedimiento con sustancia propia, para los segundos sí tendría tal entidad en tanto respondía a un derecho con vida independiente y fin separado del social, aunque fuera armónico con él.

A tenor de la primera interpretación, cuando el proceso estuviera ya incoado a instancias del MF y se estuvieran practicando diligencias, sería de aplicación el art. 113 LECrim, el cual obliga a litigar bajo una misma dirección y representación a juicio del Tribunal. La "acción penal para el castigo de los delitos" ya estaría en este caso agotada, en tanto ya se habría puesto en ejercicio y sólo al MF le competería la intervención en el proceso como acusador. La acción popular serviría, por tanto, sólo para dar comienzo al proceso tratándose de delitos olvidados o desconocidos, pero cuando el MF ya hubiera actuado, se consideraría cumplido y satisfecho suficientemente el fin social perseguido. Por el contrario, para SILVELA, defensor de la naturaleza independiente del derecho de acusación, afirmar esa posibilidad significaría tanto como haber introducido con las leyes de 1872 y 1882 una menguada reforma en el antiguo sistema, que ya había caído en desuso, y hacer que la intervención del acusador popular fuera reducidísima, nula en la práctica y subordinada en todo caso a la unidad de dirección que el arbitrio del Tribunal le trazara. Al amparo de la doctrina establecida hacía muy poco tiempo por la Audiencia de Madrid, en la que se reconocía que no habría inconveniente en igualar a ofendidos y no ofendidos en lo referido a mostrarse parte en la causa, extraía SILVELA la naturaleza y condición de la acción popular. No se trataría de la participación en la soberanía, ni de un derecho natural o individual específico, sino de la atribución de la categoría de perjudicado por el delito, desde el momento en que un ciudadano cualquiera se presenta ante los Tribunales, procurando la persecución del crimen, la averiguación de sus autores y la fiscalización de lo que los representantes del Estado hubieran hecho o dejado de hacer para cumplir debidamente su misión. Su principio no sería otro que el derecho del ciudadano a perseguir el fin social de la justicia, independientemente de la actuación del Estado $^{229}$. Esta concepción, basada en una confianza en la bienintencionada intervención del ciudadano, ha gozado de éxito y pervive aún en la mayoría de la doctrina sobre la materia que nos ocupa.

\footnotetext{
${ }^{229}$ Op. cit. pp. 482 y s.
} 
Entre los primeros comentaristas a la LECrim de 1882, la crítica del precepto es ciertamente escasa y se limita a distinguir la acción pública penal de la civil nacida del delito y de la que se ejercita por el ofendido para la represión de los delitos privados ${ }^{230}$. Para AGUILERA DE PAZ la publicidad de la acción a que se refiere el art. 101 LECrim no se concede en razón del interés al que afecta, como sucede en otras legislaciones, sino atendiendo a la extensión dada a su ejercicio. La acción para perseguir el delito sería de derecho natural para todos los ciudadanos puesto que a todos afecta la infracción de la ley y la perturbación del orden jurídico en su cualidad de participantes del interés público lesionado ${ }^{231}$. La intervención conjunta del MF se fundamentaría en razones de utilidad práctica en tanto cabe la posible dejación de la acción por el querellante particular, quien, al estar legitimado para desistir, podría dejar en desamparo el interés público perturbado. Las acciones que nacen del delito son distintas en función del sujeto que las ejercite, pero interviniendo los particulares, las facultades propias de éstos serán las mismas que las concedidas al Ministerio Público, diferenciándose únicamente en que estarán sujetas a determinadas incapacidades o incompatibilidades ${ }^{232}$. La acción popular constituye un derecho y la acción pública encomendada al MF entraña una obligación exigible que no puede dejar de cumplirse ${ }^{233}$. Si no hubiera acción popular, en caso de notorio y evidente error o falta de diligencia del MF, el Tribunal no podría "imponer penas a los culpables" ${ }^{234}$, salvo haciendo uso de las posibilidades que la LECrim le ofrece en los arts. 642 y ss. La acusación popular se presenta así como garantía del carácter acusatorio del proceso, pues, como ya expresamente recoge AGUILERA DE PAZ, "donde no hay

\footnotetext{
${ }^{230}$ Así por ejemplo REUS, que no entra en la justificación de la acción popular sino simplemente en su distinción con la dirigida al castigo de los delitos privados. La acusación pública era a su juicio un principio general que debía ser interpretado teniendo en cuenta las correcciones que se realizan en los siguientes artículos. REUS, E., Ley de Enjuiciamiento Criminal concordada y anotada extensamente, Madrid 1883, T. I, pp. 75 y ss.

${ }^{231}$ Vid. AGUILERA DE PAZ, E., Comentarios a la Ley de Enjuiciamiento Criminal, Madrid 1914 (1 ${ }^{\mathrm{a}}$ ed.) y 1923 ( $2^{\mathrm{a}}$ ed.), T. I, p. 534. Indudablemente esta afirmación entra en la concepción liberal y, como tal, formal, dado que, si bien ab initio todos los ciudadanos son "titulares" de la acción popular, en verdad, amén de las excepciones (mujeres, jueces, etc.), sólo los que tenían medios económicos para afianzar podrían deducirla.

${ }^{232}$ AGUILERA DE PAZ, E., Comentarios..., op. cit. T. I, p. 523.

${ }^{233}$ Admite AGUILERA DE PAZ sin embargo, que el MF pueda eximirse o excusarse del ejercicio de la acción en determinados casos y por razones especialísimas del interés o conveniencia políticos. op. cit. pp. 570 y ss.

${ }^{234}$ AGUILERA DE PAZ, E., op. cit. p. 571.
} 
acusador, no hay juez",235.

Así como las primeras críticas doctrinales a la LECrim en el caso de la de 1872 habían sido especialmente benévolas con la acusación popular, para la actualmente vigente no puede decirse otro tanto. Los reproches de los tratadistas del momento abarcaban diferentes aspectos, pero en general el denominador común era una desconfianza hacia ella por su carácter innecesario o por el peligro de utilización fraudulenta que conllevaba:

* MARTÍNEZ DEL CAMPO, buen conocedor de los sistemas acusatorios vigentes en el derecho comparado del momento, destacaba ya desde los primeros momentos de vigencia de la LECrim (1885) que la acusación popular patentizaba el carácter público del delito y la solidaridad de los elementos del cuerpo social, pero que la amplitud en la atribución de titularidad para su ejercicio sería superflua. En su opinión “es más usada por movimientos pasionales que por espíritu de rectitud, amor a la justicia o temor de impunidad". Añade el citado autor que "no se contrabalancean ni compensan siempre los males ocasionados por la malquerencia" y a su juicio "inútil es esa delegación en los ciudadanos; ningún principio de derecho la aconseja, ningún interés político la mantiene, antes al contrario, la rechazan el supremo interés de apartar del pretorio la pasión y la venganza, y las viles especulaciones a que convida, no remediadas siempre por los resultados posibles para el actor, que rara vez reparan el mal moral y material causado por los procesamientos. Tampoco la abona el recuerdo de antiguos tiempos en que se aprovechaban como medio de opresión y de terror las acusaciones; de lo cual son ejemplo las ya conocidas en Grecia y en Roma, en los pueblos germanos y en los propios Tribunales de la Iglesia Católica, aun antes del siglo XIII, en que el procedimiento acusatorio fue sustituido por el inquisitivo por las razones que en Roma se introdujo paulatinamente el de oficio". Concluía MARTÍNEZ DEL CAMPO afirmando que sería suficiente atribuir al ofendido por el delito la acción civil, como en Francia, o una acusación privada subsidiaria, como en Alemania ${ }^{236}$ y Austria. Con ello se garantizarían todos los intereses " $y$ el derecho de acusar no queda expuesto a convertirse en motivo de granjería, ni en ciertos delitos de carácter político en ocasión de perturbaciones que

\footnotetext{
${ }^{235}$ AGUILERA DE PAZ, E., op. cit. p. 571, en la que el autor dice que se trata de "un conocido aforismo alemán".

${ }^{236}$ Nos imaginamos que se refirirá el autor a la Nebenklage (acusación adhesiva) por cuanto no existía en el ordenamiento alemán acusación privada subsidiaria.
} 
socaban abismos de odio, y ponen barreras insalvables entre los ciudadanos de un Estado, que viven más próximos y más necesitan la paz moral" ${ }^{237}$.

* Otra de las críticas reseñables de estos primeros momentos de vida de la LECrim es la que se encuentra en la memoria publicada por el jurista catalán BONELL SÁNCHEZ, aprobada por la Academia de Derecho de Barcelona que él mismo presidía. En esta se destacaba el acusado tinte liberal de la Ley, que se mostraría más atenta a los intereses individuales que a los de la sociedad. Aceptando la norma, BONELL expone y razona entre otras varias cuestiones que, con el fin de evitar males mayores, el ejercicio de la acusación popular debía limitarse de forma clara en la Ley únicamente a los primeros días del procedimiento ${ }^{238}$.

* Algunos años más tarde y en sentido más benévolo pero en ningún caso favorable, GONZÁLEZ DE ALBA presentaba la acusación como un inexcusable deber de ciudadanía a lo largo de toda la historia por el que la colectividad social participaba en la "función justiciera a veces absorbida totalmente en su efectividad por el Estado". No concebía mayor arbitrariedad ni injusticia que la violación de la ley efectuada en nombre de un poder que desconociese la libertad de los asociados para reclamar en todo momento fuese aquella cumplida sin excepciones ni privilegios. Para describir el antiguo derecho de acusación utilizaba calificativos tales como "prerrogativa de ciudadanía" o "preciado derecho individual de populares libertades" 239 , pero no por ello dejaba de advertir sobre los peligros de intranquilidad jurídica derivados de las "pasiones insanas al servicio de los más miserables propósitos de difamación y calumnia" que desembocaron en persecuciones inspiradas en venganza de los acusadores. Hacía valer el derecho romano como ejemplo para mostrar los riesgos de su mala utilización y relataba que en la Roma Imperial se acusaba por "deseos ambiciosos de medro personal puesto que la acusación se formulaba para derribar a quienes por la elevación de su altura pudieran concitar los odios populares, siempre propicios a la agitación en las luchas de la vida pública(...) Todo ello hizo que en Roma se extinguieran y secaran las raices que en la conciencia

\footnotetext{
${ }^{237}$ MARTÍNEZ DEL CAMPO, E., Notas al Libro $1^{\circ}$ de la Ley de Enjuiciamiento Criminal, Madrid 1885, pp. 268 y s.

${ }^{238}$ La reseña se toma de COMISIÓN GENERAL DE CODIFICACIÓN, op. cit. p. 309.

${ }^{239}$ GONZÁLEZ DE ALBA, P., “El derecho de acusación como función de ciudadanía”, RGLJ, T. 115 (1909), pp. 29 y ss.
} 
pública debian alimentar esta institución, sin que nadie las arrancara del cuerpo del derecho positivo, donde quedaron olvidadas y estériles ${ }^{240}$. Por lo que se refiere a nuestro derecho, sostenía GONZÁLEZ DE ALBA que la ley española, aun restableciendo la "acción pública acusatoria" no habría hecho revivir en "toda su libérrima expresión la actio popularis romana" ${ }^{241}$. Reconocía no obstante que la acusación habría de someterse a la actualidad del sentido jurídico predominante, y se lamentaba de que "por desgracia, no es de modo general, la voluntad honrada del ciudadano percatado de sus deberes cívicos, la que ayudando a Jueces y Tribunales pone en movimiento la acción penal', y que el ciudadano más bien rehuye que se afana por cumplir sus deberes para con la justicia ${ }^{242}$. Advertía que "si se diese el excepcional espectáculo de un acusador, que noble y desinteresadamente acusase a los delincuentes y se convirtiese en vigilante activo de las demasías del crimen, restos sentimentales de trasnochadas ideas de andastescas protecciones al criminal desgraciado le mirarían con prevención y como ser casi repulsivo y desequilibrado" ${ }^{243}$. No podía por menos que prevenir la percepción en la masa honrada de la colectividad de "aquel que sin ser ofendido por el delito, ni afectar éste a sus deudos o parientes, se convierte en paladín de desfacedor de ajenos agravios, disimulando en el fondo de su conducta odios y rencores, traducidos en empresas de deshonor y persecución implacables". Todo ello le conducía a afirmar la conveniencia de la acusación popular sólo en aquellas sociedades donde se careciera de un órgano encargado de esta función, pero en ningún caso en nuestro sistema, en el que el MF ostentaría la representación legítima de la potestad acusatoria que le viene atribuida de la nación ${ }^{244}$. De este argumento derivaba su pretensión de limitarla a sus "racionales y

${ }^{240}$ GONZÁLEZ DE ALBA presenta las acusaciones en la Roma posterior a la muerte de César como patrimonio de "jóvenes educados en los artificios de la retórica que, siguiendo las enseñanzas de Ciceron, se ejercitaban en pronunciar acusaciones calumniosas contra hombres integérrimos para saciar el pueril deseo de la celebridad, meditando algunos sus denuncias en los lupanares, o en las casas de juego, y dirigiendo siempres sus diatribas a quienes por ser los más distinguidos hombres públicos, eran más fácil blanco de la calumnia” (p. 81).

${ }^{241}$ La explicación histórica de su abandono la cifraba, al igual que SILVELA, en su inadecuación al espíritu de la época, puesto que, tras su inclusión en las Partidas, desapareció más tarde como "planta exótica sin medio ambiente de vida en aquel estado de absorbente centralización del poder público" para reaparecer con algunas novedades, en nuestras normas procesales penales de 1872 y 1882. GONZÁLEZ DE ALBA, P., "El derecho de acusación...”, op. cit. p. 41.

\footnotetext{
${ }^{242}$ GONZÁLEZ DE ALBA, P., “El derecho de acusación...”, op. cit. p. 45.

${ }^{243}$ GONZÁLEZ DE ALBA, P., “El derecho de acusación...”, op. cit. p. 46.

${ }^{244}$ GONZÁLEZ DE ALBA, P., “El derecho de acusación...”, op. cit. pp. 47 y 50.
} 
justos límites", impidiendo el ejercicio de la acusación popular cuando ya haya sido legítimamente ejercitada la acción penal ${ }^{245}$. Se mostraba así partidario de la unidad e identidad de la acción penal o pública, fuera quien fuera su ejercitante, Ministerio Fiscal, ofendido, perjudicado o cualquier otro ciudadano. Era incuestionable para él que las facultades en manos de la víctima del delito debieran ser mantenidas, no sólo para que por su actividad se inicie la persecución, sino para intervenir en cualquier fase del procedimiento. Tales prerrogativas no deberían ser extensibles al acusador popular ${ }^{246}$, cuya función en el proceso sería únicamente evitar que los delitos quedasen en secreto y los criminales en la impunidad.

Otra de las notas que llevaban a la desconfianza hacia la acusación quivis ex populo era la libertad de los pobres para acusar y los peligros que pudiera llevar consigo, al constituirse en acusadores con fianza personal al amparo del art. 591 LECrim. Afirmaba así GONZÁLEZ DE ALBA que "no ha de ser raro en la realidad de la vida que al amparo de una insolvencia surjan los acusadores de oficio, para quienes no les será dificil una fianza personal, toda vez que para nadie es un misterio la existencia de gentes dedicadas a fiadores personales, que resultan insolventes al hacerles efectivas las fianzas para garantizar la libertad provisional de los procesados" ${ }^{247}$. Concluía, a pesar del título que lleva su artículo, recordando "el invencible movimiento repulsivo hacia todo aquel, que sin ser perjudicado por el crimen, acepta el triste papel de delator en procesos criminales" y con la prevención de que "debe apercibirse a la defensa contra el abuso de una potestad, que en la realidad injusta perturba la tranquilidad jurídica de los asociados, proclamando el triunfo de la iniquidad con intolerables y calumniosas

\footnotetext{
${ }^{245}$ Señala sin embargo una excepción posible: los supuestos de juicios ante el Jurado. GONZÁLEZ DE ALBA, P., "El derecho de acusación...”, op. cit. p. 49.

${ }^{246}$ De ahí que éstos sólo pudieran personarse mediante la querella, única forma de iniciación procesal que la LECrim admite para un acusador no ofendido.

${ }^{247}$ GONZÁLEZ DE ALBA, P., “El derecho de acusación...”, op.cit. p. 45. No ha de pasarse por alto sin embargo que para constituirse en fiador personal era preciso acreditar cierta solvencia económica. El art. 409 de la LECrim de 1872 exigía que fuera "contribuyente al Tesoro por cualquier concepto" y el 592 de la de 1882 en su redacción vigente cuando GONZÁLEZ DE ALBA redacta su artículo establecía que podría ser fiador personal "todo español de buena conducta y avecindado dentro del territorio del Tribunal, que esté en el pleno goce de los derechos civiles y políticos y venga pagando con tres años de anterioridad una contribución directa, al ménos, de 50 pesetas anuales, procedente de bienes inmuebles de su propiedad personal, ó de 100 por razon de subsidio con establecimiento abierto". Es, por tanto, requisito sine qua non para constituirse en fiador personal la tenencia de cierto patrimonio, lo que nos viene a decir que los pobres nunca podrían asumir esa condición.
} 
acusaciones" 248 .

* En un sentido similar, pero pronunciadas algunos años más tarde (en 1929), se sitúan las críticas de ALCALÁ ZAMORA que, dirigidas a la acusación popular en su formulación vigente, pasan por ser las más aceradas de entre las planteadas por la doctrina. En su opinión, la acción popular "acogida a la ambigüedad del art. 101" estaría llamada a desaparecer, "bien porque en la mayor parte de los casos permanece en el olvido más completo, mostrando su inutilidad, bien porque, cuando aparece, es injusta y peligrosa. Injusta, porque desequilibra el proceso en perjuicio del acusado (...). Peligrosa, porque esa ausencia de interés determinado se presta a que la acusación popular sea el arma de las pasiones excitadas, la representación de los más audaces, y no, como su nombre parece indicar, la de los más numerosos; hasta puede ser (el caso se ha presentado, desgraciadamente) la confabulación de Abogados sin escrúpulos con la defensa. Para todo sirve, menos para algo medianamente provechoso, sin contar con la pérdida de tiempo y dinero que una intervención superflua supone" ${ }^{249}$.

\subsubsection{Régimen de la acusación popular en la originaria LECrim}

I.

Examinando la originaria LECrim sin ninguno de sus añadidos posteriores, es posible constatar que la idea directriz que fundamentaba la presencia de tan gran apertura de la legitimación en el proceso penal era la incompatibilidad entre la acusación ejercitada por el MF y por un particular no ofendido. Su sentido originario era así la intercambiabilidad entre su ejercicio por uno u otro, pero nunca la actuación simultánea sobre el mismo objeto. Es indudable que cuando el art. 101 de la LECrim se refería a la acción penal como "pública" no lo hacía en el mismo sentido que lo hacían los demás códigos procesales de nuestro entorno. Mientras que en todos ellos, la caracterización como pública implicaba ya su consideración oficial, estatal o burocrática, en el nuestro, decir pública equivalía, a tenor del segundo párrafo del mismo art. 101, a decir que todos

\footnotetext{
${ }^{248}$ GONZÁLEZ DE ALBA, P., “El derecho de acusación...”, op. cit. p. 50.

${ }^{249}$ ALCALÁ-ZAMORA Y CASTILLO, N., "Lo que debe ser el Ministerio Público", en Estudios de Derecho Procesal, Madrid 1934, p. 20. Publicado originariamente en RGLJ, T. 155, nº 5, de noviembre. 1929, pp. 519 a 531.
} 
los ciudadanos españoles estaban habilitados para ejercitarla con arreglo a las prescripciones de la ley. Pero lo que no se decía en ningún momento es que esa distribución generalizada de la facultad de acusar fundamentase una libertad ilimitada para la iniciativa de la persecución penal y la participación en el proceso de los sujetos autorizados.

La interpretación en ese sentido se basa, cuando menos desde el siglo pasado, en unos presupuestos interpretativos de carácter liberal e individualista que, como consecuencia de una consolidada tradición histórica, consideraban la existencia de un derecho a acusar como cauce adecuado para la legítima defensa de un interés de todo ciudadano en tanto ofendido por la lesión social producida por el delito. A tenor de esa concepción, aquel derecho sería de carácter originario y previo a la ley y existiría siempre que ésta no lo prohibiera, lo cual, por otra parte, sólo sería admisible en presencia de intereses de naturaleza superior. Entendemos, no obstante, que a pesar del espíritu liberal que inspiró en su origen todo el texto de la LECrim, ni siquiera en la mente del legislador de 1882 se contemplaba la existencia de un derecho con la amplitud que hoy se le confiere en la práctica.

Sólo con posterioridad y sobre premisas no siempre acertadas, se ha llegado a abrir la legitimación para la intervención en el proceso de los no ofendidos de igual manera que se hace con las víctimas del delito, con la única excepción de ciertos requisitos formales (art. 280 LECrim). Lo que se diseñó entonces de forma ciertamente equívoca, al amparo de una manifiesta desconfianza en un MF aun no consolidado como defensor del interés público y con la firme voluntad de desterrar las manifestaciones inquisitivas del sistema, era un régimen en el que la posición activa para la exigencia del cumplimiento de la vindicta pública pudiera ser ocupada por un sujeto cualquiera y no sólo por un funcionario del Estado ${ }^{250}$. Pero lo que de ninguna manera se estaba diciendo era que ambos, oficial público y ciudadano común, pudieran ocupar simultáneamente tal posición, por la simple razón de que estaba claro que aquélla era una función única y que, una vez que alguien hubiese ejercitado la "acción penal para el castigo del culpable" (art. 100 LECrim), satisfaciendo con ello la pretensión de vindicta pública, no tenía sentido que nadie más lo

\footnotetext{
${ }^{250}$ Un ejemplo de esta concepción única de la acusación y su carácter público se encuentra en la Exposición de Motivos. Así, en relación con la igualdad de las partes en el juicio oral se nos dice que "están enfrente uno de otro, el ciudadano y el Estado. Sagrada es sin duda la causa de la sociedad, pero no lo son menos los derechos individuales".
} 
hiciera.

El legislador de la LECrim, firmemente sujeto a la doctrina romanista de las obligaciones $^{251}$, diseñó un marco en el que se reconocía la existencia de dos tipos de acciones diferentes cuyo destinatario era el autor del hecho criminal, encaminadas a la consecución de diversos fines: una para el castigo del culpable (la "acción penal") y otra para la restitución de la cosa, la reparación del daño o la indemnización (la "acción civil"). Pero además de esa distinción, la Ley lleva a cabo un reconocimiento implícito que no hacía falta poner al descubierto en cuanto era tan lógico y estaba tan ligado a los precedentes legislativos, que no cabía que fuera de otra manera: el diferente carácter que tiene la acción penal para el castigo del delito en los supuestos en que es ejercitada por el ofendido y la de aquellos en que lo es por cualquier otro sujeto, incluido el MF. En el primer caso, ideado como una vía de satisfacción personal de la venganza dentro del sistema, el castigo (o mejor, la condena) constituirá el fundamento de la reparación a la que el imputado estará obligado. De ahí que, aunque no sea del todo biensonante y quizá por eso no lo diga la ley, el lesionado por el delito tuviere un evidente y legítimo interés (privado) en la condena. En el segundo caso, lo que se defenderá con carácter primario es el interés (colectivo) en que se persiga el delito con el objeto de garantizar la paz social por la eventual satisfacción de la vindicta pública ${ }^{252}$. Sólo como consecuencia, si el ofendido no hubiera hecho uso de la reserva que la ley le reconoce (art. 108 LECrim), se satisfaría también el interés privado a través del ejercicio de la acción civil. Esa búsqueda del interés general determinaba que la ley estableciera la obligación al MF de ejercitar la acción pública “haya o no acusador particular" (art. 105 LECrim).

Sin entrar ahora en el análisis de su contenido, podría afirmarse que lo que nuestra LECrim llama "acción penal" servía a un doble interés, público y privado, dependiente del fin al que se dirigían los que la dedujeran. Al amparo de la originaria LECrim, cabía un ejercicio privado de la "acción penal" (acción penal privada) y un ejercicio público de

\footnotetext{
${ }^{251}$ La comisión del hecho delictivo se constituye como la obligación que genera las correspondientes acciones.

${ }^{252}$ Tal distinción fue intuida por los primeros comentaristas de la LECrim al advertir que "no toda acción popular es pública" y es también de la que se sirve GIMENO SENDRA para hablar de la diferencia entre "querella pública" y "querella privada": "no creemos que el carácter de la acción penal consagrado en el art. 270 LECrim sea en todo momento público; lo es solamente (...) cuando quienes la ejercitan es el Ministerio Fiscal o el ciudadano acusador público. Pero cuando el particular ofendido o su "sustituto" hacen uso del derecho cívico consagrado en dicho precepto, no hacen más que ejercitar una acción penal privada con las posibles corruptelas que ello pueda implicar". Vid. GIMENO SENDRA, V., La Querella, op. cit. pp. 59 y 85 y ss.
} 
la misma (acción penal pública) y la propia ley, aun sin decirlo, las considera implícitamente dos acciones diversas de las que se derivaban obligaciones diversas del acusado $^{253}$. Sólo la última y no la primera era la que podría ser ejercitada por el MF o por cualquier ciudadano, con la salvedad de que de ser éste el que interviniera y en prevención de su uso fraudulento, se le exigiría el depósito de una caución con el fin de estar a las resultas del juicio (art. 280 LECrim). Pero no podía caber nunca el ejercicio de dos acciones penales públicas diversas sobre los mismos hechos presuntamente delictivos porque éstos generaban una única obligación: la acción era, por tanto, única y una vez ejercitada no cabía su reiteración ${ }^{254}$.

La originaria LECrim admitía ciertamente el ejercicio de acciones penales o civiles por más de una persona, pero sólo cuando éstas fueran diferentes entre sí. Cuando la ley habla en plural de "las acciones", y lo hace con frecuencia, se refería primitivamente a tres hipótesis: a) las acciones privadas individuales contra el autor del delito de una pluralidad de ofendidos, los cuales tendrían cada uno una acción propia; b) las de alguno de éstos junto con la pública para la satisfacción del interés público (la que pueden deducir el MF o cualquier otro ciudadano); c) el supuesto de ejercicio de las acciones civil y penal por sujetos diversos. Dentro del diseño de la ley, la acción de cada ofendido era individual y le pertenecería sólo a él, pero la penal para la represión del delito era única y, aun cuando la facultad de ejercitarla correspondiera a todo ciudadano, no por ello perdía su unidad. El delito generará una sola "acción penal" (para su castigo) que, eso sí, podría ser ejercitada en interés público por los sujetos no excluidos por los arts. 101 y ss., pero a su vez generaba tantas otras acciones penales de interés privado como ofendidos hubiera producido. Mientras que acción pública sólo habrá una, que tendencialmente irá dirigida a un fin único sea quien sea el que la ejercite (posibilitar la eventual satisfacción a través del proceso de la vindicta pública), cada sujeto ofendido podría por contra deducir su acción penal propia, dirigida a la satisfacción de un interés privado no coincidente en todos ellos. Es decir, la Ley no estaba atribuyendo al ejercicio de la acción penal un carácter de derecho de contornos ilimitados, sino única y exclusivamente el de una

\footnotetext{
${ }^{253} \mathrm{La}$ distinción entre delitos privados y delitos públicos, se realiza sólo posteriormente a ésta y precisamente como consecuencia de ella.

${ }^{254}$ Bastaría con considerar el principio romanista de que cuando concurrieran varias acciones sobre la misma cosa, se deba demandar por una sóla (Quotiens concurrunt plures actiones eiusdem rei nomine, una quis experiri debet). Dig. 50, 17, 43, 1 (ULPIANO).
} 
facultad dirigida a la defensa de un interés, público en unos casos y privado en otros.

Centrándonos en el referido interés público, bastaría con que cualquier sujeto lo estuviera defendiendo para que el contenido de la acción quedara agotado, por lo que ciertamente todos los españoles podrían ejercitarla, pero sólo cuando no la hubiera deducido otro sujeto. Quienes hicieran valer aquel interés no ejercitarían acciones diferentes sino sólo la misma, por lo que admitir que el acusador popular pudiera concurrir simultáneamente con el MF, es decir, que pudiera ejercitar una acción diferente, significaría tanto como reconocer que estarían defendiendo intereses diversos. De ahí que parezca claro que una querella interpuesta por un ciudadano cualquiera cuando ya hubiera sido ejercitada la "acción penal" pudiera ser desestimada por el instructor simplemente por considerarla improcedente al amparo del art. 312 LECrim, sin necesidad de entrar en el análisis de su contenido para desestimarla aplicando el artículo siguiente.

Si la propia Ley hablaba del ejercicio por más de una persona de cada una de "las dos acciones" (la civil y la penal) imponiendo se verificasen en el mismo proceso $\mathrm{y}, \mathrm{si}$ fuere posible, bajo una misma dirección y representación a juicio del Tribunal (art. 113 LECrim) no parecía ser partidaria de la presencia de una pluralidad de intervinientes. Es más, de ello cabe inferir que, en determinadas hipótesis que no quedan legalmente identificadas, sino que se dejan a criterio del Tribunal, éste no podrá impedir el ejercicio de la acción penal por varios sujetos, pero sí obligar a que se sirvan de la misma dirección y representación. En el caso de la acción penal pública, contando con el dato de que el MF tiene que tener conocimiento de la incoación de cada sumario (art. 306 LECrim) y que además viene obligado a ejercitar "todas las acciones que considere procedentes, haya o no acusador particular en las causas" (art. 105 LECrim), la defensa y representación de los intereses que se dilucidan en el proceso podría perfectamente quedar encauzada a través de él. Si se previó la posibilidad de un ejercicio conjunto de la acción, en tanto lo que se perseguía era el mismo y único objeto ("el castigo del culpable"), mal estaría pensando el legislador en que, junto con el MF, pudiera haber un acusador que sólo persiguiera la vindicta pública. Entre las facultades del Juez entraría el determinar si se estaba en presencia o no de un interés específico que fundamentase la intervención independiente de un particular. Y éste sólo existiría cuando se defendiera una acción propia y específica diversa a la de los demás sujetos, pues cuando no existiera interés, tampoco podría haber acción.

Dado que el mecanismo clásico para la iniciación del proceso presente en nuestra 
tradición histórica previa a la vigencia del principio inquisitivo era la acusación, y el instrumento formal a través del que se instaba ésta y se adquiría la condición de acusador era la querella, la ley se refiere con los términos acusación/acusador y querella/querellante a la acción y al sujeto que la ejercita. Identifica así lo que era un conjunto de actos tendentes a la solicitud de una resolución jurisdiccional con el acto formal en el que comienza a ejercitarse. Pero la falta de consecuencia y la confusión terminológica que se ha achacado tantas veces al legislador ${ }^{255}$ no era en origen tal equivocación ya que para él, los conceptos de querellante, actor o acusador particulares o privados, eran términos sinónimos que se referían en todo caso al ejercitante privado de la acción penal. Abarcaban tanto los actos procesales de lo que hoy denominamos "actores privados" como los de los "acusadores particulares" o "acusadores populares", en cuanto para el legislador carecía de trascendencia el dato que hoy sirve para establecer estas diferencias $^{256}$. Las dos primeras denominaciones, formas de designar al sujeto cuya participación en el proceso no se dirigía a la satisfacción de un interés público sino a la de un interés privado cuyo fundamento radicaba en la afección directa por el hecho delictivo, quedan así entremezcladas y confundidas con la que hacía referencia a todos los demás ciudadanos que no fueran el MF.

A tenor de lo expuesto, como conclusión e intentando realizar una interpretación desde los postulados de la originaria mens legislatoris, podría en estos momentos describirse el régimen del ejercicio de las acciones derivadas del delito bajo las siguientes premisas:

1) Ejercitar la acción penal para el castigo de los delitos, es decir, acusar, era facultad de todos los ciudadanos de la que sólo podrían ser excluidos algunos: a) por razón de la persona acusadora, el que no gozara de los derechos civiles, el condenado dos veces por acusación o denuncia calumniosa y el Juez o Magistrado; b) por razón de la persona acusada, el que pretendiera acusar a sus parientes y c) por razón del delito, el que no hubiera sido ofendido en los delitos perseguibles sólo a instancia de éste.

2) El ofendido siempre podría ejercitar las dos acciones derivadas del delito para la satisfacción de sus intereses: la penal, que en este caso posee tintes privados y no tiene

\footnotetext{
${ }^{255}$ Vid. por todos GÓMEZ ORBANEJA, E., Comentarios..., op. cit. T. II, p. 243.

${ }^{256}$ Este dato consiste en si el ofendido es o no el único que puede ejercitar la acción penal, en el caso de la primera denominación, o si el acusador es o no ofendido en el caso de las dos últimas respectivamente.
} 
que ver sólo con la vindicta pública sino que va dirigida principalmente al aseguramiento de la satisfacción de sus legítimos derechos mediante la condena del culpable, y la civil derivada del delito. Es así defensor de un derecho privado propio que se intersecciona con el interés público.

3) El MF debía plantear acusación para satisfacer, en su caso, la vindicta pública, aunque el ofendido ya hubiera hecho valer en el proceso sus derechos que, aun siendo eminentemente privados, pueden coincidir con los públicos. El interés público en la persecución y, en su caso, castigo del delito tiene que quedar necesariamente satisfecho, a pesar de que el ofendido hubiera recibido ya la satisfacción que la ley le reconoce.

4) Cabe la posibilidad de que al proceso concurra una pluralidad de personas sosteniendo la acción penal, pero sólo cuando con ello se hicieran valer intereses diferentes, es decir, cuando el imputado estuviera obligado frente a ellos por conceptos distintos. En concreto eso puede ocurrir en dos ocasiones: en supuestos en los que se comparezca para la defensa de los diferentes intereses que la acción penal alberga en su interior (públicos y privados), o dada una pluralidad de intereses privados diversos y derivados del mismo hecho criminal (pluralidad de afectados o de beneficiarios del resarcimiento o la indemnización ex delicto).

5) La Ley pensaba en una acusación cuyo ejercicio por particulares no ofendidos sería alternativo al que pudiera realizar el MF, pero no podría en ningún caso ser concurrente con éste por la simple razón de que, por ir ambas actividades dirigidas a la defensa del mismo derecho, eran exactamente la misma cosa. Sin interés el ordenamiento jurídico no concede acción y en este caso el interés pudiera quedar satisfecho suficientemente por la actuación de un oficial encargado de su defensa.

II.

El papel teórico que la ley reconocía al ejercicio quivis ex populo de la acusación podría cifrarse, a nuestro juicio, únicamente en la defensa de aquel interés público al que hemos hecho referencia, el cual quedaría satisfecho una vez iniciado el procedimiento por virtud de la presencia de un acusador oficial. La Ley se movía siempre en el intento, a veces complicado, de conjugar la actuación del MF, la de posibles acusadores en los que concurra la condición de víctima y la de unos también posibles actores civiles, por lo que introducir en el proceso un sujeto privado más, articulando una pretensión distinta, no 
entraba dentro de sus previsiones. Por fuerza, la función de aquél tenía que terminar una vez instada la acción penal e iniciado el procedimiento, siempre y cuando la misma acción fuera ejercitada también por el Ministerio Público o éste se incorporara al proceso.

Esto es precisamente lo que dio pie a que, en un primer momento, el ejercicio popular de la acusación fuera interpretado por un sector de la doctrina como mera forma de iniciación del procedimiento, sin que en el resto de la LECrim se considerase para nada la intervención posterior de un ciudadano que, sin ser ofendido por el delito, acude al proceso de forma altruista en defensa del interés general. Según esta primera lectura, la acusación popular carecía de cauce de representación en el proceso, por lo que dado comienzo éste no contaría con capacidad independiente de actuación. El reconocimiento que la Ley hacía de la acción popular se limitaría a los momentos iniciales del proceso, pero a partir de ahí, no volvería a contemplarla expresamente en ningún otro momento. No se trataba sólo de que un actor popular no pudiera intervenir en el sumario cuando ya estuviera personado el MF, sino que ni siquiera se contemplaba momento procesal alguno para que realizara ningún otro acto procesal. Así por ejemplo, ni siquiera el acto acusatorio por excelencia en que consiste la calificación del delito contaba con una previsión expresa de ejercicio por un defensor privado del interés público: la causa se notificaría al fiscal, luego pasaría al acusador particular (que sólo podría ser quien ejercitara una acción distinta a la del fiscal) y de éste al actor civil, al procesado y a los civilmente responsables, sin que la Ley hiciera mención alguna sobre la intervención del ejercitante privado de la acusación pública $^{257}$. Y si no realizaban calificaciones provisionales, menos aún pensaba el legislador en la posibilidad de tener a un acusador extraño en el juicio oral, ya que ni rastro se puede encontrar en la norma que demuestre tal previsión ${ }^{258}$. La dicción del art. 101 en el sentido de que todos los ciudadanos españoles podrían "ejercitarla con arreglo a las prescripciones de la ley" se quedaba en

${ }^{257}$ Arts. 649 y ss. LECrim.

${ }^{258}$ Cuando la Ley hablaba de las "partes acusadoras" (art. 655 p. ej.) o de "los acusadores" (art. 680 p. ej.), se estaba refiriendo únicamente al fiscal y al acusador particular ofendido y cuando decía "partes" o "parte" a secas, lo hacía en relación bien con el MF, el acusador particular ofendido o el actor civil, bien con el acusado o el responsable civil. Incluso cuando se habla de varias calificaciones de querellantes particulares (p. ej. art. 689) ello debe entenderse bajo la premisa de la concurrencia al proceso de varios ofendidos por el delito. Aun cuando hay expresiones del tipo "el MF y las demás partes", "el MF y los demás actores (penal y civil)" (art. 701 y ss), en ningún momento se dice algo como "el Ministerio Fiscal y las demás partes acusadoras", simplemente porque ni siquiera se consideraba la existencia de una pluralidad de éstas a no ser en calidad de ofendidos o perjudicados por el delito. 
pura retórica puesto que la norma no prescribía nada de su ejercicio más que lo referido a la interposición de querella para su iniciación (art. 270 LECrim).

Los que accediesen al proceso sólo lo podrían hacer para la defensa de intereses o derechos diferentes y, si tales intereses se confunden en uno, como ocurre con los ejercitantes de la "acción penal" pública (MF y acusadores no agraviados), la acción es también única y la presencia de más de uno de ellos carecería de sentido. La atribución de la facultad de acusar no se encontraría activa permanentemente, sino que tendría vigencia sólo en tanto ningún otro sujeto privado se hubiera servido de su propio derecho a ejercitarla o el MF hubiera cumplido su deber, agotando así objetivamente en ambos casos su contenido. Puesto que al MF, vinculado a la legalidad y obligado por el art. 105 LECrim a ejercitar todas las acciones que considere procedentes, le competía la satisfacción de aquel interés, el ejercicio de la acción por el no agraviado sería más quimérico que real en la mayoría de $\operatorname{los} \operatorname{casos}^{259}$. Expresándolo de otra manera podría afirmarse que la acusación de los particulares se previó como facultad alternativa de intervención para supuestos en los que el MF se desvinculara de la obligación a la que le sometía el art. 105 LECrim.

Lo que se estaba reconociendo teóricamente con la previsión de una facultad de acusación generalizada no sería más que una retórica declaración de buenas intenciones, carente de toda eficacia práctica. Una manifestación programática de tales características alcanzaba una dimensión política incuestionable por su mera existencia, pero no porque el legislador pensara que en alguna ocasión iba a ser utilizada. Si bien no se prohibía el ejercicio de la acusación ni se limitaba expresamente más que en contadas ocasiones, lo cual habría acarreado la crítica de los sectores conservadores, tampoco era tomado en absoluto en consideración. La Ley afirmaba claramente que cualquier ciudadano podría interponer querella "ejercitando la acción popular establecida en el art. 101"260, pero una vez satisfecho ese trámite, en ningún momento vuelve a considerar la posibilidad de que

\footnotetext{
${ }^{259}$ Cabe recordar que ya el art. 838.8 de la LOPJ de 1870 establecía que le correspondía al MF “...ejercitar la acción pública en todas las causas criminales, sin más excepción que la de aquellas, que según las leyes, sólo pueden ser promovidas a instancia de parte agraviada" y que la Circular de la Fiscalía del TS de 2 de septiembre de 1884 reconocía que "lo que para los ciudadanos constituye un derecho, es deber ineludible del MF...".

${ }^{260}$ Art. 270 LECrim. Por si quedara alguna duda, el art. 280 dice que el particular querellante prestará fianza para responder de las resultas del juicio y el 281 excluye al ofendido, por lo que es claro que no sólo los ofendidos pueden ser querellantes.
} 
realmente una persona no agraviada pudiera en alguna ocasión tomar parte en el proceso. El no agraviado podría dar comienzo al proceso, pero ahí se acababa su función puesto que para el desempeño de tal tarea estaría el MF y no hay momento procesal alguno, una vez comenzado el proceso, en el que se previera la intervención de sujetos no ofendidos, y no se establece cauce alguno a través del que pudieran intervenir.

Todas las referencias al acusador privado se hacen en relación con aquél que, por ser ofendido por el delito, defiende un interés privado, lo cual es en principio ajeno a la naturaleza de la acusación popular. Cuando la ley se refiere a "particulares querellantes" se ha interpretado que estaría incluyendo teóricamente también a acusadores no ofendidos, pero en realidad, ni siquiera pensaba el legislador en que nadie osase usar tal facultad, por lo que todos los actos procesales en los que interviene un actor particular son supuestos de intervención de ofendidos ${ }^{261}$. Parece lógico pensar que, de lo contrario, en algún momento se hubiera debido establecer una prelación entre diversos acusadores privados, que en ningún caso se hace. El que el régimen de su intervención en el proceso se haya articulado posteriormente tomando como base la previsión que la ley hacía para todos los ejercitantes privados de la acusación, fuera ésta pública o privada, nos aporta ya una pista de la inexistencia de otros preceptos sobre los que sustentaran sus facultades de intervención.

Sólo a raíz de una interpretación jurisprudencial y doctrinal posterior, realizada al amparo de la imprecisión legal e imbuida de desconfianza hacia el MF, se consolidó la concepción de la acusación popular que se mantiene hasta hoy, según la cual la intervención en el proceso de ofendidos y no ofendidos queda equiparada, ya que todo ciudadano es víctima de la lesión social que el delito origina. Allí donde la ley se refiriera a un querellante, actor o acusador con el apelativo de particular o privado, se hizo entrar a todo sujeto particular que asumiera una posición acusadora en el proceso, aunque su "derecho" estuviera ya representado. El sujeto particular que interponía querella, fuera en la condición que fuera, quedó comprendido bajo los términos "actor particular" o "actor

\footnotetext{
${ }^{261}$ Es clara expresión de la identificación entre querellante particular y ofendido por el delito por ejemplo el art. 623 LECrim: el auto de conclusión del sumario se notifica al querellante particular si le hubiese "aun cuando sólo tenga el carácter de actor civil". Sería impensable un acusador no ofendido que tuviera sólo el carácter de actor civil. En el mismo sentido ha de interpretarse la mención a los herederos o representantes legales en los arts. 52.2, 276 y 854 LECrim: carecería de sentido el que un acusador particular interviniera en el proceso penal en calidad representante legal. Tampoco tendría sentido la intervención de un heredero si no es por la activación de una sucesión procesal de un ofendido por el delito. De lo contrario cabría entender que el sujeto pudiera ejercitar la correspondiente acción por sí mismo y no por su condición de heredero.
} 
privado", y sólo bien avanzado el siglo XX se consolidaron las denominaciones con las que hoy estamos familiarizados y que se dirigen a marcar las diferencias entre el acusador agraviado por el delito y quien no lo es.

De esta forma, los cauces de intervención que la ley había habilitado originariamente sólo para la defensa de intereses privados coincidentes parcialmente con los públicos (la acción penal privada), se abrieron a todos los sujetos legitimados. La acusación en su ejercicio por particulares se desvinculaba así de la sujeción estricta a la defensa de un interés público, el cual por otra parte podía ya estar suficientemente defendido, y se elevaba a categoría de derecho autónomo integrante de la esfera subjetiva de los individuos. Lo que en la LECrim hubiera podido ser interpretado como facultad justificable desde su contribución a la consecución de un fin público, adquiría así la dimensión de un derecho subjetivo frente al Estado, con independencia de su actividad procesal. De esta manera, y de soslayo, se estaba posibilitando de facto el que se hicieran valer intereses privados de los no ofendidos juntamente con el interés público que teóricamente motivaba su intervención. Las vías no explícitas pero sí ínsitas en la ley para la defensa procesal de la vindicta privada a través del ejercicio de la "acción penal", se abrían y trasferían del ámbito de los agraviados por el delito al de todos los demás ciudadanos, que en principio eran totalmente ajenos a ella. Se reconoció, en definitiva, en aquel momento el que un cauce de defensa de intereses privados podría ser válido también para la defensa del interés público, confundiendo el sentido de las aspiraciones de la Ley. De ahí que la intervención de los particulares en nuestra LECrim no pudiera ser interpretada como un progreso ni siquiera en el momento de su promulgación, sino como una institución conservadora que contribuía a perpetuar una visión civilista del proceso penal.

Dadas estas premisas, debemos plantearnos ahora por qué se produjo aquel radical cambio de opinión hasta equiparar a ofendidos y no ofendidos, habilitando la participación de éstos en una posición similar a la de aquéllos. ¿Cuáles fueron las razones de que el ejercitante de la acusación no ofendido, configurado en la LECrim como coadyuvante del MF para la iniciación del proceso, fuera asumiendo la posición de litisconsorte con éste a lo largo de todo su desarrollo?. Los factores que determinaron tal traslación, y que hoy precisan ser sometidos a una profunda revisión, se podrían cifrar en los siguientes aspectos:

a) Desconfianza profunda del legislador de la LECrim hacia un MF cuya posición 
en el proceso era la de un funcionario subrogado en el ejercicio de una facultad de los ciudadanos. Muestra de ello es la ordenación sistemática de los arts. 101 y 105 así como del 270 y el 271, con prevalencia de los primeros sobre los segundos respectivamente, a los que, además, engloban. La reacción contra las reminiscencias inquisitivas que pudieran percibirse en la actividad de un oficial encargado de la acusación originó la insuficiente consolidación del principio de oficialidad en la persecución, sin que se considerara que el principio de legalidad pudiera erigirse en garantía suficiente.

b) Aceptación de la intervención privada en el proceso penal en un momento en que los principios esenciales de éste estaban todavía en proceso de consolidación. Enmarcado en el espíritu de la época, el proceso penal era concebido sin problemas teóricos también como lugar para la defensa de intereses privados por cualquier sujeto, haciendo predominar el valor de la autonomía individual sobre cualquier otra serie de consideraciones. El ejercicio de la acusación por algún ciudadano era así una forma de vigilancia en la aplicación de la ley penal entendida ésta como instrumento al servicio de la ley civil, la de los propietarios. Con ella se cerraba el círculo de control en manos de las clases burguesas: la ley penal se realiza y promulga por un Parlamento elegido con la premisa del sufragio censitario, se aplica a través del jurado y tal aplicación no se cede al Estado con carácter de monopolio, ya que se podría instar la activación del proceso penal a través de "acción popular" (sujeta por otra parte a restricciones económicas que impedían su generalización).

c) Consideración de todo ciudadano como ofendido por todos los delitos bajo la premisa de una generalizada e idéntica afección por la infracción social en que el delito consiste $^{262}$. Irrumpen así elementos materiales en el proceso si se tiene en cuenta que el carácter de ofendido, vinculado necesariamente a un interés material, en tanto se refiere al titular de un bien jurídico específico tutelado por la norma penal, constituye el presupuesto habilitante de la intervención. Apuntalando una visión individualista del mundo se considera, a tenor de aquella clásica concepción procedente del Derecho Romano que, puesto que cada integrante de la comunidad es ofendido cuando se vulnera la ley penal, todo ciudadano tiene que tener derecho a defenderse frente al mal infligido.

\footnotetext{
${ }^{262}$ Destacaba GÓMEZ ORBANEJA que no habría nada en la ley que atribuyera un “derecho de ejercitar la acción penal" al ofendido o perjudicado por el hecho de serlo y "si suprimiéramos en LECrim 101 y 270 \& 1 (...) sin añadir nada, el ofendido por el delito quedaría tan despojado de la acción como el no ofendido". GÓMEZ ORBANEJA, E., Comentarios..., op. cit. T. II, pp. 181 y 225.
} 
La acusación no sería más que un derecho de defensa individual frente a las conductas criminales y ninguna autoridad estatal podría privar al ciudadano de tal facultad en cuanto su única misión consistiría precisamente en la garantía del ejercicio de los derechos ${ }^{263}$. El derecho de castigar se habría expropiado, pero no cabría hacer lo mismo con el de solicitar la imposición del castigo.

d) Numerus clausus en los motivos para la desestimación de una querella al amparo de una estricta aplicación del art. 313 LECrim y no de la más amplia permitida por el 312, en el que se habla de la procedencia como criterio de admisión de las querellas, sin que sea preciso un examen sobre su fundamentación para determinar si los hechos constituyen o no delito.

\subsubsection{Intentos posteriores de reforma}

A pesar de su larga tradición histórica, la permanencia de la acusación popular en nuestro sistema no ha estado nunca garantizada firmemente en el ordenamiento español. Su pervivencia, expuesta a vaivenes y tambaleos políticos, ha sido discutida o defendida con ocasión de las más variadas reformas y en diversos periodos históricos esgrimiendo para ello argumentos no siempre idénticos.

Ya desde los primeros momentos de existencia de la LECrim, en concreto en el Proyecto de reforma de VILLAVERDE (1891), se contempló la prohibición de doble representación o defensa en los casos de pluralidad de querellas sobre un mismo hecho, corrigiendo así la imprecisión de la ley a este respecto. En los delitos castigados con pena correccional, se promovería el juicio por escrito del fiscal o del ofendido, con lo que se excluía expresamente el ejercicio popular de la acusación ${ }^{264}$. Poco después, en una proposición de Ley de 23 de febrero de 1899 para reformar setenta artículos de la LECrim presentada por los diputados RUIZ JIMÉNEZ, ROMANONES y FRANCOS RODRÍGUEZ se mantenía, sin embargo, esa facultad de los particulares. La proposición contenía entre una variedad de propuestas de reforma, el que el ofrecimiento de la acción

\footnotetext{
${ }^{263}$ La característica fundamental a que debía responder el Estado liberal era precisamente el abstencionismo con respecto a las necesidades de la sociedad civil. Los derechos y libertades de los ciudadanos formarían parte de un estricto sistema de límites de no intervención estatal.

${ }^{264}$ COMISIÓN GENERAL DE CODIFICACIÓN, op. cit. p. 309.
} 
se realizara a cualquier persona en caso de petición de absolución por el acusador, con lo que se asumiría abiertamente el carácter subsidiario de la acusación ejercitada por cualquiera $^{265}$.

La acusación quivis ex populo para los delitos perseguibles de oficio se mantuvo en las Bases para la reforma de la LECrim según el Proyecto de Ley votado definitivamente por el Senado y propugnado por el Partido Conservador en julio de 1918 (Proyecto de Maura). Pero la Circular de la Fiscalía del TS de 11 de mayo de 1921 se refirió tangencialmente a ella, y no precisamente de forma demasiado positiva aseverando que "aunque no hemos quitado a la ación penal su carácter popular, es una verdad palmaria que cada día la señala la Ciencia, de acuerdo con la práctica, nuevos inconvenientes y sobre todo falta de eficacia" ${ }^{266}$.

Allí donde se utilizaba la acción popular penal o las facultades de acusación de los particulares se originaban manejos en los que el interés ciudadano por la persecución del delito no era siempre la motivación preponderante. Por ello en la Dictadura de Primo de Rivera y con la finalidad de evitar utilizaciones torticeras y colusiones fraudulentas, en lugar de modificarse la propia LECrim se dictó para su interpretación el Decreto de 13 de junio de 1927, relativo a normas para el ejercicio de las acciones penales a que se refiere el Tít. IV del Libro I de la LECrim. A su tenor, y para evitar simulaciones o fraudes por los que ejercitasen acciones penales, se posibilitaba su desistimiento en cualquier momento del proceso pero exigiendo que, mientras actuasen, lo hicieran exclusivamente en forma acusatoria y con tesis concretas ${ }^{267}$. Se imponía también la obligación de no limitarse a manifestar que se deseaba ser parte, sino que habría de expresarse categóricamente cual era la acción ejercitada, haciéndolo en forma de querella (art. 2). Para ello se exigían los requisitos del art. 277 LECrim, salvo el $6^{\circ}$ en lo que se

\footnotetext{
${ }^{265}$ COMISIÓN GENERAL DE CODIFICACIÓN, op. cit. p. 324.

${ }^{266}$ Nuevo Diccionario Aranzadi de Legislación, $\mathrm{n}^{\circ} 424$.

${ }^{267}$ El Decreto fue dictado probablemente a raíz del entonces reciente caso de la acusación popular ejercitada en favor del reo en el asunto del torero "Nacional II" y en el que precisamente se utilizó la acusación popular curiosamente con el objetivo de defender al imputado. El decreto, publicado el 14 de junio, se dirige principalmente a las acciones ejercitadas por ofendidos o perjudicados por la infracción penal, pero incluye también a aquellos otros que ejerciten la denominada acción pública. Vid. ALCUBILLA, Apéndice de Legislación 1927, p. 183. A pesar de que su existencia fue hecha valer durante mucho tiempo, este decreto fue derogado por el art. 1 del decreto de 31 de mayo de 1931 sobre revisión de la obra legislativa de la dictadura.
} 
refiere a la petición de la admisión sustituido por la petición de la admisión como parte acusadora en el concepto concreto que manifieste el solicitante en relación con la acción ejercitada. Con ello se venía a equiparar la admisión de la querella con la aceptación en calidad de parte acusadora del que pretendiera el ejercicio de acciones penales. En el art. 4 se concretaba la obligación de formular conclusiones exclusivamente acusatorias para el ejercitante de acciones penales que hubiera solicitado la apertura del juicio oral o sido admitido como parte después de haberse abierto el juicio oral pero antes de la calificación, otorgando el valor de desistimiento a la formulación de conclusiones absolutorias ${ }^{268}$. Para reprimir cualquier intento de avenencia o acuerdo entre acusador y acusado, motivado por el ánimo de lucro u otro provecho en el primero, a cambio de desistir en el ejercicio de las acciones o de atenuarlo, se hacían equivalente este tipo de conductas a las del delito de chantaje, imponiéndose la pena a él correspondiente ${ }^{269}$.

Poco después, sin embargo, en el Anteproyecto de Bases para la Reforma del Procedimiento Penal de la Comisión Reorganizadora de la Administración de Justicia (tercera ponencia) de 1929, (Base $3^{\text {a }}$ ) se aceptaba la acusación del no perjudicado por el delito sólo con carácter supletorio o subsidiario en el caso de que el MF o las demás personas a quienes correspondía su ejercicio (ofendidos o perjudicados por la infracción, cónyuge, padres o hijos de éstos y demás personas a quien se hubiera conferido tal derecho por disposición legal) hubieran solicitado el sobreseimiento o la absolución. En contra de la acusación popular, aun con carácter subsidiario, se pronunciaron los votos particulares de GALLARDO y LONGUÉ ${ }^{270}$.

El cambio de dirección vino representado por el Proyecto de Ley de Bases para la Reforma del Procedimiento Penal de 1929 en el que GALLARDO y LONGUÉ propusieron la abolición total de la acusación popular por ser en realidad subterfugio de la defensa del inculpado. En contra se situaba la opinión de ELOLA quien se opuso

\footnotetext{
${ }^{268} \mathrm{Si}$ solicitase el acusador la absolución en el acto del juicio oral se le tendrá igualmente por desistido y su representación y defensa deberán retirarse de la Sala donde la vista se celebre (art. 4, $2^{\circ}$ párrafo).

${ }^{269}$ Contiene el art. 6 una remisión al R.D. Ley de 21 de febrero (publicado el 23) de reforma del Código Penal en materia de punición de estafas y delito de chantaje. Esta norma incluía ya como conducta susceptible de ser calificada de delito de chantaje la amenaza directa de querellarse con el objeto de obtener lucro (art. $5.3^{\circ}$ ) y preveía pena de presidio correccional y multa para este supuesto.

${ }^{270}$ GÓMEZ ORBANEJA, Comentarios a la Ley de Enjuiciamiento Criminal, Barcelona 1951, T. II. vol. I, p. 235 , que se remite a la p. 74 de la edición oficial.
} 
aduciendo su raigambre democrática, sus precedentes históricos, "sin que además signifique entorpecimiento alguno para la sanción penal siquiera tenga ésta por fundamento el criterio clásico de la responsabilidad moral del delincuente que no está conforme en buenos principios de política criminal, aunque tenga que acatar el régimen vigente en obediencia al estado actual de nuestra legislación...". Prevaleció en el texto la solución ecléctica propugnada por el Presidente y por BUFORN, que es la que se llevó a la Base 10 y que condicionaba el ejercicio popular de la acusación al depósito previo de la caución o fianza que señalare el Tribunal ${ }^{271}$.

En la Constitución republicana de 1931 sólo encontramos una referencia tangencial a la acusación popular. Se halla contenida en el art. $29.5^{\circ}$, incardinado entre las "Garantías individuales y políticas" del Capítulo I, Título III, y preveía que la acción para perseguir los delitos de detención y prisión ilegal sería pública y sin necesidad de prestar fianza ni caución de ningún género ${ }^{272}$. Pero en la Base $1^{\text {a }}$ del anteproyecto de Bases discutido por la Comisión Jurídica Asesora en 1932 se dice que "se suprimirá la acción popular salvo en los casos en que una Ley especial disponga otra cosa, dando para lo futuro al art. 270 de la actual ley la siguiente redacción: Todos los ciudadanos españoles que hayan sido directa o indirectamente perjudicados por la infracción penal, jamás los que esta condición no tengan, podrán ejercitar la acción penal, salvo lo que en las leyes especiales se declare", lo cual se ajustaba a las opiniones formuladas con anterioridad por LONGUÉ.

El siguiente paso en la discusión sobre la acusación popular, orientado desde una óptica política radicalmente diferente e iniciador de un absoluto cambio de rumbo político fue el Anteproyecto de Ley de Enjuiciamiento Criminal por la Delegación Nacional de Justicia y Derecho de Falange Española Tradicionalista y de las JONS de 1938. En éste se situaba al juez en el papel de árbitro de la cuestión penal entre, por una parte, el interés social representado por el Ministerio Público, quien se encargaría de la instrucción y acusación, y por otra la libertad individual del acusado. En consonancia con la tendencia autoritaria del sistema que se pretendía instaurar, y no muy alejado de las contemporáneas

\footnotetext{
${ }^{271}$ COMISIÓN GENERAL DE CODIFICACIÓN, op. cit. p. 341. Debemos reseñar también la previsión de una acción popular específica en la base 30 para la exigencia de la responsabilidad criminal de jueces y fiscales, haciendo revivir el espíritu de la Constitución de 1812 y su reflejo en la LOPJ de 1870.

${ }^{272}$ Otro ejemplo de acción popular si bien no penal, sino constitucional podía ser considerada la legitimación abierta para el recurso ante en Tribunal de Garantías Constitucionales.
} 
orientaciones del mismo signo en Alemania e Italia, la participación de los ciudadanos en el proceso penal sólo tenía sentido en la medida que reforzara el carácter imbuido de estatalismo que reinaba en la persecución del delito. El no reconocimiento de la facultad de acusar no se basó por consiguiente en criterios técnicos sino políticos. Aunque tal intento no culminó con éxito, las Bases para la reforma de la LECrim según el Anteproyecto redactado por la Comisión de Codificación del Ministerio de Justicia en 1942 contenían referencias explícitas que limitaban la acusación popular (Base $5^{\text {a }}$ : "Ejercicio facultativo de las acciones penales"). Cuando no fuera necesaria querella de persona determinada, las acciones penales podrían ser ejercitadas sólo por los ofendidos o perjudicados, por su cónyuge, padres e hijos o por sus herederos y sólo en último lugar por aquéllos a quienes una disposición legal confiriera tal derecho. Acción popular como tal existiría únicamente para exigir responsabilidad a Jueces y Magistrados y, señaladamente, a los funcionarios públicos por delitos cometidos en el ejercicio de sus funciones ${ }^{273}$. El borrador de la exposición al Ministro en el proyecto de Ley de Bases traslucía la falta de simpatía que la acción popular tenía para los vocales de la Comisión de Codificación, para los que el Fiscal debería contar con un "preeminente rango en la contienda penal'. Por ello se intentó limitarla únicamente y en principio a la petición de responsabilidad criminal de los Jueces, Magistrados y funcionarios fiscales, y con posterioridad a eliminarla directamente del texto ${ }^{274}$. De ahí que en la Base $3^{\text {a }}$ del Proyecto de Ley de Bases para la Reforma de la Ley de Enjuiciamiento Criminal elevada al Gobierno por AUNÓS en 1945, y que no alcanzó mayor desarrollo, se suprimiera la acusación popular salvo lo que dispusieren leyes especiales.

La opinión doctrinal del momento tampoco se mostraba favorable a su mantenimiento. Afirmaba VIADA que "el querellante, en pura teoría, no tiene razón de ser, ya que existe el Fiscal, que, como órgano del Estado, debe velar por la efectividad de la acción y debe tenerse suficiente confianza en el mismo. En la práctica, su existencia tiene como inconveniente la desigualdad citada (en la posición entre imputado y querellado), que es un arma para coacción para transacciones, y la supresión de pleitos al amparo, generalmente, de lo dispuesto en el art. 514 de la LEC. Los fiscales, en vez de tener estímulo con su presencia, como se alega, suelen, por el contrario, descansar en

\footnotetext{
${ }^{273}$ GÓMEZ ORBANEJA, Comentarios..., op. cit., p. 235.

${ }^{274}$ COMISIÓN GENERAL DE CODIFICACIÓN, op. cit. pp. 364 y 367.
} 
ellos. Por ello al querellante sólo debía reservársele el ejercicio de la acción civil, pero no la criminal, excepto en los procesos por delitos privados"275. JIMÉNEZ ASENJO propugnaba también el monopolio del Ministerio Fiscal, que únicamente habría de quebrar en favor del perjudicado en los delitos menores ${ }^{276}$. ZAFRA consideraba injustificable la existencia de acción penal popular en nuestro ordenamiento, ni aun siquiera con carácter subsidiario, por el peligro de que fueran móviles egoístas los que motivaran a actuar a los acusadores. Ello por sí sólo la descalificaría para constituirse en elemento de control de los órganos de persecución oficial, pero habría de añadírsele además el desuso prácticamente absoluto en que se encontraba.

En favor de la acusación popular se pronunciaba, sin embargo, FERNÁNDEZ MONTES, basando su defensa en el reconocimiento de un derecho de acusar al ciudadano que no podría restringirse ${ }^{277}$.

El Anteproyecto de Código Procesal Penal de 1962 elaborado por la Comisión General de Codificación supuso un nuevo intento de desgajar definitivamente de nuestro sistema la acusación popular ${ }^{278}$. En la base $10^{\mathrm{a}}$, referida a la instrucción judicial preliminar, se decía que el juez podría iniciarla de oficio, pero normalmente dicha fase se iniciaría por querella del MF o de los legitimados para el ejercicio de la acción penal, que no podrían ser sujetos no ofendidos por el delito.

La consolidación de la acusación popular en términos no absolutos pero sí muy

${ }^{275}$ VIADA LÓPEZ-PUIGCERVER, C., "Notas sobre la necesidad de reforma de la Ley de Enjuiciamiento Criminal (fase instructoria)", RGLJ, T. 187, 1950, pp. 339 y s.

${ }^{276}$ JIMÉNEZ ASENJO, E., “Orientaciones para la reforma de la LECrim”, RDProc. 1952, p. 87. Lo peculiar es que el autor dice construir su sistema "sobre las bases fundamentales del sistema de acusación y contradicción clásicos en nuestra LECrim". Parece claro que o bien la acusación popular no era considerada una de las bases del sistema acusatorio o que su presencia, en tanto rara avis procesal le pasaba desapercibida. Vid. también JIMÉNEZ ASENJO, E., Derecho Procesal Penal, Madrid s.f. pp. 147 y ss.

${ }^{277}$ Boletín Informativo del Instituto español de Derecho Procesal, nº 93, mayo 1960.

${ }^{278}$ VIADA dio en octubre de 1962 una nueva redacción al proyecto de bases con vista de los informes y dictámenes reunidos. Pero con anterioridad, concretamente en 1960, VIADA se había manifestado en favor de la pervivencia de la acción popular solamente como "pieza de museo" o como "producto para la exportación", justificando únicamente su mantenimiento en "razones de orden político" sin especificar de qué alcance. VIADA LÓPEZ-PUIGCERVER, C., "Orientaciones y líneas generales de la Reforma del Proceso Penal en España". Conferencia pronunciada ante el Ilustre Colegio de Abogados de La Coruña el 6 de septiembre de 1960 citada por ZAFRA, J., "Posición del Ministerio Fiscal en el futuro proceso penal”, RDProc. 1961, n 4, pp. 769 y 796. 
amplios se pretendió certificar en el Anteproyecto de Bases para el Código Procesal Penal de 1967 (Base 18), reconociéndola en los siguientes términos: "Se mantendrá la acusación popular conforme al régimen vigente". Su actuación se limitaría en la instrucción a solicitar la constatación de los hechos y la adopción de medidas cautelares, y en el juicio oral a formular acusación ${ }^{279}$. En la opinión que FAIRÉN manifestó al respecto, la acusación popular debería tener un carácter subsidiario que completara o supliera la inacción del MF, pero a la vez que hiciera imposibles las exageraciones a que se prestaba el sistema entonces vigente. Una vez fijado el principio de subsidiariedad de la "acción pública" -que identifica con "acción popular"-, ésta precisaría ser conectada, desde su inicio, con la ulterior acusación formal del particular a través de un juicio de acusación, situado al final de la instrucción, mediante el que el Juez pudiera valorar la constatación de los hechos en que se base la querella. El mantenimiento de la acción penal popular debería, para FAIRÉN, significar un incremento en la contradictoriedad de la instrucción, a fin de evitar la desigualdad de las partes ${ }^{280}$.

\footnotetext{
${ }^{279}$ El Anteproyecto fue publicado en la RDProc. 1968 , pp. 710 y ss.

${ }^{280}$ Vid. FAIRÉN GUILLÉN, V., Presente y futuro del proceso penal español (El "Anteproyecto de Bases para el Código procesal penal" de 1967; la Ley de 8 de abril de 1967), Valencia 1967, pp. 48 y s., aun cuando posteriormente, a la vista de la necesidad de rígidos controles sobre el MF, FAIRÉN defienda la acción popular en toda su plenitud y no sólo con el carácter subsidiario que aquí le otorgaba.
} 



\section{LA DISCUSIÓN HISTÓRICA SOBRE LA ACUSACIÓN POPULAR EN EL DERECHO COMPARADO}

Aun conscientes de la diferencia conceptual entre los principios y valores propugnados por los autores decimonónicos en relación con los manejados más de un siglo después, el análisis histórico de las discusiones en torno a los cauces de participación de los particulares en la persecución penal, se presenta revelador de una notabilísima semejanza entre aquellas aspiraciones y muchas de las que hoy día son moneda común. La discusión sobre quiénes deberían ser las personas competentes para acusar fue una de las materias sobre las que se virtieron opiniones más controvertidas durante el periodo de elaboración de los primeros códigos procesales penales en la Europa del siglo XIX. Se trataba de una cuestión muy polémica puesto que la naturaleza claramente política de una función que ya se consideraba de carácter público, hacía que el tema se suscitara una y otra vez en la elaboración de los textos procesales. Más pronto o más tarde, con mayor o menor intensidad, el debate se produjo en todos los paises europeos que acometieron la tarea de redactar un código procesal penal, haciéndose valer similares argumentos bien para rebatir, bien para defender la participación de los particulares en la persecución del delito. Tales razones son, en muchos casos, las mismas que aún hoy se siguen utilizando al abordar el tema de la acusación popular, por lo cual conviene hacer un repaso histórico que desempolve algunas de aquellas viejas discusiones que, en no pocas ocasiones, serían suscribibles por la doctrina de nuestros días. Se pretenderá, además, buscar las claves determinantes de su completa erradicación de otros sistemas procesales, cuando la base histórica sobre la que se asentaba el derecho continental era la misma, en tanto enraizada en la recepción romano-canónica.

En el tránsito entre el proceso inquisitivo y uno de corte acusatorio, salía a la luz una y otra vez el pronunciamiento de THOURET frente a la Asamblea revolucionaria francesa en 1790 al responder la cuestión de si las acusaciones públicas deberían ser populares o la facultad de promoverlas debía delegarse en un funcionario público. Decía THOURET que "cuando todos toman el encargo de velar, llega un momento en que nadie vela; y cuando todos pueden acusar, el espiritu de partido, las preocupaciones vulgares, los resentimientos individuales, pueden fácilmente turbar la tranquilidad 
pública bajo el pretexto de asegurarla"281. Pero la desconfianza en un órgano público que monopolizara el ejercicio de la acusación era tan intensa al calor de la ideología liberal y con base en el recelo hacia el proceso inquisitivo hasta entonces vigente, que se trató de garantizar a toda costa una libertad que se entroncaba con la personalidad humana: la acusar para defenderse contra la ofensa social en que el delito consiste.

El espíritu romántico, reivindicativo de épocas pasadas y anhelante de reformas garantizadoras de las libertades individuales, afloraba en cada ocasión que el tema era objeto de polémica. De esta manera, el tema de las formas de acusación, la distinción entre la mera denuncia y el ejercicio de ésta, la participación de particulares en el proceso penal y, específicamente la acusación popular, trajo su origen del apasionado debate de la doctrina romanista de mediados del siglo pasado sobre la naturaleza jurídica de las acciones populares romanas ${ }^{282}$.

\subsection{Modelos precedentes de referencia}

Con la intención de criticar el sistema inquisitivo y secreto entonces imperante, advertía FILANGIERI a finales del siglo XVIII que todas las legislaciones antiguas examinadas por él contemplaban el derecho y la libertad de acusar de todos los ciudadanos en la mayor parte de las ofensas junto con las garantías frente a la acusación calumniosa ${ }^{283}$. Tal constatación era cierta, pues todas ellas tenían un origen común de base romanista. Analizaremos en este sentido cuáles eran los modelos precedentes sobre los que se estableció la controvesia en torno a la acusación popular en la Europa decimonónica.

\subsubsection{Francia}

El Ministerio Fiscal es, por origen, una institución netamente francesa, procedente de su antiguo Derecho y modulada de forma característica durante el periodo

\footnotetext{
${ }^{281}$ Reseñado entre otros por SILVELA, F., "La Acción Popular", op. cit. p. 470 y por GARRAUD, R., Traité théorique et pratique d'instruction criminelle et de Procédure Pénale, T. I, p. 161.

${ }^{282}$ Sobre este debate vid. COSTA, E. "Nota a proposito di alcuni recenti studi sulle azioni popolare romane", Rivista italiana di scienze giuridiche, 11 (1891), pp. 360 y ss.

${ }^{283}$ FILANGIERI, C., Ciencia de la Legislación, op. cit. p. 26.
} 
revolucionario $^{284}$. La acción popular era contemplada en Francia, por el contrario, como una institución ajena a sus costumbres y a su carácter, habituado a reclamar la intervención del Estado como garante de la seguridad y protección ${ }^{285}$. Los temores que en otros lugares se hicieron valer como oposición a la figura del MF apenas fueron motivo de discusión en Francia, y parecía claro que asustaba menos la idea de conferir la persecución de los delitos "a 300 funcionarios que a 3 millones de personas" ${ }^{286}$. No por ello el MF ostentó siempre el monopolio de la iniciativa penal, el cual no se vió confirmado hasta mediados del siglo pasado, y la actividad de los particulares fue durante largo tiempo determinante en la persecución del delito ${ }^{287}$.

Históricamente la acusación de parte privada era una de las formas de iniciación del procedimiento y llevaba aparejada la pena de talión para el acusador que no

${ }^{284}$ ESMEIN, A., Histoire de la Procédure Criminelle en France et spécialement de la procédure inquisitoire depuis le XIII siècle jusqu'à nos jours, París 1882, (Reedición, Francfort 1969), pp. 100 y ss. y 417 y ss. Ya MONTESQUIEU había resaltado las virtudes del Ministerio Fiscal, calificando de "ley admirable" la que lo instituía frente a la presencia de los delatores como especie indeseable. MONTESQUIEU, "De las acusaciones en los distintos gobiernos” en El Espíritu de las Leyes, L. VI, Cap. VIII, Tecnos, Madrid 1972, p. 103: “En Roma (...) se vió aparecer un tipo de individuos funestos, un ejército de delatores. Cualquiera que tuviese vicios y talentos, un alma baja y un espíritu ambicioso, buscaba a un delincuente cuya condena pudiera agradar al príncipe; este era el camino que llevaba a los honores y a la fortuna, cosa que no sucede entre nosotros. Tenemos en nuestros días una ley admirable: es aquella que dispone que el príncipe, instituido para hacer cumplir las leyes, proponga un fiscal en cada tribunal, para perseguir en su nombre todos los delitos, de manera que la función del delator es desconocida entre nosotros. (...) La acusación pública vela por los ciudadanos; ella actúa y éstos están tranquilos". El argumento es recogido también por el marqués de BECCARIA en su obra De los Delitos y las Penas (cap. XV) para contraponer el gobierno republicano al monárquico: "es un excelente establecimiento destinar comisarios que en nombre público acusen a los infractores de las leyes". BECCARIA defiende la aplicación del Talión para los calumniadores, imponiéndoles la misma pena que le correspondería al acusado.

${ }^{285}$ MERLE, P., Droit de Poursuite des particuliers (en matière d'Infraction à la loi pénale), Toulouse 1906, p. 162.

${ }^{286}$ Vid. ESMEIN, A., Histoire de la Procédure Criminelle..., op. cit. p. 456 citando a Gillet: "asusta la idea de conferir en el futuro la acción y la persecución de los delitos a 300 funcionarios y no nos asustamos de que en el presente esa acción exista en manos de 3 millones de hombres".

${ }^{287}$ Es digno de reseñarse que, aun cuando por razones técnicas y sobre todo ideológicas o políticas, el MF había sido configurado desde la época del Consulado y de Bonaparte como una institución jerarquizada, autoritaria y subordinada a la Cancillería, no se le atribuía sin embargo de manera rígida el monopolio de la acusación penal. Los particulares mantuvieron su posibilidad de mostrarse parte civil y determinados departamentos de la Administración (aguas, bosques, aduanas) siguieron teniendo un importante papel activo en la persecución de los delitos cometidos en relación con su ámbito competencial. GARRAUD, R., Traité..., op. cit., pp. 198 y ss., SCHNAPPER, B., "L'Action pénale, le ministère public et les associations: naissance et contestation d'un quasi-monopole (XIX-XX siecles)", Travaux du XXIII Congrès de l'Association française de criminologie, organisé par la'Association française de criminologie et par le Centre de recherches de politique criminelle (París, 17 y 18 de octubre de 1986), publicado en Archives de Politique Criminelle $\mathrm{n}^{\circ}$ 10, 1988. pp. 21 y s. 
demostrara la culpabilidad del reo. Por el grave riesgo que acarreaba, desde el siglo XIV desaparece prácticamente, ocupando su lugar la mera denuncia que da lugar a procedimiento de oficio ${ }^{288}$. En el siglo XVI, la acusación de los particulares era ya desconocida en la práctica y la iniciación del procedimiento penal estaba por una parte en manos de oficiales públicos (procureur du roi) defensores de la res publica, y por otra en manos de los que demandaran la reparación de su interés civil afectado ${ }^{289}$. Si bien la parte pública tenía siempre preeminencia frente a la privada, la iniciativa de la persecución penal estaba en gran medida asumida por los interesados, ya fuera la víctima, sus parientes o sus conciudadanos, pero en calidad de actor civil. La presión jurídica y financiera a que se sometía a los parientes para actuar como parte civil en el proceso era tan fuerte que la no persecución del delito conllevaba determinadas sanciones a quien no la asumiera ${ }^{290}$. De esta manera, la constitución en parte civil del afectado por el delito llegó a ser una mezcla de las antiguas acusación formal de parte y denuncia de parte ofendida y adoptó un papel que, yendo más allá del de la mera instigación del proceso a través de la denuncia, no llegaba a asumir las responsabilidades subsiguientes a la acusación $^{291}$.

Con la Revolución, el papel que se confiere a los oficiales públicos de toda naturaleza cambia de consideración. La aversión popular hacia la Magistratura hizo que se despojara al Ministerio Público de todas las funciones políticas y administrativas extraprocesales que venía desempeñando, para atribuirle la sóla función acusatoria en nombre de la comunidad ${ }^{292}$. Desde la Ley de 16 y 29 de septiembre de 1791 la acción de los particulares aparece como una suerte de acusación subsidiaria, caracterizada como exótica imitación de las costumbres inglesas, pero se hace desaparecer toda forma de

\footnotetext{
${ }^{288}$ El papel del mero denunciante en el proceso penal medieval francés puede verse en ESMEIN, op. cit. pp. 109 y ss., si bien su análisis excede de los límites de nuestro estudio. En opinión que GARRAUD sostiene en concordancia con textos de la época, el derecho de acusación estaba reservado exclusivamente a la parte lesionada por el delito y en caso de homicidio, a sus parientes. GARRAUD, R., Traité..., op. cit., p. 43.

${ }^{289}$ ESMEIN, A., Histoire de la Procédure Criminelle..., op. cit. p. 133.

${ }^{290}$ SCHNAPPER relata que no asumir la partie civile para la "venganza" del asesino del marido o el padre era causa de indignidad para la viuda o los hijos en relación con los derechos sucesorios. Se daba así rienda a lo que este autor caracteriza como "espiritu de venganza o de solidaridad". SCHNAPPER, B., "L'Action pénale...", pp. 19 y ss.

${ }^{291}$ ESMEIN, A., Histoire de la Procédure Criminelle..., op. cit. p. 134.

${ }^{292}$ MOLINARI, F., "Pubblico ministero e azione penale nell'ordinamento francese” en CONSO, G., Pubblico Ministero e accusa penale, Bolonia 1979, p. 213.
} 
acusación popular. La parte lesionada, nunca el no ofendido, podía poner en movimiento el proceso penal, pero será el acusador público, funcionario o persona comisionada por los municipios ante los tribunales de policía correccional, quien la mantuviera ante el jurado $^{293}$. Es en el Code des délits et des peines de 3 de Brumario del año IV (arts. 5 y 6 ) donde se realiza la distinción que permanece vigente en el ordenamiento francés entre una acción pública, que tiene por objeto punir las infracciones y que "pertenece esencialmente al pueblo", y una acción civil cuyo objeto es la reparación del daño y que "pertenece a quien hubiere sufrido el daño". Con la atribución del ejercicio de la primera a funcionarios públicos como representantes o delegados de la colectividad afectada, germen de la reconstitución del Ministerio Público, se consagró la desaparición de todo vestigio de acción popular o de participación del no ofendido por el delito ${ }^{294}$ y se reafirmó la identificación del concepto de "lo público" con lo correspondiente a la esfera estatal $^{295}$. La acusación no era discrecional puesto que el control de la fundamentación de los cargos solicitados se realizaba a través del Jurado de acusación (Jury d'accusation) ${ }^{296}$, verdadero filtro sobre lo actuado por el acusador.

Ni el Code d'instruction criminelle de 1808 ni las posteriores reformas de éste, modificaron sustancialmente, en lo que a nuestro tema respecta, el sistema de iniciación del procedimiento penal. El MF estaba ya firmemente asentado y no se cuestionaba la necesidad de abrir el proceso a otros acusadores por los peligros que ello acarrearía ${ }^{297}$. La acusación popular seguía siendo algo totalmente extraño a la mentalidad jurídica francesa y la doctrina de la época sólo se ocupó de ella para poner al descubierto todos los males

${ }^{293}$ GARRAUD, R., Traité..., op. cit., pp. 152 y s. No entramos a analizar el papel del «plaignant» (demandante) asimilado a la parte civil, quien sí mantuvo un papel activo en el proceso limitado en gran medida a las pretensiones de naturaleza civil. Al respecto vid. SCHNAPPER, B., “L'Action pénale...”, op. cit. p. 21.

${ }^{294}$ Dejando a un lado la "denuncia cívica”, posibilidad que en todo momento permanece vigente.

${ }^{295}$ ESMEIN, A., Histoire de la Procédure Criminelle..., op. cit. p. 443. GARRAUD llega a contraponer los sistemas de acusación pública (monopolio del ministerio fiscal) con los de acusación popular, mientras que en nuestro país ambas denominaciones se consideran idénticas: la acción es pública porque es popular. GARRAUD, R., Traité..., op. cit., p. 164.

${ }^{296}$ Art. 219 y 220 Código de Brumario.

${ }^{297}$ En la exposición de motivos de la Ley de reforma del Código de 1808 se reconoce textualmente en 1880 que "L'Institution du ministére public est louée hautement, et l'on signale avec énergie les dangers que présente l'accusation populaire". Journal officiel du 14 janvier 1880, p. 303, col. 1, cit. por ESMEIN, A., Histoire de la Procédure Criminelle..., op. cit. p. 581. 
que llevaría consigo su instauración: al ser algo ajeno al carácter francés sólo estaría al servicio de la especulación y de las más bajas pasiones ${ }^{298}$. El sistema de acusación exclusiva por funcionarios públicos ya había sido por tanto fijado y el acusador popular no era más que un indeseable símbolo de un modelo extraño. Todo ello determina que la discusión de la intervención de los particulares en el ejercicio de la acusación no fuera tan viva como la que tuvo lugar a lo largo de todo el siglo XIX en Alemania y en Italia.

\subsubsection{Alemania}

El antiguo proceso germánico para el castigo de los delitos era básicamente de instancia privada y en él toda la actividad necesaria para llegar al veredicto, y no sólo la acusación, se confería íntegramente a la iniciativa de particulares ${ }^{299}$. El delito era percibido como un ataque directo contra el ofendido, contra su grupo familiar (Sippe) o contra su tribu (Stamm) y eran ellos, fundamentalmente, los encargados de hacer valer sus intereses perjudicados. Aun así no estaba excluida la posibilidad de que cualquier persona pudiera constituirse en acusador y la institución de la acusación popular puede ser considerada común a los diferentes pueblos germánicos durante la Edad Media ${ }^{300}$.

${ }^{298}$ Vid. p. ej. MERLE, P., Droit de Poursuite..., op. cit. p. 162.

${ }^{299}$ Para una introducción histórica al proceso penal alemán puede verse ROXIN, C., Strafverfahrensrecht, $22^{\mathrm{a}}$ edición, Munich 1991, pp. 433-453; RÜPING, H., Grundriß der Strafrechtsgeschichte, Munich 1981, pero sin referencia alguna a la acción popular. Un clásico de obligada referencia es la obra de SCHMIDT, Eberhardt, Einführung in die Geschichte der deutschen Strafrechtpflege, $3^{\mathrm{a}}$ edición, Göttingen 1965. En español puede verse GÓMEZ COLOMER, J.L., El proceso penal alemán. Introducción y normas básicas, Barcelona 1985, pp. 29 y ss., que contiene una amplia reseña bibliográfica.

${ }^{300}$ Una justificación histórica del principio de la acusación popular en el antiguo derecho alemán y, específicamente, en diversos pueblos germánicos se puede deducir de la exposición de OPET, O., "Die Popularklage der Berner Handfeste. Ein Beitrag zur Geschichte der Popularstrafklage im deutschen Recht", sostenida como lección inaugural el 4 de noviembre de 1893 y publicada en Zeitschrift für Schweizer Strafrecht, T. VII, Berna 1894, pp. 15-43. En ella se detalla la acusación popular en caso de homicidio dentro de la ciudad documentada en las Berner Handfeste (art. 30): el fallecido podría ser algún foráneo cuyos allegados nunca podrían perseguir el delito, con lo que de otra manera, éste podría quedar impune. Justifica el autor la existencia como principio general de la facultad de acusar por cualquiera que sintiera la infracción penal como una ofensa propia y no sólo por el ofendido por el delito, y relaciona su reflejo en los cuerpos normativos de diversos territorios germánicos (pp. 23 y ss). Analizando el amplísimo y diverso ámbito de existencia de las acciones populares, OPET excluye una influencia de las actiones populares romanas sobre las germánicas, puesto que aquéllas no serían de utilidad para perseguir los graves delitos a que estaban abiertas las Popularklagen (p. 27). Sin embargo, al hilo de la Recepción del derecho común, admite la comparación con las ciudades italianas del norte. Así, relata el autor que la máxima dimensión otorgada a las acciones populares es la realizada en los Estatutos de Casale y Neucomo, que atribuían la posibilidad de una acusación popular frente a todo quebrantamiento de sus normas. Algo menor sería la extensión de ésta en los 
El cambio esencial con respecto a la participación de los particulares en la acusación y a su progresivo alejamiento del papel esencial que en el primitivo proceso penal se les adjudicaba, tiene lugar entre los siglos XII a XIV. En este periodo, en el que se inicia la construcción de un poder estatal organizado capaz de asumir determinadas funciones de interés supraindividual y en el que la influencia del derecho romanocanónico se deja sentir con intensidad, el proceso penal empieza a ser contemplado como de interés público y se abre paso a la sustitución de la iniciativa particular por la oficial y a la de la reparación privada por la sanción penal pública ${ }^{301}$. De esta manera, es posible afirmar que ya en la alta Edad Media existían indicios de la progresiva instauración de un procedimiento penal fuertemente intervenido por el poder público y es en este momento cuando hacen su aparición dos novedades que supondrán en la práctica el apartamiento de los particulares de la función acusatoria: el principio de oficialidad en la iniciación del proceso penal (Officialmaxime) y el principio inquisitivo, por el que el esclarecimiento de los delitos se realizaba de oficio (Inquisitionsmaxime). La concurrencia de ambos principios, aún vigente el proceso acusatorio, acabó progresivamente con el dominio por el perjudicado o su grupo familiar de la investigación, la acusación y la aportación de la prueba $^{302}$.

El principal hito de la recepción romano-canónica en Alemania fue la Constitutio Criminalis Carolina o Peinliche Gerichtsordnung del Emperador Carlos V, promulgada en 1532. En ella se regulan conjuntamente el proceso de partes acusatorio vigente hasta

derechos vigentes en ciudades como Bolonia y Padua, en las que era necesario consentimiento del perjudicado; en Verona, Brescia, Parma y Roma, a cuyo derecho se asimilaría el de Lucerna, sólo conocían la acusación popular para determinados grupos de delitos; etc. y en todo caso existirían especificidades propias de cada lugar (pp. 27 y 28). Incluso en un esfuerzo de justificación de la raíz indogermánica de las acciones populares, acorde con el espíritu romántico que impulsaba a muchos de los autores que abordaban el tema, vislumbraba también éstas en fuentes islandesas (p. 28) y suecas (p. 30). Por último, concluye el autor reconociendo la escasa vigencia práctica de la acusación popular excepto "allí donde una forma de Estado democrático aseguraba la participación de todos los ciudadanos del Estado en la vida pública" (Italia, los cantones democráticos suizos e Islandia) (p. 39). La mezcla que realiza el autor entre la auténtica participación en el proceso que debería suponer la acusación popular y el mero derecho de denuncia, que no podría culminar en sentencia sin la intervención oficial en alguno de los casos a los que él se refiere, ha sido puesta en entredicho como uno de los puntos débiles de su estudio. En este sentido vid. PFENNINGER, H.F., "Die Popularstrafklage. Ein Beitrag zur Strafprozessreform”, Schweizerische Zeitschrift für Strafrecht / Revue Pénale Suisse, T. XIX (1916), p. 260.

${ }^{301}$ Para la evolución del apartamiento de los particulares del proceso penal en relación con el perjudicado vid. la detallada exposición histórica de WEIGEND, T., Deliktsopfer und Strafverfahren, Berlín 1989, pp. 24 y ss. y NEUMANN, U., "Die Stellung des Opfers im Strafrecht" en HASSEMER, W. (editor), Strafrechtspolitik. Bedingungen der Strafrechtsreform, Francfort, Berna, Nueva York 1987, p. 225.

${ }^{302}$ SCHMIDT, E., Einführung..., op. cit. y WEIGEND, T., Deliktsopfer..., op. cit. p. 83. 
entonces (art. 11-17) y el de iniciación de oficio inquisitivo (art. 6-10), designando al primero como processus ordinarius, puesto que supondría la regla, y al segundo, que debía ser la excepción, como processus extraordinarius. En la práctica sin embargo, el proceso acusatorio de partes no constituyó más que una previsión de la norma sin reflejo real. En opinión de E. SCHMIDT, el proceso acusatorio de la CCC (y el de la Constitutio Criminalis Bambergensis que le sirvió de fundamento), no tenían nada en común con el antiguo proceso germánico, a excepción de que podía ser un acusador privado quien lo iniciara. Se trataría en realidad de un auténtico proceso inquisitivo puro, en el que la acusación privada se mantiene como una más de las formas que provocan su iniciación. Una vez deducida acusación, la contribución del sujeto acusador al desarrollo del proceso era prácticamente nula y se desarrollarían de oficio todas las averiguaciones necesarias para el esclarecimiento del delito ${ }^{303}$. La vigencia de acusación popular, traducida en que su ejercicio pudiera ser deducido por cualquiera, incluyendo a los no perjudicados por el delito, liberaría la función del acusador privado de reminiscencias de la venganza $\operatorname{privada}^{304}$.

La vigencia de la acusación popular en Alemania no fue una opinión compartida unánimemente por la literatura del siglo XIX, llegándose a afirmar por alguna cualificada personalidad contraria a la acusación privada, como fue BINDING, que la acusación popular era totalmente ajena al derecho germánico. A su juicio, la teoría sostenida entre otros por GNEIST según la cual llevaría vigente en Alemania mil años y que durante los siglos XIV y XV no hubo más acusación que la popular" ${ }^{305}$ era como "un puñetazo en el rostro de la historia" ${ }^{306}$. Negaron también la existencia de acusación popular quienes

${ }^{303}$ SCHMIDT, E., Einführung..., op. cit. p. 126. Con todo y con ello, el mantenimiento teórico del proceso acusatorio, aun con amplias facultades inquisitoriales en manos del Tribunal, puede ser contemplado como un reflejo de la ancestral concepción germánica de que la persecución del delito debía de ser rogada según el principio wo kein Kläger, da kein Richter bien por el perjudicado o sus allegados, bien por cualquier otra persona.

${ }^{304}$ En este sentido vid. KLEINHEYER, G., "Tradition und Reform in der Constitutio Criminalis Carolina" en LANDAU, P. y SCHROEDER, F-C., Strafrecht, Strafprozeß und Rezeption, Francfort 1984, p. 22. En su opinión, en esta función pública se puede ver el fundamento de la defensa de la necesidad de un acusador oficial, sobre todo allí donde se percibió que el acusador privado personificaba el interés público en la persecución penal. PFENNINGER afirmaba que la acusación popular era "hija directa de la idea de ciudadanía del estado" o "la más bonita expresión en el proceso penal de la solidaridad ciudadana". "Die Popularstrafklage...", op. cit. pp. 261 y 263 respectivamente.

${ }^{305}$ GNEIST, R., "Die Staatsanwaltschaft und die Privatanklage", en Vier Fragen zur deutschen Strafprozeßordnung, Berlín 1874, p. 47.

${ }^{306}$ BINDING, K., Die drei Grundfragen der Organisation des Strafgerichts, Leipzig 1876, p. 4 (en nota). BINDING, que además de jurista era historiador, calificaba la obra de GNEIST como "el libro más peligroso sobre 
sustentaban que sólo el ofendido y un acusador de oficio estaban legitimados para interponer acusación ${ }^{307}$. Sin embargo estas opiniones son hoy rechazadas mayoritariamente, en tanto se admite generalmente que la competencia para acusar en los pueblos germánicos venía atribuida al quivis de populo ${ }^{308}$.

El sistema históricamente vigente no se diferenciaba apenas del romano y las personas autorizadas para el ejercicio de la acusación no sólo eran aquéllos a los que el delito hubiera ofendido sino en principio cualquiera, incluyéndose las personas jurídicas $^{309}$. Se exceptuaban de este reconocimiento varios grupos de personas en función de sexo, edad, incapacidad civil, incapacidad psíquica, mala reputación, enemistad, infamia o sumisión. Siguiendo lo expuesto por CARPZOVIUS ${ }^{310}$, las mujeres estaban excluidas de la acusación, excepto cuando hubiera de perseguirse delito contra ellas mismas o sus parientes o cuando el delito fuera de los considerados extremadamente graves (crimen majestatis, sacrilegio o herejía). Los menores de 20 años (pupillus) podrían acusar a través de su tutor cuando fueran víctimas del delito. Los que no gozaran de la incapacidad civil podrían hacerlo solamente en los casos de delitos graves citados, así como cuando les fuera conferido explícitamente un ius accusandi mediante supplicatio o cuando el siervo acusara por la muerte de su señor ${ }^{311}$. En cambio los que padecieran Defectus mentis (enfermedad psíquica, imbecilidad, prodigalidad o incluso los hijos menores de edad) estaban excluidos totalmente de esta facultad. Otras causas de exclusión

cuestiones procesales penales que se haya escrito desde hace mucho tiempo".

${ }^{307}$ Vid. SCHOETENSACK, A., Der Strafprozeß der Carolina, Leipzig 1904.

${ }^{308}$ Vid. PFENNINGER, WEIGEND, op. y loc. cit. y KLEINHEYER, G., "Tradition und Reform...”, op. cit. p. 22. GNEIST, R., Vier Fragen zur deutschen Strafprozeßordnung, Berlín 1874, p. 38, para quien la evolución de la actio popularis pertenece al ámbito germánico, puesto que ya era tenida por imprescindible en el antiguo Estado y se mantuvo en la débil organización estatal del Imperio Cristiano; SCHÜTZE, T.H., Das Staatsbürgerliche Anklagerecht in Strafsachen, Antritts Vorlesung, Graz 1896, p. 12; COENDERS, A., Der Strafantrag und die Privatklage der Nichtverletzten, Stuttgart 1915, p. 12; PFENNINGER, H.F., "Die Popularstrafklage. Ein Beitrag zur Strafprozessreform”, Schweizerische Zeitschrift für Strafrecht / Revue Pénale Suisse, T. XIX (1916), pp. 259 y ss.

${ }^{309}$ Así lo reconocía el célebre inquisidor CARPZOVIUS (o CARPZOW). Vid. DÖRING, W., Der Anklage- und Inquisitionsprozeß bei Carpzow, Emsdetten 1935, p. 15. Éstas deberían ser representadas en el proceso por un Syndikus.

${ }^{310}$ CARPZOVIUS, B., Practica Nova Imperialis Saxonica Rerum Criminalium, Wittemberg-Francfort, 1635.

${ }^{311}$ DÖRING, W., Der Anklage- und Inquisitionsprozeß..., op. cit. p. 16, que reproduce los argumentos de Carpzovius. Ello supone una excepción al principio de la incapacidad civil del siervo. 
eran la mala reputación (Fides suspecta), supuesto en el que se englobaba a aquellos que hubieren incurrido en falso testimonio; la pobreza, cuyo límite estimaba CARPZOW en la posesión de 50 Táler $^{312}$; la enemistad grave apreciable por el juez o la consideración como infame que acarreaban bien la condena por algunos delitos graves (robo, homicidio, etc.) o bien la excomunión ${ }^{313}$. Por causa del debido respeto existían también causas específicas que impedían formular acusación y en virtud de ellas no eran las dirigidas entre parientes consanguíneos ni entre los que se debían reverencia o sumisión: el hijo a su padre, el discípulo a su maestro o el siervo a su señor. Una vez más cedía aquí esta prohibición en los casos en que concurriera en ellos la condición de ofendido por el delito o en los de crimen majestatis ${ }^{314}$.

La propia Constitutio Criminalis Carolina establecía también algunas excepciones a la persecución popular, determinando los delitos que podrían ser perseguidos por los que la ley contemplaba como perjudicados: el rapto (art. $118 \mathrm{CCC}$ ), perseguible sólo por el padre o marido, el estupro (art. 119 CCC) y el adulterio (art. 120 CCC) ${ }^{315}$.

La persona que quisiera intervenir como acusador tenía la obligación de compensar los daños ocasionados al acusado si no lograba proporcionar prueba de su culpa. Al objeto de afianzar esta obligación, desde el momento en que elevare la acusación se le exigía una caución (Bürgschaft) y en caso de que no la pudiera prestar, se le apresaba junto con el acusado hasta que se dictara la sentencia ${ }^{316}$. Por último, como no podía ser de otra

\footnotetext{
${ }^{312}$ Sin embargo no justifica en absoluto esta exclusión y reconoce la posibilidad de que pobreza y honradez puedan darse conjuntamente. DÖRING, W., Der Anklage- und Inquisitionsprozeß..., op. cit. p.17.

${ }^{313}$ Con respecto a estos últimos dice CARPZOVIUS: "nam qui ob malam vitam et perditos mores incurrit infamiam, praesumitur etiam in accusando malus et calumniator", quien a pesar de ello les reconoce capacidad para acusar por crimen majestatis. DÖRING, W., Der Anklage- und Inquisitionsprozeß..., op. cit. p. 18.

${ }^{314}$ DÖRING, W., Der Anklage- und Inquisitionsprozeß..., op. cit. p. 18.

${ }^{315}$ WEIGEND, T., op. cit. p. 98, que excluye la posibilidad de integrarlos en los términos actuales de "delitos privados" o "delitos perseguibles a instancia de parte", puesto que en su opinión se trataría de supuestos completamente diferentes.

${ }^{316}$ Art. 12 a 15 Constitutio Criminalis Carolina. En concreto el art. 12 («Von verhefftung des anklägers bis er bürgschaft gethan hat») es el que establece la prisión para el acusador que no garantice sus responsabilidades en los siguiente términos: «soll der anklager oder sein gewalthaber, mit seinem leib verwart werden, biß er mit bürgen, Caution, bestand vnd sicherung die der richter... für gnugsam erkent, gethan hat». Manejamos la edición de RADBRUCH / KAUFMANN, A., Die peinliche Gerichtsordnung Kaisers Karls V. von 1532, Reclam, Munich 1975. A pesar de la extremada dureza de estas cautelas, ha sido advertido por la doctrina que supusieron una atenuación frente al antiguo sistema del Talión, por el que el acusador que no tuviera éxito en su acusación sería condenado a la misma pena que hubiere solicitado para el imputado. Así WEIGEND, Deliktsopfer..., op. cit. p. 86,
} 
manera, el acusador debería hacer frente a los costes del proceso en caso de absolución. Todas estas dificultades, que se cernían como una verdadera espada de Damocles sobre el acusador, junto con la consideración por parte de los Príncipes y de las ciudades de la persecución penal como una función estatal, condujeron a un abandono definitivo de la acusación privada junto con la del proceso acusatorio ${ }^{317}$.

\subsubsection{Italia}

Los estatutos de las ciudadades italianas del medievo contenían diferentes regímenes en lo referido a la legitimación activa para la acusación, pero la recepción romano-canónica contribuyó a afianzar en los diversos estados un sistema muy similar a los ya expuestos hasta ahora, por lo que no entraremos en su análisis en profundidad. Mientras que en algunos casos esta legitimación no existía, en los estatutos que no contenían restricciones a la acusación (entre otros Milán, Lodi, Brescia o Bergamo), se contenían fórmulas del tipo "quilibet possit accusare; quilibet sit accusator" o bien "quilibet possit accusare, notificare, denunciare". A tal facultad se conectaban ciertas limitaciones, sobre todo con respecto a la cualidad moral del acusador, utilizándose habitualmente para designar a quienes podían acusar las expresiones bonae fama, bonae persona, bonae opinionis, fide dignus u honesta persona ${ }^{318}$. El acusador venía obligado a prestar juramento sobre la verdad del hecho por el que se proponía la acción y sobre él pesaba también la amenaza de pena en caso de que no se condenara al imputado ${ }^{319}$. La cantidad obtenida como multa en la condena se repartiría por mitad entre el acusador popular y la comunidad ${ }^{320}$.

Partiendo del análisis del ordenamiento de Lodi (Statuta Laudensium), LUÉ

que recoge la opinión de KLEINHEYER, G., en Zur Rechtsgestalt von Akkusationsprozeß und peinlicher Frage im frühen 17. Jahrhundert. Ein Regensburger Anklageprozeß vor dem Reichshofrat. Opladen 1971, pp. 17 y ss.

${ }^{317}$ SCHMIDT, E., Einführung..., op. cit. p. 126; ROXIN, C., Strafverfahrensrecht, $22^{\mathrm{a}}$ edición, Munich 1991, p. 439.

${ }^{318}$ Vid. FADDA, C., "Le qualità morali dell'attore popolare" en Raccolta di scriti offerti al prof. Pessina nel cinquentesimo anno d'insegnamento, FILANGIERI (Editor), cit. por LUÉ, G.B., Voz “Azione popolare”, Enciclopedia Giuridica Italiana, vol. I, parte V, Milán 1904, pp. 1420 y s.

${ }^{319}$ La obligación venía expresada en los siguientes términos: "et quilibet possit notificar et credatur cum sacramento".

${ }^{320}$ LUÉ, G.B., voz “Azione Popolare” en Enciclopedia Giuridica Italiana, vol. I, parte V, Milán 1904, p. 1421. 
distingue varios supuestos entre diversas acciones populares previstas específicamente. En unos casos se refieren éstas a la represión de actos contra la seguridad pública (p. ej. señalización y hora de cierre de las tabernas, formas de conducción de carros, garantía de la libre circulación en la ciudad), en otras contra la sanidad e higiene públicas (p. ej. vertidos de aguas negras, enterramiento de cadáveres, curtido y lavado de pieles), contra los fraudes en el comercio, contra el sistema de medidas, por daños cometidos contra bienes públicos, etc ${ }^{321}$. En los fines perseguidas a través de su utilización se identificaban, como se ve, con las acciones populares romanas ${ }^{322}$.

Al igual que en el resto de Europa, en el proceso criminal de los diferentes estados italianos la iniciativa en la persecución se fue confiriendo posteriormente al juez, ya fuera de oficio o ya por denuncia, aun cuando desde la Edad Media existieron diferentes oficiales encargados de la acusación (ministrales, consules, syndici y, posteriormente, procuratores $^{323}$. La influencia del Code d'Instruction Criminelle francés se dejó sentir en el Código italiano de 1865, y con ello se empezó a consolidar el monopolio acusatorio del MF y la participación privada en el proceso penal únicamente a través de la acción civil $^{324}$. A partir de esos momentos, con la discusión sobre la vigencia de las acciones populares romanas y la elaboración de nuevos cuerpos legales para el estado unificado, volvieron sin embargo a aflorar con vigor las peticiones de quienes veían en la participación privada en el proceso penal una garantía contra la inactividad del Ministerio Público.

\subsection{Resistencia a la instauración de un órgano público acusador y acusación por particulares}

\subsubsection{Alemania}

\footnotetext{
${ }^{321}$ LUÉ, G.B., voz “Azione Popolare”, op. cit. pp. 1422 y ss.

${ }^{322}$ El derecho canónico, informado principalmente por el derecho romano, no podía sino reconocer también las acciones populares, por lo que en su ámbito y dentro de ciertos márgenes también gozaban de cierta operatividad.

${ }^{323}$ MALIVERNI, A., Studi sul processo penale, Turín 1983, pp. 56 y s.

${ }^{324}$ BARONE, G., Enti collettivi e processo penale. Dalla Costituzione di parte civile all'accusa privata, Milán 1989 , p. 7.
} 
La participación de particulares en la persecución penal de delitos públicos y en particular, por lo que a nuestro tema respecta, la acusación popular (Popularstraf(an)klage), fueron motivo de amplio debate en los diferentes territorios alemanes desde mediados del siglo XIX, una vez superadas las concepciones que se oponían al proceso acusatorio. Puesto que la acusación privada había sido apartada por un sistema inquisitivo e intervencionista en el que el Tribunal acaparaba toda las iniciativas en el proceso, una vez en declive o abandonado aquél, y abierta la posibilidad de intervención de otros sujetos, su reinstauración encontraría nuevamente una adecuada base $^{325}$. Las diversas maneras para que ello se hiciera realidad fueron sentidas por determinados sectores liberales de la doctrina y la política, al contemplarlas como deseables garantías frente a la amenaza que para la libertad pudieran suponer hipotéticas arbitrariedades atribuibles al monopolio acusatorio del MF. Al tratarse éste de un órgano de carácter político o, cuando menos, administrativo, sometido y dependiente del Ejecutivo, en él se sentía la personificación de una quiebra del principio de división de poderes y una imposición del Estado en esferas donde la iniciativa de la sociedad civil podría ser suficiente para garantizar el bienestar general ${ }^{326}$. Una prueba palpable de esta desconfianza puede ser deducida del hecho de que en los Estados en los que la fiscalía se había introducido orgánicamente en la administración de la justicia, confiriéndola un estatus de independencia similar al de los jueces, la discusión sobre la acusación privada tuvo una trascendencia mínima ${ }^{327}$.

Otras causas que podemos señalar junto a este recelo venían constituidas por las siguientes: a) la memoria histórica del sistema germánico tradicional de persecución penal, que hacía que se viera en la acusación privada un "derecho sagrado de cada alemán” (FISCHER) 328 " "uno de los más primitivos Derechos Humanos sustentado en el

\footnotetext{
${ }^{325}$ La constitución de la Pauluskirche de Francfort de 1848/49 había reconocido entre los Derechos Fundamentales de la nación alemana el proceso acusatorio en los siguientes términos: "In Strafsachen gilt der Anklageprozeß" (Art. X, parágrafo 179). HUBER, E.R., Dokummente zur deutschen Verfassungsgeschichte, T. I (1803-1850), $3^{\text {a }}$ ed. Stuttgart 1978, p. 394.

${ }^{326}$ HEFFTER, H., "Die nachmärzliche Liberalismus: die Reaktion der fünfziger Jahre" en WEHLER, H.U., (editor) Moderne deutsche Sozialgeschichte, Düsseldorf 1981, pp. 193 y s.; WEIGEND, Deliktsopfer..., op. cit. pp. $111 \mathrm{y}$ ss.

${ }^{327}$ Así ocurrió por ejemplo en Sajonia, Oldenburg o Braunschweig. Vid. WEIGEND, Deliktsopfer..., op. cit. p. 116, n. 367.

${ }^{328}$ FISCHER, Verhandlungen des 1. Deutschen Juristentages (1860), p. 255.
} 
derecho natural" (von TIPPELSKIRCH) ${ }^{329}$ o un "principio de toda existencia jurídica libre" (SUNDELIN) ${ }^{330}$; b) la actualidad de los estudios romanistas sobre las acciones populares, junto con la defensa del origen germánico de la acusación quivis ex populo ${ }^{331}$ y c) el profundo sentimiento nacionalista del momento, que hizo que la importación procedente del sistema francés de la figura de un funcionario público que con carácter exclusivo detentara aquella alta misión no pudiera por menos que chocar con la oposición de sectores liberales y burgueses ${ }^{332}$.

${ }^{329}$ Von TIPPELSKIRCH, “Ueber das Verhältniß der öffentlichen zur Privatanklage”, Der Gerichtsaal T. 11 (1859), pp. 183 y 277. Negaba incluso la necesidad de que el Estado adoptara medidas para proteger intereses que no fueran suyos sino de ciudadanos afectados en particular.

${ }^{330}$ SUNDELIN, Die Staatsanwaltschaft in Deutschland, Anclam 1860, p. 44. SUNDELIN era declaradamente hegeliano. Con su calificativo se refería no exactamente a la acusación, pero sí al "derecho de libre acceso a los tribunales penales".

${ }^{331}$ BRUNS, C.G., "Die römischen Popularklagen”, en Kleinere Schriften, 1, Band, Weimar 1882, p. 313. BRUNS realiza un estudio sobre las acciones populares romanas que ha llegado a ser clave para la interpretación del tema, con la vista puesta en las "preocupaciones actuales de que la facultad generalizada de acusación penal arraigue entre nosotros como en el derecho inglés". Los esfuerzos de la doctrina romanista iban encaminados también a reivindicar la actualidad de los principios del derecho romano y su aplicabilidad en lo referido a la titularidad del derecho de iniciación del proceso penal (p. 371 y ss.). Tomando como base las características esenciales de las acciones populares romanas y sosteniendo su vigencia en el proceso penal señala los puntos básicos sobre los que establecer la discusión en su momento: 1) ¿deben poder tener también los ciudadanos individuales derecho a solicitar la imposición de penas públicas; 2) ¿debe premiarse esta actividad con recompensas o se debe considerar cuestión de mero patriotismo?; 3) en el primer caso, ¿debe concederse al actor el importe completo de la multa o repartirla con el erario público?; 4) ¿podrá demandarse a través del proceso civil, del penal o de los dos?. Sin llegar a pronunciarse en favor o en contra de su instauración en el derecho alemán, advierte su papel como forma de viva participación ciudadana y del riesgo de las posibles acusaciones maliciosas. Hubo, sin embargo, quien contempló negativamente la acción popular como una institución romanista, alejada del espíritu, la historia y el derecho de Alemania. Vid. GNEIST, R., Vier Fragen..., op. cit. p. 47 relatando los motivos que originaron su rechazo por la Comisión para la elaboración de un código procesal penal alemán. Para refutar esa afirmación GNEIST concluye diciendo que "tras un corto periodo de tiempo, los criminalistas reconocerán que la acción popular penal pertenece al primitivo espíritu de la nación teutona".

${ }^{332}$ Sobre la aún controvertida historia del Ministerio Fiscal en Alemania puede consultarse la bibliografía citada en la introducción de este capítulo y, más específicamente, la reciente monografía de WOHLERS, W. Entstehung und Funktion der Staatsanwaltschaft. Ein Beitrag zu den rechtshistorischen und strukturellen Grundlagen des reformierten Strafverfahrens, Berlín 1994, esp. pp. 43 y ss. o la clásica de CARSTEN, E., Die Geschichte der Staatsanwaltschaft in Deutschland, Aalen 1971, reimpresión de la edición de Breslau, 1932. Sin entrar a analizar el proceso histórico que condujo progresivamente a la instauración del Staatsanwalt (literalmente, el abogado del Estado) en los diferentes Estados alemanes, sobre la que la doctrina no es en absoluto unánime, debemos sin embargo hacer algunas breves consideraciones al hilo de la explicación en torno a la acusación privada. La introducción del Ministerio Fiscal en Alemania comenzó por el Estado de Baden en 1832 y, curiosamente, como policía de prensa con el objeto de perseguir los delitos de esta naturaleza. Posteriormente se le añadieron nuevas funciones, primero en el marco de la ley de agravios cuando existieran calumnias a personas de la vida pública y por último, en 1837, el resto de las funciones de acusación penal hasta llegar a un modelo similar al francés. Con la StPO de Baden de 18 de marzo de 1864 obtiene el fiscal el monopolio de la acusación que simultáneamente se unió como 
El temor hacia lo que se sentía como una limitación de las libertades ligada a la privación al ciudadano del derecho de acusación, era directamente proporcional al contenido político de la naturaleza de los diferentes delitos. Si hubo una preocupación por la posible inactividad del MF que dejara impunes algunas conductas, ésta no se debía precisamente a que se alegara la necesidad de limitar una saturada actividad persecutoria ${ }^{333}$, sino fundamentalmente por la sospecha de que la no persecución se debiera a razones de índole política. Esta inseguridad alcanzaba su máximo nivel precisamente en las figuras delictivas en las que no hubiera un perjudicado individualizado, es decir, allí donde el interés particular podría ceder con mayor facilidad en beneficio de un abstracto interés público vinculado siempre a una determinada opción política. Este temor se refería sobre todo a los delitos cometidos por los funcionarios públicos y a los de prensa, pero englobaba también los delitos electorales y los cometidos contra la libertad de asociación, para cuya persecución, un fiscal dependiente no intervendría con la misma intensidad sin considerar el color político de los sujetos frente a los que actuase ${ }^{334}$. Era precisamente en este ámbito donde la acusación popular mostraba sus ventajas frente a otras variantes de acusación de carácter privado y donde los argumentos en favor de ésta encontraban un mayor número de defensores.

Cuestión esencial que no puede ser obviada aquí, fue la necesidad percibida por

garantía al principio de legalidad. En otros Estados, como Baviera, no existía un monopolio acusatorio del fiscal, puesto que compartía con los jueces la iniciativa penal. En Austria el Fiscal era órgano de acusación en la ley de prensa de 29 de marzo de 1848, al que se amplían las competencias siguiendo el modelo francés. Ya en 1850 se instituyen unos fiscales independientes de los Tribunales encargados de perseguir de oficio todos los delitos de los que tengan conocimiento. En este caso representaban al Estado perjudicado por el delito. En Württemberg también se le atribuyen en primer lugar los delitos de prensa (1848), pero en 1868 esta competencia se amplía a todos aquellos de los que tuviera conocimiento. En Prusia la reforma se realizó a partir de 1849 previéndose que la intervención del MF se produjera sólo donde existiera un interés público. Se referían a la presencia de interés público como motivo de la intervención del MF, que en algunos casos incluía también el interés del Estado, tal y como ocurría por ejemplo en las legislaciones de Hannover, Sajonia, Braunschweig, Sajonia-Altenburg, Sajonia-Coburg-Gothar o Anhalt-Dessau.

${ }^{333}$ Tal y como hoy día es defendido con frecuencia para introducir excepciones al principio de legalidad.

${ }^{334}$ Vid. GNEIST, Vier Fragen..., op. cit. pp. 22 y 46 quien utiliza este argumento para criticar la insuficiencia de una acusación del perjudicado: "allí donde empieza el peligro del gobierno de partidos, termina la acción del perjudicado. ¿o soy el perjudicado cuando el fiscal no persigue un delito de prensa porque es favorable a su partido? ... ¿o cuando las leyes de policía se me aplican a mi en toda su intensidad y a los potentados del lugar no?..." y MITTNACHT en HAHN, Die gesammten Materialien, op. cit. p. 500. Vid. también WEIGEND, T., Deliktsopfer und Strafverfahren, Berlín, 1989, pp. 113, 117 y ss y 130, n. 423. quien destaca la radical afirmación de SUESS para el que de esta manera, la pena vuelve a asumir su carácter privado, pero no referida al ofendido, sino al partido que en cada momento tenga las riendas o peor aún, a la clase social dominante: SUESS, E., Die Stellung der Parteien im modernen Strafprocesse, Viena 1898, p. 85. 
algún sector de la doctrina de introducir algún correctivo en garantía de la legalidad frente al dominio absoluto del ejercicio de la acusación por el MF. Muchos de los que se manifestaron en favor de una amplia aplicación del principio de oportunidad, propugnaron como necesario contrapeso a esta flexibilidad la introducción de la acusación privada en alguna de sus diversas variantes, bien del perjudicado o bien de cualquier ciudadano, haciendo de este impulso particular una función cuasi-pública ${ }^{335}$. En especial en Estados como Prusia, en los que el acusador público no estaba ligado por la obligatoriedad en la acusación, el peligro era más amplio ${ }^{336}$.

En cualquier caso, la historia de la acusación popular en Alemania durante el siglo XIX se reduce a una intensa discusión doctrinal que evidencia su trascendencia política, pero que no llegó a tener reflejo legal alguno ${ }^{337}$. Pese a los esfuerzos de sus partidarios, e incluso a pesar de las concesiones realizadas por éstos, nunca y en ninguna de sus posibles modalidades llegó, una vez instaurado el MF, a estar vigente allí un sistema de acusación privada para delitos públicos ${ }^{338}$. Podemos afirmar únicamente que fruto indirecto de aquella discusión, y sobre todo de la opinión mayoritaria en el sentido de acentuar el control de la actividad del Ministerio Fiscal ${ }^{339}$, son alguna de las instituciones

${ }^{335}$ En este sentido vid. GLASER, op. cit. p. 533; GNEIST, Vier Fragen..., op. cit. p. 53; von BÄHR en HAHN, Die gesammten Materialien zur StPO, Berlín 1885, p. 1064. Con motivo de la reforma de la StPO de 1873 y la GVG, el tema fue ampliamente discutido. Vid. "Legalitätsprinzip und Ausdehnung der Privatklage", en ASCHROTT, P.F., Reform des Strafprozesses. Kritische Bemerkungen der von der Kommission für die Reform des Strafprozeßes gemachten Vorschläge, Berlín 1906, pp. 147 y ss; DIETZ, Verhandlungen des 29. deutchen Juristentages, T. 3 , Berlín 1908, p. 89.; NAGLER, J., “Die Protokolle der Strafprozeßkommision” Gerichtssaal 73, (1909), pp. 97 y 171 y OETTINGER, H. Anklage Tätigkeit des Privaten im Strafprozess unter besonderer Berücksichtigung der Regelung in Basler Recht, Berna 1914, p. 23.

${ }^{336}$ SAVIGNY, que fue el ministro que preparó la legislación reformadora, se basó en las ideas de MITTERMAIER favorables a la introducción del principio de oportunidad. Así, el artículo 6 de la Orden de 3 de enero de 1849 establecía que sólo existiría persecución por el ministerio fiscal cuando "haya un interés público". Vid. MARQUARDT, H., Die Entwicklung des Legalitätsprinzip. Ein historisch-empirischer Beitragung zur Gesetzgebung, Mannheim 1982, p. 30.

${ }^{337}$ Sobre la discusión parlamentaria en relación con la acción popular pueden consultarse los debates y las razones esgrimidas en HAHN, Die gesammten Materialien, op. cit. T. 1, pp. 1059 y ss y T. 2, pp. 1439 y s. El debate doctrinal alemán fue conocido en Italia a través de la crónica del $12^{\circ}$ Congreso de los Juristas alemanes publicado por CARRARA en Rivista Penale vol. III (1875) pp. 392 y ss, y pudo también difundirse en España a través de la traducción de Angel Pintos y Pintos de la obra de MANDUCA El procedimiento penal y su desarrollo científico, Madrid 1888, especialmente pp. 141 y ss.

${ }^{338}$ Dejando al margen la acusación privada subsidiaria del perjudicado en el derecho austriaco.

${ }^{339}$ Vid. por ejemplo en la discusión parlamentaria sobre la Ordenanza Procesal Penal, HAHN, K., Die gesammten Materialien zur Strafprozeßordnung, Berlín 1885, pp. 268 y ss. 
todavía hoy vigentes en el proceso penal alemán como el Klageerzwingungsverfahren (proceso para compeler al ejercicio de la acción penal), garantía del principio de legalidad frente a la inactividad del fiscal, o la Nebenklage (coacusación o acusación adhesiva), hoy por hoy, el principal cauce de participación activa en el proceso penal del perjudicado por determinados delitos.

\subsubsection{Italia}

Si bien no alcanzó reconocimiento entre el resto de la doctrina italiana la afirmación de FILANGIERI de que el derecho de acusar sería inseparable de la condición de ciudadano y el Ministerio Público un instrumento del despotismo ${ }^{340}$, no por ello las iniciativas en pro de un reconocimiento de la actividad acusatoria privada dejó de ocupar un lugar importante en el fin del siglo XIX. La discusión fundamental se realizó en el III Congreso Nacional jurídico-forense de 1891 y, sobre todo, con motivo de los trabajos preparatorios y posterior aprobación del Proyecto FINOCCHIARIO-APRILE en $1913^{341}$. En esta discusión es perceptible la reproducción sustancial de muchos de los argumentos expuestos en Alemania algunos años antes y también los pensadores italianos del que defendían la acusación popular en aquel momento le atribuían junto a su contenido jurídico un fin esencialmente político. Su deseo no era tanto reconstruir una institución jurídica del pasado romano, como instaurar un instrumento de participación en la (o de control sobre la) gestión de la cosa pública particularmente adecuado a la ideología liberal ${ }^{342}$. De esta forma se pretendió rescatar del pasado común principios análogos a aquéllos sobre los que se quería fundamentar la base constitucional del nuevo Estado unificado $^{343}$.

${ }^{340}$ FILANGIERI, C., Ciencia de la Legislación, T. III, Madrid 1821, pp. 35 y ss.

${ }^{341}$ El Código Procesal Penal de 1913 (Finocchiario-Aprile) fue una de las más señaladas y típicas expresiones de la ideología liberal en el campo de la legislación penal procesal. El Código Rocco de 1931 estaba sin embargo principalmente orientado hacia el reconocimiento de una preeminencia de las posiciones del Estado sobre las del individuo como expresión de una potestad original y autónoma. Quizá por ello en las discusiones que lo precedieron, el tema de la atribución a los particulares de facultades de acusación quedó totalmente abandonado. Vid. BETTIOL, G. Instituciones de Derecho Penal y Procesal, traducción de GUTIÉRREZ-ALVIZ Y CONRADI, F., Barcelona 1977, pp. 215 y ss. En la siguiente edición las referencias al Código Finocchiario-Aprile son sólo tangenciales: vid. BETTIOL, G. y BETTIOL, R., Istituzioni di diritto e procedura penale, $4^{\mathrm{a}}$ ed., Padua 1989, p. 135.

\footnotetext{
${ }^{342}$ Son ejemplo de esta tendencia las leyes sardas de 1859 en materia de derecho electoral.

${ }^{343}$ BORGHESI, D., Voz “Azione popolare”, Enciclopedia Giuridica, Roma 1988, p. 2. Por ejemplo, afirmaba
} 
Un buen ejemplo de esta concepción es representado por FADDA, que intentaba superar la dicotomía dejada abierta por el romanista BRUNS y resolvía el problema de la naturaleza jurídica de la acción popular romana haciendo referencia al concepto de soberanía popular, concepto que se prestaba especialmente bien para su traslado al contexto político de la Italia postunitaria. La acción popular constituiría una garantía de un principio de soberanía atribuida a todo ciudadano individual que considerada en sí misma podría parecer excesivamente abstracta ${ }^{344}$. Nos encontramos así con un concepto individualista de la soberanía popular, ya que ésta podría ser descompuesta en una serie de derechos subjetivos públicos correspondientes a cada individuo y todos ellos estarían consecuentemente legitimados para reclamar su tutela haciendo valer una acción encuadrable en los esquemas del derecho común. La pretensión perseguida era la de recuperar el nexo entre acción (popular) y derecho subjetivo sobre la base de la no separación rígida entre derechos públicos y privados. Entre éstos no se veía solución de continuidad sino progresión, de forma que cuando el ciudadano hiciera valer un derecho correspondiente a todos los miembros de la comunidad, la popularidad se presentaría más natural y más afín a la acción fundada sobre el propio interés, y tal afinidad no podría más que "hacer vivir prosperamente el instituto de la acción popular" 345.

Los opositores a las tesis de BRUNS, SCIALOJA o FADDA sostenían una divergente concepción del Estado liberal, inspirada en una diversa relación entre el Estado y el individuo según la cual el segundo habría de ser considerado como órgano y como parte del todo ético en el que vive. Por esta razón, tendría un carácter de imperfección y de accidentalidad que sólo podría ser eliminado por la investidura de la que goza el poder público. En este sentido, parecía difícilmente concebible afirmar la existencia de derechos públicos subjetivos entendidos como momentos de contraposición del ciudadano frente al

COSTA, op. cit. que "esta acción puede servir a restituir más viva y sentida nuestra vida comunal y a reforzar el organismo comunal que responde históricamente a nuestra tendencia y naturaleza civil". Para CARNAZZAAMARI, la acción popular sería "una de las más grandes garantías de los intereses del pueblo y la más bella manifestación de aquel sentimiento filantrópico que impulsa a uno a asumir la defensa de los débiles y de los oprimidos", cit. por LUÉ, op. cit. 1467.

\footnotetext{
${ }^{344}$ BORGHESI, D., Voz “Azione popolare”, op. cit. p. 2 y CASAVOLA, F., Studi sulle azioni popolari romane. Le «actiones populares», Nápoles 1958, p. 149. SCIALOJA es una muestra más de esta tendencia a identificar el mundo jurídico romano con el Estado italiano de su época. En sus palabras "el pueblo tiende a identificarse de nuevo con el Estado". SCIALOJA, V., Prefazione a Le azioni popolari romane di Bruns, en Studi Giuridiche, I, 1, Roma 1933, p. 109.
}

${ }^{345}$ SCIALOJA, op. cit. p. 117, esp. n. 1, cit. por BORGHESI, D., Voz “Azione popolare”, op. cit. p. 2. 
Estado $^{346}$, por lo que la participación del individuo debería darse principalmente en la formación de la voluntad del Estado, el cual actuaría a través de sus órganos ${ }^{347}$.

La discusión de los romanistas de la segunda mitad del siglo XIX permitió vislumbrar dos concepciones sobre la naturaleza de las acciones populares que son utilizadas por la doctrina italiana también en nuestros días: la de quienes la configuraban como manifestación de la soberanía popular y la de aquellos para los que no sería otra cosa que el ejercicio de una función esencialmente pública. Para los primeros, sostenedores de un concepto individualista de la soberanía popular y fieles a los esquemas de la acción en el derecho civil, el ciudadano que hace uso de la legitimación que le proporciona la acción popular solicitaría la tutela de alguno de los derechos subjetivos públicos en que se descompone aquel concepto de soberanía popular ${ }^{348}$. Por ello serían favorables a una amplia introducción de la acción popular en el ordenamiento positivo. Los segundos, por el contrario, minimizan o niegan el nexo de unión entre acción popular y soberanía popular y enfatizan la función pública desarrollada por el actor popular, no sólo su identificación como órgano del Estado. En este caso, mantienen una posición de acercamiento crítico a la acción popular y sostienen una introducción de ésta limitada a casos taxativamente previstos. Dada la "imperfección” que se deriva del hecho de que el actor no está investido del carácter de oficialidad, cuando se admitiera la acción popular, ésta debería ser rodeada de todo tipo de penetrantes controles ${ }^{349}$.

A todo ello se debe añadir un dato más que constituye observación común de gran parte de la doctrina también en Italia: la desconfianza que generaba la posición de un Fiscal sometido a control del Ejecutivo ${ }^{350}$.

\footnotetext{
${ }^{346}$ BORGHESI, D., Voz “Azione popolare”, op. cit. p. 2.

${ }^{347}$ CODACI-PISANELLI, op. cit. pp. 85 y ss.

${ }^{348}$ Son también interesantes las consideraciones realizadas por LUÉ acerca del Estado, la soberanía popular y los derechos públicos subjetivos en relación con la acción popular. LUÉ, G.B., Voz “Azione Popolare” en Enciclopedia Giuridica Italiana, vol. I, Parte V, Milán 1904, pp. 1391 y ss.

${ }^{349}$ BORGHESI, D., Voz “Azione popolare”, op. cit. p. 3.

${ }^{350}$ En el origen de la propuesta de la acción popular como freno a las discrecionalidades del Ministerio Fiscal están las tesis del publicista alemán GNEIST. Nos dice LUÉ que en muchas ocasiones el Ministerio Público no representa al Estado sino a la mayoría que lo gobierna. LUÉ, G.B., Voz “Azione Popolare” op. cit. p. 1391.
} 


\subsection{Defensa de la acusación privada}

\subsubsection{Tendencias ultraliberales: acusación exclusivamente privada}

La concepción de MONTESQUIEU de que era una "admirable ley" la que instauraba el Ministerio Fiscal para el ejercicio de la acusación no fue compartida por quienes veían en el "vengador público" un instrumento del Ejecutivo que serviría sólo a sus intereses y no a los de los ciudadanos ${ }^{351}$. La libertad civil no quedaría suficientemente garantizada con esa presencia ya que sus facultades podían provocar muchos más excesos que los que se derivarían de la intervención controlada de los particulares. El sistema inglés de acusación privada constituyó con esta premisa un modelo para un sector de la ciencia, en concreto para aquel cuya ideología comulgaba con los postulados más liberales de la época.

El primer representante de esta tendencia al que debemos referirnos es FILANGIERI, cuyas ilustradas opiniones no fueron siquiera tenidas en cuenta en su país, pero parece clara la influencia que directa o indirectamente ejercieron sobre el pensamiento liberal en el nuestro. Observaba este autor la contradicción que suponía el que todos pudieran denunciar, incluso en secreto y sin la amenaza de las penas por calumnia, y que sin embargo no pudieran acusar aun cuando ésto tuviera que hacerse "en un duelo que se hace a pecho descubierto y con armas iguales". De ahí que propugnara el reconocimiento de la facultad de acusar prácticamente en los mismos términos que en la legislación romana actualizada según el modelo inglés. Siempre y cuando se rodeara de las adecuadas cautelas, tal derecho debería ser entendido como una prerrogativa que no se podría separar de la ciudadanía sin incurrir en los más graves desórdenes. Con el "derecho de acusación popular" se establecería una inspección recíproca entre los ciudadanos, se harían menos frecuentes los delitos, más difícil su ocultación y más rara su impunidad ${ }^{352}$.

${ }^{351}$ FILANGIERI califica a este "vengador público" como "un magistrado creado por el Príncipe, pagado por el Príncipe, que ha recibido del Príncipe todo cuanto tiene y que puede ser despojado de ello por el Príncipe". FILANGIERI, C., Ciencia de la Legislación, op. cit. p. 42.

${ }^{352}$ FILANGIERI, C., Ciencia de la Legislación op. cit. pp. 47 y ss. Se proponía FILANGIERI recuperar también la distinción entre delitos públicos y privados sobre el fundamento de los sujetos autorizados para su persecución. Mientras que en los primeros todo ciudadano que no estuviese privado por la ley de la libertad de acusar debería tener el derecho de presentarse como acusador, en los segundos sólo correspondería esta facultad a los ofendidos o sus parientes más inmediatos en tanto el cuerpo social puede tolerar la impunidad que podría llevar su no ejercicio por éstos. Ciencia de la Legislación, T. IV, Madrid 1822, p. 141. 
Como contrapartida, en las hipótesis en las que no hubiera acusador privado, se debería iniciar de oficio una pesquisa para la averiguación del delito, responsabilidad que no debería recaer sobre los jueces sino sobre unos "magistrados acusadores", sometidos a las mismas cautelas que los acusadores privados. Estos sujetos deberían ser personas distinguidas, de probidad acreditada y estar libres de toda sospecha de venalidad y prevaricación, de forma que fueran vistos no como instrumento de opresión sino como ejercitantes de una función que la sociedad les encomienda. De esta manera quedaría garantizado formalmente el principio de la separación entre acusar y juzgar y se impediría el control de la acusación por el Ejecutivo ${ }^{353}$.

En Alemania el sistema acusatorio inglés había sido difundido en la primera mitad del siglo XIX por una personalidad tan relevante como fue MITTERMAIER $^{354}$, y la idea de que todo ciudadano pudiera acusar no dejaba de ser atractiva para los defensores de la mínima intervención estatal en la esfera de actividad de los ciudadanos ${ }^{355}$. La propuesta más radical en este sentido se mantuvo en un artículo significativamente publicado de forma anónima en 1859, que proponía un cierto regreso al antiguo sistema germánico de acusación de los particulares, complementado con algún matiz característico de la

${ }^{353}$ FILANGIERI, C, Ciencia de la Legislación, op. cit. p. 63. En una edición posterior de la Ciencia de la Legislación publicada en París en 1836 se añaden a estas opiniones los comentarios radicalmente opuestos de CONSTANT. Afirma el comentarista que "la acusación facultativa a cada ciudadano es imposible en las naciones modernas (...) la acusación confiada al ciudadano sería enteramente ilusoria (...) Diga lo que quiera FILANGIERI, eterno admirador de todo lo antiguo, es necesario una persona pública constituida por la ley para perseguir a los criminales e instar su castigo". La acusación de quien no viene obligado ni tiene interés en ello sería vista con animadversión por los demás ciudadanos en tanto parecería una malicia gratuita. Y la de los "magistrados acusadores" llegaría mucho más allá de lo necesario al verse privilegiadamente investidos de potestades y con el objeto de poder justificar su función. En su opinión, la mejor forma de resolver la desconfianza en el ejercicio de la función acusatoria es confiar en un jurado que valore el fundamento de la persecución. Vid. los comentarios de CONSTANT, B. a la edición de 1836 de la Ciencia de la Legislación de FILANGIERI, T. IV, pp. 277 y ss.

${ }^{354}$ Vid. p. ej. MITTERMAIER, C.J.A., Das deutsche Strafverfahren, $1^{\text {a }}$ parte Heidelberg 1839, pp. 105 y ss. y 157 y $2^{\text {a }}$ parte, Heidelberg 1840, pp. 113 y ss. MITTERMAIER fue uno de los primeros cultivadores del derecho comparado en materia procesal penal y tuvo contacto directo con la praxis jurisdiccional en varios países europeos, entre los que se encontraba el Reino Unido. Posteriormente otros autores profundizan en la comparación con este país. Vid. en este sentido el otro clásico entre los procesalistas y penalistas alemanes de mediados delsiglo XIX: ZACHARIAE, H.A., Handbuch des deutschen Strafprocesses, T. I, Gotinga 1861, pp. 151 y ss.

${ }^{355}$ Apenas comenzado el siglo XIX, la garantía del proceso acusatorio frente al inquisitivo reafirmada mediante la acusación popular privada y la acusación pública subsidiaria de ésta, ya había sido propuesta por KLEINSCHRODT, Gallus Alons, "Ueber den Werth des Anklage und Untersuchungsprozesses gegen einander, nebst Vorschlägen zur Verbesserung des peinliches prozesses im Allgemeinem", publicado en Archiv des Kriminalrechts, 1800, T. 2, 4. parte, pp. 7 y ss. pero no nos consta que contara con repercusión entre la doctrina. 
influencia de los sistemas inglés y escocés ${ }^{356}$. En opinión del hiperliberal y desconocido autor, la "acusación cívica" (Bürgerliche Anklage) se correspondería con la libertad civil y la comunidad jurídica, principios sobre los que propugna la edificación del Estado y la Sociedad del futuro. La acusación sería una "hija del autogobierno cívico" (Kind der bürgerlichen Selbstregierung), por lo que debiera arrebatarse al Estado la función de su ejercicio en tanto no le correspondería más que cuando actuara para hacer valer sus intereses como Fiskus, atribuyéndolo consecuentemente a la sociedad civil (Bürgerliche Geschellschaft) que es la que sufre las consecuencias del delito aunque sólo sea uno de sus miembros el afectado. La sociedad sería la llamada a hacer realidad la norma penal y, cuanto más grave fuera el delito, mayor interés habría en ella para perseguirlo, porque afectaría no sólo al perjudicado sino también a todos sus conciudadanos. La persecución penal estaría de esta manera controlada en su ejercicio y se limitaría a las infracciones que la opinión pública considerase dignas del esfuerzo que supone, por lo que la acusación privada sería la vía a través de la que se introduciría en el proceso el sentimiento social y la adecuada proporción en la persecución del delito ${ }^{357}$. La acusación debería poder ser desempeñada por cualquiera que se sintiera con fuerzas para ello, pero para su ejercicio habría de habilitarse a unos encargados representantes de la sociedad civil y no del Estado, quienes como mandatarios de acusadores privados asumirían la persecución en nombre de aquélla ${ }^{358}$. De este modo se devolvería la cuestión a lo que él entendía su lugar natural: la acusación cívica representaría los intereses de la sociedad, mientras que los intereses del Estado deberían ser representados y defendidos por sus propios funcionarios ${ }^{359}$.

${ }^{356}$ ANÓNIMO, “Das Prinzip der Strafverfolgung”, Deutsche Vierteljahreschrift, $\mathrm{n}^{\circ} 87,(1859)$ Cuaderno 3, $1^{\mathrm{a}}$ Parte, pp. 71-149.

357، "Das Prinzip...", op. cit. pp. 117 y 144. El autor había afirmado en el encabezamiento del artículo que "el proceso judicial, como todo Derecho, que es sólo la manifestación del pensamiento vivo del pueblo, no puede por menos que seguir las evoluciones y cambios de la percepción del pueblo (Volksanschauung)".

${ }^{358}$ Utiliza como modelo el public prosecutor escocés, cuyo poder procede según el autor no del Estado sino de la colectividad jurídica. "Das Prinzip...", op. cit. p. 133. Con respecto al peligro que conlleva este modelo de que se multiplicasen las acusaciones falsas o frívolas, el autor responde que no son menores que los de una denuncia falsa sobre la que actúe el Ministerio Fiscal y que, precisamente, en el caso de una persecución infundada, la igualdad de las partes presta mejor servicio a la justicia que si una de las dos tuviera atribuida una posición preeminente (p. 138).

${ }^{359}$ En este sentido, von TIPPELSKIRCH, “Das Princip der Strafverfolgung”, Allgemeine Schwurgerichts-Zeitung für Deutschland und die Schweiz 4 (1860), T. VI, p. 8 aceptaba esta propuesta, sugiriendo que las fiscalías dependieran del nivel municipal para que, de esta manera, no fueran representantes del Estado sino de la sociedad. 
Proposiciones de este carácter tan marcadamente liberal no podían alcanzar predicamento en el clima intelectual dominante en la Alemania de aquella época. No sólo podría objetarse las dificultades prácticas de un sistema de acusación basado en la iniciativa privada (inactividad que lleva a la impunidad, persecuciones maliciosas, etc.), sino que la ya de por sí inadmisible separación entre Estado y sociedad civil que sustentaba esta "acción popular única", se presentaba sospechosa en un país y en una época en los que precisamente se estaba enfatizando el aspecto de desobediencia frente al Estado que suponía la comisión de un delito ${ }^{360}$. La respuesta doctrinal a aquella propuesta fue rápida y vió la luz poco tiempo después, de forma igualmente anónima, con el mismo título y en la misma publicación ${ }^{361}$. Para este segundo autor, que se declara firme partidario del principio acusatorio pero no defensor del sistema francés, la acusación de oficio por el Estado y a través de un órgano suyo (el MF), se corresponde con la naturaleza del delito y con las propias obligaciones del Estado, del que es predicable una objetividad en la aplicación del derecho no atribuible a otros sujetos. Por ello la acusación se tendrá que hacer en nombre de la sociedad estatal, la colectividad de ciudadanos unidos bajo la tutela del ordenamiento jurídico del Estado, no existiendo hueco para la intervención de los particulares, a no ser en ciertos casos leves (injurias, faltas leves, etc.), únicos momentos donde el monopolio del Estado debería quebrar ${ }^{362}$.

\title{
3.3.2. Diferentes modalidades de acusación privada como fórmula complementaria al monopolio del MF
}

\subsubsection{Las diversas propuestas}

\author{
1.1.1.1.1 En Alemania
}

\footnotetext{
${ }^{360}$ Vid. HEGEL, G.F., Filosofia del Derecho, § 218; WEIGEND, T., Deliktsopfer und Strafverfahren, op. cit. p. 119.

${ }^{361}$ Si bien el artículo de respuesta apareció de forma anónima, posteriormente se atribuyó al Fiscal General von GROSS. "Das Prinzip der Strafverfolgung", Deutsche Vierteljahrsschrift, $\mathrm{n}^{\circ} 90$ (1860), 2, pp. 250-295. La polémica generó un importante debate doctrinal y, así, con el mismo título se publicaron otros artículos: GLASER, J., "Das princip der Strafverfolgung", Allgemeine österreichische Gerichtszeitung 1860, pp. 87 y ss y en Kleinere juristische Schriften, Viena 1883, pp. 523 y ss.; von TIPPELSKIRCH, "Das princip der Strafverfolgung", Allgemeine Schwurgerichts-Zeitung für Deutschland und die Schweiz 4 (1860), T. VI, pp. 1 y ss.
}

${ }^{362}$ Von GROSS, “Das Prinzip der Strafverfolgung”, op. cit. p. 258. 
GLASER fue el primero en propugnar una acusación subsidiaria que pudiera deducir solamente el perjudicado, en razón de que éste sustentaría un interés en el resarcimiento como elemento esencial de la pena, el cual sería "especifico y diferente del de los demás ciudadanos en el mantenimiento del ordenamiento jurídico". Si el órgano público rehúsare proteger ese interés, el perjudicado, privado por el Estado de la venganza, debe poder encontrar una vía para defenderlo adecuadamente en el proceso ${ }^{363}$. Esta visión, que WEIGEND estima basada más en consideraciones prácticas de psicología social que de teoría jurídico-pública o jurídico-penal ${ }^{364}$, tuvo reflejo en los dos primeros Congresos de los Juristas Alemanes (Deutsche Juristentag) de 1860 y 1861. En el primero de ellos, el abogado LEWALD propuso sin éxito un pronunciamiento en favor de la acusación privada en los casos en los que el fiscal se negare por cualquier causa a elevar la acusación, incluyendo entre éstas las razones de oportunidad. Al acusador privado se le debería reconocer el papel de parte en el proceso, no sólo para obtener una satisfacción civil según el sistema francés, sino también para cooperar en la condena del imputado ${ }^{365}$. Teniendo en cuenta la imposibilidad de determinar quién fuera el perjudicado en

${ }^{363}$ GLASER, J., "Das Prinzip der Strafverfolgung" op. cit. pp. 527 y ss. quien estima innecesario un derecho de acusación privada más amplio, puesto que parece suficiente la facultad de denunciar los delitos por sus menores esfuerzos, costes y peligros (p. 529). Joschua Glaser, Ministro de Justicia de Austria fue posteriormente el responsable máximo de la Strafprozeßordnung austriaca de 1873, de la cual nuestra Ley de Enjuiciamiento Criminal se declara tributaria en su Exposición de Motivos. En concreto relata Alonso Martínez en 1882: "únicamente al Ministerio Fiscal o al acusador particular, si le hubiere, corresponde formular el acta de acusación ... siguiendo en esto al Código de instrucción criminal austriaco, que es acaso, de los actualmente vigentes en la Europa continental, el que ha desarrollado con más lógica y extensión el sistema acusatorio". En el ordenamiento austriaco continúa vigente más de un siglo después, aquella acusación subsidiaria del perjudicado que por impulso de GLASER se introdujera en la Ley de 1873. Concretamente se regula en sus arts. 48 y 49.

${ }^{364}$ WEIGEND, Deliktsopfer..., op. cit. p. 114. Algunas opiniones manifestadas al hilo de la consideración de la víctima en el proceso penal a la que estamos asistiendo en la actualidad no pueden entenderse demasiado alejadas de lo aquí expuesto. Vid. en este sentido por ejemplo SCHULZ, J., Beiträge zur Nebenklage, Berlín 1982, pp. 183 y ss.

\footnotetext{
${ }^{365}$ Sobre esta cuestión se debatió ampliamente en ambas ocasiones pero quizá la discusión más sustanciosa, que además culminó con la aprobación de una propuesta favorable a la acusación subsidiaria del perjudicado, fue la del segundo Deutsche Juristentag. Vid. Verhandlungen des 2. deutschen Juristentages, $1^{\mathrm{a}}$ parte Berlín 1861, esp. pp. 131 y ss. y $2^{\mathrm{a}}$ parte, Berlín 1862, pp. 376 y ss., así como el resumen en Goltdammers Archiv, T. X, (1862), pp. 201 y ss., y la reseña con las deliberaciones y decisiones, así como la opinión del autor claramente favorable a la acción privada en KELLER, G. Die Staatsanwaltschaft in Deutschland (Ihre Geschichte, Gegenwart und Zukunft), Viena 1866, pp. 214 y ss. Vid. también MARQUARDT, H., Die Entwicklung des Legalitätsprinzip...., op. cit. pp. 38 y ss. El objetivo no era tanto la garantía de los intereses del particular cuanto evitar a través de éste el monopolio acusatorio del Fiscal. Lewald calificó la supresión del monopolio del Ministerio Fiscal, el cual constituía una amenaza para la libertad y la igualdad, como "paladión para la libertad civil" (Palladium für die bürgerliche Freiheit). Vid. también HAHN, C., Die gesammten Materialien zur Strafprozeßordnung, Berlín 1885, p. 442; WEIGEND, Deliktsopfer..., pp. 116 y ss.
} 
determinados delitos (de imprenta, políticos, etc.), se propuso también de forma complementaria el reconocimiento para estos supuestos de un ejercicio popular de la acusación $^{366}$. No faltó quien, para apoyar esta postura, argumentara que una acusación subsidiaria permitiría una más adecuada defensa por el MF de los intereses públicos puesto que actuaría con la certeza de que, en caso de rechazar la persecución, podría incorporarse al proceso el acusador privado, de forma que se le descargaría de trabajo ${ }^{367}$.

Las críticas no sólo procedieron de los partidarios del monopolio del Ministerio Fiscal, sino también de los que vieron en estas propuestas un excesivo peso de los intereses privados en la satisfacción. Para salvar tales inconvenientes, fue elaborada la tesis que propugnaba la acusación popular subsidiaria, planteada principalmente por Rudolf von GNEIST en su obra publicada en 1874 Vier Fragen zur Deutschen Strafprozeßordnung ${ }^{368}$. Este profesor de Derecho Público y político liberal defendió apasionadamente su propuesta con relativo éxito en el $12^{\circ}$ Congreso de los juristas alemanes de $1875^{369}$ y en los debates parlamentarios de la Ordenanza Procesal Penal del Reich de 1877, recibiendo apoyos que llevaron a la aprobación de su propuesta en el primero, pero no a su definitiva incorporación al ordenamiento jurídico.

${ }^{366}$ Vid. por ejemplo STAUB, K., Über den Geschädigten nach zürischem Strafprozessrechte, Zürich 1905, p. 46.

${ }^{367}$ SCHWARZE, F.O., "Die Reform der Staatsanwaltschaft”, Der Gerichtssaal 16 (1864), p. 401.

${ }^{368}$ Propugnaron también una acusación popular subsidiaria von HOLTZENDORFF y von BAR. El primero de ellos, ilustre publicista, la bautizó como "acusación de los ciudadanos del Estado" (Staatsbürgerklage) y vió en ella una poderosa garantía de defensa del derecho público; von HOLTZENDORFF, Die Umgestaltung der Staatsanwaltschaft von Standpunkt unabhängiger Strafjustiz, Berlín 1865, pp. 38 y ss. y Verhandlungen des 12. Deutschen Juristentages, $1^{a}$ parte, Berlín 1874, pp. 64 y ss. Vid. también von BAR, Kritik der Principien des Entwurfs einer Deutschen Strafprozeßordnung von Januar 1873, Berlín 1873, pp. 9 a 12, que hace valer el aspecto político de determinados delitos. Posteriormente también ULLMANN, E., Lehrbuch des deutschen Strafprozessrechts, Munich 1893, pp. 207-211 que destaca su papel garantizador frente a la introducción de un principio de oportunidad del que es ferviente partidario, y GEYER, A., Lehrbuch des gemeinen deutschen Strafproceßrechts, Leipzig 1890, pp. 407 y ss. Por último, Franz LISZT vió también en ella una garantía y propuso la introducción de una acusación ciudadana subsidiaria (staatsbürgerliche Subsidiaranklage) que sustituyera en Austria a la acusación subsidiaria del perjudicado: LISZT, F., "Das Prinzip der Strafverfolgung nach dem österreichische Strafgesetzentwurfe", Strafrechtliche Aufsätze und Vorträge, T. 1, Berlín 1905, p. 35. Vid. también su opinión en favor de la acusación popular subsidiaria en Mitteilungen der Internationalen Kriminalistischen Vereinigung, T. 16, Berlín 1909, p. 39 y ss. y la réplica de ROSENBERG (p. 248 y s.) para el que, sin limitar la acusación al particular ofendido, ésta sólo debería extenderse a aquellos que demostraran un interés en la persecución y no a todos los ciudadanos.

${ }^{369}$ En el $12^{\circ}$ Deutsche Juristentag (DJT), celebrado en Nüremberg en 1874 GNEIST fue ponente. Von HOLTZENDORF defendió el papel del principio de legalidad y von GNEIST se pronunció por una actio popularis como garantía de éste. Su propuesta de introducción de la acusación privada como complemento general a la del fiscal para el mantenimiento del derecho público recibió un apoyo general y se asumió por mayoría. 
GNEIST consideraba la obligación de acusar como un deber ciudadano, principal fundamento de la libertad civil contra las transgresiones del poder estatal y su idea de la acusación popular se enmarcaba en un sistema de participación de los ciudadanos en la Administración Pública ${ }^{370}$. El derecho privado de acusación que garantizase la actividad persecutoria pública debería corresponder a todo ciudadano sin distinguir la incidencia del delito en su esfera personal o patrimonial, ya que el concepto de perjudicado vendría a contradecir la naturaleza del derecho penal y, por su imprecisión, nunca podría llegar a ser definido jurídicamente. Superando la idea de la mera compensación al dañado por el delito, la acusación de los particulares podría servir de esta manera al interés público en la persecución criminal $^{371}$.

El máximo defensor en Alemania de la acusación popular era consciente de que sería utilizada en escasas ocasiones, pero lo decisivo no sería tanto el número de éstas, cuanto la garantía de la correcta actividad de la Administración ${ }^{372}$. Aun sin llegar a ejercitarse, asumiría un carácter de correctivo del MF frente al serio peligro de que éste pudiera convertirse en correa de transmisión del partido dominante, sirviendo a los intereses del gobierno de turno. Si el fiscal considerara que un hecho no era digno de persecución o si abandonara la acusación una vez iniciada, no habría mejor prueba de que se hace correctamente que el que no concurriera un acusador privado. En cualquier caso,

${ }^{370}$ La llamada Selbstverwaltung, según el modelo administrativo inglés del que era buen conocedor. Vid. por ejemplo sus obras Das Selfgovernment in England; Geschichte und heutige Gestalt der englischen Communalverfassung, pp. 569 y 629 y ss. En su más conocida publicación de temática procesal penal, Vier Fragen...op. cit., pp. 16 y ss. incardina la persecución penal en el derecho administrativo. Dentro de su visión liberal, el Estado habría asumido funciones que no serían compatibles con la libertad de los ciudadanos haciendo que éstos permanecieran en un papel pasivo. No ha de pasarse por alto que, según lo manifestado por GNEIST, la participación honoraria en asuntos de autoridad (Honorationselbverwaltung), debería permanecer solamente en manos de la alta burguesía y los nobles.

${ }^{371}$ PFENNINGER, advirtiendo también la dificultad de distinguir quien sería el perjudicado (directo, indirecto, por derivación, etc.) y conocedor de la doctrina italiana, diría casi cuarenta años después que la limitación de la acusación al ofendido sería un atavismo y que sólo funcionaría precisamente en los delitos cuya persecución precisa menos garantía. PFENNINGER, "Die Popularstrafklagen...", p. 275, que reitera así un argumento de los expuestos por ALIMENA y LUCCHINI. Él se muestra partidario de introducir en Suiza la acción popular subsidiaria, limitando el derecho de acusación a todos los ciudadanos con derecho a voto, lo cual daría una muestra de diferentes grados de participación ciudadana en la vida pública en los distintos cantones (p. 279). Esta opinión fue compartida por SCHWEIZER, M., Die Mitwirkung..., op. cit. p. 32, quien de paso se declaraba partidaria de negar el derecho de acusación a las mujeres en los cantones donde no pudieran votar.

\footnotetext{
${ }^{372}$ Advierte GNEIST que "deducir que porque se use poco sea innnecesaria es como decir que la responsabilidad de los Ministros también lo es porque se usa escasamente". Vier Fragen..., op. cit. p. 56. En opinión de PFENNINGER, "Die Popularstrafklage", op. cit. p. 273 "la acción popular cumpliría también sus objetivos aunque en la práctica no se hiciera nunca uso de ella". De ahí que la califique como "válvula de seguridad".
} 
la posibilidad de acusar debería quedar garantizada a través de la competencia (Concurrenz) entre la popular y la del Fiscal, agotándose la pretensión penal una vez ejercitada por cualquiera de ellos e impidiéndose volver a acusar ${ }^{373}$. Consideraba conveniente también establecer una serie de garantías: que el ejercicio se realizase mediante abogado ${ }^{374}$, que se depositase fianza, que fuera aceptada por resolución del Tribunal y, lo más característico de su propuesta: que tuviera únicamente una función subsidiaria. Además, el acusador estaría sujeto a responsabilidad por calumnia o falsedad, la retirada de la acusación debería contar por lo menos con la aprobación del fiscal para impedir su utilización como arma de chantaje o presión, debería evitarse preventivamente la concurrencia de varios acusadores y sería necesario mantener la investigación judicial y un juicio sobre la acusación de forma que se garantizase la fundamentación del procesamiento mediante una resolución jurisdiccional ${ }^{375}$.

Las muestras de conformidad con las tesis de GNEIST iban más allá de sus propios razonamientos. Por ejemplo, aun apoyando éstas, el diputado WINDHORST vió en la acusación popular una forma de participación de las minorías en la vida estatal, von PUTTKAMER una garantía frente a la jerarquización de la fiscalía y von SCHWARZE la forma ideal de participación de la sociedad civil ${ }^{376}$. Estas propuestas fueron también defendidas incluso fuera de Alemania ${ }^{377}$.

El tema se suscitó nuevamente ya en nuestro siglo con ocasión del debate sobre la instauración de mecanismos de aplicación del principio de oportunidad en el proceso penal en el periodo de entreguerras. MANNHEIM puso el acento para la defensa de la acusación popular en el afianzamiento del principio de legalidad por razón de los intereses de la colectividad allí donde más peligro corrían, es decir, principalmente

${ }^{373}$ GNEIST, R., Vier Fragen..., op. cit. pp. 53 y 55.

${ }^{374}$ El ejercicio de la acusación privada exclusivamente por abogados había sido defendido en el $2^{\circ}$ Deutsche Juristentag de 1861 por HEINZE, que en este colectivo veía una mayor afinidad al interés público que en los demás ciudadanos. Vid. Verhandlungen..., $2^{\mathrm{a}}$ parte, p. 381.

${ }^{375}$ GNEIST, R., Vier Fragen..., op. cit. pp. 54 y 55.

${ }^{376}$ Vid. HAHN, Die Materialien..., op. cit. pp. 544, 1063 y s. Aun rechazándose esta propuesta, la comisión aceptó que estuviera legitimado para instar el Procedimiento para forzar el ejercicio de la acción no sólo el perjudicado sino cualquier denunciante. Vid. pp. 1071 y ss.

${ }^{377}$ Así por ejemplo en Francia esta opinión fue mantenida por ODILON BARROT. 
tratándose de delitos sin un perjudicado en sentido estricto ${ }^{378}$. STUMM se pronunció en favor de una acusación popular subsidiaria que colmase las lagunas de la actividad del fiscal acompañada de ciertos contrapesos ${ }^{379}$. Von LOBE, con motivo de la discusión acerca del mantenimiento o no del principio de legalidad en el $28^{\circ}$ Congreso de Juristas alemanes, propuso la instauración de una acusación privada subsidiaria en favor del ofendido por el delito para el caso de que el fiscal rechazara acusar, pero, precisamente con la excepción de las hipótesis en que ese rechazo se debiera a razones de oportunidad, supuestos en los que el oficial acusador debería tener capacidad para decidir si se perseguía o no ${ }^{380}$. HÖPLER, aun haciendo valer la especificidad de los delitos políticos, sugería la extensión de aquella legitimación a todos los ciudadanos en todos los delitos ${ }^{381}$.

Sus adversarios fueron muchos más que sus defensores y propuestas de este calado no llegaron a plasmarse normativamente. No quisiéramos pasar por alto en este momento una expresión elaborada para la crítica a esta teoría: “Es un lujo legislativo el habilitar una posibilidad de acusación que no será nunca utilizada para fines rectos" ${ }^{382}$. Con ello lo que se quiso fue introducir un matiz negativo en el haber de la acusación popular. Se alegaba que sería una utopía entender que el no perjudicado por el delito va a tomarse la molestia de acusar y, probablemente, la única utilidad a la que sirviera sería la de acusar a

${ }^{378}$ MANNHEIM, "Die Durchbrechung der Legalitätsgrundsatze”, Juristische Wochenschrift, T. LIII (1924), pp. 1646 y ss. aun cuando él sea partidario de su intangibilidad, a diferencia de otros autores citados anteriormente que propugnaban la acusación popular como contrapeso a la introducción de la oportunidad.

${ }^{379}$ STUMM, H.R., Der Antrag auf gerichtliche Entscheidung nach par. 172 StPO, Leipzig 1927, pp. 7 y 8.

${ }^{380}$ Von LOBE, Reform des Strafverfahrens. Zweite Sitzung der Dritten Abteilung. Abhandlungen des 35. Deutschen Juristentages (1928), Berlín, Leipzig 1928, p. 572. En cualquier caso el perjudicado tendría que estar informado de los motivos que el fiscal adujera para no perseguir. Vid. también del mismo autor "Zur Reform des Strafprozesses", $G S$ (1928), pp. 37 y ss., esp. p. 45 donde se opone a la acusación popular subsidiaria por los peligros de manipulación y persecuciones fraudulentas a que podría dar lugar.

381“Reform des Strafverfahrens. Zweite Sitzung der Dritten Abteilung. Abhandlungen des 35. Deutschen Juristentages (1928)”, Berlín, Leipzig 1928, p. 632.

${ }^{382}$ Aun cuando no sea atribuible a él, la frase la tomamos de PFENNINGER, "Die Popularstrafklagen", op. cit. p. 266, cuando expone, basándose en GLASER, SÜSS, OETTINGER, CARRARA, CASORATI, BENEVOLO Y HÉLIE los argumentos en favor de la acusación subsidiaria solamente del perjudicado por el delito. Calificar a la acusación popular como "lujo del derecho" es, sin embargo, frecuente hoy entre la doctrina procesal española para ensalzar las virtudes que de ella se afirman. Vid. por todos y como ejemplo ALMAGRO NOSETE, J., "La acción popular ante el Tribunal de Garantías Constitucionales. Valoración crítica", Revista de Derecho Político. UNED. $\mathrm{n}^{\circ}$ 12, invierno 1981/82 pp. 66-83, p. 85 o LOZANO-HIGUERO y PINTO, M., La protección procesal de los intereses difusos, Madrid, 1983, p. 253. 
inocentes y con ello desviar la atención del Tribunal o la de proteger a un culpable con acusaciones simuladas.

\section{En Italia}

ALIMENA defendió en Italia la idea originaria de GNEIST sobre la acusación popular subsidiaria en una propuesta ante el V Congreso Nacional Jurídico y Forense de 1903. A tenor de ésta debería reconocerse la facultad de acusar con carácter subsidiario al MF sin hacer distinción entre ofendidos y no ofendidos en todos los delitos públicos ${ }^{383}$. Sus opiniones se cuentan aun hoy día entre las más reproducidas en nuestro país al referirse a la doctrina extranjera sobre la acción popular. Suya es la frase que ha devenido célebre en nuestra doctrina: "pienso que el ciudadano particular, encontrándose en la calle con los oficiales del Ministerio Fiscal no deba decirse a si mismo: he ahi los hombres que podrían dejar impune a mi asesino" 384 . A él pertenecen también muchos de los argumentos que se reiteran entre los defensores de la acusación popular en nuestro país $^{385}$. ALIMENA se sirvió de los razonamientos de la doctrina publicista alemana defensora de la participación ciudadana en la acusación y de la teoría del contrato social para afirmar que el ciudadano, como miembro del Estado, debería poder llevar a cabo todo lo que los oficiales públicos no hubieran hecho, siempre que fuera posible sin trastornar el mecanismo que se pretende activar, por lo que bastaría con quebrar el monopolio del Fiscal para que la educación de los ciudadanos hiciera el resto ${ }^{386}$. La oposición a ella basada en preocupaciones o prejucios políticos debería ceder, puesto que

${ }^{383}$ ALIMENA, B., "La azione penale popolare", Relación publicada en las Atti del V Congresso nazionale giuridico e forense, T. II, Palermo 1903, que se cita según su publicación en Studi di Procedura Penale, Turín 1906, pp. 204 y ss. Vid. también Accusa penale e parte civile (Pel cinquantesimo anno d'insegnamento di E. Pessina), Nápoles 1899, p. 239.

${ }^{384}$ ALIMENA, B., "L'azione penale popolare”, op. cit. p. 206. La expresión fue reproducida por GÓMEZ ORBANEJA en sus Comentarios..., op. cit., T. II, vol. I, p. 229 y es reiterada en múltiples ocasiones por FAIRÉN, uno de los principales paladines de la acusación popular en España.

${ }^{385}$ Tal y como ocurre con el que se afirma carácter absurdo de la atribución del ejercicio de la acción penal al ofendido por el delito y no al resto de los ciudadanos. A su juicio sería un absurdo: a) jurídicamente porque se excluye a los ciudadanos que, en cuanto tales, tienen interés en la persecución del delito, para admitir sólo a aquellos que, junto al interés común de todos los ciudadanos, tienen un interés pecuniario, y lo que es peor, un interés de venganza; b) políticamente, porque con ello los ciudadanos se acostumbrarían a dormitar, para despertar únicamente cuando el delito les afectase directamente; c) históricamente porque sería el retorno atávico a aquellos tiempos en que la justicia penal se encarnaba en la venganza del ofendido. ALIMENA, B., "L'azione penale popolare", Studi... op. cit. pp. 207 y ss.

${ }^{386}$ ALIMENA, B., “L'azione penale popolare”, Studi..; op. cit. p. 215. 
una institución puede ser aceptable aunque la propugnen los adversarios políticos ${ }^{387}$. Y por último, con respecto a su posible utilización fraudulenta, bastarían como garantías el consentimiento del Juez para su ejercicio y la prestación de una caución ${ }^{388}$.

Cualificados representantes de la llamada Scuola Positiva, aunque con la salvedad representada por FLORIAN, se pronunciaron también en favor de la participación de los particulares en la persecución, y en especial de la acusación popular. FERRI resaltaba la importancia de la actividad de los ciudadanos particulares, cuya acción debería unirse a la del Ministerio Público sin sustituirla para secundar lo que él denomina "reacción social defensiva ejercida por el Poder Judicial". Incluye en este sentido la acusación popular como una de las propuestas de la Escuela Positiva para dotar al proceso penal de "un mejor equilibrio entre los derechos y garantías del individuo y los de la sociedad" 389 .

En otros casos, sin realizar una distinción entre delitos públicos y privados, se admitía la acusación privada como principal o como subsidiaria, atribuyendo la titularidad para su ejercicio a todo ciudadano. Curiosamente, sin embargo, se exceptuaba al lesionado por el delito, con la intención de evitar la carga vindicativa que de su actuación pudiera derivarse ${ }^{390}$.

El sistema que gozó de cierto predicamento en Italia fue el del ejercicio subsidiario de la acusación por el perjudicado. En palabras de CARRARA, uno de los más elocuentes criterios para juzgar el mayor o menor grado de libertad civil permitido a los ciudadanos para regir la nación, es el que deriva de la mayor o menor participación que tienen los particulares en el ejercicio de la acusación de un delito. Sirviéndose de un concepto iusnaturalista, afirmaba CARRARA que el sistema natural sería la atribución de la acusación subsidiaria al ofendido o perjudicado, directo o indirecto, negándosela sin embargo a aquél en el que no concurriera esta condición ${ }^{391}$. El sistema en el que cualquier

${ }^{387}$ ALIMENA, B., “L'azione penale popolare”, Studi..., op. cit. p. 219.

${ }^{388}$ ALIMENA, B.,“L'azione penale popolare”, Studi... op. cit. p. 214.

${ }^{389}$ FERRI, Sociologia criminale, cit. según la traducción de SOTO Y HERNÁNDEZ, A., Sociología Criminal, Madrid s.f., T. II, pp. 199 y ss. En el mismo sentido, SETTI, L'azione penale e la scuola positiva, Roma 1888, p. 4.

${ }^{390}$ BERENINI, Azione ed istruzione penale, organi e funcione, Parma 1888, p. 298.

391 "Diritti que la legge di natura attribuici ad ogni individuo offeso per un delitto". Frente a este sistema, en favor del que él se pronuncia, existirían un sistema "liberal" que podríamos identificar con una acusación quivis ex populo y un sistema "restrictivo" al que CARRARA considera una tradición del despotismo. CARRARA, F., "La azione penale", Rivista Penale, vol. III (1875), pp. 6 y ss y 16. Nos encontramos ante los "principios de la razón 
ciudadano podría perseguir el delito (en su terminología, el "sistema liberal") sería propio de épocas pasadas, y su defensa formaría parte de una utopía que se estaba queriendo restaurar en aquellos momentos pero que no podría apoyar por ir "en contra del orden ${ }^{392}$. Su rechazo al sostenimiento del monopolio acusatorio del Ministerio Fiscal es, sin embargo, rotundo y a su juicio, la utilización artificiosa de las palabras habrían hecho la guerra a las ideas: la fórmula de que la acción penal es siempre pública es de creación moderna y consecuencia del monopolio del MF y se querría justificar el monopolio con aquella fórmula, cuando fue el monopolio el que la creó ${ }^{393}$. La acción penal será pública independientemente de quien la ejercite porque lo hará en interés de la colectividad y este derecho se concedería al ciudadano en cuanto tal y no como mero individuo. El proceso penal no podría ser camino para realizar la vindicta, aunque sea la pública, sino el existente para hacer operante la justicia ${ }^{394}$.

BENEVOLO fijó su atención especialmente en la posibilidad de que el fiscal no continuase una persecución por razones de oportunidad ${ }^{395}$. En este caso el ofendido

absoluta" sobre los que CARRARA hace descansar el saber científico en los procesos penales. Bajando al terreno práctico, él se confiesa admirador del entonces reciente sistema austriaco de acusación subsidiaria. Para defender su propuesta de acusación privada argumentaba que la querella criminal contra un inocente sería una perturbación y un perjuicio menores que los que ocasionan ciertos litigios civiles que se prolongan durante años por la solvencia económica del contrincante. CARRARA, "Azione penale”, op. cit., p. 13. MANDUCA considera este argumento impropio del ilustre jurisconsulto, ilógico y débil: mientras que para ejercitar la acción penal ya existe un funcionario imparcial a quien se atribuye esa misión, la acción en el proceso civil sólo se confía al interesado. Además, continúa MANDUCA, en la Italia meridional o insular, donde la veganza tiene tal poder, conceder el derecho de acusación sería lo mismo que cooperar al aumento de la delincuencia. MANDUCA, El Procedimiento penal y su desarrollo cientifico, Madrid s.f., p. 168.

${ }^{392}$ Ello aun autocalificándose como liberal, y mostrando ciertas simpatías por un sistema donde primaría "el amor a la libertad". CARRARA, F., "La azione penale", op. cit. pp. 7 y 10.

${ }^{393}$ Con ello estaríamos entrando en un un círculo vicioso. Sólo podría adoptarse el monopolio de la acusación por el MF cuando quedase garantizado simultáneamente el principio de legalidad. CARRARA, F., "La azione penale", op. cit. pp. 15 y 18. GÓMEZ ORBANEJA recoge la opinión de CARRARA afirmando que la realiza "rompiendo una lanza en favor de la acción popular". El autor italiano ya se había pronunciado algunas páginas atrás en contra de la acusación popular para defender una participación exclusiva del ofendido, por lo que sólo es admisible la afirmación de GÓMEZ ORBANEJA teniendo en cuenta que con ella incluía la acusación del ofendido en un concepto amplio de acción popular penal. Vid. GÓMEZ ORBANEJA, E, Comentarios..., op. cit., T. II, vol. I, p. 216.

${ }^{394}$ Se puede encontrar una concisa exposición de las opiniones de CARRARA sobre el proceso penal en BETTIOL, op. cit. p. 183.

${ }^{395}$ BENEVOLO, F., “Le riforme al codice di procedura penale”, Riv. Pen., vol XXXII (1890), pp. 109 y ss. Otros autores no son partidarios de la acusación privada pero como contrapeso solicitan la garantía del principio de legalidad. En este sentido vid. BERENINI, Azione e istruzione penale, op. cit., pp. 185 y s. 
tendría un derecho natural a excitar la actividad de la jurisdicción penal, ostentando una función de cooperador con el Ministerio Público en la acusación. Se le debería reconocer por ello la potestad bien de actuar conjuntamente con él, bien al menos subrogarse en su misión, de forma que pudiera dar el impulso necesario a la acusación y corregir su desviación caso de ser necesario ${ }^{396}$. Sería menester únicamente el depósito de una caución de cuantía proporcionada y establecida por el juez con la que poder hacer frente a los perjuicios que en su caso se originaran a un acusado inocente ${ }^{397}$. La acusación popular carecería de sentido desde el momento en que ya existía un órgano público acusador junto con la facultad de cualquier ciudadano de poner en su conocimiento la comisión de un delito a través de la denuncia. Además de constituir "una utopía" el que alguien fuera a participar voluntariamente en la persecución, un no ofendido podría tener interés en desviar la instrucción de la causa o buscar solamente un provecho personal en ella ${ }^{398}$.

Esta opción ha encontrado algún apoyo posteriormente. Por ejemplo, LEONE la vió como una de las formas adecuadas para la intervención de la víctima titular de los bienes y derechos tutelados por la norma, que estaría interesada en el efectivo cumplimiento de ésta. Sin embargo, la extensión absoluta de esta facultad a todos los ciudadanos concibiendo alguna forma de acusación popular, carecería de sentido: no se podría tolerar una tutela individual de intereses generales, para lo cual contaríamos ya con el Ministerio Público ${ }^{399}$. Admite también GUARNIERI la acusación subsidiaria del perjudicado rechazando la acusación popular porque no considera conveniente conceder a cualquier ciudadano a capricho el control sobre la actividad de un funcionario público. La extensión en el ámbito de participación en el proceso penal vendría a expresar una exigencia de mayor participación del ciudadano en la vida pública (democracia) así como la más alta tutela de los derechos individuales (liberalismo), por lo que la acusación del ofendido respondería a las exigencias sociales y se encuadraría en una concepción

\footnotetext{
${ }^{396}$ Ibídem.

${ }^{397}$ BENEVOLO, op. cit. p. 116.

${ }^{398}$ Citando a CASORATI, partidario también de la titularidad de la acusación en manos del perjudicado, sostiene que pensar que un ciudadano asuma el peso de ejercitar la acción penal cuando no tenga un interés personal en ello es una utopía. CASORATI, "Il processo penale e le riforme" en Monitori dei tribunali, XIX, XX; BENEVOLO, op.
} cit. p. 115.

${ }^{399}$ LEONE, "Linee generali di una riforma del processo penale", Riv. It. dir. pen. (1948), pp. 235 y ss. 
democrática y liberal de la sociedad ${ }^{400}$.

Una teoría de la participación popular en la acusación genuinamente italiana, elaborada como solución de compromiso, trató de conjugar el control de la (in)actividad del MF con la defensa de intereses de carácter social, intentando en alguna medida hacer revivir la división procedente del derecho romano entre crimina publica y delicta privata. El perjudicado por el delito tendría una vía de control a través de la acción civil, pero era constatable que en determinados casos ello carecería de efectividad por lo que sería preciso abrir los cauces legitimatorios cuando no hubiera un ofendido directamente. En este sentido se propugnó la admisión de la acusación popular solamente en delitos contra el Estado o intereses públicos o sociales, hipótesis en las que se debiera admitir la acusación de ciudadanos en pleno goce de sus derechos civiles y políticos, permitiendo así su intervención en delitos de naturaleza política ${ }^{401}$. CODACI-PISANELLI sostenía una concepción de la acusación popular como "válvula de seguridad" frente a la sospecha de inactividad del órgano público de la acusación, al cual debería venir atribuida como regla esta competencia ${ }^{402}$. La acusación quivis ex populo, utilizada de forma excepcional en circunstancias extraordinarias, garantizaría el correcto desempeño de una función sustancialmente pública y, en los momentos de normalidad, tendría una eficacia preventiva puesto que bastaría la posibilidad de su ejercicio para impedir los abusos frente a los cuales se erige en defensora ${ }^{403}$. Advertía también de la inutilidad de abrir válvulas de seguridad si no se repara previamente la maquinaria a la que sirven, por lo que se mostraba favorable a colmar en primer lugar las lagunas existentes en la materia jurídica a la que debía referirse y a la configuración orgánica del mejor modo posible del Ministerio

\footnotetext{
${ }^{400}$ GUARNIERI, G., Le parti nel processo penale, Milán 1949, pp. 162 y s. Destaca el autor también su predilección por este sistema frente a otras formas de control del Ministerio Fiscal como el control parlamentario, que él considera inconsistentes prácticamente y contraproducentes.

${ }^{401}$ CODACI-PISANELLI, "Se, in quale limite, e con quali cautele, possa, in relazione ad alcune categorie di reati, ammetersi sussidiariamente l'azione penale civica o popolare", Atti del III Congresso giuridico nazionale, $\mathrm{p}$. 171. En la interesante obra Le azioni popolare, Nápoles 1887, CODACI-PISANELLI había realizado ya una detallada exposición sobre las acciones populares romanas y sobre su función en aquel momento. Defiende su concepción subsidiaria de la acusación popular en las páginas 112 y ss. En la obra propone la distinción, que ha devenido clásica en la doctrina italiana, entre acciones populares supletivas y acciones populares correctivas (pp. 169 y s.).

${ }^{402}$ Con ello se aparta expresamente de los modelos del Derecho Romano y del Derecho Inglés, puesto que ni en uno ni en otro existía un órgano público con aquella función.

${ }^{403}$ CODACI-PISANELLI, Azione popolare, op. cit. pp. 112 y s.
} 
Público al que debía suplir ${ }^{404}$. El acusador popular sería una garantía de la represión de determinados tipos de delitos, pues supliría la inercia del oficial público asociándose a él cuando, por falta de tiempo o por parcialidad pudiera no perseguir las infracciones a la ley.

CODACI-PISANELLI defendió en el III Congreso Jurídico Nacional de 1891 (y consiguió que el pleno aprobara) una propuesta de introducción gradual de una "acción cívica" en materias en las que pudiera ser de utilidad. Se planteó así el acogimiento del ejercicio quivis ex populo de la acusación por delitos relativos a salud pública, para la exigencia de responsabilidad de los funcionarios públicos por concusión o corrupción y para las infracciones de reglamentos locales o generales (medios de transporte, emigración, policía industrial, rural o edilicia, etc.). La forma de hacerla valer sería la misma que en el caso de las acciones privadas, no se necesitaría abogado ni procurador para las dirigidas contra funcionarios y la totalidad o parte de lo recaudado en concepto de multas impuestas a instancias de acusadores populares se destinaría a instituciones públicas de beneficencia. Por último, debería ser exigible también un depósito que se destinaría a las mismas instituciones de beneficencia en caso de absolución y que, junto con una multa, hiciera frente a posibles abusos de acusadores privados ${ }^{405}$. La discusión al respecto continuó en el proceso de elaboración del Código FINOCCHIARIO-APRILE, sobre el que volveremos algunas páginas más tarde.

CESARINI admitía el ejercicio de la acción penal por el ciudadano ofendido o perjudicado, pero admitía la acusación subsidiaria de cualquier ciudadano, ofendido o no, como suplemento de la inacción del MF en delitos que produjeran daño público inmediato $^{406}$.

\footnotetext{
${ }^{404}$ Ibídem. Con relación a la dependencia del Ejecutivo, que originaría diferente interés en la persecución en función del delito y de la afinidad ideológica de su autor, entiende CODACI-PISANELLI que es un inconveniente corregible pero no eliminable. Por ello, con la introducción de la acción popular, "nadie podría decir que este o aquel individuo gozan de una inmunidad parcial y culpable".

${ }^{405}$ En materia de derecho de asociación y de reunión se prescindió de solicitar acción popular puesto que las legislaciones específicas no estaban delineadas con claridad, y la acción popular originaría distorsiones en ellas. Con respecto a delitos graves como los dirigidos contra la seguridad del Estado, la administración pública, la revelación de secretos oficiales, etc. no se creyó conveniente que pudieran ser perseguidos por alguien no investido de potestad pública. Los delitos de distracción de caudales públicos o de abuso de autoridad no podrían ser perseguidos por el Fiscal puesto que sólo difícilmente pueden ser conocida su existencia fuera de la Administración. Vid. BRUNO, T. op. cit. p. 958 y LUÉ, op. cit. pp. 1433 y ss.
}

${ }^{406}$ CESARINI, Della libertá ed independenza di apprezamento del P. M. di fronte alle parti private. Discorso 
STOPPATO vinculaba la ofensa al derecho de acción, subordinando la actividad del particular en el proceso penal al daño sufrido en sus derechos o en la esfera de su actividad jurídica. Donde hubiera ofensa debería haber acción, pero la relación entre acción y daño podría ser más o menos estrecha, lo que llevaría a distinguir entre diferentes supuestos. Rechazaba así la admisión pura y simplemente de la actio popularis y proponía una "acusación cívica" (acusación subsidiaria de todos los ciudadanos) sólo en los delitos que acarrearan daño público inmediato, dejándola en manos de los concretos particulares donde el daño fuera individualizable ${ }^{407}$. La única garantía exigible a quienes quisieran hacer uso de ella sería el depósito de una caución dirigida a hacer frente a las responsabilidades en supuestos en que se apreciare temeridad ${ }^{408}$. La acusación popular ilimitada sería rechazable porque introduciría perturbaciones en el orden, pero no porque no se adaptara a su época, como afirmaba CARRARA, según demostraría la pervivencia de acusación popular para los delitos electorales. Precisamente por ese potencial que llevaba consigo, podría resultar de utilidad para la persecución de conductas criminales que atacaran bienes colectivos, lesionando derechos sociales y públicos, turbando la tranquilidad y el buen orden social y, sólo de forma refleja, dañando intereses individuales $^{409}$. La acusación popular sería para STOPPATO, suscribiendo las palabras de CODACI-PISANELLI, una forma de participación voluntaria en la vida pública tendente a garantizar la aplicación del control judicial a un determinado acto. Con ella se desarrollaría un sentido de solidaridad entre los ciudadanos que les llevaría a desear

inaugurale del 1872, p. 158, cit. por MANDUCA, El procedimiento penal..., op. cit. p. 142 y por STOPPATO, quien muestra su adhesión a esta opinión: STOPPATO, A., "L'esercizio dell'azione penale" en Riv. Pen. vol. XXXVIII (1893), p. 7, n. 2. Incluye Manduca entre los que sustentaban esta teoría al también magistrado BORGATTI.

\footnotetext{
${ }^{407}$ El autor cifra gran parte de su empeño en establecer una nítida distinción entre delitos de acción privada y de acción pública, para dedicar su atención a estos últimos. Ello le lleva a hacer un interesante repaso de las opiniones doctrinales al respecto de los autores de la Scuola positiva así como de sus detractores. STOPPATO, A., "L'esercizio dell'azione penale" en Riv. Pen. vol. XXXVIII (1893), pp. 5 y ss. A su opinión se adhirieron la Corte de Casación de Florencia y la Facultad de Derecho de Pisa: Osservazioni e pareri. Lavori preparatorii per la riforma del codice di procedura penale per il Regno d'Italia, Vol. IV, Roma 1902, pp. 17, 18 y 23.

${ }^{408}$ STOPPATO, A., "L'esercizio dell'azione penale", op. cit. p. 10.

${ }^{409}$ Serían en general aquellos delitos de mera creación política en los que el daño no es de carácter personal y fácilmente individualizable. Entre éstos se incluirían los electorales y de imprenta, los relativos al derecho de asociación y reunión, los de los funcionarios públicos, los cometidos contra la salud y la alimentación públicas, los delitos contra el orden público como la incitación a delinquir, contra la libertad de culto, la libertad del trabajo, de la industria y el comercio, los abusos de los ministros del culto, las infracciones contra la salud pública, sobre la seguridad de los medios de transporte y de comunicación, los fraudes en subastas, en el comercio y la industria o los delitos de peligro común. Op. cit. p. 8 .
} 
defender a sus consociados y se produciría un aumento en las energías del Ministerio Público ${ }^{410}$. Sin embargo, en su participación en la discusión parlamentaria sobre el proyecto de ley, STOPPATO no pudo por menos que apartarse de su teoría confesando lo que el denomina "pecado de juventud" por haber querido extender tanto la titularidad para el ejercicio de la acusación. Aun afirmando que teóricamente la acción como reacción al delito es un derecho humano y una potestad natural, prácticamente, es decir, políticamente no necesitaría reconocerse una especie de derecho constitucional de actuar o de mover por propia iniciativa la pretensión punitiva. Mientras la acción penal en sí sería una potestad natural, su ejercicio constituiría una potestad política, y a su parecer, no se habría llegado a tal nivel de elevación política y educación moral y social como para conceder a todo ciudadano la habilitación para deducirla ${ }^{411}$.

Un modelo ciertamente novedoso y con alguna similitud al sistema acusatorio español pero limitado a ciertos delitos, fue el propuesto por LUCCHINI en la Comisión

${ }^{410}$ CODACI-PISANELLI, op. cit. p. 171. El Ministerio Público, sometido a las variables condiciones de la política y la consecuente dependencia del Ejecutivo, se sentiría aguijoneado cuando fueran estimadas las pretensiones de un particular y él no hubiera contribuido a ello (p. 11). Incluso aun no estando sometido a presiones políticas, el fiscal podrá errar en su actividad y en este caso tampoco sería justo evitar la participación privada.

${ }^{411}$ Vid. la narración de este cambio entre el STOPPATO científico y el legislador, realizada por BATTAGLINI, G., La querela, Turín 1958, pp. 138 y s. 
para la elaboración de un nuevo Código procesal penal en 1899 de la que era relator ${ }^{412}$. Según éste, el Ministerio Público bajo la dirección y responsabilidad del Ministro de Justicia, seguiría siendo el encargado de la acusación con carácter exclusivo para la generalidad de los delitos públicos. Sin embargo, previa autorización del juez, también se consentiría la acusación deducida por ciudadanos particulares exclusivamente para los delitos que interesan especialmente a la res publica (delitos contra la libertad, la Administración Pública, la fe, la salud pública, etc). Los interesados deberían gozar de determinadas condiciones de reputación y de capacidad y habrían de preverse oportunas sanciones para el caso de que se abusara de tal facultad. Ello beneficiaría al reforzamiento de la acusación y contribuiría a solventar posibles deficiencias e incurias del fiscal, constituyendo un eficaz sentimiento de cooperación y de solidaridad en la administración de la justicia penal ${ }^{413}$.

En Italia se han dejado oír posteriormente, aunque no con demasiada intensidad,

\footnotetext{
${ }^{412}$ Sobre el proceso de aprobación del Código FINOCCHIARIO-APRILE puede verse VACCA, G., Commento al CPP, vol. I, Turín 1913, pp. 93 y ss. LUCCHINI, L., “Azione penale. Appunti di reforma legislativa. Relazione alla Commissione nominata dal ministro Finocchiaio-Aprile per la riforma del codice di procedura penale", Riv. Pen. vol. XLIX (1899), pp. 5 y ss. Publicada también en las Atti della Commisione, vol. 1, pp. 17 y ss, Roma 1900 junto con la interesante discusión en el marco de la Comisión legislativa en la que sostuvo sus posiciones frente a NOCITO, MAZELLA y MARSILIO, contrarios a la acción popular. Debe reseñarse que los autores citados conocían no sólo las normas procesales penales, sino también las opiniones de la doctrina alemana. Sus puntos de vista fueron originariamente expuestos en Il caratere preventivo e il meccanismo istruttorio che vi si riferisce nel processo penale: Schema progetto di legge, Venezia 1883 según se recoge en el Progetto del Codice di Procedura Penale per il Regno d'Italia (Finocchiario-Aprile). Parte I. Relazione Ministeriale, Roma 1905, p. 38. Asimismo expuso LUCCHINI sus opiniones en favor de una extensísima acción popular de carácter administrativo e incluso civil ante la Cámara de Diputados en 1885 con motivo de un proyecto de ley. En concreto se atribuiría legitimación a todo ciudadano con capacidad civil y residente en la correspondiente provincia para a) hacer valer los derechos civiles del pueblo o de ciertas clases contra actos de la Administración; b) contra aquellos que incumplieran sus obligaciones con un ente público; c) para hacer declarar la ilegalidad de las elecciones o de un nombramiento; d) para demandar la reparación de un daño causado por la actividad de la Administración. En estos casos, el Ministerio Fiscal estaría obligado a intervenir y el actor a depositar una fianza, sufrir la condena en costas si su demanda es rechazada y no renunciar a su acción. La sentencia sería válida erga omnes y todos los trámites del procedimiento estarían exentos de las tasas que se imponían comunmente. La acción popular incluiría también el derecho de constituirse como parte civil en el procedimiento penal así como de interponer los oportunos recursos. La referencia está tomada de CODACI-PISANELLI, op. cit. p. 113 pero se refieren a ella también LUÉ, op. cit. p. 1428 y BORGHESI, op. cit. p. 3.

${ }^{413}$ LUCCHINI, “Azione penale...”, op. cit. p. 11. Curiosamente propone apartar al perjudicado, ya sea en vía principal, ya sea en vía subsidiaria de la acusación. Sugiere en su lugar la instauración de un recurso ante el órgano jurisdiccional contra el fiscal que rehuse el ejercicio de la acción penal. Ello no se encuentra demasiado lejos del Klageerzwingungsverfahren alemán, al que en aquel país se había llegado como solución de compromiso. En Italia se alcanza de forma similar: el principal partidario de la acción popular en la Comisión legislativa lo propone para el perjudicado y en el debate posterior, esta facultad se extenderá a todos los denunciantes, impidiendo la participación popular directa en la acusación. Vid. también las discusiones en el marco de la Comisión. Atti della Commisione op. cit.
} 
voces en favor de la intervención de los particulares en la persecución. Una de éstas es la de MASSA, quien consideraba necesario reconocer eficacia a la voluntad privada de promover acusación, para lo que propuso su ejercicio subsidiario por el ofendido y el denunciante $^{414}$. Pero el debate sobre la acusación popular en Italia se reabrió fugazmente de nuevo a finales de los años 60 de nuestro siglo con motivo de una enmienda incluida en los trabajos preparatorios de un nuevo Código. El Diputado comunista GUIDI fue el principal valedor de esta propuesta, retomada de las tesis liberales sostenidas a principio de siglo, solicitada por gran número de magistrados y encuadrada por su defensor "entre las más avanzadas del pensamiento jurídico" $" 415$. Mediante la acusación popular se otorgaría a los ciudadanos un cauce de participación en la Justicia ${ }^{416}$, y se contribuiría a configurar mejor la posición del Ministerio Público, quien seguiría siendo titular indiscutible del ejercicio de la acción penal ya que el ciudadano sólo la deduciría de forma subrogada ${ }^{417}$.

El rechazo a esta iniciativa se basó principalmente en los dos mismos argumentos que a sus homólogas de varias décadas atrás: en primer lugar, la acusación popular nos haría retornar al proceso civil romano o al guidrigildo de los longovardos, y no se correspondería con la organización del Estado moderno, en el cual no se debería tolerar una tutela individual del interés público; y en segundo lugar el riesgo de "contiendas sin fin" abriría la puerta en la lucha política y administrativa a las más desordenadas pasiones de persecución y venganza, degradando el tono de las costumbres sociales y políticas. Con respecto a su valor como institución de participación democrática, se argumentaba que ésta debería encauzarse a través del control que el Parlamento debiera ejercitar sobre el Ejecutivo. Se refutó además el argumento de su incardinación constitucional para justificar todo lo contrario, o sea su exclusión, teniendo en cuenta la previsión del art. 112 de la Constitución italiana, que establece la obligatoriedad de la acusación del Ministerio

\footnotetext{
${ }^{414}$ MASSA, C., Voz “Azione popolare (dir. pen.)” en CALASSO, F. (Dir.) Enciclopedia del Diritto, 1957, p. 874.

${ }^{415}$ CAMARA DEI DIPUTATI, Delega al Governo per la riforma del codice di procedura penale, $\mathrm{n}^{\mathrm{o}} 1,1967, \mathrm{p}$. 533.

${ }^{416}$ Derecho constitucional que se derivaría del art. 102 de la constitución italiana, justamente y de manera similar a nuestro $125 \mathrm{CE}$, el que prevé que "la ley regulará los casos y la forma de la participación del pueblo en la Administración de Justicia".

${ }^{417}$ Ibídem. La acción popular, se decía, introduciría de este modo un elemento de corrección y de integración.
} 
Público y compele a éste a ejercitar la pretensión penal en el momento en que le conste una notitia criminis. En este caso, si por inercia o negligencia el fiscal considera que no concurren las circunstancias para la no perseguibilidad de una determinada conducta, estaría sujeto a responsabilidades que podrían incluso ser de naturaleza penal. Si la valoración en el sentido de la no concurrencia de las circunstancias que determinan la obligación de perseguir se realizase correctamente, no se entendería la función del particular acusador, que quedaría privada de toda justificación por la propia esencia del proceso $^{418}$.

\section{Modelos equiparables al español}

El modelo español de concurrencia de un sistema de acusación popular con la del Ministerio Fiscal ${ }^{419}$ apenas fue defendido en otros países, y sólo contó como valedor a SCHÜTZE, al que apoyó ZUCKER en las discusiones del $12^{\circ}$ Congreso de Juristas alemanes de $1874^{420}$. SCHÜTZE recogió los argumentos de GNEIST en favor de la extensión a todos del derecho de acusar junto con su idea de la Selbstverwaltung, pero, en su opinión, no por ello se habría de esperar a que el MF incumpliera sus obligaciones. Desde un punto de vista histórico, el derecho de acusación se situaría en un plano anterior a la existencia (y a la actividad) del Fiscal y constituiría un derecho natural del ciudadano, por lo que la presencia de un órgano estatal acusador en el proceso no podría privar al ciudadano de aquella facultad que tiene atribuida con carácter principal ${ }^{421}$. No sólo por razones históricas, sino también con fundamento en la propia estructura del proceso alegaba que si es necesario un control de su actividad acusatoria para que ésta se produzca sin fisuras, la subsidiariedad no es suficiente, sino que se convertiría en un arma de doble filo. Sirviéndose de razonamientos económicos argüía: "Si se quiere apartar un

\footnotetext{
${ }^{418}$ CAMERA DEI DIPUTATI, Delega al Governo per la riforma del Codice di procedura penale, Indagini conoscitive e documentazioni legislative, 1967, p. 536 y Discusse in assemblea, 1970, pp. 929 y ss. Vid en especial la intervención del ministro GAVA en la sesión de 21 de mayo de 1969.

${ }^{419}$ PFENNINGER, “Die Popularstrafklage...”, op. cit. p. 267, lo designa como “el modelo español”.

${ }^{420}$ Vid. Verhandlungen des 12. deutchen Juristentages, Berlín 1875, pp. 206 y 208 y SCHÜTZE, T.H., Das Staatsbürgerliche Anklagerecht in Strafsachen, Antritts Vorlesung, Graz 1896, pp. 13 y ss.

${ }^{421}$ SCHÜTZE, T.H., Das Staatsbürgerliche Anklagerecht.., op. cit. p. 13.
} 
monopolio, ello sólo se podrá hacer mediante la apertura de la competencia", con lo que su propuesta iba en el sentido de establecer un sistema en el que acusación del fiscal y acusación popular compitieran libremente ${ }^{422}$. Como correctivos frente a hipotéticas acusaciones abusivas citaba la necesidad de abogado, la fianza, el agotamiento de la pretensión penal una vez deducida, la intervención del Ministerio Fiscal en cualquier momento procesal y las prevenciones con que cuenta el ordenamiento jurídico contra las acusaciones falsas ${ }^{423}$. Incluso los partidarios de una acusación popular subsidiaria, como LISZT, vieron en estos argumentos una mera elaboración teórica sin fundamento jurídico alguno y sin posibilidad de materialización práctica real, por lo que la propuesta de SCHÜTZE no recibió apoyo alguno ${ }^{424}$.

PFENNINGER y STAUB fueron los únicos autores en lengua alemana que hicieron referencia a la acusación popular existente en el derecho español, y ello aun restándole importancia por su escasa utilización ${ }^{425}$. La mayoría de los que se ocuparon del tema de las acusaciones privadas no conocían la acusación popular española o, cuando menos, no hacieron referencia a ella. Así por ejemplo SUESS afirmaba textualmente que "la acción popular concurrente con la del Fiscal no está presente en ninguna de las leyes de los grandes países europeos". Desconociendo su ya consolidada existencia en España, apuntaba así sólo la vigencia en algún cantón suizo de manifestaciones de acusación popular $^{426}$. ALIMENA conocía y admiraba la acusación popular española, aunque relataba basándose en informaciones privadas su escasa utilización. En su opinión armonizaría de modo admirable las exigencias teóricas con las prácticas aun cuando no se hacía ilusiones sobre la intervención real de los particulares. Destacaba también la

${ }^{422}$ SCHÜTZE, T.H., Das Staatsbürgerliche Anklagerecht..., op. cit. p. 14.

${ }^{423}$ Afirmaba por último que si existiese peligro de que las acusaciones sirvieran como arma de presión, ello sería achacable de igual forma a los delitos privados, los perseguibles a instancia de parte e incluso a la propia facultad de denuncia de todos los ciudadanos. SCHÜTZE, T.H., Das Staatsbürgerliche Anklagerecht..., op. cit. p. 15.

${ }^{424}$ LISZT, ’Das Prinzip...”, op. cit. p. 33.

${ }^{425}$ PFENNINGER, H.F., “Die Popularstrafklage. Ein Beitrag zur Strafprozessreform”, Schweizerische Zeitschrift für Strafrecht / Revue Pénale Suisse, T. XIX (1916), p. 262.

${ }^{426}$ SUESS, E., Die Stellung der Parteien im modernen Strafprocesse, Viena 1898, p. 93.Vid también von HIPPEL, Deutsches Strafrecht, T. I, Berlín 1925, p. 106; DÖRING, W., Der Anklage- und Inquisitionsprozeß bei Carpzow, op. cit. p. 18; SCHWEIZER, M., Die Mitwirkung privater bei der Strafverfolgung, Dissertation, Zürich 1940, p. 18, así como el exahustivo trabajo de WEIGEND, T., Deliktsopfer und Strafverfahren, Berlín 1989, p. 86, n. 265 y 98, n. 296. 
posibilidad de que, si se retirase la acusación, le restaría al juez la facultad de llamar a los interesados en el ejercicio de la acción (art. 642 LECrim) ${ }^{427}$.

\subsubsection{Causas de su rechazo}

(a) En Alemania

El rechazo de la participación privada en el ejercicio de la pretensión por delitos públicos $^{428}$, fuera del tipo que fuera, vino de la mano del entendimiento de la acusación como función estatal ligada indisolublemente a la aplicación del ius puniendi. El particular carecería de toda pretensión para la imposición de la norma penal, puesto que ello sería una tarea pública. La acusación privada nos haría retroceder a modelos históricos ya superados que no se correspondían ni con el espíritu de la época ni con el desarrollo y la complejidad que el proceso penal había adquirido ${ }^{429}$. La idea predominante en aquellos momentos de que la pena era retribución al Estado, y no a un particular, hizo impensable que a éste le pudiera incumbir de alguna manera la persecución penal ${ }^{430}$. Se adujo incluso que la acusación popular sólo sería posible allí

${ }^{427}$ Vid. ALIMENA, B., “Accusa privata e parte civile” en Studii..., op. cit. p. 174. Esta última afirmación llevó a GÓMEZ ORBANEJA a deducir que ALIMENA no se movía en el terreno de la experiencia cuando la hizo. GÓMEZ ORBANEJA, E, Comentarios..., op. cit., T. II, vol. I, p. 229. Vid. en concordancia con lo expuesto por ALIMENA, FLORIAN, E., "Degli organi per l'esercizio dell'azione penale e de gli scopi del processo", Riv. Dir. Proc. Penale, vol. III (1912), p. 421, n. 7, que toma la referencia de la traducción comentada de la LECrim al francés realizada por VERDIER et DEPEIGES, París 1898, p. XXXIX, n. I. En este mismo sentido se dirigía la propuesta de LUCCHINI, L., “Azione Penale (Appunti di reforma legislativa)” en Rivista Penale di dottrina, legislazione e giurisprudenza, T. XLIX, (1899).

${ }^{428}$ La discusión con respecto a la acusación privada en los llamados delitos privados no fue tan intensa y en general, con base en unas u otras razones, gozó de aceptación general el que el Estado no asumiera la persecución de algunas conductas penales sino que lo dejara exclusivamente en manos de los particulares. Vid. WEIGEND, Deliktsopfer..., op. cit. pp. 122 y ss.

${ }^{429}$ Vid. por ejemplo BIRKMEYER, K. Deutsches Strafprozeßrecht, Berlín 1898, p. 304; GOLDSCHMIDT, J., Zur Reform des Strafverfahrens, Tübingen 1919, p. 21. WEIGEND se refiere a ello afirmando que la idea de acusación popular poseía aspectos romántico-nostálgicos pero que "no sólo las condiciones de vida en general sino las exigencias necesarias para probar la culpabilidad del delincuente se habían tornado muy dificiles como para que se pudiera transferir a los particulares la obligación cívica de asumir los intereses de una comunidad perjudicada por el delito". Por ello, en su opinión, no habría de lamentarse el que no encontrara lugar en la legislación alemana. WEIGEND, T., Deliktsopfer..., op. cit. pp. 121 y s.

${ }^{430}$ En palabras de TIEDEMANN, "el Estado ha de castigar, para la realización de la justicia absoluta, cada violación de una ley penal sin excepción”. TIEDEMANN, K., "El Derecho Procesal Penal”, en el volumen colectivo Introducción al Derecho Penal y al Derecho Penal Procesal, Barcelona 1989, p. 171. 
donde contara con una larga experiencia, de la cual se carecería en Alemania ${ }^{431}$.

Parte de la literatura consideraba superflua la acusación de particulares, negando la necesidad de un remedio de esta naturaleza para suplir la desconfianza en el MF, puesto que ésta sería injustificada ${ }^{432} \mathrm{y}$, en todo caso, de una circunstancia que sólo se presentaría de forma aislada no podrían extraerse razones para establecer normas generales. Su sujeción al principio de legalidad operaría como suficiente garantía, en tanto lo contrario hubiera supuesto una muestra de la insuficiente e indeseada consolidación del principio de oficialidad. Aunque existiese esa necesidad, la acusación popular tampoco sería un método indicado puesto que, al dotarla de las necesarias cautelas, las condiciones serían tan gravosas que nadie de forma particular, a no ser los pudientes, aceptaría la molestia que supondría el acusar ${ }^{433}$.

Por otro lado, el daño al imputado cuando menos en su honor, si no también en su libertad personal, ya se habría producido de forma irreparable con la mera acusación aunque posteriormente se declarara infundada y el acusador tuviera que hacer frente a los perjuicios de su acción ${ }^{434}$. Se alegó asimismo que el efecto que podría originar una acusación particular sobre la actividad del fiscal sería negativo, puesto que éste actuaría con desidia o pereza, dejando lo que constituye su obligación en manos del perjudicado o de algún quivis ex populo que quisiera satisfacer intereses de venganza ${ }^{435}$. Por todo ello se estimaba que sería mucho más efectiva la exigencia de responsabilidades políticas al ministro bajo cuyo ámbito competencial recayera la actividad del MF a través de la

\footnotetext{
${ }^{431}$ El ilustre procesalista Adolf WACH sostuvo esta postura en el homenaje a BINDING: WACH, A., "Struktur des Strafprozesses” en Festgabe der Leipziger Juristenfakultät für Karl Binding, Munich, Leipzig 1914, p. 15.

${ }^{432}$ JANKA, K., Staatliches Klagmonopol oder subsidiäres Strafklagrecht, Erlangen 1879, p. 23, que veía incompatible con el Estado de Derecho el que el Fiscal actuara con criterios políticos y no de legalidad. En cualquier caso, cifraba sus esperanzas de independencia sobre todo en la función judicial (p. 40).

${ }^{433}$ JANKA veía el peligro de que, debido a los altos costes, se convirtiera en una acción clasista (Klassenklage), op. cit. p. 35 y HANAUER en HAHN, Materialien..., op. cit. p. 1066 quien expuso este argumento en la discusión de la RStPO justificando la insuficiencia de las cautelas económicas: los ricos podrían hacer uso de ella y los pobres solicitarían el beneficio de pobreza e impugnarían su denegación.

${ }^{434}$ SUESS, Die Stellung..., op. cit. p. 91.

${ }^{435}$ En este sentido MEYER, C., Strafverfolgung und Voruntersuchung, Leipzig 1897, p. 32, que se refiere al derecho suizo.
} 
opinión pública, la prensa o de los votos de los representantes del pueblo ${ }^{436}$.

Aún más negativamente se presentaban los peligros de abuso a que se pudiera prestar un derecho ilimitado de acusación, el cual, cuando menos, era calificado como arma de doble filo o herramienta de aspiraciones egoístas. Las posibles desdichas que se atribuían a la acusación popular caso de ser instaurada en el ordenamiento alemán, fueron comparadas con la apertura de la caja de Pandora: odios, deseos de venganzas, intereses personales, intrigas políticas o frivolidades se convertirían en moneda común, especialmente con motivo de delitos políticos en los que las facciones contrapuestas iniciarían una carrera de imputaciones llenas de odio ${ }^{437}$. BINDING vió en ella una “desgracia nacional” (nationale Unglück) que podría caer sobre el pueblo alemán por la avalancha de querellas (Mässenklagerei) que se avecinarían en la acusación de todos contra todos y que harían que acusadores profesionales les condujeran a los peores tiempos de la República y el Imperio romanos ${ }^{438}$. "Espada de Damocles para la tranquilidad de los ciudadanos" o "Caballo de Troya en el sistema" fueron otros de los calificativos empleados por sus opositores, expresivos de su contemplación como un instituto que haría quebrar los principios básicos sobre los que se asentaba el sistema. SCHMIDT-ERNSTHAUSEN aventuró incluso el argumento de que si se introdujera una acusación popular para delitos en los que no hubiera un perjudicado directo titular de bienes jurídicos protegidos, acecharía el peligro de una especie de gobierno paralelo de grandes asociaciones que en la persecución se mostrarían parciales ${ }^{439}$.

${ }^{436}$ JANKA, op. cit. p. 48 y WEIGEND, T, Deliktsopfer..., p. 121.

${ }^{437}$ JANKA, op. cit. pp. 27, 35 y s., HANAUER, en HAHN, Materialien, op. cit. p. 1066 y SUESS, Die Stellung... op. cit. pp. 90 y s., quien veía dos posibilidades: bien que no se utilizara en absoluto, con lo que estaría claro su carácter superfluo, bien que hubiera tal cúmulo de acusadores que la idea de unos nobles pensadores se transformara en una verdadera calamidad del Estado y sus ciudadanos por la sobrecarga de los Tribunales y la intranquilidad de amplios círculos de población.

${ }^{438}$ Dice BINDING: “Dejemos correr a la jauría y los más corrompidos tiempos de la república y el Imperio romano volverán. Los acusadores profesionales, denominados por Tacito como "unum maximum humanae vitae malum, delatorium execranda pernicies", crecerán como las setas después de la lluvia; con testigos sobornados, indicios preparados, quizá también sencillamente con la maleable dicción de un artículo flexible llevarán ante los tribunales día tras día con motivo de las pretensiones más diferentes el deudor al acreedor, el comunista lleno de odio al ciudadano considerado, el operario ineficiente al patrón estricto, el apóstata al creyente, el hijo expulsado por su padre a éste, la madre desconsolada a la hija rebelde, el inferior azuzado al superior intolerante". BINDING, Die drei Grundfragen..., op. cit. p. 5.

${ }^{439}$ SCHMIDT-ERNSTHAUSEN, “Legalitätsprinzip und Ausdehnung der Privatklage”, en ASCHROTT, P.F., Reform des Strafprozesses. Kritische Bemerkungen der von der Kommission für die Reform des Strafprozeßes gemachten Vorschläge, Berlín 1906, p. 197, tal y como relata ya ha ocurrido en otros países en conexión con los 
A pesar de todas estas opiniones, seguía presente la idea de encontrar un método de control privado de la actividad acusatoria monopolizada por el Estado, el cual se halló en el Klageerzwingungsverfahren (Procedimiento para compeler al ejercicio de la acusación). Precisamente con la intención de concebir para el ordenamiento procesal penal un instrumento de vigilancia de la actividad del Ministerio Fiscal, el diputado WOLFFSON introdujo en el debate parlamentario la propuesta de que todo denunciante pudiera recurrir ante un órgano jurisdiccional en caso de que el fiscal rechazara plantear acusación en el supuesto denunciado. El Tribunal debería tomar una decisión sobre la suficiencia de indicios para acusar, la cual, de ser afirmativa en el sentido de lo pedido por el particular, abriría la puerta del proceso al denunciante. Éste podría optar por dejar la acusación de nuevo en manos del fiscal o, si desconfiaba de su imparcialidad, contratar por sus propios medios un abogado que hiciera valer sus pretensiones ${ }^{440}$.

La Comisión Parlamentaria, aun consciente del papel activo que para la autorización de la acusación se confería al Tribunal ${ }^{441}$, encontró preferible esta propuesta frente a la que propugnaban la acusación popular subsidiaria. Sin embargo, la idea de que fuera un abogado particular el encargado de acusar no fue aceptada, pues se pretendía asegurar formalmente el monopolio del MF. La solución consensuada fue la de autorizar que cualquier denunciante estuviera legitimado para plantear acusación, pero en el supuesto de que éste fuera exitoso, sólo el perjudicado por el delito podría actuar en el proceso junto al MF como Nebenkläger (acusador adhesivo) ${ }^{442}$. El resto de los

detectives privados. En su opinión, en estos delitos graves, con la acción popular se abriría el camino a los tribunales a la envidia, el deseo de venganza, la presión y otras manifestaciones indeseadas, que en el extranjero ya se habían hecho patentes.

\footnotetext{
${ }^{440}$ A este tenor debemos recordar la opinión de SUESS quien, criticando el que como correctivo del monopolio acusatorio se encomendara el ejercicio forzoso de la acusación al MF, afirmaba que ello sería como encomendar las ovejas al lobo (textualmente, hacer jardinero al chivo, “den Bock zum Gärtner machen”). SUESS, Die Stellung..., op. cit. p. 107.
}

${ }^{441}$ GNEIST había vinculado la acción popular con el principio acusatorio y su defensa y veía en esta intervención de los Tribunales el primer paso hacia el regreso del proceso inquisitivo. Vid. HAHN, Materialien..., op. cit. p. 727 y JANS, p. 13. Las abundantes críticas que posteriormente recibió el Klageerzwingungsverfahren se fundamentaron precisamente en que era percibido como una manifestación del sistema inquisitivo puesto que, al forzar el Tribunal al ejercicio de la acción, se unificaban las funciones de acusación y fallo. Vid. p. ej. OSTLER, F., Das Klageerzwingungsverfahren, Breslau 1931, pp. 9 y s.

${ }^{442}$ La discusión al respecto se puede deducir de las opiniones de los diputados von PUTTKAMMER, von SCHWARZE, OEHLSCHLÄGER y GNEIST, todas ellas publicadas en HAHN, Die gesammte Materialien, op. cit. pp. 1063 y ss y 1078 y ss. Vid. el resumen y la interesante exposición que de toda la discusión realiza WEIGEND en Deliktsopfer..., pp. 142 y ss. En su opinión la Nebenklage tenía en aquellos momentos un papel marginal y una 
particulares denunciantes deberían asumir que la acusación se realizara por el MF aun cuando originariamente éste se hubiera opuesto. El modelo no fue aprobado por los gobiernos participantes en el proceso legislativo a través del Bundesrat, precisamente por la amplitud con que se había conferido el derecho de recurso (a cualquier ciudadano denunciante) ${ }^{443}$, así como por estimarse que no concurría la necesidad de tal garantía. La solución de compromiso alcanzada fue la de limitar esta facultad a los denunciantes en quienes concurriera la condición de ofendidos, manteniendo a quienes carecieran de esta condición únicamente un derecho de información sobre la marcha del proceso. La participación de los ciudadanos en cuanto tales, y no por su condición de afectados por el delito, quedó desdibujada en la norma procesal. La instauración del Klageerzwingungsverfahren a iniciativa del ofendido y la facultad de denunciar los delitos para todos los demás fueron considerados entonces en Alemania, y lo son hoy, cauces suficientes de intervención activa de los particulares en la promoción del juicio criminal $^{444}$.

\section{En Italia}

Los opositores a la intervención privada en el proceso fueron también aquí muchos y muy significados y su opinión se basaba de igual manera en la falta de adecuación de la acusación quivis ex populo a su momento histórico. La opinión de todos ellos partía además de un elemento común: la defensa de un MF independiente del Ejecutivo.

$\mathrm{Al}$ frente de quienes se enfrentaron ferozmente a la acusación privada de cualquier tipo se situó destacadamente MANDUCA, cuyos argumentos son tan contundentes que no nos resistimos a reproducir con detalle. La razón de su oposición frente a cualquier participación de ciudadanos en la persecución de delitos públicos, aun cuando fueran los

función totalmente accesoria y sólo en relación con la acusación en los delitos privados y en el Klageerzwingungsverfahren.

${ }^{443}$ El rechazo a aquella propuesta se debió a la negativa de configurar una acusación adhesiva popular (Popularnebenklage) puesto que ya había sido desestimada una acusación popular (Popularklage). El imputado podría tener que hacer frente a una innumerable cantidad de intrigas personales de los acusadores adhesivos. Vid. entre otros AMBSBERG, en HAHN, Die Gesammten Materialien..., T. 1, op. cit. pp. 1099 y ss.

${ }^{444}$ Vid. WEIGEND, Deliktsopfer..., op. cit. pp. 144 y ss. y NEUMANN, U., "Die Stellung des Opfers im Strafrecht" en HASSEMER, W. (editor), Strafrechtspolitik. Bedingungen der Strafrechtsreform, Francfort, Berna, Nueva York 1987, p. 244 quien ve en el reconocimiento de legitimación a los ofendidos por el delito una doble motivación: por una parte evitar las "acusaciones populares querulantes" y por otra convertir al perjudicado en vigilante del cumplimiento del principio de legalidad en el proceso concreto de que se trate, puesto que él mismo presionará por el cumplimiento de este principio. 
ofendidos, se cifraba en que sólo en un funcionario representante del poder social podrían darse los requisitos de rectitud, seguridad, energía y autoridad que personifican el principio de la justicia. La participación privada evocaría un pasado lejano de venganzas, y "la justicia no podría serena y tranquila describir su órbita, a fin de asegurar al ciudadano en los sagrados derechos de la libertad individual. A su acción tranquila, plácida, fría, acompasada, reemplazaría la apasionada, violenta, turbulenta, agitada del ciudadano" ${ }^{45}$. La justicia punitiva sería superior al individuo y hasta al mismo Estado, y aun reconociendo la necesaria garantía de la libertad individual, se habría de impedir que las iniciativas para su defensa obrasen en perjuicio de la iniciativa y libertad ajenas. Esa garantía se cifraría en la prohibición de intervenir el ciudadano, ofendido o no, en la formulación de la acusación pública, puesto que lo contrario no produciría más que daño. El derecho de constituirse acusador para suplir la presunta inacción del Ministerio Público no estaría por ello conforme ni con el derecho, ni con la política, ni con la psicología ${ }^{446}$.

No considera necesaria una garantía frente a la actuación del MF, quien según su planteamiento, por su independencia del poder Ejecutivo no tendría otro objetivo que la justicia y el derecho y cuyos actos no podrían ser más que efecto de la imparcialidad y estar separados de la pasión o la predilección ${ }^{447}$. Se muestra contrario a otro tipo de participación en el planteamiento de la pretensión penal, sea de la modalidad que sea, por cuanto causaría efectos contrarios a los que, de buena, fe creen los publicistas que, en

${ }^{445}$ MANDUCA, F., La procedura penale e la sua evoluzione scientifica, Nápoles 1888. Citado según la traducción de PINTOS, Á., El procedimiento penal y su desarrollo científico, Madrid s.f., pp. 143 y ss. El ofendido no es impulsado por un motivo altruista, sino por el egoísmo producido por comprensibles causas psíquicas y económicas y el abogado que le representara sería duro, feroz, y cualquier fiscal rígido sería débil a su lado. MANDUCA recordaba "abogados, distinguidos abolicionistas, sostener con la mayor frialdad, con repugnante cinismo, conclusiones que darían lugar, como consecuencia lógica, a un veredicto para imponer la pena de muerte" (p. 145) y continuaba preguntándose “¿Cuál de los dos sistemas es más estimable: el que se apoya en la calma, la serenidad, el amor a la justicia, o el que se funda en la agitación, en la ofuscación moral, en el odio, en la pasión, en la venganza? En pocas palabras, ¿Cual es el sistema más aceptable, el de la iniciativa individual, interesada directa o indirectamente en el castigo, o el de la iniciativa social, que no tiene otra aspiración que la justicia? No dudamos en escoger el segundo, porque responde a las exigencias sociales." (pp. 149 y s.). No creía además que acusación popular y Jurado tuvieran el mismo fundamento filosófico: mientras que éste, institución jurídica y a la vez política, sería a su juicio sinónimo de gobierno democrático, aquélla no dejaría de ser una manifestación de la reprobable venganza privada (p. 164).

${ }^{446}$ MANDUCA, F., La procedura penale..., op. cit. p. 147.

${ }^{447}$ MANDUCA, F., La procedura penale..., op. cit. p. 150. Para garantizarlo propone como principios de actuación del Ministerio Fiscal: a) independencia absoluta del Poder Ejecutivo; b) inamovilidad del cargo, como en la judicatura; c) independencia, libertad absoluta en el ejercicio de la acción penal; d) exclusivismo en el ejercicio de la acción penal; e) intervención del Ministerio Fiscal en el juicio civil. op. cit. p. 167. 
interés de la sociedad, la defienden ${ }^{448}$. La acusación popular subsidiaria degeneraría en arma de rencores privados, abriría la puerta a molestias injustificadas, alteraría la paz de las familias, quitaría prestigio al MF y atentaría a los derechos del Estado puesto que éste, por interés colectivo, tendría derecho para su existencia política, moral, económica y social a tener un órgano que represente el poder social y ejerza la acusación penal para la actuación de la justicia punitiva ${ }^{449}$. La opinión pública suficientemente informada como consecuencia de la garantía de la libertad de imprenta y prensa, sería suficiente freno ante posibles imposiciones del Gobierno a la actividad del Fiscal.

Recordando la utopía de ROUSSEAU, admite que la fórmula del mandato y delegación de la sociedad o de la autoridad social en el individuo particular para el castigo de los delitos contendría dos errores, los dos extremos igualmente peligrosos y absurdos (la estatolatría y omnipotencia del Estado y el arbitrio individual), pero no podría aceptar las conclusiones que de ello había extraído algún autor ${ }^{450}$. Los procedimientos penales no se determinan por el daño privado sino por el social y por ello al ejercitarse la acción penal por el fiscal no se anula la actividad individual ni la libertad personal sino que se afirman indirectamente. Concluye MANDUCA afirmando que la "acción penal cívica" (expresión que utiliza para referirse a la acusación popular), en vez de completar la que se ejerce de oficio, la neutralizaría, confundiría, destruiría en su fin y en sus efectos e implicaría diferencias sociales que no admite el derecho público porque el interés del ciudadano se compenetra con el interés general donde encuentra su potencialidad. Ni siquiera en delitos políticos la "acción cívica subsidiaria" sería garantía constitucional, ni tampoco decisivo o sólido fundamento de la obediencia al Estado y de la libertad civil porque en el delito político entran el odio, el rencor, la pasión, el fanatismo y las

${ }^{448}$ MANDUCA, F., La procedura penale..., op. cit. p. 151. Por ello también es contrario al ejercicio de la acción penal por los electores que según el art. 97 de la Ley electorial de 1882 tenían el derecho de promoverla y a la introducción de esta posibilidad en materia de obras pías para proteger y reivindicar los derechos de la beneficencia pública. Incluso censura el que acaparen esta misión otros funcionarios que no sean el Ministerio Público aunque sea para la persecución de delitos contenidos en normas penales especiales y se refieran a su ámbito de competencias (por ejemplo, la administración forestal). Op. cit. p. 160.

${ }^{449}$ Con respecto a la acusación concurrente propugnada por SCHÜTZE, similar como se ha visto al modelo español, sostenía también una visión negativa puesto que a su juicio esa teoría amalgama dos funciones diversas y separadas, destruye la libertad de apreciación del MF y le hace feudatario del ofendido o denunciante. MANDUCA, F., La procedura penale..., op. cit. p. 148.

${ }^{450}$ MANDUCA, F., La procedura penale..., op. cit. p. 152, haciendo referencia a la opinión de CESARINI, Della libertá ed independenza di apprezamento del P. M. di fronte alle parti private. Discorso inaugurale del 1872, pp. 156 y ss. 
convicciones. En estos casos, poner al Ministerio Fiscal en medio de estas fuerzas movidas por la pasión, el odio, el fanatismo, el convencimiento, la ambición de poder sería hacerle cómplice de hechos turbulentos de mayorías y minorías ${ }^{451}$.

FLORIAN, único representante de la Scuola Positiva que no se muestra en favor de algún tipo de acusación popular, era partidario de un monopolio del MF, si bien con ciertas formas de control. La acusación pública debería ser a su juicio competencia de un órgano público estatal como mejor corresponde al título que la determina, como idónea para el fin que se propone y como más sincera expresión de los intereses colectivos que en la acción penal se comprenden. En su tiempo no existirían ya las condiciones psicológicas, sociales y políticas que en otras épocas explicaban que se dejase a los ciudadanos la función de acusar. Su planteamiento popular, contrariamente a la opinión tradicional, no tendría nada de democrático ya que cuando no fueran agentes de los partidos políticos o de la parte ofendida quien lo realizara, sólamente podrían ser los ricos y no quienes no gozasen de los conocimientos adecuados y de los medios financieros oportunos $^{452}$. Importantes premisas básicas de garantía serían: a) vinculación a la legalidad y obligatoriedad para ese órgano de iniciar el procedimiento por todo delito, garantizando esta obligatoriedad incluso con la amenaza penal para quien no la cumpla y b) obligación de provocar siempre una decisión del órgano jurisdiccional con notificación

\footnotetext{
${ }^{451}$ MANDUCA, F., La procedura penale..., op. cit. pp. 155 y s. Añade el autor “¿Quién desconoce las ardientes luchas de los partidos politicos? ¿Quién ignora las exigencias, a menudo exageradas, de las más avanzadas minorías? (...) ¿Quién no recuerda los elementos en que se apoyan las doctrinas de los modernos ultramontanos, socialistas, comunistas, internacionalistas, colectivistas, anarquistas? Conceder a los defensores de estas ideas subversivas, a estos elementos políticos la acción privada o cívica, ¿no sería atentar a la pública tranquilidad, provocar escándalos, exponer nuestro derecho público interno a los ataques de tales individualidades?». Para concluir vinculando un sistema democrático representativo con la titularidad de la acción penal: «Los que bajo un Gobierno despótico o antinacional son los verdaderos precursores del movimiento progresivo de la humanidad, en otro caso son minorías que, empujadas por el fanatismo o la exageración de un sentimiento político-religioso o social, acarician ideales retrógrados o anárquicos, y constituyendo facción más que partido, son muy peligrosos por su profundo odio y por su salvaje venganza; concederles la acción penal produciría efectos contrarios a la justicia, al fin social a que aquella se encamina". Por todo ello concluye "aunque admitieramos la acción subsidiaria penal, privada o civica, jamás debería extenderse a los delitos políticos”. Op. cit. pp. 156 y ss.

${ }^{452}$ FLORIAN, E., Il processo penale e il Nuovo Codice, Milán 1914, p. 45. En los particulares, ofendidos o no, e incluso en las asociaciones profesionales, residiría únicamente una importante función: la de comunicación e información al órgano estatal de acusación. FLORIAN, E., Elementos de Derecho Procesal Penal, traducción de PRIETO CASTRO, Barcelona 1934, pp. 188 y ss. La apertura del proceso al lesionado introduciría en el proceso un elemento de indudable carácter privado. Con respecto a la intervención de asociaciones o entidades profesionales homogéneas en relación a ciertas clases de delitos, su opinión también es negativa pues no se les puede considerar como órganos del interés colectivo. Todo lo más que podría hacerse es ampliar para ellos la facultad ordinaria de denunciar, otorgándoles poderes más extensos.
} 
al denunciante que le abra la vía para aportar éste al MF las alegaciones que estime pertinentes con el fin de que el procedimiento siga su curso ${ }^{453}$.

RANIERI incidió en la necesaria independencia del Ministerio Público como garantía de la promoción imparcial de la actuación de la justicia ${ }^{454}$. TOLOMEI, otro de los opositores a la acusación popular, consideraba que constituyendo una infiltración de elementos privatísticos, no se respondería a las verdaderas necesidades del proceso penal en su momento y su defensa se estaría basando en una noción falaz de las atribuciones y deberes del ciudadano y el Estado en la edad moderna. A la afirmación de la inmadurez del pueblo italiano para asumir la acusación popular, él no podría por menos de expresar su felicitación (“ifeliz inmadurez!", afirma) y, precisamente su rechazo después de haber sido tercamente propuesta, habría constituido una prueba de madurez de las costumbres de los italianos ${ }^{455}$.

Fue sin duda durante la discusión del proyecto de Código de FINOCCHIARIOAPRILE donde la confrontación en Italia entre defensores y adversarios de la acusación popular quedó palmariamente expuesta. Tras un interesante repaso sobre las diversas posiciones al respecto, el Ministro de Justicia FINOCCHIARIO-APRILE se apartó del proyecto presentado por la Comisión que contenía el concurso de los particulares en el ejercicio de la acusación y así de los que propugnaban la participación privada en la acusación de delitos públicos ${ }^{456}$. A ello le condujeron no sólo sus apreciaciones personales, sino también la experiencia precedente, la Comisión ministerial y lo que denominaba "el Cuerpo Judicial y científico", que en numerosa mayoría se pronunciaba en contra de la acusación popular ${ }^{457}$. La conveniencia del monopolio del MF se

${ }^{453}$ FLORIAN, E., "Degli organi per l'esercizio dell'azione penale e gli scopi del proceso", Riv. Dir. Proc. Pen., vol. III, (1912), 2ª parte, p. 470; Il Processo Penale e il Nuovo codice, Milán 1914, pp. 44 y ss.

${ }^{454}$ RANIERI, S., L'azione penale. Contributo alla teoria dell'azione nel diritto processuale penale, Milán 1928, pp. 77 y ss.

${ }^{455}$ TOLOMEI, A. D., Il principi fondamentali del processo penale, Padua 1931, pp. 37 y ss. La oficialidad de la acusación exigiría también a su juicio la obligatoriedad de su ejercicio.

${ }^{456}$ La Comisión propuso la acción de los no ofendidos y el recurso del ofendido a la autoridad judicial: “ 1 . L'esercizio dell'azione penale deve potere essere eccitato e sussidiato anche dai privati cittadini, nella forma e con le condizioni che saranno determinate. 2. La parte lesa non deve essere ammesa ad esercitare direttamente l'azione penale; e soltante deve avere facoltá di ricorrere al Magistrado contro il P.M. che si rifiuti di esercitare l'azione penale sulla querela".

${ }^{457}$ Vid. esp. Osservazioni e pareri. Lavori preparatorii, op. cit. pp. 17 y ss. que contiene las opiniones 
contempló desde un doble aspecto jurídico y político o de oportunidad: a tenor del primero, la acción penal sería una necesidad y una obligación del Estado, pero teniendo en cuenta el enfoque político, esa actividad debería poder ser controlada frente a posibles errores. Con respecto a la acusación popular, el Ministro tuvo en cuenta consideraciones de índole política para justificar la inexistencia de condiciones reales en Italia para instaurar tal sistema, a pesar de reconocer que en abstracto es un sistema de carácter liberal y democrático. La acusación popular necesitaría de los ciudadanos actividad, amor, celo por la cosa pública, serenidad e imparcialidad, y todo ello únicamente en interés del bien público. En ese momento histórico, relata el ministro, faltaba la necesaria educación cívica y ni siquiera cuando se reclama la cooperación de los ciudadanos como denunciantes, testigos o jueces es fácil obtener ésta. La acción popular podría ser oportuna en el derecho político y en la Administración Pública, pero no en el derecho penal en el que se trata de la libertad y el honor de las personas y en el que podría utilizarse para apagar odios, suscitar venganzas o para sórdidas especulaciones ${ }^{458}$.

En defecto de acusación privada se propuso como garantía la obligación de que el Fiscal requiriera del juez un pronunciamiento sobre cada denuncia que recibiera, fuera del perjudicado o de cualquier otro ciudadano. Se optaba así por un modelo de cierta “cooperación cívica" entendida ésta como vigilancia de los particulares a través de un recurso al órgano jurisdiccional por la inactividad del Ministerio Público. Es decir, una suerte de Klageerzwingungsverfahren logrado en Italia también como solución de

manifestadas por diversos órganos jurisdiccionales, por representantes de las Facultades de Derecho y por especialistas extranjeros. Entre las de éstos últimos quisieramos destacar la de SPEYER, del que no se cita publicación alguna, valedor convencido de la acción popular para quien ninguna otra solución sería más eficaz para desarrollar en todo ciudadano el sentimiento de la responsabilidad, el respeto a la justicia y el hábito de la libertad. op. cit. p. 26. Se mostraron favorables en diversa medida a una participación cívica en la acusación las Cortes de Casación de Ancona, Brescia, Casale, Catania, Lucca, Parma y Venecia (pp. 20 y ss.).

${ }^{458}$ FINOCCHIARIO-APRILE, Progetto del Codice di Procedura Penale per il Regno d'Italia, Parte I, Relazione Ministeriale, Roma 1905, p. 46. Publicado también en Commento al Codice di Procedura Penale, vol. II, Turín 1913. En contra se mostraba, p. ej. LUÉ que, lamentando su supresión, defendía la función educativa y la condición eminentemente conservadora de la acción popular. LUÉ, op. cit. p. 1467. Comparte esta opinión GUARNIERI, que se fija en el carácter de los italianos, determinado por la tendencia a servirse de la autoridad pública para actuar vengativamente o tomar represalias, especialmente inmediatamente después de la guerra. La participación de los particulares en la promoción de la acción penal sería una fuerza potente, y como todas las fuerzas potentes, demasiado peligrosa. Haciendo uso de sus palabras, sería como "un río crecido, que para que no se desborde y cause daños, necesita sólidos diques de contención", los cuales no parece que existieran en Italia. GUARNIERI, G., Le parti..., op. cit. p. 160. En el mismo sentido BATTAGLINI, G., La querela, Turín 1958, p. 134, que veía evidente el resultado negativo para el orden público y la paz social.

${ }^{459}$ Ese era el nombre oficial, vid. Lavori preparatori, op. cit., vol. IV, p. 20 y vol. V, p. 90. 
compromiso entre la extensión de las facultades de acusación a los particulares y el control de la actividad del fiscal sometido por aquellos a decisión judicial ${ }^{460}$. Sin embargo, tal propuesta no llegó nunca a hacerse realidad normativa.

Según el Proyecto de 1911 podrían deducir acusación además del fiscal: a) las asociaciones legalmente constituidas para un fin de interés profesional o público, en relación con los delitos que les conciernan; b) las instituciones públicas de beneficencia en los delitos cometidos en perjuicio de las mismas; c) todos los electores en los delitos contra la libertad política. Pero la nueva propuesta tampoco logró el apoyo de la Cámara, que rechazó tanto un sistema que contemplara alguna modalidad de acusación popular como la propuesta de atribuirla a algunas asociaciones. El carácter anónimo de las acciones ejercitables por entes colectivos, la falta de un interés de tipo individual que hubiera podido llevar a "exageraciones ridiculas" sobre la base de fines políticos, de prejuicios o de sentimientos filantrópicos, el peligro de ocasionar incalculables molestias a la convivencia civil, fanatismo, persecuciones, etc., según la opinión que prevaleció, hubieran llegado a crear una forma de privilegio ante la ley ${ }^{461}$. De ahí que el art. 1 del Codice de 1913 dispusiera el monopolio del MF para el ejercicio de la acción penal ${ }^{462}$.

\subsection{El caso inglés}

\subsubsection{Apuesta por un sistema teóricamente privado de persecución de los delitos}

El sistema legal británico se ha desarrollado históricamente siguiendo un esquema en el que el monarca no sería más que un individuo independiente situado en la cumbre de la sociedad, el primero de entre un grupo de individuos iguales (primus inter pares). El

\footnotetext{
${ }^{460}$ Op. cit. p. 50. Esta intervención judicial fue calificada por algunos miembros de la judicatura como una inaceptable injerencia en el ejercicio de la acción penal. Osservazioni e pareri, op. cit. pp. 27 y ss.

${ }^{461}$ FLORIAN, E., “Degli organi...”, op. cit. p. 429. BARONE, G, Enti colletivi..., op. cit. pp. 11 y ss. En opinión de TONINI, el mundo político rechazó la acción popular porque habría supuesto un control mucho más penetrante del que ejercitaría el ministerio Público, representante del Ejecutivo, y no era aceptable el que no hubiera un filtro sobre las acusaciones. TONINI, "L'intervento di sindacati es associazioni nel processo penale" en Riv. Trim. dir. pubbl., 1976, p. 1440.

462 “L'azione penale è pubblica ed è esercitata dal pubblico ministero".
} 
derecho común inglés no hacía una rígida división entre el injusto civil y el penal y todas las violaciones de la ley eran ofensas cometidas por un individuo contra otro que debían ser llevadas ante el Tribunal por la víctima o sus familiares. El sistema privado de acusación sin intervención estatal fue por ello tenido durante un largo periodo de tiempo en Inglaterra y Gales como el único de los admisibles, como consecuencia de un derecho histórico heredado, que se remontaría a los más tempranos días del sistema jurídico británico, y que seguiría vigente como valiosa salvaguarda constitucional contra la inercia o parcialidad de las autoridades públicas en la persecución de las violaciones de la ley penal $^{463}$.

Afirmaba Lord SIMON en la discusión de la Prosecution of Offences Act de 1985 ante la House of Lords que subyacente al derecho de persecución privada se encontraría la

\footnotetext{
${ }^{463}$ Se ha dicho que "a oídos ingleses, la doctrina de que lo oficial es mejor guardián de la conciencia que lo individual tiene un sonido ominoso". WILCOX, A.F., The Decision to Prosecute, Londres 1972, p. 6. Este principio ha sido reiterado en multitud de ocasiones, de entre las cuales destacamos significativamente la sentencia civil de la House of Lords con importantes repercusiones en el ámbito penal Gouriet v. Union of Post Office Workers, (1978) A.C. 435; (1977) 3 All E.R. 70; (1977) 3 W.L.R. 300 y la opinión de variadas organizaciones que se pronunciaban demandando mayor libertad para invocar la aplicación de la ley en el ámbito de sus competencias. Vid. HARLOW, C. y RAWLINGS, R., Pressure trough Law, Londres 1992, p. 202 . Sin embargo también han existido críticas sobre su mantenimiento, considerándola bien un anacronismo fuera de lugar, bien un privilegio al alcance solamente de unos pocos. En opinión de JACOBY, p. ej., el sistema británico se desarrolló como consecuencia de un esquema social y gubernamental que tenía sus raices afincadas en un contrato social más medieval que moderno. El derecho común inglés no haría fuertes distinciones entre ilícitos civiles y penales y todas ellos serían cometidos por un particular contra otro. Sería por tanto un sistema diseñado para proteger la propiedad en una sociedad basada en la propiedad. Hoy la persecución privada favorecería también a la clase pudiente y a la profesión legal y por ello tendría el apoyo de grupos de influencia y poder. JACOBY, J.E., The american Prosecutor: a search for Identity, Massachusets-Toronto 1980, pp. 8 y ss. En otras ocasiones se ha dicho sarcásticamente que a la vista del sistema inglés, la justicia estaría abierta igualmente para ricos y pobres de la misma manera que el Hotel Ritz. Vid. LIEBEHENTZE, A., Opportunitätsprinzip und Legalitätsprinzip in England, Dissertation, Marburg 1971, p. 94, e incluso se ha afirmado que la existencia de la acusación popular principal es la única causa del principio de oportunidad en el sistema británico. Cfr. WILLIAMS, "Discretion in Prosecuting", Crim. L. R. (1956), p. 223 y LIEBENHENTZE, A., op. cit. pp. 96 y ss. Por último, no puede pasar desapercibida la crítica que realizara, entre otros, el Legal Action Group en 1979 al propugnar la abolición del sistema de acusación privada. Esta asociación, que agrupaba a más de 3500 miembros entre abogados, trabajadores sociales y comunitarios, profesores y otros interesados en mejorar los servicios legales desde una óptica progresista, afirmaba en un informe que "el derecho de acusación privada es importante dada la parcialidad de la policía... pero si va a haber un sistema de acusadores públicos, en particular si va a ser un sistema responsable democráticamente, no tendría sentido mantener la acusación privada. El mismo resultado se conseguiría dando a los individuos a título particular el derecho de acceso directo al acusador si la policía rehusara transmitir el caso a éste y/o el derecho a comunicarlo directamente al Ministro de Justicia. Todo ello debería combinarse con la responsabilidad de los acusadores y ministros". THE LEGAL ACTION GROUP, Legality in the Criminal Process. Evidence of the Legal Action Group to the Royal Commision on Criminal Procedure, 1979, p. 74. Sobre otros grupos progresistas minoritarios (National Council for Civil Liberties, London Gay Activist Alliance, etc.) o autoridades (Association of Metropolitan Authorities, Association of Chief Police Officers) que manifestaron su discrepancia con el mantenimiento del derecho de acusación privada, vid. HAY, D., "Controlling the english prosecutor", Osgoode Hall Law Journal, vol. 21 (1983), n 2, p. 183, n. 71, HARLOW, C. y RAWLINGS, R., Pressure..., op. cit. p. 202.
} 
libertad del individuo y su posibilidad de imprecar a los funcionarios públicos sosteniendo que "Tú podrás ser una Autoridad, tú podrás ser una persona importante en el Estado, tú podrás estar investido con toda la pompa del Estado, tú pretenderás saber mejor que nadie lo que se debe hacer, pero sin embargo yo, un pobre ciudadano, uno de los más humildes del país, vivo sometido a la misma ley que tú y reclamo la aplicación del poder de la ley incluso aun cuando tú pienses en tu grandeza que no se debería aplicar". La certeza de esta afirmación se ve ratificada por el hecho de que tardara tanto en surgir la convicción de que debería ser un cuerpo específico de funcionarios públicos, actuando por mandato de la comunidad, el que se encargara de la acusación. Hasta la entrada en vigor de la Prosecution of Offenses Act (1985), no había existido en Inglaterra y Gales ${ }^{464}$ un cuerpo encargado de forma exclusiva de su ejercicio separado de las funciones de mera investigación del delito. La acusación era deducida en nombre de la Corona, en la inmensa mayoría de los casos por la policía o un organismo público ${ }^{465}$, pero se mantenía la ficción de que este ejercicio se realizaba de forma privada, de la misma manera que podría hacerlo a título particular cualquier ciudadano interesado en el mantenimiento de la ley y el orden ${ }^{466}$. De ahí que se afirme que el funcionario de policía encargado de la acusación no fuera, teóricamente, más que un ciudadano de uniforme ${ }^{467}$.

\footnotetext{
${ }^{464}$ En Escocia, por el contrario, sí que ha existido históricamente una institución encargada del ejercicio de la acusación penal: el Procurator Fiscal quien actua bajo la supervisión del Lord Advocate. Con carácter ciertamente excepcional, se ha conservado una restringida facultad de acusación privada, en manos únicamente del perjudicado por el delito, la cual es de carácter subsidiario y sólo opera tras la decisión denegatoria del Procurator Fiscal. Este ejercicio está sujeto a la autorización de la High Court. Si bien se trata de supuestos extremadamente escasos, existen algunos ejemplos. Vid. p. ej. el último en que se trataba de un caso de violación X. v. Sweeney (1982) J.C. 70. La facultad de acusar sin ser víctima tiene que venir conferida por la norma material correspondiente, hipótesis casi inexistentes. Sin embargo, se considera que no es acusador privado aquella persona que persigue un interés público amparado en un título legal, por lo que no necesita la autorización del Procurator Fiscal. Vid. RENTON / BRONNN'S, Criminal Procedure according to the law of Scotland, 1994, pp. 24 y ss. y 234 y ss. y SHEHAN, A.V. et. al. Criminal Procedure. Scottish criminal Law and Practice Series, Edimburgo 1990, pp. 53 y ss. Sobre el sistema de acusación escocés puede verse más específicamente MOODY, S.R. y TOMBS, J., Prosecution in the Public Interest, Edimburgo 1982; EDWARDS, The Attorney General, 1984 y con una perspectiva comparada, SHEEMAN, A.V., Criminal Procedure. Scotland and France, cit.

${ }^{465}$ Aun cuando carecía de fundamento legal, la mayoría de los cuerpos de policía contaban con un departamento de abogados encargados de forma especializada de la persecución (Prosecution Solicitors Department). Cfr. JUSTICE, A public defender, Londres 1987.

${ }^{466}$ De hecho, puesto que todas las acusaciones son en teoría privadas, para evitar la confusión terminológica que se produce, DEVLIN opta por denominar "acusaciones no oficiales" (unofficial) a aquellas que ejercitan los ciudadanos a título particular. Vid. DEVLIN, P., The Criminal Prosecution in England, Oxford 1960, pp. 16-17.

${ }^{467}$ Tratando de comparar el sistema inglés con otros sistemas de su época MAITLAND afirmaba en 1885 que "hablar del sistema inglés como un sistema de acusación privada es erróneo; en el extranjero lo que tienen son
} 
Desde una óptica crítica con tal principio, relata HAY que se pensaba a menudo que porque los individuos persiguieran los delitos a título particular, cambiaría la percepción que se elaborasen de la Ley y sus agentes. Esta visión atribuiría a todos los grupos sociales capacidad para formarse un criterio acerca de las funciones y de la legitimidad de la Ley, pero parece claro que ello sólo se encontraría generalizado entre los profesionales o los ideólogos de la Ley, o simplemente entre la alta burguesía y la clase media. La actitud frente a la Ley es en gran medida instrumental y está profundamente relacionada con el beneficio propio, y aquella idea de que las clases sociales más pobres pudieran llegar a creer que era básicamente justa porque algunas veces estuvieran habilitados para acusar parece, pues, poco probable ${ }^{468}$. El que la norma pudiera ser aprovechada para fines personales del acusador pudo hacer tomar conciencia de que era suya a más personas en Inglaterra que en otros sistemas inquisitivos de la época, pero contribuyó también a acostumbrarles a pensar que podían usarla para sus propios intereses, asentando así una inadecuada definición profana de la justicia penal ${ }^{469}$.

STEPHEN describe el sistema acusatorio inglés en 1860, pero afincado en una honda tradición histórica, de la siguiente manera: "La acusación está conferida a los ciudadanos que consideren haber sido dañados (...) No hay ningún funcionario público cuyo deber sea la investigación de los cargos ni la obtención de las pruebas requeridas para sostenerlos. El acusador es generalmente una persona privada, y como tal, no tendrá nunca una autoridad oficial. Emplea su propio abogado, igual que lo haría en un acción civil, y en la práctica es el dominus litis" ${ }^{470}$. Dos eran, por tanto, las características claves del sistema acusatorio inglés en la época en la que se introdujo la acusación popular en nuestra primera LECrim: la inexistencia de un acusador público equiparable a un Ministerio Fiscal y la absoluta disponibilidad del acusador sobre la pretensión penal,

acusaciones estatales o acusaciones oficiales". MAITLAND, F.W., Justice and Police, Londres 1885, p. 141.

${ }^{468}$ HAY, D., "Prosecution and Power: Malicious Prosecution in the English Courts, 1750-1850" en HAY, D. y SNYDER, F. (editores): Policing and Prosecution in Britain 1750-1850, Oxford 1989, pp. 391-392.

${ }^{469}$ Por ello destaca HAY que " a diferencia de lo que pudiera considerarse desde una sociología inocente, una jurisprudencia acrítica o una concepción histórica no inquisitiva, tanto para las clases sociales pobres como para las medias la opción no era simplemente entre creer en la ley y obedecerla o no creer en ella y oponerse o sublevarse, sino que cuando podian la usaban y sacaban provecho de ella". HAY, D., "Prosecution and Power...", p. 394.

${ }^{470}$ STEPHEN, “The Criminal Law and the Detection of Crime”, 2 Cornhill Magazine 1860, pp. 697 y 698 recogido por KURLAND, P. y WATERS, D.W.M., "Public Prosecutions in England 1854-79: an Essay in English Legislative History", Duke Law Journal 1959, p. 493. 
que no se separaba mucho de la disponibilidad de la que gozaba el demandante civil.

1) Con respecto a la primera de estas notas, la inexistencia de un órgano público encargado de la acusación, se puede advertir que ya el propio rey Enrique VIII propuso en 1534 la creación de unos "Sergeants of the Common Weal" para la ejecución de las normas, observando que "las leyes no se aplican a no ser por malicia, rencor o mala voluntad y que sería mejor que no se hubieran hecho a menos que no se ejecutaran perfectamente" ${ }^{471}$. Este deseo no llegará a convertirse en realidad, sin embargo, hasta finales del siglo XIX debido a la constante oposición por parte de variados sectores a un órgano de esa naturaleza. Los procedimientos penales continentales, y en especial el francés, eran objeto de afiladas críticas que identificaban la justicia inquisitorial del siglo XVIII y principios del XIX con "Lettres de cachet" 472 , tortura y tribunales secretos. La histórica pasión por la libertad personal, que se afirmaba propia del pueblo inglés, hacía que un acusador público no fuera más que una pieza que formaba parte de un sistema repudiado y, por ello, la generalidad de la doctrina se mostraba dispuesta a seguir pagando el precio de la ocasional impunidad de algún delincuente a cambio de no estar sujeto al riesgo de la existencia de un funcionario "investido de poderes inquisitoriales para perseguir el crimen" ${ }^{473}$.

Uno de los grandes mitos del pensamiento constitucional inglés del siglo XVIII era la ventaja que para la salvaguardia de las libertades tenía el sistema del procedimiento descentralizado y la acusación privada frente al sistema centralizado e inquisitorial del continente. Aunque se le pudieran achacar otros defectos, por lo menos el sistema

\footnotetext{
${ }^{471}$ Cit. por LIDSTONE, K.W, HOGG, R. y SUTCLIFFE, F., Prosecution by Private Individuals and Non-Police Agencies. Royal Commission on Criminal Procedure. Research Study nº 10. Londres 1980, p. 2.

${ }^{472}$ Las Lettres de cachet eran la palpable demostración de la posición del monarca como fuente de toda justicia. En ejercicio de su mandato podría disponer en todo momento de la voluntad y los bienes de sus súbditos a través de cartas certificadas con el sello real. Vid. ESMEIN, A., Histoire de la procédure criminelle en France, París 1882, p. 257.

${ }^{473}$ STEPHEN, “The Criminal Law...”, op.cit. pp. 697-699. Un exaltado articulista del Law Times escribía sobre la materia en 1843: "No olvidemos que somos un pueblo sajón...No queremos ni derecho romano ni funcionarios romanos". Por otra parte, BROUGHAN, aun siendo partidario de establecer un sistema de acusación pública, afirmaba refiriéndose a Francia que "es imposible imaginar un proceso penal peor". Vid. HAY, D. y SNYDER, F., "Using the Criminal Law, 1750-1850: Policing, Private Prosecution, and the State"en HAY, D. y SNYDER, F. (editores) Policing and Prosecution in Britain 1750-1850, op. cit., p. 33. Es de señalar que la pervivencia de la acusación privada en el Reino Unido ha sido vista también por algún autor no como algo típicamente inglés sino como la continuación del Rügeverfahren de los antiguos germanos. Vid. PFENNINGER, H.F., "Die Popularstrafanklage", SchwZStR 29 (1916), p. 261.
} 
continental estaba basado en la búsqueda de la verdad, frente al inglés donde la actividad de los individuos se debía a sus propios intereses y los motivos que la inspiraban no siempre estaban claros ${ }^{474}$. A mediados del siglo XVIII el $80 \%$ de los delitos graves eran perseguidos en Inglaterra por la propia víctima, mientras que el resto lo eran por ciudadanos normales que ocupaban el cargo de Parish Constable ${ }^{475}$. Solamente en delitos de alta traición o sedición eran el Attorney-General o sus agentes quienes iniciaban la acusación, del mismo modo que intervenían también en supuestos de delitos muy graves o con un inusual grado de interés en la opinión pública. Si bien estos casos no llegaban a un porcentaje superior al 1\%, la constante desconfianza en los órganos públicos originó duras críticas parlamentarias procedentes de quienes veían cercano el riesgo de la tiranía, impidiendo el que se pudiera contemplar a estos cuerpos como protectores del ciudadano común $^{476}$. Para inducir a los particulares a promover la persecución penal y con ello satisfacer una necesidad que, eso sí, era vista como de interés público, se incrementaron considerablemente las partidas de dinero destinadas a la devolución de los gastos originados por los procesos a quienes desempeñaran funciones de esta naturaleza ${ }^{477}$.

La necesidad de un órgano acusatorio no dejó de estar presente en la Inglaterra del siglo XIX tanto en la obra de los teóricos como en el terreno político ${ }^{478}$. Ya en 1790 BENTHAM había comparado los sistemas acusatorios francés e inglés, a los que calificó como "cerrado" y "abierto" respectivamente, aludiendo así a las personas autorizadas para el ejercicio de la acusación. A la vista de ello, abogaba por un sistema de carácter mixto

\footnotetext{
${ }^{474} \mathrm{La}$ clave para acceder al sistema legal no sería el dinero, sino los conocimientos. Se ha afirmado por todo ello que el precio a pagar por la protección de las libertades inglesas era demasiado alto. Así PALEY, R., "London Thief-takers in London in the Age of The McDaniel Gang, c.1745-1754" en HAY y SNYDER, Policing and Prosecution..., op. cit. p. 338.

${ }^{475}$ Éstos constituían el embrión de lo que, posteriormente, serían cuerpos de policía, y estaban organizados en cada parroquia.

${ }^{476}$ HAY, D., "Controlling the English Prosecutor”, op. cit. pp. 167 y 171; KURLAND, P. y WATERS, D.W.M., "Public Prosecutions in England 1854-79..." op. cit. p. 495.

${ }^{477}$ La autorización para el reembolso de los gastos ocasionados por el proceso tiene su origen en una ley de 1752 , pero el problema siguió persistiendo a lo largo del tiempo e incluso hoy día es una de las principales causas que contribuyen al escaso uso que el ciudadano inglés hace de su derecho a la acusación privada. STEPHEN, F., The History..., op. cit. calificaba en 1883 el sistema como "disperso, engorroso y en algunos puntos caprichoso".

${ }^{478}$ Aportan un estudio exhaustivo de los sucesivos intentos para la creación de un acusador público en Inglaterra durante el pasado siglo KURLAND, P. y WATERS, D.W.M., "Public Prosecutions in England 1854-79...", op. cit. pp. 493-562.
} 
en el que se mantuviera el derecho de cualquier miembro de la sociedad a acusar en supuestos de carácter leve, de manera que el individuo pudiera perseguir las ofensas que le afectasen personalmente, pero unos oficiales públicos serían los encargados de hacerlo con respecto a delitos que afectasen a la sociedad en general. La principal desventaja que veía en un sistema enteramente "abierto" como el inglés era que en aquellos supuestos en que la sociedad en general, y no sólo un individuo, hubiera sufrido el daño, había muy poco incentivo para que ningún particular actuase. Por el contrario, un sistema enteramente "cerrado" adolecería del inconveniente de que vendría a establecer un poder susceptible de ser ejercitado arbitrariamente ${ }^{479}$. En este sentido elaboró dos proyectos legislativos que no llegaron a ver la luz, y en 1818 el Parlamento, a la vez que rechazó la creación de un cuerpo de policía, desestimó la creación de un acusador público, calificado como "oficio de odioso nombre" $" 480$.

Los defectos y corruptelas en la persecución de los delitos originaron abundantes discusiones parlamentarias sobre la materia. Así por ejemplo, en 1854 con ocasión de la defensa de un proyecto de ley creando un acusador público, el Ministro PHILLIMORE expuso a la House of Commons algunos de los males de los que adolecía el sistema inglés de persecución del delito: excesivo número de persecuciones frívolas ${ }^{481}$, acuerdos entre abogados, acusación y policía en ocasiones tras un arreglo económico, mala dirección de la acusación o incapacidad de los pobres que hubieran sufrido los efectos del delito para iniciar su persecución ${ }^{482}$. El objetivo perseguido con la creación en Inglaterra y Gales de un oficial acusador era en último término "que la justicia fuera administrada correctamente sin la presencia de animosidad privada", pero al igual que en todos y cada uno de los sucesivos proyectos en esta materia, se mantuvo una claúsula de salvaguardia del derecho de iniciación y dirección de la persecución penal por ciudadanos privados. En este caso se hacía constar expresamente la garantía de la pervivencia de la acusación

\footnotetext{
${ }^{479}$ BENTHAM, J., Organisation of the Judicial Establishment, publicada originariamente en Francia en 1790 y con traducción al castellano Tratados sobre la organización Judicial, cap. XX, pp. 89 y ss. Cit. también por HETHERINGTON, T., Prosecution and the Public Interest, Londres 1989.

${ }^{480}$ HAY y SNYDER, “Using the Criminal Law...”, op. cit. p. 33.

${ }^{481}$ Por ejemplo el número de las absoluciones era dos veces superior a lo que ocurría en Escocia, donde las acusaciones las mantenían funcionarios profesionales, responsables y con experiencia.

${ }^{482}$ Argumentos que se reiteraron una y otra vez en las sucesivas discusiones sobre la materia, haciendose hincapié en la corruptela que suponía el que los acusados pudieran escapar a la aplicación de la pena llegando a acuerdos económicos con los acusadores. KURLAND y WATERS, op. cit. pp. 499 y 515.
} 
popular, afirmando que "nada de lo expuesto impedirá que cualquier persona (o personas) a sus propias expensas inicie el procedimiento en los supuestos en que la ley se lo permite en la actualidad" ${ }^{483}$. De esta manera recaería sobre el ciudadano un papel complementario al del acusador público en el planteamiento de la acusación, concurriendo ambos en ese derecho. La convicción, profundamente arraigada en la mentalidad inglesa, de que el derecho de cualquier ciudadano a acusar es anterior a la potestad de un órgano público para hacerlo, afloraba como se ve siempre que la cuestión salía a debate.

Aun manteniéndose en todo momento la teórica garantía del derecho de acusación por los particulares, posteriores propuestas lo restringirían relegándolo a un papel subsidiario con respecto a la acusación oficial y haciendo incompatible su existencia simultánea. En este sentido se propuso por un lado la necesidad de que el acusador privado comunicara por escrito su intención de deducir la pretensión al Attorney-General, para que éste pudiera asumirla si lo considerase necesario, y por otro la prohibición de abandonar la acusación una vez que se hubiese iniciado sin que aquel diese su consentimiento. Una garantía quedaría en estas ocasiones en manos del particular: la necesidad de que el acusador público le informara en caso de abandono del procedimiento, supuesto en el cual, sin que se le abonaran los gastos, el acusador privado sería libre de continuarlo ${ }^{484}$. Otras restricciones propuestas tomaron un camino diferente, distinguiendo varios tipos de delitos y dejando en manos del acusador privado sólamente la iniciación de procedimientos penales en cuestiones menores, injustos de naturaleza privada que podían estar sujetos a compensación entre los particulares. De esta manera, tal y como resaltaron sus promotores en una afirmación que con el paso del tiempo resultaría profética, las acusaciones privadas dejarían de emprenderse ${ }^{485}$.

\footnotetext{
${ }^{483}$ Es significativo que tanto el proyecto de ley para la creación de un órgano público de acusación de 1870, como la ley de 1879 o la sección 4 de la Prosecution of Offences Act de 1979 reproduzcan de manera prácticamente literal esta previsión. De hecho, incluso la sección 6 de la actualmente vigente Prosecution of Offences Act de 1985 tiene una redacción muy similar.

${ }^{484}$ Propuestas del SELECT COMMITTEE y Proyecto de Ley de 1870 a los que hacen referencia KURLAND y WATERS, "Public Prosecutions...", op. cit. pp. 521, 525, 527. En el caso del proyecto de ley de 1870 se exigía notificación al Public Prosecutor sólo en los supuestos de delitos graves, aquellos de los que conocía el Grand Jury. Para fortalecer la acusación pública a costa de la privada se propusieron en un proyecto de 1872 restricciones en la acusación de los delitos contra la propiedad a aquellos propietarios que no hubieran dado toda la información y asistencia necesaria al acusador público en relación con el delito.

${ }^{485}$ Propuesta de BLACKBURN recogida por KURLAND y WATERS, “Public Prosecutions...”, op. cit. p. 549.
} 
Hasta la década de los setenta del siglo XIX, la mayoría de las acusaciones policiales se referían a los denominados "delitos sin víctima", especialmente los relacionados con la embriaguez, los desórdenes públicos y las violaciones a las leyes de policía y de vagabundos. La policía tenía ya un papel fundamental en la lucha contra el delito y en especial en la detención de los sospechosos, pero es a partir de esa fecha cuando empieza a tomar un papel activo con respecto a delitos comunes (robo, agresiones...) alentando a las víctimas a que acusasen cuando no lo hubieren hecho ${ }^{486}$. En definitiva, aunque la acusación siguiera siendo privada por definición y en la gran mayoría de los casos, la existencia de una corporación de carácter público comprometida en su deducción fue adquiriendo de facto el papel que le corresponde en una sociedad moderna $^{487}$.

Los cambios económicos sufridos por el país durante la época victoriana había generado nuevas bolsas de población agrupadas en torno a los núcleos industriales y con ello un aumento de la delincuencia que hacía inviable el mantenimiento de un sistema de persecución del delito anclado en el pasado. Los magistrados y los periodistas no cejaban en señalar los defectos que el sistema tenía: el arreglo económico para no perseguir algunos delitos ${ }^{488}$, la acusación maliciosa de inocentes por acusadores con interés personal o chantajistas, la incapacidad de los jurados de valorar adecuadamente las pruebas por el gran volumen de asuntos que se ponían en sus manos, la pérdida de la legitimidad de la ley cuando los delitos graves no son perseguidos por causas relativas a la pobreza, incapacidad o falta de voluntad de la víctima, etc. Incluso, cuando con el tiempo se empezó a garantizar la devolución de los gastos de la persecución, se dió acceso al sistema a acusadores de escasos recursos que se servían de su condición de pobres para la consecución de dudosos fines ${ }^{489}$. HAY destaca además variados factores que conferían

\footnotetext{
${ }^{486}$ DAVIS, J. S., "Prosecutions and their context: The use of the Criminal Law in Later Nineteenth-Century London" en HAY, Douglas y SNYDER, Francis (editores), Policing and Prosecution in Britain 1750-1850, op. cit. p. 420 .

${ }^{487}$ Así todo, refiriendose al caso de Londres, DAVIS hace notar las deficiencias en la persecución de los delitos, en primer lugar por el número de éstos de los que no se da cuenta y en segundo lugar por las carencias de una policía insuficiente en número. DAVIS, "Prosecutions and their context...”, op. cit. p. 420.

${ }^{488}$ El acuerdo de compensación económica o de restitución de la cosa robada era muy frecuente puesto que para la víctima era mucho más fácil y sobre todo no acarreaba más costes.

${ }^{489}$ En algunos casos los procesos eran dirigidos por representantes de los más bajos estratos sociales, delincuentes habituales conocedores de los procedimientos legales y de la corrupción que se desenvolvían con destreza en los Tribunales y podían obtener provecho económico de ello. Vid. HAY, D., "Prosecution and Power...",
} 
relevancia social y probabilidades de éxito a una acusación, de entre los cuales no era el menos importante la relación entre acusador y acusado y el cómo éstos eran vistos a los ojos del juez y del jurado: la trayectoria pública de los sujetos procesales y el trasfondo de la acusación eran a menudo más importantes que el hecho imputado en sí, y en esa medida, la norma estaría más a disposición de los pudientes que de los pobres ${ }^{490}$.

Todo ello llevó a sucesivos intentos parlamentarios para la introducción de un sistema público de acusación que pudiera desempeñar adecuadamente la tarea que, como había quedado demostrado, no podían desempeñar los individuos a título particular. Pero, a diferencia de lo que había ocurrido en la mayoría de los países del continente, nadie osó en Inglaterra incluír en sus propuestas la supresión del derecho privado de acusación, el cual constituía siempre una garantía frente a irregularidades en su ejercicio oficial. Para el mantenimiento de un sistema que estaba siendo sometido a intensa crítica se han apuntado varias razones. El primer factor a destacar era la resistencia a ver reducidos sus ingresos por parte de los abogados, que en torno a 1850 eran ya un sector muy bien organizado y temeroso de que la creación de un órgano de naturaleza pública pudiera detraer importantes cantidades de los honorarios que percibían por el ejercicio de la acusación ${ }^{491}$. A ello se añadían también los temores expresados en el Parlamento acerca de los efectos políticos y económicos derivados de la creación de un nuevo cuerpo ${ }^{492}$. Pero subyacente a ese debate se encontraba la larga tradición, el argumento ancestral, a veces sólo implícitamente expresado, a veces manifestado en sus más claros términos, de que las consecuencias de la persecución del delito eran demasiado importantes para las libertades políticas de la nación como para confiar ésta al Ejecutivo. La Ley penal, la policía y la persecución del delito han sido y serán siempre en el más amplio sentido un foco de

op. cit. p. 391.

${ }^{490}$ HAY, D., “Prosecution and Power...”, op. cit. p. 392.

${ }^{491}$ En especial en el caso de los Solicitors' Clerks, letrados que actuaban desde dentro del sistema judicial como escribanos y frecuentemente como acusadores privados. HAY, D, “Controlling the English...” op. cit. p. 176. Una de las causas del incremento en la asunción de las funciones de persecución del delito por la policía en décadas posteriores fue el que ésta absorbiera parte de las abultadas cifras de desempleo de los letrados. Por ello se puede afirmar que la abogacía en su conjunto no se vió perjudicada con la progresiva pérdida de esa función. HAY y SNYDER, "Using the Criminal Law...", op. cit. p. 46. La acusación privada suponía una importante fuente de ingresos, lo cual hacía que que autores como JACOBY hayan afirmado que la acusación privada favoreciera sólo a los ricos y a los juristas, por lo que contó con el apoyo de dos poderosos grupos de presión e influencia. JACOBY, J.E., The american Prosecutor: a search for Identity, op. cit., p. 9 in fine.

${ }^{492}$ Vid. KURLAND, P. y WATERS, D.W.M., “Public Prosecutions in England 1854-79...”, op. cit. pp. 493-562. 
conflicto para definir los límites de los poderes del Estado, los grupos o la persona y en Inglaterra esa realidad ha estado siempre presente y se ha manifestado a simple vista ${ }^{493}$.

Finalmente la ley aprobada en 1879 estableció un sistema centralizado de persecución pública dirigido por el Director of Public Prosecution, el cual actuaría bajo la dirección de un Ministro de la Corona, el Attorney-General, reafirmando el derecho de acusación privada con ciertas salvaguardas. En la práctica esto supuso el final del ejercicio generalizado de la acusación por particulares, transfiriendo esta función a la policía, órgano a la vez investigador y acusador en la inmensa mayoría de los casos hasta la creación del Crown Prosecution Service en 1985. Esta norma siguió sin tener la aprobación general, y en este sentido desde las páginas del periódico The Times, que se había comprometido desde hacía más de 30 años en la defensa de la necesidad de un órgano público de acusación penal, se manifestaba aquel descontento afirmando que "seguirá existiendo la gran anomalía de que el Estado considera que la persecución del delito no le concierne y que los individuos privados son libres de gratificar sus pasiones en un campo del que las pasiones deberían estar excluidas (...) El gran defecto de nuestro sistema es que mientras sea de todos el derecho de acusar no será asunto de nadie el hacerlo...".

El sistema inglés no fue exportado a las colonias americanas y en la época de la independencia de los Estados Unidos practicamente ya se había conseguido eliminar la acusación privada de los delitos graves. El establecimiento en los Estados Unidos de un monopolio acusatorio en manos de funcionarios públicos se ha explicado como un modo de evitar abusos tales como las acusaciones maliciosas (al igual que fue argumentado en Escocia), pero también precisamente como una innovación democrática contra las desigualdades de clase generadas por la acusación privada ${ }^{494}$. El delito se entendía como

${ }^{493} \mathrm{La}$ interrelación entre acusador oficial y jurado no pasó desapercibida en este debate. Así, se llegó a comparar la vulnerabilidad política de ambas instituciones, afirmando la mayor garantía que ofrece la acusación privada. Se llega a afirmar que "incluso en los casos de delitos políticos, la prevalencia de los sentimientos de parte en tiempos turbulentos hace pensar en la deformación del jurado. Mientras que el acusador oficial, del que pudiera pensarse lo mismo, está sujeto a una responsabilidad, la mayoría de los miembros del jurado no". BROUGHAM cit. por HAY, D. y SNYDER, F., "Using the Criminal Law...", op. cit. p. 33. En otros ámbitos se destaca la complementariedad de el Jurado de acusación (Grand Jury) como freno a la iniciación de persecuciones arbitrarias por parte del acusador público y de la acusación privada que lo sería para el rechazo arbitrario de esta iniciación. Propuesta del LORD CHANCELLOR recogida por KURLAND, P. y WATERS, D.W.M., "Public Prosecutions in England 1854-79...”, op. cit. p. 513.

${ }^{494}$ JACOBY, J.E., “The American Prosecutor: A Search for Identity”, Massachussets 1980, cap. I passim. En su opinión, el sistema inglés acuñado a lo largo de la historia está diseñado para proteger la propiedad en una sociedad basada en la propiedad, con lo que la ventaja es siempre para los ricos y los poderosos. Centrándose en la actualidad, 
un ataque a la sociedad en su conjunto, y no como una agresión a un individuo, razón por la que debería ser una representación de toda la comunidad quien se encargara de la persecución $^{495}$.

2) En cuanto a la disponibilidad del acusador privado sobre el proceso, ha de resaltarse que la capacidad de actuación del acusador privado era amplísima, sin temor o esperanza de que ninguna otra persona, y en especial ningún funcionario, pudiera interferir en ella ${ }^{496}$. Ya a mediados del siglo XVIII esta capacidad abarcaba la dirección del procedimiento, primero por sí mismo y posteriormente mediante letrado, la aportación de prueba e interrogatorio de testigos, selección de los cargos que se habrían de imputar, asistencia a los escribanos, acusación en la vista oral, solicitud de recompensas y otros fondos públicos habilitados por el Tribunal para hacerse cargo de los costes de la acusación así como asignación de éstos a los testigos, pago de honorarios a los letrados, y, finalmente en las causas en que se conseguía una condena, intervención si el condenado o su familia solicitaban el perdón ${ }^{497}$.

\subsubsection{Las asociaciones inglesas para la persecución de los delitos}

A la vista de su complejidad, la acusación era una carga difícil de soportar de manera individual para los particulares puesto que, además de molestias, llevaba consigo peligros y cuantiosos gastos de documentación y de asistencia letrada. No es de extrañar por ello la idea de muchos propietarios de asegurarse frente a los costes de la acusación compartiendo los servicios de un letrado ${ }^{498}$ y el resultado de esta evolución fue la

JACOBY afirma que la acusación privada se mantiene en Inglaterra porque es el procedimiento establecido, no porque sea equitativa puesto que favorece a los pudientes y a los juristas, y por ello cuenta con el apoyo de dos grupos influyentes y poderosos. Vid. p. 9 in fine.

${ }^{495}$ El tema de la acusación privada se ha vuelto a suscitar en los EEUU en tiempos recientes en conexión con la protección de la víctima. Vid. por ejemplo GITTLER, J., "Expanding the Role of the Victim in a Criminal Action", Pepperdine Law Review 11 (1984) p. 117, quien considera deseable transplantar la acusación privada británica a los EE.UU.

${ }^{496}$ SIGLER, J.A., "Public Prosecution in England and Wales”, Crim. Law Rev. 1974, p. 643.

${ }^{497}$ HAY, D. y SNYDER, F., "Using the Criminal Law, 1750-1850: Policing, Private Prosecution, and the State", en HAY, D. y SNYDER, F. (editores), Policing and Prosecution, op. cit. pp. 25-26.

${ }^{498}$ Vid. PHILIPS, D., "Good Men to Associate and Bad Men to Conspire: Associations for the Prosecution of Felons in England, 1760-1860”, en HAY, D. y SNYDER, F. (editores) Policing and Prosecution, op. cit. pp. 115116, que describe los desproporcionados costes que suponían para la víctima de un delito la persecución de éste. 
distintiva institución inglesa de los siglos XVIII y XIX de las asociaciones para la persecución de los delitos. Tales colectivos estaban formados en su gran mayoría no por ciudadanos altruistamente interesados en el efectivo cumplimiento de la ley y en el mantenimiento del orden, sino por quienes con mayor frecuencia eran víctimas de los crimenes más comunes, los delitos contra la propiedad.

Inglaterra tenía ya una larga tradición histórica de asociacionismo voluntario de todo tipo $^{499}$, que incluía desde asociaciones para la mera diversión, a asociaciones de tipo moralizante como las "Societies for the Reformation of Manners" o las Evangélicas "Societies for The Suppresion of Vice" e incluso algunas de naturaleza política como las "Loyalist Associations" cuya tarea era la defensa del Rey y la Constitución ${ }^{500}$. A esta

Además, casi todos los robos, incluso los más leves, debían ser juzgados por un jurado, lo cual hacía complejos y caros la mayoría de los procesos. HAY y SNYDER, "Using the Criminal Law...”, op. cit. p. 26.

${ }^{499}$ Las asociaciones de todo tipo eran instituciones muy típicamente inglesas, expresión de la agrupabilidad ("clubbability") de los ingleses, que el propio sistema jurídico no sólo autorizaba sino también favorecía. Sus buenas relaciones con las capas más altas de la sociedad, sus conexiones políticas e incluso el patronazgo real de alguna de ellas (las "Royal Society for...") atestiguan el lugar que ocupaban y aún hoy día ocupan en la sociedad británica.

${ }^{500}$ La bibliografía extranjera se encargó de destacar en su momento las virtudes e inconvenientes de este aspecto tan peculiar del sistema inglés, haciéndolo en ocasiones desde una percepción falseada de un sistema que estaba ya en clara decadencia y que se basaba en principios muy distantes de los imperantes en otros lugares. En nuestro país existían abundantes referencias al sistema acusatorio británico, vistas y valoradas desde muy diferentes ópticas, unas veces favorables y otras despiadadamente críticas. Entre estas últimas se encuentra la de GONZÁLEZ NANDÍN, que dedicó toda su monografía Reflexiones sobre la legislación penal, el jurado y las costumbres judiciales de Inglaterra, Madrid 1877, a censurar, y en ocasiones a fustigar, algunas de las instituciones del ordenamiento jurídico penal inglés basándose con frecuencia en noticias periodísticas. Tras criticar la, en su opinión, deplorable carencia que supone el que no exista un Ministerio Público encargado de la persecución del delito, relata que "el buen sentido práctico del pueblo ha organizado asociaciones de todas clases, cada una de las cuales trabaja en su línea, para la persecución de que se ha reservado conocer, como conservadora de la Paz del Reino, entregando a los Tribunales a los autores de los crimenes o delitos de su especial incumbencia". Una vez ennumerados algunos ejemplos de asociaciones de esta naturaleza añade sin embargo que "si remedian, en parte, con su ingerencia, la falta de Ministerio Público, únicamente lo consiguen para los hechos especiales de la asociación, y sólo en las grandes capitales, donde estas sociedades existen, continuando, integro, el mal, en los Condados, donde no las hay, y en los que queda, por tanto, el interés general, subordinado al particular cuya acción, por los motivos expuestos es nula o de escasa importancia".

Dentro de una exposición de Derecho Comparado en relación con la entonces reciente LECrim. de 1882, MARTÍNEZ DEL CAMPO, E., Notas al Libro $1^{\circ}$ de la LECrim. , Madrid 1885, p. 260, toma como argumento para la crítica a nuestra acción popular la insuficiencia de este tipo de medios "aun en aquel pueblo cuyas costumbres responden a cierta loable solidaridad entre los ciudadanos, que ni ayudados por el espiritu de asociación allí vigoroso y enérgico y por las previsiones de algunos cuerpos municipales de populosas ciudades, preocupados de la conveniencia de acción eficaz contra la impunidad, lograban la defensa de los intereses colectivos atacados por el delito". El autor es conocedor de las reformas introducidas en aquella época, que introdujeron la función del DPP, que es calificado de un "esbozo del Ministerio Público existente en Europa".

Sin embargo, para SILVELA el pueblo y el sistema acusatorio británicos no merecían más que elogios. De su argumentación no sólo se deducen sus simpatías por el sistema de acusación privada vigente, sino que en su opinión sería de desear que el Ministerio Fiscal perdiera su función de persecución del delito para que la sociedad en 
vertebración social debe añadirse la naciente costumbre, en los momentos de comercio floreciente que estaba atravesando Gran Bretaña, de asegurar el riesgo económico mediante agrupaciones de carácter mutualista entre industriales, con el objeto de compartir los riesgos. Desde esta perspectiva, la carencia de un órgano oficial para la persecución de los delitos fue vista como una laguna en la actividad del Estado que podía ser colmada mediante la colaboración y la agrupación de aquellos que sufrían los efectos del delito como si éste fuera un riesgo más al que debían hacer frente. Las nuevas asociaciones para la persecución de los delitos adquirieron pronto el carácter de foro de discusión de problemas concernientes a sus miembros, a la vez que desempeñaban un papel útil a éstos ${ }^{501}$. No es de extrañar por ello la idea generalizada en la sociedad británica de los siglos XVIII y XIX de que "siempre habrá hombres buenos para asociarse, mientras haya hombres malos para conspirar" "502 o de que "cuando los hombres malos se unen, los hombres buenos deben asociarse" ${ }^{, 503}$.

La creación de agrupaciones de ciudadanos que mediante la ayuda mutua pudieran hacer frente común para la averiguación de los delitos cometidos contra ellos o sus propiedades, el arresto de los delincuentes y la acusación de éstos ante los Tribunales fue un fenómeno muy frecuente en Inglaterra y Gales en el periodo comprendido entre finales

su conjunto la asumiera. Él basa esta posibilidad en "la existencia real y positiva de un gran espíritu individual, temeroso de los abusos del Poder Ejecutivo, y dispuesto a imponerse sacrificios considerables y espontaneos de tiempo, de responsabilidad y de dinero, a trueque de participar directamente en el ejercicio del poder". Relata la creación de asociaciones privadas "que se cuentan ya por centenares, encargadas de perseguir determinadas clases de delitos, como los escritos o grabados obscenos, los fraudes y falsedades en documentos mercantiles, los abusos de trabajo de los niños...", para lamentarse posteriormente de que en nuestro país no podamos contar con tales iniciativas y argumentar que "es deber de legisladores, jurisconsultos y ciudadanos que se crean en situación de educar y dirigir a los demás, facilitar los medios y perfeccionar los procedimientos que más favorezcan tan progresivos movimientos de la opinión". SILVELA, F. "La acción popular”, RGLJ T. 73, 1888, p. 484 y ss.

Entre la doctrina alemana, y a través de las traducciones de su obra, en Italia y Francia, el sistema inglés fue conocido a través de MITTERMAIER. Vid. Das deutsche Strafverfahren, $2^{\text {a }}$ parte, pp. 113 y ss., que constataba la existencia de más de 500 asociaciones para la persecución del delito. Pero, sin duda, su principal valedor fue GNEIST a través de su idea de la "Autoadministración" (Selfgovernment o Selbstverwaltung), que motivaba su propuesta de instauración de una acusación popular subsidiaria en Alemania. Vid. al respecto lo ya relatado supra.

${ }^{501}$ KING, P.J.R., "Prosecution Associations and their Impact in Eighteen-Century Essex" en HAY, D. y SNYDER, F. (editores), Policing and Prosecution in Britain 1750-1850, op. cit. p. 205.

${ }^{502}$ Brindis en la "Society for Prosecuting Felons, Forgers, etc..." en la cena de aniversario el 18 de abril de 1798, cit. por PHILIPS, D., "Good Men to Associate and Bad Men to Conspire: Associations for the Prosecution of Felons in England, 1760-1860”, en HAY, D. y SNYDER, F. (editores), Policing and Prosecution in Britain 1750-1850, op. cit. p. 113.

${ }^{503}$ Lema de la "Society for the Suppresion of Vice". 
del siglo XVIII y mediados del XIX e incluso a partir de 1780 los propios colectivos difundían sus estatutos y actividades con el objetivo de crear otros a imitación suya ${ }^{504}$. Con la asociación se obtenían mejores resultados y no era difícil conseguir del Tribunal el reintegro de los costes tras una persecución culminada con éxito. Se suplía o complementaba de esta forma la acción del Estado con el objeto de resolver lo que sus miembros percibían como una crisis en la aplicación de la ley y el mantenimiento del orden $^{505}$, pero en origen se trataba de instituciones estrictamente privadas con un interés limitado a la aplicación de la ley penal en la medida en que una violación de ésta hubiera afectado a alguno de sus miembros.

Su contribución al efectivo cumplimiento de la ley no era la de aplicar la justicia directamente $^{506}$, sino la de facilitar la tarea de los Magistrados, alguno de los cuales no pocas ocasiones también formaban parte de ellas colaborando en sus empeños. Tenían en común básicamente dos objetivos: en primer lugar reducir los costes de la persecución y

${ }^{504}$ PHILIPS, D., “Good Men to Associate...”, op, cit. p. 126.

${ }^{505}$ Por eso ha sido destacado por SCHUBERT, el que con su actividad se originara la transformación del antiguo sistema laxo y discrecional de aplicación de la norma penal abierto a la negociación, en un estricto sistema sujeto a la ley inspirado en BECCARIA y BENTHAM. Este autor llega a afirmar que las asociaciones demandan una reforma del sistema penal en la forma en que BENTHAM, COLQUHOUN o ROMILLY estaban proponiendo. Vid. SCHUBERT, A., "Private Initiative in Law Enforcement: Associations for the Prosecution of Felons, 1744-1856", en BAILEY, V. (editor) Policing and Punishment in 19th-Century Britain, Londres 1989, p.37-39. PHILIPS, considerando demasiado simplistas esos argumentos, no ve ninguna razón en la que apoyar esta afirmación sino más bien sostiene la opinión contraria: si bien es cierto que las asociaciones reconocen las ventajas de prevenir el delito antes de perseguirlo, no hay ninguna prueba de que apoyaran campañas en este sentido, sino precisamente en el contrario: endureciendo los castigos previstos en la ley. PHILIPS, D., “Good Men to Associate...”, pp. 128 y 132. Por otra parte KING, replica la afirmación del cambio hacia un sistema rígido de la aplicación de la ley, ya que si esto hubiera sido así las asociaciones no hubieran tenido un papel en la aplicación del perdón, circunstancia que no se ajusta a la realidad en el condado de Esex. KING, P.J.R., "Prosecution Associations and their Impact in Eighteen-Century Essex” en HAY, D. y SNYDER, F. (editores) Policing and Prosecution ..., op. cit. p. 203.

${ }^{506}$ A diferencia de asociaciones coetáneas en los EEUU que se adueñaban de todas las fases del proceso detención, juicio y aplicación de la pena (a menudo la penal capital)-, las asociaciones inglesas una vez que habían detenido al delincuente, conducían el proceso por los cauces estrictamente legales. Sin embargo ha sido destacada la similitud entre las asociaciones para la persecución de los ladrones de caballos inglesas y americanas, las cuales cumplían su función poniendo a los delincuentes a disposición de las autoridades. Tratando de buscar analogías modernas a estas asociaciones, se han citado a los servicios privados de seguridad u otras formas de "policía privada" puesto que en algunas ocasiones ellos mismos formaban patrullas de autodefensa. Sin embargo, en la mayoría de las ocasiones no llegaban tan lejos y trabajaban en colaboración con las autoridades policiales, primero con los Parish Constables y luego con las nuevas fuerzas de policía. En este sentido se acercarían más al actual “Vigilante Movement” de los EEUU. Vid. PHILIPS, D., “Good Men to Associate...”, op. cit., p. 119 y la bibliografía sobre el tema en los EEUU a que hace referencia. Para un estudio relativamente reciente, centrado en la experiencia británica de control vecinal del delito y colaboración con la policía vid. BENETT, T., "Evaluating Neighbourhood Watch", Cambridge Studies in Criminology nº 61, Cambridge 1990. 
de la acusación compartiendo los gastos y en segundo lugar dar a conocer públicamente su disposición para perseguir aquellos delitos que se cometieran contra sus propiedades, intentando de esa manera disuadir a aquellos que pudieran atacarlas ${ }^{507}$. Con respecto al papel que desempeñaban en el ejercicio de la acusación, la asociación asumía todas las responsabilidades y desembolsos necesarios: acopio de material probatorio incluyendo los testigos, dirección del proceso, etc.

A mediados del siglo XIX, que se puede señalar como el momento culminante de las asociaciones inglesas para la persecución del delito, el número de éstas en todo el país podría oscilar entre las 500 que reconocía la "Royal Commission on a Constabulary Force for England and Wales" y las 4000 a las que hacen referencia algunas fuentes, aunque lo cierto es que su número pudiera con seguridad ser estimado en más de mil ${ }^{508}$. Si bien su repercusión sobre los índices de condenas en los principales Tribunales fue escasa, su número y fuerza no declinó hasta la segunda mitad del siglo XIX ${ }^{509}$. Básicamente estaban compuestas por "caballeros, granjeros y comerciantes del distrito", tal y como con frecuencia figuraba en sus artículos y carteles, y la cifra de sus miembros oscilaba por término medio entre 20 y $60^{510}$. En muchos casos, clérigos y nobles tenían un papel prominente aunque no importante en cantidad. Solían estar organizadas localmente, tanto en el ámbito rural como en el urbano, bajo una denominación genérica del tipo "Asociación para la persecución de los delitos de..." (Association for the Prosecution of Felons of...). Entre ellas había también algunas especializadas en cuestiones específicas: los propietarios de terrenos de caza vigilan la observancia de las leyes en esta materia, los industriales y comerciantes perseguían la malversación o el robo cometido por sus empleados, los terratenientes vigilan los incendios provocados en sus

${ }^{507}$ En ocasiones se anunciaba públicamente los nombres de los integrantes de la asociación con finalidad preventiva: de esta manera los delincuentes se lo pensarían dos veces antes de elegir su víctima. Vid. PHILIPS, op. cit. p. 139 y HAY, D. y SNYDER, F., "Using the Criminal Law, 1750-1850: Policing, Private Prosecution, and the State”, en HAY, D. y SNYDER, F. (editores) Policing and Prosecution... op. cit. p. 27.

${ }^{508}$ PHILIPS, D., “Good Men to Associate...”, op, cit. p. 120. Algunos autores han deducido de este alto número las deficiencias y el descontento con la protección que el sistema otorgaba a las personas y propiedades. SCHUBERT, A., "Private Initiative...” op. cit. p. 39 y PHILIPS, D., “Good Men to Associate...”, op. cit. p. 127.

${ }^{509}$ KING, P.J.R., “Prosecution Associations...” op. cit. p. 172.

${ }^{510}$ Basándose en un estudio realizado en Staffordshire, HAY cifra este número en el $10 \%$ de la población masculina. HAY, D., “Controlling the English Prosecutor...”, op. cit. p. 172. Éste fue un fenómeno en el que sólo se implicó la población masculina. Vid. también PHILIPS, D., “Good Men to Associate...”, p. 120. 
posesiones, los artesanos el cumplimiento de las normas de aprendizaje, etc., pero en la inmensa mayoría de los casos la ocupación exclusiva de estas agrupaciones de defensa mutua eran los delitos contra la propiedad ${ }^{511}$.

Las asociaciones para la persecución de los delitos, totalmente heterogéneas entre sí, no constituyeron en ningún sentido un sustitutivo adecuado para cubrir la carencia de un acusador público, sino que reforzaban la naturaleza privada de la persecución del delito $\mathrm{y}$, en concreto, de la acusación ${ }^{512}$. Los motivos para la elección de las oportunidades en que actuaban no eran desinteresados y su único compromiso con la defensa de valores que no fuera la defensa de sus propiedades se demostraba en muy escasas ocasiones ${ }^{513}$. Una de éstas era su eventual intervención para asumir casos en representación de víctimas de delitos cuando éstas carecieran de recursos, lo cual en abundantes ocasiones reportaba también no despreciables beneficios de carácter pecuniario a la asociación ${ }^{514}$. Una segunda intervención que iba más allá de la defensa de los intereses de sus miembros era la que se realizaba para cubrir las deficiencias en la actuación del Attorney-General en los limitados supuestos en los que éste era competente para la acusación, es decir, en los delitos contra la Corona y en especial en el de sedición ${ }^{515}$.

${ }^{511}$ Para un estudio en profundidad sobre la composición, extracción social de los miembros, delitos que se persiguen, reparto de los gastos y otros detalles sobre estas sociedades Vid. PHILIPS, “Good men to Associate...”, op. cit. pp. 133 y ss.

${ }^{512}$ En lo cual se muestra de acuerdo la generalidad de la doctrina. Vid. p. ej. HAY, D. y SNYDER, F., "Using the Criminal Law...”, p. 28. y KING, P. “Prosecution Associations...” op. cit. p. 202.

${ }^{513}$ Aunque una asociación de Nottingham solicitara la exención de un impuesto sobre el suelo en 1843 alegando ser una "Sociedad Caritativa". PHILIPS, op. cit, p. 141. KING, op. cit. p. 202 señala que en el caso de Essex sólo se ofreció asistencia a no miembros de las asociaciones en una o dos ocasiones.

\footnotetext{
${ }^{514}$ Aunque algunas asociaciones establecían entre sus normas una claúsula específica habilitándolas para acusar en nombre de personas pobres, ésta debe entenderse más bien como una continuación de la labor caritativa de muchos caballeros pudientes que en siglos precedentes cubrían los gastos de los procesos de las personas sin recursos. PHILIPS, op. cit. p. 140. HAY relata el caso de una asociación de Birmingham que en 1785, en nombre de una viuda pobre, dirigió la acusación obteniendo cuantiosos beneficios derivados de la sustanciosa recompensa por obtener una condena a la pena capital y de la devolución de los gastos ocasionados por el proceso. Así, las 39 libras obtenidas (cerca del doble de los ingresos anuales de un trabajador normal) fueron presumiblemente usados para sufragar los gastos de la asociación, con lo que la resignada viuda afirmó que "la asociación le había robado de lo que le correspondía más de lo que lo había hecho el ladrón". HAY, D., "Controlling the English Prosecutor...” op. cit. p. 172 y HAY y SNYDER, “Using the Criminal Law...” op. cit. p. 28.

${ }^{515}$ De esta manera fue muy activa en especial la John Reeves' Association for the Preservation of Liberty and Property against Republicans and Levellers, fundada en 1792. Vid. HAY y SNYDER, "Using the Criminal Law...”,
} 
Con respecto a las materias donde estas asociaciones tuvieron un papel relevante en la defensa de intereses no estrictamente privados, tomadas como paradigma del papel de la persecución particular agrupada a los ojos de observadores foráneos como MITTERMAIER, GNEIST o SILVELA, podemos destacar las siguientes:

1) la protección de la infancia en la actividad laboral ${ }^{516}$ : algunos exitosos casos de acusación realizada por iniciativa de Lord Shaftesbury como consecuencia de la muerte de niños deshollinadores adquirieron relevancia pública. A instancias de éste se fundó en la década de 1840 la Climbings' Boys Society, una sociedad para la persecución del delito específicamente encargada de la explotación de los niños en la limpieza de chimeneas. A su vez se fundaron en los Midlands asociaciones locales de esta naturaleza, algunas con relativo éxito, otras con una vida efímera. Sin embargo, las carencias del sistema seguían siendo patentes y en 1875, con ocasión de una nueva ley, se implica por fin a la policía en el cumplimiento efectivo de las leyes en esta materia, con lo que la actividad de los particulares pierde en gran medida su sentido ${ }^{517}$.

2) la defensa de la moralidad pública: la actividad de las asociaciones en este sector se centró en la persecución de conductas que se oponía a las "buenas costumbres", empezando por la violación del descanso dominical y siguiendo por todo aquello que se considerase atacara las leyes contra el vicio y la inmoralidad (obscenidad, blasfemia, libelo sedicioso, etc. $)^{518}$. Especialmente activas fueron las asociaciones "Proclamation for

p. 28. La Revolución Francesa también había tenido efectos en las islas Británicas y esto llevó a un alto número de acusaciones contra los difusores de las ideas de la revolución en suelo inglés: por ejemplo Tom Paine fue objeto de una acusación oficial por libelo en 1792 respecto a su obra Rights of Man y sus correligionarios de la Society for Constitutional Information por traición dos años más tarde. Vid. HARLOW, C. y RAWLINGS, R., Pressure Through Law, op. cit. p. 31.

${ }^{516} \mathrm{Si}$ bien existían normas reguladoras de las condiciones en que se utilizaba a los aprendices, éstas no contemplaban formas para hacerlas efectivas, con lo que las vías de participación estaban en cierto modo cegadas. Estas normas han sido por ello calificadas como "leones sin dientes" ya que eran duras pero carecían de efectividad para su aplicación. En algunos casos el efectivo cumplimiento se dejaba en manos de los jueces quienes deberían inspeccionar fábricas y talleres. Sin embargo, bien porque los propios jueces tenían interés personal en la producción, bien porque les unían estrechos vínculos con los productores, se oponían con frecuencia a su cumplimiento cuando fuera contra sus propios intereses. Vid. HARLOW, C. y RAWLINGS, R., Pressure Through Law, op. cit. p. 28.

${ }^{517}$ Cfr. HARLOW, C. y RAWLINGS, R., Pressure..., op. cit. p. 29.

${ }^{518}$ Las ideas de lo inaceptable políticamente, de lo inmoral y de lo ilegal estaban con frecuencia muy cerca, por lo que no ha de olvidarse el componente político junto al estrictamente moral y religioso que suponía la lucha contra todo lo que poseyera connotaciones de ateísmo o republicanismo en unos momentos de amenaza de difusión de las ideas revolucionarias francesas y en una sociedad en la que Iglesia y Estado estaban estrechamente relacionadas. Así, 
the Encouragement of Piety and Virtue", de la cual formaban parte miembros de las capas más altas de la sociedad y del clero, y la "Society for the Suppresion of Vice", más conocida como "Vice Society", integrada principalmente por clases medias urbanas pero muy activa y muy numerosa a principios del siglo XIX ${ }^{519}$. Su activismo fue ampliamente discutido y sus actuaciones llegaron a poner sobre la mesa del debate parlamentario en 1821 la titularidad pública o privada de la acusación, optándose claramente en opinión de todos los que intervinieron en aquel momento por mantenerla encomendada a los sujetos privados $^{520}$. La propia asociación se presentaba como el medio más apropiado para la persecución del delito en un país libre, y en la mayoría de los casos los jueces le concedían la razón.

Más avanzado el siglo, emprendieron campañas de presión pública mediante la efectiva aplicación de la ley también grupos comprometidos con la persecución de la prostitución. Éstas comenzaron por la actividad del "National Committee for Repeal of the Contagious Diseases Act" ${ }^{, 521}$ y fueron continuadas por la "National Vigilance Association" a partir de 1885, cuando la acusación ya se había oficializado de facto. A pesar de ello, ésta última mantuvo una política de persecución penal llevando casos modelo (test cases) hasta la Corte Suprema en hipótesis en las que estimaban necesaria la reforma de la ley: recogiendo el testigo de la desaparecida "Vice Society", emprendió la persecución contra los editores de autores franceses como Zola, Flaubert y Maupassant, y ejercitó una férrea vigilancia sobre el music-hall, la fotografía y las postales que rozaran

por ejemplo, las acusaciones se dirigían más a obras de los racionalistas o los radicales que a libros pornográficos, con la lógica protesta de aquéllos que aún respetando a las sociedades no les reconocen el derecho a encumbrarse como custos moram. Vid. HARLOW, C. y RAWLINGS, R., Pressure Through Law, op. cit., pp. 31 y s. que se hacen eco de las palabras de Williams, editor de la obra de Paine The Age of Reason. Las condenas logradas por la "Vice Society" en materias políticamente sensibles originaron con posterioridad la creación del primer movimiento de librepensadores organizado como respuesta a sus acciones, cuando los grupos de apoyo a las víctimas de sus persecuciones se organizaron en sociedades racionalistas de carácter permanente.

${ }^{519}$ En 1803/1804 contaba con 1200 miembros y, sólo en Londres en 1803 consiguió 678 condenas de las cuales 623 fueron por violación de la obligación del descanso dominical. Vid. ROBERTS, M., "The Society for the Suppresion of Vice and Its Early Critics, 1802-12", Historical Journal 16, 1983 p. 168. Su verdadero color político se vio cuando se unió en 1820 a la "Constitutional Association for Suppresing the Progress of Disloyal and Seditious Principles".

${ }^{520}$ Vid. HARLOW, C. y RAWLINGS, R., Pressure Through Law, op. cit. p. 33.

${ }^{521}$ Grupo de oposición a una norma que pretendía evitar la extensión de enfermedades venéreas entre los soldados mediante el arresto forzoso y los exámenes médicos a las prostitutas. En opinión de esta asociación ello violaba las libertades civiles de las mujeres e incitaba a comportamientos deshonestos de los hombres. Vid. HARLOW, C. y RAWLINGS, R., Pressure Through Law, op. cit., p. 37. 
la inmoralidad ${ }^{522}$. A pesar de que en esa época la acusación privada residual empezaba a ser mayoritariamente de carácter singular, otros grupos muy activos fueron la "Society for the Prevention of Cruelty to Children" y la "Royal Society for Prevention of Cruelty to animals", que fundada en 1824 con fines educativos, asumió pronto también un papel en la inspección y persecución penal ${ }^{523}$.

La dificultad para la defensa de intereses que no fueran estrictamente los de los miembros de las asociaciones se debía también al hecho de que, del coste económico que suponían procesos complejos, no se recuperaba más que una mínima parte. Así, HARLOW y RAWLINGS relatan un caso de lo que en términos actuales sería protección del Medio Ambiente, al amparo de la Nuisances Abatement Act de 1821, en la que ya se vislumbran los principales problemas prácticos que hoy día encuentran los grupos para la defensa del medio ambiente ante los tribunales penales: la dificultad de obtener prueba en esta materia. Ello originaba inmensas inversiones de tiempo y dinero que desalentarían a quienes tuvieran una mínima preocupación por los asuntos de interés público ${ }^{524}$.

Las acusaciones colectivas no impedían que en el sistema jurídico inglés su ejercicio tuviera un carácter intrínsecamente individualista y que siguiera siendo visto tanto política, como legalmente, como un procedimiento contradictorio desarrollado exclusivamente entre individuos. Esta convicción generaba el que ocasionalmente estas asociaciones fueran sometidas a crítica por los posibles abusos inherentes a la toma de

${ }^{522}$ Aun cuando mantenían un estrecho contacto con la policía y tenían contactos políticos a los más altos niveles que les permitía ejercer de grupo de presión frente al poder legislativo, no por ello dejaron de iniciar numerosas acusaciones en esta materia, deduciendo la sección de Londres anualmente durante la década de los 90 más de 200 acciones penales. HARLOW, C. y RAWLINGS, R., Pressure Through Law, op. cit. p. 40.

${ }^{523}$ El número de persecuciones de ésta última aumentó de 1.357 en los años 1830 a 1839, a 71.657 en la década de los 90, alcanzado unos considerables niveles de éxito mediante la centralización y especialización en la dirección de las acusaciones. HARLOW, C. y RAWLINGS, R., Pressure Through Law, op. et loc. cits. En estos casos el objetivo se situaba sobre todo en el ejercicio de presión sobre las autoridades públicas, bien para el cumplimiento efectivo de unas normas cuya aplicación se había flexibilizado, bien para modificarla eligiendo casos modelo que pudieran sentar un precedente jurisprudencial en el sentido de sus demandas. Estos grupos se convirtieron así en lo que es conocido hoy día como "repeat players", especialistas en la presión para el cumplimiento de las normas en los sectores de los que se ocupaban y en los que están muy intensamente involucrados.

${ }^{524}$ HARLOW, C. y RAWLINGS, R., Pressure..., op. cit., pp. 27 y s. Relatan el caso de Mr. Garvey, abogado especializado en las leyes anticontaminación de la época que se encarga de informar a un Select Committee of the House of Lords de las dificultades en la aplicación de ese tipo de normas. Debido a la dificultad que para el individuo supone el hacer cumplir la ley, se muestra partidario de que sea una autoridad pública a petición de los vecinos de una parroquia la encargada de la dirección de este tipo de demandas. 
decisión colectiva ${ }^{525}$. En otras ocasiones, se ha dicho que las asociaciones eran una plataforma útil para llegar a componendas económicas que evitaran la persecución, con lo que se reproducía uno de los males que teóricamente se pretendía evitar con su creación ${ }^{526}$. Pero quizá sería más apropiado decir que este tipo de arreglos siguieron existiendo en la medida en que se mantuvo la acusación privada a título particular, ya que el espíritu liberal que impregna el sistema británico impedía que el individuo se disolviera en la comunidad ${ }^{527}$.

Pero la crítica no se agotaba en su naturaleza, sino que atacaba también su actividad acusándolas de ser ineficientes y discriminatorias en sus objetivos ${ }^{528}$. Tradicionalmente los propietarios o industriales buscaban su apoyo en empleados o vigilantes a los que se pagaba por los trabajos desempeñados, y éstos no tuvieron inconveniente ninguno en servir a las asociaciones cuando crecieron en número e importancia ya que no eran más que sus antiguos clientes actuando de forma colectiva. De hecho, con posterioridad, la recién creada policía tuvo en sus inicios en muchas partes del país una relación muy similar con este tipo de grupos, constituyendose de facto en su brazo armado $^{529}$.

El declive de las agrupaciones para la persecución del delito y de sus acusaciones ante los tribunales llegó a mediados del siglo XIX de la mano de la asunción de esa tarea por parte de la policía u otras instituciones estatales. La labor persecutoria y acusatoria cambia de manos y va adquiriendo de facto carácter oficial ${ }^{530}$. Aunque perdieran gran

\footnotetext{
${ }^{525}$ Vid. por ejemplo HAY y SNYDER, “Using the Criminal Law...”, op. cit. p. 35.
}

${ }^{526}$ PHILIPS demuestra que ello no es así sino que, antes al contrario, el evitar este tipo de arreglos económicos para eludir la acción de la justicia estaba entre las finalidades teóricas de las asociaciones, habiéndose establecido sanciones como la expulsión para los miembros que no observaran esta norma de conducta. Sin embargo reconoce la escasa aplicación práctica que encontró ese tipo de disposiciones. PHILIPS, “Good men...”, op. cit. p. 127.

${ }^{527}$ KING, op.cit. p. 203. En contra SCHUBERT, “Private Initiative...” op.cit. p. 37, para el que se había abandonado el derecho a actuar como individuo en el área legal.

${ }^{528}$ La "Vice Society" y la "Royal Society for the prevention of cruelty to animals" recibían críticas por la selección clasista del objeto de sus acusaciones, que les llevaban a la persecución de las actividades o diversiones de los pobres, pero no de las clases medias que con ellas se enriquecían. HARLOW, C. y RAWLINGS, R., Pressure Through Law, op. cit., pp. 32 y 42.

${ }^{529}$ HAY y SNYDER, “Using the Criminal Law...”, op.cit. pp. 37-38.

${ }^{530}$ En Leeds, por ejemplo, donde era notoriamente aceptado por los magistrados que el responsable de la acusación era el jefe de policía y que esta tarea era desempeñada por dos abogados, nombrados cada uno por uno de 
parte de su razón de existir, las asociaciones no desaparecieron inmediatamente sino que algunas de ellas continuaron durante un largo período manteniendo una relación con las nuevas fuerzas policiales similar a la que habían tenido anteriormente con los Parish Constables. Algunas no se disolvieron hasta el final de la Primera Guerra Mundial, e incluso otras mantienen hoy día una existencia activa a veces como asociaciones de tipo filantrópico ${ }^{531}$ o a veces con un carácter meramente formal, más pensadas como clubs de convivencia que celebran una cena anual que como herederas de su originaria función ${ }^{532}$.

los dos partidos políticos, el número de acusaciones privadas en 13 años de los que se da cuenta ante el Parlamento en 1856 fue de solamente 2. Vid. HAY y SNYDER, "Using the Criminal Law...", op. cit. p.39. Aunque no se pueda hablar de una situación homogénea en todo el país, ya que ésta variaba de unos condados a otros, es a partir de 1856 con el funcionamiento de las policías de Condados, cuando las asociaciones dejan aceleradamente de cumplir esa función que ahora ya tiene un responsable definido. PHILIPS, D., "Good Men to Associate...", op. cit. p. 123. Este reforzamiento de la policía también encontró resistencia entre los que preferían pagar una cuota de suscripción a una asociación que protegía sus propiedades en vez de pagar una tasa con la que financiar la policía, que desde luego era más cara. PHILIPS, “Good Men to Associate...", op. cit. p. 150.

${ }^{531}$ Un buen ejemplo de ello es la NVA ("National Vigilance Association") que puede ser calificada como la heredera directa de la "Vice Society", y que ha adquirido mucha fama en su ultraconservadora defensa de los valores morales tradicionales. Incluso en opinión de algún autor la tarea de ésta última sigue hoy en pie personificada en la Señora Whitehouse, una incansable y muy célebre luchadora en la cruzada contra la inmoralidad, en el intento de rehabilitar en la actualidad los moribundos delitos de obscenidad y blasfemia. Vid. HARLOW, C. y RAWLINGS, R., Pressure Through Law, op. cit. p. 59.

${ }^{532}$ Entre ellas la "Salt Hill Society for the Protection of Person and Property from Thieves" (fundada en Buckinghamshire en 1783), la "Tanworth Association for the Apprehension and Prosecution of Felons" (fundada en 
En la actualidad son mucho más operativas las asociaciones de afectados para la defensa de intereses comunes, y en ese sentido se destaca singularmente la CADD (Campaign against drinking and driving), dedicada a la persecución de las infracciones cometidas por conductores bajo la influencia de bebidas alcohólicas. Sobre la cuestión se volverá en otro lugar de este trabajo.

Warwickshire en 1784), la "Lincoln and Linconshire Association for the Prosecution of Felons" (fundada en 1802) o la "Leamington New Association for the Prosecution of Felons and for the Protection of Property" (establecida en Warwickshire desde 1824). Vid. la relación de asociaciones y acuerdos elaborada por PHILIPS, "Good men..." op. cit. Apéndices 1 y 2, pp.152 y ss y 160 y ss. 



\section{Segunda parte:}

\section{Naturaleza jurídica de la acusación popular}





\section{LA PREVISIÓN CONSTITUCIONAL DE LA ACCIÓN POPULAR}

\subsection{El proceso constituyente}

\subsubsection{Plasmación en el texto constitucional}

La correcta interpretación de la mens legislatoris constitucional en la previsión por el art. $125 \mathrm{CE}$ de la acción popular exige acudir con carácter previo a un análisis del proceso de formación de aquel precepto. Con tal premisa se obtendrán datos clave acerca de la presencia en nuestro ordenamiento de un reconocimiento tan singular como es éste ${ }^{533}$.

\footnotetext{
${ }^{533}$ Sólo conocemos en derecho comparado un precepto constitucional que reconozca la acción popular con el
} carácter generalizado que lo hace nuestro art. 125: el hoy derogado art. 49.2 de la Constitución portuguesa de 1976, que establecía: "Se reconoce el derecho de acción popular en los casos y términos previstos en las leyes". Tras la reforma constitucional de 1989 la acción popular se prevé en la actualidad junto con el derecho de petición en su art. 52.3. En este precepto se reconoce la posibilidad de su ejercicio personal o a través de asociaciones, pero delimitada objetivamente por deber dirigirse siempre a la defensa de intereses colectivos (acciones de prevención, cesación o persecución judicial de las infracciones contra la salud pública, la degradación del medio ambiente y la calidad de vida o la del patrimonio cultural). Vid. MAGALHÃES, J., "Ambiente de perdição, Acções de Salvação: A Acção Popular Ecológica e o Direito às Compensações por Prejuízio Ambiental no Horizonte Português de 1992”, Revista de Direito Público, $\mathrm{n}^{\circ}$ 8, 1990, pp. 9 y ss.; COLAÇO ANTUNES, L.F., "Los intereses difusos: ubicación constitucional, tutela jurisdiccional y «acción popular de masas» (En torno a la revisión de la Constitución Portuguesa de 8 de julio de 1989)", RAP n n $^{0}$ 124, enero-abril 1991, pp. 417-435. Si se quieren rastrear otros precedentes al margen de nuestro propio ordenamiento jurídico, podríamos referirnos también a la Constitución del Estado Federado de Baviera, cuyo art. 98.4 reconoce una ilimitada legitimación para el control de constitucionalidad de las normas en los siguientes términos: "La inconstitucionalidad de una ley puede hacerse valer por cualquiera". Al respecto vid. KOCH, $\mathrm{H}$;; Prozeßführung im öffentlichen Interesse. Rechtsvergleichende Entwicklungsbedingungen und Alternativen objektiver Rechtsdurchsetzung, Francfort 1983, p. 194, donde se destaca la positiva valoración político-jurídica de esta previsión entre la doctrina, aun cuando no se fundamente sobre una utilización cuantitativamente importante. En relación con la conveniencia de una acción popular en el proceso penal existe un antecedente de discusión cercano en el tiempo y en el espacio: el debate para la elaboración de un nuevo Código Procesal Penal en Italia que se desarrolló a finales de los años 60 y primera mitad de la década de los 70 . En él se propugnó desde los bancos ocupados por los partidos de izquierda la introducción de formas de "control social" y "participación democrática en el proceso penal", entre las cuales se incluía la acusación popular. Sin embargo aquella propuesta que realizara el diputado GUIDI nunca vió la luz y ni siquiera fue considerada en el debate para la elaboración del Codice di Procedura Penale hoy en vigor. Vid. especialmente UBERTIS, G., "Azione penale e sovranità popolare", Riv. Ital. Dir. proc. pen. 1975, pp. 1200, n. 31 y GHIARA, A., "Partecipazione popolare 
El art. 115 del Anteproyecto constitucional sólo se refería a la participación de los ciudadanos en la justicia en términos muy generales ("Los ciudadanos participarán en la administración de justicia en los casos y formas que la ley establezca"), creando lo que PECES-BARBA definió como "norma de organización", que permitía que el legislador ordinario estableciera los casos y formas en que los ciudadanos pudiesen intervenir activamente en la justicia. Estas formas de participación en las que había pensado la Ponencia constituyente no sólo eran el jurado o la acción popular, sino que abarcaban un espacio más amplio, incluyendo también, por ejemplo, el ejercicio y la obligación de denunciar o de prestar testimonio ${ }^{534}$.

La primera referencia a la acción popular se introdujo en nuestra Carta Magna mediante la enmienda número 553 al Anteproyecto de Constitución, defendida por D. Raúl Morodo Leoncio, Diputado del Partido Socialista Popular e integrante del Grupo Parlamentario Mixto. El primer número de la enmienda se refería a la acción popular como una forma de participación en la administración de la Justicia "en los delitos públicos, así como en los asuntos y procedimientos que afecten a los intereses generales", extremos que, sin embargo, no fueron aprobados por la ponencia. La enmienda $\mathrm{n}^{\circ} 444 \mathrm{del}$ Grupo Socialista del Congreso, apoyada por la $n^{\circ} 64$ del Sr. Letamendía contenía también una referencia que contribuía a favorecer su ejercicio en los siguientes términos: "En los asuntos de interés público la acción popular no estará sujeta a limitaciones". Sin embargo esta previsión fue también rechazada por la Ponencia considerando que "era más apropiado dejar a la ley el establecimiento de los casos y formas de participación, así como la regulación concreta del ejercicio de la acción popular" (el subrayado es nuestro). De este modo quedó fijado el primer inciso del vigente art. 125 ("Los ciudadanos podrán ejercer la acción popular y participar en la Administración de Justicia"), el cual permaneció inalterado a lo largo de todo el posterior iter constituyente a pesar de la intensa discusión sobre la conveniencia o no de constitucionalizar el jurado, institución que en último término le acompañó en el mismo artículo. El intento de concretar cuáles fueran esas formas de contribución de los ciudadanos a la administración de la Justicia se reflejó en el texto de la Primera Norma mediante la escisión del ejercicio de la acción popular (sin referencia ninguna a los supuestos en que se podría utilizar) del

all'esercizio dell'azione penale", p. 263 n. 20, 25 y 30.

\footnotetext{
${ }^{534}$ Vid. Debate en la Comisión de Asuntos Constitucionales y Libertades Públicas del Congreso de los Diputados de 8 de junio de 1978, en CONSTITUCIÓN ESPAÑOLA. Trabajos Parlamentarios. vol. I. Madrid 1980, p. 1375.
} 
concepto "participación de los ciudadanos en la Administración de Justicia", ${ }^{535}$. El ejercicio de la acción popular se separó así de las formas participativas representadas por el ejercicio de la función jurisdiccional a través del Jurado y de los Tribunales Consuetudinarios y tradicionales, únicas vías de "participación en la Administración de Justicia" reconocidas expresamente como tales en el texto aprobado ${ }^{536}$.

La referencia del art. 125 CE a la intervención ciudadana en la Justicia, sitúa a la acción popular sobre un plano similar a otra institución de rancia raigambre liberal como es el jurado ${ }^{537}$. Pero mientras el Tribunal del Jurado no se introdujo en nuestro sistema

\footnotetext{
${ }^{535}$ Las formas de participación, que en las enmiendas de MORODO y del Grupo Socialista se concretaron en la acción popular y el jurado, incluían en las del Grupo de Unión de Centro Democrático también la elección por sufragio directo de los Jueces y Fiscales que sirvieran a los Juzgados de Paz. Incluso el Diputado CASTELLANO CARDALLIAGUET llegó a citar como futuras formas de participación del pueblo en la Justicia la vinculación a la elección de "sus" fiscales, a la elección de "sus" jueces o a la constitución de organismos colegiados que suministrasen elementos destacados para la administración de la justicia en determinadas audiencias como ocurría en algunos Juzgados de Paz. Como se podrá ver, un amplio elenco de vías de participación en la Justicia que en último término no vieron la luz. Vid. Trabajos Parlamentarios cit. pp. 348, 497 y 2302.
}

536، Ejercer la acción popular” y "participar en la Administración de Justicia mediante la institución del Jurado" son, además, dos manifestaciones de la intervención de los ciudadanos en la justicia conectadas por lazos comunes (el papel activo de los legos), con frecuencia incluidas en el mismo bloque, pero cuyos contenidos son difícilmente compatibilizables. Centrándonos en el proceso penal, cabría decir que mientras el ejercicio de la acción popular se dirige al cumplimiento de la competencia estatal de acusación, en el caso del jurado se trataría de juzgar. Como es fácil comprobar, se trata de dos funciones de muy heterogénea finalidad, carácter y naturaleza. Tales diferencias han sido resaltadas por significados tratadistas en su defensa del jurado. Así VARELA CASTRO por ejemplo niega la asimilación a un derecho fundamental (el de participación del art. 23) de la participación de los ciudadanos en la Jurisdicción a través del Jurado, resaltando lo arduo que sería tal interpretación a diferencia de lo que ha ocurrido con la acción popular y el derecho a la tutela judicial efectiva del art. 24.1. VARELA CASTRO, L., "Fundamentos político-constitucionales y procesales" en el volumen colectivo, coordinado por él mismo El Tribunal del Jurado, Cuadernos de Derecho Judicial, CGPJ, octubre 1995. Cfr. también con la configuración del jurado realizada en sentido radicalmente diverso por PEDRAZ PENALVA en varios de sus trabajos. Vid. por todos "Sobre el significado y vigencia del Jurado", en Constitución, Jurisdicción y Proceso, Madrid 1990, pp. 59 y ss, "El Jurado como vía de participación popular", en La Ley 1994-2, pp. 1006-1014 y en "Notas sobre el Jurado que viene", Revista del Ilustre Colegio de Abogados del Señorío de Vizcaya, $2^{\mathrm{a}}$ época, $\mathrm{n}^{\mathrm{o}}$ 1, enero-marzo 1996, p. 758. No cabe sin embargo obviar la absolutamente errónea incardinación del jurado en el ámbito del derecho de participación del art. $23 \mathrm{CE}$ realizada en la Exposición de Motivos de la LOTJ. La participación a que este artículo se refiere es única y exclusivamente la participación política y no podría incluir en ningún caso al jurado ni por supuesto a la acción popular.

\footnotetext{
${ }^{537}$ Esta idea de intervención del pueblo ha llegado hasta el punto de atribuirse por algún sector doctrinal a este precepto el título de "democracia y justicia". Vid. así SERRANO ALBERCA, J.M. en los Comentarios a la Constitución dirigidos por GARRIDO FALLA, F., Madrid, 1985, p. 1847. Cfr. por el contrario desde una óptica crítica especialmente los trabajos de PEDRAZ PENALVA "Sobre el significado y vigencia del jurado" y "El Jurado
} 
hasta 1995 puesto que el precepto constitucional contenía sólo una habilitación al legislador dirigida hacia el futuro ${ }^{538}$, la previsión constitucional de la acción popular vino en cierto modo a otorgar notoriedad a la existencia de diversos preceptos de larga solera en diversos ámbitos de nuestro ordenamiento jurídico ${ }^{539}$. Sin embargo toda la posterior discusión parlamentaria sobre el artículo donde se constitucionalizaba la acción popular pasó por alto esta materia, centrándose el debate de lleno en la oportunidad del reconocimiento constitucional del Jurado y prescindiendo del primer inciso que en todo momento se dio por bueno ${ }^{540}$. Frente a la abundancia de consideraciones sobre la democracia participativa, la soberanía popular y sus respectivos acomodos en la Justicia, es, cuando menos, significativa la falta de referencias en clave bien apologética, bien crítica, a una institución ya presente en variadas manifestaciones en nuestro ordenamiento, más que centenaria en alguna de éstas, profundamente liberal en su espíritu y supérstite a una variedad antagónica de sistemas políticos. Quizá una de las razones estribara en el voluntarismo democrático y participativo que, a primera vista, parece llevar consigo, pero también debemos considerar que, debido a que apenas era utilizada en la práctica, sus posibles inconvenientes no saltaban a la vista, máxime cuando existían "frenos" que se consideraban ya suficientemente garantizadores de su correcta utilización.

Del proceso de elaboración de la Carta Magna podemos deducir que el interés pretendido con la inclusión constitucional de la acción popular se centraba en la potenciación de la participación ciudadana en determinados ámbitos de la vida pública. Una de las modalidades de esta intervención vendría de la mano de la apertura de un

como vía de participación popular"citados.

\footnotetext{
${ }^{538}$ Con frecuencia se ha sostenido que tal previsión no contendría sólo una habilitación sino un mandato expreso. Sobre el sentido de la expresión "podrán", incluida en el art. 125 CE vid. PEDRAZ PENALVA, E., "Sobre el significado y vigencia del jurado", op. cit. pp. 64 y s.

${ }^{539}$ La regulación del jurado ha venido a introducir posteriormente una diferencia sustancial a este respecto: mientras que el ejercicio de la acción popular es siempre una facultad de los ciudadanos, el formar parte del Tribunal del Jurado es también un deber (Vid. Exposición de Motivos y art. 6 LOTJ).

${ }^{540}$ A excepción de alguna referencia tangencial como la de D. Licinio DE LA FUENTE, que modificó su opinión en la que abogaba por la supresión de todo el artículo, para postular, exclusivamente, la de la parte del mismo "que se refiere a la participación popular en la administración de justicia”. Con respecto a la acción popular, a la que excluye de esta participación, su opinión era que, aunque valdría la pena que el texto constitucional precisara un poco más su concepción excesivamente vaga e imprecisa, el tema no era suficientemente importante y podría precisarse posteriormente. Vid. Debate en la Comisión cit. p. 1372.
} 
portillo a los ciudadanos para asumir la iniciativa en la tutela de intereses generales o de utilidad pública, lo cual se concretaría en el proceso penal a través de la acusación popular. La defensa de ese tipo de intereses ha sido precisamente el ámbito en el que posteriormente el Tribunal Constitucional ha reconducido de alguna manera el ejercicio de la acción popular en el proceso penal a los derechos fundamentales. Lugar único en el que la acción popular, entendida como atribución a los ciudadanos de la facultad de asumir un papel activo en defensa de intereses de carácter material y de titularidad supraindividual, adquiere carta de naturaleza constitucional. El constituyente no estaba pensando por tanto en la atribución de un genérico derecho de acción popular en todos los ámbitos, y por ende tampoco de una ilimitada facultad de acusar en el proceso penal, sino en que la participación ciudadana en asuntos públicos para la defensa de intereses generales pudiera en algún caso realizarse sin restricciones en la legitimación activa. Lo que se constitucionaliza a través del art. $125 \mathrm{CE}$ es un derecho a la intervención de los ciudadanos bajo las premisas legales en procesos donde se ventilasen intereses públicos, pero no un abstracto derecho al ejercicio de la acción popular integrante del catálogo de derechos de los ciudadanos. Ese es el dato esencial a retener en este primer momento, pues del precepto sólo podrá entenderse derivado un derecho al ejercicio de la acción popular allí donde, concurriendo un interés público, la ley ordinaria lo posibilite.

Cabe advertir, además, que la previsión del art. 125 CE no se limitó al propio texto de la Carta Magna, sino que, con posterioridad, se introdujo expresamente un reconocimiento cuasi-constitucional de la acción popular en dos de los diecisiete Estatutos de Autonomía prácticamente en los mismos términos en que se recogía en aquel precepto. Se trata en concreto del art. 34.3 de la LO 3/1979 de 18 de diciembre de Estatuto de Autonomía para el País Vasco (“En la Comunidad Autónoma se facilitará el ejercicio de la acción popular y la participación en la Administración de Justicia mediante la institución del Jurado, en la forma y con respecto a aquellos procesos penales que la Ley procesal determine"); y del art. 48 de la LO 1/1983 de 25 de febrero de Estatuto de Autonomía de Extremadura ("En Extremadura se propiciará el ejercicio de la acción popular y la participación en la Administración de Justicia mediante la institución del Jurado en la forma que las leyes determinen, de acuerdo con lo dispuesto en el art. 125 de la Constitución") ${ }^{541}$.

\footnotetext{
${ }^{541}$ En otros dos hay una referencia a la participación popular en la Justicia pero sólo en relación con el Jurado: art. 51 del Estatuto de Autonomía para Andalucía (LO 6/1981 de 30 de diciembre): “Los andaluces podrán participar en la Administración de Justicia, mediante la institución del Jurado...” y art. 28 de la LO 9/1982 de 10 de agosto de
} 


\subsubsection{Concreción en la LOPJ}

En el desarrollo del Título VI de la Constitución, la LOPJ de 1985 supuso la delimitación de lo previsto en la Primera Norma. El art. 19.1 LOPJ vino a reconocer expresamente que "los ciudadanos de nacionalidad española podrán ejercer la acción popular, en los casos y formas establecidos en la ley", añadiendo además en su art. 20.3 un poco claro pero importante matiz consistente en que "no podrán exigirse fianzas que por su inadecuación impidan el ejercicio de la acción popular, que será siempre gratuita". Además, el art. 406, siguiendo una tradición que se remonta a la Constitución de Cádiz de 1812, prevé el ejercicio de la acción popular como una de las formas de iniciación del juicio de responsabilidad penal contra Jueces y Magistrados.

La incardinación constitucional de la acción popular y su inclusión en la legislación orgánica nos otorgan así un primer punto de apoyo para su consideración como uno de los elementos para la articulación de la Justicia antes que como facultad de los ciudadanos. No olvidemos que una interpretación sistemática de la Suprema Ley nos llevaría a constatar que el art. $125 \mathrm{CE}$ se encuentra en su parte orgánica, no en la dogmática, y que por consiguiente no se refiere tanto al reconocimiento de derechos a los ciudadanos cuanto a la organización y funcionamiento de los Poderes Públicos ${ }^{542}$. Su concreta plasmación en la LOPJ nos permite además reafirmar este argumento ya que la inclusión en el art. 19.1, dentro del Título Preliminar ("Del Poder Judicial y del ejercicio de la Potestad Jurisdiccional"), nos estaría hablando de una norma de organización de la Justicia. Debemos destacar, sin embargo, que sostenemos este criterio conscientes de nuestro desacuerdo con el manifestado por un importante sector doctrinal, para el que la acción popular no tendría necesariamente que haber sido abordada por una norma cuyo contenido fundamental es la organización del Poder Judicial ${ }^{543}$.

Estatuto de Autonomía de Castilla-La Mancha: “Los ciudadanos de Castilla-La Mancha podrán participar en la administración de justicia mediante la institución del Jurado...”.

\footnotetext{
${ }^{542}$ En sentido contrario vid. GIMENO SENDRA, V., "La acción popular, el jurado y los Tribunales de escabinos", en COBO DEL ROSAL y BAJO FERNÁNDEZ, Comentarios a la legislación penal, T. I. 1982, pp.337 y ss. En su opinión el art. 125 CE consagra tres “derechos cívicos constitucionales”, por lo que este precepto podría estar incluido en la parte dogmática y no en la orgánica de la Constitución.

${ }^{543}$ Así por ejemplo FAIRÉN critica la inclusión de la acción popular en la LOPJ ya que, en su opinión, debería hallarse en los textos procesales más que en ella. FAIRÉN GUILLÉN, V., "La independencia judicial en España en
} 
El iter legislativo de la LOPJ tampoco aporta demasiados datos clarificadores en torno a la acción popular en nuestro sistema procesal, salvo en lo atinente a la imposición de fianza para su ejercicio. El nonato primer Proyecto de LOPJ de 1980 no hacía más que repetir en su art. 18 lo previsto en el 125 de la $\mathrm{CE}^{544}$, por lo que el precedente directo de la previsión de la acción popular en este caso ha de situarse en la enmienda a la totalidad a aquel proyecto presentada por el Grupo Parlamentario Socialista del Congreso ${ }^{545}$. En concreto, el primer párrafo del art. 20 del texto alternativo, presentado como enmienda, decía: "Los ciudadanos y las personas jurídicas de nacionalidad española podrán ejercer la acción popular en los casos y formas establecidas en la ley". Tal fue el texto que se recogió en el mismo artículo del Anteproyecto de LOPJ enviado por el Gobierno para informe al CGPJ en diciembre de 1983, sin que por éste fuera alegada ninguna cuestión al respecto $^{546}$.

En el Proyecto de Ley remitido al Congreso en $1984^{547}$ ya figuraba el art. 19.1 en los mismos términos en los que hoy lo conocemos: "Los ciudadanos de nacionalidad española podrán ejercer la acción popular, en los casos y formas establecidos en la $l e{ }^{" 548}$. Cabe por tanto reseñar que con respecto al Anteproyecto se había suprimido la mención a las personas jurídicas, lo cual ha sido interpretado en alguna ocasión como una muestra de la voluntad del legislador para excluirlas del ejercicio de la acción popular ${ }^{549}$.

la actualidad" (Addenda), Ponencia Nacional para el VII Congreso Internacional de Derecho Procesal, incluida en Estudios de Derecho Procesal civil, penal y constitucional, vol. I, Madrid 1983, p. 102.

${ }^{544}$ BOCG, Congreso de los Diputados, Serie A, II Legislatura, nº 129-I, 16 de abril de 1980, p. 883.

${ }^{545}$ Publicado en Poder Judicial (Documentación preparada para la tramitación del Proyecto de Ley Orgánica del Poder Judicial). Congreso de los Diputados, Documentación, nº 28 (T.II), octubre de 1984, p. 739.

${ }^{546}$ Boletín de Información del CGPJ, no extraordinario, Madrid, marzo de 1994, p. 16 (texto del Anteproyecto) y 170 (informe del CGPJ al art. 20).

${ }^{547}$ BOCG, Congreso, II Legislatura, Serie A, 19 de septiembre de 1984, 118-I, p. 1374.

${ }^{548}$ La referencia a la "nacionalidad española" fue suprimida en el informe de la Ponencia del Congreso, pero se volvió a introducir tras la discusión en el pleno con el objeto de dar más precisión al precepto. Vid. BOCG (Congreso), Serie A, 23 de febrero de 1985, nº 118-I-1, pp. 1148/18 y BOCG (Congreso), año 1985, nº 191, 21 de marzo de 1985, pp. 8756,8782 y 8787.

${ }^{549}$ Así MARTÍN BERNAL, J.M., "La acción popular y la tutela de los grupos”, Actualidad Penal 1988, n 16, Marginal 296, p. 819. Advierte el autor citado: "nótese que la redacción del proyecto lo que suprimió fue la copulativa y, seguida del término personas jurídicas, que no puede obedecer a una omisión de puro estilo, sino que fue el designio deliberado del legislador el erradicar la expresión, porque son los ciudadanos, y no la persona jurídica que carece por lo demás de ciudadanía, los que pueden ejercitar la acción popular". 
Puesto que no hay ningún otro dato que apoye esta conclusión, estimamos sin embargo más adecuado pensar que el prelegislador estaba simplificando el texto y entendía incluidas a las personas jurídicas en un concepto amplio de "ciudadanos". Puesto que la posición del grupo político que sustentaba al Gobierno permanecía invariable desde el primer proyecto, y siguió así en la tramitación parlamentaria de éste, no hay razón para pensar lo contrario. Debe también agregarse que en el Proyecto no se contemplaba la prohibición hoy contenida en el 20.3 concerniente a la exigencia de fianzas.

La discusión parlamentaria no puede juzgarse demasiado fructífera sobre la cuestión. Aun así, es posible encontrar alguna referencia colateral, principalmente al hilo del debate sobre el jurado. El diputado VIZCAYA RETANA defendió que la acción popular requeriría solamente un tratamiento básico que después fuera desarrollado por leyes posteriores. Añadía, además, que sería necesario que "los ciudadanos que creemos en la acción popular, que creemos también en la institución del Jurado, recibiésemos más dosis de esperanza respecto a su futura regulación..." ${ }^{550}$. La polémica sirvió también para enmendar el contenido del art. 429 del Proyecto (art. 406 de la Ley actual) que impedía el ejercicio de la acción popular para la exigencia de responsabilidad criminal de Jueces y Magistrados ${ }^{551}$.

La previsión sobre las fianzas exigibles, no contenida en el proyecto original, fue introducida en la Comisión de Justicia e Interior del Congreso como añadido al actual art. 20.1 en relación con la justicia gratuita ${ }^{552}$. La enmienda originaria fue suscrita por el diputado BANDRÉS MOLET, y pretendía la eliminación de la fianza para el ejercicio de la acción popular con la finalidad de hacer posible y viable lo que se calificaba como "joya de nuestro derecho procesal" o "hermosa y democrática institución, que, por cierto, no aparece en las legislaciones de nuestro entorno jurídico cultural". Afirmaba

\footnotetext{
${ }^{550}$ Diario de Sesiones del Congreso de los Diputados, II legislatura, $\mathrm{n}^{\mathrm{0}}$ 164, sesión plenaria celebrada el día 13 de noviembre de 1984, p. 7371.

${ }^{551}$ Parece que se trataría de un simple error, aun cuando fuera tachado en su momento de omisión expresa y voluntaria del redactor del proyecto. Vid. la intervención del diputado ALZAGA VILLAAMIL, Diario de Sesiones del Congreso cit. p. 7389. La mención expresa a la acción popular en esta materia se introdujo en el informe de la ponencia del Senado (art. 412) a través de la enmienda del Senador FERNÁNDEZ-PIÑAR (Grupo Mixto). BOCG (Senado), Serie II, 28 de mayo de 1985, nº 243 (d), pp. 528 y 618.

${ }^{552}$ Vid. la discusión en el Diario de Sesiones del Congreso de los Diputados, Comisión de Justicia e Interior, II legislatura, Sesión de 4 de marzo de 1985, n 272, pp. 8459 a 8461. Vid. Dictamen de la comisión del Congreso en BOCG, Serie A, n 118-II, pp. 1448/97.
} 
BANDRÉS que el señalamiento de fianzas ha sido utilizado históricamente, y seguía siéndolo, como un freno o una dificultad que hacía muchas veces imposible, inviable el ejercicio de la acción popular ${ }^{553}$. Por ello, mantenerla sería poner una valla o un impedimento muy serio e importante en el ejercicio de la acción. Para prevenir y evitar posibles abusos procedentes de "entidades y gentes poco interesadas realmente en el procedimiento penal" estaría la posibilidad de condenar en costas una vez que el juez, $a$ posteriori y a la vista del ejercicio en su caso abusivo, podía utilizar en el momento de dictar sentencia.

Sin embargo, el Grupo Socialista del Congreso, que se manifestaba sensible a aquellos razonamientos, juzgó demasiado rotunda la prohibición de imponer fianzas de “...ningún tipo” (Diputado GRANADOS CALERO). De ahí que como enmienda transaccional se redactara por iniciativa suya el precepto casi en los términos que hoy conocemos: "La acción popular será siempre gratuita y no podrá exigirse fianza que por su inadecuación impida el ejercicio de la misma". Tal redacción gozó de la aprobación unánime de la Comisión e incluso el Diputado BANDRÉS reconocía que mejoraba la presentada por él, cumpliendo lo que en el fondo pretendía preservar con su enmienda ${ }^{554}$.

La utilización del plural (“fianzas... que impidan”) y su colocación definitiva como número 3 del mismo artículo proceden de una enmienda del Grupo Socialista del Senado, justificada simplemente por razones de sistemática ${ }^{55}$. Con respecto al primero de estos cambios, no puede entenderse que sea irrelevante como a primera vista puede parecer. El

\footnotetext{
${ }^{553}$ Para demostrar lo politizada que ya estaba la justicia a la vista de las resoluciones de los jueces se servía de un ejemplo: "Si, como ha ocurrido en alguna ocasión, se hunde una bóveda del metro de Madrid donde están haciendo unas obras y mueren varios obreros, y alguien como el Obispo Auxiliar de Madrid o unas asociaciones ciudadanas quieren formular una acusación popular y presentan sus escritos planteando esta posibilidad en el procedimiento penal oportuno, si el juez señala una fianza de 1.000 pesetas, yo sé como piensa ese juez; si se señala una fianza de 10 millones de pesetas, yo también sé como piensa ese juez". Vid. Diario de Sesiones cit. p. 8460. No reparaba el Diputado proponente, sin embargo, en otros criterios objetivos que hubieran podido tenerse en cuenta para la imposición de la fianza con independencia de la confianza que le mereciera el sujeto actor tales como su diligencia procesal, la riqueza o pobreza argumental de lo expuesto, la actuación del MF en la causa, la actuación procesal de los perjudicados por el delito, etc.

${ }^{554}$ También el grupo comunista intentó la supresión expresa de la fianza para el ejercicio de la acción popular, aun cuando igualmente dio por buena la referencia introducida en la ley. Vid. BOCG (Congreso), año 1985, nº 191, 21 de marzo de 1985, p. 8783.

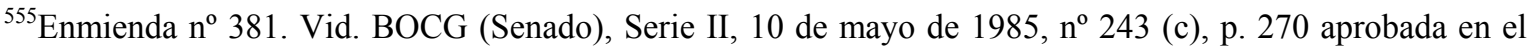
informe de la ponencia. BOCG (Senado), Serie II, no 243 (d), pp. 502 y 549.
} 
cambio del singular al plural puede leerse como el deslizamiento de la prohibición absoluta de imposición de fianzas hacia la prohibición solamente de las inadecuadas que impidan su ejercicio. Lo que en la enmienda del Diputado BANDRÉS amparaba el deseo de supresión de la fianza, en el texto definitivo suponía la admisión genérica de la imposición de fianzas con la única salvedad de aquéllas que se considerasen inadecuadas.

\subsection{Las "acciones populares" en la Constitución}

\subsubsection{Datos predicables de las "acciones populares"}

La Carta Magna no contiene dentro de la ambigua y confusa redacción de su art. $125^{556}$ un perfil acotado de lo que haya de entenderse comprendido en los términos "acción popular". De su observación un único dato se presenta claro ab initio: el deseo expresado por el constituyente de que en nuestro ordenamiento existan supuestos en los cuales venga simultáneamente atribuida legitimación a una pluralidad indefinida de ciudadanos. Sus notas esenciales habrán de extraerse tomando en cuenta algunas de las características comunes a las realidades normativas a las que estaba dirigiendo su mirada el constituyente. En este sentido debemos reseñar como propias de las "acciones populares" las siguientes características:

1) Habilitación para deducir una pretensión dirigida a la defensa de intereses difundidos

El reconocimiento de la acción popular se refiere a una habilitación para el ejercicio en el proceso de una pretensión dirigida objetivamente a la satisfacción de un interés no meramente individual. Esto podrá ocurrir únicamente en ámbitos sectoriales

\footnotetext{
${ }^{556}$ GUTIÉRREZ-ALVIZ y ARMARIO, F. y MORENO CATENA, V. señalan la notable inconcreción y el modo esquemático de la redacción del precepto, por lo que prima facie pocas consecuencias se pueden extraer de él. "Art. 125. La participación popular en la Administración de Justicia" en ALZAGA, O. (Director) Comentarios a las Leyes Políticas T. IX, p. 599. También es presentado como ejemplo de mala técnica legislativa por FAIRÉN GUILLÉN, V., Comentarios a la LOPJ, Madrid 1986, p. 52, n. 81 ya que comprende tres problemas muy diferentes sin siquiera puntos de separación. Por su parte, LOZANO-HIGUERO PINTO sostiene desde otro punto de vista la innecesariedad de la previsión específica de la acción popular. En su opinión "la fórmula del 125 CE es incorrecta, imperfecta técnicamente y, por lo mismo, limitativa". Sostiene este autor que, al establecerse la libertad de acción y el derecho a la Jurisdicción en el art. 24, ya se habría conferido el cauce de participación principal. "Notas sobre la participación procesal y su proyección en las formas alternativas de justicia”, RUDProc, $\mathrm{n}^{\circ}$ 0, 1988, p. 55.
} 
tales como el control del cumplimiento de las normas administrativas o en hipótesis en las que concurra un interés que, de alguna manera, se generaliza, y difunde entre todos. Por el contrario, en los procesos civil y laboral, en tanto en ellos se debaten normalmente cuestiones relativas a intereses privados, no cabría nunca el establecimiento de "acciones populares" ${ }^{557}$. Parece además que no sería apta tampoco en otros ámbitos una acción popular para la defensa de situaciones jurídicas individualizables o individualizadas ${ }^{558}$.

La atribución de la facultad de defender procesalmente tales intereses no lleva consigo necesariamente el reconocimiento o la concesión de su titularidad, por lo que la legitimación se reconoce independientemente de la vinculación entre el legitimado y el interés que motive su intervención en el proceso. No nos movemos por tanto en el ámbito de los intereses, personales o colectivos, sino en el de la actividad necesaria para su tutela jurisdiccional, en el plano procesal ${ }^{559}$.

\footnotetext{
${ }^{557}$ En opinión de MONTERO, de llegar a concederse ésta significaría que ninguna persona podría afirmar que un derecho subjetivo era únicamente suyo y no cabrían relaciones jurídico materiales entre dos sujetos, que es lo que ocurre en el derecho penal en el que no existen relaciones jurídico-materiales penales. MONTERO AROCA, J., $L a$ legitimación en el proceso civil (Intento de aclarar un concepto que resulta más confuso cuanto más se escribe de él), Madrid 1994, p. 75. Jurisprudencialmente se ha convalidado el no reconocimiento de una acción popular en el ámbito civil. Así las SSTS de 2 de diciembre de 1991 (RAJ 8904) (no hay acción popular para impugnar los actos de un Registrador de la Propiedad) o de 29 de octubre de 1992 (RAJ 8182) (no hay acción popular para solicitar la demolición de obra realizada en dominio público). Vid. también SAP (Barcelona) (secc. 16 ${ }^{\mathrm{a}}$ ) de 5 de abril de 1991 (publicada en RJC II, 1991 y referida a derecho de los consumidores) y SAP (Sevilla) de 3 de octubre de 1991 (no hay acción popular para el ejercicio del derecho de rectificación de noticias).

${ }^{558}$ En relación con la acción popular urbanística, afirmaba CORDÓN MORENO que no constituiría cauce adecuado para el ejercicio de pretensiones cuyo contenido fuera el restablecimiento de una situación jurídica individualizada, sino solamente para pretensiones de anulación de un acto. Vid. CORDÓN MORENO, F., La legitimación en el proceso contencioso-administrativo, Pamplona 1979, p. 156. Ello se ha calificado como una "resurrección de la doctrina de las acciones de anulación frente a las de plena jurisdicción". Cfr. XIOL RIOS, J.A., "Consideración de algunos aspectos del proceso contencioso administrativo como respuesta a los fenómenos de masificación social: la legitimación, la limitación de las instancias, el tratamiento en serie de los recursos y los efectos de la sentencia", Cuadernos de Derecho Judicial, $\mathrm{n}^{\circ} \mathrm{XV}$, Jurisdicción Contencioso-Administrativa: aspectos procesales, Madrid 1992, p.169.

${ }^{559}$ En sentido contrario puede entenderse lo afirmado para el contencioso administrativo por CORDÓN MORENO que, basándose en la atribución en ocasiones de un interés a la generalidad de los ciudadanos, consideraba que las normas que establecen la acción popular no son procesales, sino materiales. A través de ellas la Ley consideraría a todos los ciudadanos titulares de una situación material en determinados ámbitos y, por tanto, interesados, otorgándoles el derecho de acción para reaccionar frente a la actuación administrativa ilegal. El ordenamiento jurídico otorgaría un ius activae civitatis para la defensa de intereses que son, a la vez, particulares y comunitarios, intereses autónomos que son de naturaleza cívica aun cuando coincidan con el interés público. En el
} 
El art. 125 CE no constituye una norma que contenga un reconocimiento de carácter absoluto, sino que se trata más bien del reconocimiento de una facultad individual configurada sólo como medio para un bien colectivo. De ahí que no quepa colisión entre un hipotético derecho al ejercicio de la acción popular y un bien cifrado en la búsqueda del interés general: si la facultad pierde su condición de medio para la consecución del fin al que va dirigido, la habilitación para su ejercicio no existirá como tal, porque no se integra. No habrá razón alguna, por tanto, para afirmarlo o mantenerlo. En tales circunstancias no sería posible su invocación como derecho fundamental, y lo que es más importante, ni siquiera como mero derecho subjetivo ${ }^{560}$. Es, en definitiva, una facultad cuya concesión sólo puede ir encaminada al logro de un fin de interés general, pero no contiene el reconocimiento en abstracto de una libertad de actuar, en este caso procesalmente.

El sujeto que deduce la pretensión realiza en beneficio de la comunidad exactamente la misma actividad que podrían hacer otras personas, es decir, asume voluntariamente una carga de la que hubieran podido ocuparse otros ciudadanos que, sin embargo, han preferido permanecer en una actitud pasiva. Una vez reclamada procesalmente por uno de los habilitados la tutela de aquel interés perturbado, se habrá satisfecho plenamente el contenido de la pretensión y no habría lugar a reiterar el ejercicio de ésta

contencioso administrativo se harían valer pretensiones individuales que se han incorporado a su esfera jurídica, y que operan unas en el ámbito puramente individual y otras, como aquéllas para la que se concede acción popular y, precisamente por este hecho, en una dimensión intersubjetiva. CORDÓN MORENO, F., La legitimación..., op. cit. p. 151. Por ello citando a PALADIN, Voz “Azione Popolare”, Novissimo Digesto italiano, II, Turín 1964, p. 90, afirma que la atribución de la acción popular no tiene por fin la salvaguardia de la esfera jurídica de la Administración Pública, sino que tiende al reconocimiento de un sustancial interés del ciudadano, otorgando un nuevo poder a su esfera jurídica. Para GONZÁLEZ PÉREZ, sin embargo, la regulación de la acción pública de la Ley del Suelo no es material, sino de indudable carácter procesal, razón por la cual su regulación es competencia del Estado y no de las Comunidades Autónomas (art. 149.1.6 ${ }^{\mathrm{a}} \mathrm{CE}$ ). Estaríamos en este caso ante una norma que se refiere única y exclusivamente a la legitimación, la cual viene conferida sin condición especial alguna ni titularidad de un derecho subjetivo, de interés personal, directo o legítimo (GONZÁLEZ PÉREZ, J., Comentarios a la Ley del Suelo, Madrid 1988, p. 2336). La vieja jurisprudencia del TS señalaba en sentido contrario el carácter material de la norma contenida en el hoy art. $304 \mathrm{LS}$, aun cuando evidentemente de ella fueran predicables efectos procesales. Vid. por ejemplo en la STS de 8 de noviembre de 1971 en la que se afirma, a nuestro juicio erróneamente, que "la norma excepcional que el artículo invocado establece no es una norma sobre jurisdicción o sobre procedimiento, sino una norma de derecho material en cuanto regula la acción como derecho, con efectos procesales en su caso, en orden a la legitimación".

${ }^{560} \mathrm{Cfr}$. ALEXY, R., Teoría de los Derechos Fundamentales, traducción de GARZÓN VALDÉS, E., Madrid 1993 , p. 110, n. 79 . 
por ningún otro sujeto.

2) La facultad para su ejercicio debe estar generalizada subjetivamente, sin que precise vinculación con el interés defendido

La atribución de la facultad para deducir en el proceso esa pretensión deberá estar extendida subjetivamente, pues es consustancial a la idea de acción popular el dato de que su ejercicio pueda ser realizado por todas las personas a las que no se les impida expresamente. No cabría elaborar un catálogo de sujetos habilitados para realizar esa actividad, pero sí de los sujetos que no pueden deducir la pretensión o de supuestos específicos en los que un determinado sujeto pueda quedar excluido. La atribución genérica al quivis de populo es uno de los elementos inherentes al concepto de acción popular, y bastará la mera pertenencia a la comunidad estatal, y su no exclusión expresa, para que la facultad se active.

Dados estos presupuestos, no será necesario para el actor acreditar vinculación alguna con el interés que se ventila en el proceso puesto que, tratándose de una acción popular, tal nexo no será relevante para determinar la existencia de legitimación activa. La exigencia de un interés de cualquier tipo que éste sea, directo ${ }^{561}$, personal o legítimo, para la asunción de facultades activas en el proceso excluye de raíz la presencia de una acción popular. Ella nos estaría hablando de otra forma de conferir legitimación, aun cuando ésta pueda ser también muy abierta.

\section{3) Necesario reconocimiento legislativo expreso}

Sólo será posible el ejercicio de una pretensión mediante "acción popular" si existe un reconocimiento legislativo expreso de tal posibilidad en las normas procesales. El precepto constitucional deja en manos del legislador ordinario la determinación de los supuestos en que deberá activarse la habilitación que en él se reconoce ("los ciudadanos podrán...”). La amplitud y las formas de este reconocimiento dependerán de una opción valorativa cuyos límites no vienen prima facie determinados constitucionalmente ${ }^{562}$. El

\footnotetext{
${ }^{561}$ Lo que hayamos de entender por interés directo no es nada claro, por cuanto se trata de un concepto objeto de constante discusión y elaboración jurisprudencial. Sobre la cuestión consideramos esclarecedor el magnífico trabajo de BUJOSA VADELL, L.M., La protección jurisdiccional de los intereses de grupo, Barcelona 1995, pp. 25 y ss.

${ }^{562}$ Como corrobora el art. 19.1 LOPJ, la acción popular se podrá ejercitar “...en los casos y formas establecidos en la ley".
} 
art. $125 \mathrm{CE}$ constituye un principio y no una regla, por lo que su optimización habrá de estar sujeta a una ponderación delimitada por sus posibilidades jurídicas y reales. No existe un derecho genérico de todos los ciudadanos que el constituyente quisiera convalidar cuyo contenido fuera ejercitar una acción popular, sino una previsión constitucional, de que en alguna ocasión, bajo los presupuestos establecidos por el legislador, quepa esa posibilidad.

La ampliación de los supuestos de acción popular precisaría de una expresa consagración legal, por lo que ha de considerarse en todo caso una cuestión de lege ferenda ${ }^{563}$. Su otorgamiento deberá además respetar necesariamente el límite máximo que determine su ponderación frente a derechos o intereses que puedan ser considerados superiores. No cabría reclamar la admisión de una legitimación procesal abierta siempre que se pretenda la tutela de intereses superadores de la esfera individual sobre la base de alegar un mero interés en la legalidad ${ }^{564}$. Aceptar lo contrario nos llevaría a conclusiones inaceptables que, además, vendrían a trastocar seriamente el sistema ${ }^{565}$.

El constituyente configuró subjetivamente el límite máximo del ámbito de la acción popular -sólo podrá ser ejercitada por los ciudadanos-, pero el precepto precisa de la concreción objetiva que en cada supuesto estime necesaria el legislador. No puede por tanto afirmarse que la Carta Magna viniera a "petrificar" el régimen de las "acciones populares" presentes en nuestro ordenamiento jurídico en 1978, constitucionalizándolas y

\footnotetext{
${ }^{563}$ En este sentido se pronunciaba en el ámbito administrativo REBOLLO PUIG y, aun sin entrar a discutir la oportunidad de tal generalización, afirmaba este autor que los motivos que la justificaron en el urbanismo serían hoy extensibles a otros muchos ámbitos. REBOLLO PUIG, M., "Interesados y denunciantes en el procedimiento administrativo sancionador", $P J, \mathrm{n}^{\circ} 29$, p. 60, n. 2. Sin llegar a una solución radical de admisibilidad generalizada de la acción popular pretende poner de relieve un concepto más amplio de interesado en el procedimiento sancionador. En última instancia trataría el autor de establecer un cauce para la defensa de los intereses públicos y colectivos sin esperar a la consagración de la acción popular.

${ }^{564}$ En contra de esta opinión cabe reseñar la de los autores para quienes la acción popular integraría el derecho a la tutela judicial efectiva cuando se dirija a la defensa de intereses colectivos o difusos. Así por ejemplo ALONSO GARCÍA, E., "El art. 24.1 de la CE en la Jurisprudencia del TC: problemas generales", en MARTÍN-RETORTILLO, S. (Coordinador), Estudios sobre la Constitución Española. Homenaje al profesor Eduardo García de Enterría, T. II, pp. 1008 y ss.

${ }^{565}$ Bastaría con pensar en el caso de los procesos sobre el estado civil de las personas en los que existe un interés eminentemente público. Atendibles razones de interés social obligan a que se reconozca legitimación activa en favor del MF, pero sería de todo punto insostenible que tal apertura de la legitimación incluya a sujetos que no ostenten en la causa un interés propio e individualizable.
} 
sustrayéndolas del debate parlamentario configurador de la norma. Tan plenamente aceptable desde un punto de vista de adecuación constitucional ha de entenderse la creación normativa de nuevos supuestos de acción popular, como la modulación, adaptación o, incluso, supresión de los vigentes. Ante una hipótesis de acción popular, las facultades del legislador abarcarán también la de delimitarla, constreñirla e incluso derogarla, sin que con ello queden afectados derechos inalienables de los ciudadanos. Ello tendría eventualmente una clara significación política, pero no toparía con limitaciones impeditivas derivadas de la Primera Norma.

Los destinatarios del precepto contenido en el art. $125 \mathrm{CE}$ en relación con la acción popular no son directamente los ciudadanos, sino en primer lugar los Poderes Públicos. Una detenida lectura de su contenido no nos lleva a entender "la libertad (o el derecho) de todo ciudadano a ejercitar la acción popular", sino "la obligación del legislador de que existan supuestos en los que quepa un ejercicio subjetivamente abierto de una pretensión", proposición que no tiene por qué implicar necesariamente la anterior. De este deber derivarán efectivamente facultades de actuación de los ciudadanos, pero sólo comprensibles en tanto resultasen útiles a la consecución del amparo de intereses generales. La determinación en abstracto de la presencia de éstos y, por tanto, la plasmación normativa de las acciones populares, permanecerá abierta a la voluntas legislatoris, a la que se compele a adoptar medidas destinadas a su potenciación siempre que ello sirva a la satisfacción de los fines constitucionales. No es por tanto una facultad que integre la esfera jurídica del particular con carácter previo y de manera preponderante a su reconocimiento legislativo, sino que es a través de éste como adquiere forma y entidad propia ${ }^{566}$. La Norma Fundamental fija la existencia de acción popular, pero el quién, el cómo, el cuándo y el dónde de su presencia en el ordenamiento jurídico no pueden ni deben ser vedados al libre y plural debate legislativo.

La acción popular no es un derecho constitucional garantizado que contenga una libertad de actuar, sino un instrumento procesal cuyo contenido se desarrolla, se agota y termina enteramente dentro del proceso. Es una competencia ínsita en la organización de la Justicia, articulada para demandar procesalmente la tutela de determinados intereses superadores de la esfera individual, lo cual se podrá realizar en algún caso a través del planteamiento de una pretensión por particulares que, voluntariamente, asuman esa carga

\footnotetext{
${ }^{566}$ Tal y como se recoge en el ATC 327/1984 de 30 de mayo "no puede estimarse contrario al art. 24.1 CE el rechazo de la acción popular salvo en aquellos casos en que venga reconocida en las propias leyes".
} 
en beneficio de la colectividad. Se trata, por ende, de una pura cuestión de técnica procesal, resultado de una opción valorativa en la que el constituyente ha percibido la conveniencia de ampliar las posibilidades de control judicial sobre la efectiva y constitucional vigencia de las normas materiales con el plus que otorgará en algún caso la intervención de una pluralidad indefinida de ciudadanos.

Cabe concluir este apartado señalando que, tras la acción popular del art. $125 \mathrm{CE}$, se encontraba sobre todo una declaración programática, establecida como reacción frente a un precedente déficit absoluto de participación política y enmarcada dentro del espíritu pactista que inspiró todo el texto constitucional. En ella es perceptible el intento de ampliar sobre el papel las esferas de participación ciudadana al mayor número de ámbitos de la vida social, o, específicamente a aquéllos en los que se dilucidaran aspectos de sensible interés general.

\subsubsection{Manifestaciones de "acción popular" contenidas en la previsión constitucional}

La referencia constitucional a la acción popular, pese a su ambigüedad, no puede ceñirse únicamente al proceso penal, a diferencia de lo que ocurre con la del Jurado. La restricción "a aquellos procesos penales que la ley determine" ha de entenderse predicable del segundo, pero no de la primera. A esta conclusión nos conduce la constatación de que lo que el constituyente pretendió salvaguardar aludiendo a la acción popular era la presencia de un cauce de intervención procesal de los ciudadanos allí donde se afirmaran intereses generales, sin que se especificara ninguno en concreto en tanto la delimitación objetiva corresponde al legislador ordinario. Si bien es cierto que la acción popular del proceso penal es la que goza de más honda raigambre en nuestra tradición histórica, no podría haberse pasado por alto el que la misma denominación servía entonces, y sirve hoy, para designar otras realidades que comparten con ella alguna de sus notas esenciales $^{567}$.

\footnotetext{
${ }^{567}$ En contra de esta opinión se ha sostenido por algún sector de la doctrina administrativista que la previsión constitucional de la acción popular no alcanzaría en la actualidad más supuestos que los penales y que las acciones populares administrativas no estarían amparadas por el art. 125 en tanto éste, encuadrado en el Título VI de la Constitución se referiría solamente al "Poder Judicial”, excluyendo por ello el procedimiento administrativo. Así se pronunciaba entre otros JIMÉNEZ HERNÁNDEZ, J.I., “Algunos problemas en torno al desarrollo del art. 125 de la Constitución” en VVAA, El Poder Judicial, Dirección General de lo Contencioso del Estado, T. II, Madrid 1983, p.
} 
La potencial expansividad de la acción popular hacia campos no estrictamente penales ha sido abordada por la doctrina, llegándose en alguna ocasión a ampliar su radio de actividad hasta límites que, a nuestro juicio, estaban también lejanos de la voluntad del constituyente. Así por ejemplo GIMENO y GARBERÍ se han planteado este tema al hilo de lo que designan "acción popular medioambiental", concluyendo que la esfera aplicativa de la acción popular no puede circunscribirse al proceso penal por la vinculación de todos los Poderes Públicos a los derechos constitucionales (arts. 9.1 y 10.1 $\mathrm{CE}$, en este caso en relación con el 125). La acción popular habrá de ser reclamable ante todos los órdenes jurisdiccionales, aun cuando a su juicio, tratándose de los "derechos sociales" del Capítulo $3^{\circ}$ del Título $1^{\circ} \mathrm{CE}$, ningún obstáculo constitucional existirá para que pueda sufrir ciertas modulaciones por el legislador ordinario ${ }^{568}$. Por ello, y siguiendo con su razonamiento, cabría que una ley ordinaria limitara el ejercicio de la acción popular a determinados tipos de pretensiones ${ }^{569}$. En otras ocasiones se ha alcanzado a derivar del precepto constitucional que nos ocupa la extensión del reconocimiento constitucional de la acción popular al derecho administrativo sancionador, realizándolo mediante una interpretación conjunta de los artículos 24.1 y $125 \mathrm{CE}$ en conexión con los

1589. En opinión de GARCÍA-TREVIJANO no cabría desconectar el reconocimiento de la acción popular por el art. 125 del resto del precepto, pues todo él vendría referido a los procesos penales. Niega una interpretación expansiva del precepto constitucional ya que no sería viable diseccionarlo sacando del contexto en el que se inserta a la acción popular. Además la conexión que ha realizado el TC siempre se habría hecho en relación con los procesos penales, por lo que, si bien a su juicio sería admisible su consideración de derecho fundamental en el proceso penal, no lo sería en otros ámbitos. GARCÍA-TREVIJANO GARNICA, E., "Consideraciones sobre la acción pública y el Medio Ambiente". Revista de Derecho Urbanistico y Medio Ambiente, oct.-dic. 1995, nº 145, pp. 154 y s.

${ }^{568} \mathrm{De}$ esta opinión se podría inferir que en otros supuestos no cabría esa modulación legislativa. A nuestro modo de entender no cabría derivar una diferencia trascendental del hecho de que nos encontremos ante uno de los derechos encuadrados entre los "principios rectores de la política social o económica" o de cualquier otro en el que haya en juego intereses generales.

${ }^{569}$ GIMENO SENDRA, V. y GARBERÍ LLOBREGAT, J., "La protección procesal del Medio Ambiente", PJ, $\mathrm{n}^{\circ}$ 37, p. 151. Esto sería lo que acontece con las normas procesales civiles que disciplinan la legitimación ordinaria, y de cuyo régimen, como ocurre con la protección de los intereses difusos, tampoco se deduciría la existencia de una acción popular para el planteamiento de pretensiones civiles de condena. Según su criterio, y como consecuencia de la aplicación inmediata y directa de los artículos 45.1 y $125 \mathrm{CE}$, debiera reconocerse en el ámbito contenciosoadministrativo la acción popular para deducir pretensiones administrativas de condena dirigidas a la reintegración del ordenamiento administrativo perturbado por la comisión de ilícitos administrativos, a la adopción de medidas correctoras y respetuosas con el medio ambiente e incluso pretensiones de anulación de licencias o de revocación de concesiones por incumplimiento de la legislación de medio ambiente, excluyéndose las pretensiones de "plena jurisdicción" dirigidas al restablecimiento de derechos subjetivos del art. 28.2 LJCA. 
arts. 19.1 LOPJ y 100, 101 y 270 LECrim $^{570}$. Incluso algún autor ha ido más allá todavía, llegando al extremo de mostrar su deseo de que la acción popular se extienda por todo el ordenamiento jurídico $^{571}$.

A nuestro juicio tales interpretaciones extensivas de la plasmación constitucional de la acción popular sobrepasan con creces la voluntad del constituyente, dado que no cabría afirmar que éste pretendiera constituirla en un principio que inspirase la totalidad del ordenamiento administrativo general o del derecho sancionador en particular ${ }^{572}$. No cabe sobredimensionar lo querido por el constituyente, que vino a dejar en manos del legislador ordinario la concreción objetiva de la genérica facultad contenida en el art. 125 CE. La plasmación legal de la acción popular (o pública) ${ }^{573}$ en el ámbito administrativo

\footnotetext{
${ }^{570}$ Así parece deducirse de la opinión de GARCÍA DE ENTERRÍA, E.; con FERNÁNDEZ, T. R., Curso de Derecho Administrativo, T. II, $4^{\mathrm{a}}$ ed. Madrid 1993, p. 188. Cfr. en el mismo sentido la Ponencia para el VI Congreso de Jueces para la Democracia, Logroño 20 a 22 de junio de 1991 donde se propone la admisibilidad de la acción pública para exigir ante los órganos administrativos y ante los tribunales de lo Contencioso-Administrativo la aplicación de la legalidad en defensa de los intereses colectivos (Cap. III, Tít. I de la Constitución) al tratarse de derechos que, por su naturaleza, son de más difícil individualización y que, por ello, se encuentran más desprotegidos. Ponencia publicada en Jueces para la Democracia, $\mathrm{n}^{\mathrm{o}} 12$, I/1991, pp. XXV y ss. Ello no parece sin embargo concorde con lo previsto en el Reglamento de Procedimiento para el Ejercicio de la Potestad Sancionadora (RD 1398/1993 de 4 de agosto). En concreto en su art. 11 se dice que "los procedimientos sancionadores se iniciarán siempre de oficio por acuerdo del órgano competente bien por su propia iniciativa o como consecuencia de orden superior, petición razonada de otros órganos o denuncia”. No cabe por tanto ejercicio de acción popular alguna.
}

${ }^{571}$ En este sentido LOZANO-HIGUERO PINTO, M., La protección procesal de los intereses difusos, Madrid 1983, p. 253.

${ }^{572} \mathrm{Si}$ se tiene en cuenta por ejemplo que ni siquiera en el ámbito penal la acusación popular abarca todos los supuestos (así v.gr. en la Jurisdicción de menores, en la Jurisdicción militar, en los delitos “privados”, etc.), aunque admitiéramos la discutida extensión por irradiación de los principios generales del derecho penal al derecho administrativo sancionador, el entendimiento de la acción popular como parte del contenido de esta extensión es desde nuestra óptica de todo punto inadmisible. Sin previsión expresa del legislador no cabe hablar de posible ejercicio de la acción popular, y en este ámbito, el legislador ha optado sin ambages por su exclusión. En relación con esta materia no cabe obviar el estudio de NIETO, A., Derecho Administrativo sancionador, Madrid 1994 y su posicionamiento hostil hacia la acción popular. Vid. especialmente la p. 35, donde se afirma que "la acción popular gozó un tiempo de buena fama, y en ella se pusieron grandes esperanzas, que el tiempo se ha encargado de desmentir. La acción popular en los escasos ámbitos donde ha sido recogida legalmente desde antiguo, como es el urbanismo y el Derecho local, ha demostrado que es patrimonio casi exclusivo de extorsionistas cuando no instrumento de venganzas personales o políticas. De aqui que los Tribunales las consideren, con razón, sospechosas y que no valga la pena detenerse más en su análisis".

${ }^{573}$ Existe una tendencia generalizada a utilizar indistintamente las expresiones "acción pública" y "acción popular", tanto por el legislador como por los Tribunales y la doctrina tal y como ya hacía notar explícitamente 
es la que es, sin que pueda ser extendida analógicamente más allá de lo querido por el legislador. Eso sí, nos permite advertir que todos los supuestos presentes en nuestro ordenamiento tienen relación con materias en las que se dilucidan intereses colectivos, razón que hace que los motivos alegados para fundamentarlos partan de la idea de participación ciudadana en garantía de la legalidad de la actuación administrativa en ámbitos de especial trascendencia general (urbanismo y medio ambiente) ${ }^{574}$. De ahí no se deduce necesariamente que el ejercicio de la acción popular sea ejercicio de una función pública, sino que se tratará simplemente de un supuesto de colaboración eventual en tareas públicas realizada por sujetos privados ${ }^{575}$.

FERNÁNDEZ DE VELASCO, R., La acción popular en el Derecho Administrativo, Madrid 1920, p. 85, n. 2. En tiempos más recientes se ha llamado la atención sobre la improcedencia de tal equiparación atendiendo a que la acción popular en el derecho administrativo tendría un marcado carácter subrogatorio del que se dice tradicionalmente no ha gozado la acción pública. Un ejemplo de ello se encontraría en el art. 68 de la Ley 7/1985 de 2 de abril, reguladora de las Bases del Régimen Local, en el que se reconoce el derecho de los vecinos a ejercer -tras haber requerido a la entidad local- la acción correspondiente "en nombre e interés de la entidad local". Asimismo el art. $18.1 \mathrm{~g}$ ) de la misma ley establece el derecho a exigir "la prestación y, en su caso, el establecimiento del correspondiente servicio público, en el supuesto de constituir una competencia municipal propia de carácter obligatorio". No será preciso acreditar ningún interés personal y el servicio se reclamará uti universi y no uti singuli, aunque evidentemente de su concesión se derivarán beneficios para el concreto individuo solicitante. Vid. GARCÍATREVIJANO GARNICA, E., "Consideraciones sobre la acción pública y el medio ambiente", Revista de Derecho Urbanístico y Medio Ambiente, octubre, noviembre, diciembre 1995, pp. 153 y 160, con apoyo en GARCÍATREVIJANO FOS, Tratado de Derecho Administrativo, T. I, 1974, p. 565. LOZANO-HIGUERO se muestra partidario también de la utilización del término "acción popular", puesto que según su criterio la acción pública sería aquella mediante la que se ejercita una pretensión pública, frecuentemente mediante un órgano específicamente establecido al efecto (p. ej. el MF). LOZANO-HIGUERO PINTO, M., "De nuevo sobre la tutela de los intereses difusos (en especial el patrimonio histórico artístico", JUSTICIA 96, nº II, pp. 296 y ss.

${ }^{574}$ Destaca entre los estudios sobre la acción popular administrativa en nuestra doctrina en primer lugar y significativamente la monografía de FERNÁNDEZ DE VELASCO, R., La acción popular..., op. cit. Vid. también CORDÓN MORENO, F., La legitimación..., op. cit., esp. pp. 139 y ss. Específicamente sobre la acción popular urbanística se pueden consultar PÉREZ MORENO, A., "La acción popular en materia de urbanismo", Revista de Derecho Urbanístico no 15 (1969), pp. 71 y ss; COSCULLUELA MONTANER, L., "Acción pública en materia urbanística”, RAP 71 (1973), pp. 9 y ss; GONZÁLEZ PÉREZ, J., Comentarios a la Ley del Suelo, $5^{\circ}$ ed., Madrid 1988, pp. 2333 y ss. En materia de Medio Ambiente, GIL-ROBLES GIL- DELGADO, J., "La acción judicial popular y la audiencia de los ciudadanos en el área del derecho ambiental", Ponencia presentada en las Jornadas Sobre el Medio Ambiente (Segovia, 29 sept.-1 oct. 1988), publicada en $P J, \mathrm{n}^{\circ}$ especial IV, Madrid 1989; GARCÍATREVIJANO GARNICA, E., "Consideraciones sobre la acción pública...”, op. cit. pp. 153 y ss; GIMENO SENDRA, V. y GARBERÍ LLOBREGAT, J., "La protección procesal del medio ambiente”, op. cit. pp. 141 y ss.

${ }^{575}$ Cfr. SANTAMARÍA PASTOR, J.A., Fundamentos de Derecho Administrativo, I, Madrid 1988, p. 956. En opinión de SANTAMARÍA PASTOR no serían supuestos de ejercicio privado de funciones públicas los que podrían calificarse de colaboración o cooperación eventual en tareas públicas tales como el ejercicio de la acción popular, la 
Los supuestos legales de acción popular administrativa a los que nos referimos han sido divididos por GIMENO y GARBERÍ en dos grupos ${ }^{576}$ :

\section{A) Impropios o de iniciación del procedimiento administrativo o sancionador}

Así pudieran conceptuarse el art. 58 Ley de Pesca Fluvial de 20 de febrero de $1940^{577}$, el art. 47. 1 de la Ley de Caza, el art. 16 del Decreto 833/1975 de 6 de febrero que desarrolla la Ley 38/1972 de Protección del Ambiente atmosférico de 22 de diciembre de 1972 y art. 6 RD 1613/1985 de 1 de agosto (por el que se modifica parcialmente el anteriormente citado $)^{578}$. Además habría que incluir en este grupo el reconocimiento que en diversas formas se hace de la acción popular en normas referidas a espacios naturales $\operatorname{protegidos}^{579}$.

denuncia, la detención por particulares, la actuación procesal como perito o testigo, las prestaciones personales en caso de urgencia, el servicio militar, etc. El carácter de cierta permanencia y el de no eventualidad sería precisamente el que definiría el ejercicio privado de funciones públicas.

${ }^{576}$ GIMENO SENDRA, V, y GARBERÍ LLOBREGAT, J., "La protección procesal del Medio Ambiente", PJ, $\mathrm{n}^{\circ}$ 37, p. 152. En opinión de los autores citados se debería hoy reconocer legitimación para todos los supuestos de incoación de procedimientos administrativos de carácter sancionador o dirigidos a la a la obtención de medidas correctoras, de clausura, oposición o revocación de concesiones o licencias en los procedimientos administrativos dirigidos a la protección del entorno natural. A ello conduciría una lectura conjunta del art. $45.1 \mathrm{CE}$ con el 31.1.a) LRJPAC (interesado es el titular de derechos colectivos).

577“La acción para denunciar y perseguir a los infractores de la presente Ley de Pesca Fluvial es pública”.

${ }^{578} \mathrm{~A}$ tenor de ellos "cualquier persona, natural o jurídica, pública o privada, podrá dirigirse por escrito motivado al Alcalde, Gobernador Civil o Director General de Sanidad expresando razonadamente la situación de contaminación y solicitando la tramitación del expediente para la declaración, si procede, de zona de atmósfera contaminada".

${ }^{579}$ Cabe citar aquí el art. 11 de la Ley de 28 de diciembre de 1978 del Parque Nacional de Doñana, el art. 13 de la Ley de 3 de mayo de 1980 del Parque Nacional de las Tablas de Daimiel, el art. 17 de la Ley 3/1981 de 25 de marzo de 1981 del Parque Nacional de Garajonay, el art. 17 de la Ley 4/1981 de 25 de marzo de 1981 del Parque Nacional de la Caldera de Taburiente, el art. 17 de la Ley 5/1981 de 25 de marzo de 1981 del Parque Nacional del Teide, el art. 17 de la Ley 6/1981 de 25 de marzo de 1981 del Parque Nacional de Timanfaya, el art. 17 de la Ley 52/1982 de 13 de julio del Parque Nacional de Ordesa y Monte Perdido o el art. 9 de la Ley 5/1992 de la Reserva Natural de las Marismas de Santoña y Noja. La legislación de las CCAA también contiene en este sector el reconocimiento de la acción popular en diversas normas. GARCÍA-TREVIJANO cita las siguientes: art. 39 Ley Canaria 11/1990 de 13 de julio sobre medio ambiente y prevención del impacto ecológico, art. 35 Ley de Castilla y León 8/1994 de 24 de junio de evaluación de impacto ambiental y auditorías ambientales, Ley de Aragón 5/1991 de Reserva Natural de los Galachos de La Alfranca de Pastriz, La Cartuja y El Burgo de Ebro. GARCÍA-TREVIJANO GARNICA, E., “Consideraciones sobre la acción pública...”, op. cit. p. 156, n. 20. 
B) Propios o auténticos supuestos de ejercicio de la acción popular ante los Tribunales de lo Contencioso:

En este grupo habrían de incluirse el art. 8.2 Ley 16/1985 de 25 de junio del Patrimonio Histórico español ${ }^{580}$, el art. 109 de la Ley 22/1988 de 28 de julio, de Costas ${ }^{581}$ y el art. 304 de la Ley del Suelo (RDLeg. 1/1992 de 26 de junio) ${ }^{582}$.

Podríamos reseñar también aquí, siquiera "a beneficio de inventario", el supuesto

580 “Será pública la acción para exigir ante los órganos administrativos y los tribunales ContenciosoAdministrativos el cumplimiento de lo previsto en esta Ley para la defensa de los bienes integrantes del Patrimonio Histórico Español". Al respecto vid. LOZANO-HIGUERO PINTO, M., "De nuevo sobre la tutela de los intereses difusos...”, op. cit, pp. 296 y ss.

${ }^{581}$ Se reconoce la acción pública para exigir ante la Administración y los Tribunales la observancia de lo previsto en la propia Ley y en sus normas de desarrollo.

${ }^{582}$ El estudio de la acción popular ha sido abordado por la doctrina administrativista fundamentalmente en relación con el supuesto con más solera en nuestro ordenamiento: el contemplado hoy en el art. 304 de la Ley sobre el Régimen del Suelo y Ordenación Urbana. Su primer número, heredero del anterior art. 235.1 de la Ley del Suelo de 1976 y del 223 de la de 12 de mayo de 1956, regula la acción pública en los siguientes términos: "Será pública la acción para exigir ante los órganos administrativos y los Tribunales Contencioso Administrativos la observancia de la legislación urbanística y de los planes, programas, proyectos, normas y ordenanzas". 
de acción pública previsto en el art. 47.3 LO 2/1982 de 12 de mayo del Tribunal de Cuentas $^{583}$.

En relación con el proceso penal, la previsión constitucional de la acción popular ha de entenderse referida a la acusación popular del art. 101 LECrim, la manifestación de generalizado reconocimiento de la legitimación con mayor solera, mayor trascendencia y mayor amplitud de cuantas existen en nuestro ordenamiento. Ello ha originado que, en muchas ocasiones, sea considerada como el paradigma de las demás, el filtro a través del que deban contemplarse aquéllas. Momento es ya de proceder al análisis de su configuración doctrinal y jurisprudencial así como de los que consideramos sus elementos esenciales.

\footnotetext{
${ }^{583}$ Completado en lo que se refiere a su procedimiento por el art. 56 de la Ley 7/1988 de 5 de abril de funcionamiento del Tribunal de Cuentas. Al respecto vid. desde una óptica de defensa "militante" de la acción popular CUBILLO RODRÍGUEZ, C., "La «acción popular» en el orden jurisdiccional contable", RDProc. 1992, n 2 , pp. 253-263 (consideraciones generales) y pp. 263 y ss. (acción popular contable). Según sus optimistas criterios, a través de la «acción popular contable» se conseguiría obtener "la necesaria armonía entre el deber del ciudadano de pagar sus impuestos y el de los poderes públicos de gastar con rectitud y sensatez" (p. 265). La acción popular en su opinión sería para el orden jurisdiccional contable "la más eficaz «hormona» para su desarrollo" (p. 282).
} 


\section{ACUSACIÓN POPULAR Y DERECHOS FUNDAMENTA- LES: SU RECONDUCCIÓN AL ART. 24 CE}

\subsection{La acusación popular como derecho abstracto a la actividad jurisdiccional: el denominado «ius ut procedatur»}

El constituyente no quiso (o al menos no lo hizo) sancionar formalmente como derecho fundamental el ejercicio de la acusación popular, puesto que no lo incluyó en la Sección $1^{\mathrm{a}}$ del Capítulo $2^{\mathrm{o}}$ del Título I. No constituye, por tanto, un derecho tutelable mediante el amparo constitucional (art. 53.2 CE y 2.b, 41 y ss. LOTC), protección reforzada de la que sólo gozan las exigencias básicas comprendidas en los arts. 14 a 29 y 30.2 CE. La ubicación del art. 125 en la parte orgánica y no en el Título I ni en la parte dogmática de la Constitución, no ha constituido, sin embargo, obstáculo suficiente para que se haya llegado a reconocer en algunas circunstancias la condición de auténtico derecho fundamental al planteamiento de la acusación. Se ha entendido así que la tarea de reelaboración y sistematización de los derechos fundamentales debería tomar más en consideración la interdependencia y conexión material existente entre distintos derechos reconocidos en la Constitución, que su posición formal en diversos títulos o incluso partes del texto, fruto de lo que pudieran considerarse deficiencias técnico-jurídicas que necesariamente habrán de ser superadas ${ }^{584}$. El apoyo doctrinal y, singularmente, la interpretación realizada por el $\mathrm{TC}$, ha posibilitado la reconducción del contenido del precepto, si bien sólo bajo determinadas premisas, al ámbito de los derechos fundamentales, en concreto al del derecho a la tutela judicial efectiva del art. $24.1 \mathrm{CE}^{585}$. Veamos pues cómo se ha desarrollado este proceso a través sólo del examen de alguno de sus hitos esenciales, conscientes del reduccionismo que ello supone, pero obligados a la

\footnotetext{
${ }^{584}$ En relación con la acusación popular hacen este planteamiento GIMENO SENDRA en su comentario al art. 125 CE ya citado “La acción popular, el jurado...", y PÉREZ LUÑO, A.E, Derechos Humanos, Estado de Derecho y Constitución, $5^{\mathrm{a}}$ ed. Madrid 1995, p. 70. PECES-BARBA hace alusión a este mismo argumento para señalar la autonomía y el valor propio del sistema de derechos como conjunto o como institución. PECES-BARBA MARTÍNEZ, G., Curso de Derechos Fundamentales. Teoría General, Madrid 1995, p. 449.

${ }^{585}$ En ningún caso sería admisible, pese a lo que se ha pretendido con el jurado (vid. Exposición de Motivos LOTJ), su reconducción al art. $23 \mathrm{CE}$, precepto exclusivamente referido a la participación política, lo que comporta el rechazo radical de cualquier extravagante intento de desvirtuar su genuino significado.
} 
síntesis por el objetivo de evitar enturbiar la exposición.

\subsubsection{La opinión de la doctrina anterior a la Constitución}

Considerar el ejercicio de la acción como derecho de naturaleza constitucional no era nuevo entre la doctrina en 1978, sino que ya había sido incardinado con bastante anterioridad en un ámbito constitucional ${ }^{586}$, político $^{587}$ o programático superador de la literalidad de la ley ordinaria. Tal perspectiva se presentaba clara y acertada, en la medida en que la acción tendría que ver con el derecho procesal, pero se encontraría en un plano superior a él. Como una de las manifestaciones de tal derecho, ciertamente específica, se ha contemplado lo que LECrim denomina “acción penal”, de la que la acusación popular no sería más que su diseminación subjetiva ${ }^{588}$.

\subsubsection{La concepción de BELING}

El primer autor conocido en nuestro país que sostuvo la teoría de la querella como un ius ut procedatur fue BELING, que lo hizo en relación con los impedimentos procesales. Según esta formulación, el contenido del Strafklagerecht (literalmente, derecho de querella, pero traducido como derecho de acción penal e identificado en nuestro país con ella), es un ius ut procedatur y a raíz de su ejercicio, la actividad judicial

${ }^{586}$ Vid. por todos FAIRÉN GUILLÉN, V., "La acción, Derecho Procesal y Derecho Político", Estudios de Derecho Procesal, Madrid 1955, pp. 88 y ss.; "Para una teoría general del derecho procesal" en Temas del Ordenamiento Procesal, T. I, p. 306 o la voz “Acción” en Nueva Enciclopedia Jurídica, T. II, Barcelona 1975, p. 193.

${ }^{587}$ Vid. CALAMANDREI, P., Istituzioni di Diritto Processuale Civile, p. 115; GUASP DELGADO, J., La pretensión procesal, publicado inicialmente en Anuario de Derecho Civil, enero-marzo 1952, fasc. 1, T. V y reeditado como libro con el mismo título, Madrid 1981, p. 52. La acción es un puro poder político o administrativo, pero previo al proceso y previo al mundo procesal. El concepto que se tenga de la acción procesal es intrascendente para el proceso y partiendo de concepciones totalmente diversas del derecho de acción podrá llegarse a conclusiones semejantes.

${ }^{588}$ En relación con el ejercicio de la acusación, y con carácter histórico, cabría remontarse incluso a MARTÍNEZ DEL CAMPO, que veía en el poder de perseguir los delitos un derecho de naturaleza constitucional para cuyo desempeño se hallaba instituido el MF pero compartiendo con todos los ciudadanos el derecho de acción pública, de forma que éstos recibían una delegación de carácter revocable derivada de un derecho esencialmente político. El fundamento lo encontraba en el art. 54.2 de la Constitución de 1876 al encomendar al Rey el cuidado de que "en todo el reino se administre pronta y cumplidamente la justicia”. MARTÍNEZ DEL CAMPO, E., Notas al libro $1^{\circ}$ de la Ley de Enjuiciamiento Criminal. Tomo 1º, Madrid 1885, p. 263. 
aparece como una prestación debida al actor ${ }^{589}$. BELING sostenía que, al existir todas las condiciones positivas y al estar ausentes los impedimentos procesales, "el Estado «qua» Tribunal (sujeto garante de la protección jurídica) tiene autorización de «procedere», el “ius procedendi”, el "derecho subjetivo al proceso penal". La totalidad de esas condiciones vincula al Estado, de suerte que al querellante le corresponde un derecho frente al Estado a la protección jurídica por éste, un derecho a que se proceda (ius ut procedatur, Recht aufdas Rechtsgang), verdadero contenido del derecho de querella ${ }^{590}$. El contenido de este derecho no se agotaría con la facultad de querellarse para constituir un presupuesto para la puesta en marcha del proceso, sino que habría de contener también el derecho a continuar el proceso ${ }^{591}$.

Este derecho debería ser distinguido del ius puniendi (que pertenece al derecho material) en relación con: 1) los presupuestos, en tanto depende de las condiciones formales de perseguibilidad y sólo de éstas, mientras que el ius puniendi depende sólo del acto punible; 2) el contenido, porque el derecho de querella no se encamina a la pena ni a la condena, sino al desarrollo reglado que conduzca a una resolución jurisdiccional en la que se diga si el imputado es el autor o no de los hechos punibles; 3) la persona obligada, que en la acción penal no es el autor del delito, sino el Estado y 4) el titular, que puede ser diferente: el del ius puniendi es siempre el Estado, pero el del derecho de querella, p. ej. en los delitos privados, es un particular. Advertía BELING que esta distinción entre punibilidad (referida al ius puniendi) y perseguibilidad (referida al derecho de querella) sería de utilidad dentro del proceso, pues el Tribunal se cerciorará primero de si existe el derecho a interponer querella para, en caso negativo, no tener en cuenta el hecho y su punibilidad $^{592}$.

${ }^{589}$ BELING, E., Deutsches Reichsstrafprozeßrecht, Berlín, Leipzig 1928, p. 97. Puede consultarse Derecho Procesal Penal, según la traducción signada por FENECH, Barcelona 1943, pp. 72 y ss.

${ }^{590}$ Strafklagerecht en el original, repetimos una vez más, aunque traducido como "derecho de acción penal". Ibídem.

${ }^{591}$ BELING, E., Deutsches Reichsstrafprozeßrecht, op. cit. p. 99.

${ }^{592}$ BELING, E., Deutsches Reichsstrafprozeßrecht, op. cit. p. 99. BELING advertía de la confusión a la que se induce utilizando el concepto de Rechtschutzanspruch que WACH elaboró para el proceso civil como derecho del actor a vencer en el proceso Asumir esta concepción obligaría a distinguir entre un "derecho formal de acción", como derecho a una resolución, y un "derecho material de acción", como derecho a una sentencia penal de condena. El primero dependería de los presupuestos formales o procesales de la querella, y el segundo de los presupuestos de derecho material de la querella (la existencia del Strafanspruch, el ius puniendi). Todo ello no sería más que una construcción innecesariamente complicada y cuya terminología pondría en peligro la claridad. Es esta la 


\subsubsection{La adaptación realizada por GÓMEZ ORBANEJA}

El Profesor GÓMEZ ORBANEJA fue el principal responsable entre la doctrina procesalista de nuestro país de un intento de aclaración conceptual sobre la cuestión ${ }^{593}$, a través del cual se difundió la concepción de la acción penal como derecho al proceso ${ }^{594}$. Sin embargo, en muchas ocasiones, se ha utilizado en referencia a esta materia sólo su enunciado o designación (el célebre ius ut procedatur ${ }^{595}$ ), sin respetar estrictamente su contenido, el cual se ceñía principalmente al entendimiento de la "acción penal" como un derecho a la apertura del juicio oral y como presupuesto de la acusación en éste.

GÓMEZ ORBANEJA configuró en principio la "acción penal" como un ius ut procedatur, un derecho al proceso y a la sentencia en la que se declare la existencia o inexistencia del derecho subjetivo de penar. Se trataría de un poder jurídico de iniciativa procesal y de constituir la obligación del juez de comprobar la situación de hecho que se le somete, por lo que frente al derecho de acción se presentaría la actividad judicial como una prestación debida al actor. Sólo secundariamente sería el derecho de afirmar y probar ante el órgano judicial el derecho de penar, competencia exclusiva del Estado. La acción existirá aunque no exista el derecho de penar, por lo que la resolución judicial desestimando la querella no se pronunciaría sobre la relación jurídico procesal y sobre el derecho subjetivo de penar del Estado, sino sobre la acción misma. Mientras el

construcción a la que según BELING se ve avocado GOLDSCHMIDT. En su opinión, si se confrontan Strafklagerecht (derecho de querella) y Strafanspruch (pretensión penal, exigencia punitiva) tal y como él hace, se podría hablar de un "derecho a la tutela jurídica" del actor como derecho a vencer en el proceso, pero no se puede desconocer que eso es sólo una idea compleja. En nota afirma BELING que la teoría publicista del derecho a la protección jurídica (o del derecho de acción) en el sentido de DEGENKOLB no interesa para el proceso penal, puesto que el "público susceptible de proteger jurídicamente" no tiene derechos de acción frente al Tribunal, sino sólo acceso a las autoridades de acusación (a la fiscalía).

${ }^{593}$ GÓMEZ ORBANEJA, E., “La acción penal como derecho al proceso", Revista de Derecho Privado, $\mathrm{n}^{\circ} 371$, febrero de 1948, pp. 72 a 97, cuyas ideas principales luego fueron expuestas en sus Comentarios a la LECrim, Barcelona 1951, T. II, vol. I, pp. 188 y ss.

\footnotetext{
${ }^{594} \mathrm{Ha}$ de advertirse además que tal intento se realizó tomando como fundamento dos realidades normativas diferentes, en tanto el derecho de querella como presupuesto de la iniciación del procedimiento penal en los delitos privados y semipúblicos a los que se refería BELING, no es comparable a nuestra querella pública. Mientras que en ellos adquiere pleno sentido la expresión "ius ut procedatur", que debemos entender como "derecho a que se proceda", su adaptación al sistema español no puede realizarse más que de una manera forzada.

${ }^{595}$ Incluso el TC ha usado frecuentemente la fórmula latina. Vid. como ejemplo las SSTC 106/1983 de 29 de noviembre, 148/1987 de 2 de septiembre o 199/1996 de 3 de diciembre.
} 
sobreseimiento negaría la acción penal, la apertura del juicio oral la reconoce y satisface definitivamente. La acción penal no radicaría según la primera visión de GÓMEZ ORBANEJA en la calificación que hace el actor sino en la petición de apertura, por lo que el derecho de acción no hace valer un derecho dispositivo sobre la pretensión ni un derecho subjetivo sobre lo que la sentencia declara ${ }^{596}$.

El procedimiento penal comienza siendo una investigación judicial, con contenido no totalmente condicionado por las concretas peticiones del querellante, cuya función principal no es la de preparar el juicio, sino la de proporcionar las bases para decidir si debe haber o no juicio. Esta decisión alternativa se basa en el resultado del sumario y es afirmación o negación definitiva de la acción penal: no acceder al procesamiento del querellado se traduce en una denegatio actionis. La acción era en este momento para GÓMEZ ORBANEJA un derecho que para producir su efecto necesitaba ser reconocido en su fundamentación misma (y no sólo en su admisibilidad) en relación con el objeto deducido, por lo que el sumario sería precisamente la forma de comprobar la existencia de acción $^{597}$. Lo que funda ésta es la sospecha, puesto que bastará la posibilidad de delito para su admisión y el tribunal se habrá pronunciado definitivamente sobre la acción al abrir el juicio, habrá afirmado su deber de fallar sobre el derecho de penar afirmando o negando el ius puniendi. La acción sería por tanto un derecho cuyo contenido es que se formen todas esas expectativas sucesivas en el acto del juicio oral y quedará satisfecha en el momento en que se constate que habrá una sentencia condenatoria o absolutoria ${ }^{598}$.

Mientras que el presupuesto de la pena sería un delito real y existente ${ }^{599}$, el de la

${ }^{596}$ GÓMEZ ORBANEJA, E., "La acción penal como derecho al proceso”, op. cit., p. 86 y Comentarios..., op. cit. T. II, vol. I pp. 188 y ss. Acogen esta misma opinión entre otros CORTÉS DOMÍNGUEZ, V., La cosa juzgada penal, Bolonia 1975, passim, singularmente pp. 19 y ss.; SOTO NIETO, F., Correlación entre acusación y sentencia, Madrid 1979, pp. 64 y ss.; GONZÁLEZ MONTES, F., “Acción penal y perdón del ofendido en los denominados delitos semipúblicos”, RFDU Granada, n² 2, 1983, p. 93 y VÁZQUEZ SOTELO, J.L., "El principio acusatorio y su reflejo en el proceso penal", RJCat. 1984, p. 391.

${ }^{597}$ GÓMEZ ORBANEJA, E., “La acción penal...”, op. cit. p. 95.

${ }^{598}$ GÓMEZ ORBANEJA, E., “La acción penal...”, op. cit. pp. 87 y ss.; Comentarios..., op. cit. p. 201. Este es el sentido con el que el legislador y la jurisprudencia del TS siguen percibiendo en ocasiones el "derecho de acción" en el proceso penal. Vid. la reciente STS de 29 de enero de 1996 (RAJ 54) FD 1'o en la que se dice textualmente: " $E l$ auto de procesamiento... no es el instrumento de ejercicio de la acción penal, que únicamente se entiende fijada y promovida en el escrito de calificación de la acusación". Esta idea encuentra también manifestaciones en la Ley: vid. por ejemplo el art. 781. II in fine LECrim.

\footnotetext{
${ }^{599}$ No podemos pasar por alto la conexión de esta argumentación con el utópico planteamiento de la búsqueda de la verdad material en el proceso. La declaración judicial en la que se reconozca la existencia de delito sólo podrá
} 
acción penal serán simplemente los hechos con apariencia de delito. El proceso se abre para pasar de la duda a la certeza, y se presenta como condición necesaria para actuar la obligación estatal de castigar las conductas punibles. La acusación formulada en la querella será únicamente pretendida y, sólo cuando sea reconocida a través del auto de apertura del juicio oral, concurriría el presupuesto necesario para poder proceder: la necesidad de acusación impuesta por el principio acusatorio ${ }^{600}$. Existiendo una de las causas determinantes del sobreseimiento (art. 637 LECrim) no se tendrá acción, y no dándose sí. El auto de sobreseimiento y el de apertura del juicio oral no se podrán entender sino como la respuesta negativa y positiva del órgano judicial a la acción ejercitada por el querellante, como las respuestas posibles sobre la concurrencia o no del presupuesto de la acusación. Los sujetos querellantes ponen de manifiesto un pretendido derecho de acción penal por lo que el tribunal, para pronunciarse sobre el derecho de cualquier ciudadano a acusar, tiene que esperar la incitación de éste a fin de poder pronunciarse $^{601}$.

GÓMEZ ORBANEJA estaba pensando en el desarrollo de un proceso, cuando menos en su fase inicial, por lo que el contenido de la acción penal venía referido a una facultad de los individuos en conexión con concretos actos dentro de un proceso determinado. No cabría afirmar en este sentido la titularidad del derecho de acción con carácter previo y en abstracto, sino sólo en relación con un hecho delictivo determinado y sólo en el sumario abierto para su investigación. El momento en el que se constata su existencia o inexistencia es aquel en el que se estima judicialmente que concurren los presupuestos necesarios para la apertura del juicio oral. Sería menester, pues, realizar un análisis acerca de la fundamentación de lo contenido en la querella para poder saber si se tiene o no derecho de acción ${ }^{602}$, que sería tanto como decir derecho al proceso.

La opinión posterior del Prof. GÓMEZ ORBANEJA pareció sufrir una radical rectificación, tal y como se deduce en las páginas que en su manual dedica a la acción en el proceso penal. En ellas, manteniendo prácticamente la misma definición de acción

significar la constatación más allá de toda duda razonable de su comisión y atribución al acusado.

${ }^{600}$ CORTÉS DOMÍNGUEZ, V., La cosa juzgada, op. cit. pp. 88 y ss.

${ }^{601}$ Ibídem.

${ }^{602}$ En ello puede verse una muestra de que bajo este planteamiento estaba latente una concepción concreta del derecho de acción. 
penal, ya no se habla expresamente de un derecho al proceso ${ }^{603}$. La querella, afirma en este caso, "es ya ejercicio de la acción -y más aún, la forma específica de ese ejercicio-", por lo que deducimos que, según este criterio, no cabe el que para constatar la existencia del derecho de acción tenga que ser comprobada su fundamentación sino que bastará con su admisibilidad. La facultad en que la acción penal consiste no precisaría por tanto ser reconocida, sino que existiría con carácter previo y no podría ser denegada sino con la inadmisión de la querella. A pesar de ello no quedaría tampoco satisfecha con la apertura del juicio oral (o la denegación de ésta), sino que iría más allá y penetraría también en la fase de juicio oral en la medida en que su contenido incluiría también una acusación. Aunque la acción penal consista en el acto de acusar, no se reduciría a su concreto contenido acusatorio, pues no sólo esa solicitud, sino también todas las demás peticiones que el acusador formula a lo largo del proceso (práctica de diligencias, adopción de medidas cautelares, etc.) vendrían a albergarse en la acción penal, pero ninguna de ellas, ni todas juntas son por sí la acción ${ }^{604}$.

Cuando posteriormente se ha hablado de un ius ut procedatur, se ha hecho en la mayoría de las ocasiones sin respetar íntegramente los planteamientos formulados originariamente por GÓMEZ ORBANEJA, en tanto se utiliza sólo formalmente esta denominación para designar otra realidad: el entendimiento de la "acción penal" como derecho a que se dicte una resolución jurisdiccional que dé inicio al proceso, creando en el órgano jurisdiccional una obligación de pronunciarse. Puesto que esta resolución puede ser también de inadmisión, se está hablando de un "derecho a que se proceda" pero sosteniendo una idea devaluada con respecto a la originaria de lo comprendido dentro de él.

\subsubsection{FAIRÉN: máxima abstracción de la acción}

FAIRÉN elaboró un concepto de acción incardinado en el derecho constitucional, válido para los procesos civil y penal y, por ello mismo, con un carácter amplísimo

${ }^{603}$ Vid. p. ej. el $\S 9$ de su obra (con HERCE QUEMADA), Derecho Procesal Penal, $10^{a}$ edición, Madrid 1987, pp. 86 y ss. Este aspecto fue puesto de manifiesto en relación con ediciones anteriores por DE LA OLIVA SANTOS, A., Sobre el derecho a la tutela jurisdiccional, Barcelona 1980, p. 120, n. 126, quien, conscientemente, ya no se refiere a las ideas defendidas por GÓMEZ ORBANEJA en sus obras previas.

${ }^{604}$ GÓMEZ ORBANEJA, E., Derecho Procesal Penal, op. cit. p. 90. 
tendente a la máxima abstracción. La acción, según entiende este autor, sería “un derecho cívico de requerir la prestación de una actividad jurisdiccional', y estaría centrado únicamente en el momento inicial del proceso. Desde el momento en que la iniciativa de una parte provoque una actividad jurisdiccional, la acción ya habrá tenido éxito y el resto es materia que rebasa el derecho de acción. En su criterio, lo que GÓMEZ ORBANEJA denominaba actos a través de los que se desarrolla la acción penal no serían sino actos a través de los cuales se sigue preparando o se interpone la pretensión ${ }^{605}$. Por ello la mera denuncia, recogida en la LECrim como obligación (art. 259), siempre que se realizara ante órgano jurisdiccional, sería suficiente para excitar la actividad de los tribunales y para obtener una actuación de los mismos y constituirá ejercicio del derecho de acción. El denunciante no está obligado a probar nada y podrá ser llamado como testigo, por lo cual, no ha desarrollado su acción preparando e interponiendo la pretensión (no está obligado a fundamentar) y además no es parte en el proceso. Una vez puesto en conocimiento del órgano jurisdiccional a través de la denuncia, el titular del derecho de acción cambia, y esta función es asumida por el MF tras la notificación del juez instructor (art. 308 LECrim) para, ulteriormente, interponer la pretensión ${ }^{606}$. La interposición de la querella, tanto por el MF como por los particulares, sí constituye un modo de ejercitar la acción penal, pues, en todo caso, produce una actuación judicial directa (aunque sea para no admitirla). Pero contiene un plus: la preparación de la pretensión. En ella se ha de designar la persona contra la que se dirige (la persona a la que se imputan los hechos), se han de exponer circunstanciadamente los hechos y se pueden proponer determinadas medidas para la averiguación de los hechos y para demostrar la veracidad de su exposición (art. 277 LECrim) ${ }^{607}$. No empece esta lectura la opinión de que la querella "anuncia la intención de acusar, pero no acusa" en tanto, dada la naturaleza del sumario como fase procesal, la acción ya habría sido ejercitada ${ }^{608}$. Por último, en los casos en que

${ }^{605}$ FAIRÉN GUILLÉN, V., Voz “acción”, en Nueva Enciclopedia Jurídica Seix, Barcelona 1975, pp. 199 y ss.

${ }^{606}$ FAIRÉN GUILLÉN, V., Voz “acción”, op. cit. p. 204. FAIRÉN argumenta que “consideraciones de equidad promueven el que la comunidad no imponga a quien ha denunciado un delito la carga de llevar por sí el proceso; como éste busca la satisfacción de un interés social, es ella misma, representada por un organismo especializado (el MF), la que entra en funciones para desarrollar la primera actividad que uno de sus miembros había mostrado con la denuncia. Así se evita el peligro que sobrecargar excesivamente de esfuerzos al denunciante lleva consigo (desinterés por el éxito del proceso, falta de conocimientos adecuados, etc.)".

${ }^{607}$ FAIRÉN GUILLÉN, V.,Voz “acción”, op. cit. p. 205.

${ }^{608}$ Ibídem. Con ello se refiere a la crítica de ALCALÁ-ZAMORA CASTILLO, expresada en Derecho Procesal Criminal, pp. 85 y ss. 
el juez actúa de oficio, lo que ocurriría es que éste "interpone la acción ante sí mismo", pues excita la actividad jurisdiccional. Pasada la urgencia por reaccionar ante la comisión de un delito, el juez deberá adoptar de nuevo una posición jurisdiccional y el MF habría de intervenir asumiendo la calidad de "parte instrumental peticionaria"609.

\subsubsection{A raíz de la Constitución}

Nota esencial de las teorías abstractas sobre la acción es que se limitan a reconocer como objeto del derecho de acción únicamente la actividad jurisdiccional, sin considerar el sentido en que ésta opere, favorable o adverso a lo pedido por el actor ${ }^{610}$. De ahí que se hable de derecho de acción como derecho al proceso o como derecho a la actividad jurisdiccional que amparará la facultad de dirigir peticiones a los tribunales, provocando una actividad de éstos que origine una resolución. La acción del art. 24.1 CE puede ser, por tanto, concebida como un derecho subjetivo público y abstracto, atribuible a todas las personas, cuyo contenido se cifra en la exigencia dentro de los límites del ordenamiento jurídico de la puesta en marcha de la actividad de los órganos jurisdiccionales y la obtención a través del debido proceso de una respuesta jurisdiccional motivada. Con estas premisas, y a la vista del art. $125 \mathrm{CE}$ se vio entre la literatura en la facultad de ejercitar la “acción penal" la consagración de un derecho cívico enmarcable dentro de la órbita del derecho de acción. Fue advertido que ello vendría a suponer una ampliación del derecho a la Jurisdicción, alcanzando éste también a impetrar la tutela del interés público entendido con un carácter amplio. La acusación popular sería una manifestación del derecho subjetivo público de libre acceso a los Tribunales en el que la pretensión, por fundarse en el interés público, no precisaría el requisito de la legitimación en la medida en que lo que se pretende es el cumplimiento del ordenamiento jurídico ${ }^{611}$.

\footnotetext{
${ }^{609}$ Ibídem. Posteriormente FAIRÉN matiza su posición como respuesta a la crítica de que esta argumentación daría entrada al sistema inquisitivo en su máxima expresión. En su opinión es cierto que todo el ordenamiento jurídico se volvería, en «estado de necesidad» hacia el sistema inquisitivo, pero ese momento sería muy corto, ya que inmediatamente el Juez pondrá en conocimiento del MF la «notitia criminis» y éste habrá de acudir a la acción penal. FAIRÉN GUILLÉN, V., “De nuevo sobre el concepto de acción y pretensión”, RDProc. 1988, nº 1, p. 22.

${ }^{610}$ Para una exposición clara dentro de la complejidad del tema, en la que se distinguen las diversas orientaciones en la evolución de las teorías abstractas de la acción vid. ORTELLS RAMOS, M., Derecho Jurisdiccional, vol I, parte General (con MONTERO AROCA et al.), pp. 405 y ss.

${ }^{611}$ Vid. a título de ejemplo SERRANO ALBERCA, J.M., Comentarios al art. 125 CE en GARRIDO FALLA (Director), Comentarios a la Constitución, Madrid 1985, p. 1849.
} 
Según esta concepción, hoy dominante en nuestra bibliografía especializada y con amplio reflejo en la Jurisprudencia, la acusación popular en el proceso penal sería un "ius ut procedatur", un derecho a la actividad jurisdiccional, o un derecho a la jurisdicción. $\mathrm{Su}$ ejercicio se deberá traducir en permitir la participación como acusador de un particular y, simultáneamente, poner el proceso penal en marcha con una resolución sobre las pretensiones deducidas. La acusación popular como ejercicio de la "acción penal" quedaría así incluida en el derecho de acción, y podría ser identificada con un derecho subjetivo de todos los ciudadanos a la iniciativa procesal penal y, una vez comenzado el proceso, a su intervención como acusadores en él. Veamos ahora en concreto alguno de los pareceres que sustentan esta concepción de la acusación popular cercana a, o integrante de, un derecho fundamental.

\subsubsection{Las diversas opiniones doctrinales}

Para GIMENO, el autor que con mayor frecuencia ha abordado el tema que nos ocupa, la acción es un derecho subjetivo público concretado en un poder que asiste a todos los sujetos de derecho mediante el que se puede constreñir a que un órgano jurisdiccional emita un pronunciamiento sobre la solicitud de apertura del proceso ${ }^{612}$. La "acción penal" sería un "derecho subjetivo constitucional mediante cuyo ejercicio, a través de la puesta en conocimiento al órgano jurisdiccional de una notitia criminis, se solicita la apertura del proceso penal, haciendo surgir en aquél la obligación de pronunciarse sobre la misma mediante resolución motivada" ${ }^{\prime 13}$. Define este autor la acción penal popular como "el derecho que asiste a todos los sujetos no titulares de un derecho, interés o bien jurídico vulnerado, a incoar un proceso y a deducir en él una pretensión, en nombre de la sociedad, mediante la cual se reconozca una determinada situación o derecho subjetivo y/o se condene a una determinada persona al cumplimiento de una prestación". A su juicio "la acción popular es un verdadero derecho de acción y, como tal, asiste a todas las personas, sean fisicas o jurídicas" ${ }^{\prime 14}$. Sin embargo, a pesar de

${ }^{612}$ GIMENO SENDRA, V., Constitución y Proceso, Madrid 1988, p. 74, sostiene la nítida adecuación al proceso penal de la teoría abstracta de la acción, por cuanto es claro que el derecho subjetivo de penar no asiste a las personas individualmente consideradas, sino al Poder Judicial (117.3 CE) y en última instancia al pueblo español, de donde recibe su encargo (art. 117.1 y $2 \mathrm{CE}$ ).

${ }^{613}$ Ibídem.

${ }^{614}$ GIMENO SENDRA, V., Constitución y Proceso, op. cit. pp. 83 y ss. Considera también la acción popular 
venir caracterizado por ser una "acción quivis ex populo" y no exigir ningún tipo de legitimación específica para su ejercicio, es claro que tal derecho no se distribuye subjetivamente con carácter ilimitado: para ejercitarlo es requisito indispensable ostentar capacidad para ser parte y capacidad procesal en las personas físicas. No tendría sentido que un representante legal obrara en nombre de su representado, puesto que no haría valer un derecho suyo, sino que accionaría en nombre de la sociedad. La legitimación procesal se diluye y confunde con la capacidad procesal y para ser parte, sin que sea preciso alegar interés legítimo alguno. El particular no acciona en nombre o interés propio o ajeno, sino en el de la sociedad, viniendo a asumir dentro del proceso un rol similar al del Ministerio Público: la protección de la legalidad y el interés social ${ }^{615}$.

GUTIÉRREZ-ALVIZ Y ARMARIO y MORENO CATENA tomaron también como punto de referencia el art. 24.1 CE para la explicación del primer inciso del 125, resaltando algunas diferencias estructurales de relieve entre la acción popular y el derecho a obtener la tutela judicial efectiva en el ejercicio de los derechos e intereses legítimos. Según estos autores, la acusación popular es un derecho de acción, un derecho a que se dicte una sentencia sobre el fondo del asunto respecto de la que queda ampliada quivis ex populo la legitimación activa. Será un derecho a iniciar el proceso y deducir una pretensión, pero no por un derecho o interés propio, sino accionando en nombre o interés de la sociedad, por lo que su actividad procesal deberá encaminarse a solucionar un conflicto, a reponer el orden jurídico perturbado cuando no se ostente legitimación material alguna, siendo su título legitimador el simple carácter de ciudadano. Añaden además un ulterior argumento diferenciador entre ambos preceptos constitucionales: mientras que el art. 24 se refiere a todas las personas, con independencia de su nacionalidad, la expresión "ciudadanos" del art. 125 hace que se limite su contenido a los españoles, puesto que este derecho surge como corolario de la ciudadanía y es precisamente una acción uti cives ${ }^{616}$.

MONTERO AROCA conceptúa la "acción penal”como un derecho al proceso, un

como derecho de acción por ejemplo VIVES ANTÓN, T. S., "Doctrina constitucional y reforma del proceso penal" en $P J \mathrm{n}^{\circ}$ especial II, p. 103.

${ }^{615}$ GIMENO SENDRA, V., Constitución y Proceso, pp. 83 y ss.

${ }^{616}$ GUTIÉRREZ-ALVIZ Y ARMARIO, F. y MORENO CATENA, V., "La participación popular en la administración de justicia" en Comentarios a las Leyes Políticas, dirigidos por ALZAGA, O., Constitución Española de 1978, T. IX, pp. 599 y ss. 
“ius ut procedatur" tanto si la ejerce un particular como si lo hace el Ministerio Público. Incluiría únicamente, a su juicio, el derecho a la iniciación del proceso y a la realización del mismo, practicando el juez instructor toda la actividad oportuna para investigar los hechos y descubrir a sus autores. El proceso penal no sería consecuencia inevitable de una denuncia o una querella, de modo que no quedaría sólo en manos de la parte activa la incoación del proceso. En el proceso penal la tutela efectiva se produce también cuando el órgano judicial, sin llegar a la sentencia, se pronuncia motivadamente considerando que los hechos imputados por el acusador a una persona, aun en el caso de que fueran ciertos, no son constitutivos de infracción penal ${ }^{617}$. Además, el derecho a la tutela judicial efectiva incluiría también el derecho de todas las partes al recurso ${ }^{618}$.

ORTELLS RAMOS considera por su parte que la atribución con carácter general de la "acción penal" a cualquier ciudadano con capacidad de obrar es adecuada al destino de la acción y del proceso penal, en tanto tenderá a la aplicación del derecho objetivo no condicionada por intereses particulares ${ }^{619}$.

GONZÁLEZ MONTES sostiene que el hecho de reconocer que la "acción penal" no puede confundirse con el ius puniendi, y que no puede suponer tampoco un derecho concreto como el expresado para el proceso civil, no obliga necesariamente a deducir que haya de configurarse como un derecho abstracto, y menos tal y como se ha entendido éste para el proceso civil. La acción penal habrá de venir referida al proceso en cuanto derecho fundamental a la tutela de los jueces, por lo que habría sido frecuente y diversamente caracterizada como un derecho al proceso (ius ut procedatur). Sin embargo la "acción penal" no puede ser siempre un derecho de iniciativa del proceso, dado que el procedimiento ha podido iniciarse de oficio e incluso el ofendido personarse antes del trámite de calificación del delito. Dada la estructura escalonada del proceso penal, la acción se iría reconociendo o satisfaciendo gradualmente a lo largo del proceso según el

${ }^{617}$ MONTERO AROCA, J., Derecho Jurisdiccional, T. III, 1996, p. 25 y "La garantía del proceso penal y el principio acusatorio", La Ley 1994, vol. I, pp. 973 a 984.

${ }^{618}$ MONTERO AROCA, J., Derecho Jurisdiccional, op. cit. p. 26. El fundamento no se encontraría en la CE sino en el PIDCP y en el reconocimiento que en él se hace del derecho al recurso en favor del condenado. Su integración en nuestro ordenamiento jurídico tendría que tomar como base el principio de igualdad entre las partes, por lo que no pueden surgir impugnaciones privilegiadas en favor de una de ellas.

${ }^{619}$ ORTELLS RAMOS, M., Derecho Jurisdiccional, vol I, parte General (con MONTERO AROCA et al.), p. 400. 
grado de certeza que se reconozca al hecho en que se funda ${ }^{620}$.

ANDRÉS IBÁÑEZ y MOVILLA ÁLVAREZ ponen también en relación el primer inciso del art. 125 con el $24 \mathrm{CE}$, de forma que la acción popular se elevaría desde la simple consideración de una técnica procesal a una manifestación de la participación popular en la "Administración de Justicia", en el sentido de hacer al ciudadano, en cierta medida, garante de intereses públicos. La dicción del art. 125 CE supondría un mandato al legislador ordinario de potenciar y posibilitar en su mayor grado el ejercicio de la acción popular por lo que ésta, que hasta ahora tenía un carácter excepcional y de restringida funcionalización, adquiriría carta de normalidad ${ }^{621}$.

En otro sentido, BANDRÉS SÁNCHEZ-CRUZAT entiende la acción popular del art. 125 CE como un principio básico de la Jurisdicción y del proceso, profundamente hermanado con el derecho al debido proceso ${ }^{622}$. El derecho al proceso debido se ejercita en cuanto derecho subjetivo por la actividad de la parte en el proceso, e implica la actitud de los jueces de no poner trabas indebidas a la actuación procesal del litigante. Concebido como un derecho de prestación, su ejercicio implicaría necesariamente la actividad del poder judicial en la dirección del proceso ${ }^{623}$.

Por último, debemos hacer una reseña a la postura de DÍEZ-PICAZO, para quien la acusación popular debería ser incluida no en los derechos fundamentales sino dentro de la categoría de las garantías institucionales. Al referirse al art. $125 \mathrm{CE}$ dice este autor que “contiene, ante todo, una garantía institucional de la acción popular en materia penal, que, por lo demás no hace sino elevar a rango constitucional una norma tradicional del Derecho Penal español'. No es por tanto incompatible con la modulación legislativa de la

${ }^{620}$ GONZÁLEZ MONTES, J.L., "Notas en torno a la acción penal y su ejercicio”, en MORENO CATENA, V. (Coordinador), Problemas actuales de la Justicia. Homenaje al Profesor Gutiérrez-Alviz, Valencia 1988, pp. 739 y ss. El autor parece en este sentido seguir a FENECH.

${ }^{621}$ ANDRÉS IBÁÑEZ y MOVILLA ÁLVAREZ, El Poder Judicial, op. cit. pp. 313 y s.

${ }^{622}$ BANDRÉS SÁNCHEZ-CRUZAT, J.M., El Derecho Fundamental al proceso debido y el Tribunal Constitucional, Pamplona 1992, p. 38. Este sería uno de los “derechos novedosos" a disposición de los ciudadanos que habría adquirido per se rango de derecho fundamental cuando se trate de la defensa de intereses colectivos, por lo que en la perspectiva del Estado democrático y participativo no se podría compartir el monopolio de la acción pública de promoción del proceso (pp. 103 y 108 y ss.).

${ }^{623}$ BANDRÉS SÁNCHEZ-CRUZAT, J.M., El Derecho Fundamental..., op. cit. p. 114. 
institución, de suerte que cabría que el legislador le estableciera límites ${ }^{624}$. Sostenía sin embargo DÍEZ-PICAZO que el TC no habría llegado a afirmar todavía, si bien habría dejado abierta la posibilidad de que la acción popular tuviera conexión directa con el art. $24 \mathrm{CE}^{625}$. Debemos advertir no obstante que, sin dejar de reconocer la vigencia en la doctrina alemana de la categoría de las garantías institucionales, su utilidad hoy día en nuestro sistema es dudosa ${ }^{626}$. Adscribir la acusación popular a ellas podría obstaculizar su funcionalidad con el agravante de la dificultad para constituir un soporte válido clarificador de su naturaleza ${ }^{627}$.

${ }^{624}$ DÍEZ-PICAZO, L.M., Régimen Constitucional del Poder Judicial, Madrid 1991, p. 66.

${ }^{625}$ Ibídem.

${ }^{626}$ La categoría de las garantías institucionales (o garantías de instituto) tuvo su origen en la doctrina publicista alemana de la época de Weimar, si bien ha sido mantenida firmemente con posterioridad tanto en aquel país como en el nuestro, donde han visto la luz trabajos doctrinales favorables o críticos al respecto e intentos de transplante, en la mayoría de las ocasiones infructuosos. Aun cuando el concepto ya había sido utilizado por GIESE en 1919, WOLFF en 1923 o SMEND en 1927, es C. SCHMIDT quien elabora la categoría de garantías institucionales de forma sistemática por contraposición a los derechos de libertad, los cuales serían ilimitados y preestatales. Vid. SOLOZÁBAL ECHAVARRÍA, J.J., "La libertad de expresión desde la teoría de los derechos fundamentales", Revista Española de Derecho Constitucional, $\mathrm{n}^{\mathrm{o}}$ 32, mayo-agosto 1991, pp. 86 y ss. Su presunto valor se debe a que suministraría un eje clasificatorio frente a los derechos fundamentales que dejara claros los límites a la discrecionalidad con la que el legislador se enfrentaría al modelar normativamente un determinado instituto reconocido en el texto constitucional. De esta manera, la garantía institucional sería una prohibición dirigida al legislador de no eliminar determinadas competencias del ciudadano, y en particular instituciones jurídicas del derecho privado. ALEXY, R., Teoría de los Derechos Fundamentales, op. cit. pp. 237 y s. Entre los trabajos sobre las garantías institucionales en nuestro país, y sin ánimo de exhaustividad, cabe destacar BAÑO LEÓN, J.M., "La distinción entre derecho fundamental y garantía institucional en la Constitución Española", Revista Española de Derecho Constitucional, nº 24, sept.-dic. 1988, pp. 155-179; SOLOZÁBAL ECHAVARRÍA, J.J, op. cit. y "Algunas cuestiones básicas de la Teoría de los Derechos Fundamentales", RAP 71, enero-marzo 1991, pp. 87-109; JIMÉNEZ BLANCO, "Garantías institucionales y derechos fundamentales en la Constitución", en Homenaje a García de Enterría (1991), T. II, pp. 635 y ss., GALLEGO ANABITARTE, A., Derechos Fundamentales y Garantías Institucionales: análisis doctrinal y jurisprudencia, Madrid 1994 y REY MARTÍNEZ, F., La propiedad privada en la Constitución Española, Madrid 1994, pp. 220 y ss.

${ }^{627}$ Ello no haría más que aportar un nuevo elemento de confusión a una materia ya de por sí compleja. Dada la dimensión objetiva de los derechos fundamentales junto a su dimensión subjetiva tradicional, que nos lleva a configurarlos también como principios o valores fundamentales del ordenamiento jurídico, esta categoría carecería de contenido específico: el aspecto jurídico objetivo de los derechos fundamentales cubriría todo lo que pueda dar la llamada garantía institucional. Vid. GALLEGO ANABITARTE, A., op. cit. pp. 96 y ss. Independientemente de éstas -señala GALLEGO-, existen instituciones garantizadas por la Constitución que nada tienen que ver con los derechos fundamentales (autonomía local, universidad, independencia judicial, el jurado, colegios profesionales, etc.), siendo tarea del intérprete jurisdiccional y de la ciencia ir perfilando cuales son estas instituciones garantizadas constitucionalmente, lo cual significa un cierto límite a la discrecionalidad configuradora del legislador (op. cit. $\mathrm{p}$. 99). En contra de esta postura vid. BAÑO LEÓN, A., op. cit. pp. 155 y ss. 


\subsubsection{La jurisprudencia del TC}

Nuestro Tribunal Constitucional ha incardinado el acceso al proceso penal en calidad de acusador popular en un concepto de tutela judicial efectiva si no idéntico sí paralelo o cuando menos equiparable al que viene aplicando a la generalidad de los procesos. La facultad de ejercitar la pretensión penal se incluiría, al igual que el genérico derecho de rogar la tutela jurisdiccional, en el contenido del derecho constitucional a la tutela judicial efectiva en cuanto éste llevaría implícito el derecho de libre acceso al proceso. Según la reiterada doctrina que el máximo intérprete de la Norma Fundamental aplica a todos los órdenes jurisdiccionales y, especialmente por lo que a este trabajo afecta, también al penal, "el primer contenido del derecho a la tutela judicial efectiva es el acceso a la Jurisdicción, que se concreta en el derecho a promover la actividad jurisdiccional" ${ }^{\prime 28}$. O dicho con otras palabras, "la primera nota esencial del derecho a la tutela que han de cumplir los Tribunales es la de posibilitar el libre acceso de las partes al proceso" ${ }^{629}$. Es perceptible en los criterios del TC también en esta materia una visión omnicomprensiva del derecho a la tutela judicial efectiva, que pretende atraer a su órbita de gravitación muchas de las esferas más o menos cercanas a él ${ }^{630}$.

Bien es cierto que la petición de que se incoe un proceso penal y de poder intervenir en él no ha de ser indeferenciadamente efectiva siempre y en todo caso, ni que deba verse sometido en exclusiva a la libre voluntad del actor, sino que el derecho a la tutela judicial quedará también satisfecho con una resolución jurisdiccional motivada sobre la pretensión deducida. No hay un derecho incondicionado a la apertura y plena sustanciación del proceso, por lo que la inadmisión de la querella, el sobreseimiento o el archivo de las actuaciones, siempre que se hagan en aplicación razonada de una causa legal, respondiendo el razonamiento a una aplicación de las normas legales de conformidad con la Constitución y en el sentido más favorable para la efectividad del derecho fundamental, no vulnerarían "el ius ut procedatur en que la acción consiste". En estas condiciones, el contenido de la resolución que recaiga sobre una petición para ejercitar la

\footnotetext{
${ }^{628}$ SSTC $115 / 1984$ de 3 de diciembre, 63/1985 de 10 de mayo, 147/1985 de 29 de octubre, 131/1991 de 17 de junio, 37/1993 de 8 de febrero, 217/1994 de 18 de julio y 111/1995 de 4 de julio.

${ }^{629}$ STC 40/1994 de 15 de febrero, FJ. 2.

${ }^{630}$ Vid. la crítica que se le opone por PEDRAZ PENALVA, E., en su reciente artículo "El Derecho al proceso sin dilaciones indebidas", $P J, \mathrm{n}^{\circ} 43-44$, pp. 225 y ss.
} 
acusación popular será irrelevante para constatar el respeto del derecho de acción. O para decirlo en palabras reiteradas hasta la saciedad por el TC, "el ius ut procedatur no sería un derecho absoluto a la apertura y plena sustanciación del proceso penal, sino tan sólo el derecho a una decisión judicial razonada sobre las pretensiones deducidas que bien puede ser de sobreseimiento o archivo de las actuaciones o incluso la inadmisión de la querella" ${ }^{631}$. El derecho de ejercitar la acusación popular alcanza así protección constitucional en tanto se trate de obtener una resolución jurisdiccional fundada jurídicamente sobre una pretensión acusatoria deducida ante los tribunales de conformidad con el imperativo procesal.

Este derecho a obtener una actuación de los órganos jurisdiccionales quedará satisfecho bien en el momento en que aquella resolución se dicte, si es que ésta es de inadmisión y se basa en una de las causas reconocidas por la ley, bien con la resolución firme que ponga fin al proceso. Se trataría, por tanto, sólo de un punto de partida, del presupuesto básico sobre el que se asienta la formulación de las pretensiones del acusador popular.

La referencia del art. 125 CE a "los ciudadanos" no comportaría óbice alguno para incluir a todas las personas, físicas o jurídicas, puesto que al quedar englobado su contenido en el del art. 24.1, deberá entenderse subsumido el derecho de "todas las personas" a la Jurisdicción ${ }^{632}$.

No podemos pasar por alto en este momento el dato de que a la actividad acusadora del ofendido por el delito se haya extendido sin problemas la máxima protección constitucional al socaire del derecho a la tutela judicial efectiva, sin que ocurra lo mismo con la acusación ejercitada por el particular no ofendido. En este supuesto la garantía no alcanza el mismo nivel de amparo, a no ser que la defensa de un interés general sea la única forma de defender un interés personal ${ }^{633}$. El TC distingue un doble

\footnotetext{
${ }^{631}$ Este razonamiento es el que ha llevado en ocasiones a considerar que el TC está optando por una concepción abstracta del derecho de acción penal. Vid. STC 40/1994 de 15 de febrero cit. pero cfr. también una larga y reiterativa serie entre las que podríamos citar las SSTC 11/1985 de 30 de enero, 148/1987 de 28 de septiembre, 33/1989 de 13 de febrero, 203/1989 de 4 de diciembre, 191/1992 de 16 de noviembre, 37/1993 de 8 de febrero, 217/1994 de 18 de julio, 111/1995 de 4 de julio y 199/1996 de 3 de diciembre.

${ }^{632}$ STC 241/1992 de 21 de diciembre. El art. 125 CE se asimila aquí al art. 53.2 CE que también se refiere a los ciudadanos.

${ }^{633}$ STC 62/1983 de 11 de julio, 173/1987 de 3 de noviembre, 37/1993 de 8 de febrero, 34/1994 de 31 de enero. A pesar de esta diversidad de fundamento constitucional, la negación de la cualidad de ofendido no es considerada una
} 
nivel de tutela entre el acceso al proceso a través de la acción popular del art. $125 \mathrm{CE}$ y el que se realiza mediante la llamada acusación particular y privada, cuya salvaguardia se encuentra garantizada directamente por el art. $24 \mathrm{CE}$. En este último caso sostiene el Tribunal que "es un interés digno de protección el que el ofendido tiene en orden a solicitar la actuación del ius puniendi del Estado a fin de obtener la plena vigencia del principio sustantivo de legalidad" ${ }^{34}$.

\subsubsection{La jurisprudencia del TS}

La Sala $2^{\mathrm{a}}$ del TS ha seguido en general las pautas marcadas por el TC, configurando también la acusación popular como un derecho a promover la actividad jurisdiccional integrado en el derecho constitucional de acción. La acción popular del proceso penal respondería "a las exigencias de lo que, en una de sus facetas, representa la tutela judicial efectiva" ${ }^{635}$, por lo que, por ejemplo, sería también invocable por las personas jurídicas ${ }^{636}$. No obstante, el TS no siempre se ha manifestado abiertamente favorable a la deducción por particulares de la acusación, sino que en ocasiones se percibe en sus sentencias un cierto recelo frente a ella ${ }^{637}$.

Sin perjuicio de ir glosando las opiniones mostradas por el TS en diferentes partes de este trabajo, queremos mostrar aquí el planteamiento de la sentencia de 10 de julio de 1995 citada, en la que se abordó la relación del art. 125 CE con normas preconstitucionales que podrían hacer cuestionar la posibilidad de la acusación popular en determinados supuestos. En concreto la duda se suscitaba con respecto al art. 47 de la hoy derogada Ley de Régimen Jurídico de la Administración del Estado, atinente al procedimiento penal contra Autoridades ${ }^{638}$. El recurrente, Presidente de una Comunidad Autónoma, alegaba

vulneración con trascendencia constitucional en tanto no conlleva necesariamente la negación del acceso al proceso. Vid. STC 326/1994 de 12 de diciembre.

${ }^{634}$ STC 40/1994 de 15 de febrero reiterando así lo expuesto en la citada 37/1993.

${ }^{635}$ STS de 10 de julio de 1995 (RAJ 5400).

${ }^{636}$ STS de 4 de marzo de 1995 (RAJ 1802).

${ }^{637}$ Vid. por ejemplo las SSTS de 12 de marzo de 1992 (RAJ 2442) y la de 5 de junio de 1993 (RAJ 4824).

${ }^{638}$ El precepto citado, procedente de un momento en el que la acusación popular no era más que una institución totalmente arrinconada en nuestro proceso penal, rezaba de la siguiente manera: "El procedimiento judicial penal 
que la petición de responsabilidad a un gobierno regional únicamente cabría en un procedimiento incoado a instancia del Ministerio Fiscal o del perjudicado u ofendido, por lo que en éste, que traía origen de una acusación popular, la infracción procesal sería grave e invalidante de toda la causa. El alto Tribunal estimó por el contrario que una vez configurada por el TC como manifestación del derecho a la tutela jurisdiccional en materia penal "la prosperabilidad de la tesis del recurrente supondría una directa amenaza a la acción popular". La desestimación del recurso se justificó, pese a que el citado artículo no hubiera sido formalmente derogado, en que "su contenido jurídico ha de quedar condicionado por la Constitución de 1978 y, concretamente, por el art. $125^{\prime}\left(\mathrm{FD} 6^{\circ}\right)$. El TS reconoció además que el propio texto del artículo permitiría una interpretación no tan radical como la que se pretendía, puesto que su texto rezaba "podrá iniciarse...", sin excluir en ningún caso explícitamente otras modalidades, por lo que no habría necesitado una expresa derogación si su contenido hubiera resultado totalmente contradictorio con cuanto la Constitución representa en este aspecto. A sensu contrario cabe entender que, para el TS, si tal precepto se opusiera a la acción popular habría que inaplicarlo o promover su declaración como inconstitucional.

\subsubsection{No es un derecho a la tutela jurisdiccional concreta}

Hay acuerdo unánime entre la literatura procesalista en que la "acción penal" en su ejercicio por los ciudadanos no puede ser un derecho a la tutela jurisdiccional concreta ${ }^{639}$. De considerarla así, tendría que ser un poder consistente en la facultad de desencadenar la actividad jurisdiccional para que los órganos jurisdiccionales se pronunciasen sobre una

contra las autoridades podrá iniciarse por el Ministerio fiscal o a instancia del ofendido o perjudicado". Hoy se encuentra derogado por la Ley de Organización y Funcionamiento de la Administración General del Estado (LOFAGE), Ley 6/1997 de 14 de abril.

\footnotetext{
${ }^{639}$ Así como en el ámbito procesal civil el derecho de acción como derecho a obtener una concreta tutela jurisdiccional es defendido con vehemencia por un sector doctrinal (GÓMEZ ORBANEJA, E., Derecho Procesal Civil, pp. 227 y ss.; DE LA OLIVA SANTOS, A., Sobre el derecho a la tutela jurisdiccional, passim.), en el procesal penal es unánime la posición de que no pueden surgir genuinos derechos subjetivos públicos a obtener tal tutela concreta. La separación entre el derecho sustancial y el derecho procesal ha seguido en el tema de la acción una escalada de progresiva abstracción y desvinculación con respecto a derechos subjetivos materiales, que no ha sido aceptada en la misma medida por toda la literatura procesal. Como resaltara FAIRÉN, al incrementar la abstracción del concepto lo alejamos del campo del proceso, pero lo aproximamos a su verdadero «centro de gravedad»: a la teoría general del Derecho, desde donde puede irradiar mejor todas sus manifestaciones. FAIRÉN GUILLÉN, V., "De nuevo sobre el concepto de acción...”, op. cit. p. 14. Este debate cambia en relación con la "acción penal", y la idea de radical abstracción predomina sobre cualquier otra serie de consideraciones.
} 
determinada pretensión de naturaleza penal sometida a su consideración. En este caso habría de formularse la acción penal como un derecho subjetivo público que, concurriendo determinados presupuestos (que X haya realizado la conducta Z) implicaría que cualquier ciudadano tendría derecho -un verdadero derecho y no una mera expectativa- a una sentencia de condena con un contenido determinado. Dados los presupuestos necesarios y probado el hecho, una absolución no satisfaría el derecho de acción, y una sentencia de condena, aun no imponiendo la pena que se solicite en la calificación del actor, sí lo haría ${ }^{640}$.

Sin negar la necesidad de que todos los ciudadanos deban estar protegidos por el sistema penal, no es sin embargo concebible el que puedan ser titulares de un auténtico derecho subjetivo a obtener una sentencia de condena. Una cosa es que, proscrita por el Estado la autodefensa, los individuos tengan que ser tutelados por aquél, y otra diferente el que se les confiera un derecho a obtener una resolución de contenido determinado a sus peticiones de condena. La existencia de un derecho de los particulares a castigar o sancionar está fuera de toda duda, pero admitiendo la existencia en los términos expuestos de un derecho a una sentencia de condena, tendríamos que admitir que su contenido sería un hipotético derecho a que el Estado castigara penalmente ${ }^{641}$. El debido proceso, garantía exigible por el justiciable de la que se dota el Estado para perseguir jurídicamente las conductas con apariencia criminal, podrá concluir declarando la responsabilidad penal de un sujeto, pero no parece que en él tenga o deba tener cabida derecho de particular

${ }^{640}$ Así lo hace como mera hipótesis de trabajo y con el ánimo de refutarla DE LA OLIVA SANTOS, A., Sobre el derecho a la tutela jurisdiccional, Barcelona 1980, p. 112 y en la obra colectiva Derecho Procesal Penal, Madrid 1993, p. 171.

${ }^{641}$ DE LA OLIVA SANTOS, A., Sobre el Derecho a la Tutela Jurisdiccional, op. cit. p. 33. Ésta parecería no obstante ser la interpretación más acorde a la literalidad del texto del art. 100 LECrim que se refiere a la acción "...para el castigo del culpable". Aun teniendo en cuenta que no siempre a la condena sigue el castigo efectivo, la Ley parece hablar de "acción" como un derecho, atribuido a casi todos los ciudadanos, a una sentencia de condena como presupuesto básico del castigo. Otra razón señalada por DE LA OLIVA para negar la concepción concreta sería la eficacia intraprocesal de actos de ejercicio del derecho de gracia. Si el indulto afectara a causas pendientes, tal y como según afirma ha sucedido en varias ocasiones, la construcción se viene abajo: en la medida que tal acto de disposición sobre la sanción es capaz de poner fin al proceso con sobreseimiento (Cfr. art. 666.4 ${ }^{\circ}$ LECrim), cabe pensar que el particular no tiene derecho a la condena, pues resultaría forzado considerar el indulto como un contraderecho que enerva el del accionante. Sobre la tutela..., p. 114 y Derecho Procesal Penal, op. cit. p. 172. No podemos más que sumarnos a la crítica de aquéllos que, afirmando su naturaleza penal, señalan lo irregular de declarar la extinción de una responsabilidad penal que aún no se ha declarado judicialmente. Pudiera ser explicado por economía procesal, por un justificado interés en no afectar la buena fama del imputado cuya hipotética pena no va a ser cumplida, lo cual conllevaría la necesidad de reconducir su naturaleza al ámbito procesal. Sin avanzar más en el tema, parece, pues, que el indulto constituye así no una causa de inimputabilidad, sino de no perseguibilidad. 
alguno a una concreta tutela jurisdiccional, a una sentencia de contenido determinado. Un derecho a un pronunciamiento condenatorio del acusado sería una engañosa imagen que a nuestros ojos presentaría el derecho a la protección jurisdiccional contra el delito, el cual es de contenido abstracto ${ }^{642}$. DE LA OLIVA, firme defensor de la concepción concreta de la acción en el proceso civil, llega así al convencimiento de que, como ya destacara CALAMANDREI, la acción en materia penal únicamente puede concebirse como poder y sólo en sentido abstracto ${ }^{643}$, confirmando de este modo la dificultad, si no imposibilidad, de salir triunfantes de un intento de adaptar la concepción concreta de la acción al proceso penal y reconociendo que, ni aun como hipótesis, podría ser asumible la defensa de la acusación popular como un derecho a la tutela jurisdiccional concreta.

Algunas otras razones más han sido apuntadas por la literatura en sentido semejante: en primer lugar, que un derecho de ejercitar la "acción penal", resultaría plenamente satisfecho o negado antes de la sentencia (en el auto de apertura del juicio oral o en el de sobreseimiento) ${ }^{644}$ y en segundo, que el objeto del proceso penal no podría configurarse como una pretensión, porque la calificación y petición de pena del acusador no determina en su totalidad la resolución del órgano jurisdiccional ${ }^{645}$.

Por otra parte, al hilo de la explicación sobre la naturaleza y contenido del derecho constitucional de acción, algún sector doctrinal ha destacado para criticar la teoría concreta de la acción el que ésta no sería aplicable al proceso penal precisamente por la existencia de sujetos (MF, querellante popular o público) que no ejercitan la "acción" para obtener la tutela de un derecho o interés propio vulnerado, sino que accionan en nombre

${ }^{642}$ Por ello, en su opinión, "si se logra explicar satisfactoriamente la especialidad de nuestro sistema procesal penal consistente en la acción popular por una vía que no sea la del derecho de acción en sentido concreto, habremos evitado definitivamente el espejismo". DE LA OLIVA SANTOS, A., Sobre el Derecho a la Tutela Jurisdiccional, p. 119.

${ }^{643}$ CALAMANDREI, P., "La relatività del concetto d'azione", Riv. Dir. Proc. Civ. 1939, I, pp. $22-46$ y en Opere Giuridiche I, Nápoles 1965, p. 431. Existe traducción de SENTÍS MELENDO: Estudios sobre el proceso civil, Buenos Aires 1945, pp. 137 y ss (vid. p. 156). La incoherencia de la aplicación de las teorías concretas de la acción como derecho en el proceso penal fue advertida por CALAMANDREI para quien no tendrían sentido más que en el campo civilista.

${ }^{644}$ Siguiendo la primera concepción de GÓMEZ ORBANEJA que ya hemos abordado en páginas anteriores.

${ }^{645}$ Así lo recoge ORTELLS RAMOS, M., Derecho Jurisdiccional, vol I, parte General (con MONTERO AROCA et al.), p. 400 . 
de la sociedad y en defensa de la legalidad material ${ }^{646}$. La inexistencia de un vínculo material entre actores y específicos intereses defendidos mediante el proceso impediría de todo punto el poder hablar de un derecho a una tutela jurisdiccional concreta de éstos.

Ha de observarse en este momento, sin embargo, que la acusación popular sí exige cierto grado de concreción puesto que en la querella, el necesario instrumento formal para su ejercicio, tiene que figurar una relación circunstanciada de los hechos reputados delictivos y, dentro de lo posible, de su presunto autor (art. 277.4 $4^{\circ}$ y $3^{\circ}$ LECrim respectivamente) y que además la factibilidad de ejercitarla depende en algunos casos del sujeto frente al que se ejercite (art. 103 LECrim). Sobre estas cuestiones volveremos posteriormente.

\subsection{El ejercicio de la acusación popular no integra el derecho de acción}

\subsubsection{Derecho de acción y acción penal}

\subsubsection{Relatividad del concepto de acción}

El problema de la acción surgió durante el siglo XIX en Alemania con la teorización de los derechos subjetivos y la exaltación del individuo y la soberana libertad dimanante de su voluntad ${ }^{647}$. La evolución del concepto de acción hacia el derecho público llega en un momento posterior, siempre sobre la base del mismo término de origen romano $(\text { actio })^{648}$. Por tratarse de un concepto eminentemente dogmático, su estudio ha sobrepasado las fronteras delimitadas por los singulares sistemas de derecho positivo, con la intención de abrir un espacio común en todos ellos. Pero han de traerse

\footnotetext{
${ }^{646}$ GIMENO SENDRA, V., Constitución y Proceso, p. 74. Reseñamos aquí nuestra reticencia a admitir la idea de existencia de "partes" en el proceso penal, aun cuando sobre la cuestión retornaremos más adelante.

${ }^{647}$ Para un repaso histórico esclarecedor, lo cual ha de considerarse digno de agradecimiento en esta materia en ocasiones tan oscura, vid. ORESTANO, R., Azione, diritti soggettivi, persone giuridiche, Bolonia 1978, pp. 15 y ss.

${ }^{648}$ Conocido es que la distinción entre acción y derecho material, así como la relación entre ambas, es considerada como uno de los puntos de partida de la relativamente moderna ciencia procesal y que el desdoblamiento entre lo que consideramos derecho procesal y el llamado "derecho sustantivo" constituye uno de los extremos determinantes de aquella disociación.
} 
inevitablemente a colación las célebres palabras de CALAMANDREI advirtiendo de la relatividad del concepto de acción, a su juicio carente de vigencia universal, y que ni siquiera sería adaptable a todas las formas de actuación de los derechos en un mismo ordenamiento jurídico. La inutilidad del trabajo requerible para encontrar en este sentido un verdadero y único concepto era también argumentada por este autor por cuanto la acción sería sólo un aspecto de las relaciones entre el ciudadano y el Estado, que varía y se modifica según la mayor o menor injerencia del mismo en las relaciones privadas. Por ello, en su opinión, no existiría una solución satisfactoria y ésta quizá no llegaría nunca a existir $^{649}$.

Entre nuestra doctrina, ya en 1946, advertía ALCALÁ-ZAMORA que de no ser el concepto de acción esencial, útil y trascendente, y “de haber servido sólo para producir una literatura brillante, pero también en ocasiones logomáquica y confusa, sin más repercusión que la de reservársele un capítulo-homenaje en las obras doctrinales, probablemente habría llegado la hora de que los procesalistas, agradecidos a la elevación cientifica que merced a los estudios sobre ella ha logrado el derecho procesal en los últimos noventa años, pero al mismo tiempo, convencidos de su infructuosidad, le organizásemos unos solemnes funerales... y concentrásemos nuestros esfuerzos en otras direcciones..." ${ }^{650}$. En opinión de ALCALÁ-ZAMORA, lo que denominaba con buen criterio "hipertrofia formal con respecto a la acción", se habría manifestado constantemente en el carácter exageradamente historicista y teórico de un buen número de ensayos, con todo el brillo y la intrascendencia de los fuegos de artificio ${ }^{651}$. FENECH señalaba que, sea cual sea la naturaleza del poder o potestad de acción, en nada afectaría a la problemática del derecho procesal. Por ello entendía que habría comenzado a abrirse paso la idea de que convendría abandonar este tema como estéril, aun reconociendo su importancia histórica en la ciencia del proceso ${ }^{652}$. FAIRÉN ha hecho ver que la exposición de

${ }^{649}$ CALAMANDREI, P., "La relatività del concetto d'azione”, Riv. Dir. Proc. Civ. 1939, I, pp. 22-46 y en Opere Giuridiche I, Nápoles 1965, p. 431. Existe traducción de SENTÍS MELENDO: Estudios sobre el proceso civil, Buenos Aires 1945, pp. 137 y ss. Entre nuestros autores vid. FAIRÉN GUILLÉN, V., Voz "Acción” en Nueva Enciclopedia Jurídica, Barcelona 1975, T. II, p. 192 y "De nuevo sobre el concepto de acción y pretensión”, RDProc $1988, \mathrm{n}^{\circ} 1$, pp 12 y ss.

${ }^{650}$ ALCALÁ-ZAMORA y CASTILLO, N., "Enseñanzas y sugerencias de algunos procesalistas sudamericanos acerca de la acción", publicado en Estudios de Derecho Procesal en honor de Hugo Alsina, Buenos Aires 1946 y en Teoría General e historia del Proceso, 1945-72, México 1974, p. 323.

${ }^{651}$ ALCALÁ-ZAMORA y CASTILLO, N., “Enseñanzas y sugerencias...”, op. cit. p. 328. 
tanta teoría dispar sobre la acción es "calumniosa" para la ciencia procesal, constatando su carácter relativo y no absoluto y su incardinación en el derecho político ${ }^{653}$.

Un inconveniente más debe ser añadido también a la posibilidad de construir un concepto de acción universalizable en sentido vertical a través de la historia, y válido en sentido horizontal para los procesos civil y penal. Se trata del estrecho maridaje entre la acción penal y las diversas concepciones políticas, oscilantes entre libertad o liberalismo y autoritarismo. Tal cuestión, argumentada ya por CALAMANDREI ${ }^{654}$, ha sido puesta de manifiesto en nuestra bibliografía por FENECH y FAIRÉN. Así, para FENECH, la relación entre el interés individual y el interés público y entre la libertad y la autoridad, harían que no se hubiera podido llegar a conclusiones satisfactorias unánimemente aceptadas ${ }^{655}$. Para FAIRÉN toda doctrina sobre la acción debe ser considerada en función del nexo que exista entre el interés público y el privado, y el punto de equilibrio entre ambos sería inestable ya que el problema de las relaciones entre el Estado y el individuo depende de cómo se estructure aquél por éstos ${ }^{656}$.

${ }^{652}$ FENECH, M., Derecho Procesal Penal, Barcelona 1960, pp. 279 y ss. En su opinión la acción, como potestad o poder que compete al particular para conseguir que se inicie la actividad jurisdiccional, no tiene otra relevancia que el ser un derecho de iniciativa, y cuando el Estado tiene interés en asegurar que la norma sea observada, ni siquiera este derecho de iniciativa sería fundamental como presupuesto del ejercicio de la Jurisdicción. La innecesariedad de la acusación popular propugnada por FENECH, conjugada con su defensa de la aplicabilidad de principios autoritarios al proceso penal, han restado lógicamente credibilidad entre nuestra doctrina a una concepción parcialmente válida. No obstante, algunas de sus afirmaciones podrían ser reinterpretadas hoy desde los parámetros del Estado democrático, social y de derecho, de los que el citado autor nunca fue partidario como demuestra bien a las claras en su obra La posición del Juez en el Nuevo Estado.

${ }^{653}$ FAIRÉN GUILLÉN, V., Voz “Acción”, op. cit. p. 192. FAIRÉN recoge la enumeración realizada por PEKELIS sobre las innumerables acepciones diversas con las que se puede utilizar el término "acción". Vid. PEKELIS, voz “Azione” en Nuovo Digesto Italiano, traducido en RDProc (Argentina), año VI (1948), n II, parte I, pp. 116 y ss.

${ }^{654}$ CALAMANDREI, P., "La relatività del concetto d'azione" en Riv. Dir. Proc. Civ. 1939, I, pp. 22 y ss. y en Opere Giuridiche I, Nápoles 1965, p. 431. Existe traducción de SENTÍS MELENDO: Estudios sobre el proceso civil, Buenos Aires 1945.

${ }^{655}$ FENECH, M., Derecho Procesal Penal, vol. I, 3ª ed., 1960, p. 270.

${ }^{656}$ La vinculación de la noción de acción con concepciones de naturaleza política ha sido sin embargo criticada. En este sentido, afirma SERRA, con fundamento en SATTA que "se puede discutir si la acción debe, o no, ser concedida al ciudadano; pero una vez concedida, la acción es lo que es, su concepto es único y el deber del jurista es fijarlo. El problema de la acción es un problema jurídico y querer resolverlo con elementos políticos es hacer politiquería de pésimo gusto". SERRA DOMÍNGUEZ, M., "Evolución histórica y orientaciones modernas del concepto de acción”, RDProc. 1968, III, julio-sept. 1968, p. 42. El artículo está publicado también en Estudios de Derecho Procesal, Barcelona 1969, pp. 118-158. 
Por estas razones se ha afirmado que el problema de la acción, como el del derecho subjetivo se resolvería en su historia, o mejor, en la historia de sus múltiples y mutables concepciones, identificándose enteramente en ésta, con todas sus inherencias, sus conexiones, sus condicionamientos, sus retornos y sus caídas. Por ello, dentro del problema de la acción en sentido ontológico no habría nada de real, efectivo o concreto, sino el modo en que tal concepto ha sido extraído, formulado, definido, empleado, discutido, exaltado o negado ${ }^{657}$. De ello cabría inferir que, puesto que existen tantas formas posibles de entender la acción cuantos sistemas procesales vigentes, se debería negar la vigencia de un concepto de acción en cuanto fórmula reconstructiva universalmente válida ${ }^{658}$. El relativismo histórico y conceptual sería de tales dimensiones que el problema de la acción debería considerarse irreal, sin que cupiera concebir una sola solución para él ${ }^{659}$.

\subsubsection{Acción y “acción penal”}

Si el intento de elaborar un concepto de acción es ciertamente difícil en sede civil, en la penal puede considerarse fallido y, hoy, lo destacable es bien la resignación y renuncia a tal construcción o bien el apego estricto a los textos procesales que impiden una concepción uniforme de un derecho de acción. Ubicándonos en el proceso penal, es señalable que la acción también ha representado históricamente una de las premisas de sus formulaciones conceptuales, pero la peculiaridad en la noción que de la "acción" mantiene nuestra LECrim permite que, a diferencia de otros países, en España se siga conectando directamente, y en nuestra opinión de manera inadecuada, el ejercicio de la acusación penal a un auténtico derecho de acción.

En el ámbito penal, el mérito del aislamiento como concepto autónomo de la noción de acción corresponde a Karl BINDING, que la definió en 1884 como un derecho

${ }^{657}$ ORESTANO, R., Voz “Azione (in generale)”, Enciclopedia del Diritto, Milán 1959, p. 853 y Azioni, diritti soggetivi, persone giuridiche, Bolonia 1978, p. 85. Vid. en especial en esta última obra el catálogo recopilatorio de la ingente e inabarcable cantidad de bibliografía producida en Europa a lo largo de la historia sobre el tema de la acción. (pp. 101 a 111). A la vista de ello y tal como se ha dicho, las teorías sobre la acción son tantas como autores (SATTA) o como las noches de las leyendas: mil y una y todas maravillosas.

\footnotetext{
${ }^{658}$ Cfr. LALLA, P., Il concetto legislativo di azione penale, Nápoles 1966; VALENTINI REUTER, C., Le forme di controllo sull'esercizio dell'azione penale, Padua 1994, p. 5.

${ }^{659}$ ORESTANO, R., Azioni, diritti soggetivi, persone giuridiche, op. cit. p. 85.
} 
público independiente del derecho de penar, dirigido no sólo al culpable sino también al inocente. Sería un derecho público a la constitución de la relación jurídico procesal y a la terminación de la misma por sentencia ${ }^{660}$. Dicho de otro modo, la acción consistiría sólo un medio de que se dota el Estado para hacer valer su exigencia punitiva, pero nunca un derecho subjetivo de ningún sujeto particular, puesto que su titularidad sería siempre estatal y el MF o el acusador privado tendrían sólo el carácter de representantes del Estado mismo. Conviene recordar aquí que en el haber de BINDING figuran significativamente algunas de las más despiadadas expresiones en contra de la acusación popular. De su visión publicista del proceso penal sin intervención activa de los particulares, dimanaba el rechazo de una concepción de la acción conducente a un sistema intrínsecamente perverso e inadmisible por anacrónico ${ }^{661}$.

Hace tiempo que se produjo fuera de nuestras fronteras el abandono de los intentos de configurar la acción penal como trasposición mecánica de los esquemas procesalcivilistas, y hoy es una cuestión casi definitivamente zanjada ${ }^{662}$. La elaboración de un concepto de acción en el que cupieran los datos normativos propios del proceso penal se reveló imposible e intrascendente por carecer de utilidad práctica. La inexistencia de una posible actividad acusatoria de los particulares, ni del ofendido ni de ningún otro, ha hecho inútil en este sentido la construcción por la doctrina extranjera de un concepto de acción penal como demanda de decisión ${ }^{663}$. Por ello, aun reconociendo su validez como

${ }^{660}$ La posición de BINDING es sintetizada y expuesta magistralmente por GÓMEZ ORBANEJA en sus Comentarios a la LECrim..., op. cit. pp. 167 y ss. y por GOLDSCHMIDT, J., Problemas jurídicos y políticos del proceso penal, y en "Derecho Justicial Material (pretensión de tutela jurídica y derecho penal)", RDProc. (Arg.), 1946, T. I, pp. 18 y ss., como traducción de "Materielles Justizrecht", aparecido en 1905 en el homenaje a B. HÜBLER.

${ }^{661}$ Como ya se abordó supra, BINDING calificó a la acusación popular de "desastre nacional” ("nationale Ungluck") y temía que en caso de aprobarse en Alemania volvieran los más corruptos tiempos de la República y el Imperio Romano por la cantidad de acusaciones fraudulentas que se producirían. BINDING, K., "Drei Grundfragen der Organisation des Strafgerichts", 1876, publicado en Abhandlungen, T. II, p. 12. Posteriormente calificó además a la acción privada subsistente en la StPO como un inadmisible anacronismo que debería ser rechazado. BINDING, K., "Der Entwurf einer neuen StPO”, GS 74 (1909) p. 43. Nos tenemos que remitir necesariamente a lo expuesto en la primera parte de este trabajo acerca del debate sobre la acusación popular en Alemania durante el siglo XIX.

${ }^{662}$ Haciéndose eco de la doctrina procesal del momento (1968), fue advertido el abandono del concepto de acción y su absoluta inutilidad por SERRA DOMÍNGUEZ, M., "Evolución histórica y orientaciones modernas del concepto de acción", op. cit. p. 37.

\footnotetext{
${ }^{663}$ Vid. en este sentido DOMINIONI, O., Voz “Azione penale”, en Digesto de la Discipline Penalistiche, 1987, p. 399.
} 
histórico punto de partida, es realmente difícil encontrar en la literatura comparada actual elaboraciones teóricas sobre la "acción penal".

Si ya GOLDSCHMIDT se felicitaba en 1905 porque las leyes alemanas hubieran dejado de adoptar el término "acción penal" usado en el $\S 3$ de la Ordenanza Procesal Penal prusiana de $1867^{664}$, hoy por hoy, tanto el término como las teorías de la acción en el proceso penal son algo totalmente extraño a la literatura procesal germánica ${ }^{665}$. El concepto de acción es visto así como algo absolutamente ajeno al proceso penal y la Anklage (acusación) es totalmente extraña al concepto de actio. Afirmaba H. KAUFMANN, una de las escasas representantes de la doctrina alemana de este siglo que ha reparado en el tema, que "el concepto de derecho de querella (Strafklagerecht) es un componente histórico dogmático de la idea de acción (Aktion), que en el moderno pensamiento jurídico habría devenido inaplicable con el abandono de aquel concepto de Aktion" ${ }^{\prime 666}$. La pretensión penal (el Strafanspruch) tiene hoy sólo el valor de una imagen que representa la búsqueda de la satisfacción del deber estatal de protección general de los bienes jurídicos, y en ningún caso se correspondería con un derecho de los ciudadanos a ejercitarlo por sí mismos.

En Italia son dignos de elogio los esfuerzos realizados por CARNELUTTI con su intento de elaborar un concepto unitario de litis ${ }^{667}$, aun cuando el propio autor terminara

${ }^{664}$ GOLDSCHMIDT, J., “Derecho Justicial Material (pretensión de tutela jurídica y derecho penal)” RDProc. (Arg.), 1946, T. I, p. 48, n. 244. Se trata de la traducción del artículo "Materielles Justizrecht", publicado originalmente en 1905 en el homenaje a B. HÜBLER.

${ }^{665} \mathrm{El}$ art. 103.1 GG (Derecho a la audiencia judicial) no extiende su protección al ámbito penal si no lo es tangencialmente, y sólo a aquellos supuestos en los que los particulares tienen atribuidos procesalmente derechos de intervención (el Klageerzwingungsverfahren y los supuestos de delitos privados). Se podría afirmar que incluso entre la dogmática procesal civil de nuestros días en aquel país, la discusión sobre la acción está totalmente concluida y pertenece únicamente al pasado. Vid. como ejemplo BOOR, H. O. de, "Der Begriff der actio im deutschen und italienischen Prozeßrecht” en Festschrift für Gustav Boehmer, Bonn 1954, pp. 99-110, quien sin embargo resalta con razón su importancia como problema fundamental en la relación entre el derecho privado y el proceso y su conexión con el sentido y la finalidad del proceso civil.

${ }^{666}$ KAUFMANN, Hilde, Strafanspruch, Strafklagerecht, 1968, p. 130. Con la distinción entre "Strafanspruch" y "Strafklagerecht" quiso la autora trazar una línea divisoria entre el derecho penal material y el derecho procesal penal.

${ }^{667}$ CARNELUTTI, F., "Saggio di una teoria integrale dell'azione”, Riv. Dir. Proc. 1946, pp. 7 y ss. y en Questioni sul Processo Penale, Bolonia 1950. Existe traducción de SENTÍS MELENDO: CARNELUTTI, Cuestiones sobre el proceso penal, Buenos Aires 1961. Para CARNELUTTI la acción representa el puente entre el derecho subjetivo material y la potestad jurisdiccional: la acción privada va del derecho subjetivo a la potestad jurisdiccional y la acción pública (penal) de la potestad jurisdiccional al derecho subjetivo (p. 37). Por ello la acción encomendada al Ministerio Público, que es derecho a provocar del juez el ejercicio de la potestad, se separa de la 
por reconocer en el concepto de acción penal solamente una «superstición»: “Creo poder llegar la hora de afirmar que la acción penal, entendida como un poder, y más aún como un poder exclusivo del Ministerio Público, es una superstición. La superstición es el «ne procedat iudex ex officio» extendido del proceso civil al proceso penal (...) La acción no puede ser más que un derecho subjetivo, y el derecho no puede ser un deber" ${ }^{\prime 66}$. LEONE sí llegaba a admitir cierto predicamento al concepto de acción, pero destacando que su fatigosa elaboración en el derecho procesal civil sólo podría aspirar a constituir una plataforma para fijar premisas con las que determinar el concepto de acción penal. Para el resto de la problemática que el tema suscita, constataba que nos encontraríamos ante dos realidades absolutamente diversas ${ }^{669}$. Las razones de tan escéptica visión podrían situarse en la imposibilidad de equiparar o siquiera comparar los respectivos territorios de investigación, motivada por un lado por la compenetración entre acción civil y derecho material subyacente y, por otro, por el carácter de la acción penal como demanda de decisión enlazado con una obligación estatal más que con un derecho de los particulares.

Sólo recientemente ha vuelto a ser aceptado el concepto de acción penal en Italia, y lo ha sido sobre unas premisas que entendemos demasiado relativizantes respecto al originario concepto, devaluándolo de su configuración dogmática para dejarlo en un plano solamente normativo ${ }^{670}$. A tenor de ellas, el contenido esencial de la acción penal sería simplemente una demanda de resolución jurisdiccional, pero a partir de ese instante, todo el resto de su contenido habrá de construirse atendiendo a las específicas previsiones normativas. No es que tal concepción nos parezca desacertada, antes al contrario, su apego a la norma la dispone en mucho mejor lugar para su aplicación, pero ello trae como consecuencia el reconocimiento de la imposibilidad de elaborar un concepto universalmente válido de acción penal y la renuncia a su construcción alejada del derecho positivo. De ahí que su traslado a nuestro proceso penal pueda juzgarse a priori como una labor

Jurisdicción como lo hace la acción de la parte privada en el proceso civil del derecho subjetivo (material). Tal configuración del MF sería una de las señales del intento de aislamiento de la acción con respecto a la Jurisdicción.

${ }^{668}$ CARNELUTTI, F., Publicado en Riv. dir. Proc, 1953, I, p. 257, "Poner en su puesto al Ministerio Público". Cuestiones sobre el proceso penal (traducción de SENTÍS MELENDO), p. 215.

${ }^{669}$ LEONE, G., Voz “Azione penale”, en Enciclopedia del Diritto, p. 851.

${ }^{670}$ LALLA, P., Il concetto legislativo..., y VALENTINI REUTER, C., Le forme di controllo sull'essercizio dell'azione penale, Padua 1994. En contra de cualquier tipo de elaboración conceptual sobre la acción penal, ni siquiera como demanda de decisión, puede verse TAORMINA, C., “«Vecchio e nuovo nella teoria dell'azione penale» alle soglie del nuovo codice di procedura”, La Giustizia Penale 1988, $3^{\mathrm{a}}$ parte, pp. 129 a 162, esp. p. 153. 
imposible o, por lo menos, infructuosa.

La Anklageerhebung del proceso penal alemán o el essercizio dell'azione penale italiano no se podrían equiparar a todo lo que en nuestro país se entiende por "ejercicio de la acción penal" sino, salvando las necesarias distancias, a nuestros escritos de acusación o de calificación provisional. Son los actos con los que se realiza la imputación de un determinado delito a un sujeto concreto y se solicita que el órgano jurisdiccional se pronuncie sobre la existencia o no del delito como condición para la imposición de una pena. El que ello sea obligatorio, se ejercite de oficio (en los delitos públicos) y sea irretractable, hace que, por ejemplo, la doctrina italiana de manera mayoritaria lo separe radicalmente del ejercicio de la actio en el proceso civil. Aun en las opiniones de quienes reconocen su carácter de ejercicio de la acción, en tanto constituye un acto por el que se solicita una resolución jurisdiccional, su enraizamiento en el derecho positivo es tan fuerte que impide toda posibilidad de extender tal apreciación más allá de las fronteras delimitadas por los específicos contextos legales ${ }^{671}$.

En nuestro país por el contrario, el ánimo de trasplantar al ámbito penal el concepto de acción, elaborado en Alemania e Italia sobre la base del derecho romano y para el proceso civil, ha originado un forzado encuadre dentro de una categoría procesal en franco retroceso en sus países de origen ${ }^{672}$. Se ha destacado que el concepto de acción penal no pertenece históricamente a la clásica controversia doctrinal sobre la acción, cuyo contenido se agotaba con frecuencia en la acción civil, y por ello mismo no ha sido sometido a una equiparable depuración doctrinal ${ }^{673}$. Cuando nuestra bibliografía recogió

${ }^{671}$ Así VALENTINI REUTER, C., Le forme..., op. cit. p. 149. Para la autora además del núcleo esencial (provocar la intervención del órgano jurisdiccional), la acción posee características libremente delineadas por el legislador en coherencia con el fin que persigue cada vez. Por ello afirma que "en particular podrá ser abstracta o concreta, podrá consistir en una excitación de la Jurisdicción pero también en una petición de condena".

${ }^{672}$ Es cierto sin embargo que la no intervención de particulares en el proceso penal de aquellos sistemas con un carácter tan abierto como ocurre en el nuestro, determina la carencia de sentido de referencias a un derecho que no parece pertenecerles en ningún caso. De aquí que todo nuestro análisis tenga que basarse únicamente (o prioritariamente) en la literatura procesal española, sin renunciar a la reseña de alguno de los puntos culminantes de la extranjera.

${ }^{673}$ Vid. en particular DE LA OLIVA SANTOS, A., Sobre el derecho a la tutela jurisdiccional, op. cit. p.108 y ss. La comparación entre la ciencia procesal penal y la Cenerentola de CARNELUTTI, que sólo se viste con los ropajes de sus hermanas mayores, encuentra perfecto acomodo en el tema de la acción. Así en palabras de DE LA OLIVA referidas al excesivo celo en la aplicación de las instituciones del proceso civil al penal afirma que "hay quienes, exagerando el ahorro y el aprovechamiento hasta el extremo vicioso de la cicatería o la obnubilación, se niegan a reconocer que incluso con arreglos de cierta monta los vestidos usados resultan adefesios para la hija más pequeña: son madres que parecen querer más a los ropajes que a la hija menor". Vid. en el mismo sentido su 
la aportación de BINDING, lo hizo, lógicamente, dentro de los márgenes e incluso en los términos de nuestra LECrim, forzando lecturas que son fruto más de un propósito de desarraigar del entendimiento del proceso penal viejas concepciones privatistas procedentes del derecho romano y recibidas a través de nuestro derecho histórico, que del explícito reconocimiento de que el carácter público (oficial o estatal, que no popular) exigiría una reconceptualización de lo que nuestra norma procesal denomina "acción penal". Ello no ha impedido que, como se ha expuesto antes, nuestra literatura especializada y nuestro TC hayan asimilado aquel término al concepto de actio, doctrinalmente bien perfilado y elaborado para el proceso civil muy posteriormente a que el legislador de 1882 lo incluyera en la LECrim. El punto de enlace esencial que se ha tomado para la identificación entre acción civil y acción penal es su intrínseca capacidad para provocar una resolución jurisdiccional, desconociendo con frecuencia que a partir de ese dato comienzan las divergencias entre ambos.

La caracterización de la acción penal como algo diverso al derecho estatal de penar estaba ya implícita en nuestro sistema de forma intuitiva: a ninguno de nuestros juristas decimonónicos se le hubiera ocurrido defender la facultad de los particulares de imponer una pena, pero sí es frecuente encontrar acérrimas defensas del derecho de acusar. La diferencia estaría en que lo que para BINDING eran dos derechos con la misma titularidad (oficial, estatal, pública) y distinto contenido (acusar y castigar la comisión del delito -el ius puniendi-), para nuestro legislador cambiaban de titularidad en virtud del contenido (privado en el caso del ejercicio de la acusación y oficial en el ius puniendi). El ejercicio de la "acción penal" no era más que una prolongación de las libertades del individuo frente al Estado, o sea, el derecho de rogar la tutela de los órganos jurisdiccionales para que éstos defendieran su interés individual, que, coincidente con el interés público en la represión penal, formaba un todo complejo en el que se contenía un derecho a la condena. De esta manera, al tiempo que se evitaba la realización arbitraria de los propios derechos, se propiciaba la asunción por los particulares de responsabilidades conducentes al bien común. Esta idea de autonomía individual, enraizada en los fundamentos del liberalismo, no estaría muy lejos de lo que en economía significaría la presencia de una mano invisible que haría que defendiendo intereses particulares se consiguiera el interés de la sociedad en su conjunto ${ }^{674}$, o de los planteamientos de IHERING, en el sentido de

Derecho Procesal Penal, Madrid 1993, p. 176.

\footnotetext{
${ }^{674}$ Según la clásica formulación de la economía de libre mercado que hiciera ADAM SMITH en 1776 en su obra Investigación sobre la naturaleza y las causas de la riqueza de las naciones, $1^{\mathrm{a}}$ ed. en español, México 1958. En ella
} 
que la lucha por los derechos de cada uno contribuye a la realización del derecho sobre la tierra $^{675}$. Al fin y al cabo no era más que manifestación de la idea hegeliana de que la individualidad personal y los intereses particulares son plenamente reconocidos como "derechos" del sujeto y, sin embargo, a través de ese reconocimiento revierten al mismo tiempo en el fin de la totalidad estatal ${ }^{676}$.

\subsubsection{La pluralidad de significados del término "acción penal” en la LECrim}

"Acción penal" es un término polivalente que, además, desde su polisemia origina en demasiadas ocasiones que las palabras se superpongan a las ideas originando perniciosas confusiones. De manera gráfica lo expone REDENTI al decir que con el término "acción" se designa tanto la actividad como la pretensión e, incluso, la misma acusación: “con la acción (actividad procesal) se propone al juez la acción (pretensión), y él dirá si existe la acción (el derecho)" ${ }^{677}$. El de la acción penal es, por ello, uno de los puntos del ordenamiento donde se manifiesta con más claridad la divergencia entre lo dicho por el legislador y su concreción real en el sistema. Una cosa es la concepción que el legislador tuviera al promulgar los preceptos relativos a la acción penal, y otra muy distinta la función que estos mismos preceptos cumplen en la actualidad en el sistema legal globalmente considerado. Estamos ante un vocablo equívoco que debe ser evitado o manejado con precaución ya que responde a una conceptualización que, además de no partir de premisas interpretativas seguras, se superpone a doctrinas ya superadas que han

se argumentaba que un grupo de individuos que siguiera cada uno su propio interés sin una dirección central, podría crear una sociedad coherente en lugar de una jungla.

${ }^{675}$ IHERING, R. v., La lucha por el Derecho, traducción española de POSADA, A., con prólogo de ALAS, Leopoldo; Madrid 1921, (se cita por la reedición en Cuadernos Civitas, Madrid 1985), passim y esp. pp. 60 y ss.

${ }^{676}$ Cfr. la exposición realizada por BARCELLONA, P., en Postmodernidad y Comunidad. El regreso de la vinculación social, Madrid 1992, p. 19.

${ }^{677}$ REDENTI, E., Diritto Processuale Civile, T. I, Milán 1949. Tal argumentación fue reproducida en esos mismos términos pero referida a nuestro proceso penal, por SÁEZ JIMÉNEZ, J. y LÓPEZ FERNÁNDEZ DE GAMBOA, E., Compendio de Derecho Procesal Civil y Penal, Madrid 1966, T. IV, vol. I., p. 827. FENECH estimaba que la LECrim distinguiría cuando menos tres acepciones del término "acción penal": acción como derecho de iniciativa (p. ej. en los llamados "delitos privados"), acción como derecho a mostrarse parte acusadora (en la acusación ejercitada por los particulares) y acción como presupuesto de la apertura del juicio oral, consecuencia del principio acusatorio y de la necesidad de la existencia de una parte acusadora. FENECH, M., Derecho Procesal Penal, op. cit. p. 286. 
dejado su impronta terminológica en la Ley. Si, a diferencia de lo que ocurre en otros sistemas, por nuestra doctrina se sigue hablando de actio como derecho a la tutela judicial efectiva en el proceso penal, ello es en relevante grado fruto precisamente de la peculiaridad que supone la concurrencia, junto con el MF, de los particulares en el ejercicio de lo que la ley denomina "acción". A ello ha de agregarse, además, la falta de identificación entre el concepto legislativo de "acción” y el concepto dogmático amparado en el mismo término, y dentro de éste último, las múltiples variantes presentes en las diversas opiniones doctrinales. El panorama que se intenta describir resulta así singularmente confuso. Ya que el legislador de la LECrim ha incurrido con demasiada frecuencia en asimilaciones terminológicas del proceso penal al proceso civil, no parece de recibo que los estudiosos de estas materias pequemos de ingenuos por no estar prevenidos frente a ellas. Aunque no se pueda decir que el error se produzca por falta de advertencias doctrinales sobre aquella confusión de conceptos, lo cierto es que, en demasiadas ocasiones, los términos seducen a quienes hacemos uso de ellos o los aplicamos sin reparar en su absoluta ausencia de depuración.

El término "acción penal" encuentra su origen en los tratadistas de principios del siglo XIX sobre la base del concepto romano de actio y no está muy lejano a su identificación con un derecho material o a su integración dentro de éste. En concreto sería un derecho que genera el delito y que consiste en imponer la pena correspondiente y hacer que se cumpla. Partiendo de la célebre definición de CELSO (acción como "derecho a perseguir en juicio lo que se nos debe") ${ }^{678}$ en su traslado al ámbito criminal, "tener acción" sería tanto como ser titular del poder que habilitaba para exigir en juicio la obligación que nacía de la comisión de un delito frente a su presunto autor. El derecho a imponer la pena por el Estado llevaba aparejada la facultad de autodefensa que se encarnaba en el derecho de acción frente al adversario delincuente, de la misma manera que a los derechos privados en materia civil se seguiría el derecho a exigirlos en juicio. La acción sería, por tanto, un poder jurídico de producir frente al adversario el efecto de la actuación de la Ley ${ }^{679}$, al que se corresponderían deberes de este sujeto: estar y pasar por

${ }^{678}$ Actio nihil aliud est quam ius persequendi in iudicio quod sibi debeatur (Dig. 44, 7, 51).Viene así a identificarse con el derecho subjetivo material que se persigue en el juicio.

${ }^{679}$ En el sentido al que se refiere CHIOVENDA, aun cuando su doctrina incluya ya la separación entre el derecho subjetivo material y la acción, concibiendo ésta última como un puro poder jurídico independiente. CHIOVENDA, G., "La acción en el sistema de los derechos" en Ensayos de derecho procesal civil, traducción de SENTÍS MELENDO, vol. I, Buenos Aires 1949, pp. 6 y 16. 
lo actuado y, en último término, someterse a la pena.

Ese fue el sentido con el que se recibió en Españá y con el que lo recogió nuestra LECrim, fiel al sistema romano de las fuentes de las obligaciones. La regulación de la "acción penal" y de las formas de su ejercicio se introdujeron en nuestro derecho positivo al amparo de un concepto en crisis en otros lugares y con base en las ideas políticas y técnicas de nuestros legisladores del pasado siglo, considerando la acción como una derivación del derecho subjetivo material. No puede darse otro sentido al art. 100 LECrim, en el que se afirma que "De todo delito o falta nace acción penal para el castigo del culpable, y puede nacer también acción civil para la restitución de la cosa, la reparación del daño y la indemnización de perjuicios causados por el hecho punible" ${ }^{680}$.

No es decir nada novedoso afirmar que la LECrim no contiene una definición clara de lo que haya de entenderse por "acción penal", por lo que inevitablemente habrán de tomarse en consideración otras notas que se derivan de la función que cumplen esos preceptos en todo el sistema penal. En tanto la LECrim recoge bajo la misma rúbrica diversos contenidos, el concepto de "acción penal" no puede ser extraido sólo de la literalidad de aquélla, y las conclusiones deberán apoyarse en otra serie de datos que lo sitúen en su verdadero significado dentro del sistema de persecución de los delitos.

Cabe distinguir al menos tres visiones de la ACCIÓN que pudieran entenderse presentes en la LECrim.:

a) Acción como actividad o procedimiento.

Podríamos hablar en esta perspectiva de la función estatal de persecución penal que abarca todas las actividades necesarias para que se llegue a la sentencia, así como la resolución que pone fin al proceso. Incluiría tanto la actividad investigadora (en la que intervendrán en papeles diversos el juez instructor, Ministerio Fiscal, policía, acusadores particulares), como la decisora del órgano jurisdiccional. En este caso, lo que pueden

\footnotetext{
${ }^{680}$ El precepto está claramente entroncado con el sistema romano de las acciones en el que a cada derecho correspondería una acción (o como se ha defendido en alguna ocasión, a cada actio correspondería un derecho). Ya HEVIA BOLAÑOS afirmaba en la Curia Philippica (III, §14, 6, p. 223) que "de cualquier delito resultan dos acciones: una criminal tocante a la vindicta y castigo; $y$ otra civil, en quanto al interes, y daños pertenecientes a la parte agraviada". Sin embargo parece claro que del delito no nace la acción civil (que nace del hecho antijurídico en el que intervenga culpa o negligencia (art. 1089 CC)) ni puede surgir la acción penal puesto que no se sabe todavía si se ha cometido el delito. Tal y como indicara CARNELUTTI, la acción penal nace de la sospecha de la comisión de un hecho punible. En igual línea señalaba GÓMEZ ORBANEJA que "decir que del acto dañoso nace una acción ya es una impropiedad; lo que nace es una obligación y, correlativamente, un derecho del perjudicado", Derecho Procesal Penal, pp. 92-93. Cfr. también GIMENO SENDRA, V., Constitución y Proceso, op. cit. p. 78.
} 
hacer los particulares es PROVOCAR la "acción penal” a través de la denuncia, INSTAR o INICIAR la acción penal mediante la interposición de la querella, pero no ejercer la acción penal puesto que su ejercicio es un deber del Estado que realiza a través de los órganos de los que se ha dotado. Basta la mera transmisión de la notitia criminis para que se tenga que iniciar la actividad del Estado, y cualquier acto de investigación o meramente cautelar dará lugar a su puesta en marcha. La acción física directa contra el adversario, quedaría así suplantada por la acción del Estado para la inicial averiguación y eventual persecución y punición de los hechos que resulten constitutivos de delitos ${ }^{681}$.

En este sentido podría interpretarse la "acción penal" contemplada desde el punto de vista del destinatario y siguiendo la literalidad de la LECrim. El sujeto activo de la "acción” típica, antijurídica y culpable en que el delito consiste deberá ser el sujeto pasivo contra el que se dirigirá la "acción penal". Esa actividad se desenvuelve pues contra un sujeto determinado o por determinar, presunto autor de un hecho delictivo, y de ahí que la acción penal nazca ya con un destinatario, aunque éste tenga que ser individualizado a lo largo del proceso: "de todo delito nace acción penal para el castigo del culpable..." (art. 100 LECrim). De hecho, el art. 103 LECrim nos habla de las prohibiciones de "ejercitar acciones penales entre si" en relación con varios sujetos, lo cual se refiere ya a que la acción se ejercita contra un sujeto. El mismo término "querella contra" o "querella de", es decir queja contra o de alguien, nos hablaría de que la "acción penal" se realiza a través de los órganos jurisdiccionales, pero en relación con un acusado concreto. Incluso el art. 115 LECrim declara extinguida la "acción penal" por la muerte del culpable, por lo que si con su muerte no cabe hablar ya de acción penal, parece claro que el propio concepto estará en relación directa con el sujeto presunto autor del delito y no con los titulares de su ejercicio ${ }^{682}$.

Por algún autor extranjero se ha afirmado que con el término "acción penal" se pretendía designar no sólo un mecanismo de iniciación del proceso penal por una de las partes, sino toda la actividad procesal conducente a la averiguación de las circunstancias del delito y el logro, eventualmente, de una condena. Según esta concepción, decir

${ }^{681}$ Cfr. ALCALÁ-ZAMORA y CASTILlO, N., Proceso, Autocomposición y Autodefensa, $2{ }^{\mathrm{a}}$ ed. México 1970, pp. 164 y ss.

${ }^{682}$ Tal dato nos conduce a descartar ya desde este primer momento que el ejercicio de la "acción penal" sea un ejercicio de la acción, en tanto una de las notas consustanciales del derecho de acción tal y como hoy lo conocemos es precisamente que el destinatario de ésta sea siempre el Estado. 
“acción penal" equivaldría a decir "procedimiento penal", y no se referiría sólo al acto de acusar en aquel procedimiento ${ }^{683}$. Pero, si parece claro que este no era el sentido con el que se recibió en otros ordenamientos, tampoco creemos que lo fuera en nuestra LECrim. Para los autores decimonónicos, el derecho penal tenía como consecuencia necesaria una facultad de autodefensa que se vendría a encarnar en el derecho de ejercitar algo que la Ley llama "acción” y que no incluye todos los actos que se engloban en el procedimiento, sino sólo unos muy concretos dentro de éste. El que el mismo término sirviera para definir en alguna ocasión todo el procedimiento no debería inducir por ello a error.

\section{b) Acción penal como acusación}

Parece existir acuerdo doctrinal en que, frente a la dicción del art. 100 LECrim, del delito lo único que nace es el derecho (en verdad el deber) del Estado de imponer la consecuencia jurídica prevista en la norma, es decir, el ius puniendi ${ }^{684}$. Para ello la "acción penal" es un elemento esencial e imprescindible, que aparece como conjunto de actos cuyo ejercicio supone el de un poder autónomo pero ligado a la facultad estatal de imponer las penas. Ha sido definida de esta manera como la manifestación en el proceso del derecho subjetivo material de penar del Estado, del que se haría titular a todo ciudadano puesto que a todos se les concede una llamada "acción popular o pública" ${ }^{685}$. La acción penal será la figura que adopta el derecho de penar en el proceso, asimilado a una contienda entre partes, o dicho de otro modo, el medio procesal de hacer valer la exigencia punitiva ${ }^{686}$. Estaríamos en definitiva ante el mecanismo que abre la posibilidad de realizar el derecho de penar por su único titular, el Estado, quien, a consecuencia de la prohibición de la autotutela, ha asumido el monopolio de la función de administrar justicia $^{687}$.

Destaca así el carácter de la acción penal como actividad, como poder o como

${ }^{683}$ LALLA, P., Il concetto legislativo di azione penale, Nápoles 1966, pp. 53 y ss.

${ }^{684}$ La configuración de la potestad estatal de penar como ius puniendi es criticada por FAIRÉN. Vid. FAIRÉN GUILLÉN, V., Voz “acción” en Nueva Enciclopedia Jurídica, op. cit. p. 201.

${ }^{685}$ En este sentido vid. FENECH, M., Derecho Procesal Penal, vol. I, $3^{\text {a }}$ ed., 1960, pp. 285 y s.

${ }^{686}$ GÓMEZ ORBANEJA, E., Derecho Procesal Penal, op. cit. p. 88.

${ }^{687}$ Vid. en este sentido ALCALÁ-ZAMORA, N., "Enseñanzas y sugerencias de algunos procesalistas sudamericanos acerca de la acción”, en Teoría General e Historia del Proceso T. I, p. 333. 
instrumento, pero no como derecho. Constituye un presupuesto de la resolución jurisdiccional y habrá de considerarse algo único y objetivamente idéntico sea quien sea el que en la práctica realice el conjunto de actos que encierra. De ahí que su contenido no venga determinado sólo por una concreta calificación jurídica del hecho presuntamente delictivo, sino por la actividad conducente a la averiguación de sus circunstancias, con el objeto final de provocar eventualmente una resolución de condena de un sujeto por unos hechos singulares. La "acción penal” de la LECrim sería por tanto un cúmulo de actos dirigidos a poner la base que precisa una sentencia al amparo de una concepción acusatoria del proceso, determinando si concurren los presupuestos para el enjuiciamiento y eventual condena. Esto es, la petición de una resolución jurisdiccional realizada por sujeto diverso al competente para dictarla, con delimitación de los presupuestos subjetivos y de la causa petendi integrada por un concreto hecho que se reputa delictivo. La "acción penal" no es por ello sólo lo que se pide (la res in iudicio deducta) sino también todo el conjunto de actividades realizadas por sus ejercitantes y dirigidas a fundamentar tal petición $^{688}$.

Este es el sentido en el que, en nuestra opinión, ha de entenderse el término "acción penal" en la LECrim, pero haciendo ya con carácter previo dos salvedades: 1) el concepto de "derecho de acción" que se maneja habitualmente no es válido para englobar la "acción penal", sino que habremos de recabar el apoyo del concepto de pretensión. 2) En la "acción penal" no puede verse la existencia de un derecho, sino sólo la de una obligación estatal conducente en último término a la aplicación de una pena a través de una resolución jurisdiccional como respuesta social a una conducta dañosa o peligrosa para bienes jurídicos esenciales. Cuestión diferente es que su ejercicio se transfiera también a los ciudadanos, otorgándoles de esa manera no la acción penal, sino sólo la facultad de hacer valer esa obligación estatal.

c) “Acción penal” como derecho de todos los ciudadanos y deber del MF.

No cabe duda de que nuestro sistema procesal penal goza de una peculiaridad que le aparta de todos los demás: el que se confiera a todos los ciudadanos que cumplan determinados requisitos (art. 101, 102 y 103 LECrim) algo que la Ley denomina "acción

\footnotetext{
${ }^{688}$ Resaltaba LEONE que con el término "azione penale" podríamos entender el derecho subjetivo de provocar una decisión del juez sobre un determinado hecho, pero también el acto o complejo de actos a través de los cuales ese derecho subjetivo se hace valer, incluyendo tanto su inicio como su ejercicio. LEONE, G., Voz "Azione penale", en Enciclopedia del Diritto, p. 858.
} 
penal". Es posible constatar así que la realización del deber estatal de concretar las bases precisas para que se dicte una resolución sobre un hecho presuntamente delictivo supone también una facultad atribuida a los ciudadanos, quienes, dadas ciertas premisas, podrán actuarla formulando la oportuna querella. En este caso deberíamos hablar de acción como ejercicio de la acusación, o bien de acción como interposición de querella -en tanto ésta es su instrumentación formal-.

Si para la mayoría de los ordenamientos penales extranjeros la obligatoriedad de la “acción penal" y el sometimiento a la legalidad del órgano acusatorio son, en principio, suficientes garantías del adecuado funcionamiento del sistema de persecución, el nuestro se dota de lo que parece ser una salvaguarda, admitiendo la participación de los ciudadanos en el ejercicio de la acusación.

No debe confundirse, por ende, la "acción penal", como conjunto objetivo de actividades dirigidas a un fin (la resolución jurisdiccional), con el ejercicio efectivo de ellas. O dicho en otras palabras, no puede ser lo mismo la acusación que el acto de acusar, en tanto con la acusación nos referimos a algo estático y susceptible de ser descrito en abstracto, mientras que en el acto de acusar habremos de descender al plano de lo concreto. De ahí que esta interpretación de lo que es la "acción penal" no describa su naturaleza misma, sino que sólo nos habla de los sujetos a los que compete o se les reconoce la facultad de deducir en juicio esa actividad. Ante la intervención de los ciudadanos o del MF estaremos por tanto ante modalidades de ejercicio o de formas para llevarla a la práctica, pero no ante un cambio en su naturaleza objetiva.

\subsubsection{Balance}

El concepto de acción, tal y como lo ha venido entendiendo históricamente la doctrina procesalista tras realizar su trasvase desde la dogmática del proceso civil al penal, no realiza una aportación sustancial e imprescindible para la adecuada comprensión del proceso penal de nuestros días. Todo intento de transformación, retoque o adecuación de aquél, que es ciertamente público pero en el que permanecen con demasiada frecuencia reminiscencias civiles determinantes, debe considerarse si no como un elemento de confusión, sí cuando menos infructuoso. El sustrato donde se intenta transplantar y hacer germinar aquella concepción del derecho de acción, entendida en esencia como una facultad de iniciativa procesal que se mantiene viva a lo largo de todo el proceso y que se 
dirige a la tutela de los propios intereses legítimos, carece en el proceso penal de las notas esenciales que sostienen su vigencia en el civil. La traslación de la idea de que no puede haber proceso sin que un sujeto vinculado en alguna medida con unos intereses subyacentes pueda dirigir a los Órganos Jurisdiccionales pretensiones de tutela de éstos, se ha superpuesto a la de la especial participación de los particulares en nuestro proceso penal y ambas realidades, conjuntamente, han transmitido una idea distorsionada de lo que se deba entender por "acción" en el proceso penal.

Así como el acto de demandar en el proceso civil es, en general, un acto privado aun cuando sea el instrumento a través del que se hace valer el derecho de acción, en el proceso penal, la decisión de acusar -salvo en los delitos privados-, comporta la asunción de una actividad pública aun en su ejercicio por particulares no ofendidos. Admitir que pueda ser en algún caso un derecho privado, posibilidad que no está muy lejana de la voluntad del legislador decimonónico liberalmente influenciado, sería realizar una asimilación de lo penal a lo civil que no parece de recibo hoy día. No estamos ante un derecho de ejercitar la acusación al servicio de la defensa de un interés propio, que estuviera entroncado con la esencia de la persona y que careciendo de él se vería privado de un preciado tesoro componente de su libertad individual, sino ante una mera facultad cuyo reconocimiento y ejercicio en la práctica se dirige a desempeñar la misma actividad que desenvuelve un órgano estatal, constitucionalmente vinculado al principio de legalidad.

El entendimiento de la "acción" como derecho carece de posible aplicación en el proceso penal e induce a innecesarios errores de apreciación. Por ello sería conveniente para evitar equívocos dejar de utilizar el término "acción" cuando hablemos de la "acción penal" o de la "acción popular". La peculiaridad del proceso penal español consistente en que los ciudadanos no ofendidos puedan intervenir en él para solicitar un pronunciamiento judicial, a pesar de su denominación tradicional, no es caracterizable como un derecho de acción sino que constituye una de las modalidades en que la pretensión penal se ejercita. No se trata ya de diferenciarlo del ius puniendi, que evidentemente se encuentra monopolizado por el Estado, sino de que esa facultad de los sujetos privados se dirige necesariamente a la satisfacción de un interés público, el que se busca con el ejercicio de la "acción penal" entendida como acusación. La consideración de la acción penal como derecho subjetivo de los ciudadanos a la que parece invitar el texto de la LECrim no haría a nuestro juicio más que reflejar una visión pancivilista del sistema, no alejada de la doctrina romanista sobre las acciones populares, en la que los poderes de 
iniciativa procesal serían reconducibles en gran medida a categorías privadas. La presencia de sujetos particulares en el papel de acusadores en nuestro proceso penal ha contribuido a reforzar esa visión y supondría una rémora para el avance doctrinal hacia un cambio de rumbo en la concepción que se mantenga en torno a lo que conocemos como "acción penal".

Por todo ello cabría expresar ya en este momento, y con vista a futuras reformas, el deseo de que se supriman una serie de términos equívocos en las normas procesales, evitando confusiones que en nada ayudan a la comprensión de la voluntad del legislador. Sería conveniente en este sentido la sustitución del término "acción penal" por el de "pretensión penal" o simplemente por el de "acusación", y referirnos, en función del sujeto que la deduzca, a ejercicio "oficial” de la acusación si es el MF quien lo realiza, o a ejercicio "popular" o "cívico" de la acusación si son los particulares no víctimas del delito. Los términos "particular" o "privado", consolidados ya en la práctica para designar el ejercicio de la acusación por el ofendido por el delito, podrían quedar reservados únicamente para esta función.

\subsubsection{El derecho constitucional de acción no es invocable para el ejercicio de la acusación}

La sospecha de la comisión de un delito activa un interés público en la resolución pacífica de los conflictos. Una vez vedada la autodefensa por el Estado, este interés se cifrará en el pacífico examen de una conducta, el cual sólo será factible mediante la actuación jurisdiccional de la ley a través de un proceso en el que se constate su existencia más allá de toda duda razonable, dándole eventualmente la respuesta prevista por el ordenamiento jurídico ${ }^{689}$. Este interés público quedará satisfecho tanto con la imposición de condena al culpable y su ejecución como con la absolución del inocente, pues tiene por

\footnotetext{
${ }^{689}$ No cabe olvidar que junto a ese interés público pueden situarse concretos intereses privados de los ofendidos o perjudicados por el hecho ilícito que el delito implica. Vid. GÓMEZ ORBANEJA, E., Comentarios... T. II, op. cit. p. 331; PEDRAZ PENALVA, E., Las medidas cautelares reales en el proceso penal español, Madrid 1985, pp. 18 y ss. Puesto que el sistema de normas penales cuya materialización se propugna mediante el proceso penal constituye un mecanismo del que se ha dotado la comunidad social para la protección de aquellos bienes o intereses que estima conveniente tutelar, la exigencia de cumplimiento de todas ellas, asignando la consecuencia jurídica a los supuestos de hecho previstos, se dirige a la satisfacción de un interés general. Cfr. DE LA OLIVA SANTOS, A., en la obra colectiva Derecho Procesal Penal, Madrid 1993, pp. 175 y s.
} 
objeto no la explícita búsqueda de una sanción, sino la garantía de la paz social a través del exclusivo recurso al proceso que, al repeler la venganza privada y posibilitar la actuación no discriminatoria de la ley, integra uno de los pilares básicos del Estado de Derecho, posibilitador máximo de la libertad individual.

El debido proceso no es considerable ni como pena ${ }^{690}$, ni como conjunto de simples cargas ${ }^{691}$, sino que en su formulación constitucional constituye un imperativo que a todos los ciudadanos pertenece, posibilitador de una aplicación imparcial de la ley. El proceso penal revela así su fin al ofrecer un modo pacífico $\mathrm{y}$, en cuanto reglado, previsible de solución de conflictos, proscribiendo la autodefensa e implicando positivamente una garantía para el justiciable. El delito sólo surge como resultado del proceso, siendo por ende determinante del mismo y de la pena imponible. Afirmar como criterio decisivo la instrumentalidad del proceso, significaría defender simplistamente únicamente su puesta a disposición para la realización de la norma material como servidor exclusivo de ésta. Con ello podría entenderse carente de entidad bastante para exteriorizar su verdadera función constitucionalizadora y, así, de creación y determinación jurídica. Dicho de otro modo, el debido proceso en su concreción ordinaria criminal vale para aplicar la ley, pero de modo conceptualmente identificativo sirve para actuar con exclusividad el ius puniendi desde la compleja interacción en él de potestad jurisdiccional y tutela judicial efectiva, plasmados dinámicamente en función y pretensión ${ }^{692}$. Cabría

${ }^{690}$ Sobre la cuestión del proceso como pena se ocupó en reiteradas ocasiones CARNELUTTI, quien llegaba a hablar de la pena-juicio frente a la pena-acción. Señalaba este autor que "no es posible juzgar sin castigar ni castigar sin juzgar; en otras palabras, no hay acto del juicio que no ocasione un sufrimiento a quien es juzgado, $n i$ hay acto del castigo el cual no requiera un juicio a quien lo inflige; basta que sobre alguno recaiga una sospecha de haber cometido un delito para hacerlo sufrir...". Vid. sus Lecciones sobre el proceso penal, T.I. Buenos Aires 1950, p. 72, (traducción de SENTÍS MELENDO). Con posterioridad añadía CARNELUTTI que "la pendencia del proceso criminal, aunque no exista todavía la condena ni tampoco el inculpado esté detenido, es suficiente para procurarle un sufrimiento; y como este sufrimiento no tiene otra razón sino la de combatir el delito, no se le puede negar el carácter de pena".(“Auto de procesamiento", en RDProc (Arg.), 1948, I, p. 216, y en Cuestiones sobre el proceso penal, Buenos Aires 1961, p. 145.). Veía, incluso, el proceso como una verdadera tortura: "Desgraciadamente, la justicia humana está hecha de tal manera que no solamente se hace sufrir a los hombres porque son culpables sino también para saber si son culpables o inocentes" (Las miserias del proceso penal, Buenos Aires 1959, p. 75).

${ }^{691}$ Tema el de las cargas procesales de no fácil delimitación. Junto al clásico de GOLDSCHMIDT Der Prozeß als Rechtslage. Eine Kritik des prozessualen Denkens, Berlín 1925, reimpresión Aalen 1962, vid. también DE STEFANO, Voz “Ònere”, en Enciclopedia del Diritto XXX, Milán 1980, pp. 114 y ss.

${ }^{692}$ Así PEDRAZ PENALVA, E., “El objeto del proceso civil”, en El objeto del proceso civil, MARÍN CASTÁN, F. (Director), Escuela Judicial/CGPJ, Madrid 1996, pp. 16 y s.; y del mismo autor "Publicidad y derecho al debido proceso. Publicidad y derecho de acceso a la información contenida en los ficheros de datos jurisdiccionales", $R G D$, $\mathrm{n}^{\circ} 631$, abril 1997, pp. 3892 y s. 
acaso hablar, por consiguiente, de su aptitud para crear la ley, ya anómalamente de modo directo, ya para su fijación mediante una hermenéusis individualizadora.

Es perceptible con claridad en la historia ${ }^{693}$ y en el evolucionado Estado de Derecho vigente que aquel interés público, resumible en el mantenimiento de la paz social asegurada por el Estado, podrá complacerse en exclusiva e íntegramente a través del proceso. La "acción penal” se agota en el concreto proceso y tiene un fin en sí misma activar el propio enjuiciamiento-, sin perjuicio del resultado último que se obtenga. El ejercicio de la "acción penal" irá dirigido a la satisfacción del interés público una vez que se afirme atacado, pero no puede en sí confundirse con tal interés. La meta por él perseguido es la de satisfacer la legalidad, o mejor dicho, actuar la ley en el caso, tarea a realizar por el Juez mediante la creación del necesario e imprescindible presupuesto a espaldas del fruto: condena, sobreseimiento o absolución. El interés contenido en la "acción penal" reside únicamente en posibilitar la solución pacífica de los conflictos, abriendo paso a la actuación jurisdiccional de la ley en el debido proceso ${ }^{694}$.

Aun cuando en nuestro ordenamiento jurídico la facultad de demandar la satisfacción del interés público se halle dispersa, éste no se modifica ni cambia de naturaleza. La distribución entre la mayoría de los ciudadanos de la aptitud para instar su defensa no hace que se desgaje en tantas porciones de interés como individuos, ni tampoco que se atribuya algo diferente a cada uno de ellos, sino que viene a decir que, dada la trascendencia social de ese interés, cualquiera de los legitimados podrá asumir la iniciativa para su amparo. El propio ejercicio de la "acción penal" no constituye la cuestión que se dilucida en el proceso, sino que es una mera facultad procesal, diseñada para invocar la tutela del interés cuya satisfacción es el objetivo último del proceso penal. No cabría por tanto identificar el interés procesal en la resolución pacífica de los

\footnotetext{
${ }^{693} \mathrm{Al}$ respecto vid. por ejemplo las obras de SCHMIDT, E., Einführung in die Geschichte der deutschen Strafrechtspflege, Gotinga 1965, pp. 48 y ss y Lehrkommentar zur StPO und zum GVG, T. I. Göttingen 1964, pp. 35 y ss.

${ }^{694}$ Problema distinto aunque íntimamente conexo es el de si a tal fin la Jurisdicción aparecería como concreción del ordenamiento en tanto éste no existe sino como abstracción. Vid. SATTA, S., Voz "Giurisdizione (nozioni generale)" en Enciclopedia del Diritto, XIX, Milán 1970, pp. 218 y ss. y SATTA, S. / PUNZI, C., Diritto Processuale Civile, Padua 1993, pp. 10 y ss. Para ALLORIO, sin embargo, el derecho sustancial era el objeto predeterminado de la "declaración judicial" (accertamento giudiziale), que formaría parte del entero y unitario fenómeno jurídico (ALLORIO, "L'Ordinamento giuridico nel prisma dell'accertamento giudiziale", originariamente en Rivista di Diritto Civile 1955, e incluido en sus Problemi di Diritto, Vol. I, Milán 1957, pp. 3 y ss. Existe traducción de SENTÍS MELENDO, El Ordenamiento Jurídico en el prisma de la declaración judicial, Buenos Aires 1958).
} 
conflictos con las facultades procesales reconocidas a cada uno de los ciudadanos legitimados.

Este interés público al que hemos hecho referencia ha sido identificado en alguna ocasión con el derecho (o más bien, el deber) estatal de imponer la pena, remarcando que la acusación es sólo una facultad procesal abstracta. Señalaba GOLDSCHMIDT que el enfoque civilístico en que arraiga el concepto de "acción penal", lleva consigo el que éste aparezca en el art. 100 LECrim como un derecho material y concreto nacido del delito. El legislador parte de la representación de que el concepto "acción penal" correspondiente con su antítesis "acción civil", tiene una exigencia punitiva no sólo por base, sino también por contenido. Por ello llegaba a la conclusión de que la acción a que se refiere la LECrim no sería otra cosa que el derecho de penar, que sólo puede declararse a través del proceso (nulla poena sine iudicio) que, a su vez, precisa de alguien que sostenga la acusación ${ }^{695}$. $\mathrm{Su}$ criterio es el de que la pretensión del querellante consistiría en la afirmación del nacimiento de un derecho judicial de penar y en la exigencia de ejercicio de ese derecho (que a la vez representa un deber). La diferencia entre los conceptos de acción (en el proceso civil) y de "derecho de acusación" sería clara: mientras que el actor pide la adjudicación de un derecho propio, el acusador lo que solicita es el ejercicio del derecho judicial de penar. La "acción penal” del art. 100 y ss. LECrim es así una facultad formal y abstracta, perteneciente al derecho procesal y, por tanto, no parangonable con el derecho estatal de penar que es lo que constituiría el objeto material del proceso. El querellante está ayuno de otro derecho que no sea el de acusación, es decir, el consistente en pedir al juez que ejercite contra el culpable su poder de condenar. Carece de un derecho frente al titular de una hipotética exigencia punitiva para que la haga valer, por la sencilla razón de que esa exigencia punitiva no es independiente del propio derecho de penar ${ }^{696}$.

${ }^{695}$ GOLDSCHMIDT, J., Principios jurídicos y políticos del proceso penal, Barcelona 1935, p. 33.

${ }^{696}$ GOLDSCHMIDT, J., Principios, op. cit. pp. 34 y s. DE LA OLIVA estima que la facultad de acusar tendría como contenido únicamente lo que califica como un simple ius persequendi, para el cual, por un artificio jurídico, se estima conveniente otorgar a los particulares y a otros ciudadanos un derecho subjetivo exclusivamente procesal que es el de ser partes acusadoras formales. En el ejercicio de lo que él conceptúa como derecho y que en su opinión no sería ni siquiera de necesaria o esencial importancia aun cuando lo incluya la Constitución, los acusadores no piden nada para sí, sino que se les admite sólo por razones de conveniencia, con el efecto de dinamizar la contienda procesal otorgándoles un derecho de índole meramente procesal. Los actores sólo podrán renunciar a los derechos procesales que tienen, por lo que su máxima renuncia posible será el abandono de la parte acusadora, el ius persequendi. Afirmando la imposibilidad de traslación del concepto de acción civil al proceso penal, DE LA OLIVA sigue configurando la acción penal como derecho, pero de forma radicalmente diversa a aquél: mientras que en el proceso civil, contempla la acción como un derecho a la concreta tutela jurisdiccional, en el penal, la acción tendría un contenido abstracto. DE LA OLIVA, A. et al., Derecho Procesal Penal, Madrid 1993, pp. 9 y ss. 
Quien formula acusación, es decir el Estado (como acusador) o el particular, se dirige al Estado (como Tribunal) para que sea él quien ejerza su derecho de penar, exige a la justicia penal que actúe su derecho punitivo, pero no que se lo atribuya a él o a un tercero $^{697}$. Afirmaba por ello GOLDSCHMIDT que "los funcionarios del MF como querellantes no tienen una posición distinta de la de los demás querellantes, si se prescinde de que el MF es el promotor iustitiae". De ahí que según su opinión, que compartimos plenamente, no mereciera aplauso la expresión "acción penal" de los arts. 100 y ss LECrim, puesto que al oponerla a "acción civil" se favorece la concepción de que el querellante hace valer una exigencia punitiva correspondientemente como el actor del proceso civil haría valer una exigencia civil ${ }^{698}$.

II.

FAIRÉN sostenía que entre la pretensión dilucidada en el proceso penal y en el civil hay una diferencia cuantitativa en cuanto a la amplitud de la legitimación activa debida precisamente a la entidad del interés jurídico que se hace valer -o mejor, que se evidencia-. Mientras que en el proceso penal éste sería un "derecho a la seguridad jurídica frente al acto delictivo que ataca gravemente a la paz social", en el proceso civil la evidencia del interés turbado sería predominantemente una evidencia de derecho privado violado. Por ello mientras en el primero se concede su titularidad a cada uno de los interesados, es decir a todos los ciudadanos, en el segundo sólo se le concede al titular del mismo ${ }^{699}$. A nuestro juicio, la diferenciación propuesta impone plantearnos si entre los derechos e intereses legítimos a los que se refiere el art. 24.1 CE cabría entender incluido un genérico y abstracto derecho a la legalidad penal, para cuya defensa el

${ }^{697}$ GOLDSCHMIDT, J., "Derecho Justicial Material (pretensión de tutela jurídica y derecho penal)” RDProc. (Arg.), 1946, T. I, p. 48.

${ }^{698}$ GOLDSCHMIDT, J., Problemas jurídicos y politicos..., op. cit. pp. 29 y s. Deberá evitarse toda conmixtión entre la exigencia del ámbito civil y la exigencia de protección jurídica del proceso penal, donde lo que se dilucida es el poder de condenar del Estado.

${ }^{699}$ FAIRÉN GUILLÉN, V., Voz “acción” en Nueva Enciclopedia Jurídica, op. cit. p. 202. Uno de los efectos de esta cuestión sería el que esta "extraordinaria generosidad y amplitud de la legitimación activa" dificulta la distinción entre pretensión y acción. No obstante, en opinión de FAIRÉN, mientras "la acción penal es un derecho cívico de petición", la pretensión procesal penal es "un acto por el cual se pide que se sujete a otra persona a una pena”. A este respecto FAIRÉN se sirve de CARNELUTTI, Lezioni sul processo penale, T. I, p. 130. 
ejercicio de la acusación fuera un mecanismo hábil. Aun aceptando la dudosa existencia de un derecho de cada uno de los ciudadanos a la legalidad ${ }^{700}$, más difícil sería hablar de las formas en que éste se podría hacer valer y de su vínculo con la dicción del art. 24.1 $\mathrm{CE}$, que se refiere a la tutela jurisdiccional en el "ejercicio de sus derechos e intereses legítimos". Si bien la legalidad constituye premisa básica en el Estado de Derecho (9.3 $\mathrm{CE}$ ), no parece que fuera voluntad del constituyente la articulación de un "derecho a la legalidad" ejercitable como tal. Y si no puede ser ejercitado, no sería admisible referirnos a la acusación popular como parte del contenido de ese ejercicio.

En los primeros momentos de vigencia de nuestra Magna Carta fue ya advertida la dificultad de que el art. 24.1 contuviera la realidad jurisdiccional penal, en tanto parecía dudoso que con el inciso "en el ejercicio de sus derechos e intereses legítimos" se hiciera referencia a otros derechos e intereses que los materiales o sustantivos ${ }^{701}$. Aun cuando en un principio pareciera claro que, en materia penal, los derechos e intereses a los que hace referencia el art. 24.1 CE no serían atribuibles a los justiciables, el TC ha entendido que, en ciertas condiciones, sí cabría asimilar el ejercicio de la acusación por los no ofendidos a derechos e intereses para los que alcanzando la categoría de derecho fundamental pueda ser recabable la tutela de los órganos jurisdiccionales. De ahí que haya llegado a afirmar que "entre los derechos e intereses legítimos para los que, como derecho fundamental, se tiene el de recabar la tutela judicial efectiva, figura el de ejercitar la acción pública en su régimen legal concreto (...) Esta reconducción del contenido del 125 al 24, para la que se busca el amparo constitucional, descansa a su vez en una identificación entre el derecho procesal en el que la acción pública o popular consiste con los derechos o intereses legí-

\footnotetext{
${ }^{700}$ Debe no obstante matizarse que nuestro cuestionamiento del derecho a la legalidad predicable de cada ciudadano se justifica y apoya en la inexistencia de un derecho a una legalidad determinada o, si se quiere, a una ley con un contenido específico. Lo que existe en verdad es el derecho a que la ley sea fruto del procedimiento constitucionalmente establecido, y así democrático, emanada de la representación política afirmada como tal. Acerca del valor legitimatorio del procedimiento vid. especialmente LUHMANN, N., Legitimation durch Verfahren, publicada en 1969. Se ha manejado la edición de Suhrkamp, Francfort 1983. Sobre la posibilidad de hablar de un derecho subjetivo a la legalidad, tema objeto de debate en Francia y matizadamente en Alemania, puede verse ESTEBAN DRAKE, A., El Derecho Público Subjetivo como instrumentación técnica de las libertades públicas y el problema de la legitimación procesal, Madrid 1981, p. 156. Su ámbito de elaboración ha sido el relacionado con el control jurisdiccional de la actividad administrativa y la discusión se ha centrado en el sujeto de imputación de aquél. Se ha señalado así que, mientras que en Alemania se optó por una patrimonialización del derecho a la legalidad a través de la introducción de un derecho subjetivo a la legalidad, en Francia, la libertad que la legalidad protege no es la de un sólo administrado (ciudadano), sino la libertad del conjunto de todos ellos.

${ }^{701}$ En este sentido vid. DE LA OLIVA SANTOS, A., Sobre el derecho a la tutela jurisdiccional, Barcelona 1980, p. 142.
} 
timos de carácter sustantivo para los que, en el entendimiento común, se garantiza la tutela judicial efectiva" (STC 147/1985 de 29 de octubre, FJ 3). Si bien esta identificación no es aceptada por el TC de forma absoluta cuando sea establecida de modo incorrecto y pretenda ser utilizada como un instrumento para alterar la configuración legal del derecho mismo que se pretende hacer valer (el acceso a la jurisdicción penal), tampoco podría ser a juicio del alto Tribunal en sí misma rechazada ${ }^{702}$.

A tenor de esta lectura, el interés legítimo para el que se impetra la tutela jurisdiccional no es ya un derecho material, sino la habilitación para acusar dentro de los márgenes delimitados por el legislador. Se confiere así al ejercicio de la acusación por los particulares una sustantividad e independencia que no le son propias en tanto originariamente constituye sólo una facultad procesal teleológicamente orientada a poner las premisas para la eventual actuación procesal del ius puniendi. La acusación ejercitada por los ciudadanos no ofendidos por el delito pasa así, a juicio del alto Tribunal, de ser uno de los presupuestos para la tutela del interés público en la solución pacífica de los conflictos, a constituir ella misma objeto de tutela. Aceptando esta visión parecería lógico considerar que el acceso al proceso, en su calidad de derecho fundamental, operará también cuando se realice para acusar dentro de los márgenes de su régimen legal.

Tal concepción no puede sin embargo ser considerada de recibo tras realizar un mínimo análisis. El acusador no ofendido ejercita la "acción penal" para posibilitar una resolución jurisdiccional, es decir, hace uso de una facultad orientada a la tutela de un interés público consistente en permitir la actuación jurisdiccional del ius puniendi a espaldas de cualquier interés personal que no sea el general en posibilitar la eventual aplicación de la ley. En ese sentido el mero ejercicio de la acusación no puede encontrar un cauce de tutela al amparo del art. 24.1, puesto que no es más que un imperativo procesal necesario para permitir la eventual satisfacción del deber estatal de garantizar la solución pacífica de los conflictos. Incluir su ejercicio por los ciudadanos en el "ejercicio de sus derechos e intereses legítimos" a que se refiere el art. 24.1 sería tanto como hablar de un derecho a la tutela jurisdiccional de una facultad procesal conceptualmente derivativa, dirigida a la defensa de un interés que no se puede afirmar propio. Puesto que no parece que fuera esa la voluntad del constituyente, que evidentemente pensaba en la

\footnotetext{
${ }^{702}$ En este sentido se enmarcan también las SSTC 62/1983 de 11 de julio, 241/1992 de 21 de diciembre, el ATC 327/1984 de 30 de mayo, o las más recientes SSTC 34/1994 de 31 de enero, 40/1994 de 15 de febrero y 326/1994 de 12 de diciembre.
} 
tutela por los Jueces y Tribunales de derechos e intereses materiales, la equiparación de éstos al ejercicio de la acusación popular ha de considerarse inaceptable. En tanto la tutela jurisdiccional no puede ser invocada en abstracto o para la defensa genérica de un interés no específicamente propio, negar el acceso a la Jurisdicción penal sólo puede constituir una vulneración de la tutela judicial efectiva si tal acceso se dirigiera a la consecución de un fin tuitivo en relación con un interés material legítimo cuya titularidad se habría de afirmar.

Es cierto que, en ocasiones, el ordenamiento jurídico reconoce legitimación procesal también a sujetos privados no titulares del derecho material que se dilucida en el proceso, tal y como ocurre por ejemplo en la sustitución procesal. Tales supuestos no admiten, sin embargo, ser equiparados con la acusación popular, en la medida en que el sujeto que actúa por un derecho ajeno, lo hace siempre en interés propio. Es este último interés el que ha de entenderse recogido en la dicción del art. 24.1 CE, pero no la herramienta procesal específica que el ordenamiento jurídico reconoce para su concreción ${ }^{703}$ y que puede pasar por la atribución de legitimación extraordinaria. En el proceso penal la existencia de un derecho propio, personal e individualizable de un sujeto no ofendido debe quedar radicalmente excluida en la medida en que el juicio criminal tiene por objeto establecer la concurrencia o no de los presupuestos necesarios para la actuación por el órgano jurisdiccional de la ley. Afirmar que la titularidad de este interés corresponde a todos y cada uno de los ciudadanos supone pasar por alto dos hechos: 1) que nos encontramos ante una única e indivisible realidad, cuya defensa es una obligación asumida por el Estado actuando jurisdiccionalmente, y 2) que ni siquiera la facultad procesal reconocida a los no ofendidos que pervive en nuestro ordenamiento tendría sentido desde la objetividad e imparcialidad constitucionalmente asignadas a la tarea procesal desempeñada por el MF, difícilmente predicables del particular e inútiles en su duplicidad.

La defensa de intereses generales a través del planteamiento de la acusación fue abordada por el TC en su equívoca sentencia 62/1983 de 11 de julio en relación con un delito contra la salud pública. Esta resolución ha devenido célebre entre la doctrina y sus argumentos son reproducidos con frecuencia cuando se aborda la cuestión que nos ocupa. En su FJ 2 se afirmaba en relación con la defensa de intereses comunes a través de las "acciones públicas" que "cuando un miembro de la sociedad defiende un interés común

\footnotetext{
${ }^{703}$ Vid. SATTA, S., Voz “Giurisdizione...”, op. et loc. cit.
} 
sostiene simultáneamente un interés personal o, si se quiere desde otra perspectiva, que la única forma de defender el interés personal es sostener el interés común". En esta ocasión, apelando a la "solidaridad e interrelación social", partía el Alto Tribunal de una idea de "interés común" entendida como agregación o superposición de intereses individuales. A tenor de esta lectura, aceptada hoy en general sin excesiva crítica, la idea de interés directo y particular como requisito de legitimación debería quedar englobada en el concepto más amplio de interés legítimo y personal, el cual podría ser o no directo.

No debe olvidarse que en el delito que se enjuiciaba en la causa de la que traía su origen la petición de amparo -el tristemente célebre asunto de la colza- no sólo había un perjuicio para personas que sufrieron directamente la enfermedad sino que, por tratarse de un delito de peligro, cabía hablar de una amenaza para un bien jurídico del que eran titulares todos y cada uno de los ciudadanos. O en palabras del TC, "el bien común en que la salud consiste, que se refleja en definitiva en la salud personal de los ciudadanos" (FJ. 2). La doctrina emanada de esta sentencia, plenamente válida en supuestos donde haya un daño subjetivamente extendido, no puede ser, sin embargo, aplicable en general al ejercicio de la acusación popular. La facultad procesal de acusar se estaba utilizando no para activar la defensa del interés público derivado de la resolución de los conflictos a través del proceso, sino para invocar la tutela de un concreto interés material: la defensa de la salud puesta en peligro presuntamente por la acción delictiva. La diferencia con otros supuestos en los que la figura de la víctima se presenta de forma clara se cifra en que en este caso, por razones de utilidad, los concretos intereses materiales se hacen representar procesalmente mediante la actuación de unos sujetos específicos. Puesto que tales sujetos no son los titulares del interés defendido, el mérito de la resolución es precisamente el reconocerles la condición de portadores de su representación.

Entendemos por ende, en contra de la doctrina sentada por el TC, que la acusación popular no puede ser vista como un interés tutelable per se, sino sólo como la satisfacción de una exigencia necesaria para activar la defensa del interés público. La acción popular del proceso penal, que en el siglo pasado iba de lo individual a lo colectivo (un derecho subjetivo de los ciudadanos que contribuye al bien común), debe ser contemplada hoy siguiendo un camino inverso (algunos ciudadanos podrían contribuir a la realización del interés general). No nos encontramos por tanto en el ámbito de las libertades como meta y objetivo de la Constitución, sino en una esfera diferente: la de la los criterios de utilidad para la mejor satisfacción del interés público a través de la persecución penal. 


\subsubsection{La acusación popular ni es, ni integra el derecho fundamental a la tutela jurisdiccional}

Para constatar la veracidad de tal afirmación habremos de tener en cuenta las titularidades, los fundamentos, y el propio contenido del derecho de acción y de la facultad de acusar:

\section{a) En cuanto a los titulares:}

Mientras que el derecho de acción pertenece a todas las personas, de la facultad de ejercitar la "acción penal" sin ostentar la condición de ofendido pueden quedar excluidos legalmente algunos sujetos sin obstáculo constitucional alguno. La expresión "todos los españoles..." contenida en el art. 101 LECrim no refleja en rigor la realidad, en la medida que la propia ley se encarga a continuación de excluir a determinados sujetos cuando no sean titulares del interés jurídicamente protegido por la norma sustantiva. Desde una perspectiva constitucional no sería de recibo admitir que se excluya a determinadas personas de la titularidad de un derecho fundamental, por lo que parece claro que nos encontramos ante una realidad claramente diferente. Extranjeros, menores, incapaces, jueces o condenados por acusación falsa no son titulares de esta facultad (art. 101, 102 y 270 LECrim) sin que por ello quepa estimar que alguno de sus derechos fundamentales se halle menoscabado ${ }^{704}$.

La acción exige únicamente la capacidad para ser parte, pero el ejercicio de la acusación exige legitimación, aun cuando ésta venga conferida de manera muy abierta. Ha de entenderse la acusación popular de los arts. 101 y ss. LECrim, pues, no como un reconocimiento, sino como una atribución bajo una formulación de carácter positivo en la que se afirma que "Todos los ciudadanos españoles que gocen de la plenitud de los derechos civiles, que no hubieran sido condenados dos veces..., que no sean Juez o Magistrado, podrán ejercitar la acusación penal con arreglo a las prescripciones de la

\footnotetext{
${ }^{704}$ Han de considerarse por tanto contradictorias algunas afirmaciones en las que se conceptúa la acción popular como un verdadero derecho de acción para a renglón seguido tener que asumir que para su ejercicio ha de ostentarse capacidad procesal. En este sentido GIMENO SENDRA, V., Constitución y Proceso, p. 83. Es cierto que sería incoherente que, por ejemplo, el representante de un incapaz accionará por éste en nombre de la sociedad cuando podría hacerlo por sí mismo, pero entonces concluiremos que no estamos ante un derecho de acción, sino ante otra realidad.
} 
ley" ${ }^{705}$.

Es además factible y plenamente admisible el que a sujetos titulares de la facultad de acusar se les impida su ejercicio por razones que en ningún caso podrían impedir el ejercicio de un derecho fundamental. Esto es lo que sucederá por ejemplo en caso de existir una relación de parentesco entre acusador y acusado cuando el primero no haya sido ofendido por el delito (art. 103 LECrim) ${ }^{706}$.

\section{b) En cuanto al fundamento}

La posición del derecho constitucional de acción del art. 24.1 CE y de la acusación popular amparada por el art. 125 son absolutamente diversas, no sólo ya por la diferente adscripción sistemática a la parte dogmática y a la orgánica de la Constitución, sino por su propia naturaleza. Mientras que en el primer caso estamos ante un derecho fundamental, en el segundo estamos ante una simple opción valorativa del legislador, fruto de un juicio de oportunidad, investido así de plena libertad para asignarle las dimensiones que estime oportunas. Su planteamiento es sólo posible previo reconocimiento legal expreso y en las condiciones normativamente fijadas, sin que pueda afirmarse que la capacidad de irradiación por todo el ordenamiento jurídico predicable de los derechos fundamentales alcance también al ejercicio de la "acción penal"707. Esa fuerza expansiva no le es en ningún caso propia, razón por la que ni siquiera es susceptible de ser utilizada la acusación popular en todos los procedimientos penales, su ámbito objetivo natural. Esto es lo que sucede por ejemplo en el caso de los delitos "privados", la Jurisdicción militar o la Jurisdicción de menores, sin que quepa reproche alguno de inconstitucionalidad. En sentido similar han de ser interpretadas otras garantías formales para el ejercicio de la acusación tales como la interposición de querella o el depósito de fianza, que aun suponiendo restricciones en la actividad de los particulares, no son más que condiciones

${ }^{705}$ Cfr. GÓMEZ ORBANEJA, E., Comentarios..., op. cit. T. II, p. 465.

${ }^{706}$ En este caso el interés colectivo en el mantenimiento de las buenas relaciones familiares y la protección de la familia como interés socialmente tutelable y principio rector de la política social y económica (art. 39.1 CE) se juzga preponderante a la atribución de legitimación para acusar. El mantenimiento de la armonía familiar como criterio de política social, cuando en determinados casos puede ser ajeno a la voluntad del individuo, no podría nunca alcanzar un nivel de tutela mayor que un derecho fundamental.

${ }^{707}$ Sobre el efecto de irradiación de los derechos fundamentales vid por todos BÖCKENFÖRDE, E-W., Escritos sobre Derechos Fundamentales, traducción de REQUEJO PAGÉS y VILLAVERDE MENÉNDEZ, Baden-Baden 1993, pp. 110 y ss. y ALEXY, R., Teoría de los Derechos Fundamentales, op. cit. pp. 506 y ss. 
que el legislador estima necesarias para hacer uso en un caso concreto de una facultad que en abstracto reconoce.

En el art. $125 \mathrm{CE}$ no se contiene un derecho ilimitado de acceso al proceso penal sino sólo una habilitación para que el legislador ordinario pueda reconocerlo en los supuestos en que lo estime pertinente. Con él no quedó instituido un sistema de acusación popular extensible a todos los supuestos de delito, sino que será preciso un reconocimiento legislativo explícito, no sólo en cuanto a su existencia, sino también en cuanto a su contenido. Es perfectamente admisible la modulación legislativa de la acusación popular, pudiéndose llegar incluso a su exclusión. Dado que su configuración legislativa no encuentra una garantía que sobrepase el nivel de la ley ordinaria, la reforma del sistema de acusación no afectaría para nada al derecho de acción, por lo que no debe ser sustraído del debate legislativo creador de la norma. El legislador podrá adaptar la configuración normativa a lo que se considere más adecuado para la consecución de los intereses públicos, podrá determinar cuáles son delitos públicos o "delitos privados", podrá limitar la acusación de los particulares en hipótesis singulares al ofendido por el delito estableciendo un catálogo de supuestos para los que se excluya la acusación popular o podrá especificar los requisitos formales para la admisión de acusadores, sin que en ninguno de estos casos quepa afirmar que quede afectado en absoluto el derecho constitucional de acción.

Es cierto que todos los sujetos, legitimados o no, pueden acudir ante el órgano jurisdiccional competente y solicitar su admisión como acusadores para que, a la vista de las previsiones legales, se determine mediante resolución motivada si pueden acusar o no. $\mathrm{Si}$, por ejemplo, quien demanda su intervención como acusador no fuera plenamente capaz (y no se tratara del ofendido por el delito), la respuesta a una petición en ese sentido tendría que ser negativa sin entrar a valorar ningún otro dato más (art. 102.1 y 312 LECrim). Pero ello no puede hablarnos tampoco de un derecho, sino que tal facultad de pedir, ciertamente existente, no integra la esfera de derechos subjetivos de los ciudadanos si no lo es en tanto constituye parte del diseño orgánico del sistema de acusación. Al establecerse la posibilidad de que la acusación sea sostenida por sujetos privados, pero no por todos ni en todos los supuestos, se hace precisa la imposición de filtros adecuados para determinar en cada caso concreto quiénes son los que han de ser admitidos. 


\section{c) En cuanto al contenido}

El contenido del derecho constitucional de acción es el de poder provocar una actividad jurisdiccional en relación con una pretensión deducida, por lo cual el derecho existe antes de su ejercicio. La "acción penal" no reúne las características de un derecho, sino que designa una actividad, un conjunto de actos que en sí mismos son ya pretensión. La "acción penal" que ejercitan los ciudadanos no ofendidos por el delito y la que formula el MF se dirigen al mismo fin y surten los mismos efectos, por lo que no cabría sostener la diferente naturaleza de una y otra. No compartimos por tanto la idea de establecer diferencias entre lo que sea la "acción penal" en función de quién sea el sujeto que la ejercite sino que, en nuestra opinión, son exactamente la misma cosa: la afirmación de la existencia de los presupuestos necesarios para el enjuiciamiento, objetiva y subjetivamente delimitado que ha de culminar con una resolución en la que eventualmente se aplicará la norma penal.

Admitiendo que esa realidad pudiera considerarse un derecho de acción, tendríamos que hablar de un derecho subjetivo del Estado (encarnado en el MF) frente al mismo Estado (encarnado en los órganos jurisdiccionales). Esto nos conduciría a una incoherencia que ha de rechazarse, en tanto en el ejercicio de la "acción penal" por el MF, al igual que ocurre con la actividad de los órganos jurisdiccionales, no puede haber nada reconducible a la idea de derecho subjetivo, sino únicamente a la de un puro deber.

No puede ser tampoco pasada por alto la vinculación entre la querella, instrumento formal a través del que se ejercita la "acción penal" y los hechos objeto del proceso, lo cual nos viene a hablar ya de cierto grado de concreción presente en ella. Señalaba FENECH que "el ejercicio de la acción no está por completo desvinculado del hecho de que realmente exista una infracción, o que, por lo menos, este hecho sea probable racionalmente ${ }^{, 708}$. El Juez tiene que realizar una apreciación sobre el contenido de la querella y sobre la existencia del delito y su adecuación a lo que se le expone. Cuando tras ese previo examen, la estime improcedente, la inadmitirá, y cuando los hechos en que se funde no constituyan delito, o cuando no se considere competente para instruir el sumario objeto de la misma la desestimará (arts. 312 y 313 LECrim.). Aceptando que estuviéramos en presencia de un derecho de acción, esto podría llevarnos, según se ha advertido en alguna ocasión, a la paradoja de deducir que la "acción penal" tendría un grado de

\footnotetext{
${ }^{708}$ FENECH, M., El proceso penal, T. I, Barcelona 1952, p. 351.
} 
abstracción menor que la acción del proceso civil. Tal incongruencia se produciría si se considera ésta como un mero derecho a la actividad jurisdiccional y se exige que en el ejercicio de aquélla se concrete la presunta infracción ${ }^{709}$. Esta aparente incongruencia del sistema sólo se podrá resolver atendiendo al hecho de que estamos en presencia de una realidad diversa a la que se engloba en el derecho de acción, lo cual nos obliga a descender necesariamente a un plano procesal o dinámico: a la pretensión.

La confusión o mezcla entre derecho de acción la "acción penal" nos habla del anhelo por buscar conexión entre lo que la ley procesal penal denomina "acción" y lo que dogmáticamente ha de entenderse comprendido en el mismo término. Pero el intento resulta infructuoso, puesto que se ha de reconocer la imposibilidad de realizar una formulación en la que entren los datos básicos de este derecho constitucional que englobe a su vez todo lo que la LECrim denomina "acción penal". La formulación válida de lo que haya de entenderse contenido en el derecho de acción sólo puede proceder de la máxima abstracción y de la búsqueda en un ámbito constitucional del punto de partida habilitante para el poder de los ciudadanos de obligar a los órganos jurisdiccionales a dictar una resolución dirigida a la defensa de sus derechos e intereses legítimos. Derecho de acción y "acusación popular" son, pues, dos realidades diversas, respuesta que el ordenamiento jurídico da a dos necesidades de naturaleza diferente.

El que los particulares contribuyan al sostenimiento de la pretensión penal, soslayando en este momento las razones subsistentes que lo explican, podría constituir un medio que, teóricamente, mejorara la realización de esa tarea. Pero deducir de ahí un derecho originario y propio de los particulares a acusar, enraizado en los derechos inalienables de la persona, significaría dar un salto cualitativo que no puede considerarse conveniente. Y no es sólo mera retórica, sino que las repercusiones que se pudieran deducir son de radical importancia:

1) Si hubiera un derecho originario a la acusación, carecería de sentido hablar de principio de oficialidad de la acusación en nuestro sistema. Hablaríamos de un derecho de todos y cada uno de los ciudadanos ("la acción penal es pública", es decir se extiende a todos), para cuya efectividad se garantiza además que un órgano público asuma tal papel.

\footnotetext{
${ }^{709}$ GONZÁLEZ MONTES, J.L., "Notas en torno a la acción penal y su ejercicio", en MORENO CATENA, V., (Coordinador), Problemas actuales de la Justicia. Homenaje al Profesor Gutiérrez-Alviz, Valencia 1988, pp. 739 y ss. En este sentido el autor se apoya en FENECH.
} 
Este era el sentido de la originaria LECrim, como demuestra el hecho de que los preceptos contenidos en los arts. 101 y 270 LECrim precedan a los de los arts. 105 y 271 , que se encuentran subsumidos en aquéllos. El punto de partida era el individuo y su voluntad soberana, la inatacable esfera en que su libertad se desenvuelve y de la que formaba parte el derecho a acusar. Puesto que de la autonomía de la voluntad del sujeto nace un espacio exento del poder del Estado y existirá un ámbito estrictamente individual en el que ésta se puede desarrollar, el derecho a acusar podrá ser activado por él una vez que se diesen los presupuestos necesarios. El actor popular, mediante el ejercicio individual de su acción, haría nacer algo que cualquier otro también podría haber hecho: poner en marcha la Jurisdicción para la defensa de su interés particular como ofendido por el delito en tanto éste es ofensa a todos a la vez. Nadie tendrá que hacer nada más, porque él se encargará de mantener vivo el proceso evitando que su interés, coincidente con el de todos los demás, pueda no ser satisfecho. La acusación sería ejercicio privado en el proceso penal de un derecho también privado originado por la ofensa recibida con el delito, coincidente con el deber público de perseguir todos los delitos ${ }^{710}$.

Los términos se deben sin embargo invertir para afirmar que, a pesar del carácter público (estatal) que la acusación tiene, o precisamente por la trascendencia que a ese dato se debe otorgar, nuestra LECrim persiguió garantizar su mejor efectividad. Por ello no se conformó con atribuir la facultad para deducirla a una autoridad pública aun no plenamente arraigada, sino que admitió que algunos particulares pudieran también contribuir a una función a la que en principio no estaban llamados. El actor popular plantea acusación solamente en tanto representante de un interés que no es privativamente suyo, sino que, por pertenecer a todos, debe ser ejercitado por el Estado. En este caso sería ejecutor privado de un deber público (la acusación) con el fin de que se cumpla una de las obligaciones del Estado (la persecución de todos los delitos). No es por tanto que haya coincidencia entre un derecho integrado en la esfera jurídica del particular y el deber estatal, como ocurriría a tenor de la concepción contraria, sino que la facultad de los particulares se activa sólo cuando pueda ser encuadrable en la finalidad a la que sirve.

2) Si consideramos el ejercicio de la pretensión penal a través de la acusación popular un derecho autónomo propio de los particulares, habremos de aceptar la intervención de todos los que deseen ser admitidos en el proceso. A pesar de la dicción

${ }^{710}$ Ya resaltaba GÓMEZ ORBANEJA en Comentarios..., op. cit. T. II, p. 457 que el sistema se presenta paradójicamente como una acentuación del interés privado en la represión. 
del art. 113 LECrim, el rechazo de los actores que quisieran concurrir aisladamente al proceso, vulneraría su derecho a la tutela judicial efectiva en tanto se les ocasionaría indefensión al no poder hacer valer por sí mismos en el proceso un legítimo derecho integrante de su esfera jurídica. No importaría que ya estuvieran personados otros sujetos, puesto que cada uno defendería con carácter individual su propia pretensión tuteladora de un derecho propio.

Por el contrario, considerar que los acusadores privados asumen una función pública y no defienden ningún derecho material integrante de su esfera jurídica nos conduciría a otra lectura del art. 113 LECrim. En este sentido podríamos decir que allí donde un sujeto haya deducido la pretensión penal, si otro quisiera contribuir a su sostenimiento tendría que hacerlo junto con él y bajo una misma dirección y representación cuando fuera posible a juicio del Tribunal. Sólo cabría su admisión individual cuando la pretensión deducida fuera otra diferente, tal y como ocurriría en el caso de existir varios agraviados directamente por el delito, titulares individuales de derechos específicamente propios. El particular no ofendido no tiene derecho a entablar de manera singular e independiente una pretensión propia derivada de un derecho individual, sino que puede cumplir un deber estatal (la acusación), pero siempre supeditado a la eventualidad de que otro sujeto lo haya realizado ya.

3) Si fuera un derecho originario, el legislador debería admitirla necesariamente para todos los sujetos y en todos los procesos penales. En caso contrario estaría incurriendo inevitablemente en un insubsanable defecto de constitucionalidad pues se privaría a los ciudadanos de un derecho o interés legítimo cual sería el que defienden al ejercitar la facultad procesal de acusar.

Puesto que nos encontramos ante una concesión del legislador, ésta puede ser acotada. Aun cuando el ciudadano perdiera esta facultad, no perdería algo fundamental que integrase su personalidad y dado tiene un carácter diferido y no originario, sólo cuando exista una norma que se la confiera, el sujeto podrá reclamarla y hacerla valer. El objetivo de estas normas y su verdadero valor podría cifrarse únicamente en su ideológica capacidad de transmisión de una imagen de "popularidad" de un sistema estructurado en pro de la tutela del interés general -compresivo de la totalidad de los individuales-, pero no en que con su atribución se otorgue algo más a los particulares.

4) Si cada uno de los ejercitantes de la pretensión penal hiciera valer un derecho propio no se podría hablar de una única "acción penal", sino de varias, tantas como 
sujetos titulares de la facultad de plantearla. Pero parece claro por el contrario, como ya señalaba GÓMEZ ORBANEJA, que la "acción penal" es única, sin que importe la pluralidad de querellantes ni la diversidad de calificaciones entre ellos ${ }^{711}$.

La acusación quivis ex populo constituye ciertamente una muy característica peculiaridad de nuestra política criminal, pero no conlleva el reconocimiento de un derecho fundamental al ejercicio de la acusación ni siquiera limitado a su régimen legal específico. La acusación popular stricto sensu, no puede ser formalmente un derecho fundamental, pero tampoco puede serlo materialmente, en cuanto no sería de recibo afirmar que, indiferentemente de su objetivo, forme parte de la estructura normativa básica del Estado y de la Sociedad. No se puede decir, a no ser realizando alguna equiparación demasiado voluntarista o asumiendo una gran dosis de optimismo, que la acción popular en el proceso penal tenga carácter informador de todo el ordenamiento jurídico, tal y como debe ser predicable de los derechos fundamentales. Un derecho fundamental es directamente exigible sin desarrollo legal y tiene una posición prevalente en el ordenamiento jurídico sin perjuicio de su limitación de acuerdo con el imperativo de la proporcionalidad ${ }^{712}$, cualidades que no son predicables de la acusación.

La posibilidad de acusar cuando no se sea ofendido por el delito no forma parte de la esfera de los derechos inalienables de la persona, sino que se orienta a subsanar el déficit real del contenido constitucional de la función del MF como órgano público defensor de la legalidad, de los derechos de los ciudadanos y del interés público legalmente tutelado (art. $124 \mathrm{CE}$ ) y, en la especie, titular de la acusación pública (art. 105 LECrim). Debe ser entendida hoy dicha posibilidad bajo nuevos criterios que tengan presente el trascendental papel del acusador oficial enraizado en nuestro sistema jurídicofundamentalmente. No es una emanación genérica de la personalidad, sino que su ámbito se sitúa entre las reglas orgánicas de la administración de la justicia penal. No es un derecho subjetivo inherente al ciudadano, originario o de carácter previo a su reflejo

${ }^{711}$ GÓMEZ ORBANEJA, E., Comentarios..., op. cit. T. II, p. 459.

\footnotetext{
${ }^{712} \mathrm{La}$ evidente falta de juego del principio de proporcionalidad en la acusación popular pudiera ser expresiva de la carencia del contenido jurídico objetivo de derecho fundamental. Como señala BÖCKENFÖRDE, Escritos sobre Derechos Fundamentales, op. cit., p. 124, los derechos fundamentales tienen tendencia a la asimetría y, "si no se llega a una ponderación, ciertos contenidos de derecho fundamental se extienden unilateralmente a costa de otros contenidos de derecho fundamental ofrente a otros titulares de derechos fundamentales. Precisamente por ello es necesaria la construcción del principio de proporcionalidad en la utilización de contenidos jurídico-objetivos de derecho fundamental".
} 
positivo, sino que es sólo una facultad residual otorgada por la ley susceptible de ser matizada normativamente en su existencia, extensión y cualidades. Estamos por ende no ante un derecho fundamental, sino ante una facultad procesal delimitada por un régimen legal concreto, para unos sujetos concretos, unos procedimientos penales determinados y con un fin específico: el ejercicio de la pretensión penal.

Es, por tanto, un modo históricamente inteligible para configurar la administración de la justicia penal asumido por el legislador, pero no sujeto a una extensión delimitada estrictamente por la Constitución. Su razón de ser en nuestro ordenamiento procesal penal no deriva de la garantía de un originario derecho individual y difundido de acusar, sino del cumplimiento de una misión a la que el Estado se obligó con la privación de la autotutela. La dificultad de soltar amarras con respecto a viejas concepciones romanistas, el deseo de mantener un sustrato liberal pretendidamente antiabsolutista y garantizador de derechos individuales del acusador en el proceso penal, la necesidad de conferir un fundamento constitucional a significativas actuaciones de los particulares en procesos penales, expresivas de las insuficiencias del órgano público constitucionalmente encargado, ofrecen como resultado el esfuerzo de inclusión del ejercicio privado de la acusación como facultad de iniciativa procesal en el derecho a la tutela judicial efectiva. Pero esta apreciación yerra entre otros aspectos en tanto los derechos fundamentales que los ciudadanos ostentan en relación con la instauración de un proceso penal allí donde sea menester, deben operar en un momento previo a él e independientemente de la comisión criminal.

El fundamento de la acción popular del proceso penal no se debería buscar en la vieja idea del derecho de acusación como derecho subjetivo individual dirigido a la obtención de una condena en tanto forma de defensa de la paz social vulnerada por el delito, sino que sólo puede entenderse residualmente subsumida en los mecanismos de que se ha dotado el Estado para el enjuiciamiento de las conductas afirmadas como delito. La acusación popular de nuestros días ha de vincularse, pues, a un MF sujeto al principio de legalidad en su actuación, por lo que el art. $125 \mathrm{CE}$ exige su contemplación en conexión directa con el 124 . 



\section{ACUSACIÓN POPULAR COMO MODALIDAD DEL EJER- CICIO DE LA COMPETENCIA ESTATAL DE ACUSAR}

\subsection{Las diversas denominaciones de la acusación}

\subsection{1. "Acción pública" y "acción popular"}

\subsubsection{Publicidad de la acción}

El concepto "publicidad de la acción" carece de un unívoco significado político, jurídico e institucional. De él los distintos ordenamientos positivos han deducido bien el carácter oficial o estatal del ejercicio de la "acción penal", bien la acción popular y, como caso excepcional, del nuestro se ha dicho que reconocería una y otra cosa a la vez ${ }^{713}$. Resaltaba GIMENO, inspirado en este punto en las tesis de GÓMEZ ORBANEJA, que el significado del art. 101 en concordancia con la dicción del 270, querría decir que la acción no es totalmente oficial, que no se correspondería con el monopolio del Ministerio Público $^{714}$. Lo que la Ley llama "acción penal pública” tendría entonces para él un doble significado: sería pública porque se atribuye a todos los ciudadanos ${ }^{715}$ y sería pública también porque simultáneamente se confiere a un órgano público. Entendemos, sin embargo, que ni la originaria Ley alcanzaba a hacer esa diferenciación, ni puede ésta ser sostenida hoy a la luz de una concepción de la competencia estatal de acusación que venga a incardinarla en el marco del Estado social y de Derecho.

Con relación a la publicidad de la acción penal salta también a la vista y debe ser

${ }^{713}$ GÓMEZ ORBANEJA, E., Comentarios a la Ley de Enjuiciamiento Criminal, Barcelona 1951, T. II, vol. I, p. 457.

${ }^{714}$ GIMENO SENDRA, V., “La fianza...”, op. cit. p. 72.

${ }^{715}$ Cfr. tal intelección de lo "público", subsumible más técnicamente en otros términos como "colectividad", “sociedad”, etc., y en otro sentido en “popularidad”, con lo expuesto por BULLINGER, Derecho Público y Derecho Privado, Madrid 1976, passim.; HABERMAS, J., Strukturwandel der Öffentlichkeit, $5^{\text {a }}$ ed. Neuwied y Berlin, 1971, pp. 13 y s. y PEDRAZ PENALVA, E., "Notas sobre publicidad y proceso", en Constitución, Jurisdicción y Proceso, op. cit. pp. 203 y ss y 215 y ss. 
someramente examinado un primer elemento: el que todos los códigos procesales penales de nuestro entorno hablen del carácter público de la acusación en un sentido que se interpreta de forma diversa a como se hace en nuestro país. La afirmación de la publicidad de la "acción penal", según el entendimiento general en estos sistemas, no sería más que el corolario procesal del interés colectivo, público o estatal en la represión de los delitos ${ }^{716}$. Es una característica innata, derivada de la naturaleza de los intereses realizados a través de ella, que no pueden ser otros más que los intereses de la comunidad en enjuiciar las conductas sospechosas de constituir delitos con el objeto de su represión. La publicidad es entendida, por tanto, como una cuestión cualitativa y no cuantitativa, ya que no se refiere a quiénes o cuántos sean los que la vayan a poder deducir, sino a que, hablando de "acción penal", no nos referimos a una actividad privada, sino propia del Estado, cualitativamente pública. Fuera de nuestras fronteras la fórmula "la acción penal es pública" ha tenido siempre un sentido de vinculación al principio de oficialidad en la persecución, entendiéndose que, perteneciendo la "acción penal al pueblo", su ejercicio se encomienda en exclusiva a funcionarios para ello diputados ${ }^{717}$.

En otros casos, incluso, la doctrina ha interpretado el carácter de pública de la acción precisamente sobre la base de la reserva que el propio Estado hacía en favor de sus órganos por contraposición a los supuestos en que transfería esta facultad a los particulares, por lo que habría de estarse al régimen legal concreto para la determinación normativa de la titularidad de la acción penal ${ }^{718}$. Estimaba CARRARA que la formulación como pública era consecuencia del monopolio del Ministerio Público, por lo que no sería lógico defender con ella misma el monopolio acusatorio de éste ${ }^{719}$. La acción

\footnotetext{
${ }^{716}$ En otros sistemas cuando se habla del principio de publicidad se quiere decir algo muy diferente a lo que en el sistema español se entiende como acción penal pública. En todo caso se vincula con la oficialidad en el ejercicio de la acusación, con la atribución de la competencia a un órgano público para su realización. Vid. por ejemplo los arts. 152 StPO, 1 y 31 CPPFranc. o 50 CPPItal.

${ }^{717}$ Ya desde el Code des délits et des peines francés de 3 de Brumario del año IV. En su su art. 5 se establecía “L'action publique a pour objet de punir les atteintes portées à l'ordre social. Elle appartient essentiellement au peuple. Elle est exercée en son nom par des fonctionnaires établis à cet effet". Vid. ESMEIN, A., Histoire de la procédure criminelle en France..., op. cit. p. 442.

${ }^{718}$ SABATINI, G., "Vecchio e nuovo nella teoria dell'azione penale”, Archivo Penale 1962, I, pp. 166 y ss.

${ }^{719}$ CARRARA, F., "La azione penale”, Rivista Penale, vol. III (1875), p. 15. La opinión de CARRARA fue recogida por GÓMEZ ORBANEJA (Comentarios..., op. cit., T. II, vol. I, p. 216), estimando que con ello se "rompía una lanza en favor de la acción popular". Tal afirmación no puede ser aceptada como absolutamente cierta porque lo que defendía CARRARA era únicamente la acusación del ofendido por el delito, pero nunca la de quien no lo fuera.
} 
penal sería en consecuencia pública también por la naturaleza objetivamente pública de la represión penal pero además, por el carácter del sujeto que la ejercita, característica que se vería determinada o absorbida por la anterior ${ }^{720}$.

\subsubsection{Acción popular y acción pública: términos originariamente sinónimos}

De una primera lectura del art. 101 LECrim puede deducirse ya que en nuestro sistema no ocurre lo mismo que en otros: el Estado, que también se reserva la persecución de los delitos, difunde en cambio posteriormente el planteamiento de la acusación entre todos los españoles, excluyendo el monopolio del MF. Mientras que en el resto de Europa se juzgó suficiente la sujeción al principio de legalidad y la obligatoriedad del ejercicio de la acusación, en nuestra LECrim, en la que también existían esas garantías, se estableció una más: la del mismo ejercicio de la pretensión penal por los particulares.

De la interpretación conjunta de los preceptos de la Ley es fácil deducir que la caracterización de "pública" de la "acción penal” se centraba en un aspecto cuantitativo en el que se remarcaba la capacidad de todos los sujetos para su ejercicio (siempre que no se encontraran excluidos expresamente). La peculiaridad de nuestro sistema frente a otros radicaría en que la facultad necesaria para poder activar el ius puniendi estaba difuminada en España entre todos los ciudadanos, mientras que en otros lugares, donde la presencia estatal era más intensa o la influencia de las corrientes liberales más débil, permaneció íntegramente dentro de la órbita del Estado. Se mantuvo aquí, por tanto, una singularidad cuyas consecuencias perduran aún hoy: el llevar a cabo una actividad precisa para el enjuiciamiento conducente a la imposición de la pena como signo de autodefensa social frente al delito era responsabilidad del cuerpo social antes que del Estado mismo, aunque también lo fuera de éste. De ahí que se reconociera como propia de todos los ciudadanos una facultad que les habilitaba para acusar ("Todos los ciudadanos españoles podrán ejercitarla" (art. 101 LECrim)). El derecho de autodefensa en que consiste la "acción" física directa contra el adversario era así sustituido en ese estadio evolucionado de la humanidad por la noción de "acción penal" contra el sujeto autor de un delito a través de su ejercicio ante la Jurisdicción. El ejercicio de la pretensión se constituyó de esta manera

\footnotetext{
${ }^{720}$ Vid. por ejemplo MASUCCI, “Azione penale”, en Enciclopedia del Diritto Penale Italiano, p. 106 o LEONE, G., Voz “Azione penale”, Enciclopedia del Diritto, pp. 851 y ss.
} 
en la manifestación en nuestro ordenamiento del derecho de todo hombre a acusar, fundamentado en la facultad de hacer todo aquello no expresamente prohibido, que, procedente del Derecho Romano, se había recibido en las Partidas. La fijación de los presupuestos esenciales para el ejercicio por el Estado de su “derecho de penar", subsistía por ende enmarcado en la esfera privada como derecho inexpropiable de los particulares.

El acusador privado en cualquiera de sus modalidades no era para el legislador de 1882, ni lo fue antes para el de 1872, un representante del Estado, sino un sujeto que defendía un derecho propio coincidente con el interés público. De ahí que las actuaciones integrantes del necesario presupuesto para el enjuiciamiento (la "acción penal") se reconocieran prioritariamente, y con carácter previo, como derecho de todos los ciudadanos miembros del cuerpo social ofendido por el delito. Una función imprescindible para la convivencia social, la de instar la aplicación de las penas, no se reservaba al Estado, como ocurrió en el resto de los países de nuestro entorno, sino que permaneció en la esfera de la "sociedad civil"721. Quien ejercitara la "acción penal" podía no ser representante del Estado, sino de la sociedad ofendida en su totalidad por el delito, aunque quien tenía la obligación de imponer la condena legalmente prevista fuera el Estado por mediación de sus órganos jurisdiccionales ${ }^{722}$.

El derecho subjetivo de ejercitar la "acción penal” serviría para defender un interés propio, pero sería coincidente además con un interés general digno de protección. Esta facultad se concedía por ello también a un funcionario público, al que además se obliga a ejercitarla (art. 105 LECrim) ${ }^{723}$, pero, todo sea dicho, sin demasiada fe en que fuera a desempeñar óptimamente su función. Aun cuando el papel del MF radicaba en servir a los intereses públicos, entre los cuales se encontraría prioritariamente el de ejercitar la “acción penal”, su vínculo con el Gobierno generaba más recelos que confianza a unos

${ }^{721}$ Entendida en el concepto decimonónico de "bürgerliche Geschellschaft" con fundamento en HEGEL.

${ }^{722}$ En esta generalizada atribución de la facultad de acusar se puede percibir ya una inherente separación entre derecho de penar y el derecho de ejercitar la pretensión, quizá no buscada explícitamente por el legislador, pero que nos aporta una idea de la superación de la identificación entre derecho material (el derecho de penar) y derecho procesal (la afirmación de la concurrencia de los presupuestos para la aplicación de la pena), siquiera en sus titularidades.

\footnotetext{
${ }^{723}$ La circular de la Fiscalía del TS de 2 de septiembre de 1884 ya advertía en concordancia con la LOPJ de 1870 que “... lo que para los ciudadanos constituye un derecho, es deber ineludible del MF, a quien, aparte de otras muchas disposiciones, la citada ley, en el art. 105, impone la obligación de ejercitar, con arreglo a la misma, todas las acciones penales que considere procedentes, haya o no acusador privado en las causas, menos aquellas que el CP reserva exclusivamente a la querella privada". En el mismo sentido vid. STS de 28 de enero de 1888.
} 
espíritus impulsados por el ansia de garantizar ámbitos de libertad individual en los que el Estado no pudiera incidir. De ahí que, aun estableciendo su obligación para deducir pretensiones conducentes a la realización del ius puniendi, privar a los ciudadanos de un derecho a acusar no fuera adecuado a la ideología que impulsaba a los legisladores ${ }^{724}$.

La pretensión que deduciría el fiscal al acusar era, atendiendo el tenor literal de la Ley y siguiendo la ordenación sistemática de sus preceptos, exactamente la misma que podrían deducir todos los demás ciudadanos. Nos hallamos en ambos casos ante un idéntico objeto que se articula a través del mismo instrumento formal (la querella), sin que ello se haga depender del sujeto que lo haga valer ${ }^{725}$. Afirmó por ello el TS que la función del MF era "precisamente el ejercicio de la acción popular o pública, que son palabras que significan lo mismo en orden a la persecución de los delitos" y que "ni la ciencia ni la ley reconocen otra distinción en la acción penal, en cuanto a su ejercicio se refiere, que la de pública cuando lo sea el delito de que nace, y privada siempre que se dirija a perseguir uno de esta clase" 726 . La "acción para el castigo del delito" era siempre la misma y siempre única, y lo que estaba sujeto a variación era únicamente la persona que la deducía.

Para la LECrim lo popular no es el actor sino la propia acción, o más correctamente, el ejercicio de ésta. Las expresiones "actor popular" o "acusador popular" son algo totalmente extraño a nuestro Código procesal penal en su concepción primitiva. El término “acción popular” aparece únicamente en el art. 270 para referirse a lo que el 101 denomina "acción pública", es decir, la que pueden ejercitar todos los españoles. En la primera jurisprudencia, emanada de las SSTS de 28 de enero, 9 y 24 de febrero de 1888 , se decía expresamente que "el adjetivo popular, aplicado a dicha acción, tiene el mismo valor que el de pública de que se vale el art. 101 de la LECrim”. Decir popular sería tanto como decir pública, y en este sentido no se hacía más que seguir la doctrina tradicional de

\footnotetext{
${ }^{724}$ Es más, a aquéllos que percibieran más cercana la ofensa del delito, se les tendría que eximir de ciertos requisitos formales que se imponen a los demás (v.gr. la fianza).

${ }^{725}$ Con la excepción del ejercicio de la acusación por el ofendido, que ostentaría un interés específicamente privado, propio y cualificado.

${ }^{726}$ STS de $_{28}$ de enero de 1888, JC 1888, sentencia n ${ }^{\circ} 86$, p. 174. Así contemplaba también GOLDSCHMIDT el régimen vigente en nuestra LECrim, puesto que para él los funcionarios del MF como querellantes no tendrían una posición distinta de la de los demás querellantes, siempre que se prescinda de que el MF es el promotor iustitiae. GOLDSCHMIDT, J., Principios Jurídicos y Políticos..., op. cit., p. 28.
} 
equiparación entre ambos términos en el ámbito penal y en el administrativo ${ }^{727}$.

Dentro de la terminología legal cabrían únicamente sujetos que dedujeran la “acción popular o pública" (la “acción penal”), los cuales serían más específicamente "querellantes", en tanto acusaban a través de querella. Y puesto que esto podría hacerlo cualquier ciudadano (art. 101, 270 LECrim), incluido el MF que venía obligado específicamente (art. 105, 271 LECrim), estaríamos en cualquier caso ante el ejercicio de la “acción penal”, la única posible, la acción popular o pública para la persecución de los delitos. El MF constituía así un oficial cualificado por la obligación de ejercitar lo que para los demás ciudadanos era un derecho, y lo que hacía era cumplir en razón de su cargo exactamente la misma función que voluntariamente podrían satisfacer los particulares. Entre quienes podían ejercitar la "acción penal" no existiría más distinción que la que se establece entre querellante particular y MF, en tanto ambos se sirven de lo que la ley define como una facultad pública, es decir, abierta ${ }^{728}$.

La interpretación que hemos expuesto no es, sin embargo, la que se ha venido sosteniendo tradicionalmente. AGUILERA DE PAZ aludía ya en los momentos iniciales de vigencia de la LECrim a las críticas de algún sector doctrinal sobre la inconsecuente utilización del término "acción popular" en el art. 270, en relación con el de "acción pública" del 101. A juicio de los autores de los que da noticia, la previsión del último precepto citado denotaría ya la generalidad de su ejercicio ("la manifestación ostensible de que a todos pertenece"). Para ellos, "al decir acción popular no parece sino que a este efecto la sociedad se ha dividido en clases determinadas, siendo sólo patrimonio de alguna de ellas la acción penal y que ésta ha tenido necesidad de vulgarizarse en cierto modo, para que el común de los ciudadanos invoque su adopción”. Sin embargo, en su

${ }^{727}$ ARRAZOLA, Enciclopedia española de Derecho y Administración, Madrid 1848, T. I, p. 324, unificando ámbitos administrativos y penales, se refiere a la acción popular en los siguientes términos: "Se llama así la que puede ejercitar cualquier vecino de un pueblo, y aun muchos unidos, sin necesidad de elegir el más idóneo, por interesarse en el ejercicio de ella el bien pro comunal, como sucede, verbi gracia, en las usurpaciones de caudales y fondos públicos, y en los delitos que ofenden al cuerpo entero de la sociedad". En el Diccionario de ESCRICHE se definía de forma muy similar: “Acción pública o popular es la que se concede por la ley á cualquiera vecino en los asuntos que interesan al pueblo, como v.gr. las usurpaciones de caudales y fondos públicos; y asimismo, en los delitos que se llaman públicos y causan daños al cuerpo social". Con respecto a estos últimos se remite a las voces «acusación», «denuncia», «acusador», «acción civil y criminal». ESCRICHE, J., Diccionario razonado de Legislación y Jurisprudencia, T.I, Madrid 1874, p. 191. ALCUBILLA relata en su Diccionario también: “dábase antes el nombre de acción popular a la que podía ejercitarse por cualquier vecino o muchos unidos en los asuntos que interesan al pueblo, como en lo relativo a caudales, servidumbres públicas, etc.".

\footnotetext{
${ }^{728}$ No hay mención todavía a ofendidos o perjudicados por el delito, sino únicamente a MF y acusador particular (y/o privado).
} 
opinión, la acción ejercitada por los particulares independientemente de su vinculación con el objeto procesal sería la misma y la denominación "popular" sería la adecuada para establecer diferencias con respecto a la deducida por el MF, que sería la "pública". Por ello sostuvo que "la diferente denominación no implica alteración alguna en su naturaleza ni en su carácter, ni constituye modificación alguna en las condiciones de su ejercicio, sino que únicamente se le designa con ese nombre para distinguir el caso de ser utilizada por persona extraña al delito, a fin de que no se confunda con la acción ejercitada por el Ministerio Fiscal, que por ser el representante del interés público o social, se le da el nombre de pública" "729. AGUILERA DE PAZ reserva así la denominación "pública" para la "acción penal" deducida por el MF como representante del interés social.

A nuestro juicio, y a pesar de esta voluntarista hermenéusis del comentarista, no parece que el legislador intentara introducir ninguna diferencia de matiz al usar los términos "acción pública" o "acción popular", por lo que ambos debieron tener significados coincidentes. La distinción posterior entre ellos se basa más en el lógico deseo de diferenciar la actividad del MF de la de los particulares, que en el propio texto de la Ley y en el contexto normativo en el que el código procesal criminal se enmarcaba. Lo que se reconocía era únicamente que la "acción penal" podría ser deducida por todos los ciudadanos y por eso era pública o popular, entendiendo tales palabras como sinónimos. La atribución difusa de la titularidad de la "acción penal" de esta forma no se encontraría sólo en el segundo inciso del art. 101 (“Todos los españoles...”), sino también en el primero ("La acción penal es pública"). El matiz introducido por la consideración de que es pública en cuanto ejercitada por un órgano público parece razonable y se sitúa en la lectura que del mismo término se hace en el derecho comparado, pero no puede considerarse acorde con la literalidad de la originaria Ley. La contraposición públicaprivada no se verificaba en función de los intereses que se defendían en el proceso penal, sino atendiendo únicamente al carácter difundido o restringido de la titularidad de derecho de ejercitarla. Así como lo contrapuesto a la "acción penal" era la "acción civil" (art. 100 LECrim), lo contrario de la "acción pública" no sería la particular acción ejercitada por el

${ }^{729}$ AGUILERA DE PAZ, Comentarios, op. cit. T. III, p. 111. En idéntico sentido ha de reseñarse también a LÓPEZ-MORENO, S., Principios Fundamentales del Procedimiento Civil y Criminal, T. II, Madrid 1901, p. 511, quien afirmaba que "por eso algunos distinguen entre la acción pública, y la acción popular, entendiendo por la primera la que en nombre de la ley, de la sociedad, del Estado y de la Nación o del Rey ejercitaban los funcionarios encargados de pedir ante los Tribunales de Justicia pena para los culpables, y por la segunda, la que se entabla por uno o varios particulares que no fueron perjudicados inmediatamente por el delito". 
ofendido en los delitos públicos (aunque defendiera primordialmente su interés privado), sino la "acción privada" que podrían ejercitar los ofendidos por determinados delitos y sólo ellos, sin que cupiera la intervención de otros sujetos (art. 104 LECrim).

El legislador de 1882 se estaba sirviendo de un vocablo anfibológico que se prestaba en su día, y se sigue prestando en la actualidad, a variadas interpretaciones que han inducido a adoptar diversas posturas ante la cuestión ${ }^{730}$. Pero parece claro que al amparo de una concepción plenamente liberal, se utilizaba un término que ya aparecía en muchas otras de nuestras decimonónicas normas en un sentido de difusión de la facultad de instar un procedimiento. Sirviéndonos de las palabras de PEDRAZ, la publicidad así entendida no era más que la "generalización de los contenidos burgueses constitutivos de la privaticidad" 731 . Por ello, mediante la "publicitación" ni se pretendía su "estatalización", ni se definía teleológicamente como la ejercitada para la defensa de un interés público, sino que simplemente respondía al deseo de su difusión entre todos los componentes de la sociedad. Hablando de "publicidad de la acción" la LECrim no quería decir "oficialidad", ni englobarla en la esfera pública o estatal, ni venía tampoco a definir los fines a los que podría servir, sino que se estaba refiriendo únicamente a una distribución plurisubjetiva de la facultad de entablar lo que se designaba como "acción penal", que comprendería a todos los ciudadanos no excluídos expresamente.

Se venía a decir así implícitamente que la función que en el proceso se encomendaba como deber al MF era la que hubiera podido cumplir cualquier otro ciudadano, anteponiendo y priorizando en el ejercicio de la "acción penal" la teórica condición de

\footnotetext{
${ }^{730}$ Sobre el carácter historicista y anfibológico del término publicidad vid. PEDRAZ PENALVA, E., "Notas sobre publicidad y proceso", op. cit. pp. 203 y ss. y 215 y ss. En este aspecto es además de obligada referencia la obra de HABERMAS, J., Strukturwandel der Öffentlichkeit, op. cit. Se refire este último autor (pp. 13-14) a los múltiples significados a los que se hace referencia con el término «publicidad», y así puede decirse que una institución, plaza o casa, es «pública» cuando, contrariamente a las sociedades o lugares cerrados, sea accesible a todos. Publicidad y accesibilidad no son sin embargo siempre equivalentes: un edificio público no es aquél susceptible de acceso general sino que es el destinado a albergar instituciones del Estado que, en cuanto tales, son públicas. Cuando se utiliza para calificar una recepción como pública existirá una representatividad en cuya «publicidad» se ve implicado algo de reconocimiento público. En el ámbito de los medios de comunicación de masas la «publicidad» también varía su significado. La publicidad misma se ofrece como una esfera: frente al ámbito privado está el público; ámbito público que a veces aparece simplemente como la esfera de la opinión pública, que precisamente se contrapone al poder público. De este modo, se usa el vocablo publicidad para aludir a los órganos del Estado o, contrariamente, a medios que, como la prensa, sirven a la comunicación con el público.

${ }^{731}$ PEDRAZ PENALVA, E., "Notas sobre publicidad y proceso”, op. cit. p. 219 en relación con la noción liberal de la "publicidad" de la ley. La evolución de la distinción entre lo "privado" y lo "público" se encuentra expuesta en las pp. 217 y ss. Vid. también "Publicidad y derecho al debido proceso. Publicidad y derecho de acceso a la información contenida en los ficheros de datos jurisdiccionales”, en $R G D \mathrm{n}^{\circ}$ 631, abril 1997, pp. 3894 y ss.
} 
derecho individual frente a la de obligación estatal. El trasfondo ideológico, político y filosófico de la cultura penal predominante se superpuso en la acusación popular a una institución histórica de nuestro derecho ${ }^{732}$, que venía a concitar aspiraciones de libertad individual entroncadas en el pensamiento de la época. No era admisible que la racionalidad y fiabilidad del juicio penal pudieran depositarse por completo en una autoridad estatal ligada histórica y orgánicamente al Ejecutivo ${ }^{733}$, expropiando explícitamente una facultad, teóricamente consustancial a la condición ciudadana. El que en España no se alzaran apenas o no prevalecieran las voces que defendían la subsidiariedad del ejercicio de la acusación nos proporciona una pista sobre la visión prioritariamente privada y no oficial de la acusación en nuestra bibliografía decimonónica: no era una función estatal que en determinados casos pudiera atribuirse a los ciudadanos sino, antes al contrario, una actividad privada que sólo a posteriori se atribuyó al MF y para la que tanto a éste como al ofendido se eximía de ciertos requisitos formales (fianza, prohibiciones, etc.). El entendimiento de la acusación pública como función estatal no habría hecho en aquel momento sino recordar consideraciones entroncadas con una visión inquisitiva del proceso penal ${ }^{734}$ y hubiera significado depositar una confianza casi ilimitada en la bondad del Estado como fuente de todo poder. Todo ello resultaba simplemente inadmisible para la mentalidad imperante en ese momento de nuestra historia y, por ende, también para la de nuestro legislador. En vías de instauración del régimen liberal, puede ello considerarse muestra de una concepción conservadora del derecho penal entendido como fórmula ideal de control social, garantizado a su vez por un derecho a una acción negativa del Estado: la no intromisión en el ejercicio de la acusación ${ }^{735}$.

\footnotetext{
${ }^{732}$ Y que por otro lado no es ajena a algún momento intermedio en el tránsito entre la primitiva justicia penal privada basada en la venganza de los próximos y la administración de la justicia penal entendida como función exclusiva y excluyentemente estatal, en la que progresivamente asume el Estado la determinación del castigo y el procedimiento para su imposición. Ello sin perjuicio de singulares modulaciones como las que supuso el juicio de manifestación. Al respecto, además de la inglesa Carta Magna, vid. FAIRÉN, V., "El proceso aragonés de Manifestación y el británico de «Habeas Corpus»" en Temas del Ordenamiento procesal, T. I, pp. 131 y ss.

${ }^{733}$ Conviene recordar que hasta 1881 se confundían en un mismo cuerpo las funciones que hoy desempeñan los Abogados del Estado y el MF.

${ }^{734} \mathrm{Al}$ fin y al cabo es incuestionable que el carácter público y no privado de la acusación es de ascendencia inquisitiva. Sólo en la separación en diferentes personas del ejercicio de las funciones de acusar y juzgar se puede detectar el tránsito entre ambas concepciones.

${ }^{735}$ Cabe recordar aquí, en conexión con la parte histórica de este trabajo, que tal reconocimiento se hacía sin embargo sólo sobre el papel y con una fórmula que tenía más de retórica que de verificable en la práctica. Una vez comenzado el proceso, y puesto que el fiscal estaba obligado a personarse en todos los sumarios aunque no hubieran
} 


\subsubsection{Inadecuación del término "acción pública” para designar la acusación de los particulares no ofendidos}

El sentido del término "acción pública", entendido como pretensión deducible en defensa del interés general, se ha visto supeditado doctrinalmente con el tiempo a otro en el que sólo permanece el objetivo perseguido con ella, sin atención al sujeto que pudiera plantearla. A su tenor, la publicidad de la "acción" se basaría en la finalidad, en las notas que la acompañan y en los efectos que produce ${ }^{736}$. Si en el caso del MF este ejercicio se trataría de un deber (art. 105 LECrim), en el de los particulares el dato clave sería el de estar "animada por un interés cívico en restablecer el orden jurídico perturbado por la comisión del delito" ${ }^{" 737}$. La coincidencia entre las metas que persiguen la actividad del MF en el proceso penal y la de los sujetos no ofendidos es, sobre todo, la que ha provocado con el tiempo la inclusión de ambas "acciones" bajo el adjetivo "pública".

Esta lectura de la publicidad de la "acción penal" se basa sobre un fundamento que ha de ser ineludiblemente aceptado, en cuanto efectivamente con el ejercicio de la pretensión penal se deducen intereses públicos, aunque para nosotros no sea extensiblemente aplicable a lo previsto en la LECrim sobre la actividad de los acusadores privados no ofendidos. Dado que los términos de la Ley respondían a una idea de la "publicidad" vinculada a su generalización subjetiva y no a su finalidad, la identificación entre ambos significados se estaría haciendo por tanto sobre planos diferentes. Tal hermenéusis respondería sólo a una racional necesidad, cual es la de distinguir las motivaciones de los sujetos no ofendidos por el delito frente a la de los que sí lo han sido, sean éstos los únicos habilitados para su ejercicio o no, pero vendría a desconocer que, en último término, lo que originariamente se contenía bajo el término "pública" era la extensión plurisubjetiva del reconocimiento de un puro y genuino interés privado en la persecución de los delitos, atribuido singular y específicamente a cada ciudadano.

sido incoados a su instancia (art. 306 LECrim), sólo cuando no quisiera acusar tendría sentido la intervención en defensa del interés público de un acusador no ofendido. Simplemente no cabría ejercitar una acción que ya estaría siendo sostenida por otro sujeto.

${ }^{736}$ MUÑOZ ROJAS, T., "En torno al acusador particular en el proceso penal español”, RDProc (Ibam) 1973, p. 117.

${ }^{737}$ Así p. ej. GIMENO SENDRA, V., La Querella, op. cit. p. 88, n. 209. 
La disimilitud entre la actividad del fiscal y la de los sujetos privados no admite, por tanto, su trasplante a la actualidad con base en una visión desconocedora de los parámetros desfasados en los que nuestra ley procesal recogió el término "pública", modulándolo de manera acomodaticia al deseo de que se refiera a la abstracta defensa de intereses generales. Por ello, y para no caer en errores interpretativos, se hace menester el reconocimiento expreso de que la "publicidad de la acción" en el sentido de la LECrim no es la "publicidad" que hoy ha de predicarse del ejercicio de la pretensión en el proceso penal. Por la anfibología del término y por su posible confusión con lo "público", lo "oficial" o lo "estatal", en nuestro criterio, los términos "acusador público" o "querellante público" no deben ser estimados válidos para designar a los acusadores no ofendidos por el delito. Es más, a tenor de la concepción que mantenemos en torno a lo que haya de entenderse por "acción penal", toda "acción penal" habrá de ser considerada pública ya que ciertamente persigue un interés social, y como tal se integra en la esfera estatal constituyendo la debida respuesta procesal a un deber público.

El término "acción pública"738 no nos serviría para distinguir la actividad del MF frente a la de los ciudadanos que, aguijoneados por su espíritu cívico o por intereses específicamente privados nunca descartables, se sirven de las facultades que la ley les otorga en este sentido. No obstante, ello no obedece a la posibilidad de que ambos estén movidos por un diferente interés, sino precisamente a que no cabe distinción alguna en función de la naturaleza de su actividad, ni en la propia actividad en sí: lo que ejercitan es exactamente la misma "acción", la única posible, la pretensión estatal en que consiste la acusación por delito. No cabrá en definitiva hablar de una "acción pública" entablada por el MF y de otras deducidas por cualquier ciudadano, sino que sólo en singular podremos referirnos a la "acción penal pública" o más correctamente a la "pretensión penal" o "acusación", promovida por uno o por otros, e incluso al amparo del régimen legal vigente, por ambos simultáneamente.

\subsubsection{La denominación de los diversos sujetos acusadores}

El hecho de que las personas que, junto con el MF, se sitúan de forma contingente

\footnotetext{
${ }^{738}$ Y de la misma manera, tampoco el de "querella pública". Dada la falta de claridad de la Ley, con frecuencia se ha recurrido para definir la "acción penal" a características propias de la querella, en tanto ésta es la forma principal en que aquélla se ejercita. Se ha operado así en ocasiones una inadecuada permuta entre lo que es un mero instrumento, desde luego no carente de trascendencia, y el conjunto de actos a cuya realización sirve.
} 
en la acusación sean designadas de muy diversas formas por el legislador de 1882, ha sido fuente de numerosas, y en gran parte comprensibles, confusiones por parte tanto de la doctrina como de la jurisprudencia. En la LECrim se puede encontrar un amplio conjunto de denominaciones en el que puede entenderse englobados a los acusadores, sin que quepa atribuir el mismo sentido a éstas en todas las ocasiones en que son utilizadas. Ni siquiera cabe establecer diferencias en función de las diversas fases por las que atraviesa el procedimiento, porque la Ley habla de acusadores desde los primeros momentos procesales $^{739}$.

Los acusadores diferentes al MF son designados en la LECrim bajo las siguientes denominaciones:

$1^{\circ}$ ) QUERELLANTE: en los arts. 275, 276, $277.2^{\circ}$ y 7, 448, 468, 471, 476, 627, $629,638,962,969$

$\left.2^{\circ}\right)$ QUERELLANTE PARTICULAR: en los arts. 240.3 , 317, 385, 501, 529, 623, $642,644,645,689,967,969$.

$3^{\circ}$ ) PARTICULAR QUERELLANTE: en los arts. $273^{740}, 274,280$

$\left.4^{\circ}\right)$ PARTES $^{741}$ : en los arts. 23, 26, 34, 36, 38, 39, 44, 54.2 ${ }^{\circ}$ y $4^{\mathrm{o}}, 76,81,472,483$, $621,653,654,656,662,669,673,678,685,708,712$ 724, 728, 729, 730, 732, 733, 737, $738,743,745,746,789.3$.III y $789.5 .4^{\mathrm{a}}$ y $5^{\mathrm{a}}, 792,793,794,798,850.1^{\mathrm{o}}, 854,857,858$, 861,867 bis, $874,880,882,882$ bis, $884.5^{\circ}, 894,951,952$

$5^{\circ}$ ) PARTES PERSONADAS: en los arts. 302, 311, 504.bis.2, 657, 668, 780, 782, $787.3,789,790.2,867$

$6^{\circ}$ ) PARTE ACUSADORA: en los arts. 646, 655, 790.1 y $6,793.1^{\circ}$ y $7^{\circ}, 850.2^{\circ}$,

${ }^{739}$ Ello es visto como una verdadera anticipación terminológica por MONTERO AROCA, en tanto a su juicio la acusación en sentido estricto sólo aparecerá en la segunda fase del proceso, en el juicio oral. Su mantenimiento sería razonable en opinión de este autor por ser la terminología tradicional y no existir razones de peso para su modificación. MONTERO AROCA, J., et al. Derecho Jurisdiccional, op. cit. p. 55. Lo considera también una anticipación terminológica pero se pronuncia en contra de su mantenimiento PASTOR LÓPEZ, M., El proceso de persecución. Análisis del concepto, naturaleza y especificas funciones de la instrucción criminal, Valencia 1979, pp. 68 y ss., quien optaba por la denominación "persecutor" para designar al acusador en la fase de instrucción, lo que no ha sido aceptado por el resto de la bibliografía.

\footnotetext{
${ }^{740} \mathrm{El}$ precepto se refiere exactamente al "particular que intentare querellarse".

${ }^{741}$ Incluimos aquí también las abundantes referencias a los "representantes de las partes" o a los "defensores de las partes", que evocan la defensa de pretensiones propias y personales de los acusadores.
} 
$7^{\circ}$ ) ACUSADOR PRIVADO: en los arts. $54.5^{\circ}, 385,622,659,681,875$

$\left.8^{\circ}\right)$ ACTOR: en los arts. 471, 701

$9^{\circ}$ ) ACTOR PARTICULAR: en los arts. 142, 466

$10^{\circ}$ ) ACUSADOR PARTICULAR: en los arts. $19.5^{\circ}, 37,53,105,108,141,651$, $734,790.3$ y $4,900,993$

$\left.11^{\circ}\right)$ ACUSADOR/ES: en los arts. 368, 680, 906

$12^{\circ}$ ) LA ACUSACIÓN (LAS ACUSACIONES): en los arts. 739, 741, 790.3, $793.3^{\circ}, 6^{\circ}, 7^{\circ} 8^{\circ}$ y $9^{\circ}, 851.2^{\circ}$

$13^{\circ}$ ) ACUSACIÓN PARTICULAR: en los arts. $790.6^{\circ}$

$14^{\circ}$ ) ACUSACIONES PERSONADAS: en los arts. 790.1 y 2

En la LECrim existe como se ve una grave confusión en el empleo de los términos con los que se designa a los acusadores privados, agravada por la interpretación que con posterioridad se ha dado a tales vocablos. A la vista de esta pléyade de designaciones y de su polisémica plasmación en los diversos trámites procesales, puede afirmarse que el legislador sólo atinaba a distinguir con nitidez dos supuestos en la formulación de la acusación: el ejercicio por el MF o el realizado por un sujeto particular.

El entendimiento actual de la Ley ha llevado a constatar a menudo una falta de correspondencia con el tenor literal de la norma, llegándose a argumentar a este respecto que el predicado rigor técnico de nuestra más que centenaria LECrim en otras materias, no sería más que un vano deseo en ésta ${ }^{742}$. Sin embargo tal disenso conceptual entre los términos de la Ley no procede de la propia norma, sino de forzadas lecturas de ésta por parte de la doctrina y la jurisprudencia. La presunta falta de rigor técnico no es sólo imputable a la propia Ley, sino muy significativamente a inadecuadas interpretaciones de

\footnotetext{
${ }^{742}$ MONTERO AROCA ha intentado aclarar alguno de los supuestos de posible discordancia entre el texto de la ley y su significado: 1) En ocasiones cuando habla de acusador particular se está comprendiendo a todos los acusadores, con excepción del Ministerio Fiscal, aunque otras veces se refiera al querellante particular e incluso al actor particular; 2) a veces las expresiones acusador o querellante particular no pueden incluir en ningún caso al acusador privado; 3) otras veces las diferencias entre acusador particular y privado son evidentes; 4) por último, no faltan casos en los que la expresión acusador privado tiene que significar necesariamente acusador popular. MONTERO AROCA, J., Derecho Jurisdiccional, op. cit., T. III, p. 69.
} 
su literalidad y también a poco afortunados añadidos legislativos posteriores al amparo de aquéllas, cuyo objetivo sería el de dar cabida a realidades no contempladas en origen. A tenor de visiones sujetas a concepciones diferentes de las que inspiraron al legislador, los preceptos carecen lógicamente de sentido, por lo que se ha hecho necesario adaptarlos al molde que proporcionan las nuevas ideas.

La LECrim pensaba en una única "acción penal" cuyo ejercicio se atribuía a los particulares en general y, entre ellos, al MF, al cual además se le exigía su satisfacción. Era la misma acción y no podía ser otra porque del ilícito no surgía más que ésta (y, eventualmente, la civil) pero era también lógico pensar que particulares y MF no pudieran gozar exactamente del mismo régimen procesal, por lo que la intervención de los primeros se tendría que encauzar por una vía y la del segundo por otra. En ausencia de una vía específica para la intervención de los no ofendidos, ésta se encontró no a través de la que la Ley habilitaba para el defensor del interés público, sino de la prevista para la defensa de un interés genuínamente privado: el del ofendido por el delito. Allí donde la ley decía "querellante particular" o "actor particular", cualquier ciudadano quedaba englobado en la denominación. Con ello se incurría en una contradicción en el caso de los acusadores no ofendidos: mientras que el único interés que pueden defender es el público en el enjuiciamiento, la articulación de su intervención procesal se sustenta sobre la base de las vías habilitadas para la defensa de intereses materiales privados ${ }^{743}$.

\subsubsection{Acusación popular, acusación particular y acusación privada}

La distinción terminológica a la que nos referimos a continuación no se deduce de la propia Ley, sino de la práctica judicial ${ }^{744}$, se consolidó con la legislación procesal complementaria $^{745}$ y adquirió plena carta de naturaleza a través de su aceptación

\footnotetext{
${ }^{743}$ Tal equiparación sólo puede ser explicada teniendo en cuenta que lo que el legislador estaba haciendo era una mera declaración retórica de trascendencia política, pero sin visos ni esperanzas de que pudiera en algún caso ser utilizada por los no ofendidos.

${ }^{744}$ De ella daba noticia por ejemplo BELLÓN GÓMEZ, I., Apuntes de procedimientos judiciales y práctica forense, T. III, Procedimientos Penales, Madrid 1941, p. 154. En este caso se fijaba el autor en la obligatoriedad de prestar fianza como criterio de distinción entre el "acusador privado" y el "acusador popular".

${ }^{745}$ Vid. el Decreto de 13 de junio de 1927 relativo a normas para el ejercicio de las acciones penales a que se refiere el Título IV del Libro I LECrim. Su art. 2 especifica ya que cabe un ejercicio privado y un ejercicio público de la acción penal en los siguientes términos: “cuantos pretendan ser admitidos como parte..., sea como ofendidos o como perjudicados por un delito, o ejercitando la acción pública”.
} 
doctrinal ${ }^{746}$. De ahí que hoy se reserve habitualmente el nombre de "acción popular" o "acusación popular" a la ejercitada por quien no ha sido ofendido (o perjudicado) por el delito, prefiriéndose la de "acusación particular" para quien sí lo haya sido y la de "acusación privada" para la que realiza de forma exclusiva el particular ofendido en los delitos privados. Esta clasificación es una creación artificiosa, sin correspondencia exacta con el texto de la Ley, pero que ha de entenderse útil para designar lo que en verdad son realidades muy diferentes entre sí. Puesto que la Ley sólo distinguía subjetivamente entre MF y acusadores privados, independientemente de si éstos eran los únicos que podían ejercitar la pretensión o si cabía su ejercicio también por otros sujetos, la confusión era en este sentido determinante de posibles errores. Los intentos de aclaración han de considerarse por ello bienvenidos.

El art. 270 LECrim prescribe que "Todos los ciudadanos españoles, hayan sido o no ofendidos por el delito, pueden querellarse ejercitando la acción popular establecida en el art. 101 de esta Ley". El precepto habilitante para el ejercicio de la acusación es, por tanto, idéntico para todos los ciudadanos, y al ofendido por el delito, como fue señalado por GÓMEZ ORBANEJA, parece venirle atribuida la facultad de deducir la pretensión penal en cuanto ciudadano y no precisamente por su calidad de perjudicado por aquél. La "acción penal" entablada por él será también una acción popular, pues la LECrim no hace distinción entre ofendidos o no por el hecho perseguido ${ }^{747}$. La titularidad de esta facultad no la daría el carácter de ofendido sino la condición genérica de ciudadano español ${ }^{748}$. La

\footnotetext{
${ }^{746}$ La autoría de esta distinción, que se mantiene hoy día, fue no obstante reclamada por FENECH en su Derecho Procesal Penal, $3^{\mathrm{a}}$ ed. Barcelona 1960, p. 137, al decir que "esta distinción implícita en la ley fue puesta de relieve por nosotros, recogida luego en los programas de oposiciones y obras doctrinales y trabajos aunque sin hacer referencia a su origen". Con ello omitía los precedentes legales y de la práctica forense sobre los que se basaba.

${ }^{747}$ Incluso la Jurisprudencia olvidó durante mucho tiempo, quizá por la falta de uso, que la previsión de la Ley reconociendo la posibilidad de acusar incluía también a los no ofendidos, poniendo trabas a su ejercicio cuando era el caso. Vid. por ejemplo STS de 15 de febrero de 1927 (Jurisprudencia Criminal 1927, p. 201), que tratándose del delito público de estafa afirma "la acción penal puede ser ejercida por el ofendido y sus herederos, concepto que no alcanza al endosatario de un crédito impagado". En el mismo sentido, algo más cercana en el tiempo, la STS de 4 de noviembre de 1971 (RAJ 4470) afirma que la acción penal se ejercita "por su cualidad de ofendidos".

${ }^{748}$ Como señalaba GÓMEZ ORBANEJA, “si suprimiéramos en LECrim 101 y 270 \& 1 -si se quiere, con las reglas instruccionales que de ellos derivan-, sin añadir nada, el ofendido por el delito quedaría tan despojado de la acción como el no ofendido". Quien no goce de la plenitud de los derechos civiles no adquiere la capacidad por el hecho de ser el ofendido; lo que adquiere es la titularidad en la acción. La distinción terminológica se habría hecho sólo en la práctica judicial, reservándose el nombre de acción popular a la ejercitada por quien no sea ofendido (o perjudicado) por el delito. Debemos reseñar que, si bien es cierto que la LECrim no distinguía expresamente, sí permitía hacerlo implícitamente, y de hecho en otros de sus preceptos lo está haciendo. La ley utiliza la vía del 101 para que el ofendido entre en el proceso como los demás particulares, pero una vez dentro de éste, a él le marcaba el
} 
Ley tendría en cuenta la condición de ofendido únicamente a efectos del diferente régimen procesal de su intervención frente al del resto de los ciudadanos, pero no directamente en cuanto a la propia atribución de la facultad procesal ${ }^{749}$. Los arts. 101, 270 y concordantes LECrim se refieren a modalidades del ejercicio, pero no a la atribución de la capacidad para el ejercicio de la pretensión penal, ni al título constitutivo de tal atribución $^{750}$.

El diverso entendimiento de los términos de la Ley sigue vigente en la literatura según es comprobable, sin ánimo de exhaustividad, en algunas de las denominaciones utilizadas para designar la misma realidad: MUÑOZ ROJAS incluye en el concepto de "acusador particular" también al no ofendido por el delito ${ }^{751}$; ALMAGRO, a la inversa, extrae el de "acusación particular" de la "acción popular" "752, término que ha encontrado el respaldo constitucional; ROBLES GARZÓN habla en general de "acusadores privados"753; GIMENO por su parte se refiere a "querella pública"754 y "querellantes públicos", pero no pone en cuestión las denominaciones "acción popular", "755 o "acusación popular" "756 ; MUERZA ESPARZA incluye en la rúbrica "acusador particular" a todas las

camino por el que ha de desarrollar su actividad y a los demás no.

${ }^{749}$ Estas diferencias eran observables en lo referido a la notificación ordenada en el art. 109 y concordantes LECrim, en relación con el derecho del actor habilitado para obtener beneficio de justicia gratuita (119 LECrim, hoy derogado) o en la exención de fianzas (280 y 281 LECrim).

${ }^{750}$ GÓMEZ ORBANEJA, E., Comentarios..., op. cit. T. II, p. 225. Atendiendo al hecho de que en todo caso se está ejercitando la acción popular, GÓMEZ ORBANEJA se refiere siempre con buen criterio a la acusación ejercitada por el no ofendido ni perjudicado por el delito como "acción popular stricto sensu". De esta manera pretende establecer una diferencia de matiz esencial, que aun cuando no se contiene expresamente en la ley, sí está implícito en ella.

${ }^{751}$ MUÑOZ ROJAS, T., "En torno al acusador particular en el proceso penal español”, RDProc (Ibam), 1973, pp. 105-107 passim.

${ }^{752}$ ALMAGRO NOSETE, J., "La acción popular" en La Reforma del Proceso Penal, II Congreso de Derecho Procesal de Castilla y León, Madrid 1989, p. 226: "la acusación particular, expresión de la acción popular...".

${ }^{753}$ ROBLES GARZÓN, J.A., “El acusador privado”, RDProc 1978, pp. 533-571.

${ }^{754}$ GIMENO SENDRA, V., La Querella, op. cit. passim.

${ }^{755}$ GIMENO SENDRA, V., "La acción popular, el jurado y los Tribunales de escabinos”, en COBO DEL ROSAL y BAJO FERNÁNDEZ, Comentarios a la legislación penal, T. I, pp. 338 y ss.

${ }^{756}$ GIMENO SENDRA, V., “La acusación popular”, $P J \mathrm{n}^{\mathrm{o}}$ 31, septiembre 1993, pp. 87 y ss. En la traducción al francés de este artículo el autor ha optado por la denominación "accusation publique". Vid. "L'accusation publique 
personas distintas del Ministerio Fiscal que ejercitan la "acción penal" por hechos que revisten caracteres de delito de los llamados públicos o semipúblicos (en los privados será el acusador privado ${ }^{757}$. La doctrina se ha servido además para designar el ejercicio de la acusación por los particulares de términos tales como "persecución particular genérica",758, "acusación pública",759, "persecución particular"760, "acción pública penal" 761 , "acusación no oficial" 762 , etc., intentando marcar en todo caso distancias entre la acusación planteada por el MF y la de los ofendidos por el delito.

Hoy es generalmente aceptada por todos, utilizada en la práctica forense y en la jurisprudencia, la denominación "popular" para referirnos al desempeño de la acusación por cualquier ciudadano no ofendido y la de "particular" para la hipótesis en que sea el ofendido o perjudicado quien acuse. Parece coherente pensar que, a diferentes supuestos de hecho que acarrean desemejantes consecuencias jurídicas, realidad con la que nos enfrentamos, deban darse diversas denominaciones. En ese sentido, la distinción terminológica, aun no presente originariamente en la ley, está plenamente consolidada y puede ser considerada válida sin reproche alguno. Como se verá a continuación, lo popular no es la acusación en sí, calificativo que en verdad acota una modalidad de su ejercicio, por lo que podríamos hablar de "acusación ciudadana", "acusación cívica",

en Espagne”, Revue de Science criminelle et de droit pénal comparé, nº 4, 1994, pp. 739 y ss.

${ }^{757}$ MUERZA ESPARZA, J., en DE LA OLIVA, A., et al. Derecho Procesal Penal, Madrid 1993, p. 133.

${ }^{758}$ ZAFRA, J., "Posición del Ministerio Fiscal en el futuro proceso penal”, RDProc. 1961, n 4, p. 790. ZAFRA designa con el término "persecución particular genérica" al conjunto de actividades (presentación de la querella, proposición de diligencias instructorias, formulación de conclusiones, etc.) en que se manifiesta el ejercicio de la acción popular.

${ }^{759}$ GIMENO SENDRA, V., "La fianza...”, op. cit. p. 65, y por derivación también el de "querella pública”, $L a$ Querella, op. cit. passim.

${ }^{760}$ PASTOR LÓPEZ, M., El proceso de persecución, pp. 69 y ss. En este caso se refiere sólo a su intervención en la fase de instrucción en tanto no acusa propiamente hasta no deducir el escrito de calificación provisional. El persecutor particular pasa a asumir la calidad de acusador particular al deducir acusación concreta contra el inculpado, es decir, al ejercitar la pretensión punitiva y de resarcimiento en su caso en el escrito de calificación provisional.

${ }^{761}$ LOZANO-HIGUERO y PINTO, M., La protección procesal de los intereses difusos, Madrid 1983, p. 28.

${ }^{762}$ ORTELLS RAMOS, M., "El nuevo procedimiento penal abreviado: aspectos fundamentales”, JUSTICIA 89, p. 548, "Las partes no oficiales en el proceso penal abreviado", en LA LEY n ${ }^{\circ} 3983$, pp. 1-7 passim. Ambos artículos han sido incluidos en el volúmen El proceso penal abreviado (nueve estudios), Granada 1997, pp. 1 a 24 y pp. 79 a 102 , respectivamente. 
"acusación sostenida por particulares" e, incluso, de ejercicio popular de la acusación, ejercicio particular de la acusación, ejercicio cívico de la acusación, ejercicio privado de la acusación, etc. Debe advertirse que si a partir de este momento seguimos hablando de “acusación popular” es, únicamente, con el ánimo de procurar no oscurecer la exposición. En modo alguno se intenta designar por ende un objeto diverso, sino una de las formas para hacer valer la acusación.

\subsection{La pretensión penal: la acusación}

\subsubsection{Adaptación del concepto de pretensión al ámbito penal}

El concepto de "pretensión” fue desarrollado por ROSENBERG al oponerse a la teoría de la acción como "pretensión de tutela de derecho" (Rechtsschutzanspruch)" pero es a GUASP a quien corresponde el mérito de haberlo aislado frente al de acción en el ámbito civil ${ }^{764}$. Para GUASP no existiría una acción y una pretensión como conceptos distintos, sino simplemente un derecho de acción, no procesal, que se concreta en una pretensión procesal considerada no como acto único, sino como conjunto de actos realizados por la parte. La pretensión constituiría el inequívoco objeto del proceso civil, es decir, sería la reclamación que una parte dirige a la otra ante el Juez sobre un bien de la vida en litigio ${ }^{765}$.

En sede criminal, la bibliografía tradicional ha visto la pretensión en nuestro

${ }^{763}$ ROSENBERG define la pretensión como la petición dirigida a la declaración de una consecuencia jurídica con autoridad de cosa juzgada que se señala por la solicitud presentada y por las circunstancias de hecho propuestas para su fundamentación. El Juez está obligado sólo por esto, pues sólo debe decidir si la consecuencia jurídica pretendida por el actor se ha producido y existe o no, y no puede concederle ninguna otra consecuencia jurídica. Derecho Procesal Civil II, Buenos Aires 1955, Traducción de ROMERA VEGA, A., pp. 30 y ss.

${ }^{764}$ GUASP DELGADO, J., La pretensión procesal, publicado originariamente en Anuario de Derecho Civil, enero-marzo 1952, fasc. 1, T. V y reeditado como libro con el mismo título, Madrid 1981. La concepción de GUASP, aceptada mayoritariamente entre nuestra doctrina, se encuentra muy bien expuesta e incluso glosada en sus aspectos más oscuros en SERRA DOMÍNGUEZ, M., "Evolución histórica...”, op. cit. pp. 74 y ss.También ALCALÁ-ZAMORA hizo ver la gravitación romanista que se advierte en la persistencia con que se sigue hablando de acción en hipótesis donde el término correcto a emplear sería el de pretensión. ALCALÁ-ZAMORA y CASTILLO, N., "Enseñanzas y sugerencias de algunos procesalistas sudamericanos acerca de la acción”, publicado en Estudios de Derecho Procesal en honor de Hugo Alsina, Buenos Aires 1946 y en Teoría General e historia del Proceso, 1945-72, México 1974, p. 325.

${ }^{765}$ GUASP, J., La pretensión procesal, op. cit. p. 58. 
ordenamiento jurídico como una declaración de voluntad por la que se pide la imposición de una determinada pena con base en un fundamento fáctico, el hecho de la vida real, y un fundamento jurídico, la norma material penal ${ }^{766}$. A tenor de este criterio, podría estimarse que en el proceso penal es dable hablar de una verdadera pretensión ${ }^{767}$, que implica una petición de pena respecto de un hecho aparentemente antijurídico y que se plasmará en las conclusiones definitivas, una vez finalizada la práctica de la prueba. Dentro de los principios básicos respetados comúnmente en orden a la no vinculabilidad de la calificación jurídica o de la pena, toda condena habrá de requerir el mantenimiento a lo largo de todo el procedimiento hasta su terminación de una acusación. No sólo es un requisito para la incoación del procedimiento, sino que también es presupuesto ineludible para poder emitir un fallo condenatorio. La adscripción del ius puniendi al Estado en régimen de monopolio no implica que éste sea dueño absoluto de la aplicación o individualización de la pena, pues los acusadores pueden establecer, como así ocurre, ciertos límites a la actividad decisoria del tribunal mediante la determinación de los hechos objeto del proceso o, precisamente, por vía de sus pretensiones ${ }^{768}$.

Sobre la pretensión en el proceso penal y su relación con el principio acusatorio destacadamente se ha ocupado, entre otros autores, ASENCIO MELLADO. Admite este autor la existencia de pretensión en el ámbito penal entendida como el presupuesto ineludible para la punición consistente en una declaración de voluntad que se ejercita en las conclusiones definitivas, tendente a la imposición de una pena respecto de un hecho aparentemente antijurídico ${ }^{769}$. La pretensión punitiva, identificada con el derecho subjetivo estatal de penar sería la pretensión estatal a la pena frente al autor del delito, si

\footnotetext{
${ }^{766}$ Cfr. FENECH, M., Derecho Procesal Penal, p. 393; FAIRÉN GUILLÉN, V., Voz “Acción”, op. cit. p. 202; GIMENO SENDRA, V., La Querella, op. cit. p. 241.

${ }^{767}$ FAIRÉN se refiere a ella como "pretensión procesal penal", distinguiéndola de la "pretensión punitiva" puesto que ésta sería la potestad de penar y la primera ocupa el lugar correlativo al de la pretensión procesal civil. FAIRÉN GUILLÉN, V., Voz “Acción”, op. cit. p. 202, n. 122.

${ }^{768}$ En este sentido vid. GIMENO SENDRA, V., Fundamentos..., op. cit. p. 190. Cfr. también MORENO CATENA, V., "La justicia penal y su reforma", JUSTICIA 1988, n 2, p. 316, para quien la aplicación de fórmulas de transacción como las del 793.3 LECrim implicaría ya una cierta disposición sobre el objeto por parte tanto de los acusadores cuanto de la defensa.

${ }^{769}$ ASENCIO MELLADO, J.M., Principio acusatorio y derecho de defensa en el proceso penal, Madrid 1991, pp. 37 y s.
} 
bien subordinada a la petición de un tercero que solicita su actuación ${ }^{770}$. Sería posible en el juicio penal sostener la existencia de verdaderas pretensiones punitivas vinculantes cuya ausencia, ab initio o constante el proceso, implicaría privarle de objeto con la imposibilidad de condenar, por tanto, a un no acusado ${ }^{771}$. El concepto de pretensión se habrá de reconducir a criterios estrictamente procesales, sin definirse por ello sobre datos atinentes a la titularidad del derecho afirmado. La pretensión no es equivalente al derecho material, el cual puede efectivamente existir o no, aun cuando en la pretensión se afirme como existente, sin que su posible inexistencia sea óbice para su operatividad ${ }^{772}$. La pretensión será por tanto, dice ASENCIO, la mera afirmación de la existencia del derecho, y en este caso, del ius puniendi ${ }^{773}$.

La aplicabilidad del concepto de pretensión en el proceso penal como declaración de voluntad a través de la que se solicita la imposición de una pena ha sido sin embargo criticada de un lado por quienes ven en ella una vía de privatización de la imposición de las penas, en cuanto se deja en manos de particulares o del $\mathrm{MF}^{774}$, y por otro por los que entienden que en el proceso penal no se darían todos los elementos identificadores de una verdadera pretensión ${ }^{775}$.

${ }^{770}$ ASENCIO MELLADO, J.M., Principio acusatorio..., op.cit. pp. 22 y ss.

${ }^{771}$ ASENCIO MELLADO, J.M., Principio acusatorio..., op. cit. pp. 27 y 34 y ss. Tal afirmación es sostenida teniendo en cuenta que los acusadores sí pueden establecer límites a la actividad decisoria del tribunal, no sólo por medio de la determinación privativa de los hechos a enjuiciar, sino en virtud de sus pretensiones en sentido más amplio, por lo que a los acusadores se les otorga cierto poder de disposición sobre el derecho de penar. El Estado, en tanto Poder Judicial, está subordinado en la imposición de penas a la petición de otros sujetos los cuales no han de ser necesariamente públicos. Viene así a identificarse la pretensión con el objeto del proceso, considerando que éste está constituido por el hecho punible encajado en un acto o derecho más general. El hecho es el elemento objetivo de la pretensión, que a su vez deberá contemplarse desde su vertiente de antijuricidad. La pretensión penal se identificará en atención al hecho punible, jurídicamente relevante y que no será susceptible de mutación, pero nunca por un específico título de condena o por un petitum determinado.

${ }^{772}$ ROSENBERG, L., Tratado de Derecho Procesal Civil, T. I, Buenos Aires 1951, p. 211; GUASP DELGADO, J., La pretensión procesal, op. cit. pp. 58 y ss.

${ }^{773}$ ASENCIO MELLADO, J.M., Principio acusatorio...., op. cit. pp. 38 y s.

${ }^{774}$ Así CORTÉS DOMÍNGUEZ que rechaza la teoría de la pretensión jurídica punitiva. Vid. La Cosa Juzgada Penal, op. cit. pp. 35 y ss.

${ }^{775}$ Este argumento se basa, según ha sido formulado por MONTERO AROCA, en las siguientes razones: 1) para la determinación del objeto del proceso penal es indiferente quién sea el acusador, porque no puede alegar un derecho subjetivo penal, no tiene un interés protegido por la ley en la imposición de una pena concreta. Lo único trascendente es la persona imputada. 2) Con respecto a la petición ha de tenerse en cuenta: a) no cabe en el proceso 
El concepto de pretensión sí puede en nuestro criterio ser útil en sede procesal penal, haciendo siempre la salvedad de no identificar estrictamente su contenido con el homónimo civil. El esfuerzo asimilador de las instituciones del enjuiciamiento criminal a las del civil no es válido a cualquier precio, y en relación con esta materia, aun asumiendo la deuda a la dogmática procesal civil, será preciso reconocer desde el principio que, puesto que es claro que en el proceso penal no puede existir una pretensión entendida en el mismo sentido que en el ámbito civil, no cabrá hablar de una declaración de voluntad o de una petición de reconocimiento de un derecho propio. Mientras que la acción no nace de su ejercicio, sino que existe con carácter previo a éste ${ }^{776}$, la pretensión es puro ejercicio, acto, movimiento y es un concepto más adecuado para aprehender la realidad que la LECrim llama "acción penal" y que configura como popular o pública. La acusación en el proceso penal cumple así la función de reflejo o sustitución de la pretensión de la comunidad organizada en el Estado, consistente en la demanda ante los órganos jurisdiccionales del cumplimiento a través del proceso de las normas de las que se ha dotado ${ }^{777}$.

El objeto del proceso es el conocimiento por parte del órgano jurisdiccional de una pretensión, por lo que aquello que se dilucide en el juicio criminal podrá identificarse como la pretensión penal. Ésta no podría ser nunca entendida como la alegación de un derecho propio, puesto que lo que se dilucida procesalmente no es derecho alguno, sino la concurrencia o no de los presupuestos para enjuiciar criminalmente una determinada conducta atribuible a un sujeto concreto, lo que en su caso puede dar lugar a la aplicación

penal más tutela judicial que la de condena (no es declaración pura, ni creación, modificación o extinción de relaciones penales), por lo que la petición del acusador sólo puede ser de esa naturaleza. b) La petición que se dirige a la pena tampoco sirve para delimitar el objeto del proceso, por lo que es innecesaria: acusador y juez están sometidos a la legalidad y nada tiene que ver con la imparcialidad el que el juez no quede vinculado con la petición concreta del acusador. Lo contrario podría significar atribuir al acusador un derecho subjetivo penal. 3) La causa de pedir es el hecho imputado al acusado y no puede quedar en manos del Tribunal porque afectaría a su imparcialidad. Para la calificación jurídica es de aplicación el principio iura novit curia, que no cabe relacionar con una merma de la imparcialidad. MONTERO AROCA, J., "La garantía procesal penal y el principio acusatorio”, op. cit. pp. 980 y s.

${ }^{776}$ DE LA OLIVA SANTOS, A., Sobre el derecho a la Tutela Jurisdiccional, op. cit. p. 67.

${ }^{777}$ El entendimiento de la pretensión como reflejo o sustitución de la pretensión social procede de GUASP DELGADO, J., La pretensión procesal, op. cit. p. 43, que configuraba el proceso como "un instrumento de satisfacción de pretensiones" y llegaba a afirmar que "más allá del derecho procesal no hay derecho civil o derecho penal, sino pura y simple sociología". En conclusión sostenía GUASP que "la idea de la pretensión es insustituible para la elaboración de la noción procesal" en la medida que "todo proceso supone una pretensión, toda pretensión origina un proceso y ningún proceso puede ser mayor, menor o distinto que la correspondiente pretensión". Op. cit. pp. 44-46. 
subsiguiente de la consecuencia prevista en la norma. El delito no existe como tal antes del proceso (nulla poena sine previo iudicio), y corresponde al Juez (único competente para actuar el ius puniendi estatal) declarar a través de su sentencia más allá de toda duda razonable a la vista de las pruebas practicadas, que un determinado sujeto ha realizado la conducta típica. El debate procesal se dirigirá, por ello, a crear en el juzgador la convicción sobre si ese sujeto ha cometido unos hechos que podrían ser constitutivos de delito así como a fijar todos los elementos esenciales en torno a la autoría, a las circunstancias atenuantes o agravantes, etc. Lo que en él se debate es, pues, la razonabilidad de una afirmación sobre la concurrencia del imperativo legalmente previsto para la realización del deber estatal de actuar la norma. Pretensión penal y acusación se identifican así en su condición no de exigencia de condena, sino básicamente en lo que comportan de pilar o presupuesto imprescindible para la apertura y desarrollo del proceso contra una persona y por un hecho determinado.

\subsubsection{La acusación: afirmación de la concurrencia de presupuestos objetivos y subjetivos para el enjuiciamiento}

En el lenguaje ordinario, acusar es atribuir un hecho moral o jurídicamente ilícito en función de una atribución de responsabilidad o, según el Diccionario de la Real Academia en su primera acepción, "imputar a alguien algún delito, culpa, vicio o cualquier otra cosa vituperable" ${ }^{, 778}$. Empero esta respuesta no es ni la única ${ }^{779}$ ni la más precisa. Trataremos ahora de determinar qué es lo que haya de entenderse por "acusar" y si ello puede abarcar una pluralidad de actos o se refiere a uno solo en que se realiza una imputación.

La querella, como típica forma de ejercicio de la pretensión penal, contiene ya una inculpación (de una persona determinada y por un hecho determinado), la petición de realización de determinadas diligencias, etc ${ }^{780}$. Pero su mera interposición no es

\footnotetext{
${ }^{778}$ Diccionario de la Real Academia, 21 a ed., 1992.
}

${ }^{779}$ CONSO, G., Accusa e Sistema Acusatorio, Milán 1961, p. 5, destaca, que de la variedad de significados que caracteriza el uso del término "acusación" una sóla nota emerge pacífica y segura: la contraposición a la idea de defensa. CARNELUTTI se quejaba de que "acusación" era una hermosa palabra que la ley, no se sabe bien por qué, había eliminado de su vocabulario. Era además el término más adecuado para contraponer a "defensa". CARNELUTTI, F., Lecciones..., op. cit. p. 222.

${ }^{780}$ No contiene sin embargo una solicitud de condena (art. 277 LECrim). Señalaba DE LA OLIVA que, aun 
suficiente para describir todo lo que en la acusación se contiene, pues pese a su importancia, parece claro que no sería bastante para conseguir el objetivo que persigue el ejercicio de la pretensión penal.

En alguna ocasión se ha equiparado la acusación al reconocimiento del fundamento de la querella al final de la instrucción, una vez constatado que su contenido es verosímil, para lo cual sería precisa una actividad judicial tendente a la averiguación de sus elementos esenciales ${ }^{781}$. La "acción penal", equiparada al ejercicio de la acusación, sería un derecho que, como tal, tiene que ser declarado por el órgano jurisdiccional para que exista $^{782}$. El sumario aparecería como el juicio de la acusación y las resoluciones que lo terminan (auto de apertura del juicio oral o auto de sobreseimiento) como declaración o negación de su existencia ${ }^{783}$. Una vez constatada la existencia de acusación, conforme al principio acusatorio, se proporciona al órgano jurisdiccional sentenciador la base legal para que pueda conocer y proceder contra una determinada persona ${ }^{784}$. Ello no parece responder sin embargo a la realidad en tanto la "acción penal" o acusación no sólo existe en la fase de instrucción, sino que penetra también en la del juicio oral en la medida que su contenido incluye también actos acusatorios ${ }^{785}$.

cuando esa petición de condena pudiera estimarse implícita en la querella, más importante que el dato legal sería el dato empírico de que los querellantes no afirman interiormente o implícitamente tener ese derecho a la condena, porque no tienen conciencia de él. Si se acusa a una persona de un hecho que reviste los caracteres de delito e incluso se solicitan una serie de medidas contra ese "presunto culpable", no considera exagerado DE LA OLIVA interpretar el silencio del art. 277 sobre la petición de condena y sobre la pretensión punitiva como consecuencia de la función procesal que a la querella se atribuye, y que para nada precisa la manifestación explícita de esos extremos. Vid. DE LA OLIVA SANTOS, A., Sobre el derecho a la tutela jurisdiccional. La persona ante la Administración de Justicia: derechos básicos, Barcelona 1981, p. 116.

${ }^{781}$ Así CORTÉS DOMíNGUEZ, V., La cosa juzgada penal, Bolonia 1975, pp. 80-1. En su opinión se trata de decir que la "legalidad del proceso penal en cuanto a ese requisito de la acusación, no está en el mero derecho de acusar, sino en la comprobación del derecho de acusar".

${ }^{782}$ También CORTÉS DOMÍNGUEZ, V., La cosa juzgada penal, op. cit. p. 101.

${ }^{783}$ Señalaba CORTÉS DOMÍNGUEZ que el acusador no pide una consecuencia jurídica, primero porque no puede pedirla, y segundo porque el juez es libre de darla o no, o de dar otra cualquiera, y suponiendo que se pidiera una consecuencia jurídica, ésta sería el proceso y no la pena. Pensaba este autor por tanto en una pretensión, pero sólo con contenido delimitado: la pretensión al proceso cuya base estuviera en hechos, que no son todavía delito, y sí, en cambio, que revisten apariencia de delito. CORTÉS DOMÍNGUEZ, V., La cosa juzgada penal, op. cit. p. 46.

${ }^{784}$ Ibídem. El Juez Instructor tendría la facultad de enjuiciar la acusación pero no la abstención de la misma, por lo que la intervención del juez en el sumario tiene su límite en el sostenimiento de una acusación dirigida a la apertura del juicio oral.

${ }^{785}$ GÓMEZ ORBANEJA, E., Derecho Procesal Penal, p. 90. 
En otras ocasiones se ha dado un contenido más limitado a la acusación interpretando que ésta es sólo la realización del acto consistente en solicitar la imposición de una pena y su contenido se restringe a esa petición. La actividad procesal que se desarrolla con anterioridad sería la de perseguir, pero no la de acusar ${ }^{786}$.

Entendemos por nuestra parte que la acusación es una afirmación realizada por un sujeto diverso al órgano jurisdiccional sobre la concurrencia de los presupuestos legalmente exigibles para el enjuiciamiento de un determinado sujeto por un hecho concreto. Con abstracción del sujeto que la deduzca, las notas esenciales predicables de ella podrían ser las siguientes:

1) El acusatorio constituye una garantía para el imputado:

La necesidad de que en el proceso penal hubiera una acusación supone históricamente uno de los medios para asegurar la objetividad del juzgador, obligando a que éste sólo pudiera actuar allí donde un sujeto diferente afirmase la existencia del delito y su imputación a un presunto autor ${ }^{787}$. Señalaba GOLDSCHMIDT a este tenor que el proceso acusatorio tiene como sentido y como fin dispensar al juez de la iniciativa de la persecución penal para garantizar su imparcialidad, es decir, hacer depender la realización de la justicia punitiva del ejercicio de la acusación dirigida a la actuación del poder punitivo del juez. Pero, aun cuando el proceso acusatorio se hubiera configurado según el modelo del proceso civil, no por ello habría de construirse mecánicamente según aquél. Sostenía acertadamente este autor que "la situación jurídica del querellante es completamente otra que la del actor. No hace valer, como éste, un derecho propio y pide su adjudicación, sino que afirma el nacimiento del derecho judicial de penar y exige el ejercicio de este derecho que al mismo tiempo representa un deber. Tal es el verdadero sentido del «j'accuse»"788.

${ }^{786}$ Así PASTOR LÓPEZ, El proceso de persecución, op. cit.

${ }^{787}$ Sobre la evolución histórica del sistema acusatorio y la configuración de las notas esenciales propias de éste vid. por todos VERGER GRAU, J., La defensa del imputado y el principio acusatorio, Barcelona 1994, pp. 15 y ss., con la amplísima referencia bibliográfica allí contenida.

${ }^{788}$ GOLDSCHMIDT, “Derecho Justicial Material (pretensión de tutela jurídica y derecho penal)”, p. 78 y esp. Problemas jurídicos y políticos del proceso penal, op. cit., p. 28. En la cualificada opinión expresada por GÓMEZ ORBANEJA, esta obra de GOLDSCHMIDT contenía el concepto de acción que mejor se compagina con la verdadera naturaleza del proceso criminal. Vid. su Derecho Procesal Penal con HERCE QUEMADA, $10^{\mathrm{a}}$ edición, Madrid 1986, p. 90. En aplicación de su teoría del "Derecho Justicial Material" afirmaba GOLDSCHMIDT que la 
GÓMEZ ORBANEJA puso de relieve también que el concepto de "acción penal" es privativo del proceso acusatorio, puesto que en él la potestad de juzgar se hace depender de que alguien -órgano público o particular, pero en todo caso independiente del que juzga-, "persiga", o como dice el EOMF, "promueva" la acción de la justicia. De ahí que, externamente, puesto que la analogía no podría ir más allá, el proceso penal se configure como el civil: sin un actor no puede haber ni juez ni juicio («nemo iudex sine actore») ${ }^{789}$.

Lo que hace el acusador es, por ende, romper una limitación en el sistema de imposición de las penas del que el Estado se ha dotado históricamente en el tránsito hacia formas evolucionadas de justicia, haciendo visible la separación entre las funciones de enjuiciar y de afirmar la concurrencia de los presupuestos del enjuiciamiento mismo (Nemo iudex sine actore, ne procedat iudex ex officio, wo kein Kläger da kein Richter). El establecimiento de este presupuesto se dirigió así a tutelar los derechos del imputado, al que no se podrá condenar si no es en virtud del debido proceso, pero no tiene por qué suponer necesariamente reconocimiento de derechos de ninguna clase a otros sujetos. Ante la acusación no estamos en presencia de algo que en abstracto tenga la naturaleza de derecho, sino sólo de un imperativo del que se ha dotado el ordenamiento que al establecer una garantía de imparcialidad en el desempeño de la actividad del juzgador ${ }^{790}$, contribuye al debido proceso.

consecuencia jurídica del derecho penal no era la pena, sino el derecho subjetivo de penar, que no podrá ejercitarse sino a través del proceso. De ahí que hubiera que diferenciar entre la "acción penal" entendida como un derecho del Estado que ostentaría el juez, y el "derecho de acusación" como una facultad de ejercicio necesario para la satisfacción del anterior. La teoría citada era formulada de la siguiente manera: "El derecho justicial se divide en el derecho justicial formal y el material. Aquél comprende los derechos procesales civil y penal, y éste, la totalidad de las normas relativas a la pretensión de tutela jurídica dirigida contra el Estado, como asimismo el derecho penal". GOLDSCHMIDT, J., “Derecho Justicial Material...”, op. cit. p. 4.

${ }^{789}$ GÓMEZ ORBANEJA, E., Derecho Procesal Penal, $10^{\mathrm{a}}$ edición, Madrid 1987, pp. 86 y ss. En ocasiones se ha defendido que la acción popular en el proceso penal se erige como postulado esencial para la configuración de un proceso como de signo acusatorio. Así ASENCIO MELLADO, J.M., Principio acusatorio y derecho de defensa en el proceso penal, Madrid 1991, p. 18, que se sirve de las opiniones de FAIRÉN y GIMENO. No compartimos sin embargo esta opinión, puesto que la naturaleza acusatoria del proceso no tiene por qué depender necesariamente del número de sujetos que puedan formular acusación y la existencia de acusación popular es indiferente para concluir que un proceso esté o no informado por el principio acusatorio. En este sentido vid. MONTERO AROCA, J., et al. Derecho Jurisdiccional, T. III, pp. 18 y ss.

${ }^{790}$ Hablamos de garantía por cuanto no cabe olvidar que con el Estado liberal la imparcialidad expresa significativamente el sometimiento del juez a la ley. 


\section{2) La finalidad de la acusación es servir a un interés público}

La acusación sirve a un interés público cifrado en la resolución pacífica de los conflictos a través del debido proceso, interés que se verá satisfecho con el enjuiciamiento objetiva y subjetivamente delimitado, sin que sea necesaria una condena ni ésta haya de buscarse explícitamente por el acusador. O dicho de otro modo, se dirige a posibilitar la verdad de la Constitución, creando el deber de los Juzgados y Tribunales de promover las condiciones a fin de que la libertad y la igualdad de los individuos y de los grupos en que se integran sean reales y efectivas (art. 9.2 CE), en la medida en que habrá de afirmarse la existencia de obstáculos que impiden o dificultan su plenitud. No se dirige a la tutela de concretos bienes jurídicos, sino a poner las bases necesarias para constatar que han sido atacados o puestos en peligro y, así, que concurren las exigencias para la actuación judicial de la ley de la única manera que es esto posible: procesalmente. Se contribuye de esta manera a la defensa del interés público en la garantía de la paz social y, simultáneamente y por razones de economía procesal aunque ello no sería imprescindible, al interés privado del agraviado por la ofensa delictiva. Para la satisfacción del interés público el proceso deberá conducir a la determinación más allá de toda duda razonable de: 1) si existió el hecho, 2) si éste es punible, 3) si el sujeto que se afirma partícipe lo ha sido y en la calidad que lo haya sido, 4) la consecuencia jurídico penal que le es atribuible (imposición de pena, juego de atenuantes, agravantes, posible suspensión del fallo, etc...).

Se pueden entender como consecuencias de lo afirmado:

a) La acusación no se dirige directamente a la tutela de un singular interés material perteneciente a un sujeto o a una pluralidad de ellos, sino que protege un interés diferente: el interés público en que consiste la activación de los mecanismos para el debido enjuiciamiento y, en su caso, condena de las conductas reputadas punibles, dirigido todo ello a servir de sustitutivo a la autodefensa prohibida por el Estado. Se trata de un único interés que no admite ser individualizado, fragmentado o desgajado en pequeñas parcelas, cuyo titular es el conjunto de todos los ciudadanos, lo cual es tanto como decir que no pertenece a un sujeto concreto, individual o colectivo, fuera de la generalidad afirmada.

Puesto que la acusación pública es conceptualmente una tarea dirigida a satisfacer un interés público, no abarcaría dentro de sí la inclusión de intereses privados, siempre extravagantes a la misión que viene a desempeñarse a través de ella. No es un mecanismo articulado para defender directamente específicos intereses materiales (vida, propiedad, 
libertad sexual...), sino sólo para poner las bases de su defensa mediante la satisfacción del interés público. No cabe por tanto confundir el interés material contenido y protegido por un concreto tipo del Código Penal con el interés público procesal derivado de la activación de los mecanismos, también procesales, para garantizar la aplicación de la norma penal. Éste existirá siempre y en la misma medida desde que se afirme la comisión de un delito de los protegidos por las normas penales, independientemente de cuál sea el precepto que lo acoja.

El ejercicio de la acusación es premisa necesaria para la defensa del interés público al que hemos hecho referencia y puede serlo también en ocasiones para la del interés privado. No por ello cabe confundir los diversos objetivos perseguidos en uno y otro caso: en el primer caso, puesto que lo que se defiende es ese único, extendido e indivisible interés público, toda la actividad requerible para su tutela estará revestida indudablemente de un carácter público ${ }^{791}$.

b) La acusación debe ser una función satisfecha desde la imparcialidad, en tanto el interés público requiere indefectiblemente el enjuiciamiento de los hechos respecto de los que fundadamente se afirme que han conculcado la norma material. De aquí que el proceso no tenga sólo como fin la imposición de la pena, sino con carácter previo y esencial el dilucidar si concurren méritos bastantes en juzgar a un sujeto por un hecho, y así estimado, extraer consecuencias materiales así como inmediata y eventualmente procesales (adopción de medidas cautelares, emplazamiento, citación, sometimiento a interrogatorios, etc.). El ejercicio de la pretensión penal exige que se hagan valer todos los elementos esenciales para el enjuiciamiento, lo cual se referirá no sólo a los de cargo, sino también a los de descargo. Y más aún, obliga a no sujetar a actuación procesal alguna a sujetos sobre los que no pese alguna fundada sospecha de comisión delictiva. La acusación pública sólo puede estar movida por un interés público, y cualquier asomo de

${ }^{791}$ Cuestión diferente será que la titularidad del específico bien jurídico, dependiendo del ámbito material de protección, corresponda a un sólo sujeto, a una cantidad más o menos grande de personas o incluso a una pluralidad indeterminada de ellas. Sirviéndonos de un ejemplo podremos afirmar que la comisión de un delito contra la propiedad afecta dos intereses diversos: uno privado que corresponderá al concreto propietario despojado de alguno de sus bienes y el público consistente en la procesal y pacífica resolución de los conflictos. De la misma manera, cuando estemos ante un delito en que se afecte un bien jurídico no individualizable como pudieran ser la salud pública o el medio ambiente seguirán existiendo dos intereses diversos: el vinculado a los bienes jurídicos materiales atacados o puestos en peligro y el interés público en que tales ataques a bienes jurídicos reciban procesalmente la respuesta prevista en la norma. En este caso seguiremos hablando de intereses de diferente naturaleza, puesto que en tanto el primero de ellos corresponderá a todos y cada uno de los sujetos y será un interés material, el segundo seguirá siendo infragmentable y de naturaleza procesal. 
interés privado al margen de los del ofendido por el delito deberá extirparse de raíz de un ámbito tan sensible como es el proceso penal ${ }^{792}$.

Cuestión diversa es que el acusador que pretende que se enjuicie al sujeto y, eventualmente, se le condene, habrá de introducir en el proceso todos los elementos precisos para convencer al juez de la razonabilidad de su afirmación. Naturalmente será menester que el acusador esté provisto y quiera utilizar todos los medios a su alcance; pero como no persigue un interés propio parcial, habrá de suministrar lo positivo y lo negativo en cuanto el enjuiciamiento ha de servir a ese interés general. Puesto que para el proceso son necesarios una causa y un interés, al igual que en sede civil no caben ni el proceso simulado ni el convenido, en sede penal diríamos que no es asumible el proceso como instrumento de venganza, de presión o de opresión.

c) Quien ejercita la pretensión penal no pide nada para sí, pero tampoco pide para nadie en especial, sino que realiza una actividad que va dirigida mediatamente en beneficio de la colectividad. Mediante su actividad se limita, pues, a solicitar del órgano jurisdiccional que actúe la ley, para lo cual la acusación es conditio sine qua non. Mediante ella no se hace valer una exigencia punitiva, sino únicamente la existencia del presupuesto normativo para que el órgano jurisdiccional deba desarrollar la actividad conducente a la averiguación del delito y de su autor y, en su caso, imponer la pena que corresponda al declarado culpable. Con la condena y su ejecución, el órgano jurisdiccional no presta u otorga la tutela jurídica pretendida por la "parte", sino que hace efectiva la potestad que en él mismo radica de enjuiciar y eventualmente castigar los delitos ${ }^{793}$.

${ }^{792}$ La sujeción al principio de imparcialidad ha sido vista como una de las causas que imposibilitan contemplar el proceso penal continental europeo como un proceso de partes, en tanto no sería de recibo la presencia de un sujeto obligado a asumir las obligaciones correlativas a lo que parecen dos posiciones contrapuestas. Cfr. HENKEL, H., Strafverfahrensrecht. Ein Lehrbuch, Stuttgart 1968, p. 107. En algún sector minoritario de nuestra doctrina se ha destacado también el elemento de servicio a intereses imparciales de justicia como lo determinante para la consideración del MF como institución, autoridad, ministerio, órgano de justicia u órgano estatal, pero en ningún caso como parte. Vid. en este sentido IRIBAS, J., "El Ministerio Fiscal no es parte”, RDProc abril-junio 1952, n 2 , p. 195.

${ }^{793}$ Vid. GÓMEZ ORBANEJA, E., Derecho Procesal Penal, op. cit. p. 90, que se basa en la comparación entre el término "lo que se pida" contenido entre los requisitos de la demanda civil (art. 524 LEC) y el n ${ }^{\circ}{ }^{\circ}$ del 650 LECrim en relación con el contenido de los escritos de calificación: "las penas en que hayan incurrido...". Por todo ello GÓMEZ ORBANEJA definía la "acción penal" como "la facultad de iniciativa procesal y de crear la obligación del juez de comprobar la situación concreta de hecho que se le somete y de declarar si constituye un delito, quién sea responsable de él y cuál la sanción adecuada a esa responsabilidad'. El que se deduzcan una serie de peticiones concretas (solicitud de diligencias, de medidas cautelares, etc...) no se opondría a esta concepción pues todas ellas se albergarían en la "acción penal", pero ninguna de ellas, ni todas juntas, son por sí la acción. La "acción penal" consistiría en el acto de acusar (a una determinada persona, por un determinado hecho), pero será irreductible al 
d) Para la validez de la acusación es absolutamente irrelevante quién sea el sujeto que realice efectivamente la afirmación de la existencia de los presupuestos para la resolución jurisdiccional, siempre que sea persona diferente del juzgador. El elemento subjetivo activo de la pretensión penal no puede servir para su identificación, y su ejercicio por unos u otros produce exactamente el mismo efecto ${ }^{794}$. Quién lo haga y cómo se lleve a cabo será intrascendente en un plano teórico, pues acusar es una función única, y tanto el número de acusadores como su carácter público o privado no son relevantes para fijar la esencia o la naturaleza de la tarea que llevan a cabo. De este modo, y siguiendo a FLORIAN, advertía GÓMEZ ORBANEJA que el problema de la pluralidad de titulares de la "acción penal" se traduce en el problema de los órganos -oficiales o no, inmediatos o mediatos- de la acción pública única ${ }^{795}$.

El trasvase de la construcción sobre la pluralidad de partes del proceso civil al penal puede contemplarse como fruto del débito histórico de la doctrina procesal al derecho privado, sin que se haya operado una depuración del concepto capaz de liberarlo de ciertas reminiscencias que le apartan de su verdadero sentido y función. No es admisible en este sentido hablar de un "litisconsorcio entre acusadores públicos" por cuanto, aun ocupando una pluralidad de sujetos la posición activa, todos ellos defenderán exactamente el mismo interés de manera conjunta ${ }^{796}$. El litisconsorcio denota la presencia de varias personas como partes que por obligaciones, derechos o intereses comunes, están unidas en una determinada posición y piden al órgano jurisdiccional el pronunciamiento

contenido concreto que la acusación adopte.

${ }^{794}$ Vid. CORTÉS DOMÍNGUEZ, V., La cosa juzgada penal, pp. 70 y s. donde se afirma con toda razón que "la acción será la misma ejercitada por A o por B, cuando ambas tienden a perseguir y acusar a una misma persona por un mismo hecho delictivo. De ahi que para los casos de cosa juzgada o de litispendencia no juegue el querellante, y sí, tan sólo, el querellado y el hecho por el que se acusa". Vid. también SSTS de 23 de diciembre de 1992 (RAJ 10327), FD. $7^{\circ}, 29$ de abril de 1993 (RAJ 3295), 12 de diciembre de 1994 (RAJ 9374), FD 6º nº 2.

${ }^{795}$ GÓMEZ ORBANEJA, E., Comentarios..., op. cit. p. 209.

${ }^{796}$ La existencia de un litisconsorcio activo en nuestro proceso penal ha sido mantenida partiendo de la existencia de diversas pretensiones que versan sobre el mismo objeto. Vid. por ejemplo ALCALÁ-ZAMORA, N., "Puntualizaciones relativas al concepto de parte", RDProc (Ibam) 1983, p. 117. GÓMEZ ORBANEJA hablaba de un "litisconsorcio virtual" puesto que es necesario no en el sentido de que todos los legitimados para el ejercicio de la pretensión hayan de ejercitarla, sino en el de que la cosa juzgada de la sentencia les alcanza lo mismo que si lo hubiesen hecho. Cfr. Derecho Procesal Penal, op. cit. p. 84. MONTERO AROCA se refiere a un "litisconsorcio cuasi-necesario" en tanto la LECrim no impone necesariamente a los litisconsortes la actuación conjunta, pudiendo el proceso desarrollarse y concluirse válidamente con la presencia de uno sólo. MONTERO AROCA, J., Introducción al Derecho Procesal, Madrid, 1976, p. 239 y Derecho Jurisdiccional, op. cit. p. 54. 
de una decisión lógica y jurídicamente única, formando así una parte única pero compleja $^{797}$. En este caso no hay, sin embargo, pluralidad de intereses individuales ni fragmentación posible del interés público, y la pretensión que se sostiene es exactamente la misma independientemente del sujeto que lo haga, por lo que será irrelevante la concurrencia de un sujeto u otro en la acusación en cuanto a determinar la litispendencia y la producción del efecto de cosa juzgada ${ }^{798}$.

De la misma manera, no cabe tampoco caracterizar la acusación de los no ofendidos como una "intervención procesal de tercero", 799 , en tanto también en este caso la participación obedece a la defensa de un interés material específicamente propio, ínsito en la esfera subjetiva del interviniente e individualizable en sí mismo, aun cuando verse sobre un derecho ajeno.

e) La consideración de la existencia de una pluralidad de pretensiones distintas en función de diversos sujetos, podría llevarnos a afirmar que de la concurrencia de una multiplicidad de acusadores resultaría un desproporcionado perjuicio para el imputado. Parece coherente pensar que el equilibrio procesal quedaría en entredicho si una misma defensa debiera hacer frente a imputaciones diversas no conectadas entre sí más que por el supuesto fáctico que sustenta las diversas acusaciones ${ }^{800}$. Esta posible

${ }^{797}$ Vid. DÁVILA MILLÁN, M.E., Litisconsorcio necesario. Concepto y tratamiento procesal, $2{ }^{\mathrm{a}}$ ed., Barcelona 1992, p. 16.

${ }^{798}$ No así en la parte pasiva, puesto que, sin perjuicio de la conexidad y sus consecuencias, podría abrirse un nuevo proceso si el primero se dirigió contra otra persona aun tratándose del mismo hecho, a no ser que la sentencia hubiera sido absolutoria por estimar inexistente el hecho.

${ }^{799}$ En la intervención, un tercero acude al proceso de manera espontánea sin estar obligado, pero en ese caso comparece para la defensa de un derecho (intervención litisconsorcial) o un interés (intervención adhesiva) material propio e individualizable. La consideración como parte del interviniente litisconsorcial en defensa de un derecho propio y su actuación en paridad procesal con la de la parte originaria, es aceptada sin excesivos problemas por la mayoría de la doctrina. En la intervención adhesiva simple el interviniente acude al proceso para defender un interés propio que es objeto de un derecho ajeno y la legitimación para intervenir le viene de un interés basado en una relación sustancial entre el interviniente y la parte con la que coadyuva, distinta a la que se está decidiendo en el pleito, por lo cual entre él y la parte contraria no media relación sustancial alguna. Vid. CALAMANDREI, P., Istituzioni di diritto processuale civile, $2^{\mathrm{a}}$ parte, Padua 1944, p. 207.

\footnotetext{
${ }^{800}$ Este desequilibrio ha sido puesto de manifiesto en Alemania en relación con el incremento de las facultades procesales del ofendido por el delito, lo cual hablaría en contra de atribuirle mayores cauces de intervención procesal activa. Vid. SCHÜNEMANN, B., "Zur Stellung des Opfers im System der Strafrechtspflege”, NZStR, 1986, p. 198; WEIGEND, T., Deliktsopfer und Strafverfahren, Berlin 1989, pp. 428 y ss. En contra de esta postura vid. SCHNEIDER, H.J., "La posición jurídica de la víctima del delito en el derecho y en el proceso penal", en Criminología y Derecho Penal al servicio de la persona. Libro Homenaje al Profesor Antonio Beristain, San Sebastián 1989, pp. 384 y s. En algún supuesto extremo pudiera darse el caso de que la negación de una de las
} 
transgresión fue propugnada en nuestra doctrina por ALCALÁ ZAMORA, para quien la acusación popular sería injusta porque desequilibraría el proceso en perjuicio del acusado $^{801}$, y por SÁEZ JIMÉNEZ y LÓPEZ FERNÁNDEZ DE GAMBOA, que estimaban que, con la pluralidad de acusadores, la defensa "no tendrá que hacer frente a una tesis acusatoria sino a múltiples", lo que haría su trabajo más arduo, difícil y complicado $^{802}$.

En otros casos, por el contrario, la variedad de sujetos acusadores ha sido contemplada como una ventaja de la que goza nuestro sistema frente a los demás, ya que otorga la posibilidad de configurar los hechos de diferente forma. GÓMEZ COLOMER, por ejemplo, veía en ello una contribución a la mejor delimitación del objeto procesal, en la medida que el hecho delictivo podría ser expuesto desde cuatro diversos puntos de vista (MF, acusador particular, acusador popular y acusado), haciendo surgir con mayor claridad todos los matices del hecho delictivo ${ }^{803}$.

diversas pretensiones tuviera que llevar necesariamente aparejada la afirmación de otra o que necesariamente se hiciese incurrir en contradicciones al imputado, con lo que se estaría incidiendo directamente en el derecho a no declarse culpable. La práctica forense es en este aspecto, sin embargo, más sensata que la norma que diseña un sistema que podría ser permisivo con el desequilibrio. Bien es cierto que el problema puede ser considerado más teórico que estrictamente real.

${ }^{801}$ Argumentaba ALCALÁ-ZAMORA que "si el delito produce un doble daño-al sujeto pasivo y a la sociedad-, son sus representantes -acusación privada o particular, cuando se persone la parte ofendida, y el Fiscal-los únicos a quienes toca actuar, a fin de que el proceso sea la reacción en el terreno judicial de dos lesiones de distinta naturaleza, causadas por el doble ataque de que fueron objeto". ALCALÁ-ZAMORA CASTILLO, N., "Lo que debe ser el Ministerio Público", RGLJ, T. 155, (1929), pp. 519-531 y Estudios de Derecho Procesal, p. 20, Madrid 1934. El mismo argumento es reiterado por el autor de forma anónima bajo el seudónimo de "Un redactor de la RGLJ" (vid. la rectificación al respecto en Rev.DProc (Argentina), 1945, T. 2, p. 88) en Derecho Procesal Criminal, Madrid 1944, publicado junto a GARCÍA VALDÉS, R., p. 89 y expresamente en Derecho Procesal Penal, T. I, Buenos Aires 1945, p. 77, publicado junto a LEVENE (hijo). Sin embargo, con posterioridad matizó esta opinión al hablar de la pluralidad de acusadores en el proceso español en los siguientes términos: "La pluralidad de acusadores, tan característica del derecho español, donde caben distinguir cinco especies (incluye al abogado del Estado) se ha organizado con tal decoro (salvo algún extravio, perfectamente corregible, de la acción popular, neutralizado, además por su uso rarísimo) que a nadie se le ha ocurrido allí tomar en serio la afirmación de que la acusación del ofendido signifique nada menos que la venganza privada. Lejos de ello, esa pluralidad ha servido para corregir las deficiencias e insuficiencias advertidas en los países con acusación penal monopolizada por el ministerio público". Vid. "Aciertos terminológicos e instituciones de Derecho Procesal Hispánico”, México 1948, publicado en Estudios de Teoría General e historia del Proceso, T. II., México 1974, pp. 470 y s.

${ }^{802}$ SÁEZ JIMÉNEZ, J. y LÓPEZ FERNÁNDEZ DE GAMBOA, E., Compendio de Derecho Procesal civil y penal, T. 4, vol. I, Madrid 1966, p. 880.

${ }^{803}$ GÓMEZ COLOMER, J.L., “Acción particular, acción popular y sobrecarga de la Administración de justicia”, $P J \mathrm{n}^{\circ} 8$, diciembre 1987, p. 30. El argumento no puede considerarse sin embargo admisible: inevitablemente nos 


\section{3) Su contenido será el objeto procesal}

La pretensión penal es presupuesto objetivo sin el cual el enjuiciamiento no es posible, en tanto el Juez sólo podrá desarrollar plenamente su actividad jurisdiccional si alguien afirma procesalmente que ha nacido su obligación de hacerlo. A través de ella no se pide nada que hubiera podido dar voluntariamente el imputado, sino que se viene a satisfacer una premisa esencial para el desarrollo de un proceso que, a la vista de los presupuestos afirmados por el sujeto activo, culmine con una resolución jurisdiccional en la que se declare o no la ocasión de actuar el deber estatal de imponer la condena del acusado. Su contenido se reduce a la afirmación realizada por sujeto diverso del juzgador de la concurrencia de los requisitos objetivos y subjetivos necesarios para la declaración por el Estado de la existencia de un delito y la aplicación al caso de lo contenido en la norma jurídica. No se puede hablar de causa petendi ni de petitum, por el simple hecho de que no hay petición de nada sino únicamente realización de la actividad necesaria para levantar un impedimento procesal, al objeto de que el órgano jurisdiccional resuelva sobre un hecho en concreto. El matiz que distingue la pretensión en el proceso penal se encuentra, por tanto, en que no se trata de una petición concreta, sino únicamente de la satisfacción objetiva de un presupuesto necesario para abrir el camino a una posible aplicación de las normas penales.

La pretensión penal determinará efectivamente el pronunciamiento judicial, pero los límites no los marca una petición que pueda realizar un sujeto por su propia voluntad, sino la afirmación que éste realiza en concordancia con la previsión de la norma sobre unos hechos y un sujeto. No debe percibirse en el ejercicio de la pretensión penal ningún otro rastro de voluntad que la única admisible: la que se deduce de la propia ley, pero nunca la propia de los sujetos que asumen la función de exteriorizar el sentido de ésta. No puede verse en ello siquiera una manifestación de voluntad estatal, porque ésta ya se explicitó con la promulgación de la norma y se actualizará y concretará en la resolución jurisdiccional que ponga término al proceso. No hay voluntad, sino pura y genuina obligación estatal de realizar el conjunto de actividades establecidas legalmente (debido proceso) para asegurar al imputado una constitucional aplicación del precepto penal.

llevaría a preguntarnos por qué no defender también la presencia en el proceso de "defensores populares", en la medida en que con su visión éstos pudieran contribuir a aportar otra serie de matices del hecho delictivo. Ello sin tomar en cuenta, además, que añadir más visiones subjetivas sobre éste se podría enmascarar la que, vinculada a la objetividad, debe proceder del órgano oficial imparcial encargado permanentemente de tal tarea. 
Admitir lo contrario sería confundir las consecuencias del principio acusatorio, que obliga a la separación acusador-juzgador, con un principio dispositivo que dejaría en manos de los acusadores la conveniencia, oportunidad o interés de deducir acusación.

Así como en el proceso civil el objeto procesal se identifica con los elementos que componen las exigencias del actor, en el penal el dato de referencia no es algo que se solicite, sino la declaración de que ha nacido el deber estatal de enjuiciar. Mientras que en el primero, el objeto procesal es la afirmación de la titularidad de un derecho, en el segundo el objeto sobre el que versa el proceso será el contenido de la acusación, esto es, la aserción de la concurrencia de los presupuestos para un concreto enjuiciamiento penal. Aquello sobre lo que versa el proceso (res de qua agitur o thema decidendi) no es ni el hecho en sí ni una concreta petición del actor, sino la mera afirmación que éste realiza sobre un objeto constituido por un acontecimiento o suceso de la vida real con apariencia de infracción criminal y sobre el sujeto que se reputa autor.

Lo que se dilucida en el proceso e identifica la acusación no será ni un concreto tipo penal en el sentido de las normas penales sustantivas, ni un petitum del actor, sino una afirmación de éste en la que se contienen dos elementos:

\section{a) Elemento objetivo:}

Los hechos que se afirmen delictivos no se tratarán sólo de un «trozo de vida», sino de una serie de acontecimientos con la trascendencia jurídica que les asigne el acusador $^{804}$. Una vez que a lo largo del proceso se tornen de una mera hipótesis a situación sobre la que pueda ser afirmada judicialmente su certeza más allá de toda duda razonable serán el elemento objetivo que sustente la imposición de la consecuencia

\footnotetext{
${ }^{804}$ Sobre la identificación de la pretensión penal vid. ASENCIO MELLADO, J.M., Principio acusatorio..., op. cit. pp. 65 y ss. y GUTIÉRREZ DE CABIEDES, E., "La correlación entre acusación y sentencia", en Estudios de Derecho Procesal, Pamplona 1974, pp. 509-535, publicado originariamente en Revista de la Facultad de Derecho de la Universidad de Madrid, vol. XIV, nº 37, 1970, pp. 73 y ss. Es preciso distinguir aquí entre la teoría de la individualización y la de la sustanciación. Mientras que a tenor de la primera la pretensión (civil o penal) habrá de identificarse por la vía de la calificación jurídica del hecho, de modo que ésta vinculará al tribunal y su modificación engendrará una variación de la pretensión, en la teoría de la sustanciación la pretensión se identificará sólo por los hechos que fundamentan el petitum. Según esta última, a la que se adscribe ASENCIO, lo relevante serían los hechos alegados en tanto éstos sean jurídicamente relevantes o, lo que es lo mismo, susceptibles de encajar en el supuesto de hecho de la norma jurídica de la que se deriva la consecuencia del mismo orden. La pretensión vendrá a identificarse por su elemento fáctico siendo posible variar la calificación jurídica sin que suponga modificar la pretensión. En consecuencia, la pretensión penal se identificará en atención al hecho punible jurídicamente relevante, el cual no será nunca susceptible de mutación, pero nunca se identificará por un específico título de condena o por un petitum determinado.
} 
prevista en la norma.

Para su determinación no será trascendente la diversidad de calificaciones que sobre los hechos pueda hacer una pluralidad de acusadores ${ }^{805}$, sino que el dato clave en el que hemos de fijarnos ha de ser la concreta afirmación sometida a la consideración del órgano jurisdiccional. De otro modo, bastaría con utilizar la pluralidad de tipos penales que protegen unos mismos bienes jurídicos o los diferentes grados de participación en la comisión de un delito para calificar una conducta de forma diferente o por sujeto diverso y burlar con ello la seguridad jurídica que proporciona el principio ne bis in idem. Lo que fundamenta la litispendencia y determina el alcance de la cosa juzgada son, por tanto, el hecho afirmado, pero no su encuadre jurídico ${ }^{806}$, y el sujeto acusado, pero no el querellante $^{807}$.

Una vez abierto el juicio oral, los hechos que en él se introduzcan y los sujetos acusados suponen la delimitación de aquello sobre lo que puede resolver el órgano jurisdiccional, pero una petición de pena no resulta relevante como petición de fondo ${ }^{808}$. La correlación del fallo con la acusación dependerá de la afirmación hecha por el acusador, pero el juzgador no está atenazado por las calificaciones jurídicas realizadas por los actores. A no ser que se incurra en una vulneración del derecho de defensa del acusado $^{809}$ o de la garantía de la contradicción entre ambas posiciones procesales, que

${ }^{805}$ Vid. GÓMEZ ORBANEJA, E., Comentarios a la LECrim, op. cit. T. II, p. 459 y Derecho Procesal Penal, op. cit. p. 91. Cfr. en sentido contrario GÓMEZ COLOMER, J.L., “Acción particular, acción popular...”, op. cit. p. 30.

${ }^{806}$ Sin embargo, es preciso reconocer con GÓMEZ ORBANEJA múltiples excepciones a la independencia entre el hecho y su calificación jurídica. Así cuando el hecho viene atribuído expresamente a la jurisdicción militar y se califica así, en caso de concurrir con un delito sólo perseguible a instancia de parte o en el caso de la extradición, en tanto el sujeto no puede ser penado por delitos no recogidos en el acuerdo internacional. GÓMEZ ORBANEJA, E., Derecho Procesal Penal, op. cit. p. 91.

${ }^{807}$ Cfr. CORTÉS DOMÍNGUEZ, V., La cosa juzgada penal, Bolonia 1975.

${ }^{808}$ De ahí que se haya admitido en ocasiones que el "derecho de acción penal" como derecho al proceso se caracteriza, entre otras cosas, por no hacer objeto del proceso una pretensión concreta, sino la atribución de unos hechos penalmente relevantes a una persona determinada. Aun así, deben admitirse ciertas reservas en el PA, por cuanto el art. 794.3 LECrim establece que "la sentencia no podrá imponer pena que exceda de la más grave de las acusaciones". La pretensión penal aparenta así ser una petición de pena concreta y no la afirmación de la existencia de los presupuestos para la aplicación de la norma penal a unos hechos concretos cometidos presuntamente por un sujeto determinado.

${ }^{809}$ Dado que el objeto del proceso no versa sobre un crimen, sino sobre un factum (un hecho de la vida), el derecho a la información de la acusación que permita una adecuada defensa, debe referirse fundamentalmente al objeto del proceso, no identificando éste con una calificación jurídica sino con un hecho individualizado como delito 
constituyen el otro elemento esencial a tener en cuenta en la llamada "correlación entre acusación y sentencia", las calificaciones no constituyen el objeto que delimita materialmente el proceso ${ }^{810}$. La concreta norma penal material presuntamente infringida no puede utilizarse como criterio identificador de la pretensión penal puesto que el titulus comdenationis no recae en un ámbito de libre configuración para el acusador, sino que viene legalmente determinado y dirigido al juzgador ${ }^{811}$. El objeto del proceso penal viene por tanto determinado exclusivamente por lo afirmado sobre la identidad del acusado (art. 659.3 LECrim), la identidad del hecho punible (art. 650.1 y 4 LECrim) y la homogeneidad del bien jurídico atacado por el delito. Proponer una calificación jurídica sin más no puede ser entendido como deducir una pretensión, sino como la realización de uno más de los actos contenidos en la acusación, por lo que ante una pluralidad de peticiones provinientes de varios querellantes no cabrá afirmar la existencia de una multiplicidad de pretensiones, sino la realización reiterada de uno de los actos acusatorios.

b) Elemento subjetivo:

que se imputa al sujeto. Vid. por todas STC 36/1992 de 12 de febrero.

${ }^{810}$ De la propia Exposición de Motivos de la LECrim ha sido deducida tradicionalmente la confusión de instituciones y la propensión de nuestro legislador al trasvase entre los procedimientos civil y penal cuando, por ejemplo, se equiparan el escrito de calificación provisional del hecho justiciable y de la persona del delincuente por el acusador y el acusado con la demanda y la contestación a ella en el proceso civil, reputándose éstos como "la acción y las excepciones". Este tipo de erróneas equivalencias llevaron también a erróneas interpretaciones del texto normativo entre los primeros comentaristas y la jurisprudencia de finales del siglo pasado, que seguía viendo en la acusación penal sobre todo un derecho incardinado en la esfera personal de los sujetos. Señala GÓMEZ ORBANEJA que cuando el legislador establece estos paralelos entre el procedimiento penal y el civil, parece optar por una concepción de los actores (MF o acusadores particulares) como representantes del Estado, que asumiendo la función estatal de acusación acuden frente al Estado juez. En relación con el ejercicio de la pretensión penal, aceptar la literalidad de la Ley en este aspecto significaría para GÓMEZ ORBANEJA que los acusadores no ejercitarían la "acción penal" hasta el momento de calificar el hecho perseguido. Pero también vendría a decir que la "acción penal", como la civil -según su concepción- consistiría en una exigencia punitiva concreta, en la pretensión que se declare y realice un efecto jurídico determinado, y que esa pretensión así individualizada constituye el objeto del proceso penal propiamente dicho (juicio oral) en el cual se entra gracias a ella, como en el juicio civil se entra por la demanda. Estos postulados, sin embargo, se conciliarían difícilmente con la estructura del proceso penal pues proponer una calificación jurídica no puede ser lo mismo que deducir una pretensión y, además, la calificación del acusador no es el acto que abre el juicio oral sino que presupone la existencia de una acción ya ejercitada. GÓMEZ ORBANEJA, E., Derecho Procesal Penal, Madrid 1987, p 88. Vid. también GONZÁLEZ MONTES, J.L., "Notas en torno a la acción penal y su ejercicio" en Problemas actuales de la Justicia. Homenaje al Profesor Gutiérrez-Alviz, MORENO CATENA, V., (Coordinador), Valencia 1988, p. 739.

${ }^{811}$ La petición de un sujeto público o privado de imposición de una concreta pena con apoyo en una calificación no es determinante para la configuración del objeto del proceso y la resolución jurisdiccional a adoptar sobre él. Sí lo será sin embargo la forma en la que queden delimitados por el actor los hechos delictivos y sus autores, lo cual al fin y al cabo es lo que sirve de fundamento fáctico a aquélla solicitud. Pero ello no es en el fondo más que un reflejo de la afirmación de que existen los presupuestos objetivos y subjetivos necesarios para la aplicación de una norma penal en la que se prevé la imposición de esa concreta pena. 
En sede civil el deudor puede dar voluntariamente lo que se le pide o puede en el proceso allanarse provocando su terminación, pero en el juicio penal, el imputado no es sujeto pasivo de la pretensión, sino que forma parte de su propio contenido identificador. En su ejercicio no se pide nada al y/o del imputado del que se afirma que hizo u omitió algo, sino que él mismo forma parte del objeto procesal en cuanto elemento esencial integrante de la afirmación en que la pretensión consiste ${ }^{812}$. Aunque el imputado quisiera, no podría nunca dar lo que constituye el objeto de la discusión, en cuanto eso sólo podrá hacerse mediante un acto jurisdiccional en el que se declare la existencia del delito.

\section{4) Goza de una naturaleza enteramente procesal}

La pretensión nace, se desarrolla, se agota y muere dentro de un concreto proceso, y no hay nada fuera del proceso donde la acusación pueda o deba adquirir relevancia. A pesar de la generosa atribución de la facultad de ejercitarla que se contiene en nuestra LECrim, no cabe afirmar que ello signifique atribución de derecho material alguno a concretos sujetos $^{813}$. No nos detenemos sobre esta cuestión, pues ya ha sido abordada en el capítulo anterior.

\section{5) La acusación deberá estar presente a lo largo de todo el proceso}

El objeto procesal se va a ir delimitando en función del momento procesal y todos los actos encaminados a ello han de entenderse englobados en la pretensión penal. La acusación está presente a lo largo de todas las fases del proceso, y adopta diferentes formas en función de las situaciones por las que éste atraviesa ${ }^{814}$. Las diversas

\footnotetext{
${ }^{812}$ En sentido contrario pueden verse entre otros ASENCIO MELLADO, J.M., op. cit. pp. 85 y ss. o MONTERO AROCA, J., "La garantía penal...", op. cit. pp. 980 y s.

${ }^{813}$ Afirma FAIRÉN que, puesto que la evidencia del interés lesionado por razón de la cual se promueve el proceso penal es una evidencia de violación de un derecho público -el derecho a la seguridad jurídica frente al acto delictivo que ataca gravemente la paz social-, su titularidad corresponde a toda la comunidad. De ello deriva sin embargo este autor como consecuencia, que nosotros no compartimos, el que "la posibilidad de pedir la tutela de ese interés se atribuya a cada uno de los interesados; a cada uno de los ciudadanos". FAIRÉN GUILLÉN, V., Voz "Acción", op. cit. p. 202. En nuestra opinión el que el interés sea público no tiene por qué conllevar necesariamente que su tutela procesal pueda ser invocada por todos. No es cierto tampoco que todos los titulares del interés puedan demandar su tutela: los sujetos excluidos de la facultad de acusar poseen exactamente el mismo interés que el rábula querellante hasta la saciedad.

${ }^{814}$ Para el entendimiento de la teoría de la situación jurídica procesal es obligada la remisión a la obra de GOLDSCHMIDT Der Prozeß als Rechtslage y a cómo es ésta recogida en Problemas Jurídicos y Políticos..., pp. 46 y ss.
} 
manifestaciones externas que la pretensión adopta vendrán determinadas por su aptitud para satisfacer la función que tienen que cumplir en cada situación jurídica, por lo que la afirmación de la concurrencia de presupuestos para el ejercicio del ius puniendi se irá configurando de manera diversa a lo largo de todo el desarrollo del proceso atendiendo a la estructura básica que soporta el entramado de éste. No es un acto único, sino un conjunto de actividades dirigidas a satisfacer el presupuesto necesario para el enjuiciamiento, desde sus momentos iniciales hasta su terminación por sentencia o auto de sobreseimiento.

\section{a) El inicio del proceso:}

El inicio del proceso penal puede venir espoleado por el ejercicio de la pretensión penal, pero ni es esencial que ello ocurra, ni es un dato esencial o suficiente para definir todo lo que en sí alberga. Es claro que puede haber actos de ejercicio de pretensión penal que no den lugar a la apertura de un proceso, por ejemplo cuando se inadmite la querella por estimar que el hecho no es constitutivo de delito, pero también que puede darse un cierto desarrollo del proceso sin ejercicio de pretensión penal. La sola iniciación del proceso no satisface tampoco el contenido de la pretensión penal, pues por trascendente que éste efecto sea, se agota simplemente con la resolución judicial que lo determina ${ }^{815}$.

El ejercicio por el MF o por los particulares de la pretensión penal no es prius necesario para que se inicie el proceso, pues una vez que conste un hecho punible podrá existir proceso penal sin ejercicio de pretensión. La querella, acto formal de ejercicio de la pretensión penal, puede hacer que se incoe un proceso, pero no es la única forma y hoy ni siquiera la más frecuente de dar comienzo al enjuiciamiento de una conducta que se afirma delictiva. El procedimiento puede haberse iniciado de oficio sin haberse solicitado explícitamente por nadie, pues la notitia criminis puede haber llegado al Juez por medio de denuncia ${ }^{816}$, atestado policial o por conocimiento directo. Puede comenzar sin

${ }^{815}$ ALCALÁ-ZAMORA reconocía que, mientras que la denuncia se limitaría a dar el empujón para que determinados hechos franquearen la puerta jurisdiccional, la querella "según el modelo español" supone verdadero ejercicio de la acción penal. Le sería aplicable por tanto su afirmación en el sentido de que "la acción no es un empujón que se le da a la pretensión litigiosa para que franquee la puerta jurisdiccional sino una vibración continuada para que llegue a su destino (pronunciamiento de fondo) (...) Toda la energía o principio anímico de la actividad procesal realizada por las partes, proviene de la acción”. ALCALÁ-ZAMORA y CASTILLO, N., "Enseñanzas y sugerencias...", op. cit. pp. 350 y 365.

\footnotetext{
${ }^{816}$ Incluso cuando se trate de una querella que adolezca de requisitos formales o sea defectuosa hasta el punto de que deba ser considerada inexistente, puesto que en este caso deberá ser considerada como denuncia, y por tanto, como medio válido de transmisión de la notitia criminis al órgano jurisdiccional. Vid. GÓMEZ ORBANEJA, E.,
} 
acusación, pues éste no se inicia como consecuencia de un derecho del acusador, sino como consecuencia de la llegada de la notitia criminis a una Autoridad Pública con función de averiguación y esclarecimiento de los delitos: Policía Judicial, MF u Órganos Jurisdiccionales. El interés que se protege con la apertura de la investigación por delitos públicos no pertenece al denunciante o al querellante, sino que es un interés propio de toda la comunidad en tanto ésta se ha dotado de órganos encargados precisamente de tal misión. Aun cuando no sea necesario excitar su actividad para que se pongan en funcionamiento, una vez que conste cierta verosimilitud en la afirmación de la existencia del delito que se impute deberán hacerlo ${ }^{817}$.

La acusación no es, sin embargo, algo absolutamente ajeno a la iniciación del procedimiento, en tanto es claro sin ella no podrá haber resolución jurisdiccional alguna en la que se aprecie comisión de un delito, pues no cabrá apertura de juicio oral sin que tal circunstancia sea afirmada. Como resaltaba FAIRÉN, es cierto que el ordenamiento jurídico, en «estado de necesidad», se vuelve hacia el sistema inquisitivo, pero ese momento sería muy corto, ya que inmediatamente el Juez tendrá que poner en conocimiento del MF la notitia criminis para que sea deducida la pretensión penal ${ }^{818}$.

b) En la investigación:

Durante la fase de instrucción, el querellante contribuye a determinar el objeto procesal (la afirmación de la existencia de un delito) aun cuando no tiene facultades para limitar el examen judicial de los hechos ${ }^{819}$. Sus calificaciones serán solamente provisionales en la medida en que el factum que se reputa delictivo, así como su conocimiento, pueden ir variando ${ }^{820}$. La pretensión se ejercita a través de la solicitud de

Derecho Procesal Penal, 10ª ed. p. 149 in fine y GIMENO SENDRA, V., La querella, op. cit., p. 253.

${ }^{817}$ Vid. por ejemplo el art. 24 LOTJ.

${ }^{818}$ FAIRÉN GUILLÉN, V., "De nuevo sobre el concepto de acción y pretensión”, op. cit., p. 22.

${ }^{819}$ No han de olvidarse las peculiaridades del proceso de la LOTJ, aptas para constituir matizaciones a lo aquí afirmado. Vid. por ejemplo art. 27. 1 y 3.

${ }^{820}$ CORTÉS DOMÍNGUEZ, V., La cosa juzgada penal, op. cit. p. 42. El hecho como tal es sin embargo esencialmente inmutable puesto que en el juicio oral no podrán ser alegados otros hechos que los que se deriven del sumario ni acusadas personas distintas a aquellas frente a las que éste se dirigía, afirmación que no deja de ser compatible con la delimitación progresiva que irá sufriendo en su curso. Podrá conocerse mejor o podrá ampliarse con hechos conexos, pero no cambia a medida que se desarrolla el proceso y si se descubren circunstancias que lo cambian, deberá iniciarse un nuevo proceso sobre el nuevo objeto. 
una investigación sobre un hecho y un sujeto que culminará con la petición de apertura del juicio oral. Se cifra, por tanto, en la preparación del material histórico-fáctico y en la delimitación subjetiva del objeto del proceso, que constituirá el fundamento de la afirmación que va a realizar el actor en el juicio oral.

c) En el juicio oral:

Una vez recopilados los elementos esenciales idóneos para permitir el reproche penal al sujeto, deberá realizarse una concreta imputación con expresa petición de que, como objetivo último del ejercicio de la pretensión penal, se dicte una sentencia en la que, estimando probado el hecho que se imputa y la culpabilidad del acusado, se imponga la consecuencia prevista por la norma penal. En el juicio oral podemos entender la acusación como la afirmación realizada ante un órgano jurisdiccional de la existencia de los presupuestos del deber estatal de imponer la pena que corresponda sobre una persona concreta y en relación con un hecho determinado.

Puede entenderse consecuencias de lo expuesto hasta aquí:

1) Mientras que en el proceso civil la calificación jurídica material de los hechos por el juez se produce por primera vez en la sentencia ${ }^{821}$, en el proceso penal sólo puede iniciarse e ir avanzando por medio de sucesivas calificaciones jurídicas materiales ${ }^{822}$. Puede decirse que, aun cuando pueda sufrir alteraciones en sus diversas configuraciones, la existencia de una pretensión es lo que sostiene con vida el proceso. En tanto la afirmación de la concurrencia de presupuestos para el ejercicio del ius puniendi permanezca, y no sea refutada por sentencia o auto de sobreseimiento motivados por la fundada convicción del órgano jurisdiccional de que el proceso deba terminar definitiva o provisionalmente, éste deberá seguir con vida.

2) En el momento en que el órgano jurisdiccional estime que la afirmación realizada por el acusador es infundada debe darlo por concluido, con diferentes efectos en función de la fase en la que se encuentre el proceso.

3) La respuesta definitiva al ejercicio de la pretensión no se otorga con la

\footnotetext{
${ }^{821}$ Sin perjuicio de que pueda pronunciarse jurídicamente antes, como ocurriría por ejemplo al declararse objetivamente incompetente por razón de la materia.

${ }^{822}$ MONTERO AROCA, J., Derecho Jurisdiccional, T. III, 1996, p. 25.
} 
resolución motivada sobre la apertura del proceso y la personación del actor en él ${ }^{823}$, ni tampoco con la que abra el juicio oral o decrete el sobreseimiento ${ }^{824}$, sino únicamente con la dictada cuando el Tribunal, a la vista de lo actuado procesalmente, se pronuncie sobre la existencia o no de un derecho estatal a imponer la pena, es decir de hacer efectivo su ius puniendi ${ }^{825}$.

\subsection{Legitimación para acusar}

\subsubsection{Principio de oficialidad de la acusación por delitos públicos}

\subsubsection{Deber estatal de garantizar la resolución de los conflictos a través del debido proceso}

Una vez proscrita la autotutela es obligación del Estado, único sujeto titular de la potestad del ius puniendi, mantener y administrar una justicia penal que conduzca al esclarecimiento, persecución y condena de todos los supuestos delictivos a través de los mecanismos jurídicamente establecidos. La asunción de la tarea de perseguir y castigar los delitos responde a una publicitación de la Justicia ya producida en el régimen absoluto. En el marco del Estado social será éste el obligado al aseguramiento de las condiciones básicas para la convivencia social, en tanto organización creada al servicio de

${ }^{823}$ En contra de lo manifestado por quienes ven en el ejercicio de la "acción penal" un derecho de acción.

${ }^{824}$ Como se desprendía de la primera concepción de GÓMEZ ORBANEJA y de la sustentada por CORTÉS DOMÍNGUEZ, en La cosa juzgada penal, op. cit. pp. 21 y ss.

\footnotetext{
${ }^{825}$ En intento de distinguir la pretensión penal de un derecho constitucional de acción cuya presencia en el proceso penal se sostiene, habitualmente se diferencian dos momentos diversos en la actividad de los acusadores: el inicial en el que se interpone la querella y el resto de actividades conducentes a la imposición de la pena. Así, en opinión de FAIRÉN, la serie de "actos a través de los que se desarrolla la acción penal" no serían sino actos a través de los que se sigue preparando o se interpone la pretensión, a la cual sirvió de preparación inicial la interposición de la acción que motivó la actividad jurisdiccional del Tribunal. Vid. FAIRÉN GUILLÉN. V., Voz “Acción”, op. cit. p. 200. No podemos sin embargo mostrarnos concordes con esta distinción entre acción y pretensión en el proceso penal, puesto que el derecho de acción de sujetos no ofendidos por el delito debe entenderse totalmente ajeno al ámbito penal. El conjunto de actos que entendemos incluye la "acción penal", es decir la actividad realizada por los acusadores y que abarca desde la interposición de la querella o la personación del actor hasta la calificación definitiva, ha de ser reconducible por entero a la idea de pretensión. Todos ellos, aun diversamente configurados, se encaminan a la afirmación de la concurrencia de presupuestos necesarios para el ejercicio del ius puniendi, requisito sine qua non de la resolución jurisdiccional en que se constate su existencia.
} 
los ciudadanos cuya única finalidad es la satisfacción de los intereses de éstos ${ }^{826}$. Ante un ataque a bienes jurídicos de alguno de los miembros de la comunidad considerados esenciales y por ello garantizados por la norma penal, será siempre deber del Estado activar todos los recursos precisos para restablecer de la mejor forma posible la paz social vulnerada. Una vez constatada la sospecha de comisión de un delito, la realización de todas y cada una de las actividades necesarias para enjuiciar esa conducta y a su autor, llegando a una apreciación más allá de toda duda razonable sobre si es constitutiva de delito, formará indudablemente parte integrante del deber estatal de garantía de justicia. El debido proceso penal es, así, parte de la obligación de garantía de la justicia encomendada a los órganos estatales que se justifica por la propia estructura del Estado de Derecho y su compromiso de garantizar la seguridad de los ciudadanos ${ }^{827}$, la protección de los bienes jurídicos de éstos y su confianza en el adecuado funcionamiento de las Instituciones Públicas ${ }^{828}$.

El enjuiciamiento y eventual sanción de los sujetos a los que se imputen hechos afirmados punibles constituye satisfacción del interés colectivo, en cuanto con ello se posibilita la realización de la verdad de la Constitución (art. 9.2 CE). La Potestad Jurisdiccional, atribuida a Jueces y Tribunales, incorpora exclusiva y excluyentemente el ius puniendi estatal, con lo que dinámicamente sólo existirá y se realizará procesalmente actuando la ley en el caso concreto: juzgando y haciendo ejecutar lo juzgado (117.3 CE). De la misma manera, también procesalmente se tendrá que crear el presupuesto necesario,

\footnotetext{
${ }^{826}$ Vid. sobre la materia la interesante introducción de HENKEL en su manual Strafverfahrensrecht, Stuttgart 1968, pp. 14 y ss. y 96.

${ }^{827}$ Sólo de esta forma triunfará la garantía que ofrece la seguridad jurídica, que nuestro TC ha definido como "la confianza que los ciudadanos pueden tener en la observancia y el respeto de las situaciones derivadas de la aplicación de normas válidas vigentes" y que "reclama que los ciudadanos posean una razonable convicción acerca de la correcta interpretación y aplicación de la legalidad y puedan ajustar a ella su comportamiento". SSTC 146/1987 de 25 de noviembre. y de 63/1984 de 21 de mayo respectivamente.

${ }^{828}$ Constituye un ineludible deber para él someter todas las conductas que se sospechen peligrosas o lesivas para los bienes jurídicos protegidos por la norma penal a verificación y, de declararse judicialmente su existencia, a imponer la consecuencia jurídica prevista por las norma material. O para decirlo en palabras del TC alemán "el principio del Estado de Derecho, la obligación del Estado de proteger la seguridad de sus ciudadanos y su confianza en el adecuado funcionamiento de las instituciones y el tratamiento igual de todos los imputados en el proceso penal exigen la puesta en marcha de todas las pretensiones penales estatales" BverfGE 51, 324, 343, publicada en $N J W 1979$, p. 2349. No sólo es obligación del Estado el mantenimiento del Estado de Derecho, sino también junto a ella la obligación de asegurar una justicia penal adecuada a sus funciones. Vid. también HENKEL, H., Strafverfahrensrecht, op. cit. pp. 96 y ss.; PFEIFFER en Karlsruher Kommentar zur StPO, $3^{\text {a }}$ edic. p. 2. y MÜLLER/SAX/ PAULUS, Kommentar zur StPO, Francfort 1988, p. 11.
} 
la acusación, conditio sine qua non del enjuiciamiento penal.

\subsubsection{Derecho de los ciudadanos al proceso penal y derecho a que se acuse}

A diferencia de los derechos de libertad o "derechos de hacer algo" que deben considerarse facultades de actuar, los derechos de prestación son derechos a algo, a que el Estado actúe. Ello se corresponde necesariamente con una expectativa de comportamiento de quien está “obligado a", es decir, del Estado en tanto responsable de los deberes públicos de hacer. Su caracterización como Social y de Derecho exige la prestación positiva en garantía de determinados derechos, lo cual nos lleva a poder fundamentar el que quepa reclamar la tutela de todos los intereses amenazados por la acción delictiva. Si el reconocimiento de los derechos individuales supuso una garantía frente al absolutismo estatal, la proclamación de los derechos sociales supone una garantía para el bienestar de los ciudadanos, consolidando el efectivo disfrute de las libertades civiles y políticas, pero exigiendo simultáneamente un comportamiento activo por parte de los Poderes Públicos $^{829}$.

Aun cuando no se halle configurado expresamente un derecho constitucional a la persecución de los delitos por las autoridades, tal derecho no parece difícil de deducir si se tienen en cuenta varios preceptos de la Carta Magna interpretados sistemáticamente. Podríamos entender así el mandato constitucional dirigido a los Poderes Públicos consistente en garantizar las condiciones para que la libertad sea real y efectiva (art. 9.2 $\mathrm{CE}$ ), el respeto a la ley como fundamento del orden político y la paz social a los que aquéllos vienen obligados (art. 10.1 en relación con el 9.1 CE) o la vinculación del MF a la defensa de la legalidad (art. 124.1 CE). No cabe sostener la existencia de un derecho de los ciudadanos a una pena ${ }^{830}$, la cual podrá no imponerse de no constatarse más allá de

\footnotetext{
${ }^{829}$ El realismo más elemental obliga a reconocer que las libertades puras, aquellas cuyo disfrute sólo dependería de la abstención del Estado, se hallan irremediablemente superadas por la evolución económica y social de nuestro tiempo. En la coyuntura actual lo mismo el disfrute de las libertades que el de los derechos exigen una política social apropiada y unas medidas económicas por parte del Estado. Sin ellas, proclamar que "la escuela o la cultura se hallan abiertas a todos" se ha dicho que sería tan ilusorio como decir que "el Hotel Ritz se halla abierto a todos". Vid. así PÉREZ LUÑO, A.E., Derechos Humanos..., op. cit. p. 91, recogiendo la expresiva frase de CALOSSO.

${ }^{830}$ La cuestión de la efectiva imposición de la sanción penal ha sido abordada por la doctrina penalista normalmente desde la perspectiva de la prevención general: el potencial delincuente debe contar con que la norma penal se aplicará en caso de que decida llevar a cabo su acción delictiva. De esta manera no se trataría tanto de fortalecer una norma penal en concreto, sino de asegurar la confianza general en el ordenamiento jurídico en
} 
toda duda razonable la afirmación contenida en la acusación, pero sin duda sí es posible referirse a un derecho de todos los ciudadanos al desarrollo del proceso vinculado con la efectiva y plena defensa de la legalidad, o más exactamente, con la obligación del Estado de garantizar la paz jurídica a través del mantenimiento del Ordenamiento Penal. Este derecho al proceso podría definirse como el derecho constitucional a la aplicación jurisdiccional de la norma, que se realizará mediante la declaración en un proceso con todas las garantías de la existencia del delito y la eventual imposición de la consecuencia legalmente prevista. La ley penal, expresión de la voluntad general de acuerdo con el procedimiento constitucionalmente previsto, materializada siempre que se cumplan sus presupuestos, adquirirá de esta manera su carácter de regla básica de ordenación de la convivencia social.

De este derecho de todos los ciudadanos al enjuiciamiento serían predicables las siguientes características: a) Es disperso, en cuanto a su atribución subjetiva, puesto que no depende de la concreta norma infringida y cualquier referencia al ofendido, perjudicado o a los representantes de intereses afectados es irrelevante; b) Es previo, en tanto no nace con el delito, sino que existe y se posee con carácter general y siempre en un momento anterior a él; c) Es abstracto, en el sentido de que será ajeno a la concreta actividad desarrollada en el proceso por los particulares, pues ésta carece de relevancia para su satisfacción. La activación del proceso penal no es algo que por principio se deba a quien actúa en concreto, sino que es una actividad debida a todos los ciudadanos, por lo que una persona ajena al proceso será titular del mismo derecho a que se desarrolle éste que quien, sin defender un interés material propio, pretenda erigirse en acusador.

La respuesta de los órganos jurisdiccionales al delito no tiene que esperar al ejercicio de pretensión alguna por particulares, sino que deberá adelantarse a través de la activa intervención estatal. El argumento que en el derecho romano y en la doctrina liberal decimonónica fundamentaba la existencia de un derecho generalizado de acusación ("puesto que el delito afecta a la sociedad, yo, miembro de la sociedad debo tener el derecho de perseguirlo") debe ser hoy revisado desde el Estado Social de Derecho. A la luz de la dimensión objetiva de los derechos fundamentales, aquella necesidad debería formularse en los siguientes términos: dado un supuesto fáctico de comisión de un delito, cualquier persona tiene derecho a que se adopten por el Estado todas las medidas necesarias para la averiguación de sus circunstancias y la deducción de las eventuales 
responsabilidades penales. La idea de la acusación propia del Estado liberal no intervencionista debe entenderse hoy superada y ampliada, en tanto no puede venir referida a la prohibición de inmiscuirse en la esfera de los ciudadanos para blindar un hipotético derecho a acusar, sino que ha de fijarse con carácter previo en la obligación estatal de actuar. Seguir afirmando el carácter de la acusación como derecho de libertad en la relación ciudadano-Estado es el insuficiente reflejo de una concepción del Estado liberal en la que sólo se incluye su consideración como objeto de prohibiciones de intervención, de prestaciones negativas en garantía de los derechos de los ciudadanos. En aquel modelo decimonónico, y desde una concepción ahistórica, natural y presocial de los derechos subjetivos, el ciudadano tendría derecho a acusar en la medida en que ostentaría un derecho a que el Estado no intervenga en una facultad que le corresponde con carácter originario. Pero hoy el Estado no satisfará plenamente los derechos de los ciudadanos con una mera actividad pasiva, de no intervención en el ámbito penal, sino que deberá ir más allá $^{831}$.

Partiendo de que la estructura acusatoria de nuestro proceso penal impide su desarrollo sin que un sujeto sostenga acusación, deberíamos concluir necesariamente en el reconocimiento de la existencia de un derecho de los ciudadanos a que se ejercite la pretensión penal en tanto premisa ineludible del enjuiciamiento. Puesto que es exigible la activación del proceso en todos los supuestos en los que de la prescripción de la norma sustantiva se haga necesario, la acusación llevará a la concreción en cada supuesto de sospecha de comisión delictiva el derecho de todos los ciudadanos al enjuiciamiento de las conductas afirmadas como delitos. Parece claro que antes de pensar en defender la necesidad de un derecho de los individuos a acusar, deberíamos por tanto hablar de un “derecho a que el Estado acuse". Aun más, la vinculación al principio de legalidad penal y su correlativo de obligatoriedad del ejercicio de la pretensión penal como garantías para la sociedad en su conjunto, llevan implícitas la concepción de la acusación penal como un verdadero derecho de los ciudadanos "a algo", un derecho a recibir una prestación estatal. Una vez sentada la premisa de que sin acusación no hay proceso, su ejercicio constituye parte de la obligación del Estado de garantizar la paz jurídica y participa por tanto de la naturaleza de los deberes estatales.

\footnotetext{
${ }^{831}$ Como recuerda FERRAJOLI, L., Derecho y Razón. Teoría del garantismo penal, pp. 861 y ss., para el ciudadano el Estado no sólo tiene que dejar de ser un inconveniente para el ejercicio de sus derechos, sino que también tiene que configurarse y ser percibido como ventaja.
} 
Un Estado que hiciera depender en alguna medida de la iniciativa privada la iniciación del proceso conducente a la declaración de la existencia de delitos públicos y la imposición, en su caso, de la consecuencia prevista en la norma no cumpliría uno de sus deberes esenciales, cual es el de la plena e igualitaria garantía de la seguridad ${ }^{832}$. Puesto que la finalidad a la que sirve la acusación en los delitos públicos es ésta, no se encuentra en una zona fronteriza, compartida o de intersección entre lo público y lo privado, sino que recae por entero dentro del primero de estos campos, independientemente de la condición pública o privada del sujeto que en la práctica la lleve a cabo ${ }^{833}$. No cabría sostener que estemos ante un doble interés público y privado o ante un interés prioritariamente público que se pueda transmitir luego a los particulares a través de su acusación, ya que no puede considerarse que se trate de algo que, en determinados casos, pueda resultar ajeno a los deberes del Estado como instrumento de satisfacción de intereses de los ciudadanos. Recae íntegramente en el ámbito de lo público y común a todos los ciudadanos y, por ende, debe ser tutelado desde la esfera estatal ${ }^{834}$. No hay tertium genus posible entre acusación pública y acusación ejercitada por el ofendido para la defensa de sus intereses privados, sino que ambas tienen que ser contempladas desde su diseño orgánico hábil para satisfacer objetivamente los concretos intereses que se dilucidan en el proceso.

El Estado, que monopolizó la imposición del castigo y correlativamente el proceso, asume la imprescindibilidad de éste para sancionar, autosometiéndose jurídicamente a la obligación de que sea un sujeto diferente a los órganos jurisdiccionales quien requiera la actuación de éstos. Esta invocación a la vista de una conducta con apariencia de delito formará parte, por tanto, del compromiso que asumió el Estado para la persecución

\footnotetext{
${ }^{832}$ O como señala MONTERO AROCA, "Si el Estado considera que un acto debe ser tipificado como delito, no puede consentir que dejen de perseguirse actos concretos que quedan subsumidos en la norma penal". Derecho Jurisdiccional, T. III, 1996, p. 17.

${ }^{833}$ Estimaba GÓMEZ ORBANEJA que perteneciendo la "acción penal" exclusivamente al Estado, éste la actuaría por medio de un representante: bien un órgano público especialmente adscrito a esa función (el MF), bien un particular cualquiera (en la acusación popular), bien un particular determinado (en los delitos que no pueden perseguirse -ni penarse- sino a instancia de parte agraviada). La idea correlativa sería que el Estado aparece en el proceso acusatorio con un artificioso doble carácter: por un lado como el sujeto que pide para sí (pero mediante un representante) el acto de tutela; por otro como el órgano jurisdiccional llamado a afirmar tal derecho, a otorgar la protección jurídica. GÓMEZ ORBANEJA, E., Derecho Procesal Penal, op. cit. p. 88

${ }^{834}$ No cabe realizar una disociación entre Estado y sociedad, sino que sólo cuando el Estado sirva para garantizar los derechos de los ciudadanos estará legitimado: el Estado social no puede perseguir intereses que no sean los de la sociedad.
} 
criminal y en esta actividad no hay atisbo ninguno de derecho, sino de auténtica y genuina obligación. Estamos por tanto ante el puro deber estatal de acusar a la vista de las premisas fácticas y jurídicas que concurran, y en ningún caso ante un derecho ${ }^{835}$ de la Autoridad Pública ${ }^{836}$, cuyo aserto sólo desviaría la atención de lo esencialmente importante: el contenido de la acusación tiene que servir únicamente a la satisfacción del interés público. Dada la premisa de la legalidad y la efectiva vinculación de los Poderes Públicos a ella (art. $9 \mathrm{CE}$ ), la función de acusación puede entenderse elevada al rango de deber constitucional para los órganos del Estado.

Podría pensarse que sosteniendo estas afirmaciones nos estamos alejando de la realidad práctica y entrando en un mundo de incorpóreos conceptos jurídicos indeterminados. Pudiera achacársenos también la crítica de que para la tutela de un intangible derecho de todos a la instauración del proceso penal la técnica del derecho subjetivo no parece dar la respuesta más adecuada. E incluso cabría tachar a ese derecho al proceso penal como ineficaz por su carácter etéreo o por no encontrar fácil acomodo entre los cauces de defensa de que el ordenamiento se ha dotado. Sin negar que efectivamente pueda ser difícil de concretar, desde luego no lo sería más que la consideración vigente de que todo delito afecta a todos y cada uno de los ciudadanos en la medida en que son miembros del cuerpo social. La diferencia entre ambas declaraciones se sitúa sin embargo en los efectos derivados de la aceptación prioritaria de una u otra, alguno de los cuales intentaremos desentrañar a continuación:

a) Referirnos al delito como una ofensa infringida a todos y cada uno de los miembros de la sociedad implicaría que todo aquel que desease ejercitar una pretensión en el proceso penal estaría defendiendo un interés propio, derivado del prorrateo entre todos los miembros del cuerpo social de la ofensa contenida en el delito. El establecimiento por

\footnotetext{
${ }^{835}$ Se ha hablado también en este caso de un supuesto derecho-deber, singular categoría que fue ya formulada por CARNELUTTI, Cuestiones sobre el Proceso Penal, op. cit. p. 33. No encontramos, sin embargo, razón de ser a su aplicación a pesar de que haya hecho fortuna entre nuestra doctrina, no sólo en relación con el ejercicio de la pretensión penal por el MF, sino también en otros ámbitos como el del jurado popular (vid. Exposición de Motivos LOTJ). Expresaba también sus dudas en torno a la categoría del "derecho-deber" LALLA, quien la califica como un "verdadero sinsentido desde el punto de vista dogmático". Apuntaba este autor la posibilidad de que tras esta categoría se disfrazase la fidelidad dogmática a la potestad "para no tener que reconocer enteramente su encuadre en la categoría de las obligaciones". LALLA, P., Il concetto legislativo di azione penale, Nápoles 1966, pp. 24 y ss.

${ }^{836}$ En alguna ocasión se ha sostenido que el derecho habilitante para ejercitar la acusación no pertenece al Estado, pero sí a todos los ciudadanos y también al MF. Vid. por ejemplo CORTÉS DOMÍNGUEZ, V., La cosa juzgada penal, op. cit., p. 87.
} 
la ley de impedimentos o trabas a la posibilidad de defender ese interés en el proceso llevaría siempre ínsita una merma de derechos individuales. La restricción podría quedar justificada sólo en virtud de intereses de carácter prevalente, únicamente tras una ponderación entre los intereses en juego en la que se constatara su superior valor frente al derecho constitucional de invocar la tutela de intereses legítimos (24.1 CE). Muy pocos intereses podemos imaginarnos que sean superiores a éste, por lo que en principio todo aquel que quisiera acusar, tendría que ser admitido al proceso para no hacer que sufriera indefensión.

$\mathrm{Si}$, por contra, consideráramos el dato de que todo ciudadano posee un derecho al proceso que conduzca en su caso a la aplicación de la norma penal, las limitaciones que se establecen a su facultad de acusar serían la frontera externa delimitadora del marco que el ordenamiento configura habilitado para su intervención. Al amparo de este criterio no habrá restricción o exclusión de un derecho inmanente al individuo por el juego de intereses superiores, sino diseño de una estructura orgánica garantizadora de la aplicación de la norma penal, entre cuyos límites no tiene por qué incluirse necesariamente a los particulares. Optando por admitirlos, no es menester que sea ni a todos los sujetos en la misma medida ni para todos los supuestos: la facultad de intervención existe sólo en tanto conferida por una norma expresa habilitante, y sólo dentro de los límites contemplados en ésta.

El matiz puede parecer trivial, pero es de carácter esencial puesto que con la acusación pública no se defiende directamente un interés propio e individual, ni siquiera siendo éste coincidente con el público en la solución a través del proceso de los conflictos, sino sólo la de éste. El derecho al proceso quedará plenamente satisfecho con una actuación procesal tendente a una resolución jurisdiccional en la que se dé respuesta a la afirmación de la concurrencia de presupuestos para estimar la existencia de delito.

b) la afección de todo sujeto por el delito como factor habilitante de una facultad de intervención en el proceso es fruto de una concepción individualista que olvida o prescinde de una realidad fundamental: la presencia del Estado como órgano de satisfacción prioritaria de intereses generales. La obligación constitucional de los Poderes Públicos de garantizar la libertad y la paz social es pasada por alto para dejar un ámbito de libre actuación al ciudadano. Se antepone la existencia de un derecho subjetivo individual de realizar algo por uno mismo frente a la de derechos subjetivos individuales generadores de obligaciones estatales. 
El ciudadano tiene derecho a la actividad estatal conducente a la realización de todos los actos necesarios para la determinación de si ha de aplicarse la norma penal no en tanto ofendido por el delito en una mínima parte, sino en tanto sujeto integrante del Estado, que no es más que un instrumento al servicio de la satisfacción de los intereses de los ciudadanos. Desde la perspectiva del Estado social, la defensa del interés público en la solución pacífica de los conflictos debe ser sin duda asumida por el Estado, y quedará satisfecho por el pleno desarrollo del proceso. Cuestión diferente será el que ese interés, que es eminentemente público, pudiera admitir ser actuado también por la iniciativa privada, pero en todo caso de ello no se deriva una transformación en su naturaleza.

c) La existencia de ese presuntamente intangible derecho al proceso dirigido al cumplimiento de la legalidad penal ofrece además una virtud que debe ser considerada prioritaria: la de consolidar un fundamento con el que reclamar de los Poderes Públicos su adecuada satisfacción, tanto en el momento legislativo (orgánica y procesalmente) como en el de su aplicación ${ }^{837}$. Y este es el punto clave sobre el que merece la pena llamar la atención. La escasez en la dotación de medios materiales y humanos de la fiscalía, la jerarquización entendida como estructura de transmisión de requerimientos arbitrarios del Ejecutivo, el desconocimiento general de los criterios de actuación del MF, etc. son algunos de los problemas que pueden enquistarse en el sistema si no asumimos que el ciudadano tiene derecho a que el órgano constitucional de acusación funcione correctamente.

Si por el contrario seguimos hablando de un derecho de acusación extendido a una pluralidad de ciudadanos y entroncado con las más profundas esencias humanas, estaremos de alguna manera, por mínima que ésta sea, permitiendo una coartada para la conservación de los vicios del sistema. Al fin y al cabo, se piensa, aunque el MF no funcione bien, no le debemos conceder tanta trascendencia puesto que todos podemos ser

${ }^{837}$ Como ha proclamado en reiteradas ocasiones el TEDH, el art. 6.1 CEDH obliga a los Estados contratantes a organizar su sistema judicial de tal modo que sus Juzgados y Tribunales puedan cumplir cada una de sus exigencias. Vid. entre otras SSTEDH Milasi de 25 de junio de 1987, § 18; Unión Alimentaria Sanders S.A. de 7 de julio de 1989, § 38; Bezicheri de 25 de octubre de 1989, § 25; Lombardo de 26 de enero de 1992, § 23; Abdoella de 25 de noviembre de 1992 § 24; Dobbertin de 25 de febrero de 1993, § 44; Bunkate de 26 de mayo de 1993, § 23; Mansur de 8 de junio de 1995, §68. Quisiéramos destacar en este sentido la STEDH Martins Moreira de 26 de octubre de 1988 , $§ 60$, en la que el TEDH afirma que "al ratificar la Convención, el Estado portugués ha contraido la obligación de observarla y el deber, en el supuesto concreto, de asegurarse con ello el respeto por sus diferentes autoridades". Sobre esta cuestión en relación con la duración del proceso vid. el reciente trabajo de PEDRAZ PENALVA, E., "El Derecho a un proceso sin dilaciones indebidas", $P J, \mathrm{n}^{\circ} 43-44$, pp. 225 y ss. 
fiscales en algún momento ${ }^{838}$. Tal apreciación no sólo pecaría de ingenua, sino que no es cierta, pues ni la inmensa mayoría de la población será nunca ese "fiscal popular" ni los intereses de los particulares que asumen el compromiso de acusar sin ser ofendidos pueden nunca quedar vinculados estrictamente al principio de legalidad. Pero lo más grave es que impedirá percibir con claridad la actividad de los fiscales con la trascendencia que ésta tiene.

Asumiendo como posible que el MF funcione incorrectamente e invistiendo a sujetos privados de facultades sanadoras de ese mal, estaremos aceptando que, en principio, el Estado esté haciendo dejación de una de sus funciones esenciales (la de promover el enjuiciamiento para que pueda verificarse la conculcación del ordenamiento jurídico penal) para ceder a los particulares una parcela muy sensible donde quedan afectados derechos fundamentales de otros de sus ciudadanos. Al aceptar como reales las deficiencias, negligencias o la presencia de intereses extravagantes en la actuación del MF, y prever su corrección a través de la intervención Deus ex Machina de los particulares acusadores, no se hace más que aprovechar un afán de venganza, de notoriedad o cualesquiera otros, en cualquier caso bastardos, para plantear el presupuesto de la satisfacción del interés público derivado del enjuiciamiento. El Estado instrumentaliza así propósitos cuando menos extravagantes y justifica la posible ineptitud o insuficiencia del órgano estatal de acusar, buscando compartir la responsabilidad en la no persecución. Al dar entrada a los particulares se transmite, por ende, el mensaje de que, si no se logra la condena, no sólo será culpa del órgano oficial encargado de acusar, sino también del particular agraviado y de los demás ciudadanos quienes, pudiendo, no han intervenido, o habiéndolo hecho, no han sido capaces de satisfacer todos los requisitos precisos para provocar en el juez la necesaria convicción para dictar un fallo condenatorio.

\subsubsection{Legitimación ordinaria para acusar: el MF}

En el conflicto generado por el delito, y dada la necesidad y complejidad de la misión de acusar, la comunidad organizada en el Estado se ha venido a dotar histórica-

\footnotetext{
${ }^{838}$ Vid. p. ej. COBO DEL ROSAL, M., "Problemas penales y procesales de la denuncia" en GONZÁLEZ MONTES, J.L. (Editor), Primeras jornadas sobre problemas actuales de la justicia penal, Universidad de Granada 1994, p. 43: "la acción popular permite que Fiscales Generales del Estado, perdón por la exageración, podamos ser todos, con tal de depositar una pequeña fianza".
} 
mente de unos profesionales a quienes encomendó su ejercicio al objeto de evitar tanto el peligro de su incorrecta realización como el de que los crímenes quedaran impunes. A la vista de los elementos esenciales sobre los que se asienta la concepción acusatoria del proceso penal y de la idea de justicia rogada, se estimó conveniente la creación de un oficial diferente a los órganos jurisdiccionales para que dedujese el interés público promoviendo la acusación: el Ministerio Fiscal ${ }^{839}$.

El propio Estado y, en última instancia, el Pueblo de quien emanan todos los poderes públicos (art. 1.2 CE) es el titular del ejercicio de la pretensión penal, pero será el MF la institución especializada orgánica y funcionalmente encargada de su materialización en la práctica. A ella se confiere la misión de promover la acción de la justicia en defensa de la legalidad, de los derechos de los ciudadanos y del interés público tutelado por la ley, así como la de procurar ante los Tribunales la satisfacción del interés social (art. 124.1 CE), tarea que habrá de realizar en cada proceso en concreto. La legitimidad de estos oficiales estatales estará sujeta a su efectivo servicio a la satisfacción de los intereses y expectativas sociales en pro del interés general. El MF es, por consiguiente, el instrumento de que se ha dotado la ciudadanía organizada públicamente en el Estado para la prioritaria satisfacción de esa esencial función, por lo que no cabrá hablar de un derecho del MF que le habilite para acusar, sino única y exclusivamente de un deber de actuar por razón de su oficio o cargo que da razón de ser a su configuración constitucional $^{840}$.

La garantía del interés público no es una facultad potestativa o arbitraria para esos órganos estatales, sino que sólo es justificable desde la estricta vinculación al principio de legalidad, verdadero anclaje de su actividad en el Estado de Derecho. Así viene a reconocerse en nuestro sistema en los arts. $124 \mathrm{CE}, 2.1,6$ y $48 \mathrm{EOMF}^{841}$ y 105 LECrim,

\footnotetext{
${ }^{839}$ Vid. DE LA OLIVA SANTOS, A., Sobre el derecho a la tutela jurisdiccional, op. cit. p. 112 y Derecho Procesal Penal, p. 170. En palabras de MONTERO AROCA, el Ministerio Público o Fiscal es una creación artificial que sirve para hacer posible el proceso, manteniendo el esquema básico de éste. MONTERO AROCA, J., "La garantía procesal penal...", op. cit. p. 977.

${ }^{840}$ Sobre el principio de legitimación formal cfr. PEDRAZ PENALVA, E., "Del Consejo General del Poder Judicial y de la selección de sus miembros”, en PEDRAZ PENALVA (Coordinador), El Gobierno de la Justicia. El Consejo General del Poder Judicial, Valladolid 1996, p. 36. Recuerda aquí el citado autor el principio nuclear del Estado de Derecho consistente en que "la titularidad del poder no legitima su ejercicio sino que el poder se legitima desde la racionalidad de su ejercicio", por lo que "la fuente de legitimación no es el poder, sino su ejercicio".

${ }^{841}$ A ellos podría añadirse el art. $408 \mathrm{CP}$ en el que se determina que incurrirá en la pena de inhabilitación especial para empleo o cargo público por tiempo de seis meses a dos años la autoridad o funcionario que, faltando a
} 
constituyendo éste un elemento esencial que determina el entendimiento de la función estatal de acusación como obligación ligada a la defensa de los valores protegidos por la norma penal ${ }^{842}$. La generalidad y abstracción de la ley y el derecho de los ciudadanos a la instauración de un proceso como garantía jurídico-fundamental confluyen en cada caso concreto a través del ejercicio de la acusación por quien constitucionalmente viene obligado.

La LECrim ha de ser leída hoy a la luz de la posición constitucional del MF, y ello nos lleva a considerar que se ha subvertido la configuración de los elementos esenciales con los que se dio forma al sistema de acusación. El legislador decimonónico pensaba en un "derecho de acusación" de ejercicio generalizado y titularidad privada, enmarcado en la inexpropiable esfera subjetiva de los ciudadanos (art. 101 y 270 LECrim), el cual debería además ser ejercitado también por oficiales públicos cuando lo considerasen procedente (art. 105, 271 LECrim). La actividad del MF era en este sentido exactamente la misma que podía realizar cualquier integrante del cuerpo social, cualificada por una teórica obligatoriedad, pero fundamentada sobre las mismas premisas. Lo procedente en la actualidad es, no obstante, la inversión de los términos en que la historia fijó el régimen legal de la acusación en nuestras normas procesales: no cabe hablar más de un derecho ciudadano asumido simultáneamente por el Estado, sino de una obligación estatal en cuyo esbozo orgánico pudiera ser conveniente la intervención de algunos ciudadanos si ello contribuyera a la mejor satisfacción del interés público.

La disociación entre un Estado perverso por naturaleza y una sociedad civil compuesta de ciudadanos bienintencionados en la que se basaba aquella primitiva concepción, no resiste un mínimo análisis bajo la óptica del Estado Social en el momento actual. La desconfianza hacia las Instituciones, no justificada más que cuando no acogen intereses o se forman a espaldas de los de los ciudadanos, no tendría por qué motivar el recelo permanente frente a unos órganos cuya misión es precisamente la de servir al ciudadano, razón única que fundamenta su existencia. La discrepancia en el momento acusatorio entre intereses del Estado frente a intereses de la sociedad no debería contar

la obligación de su cargo, dejare intencionadamente de promover la persecución de los delitos de que tenga noticia o de sus responsables.

${ }^{842}$ Como destacaba GÓMEZ ORBANEJA, el principio de legalidad es el complemento imprescindible del sistema de acusación oficial, en el que el MF está obligado a ejercitar la "acción penal" por todo hecho que reviste los caracteres de delito. Derecho Procesal Penal, 1984, pp. 115 y ss. 
con un espacio propio sino que, simplemente, tendría que ser descartada como posibilidad teórica. Los intereses del Estado sólo pueden ser los intereses de la sociedad constitucionalmente organizada, y sólo en la medida en que eso sea así y ambos se vean confundidos, se estarán satisfaciendo las razones de la existencia de la organización estatal. Aun cuando evidentemente no podemos permanecer en ese idílico panorama donde todo se cumple a la perfección, no por ello debemos flagelarnos con la idea de que nunca se pueden producir las cosas según el marco teórico en el que se las ideó. Situemos por tanto el régimen de la acusación sobre verdaderos pies democráticos ${ }^{843}$, extraigámosle sus connotaciones liberales tendencialmente privatistas y desfasadas y, desde el reconocimiento de que deducir la pretensión penal es una función estatal, analicemos la conveniencia de la intervención de los ciudadanos para dar respuesta a las necesidades de la justicia penal del siglo que va a dar comienzo.

\subsubsection{Acusación quivis ex populo}

A diferencia del proceso civil en el que el reconocimiento de legitimación activa se confiere a partir de la afirmación de la titularidad de derechos subjetivos, en el proceso penal por delitos públicos esa legitimación se ha expandido por el legislador hasta hacerla prácticamente ilimitada mediante su atribución a casi todos los ciudadanos ${ }^{844}$, sin exigirse vinculación alguna con el objeto protegido por la norma penal (art. 101 y ss, 270 y ss. LECrim). En este caso se ha estimado oportuno que, amén del MF y en los amplios términos en ella fijados, también otros sujetos pudiesen acusar con la finalidad de poner las bases necesarias para realizar la actividad conducente al enjuiciamiento y, en su caso, a la imposición de una pena.

Una peculiaridad de este reconocimiento, que hace que estemos en presencia de una "acción popular", es que no se realiza en favor de todas las personas sino que se entiende hecho para aquellos a los que no se excluya con carácter expreso. Es por tanto una extendida legitimación activa, reconocida ope legis a la mayoría de los españoles y cuya amplitud en concreto no viene delimitada de forma expresa, sino que atiende a

\footnotetext{
${ }^{843}$ Parafraseando a HÄBERLE en referencia a la teoría de los derechos públicos subjetivos de JELLINEK.

${ }^{844} \mathrm{O}$ como señala FENECH, el concepto de parte material queda desbordado "en más" en cuanto el ordenamiento positivo reconoce la posibilidad de que pueda ejercitar la acción penal quivis ex populo. FENECH, M., Derecho Procesal Penal, v. I, $3^{\text {a }}$ ed. Barcelona 1960, p. 130.
} 
criterios negativos: cuando no haya una norma que excluya la legitimación, ésta se entenderá conferida por el ordenamiento jurídico. La ley hubiera podido dejar a otros sujetos fuera de este ejercicio, pero existiendo una acusación popular no podría contener una enumeración taxativa del tipo "podrán acusar sólo los sujetos $x, y, z$.”.

El ejercicio de la acusación por los ciudadanos no ofendidos se configura como una facultad de ejercitar una competencia estatal, que sólo bajo determinados presupuestos se activará. Es algo que el ordenamiento jurídico concede, y no algo que reconozca como existente con carácter previo a la norma habilitadora. No nos encontramos pues ante el reconocimiento $u$ otorgamiento de una genérica libertad jurídica para acusar, sino ante la atribución de una facultad que añade algo a la capacidad de actuación del individuo que no poseía por naturaleza ${ }^{845}$, y que ni siquiera es necesaria. La aptitud de los no ofendidos para acusar no se refiere a una capacidad general para actuar procesalmente, sino que tiene que venir expresamente conferida por una norma en la que específicamente se les atribuya legitimación ${ }^{846}$. Su régimen debe considerar además la presencia de intereses prevalentes dignos de protección, ante los que la atribución de legitimación quivis ex populo debe ceder (confianza en los acusadores, protección de la familia, etc.).

Lo que está ausente en los supuestos incluidos en el no reconocimiento de la facultad de acusar no es en ningún caso la capacidad de los sujetos, sino únicamente la legitimación para el ejercicio de la acusación por los no ofendidos. Ésta viene conferida legalmente, por tanto, con un carácter muy amplio pero no absoluto, puesto que se halla sujeta a una serie de restricciones que determinan su exclusión cuando no se reúnan

\footnotetext{
${ }^{845}$ Mientras que permitiendo hacer algo, el ordenamiento jurídico se comportaría pasivamente frente a las posibles alternativas de acción, en el otorgamiento de esta competencia se comporta activamente y crea una alternativa de acción. Las "competencias" son junto con los "derechos a algo" y las "libertades" un segmento de las posiciones que llamamos "derechos". Pueden encontrarse en la literatura designadas también como "poder" o "poder jurídico", "autorización", "facultad", "derecho de configuración" y "capacidad jurídica". El uso por el legislador de la técnica del reconocimiento de competencias conduce necesariamente al establecimiento de deberes, de noderechos y de no-competencias. Vid. ALEXY, R., Teoría de los Derechos Fundamentales, op. cit. p. 227.

${ }^{846}$ DE LA OLIVA resalta que los artículos 102, 103 y 104 LECrim no contendrían meros presupuestos procesales para la eficacia del ejercicio de la acción, sino presupuestos de la acción misma, de la que se carecería si no concurren. Vid. DE LA OLIVA, A., Derecho Procesal Penal, Madrid 1993, p. 182. En sentido contrario vid. GIMENO SENDRA, V., La Querella, op. cit. p. 118. La diversidad de opiniones en torno a su consideración como cuestión referida a la capacidad o a la legitimación se debería en su criterio a una visión procesal civilista de tales conceptos que no tendría en cuenta que en materia penal el interés violado es el de la comunidad. Por ello, dice GIMENO en consonancia con AGUILERA DE PAZ y GÓMEZ ORBANEJA, "lo que los arts. 102 y 103 determinan es la incapacidad procesal, y para ser parte del ejercicio de la acción penal en la forma de querella pública o acusación popular". No alcanzamos nosotros a entender el sentido del término "incapacidad procesal y para ser parte", si no es interpretándolo como "ausencia de legitimación".
} 
algunos requisitos (nacionalidad española, mayoría de edad), cuando se den otros (estar incapacitado, ser juez, haber sido condenado dos veces por acusación falsa) o cuando la acusación se dirija contra los parientes ${ }^{847}$. El reconocimiento del posible ejercicio popular de la acusación no guarda por ello relación con la capacidad de los sujetos autorizados, sino con una legitimación extraordinaria que ha de venir expresamente asignada a éstos por el ordenamiento jurídico. De ahí que no quepa suplir los defectos de capacidad a través de los mecanismos establecidos en la ley (representación legal, asistencia) ${ }^{848}$, que no podrían entrar aquí en juego, no por tratarse de un derecho personalísimo e intransferible a la acusación, sino simplemente porque, encontrándose estos sujetos en las hipótesis excluidas, el ordenamiento jurídico no les otorga legitimación. De esa falta de reconocimiento no cabría concluir una quiebra del principio de igualdad, sino que lo apropiado sería contemplarla como parte de la estructura orgánica del sistema acusatorio.

No hay un "derecho a la acusación popular", sino una habilitación a unas personas y en unos supuestos otorgada con el objeto de desarrollar una función originariamente encomendada al Estado, cuyo ejercicio privado pudiera en algún caso contribuir a la defensa del interés público inherente al proceso penal. Se trata, pues, de un diseño orgánico en el que la misma función puede ser desempeñada por sujetos oficiales o privados, por lo que no hay una acusación pública y una acusación popular, sino una única acusación pública (porque se dirige a la defensa de un interés público), la cual puede ser deducida por todos los no excluidos en los supuestos previstos legalmente. Acusar no es una libertad más, sino que supone una función pública en la que, en determinadas ocasiones y bajo determinados presupuestos, podrían ser admitidos algunos particulares. Conceptuar el hecho de acusar como derecho en sí mismo no es más que una fórmula heredada de una ideología superada, una manifestación del derecho individual a la defensa en su traslado al proceso penal. Si suprimiéramos la acusación popular no estaríamos desprendiéndonos de nada propio de la esencia de los individuos, sino sólo de un elemento que pudiera estar al servicio de una actividad estatal, cual es la acusación. No podemos hablar por ende de un derecho de los ciudadanos que determine una configuración del sistema de acusación, sino de un sistema de acusación que se

\footnotetext{
${ }^{847}$ O como afirma SERRA, la legitimación de las "partes contingentes" se deriva de la concurrencia de presupuestos positivos (ser español y prestar fianza) y presupuestos negativos (no estar incursos en causa de exclusión). SERRA DOMÍNGUEZ, M., "Precisiones en torno a los conceptos de parte, capacidad procesal, representación y legitimación", JUSTICIA 87, p. 311.

${ }^{848}$ MONTERO AROCA, J., Derecho Procesal Penal, 1996, p. 64.
} 
complementa orgánicamente con la intervención de algunos particulares ${ }^{849}$.

La LECrim presume que la actividad de los ciudadanos no ofendidos se realiza siempre para el logro del interés perseguido en el proceso penal, por lo que no cabe una restricción a priori al ejercicio de la acusación atendiendo a la finalidad que mueve a su promotor, a la conveniencia o no de su uso o a que no se dirija a los objetivos con los que se concibió en origen ${ }^{850}$. Nada de eso podrá ser indagado en el momento de admisión de la querella pues no ha de buscarse nexo alguno entre sujeto y objeto procesal, sino sólo su inclusión en el marco legal. La posibilidad de acusar ha surgido a la vida desde su atribución por el legislador, por lo que los autorizados podrán hacer uso de él dentro de sus límites objetivos. El principal defecto de la acusación popular está, pues, ínsito en su propia esencia: las motivaciones del ciudadano acusador no pueden ser indagadas como exige su carácter de acción popular, por lo que es admisible que éstas se dirijan simultáneamente a la satisfacción de intereses diferentes al público en la garantía de la solución de los conflictos en el marco del proceso. Aunque existiera la constancia de que se acusara con una clara intencionalidad privada, una vez atribuida a un sujeto la legitimación, no cabría negarle la utilización de una facultad que se le ha concedido legalmente ${ }^{851}$.

${ }^{849}$ En contra de lo afirmado en alguna ocasión (GIMENO SENDRA, V., Constitución y Proceso, p. 84.), no cabe afirmar que el actor popular asuma un «rol» similar al del MF (la protección de la legalidad y del interés social), sino que sólo podría asumir exactamente ese mismo «rol».

${ }^{850} \mathrm{La}$ preponderancia de intereses privados en el acusador popular ha sido rechazada en ocasiones abiertamente sobre un plano meramente teórico. VALERO OLTRA, por ejemplo, ha reclamado para él una objetividad e imparcialidad equiparable a la del MF que se distinguiría así de la acusación particular. De ahí que entendiera fundamentada la exclusión del ofendido, basada en la búsqueda de una objetividad en su ejercicio, difícilmente compaginable con el daño propio. VALERO OLTRA, R., "Consideraciones sobre la acción popular", BIMJ $\mathrm{n}^{\circ} 1237$, 25 de abril 1981, pp. 5-12, esp. p. 8. Mucho nos tememos sin embargo que éste no sea más que un deseo retórico, pues no cabe constatación alguna en la práctica de la probidad de los intereses que mueven la actividad del acusador popular.

\footnotetext{
${ }^{851}$ En sendas resoluciones sin precedentes jurídicos, la Fiscalía de Cataluña y el Juzgado no 16 de Barcelona han limitado recientemente en un supuesto concreto el ejercicio popular de la acusación, al apreciar que el querellante se movía por afán de venganza (se trataba de una querella por un delito de tráfico contra un Magistrado, interpuesta por el hijo del ex Juez Estevill). En ellas se indica, quizá ingenuamente, que el objetivo de la "acción popular" es "que aflore la verdad judicial por el bien de la Justicia y la Sociedad". Tomamos la referencia de La Ley. Diario de Noticias, 17 de abril de 1997, p. 3. Tal doctrina no puede ser admitida fácilmente, pues no hay precepto legal que permita impedir a los ciudadanos el planteamiento de la acusación sobre la base de los móviles que les inducen a actuar. Ese tipo de argumentaciones obligarían a los instructores a realizar un verdadero "examen de conciencia" de los querellantes, hasta averiguar si están movidos por torcidas intenciones o por la defensa del interés general. El margen de apreciación sería tan amplio que lo convierte innecesariamente en un terreno resbaladizo: en este caso las motivaciones del querellante parecen saltar a la vista, pero debemos preguntarnos qué es lo que ocurrirá cuando esa
} 


\subsubsection{La "acusación particular"}

\section{I.}

El tema de la intervención de la víctima en el proceso penal ha alcanzado en las últimas décadas una trascendencia no reconocida suficientemente con anterioridad. La cuestión ha sido objeto de múltiples y muy profundos estudios, tanto dentro ${ }^{852}$ como fuera de nuestras fronteras ${ }^{853}$, ha impulsado reformas legislativas y ha incidido particularmente

apreciación no sea tan diáfana. Una vez más queda clara así la aptitud de la acusación popular para la persecución de intereses extravagantes al público que debe presidir el desarrollo del proceso penal, así como su potencialidad para constituir un elemento de presión o venganza.

${ }^{852}$ Entre nuestra doctrina pueden consultarse entre otros LIESA, I., "Sobre el concepto de ofendido por el delito", $R G L J \mathrm{n}^{\circ} .181$, 1947, p. 809; GÓMEZ-ORBANEJA, E., Comentarios a la LECrim T.II, Vol. I, pp. 256 y ss; GONZÁLEZ MONTES, F., "Acción penal y perdón del ofendido en los denominados delitos públicos", $R F D U$ Granada no2, 1983, pp. 83-93; MARTÍNEZ-ARRIETA, A., "La víctima en el proceso penal (I y II), Actualidad Penal 1990, IV y V, Marginales 41 y 49; GUTIÉRREZ-ALVIZ y CONRADI, F., "Nuevas perspectivas sobre la situación jurídica penal y procesal de la víctima" en La Reforma del Proceso Penal. II Congreso de Derecho Procesal de Castilla y León y en RUDProc 1991, no 5 pp. 161 y ss.; PERIS SIERRA, J.M., "Situación jurídico procesal y economía de la víctima en España", RJca Castilla-La Mancha $n^{\circ}$ 13, dic. 1991. pp. 45 y ss.; FAIRÉN GUILLÉN, V., "Acción, proceso y ayuda a las víctimas del delito", La Ley 1991, T. 3 pp. 862-881; ARAGONESES MARTÍNEZ, S., "Introducción al régimen procesal de la víctima del delito. Deberes y medidas de protección", RDProc. $\mathrm{n}^{\circ} 2,1995$, pp. 409-440. Desde perspectivas no estrictamente procesales vid. entre otros SILVA SÁNCHEZ, J.M., “¿Consideraciones victimológicas en la teoría jurídica del delito? Introducción al debate sobre la victimodogmática", Derecho Penal y Criminología, Revista del Instituto de Ciencias Penales y Criminológicas de la Universidad Externado de Colombia, vol. XII, n 40, enero-abril 1990, pp. 117-134; GARCÍA-PABLOS DE MOLINA, A., "Sobre la función de la víctima en el Estado de Derecho: víctima, política criminal, criminología y política social", Derecho Penal y Criminología, Revista del Instituto de Ciencias Penales y Criminológicas de la Universidad Externado de Colombia, vol. XIV n ${ }^{\circ}$ 46, enero-abril 1992, pp. 55-82; LANDROVE DIAZ, G., Victimología, Valencia 1992; LANZA, E., "Victimología: ¿Quiénes son las víctimas? ¿cuáles sus derechos? ¿cuáles sus necesidades?”, $J D \mathrm{n}^{\mathrm{o}} 15,1 / 1992$, p. 21.

${ }^{853}$ En Alemania el tema se suscitó vivamente con motivo de la Ley de Protección de las Víctimas a mediados de los años 80 . De aquella discusión se han generado frutos de muy alto valor científico. Vid. en especial el exhaustivo trabajo de WEIGEND, T., Deliktsopfer und Strafverfahren, Berlín 1989, así como del mismo autor "Das Opferschutzgesetz: kleine Schritte zu welchem Ziel?", NJW 1987, Cuaderno 20, pp. 1170 a 1177, así como RIEß, P., "Die Rechtsstellung der Verletzten im Strafverfahren", Gutachten C zum 55. Deutschen Juristentag, Verhandlungen des 55. DJT, T. I. Munich 1984. Vid. también entre otros MAIWALD, M., "Die Beteiligung des Verletzten am Strafverfahren", GA 1970, pp. 33 y ss.; KERNER, H. J., "Die Wiedereinsetztung des Opfers als Subjekt des (Straf-) Rechts" en JANSEN, H. y KERNER, H.J. (editor), Verbrechensopfer, Sozialarbeit und Justiz, Bonn 1985; KÜHNE, H. H., "Die tatsächliche Bedeutung von Opferrechten in der Deutschen Strafprozeßordnung", Monatschrift für Kriminologie und Strafrechtsreform, 1986, pp. 98 y ss.; KIRTSGEN, J.R., Das Klageerzwingungsverfahren, Dissertation, Bonn 1986, pp. 84 y ss.; NEUMANN, U., "Die Stellung des Opfers im Strafrecht" en HASSEMER, W. (editor), Strafrechtspolitik. Bedingungen der Strafrechtsreform, Francfort 1987 pp. 225 a 253; SCHNEIDER, H. J. "La posición jurídica de la víctima del delito en el derecho y en el proceso penal", en DE LA CUESTA et al. (Editores), Criminología y Derecho Penal al servicio de la persona. Homenaje al Prof. Beristain, San Sebastián 1989, pp. 379 y ss.; SEELMANN, K., "Paradoxien der Opferorientirung im Strafsachen” Juristen Zeitung 1989, pp. 
en las formas de administración de la justicia penal en todos los países de nuestro entorno y en el nuestro. La "victimología" es hoy una de las vigorosas ramas emergentes de la criminología, la "victimodogmática" es considerada parte integrante de los estudios de derecho penal, y por lo que al derecho procesal respecta, a nadie se le escapa hoy la trascendencia de la participación de los agraviados por el delito en el proceso penal, no tanto en la condición de acusador sino sobre todo en calidad de testigo cualificado, de interesado o de ejercitante de una pretensión de resarcimiento ${ }^{854}$.

Nos enfrentamos por tanto con un tema de viva actualidad en el cual sólo entraremos tangencialmente para intentar establecer una línea divisoria entre quiénes hayan de ser considerados "acusadores populares" y quiénes "acusadores particulares". La actividad acusatoria del ofendido surge en la LECrim del mismo tronco común que la del no ofendido, de lo que en el momento legislativo se percibió como un genérico derecho de todos los ciudadanos a acusar (art. 101 LECrim). Parece claro, no obstante, que el ofendido o perjudicado no es "un sujeto cualquiera" y que afirmar que tiene un simple interés por la legalidad en su actuación procesal sería negar lo evidente. Es precisa, por tanto, una diferenciación que delimite lo que haya de entenderse por ofendido, agraviado, lesionado o perjudicado que pueda servir de base a partir de la cual establecer

670 y ss. HIRSCH, H.J., "La posición del ofendido en el derecho penal y en el derecho procesal penal, con especial referencia a la reparación", traducción de SÁNCHEZ-OCAÑA, CPC 1990, n 42, pp. 561 a 575; HASSEMER, W., "Rücksichten auf das Verbrechensopfer" en KOHLMANN, G. (Editor), Festschrift für Ulrich Klug zum 70. Geburtstag Band II. Traducción de Rocío Cantarero en ADPCP, 1990, pp. 241 y ss.; HIRSCH, H. J., "La posición del ofendido en el Derecho Penal y en el Derecho Procesal Penal, con especial referencia a la reparación" CPC 1990, n 42 pp. 561-576, KAISER, M., Die Stellung des Verletzten im Strafverfahren, Friburgo 1992, ESER, A., "Zur Renaissance des Opfers in Strafverfahren", en Festschrift für Armin Kaufmann; "Funktionswandel strafrechtlicher Prozeßmaximen: Auf dem Weg zur «Reprivatisierung» des Strafverfahrens?”, en KROESCHELL, K. (editor), Recht und Verfahren. Symposion der rechtswissenschaftlichen Fakultäten der Albert Ludwigs Universität Freiburg und der Städtischen Universität Osaka”, Heidelberg 1993 y en ZStW 104 (1992) Heft 3, pp. 361-397; Voz "Opfer” en KAISER, G., KERNER, H.J., SACK, F., SCHELLHOSS, H. (editor), Kleines Kriminologisches Wörterbuch. $3^{\mathrm{a}}$ ed. En Italia además de los clásicos CARNELUTTI, F., Il danno e il reato, Padua 1926 y ANTOLISEI, F., L'Offesa e il danno nel reato, Bergamo 1930; vid. GIARDA, A., La persona offesa dal reato nel processo penale, Milán 1971; BARONE, G., Enti Colletivi e proceso penale (dall constituzioni di parti civile all'accusa privata, Milán 1989 y los comentarios correspondienetes a los arts. 90 y ss. del nuevo Codice di Procedura Penale.

Como obras de referencia pueden consultarse KÜHNE, H. H., Opferrechte im Strafprozeß. Ein europeischer Vergleich; JOUTSEN, The role of the Victim of Crime in European Criminal Justice Systems; MAWBY, R.I. y WALKLATE, S., Critical Victimology. (International Perspectives); TIEFFER SOTOMAYOR, C., "La posición jurídica del ofendido en el Derecho Procesal Penal latinoamericano. Un estudio de derecho comparado", Revista Ciencias Penales, Asociación de ciencias penales de Costa Rica año 1, nº 1, Dic. 1989.

${ }^{854}$ Sobre el contenido de la responsabilidad patrimonial derivada del hecho ilícito punible vid. por todos el estudio de PEDRAZ PENALVA, E., Las medidas cautelares reales en el proceso penal ordinario español, Madrid 1985 , pp. 31 y ss. 
el límite excluyente de la acusación popular para entrar en el ámbito de la ejercitada por la víctima del delito.

De los textos procesales no cabe extraer directamente una definición sobre quién sea ofendido y quién perjudicado por un delito, términos no utilizados con precisión ni con un sentido y significado único ${ }^{855}$. A falta de una definición legal, y como punto de partida, podríamos remontarnos a un precedente histórico: en la Base $3^{\mathrm{a}}$ de las de Reforma del Procedimiento Penal de 1929, en la que se excluía la acusación popular en sentido estricto, se seguía reconociendo la posibilidad de acusar al sujeto ofendido y éste quedaba definido como el "titular del derecho subjetivo violado por la infracción". Este concepto fue precisado por GÓMEZ ORBANEJA añadiendo que existiría un derecho subjetivo “cuando la norma tenga por fin la tutela de intereses del singular, pero no si se trata de la tutela de intereses generales; entonces no puede hablarse de derecho subjetivo del sujeto pasivo, sino meramente de un interés (reflejo) jurídicamente protegido" ${ }^{856}$. Por otra parte, el derogado art. 761.II LECrim sí establecía una definición, pero sólo en relación con la exigencia de responsabilidad criminal a Jueces y Magistrados en los siguientes términos: "se entiende por ofendido aquel a quien directamente dañe el delito". Por último, en opinión de GIMENO SENDRA, ofendido por el delito es la persona que soporta la lesión de un determinado bien de la vida social tutelado por la norma penal, en definitiva "el titular del bien jurídico protegido", el sujeto pasivo del delito en términos de Derecho penal sustantivo ${ }^{857}$.

El TC no ha elaborado un concepto cerrado de lo que debamos entender por "ofendido por el delito" alegando que carecería de trascendencia constitucional (STC

${ }^{855}$ Así por ejemplo los arts. 109, 110 y 783 LECrim parecen emplear de modo indistinto las palabras ofendido y perjudicado. Vid. MONTERO AROCA, J., Derecho Jurisdiccional, T. III, p. 65.

${ }^{856}$ GÓMEZ ORBANEJA, Comentarios..., op. cit. p. 262. En este sentido el autor se remite a CARNELUTTI, Il danno e il reato, pp. 98 y ss. y su teoría sobre la subjetivación de las normas penales que explica en los Comentarios cit. p. 176. Merecen su atención aquellas figuras en que a) la norma penal protege primordialmente un interés público, estatal y b) se ha pretendido en la doctrina que titular del interés penalmente protegido, en una u otra forma, pueda ser una pluralidad indeterminada de personas, una comunidad no organizada (Personengesamtheit); el público, la sociedad, la familia, etc. (“delitos vagos o vagantes", vage o vagierende Verbrechen de la doctrina alemana). op. cit. p. 266.

\footnotetext{
${ }^{857}$ Se trataría además de un concepto restringido, puesto que el legislador lo reserva tan sólo para el sujeto pasivo de los delitos contra las personas y la propiedad, por lo que no cabría alegar la condición de ofendido en los delitos en los que la comunidad social es el sujeto pasivo. GIMENO SENDRA, V., La Querella op. cit. pp. 131 y ss y 137 y ss.
} 
113/1984 de 29 de noviembre), en tanto que su negación no conllevaría necesariamente obstaculizar el acceso al proceso, lo que siempre factible mediante el ejercicio de la "acción popular" (40/1994 de 15 de febrero, FJ $3^{858}$; 326/1994 de 12 de diciembre, FJ $2)^{859}$. Declara, así mismo, que sería una cuestión de mera legalidad establecer si la existencia de un interés legítimo y personal convierte a un sujeto en perjudicado por el delito, concreción que en todo caso correspondería realizar a los Tribunales ordinarios, salvo que la resolución judicial denegatoria de la legitimación se manifieste arbitraria o notoriamente irrazonable (STC 34/1994 de 31 de enero, FJ 3). Aunque indirectamente, para el TC, sí parece claro que el reconocimiento de tal cualidad comporta una afección a la propia esfera jurídica $(147 / 1985 \text { de } 29 \text { de octubre, FJ } 3)^{860}$.

La jurisprudencia del TS también ha atendido a tal requisito al exigir un nexo de la esfera personal con el objeto material deducido en el proceso ${ }^{861}$, interés que debe entrar directamente en relación con el bien jurídico protegido sin que, por ejemplo, pudiera ser considerado como interés directo la defensa genérica de la moral pública. El TS ha estimado así que "tal defensa viene encomendada, por ley, a una institución del Estado como es, paradigmáticamente, el Ministerio Fiscal, cuyas pretensiones, dada su imparcialidad, están destinadas "ope legis" y con un carácter lógico, a defender a la sociedad en su conjunto, a través o por impulso del principio de legalidad" ${ }^{\circ 62}$.

Muestra de la rigidez mostrada jurisprudencialmente al apreciar la legitimación había sido la actitud contraria a considerar ofendida a una comunidad de personas físicas

\footnotetext{
${ }^{858}$ En este caso se reconoce por el TC la existencia de un "interés legítimo" en la querellante - aspirante a una plaza de Profesor Universitario- para la perseguibilidad de un delito de plagio, aun cuando no sea ofendida o perjudicada por él.

${ }^{859}$ El alto Tribunal viene a ratificar así la inexigibilidad para la interposición de una querella de demostrar una expresa vinculación material con el objeto del proceso por delito público.

${ }^{860}$ En ella se ratifica la constitucionalidad de la fianza impuesta a un funcionario que pretendía personarse en diligencias abiertas por usurpación de funciones y nombramiento ilegal alegando que "Ni su interés como simple ciudadano, en la correcta actuación de los poderes públicos, ni su interés como funcionario en el buen y legal funcionamiento de la Corporación a la que sirve permiten otorgarle la consideración de ofendido por un delito que de existir, en nada ha afectado a su propia esfera jurídica".

${ }^{861}$ Así, por ejemplo, una fábrica de discos será ofendida por un delito contra los derechos de autor, pero no por un delito de estafa o defraudación en la calidad al consumidor, supuesto en el que sólo hubiese sido posible su personación como no ofendido por el delito. STS 30 de mayo de 1984 (RAJ 3492).

${ }^{862}$ STS 5 de junio de 1993 (RAJ 4824).
} 
sin personalidad jurídica, pero con determinados lazos culturales o de parentesco (una etnia, una familia, etc.). A este respecto GIMENO constataba que se venía observando un criterio negativo opuesto a lo expresado por GÓMEZ ORBANEJA, quien afirmaba dicha cualidad cuando tales comunidades sociales tuvieran una mínima organización ${ }^{863}$. Sin embargo, al menos desde la STC 214/1991 de 11 de noviembre (FJ 3) ${ }^{864}$ es detectable una mayor flexibilidad al recoger la doctrina de la "víctima indirecta" elaborada por el $\mathrm{TEDH}^{865}$. En aquélla se reconoce que de no admitirse la legitimación activa de todos y cada uno de sus miembros para poder reclamar jurisdiccionalmente contra las intromisiones en el honor de los grupos étnicos, sociales o religiosos sin personalidad jurídica, no sólo permanecerían indemnes las lesiones a este derecho fundamental, que sufrirían por igual todos y cada uno de sus integrantes, sino que también el Estado permitiría campañas discriminatorias, racistas, etc. Aun cuando en este supuesto se trataba de una demanda civil, cabe entender que con ello se flexibiliza el concepto de ofendido cuando concurra un interés legítimo específico, aun no siendo éste estrictamente personal.

Sujeto pasivo del delito parece ser que podrá ser cualquier persona, física o jurídica, entre las cuales se ha de incluir sin duda al Estado, pero siempre un sujeto en particular o una pluralidad de ellos. El derecho penal ampara los intereses particulares que el delito lesiona o pone en peligro, pero no el interés genérico del Estado en la conservación y mejora de la sociedad, que no es más que el motivo o la razón de esa tutela jurídica y nunca su objeto. El Estado protege el interés del ciudadano porque considera que su lesión o puesta en peligro serían nocivos para la convivencia social, porque reputa necesario, o por lo menos útil, para la buena marcha de la sociedad que no sucedan ese tipo de agresiones, pero no puede adquirir la condición de sujeto pasivo de

${ }^{863}$ GÓMEZ ORBANEJA, E., Comentarios..., op. cit. T. II, p. 269. Este criterio, que GIMENO comparte, sólo sería defendible lege ferenda ya que, a tenor del art. $38 \mathrm{CC}$, sólo las personas jurídicas constituidas con arreglo a las leyes podrían ejercitar “acciones civiles y penales”. GIMENO SENDRA, V., La Querella, op. cit. p. 139.

\footnotetext{
${ }^{864}$ Se trata del célebre asunto "Violeta Friedmann", un supuesto de demanda civil de protección del honor en el que la demandante se consideraba víctima indirecta por unas declaraciones públicas de contenido antisemita en las que se negaba el holocausto nazi sobre la raza judía. El ponente en este caso fue el Prof. GIMENO. Sobre la sentencia vid. BARROMI, J., "Comentario a la STC 214/1991 de 11 de noviembre (asunto Violeta Friedmann versus Leon Degrell)”, JUSTICIA 96, n² 2, pp. 455-475.
}

${ }^{865}$ En concreto en las SSTEDH de los asuntos "Becker" (S. 7011/1975 de 3 de octubre) tutor de un grupo de huérfanos, "Bel" (C. 7467/1976 de 13 de diciembre de 1976) en la que el recurrente era hermano del dueño, s. 8416/1979, contra el Reino Unido (13 de marzo de 1980), en la que se trataba del marido de una mujer que interrumpió voluntariamente su embarazo. 
todos y cada uno de los delitos ${ }^{866}$. El ejercicio de la acusación por el Estado nunca puede ser por tanto reflejo de un derecho de defensa frente a los que ataquen bienes jurídicos de los que es titular, sino un mecanismo procesal debido a los ciudadanos dirigido a la garantía de la paz social y a la protección de los bienes jurídicos esenciales posibilitando el juicio criminal y, en su caso, el ejercicio del ius puniendi ${ }^{867}$.

${ }^{866}$ ANTOLISEI, F., L'Offesa e il danno..., op. cit. pp. 99 y ss., trató de apartarse de la doctrina mayoritaria en su época para la que el delito no sólo contenía una ofensa al sujeto particular (individual o colectivo) portador del interés ínsito en la norma jurídico-penal vulnerada, sino también al propio Estado, que de ésta manera adquiriría la condición de sujeto pasivo en toda ocasión en la que se produjera una infracción de la norma penal. Con ello el delito tendría siempre dos sujetos pasivos: el propio ofendido y el Estado. Así, por ejemplo, ROCCO distinguía un objeto genérico y un objeto específico del delito. El primero de ellos sería el interés público y social, el interés del Estado en su propia conservación y en la defensa de las condiciones fundamentales de la vida en común, el cual constituye al Estado frente a los ciudadanos en titular de un derecho subjetivo a la obediencia, mientras que el segundo sería un interés que pertenece únicamente al sujeto pasivo ofendido por el delito. CARNELUTTI (Il danno e il reato, p. 54) estimaba criticable esta teoría por cuanto confundía el objeto de la protección penal con el motivo de ésta: una cosa es el interés tutelado por la norma y otra es el interés en el cumplimiento de ésta. La norma penal no puede tutelar el interés en la tutela, es decir, no puede tutelarse ella misma. MANZINI, en otro sentido, estimaba que el objeto jurídico del delito es siempre un bien-interés público por lo que el derecho penal aporta la tutela en cuanto son intereses de todos, no sólo de aquellos a quienes lesiona o pone en peligro. CARNELUTTI objeta que esta nota no nos serviría para la distinción del ilícito penal y el civil puesto que en cada mandato legal hay implícito un interés público: «interest rei publicae no es sólo que los hombres no se maten sino también por ejemplo que el deudor pague sus deudas» (Il danno... p. 52). Son tambien partidarios de la existencia de una duplicidad de sujetos pasivos BATTAGLINI, quien se refiere al delito como puro daño público o FERRI, para el que el Estado sería el sujeto pasivo formal y el particular el sujeto pasivo sustancial. A ello objeta CARNELUTTI la confusión de estos autores con respecto a las diferentes posibilidades de intervención del Estado en el proceso, que será diferente actuando inter partes (como Estado-Administración, sujeto del proceso), que supra partes (por encima del conflicto y para resolverlo). En su opinión, la construcción del delito como lesión del derecho subjetivo del Estado aparece como un silogismo en el que una premisa consiste en la necesaria correlación entre obligación y derecho, sin que, en su opinión, pueda llegar a admitirse la existencia de un derecho subjetivo del Estado a la obediencia penal.

En relación con el daño ocasionado por el delito, CARRARA (Programma, parte generale, § 118) va más allá del mero daño privado y se refiere al daño mediato o reflejo (daño público o daño social), que contiene la alarma social, el mal ejemplo social (contagio imitativo y generación de nuevos delitos), o como se ha llegado a decir por BONUCCI, el resentimiento social. ANTOLISEI, tras admitir la existencia de "alarma social" (minoración de la fe pública en la tutela de la ley, con la consecuente disminución y prestigio del Estado) y de reconocer que el daño social ocasionado por el delito es un daño cierto, sostiene que su importancia ha sido sobredimensionada por la ciencia jurídica de principios de siglo. Los efectos psico-sociales del delito no sólo son innumerables y multiformes sino que varían infinitamente en duración, extensión e intensidad de lugar a lugar y de momento a momento, con lo que será muy difícil realizar una construcción que tenga cierta solidez y no sea arbitraria. Op. cit. p. 103.

${ }^{867}$ En opinión de GIMENO SENDRA, V., La Querella, op. cit. p. 53, n. 111, criticando las tesis de GIARDA, conceptuar el delito como ilícito que daña directamente un interés del Estado rayaría los principios del totalitarismo penal. No compartimos sin embargo su opinión expresada a continuación en el sentido de que "afirmar (...) que es el Estado el legitimado naturalmente para ejercitar la acción penal (...) recuerda el carácter "organicista” de los Estados nazi-fascista". Sin perjuicio de los argumentos expuestos en otros lugares de este trabajo, es menester recordar que de admitir tal aseveración habría de concluirse que allí donde impera un monopolio acusatorio en manos del Estado, encarnado a través del MF (es decir, prácticamente todos los países del mundo, con excepción de algunos pocos entre los que se encuentra el nuestro), habría una reminiscencia de ese carácter "organicista" de los Estados autoritarios. El monopolio de la acusación por el MF, como representante de la comunidad estatal, se consolidó prácticamente en todos los lugares durante el siglo XIX, con lo que sostener que en ello existan 
A la vista de la carencia de previsión legislativa debemos recurrir a las opiniones doctrinal y jurisprudencial a fin de intentar la delimitación entre ofendido y perjudicado por el hecho punible. Siguiendo la ya clásica distinción de ANTOLISEI entre ofensa y daño y los correlativos conceptos de ofendido y perjudicado, el ofendido será el titular o portador del interés cuya ofensa (lesión o puesta en peligro) constituya la esencia del delito, mientras que perjudicado será el sujeto que sufre las consecuencias nocivas del hecho ${ }^{868}$. A juicio de este autor, la ofensa no puede considerarse causada por el hecho ilícito, puesto que es su sustancia, es todo uno con él. Sin embargo, entre la infracción y el daño, diferentes conceptual y cronológicamente, hay una relación de causalidad puesto que éste es el resultado posible pero no necesario de aquélla ${ }^{869}$. Para la determinación de quién sea ofendido se requerirá en primer lugar, con carácter previo, una calificación jurídica provisional, dando como ciertos los hechos que deberán probarse en la causa, contemplar en abstracto la norma penal que subsume la conducta ilícita y tomar en consideración únicamente la titularidad del bien jurídico protegido por ella, pero no la de cualesquiera otros intereses que el hecho delictivo en concreto hubiere podido ocasionar. No se tendrán en cuenta ni los efectos lesivos reflejos de una acción punible ni otros intereses, aun directamente atacados, e incluso necesariamente violados por el hecho punible en su concreción material si no se corresponden con el interés específico contemplado en la norma ${ }^{870}$.

Ofendido o agraviado será, por tanto, el titular o portador del interés jurídicamente protegido lesionado o atacado, mientras que será perjudicado el titular de la esfera en que inciden directamente las consecuencias nocivas del delito, el titular de intereses

reminiscencias de tal idea nos habla de una afirmación poco meditada.

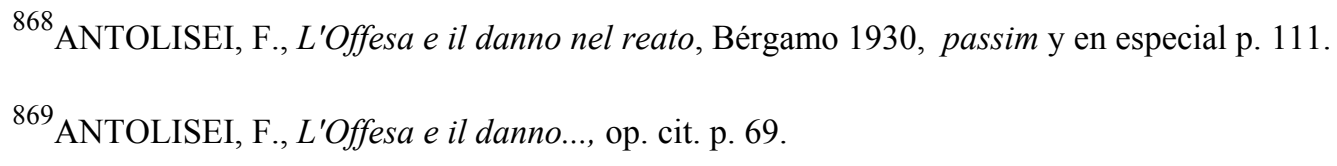

${ }^{870}$ Vid. GÓMEZ ORBANEJA, Comentarios... op. cit. p. 261, que cita como ejemplo de los primeros los aportados por BINDING: la ira de la mujer por los daños a su marido, la pena del padre por el adulterio de su hija, la disminución del valor del inmueble por el repetido incendio de la casa vecina, etc. (Handbuch..., p. 616) y como ejemplo de los intereses reflejos relata el supuesto planteado por LEVI, en el que A mata a B en casa de C, cuya valiosa alfombra queda manchada de sangre. En este caso, $C$ nunca podrá ser considerado como ofendido puesto que el daño por él sufrido, sin dejar de ser directo, no se corresponde con el específico interés protegido en abstracto por la norma que prohíbe y castiga el homicidio. CARNELUTTI, Il danno e il reato, p. 67, se refería a una gradación en la tutela de todos los intereses que el delito ofende, distinguiendo entre una tutela inmediata y otra refleja, correspondientes a intereses inmeditamente protegidos por la norma penal e intereses protegidos de forma mediata u ocasional. 
extrapenales patrimoniales y/o no patrimoniales ${ }^{871}$. Cabe además precisar que el ofendido no es quien padece directamente el delito, como el perjudicado no es quien sufre indirectamente las consecuencias nocivas de él. Ello nos haría confundir al ofendido con el objeto material del delito ${ }^{872}$ o nos forzaría a ampliar el concepto de perjudicado para acoger en él a sujetos que indirectamente hubieran sufrido cualquier tipo de quebranto con ocasión del delito ${ }^{873}$. El perjudicado sólo será, de este modo, la persona que sufra consecuencias nocivas de la infracción penal, ya sean éstas de carácter patrimonial o no patrimonial (moral).

La tarea de acometer una definición general de los sujetos comprendidos en el concepto de "víctima del delito" ha sido en ocasiones evitada conscientemente al considerar que cualquier descripción teórica llevaría bien a no decir nada o bien a meros juegos de palabras tautológicos. Se ha optado por ello por un concepto pragmático en el que se incluye a aquella persona o conjunto limitado de personas que, en cada caso concreto, resultan afectados por la infracción criminal en su esfera de intereses jurídicamente protegidos ${ }^{874}$. En este sentido ha de reseñarse la definición de víctima del delito realizada por la "Declaración de las Naciones Unidas sobre Principios Básicos de la Justicia en relación con las Víctimas de los Delitos y del abuso de poder", de carácter muy generoso y que revela un ánimo ciertamente proteccionista. A tenor de ella habrán de entenderse víctimas de los delitos "Las personas que, individual o colectivamente, hayan sufrido daños, inclusive lesiones físicas o mentales, sufrimiento emocional, pérdida financiera o menoscabo sustancial de sus derechos fundamentales, como consecuencia de acciones $u$ omisiones que violen la legislación penal vigente" ${ }^{875}$.

${ }^{871}$ ARAGONESES MARTÍNEZ, S., "Introducción al régimen procesal de la víctima del delito. Deberes y medidas de protección”, RDProc. $\mathrm{n}^{\mathrm{o}} 2$ 2, 1995, p. 417.

\footnotetext{
${ }^{872}$ Se ha hecho clásico el ejemplo de la automutilación, supuesto en el que quien se mutila no es ofendido sino objeto material del delito.
}

${ }^{873}$ ARAGONESES MARTÍNEZ, S., “Introducción al régimen procesal de la víctima del delito...”, op. cit. p. 418.

${ }^{874}$ Vid. WEIGEND, T., Deliktsopfer und Strafverfahren, Berlín 1989, pp. 22 y 414 y ss.

${ }^{875}$ La consideración de víctima se hace independiente "de que se identifique, aprehenda, enjuicie o condene al perpetrador e independientemente de la relación familiar entre perpetrador y víctima". Tal concepto incluirá también "a los familiares, personas a su cargo que tengan relación inmediata con la víctima directa y a las personas que hayan sufrido daños al intervenir para asistir a la víctima o prevenir su victimización...”. 
Cabría entender, así, que la imposibilidad de definir en abstracto y de manera excluyente quién haya de ser estimado titular de los intereses protegidos por la norma determina la necesidad de que ello sea verificado en cada caso concreto. Ha de considerarse víctima del delito, por tanto, a toda persona a la que el delito ocasione un daño o un perjuicio ${ }^{876}$.

En conexión con ello, la determinación de los sujetos titulares de la facultad de acusar sin ostentar la condición de ofendidos tiene que hacerse ineluctablemente de forma negativa: de entre todos los ciudadanos a los que el ordenamiento jurídico confiere abstractamente legitimación activa para el ejercicio de la pretensión penal, habrán de quedar excluidos quienes estén en una relación directa con el concreto bien jurídico atacado o puesto en peligro por la conducta criminal. Cuando un determinado sujeto, con exclusión de todos los demás, sea titular o portador del bien a cuya satisfacción se dirige la norma no estará realizando un ejercicio popular de la acusación, sino que tendrá necesariamente que ser considerado acusador particular, en tanto estaremos ante una realidad diversa. El planteamiento de la acusación por los restantes españoles no incursos en una de las causas de exclusión constituye el ámbito de la acusación popular stricto sensu, puesto que en el momento en que se precisa la afirmación de este vínculo entre sujeto y bien jurídico protegido la propia idea de "acción popular" carece de razón de ser. Restringimos así el ámbito subjetivo que de la acusación popular se sostiene en la actualidad, ampliando simultáneamente el de la acusación particular hasta situar ambas en los que consideramos sus verdaderos términos: el acusador popular no puede afirmar titularidad o representación de derecho material alguno, sino que ostenta simplemente una legitimación extraordinaria conferida al amparo del art. 101 LECrim que le reconoce aptitud para deducir la pretensión penal.

\section{II.}

Existen determinadas situaciones en las que, aun no dándose la condición de ofendido por el delito o no existiendo sufrimiento de perjuicio directo, la exigencia de una relación directa entre el sujeto acusador y el contenido de la norma penal sustantiva nos permite ver que no estamos tampoco ante supuestos de acusación popular, sino de acusación particular. El concepto de "acusador ofendido" resulta ampliado en estas

${ }^{876}$ Vid. en este sentido ARAGONESES MARTÍNEZ, S., "Introducción al régimen procesal de la víctima del delito...", op. cit. RDProc. $\mathrm{n}^{\circ} 2,1995$, p. 419. 
hipótesis al ponerse en relación no sólo con la titularidad de un interés dañado o puesto en peligro, sino también con su posible representación en el proceso. El interés que se hace valer en tales casos no es prioritariamente el público y abstracto que se deriva del enjuiciamiento y eventual aplicación de la norma penal, sino que se viene a propugnar fundamentalmente la reparación o restitución de un específico bien jurídico que se afirma vulnerado y del cual no se puede afirmar con carácter excluyente la titularidad. Se trata, por tanto, de supuestos de legitimación procesal extraordinaria, en los que la intervención procesal de sujetos diversos al titular del bien jurídico lesionado por el delito sirve a la representación de intereses vinculados al bien jurídico vulnerado ${ }^{877}$. Este aspecto no debería pasar desapercibido en la interpretación de nuestras normas procesales en tanto tendría importantes repercusiones sobre las facultades en el juicio de los diversos acusadores.

Estos supuestos a los que nos referimos podrían agruparse en función de las diversas razones que motivan la conveniencia o necesidad de representación de tales intereses:

a) Por imposibilidad, el interés del ofendido podrá ser sostenido procesalmente por otros sujetos cuando devenga imposible su representación por él mismo. Así ocurre en los delitos con resultado de muerte en los que la familia del fallecido se constituye en portadora de un legítimo interés que determina la exclusión del carácter popular de su hipotética acusación.

b) Por voluntad del legítimo titular del específico interés, quien podrá delegar su representación en otro sujeto. Aun cuando la cualidad de ofendido es intransmisible en tanto está directamente relacionada con el bien jurídico afectado por la conducta delictiva ${ }^{878}$, no tiene por qué serlo necesariamente su representación. En ningún caso se podrá obligar al ofendido a ceder esa representación en contra de su voluntad, pero ha de reconocerse que de la agrupación de su interés con el de otros sujetos en una situación equiparable se podría derivar un mayor beneficio para ellos que el ordenamiento indudablemente ha de tener en cuenta. Esto es lo que podrá ocurrir por ejemplo en delitos con una pluralidad grande de agraviados (delitos masa), en los que de la actuación

\footnotetext{
${ }^{877}$ Han de entenderse al margen las hipótesis de representación legal cuando el ofendido o perjudicado no ostente capacidad procesal.

${ }^{878}$ GÓMEZ ORBANEJA, E., Comentarios..., op. cit. T. II, p. 272 y GIMENO SENDRA, V., La Querella, op. cit. p. 141.
} 
procesal conjunta a través de una asociación de afectados (art. 7.3 LOPJ) se derivarán importantes ventajas. Incluso han de ser admisibles hipótesis en las que el titular del interés material, otorgando en una sola ocasión y fehacientemente su consentimiento, abra la posibilidad de que su singular posición procesal sea ocupada por asociaciones en cuyo ámbito de actuación se encuentre la defensa de los bienes jurídicos vulnerados o puestos en peligro por el concreto delito. Así podría ocurrir, por ejemplo, en un delito de terrorismo cuando el sujeto ofendido delegue su intervención como acusador en una asociación de víctimas del terrorismo.

c) Por razones de eficiencia o necesidad en tipos penales donde resulte imposible la determinación de quién sea el ofendido con exclusión de todos los demás sujetos. En estas hipótesis, el interés derivado de la afección o puesta en peligro del bien jurídico que la norma tutela deberá poder ser hecho valer prioritariamente por una asociación cuyo objetivo social sea precisamente su defensa. Este será el caso por ejemplo de la personación de una asociación ecologista en un delito contra el medio ambiente o de una de consumidores en un delito de fraude alimentario ${ }^{879}$. La cuestión se retomará más adelante.

\section{III.}

Los arts. 100 y ss. LECrim integran preceptos que se refieren al ejercicio de la pretensión penal por las víctimas y por los terceros, mezclan lo referido a la posibilidad de acusar y las condiciones para la válida realización de actos de acusación y no distinguen entre reglas que tienen que ver con la capacidad procesal de unos sujetos con la atribución de legitimación a otros. Lo que para el legislador decimonónico tuvo un sentido de reconocimiento de un derecho ínsito en la esfera jurídica de los sujetos atinente al daño que la comisión del delito les producía, merece ser hoy, sin embargo, reinterpretado con vistas a su actualización. Puesto que tanto el régimen jurídico como la tutela constitucional de la que gozan los diferentes intereses hechos valer por los particulares son muy diversos, parece aconsejable proceder a un intento de sistematización que tenga

${ }^{879}$ Cabe la posibilidad de que una sóla infracción constituya un concurso de delitos en los que la condición de ofendido pueda ser ostentada sobre un diferente fundamento. Así ocurrirá por ejemplo en un delito contra el medio ambiente en el que la misma conducta determine simultáneamente la existencia de daños a un ofendido claramente identificable (por ejemplo el propietario de un bosque colindante a una empresa contaminante) y de la puesta en peligro de un bien jurídico no individualizable (la salud pública, el medio ambiente). En estos casos ambos intereses habrán de ser considerados legítimos a efectos de la intervención de sus representantes en calidad de acusadores particulares. 
en cuenta tan esencial dato. No consideramos de recibo, pues, la doctrina sentada por el TC al afirmar que carece de relevancia constitucional la atribución del carácter de ofendido o no por el delito porque todos pueden acceder al proceso: mientras que el primero defiende procesalmente un interés singular y propio cuya tutela sí podría encontrar respaldo en el art. 24.1 CE, el segundo no hace más que cumplir una función estatal sin que haya de entenderse englobado por aquel precepto. Las diferencias entre la participación procesal de uno y otro son así proporcionadas en armonía con la finalidad de una y otra intervención.

Según la doctrina tradicional, en la acusación de los particulares la legitimación vendría determinada por la capacidad, y la LECrim atribuiría la titularidad de un "derecho de acusación" no por una relación específica con el objeto procesal, sino por la condición genérica de ciudadano español. Como ya hemos visto, afirmaba por ello GÓMEZ ORBANEJA que "si suprimiéramos el art. 101 LECrim, sin añadir nada, tan privado se quedaría del ejercicio de la acción penal el ofendido por el delito, como el no ofendido" y la legitimación se cuestionaría únicamente allí donde la condición de ciudadano faltara (los extranjeros) o excepcionalmente no bastara (supuestos de los arts. 102 y 103). Quien no gozase de la plenitud de los derechos adquiriría la titularidad de la facultad de acusar por su carácter de ofendido, aun cuando siguiera sin tener capacidad para la interposición de la querella y la realización de los demás actos procesales y tuviera que llevar éstos a cabo a través de su representante legal ${ }^{880}$. Las limitaciones de los arts. 102 y 103 se referirían a la atribución misma del derecho de acusar, pero cederían en favor del sujeto pasivo del delito ${ }^{881}$. El mecanismo contemplado en la ley a la vista de esta concepción

${ }^{880}$ GÓMEZ ORBANEJA, E., Comentarios..., op. cit. T. II, pp. 181 y 225 . A su juicio no hay en la LECrim una sola norma que atribuya el ejercicio de la "acción penal" al ofendido o perjudicado por serlo (a excepción de los delitos perseguibles a instancia de parte).

\footnotetext{
${ }^{881}$ Vid. GÓMEZ ORBANEJA, E., Comentarios..., op. cit. T. II, p. 225. A tenor de lo por él expuesto “de lo que no puede hacer uso el que no goce de la plenitud de los derechos civiles es de la atribución de la acción que atribuye 101 a todos los ciudadanos españoles; consiguientemente, siendo el sujeto pasivo del delito, la exclusión que desaparece es la relativa a la misma acción popular. Lo mismo sucede en el caso del extranjero. Precisión de importancia práctica: sirve para distinguir con relación a 101 entre 1) la capacidad para la querella y los actos del proceso y 2) la titularidad de la acción, evitando la confusión en la que incurre". En pp. 456 y ss. alega este autor que la única diferencia entre la acción de unos y otros se referiría a la capacidad para el válido ejercicio del acto procesal de su ejercicio, que estará lógicamente presente tratándose de los jueces o de los condenados por acusación calumniosa. En el caso de los que no gocen de la plenitud de los derechos civiles, la incapacidad deberá ser suplida por el representante legal, pero en tanto ofendidos, serán también titulares del derecho de acción (p. 465). Destacaba GÓMEZ ORBANEJA que "aun el incapaz puede ser sujeto activo de la acción, asumiendo la posición jurídico procesal de parte -por la misma razón que puede ser demandante en el proceso civil-. Pero para la validez de su acto se requiere que la incapacidad sea suplida con arreglo a derecho: que actúe por su representante legal' (p.
} 
podría quedar formulado de la siguiente forma: la regla general consiste en que todos los españoles pueden acusar, de entre éstos se excluyen algunos sujetos, pero los excluidos pueden no obstante acusar cuando los ofendidos sean ellos o determinadas personas de su ámbito familiar.

La identificación entre todas las modalidades posibles de querella considerando que cumplen la misma función, así como un no del todo acertado trasvase a nuestro ordenamiento de la doctrina italiana y alemana sobre su querella privada, han originado distorsiones en el enfoque que del sistema de acusación por los particulares se sostiene en la actualidad. Tanto en estos países como en el nuestro, la querella por delitos privados o semipúblicos constituye un derecho público subjetivo que tiende a la defensa de un interés que se equipara al privado: en los delitos privados porque el Estado cede una de sus funciones a los particulares, y en los perseguibles previa denuncia del ofendido porque se hace necesaria la concurrencia de la voluntad de este particular para que el Estado ponga en marcha los mecanismos de persecución ${ }^{882}$. En España entra en juego además la presunción de que los delitos públicos lesionan a la ciudadanía entera, lo cual facultaría a todos en la misma medida para la interposición de la querella sobre la base del inadmisible dato de que todos sufrimos idénticamente el perjuicio. El daño soportado por cada uno de los individuos se erigiría así siempre (con las excepciones legales) en posición habilitante para la acusación.

Fundar la intervención del acusador popular en su equiparación al ofendido comporta, sin embargo, cerrar los ojos a una necesaria distinción en tanto la diferencia entre ambos sujetos, que la ley establecía en aspectos únicamente formales e incluso tangenciales (ofrecimiento de acciones, fianza, justicia gratuita cuando se reúnan los requisitos, etc.) ha de considerarse hoy insuficientemente justificada. No podría mantenerse en la actualidad que la LECrim atribuya al sujeto pasivo del delito una facultad para acusar como "un ciudadano más" al que se exime de determinados requisitos, sino que ha de considerarse que su intervención goza de una naturaleza jurídica

459).

${ }^{882}$ A diferencia de lo que ocurre en los delitos públicos en nuestro país, sería plenamente admisible hablar de un ius ut procedatur en relación con la querella interpuesta en los delitos privados y semipúblicos, ya que en estos casos, mediante ella se deja sin efecto un impedimento procesal, constituyéndose así el presupuesto sobre el que necesariamente ha de comenzar a desarrollarse la actividad de los órganos del Estado dirigida a la aplicación del ius puniendi. Aquí sí tiene sentido hablar de un derecho de los particulares a que se proceda, en tanto que el proceso penal va a constituir una premisa absolutamente necesaria para la obtención de una efectiva tutela jurisdiccional de un interés personal. 
y una razón de ser absolutamente diversa de la de los demás. La lectura de un generalizado "derecho de acusación" de los particulares debe ceder ante la necesaria separación entre las funciones que desempeñan en el proceso los representantes de intereses de muy diversa naturaleza. Puesto que la presencia de motivaciones privadas en los deseos de participación de los particulares en el proceso penal no puede ser descartada, y ni siquiera examinada, habrá de seleccionarse de entre ellos cuáles sean los que se consideran legítimos para, en la medida de lo posible, impedir el acceso de los demás. No hay duda que situar todos los intereses privados en el proceso penal sobre un mismo plano vendrá a incidir seriamente en perjuicio de una justicia susceptible de ser manipulada por valores ajenos a ella.

La distinción entre sujetos afectados directamente por la comisión delictiva y terceros extraños a ella es además totalmente trascendente además desde un punto de vista procesal, en cuanto traducible en la diferencia acusador popular-acusador particular ${ }^{883}$ la cual, a su vez, determina la diversa ubicación en el proceso de ambos. Esta diferencia se hace perceptible entre otras cuestiones en $1^{\circ}$ ) la legitimación de determinadas personas, que podrán ser acusadores particulares, pero no populares (art. 102 y 103 LECrim); $2^{\circ}$ ) el planteamiento de la acusación por extranjeros (art. 270.II LECrim); $3^{\circ}$ ) la necesidad del acusador popular de nombrar procurador con poder especial y letrado, sin que se le pueda designar de oficio, supuesto que sí se da en el caso del ofendido. Además éste último, defensor de un interés propio, podrá ser titular del derecho de asistencia jurídica gratuita (art. 118.III LECrim en concordancia con el 6.3 LAJG); 4º La realización del llamado "ofrecimiento de acciones": instrucción al ofendido desde el momento de recibirse la declaración del derecho de personarse (109, 783.II LECrim y 25.2 LOTJ) o llamamiento a "defender su acción" en caso de sobreseimiento (642 LECrim); 5) la formulación de querella para personarse en causas seguidas por el procedimiento abreviado, que no es necesaria tratándose del ofendido (783.II LECrim); $6^{\circ}$ ) la exención de realizar el depósito de fianza (280 y 281.1 LECrim); $7^{\circ}$ ) el ejercicio de la acción civil conjuntamente o por separado con la pretensión penal (art. 110 LECrim) y la posible renuncia de ésta (art. 106 y ss LECrim); $8^{\circ}$ ) la posible representación en el planteamiento de la acusación cuando no se tenga plena capacidad procesal, que carece de sentido cuando se trate de un sujeto no

\footnotetext{
${ }^{883}$ Con carácter previo al inicio del proceso, la determinación de quien sea el ofendido por el delito adquiere relevancia puesto que ésta determinará por ejemplo si viene atribuido a la Jurisdicción española el conocimiento de delitos cometidos fuera del territorio nacional por español (o extranjero nacionalizado). A este respecto, el art. 23.2 LOPJ exige denuncia o querella del «agraviado».
} 
ofendido en tanto el representante tendría que ejercitar esa facultad no en su calidad de tal sino por sí mismo, utilizando la legitimación que como español le confiere la LECrim; $9^{\circ}$ ) la legitimación para la recusación de Jueces y Magistrados (218 LOPJ, que sólo habla de "acusador particular" cuando ya estaba consolidada la denominación "acción popular" que incluso la propia Ley recoge en sus arts. 19.1, 20.3 y 406).

Para que el ordenamiento establezca este "ejercicio preferente de la acusación" no basta con sentir el perjuicio como cercano sino que quienes lo aleguen habrán de encontrarse en una relación objetiva con el bien jurídico atacado que sea constatable y determine su singularidad respecto a los demás miembros del cuerpo social. La afección por el delito en la esfera jurídica de un sujeto determina el nacimiento de específicos intereses materiales que se van a defender en el proceso penal, pero que han de ser distinguidos frente al interés procesal en el enjuiciamiento ínsito en la acusación. En este caso estaremos frente a intereses individualizables y singularizables subjetivamente que no pertenecen a nadie más que a la víctima ${ }^{884}$; que no existen con carácter previo a la comisión de los hechos afirmados delito puesto que nacen de ellos y que no son de carácter abstracto, en tanto se conectan con el concreto bien jurídico material protegido por el tipo penal. Este nexo es precisamente el que constituye al ofendido o a su representante en valedor de específicos derechos cuya tutela merece una protección intensa que el ejercicio de la acusación no puede por sí solo proporcionar.

Estima MONTERO que en sentido técnico preciso sólo debería poder actuar como acusador particular el ofendido por el delito, pero no el perjudicado por el mismo, quedando éste reducido a convertirse en acusador popular ${ }^{885}$. Funda su argumentación en el art. 281 LECrim, que determina las personas exentas de prestar fianza al interponer querella, coincidentes con las que pueden ser acusadores particulares: en la generalidad de los delitos, sólo el ofendido y no el perjudicado por éste, con la obvia excepción de los delitos de asesinato y homicidio en los que podrán mostrarse parte en la causa sin depósito de fianza el viudo o viuda, los ascendientes y descendientes, los colaterales y los herederos, esto es, precisamente los que pueden considerarse perjudicados. En todos los demás delitos, los perjudicados no quedan exentos de fianza, lo que corroboraría en su

\footnotetext{
${ }^{884}$ Cuestión diversa es que pueda ser representada ésta por otros sujetos en los términos expuestos.

${ }^{885}$ MONTERO AROCA, J., Derecho Jurisdiccional, T. III, p. 68. Sigue así uno de los criterios utilizados por GÓMEZ ORBANEJA para demostrar el carácter de no ofendidos de los familiares del fallecido en el homicidio. Vid. GÓMEZ ORBANEJA, E., Comentarios..., op. cit. p. 263.
} 
opinión que el perjudicado hubiera de quedar relegado a la condición de acusador popular ${ }^{886}$. Tal concepción, que pudiera entenderse presente en la LECrim, no puede ser hoy mantenida, en tanto parece claro que no sólo el ofendido, sino también el perjudicado por el delito ostenta y defiende un interés cualitativamente diverso al del resto de los ciudadanos, que se basa en su específica relación con el bien jurídico material. De hecho, la diferencia de estos sujetos con el resto de la ciudadanía no ha pasado por alto a la jurisprudencia por lo que en la práctica judicial, valiéndose de la confusión terminológica de la LECrim, los Tribunales admiten habitualmente la personación del perjudicado en calidad de acusador particular con las ventajas frente a la acusación popular stricto sensu que esta posición procesal conlleva ${ }^{887}$.

La defensa del interés propio del ofendido que se pretende realizar mediante el ejercicio de la acusación particular no se ejecuta desde la objetividad e imparcialidad, sino que tiene el sesgo propio de un sujeto que reclama derechos cuya titularidad afirma. El acusador particular pedirá en el ejercicio de su pretensión algo para sí, cuyo logro será consecuencia de la condena del acusado, por lo que su actividad se dirigirá prioritariamente hacia la consecución de ésta. Al ejercicio por el ofendido de su pretensión privada se le confiere legalmente aptitud no sólo para hacer valer su específico interés, sino también para promover la actividad estatal necesaria para satisfacer el interés público. La afirmación por el ofendido de la concurrencia de los presupuestos para una resolución jurisdiccional sobre unos hechos que se afirman delictivos y sobre la persona que se reputa autor constituye, pues, un paso intermedio necesario para una sentencia condenatoria que se busca explícitamente. El ordenamiento español permite así la instrumentalización de la estructura formal del acusatorio para habilitar demandas de satisfacción de legítimos intereses diversos al meramente procesal en el enjuiciamiento. Esta circunstancia es la que ha llevado a la afirmación de que el fundamento constitucional del ejercicio popular o particular de la acusación es diferente conectando éste último directamente con el art. 24.1 CE, en tanto el ofendido defendería con su actividad un

\footnotetext{
${ }^{886}$ MONTERO AROCA, J., op. et loc. ant. cit.

${ }^{887}$ Como ejemplos de esta confusión por parte de la Jurisprudencia podrían citarse entre otras las SSTS de 31 de mayo de 1977 (RAJ 2475), en la que se considera que el carácter de perjudicado también sirve para la determinación de los "delitos contra las personas" a los que se refiere el art. 103.2 LECrim, o la de 25 de octubre de 1993 (RAJ 7957), en la que se admite la personación de los perjudicados para defender sus derechos sin necesidad de ejercitar querella alguna. De ello advierte en tono crítico MONTERO AROCA, J., Derecho Jurisdiccional, op. et loc cit.
} 
interés legítimo precisado de tutela judicial ${ }^{888}$ y susceptible de hacerse valer a través del recurso de amparo ${ }^{889}$.

El proceso penal ha de ser útil a la defensa de los legítimos derechos de la víctima, pero la actividad de ésta ha de incardinarse normativamente desde la simultánea contemplación de los objetivos, necesidades y garantías inherentes al proceso penal. $\mathrm{La}$ implicación emotiva de los sujetos afectados por el delito en el ejercicio de la acusación no es imprescindible y en ocasiones no es siquiera deseable, en tanto el interés que les mueve no es el del mero enjuiciamiento sino el de la búsqueda explícita de una condena que sirva de base al resarcimiento de los daños y perjuicios sufridos (art. 116 CP). No hay duda, aun cuando ello no ocurra siempre, que la actividad de un acusador particular puede llevar aparejada como consecuencia la defensa del interés general, en tanto el interés privado derivado de la afección directa por la conducta que se afirma delictiva sirve de manera refleja al enjuiciamiento y al eventual cumplimiento efectivo del ius puniendi. Pero aun cuando sea innegable que el ofendido comparta la titularidad del interés público en el enjuiciamiento con los demás ciudadanos, la acusación particular, necesariamente parcial e interesada, no debe ser considerada apta para su tutela.

Sin perjuicio del extendido deseo de tutelar los legítimos derechos de la víctima de los delitos en el proceso penal, no podría pasarse por alto que el ejercicio de la pretensión penal exige una serenidad, objetividad y sujeción a criterios igualitarios que sólo son imaginables desde la históricamente consolidada institucionalización de la respuesta a las conductas criminales. El proceso penal no es una confrontación entre agresor y agredido, ni resuelve un conflicto intersubjetivo privado, sino que se articula para la garantía de todos los bienes jurídicos tutelados por la norma. La afección individual por el delito no

\footnotetext{
${ }^{888}$ Vid. entre otras STC 62/1983 de 11 de julio, 34/1994 de 31 de enero, 40/1994 de 15 de febrero. La más intensa protección constitucional de la acusación particular por ir dirigida a la defensa de intereses propios queda clara por ejemplo en los pronunciamientos del TC en relación con el llamado "ofrecimiento de acciones". En el caso del ofendido, la jurisprudencia del TC ha señalado en reiteradas ocasiones que el "ofrecimiento de acciones" se trataría de un trámite con trascendencia constitucional en la medida que de su incumplimiento se deriva una vulneración del derecho a la tutela judicial efectiva del perjudicado. Vid. SSTC 31/1989 de 13 de febrero, 66/1992 de 29 de abril, 37/1993 de 8 de febrero (en el procedimiento militar), 98/1993 de 22 de marzo (FJ 4), 121/1994 de 25 de abril, 278/1994 de 17 de octubre (FJ 3) o 324/1994 de 1 de diciembre. Según la doctrina emanada de estas sentencias "cuando no se pone en su conocimiento la existencia de un proceso en que tan directamente se encuentran implicados sus intereses" y no toma parte en él por simple ignorancia y no por propia decisión o como resultado de su negligencia "se cercena su derecho a la efectividad de la tutela judicial" en tanto se menoscaba el derecho de defensa en un proceso en el que se ventilan intereses concernientes al sujeto.

${ }^{889}$ Vid. MONTERO AROCA, J., Derecho Jurisdiccional, T. III, p. 63.
} 
es determinante del nacimiento de un interés superior en la instauración de un proceso como actividad conducente a la eventual aplicación de la norma penal, sino que ese interés de naturaleza pública, es común a todos y existe con carácter previo a la comisión de las conductas que se afirman delictivas. El proceso no puede ser interpretado como una canalización de la venganza o como sustitutivo del duelo propiciado por el sistema, sino como la respuesta debida por el Estado a todos los ciudadanos para la garantía de los bienes jurídicos. De igual manera ha de sostenerse que no sería admisible tampoco la instrumentalización del impulso generado por la acusación del ofendido como criterio de oportunidad en la persecución de delitos públicos.

Queremos concluir este apartado afirmando, en contra de la doctrina sentada por el TC, que el ejercicio de un "derecho de acusación" de los ofendidos no es tampoco esencial dentro de nuestro sistema. Para que quedara satisfecho el contenido del art. 24.1 $\mathrm{CE}$ en relación con las víctimas, ciertamente presente en tanto existen derechos e intereses legítimos, bastaría con que se habilitara un cauce para la defensa de éstos. Pero éste no tiene por qué ser el que proporciona la acusación y sí, en todo caso, aquel que permita la más exacta y siempre homogénea y proporcionada satisfacción del interés que haya sido desconocido, negado o violado. En modo alguno tal interés puede ser el de venganza, coacción o incluso directo castigo penal del presunto delincuente y no sería de recibo concebir la presencia de otros intereses de particulares en el proceso penal diversos a los puramente privados consistentes en la restitución, reparación del daño e indemnización por los perjuicios sufridos (arts. 110 y ss. CP). Bastaría por ello con que quedara suficientemente garantizada en la ley la facultad de ejercitar una pretensión civil ${ }^{890}$. Cuestión diversa es que razones más sociológico-políticas que estrictamente jurídicas muestren conveniente la intervención de la víctima con un papel activo en el juicio penal, aun cuando ello no sea estrictamente necesario ${ }^{891}$.

\footnotetext{
${ }^{890}$ La praxis de nuestros Tribunales pone de manifiesto que con frecuencia en el momento en que en el curso de la causa se le abonan los daños y perjuicios el acusador particular suele abandonar sin más el proceso. En relación con este último aspecto vid. por ejemplo ESCUSOL BARRA, E., El proceso penal por delitos: estudio sistemático del procedimiento penal abreviado (LO 7/1988 de 28 de diciembre), $4^{\mathrm{a}}$ ed., 1997, p. 84.

${ }^{891}$ Profundizar en esta materia nos apartaría del tema objeto de estudio, por lo que nos debemos remitir a la abundantísima bibliografía sobre el tema, parte de la cual se ha reseñado supra.
} 


\title{
6.4. Ejercicio por particulares de la acción civil en el proceso penal
}

\author{
I.
}

La acción civil derivada del delito carece de naturaleza pública puesto que, como fue expuesto por GÓMEZ ORBANEJA, la responsabilidad civil no nace del delito sino del acto que lo constituye y que a la vez puede ser fuente de obligaciones civiles a tenor del art. $1089 \mathrm{CC}^{892}$. Si toda persona criminalmente responsable lo será también civilmente cuando del hecho se deriven daños y perjuicios (art. 116 CP) y el mismo hecho puede ser hábil para constituir simultáneamente un delito o falta que genera responsabilidad penal y un ilícito civil que engendra responsabilidad de este tipo, parece claro que la acusación sólo podría tener relación con la primera, pero en ningún caso con la segunda. Con la acusación, oficial o no, no se invoca prioritariamente la tutela de un derecho integrante de la esfera subjetiva propia de nadie en particular, sino que se articula el presupuesto para que se declare procesalmente la existencia del delito.

El ordenamiento jurídico español tiene la característica de permitir la acumulación de cuestiones civiles junto a las penales en un único procedimiento, cuyo conocimiento se atribuye por razones de economía procesal y de certeza jurídica a los órganos jurisdiccionales de lo criminal ${ }^{893}$. Pero, a pesar de su íntima conexión con el objeto del proceso penal, la acción civil ex delicto no pierde su naturaleza civil por el hecho de no ser ejercitada en un proceso de esta naturaleza (art. 100, 108, 111, 112 y 117 LECrim y

${ }^{892}$ GÓMEZ ORBANEJA, E., Comentarios..., op. cit. pp. 330 y ss.: "Las obligaciones nacen de... los actos y omisiones ilícitos o en que intervenga cualquier tipo de culpa o negligencia". El precedente puede encontrares en la distinción que realiza ANTOLISEI, F., L'offesa e il danno nel reato, Bergamo 1930, p. 49, entre ofensa y daño. Por lo que se ha de resarcir a la víctima no es por la ofensa (lesión o puesta en peligro) del interés protegido, sino por las consecuencias derivadas del delito. Vid. también a este respecto PEDRAZ PENALVA, E., Las medidas cautelares..., op. cit. pp. 31 y ss. y ARANGÜENA FANEGO, C., Teoría general de las medidas cautelares reales en el proceso penal español, Barcelona 1991, pp. 225 y ss.

\footnotetext{
${ }^{893}$ Afirma el TC en su s. 98/93 que "una de las características del proceso penal español, característica de signo progresivo conectada al sentido social del Estado de Derecho proclamado en el art. 1 CE, es la posibilidad de la concurrencia simultánea de la acción penal para la averiguación del delito con el correlativo castigo del delincuente y de la acción civil para el resarcimiento de daños y perjuicios sufridos por la víctima. Esta simultaneidad y, sobre todo, su ejercicio preceptivo por el Fiscal beneficia directamente a los sectores menos dotados económicamente, a quienes facilita la defensa de su derecho, para conseguir con esa actuación tuitiva la igualdad efectiva de individuos y grupos, a la cual encamina el art. 9 CE y, con ella, la justicia (STC 132/1992)". Sobre los diferentes sistemas de unificación o separación en el ejercicio de la acción civil en el proceso penal vid. por todos PEDRAZ PENALVA, E., Las medidas cautelares..., op. cit. pp. 20 y ss.
} 
art. 109.2 CP) y mantiene su carácter dispositivo, renunciable por su titular (art. 106 y ss. LECrim), reservable para su ejercicio en un posterior juicio civil (art. 112 LECrim y 109.2 CP) y susceptible de planteamiento también en caso de absolución del acusado no fundada en la inexistencia del delito (art. 116.1 LECrim). La acumulación de pretensiones penales y civiles no debe ocultar que nos encontramos ante dos procesos de naturaleza diversa, regidos consecuentemente por los principios propios de cada uno de ellos, aun cuando se desarrollen de forma simultanea y paralela ${ }^{894}$. Son dos pretensiones diferentes y las normas de legitimación en uno y otro caso han de ser contempladas por separado. De ahí que en el ámbito de la acusación se tenga que incluir propiamente la facultad de afirmar la existencia de los presupuestos para una resolución jurisdiccional sobre los hechos y el sujeto, pero no el ejercicio de una pretensión de diáfana naturaleza civil. El ejercicio acumulado de la acción civil admite su entendimiento no sólo como amparo de una concreta víctima sino, ítem más, como vía objetiva de tutela, lo cual exige su ajuste a la real entidad del daño o perjuicio y vendría a hacer irrelevante la presencia del particular en el proceso.

El que el proceso penal pueda ser iniciado y sostenido a instancia de cualquier ciudadano, ha originado que la cuestión del ejercicio de la pretensión civil por el acusador no ofendido haya dado lugar a diversas interpretaciones no sólo en la actualidad ${ }^{895}$, sino también a lo largo de la historia ${ }^{896}$. Pero si en la LECrim no se contiene una prohibición

\footnotetext{
${ }^{894}$ En este sentido vid. STS 7 de abril 1990.
}

${ }^{895}$ Vid. por todos PEDRAZ PENALVA, E., Las medidas cautelares..., op. cit. pp. 20 y ss.

${ }^{896}$ En nuestro derecho histórico no cabía originariamente el ejercicio simultáneo en el mismo proceso de las dos pretensiones que nacían del delito, puesto que ambas se prejuzgaban entre sí y cuando se ejercitara una, la otra quedaba excluida. Si un extraño hubiera podido deducir la "acción criminal", incompatible con la civil, se hubieran perjudicado los intereses del lesionado que se vería imposibilitado para pedir civilmente la reparación del daño. Con el tiempo se asumió que en los delitos públicos, por tratarse de hechos que ocasionan grave daño al conjunto de la comunidad aunque hubiera un lesionado concreto, no podría aceptarse en ningún caso que por el mero ejercicio de la acción civil los delitos pudiesen quedar sin pena. Puesto que las pretensiones seguían sin poder ejercitarse conjuntamente, la concurrencia en el mismo proceso de ofendido y fiscal (el acusador popular prácticamente había desaparecido), hacía que sus actuaciones concretas no se diferenciasen. Ambos debían formular pretensión penal y sólo el ofendido pedir por incidencia que el Juez condenara de oficio al reo por los daños y perjuicios. Sus respectivas actuaciones procedimentales se superponían, realizándose acusación, pruebas y alegaciones por cada uno de ellos. Podría afirmarse que de la necesidad de dar satisfacción de manera conjunta al interés público en la persecución del delito y al privado en la restitución e indemnización por la ofensa, derivó el pedir por incidencia la acción civil en las querellas criminales. Pero los acusadores extraños al delito nunca pudieron tener un papel en esta materia que sobrepasaba con creces sus facultades. ALONSO ROMERO, M.P., El proceso penal en Castilla..., op. cit. pp. 102 y s. y 142, con base en ANTONIO GÓMEZ, Variae resolutiones iuris civilis, communis et regii, Madrid 1780, Libro III, cap. I, p. 8. 
expresa de este ejercicio ello se debe a que el legislador no contemplaba siquiera la posibilidad de que el acusador popular pudiera tener un papel en el procedimiento más allá del de la mera iniciación procesal. Admitir lo contrario nos haría llegar a la conclusión, no aceptada hoy por nadie, de que del propio texto de la ley se puede inferir que cualquiera que ejercitase la "acción penal" estaría utilizando simultáneamente la civil. Sometidos a su literalidad deberíamos asumir que, puesto que "la acción penal es pública" y "todos los ciudadanos españoles podrán ejercitarla" (art. 101 LECrim), cuando se deduzca sola, se entenderá utilizada también la civil a no ser que el perjudicado renuncie a ella o se la reserve (art. 112 LECrim). Vinculando el ejercicio de la acción penal a la civil, y manteniendo la interpretación que hace equivalentes a todos los acusadores, se estaría realizando una atribución de legitimación extraordinaria a cualquier acusador para el ejercicio de la acción civil, salvo renuncia o reserva de su titular. Ello merece sin duda ser rechazado en tanto no se corresponde en absoluto con la función actual de un ejercicio popular de la acusación que sólo puede hacer valer en el proceso el interés público en el enjuiciamiento.

Podría plantearse la posibilidad de admitir legitimación para el ejercicio de la acción civil conjuntamente con la pretensión penal a los acusadores populares, de la misma manera que se prevé expresamente en el caso del MF (art. 108 LECrim). Pero este argumento tampoco sería admisible, en tanto el perjudicado habrá podido reservarse o renunciar al ejercicio de la acción civil, por lo que es claro que su contenido no integra la pretensión penal, la única deducida por el acusador popular. Aun no habiéndose realizado la reserva o renuncia, no es de recibo el reconocimiento al acusador popular de una legitimación de carácter extraordinario que el legislador no le asigna. La única pretensión cuyo ejercicio es popular es la penal, sin que en ningún caso puedan ser de ejercicio abierto las de carácter estrictamente privado ${ }^{897}$. Aunque el ciudadano acusador no pidiera nada para sí sino que lo hiciera en favor de un tercero, tal hipótesis tendría que ser rechazada a limine en tanto chocaría con la ausencia de precepto legal que la fundamentase. Ello tampoco parecería de recibo además, pues, al no ostentar un interés personal en las consecuencias del hecho perseguido, no parece admisible que pudiera instar la restitución, el resarcimiento o la indemnización del daño o perjuicio inferido por

${ }^{897}$ En este sentido MONTERO AROCA, J., Derecho Jurisdiccional, T.III, p. 90. No hay supuestos en nuestro ordenamiento de acciones populares civiles. Vid por ejemplo la STS de 2 de diciembre de 1991 (RAJ 8904) y SAP Barcelona (Secc. 16 ${ }^{\text {a }}$ de 5 de abril de 1991, publicada en RJC II, 1991, pp. 157-162. Todo lo más que se puede encontrar en el ámbito civil es bien una extensa ampliación de la legitimación activa, bien su atribución a colectivos constituidos para la defensa de intereses supraindividuales. 
la infracción criminal ${ }^{898}$.

El ejercicio de una acción civil por el acusador popular sería además inadmisible de todo punto en un plano teórico ya que significaría tanto como abrir un cauce para la manipulación procesal de los que quisieran encontrar un modo favorable, cómodo y rápido de alcanzar del imputado una sabrosa compensación pecuniaria por vía de una renuncia concertada a sostener la acusación. Ni siquiera en ausencia de actividad del MF o de los propios particulares ofendidos entendemos aconsejable la intervención de cualquier ciudadano que pudiera deducir una pretensión civil junto con la penal, en tanto ello supondría subrogarse sin su consentimiento y sin expreso fundamento legal en los derechos privados de otro sujeto al objeto de defender ajenos intereses patrimoniales.

La jurisprudencia se ha mostrado unánime en el rechazo al ejercicio de pretensiones civiles por las acusaciones populares, lo cual se ha puesto de manifiesto con ocasión de algunas causas penales con trascendencia pública por tratarse de delitos cometidos por funcionarios. En el tristemente célebre caso “Amedo y Domínguez”, la petición de responsabilidad civil se realizó por la acusación popular y fue rechazada por Sentencia de la AN de 20 de septiembre de 1991, alegando que "si la acción penal es pública, la civil solamente podrá ejercitarse por los perjudicados (art. 110 LECrim) o por el Ministerio Fiscal, junto con la primera (art. 108), por lo que la acusación popular carece de legitimación para dicho ejercicio". Los términos de esta resolución se vieron confirmados por la STS de 12 de marzo de 1992 (RA 2442) en la que se afirmaba que el acusador popular carece de legitimación activa para propugnar pretensiones civiles derivadas de un delito, puesto que su intervención en un proceso penal sólo puede entenderse en función de la defensa del orden social genéricamente conculcado. En el mismo sentido se pueden citar también las SSTS de 21 de marzo de 1994 (RA 2373) y de 2 de febrero de 1996 (RA 788). En la primera de éstas, dictada en causa seguida por

\footnotetext{
${ }^{898}$ De hecho en alguna ocasión se han fundamentado precisamente en esta imposibilidad parte de las críticas a la acusación popular puesto que su ejercicio deviene incompleto en cuanto al logro de todo lo que puede o debe abarcar una sentencia penal. Vid. SÁEZ JIMÉNEZ, J. y FERNÁNDEZ LÓPEZ DE GAMBOA, E., Compendio de Derecho Procesal Civil y Penal, Madrid 1966, T. IV, vol. 1, pp. 887 y ss. Esta posición vendría abonada por los siguientes argumentos: $1^{\circ}$ ) el fundamento filosófico de la acción, puesto que no hay interés que legitime la pretensión; $2^{\circ}$ ) no se concibe que en la reparación del daño estrictamente privado pueda tener un interés tutelable en derecho un ajeno a la persona ofendida; $3^{\circ}$ ) el art. 101 LECrim pregona el carácter público de la acción penal, pero no de la acción civil; $4^{\circ}$ ) del contenido de los arts. 107 a 112, 115 y 116, se advierte que la acción civil se reserva, aparte de al Ministerio Fiscal, a los ofendidos directa o indirectamente por el delito o a sus legítimos representantes pero nunca a los ajenos al ofendido. Cfr. también SÁEZ JIMÉNEZ, J., Enjuiciamiento Criminal. Comentarios prácticos a la LECrim referidos a la Ley de Urgencia, Madrid 1962, p. 102.
} 
asesinato cometido por un miembro de la Guardia Civil, se reiteran los mismos argumentos explicitando, en relación con la acusación popular, que "el recurso casacional se concibe para ejercitar y defender derechos propios, pero no ajenos". La de 2 de febrero de 1996, dictada también en relación con delitos cometidos por funcionarios públicos, se reafirma en relación con el acusador popular que puede ejercitar "como litisconsorte" del MF la pretensión punitiva, pero nunca la resarcitoria.

\section{II.}

No hay duda, a pesar de lo afirmado, de que la actividad del acusador popular puede repercutir sin duda en la pretensión civil de resarcimiento cuando menos en dos aspectos:

a) si bien el ciudadano acusador no agraviado no puede instar la declaración de responsabilidad, no por ello su presencia en el proceso va a dejar de determinarla en alguna medida. Teniendo en cuenta que la responsabilidad civil no se deriva del delito, sino de la comisión del hecho ilícito cuya responsabilidad se dilucida en el proceso, lo que producirá el resarcimiento y la indemnización no podrá ser la calificación que se realice de aquella conducta, sino el concreto factum jurídicamente relevante. En este aspecto, el acusador popular puede contribuir con su participación a la fijación de la convicción judicial sobre tal acaecimiento, sus circunstancias, el autor y la concurrencia de circunstancias modificativas de la responsabilidad, configurando la base fáctica sobre la que el Tribunal podrá señalar la oportuna indemnización ${ }^{899}$.

b) Cualquier ciudadano podría, de alguna manera, interferir en el ejercicio por el ofendido de una pretensión de resarcimiento ante los órganos civiles, interponiendo querella sobre los mismos hechos y determinando con su admisión la suspensión del procedimiento civil en el estado en que se hallare hasta que recaiga sentencia firme en la causa criminal (art. 114.I LECrim y 10.2 LOPJ) ${ }^{900}$. La vis attractiva del proceso penal

${ }^{899}$ Aun cuando lo efectivamente concedido no podrá en ningún caso superar lo pedido por los legitimados. Vid. p.ej. STS de 2 de julio de 1994 (RAJ 6416) y STS de 30 de septiembre de 1995 (RAJ 6896). En esta última se reconoce que "por mor del principio acusatorio que preside el ejercicio de la jurisdicción punitiva y del principio dispositivo de parte que informa el de la civil, es obvio que la condena por vía indemnizatoria no puede exceder en su importe a lo postulado por las partes".

\footnotetext{
${ }^{900}$ Ello podría tener consecuencias incluso sobre la fecha a partir de la cual computar la indemnización civil en supuestos de indeterminación del momento de la comisión delictiva (vid. en este sentido STS de 20 de octubre 1987 (RAJ 7510), $\mathrm{FJ}^{\circ}$ ), y aun en la vinculación del juez civil al pronunciamiento penal si en éste se declara la
} 
utilizada fraudulentamente por querellantes chicaneros puede así incidir gravemente en los derechos de terceros, atrayéndoles al proceso penal a raíz de la admisión de una querella aun cuando originariamente no hubiera sido el cauce procesal por ellos elegido.

\section{III.}

El no reconocimiento jurisprudencial de legitimación para el ejercicio de la acción civil a los acusadores populares cuenta, sin embargo, con una significativa excepción cuando se trata de hipótesis en las que se ventilan delitos con incidencia sobre intereses de los denominados difusos. Así en las SSTS de 1 de abril de 1993 (RA 9165) y de 24 de enero de 1995 (RA 141) se resolvió en favor de la representación de un grupo conservacionista la legitimación para la petición de responsabilidad civil en un delito de caza por la muerte de un oso por tratarse de "un bien en el que la colectividad humana se halla interesada". En el caso de un bien colectivo de este tipo "la responsabilidad civil es perfectamente postulable por cualquiera de los ejercitantes de la acción penal" ${ }^{901}$.

El TS se sirve así de una interpretación que, en nuestra opinión, apunta en la dirección correcta pero que se queda demasiado corta al no precisar cuándo volveremos a encontrarnos bienes en los que "la colectividad humana esté interesada". Lo que hubiera debido afirmar a las claras el alto Tribunal es que a los defensores de intereses supraindividuales debería asignárseles un status que va más allá del de ser meros valedores del interés público, para llegar a equipararlos dentro de los márgenes posibles al ofendido por el delito. Parece claro que los representantes de un bien jurídico lesionado (víctimas o asimilados) deben poder intervenir para la exigencia de responsabilidad civil, por lo que en este caso hubiera parecido mucho más adecuada a la función procesal de una asociación conservacionista en una causa abierta por delito de caza su consideración como acusador particular, que caracterizarla como un acusador popular más. Y lo mismo habría de entenderse en relación con otras personas jurídicas cuya existencia venga

inexistencia del hecho.

${ }^{901}$ No se entiende por el TS la concurrencia de tal interés en un delito de intrusismo, en el que se deniega la petición de responsabilidad civil por parte del correspondiente colegio profesional (STS de 28 de octubre de 1993, RAJ 7984). Sí se admite a una asociación personada como acusación popular en causa por delito ecológico la petición de responsabilidad para la restauración del medio, en defecto de la del MF (SAP Barcelona de 20 de febrero de 1988). 


\section{preordenada a la defensa de intereses supraindividuales ${ }^{902}$.}

\footnotetext{
${ }^{902}$ Podrá suscitarse en relación con estas hipótesis la duda sobre el destino de las cantidades obtenidas en concepto de responsabilidad civil por esta vía, puesto que difícilmente coincidirán el sujeto pasivo del delito constituido por una comunidad indeterminada más o menos amplia y el sujeto receptor de las mismas, que podría ser el representante de ese interés objetivo. Lo que parece claro es que la sentencia que admita esa responsabilidad civil deberá incluir además del monto o las bases para su fijación y el sujeto obligado a su abono, el destino que habrá de dársela y el destinatario de tales fondos. Lo lógico será que, en primer lugar, vaya dirigida a la restauración, dentro de lo posible, de los daños que se hubieren producido y, posteriormente, a la intervención en el ámbito afectado, canalizando su reparto bien a través de la Administración, bien a través de la propia asociación actora u otras de finalidad similar.
} 


\section{Tercera parte: \\ Régimen legal \\ de la acusación popular}





\section{SUJETOS LEGITIMADOS PARA EL EJERCICIO POPULAR DE LA ACUSACIÓN}

\subsection{Personas físicas: condiciones de atribución de legiti- mación para acusar sin ser ofendido por el delito}

\subsubsection{El criterio de la nacionalidad}

I.

Todos los ciudadanos españoles no ofendidos por un delito, a salvo de las excepciones que se verán a continuación, son aptos para el válido ejercicio de la pretensión penal. Para la determinación de quiénes sean estos sujetos habrá de estarse necesariamente a lo previsto con carácter genérico en el Código Civil en relación con la nacionalidad (arts. 17 y ss. CC), sin que parezca preciso entrar ahora con mayor detalle en la cuestión. Todos ellos serán, en principio, destinatarios del reconocimiento normativo de la habilitación para acusar sin ser agraviados por el delito.

Ofrece más problemas el análisis del posible ejercicio de la pretensión penal por extranjeros y dentro de éstos por los ciudadanos de los estados miembros de la Unión Europea.

II.

Los extranjeros no pueden acusar sin ser ofendidos, ya que tanto los arts. 101 y 270 LECrim, como el 19.1 LOPJ se refieren únicamente a "los ciudadanos españoles" y a "los ciudadanos de nacionalidad española" respectivamente ${ }^{903}$. Por si de la autorización a los españoles no pudiera inferirse claramente tal negativa a los no nacionales, el art. 270.II LECrim viene a dejar clara su exclusión abriendo la posibilidad de que los extranjeros se sirvan de la facultad de acusar únicamente cuando sea "por los delitos cometidos contra

\footnotetext{
${ }^{903}$ En el caso del art. $125 \mathrm{CE}$, si bien la prohibición no se contempla expresamente, ésta ha sido en ocasiones deducida de su regulación conjunta con el jurado. En algún comentario sistemático al art. $125 \mathrm{CE}$ se ha resaltado que no parecería de recibo permitir el ejercicio de funciones judiciales en España a extranjeros, y, en esa medida, tampoco el ejercicio de las facultades que la acusación popular conlleva. Vid. así GUTIÉRREZ-ALVIZ y ARMARIO, F. y MORENO CATENA, V., "La participación popular en la administración de justicia", Comentario al art. $125 \mathrm{CE}$, en Comentarios a las Leyes Políticas. Constitución Española de 1978, ALZAGA, O. (Director), T. IX, pp. 602 y ss.
} 
sus personas o bienes, o las personas o bienes de sus representados". Tal ejercicio de la pretensión penal se realizará siempre previo depósito de la fianza a que se refiere el art. 280 , a no ser que el sujeto se encuentre en alguno de los supuestos del 281. $2^{\circ}$.II (exención por razón de tratados internacionales o por aplicación del principio de reciprocidad) ${ }^{904}$.

La doctrina, al analizar la distinción realizada por la LECrim entre el ejercicio de la pretensión penal por los españoles y el que pueden realizar los extranjeros, ha señalado que, mientras en el primer caso, el delito se consideraría una ofensa común a toda la sociedad española, en el de los segundos, parece que el delito tuviera sólo índole privada, ya que los sujetos han de demostrar su vinculación con el mismo (MUÑOZ ROJAS) ${ }^{905}$. Esta dualidad ha sido resaltada también por GUTIÉRREZ-ALVIZ y MORENO CATENA, quienes estiman que una cosa sería para el legislador de 1882 la acción popular -o acción pública-, que se concede sólo a los españoles, y otra bien distinta la "acción penal" que pueden ejercitar los extranjeros para los supuestos de delitos por los que resulten ofendidos ${ }^{906}$. Según viene sosteniendo gran parte de nuestra literatura, la promoción de la acusación pública por los particulares ostentaría el carácter de derecho cívico-político, al igual que lo serían el derecho de sufragio o el de ejercer cargos públicos, por lo que la exclusión de los extranjeros estaría plenamente justificada ${ }^{907}$. Los españoles disfrutaríamos de un derecho que, en modo alguno, podría atribuirse a extranjeros, en tanto éstos no se encuentran en una situación jurídico subjetiva que les confiera la titularidad de derechos de esa naturaleza. La acción popular del proceso penal surgiría como corolario de la ciudadanía, resultando ser precisamente una acción uti cives,

\footnotetext{
${ }^{904}$ Para encontrar el origen de la no atribución de la aptitud necesaria deberíamos remontarnos hasta el derecho romano y su concepción de la ciudadanía, según la cual en una determinada comunidad política sólo estarán legitimados para el ejercicio de los derechos los ciudadanos de la misma. En relación con las acciones populares romanas vid. LOZANO y CORBI, E., La legitimación popular en el proceso romano clásico, Barcelona 1982, p. 97. A esa idea, recibida en nuestras normas procesales en su totalidad por lo que se refiere al ejercicio de la acusación, se le superpuso lo que GIMENO ha calificado como "exacerbación de las nacionalidades del s. XIX", haciendo que los extranjeros no fueran objeto de un reconocimiento que la ley sí hizo para los españoles. GIMENO SENDRA, V., "La acusación popular" $P J, \mathrm{n}^{\mathrm{o}} 31$, sept. 1993, Ponencia presentada para las terceras jornadas Hispano-Francesas del Bidasoa (Pau, Francia), 10-12 junio 1993, p. 91, esp. nota 6.

${ }^{905}$ MUÑOZ ROJAS, T., “En torno al acusador particular en el proceso penal español”, RDProc. (Ibam) 1973, p. 113.

${ }^{906}$ GUTIÉRREZ-ALVIZ y ARMARIO, F. y MORENO CATENA, V., Comentario al art. 125 CE "La participación popular en la administración de justicia”, op. cit. pp. 602 y ss.

${ }^{907}$ Por todos, vid. GIMENO SENDRA, V., "La fianza del acusador particular: notas sobre la legitimación activa y «caución juratoria» en el proceso penal”, RDProc (Ibam) 1976, p. 85.
} 
sin que por ello pareciera tener sentido su atribución a extranjeros ${ }^{908}$. La pertenencia a una determinada comunidad política sería, a tenor de esta interpretación, el fundamento habilitante para el ejercicio de un "derecho de acción popular" en el proceso penal.

La teórica habilitación para el ejercicio de esta facultad no tendría por qué tener en cuenta los variables intereses de un sujeto, -en todo caso extravagantes en relación con lo que se dilucida en el proceso penal- sino los de la colectividad, careciendo de sentido, pues, anteponer cualquier interés privado al público. El que se asigne la posibilidad de hacer uso de esta facultad a unas personas u otras no cambiará ni la naturaleza ni los objetivos de la acusación, ya que éstos se sitúan fuera de la disposición de un concreto sujeto, se dirigen uti universi y no uti singuli. Siempre que se limitaran los riesgos de abuso, no habría duda en que tal interés general podría ser satisfecho indistintamente por un español o por un extranjero. Pese a su larga tradición histórica y a su arraigo en nuestras leyes procesales, podría entenderse con ello que la imposibilidad de su ejercicio por extranjeros no es consustancial a la acusación popular. Dada la función que cumple dentro de nuestro sistema procesal penal, en el que constituye un instrumento tendente a someter a enjuiciamiento las conductas afirmadas delictivas, su posible empleo por no españoles, con las necesarias precauciones, no tendría por qué ser vista necesariamente con recelo, sino como ampliación o refuerzo de ese mecanismo de aseguramiento de aplicación de la ley española fuera quien fuera el que la propugnara. Nos fijaríamos así prioritariamente en un elemento de carácter funcional y no meramente subjetivo, considerando más esencial la utilidad de tal concesión a todo el que pudiera contribuir con su esfuerzo en la mejora del sistema, que en los criterios a tenor de los cuales se realiza una discriminación entre nacionales y extranjeros, propia de una época histórica ya superada de exacerbación del elemento nacional y hoy día carente en gran medida de razón de ser.

La opción que toma el legislador al prohibir la acusación de extranjeros no ofendidos por el delito (art. 101, 270 LECrim, 19.1 LOPJ) parece históricamente la más razonable de las posibles, pero pudiera entenderse insostenible hoy día a la luz del instituto al que se dirige:

a) Si atendiéramos al criterio de la afección por el delito (MUÑOZ ROJAS) cabría justificadamente pensar en su ejercicio por extranjeros residentes o por aquéllos que

\footnotetext{
${ }^{908}$ GUTIÉRREZ-ALVIZ y ARMARIO, F. y MORENO CATENA, V., Comentario al art. 125 CE "La participación popular en la administración de justicia”, op. y loc. ult. cit.
} 
tuvieran alguna relación o vinculación con nuestro país (propiedades inmobiliarias, cierto arraigo, familia, etc.), o incluso en algunos delitos especialmente graves (genocidio, terrorismo, narcotráfico) admitirla con carácter abierto, sin que hubiere de acreditarse la nacionalidad.

b) Desde el criterio formal de la ciudadanía (GUTIÉRREZ ALVIZ / MORENO CATENA) tampoco sería de recibo tal restricción en el ejercicio de la acusación popular subsumida en el contenido esencial del derecho a la tutela judicial efectiva del 24.1 CE. Este precepto comienza diciendo "Todas las personas tienen derecho a..."909 por lo que podría concluirse que este derecho debería ser ampliado a todos los que pretendan ejercitarlo. A mayor abundamiento juega el deber de acudir en materia de derechos fundamentales a una interpretación extensiva (STC 137/85 de 17 de octubre, FJ 3) y siempre favorable (SSTC 17/85 de 9 de febrero, 24/90 de 15 de febrero, FJ 2). Podría incluso citarse en defensa de esta posición el art. $27 \mathrm{CC}$, que viene a equiparar los extranjeros a los españoles en el goce de los derechos civiles. Desde esta perspectiva, pues, la legitimación para acusar se expandiría hasta coincidir con la personalidad.

El ejercicio de la acusación no podría considerarse un derecho inherente constitucionalmente a la ciudadanía, ya que el único del que puede estrictamente predicarse tal característica por excluir a los extranjeros es el de participación política del art. $23 \mathrm{CE}$-con la salvedad del 13.2- y, ni aun forzando al máximo su interpretación, podría englobar el contenido del art. $125^{910}$. El único apoyo para tal inclusión entre las facultades propias de la ciudadanía radica no en su naturaleza o en su reconocimiento constitucional sino únicamente en su configuración positiva en la LECrim y la LOPJ. Sea ésta justificada o no, a ella podría contraargumentarse que el interés en el cumplimiento de la norma penal española no tiene por qué ser necesariamente monopolio de los españoles. Mientras quedara acreditada suficientemente la fiabilidad de la pretensión deducida y la

\footnotetext{
${ }^{909}$ Que el derecho de acceso a la Jurisdicción del art. 24.1 es reconocible a todos ha sido declarado por el TC en reiterada jurisprudencia, y ello a pesar de la rúbrica inicial del art. 53.1 CE (por todas vid. STC 19/1983 de 14 de marzo FJ 2) acatando a este tenor los arts. 10.2 DUDH, 6.1 CEDH (vid. FRONEIN / PEUKERT, Europäische Menschenrecht Konvention, Kehl, Estrasburgo 1985, p. 109) y 14.1 PIDCP. Sobre el ejercicio de los derechos fundamentales por extranjeros vid. entre otros SAGARRA i TRIAS, E., Los derechos fundamentales y libertades públicas de los extranjeros en España, Bosch, Barcelona 1991; BORRAJO, I., "El status constitucional de los extranjeros" en el volumen colectivo Estudios sobre la Constitución española. Homenaje al profesor García de Enterria, pp. 607 y ss.

${ }^{910}$ Mostramos así una vez más nuestro desacuerdo con la argumentación contenida en la Exposición de Motivos de la LOTJ, al incluir el Tribunal del Jurado en el derecho de participación.
} 
posibilidad de que el acusador respondiera frente a una actuación abusiva, la nacionalidad del actor debería ser juzgada irrelevante. Su objetivo no se cifra en una modificación de normas penales, o en la utilización de un derecho de participación política encaminado a la formación de la voluntad popular, sino precisamente en poner las premisas para el cumplimiento efectivo de aquéllas, elaboradas con arreglo a la voluntad popular legítimamente representada. El ejercicio de la acusación por extranjeros no implicaría así competencia ni perjuicio alguno para los españoles que quisieran servirse de ella, y no puede ser equiparada tampoco a este respecto al ejercicio de cargos en la Administración ya que, en tanto fuera sufragada por quien la ejercita, no supondría un coste adicional que repercutiese sobre el contribuyente español.

El que la acusación popular tenga valor político en la medida que supone un control privado sobre el ejercicio de una función pública, no tendría tampoco por qué erigirse en óbice para el acceso a ella de los extranjeros. Nada impediría teóricamente el que sujetos extranjeros llevasen a cabo en España una función procesal que los españoles no podríamos por menos que alabar por suponer el desarrollo de un esfuerzo en interes rei publicae, dirigido a la garantía de normas de las que nosotros mismos nos hemos dotado. Siguiendo con esta argumentación, ni siquiera la alegación de que la posibilidad de acusar debería reconocerse sólo en términos de reciprocidad sería admisible: si los demás ordenamientos penales no reconocen la acusación popular y los españoles no podemos ejercitar en ningún otro lugar la pretensión penal, ello irá sólo en perjuicio de los sistemas que renuncian a que los ciudadanos ejerciten un control sobre la persecución de los delitos, pero no sería razón suficiente para negarlo a quien, con las debidas garantías, viene a ejercitar la acusación al amparo y con las condiciones de las normas penales (procesales y sustantivas) españolas. Considerando que supone un beneficio para la garantía del ordenamiento español, negar su ejercicio a los que no ostenten la nacionalidad pudiera ser entendido como desaprovechar positivos esfuerzos de quien voluntariamente pretende coadyuvar con nuestro interés común ${ }^{911}$.

\footnotetext{
${ }^{911}$ No olvidemos que somos un país receptor de inmigración de todo tipo y que determinadas zonas de nuestro territorio están muy pobladas por extranjeros residentes que ostentarían un interés en el cumplimiento de las normas penales en cuyo ámbito de aplicación desenvuelven su vida que, a primera vista, parece tan legítimo como el de los españoles. Pensemos por ejemplo en el extranjero residente en España o con arraigo suficiente en nuestro país, del que no cabría temer un apartamiento de la querella que origine perjuicios aparentes al imputado, o que garantice suficientemente a través de fianza el "estar a las resultas del juicio". O consideremos también el supuesto de un extranjero buen conocedor de determinadas modalidades de comisión delictiva (por ejemplo de algún tipo de criminalidad organizada) no suficientemente conocidas en España pero sí en otros países, que pudiera venir a aportar un caudal positivo de energía en la persecución de aquellos delitos en nuestro país a través de su acusación.
} 
c) En el ámbito administrativo, y concretamente en materia urbanística, el otro sector del ordenamiento jurídico donde la acción popular ha encontrado acomodo tradicionalmente, el problema de la extensión de tal derecho a los no nacionales españoles ha adquirido cierta relevancia por los intereses de inversores extranjeros en el sector de la promoción de obras en nuestro país. En relación con la titularidad del derecho a su ejercicio, la doctrina administrativista se ha cuestionado si correspondería sólo a los españoles o también los extranjeros y para ello ha sido tomada como referencia precisamente la regulación de la acción popular del proceso penal. Tratándose de una llamada del legislador a los ciudadanos para la defensa del interés público general, se ha entendido en ocasiones que sólo los españoles pueden hacer uso de esa facultad ${ }^{912}$. No ha faltado incluso quien en ella ha visto un supuesto de "legitimación por categoría", en este caso, la de ser ciudadano español ${ }^{913}$. Pero hoy día, en general, considerando las ideas anteriores como simples prejuicios doctrinales, la legitimación de los ciudadanos no españoles es aceptada en atención sobre todo a la inexistencia de una norma expresa que vete tal posibilidad ${ }^{914}$. En este sentido contamos además con algún pronunciamiento expreso del TS en el que ya se ha realizado el reconocimiento de tal derecho a los extranjeros $^{915}$.

Ni la afección, ni la ciudadanía, ni la equiparación a la acción popular administrativa son, a nuestro juicio, bastantes para explicar ni justificar su legitimación para actuar válidamente en un proceso penal determinado. Nuestra opinión se dirige así en la

${ }^{912}$ Cfr. COSCULLUELA MONTANER, L., “Acción pública en materia urbanística”, RAP 71 (1973), pp. 34 y s., esp. n. 44, para el que cualquier extranjero, incluso los que no tienen relación alguna con nuestro país, podría interponerla, lo cual llevaría a una consecuencia que considera notoriamente ilógica. A este respecto se sirve de la cita de SANDULLI, L'azione popolare contro la licenze edilizie, Riv. Giuridica dell'Edilizia, II (1968), p. 5, para quien la acción popular es un instrumento de democracia directa y su función estriba en la concepción actual de la defensa de los intereses comunitarios. Ella representaría un ius activae civitatis, razón por la que no puede considerarse que pertenezca sino a los componentes de la comunidad.

${ }^{913}$ CORDÓN MORENO, F., La legitimación en el proceso Contencioso-Administrativo, Pamplona 1979, p. 148.

${ }^{914}$ En este sentido se pronunciaba ya en 1920 FERNÁNDEZ DE VELASCO, R., La acción popular..., op. cit., p. 61. Vid. también FERNÁNDEZ RODRÍGUEZ, T.R., "La acción popular en el proyecto de LOPJ", Estudios sobre el Proyecto de LOPJ, Escola d'Administració Pública de Catalunya, Barcelona 1984, p. 268, y más recientemente GONZÁLEZ PÉREZ, J., Comentarios a la Ley del Suelo, Madrid 1988, p. 2338, n. 7. En su opinión, el art. 19.1 LOPJ al referirse a que los españoles podrán hacer uso de la acción popular no prohíbe expresamente el que sea ejercitada por los ciudadanos extranjeros.

${ }^{915}$ STS 22 de abril de 1988 (RAJ 3188). 
dirección opuesta y no consideramos aceptables ninguna de las perspectivas citadas:

a) La que alude a la afección por el delito no sería de recibo puesto que, según hemos razonado, amén de que se cumpliría su finalidad creando el presupuesto necesario para el enjuiciamiento con independencia de quien lo afirmare, no cabe aceptar en sede procesal penal intereses que no sean generales, intereses por ende individuales, propios, en ningún caso aptos para provocar la puesta en marcha del proceso y la eventual imposición de la pena por el órgano jurisdiccional ${ }^{916}$. El Juez debe actuar ante una infracción pública con independencia del vínculo sustantivo que el querellante o el mero denunciante tenga con el hecho que se afirma existente y punible. Haciendo un inciso, convendría reflexionar acerca de si en la oposición a tan amplio reconocimiento no subyace en cierta medida una lectura de la acusación popular como instrumento beneficioso para el que la ejerce, es decir, idóneo para satisfacer un interés personal, propio, particular y por ende privado, que sólo debe favorecer a los súbditos españoles. La respuesta a ello, ya reiterada, connota la objetividad y consecuente imparcialidad que ha de estar presentes en la promoción de la acusación. No se debe considerar de recibo, pues, que un ciudadano extranjero satisfaga en España una función eminentemente pública, por lo que la habilitación de éstos para su ejercicio abriría en exceso un reducto de intervención privada en el proceso que ha de ser siempre definido con un carácter restrictivo desde su papel residual. Es más, para la transmisión de la notitia criminis valdrá cualquier sujeto, extranjero o español, en todo caso obligados a ello (art. 259 con las exenciones de los arts. 260, 261 y 263 LECrim).

Sin embargo, y siempre partiendo de las vigentes circunstancias entre las que sobresale la confusa, ambigua e insuficiente regulación del MF, que hace comprensible el mantenimiento de la acusación particular y aún de la popular, hemos de admitir una legitimación limitada en atención a la naturaleza que le asignamos: comporta el ejercicio sustitutivo y/o complementario de una función pública, genuina y constitucionalmente atribuida al Ministerio Público, que comprensiblemente debiera reservarse únicamente a ciudadanos españoles. Dicho de otro modo, aunque su ejercicio vaya mediatamente destinado a poner los presupuestos para el cumplimiento de la norma penal española y pueda considerarse irrelevante quién sea la persona que se constituya en su valedor, la acusación de un sujeto no ofendido por el delito supone el ejercicio de una trascendente

\footnotetext{
${ }^{916}$ Los intereses generales serán predicables de cualquiera, y los singulares precisamente son incompatibles con el objetivo perseguido en la justicia penal. Piénsese así en los intereses inconfesables de venganza, utilización como arma política, de chantaje, etc.
} 
función pública sobre la que han de ser adoptadas las máximas cautelas por afectar zonas muy sensibles en lo relativo al espacio jurídico fundamental de nuestra Carta Magna. El ejercicio popular de la acusación, dentro de su generalidad subjetiva, debe situarse en el ámbito más restringido posible, por lo que la limitación de su ejercicio sólo a los españoles ha de entenderse amparada por un legítimo deseo del legislador de no extender más allá de lo conveniente la utilización de una facultad especialmente gravosa. Las limitaciones a las que se ven sometidos los extranjeros en el ejercicio de la acusación, aun no esenciales a ella, han de entenderse por tanto plenamente justificadas en el diseño normativo orgánico del sistema de acusación ${ }^{917}$.

En ningún caso se discute su posible intervención en tanto posibles ofendidos por el delito, sino que lo que se ve como inconsecuente sería su carácter de ejercitantes de una prestación estatal que, desvinculada de la afección por el delito, se dirige siempre a la satisfacción del interés público. La condición de ofendido por el delito alcanza en este caso relevancia fundamental en la medida en que de tal circunstancia se deriva su legitimación procesal activa y nos sirve para establecer el límite a partir del cual no cabe hablar de una atribución de facultades estatales, sino sólo de defensa de intereses propios.

b) La de la ciudadanía sería también rechazable basándonos en la única lectura jurídicamente admisible (art. 5.1 LOPJ) del art. 24.1 CE, precepto con el que además se conecta habitualmente el $125 \mathrm{CE}$. Esta argumentación debería descartarse plenamente, pues sólo tendría sentido desde la concepción de la acusación popular como derecho inherente a la personalidad de los sujetos, lo cual, como ya ha sido abordado es el residuo de una concepción histórica superada con la que no podemos mostrarnos concordes. El ejercicio de la acusación constituye una competencia estatal, eso sí, susceptible de ser realizada también por sujetos privados, pero delimitable en su ámbito objetivo y subjetivo por el legislador. Éste podrá configurarla libremente incluyendo o excluyendo genéricamente, siempre que no incurra en arbitrariedad, a los sujetos que estime oportunos, sin que de ello se derive quiebra de derecho subjetivo alguno. Aquella

\footnotetext{
${ }^{917} \mathrm{Si}$ tenemos en cuenta, además, que parece lógico que los gastos ocasionados por el acusador popular tengan que ser sufragados con fondos públicos, en tanto con su actividad no hace más que satisfacer una función pública, no parecería consecuente que la acusación de los extranjeros, por voluntariosos y altruistas que fueran, pudiera repercutir sobre las arcas estatales. Aun siendo conscientes de que en ocasiones los extranjeros también contribuyen con su aportación tributaria al sostenimiento del erario público español (por ejemplo si son residentes, propietarios de inmuebles o consumen en nuestro país), tampoco podría ésta considerarse razón suficiente para invalidar el argumento expuesto.
} 
concepción, a cuyo tenor se pretendería amparar un derecho de los extranjeros al ejercicio de la acusación, debe ser repelida a limine en tanto su amparo constitucional a la sombra del derecho a la tutela judicial efectiva es insostenible. Incluso considerando la acusación popular como un "derecho civil", el propio art. 27 CC justificaría esta exclusión en tanto deja a salvo de la equiparación entre españoles y extranjeros "lo dispuesto en las leyes especiales", supuesto en el que podemos incluir su ejercicio sin grandes problemas.

c) La equiparación entre acusación popular y acción popular administrativa no puede tampoco ser considerada de recibo a efectos de la legitimación de ciudadanos extranjeros, dado que entre sus respectivas naturalezas concurren esenciales diferencias que invalidan cualquier intento de asimilación. En ambos casos estamos ante la idea de participación ciudadana para la garantía de la legalidad en ámbitos de trascendencia general, pero la naturaleza del derecho y de las normas a cuya aplicación aspira el actor popular en cada uno de ellos debe ser considerada como el límite que determina la diferencia esencial. Aun cuando las consecuencias de ambas puedan ser muy gravosas, no parece ser lo mismo instar la aplicación de una norma administrativa para la sanción de una infracción urbanística que solicitar una resolución en la se que puede imponer una condena penal a quien se impute la comisión de un delito. Los instrumentos y garantías de que se han dotado los respectivos procesos penal y administrativo responden a necesidades diferentes derivadas del tipo de normas materiales a cuya aplicación sirven. En este contexto, por tanto, los efectos que acarrea el ejercicio de la acción popular del proceso penal o el de la del ámbito administrativo no son comparables.

$\mathrm{Al}$ amparo del régimen legal vigente no cabe, pues, pensar en una acusación popular ejercitada por extranjeros en España, ni siquiera cuando viniera legalmente garantizada por el depósito de una caución. La acusación de los extranjeros es sólo admisible cuando se trate de víctimas del delito, y previo el depósito de fianza a fin de asegurar las resultas del juicio, a no ser que esté exento en virtud de tratados internacionales o por el principio de reciprocidad (art. 280 y 281 último párrafo) ${ }^{918}$. Esta cautela se ha asimilado doctrinalmente a la cautio iudicatum solvi del art. 534 LEC $^{919}$, en tanto que

\footnotetext{
${ }^{918}$ Ha de ser advertido, sin embargo, que esperar el reconocimiento de la reciprocidad en relación con la acusación popular es tanto como impedir directamente el acceso al proceso de actores extranjeros no ofendidos. No nos consta la existencia de sistema alguno en el mundo en el que pueda considerarse vigente una facultad de acusar equiparable mínimamente a la vigente en el español, cuyos ciudadanos pudieran quedar amparados por un régimen de reciprocidad basado en la homogeneidad con nuestra acusación quivis ex populo.

${ }^{919}$ De su equiparación a tal cautela, propia del proceso civil, se ha deducido en este sentido la aplicabilidad de los
} 
coincide en su finalidad esencial: evitar el que la falta de arraigo sirva de vía de escape para no hacer frente al pago de las costas procesales ${ }^{920}$.

Hemos de hacer referencia en este apartado, por último, al ejercicio de la acusación por españoles residentes en el extranjero, de los cuales pudiera ser predicable un recelo por su falta de arraigo o sujeción a las consecuencias de una factible acusación calumniosa. En este caso no hay fundamento legal para su exclusión, por lo que no tendría por qué existir problema para que pudieran deducir la pretensión penal, siempre que cumplieran los requisitos previstos en las leyes procesales (capacidad, no estar incursos en causa de exclusión, etc.). La responsabilidad criminal en que pudieran hipotéticamente incurrir por el ejercicio de la acusación se funda en un delito cometido en España y, en este sentido, no habría duda sobre su perseguibilidad ${ }^{921}$. La falta de arraigo pudiera ser observada a efectos de determinar la cuantía de la fianza con el fin de asegurar hipotéticas responsabilidades sobre su actuación procesal, pero no ha de olvidarse que ello podría chocar con la previsión del art. 20.3 LOPJ en el sentido de que la fianza no podrá exigirse en cuantía que "por su inadecuación impida el ejercicio de la acción popular" (art. 20.3 LOPJ). Si por la falta de arraigo se impusieran a los españoles residentes en el extranjero fianzas elevadas, se estaría impidiendo de facto el ejercicio de la acusación a unos sujetos a los que se les reconoce tal posibilidad exactamente igual que a los demás. El régimen actual de la fianza se revela aquí deficiente, por lo que parece necesario revisar los

tratados y convenios internacionales ratificados por España, aun cuando vengan únicamente referidos a los procesos civiles y mercantiles. Además de los respectivos convenios bilaterales existentes en la materia, cuya existencia deberá ser probada por el querellante extranjero, vid. el art. 14 del Convenio de la Haya de 25 de octubre de 1980, tendente a facilitar el acceso internacional a la justicia, ratificado por España por instrumento de 20 de enero de 1988 (BOE 30 de marzo). A tenor de su art. 22, este convenio sustituirá en las relaciones entre los Estados que lo ratifiquen a los arts. 17 a 26 del Convenio de La Haya de 1 de marzo de 1954 ratificado por España por Instrumento de 28 de junio de 1961 (BOE de 13 de diciembre). Cabe reseñar también aquí el Acuerdo Europeo relativo a la Transmisión de Solicitudes de Asistencia Jurídica Gratuita, firmado en Estrasburgo el 27 de enero de 1977 y ratificado por instrumento de 14 de noviembre de 1985 (BOE 21 de diciembre). Vid. también GIMENO SENDRA, V., "La fianza...", op. cit. pp. 85 y s., n. 91 .

\footnotetext{
${ }^{920}$ Se ha afirmado que no es, como ocurre en el caso de los españoles no perjudicados, manifestación legal de un temor de que pueda ser utilizada como acusación calumniosa, en tanto que, tratándose del ofendido por el delito (art. 281.2.II LECrim), tal circunstancia queda teóricamente excluida por la presunción iuris tantum contenida en el régimen de la legitimación activa del proceso penal. GIMENO SENDRA, V., op. et loc. ult. cit. En nuestra opinión, sin embargo, la equiparación es perfectamente posible en tanto el acusador particular persigue, de idéntica manera que el actor en el proceso civil, un interés privado. Debemos remitirnos aqui necesariamente a lo expuesto en el capítulo anterior.

${ }^{921}$ Así GÓMEZ ORBANEJA, E., Comentarios a la LECrim, cit. p. 462 y SÁEZ JIMÉNEZ y LÓPEZ FERNÁNDEZ DE GAMBOA, op. cit. p. 892.
} 
criterios de imposición, o para ser consecuentes, del directo reconocimiento de su inutilidad en la concepción actual. Sobre el tema se regresará más adelante.

\section{III.}

El reconocimiento de la aptitud para el ejercicio popular de la acusación solamente a los españoles (arts. 101 y 270 LECrim y 19.1 LOPJ), impone un requisito que, sólo a primera vista, pudiera contrastar con principios básicos del ordenamiento comunitario aceptados por nuestro país. El Tratado de la Unión Europea tiende hacia la consecución de una verdadera "ciudadanía europea" "922, fundada sobre la base de la igualdad de todos los ciudadanos en el ejercicio de derechos reconocidos en cada uno de los Estados. El actual art. 6 TCE recoge la expresa prohibición de discriminación por razón de la nacionalidad entre los ciudadanos de los Estados miembros de la UE, exigiendo la perfecta igualdad de trato de las personas que se encuentran en una situación regida por el Derecho Comunitario con los nacionales de un Estado miembro ${ }^{923}$. Constituye, por tanto, una de las exigencias para que el principio de no discriminación opere, el que la posible

\footnotetext{
${ }^{922}$ El art 8 TCE, incorporado por el art. G.C del TUE, crea la ciudadanía de la Unión Europea, la cual se atribuye a todos los ciudadanos que ostenten la nacionalidad de uno de los Estados miembros. Aun así, no parece que suponga un gran avance sobre los derechos que ya estaban total o parcialmente contemplados con el soporte jurídico anterior al tratado de Maastricht, sino que se le atribuye en primer lugar un valor político. No es por tanto tan trascendente el nuevo aparato normativo en el plano cuantitativo como en el cualitativo. Sobre el complejo tema de la ciudadanía de la Unión vid. LIÑÁN NOGUERAS, D.J., "La ciudadanía de la Unión Europea”, en RODRÍGUEZ IGLESIAS, G.C .y LIÑÁN NOGUERAS, D.J. (Directores), El Derecho Comunitario y su aplicación judicial, Civitas, Madrid 1993, pp. 271 a 295; PÉREZ VERA, E., "La ciudadanía europea en el Tratado de Maastricht" en el volumen Hacia un nuevo orden internacional y europeo. Estudios en homenaje al profesor D. Manuel Diez de Velasco", Tecnos 1993, pp. 1123 a 1147; HIERRO HERNÁNDEZ-MORA, A., "La ciudadanía europea y la protección de los Derechos Fundamentales" en el volumen colectivo "España y el tratado de la Unión Europea. Una aproximación al tratado elaborada por el equipo negociador español en las Conferencias Intergubernamentales sobre la Unión politica y la Unión económica y monetaria", Colex 1994, pp. 175 a 200, esp. p. 191 y ss.; BIGLINO CAMPOS, P., "Ciudadanía Europea y legitimidad democrática”, Revista de Estudios Europeos, no 9 enero-abril 1995, pp. 3 a 12 y ADRIÁN ARNAIZ, A.J., "Algunas consideraciones sobre la ciudadanía de la Unión Europea y la Conferencia Intergubernamental de 1996 para la reforma del Tratado de Maastricht", Revista de Estudios Europeos, n 11 , septiembre-diciembre 1995, pp. 53 a 75.

${ }^{923}$ En la medida en que este principio se aplique, se opone por tanto a que un Estado miembro subordine la concesión de un derecho a dicha persona a requisitos que no se impongan a los nacionales. STJCE de 2 de febrero de 1989, Asunto 186/1987, Cowan, apartado 10. El TJCE ha tenido oportunidad de pronunciarse en numerosas ocasiones sobre la prohibición de discriminación por razón de la nacionalidad, generando una consolidada jurisprudencia que deja pocas dudas de la interpretación del art. 6 TCE para configurarlo como uno de los contenidos esenciales del sistema jurídico comunitario. Además, el derecho a la igualdad de trato consagrado por el Derecho comunitario no puede depender de la existencia de un acuerdo de reciprocidad celebrado entre el Estado miembro de que se trata y el país del que es nacional la persona interesada, sino que ha de verificarse sin necesidad de constatar la existencia de un acuerdo de ese tipo. STJCE de 22 de junio de 1972, Frilli, Rec. p. 457.
} 
discriminación se produzca respecto al ámbito de vigencia del propio Tratado y "sin perjuicio de las disposiciones particulares previstas en el mismo". Por ello nos vemos obligados a responder a la cuestión de si el ejercicio de la acusación en España se integra en el ámbito del Tratado y si ha de incluirse amparado por tal prohibición de trato diferente.

La cuestión puede ser abordada desde dos diversas perspectivas:

a) Por un lado, el entendimiento de la acusación popular como un derecho cívico, en conexión con la tendencia del Derecho comunitario hacia la consecución de la «ciudadanía europea», ha propiciado la proposición de admitir en nuestro país su ejercicio por nacionales de Estados miembros de la Unión Europea ${ }^{924}$. Mientras no se produjera una modificación de la norma, la solución transitoria tendría que venir en todo caso a través de una tácita asimilación de los ciudadanos comunitarios al concepto de "españoles".

b) Por otro, la especificidad del ejercicio de la acusación por los ciudadanos en nuestro sistema y su carácter único entre todos los ordenamientos jurídicos europeos, hace difícil que la cuestión hubiera podido plantearse ante la Jurisdicción comunitaria. Sin embargo, el TJCE sí ha tenido ocasión de pronunciarse expresamente sobre desigualdades de trato en la asunción de facultades procesales en el juicio criminal de otros ordenamientos, sobre cuya base pudiera extraerse alguna conclusión quizá útil en esta materia ${ }^{925}$. El propio Tribunal ha sentado el principio de que, si bien la legislación penal y las normas de procedimiento penal son de la competencia de los Estados miembros, dichas disposiciones legislativas "no pueden producir una discriminación respecto de personas a las que el Derecho comunitario atribuye el derecho a la igualdad de trato". Aun cuando la legislación penal sea competencia exclusiva de aquéllos, la apreciación de una norma se

${ }^{924}$ GIMENO SENDRA, V., “La acusación popular”, op. cit. pp. 90 y s.

\footnotetext{
${ }^{925}$ Nos referimos concretamente a alguno de los pronunciamientos del TJCE en relación con intervención de ciudadanos comunitarios en el proceso penal de otros Estados, doctrina que en algunas ocasiones ha devenido célebre entre la literatura comunitarista al abordar cuestiones de gran relevancia para la integración jurídica europea. Así ocurre, por ejemplo, con la conocida como "Sentencia Cowan", que vino a ampliar el concepto de "libre prestación de servicios", incluyendo aspectos hasta entonces no reconocidos y suponiendo un apoyo al principio de libre circulación de personas en sí mismas consideradas y no vinculadas necesariamente a una actividad económica. Vid. los comentarios a la misma de MERTENS DE WILMARS, J. en Cahiers de droit europeene 1990, n 3-4, pp. 388 y ss. y de VAQUERO LÓPEZ, M. C., "La sentencia Cowan. La ampliación del concepto de libre prestación de servicios y la Europa de los ciudadanos", Castilla y León en Europa. Revista del Centro de Documentación Europea de Valladolid, 31, noviembre, diciembre de 1991, pp. 30 y ss.
} 
debe hacer independientemente del criterio formal relativo a su origen, y únicamente en función de su contenido, sin que quepa su aplicación discriminatoria ${ }^{926}$.

El TJCE se ha pronunciado sobre la exigencia prevista en el Codice de Procédure Penale francés de ostentar la ciudadanía gala, además de la condición de víctima, para el logro de una indemnización por la comisión de un delito en Francia ${ }^{927}$. Entendió en este caso que el principio de no discriminación se opone a que un Estado miembro subordine la concesión de una indemnización del Estado, destinada a reparar el perjuicio a una víctima de agresión, al requisito de ser titular de un permiso de residencia o de ser nacional de un país que haya celebrado un acuerdo de reciprocidad con ese Estado miembro ${ }^{928}$. En su sentencia de 1 de febrero de $1996^{929}$, el Tribunal abordó de nuevo la intervención de un sujeto comunitario (en este caso persona jurídica) como actor civil en el proceso penal de otro Estado miembro, así como las condiciones en que esta intervención puede tener lugar.

\footnotetext{
${ }^{926}$ STJCE de 2 de febrero de 1989, Asunto 186/1987, Cowan, cit. apartado 19, tal y como se deduce de las conclusiones del Abogado General LENZ ( $\left.\mathrm{n}^{\circ} 45\right)$. Sentando esta doctrina el Tribunal acentuó la tendencia a expandir la prohibición de discriminación a ámbitos no estrictamente económicos, como pudieran ser consideradas las libertades básicas contempladas en los Tratados. Alcanzaba así también otras áreas reguladas en exclusiva por los ordenamientos de los Estados miembros. El posterior reconocimiento de la ciudadanía de la Unión en el art. 8 TCE puede ser interpretado, por tanto, como culminación normativa de un proceso que ya había sido iniciado con paso firme por el Tribunal al hacer progresar el concepto de "extranjería privilegiada" en que hubiera podido permanecer anclado el principio de no discriminación por razón de la nacionalidad.
}

${ }^{927}$ STJCE de 2 de febrero de 1989, Asunto 186/1987, Cowan. El presupuesto de partida es ciertamente diferente a lo que ocurre en el caso de nuestra acusación popular, en tanto aquí lo que se puso en cuestión no era el derecho de participación de la víctima en el proceso penal en los mismos términos que los ciudadanos franceses, sino sobre todo la extensión del propio concepto de "prestación de servicios" y la extensión o no de éste a la indemnización por motivo de sufrir los efectos de un delito. En este caso un ciudadano británico que había sido víctima de un delito de agresión durante una estancia en París solicitó de la Commision d'indemnisation des victimes d'infraction del Tribunal de Grande Instance la concesión de una indemnización que le fue denegada por no ostentar la nacionalidad francesa ni la de ningún otro Estado que tuviera suscrito un tratado de reciprocidad para la aplicación de tales disposiciones. La cuestión se tramitó al amparo del art. 177 y la pregunta que le fue sometida a consideración al TJCE estaba redactada en los siguientes términos: ¿Son compatibles con el principio de no discriminación que enuncia, en particular, el (antiguo) artículo 7 del Tratado las disposiciones del art. 706.15 del Codice de Procédure Pénale por el que se regula los supuestos en que un extranjero, víctima en Francia de un hecho punible, puede beneficiarse de una indemnización del Estado francés?.

\footnotetext{
${ }^{928}$ Vid. también las conclusiones del Abogado General LENZ en las que se dice ( $\mathrm{n}^{\circ}$ 44) que "la indemnización de las víctimas debe entenderse como simétrica a la obligación de garantizar el orden y la seguridad públicas. Constituye una compensación por la violación de bienes jurídicamente protegidos que el Estado, a pesar de ser competencia suya, no ha sido capaz de salvaguardar en el caso concreto". En este caso, un nacional francés residente en el extranjero se encontraría en una situación de favor en relación con otro ciudadano comunitario, lo cual se opondría al principio de la no discriminación por razón de la nacionalidad.
}

${ }^{929}$ Asunto C-177/94 Perfillli. Vid. la reseña publicada en $L A L E Y$ de 6 de mayo de 1996, pp. 9 y ss. 
En ella recordaba que es jurisprudencia reiterada que, al prohibir a cada Estado miembro aplicar su derecho de modo diferente por razón de la nacionalidad en el ámbito de aplicación del Tratado, el art. 6 no se refiere a las posibles desigualdades de trato que pueden resultar entre un Estado miembro y otro, de las divergencias que hay entre las legislaciones entre ellos, siempre que éstas afecten a todas las personas sujetas a su aplicación, según criterios objetivos y sin tener en cuenta la nacionalidad de los sujetos ${ }^{930}$. El TJCE estimó que no concurría vulneración alguna del derecho comunitario en la imposición por el ordenamiento italiano del otorgamiento de poder especial para el ejercicio de la acción civil a un sujeto de otra nacionalidad comunitaria en tanto ese requisito era exactamente igual para los nacionales italianos ${ }^{931}$.

Tales argumentos no serían suficientes, a nuestro juicio, para poder apreciar una vulneración del derecho comunitario en la prohibición de que ciudadanos nacionales de otros Estados miembros de la UE acusen en España sin ser ofendidos por el delito. Ello se deduce de la propia naturaleza y funciones de la materia que se aborda, pudiéndose afirmar en este sentido que:

a) El ejercicio de la acusación, tal y como venimos reiterando a lo largo de este trabajo, no admite ser contemplado como derecho ni como facultad para la defensa de intereses propios extraños a la naturaleza de la justicia penal. No cabría entender la existencia de discriminación alguna por razón de la exigencia de nacionalidad española precisamente porque no se trata de una actividad que quepa ser englobada dentro del ámbito del Tratado, sino sólo de una actividad dirigida a la satisfacción del interés público ${ }^{932}$. La exigencia de la nacionalidad española para ser fiscal (art. 43 EOMF), juez (art. 302 LOPJ) o jurado (art. 8.1 LOPJ) podrían servir de referente a este tenor, sin que en

\footnotetext{
${ }^{930}$ En este supuesto una compañía de seguros con sede en el Reino Unido pretendía el ejercicio de la acción civil en Italia en calidad de ofendido en causa abierta por simulación de delito, sufriendo lo que ellos interpretaron como discriminación por razón de la nacionalidad al exigírsele para su personación como actor civil un requisito formal que no contemplaba la legislación británica (en concreto la necesidad de otorgar poder especial al efecto).

${ }^{931}$ SSTJCE de 28 de junio de 1978, Kenny, 1/78, Rec. p. 1489, apartado 18; de 7 de mayo de 1992, Wood y Cowie, C-251/90 y C-252/90, Rec. p. I-2873 apartado 19; de 3 de julio de 1979, Van Dam en Zonen et. al., 185/78 a 204/78, Rec. p. 2345, apartado 10.

${ }^{932}$ Debe destacarse, además, que ni siquiera a título de proyecto es contemplada la acusación popular entre los derechos de los ciudadanos de la Unión Europea. Vid. Proyecto de Constitución de la Unión Europea, Publicado como anexo al Informe Herrmann (Informe de la Comisión de Asuntos Institucionales del Parlamento Europeo sobre la Constitución de la UE). PE 203.601 /def.2. En su art. 17.c) se establece que "El acceso a la justicia es efectivo", pero no cabe reseñar una mínima referencia a un derecho de participación en el proceso penal.
} 
ningún caso pudiera entenderse vulnerado el derecho comunitario con la imposición del requisito de ciudadanía.

b) La jurisprudencia emanada del TJCE se refiere en todo caso a intervenciones procesales dirigidas a la defensa de derechos propios, aludiendo en verdad a cuestiones patrimoniales más propias del orden jurisdiccional civil y que, como es sabido, sólo por razones históricas confluyen en el proceso penal de algunos sistemas continentales. La extensión del concepto "prestación de servicios" o la imposición de los mismos requisitos a los ciudadanos de todos los Estados para la defensa de sus intereses privados son así perfectamente comprensibles, pero nunca lo sería la atribución de una facultad que viene a sustituir la función del MF al afirmar la concurrencia de presupuestos para una resolución jurisdiccional sobre un sujeto por unos hechos que se consideran delito.

A este respecto ha de advertirse que un sujeto nacional de otro Estado que se viera acusado en España por un ciudadano que dedujera la pretensión penal no podría alegar discriminación alguna, aun cuando su ordenamiento no reconozca tal posibilidad. No cabría tampoco el que un español dirigiera una petición a los Tribunales de otro Estado para que le admitieran su querella como acusador popular. La acusación popular por ciudadanos comunitarios no españoles no es en ningún caso admisible ni parece oportuno considerar que, al excluirla, se esté vulnerando la prohibición de discriminación. Únicamente ha de ser posible la equiparación allí donde la actividad de los particulares se dirija a la tutela de derechos propios, tal y como ocurre en el ejercicio de la acción civil o, aun inapropiadamente y fuera de lugar, en el de la acusación particular ${ }^{933}$. En estos casos la discriminación podría tener lugar no sólo impidiéndose su participación, sino también si llegaran a imponerse requisitos formales más estrictos tales como la imposición de fianzas para hacer frente a las resultas del juicio allí donde no se exijan a los españoles (vid. por ejemplo art. 270.II en conexión con 280 y 281 LECrim), la necesidad de señalar un domicilio en España o la de ser representados por ciudadano español ${ }^{934}$.

\footnotetext{
${ }^{933}$ Se ha considerado por la doctrina también la personación en nuestro proceso penal de las propias Instituciones Comunitarias en caso de ser éstas las perjudicadas por la comisión delictiva. Al respecto vid. NIETO MARTÍN, A., Fraudes Comunitarios. Derecho Penal Económico Europeo, Barcelona 1996, pp. 28 y ss.

${ }^{934}$ Vid. STJCE de 20 de marzo de 1997, C-323/95, Hayes c. Kronenberg que impide la discriminación de trato en la imposición de una cautio iudicatum solvi. Parece claro que una vez reconocido un mecanismo procesal para la defensa de intereses propios, éste no podría quedar restringido a un concepto estricto de la nacionalidad, sino que la función expansiva del Derecho Comunitario haría innecesario esperar a la reciprocidad. Sin embargo, ello no implica que los españoles podamos invocar el reconocimiento por los demás ordenamientos jurídicos de las mismas facultades procesales que se nos reconocen en el nuestro.
} 


\subsubsection{No estar incurso en causa de exclusión}

El carácter "popular" de la acusación viene precisamente determinado por la autorización de su ejercicio a los sujetos a los que la ley no se lo prohíba. Los arts. 102 y 103 LECrim son los preceptos que contienen el numerus clausus de supuestos en los que no se atribuye subjetivamente legitimación para acusar y una exclusión no puede basarse en motivos diversos a ellos. Vienen éstos a señalar así el marco dentro del cual el legislador confiere a los particulares legitimación extraordinaria para el planteamiento de la pretensión estatal de acusación, lo cual, como se ha visto, entra plenamente en sus facultades.

Según la doctrina tradicional cabría distinguir las prohibiciones de acusar contenidas en la ley entre las absolutas (art. 102 LECrim) y las relativas (art. 103 LECrim). Mientras las primeras constituirían incapacidades, con independencia del hecho justiciable y de las personas responsables del mismo, las segundas se referirían a meras incompatibilidades, o sea, a hipótesis en que por razones especiales se prohíbe el ejercicio de la pretensión penal sólo con relación a determinados hechos o a personas concretas ${ }^{935}$. El art. 102 nos viene a decir por exclusión qué sujetos pueden acusar, y el 103 especificaría los casos en que, a pesar de tal genérico reconocimiento, no podrían hacer uso de esa facultad. Destacaba AGUILERA DE PAZ que, tratándose ésta de una materia de interpretación restrictiva por su propia naturaleza, no podría admitirse ninguna otra causa de incapacidad ni aun por razón de analogía: la acción para perseguir un delito sería de carácter universal y, si bien razones de orden público y social pueden justificar condiciones a su ejercicio que la limiten en determinados casos, la lógica y el buen sentido, impondrían como norma precisa e indispensable que al cesar los motivos de dichas limitaciones o cuando deba prescindirse de ellas, desaparezcan éstas, "estableciéndose en toda su pureza e integridad el derecho a la acción" ${ }^{936}$.

Para estar habilitado para acusar además del requisito de la nacionalidad deberán cumplirse las condiciones que se detallan a continuación:

${ }^{935}$ AGUILERA DE PAZ, E., Comentarios a la Ley de Enjuiciamiento Criminal, Madrid 1923, T. I, pp. 523 y 527.

${ }^{936}$ AGUILERA DE PAZ, E., Comentarios a la Ley de Enjuiciamiento Criminal, op. cit., pp. 528 y 534. 


\subsubsection{Gozar de la plenitud de los derechos civiles (art. 102.1 LECrim)}

La Ley no asigna aptitud para deducir la pretensión penal a ciudadanos no ofendidos cuando no gocen de la "plenitud de los derechos civiles". La falta de capacidad procesal opera así como el primero de los límites que privan de la habilitación para acusar $^{937}$, por lo que, con carácter general, no habiendo plena capacidad civil, tampoco existirá legitimación. Puesto que estamos en presencia de una facultad personalísima, cuyo ejercicio no puede realizarse por otro sujeto, sólo en los escasos supuestos contemplados en el segundo párrafo de este artículo puede ser completada la capacidad a través de la comparecencia de sus representantes legítimos o los que deban suplir su incapacidad con arreglo a derecho (art. 2.II LEC). Se trata por ende de la carencia de la facultad de acusar sin ser ofendido, y no sólo ante la constatación de una no habilitación para la válida realización de los actos procesales que conlleva ${ }^{938}$.

De la LECrim no se puede extraer una idea clara sobre lo que deba entenderse por "gozar de la plenitud de derechos civiles", por lo que parece necesario remitirnos a las previsiones del Código Civil a fin de establecer quiénes sean estos sujetos. Cabe así afirmar que no podrán acusar cuando no sean agraviados por el delito:

a) Los menores de edad

${ }^{937}$ MONTERO AROCA, J., Derecho Procesal Penal, op. cit., p. 65.

${ }^{938}$ El fundamento histórico de esta prohibición no sólo ha de buscarse en la necesaria exigencia de capacidad para el ejercicio pleno de los derechos, sino también en la desconfianza hacia acusadores no ofendidos que no pudieran hacer frente con posterioridad a las responsabilidades generadas por su actuación en el proceso. Advertía ya AGUILERA DE PAZ que, al establecer el legislador las condiciones para el ejercicio de las acciones penales, no había tenido otro propósito que el de "afirmar la seguridad de que los que hayan de ejercitar dichas acciones tengan la aptitud necesaria no sólo para comprender los resultados y consecuencias de las mismas, así como la trascendencia y responsabilidades de su ejercicio, sino también para que sus personales condiciones y su situación dentro de la familia ofrezcan garantía eficaz y suficiente contra las persecuciones injustas, hijas de la irreflexión o de la pasión". AGUILERA DE PAZ, Comentarios, op. cit, p. 529. Esta categoría englobaba no sólo los menores de edad, los imbéciles o locos y los pródigos, sino también a la mujer casada. La incapacidad absoluta de la mujer casada era argumentada por este autor estimando que "tiene tal abolengo en nuestras tradiciones jurídicas, que basta sólo indicarla para que se tenga por autorizada". En una interpretación aún más restrictiva, negaba ABELLA a la mujer en general (y no sólo a la casada) la facultad para ejercitar "acciones penales", excepto "cuando traten de defenderse". Busca el apoyo de su opinión en Las Partidas, concretamente en la L. $2^{\mathrm{a}}$, Tít. $1^{\circ}$ de la Partida $7^{\mathrm{a}}$, que él estima no derogada y que, con alguna excepción, se lo prohibía en general. Vid. ABELLA, J, Ley de Enjuiciamiento Criminal comentada, $4^{a}$ edición, Madrid 1894, p. 124. Con respecto al tema, GÓMEZ ORBANEJA advierte que la mujer casada podía comparecer en juicio por sí con licencia marital, pero si el marido compareciese como su representante, ésta quedaría revocada. Vid. GÓMEZ ORBANEJA, E., Comentarios..., op. cit., T. II, vol. I, p. 468. 
A tenor de lo dispuesto en el art. 12 CE y 315 CC, la mayoría de edad empieza a los dieciocho años cumplidos. A partir de este momento, los sujetos serán capaces para todos los actos de la vida civil (art. 322 CC), y de este modo también con carácter general, podrán acusar aun no siendo ofendidos.

En relación a los menores emancipados cabría decir que el art. $323 \mathrm{CC}$ establece que "la emancipación habilita al menor para regir su persona y bienes como si fuera mayor", por lo que habrá de entenderse que se encuentra en el pleno goce de sus derechos civiles. El art. 102.1 LECrim no se refiere expresamente a la mayoría de edad ${ }^{939}$, por lo que no se le podrá excluir de la titularidad de la facultad de acusar, y, además, no necesitaría servirse de representación legal en tanto el art. 323.II CC establece que podrá comparecer por sí solo en juicio ${ }^{940}$.

b) $\underline{\text { Los incapaces }}^{941}$

De los mayores de edad la capacidad se presume siempre y la incapacidad habrá de declararse necesariamente por sentencia judicial de incapacitación en virtud de las causas establecidas en la Ley (enfermedades o deficiencias persistentes de carácter físico o psíquico que impidan a la persona gobernarse por sí misma) (art. 199 y ss. CC). Aun cuando la sentencia de incapacidad determinará la extensión y los límites de ésta (art. 210 $\mathrm{CC})$, el declarado incapaz no podrá acusar al no gozar de la "plenitud de los derechos civiles" 942 .

${ }^{939}$ A diferencia, por ejemplo, de los arts. 2.1 y 6.1 de la LO 5/1985 de Régimen Electoral General en los que tal requisito es necesario para ser titular del derecho de sufragio activo o pasivo respectivamente.

${ }^{940}$ SÁEZ JIMÉNEZ y FERNÁNDEZ LÓPEZ DE GAMBOA planteaban la injusticia que supone el que un menor de edad y mayor de 16 años pueda verse sometido a un proceso penal y, sin embargo, no pueda acusar en otro. Ello les llevaba a concluir el principio de que "Todo el que tiene capacidad procesal para ser sometido a un proceso penal, la tiene para ejercitar la acción penal por delito que atente contra su persona o bienes". Tal observación ha de entenderse correcta pero incompleta, en tanto la cualidad de ofendido ha de entenderse habilitante para el ejercicio de la acusación en todo caso, y no sólo cuando se sea mayor de 16 años. Problema distinto es que hasta la mayoría de edad el menor ofendido precise ser representado para su intervención en el proceso. SÁEZ JIMÉNEZ, J. y FERNÁNDEZ LÓPEZ DE GAMBOA, E., Compendio de Derecho Procesal Civily Penal, Madrid 1966, T. IV, vol. 1, p. 908.

${ }^{941}$ Sobre la cuestión puede verse GORDILLO, M., "La incapacidad procesal por demencia del querellante", RDProc, 1947, n 1, p. 7.

${ }^{942}$ Esta exclusión, al igual que la de los declarados pródigos, se ha reputado en ocasiones excesivamente rigurosa, porque la resolución judicial puede reducir los derechos de estos sujetos en escasa medida. Vid. SALOM ESCRIVÁ, J-S., "La querella", JUSTICIA 96, n² 2, p. 401. En todo caso, advierte con razón, no cabe otra interpretación de la clara exigencia del art. 102.1 LECrim. 


\section{c) Los declarados pródigos}

Los declarados judicialmente pródigos están sujetos a curatela (art. 286.3 CC), debiendo establecer la sentencia los actos que el pródigo no puede realizar sin el consentimiento del curador (art. 298 CC). Aun cuando en este supuesto la capacidad se presuponga, entendemos que tales sujetos no se encuentran en la "plenitud de sus derechos civiles", por lo que tampoco serán titulares de la facultad de acusar sin ser ofendidos por el delito.

\section{d) Concursados y quebrados}

A tenor de lo previsto en el art. 1914 CC ("la declaración de concurso incapacita al concursado... para cualquier otra que por la ley le corresponda") y en el 1161 LEC (el concursado quedará inhabilitado para la administración de sus bienes) no se puede considerar que el concurso o la quiebra sean causas de incapacidad, por lo que estos sujetos sí podrán acusar.

e) Los condenados a pena de inhabilitación absoluta, de inhabilitación especial para empleo o cargo público o de inhabilitación para el ejercicio de determinados derechos

En este caso tampoco nos encontramos ante un supuesto enmarcable estrictamente en la prohibición del art. 102.1 LECrim, ya que la inhabilitación no conlleva impedimento en el "goce de la plenitud de los derechos civiles", sino únicamente en los declarados por la sentencia condenatoria. A tenor de lo dispuesto en el art. 39 CP, cabe la imposición por sentencia de pena de inhabilitación absoluta ${ }^{943}$ o de inhabilitación especial, entre otros derechos, para el desempeño de empleo o cargo público e incluso para "el ejercicio de cualquier otro derecho", por lo que podríamos plantearnos si sería posible impedir a través de la condena el ejercicio popular de la acusación durante un determinado periodo. Aun cuando deducir la pretensión penal cuando no se sea ofendido constituye satisfacción de una tarea pública, no parece posible su inclusión en los términos "honores, empleos o cargos públicos", en tanto parece claro que tal previsión normativa se refiere al desempeño continuado y no meramente puntual de funciones públicas.

Consideramos, sin embargo, que lege ferendae no habría traba constitucional alguna que impidiera su exclusión temporal en concretas hipótesis cuando la pena de

\footnotetext{
${ }^{943}$ Art. 41 CP: "La pena de inhabilitación absoluta produce la privación definitiva de todos los honores, empleos y cargos públicos que tenga el penado... (y) la incapacidad para obtener los mismos o cualesquiera otros (...) durante el tiempo de la condena".
} 
inhabilitación viniera expresamente prevista en la norma penal como consecuencia pretendida por el ordenamiento jurídico para la comisión de un determinado delito. En este sentido, sería aconsejable con vistas al futuro la posible privación por sentencia condenatoria de la facultad de acusar impuesta como pena accesoria a la comisión de determinados delitos, y en especial a la mayoría de los incluidos en el Titulo XX del Libro II CP ("Delitos contra la Administración de Justicia"). Los sujetos que hubieren incurrido en alguna de las conductas previstas por estos tipos penales no deben ser merecedores durante el tiempo de la condena de la confianza tácita que el ordenamiento jurídico deposita en el ejercitante popular de la acusación, confiriéndoles una capacidad de actuar dirigida a cumplir una función pública tan sensible como es ésta.

\subsubsection{No haber sido condenado dos veces por delito de acusación y denuncia falsas (art. 102.2 LECrim)}

El número 2 del art. 102 impide acusar a quien "hubiera sido condenado dos veces por sentencia firme como reo del delito de denuncia o querella calumniosas"944. La definición sobre lo que haya de entenderse como acusación o denuncia falsa, término más adecuado en la actualidad, se encuentra en el nuevo art. 456 CP. A tenor de éste, no se establecen diferencias entre denuncia y acusación, sino que el reproche penal se dirige indistintamente contra "los que con conocimiento de su falsedad o temerario desprecio hacia la verdad, imputaren a alguna persona hechos que, de ser ciertos, constituirían infracción penal, si esta imputación se hiciera ante funcionario judicial o administrativo que tenga el deber de proceder a su averiguación".

Esta limitación es una muestra de la desconfianza de la Ley frente a las personas que, reiteradamente, hayan demostrado mala fe y falta de veracidad incriminando falsariamente a inocentes. Aquél que no es digno de credibilidad en el ejercicio del deber de denuncia o en la acusación, no debe ser en ningún caso merecedor del depósito de confianza que, en tanto ejercicio de una función pública, supone poder deducir acusación. Esa falta de confianza se ha basado habitualmente en el temor a que pudiera obrar del

\footnotetext{
${ }^{944}$ Ya se preveía esta prohibición, con su redacción actual, en el art. 3 LECrim. 1872 y en el 242 de la Compilación General. Tal y como señalaba GÓMEZ ORBANEJA, el adjetivo "calumniosas", que aun se encuentra en nuestra ley, representaba ya un arcaísmo en relación al CP de 1870, que hablaba de "acusaciones o denuncias falsas", denominación que se ha mantenido. GÓMEZ ORBANEJA, E., Comentarios..., op. cit., T. II, p. 466.
} 
mismo modo de nuevo, o a la sospecha de que se trate de un acusador profesional, un chantajista o un extorsionador. El perjuicio que acarrea la falsa imputación de delitos no abarca sólo al afectado directamente que, a pesar de no ser condenado ve puesta en entredicho la presunción de su inocencia y sufre los graves efectos de verse sometido a un proceso, sino también al propio sistema de persecución penal y en general, a toda la comunidad, en tanto es de interés general que la maquinaria judicial sólo se active en los $\operatorname{casos}^{n e c e s a r i o s}{ }^{945}$.

Se ha destacado que el origen de este impedimento para acusar goza de gran abolengo histórico ${ }^{946}$, aun cuando no se haya previsto siempre dentro de los términos exactos en que hoy lo conocemos. La declaración de infamia y el tener ejercitadas ya dos acciones eran en el Derecho Romano causas suficientes para excluir la acusación de los no ofendidos por el delito $^{947}$, y su paso a nuestra LECrim se realizó a través de la recepción de aquellas prohibiciones en las Partidas (el que estuviere dado por de mala fama y aquel que ouiesse fechas dos acusaciones $)^{948}$. El legislador de 1872 y posteriormente el de 1882 refundieron el contenido de ambas previsiones y, en lugar de establecer un límite al número de acusaciones interpuestas a la vez, fijaron el requisito de la doble condena por "denuncia o querella calumniosa".

La insuficiencia de una sola condena para impedir la acusación en estos casos fue ya, con razón, criticada por la doctrina desde los primeros momentos de vigencia de la Ley $^{949}$, y lo ha sido también en nuestros días ${ }^{950}$. Aunque la LECrim exija dos condenas

${ }^{945}$ Tal y como destacara AGUILERA DE PAZ, "El legislador ha entendido que el que tiene contra si una ejecutoria de calumniador y de falsario no puede ser admitido al ejercicio de la acción penal sin grave peligro para la sociedad por temor a que obre del mismo modo (...) Las graves consecuencias de todo proceso criminal, aun cuando al término del mismo recaiga una absolución más o menos reparadora, aconsejan esta medida de precaución". AGUILERA DE PAZ, Comentarios op. cit. T.I, p. 533 y SÁEZ JIMÉNEZ, J. y FERNÁNDEZ LÓPEZ DE GAMBOA, E., Compendio..., op. cit, p. 896. En su opinión, aun cuando los graves perjuicios puedan desaparecer, "no es menos cierto que, en la realidad de la vida y de la convivencia social, el hecho puede convertirse en rumor, el rumor en crítica, y la crítica en suspicacia en la que no se logre anular su nefasta influencia en el transcurso de su vida".

${ }^{946}$ GIMENO SENDRA, V., La Querella, op. cit. p. 125.

${ }^{947}$ Dig. $48,2,8,1$.

${ }^{948}$ L. 2, T. I, P. VII.

${ }^{949}$ VALLADARES, P., “Comentarios a la Ley Provisional de Enjuiciamiento Criminal”, $R G L J 42$ (1873), p. 144.

${ }^{950}$ En opinión de GIMENO SENDRA, V., La Querella, op. cit. p. 125, dado que la necesidad de dos condenas se 
firmes, no requiere por contra que en la segunda se aprecie la reincidencia, y no excluye la posible imposición de dos o más condenas por delitos de esta naturaleza en una misma sentencia ${ }^{951}$. El indulto, el cumplimiento o prescripción de la pena o la cancelación de antecedentes delictivos no juegan en este sentido un papel relevante, en tanto la LECrim se refiere únicamente a la condena por sentencia y no establece ningún tipo de limitaciones temporales ${ }^{952}$.

Los condenados por otros delitos contra la administración de la justicia, tales como la omisión de los deberes de impedir delitos, el encubrimiento, la realización arbitraria del propio derecho, la simulación de delito, el falso testimonio o la obstrucción a la justicia, no están excluidos del ejercicio de la acusación. Aun cuando pudiera considerarse que la constatación de alguno de esos supuestos hace a este tipo de personas tan merecedoras de desconfianza como a los "acusadores o denunciantes calumniosos", lo cierto es que hoy día no hay fundamento normativo para impedirles acceder al proceso como acusadores. En cualquier caso, dado que la idea del legislador al incorporar el número 2 del art. 102 era el recelo que inspiraba su actuar precedente, se echa en falta en la Ley otro tipo de conductas también gravosas y merecedoras de una desconfianza igual o mayor ${ }^{953}$. Tampoco se hace mención de quienes hubieren observado con anterioridad, en relación con la acusación, conductas encuadrables en supuestos de fraude o deslealtad procesal tales como la colusión con el acusado a cambio de contraprestación. De lege ferenda sería conveniente establecer la posibilidad de repeler las querellas interpuestas por persona que, de forma acreditada según criterio motivado del órgano jurisdiccional, hubiera incurrido previamente en conductas graves de deslealtad procesal. El control judicial sobre los

ha mantenido por inercia legislativa, debería ser suficiente con una sentencia de acusación calumniosa para que se privara al condenado de la capacidad para el ejercicio de la "querella pública".

${ }^{951}$ GÓMEZ ORBANEJA, E., Comentarios..., op. cit. T. II p. 467; GIMENO SENDRA, V., La Querella, op. cit. pp. 125 y s.

${ }^{952}$ En relación con lo afirmado sobre los antecedentes, se manifiesta en sentido diverso SALOM ESCRIVÁ, "La querella", Justicia 96, p. 402, que estima no se trata de una prohibición temporal ilimitada. En su opinión, "si transcurridos los plazos del art. 118 (antiguo) CP el condenado obtiene la cancelación de sus antecedentes penales podrá ejercitar de nuevo acciones de esta clase mediante querella". Su apoyo podría encontrarse en la dicción del antiguo art. $118 \mathrm{CP}$, que hablaba de la extinción por rehabilitación "de todos los efectos de la pena". Sin embargo, entendemos que del régimen vigente en el nuevo CP sobre la cancelación de antecedentes delictivos (art. 136 y s.) no puede extraerse como conclusión que pueda constituir fundamento suficiente para contradecir el art. 102.2 LECrim, en el que no se establece término alguno para la prohibición.

\footnotetext{
${ }^{953} \mathrm{En}$ favor de extender esta prohibición a los condenados por simulación de delito se pronunciaban SÁEZ JIMÉNEZ, J. y FERNÁNDEZ LÓPEZ DE GAMBOA, E., Compendio..., op. cit, p. 895.
} 
ejercitantes de la acusación debería poder actuar de forma preventiva, con miras a evitar al máximo los efectos perturbadores del ejercicio de la facultad pública de acusar, impidiendo ab initio posibles maquinaciones en fraude de ley de acusadores profesionales. En atención a la naturaleza de la acusación popular, en el marco de estas limitaciones que de lege ferenda se proponen, deberían quedar también incluidos los sujetos que sufriesen pena de inhabilitación absoluta o de inhabilitación especial para el ejercicio de cargos públicos durante el tiempo que ésta durase ${ }^{954}$.

Cabe reiterar que estos cambios, teniendo siempre presente que la subsistencia de la acusación popular es admisible sólo en tanto en cuanto no se acometan las ineludibles reformas en el MF, no serían más que una muestra del giro que se la debiera imprimir. Frente a la consideración actual de que siempre se podrá acusar, excepto cuando la ley lo prevea, seríamos favorables a cambiar el punto de partida, estableciendo que sólo se podrá acusar cuando la ley así lo permita, y ello siempre bajo atenta observación por parte del instructor. No conceder la facultad de acusar a quien fundadamente merezca desconfianza no tiene por qué ser considerado como merma de sus derechos individuales, sino como la constatación de que tal persona no es acreedora de la confianza necesaria para el ejercicio de una trascendental función pública y, en esa medida, se encuentra fuera del marco orgánico diseñado por la Ley.

\subsubsection{No ser Juez o Magistrado (art. 102.3 LECrim)}

La razón de esta exclusión se ha buscado habitualmente en la percepción social de la alta misión del Juez, que aconsejaría la conveniencia de apartar todo lo posible del carácter de acusadores a los que por ministerio de la Ley deben impartir justicia. AGUILERA DE PAZ argumentaba que "no se aviene bien con el prestigio y el respeto que por razón de sus cargos merecen, la controversia y la lucha de pasiones propias de contiendas judiciales (...) Los apremiantes e ineludibles deberes propios de sus respectivos cargos, exigen que no se distraiga su atención o los cuidados de su mente, por ese o por cualquier otro motivo con perjuicio de la augusta misión que les está

\footnotetext{
${ }^{954} \mathrm{La}$ inhabilitación absoluta impide la obtención o el desempeño de cargos públicos (vid. art. $41 \mathrm{CP}$ ). Esta privación habrá de ser citada expresamente en el caso de la sentencia condenatoria a pena de inhabilitación especial: a tenor del art. 42 CP se habrán de especificar los empleos, cargos y honores sobre los que recae la inhabilitación.
} 
conferida" $"$. Sin negar que ello sea completamente cierto, entendemos que no es justificación suficiente, puesto que con el mismo razonamiento se hubiera debido excluir expresamente a otros muchos sujetos que intervienen también en la administración de la justicia (p. ej. la Policía Judicial, los Fiscales o los Secretarios Judiciales) o a quienes ostentasen otras importantes o "augustas misiones" (por ejemplo, los cargos de representación política).

El origen y la explicación de la prohibición de la LECrim ha de situarse en el recelo histórico hacia la figura del juez ejercitante de funciones acusatorias, lo cual estaría plagado de connotaciones inquisitivas contra las que el legislador decimonónico pretendía luchar. En opinión de GIMENO las exigencias del principio acusatorio y el "deseo de mantener al órgano jurisdiccional prudentemente alejado de acciones que pudieran ser efecto o motivo de apasionamiento" son sus causas. Puesto que, en el sistema inquisitivo, el órgano judicial era Juez y parte, en el acusatorio, razona GIMENO, la función de ejercitar y sostener la acusación debía ser confiada a una tercera persona distinta del Juez $^{956}$. El no reconocimiento de la facultad de acusar a los titulares de la potestad de impartir justicia, cuyo origen se encuentra ya en el Derecho Romano ${ }^{957}$, estaba expresamente recogido en las Partidas ("E aquellos que non pueden acusar son... el Alcalde, o Merino, o otro Adelantado que tenga oficio de Justicia") ${ }^{958}$, pero la explicación de la

${ }^{955}$ AGUILERA DE PAZ, Comentarios..., op. cit. p. 534 y SÁEZ JIMÉNEZ y LÓPEZ FERNÁNDEZ DE GAMBOA, Compendio..., op.cit. p. 896.

${ }^{956}$ GIMENO SENDRA, V., La Querella, op. cit. p. 119. Por ello, y siempre según el citado autor, sólo a partir de la Novísima Recopilación, influenciada por las nuevas corrientes liberales-humanistas, se procedió a declarar incapaces en el ejercicio de la acción penal a los Jueces y Magistrados. La ley citada por él (n. 269) se refiere ciertamente a una prohibición de acusar, pero que se impone a los fiscales ("Procuradores Fiscales y Promotores de la nuestra Justicia") en caso de no haber denunciante o delator, y en ningún caso a Jueces y Magistrados. En cualquier caso, difícilmente podría estar "influenciada por las nuevas corrientes liberal-humanistas" una norma dada por Juan II en 1431 aunque, eso sí, hubiera sido recopilada en 1805. Si bien compartimos la apreciación de que en el origen de esta prohibición se encuentra la necesidad de garantizar dentro del sistema acusatorio la presencia de un sujeto diferente del Juez sosteniendo la pretensión penal, no coincidimos en el dato concreto de su origen, ni por tanto en su estricta conexión con las tendencias acusatorias del proceso a partir del siglo XIX.

${ }^{957}$ Al Magistrado en ejercicio de sus funciones, se le negaba por regla general en los tiempos del Principado el derecho de acusación. Vid. MOMMSEN, T., Römisches Strafrecht, p. 371.

${ }^{958}$ L. 2, T. I, P. VII. Sin entrar en las diferentes competencias de cada uno de ellos, se puede afirmar que todas estos cargos podrían ser considerados como órganos de impartición de justicia. Vid. ALONSO ROMERO, M.P., El Proceso penal en Castilla..., op. cit. pp. 108 y ss. El papel teórico que se atribuía al Juez en el proceso acusatorio de las Partidas era el de mero árbitro de una contienda entre dos partes opuestas, y se limitaba a la garantía de la observancia de las formas legalmente establecidas. Un juez acusador, a no ser "por tuerto o mal, que ellos mesmos ouiessen rescebido...", no hubiera encajado en absoluto dentro de los parámetros de la norma. Con el tiempo y la 
prohibición en la LECrim es fácil de entender teniendo en cuenta el encomiable anhelo del legislador decimonónico en impedir la confusión de las funciones de acusación y decisión en una misma persona. La sombra del proceso inquisitivo estaba demasiado cerca, y la garantía del carácter acusatorio del proceso se encontraba entre las preocupaciones de sus autores, para los que, con buen criterio, no era deseable ver a jueces actuando de acusadores $^{959}$.

Una vez más ha de reiterarse que no estamos ante una cuestión de capacidad, dado que evidentemente los Jueces y Magistrados no han sido declarados incapaces, sino de incompatibilidad. El que el ordenamiento procesal no reconozca legitimación activa a quienes sean Jueces y Magistrados no afecta, pues, a sus derechos, sino que constituye una decisión normativa sobre los límites en los que podrá desarrollarse la acusación ${ }^{960}$.

El impedimento para deducir acusación abarca a todos los titulares de la potestad jurisdiccional, puesto que a ninguno de ellos se atribuye tal facultad sin ser ofendido por el delito $^{961}$. No tiene trascendencia el órgano jurisdiccional en que se integren, aun cuando

confusión en un sólo proceso con características del acusatorio y el inquisitivo, aquella prohibición quedó sin sentido ya que precisamente eran los jueces quienes sostenían la acusación.

${ }^{959}$ GIMENO advierte también de la deficiente redacción del precepto a tenor de la existencia en nuestro ordenamiento de la "excitación de oficio", la cual permite a Jueces y Magistrados ejercitar la "acción penal" ante sí mismos, aun cuando inmediatamente deban comunicar la apertura de la instrucción al MF para que sostenga y deduzca la pretensión penal (art. 308 LECrim). Ello no sería visto por el autor como una reminiscencia del principio inquisitivo, sino como una garantía en aquellos sistemas procesales en que el "poder efectivo" de iniciación del proceso penal se desplaza hacia órganos policiales o administrativos. GIMENO SENDRA, V., La Querella, op. cit. p. 127, n. 286. Esta opinión es deudora de la teoría de FAIRÉN sobre el ejercicio de oficio de la acción penal expresada originariamente en "La acción, el Derecho Procesal y el Derecho Político", publicada en Estudios de Derecho Procesal, Madrid 1955, pp. 64 y ss., y matizada con posterioridad en "De nuevo sobre los conceptos de acción y pretensión", RDProc (Ibam) 1988, n 1, p. 9. A tenor de la opinión expresada por FAIRÉN en esta última obra, con la iniciación de oficio, "la LECrim abre la puerta al inquisitivo, y en éste, concebido como puro, la acción, tal y como la conocemos actualmente queda barrida... Ello no quiere decir que en un sistema inquisitivo puro no exista la acción, pero con naturaleza y caracteres diferentes".

${ }^{960}$ En este caso estaríamos, una vez más, ante una consecuencia derivada de la consideración orgánica del ejercicio de la acusación por los ciudadanos, y no de su calidad de derecho inherente a la personalidad de los individuos. Aceptando este último supuesto, deberíamos entender que la privación de ese hipotético derecho sólo podría operar con carácter restrictivo, por lo que los jueces que no se encuentren en situación de actividad, habrían de ser eximidos de una prohibición limitativa para con sus derechos. Al amparo de una concepción que contemple la acusación popular desde una perspectiva de organización de la Justicia, para lo cual se atribuye legitimación a diferentes personas, el entendimiento de la expresión "Jueces y Magistrados" deberá hacerse con carácter omnicomprensivo, inclusivo de todos los que ostenten tal condición y mientras puedan ser considerados como tales.

${ }^{961}$ La LECrim incluye en su art. 53. $5^{\circ}$, como causa legítima de recusación de los Jueces y Magistrados, el ser o haber sido denunciador o acusador privado del recusante. La referencia ha de entenderse, naturalmente, a los supuestos en los que hayan sido acusadores en calidad de ofendidos por el delito, o cuando acusasen por delitos 
no sea del orden penal, ni el lugar donde pretendan acusar, aunque lo hicieran fuera de su circunscripción territorial. El precepto no especifica nada, sin embargo, sobre la necesidad o no de integración en la carrera judicial de los no legitimados para acusar, por lo que el problema se suscitará, por un lado, con los Jueces que no integran la carrera judicial al amparo de la LOPJ y por otro con los que no estén en activo. Debemos por ello interpretar qué es lo que entiende la LECrim por "Juez o Magistrado" en el art. 102.3, cuestión que habrá de ser respondida a la vista más de la función que pretendamos de la acusación popular en nuestro sistema que del origen histórico de la prohibición, el cual, hoy por hoy, y aun siendo bastante endeble, puede ser considerado como su principal fundamento. Cabrá distinguir a este respecto:

\section{a) Los Magistrados del Tribunal Constitucional}

Integran un órgano que, aunque ostente significativas singularidades y no se incluya constitucionalmente en el "Poder Judicial", sino en un título propio, tiene naturaleza jurisdiccional ${ }^{962}$. En virtud de esa atribución de ejercicio de potestad jurisdiccional y del efectivo desempeño de una actividad conceptuable como judicial aun sin integrar la "carrera judicial", entendemos que la prohibición del art. 102.3 LECrim lleva también implícita la no atribución con carácter general de la facultad de acusar a los Magistrados del TC. Se ve confirmado tal criterio por el art. 19.1 in fine LOTC (“...En lo demás, los miembros del Tribunal Constitucional tendrán las incompatibilidades propios de los miembros del Poder Judicial").

\section{b) Los Jueces integrantes de la Jurisdicción Militar}

Habrá de afirmarse una vez más la integración de ésta Jurisdicción especial en el Poder Judicial, a tenor del art. 117.5 CE en relación con los arts. 1 a 8 y concordantes de la LOPJ y los arts. 1 a 9 y demás aplicables de la LOCOJM. En este caso, no forman parte del cuerpo único de jueces y magistrados comprendidos por el art. 122.1 CE, ni integran por tanto la "carrera judicial", pero de ello no cabe deducir que no ejerciten también la

contra las personas o bienes de los que estuvieren bajo su guarda legal, dado que no cabe su ejercicio en más supuestos.

\footnotetext{
${ }^{962}$ La controversia sobre la naturaleza jurisdiccional o no del TC ha sido objeto de larga discusión. Una reseña de la misma, realizada en defensa de su carácter jurisdiccional, puede encontrarse en PEDRAZ PENALVA, E., "Del Consejo General del Poder Judicial y de la selección de sus miembros", La Ley, $\mathrm{n}^{\circ} 4018,18$ de abril de 1996, pp. 5 y n. 92 y ss. En opinión de PEDRAZ, el que no pueda ser encajado dentro del "Poder Judicial" no tiene por qué ser debido a que el constituyente español lo haya regulado en título aparte (en el IX y no en el VI).
} 
función jurisdiccional. Entendemos así que tampoco tendrán conferida legitimación activa para el ejercicio de la acusación ${ }^{963}$.

\section{c) Los Jueces de Paz}

Ostentan también la potestad jurisdiccional por expresa determinación del art. 26 en relación con los arts. 99 a 103, todos ellos de la LOPJ, pero se diferencian de los Jueces y Magistrados integrantes de la carrera judicial por la inexigibilidad de la licenciatura en Derecho (art. 102 LOPJ) y por su nombramiento de carácter temporal (art 101.1 LOPJ ). El Juez de Paz debe ser considerado, sin duda, como Juez a los efectos del art. 102.3 LECrim durante el periodo de su mandato (4 años). En este caso, dado que ejercen efectivamente funciones jurisdiccionales, incluso penales (art. 100.2 LOPJ), entendemos que durante el tiempo de su mandato tampoco podrán acusar sin ser ofendidos.

d) Los Jueces en régimen de provisión temporal

El art. 432 LOPJ establece que "los nombrados Jueces con carácter temporal quedarán sujetos, durante el tiempo en que desempeñaren dichos cargos, al estatuto jurídico de los miembros de la Carrera Judicial'. Esta equiparación viene a impedirles, de igual manera que a los Jueces profesionales, el ejercicio popular de la acusación durante el periodo en que desarrollen la función jurisdiccional.

e) Los jueces jubilados o en situación de servicios especiales, excedencia voluntaria o forzosa, suspensión (art. 348 LOPJ)

Ha sido sostenido en ocasiones que la exclusión de la facultad de acusar no les comprendería, en tanto sólo abarcaría a quienes estuvieran en activo ${ }^{964}$. En nuestra opinión, habría de distinguirse entre varios supuestos pues, si bien la jubilación, la renuncia a la Carrera Judicial, la sanción disciplinaria de separación o el incurrir en causa de incapacidad suponen pérdida de la condición de Jueces y Magistrados (art. 379.1 LOPJ) ${ }^{965}$, todas las demás causas de apartamiento del servicio activo concluyen o pueden

\footnotetext{
${ }^{963}$ No obstante, un severo obstáculo es el no ejercicio exclusivo de la función jurisdiccional por los integrantes de la Jurisdicción militar (salvo los miembros de la Sala $5^{\text {a }}$ del TS), en tanto pueden desempeñar, no simultánea pero sí sucesivamente, también tareas como las de fiscal, secretario, etc.

${ }^{964}$ GÓMEZ ORBANEJA, E., Comentarios..., op. cit. T. II, p. 467; GIMENO SENDRA, V., La Querella, op. cit. p. 126.

${ }^{965}$ Aun cuando a tenor del art. 380 puedan solicitar su rehabilitación al CGPJ aquellos que se encuentren en las causas previstas en los apartados a), b), c) y d) del art. anterior una vez obtenida la rehabilitación prevista en el CP.
} 
concluir con el reingreso en la situación de actividad. El que no se encuentren en servicio activo no es óbice para que el Juez en situación de servicios especiales, excedencia o suspensión siga siendo Juez o Magistrado, por lo que atendiendo al hecho de que no se abandona esta condición, la incapacidad para deducir la pretensión debe seguir operando sobre ellos y no cabría el ejercicio por su parte de la acusación a no ser en calidad de ofendidos por el delito.

Constituye cuestión relevante el determinar si ha de incluirse en el precepto también a las asociaciones judiciales, de las que sólo podrán formar parte quienes ostenten la condición de Jueces y Magistrados en servicio activo (art. 401.5 LOPJ $)^{966}$. En la actualidad, no hay base legal suficiente para impedir el ejercicio de la acusación a una asociación de Jueces y Magistrados, puesto que goza de personalidad jurídica diferente a la de sus miembros. Aun así, la incongruencia que supone el que los Jueces individualmente en tanto personas físicas no puedan acusar sin ser ofendidos, pero sí cuando lo hagan tras una personalidad jurídica distinta en la que sólo ellos puedan estar representados, no debiera ser algo que pasase desapercibido para el legislador en futuras reformas. Podría ser hasta cierto punto comprensible defender que no se excluya a los jueces de la facultad de acusar alegando una posible vulneración del principio de igualdad, razonamiento que no compartimos, pero lo que no se puede sostener es la dualidad de regímenes en función de si se acusa individual o colectivamente ${ }^{967}$.

La doctrina se ha planteado si en el precepto habría de entenderse incluidos a los miembros del MF y, en opinión de GÓMEZ ORBANEJA, la imposibilidad de acusar en cuanto particulares los incluiría a fortiori a tenor de los arts. 27 y 28 del antiguo Estatuto del MF en el que se equiparaban en derechos y obligaciones a los jueces ${ }^{968}$. Tal opinión

\footnotetext{
${ }^{966}$ No entramos ahora en la compatibilidad del asociacionismo judicial con su exclusión de militancia en partidos políticos o sindicatos (art. 395 LOPJ). Sobre la cuestión vid. PEDRAZ PENALVA, E., "Del Consejo General del Poder Judicial y de la selección de sus miembros", proemio a El Gobierno de la Justicia, Valladolid, 1996, pp. 38 y 39.

${ }^{967}$ Del mismo modo podría razonarse en relación con las asociaciones de fiscales (art. 54 EOMF), que tienen reconocida personalidad jurídica plena y plena capacidad para el ejercicio de sus fines. Entre estos fines lícitos está la defensa de los intereses profesionales de sus miembros y la realización de estudios y actividades encaminadas al servicio de la justicia en general, por lo que a priori no parece que puedan quedar excluidas del ejercicio de la acusación.

${ }^{968}$ GÓMEZ ORBANEJA, E.,Comentarios..., op. cit., T. II, vol. I, p. 467. Comparten esta opinión SÁEZ JIMÉNEZ y LÓPEZ FERNÁNDEZ DE GAMBOA, Compendio..., op. cit. p. 896. El art. 28 del Estatuto del Ministerio Fiscal de 21 de junio de 1926 establecía que "regirán igualmente para los funcionarios de la carrera
} 
ha sido hoy refutada por autores como GIMENO, por cuanto en su opinión, además de imposibilitar el ejercicio de la querella pública, contravendría claramente los arts. 101 y $271 \mathrm{LECrim}^{969}$. MONTERO se muestra también contrario a extender la prohibición a los integrantes del MF, ya que éstos gozarían de legitimación extraordinaria para el ejercicio de las acciones, pudiendo actuar por sí y no solamente en cuanto "titulares de la acusación estatal" ${ }^{970}$. A tenor de las opiniones de estos últimos autores la equiparación en derechos y deberes entre las carreras judicial y fiscal (art. 52 EOMF) no podría alcanzar a contradecir la rotunda literalidad del art. 102.3 $3^{\circ}$ LECrim. Ha de advertirse, no obstante, que el ejercicio popular de la acusación por un integrante de la carrera fiscal generaría una situación ciertamente extraña, cercana a lo que pudiera ser un fraude constitucional. El tema puede no ser baladí, en cuanto la acusación popular pudiera convertirse en vía de escape para que un determinado funcionario del MF, en desacuerdo con los criterios que jerárquicamente le pueden llegar impuestos, afronte como particular y no en el ejercicio de sus funciones una acusación que en otro caso no hubiera recibido el oportuno placet de sus superiores ${ }^{971}$. El propio desempeño de su función pública, que se prescribe constitucionalmente sometida a legalidad y jerarquía, se vería burlado si un miembro del MF se acogiese al art. $125 \mathrm{CE}$ al objeto de hacerlo en contradicción con el que designase la fiscalía para ocupar una posición, que en este caso, sería opuesta. La propia esencia de la acusación popular impide su ejercicio por quien, en virtud de su oficio, viene constitucionalmente obligado al desempeño profesional de tal función. En tanto acusar no es un derecho ínsito en la esfera propia de la personalidad, sino satisfacción de una misión estatal, carecería absolutamente de sentido su desempeño privado por fiscales.

fiscal las mismas prohibiciones que para los de la carrera judicial...". En el actual EOMF de 1981 no se reconoce esa equiparación con la misma amplitud aunque sí se realice una equiparación en lo referido a permisos y licencias y a régimen retributivo (arts. 52 y 53 ).

${ }^{969}$ GIMENO SENDRA, V., La Querella, op. cit. p. 126; Comentarios a la legislación penal, T. I, p. 342 y Constitución y Proceso, op. cit. p. 86. Idénticos argumentos sostiene MARTÍN BERNAL, J.M., "La acción penal y la tutela de los grupos", Act. Penal, no 16, 24 abril 1988, p. 820.

${ }^{970}$ MONTERO AROCA, J., Derecho Jurisdiccional, T. III, 1996, p. 65.

${ }^{971}$ La posibilidad de utilizar su conocimiento profesional de un determinado asunto para el planteamiento privado de la acusación ha de ser descartada en origen y en su totalidad, en tanto el art. 50 EOMF obliga a los miembros del MF a guardar el debido secreto de los asuntos reservados de que conozcan por razón de su cargo. Ello se vería seriamente puesto en entredicho por un ejercicio de la pretensión penal como sujeto privado. Ahora bien, la amplitud del reconocimiento de la facultad de acusar permite sin demasiado problema articular ésta a través de persona interpuesta, treta procesal que, si no es explícita y clara, difícilmente podrá ser evitada. 
Los Secretarios Judiciales y otros funcionarios de la justicia no pueden ser en la actualidad excluidos de la facultad de acusar, aun cuando consideramos que una reforma de la Ley en esa dirección sería altamente deseable. La exclusión de Jueces y Magistrados tuvo su sentido en un momento histórico, pero hoy creemos que no es suficiente. Coincidiríamos así, parcialmente, con MUÑOZ ROJAS en su defensa de que la prohibición debería extenderse a las personas y órganos que colaboran permanente e inmediatamente en los Juzgados y Tribunales ${ }^{972}$. A nuestro juicio, habría de irse aún más allá, pues estimamos conveniente articular un precepto que expresara la prohibición de su planteamiento a determinadas personas por razón de su cargo o función. Siguiendo el modelo del art. 10.7 LOTJ (imposibilidades para ser jurados), tal precepto podría incluir entre los no facultados como mínimo a los miembros en activo de la Carrera Judicial y Fiscal, de los Cuerpos de Secretarios Judiciales, Médicos Forenses, Oficiales, Auxiliares y Agentes y demás personal al servicio de la Justicia, así como a los miembros en activo de las unidades orgánicas de Policía Judicial. No habilitarles para acusar, como venimos reiterando, no incidiría en la esfera de sus derechos intangibles, sino en el más neutral y objetivo desempeño de esa tarea pública. Aunque el control del MF pudiera hacerse con mayor conocimiento de causa desde su interior o desde sus aledaños, los perjuicios derivados de que se asumiera la acusación serían indudablemente superiores a las ventajas. Un primer beneficio de esta exclusión se reflejaría en la confianza de la comunidad hacia la Justicia, que no tendría que percibir la sensación de que los diversos "intérpretes" pueden en ella asumir cada vez papeles diferentes.

Siendo conscientes de la posibilidad de deducir acusación utilizando como pantalla a un tercero, estimamos conveniente como contribución a la despolitización de la justicia la exclusión de su ejercicio a personas que desempeñen cargos públicos de elección durante el periodo de tiempo que dure su mandato. Se podría alegar que este es uno de los campos propicios de desarrollo para el planteamiento ciudadano de la acusación, dado que las motivaciones electorales son unas muy legítimas y poderosas razones para hacer florecer tal facultad. Pudiera estimarse, además, que dado que estas personas sí podrían ser sujeto pasivo de una querella de cualquier otro sujeto, se estaría incurriendo en una clara desigualdad en su perjuicio. Tales razones no nos hacen, sin embargo, cambiar de criterio, por cuanto los riesgos que lleva aparejados superan con creces las ventajas que de ello

${ }^{972}$ MUÑOZ ROJAS, T., "En torno al acusador particular en el proceso penal español”, RDProc (Ibam) 1973, p. 119. Debe advertirse que el artículo está redactado antes del reconocimiento constitucional de la acción popular. 
pudieran derivarse. La conversión de determinados procesos penales en una cuestión sujeta a veleidades electorales no hace ningún favor a la Justicia sino que, en todo caso, puede llegar a convertirla en moneda de cambio y transacción. La denuncia sería un cauce suficiente para la canalización de la transmisión de la notitia criminis por estas personas, pues su presencia en el proceso penal asumiendo un papel activo no se conjugaría bien con la función que desempeñan.

\subsubsection{Excepciones a la exclusión}

Las personas que por encontrarse en alguno de los supuestos del art. 102 LECrim están excluidas de la facultad de acusar sin ser ofendidos sí podrán hacerlo cuando el delito o falta objeto de la acusación haya sido cometido contra las personas o bienes del cónyuge, ascendientes, descendientes, hermanos o los sometidos a su guarda legal (art. 102. II y III LECrim). Ello quiere decir que, a quienes el ordenamiento jurídico no atribuye legitimación para acusar, sí se la reconoce por razón del ofendido por el delito cuando éste lesione su esfera subjetiva cercana, que vendrá delimitada por su ámbito familiar. Se establecen así lo que GÓMEZ ORBANEJA denominaba "legitimaciones de segundo grado", puesto que la legitimación no se atribuye solamente cuando sea el propio ofendido el que pretenda ejercitar la pretensión penal, sino también cuando se encuentre en una de las relaciones de parentesco a que se refiere el artículo. El resultado es que, en estos casos, las excepciones vienen referidas a una doble titularidad: la del ofendido mismo y la del pariente (o el guardador legal del incapaz) ${ }^{973}$.

Los preceptos a los que nos referimos no son nada claros, en tanto en ellos se confunden la facultad de acusar y el ejercicio de la representación de los sujetos que no ostenten plena capacidad legal. Atribución de legitimación y capacidad procesal se entremezclan, enturbiando el entendimiento de lo que la Ley viene a reconocer. Por ello, intentaremos analizar su contenido pretendiendo averiguar en cuáles de estos supuestos estaremos ante ejercicio popular de la acusación y cuándo ante una realidad diferente:

a) Estos sujetos tienen garantizada la posibilidad de acusar siempre que sean ofendidos por el delito o, en palabras de la Ley, cuando acusen "por delito o falta cometido contra sus personas o bienes". En este caso no estamos en el ámbito de la

\footnotetext{
${ }^{973}$ GÓMEZ ORBANEJA, E.,Comentarios..., op. cit., T. II, vol. I, p. 467. En estos supuestos DE LA OLIVA habla de "una acción popular de carácter restringido". DE LA OLIVA, A., et al. Derecho Procesal Penal, p. 183.
} 
acusación popular, sino en el de la propia del ofendido por el delito, merecedora para el legislador de la máxima tutela.

Su ejercicio en el proceso no plantea problemas en los casos de los números $2^{\circ}$ y $3^{\circ}$ del art. 102, en tanto se trata de sujetos plenamente capaces, pero sí con el reconocimiento de la posibilidad de acusar por quien "no goce de la plenitud de los derechos". En este caso, la doctrina se ha planteado si estaríamos ante una exclusión de la posibilidad de deducir la pretensión penal o simplemente de la necesidad de suplir los defectos de capacidad mediante el ejercicio de la acusación por su representante legal. Para AGUILERA DE PAZ, estos sujetos serían titulares del "derecho de acción", pero no debería haber obstáculo en que las "acciones penales correspondientes a ellos", que son los necesitados de una mayor protección, pudieran ser ejercitadas por quienes deban suplir su incapacidad con arreglo a las leyes y tengan, por consiguiente, su legítima representación ${ }^{974}$. GÓMEZ ORBANEJA estimaba, sin embargo, que en los casos del 102. II, el no gozar de la plenitud de derechos civiles, sigue jugando como causa de incapacidad del "ejercicio de la acción", para cuya validez deberá ser suplida por representante legal ${ }^{975}$. Parece claro que en este supuesto nos hallaríamos también fuera del ejercicio popular de la acusación: los que no gocen de la plenitud de sus derechos civiles podrán acusar cuando sean los ofendidos por el delito, aun cuando precisen suplir los defectos de capacidad procesal a través de sus legítimos representantes legales.

b) En el supuesto de acusación "por delito o falta cometidos contra las personas o bienes de los que estuvieran bajo su guarda legal", (art. 102.III LECrim), a pesar de que no se trate del ofendido, tampoco nos encontraremos ante un ejercicio cívico de la acusación. Lo que hace el legislador en este caso es reconocer que los sujetos sometidos a "guarda legal" deberán ser representados cuando acusen en calidad de ofendidos por el delito a través de sus tutores, aun cuando sean Jueces o hayan sido condenados dos veces por acusación o denuncia falsa. Es claro que, en este caso, del que por razones evidentes se excluye a quien no en pleno uso de sus derechos civiles, no estaremos ante una acusación popular, sino ante la incapacidad procesal de un sujeto, que precisa ser

${ }^{974}$ AGUILERA DE PAZ, Comentarios, op.cit, p. 529.

${ }^{975}$ GÓMEZ ORBANEJA, E.,Comentarios..., op. cit., T. II, vol. I, p. 465. En este sentido cita como errónea, porque sostiene la tesis contraria, la STS de 9 de junio de 1947, que confunde la falta de personalidad para la querella y la titularidad de la acción. 
complementada por aquél a quien le corresponde su "guarda legal"976.

c) En la acusación por delitos o faltas cometidos contra las personas o bienes de sus cónyuges, ascendientes, descendientes o hermanos consanguíneos o uterinos y afines, y siempre que la acusación no se ejercite en calidad de representante de alguno de estos sujetos, sí nos topamos con lo que parece un ejercicio cívico de la acusación: la acusación se ejercita sin ser el ofendido por el delito. La cuestión no ofrece problemas en las hipótesis de los números $2^{\circ}$ y $3^{\circ}$ del art. 102, ya que habrá de entenderse reconocida la capacidad para acusar a los condenados por acusación falsa y a los Jueces y Magistrados exclusivamente cuando se trate de delitos o faltas cometidos contra las personas o bienes de sus parientes. Cuestión diversa es la realización de este reconocimiento a los sujetos del $\mathrm{n}^{\mathrm{o}} 1$, quienes por no gozar de la plenitud de sus derechos civiles, precisarían necesariamente de la intervención de un representante para realizar válidamente actos procesales. El supuesto de partida es el siguiente: un menor o incapaz, que con carácter general no puede acusar cuando no sea ofendido por el delito, sí podrá hacerlo cuando se trate de un proceso penal para la persecución de los delitos cometidos contra las personas o bienes de su cónyuge, ascendientes, descendientes o hermanos.

La legitimación para acusar del incapaz, atribuida conforme al $2^{\circ}$ párrafo del art. 102, no puede superponerse a su carencia de plena capacidad civil. Ésta ha de ser suplida en todo caso mediante la representación legal para que la pretensión penal se ejercite con arreglo a las prescripciones de la Ley. Pero debe tenerse en cuenta que al representante legal, siendo ciudadano español y no estando incurso en alguno de los motivos del art. 102, le corresponde la atribución general del art. 101 por sí mismo, y no por suplir la incapacidad de su representado. De esta manera se solaparían dos fundamentos diversos para el ejercicio de la acusación: la del incapaz precisado de representación procesal y la del propio representante, quien la tendría conferida por su mera condición de ciudadano

${ }^{976}$ GÓMEZ ORBANEJA señalaba que no se trataría del ejercicio de la representación legal que la tutela implica, lo cual traería consigo importantes consecuencias prácticas: $1^{\circ}$ ) el ofendido por el delito, o legitimado de primer grado, no puede contrariar, si adquiere la mayoría de edad durante el proceso, la acción ejercitada por su representante legal en su propio nombre. $2^{\circ}$ ) Viniendo referido el nexo legitimador al momento del delito y no al acto de ejercicio, la legitimación no cesa aunque la representación desaparezca (p. ej., transmisión de la guarda legal a otra persona o muerte del ofendido). $3^{\circ}$ ) No fundándose la atribución en la representación, el legitimado de segundo grado, en el ejercicio de su derecho de acción independiente, no está exento del requisito de la fianza. $4^{\circ}$ ) No siendo ejercicio de la representación, aunque se funde en ella, la acción del representante legal en su propio nombre no estaba condicionada por la autorización judicial del art. $272.3^{\circ}$ CC. $5^{\circ}$ ) La condena en costas recae sobre el representante, no sobre el representado (que propiamente no lo es). GÓMEZ ORBANEJA, E.,Comentarios..., op. cit., T. II, vol. I, p. 469. 
español. Ello nos habla de una incongruencia de la Ley, en tanto tal previsión habrá de considerarse absolutamente innecesaria. Por el menor de edad o por el incapaz no podrá plantear la acusación su representante legal, y ello por la elemental razón de que éste puede hacerlo por sí mismo, siendo totalmente inútil el tener que acudir a la representación legal a no ser que con ello se pretenda salvar algún impedimento legal. Coincidimos, por tanto, con MONTERO AROCA en el sentido de que las causas limitadoras de la capacidad operan aquí como excluyentes de la legitimación ${ }^{977}$.

La cuestión será determinar si nos encontramos ante una concesión por la norma de la posibilidad de ejercitar la acusación sin ser ofendido o de una manifestación de la acusación particular. Entendemos que tal previsión obedece únicamente a una inercia histórica, explicable sólo desde la consideración del ejercicio de la pretensión penal como mecanismo protector contra la ofensa conferida al entorno del sujeto. Con ella lo que estaba haciendo la Ley era delimitar un ámbito de especial afección del delito sobre estos sujetos, que servía para marcar la diferencia con el resto de los ciudadanos. Se asimilaba así la lesión a las personas o bienes de determinados parientes con las sufridas por los sujetos mismos, ampliando la noción de ofendido por el delito hasta englobar los bienes y derechos de las personas de su entorno familiar cercano.

\subsubsection{El parentesco con el acusado como causa de exclusión de la legitimación (art. 103 LECrim)}

Delimitados los sujetos a quienes se reconoce la posibilidad de acusar sin ser ofendidos, el artículo siguiente especifica los supuestos en los que, a pesar de ello, no podrán hacer uso de esa facultad. Mientras que las contenidas en el art. 102 LECrim hacen referencia a las condiciones en las que se atribuye a los particulares la legitimación para acusar, las del 103 suponen un impedimento que se sitúa a posteriori de esa atribución. Tal precepto alude a razones de parentesco con el imputado, negando específicamente la habilitación legal cuando su uso se dirija a la persecución de delitos presuntamente cometidos por el cónyuge, los ascendientes, descendientes o hermanos del acusador. El parentesco entre acusado y acusador no ofendido se erige así en óbice excluyente del reconocimiento jurídico de la posibilidad de ejercitar la pretensión penal.

\footnotetext{
${ }^{977}$ MONTERO AROCA, J., Derecho Jurisdiccional, T. III, p. 61.
} 
El precepto se asienta en una consolidada tradición histórica y, en este sentido, la LECrim no hizo más que continuar la tradición que, procedente del Derecho Romano, se había recibido en nuestro ordenamiento a través de las Partidas ${ }^{978}$. Su ratio legis se ha cifrado en razones de pública moralidad ${ }^{979}$, de conveniencia social ${ }^{980}$ y en el interés por conservar la armonía familiar ${ }^{981}$, que se considerarían prevalentes al sacrificio de la facultad de acusar en determinados procesos penales. Las situaciones de vínculo familiar merecen a juicio del legislador una especial consideración y tratamiento jurídico, el cual determina la inconveniencia de que existan supuestos de acusación entre parientes sin que concurra el carácter de ofendido por el delito en el acusador ${ }^{982}$.

\footnotetext{
${ }^{978}$ Vid. las glosas de GREGORIO LÓPEZ DE TOVAR a la séptima Partida, en concreto a la L. 2, T. I, P. VII, números 16 y 17. FILANGIERI se refería a la prohibición de las acusaciones "contrarias a las normas de piedad", en tanto ello haría sospechoso al acusador que no respetara los vínculos de sangre o de gratitud. Cfr. FILANGIERI, C., Ciencia de la Legislación, pp. 19 y s. Hay alusiones a la acusación entre cónyuges en nuestro derecho histórico: L. 2a $4^{\text {a y }} 5^{\text {a }}$, T. II, P. III, L.4 T. VI, P. VI, Ley 55 de las de Toro, L. 11, T. I, Lib. 10 Nov. Rec. La prohibición de acusar a los ascendientes o a los hermanos (no así a los descendientes) se contenía expresamente en el régimen legal de la acusación: L. 2, T. I, P. VII.

${ }^{979}$ MARTÍNEZ DEL CAMPO justificaba la prohibición por razón de pública moralidad, para evitar además que las cuestiones litigiosas enciendan pasiones destructoras del hogar doméstico y por el respeto y consideración que se deben los cónyuges. Pero esta prohibición cederá en los supuestos previstos en la ley "porque puestos en choque obligaciones naturales de defensa propia y deberes de protección y sentimientos de respeto, los primeros prevalecerán". MARTÍNEZ DEL CAMPO, E., Notas al Libro Primero de la Ley de Enjuiciamiento Criminal, Madrid 1885, T. I, p. 267.
}

${ }^{980}$ AGUILERA DE PAZ, Comentarios, op. cit. p. 536. Para AGUILERA DE PAZ, la excepción al principio general del art. 101 de la LECrim se funda en el caso de los cónyuges en el propósito de evitar que las cuestiones y contiendas litigiosas entre ellos fomenten sus pasiones, concluyendo por destruir el hogar doméstico y por acabar con la consideración y el respeto que mutuamente se deben. En relación con el n ${ }^{\circ} 2$, el fundamento sería la necesidad de mantener la paz y la tranquilidad de las familias, y la necesaria armonía entre los individuos que la constituyen, para evitar las consecuencias que tendría en otro caso para el orden social el que mutuamente pudieran acusarse unos a otros (p. 537).

${ }^{981}$ GÓMEZ ORBANEJA, E.,Comentarios..., op. cit., T. II, vol. I, p. 471, para quien manifiesta el reconocimiento por el derecho del organismo jurídico y ético-sociológico de la familia, y su cuidado en conservar la armonía familiar. Lo pone, además, en relación con la renuncia del Estado a la pretensión punitiva en el art. 564 (delitos patrimoniales entre parientes) del entonces vigente CP (hoy art. 268 CP) y en las especificidades en el proceso por razón del parentesco contenidas en los arts. 261 (supuestos de no obligatoriedad de denunciar), 281 (exención del requisito de la fianza) y 416 (dispensa de la obligación de declarar en juicio) de la LECrim. SÁEZ JIMÉNEZ y LÓPEZ FERNÁNDEZ DE GAMBOA se referían también a la necesidad de evitar ver envuelta a "la familia, célula primaria de la sociedad, en reyertas, encendidos enconos y enojos". Compendio... op. cit. p. 995. MUERZA ESPARZA, J., Derecho Procesal Penal, op. cit. p. 137, añade a la protección de la armonía familiar el precepto contenido en el art. 18 antiguo $\mathrm{CP}$ (encubridores del delito).

${ }^{982} \mathrm{Ha}$ de señalarse, no obstante, que el precepto que nos ocupa no afecta para nada a la facultad de denunciar y a la eficacia procesal de la denuncia realizada por estos sujetos, con lo que estas personas pueden determinar, si no provocar, el comienzo del proceso en cualquier caso y específicamente cuando se trate de delitos semipúblicos. Vid. 
La doctrina tradicional ha contemplado esta excepción a lo contenido en el art. 101 LECrim no como una incapacidad para la acusación, sino como una serie de incompatibilidades derivadas de circunstancias personales, como un conjunto de "contraexcepciones" ${ }^{983}$, en tanto se trataría de supuestos en los que, a pesar de una genérica interdicción para deducir una pretensión penal, sí cabría ésta. Aquella posibilidad que se reconocería con carácter general, quedaría "suspendida" en estos supuestos en virtud de una determinada relación de parentesco con el presunto autor del delito y se volvería a activar cuando se tratara de un delito contra sus personas ${ }^{984}$. Las excepciones al no reconocimiento de la capacidad de acusación contenidas en el propio precepto han de considerarse, sin embargo, la clave de la regulación contenida en él. De ellas es dable extraer la conclusión de que la habilitación para acusar se confiere íntegramente al ofendido por el delito, pero no a quien hallándose en uno de los supuestos citados no ostente tal condición. En nuestra opinión no cabe su considerarlas como "excepciones que excepcionan la regla", sino como pura y simple manifestación de lo que la Ley pretendía decir: que los ofendidos por el delito podrán siempre defender su propio interés a través de la acusación, pero que esta previsión no alcanzaría al resto de los sujetos. Entendemos, por tanto, más lógica una lectura del precepto en la que se tenga en cuenta no un genérico derecho a acusar, sino, con carácter previo, la conexión de los acusadores con los bienes jurídicos atacados por la comisión de los delitos que les habilita en tanto titulares de un específico interés singular.

Para determinar cuándo estaremos ante un genuino supuesto de ejercicio popular de la acusación necesariamente deberemos analizar por separado los dos números del precepto:

\subsubsection{Prohibición de acusarse los cónyuges entre sí (art. 103.1º LECrim)}

Los cónyuges pueden acusarse entre sí en tres supuestos diversos:

\footnotetext{
GÓMEZ ORBANEJA, E., Comentarios..., op. cit. T. II, p. 475.

${ }^{983}$ El término está extraído de AGUILERA DE PAZ, Comentarios, op. cit., T. I, p. 537.

${ }^{984}$ En el art. 103 se halla la reminiscencia más clara de la concepción de la Ley de la "acción penal" como la realización de la venganza estatal sobre un sujeto determinado. La "acción penal", tal y como la entendió el legislador de 1882 con fundamento en la legislación precedente, se dirigiría contra el presunto autor de un delito, y de ahí que cupiera la exclusión de la prohibición de acusar cuando el sujeto al que se apuntaba como merecedor de la pena fuera uno de los especificados en la norma.
} 
a) Delitos o faltas cometidos contra su persona o bienes, que es una hipótesis de acusación del ofendido por el delito, por lo que evidentemente no es un ejercicio popular.

b) Delitos de bigamia ${ }^{985}$ : en este caso el cónyuge del bígamo ostenta un interés preponderante frente al de los demás ciudadanos, que le habilita en una posición especial con respecto al bien jurídico atacado por el delito. De ahí que no quepa entender que se trate de un acusador popular, sino que su intervención en el proceso penal debe gozar de una más consolidada tutela ${ }^{986}$.

c) Delitos o faltas cometidos contra la persona de sus hijos (y no otros descendientes), quienes no tienen por qué ser necesariamente hijos de acusado y acusador sino que bastará con que lo sean sólo de este último ${ }^{987}$. Podría entenderse que lo que hace la Ley aquí es extender el concepto de ofendido por el delito, y con ello la habilitación para acusar, no ya sólo cuando se ataque al propio sujeto, sino también a sus hijos. El ataque a la esfera personal de un descendiente quedaría así asimilado legalmente al ataque a la propia, estableciéndose la presunción legal de que el ascendiente sufre en su persona los delitos cometidos en la de sus hijos. A tenor de esta interpretación, en presencia de la acusación de un cónyuge frente a otro por delito cometido contra uno de sus hijos no nos hallaríamos ante una acusación popular sino ante una acusación particular en la que la condición de ofendido se confiere legalmente con un carácter más amplio de lo habitual. Cabría, por tanto, promover acusación no sólo en representación del hijo menor, sino también en nombre propio por la asimilación a la condición de ofendido contenida en la Ley. Esta hermenéusis no parece, sin embargo, adecuada al tenor literal de la norma puesto que ésta se refiere no a una ofensa directa, sino a la recibida en la persona de sus hijos. Ha de concluirse por ello que, cuando la acusación no se ejercite en calidad de representante legal de un hijo menor o incapaz, se tratará de un verdadero ejercicio popular de la acusación.

\footnotetext{
${ }^{985}$ Los delitos de adulterio y amancebamiento fueron despenalizados por la Ley 22/1978 de 26 de mayo, que derogó los artículos 449 a 452 del antiguo CP.

${ }^{986}$ Podría plantearse a este respecto la posibilidad lege ferendae de que cupiera también la acusación del cónyuge en otros delitos con importante trascendencia familiar, tales como los contenidos en el Título XII del Libro II CP ("Delitos contra las relaciones familiares"). El impedimento que para la acusación de estas conductas por el cónyuge prescribe la LECrim no se cohonesta con sus previsiones respecto de la acusación, en tanto deberá aceptarse que existe un legítimo interés vinculado con el bien jurídico contenido en la norma en intervenir activamente en la persecución de estos delitos.

${ }^{987} \mathrm{Si}$ sólo son hijos del acusado no cabrá por tanto el planteamiento popular de la acusación.
} 
Debemos ahora detenernos en una cuestión que la doctrina se ha planteado al analizar la acusación entre parientes. Se trata del sentido de la expresión "contra las personas", que se repite en los dos números del art. 103, y que no parece corresponderse estrictamente con los tipos penales contenidos en ninguno de los títulos del $\mathrm{CP}^{988}$. Parece claro a este tenor que no cabría la extensión a todo género de infracciones de la autorización para acusar, puesto que la Ley, a diferencia de lo que ocurre en el artículo anterior, no se refiere a "delitos contra sus personas o bienes". Ha de tenerse en cuenta, además, que, en relación con los cónyuges, se hace una referencia específica para incluir los delitos de adulterio, amancebamiento -hoy despenalizados- y bigamia, con lo que al incluir expresamente algunos delitos no parece que la ley se quiera referir a todos. Lo único que parece claro a primera vista es que, en virtud de la diferencia con el artículo anterior donde sí se habla expresamente de "los bienes", el precepto se dirigiría a excluir la autorización para acusar delitos patrimoniales. En opinión de GÓMEZ ORBANEJA serían delitos contra la persona los que atentaren contra la vida y la integridad corporal, los delitos contra la voluntad, la libertad y seguridad, los delitos contra el honor, los delitos contra la libertad sexual, los delitos contra el matrimonio y la familia, así como algunas faltas que inciden en la esfera personal ${ }^{989}$. Más cercanamente en el tiempo ha señalado MUERZA ESPARZA que se trataría de un concepto no técnico que debe comprender todo lo relativo al entorno personal y que habrá necesariamente de determinarse en cada caso ${ }^{990}$.

Entendemos sin embargo plenamente acertado a este respecto el criterio de

\footnotetext{
${ }^{988}$ Tal y como ha sido señalado en repetidas ocasiones, ni siquiera cabría su vinculación al antiguo Título VIII del Libro II del antiguo CP («Delitos contra las personas»). Pese a la rúbrica que lo presidía, en él se encontraban los delitos en los que el daño producido se refería a la integridad física del ofendido (homicidio, asesinato, aborto, lesiones e infanticidio). Vid. GIMENO SENDRA, V., La Querella, op. cit. pp. 128 y s.

${ }^{989}$ GÓMEZ ORBANEJA, E., Comentarios..., op. cit., T. II, vol. I, p. 474. Esta es la tesis admitida en la STS de 14 de marzo de 1990 (RAJ 2481), al referirse a supuestos delictivos que "inciden sobre bienes de la personalidad en sentido amplio como podrían ser los ataques contra el honor, honestidad, seguridad y libertad". De ello concluye el TS que "no caben más extensiones por cuanto que la intención del legislador es clara ya que, si hubiera querido dar una mayor amplitud a la vía persecutoria, hubiera utilizado la expresión del art. 102 LECrim en el que se alude a delitos contra las personas o bienes".

${ }^{990}$ MUERZA ESPARZA, en De la OLIVA et al., Derecho Procesal Penal, op. cit. p. 137. Para ilustrar esta opinión aporta el siguiente ejemplo: deberá considerarse delito contra la persona el romper un reloj del cónyuge a sabiendas de que se trata de un regalo de familia al que le une un especial afecto.
} 
LEZÓN, seguido por GIMENO, que le llevaba a concluir englobados en la expresión "delitos contra las personas" todos aquellos distintos a los comprendidos en la excusa absolutoria de los delitos contra la propiedad entre parientes del art. 564 antiguo $\mathrm{CP}^{991}$, recogida hoy en relación con los delitos contra el patrimonio del Título XIII del Libro II en el art. $268 \mathrm{CP}^{992}$. En los supuestos de comisión entre parientes de delitos contemplados en los arts. 234 y ss. CP, y siempre que no concurra intimidación o violencia, la responsabilidad criminal quedará por tanto excluida. No es ya sólo que un pariente no pueda acusar a otro, sino que, con base en ellos, no cabe ejercicio de pretensión penal alguna, puesto que únicamente cabe a los sujetos a quienes corresponda deducir acción civil. Razones de política criminal parecen aconsejar en estos supuestos que el Estado excluya la responsabilidad criminal y condicione el ejercicio del ius puniendi a valores considerados preferentes. La acusación operará, por tanto, en relación con el ámbito sustantivo no delimitado por la excusa absolutoria, es decir, allí donde el ordenamiento jurídico no haya excluido la responsabilidad criminal ${ }^{993}$. Esto ocurrirá, aun tratándose de delitos patrimoniales, por ejemplo cuando estemos en presencia de violencia o intimidación, conductas que parece claro no podrían quedar descartadas de los "delitos contra las personas", por lo que no habría problema en la interposición de una querella frente a un pariente cuando el ofendido por el delito sea un hijo.

\subsubsection{Prohibición de acusarse los ascendientes, descendientes o hermanos entre sí (art. 103.2 ${ }^{\circ}$ LECrim)}

Si bien el tenor literal del artículo pudiera resultar confuso porque diera lugar a pensar en la comisión delictiva entre todos estos sujetos ("cometidos por los unos contra las personas de los otros"), el precepto debería interpretarse en el sentido de que no

\footnotetext{
${ }^{991}$ LEZÓN, M., “El art. 103 de la LECrim”, Revista de los Tribunales y de la Legislación Universal, 1896, $\mathrm{n}^{\circ} 7$. p. 99, citado y asumido por GIMENO SENDRA, V., La Querella, op. cit. p. 131.

${ }^{992}$ En palabras del TS, a través de la integración de los dos preceptos "se ofrece una doble limitación legal respecto a la incidencia del Derecho Penal en el seno de la familia, proyectada a evitar (desde una perspectiva de búsqueda del valor concordia) un enfrentamiento de unos familiares contra otros para mejor salvaguardar la paz en el seno de las relaciones parentales más próximas, una, a través del proceso penal y otra, del derecho penal sustantivo". STS de 12 de junio de 1993 (RAJ 4996).

${ }^{993}$ Concerniente a la prohibición del ejercicio de la acusación por delitos conexos, razona GIMENO que el cónyuge incapaz para deducir querella por constituir el objeto de la misma un delito contra la propiedad, podrá no obstante interponerla por cualquier delito no exceptuado. GIMENO SENDRA, V., La Querella, op. cit. p. 134.
} 
podrán acusarse entre sí sino por delito o falta cometido contra la propia persona del acusador. La relación de parentesco a tener en cuenta será únicamente la existente entre actor e imputado, sin extender la habilitación para acusar más allá de tal vínculo ${ }^{994}$. En los supuestos previstos por este precepto no nos encontramos en ningún caso ante el ejercicio popular de la acusación, sino nuevamente en un supuesto de acusación del ofendido por el delito. La relación familiar en calidad de ascendiente, descendiente o hermano con el acusado opera, por tanto, como límite para el reconocimiento de la legitimación activa al objeto de acusar cuando el delito no haya afectado a la esfera personal del sujeto ${ }^{995}$.

\subsection{Personas jurídicas privadas}

\subsubsection{Negativa histórica a su reconocimiento}

Tradicionalmente se ha negado la aptitud de las personas jurídicas para plantear acusación cuando no fueran ofendidas por el delito ${ }^{996}$ sobre la base que proporcionan los siguientes argumentos:

${ }^{994}$ Así, por ejemplo, el hijo no estará legitimado para acusar a su padre por un delito contra la persona de su madre (y esposa de éste), ni el padre podrá acusar a un hijo suyo por delito contra la persona de otro (y hermano del anterior). GÓMEZ ORBANEJA, E.,Comentarios..., op. cit., T. II, vol. I, p. 477.

${ }^{995}$ Así se ha pronunciado, por ejemplo, la STS de 31 de mayo de 1977 (RAJ 2475), al establecer que lo la Ley quiere evitar es que estos parientes próximos puedan querellarse entre sí por delitos cometidos por el querellado pariente contra terceros, pero no cuando ellos sean los directamente afectados por la acción delictiva. Como concreción de esta doctrina puede interpretarse la STS de 14 de marzo de 1990 (RAJ 2481) antes citada, en la que se afirma que el querellante no puede acusar a su hermano consanguíneo del delito de falsedad, puesto que éste ataca bienes jurídicos de interés general, y que la propia sentencia estima como atentatorio a los intereses y fines de la Hacienda Pública. Tal posibilidad le estaría vedada por el art. 103.2 LECrim., el cual sólo permite el ejercicio de la pretensión penal entre hermanos en delitos o faltas cometidos por los unos contra las personas de los otros. Ha de recordarse, no obstante, que en los supuestos en los que un sujeto víctima del delito no puede acusar (por ejemplo delito patrimonial cometido por pariente -vid. STS 17 de febrero de 1954-) no hay óbice alguno que el impida el ejercicio de la acción civil para la reparación, restitución o el resarcimiento de los perjuicios sufridos.

${ }^{996}$ Su ejercicio, aun siendo ofendidas, también fue negado en algún caso, pero una consolidada jurisprudencia del TS vino a admitirla ya desde el siglo pasado. Señalaba MARTíNEZ DEL CAMPO en 1885 que "si las personas colectivas no son en rigor ciudadanos, y por ello no tienen derecho de ejercitar la acción pública, una práctica constante, sancionada por el Tribunal Supremo, reconoce en el orden penal el de perseguir como ofendidas a las sociedades legalmente constituidas". MARTÍNEZ DEL CAMPO, E., Notas al Libro Primero de la Ley de Enjuiciamiento Criminal, Madrid 1885, T. I, p. 273. AGUILERA DE PAZ les negaba la capacidad salvo cuando hubieren sido las perjudicadas por el delito, y en el caso de las extranjeras, con la obligación de que tengan domicilio legal y se hallen reconocidas en España. AGUILERA DE PAZ, E., Comentarios..., op. cit., p. 112. 
1) No podrían quedar englobadas estrictamente bajo la denominación "ciudadanos" de los arts. 101 y 270 LECrim, y hoy, del 125 CE y del 19.1 LOPJ. La doctrina jurisprudencial era muy restrictiva a este respecto y venía excluyendo la capacidad para el ejercicio de la acusación a las personas jurídicas, por lo que sólo podrían hacer uso de la querella cuando fueran sujeto pasivo del delito ${ }^{997}$. También GÓMEZ ORBANEJA entendía que la atribución de la facultad de ejercitar la "acción popular stricto sensu" se realizaba exclusivamente a las personas individuales, puesto que "no tratándose del sujeto pasivo del delito, "ciudadano" significa persona individual, no moral o jurídica". La consecuencia necesaria sería la asimilación de las personas jurídicas en cuanto a la atribución de la acción al incapaz para el pleno ejercicio de los derechos civiles (102.1 LECrim), equiparación que sólo jugaría en orden a la representación legal ${ }^{998}$. VIADA las excluía de la misma manera, por no referirse a ellas la Ley en concepto de "ciudadanos" 999 .

En tiempos más recientes, tras el reconocimiento constitucional de la acción popular, y calificando la acusación en su ejercicio por los ciudadanos como derecho cívico-político inherente a la ciudadanía, estimaba VALERO OLTRA que no sería predicable de las personas jurídicas. Para fundamentar su argumentación utilizaba como ejemplo lo impensable que sería que las personas jurídicas pudieran ejercer como jurados ${ }^{1000}$. MAJADA se refería también a la utilización del término "ciudadano", tanto por la Constitución, como por los arts. 101 y 270 LECrim, para concluir que el empleo de

${ }^{997}$ Así se pronunciaban, por ejemplo, las SSTS de 23 de febrero de 1887, de 3 de enero 1912, 14 de octubre de 1914, 18 de octubre de 1919, de 9 de diciembre de 1919, de 15 de febrero de 1921 y 26 de marzo de 1926. Recogidas por GÓMEZ ORBANEJA, E., Comentarios..., op. cit. T. II, p. 227 y citadas también por GIMENO SENDRA, V., La Querella, op. cit. p. 115, n. 257 y GIL-ROBLES GIL-DELGADO, J., "La acción judicial popular y la audiencia de los ciudadanos en el área del derecho ambiental", $P J, \mathrm{n}^{\circ}$ especial IV, Madrid 1989. Esta doctrina se vio resucitada ocasionalmente por la STS de 2 de marzo de 1982, y ha sido hecha valer en alguna ocasión ante los Tribunales. Vid. por ejemplo las alegaciones del Abogado del Estado en la STC 101/1989 de 5 de junio afirmando que no hay necesidad de cambiar una jurisprudencia centenaria para reconocer el ejercicio de la acusación por personas jurídicas.

\footnotetext{
${ }^{998}$ Era consciente GÓMEZ ORBANEJA, E., Comentarios..., op. cit. pp. 226 y ss. y 457 de que, no obstante, esa restricción se oponía al fundamento jurídico-político de la acusación popular en el sentido inglés, país en el que se habían desarrollado ligas y asociaciones con el exclusivo objeto de promover la persecución de los delitos en general, o más frecuentemente, de determinadas clases de delitos, con lo que quedaba subrayada la exclusión de un interés individual en la persecución.

${ }^{999}$ VIADA LÓPEZ-PUIGCERVER, C., Curso de Derecho Procesal Penal I, Madrid 1962, p. 225, y en sucesivas ediciones con ARAGONESES ALONSO, P., por ejemplo, en la 4a, Madrid 1974, p. 132.

${ }^{1000}$ VALERO OLTRA, R., “Consideraciones sobre la acción popular”, BIMJ, nº 1237, 25 de abril de 1981, p. 7.
} 
tal vocablo no es caprichoso, puesto que sólo el ciudadano es sujeto físico portador de derechos cívicos y políticos, y la acción popular del proceso penal sería uno de ellos ${ }^{1001}$. MARTÍN BERNAL alegaba que las normas legales no hablan en términos sociológicos o descriptivos, sino prescriptivos, y no ya sólo la jurisprudencia del TS de principio de siglo, sino las más recientes normas a este respecto (la LOPJ) exigirían claramente la condición de "ciudadano" 1002 . Además, una interpretación sistemática global de los arts. 37 y 38 CC, que imponen su comparecencia en juicio por medio de las personas que legalmente les representen (art. 2 LEC), y de los arts. 102 y 103 LECrim, que excluyen del ejercicio de tal pretensión en determinados supuestos, todos ellos referidos únicamente a personas físicas, llevaría a afirmar la imposibilidad de su ejercicio por quien no lo fuera. En conclusión, todo iría encaminado a que el ciudadano, que es quien goza del status activae civitatis, sea el único titular de la acción popular ${ }^{1003}$.

2) Argumentos ideológicos y políticos lo impedirían, en tanto se trataría de un derecho cívico, ligado a la personalidad de los individuos. MARTÍN BERNAL, basándose en argumentos no sólo de carácter jurídico, sino también históricos, ideológicos y políticos se manifiesta en contra de que los entes colectivos personificados intervengan activamente como acusadores en el proceso penal. En su opinión, la necesaria tutela de los grupos se llevará a cabo para la propia autorrealización del individuo, y sólo deberá operar en tanto en cada caso concreto no se demuestre su inidoneidad específica para la consecución de las relaciones humanas. El ejercicio popular de la acusación podría ser utilizado individual o conjuntamente por los miembros de una asociación (o por cualquiera), pero no en forma asociativa, con personalidad distinta a la propia: son los ciudadanos y no la persona jurídica los que pueden acusar. Entendiendo el autor citado la acusación como derecho subjetivo público, éste asistiría a todo sujeto de derecho, pero en el caso de las personas

${ }^{1001}$ MAJADA, A., Práctica procesal penal, T. I, p. 121.

${ }^{1002}$ MARTÍN BERNAL, J.M., "La acción popular y la tutela de los grupos", Actualidad Penal, nº 16, 18-24 de abril de 1988, marg. 296, p. 820. Entrando en el análisis del iter legislativo del precepto observaba también que la LOPJ eliminó la expresión “y las personas jurídicas” del art. 20.1 del Anteproyecto, para dejarlo en el hoy art. 19.1, de lo cual deducía, a nuestro juicio erróneamente, una expresa voluntad del legislador de excluirlo.

${ }^{1003}$ Ibídem. 
jurídicas no se las podría atribuir sin más ${ }^{1004}$. Los arts. 35 al 38 del Código Civil (principio de capacidad general de la persona jurídica) ${ }^{1005}$ y 7.3 LOPJ no tienen por qué empecer lo anterior: este principio ha de ponerse en relación con el de la validez de los actos que pueden exceder su objeto y finalidad, y con el régimen de capacidad civil de las asociaciones reguladas por sus Estatutos, que no supone la extensión de la capacidad jurídica de los entes colectivos, sino la de las posibilidades concretas de actuar de los gestores de cada persona jurídica, limitadas por sus Estatutos, por su función y por el fin institucional que le sean propios y que en ellos se persiga ${ }^{1006}$.

3) Las personas jurídicas sólo difícilmente podrían asumir las responsabilidades derivadas de una utilización de mala fe o fraudulenta de la acusación, en tanto sería de aplicación el principio societas delinquere non potest. Puesto que responsable de la infracción sería siempre una persona física, lo lógico sería que fuera ésta la que asumiera su ejercicio sin mediatización o interposición de personalidad diferente. Ya destacaba ALIMENA, firme promotor de la acusación popular con carácter subsidiario, que "una acción promovida en nombre de muchas personas resultaría, por necesidad, anónima. Las asociaciones, bastante probablemente, no se moverán más que por objetivos y prejuicios políticos". De ahí que se opusiera a la atribución de un derecho de acusar incluso a las asociaciones especializadas en determinadas materias ${ }^{1007}$.

4) Su reconocimiento sería superfluo, en tanto los sujetos que representen a la persona jurídica lo podrán hacer por sí mismos, y no por su carácter de representantes. MUÑOZ ROJAS destacaba que no habría problemas para admitir la acusación ejercitada al amparo de los arts. 35 y $38.1 \mathrm{CC}$, pero ni siquiera tendría sentido planteárselo, puesto que las mismas personas físicas que la dedujesen podrían por sí mismos, y no como

${ }^{1004}$ MARTÍN BERNAL, J.M., “La acción popular y la tutela de los grupos”, op. cit. pp. 809 y ss. El autor, Magistrado y profesor de Derecho Civil, había sido ponente en un proceso penal iniciado por querella de la Asociación de Mujeres de Policía Nacional de Guipúzcoa y, según confesaba, trataba de encontrar planteamientos conciliadores y armónicos entre la Magistratura y la Cátedra.

${ }^{1005}$ Art 38 CC: Las personas jurídicas pueden adquirir y poseer bienes de todas clases, así como contraer obligaciones y ejercitar acciones civiles o criminales, conforme a las reglas de su constitución.

${ }^{1006}$ MARTÍN BERNAL, J.M., "La acción popular y la tutela de los grupos”, op. cit. p. 215.

${ }^{1007}$ ALIMENA, B., Studi di Procedura Penale, Turín 1906, p. 193, que se refiere a la entonces reciente propuesta de NOURRISSON en el seno de la "Sociedad de Legislación comparada" en el sentido de abrir la posibilidad de perseguir determinados delitos a asociaciones especializadas. La propuesta fue rechazada. Vid. NOURRISSON, "Sur la poursuite criminelle par les associations" en Bulletin de la Societé de législation comparée, XXXIV. 
representantes de persona jurídica alguna, actuar en nombre propio ${ }^{1008}$. GUTIÉRREZALVIZ y MORENO CATENA destacaban, en el mismo sentido, que podría resultar superflua la atribución de un derecho de acusar a personas jurídicas aun cuando, no obstante, posteriormente defendían con intensidad su ejercicio por éstas ${ }^{1009}$.

\subsubsection{Plena aceptación en la actualidad}

Los argumentos esgrimidos en contra del reconocimiento de la facultad de acusar a las asociaciones no son aceptados en la actualidad y tanto nuestra doctrina, como la jurisprudencia del TC y el TS han venido a reconocer sin excesivos problemas la aptitud de las personas jurídicas para deducir acusación, aun sin ser sujetos pasivos de la ofensa en que el delito consiste ${ }^{1010}$. Esta afirmación se ha realizado normalmente en el marco de la protección de intereses colectivos a través del ejercicio de facultades acusatorias por agrupaciones entre cuyos objetivos se encuentre la defensa de aquéllos, pero no parece existir inconveniente en admitirlo también para otras personas jurídicas. Las motivaciones aducidas pueden ser resumidas en los siguientes aspectos:

1) El que las normas que regulan la acusación popular se refieran sólo a "ciudadanos" no impide o excluye su ejercicio por personas jurídicas aun no siendo víctimas de delito. Deducir acusación no es un derecho inherente a la ciudadanía, sino una de las formas de que se dota el ordenamiento jurídico para facultar el enjuiciamiento de un sujeto por una conducta afirmada como delito. No es un derecho cívico como pudiera ser entendido el de sufragio, sino el ejercicio de una competencia estatal diseñada con carácter necesario para la satisfacción de lo contenido en la norma penal. No está ínsita en la esfera de derechos de los ciudadanos, sino en la propia organización del sistema de impartición

${ }^{1008}$ MUÑOZ ROJAS, T., "En torno al acusador particular en el proceso penal español”, RDProc. (Ibam) 1973, p. 115.

${ }^{1009}$ Aun cuando no se hubiera recogido en los mismos términos en la redacción definitiva de la LOPJ, se apoyaban en el art. 20.1 del Anteproyecto (redacción de 14 de mayo de 1984), que reconocía que "los ciudadanos y las personas jurídicas de nacionalidad española podrán ejercitar la acción popular en los casos y formas establecidos en la ley". GUTIÉRREZ-ALVIZ y ARMARIO, F. y MORENO CATENA, V., Comentario al art. 125 CE, "La participación popular en la Administración de Justicia", en ALZAGA, O. (Director), Comentarios a las Leyes políticas. Constitución Española de 1978, Tomo IX, art. 113-127, p. 603.

${ }^{1010}$ SSTC 241/1992 de 21 de diciembre, 34/1994 de 31 de enero y SSTS de 4 de marzo de 1995 (RAJ 1802) y de 2 de febrero de 1996 (RAJ 788). 
de la justicia y no parece haber problemas aparentes en la factibilidad de su realización por personas jurídicas. Es más, razones de utilidad práctica abonan la posibilidad de su ejercicio colectivo, sin que de ello se siga una distorsión de su naturaleza, sino simplemente el otorgamiento de mayores facilidades para que la intervención de los ciudadanos pudiera contribuir a la mejor realización de una prestación debida por el Estado.

El art. $22 \mathrm{CE}$ no puede ser minusvalorado a este respecto, puesto que el derecho de asociación es un principio constitutivo del ordenamiento constitucional y sólo debe tener las excepciones que en él se especifican. En el marco del sistema de democracia plural las asociaciones no pueden ser contempladas como cuerpos extraños sino como consecuencia o condición de las libertades fundamentales (HÄBERLE). Y en ámbitos donde la intervención individual se muestra impotente o insuficiente, la intervención de las voluntades individuales agrupadas no sólo puede ser reputada conveniente, sino simplemente imprescindible. Hoy día es comúnmente admitido que los movimientos sociales deban ser integrados en la acción del Estado. La "sociedad civil" entendida como un cúmulo de asociaciones voluntarias, no estatales y no económicas, que arraigan las estructuras comunicativas de la opinión pública en el mundo de la vida ${ }^{1011}$, jugaría en este sentido un papel relevante. Se trataría de otorgar espacios de intervención para el logro de un bien público a agentes que no se incardinan dentro de las estructuras orgánicas del Estado, habilitando a cuerpos intermedios para la satisfacción en esa medida de necesidades sociales básicas.

Será necesario reconocer, además, que podrán acceder al proceso para la defensa de sus derechos e intereses legítimos sin duda alguna cuando sean ofendidas por el delito, pues es sabido hoy que de las personas jurídicas cabe también predicar la titularidad de Derechos Fundamentales ${ }^{1012}$. Es claro que tal actuación procesal deberá llevarse a cabo

${ }^{1011}$ HABERMAS, J., Faktizität und Geltung. Beiträge zur Diskurstheorie des Rechts und des demokratischen Rechtsstaats, Francfort 1992, pp. 435 y ss. El núcleo de la sociedad civil lo constituyen las asociaciones y movimientos que perciben los problemas de los ámbitos privados del mundo vital, los trabajan y los llevan a la esfera pública política. Estas asociaciones componen el sustrato organizativo de aquel conjunto ciudadano que surge de la vida privada y busca interpretaciones públicas para sus intereses y experiencias sociales y que influye en la formación institucionalizada de la opinión y la voluntad. En el mismo sentido se pronuncian otros autores como GORZ, WALZER o KEANE. Al respecto vid. CORTINA, A., "La ética de la sociedad civil”, Madrid 1994.

${ }^{1012}$ Las personas jurídicas gozan indudablemente del derecho de acceder a la Jurisdicción para solicitar la tutela de sus derechos e intereses legítimos. Tal y como resalta PEDRAZ, a diferencia de lo que ocurre p. ej. en la Ley Fundamental de Bonn, es de destacar la ausencia en nuestra Carta Magna de precepto alguno en el que expresamente se atribuya a las personas jurídicas virtualidad para ser titulares de derechos fundamentales y libertades básicas y en 
necesariamente a través de sus órganos de representación y, en definitiva, de personas físicas concretas.

2) No habría inconveniente alguno para la imposición de sanciones derivadas de una fraudulenta utilización de la facultad de acusar. El sistema penal se ha dotado de una serie de garantías para exigir personalmente de los administradores de las personas jurídicas la oportuna responsabilidad criminal (art. $31 \mathrm{CP})^{1013}$, pero para ello sería imprescindible que la agrupación gozara de personalidad propia. Los entes intermedios entre las personas físicas y las personas jurídicas, aun cuando pudieran ser ofendidos por determinados delitos (en especial los de naturaleza patrimonial), y en esa medida constituirse como acusadores particulares, no podrían ejercitar la acusación sin haber sufrido perjuicio precisamente por carecer de personalidad ${ }^{1014}$.

3) La necesidad de aunar esfuerzos, buscar el asesoramiento de especialistas o garantizar su efectividad hace en ocasiones imprescindible la agrupación de impulsos individuales para buscar una representación conjunta. Se ha señalado frecuentemente que la utilidad práctica de la acusación popular se vería muy disminuida si no se permitiera su ejercicio por personas jurídicas. Los particulares, de modo aislado, es difícil que tengan interés y medios precisos para acusar, por lo que esta posibilidad adquiere utilidad cuando

especial, el derecho a la tutela judicial efectiva del art. 24.1. A esta carencia de previsión expresa, se une además la expresión "cualquier ciudadano...", contenida en el art. 53.2, que podría entenderse como restricción de la titularidad jurídica fundamental a las personas físicas. PEDRAZ PENALVA, E., Privilegios de las Administraciones públicas en el proceso civil, Madrid 1993, p.59. La acertada doctrina sentada por nuestro TC ha proclamado la extensión de estos derechos básicos a las personas jurídicas partiendo de que no se impide la hermenéusis extensiva sino de que precisamente tratándose de cuestiones jurídico-fundamentales, la norma ha de interpretarse en el sentido más favorable para la garantía de su efectividad. Además, el art. 162.1 b) CE, concretado por el 46.1 LOTC, otorga la legitimación para interponer el recurso de amparo a toda persona natural o jurídica que invoque un interés legítimo. Así en relación con las personas jurídicas se aborda expresamente la cuestión en las SSTC 69/1984 de 11 de junio (FJ 2) y 98/1992 de 22 de junio (FJ 3). En materia de protección de los derechos garantizados por el CEDH también el TEDH ha tenido ocasión de pronunciarse en favor de tal reconocimiento. No por ello cabe olvidar que ha de considerarse en todo momento la naturaleza de los derechos a los que nos estemos refiriendo y la especificidad de los sujetos a quienes se le reconoce, para concluir que es indudable la existencia de derechos y libertades sólo predicables del ser humano individual (así la intimidad familiar, la objeción de conciencia, etc.). Así las SSTEDH de 27 de octubre de 1975, asunto Sindicato nacional de la policía belga y de 6 de febrero de 1976, asunto Sindicato sueco de conductores de locomotoras.

${ }^{1013}$ Cabe señalar, además, que el CP prevé también como posible consecuencia accesoria en determinados supuestos la disolución o suspensión de una sociedad, asociación o fundación (art. 129 b) y c) CP). Tal previsión no puede sin embargo ser extendida al delito de acusación falsa, en tanto no se considera expresamente en el tipo del art. $456 \mathrm{CP}$.

${ }^{1014}$ MONTERO AROCA, J., Derecho Jurisdiccional, T. III, Barcelona 1994, p. 61; MUERZA ESPARZA, J., en DE LA OLIVA et al. Derecho Procesal Penal, Madrid 1993, p. 135. 
se pone en manos de asociaciones ${ }^{1015}$. Señalaba GIMENO en este sentido que pretender que el ciudadano individual comparezca a ejercitar la "acción popular" prescindiendo del correspondiente movimiento asociativo significaría "condenarla al ostracismo"1016. FAIRÉN sitúa en la "acción popular" la base de la irrupción del fenómeno asociativo en nuestro proceso penal ${ }^{1017} \mathrm{y}$, aunque la frecuente actuación de sociedades en juicios penales daría lugar a complejidades en el procedimiento, sobre todo si se trata de asociaciones de carácter más o menos político, ésta no alcanzaría gran dimensión. Lo que se precisaría sería precisamente "fortificar y potenciar la acusación popular, prestando ayuda a sus formas asociativas" 1018 .

La acusación popular fue configurada históricamente como una facultad meramente individual, pero no parece que exista inconveniente que determine en nuestros días la imposibilidad de su ejercicio por personas jurídicas. Ello no debe hacernos olvidar que tal reconocimiento puede estimarse totalmente irrelevante, por cuanto cualquiera de los miembros de la agrupación, siempre que satisfaga los requisitos legales, tendrá plena aptitud para su ejercicio sin precisar ser arropado por una personalidad jurídica distinta. Es claro también que sus representantes podrían sin nigún problema acusar individualmente, contando, eso sí, con el apoyo material y humano que supone el respaldo de una colectividad organizada con intereses comunes. La función de acusación admite además ser realizada también por una pluralidad de personas que actúen no con un carácter individual, sino coordinadamente, aun cuando no lo hagan bajo una personalidad jurídica única. No es necesario que constituyan una agrupación organizada, sino que bastará la mera agregación de esfuerzos individuales para que pueda plantearse la pretensión penal de forma simultánea. Es posible por tanto la personación de una acusación popular plural, sin que para ello sea estrictamente necesaria la concurrencia de una personalidad jurídica común ya que será suficiente la de cada uno de los poderdantes en tanto titulares de la

\footnotetext{
${ }^{1015}$ MONTERO AROCA, J., Derecho Jurisdiccional, T. III, 1996, p. 64.

${ }^{1016}$ GIMENO SENDRA, V., Constitución y Proceso, op. cit., p. 86.

${ }^{1017}$ FAIRÉN GUILLÉN, V., Ensayo sobre procesos complejos, Madrid 1991, pp. 139 y ss., esp. p. 150 y ss., en un capítulo titulado precisamente "La «acción popular» y la participación de personas jurídicas en la persecución de los delitos”. Con anterioridad vid. del mismo autor Comentarios a la LOPJ, pp. 24 y ss.

${ }^{1018}$ El autor se basa a este respecto en la Recomendación del Comité de Ministros del Consejo de Europa, aun advirtiendo que ya existirían en nuestro país desde el siglo pasado. FAIRÉN GUILLÉN, V, Ensayo..., op. cit. p. 165.
} 
habilitación para acusar ${ }^{1019}$.

No cabe olvidar, empero, que tal ejercicio puede en ocasiones resultar más pernicioso que positivo, y su pretendida extensión podría originar importantes desfases en tanto la introducción de intereses en el proceso penal diversos al público que lo debe presidir, puede alcanzar dimensiones cualitativamente diversas cuando aquéllos aparezcan agrupados. A nuestro juicio, el comprensible esfuerzo doctrinal y jurisprudencial para incluir a las asociaciones para la defensa de intereses supraindividuales en el planteamiento popular de la acusación ha errado en su objetivo. Los argumentos expuestos generalmente, al vincular el objeto de ciertas asociaciones con su potencialidad para intervenir como acusadores populares en ciertos delitos, vendrían a errar en sus apreciaciones por cuanto para que una acusación sea popular, no podrá ser exigida vinculación entre su sujeto activo y el delito acusado. La solución habría de encontrarse, a nuestro entender, en el plano material equiparando a determinadas asociaciones con la víctima a efectos de su participación en el proceso. Sobre esta cuestión se regresará más detenidamente en el capítulo 12, por lo que nos debemos remitir a lo allí expuesto.

\subsubsection{Dos supuestos específicos de ejercicio de la acusación por asociaciones}

\subsubsection{Ejercicio profesional privado de la acusación. El caso "Indagatoria Popular"}

Es coherente pensar que la defensa de intereses comunes por particulares deba hacerse desde posiciones de solidaridad social y altruismo para que goce de reconocimiento general. La fiabilidad de los argumentos que se expongan estará íntimamente relacionada con los intereses que mueven a los actores y, en este sentido, la exclusión del ánimo de lucro podría constituir un principio básico que otorgase confianza y aceptación a la actividad asociativa tratándose de una materia tan sensible como lo es la de la

\footnotetext{
${ }^{1019}$ Así ocurre, por ejemplo, en uno de los ejemplos de acusación popular que ha adquirido mayor relevancia en la actualidad: la ejercitada por 104 ciudadanos particulares en el caso GAL. En este supuesto la querella se interpuso conjuntamente por las 104 personas, que, previamente, habían otorgado poder a la misma representación procesal y cuya defensa técnica se había conferido a los mismos abogados. No eran (ni son) asociación como tal, sino una suma de ciudadanos que actúan coordinadamente.
} 
intervención en el proceso penal ${ }^{1020}$. De ahí que autores como GIMENO y GARBERÍ, para quienes la principal vía de ejercicio de las "acciones populares", es la de su articulación a través de asociaciones, fundaciones y corporaciones e incluso entes sin personalidad jurídica (juntas de vecinos, parroquias o de barrio), excluyan únicamente las que tengan "espíritu de lucro" "1021. La restricción del ejercicio de la acusación por profesionales, ya sean sujetos individuales o colectivos, y ya se reconozca de manera abierta o tal carácter se encuentre encubierto, se revela por tanto necesaria para evitar la desnaturalización de un mecanismo que, por naturaleza, debería basarse en un impulso de colaboración ciudadana sin ánimo de enriquecimiento, dirigido a la consecución de una resolución jurisdiccional en la que, en su caso, se aplique la norma penal.

Esta limitación no podría articularse, sin embargo, a través de la negación en abstracto de la aptitud para acusar a estos sujetos, dada la dificultad de demostrar a limine en un caso concreto que el acusador esté motivado por un interés económico. Ello podría conducir al establecimiento de impedimentos o desigualdades objetivas e, incluso, posibles arbitrariedades. Tratar de impedir el ejercicio de la acusación a entidades con ánimo de lucro mediante una expresa prohibición supondría, una vez que se pudiera demostrar o presumir con certeza tal extremo, ya de por sí tarea difícil, una desigualdad frente a su ejercicio por particulares, de los cuales no cabe excluir a priori la búsqueda de un provecho personal que incluso también pudiera ser cuantificable en dinero.

La STS (Sala 4ª ) de 2 de marzo de 1982 (RAJ 1657), denegó la inscripción de una asociación denominada "Indagatoria popular", cuyo fin esencial consistía en la persecución de delitos de corrupción ${ }^{1022}$. Los promotores de tal iniciativa configuraban el ejercicio popular de la acusación como un instrumento procesal al servicio de la investigación y persecución de conductas antijurídicas contra las que pretendían luchar.

${ }^{1020}$ Ello no debería excluir naturalmente el reembolso de los gastos o perjuicios que se ocasionen a quienes actúen de buena fe aportando un caudal positivo al proceso.

${ }^{1021}$ GIMENO SENDRA, V. y GARBERÍ LLOBREGAT, J., "La protección procesal del Medio Ambiente", $P J$, $\mathrm{n}^{\mathrm{o}} 37$, p. 151. La referencia de estos autores se limita a la intervención de las asociaciones en materia medioambiental.

${ }^{1022}$ La sentencia confirmaba la SAN (Sala de lo Contencioso-administrativo) de 25 de enero de 1980. La asociación se había constituido en 1976, y la denegación de su solicitud de inscripción en el Registro de Asociaciones al amparo de la Ley 191/1964 se había realizado primero por silencio administrativo y posteriormente por resolución expresa de la Dirección General de Política Interior de fecha 5 de febrero de 1977. Toda la actividad administrativa se había desarrollado, como se ve, antes de la Constitución. 
Destacaba la sentencia apelada que "tal asociación perseguía una actividad y configuraba como instrumentos al servicio de la misma el ejercicio de la acción penal, pretendiendo en definitiva asumir una función pública" (Cdo. $1^{\circ}$ ), y que se resaltaban como fines lo que eran aspectos puramente instrumentales, como era el ejercicio en derecho de las acciones que se juzgaran necesarias. El rechazo de la inscripción se produjo básicamente por dos razones: en primer lugar al amparo de la vieja jurisprudencia del TS según la cual la LECrim sólo se estaría refiriendo a personas físicas al reconocer a todos los "ciudadanos" la posibilidad de ejercitar la acusación y, en segundo lugar, a la negación de que pudiera ser profesionalizada por una entidad privada una función pública como es el ejercicio de la pretensión penal, dado que tal misión corresponde a los órganos públicos encargados de ello.

La aspiración abiertamente expresada de valerse del mecanismo procesal consistente en deducir la pretensión penal, poniéndolo al servicio de sus objetivos de lucha contra determinados tipos de delito, no dejaba lugar a dudas de su intento de abrir una vía de ejercicio privado y simultáneamente profesionalizado de la función de acusación. Sin entrar ahora en el análisis sobre la procedencia del rechazo de la inscripción de una entidad que ni perseguía objetivos ni se servía de medios contrarios a la ley en un registro público con mera finalidad publicitaria, entendemos que el TS utilizó criterios demasiado restrictivos del derecho de asociación y ello le llevó a errar en sus apreciaciones. Aun compartiendo su idea contraria a la constitución de un ente que asumiera de forma profesionalizada y con ánimo de lucro el ejercicio de la función pública de acusación, ello no podría constituir fundamento para impedir su existencia o, más propiamente, su mero reconocimiento administrativo. Tema distinto será el valor que, una vez en sede jurisdiccional y para cada caso concreto, se otorgue a la personación procesal de tal corporación privada o el que se atribuya a la previsión estatutaria de servirse de la acusación popular para el cumplimiento de sus objetivos. Como resalta MONTERO AROCA, el derecho a constituir asociaciones en cuanto derecho fundamental reconocido en el art. $22 \mathrm{CE}$, aun cuando tuvieran por objeto social el de ejercitar la "acción popular", no puede verse negado por una interpretación restrictiva del art. $125 \mathrm{CE}^{1023}$. Puesto que el art. $22 \mathrm{CE}$ se refiere a un derecho fundamental, no parece posible introducir mayores restricciones al derecho de asociación que las que se deducen directamente de él (asociaciones que persigan fines o utilicen medios tipificados como delito, asociaciones

${ }^{1023}$ MONTERO AROCA, J., Derecho Jurisdiccional, (1996), pp. 63 y s. 
secretas o de carácter paramilitar).

\subsubsection{Partidos Políticos}

Los Partidos Políticos expresan el pluralismo político, concurren a la formación de la voluntad popular y son instrumento fundamental para la participación política (art. 6 CE) y, en tanto personas jurídicas, podrán tener plena capacidad para acusar. No obstante su posición constitucional, GIMENO ha llegado a propugnar que los Partidos Políticos no deberían poder acusar cuando no fueran los ofendidos directos por el delito, puesto que entre sus finalidades no se encuentra la de "ejercitar la acción popular"1024. Se defiende así que, aquello que para agrupaciones de otro tipo no sólo es válido sino también deseable, queda excluido para colectivos envueltos en la confrontación política.

No podemos mostrarnos de acuerdo con esta concepción. En primer lugar no es descartable la existencia de delitos de los que sí pudiera derivarse un perjuicio directo o indirecto para sus fines constitucionales, aun sin ser sus víctimas (por ejemplo los delitos electorales que afecten a la credibilidad del sistema político independientemente del resultado obtenido ilícitamente) y coherentemente con el resto del sistema no podría encontrar justificación el que en estos casos se les privase de la posibilidad de acusar. Pero además, tratándose de cualquier otro tipo de delitos en los que no cupiera bajo ningún concepto su caracterización como víctima, una exclusión de la capacidad para ejercitar la pretensión penal supondría una clara discriminación frente a otras agrupaciones. $\mathrm{O}$ bien se priva a todos de ella, o bien se les reconoce a todos, pero no habrá fundamento para una exclusión limitada a quienes teóricamente pudieran utilizar el proceso penal como arma en

${ }^{1024}$ GIMENO SENDRA, V., "La acusación popular", PJ, n 31 sept. 1993, p. 94. GIMENO cita a este respecto el auto del TSJ de Valencia de 17 de abril de 1990 concerniente a la exclusión de Partidos Políticos de la acusación popular, confirmado por PTC de 5 de octubre de 1990 y ATC de 14 de enero de 1991. En el auto se afirmaba que "es posible imaginar supuestos en los que a personas jurídicas se les deba reconocer la acción popular, por cuanto éste sería medio necesario, o por lo menos útil, para sus fines. (En el caso de los partidos políticos...) la acción popular no añadiría nada a su fines de expresar el pluralismo político y mezclaría fines políticos con fines jurídicos, lo que no se estima deseable en un Estado de Derecho". Podría interpretarse como un pronunciamiento en sentido contrario la STC 25/1990 de 19 de febrero, que resolvió un recurso de amparo en materia contencioso-electoral contra auto de la Sala de lo Contencioso-Administrativo del TSJ de Andalucía. En ella se reconocía la vinculación de los partidos políticos a la defensa de determinados intereses (FJ 3), y si tales intereses están presentes en el ámbito administrativo cabría preguntarse por qué no lo estarán cuando se refieran a bienes jurídicos tutelados por la norma penal. Sostenía el TC en este caso que "si no la titularidad del derecho, sí cabe reconocer a los propios partidos políticos un interés legitimo suficiente a que se respeten las adecuadas condiciones para el ejercicio del derecho de sufragio, atendida su condición de instrumento fundamental para la participación política que les atribuye el art. 6 CE”. 
la confrontación política, autorizándolo a otro tipo de entidades que pudieran servirse de él con finalidades extraprocesales. Impedir acusar a los Partidos Políticos derivaría como consecuencia lógica en la asunción de competencias acusatorias por personas físicas o jurídicas afines a ellos (fundaciones, asociaciones vinculadas, etc.), que sin utilizar la denominación del grupo político, sirvieran a sus mismos intereses y pudieran buscar también el daño público de la imagen de sus oponentes políticos ${ }^{1025}$. Aplicar en estos casos el "levantamiento del velo" con el objetivo de conocer quién es el sujeto que se encuentra realmente detrás de una acusación entrañaría tantas dificultades que puede ser considerado poco menos que imposible.

Las razones que llevan a la oposición del ejercicio de la acusación por partidos pudieren acaso explicarse por la claridad con la que se manifiesta en el ejercicio de la pretensión penal la existencia de intereses puramente políticos y totalmente extraprocesales. No cabría excluir, sin embargo, la existencia de espurios intereses, quizá incluso más peligrosos, en la actuación de asociaciones no abiertamente políticas o en la de individuos particulares que pretendan intervenir solapadamente en la confrontación política sirviéndose del proceso penal como instrumento ${ }^{1026}$. Podría aducirse, incluso, que precisamente un Partido Político, por ser una estructura organizada, preocupada por asuntos públicos aunque sea desde una óptica parcial y con una militancia amplia y difundida territorialmente, estará en mejores condiciones que otro tipo de grupos para asumir la defensa del interés público en la garantía de la paz social. Consideramos por ello que los Partidos Políticos deberían encontrarse en igualdad de condiciones con las demás personas jurídicas en el ejercicio de la acusación, tanto si son los directamente ofendidos, como si concurren al proceso en calidad de acusadores populares, sin que su especial posición constitucional sirva ni para impedírselo ni para otorgarle mayores facilidades.

\footnotetext{
${ }^{1025}$ Advierte MAJADA, con una visión negativa de la acusación de los no ofendidos, que "la acción popular prolifera en épocas de inestabilidad política, casi siempre a cargo de grupúsculos o banderías que se arrogan el honroso papel de paladines de la justicia y la democracia, alejadas de los principios en que se inspiró el legislador al regularla”. MAJADA, A., Práctica procesal penal I, Barcelona 1990, p. 120.

${ }^{1026}$ A nadie se le escapa la existencia de profesionales de la acción popular que aparecen en cuanto se anuncia la presencia de un nuevo escándalo de trascendencia política. En ocasiones hasta el propio escándalo es buscado explícitamente con el fin de rentabilizarlo en publicidad u otros activos, sirviéndose del altavoz que proporciona la intervención en el proceso penal. Como muestra de ello se puede entender un anuncio aparecido en prensa el 18 de junio de 1995, en pleno fragor de la batalla política, con el siguiente texto: "Compro escándalos políticos y económicos. Pago bien. Garantizo anonimato total. Llamar al tfno.... para concretar encuentros. Sólo temas de interés y con pruebas".
} 
La funcionalidad de la acusación popular no puede ser protegida privando de su ejercicio a quien en abstracto sea digno de sospecha, dado que en ese caso entraríamos en el resbaladizo terreno de la arbitrariedad. ¿Por qué no sospechar, por ejemplo, del militante de un partido y si del partido como tal?. Piénsese también en que, si concurren razones bastantes para negarles esta facultad a los partidos, no habría de aceptársela a los sindicatos, ya que la militancia y los planteamientos políticos son en algunos casos compartidos. De ahí que sea más adecuado delimitar claramente las funciones en el proceso de la acusación, específicamente en su planteamiento por particulares, que establecer discriminaciones en abstracto entre éstos.

\subsection{Las Administraciones Públicas como acusadores}

\subsubsection{Ejercicio de la acusación en caso de perjuicio para el Estado}

Los Poderes Públicos pueden, sin duda, ser titulares del derecho a la tutela judicial efectiva $^{1027}$, si bien en su caso reviste notas especiales en relación con el de los particulares ${ }^{1028}$. No puede olvidarse que las personas jurídicas de Derecho público podrán recabar para sí aquellos ámbitos de libertad comunes a los de los ciudadanos susceptibles de serles aplicados per se cuando intervengan como titulares de derechos o intereses legítimos. El acceso de la Administración pública a la Jurisdicción no es en ese sentido un privilegio, sino un deber constitucionalmente articulado desde su configuración jurídicofundamenta1 ${ }^{1029}$. La Administración pública, incluyendo en ella la Administración General del Estado, las Administraciones de las CCAA, las entidades que integran la Administración local o las entidades de derecho público con personalidad jurídica propia

${ }^{1027}$ Así se ha pronunciado en repetidas ocasiones el TC: en relación con Organismos Autónomos (el Fondo Nacional de Garantía de riesgos de la circulación), STC 4/1982 de 8 de febrero; sobre las CCAA y Ayuntamientos en la STC 82/1983 de 20 de octubre; y en referencia a la propia Administración del Estado en las SSTC 64/1988 de 12 de abril y 67/1991 de 22 de marzo (Instituciones Penitenciarias).

${ }^{1028}$ El rechazo minoritario a la titularidad de tal derecho obedece a la estimación de que el Estado, en cuanto tal, no podría ser por un lado creador y protector de las situaciones y posibilidades que los derechos fundamentales encierran, a la vez que por otro se sirve de ellas en tanto titular de las mismas. Como resalta PEDRAZ, en el caso de las personas jurídico-públicas la titularidad de Derechos Fundamentales se ve restringida aun más que en el caso de las jurídico-privadas. PEDRAZ PENALVA, E., Los privilegios de las Administraciones públicas en el proceso civil, Madrid 1993, pp. 55 y ss. esp. p. 63. Vid. también CRUZ VILLALÓN, P., "Dos cuestiones de titularidad de derechos: los extranjeros y las personas jurídicas", REDC, $\mathrm{n}^{\circ} 35,1992$, pp. 81 y ss.

${ }^{1029}$ PEDRAZ PENALVA, E., Los privilegios..., op. cit. pp. 65 y ss. 
vinculadas o dependientes de cualquiera de las Administraciones públicas cuando ejerzan potestades administrativas ${ }^{1030}$, goza indudablemente del derecho a la efectiva tutela judicial de sus intereses legítimos. En ese contexto, por tanto, allí donde se encuentre un derecho o interés legítimo de la Administración, lo cual no es descartable en el ámbito procesal penal, podremos referirnos sin duda a un derecho de acceso a la Jurisdicción para buscar su efectivo reconocimiento y satisfacción ${ }^{1031}$.

El Estado y las demás Administraciones públicas, en cuanto sujetos pasivos del delito (ofendidos o perjudicados), pueden adquirir sin duda la condición de acusadores particulares en aquellos procesos penales por delitos en los que ostenten la condición de víctimas $^{1032}$, pero nunca invocar la condición de "ciudadano" al objeto de acusar. La específica misión de los Abogados del Estado es la de representar al Estado defendiendo sus intereses ante los Tribunales, sin que se pueda excluir a los órganos jurisdiccionales penales $^{1033}$. La Administración puede (y debe) actuar en lo Contencioso-Administrativo

${ }^{1030}$ Art. 2 LRJAPyPAC.

${ }^{1031}$ Sobre la delimitación entre los supuestos en los que la Administración debe acudir a la Jurisdicción civil o a la administrativa, vid. PEDRAZ PENALVA, E., Los privilegios..., op. cit. p. 86. Corresponde el control judicial de la Administración a la Jurisdicción administrativa siempre que estemos ante actos emanados a virtud de imperium o en ejercicio de una potestad que únicamente ostenta como persona jurídico-pública y no privada. Es la materia, definida subjetivamente, la que sirve para fijar los contornos de la Jurisdicción administrativa.

${ }^{1032}$ Sin perjuicio de que tal función sea encomendada específicamente a un abogado colegiado designado al efecto, esta representación se llevará a cabo habitualmente a través de los Abogados del Estado (art. 447 LOPJ). Vid. D. de 21 de enero de 1925 de Estatuto de la Dirección General y del Cuerpo de Abogados del Estado, los arts. 76 a 82 del Decreto de 27 de julio de 1943, que aprueba el Texto Refundido del Reglamento Orgánico de la Dirección General de lo Contencioso y Cuerpo de Abogados del Estado (en concreto es el Capítulo VI, que se refiere a "la defensa del Estado en lo criminal" y sigue en vigor a tenor de lo previsto en la DA $1^{\text {a }}$ del RD 850/1985 de 5 de junio sobre Organización de los Servicios jurídicos del Estado). Vid. también el RD 849/1985 de 5 de junio que desarrolla el apartado $1^{\circ} .4$ de la DA $9^{\text {a }}$ de la Ley 30/1984 de 2 de agosto, por la que se crea el Cuerpo Superior de Letrados del Estado y el RD 850/1985 de 5 de junio de organización de los Servicios jurídicos del Estado, que creó la Dirección General del Servicio Jurídico del Estado en el Ministerio de Justicia. En relación con la postulación procesal de las CCAA y los entes locales, contempladas en el art. 447.2 LOPJ, son diversas normas autonómicas específicas las que vienen a regular tal materia. Un catálogo de gran parte de ellas ha sido recogido por PEDRAZ PENALVA, E., Los Privilegios..., op. cit. pp. 98 y s.

${ }^{1033}$ El Estatuto orgánico de la Dirección General de lo Contencioso y de la Abogacía del Estado determina que "en las causas por delitos comunes en que el Estado resulte perjudicado, se mostrará parte el Abogado del Estado, interviniendo en ello como acusador privado, ejercitando al mismo tiempo de la acción penal la acción civil que proceda...”. Además, según lo previsto en el no 8 de la Circular 2/1987, que establece las reglas a observar en las actuaciones que se sigan ante los Tribunales por el Cuerpo Superior de Letrados del Estado (BIMJ n ${ }^{\circ} 1463$, de 5 de agosto. RAL 2004 (1987)), los Letrados Jefes darán cuenta y consultarán a la Dirección General en las causas en que deban ser parte como acusadores, perjudicados o responsables civiles subsidiarios cuando el proceso tenga trascendencia por la naturaleza o resonancia social del mismo, relieve de las personas responsables o perjudicadas, cuantía material de los perjuicios, o cuando se prevea el planteamiento simultaneo de asuntos idénticos en distintas 
cuando actúa como persona jurídica pública (LRJAPyPAC), y aun en lo civil cuando lo haga como persona jurídica privada, pero en lo penal no puede perseguir intereses propios diversos a los generales cuya defensa asume el Ministerio Público. Su intervención procesal se encuentra justificada, pues, únicamente en atención a la defensa de un interés patrimonial específico, protegido por la concreta norma penal, el cual puede indudablemente ser de titularidad estatal. El Estado debe actuar en el proceso penal cuando sea ofendido por el delito en calidad de sujeto titular de los legítimos derechos que le otorga el encontrarse en tal posición (actor civil), haciéndolo en calidad de sujeto de relaciones jurídicas protegidas por el ordenamiento, pero no como tutelador de derechos de los ciudadanos $^{1034}$.

Cuestión relevante a este respecto es la de determinar cuándo habría de entenderse infringido un perjuicio al Estado determinante de su habilitación para actuar en defensa de un derecho propio. Si adoptáramos un concepto abstracto, amplio y peligrosamente estatalista del término perjuicio, nos veríamos obligados a aceptar que todo delito perjudica al Estado dado que supone una ruptura o quebrantamiento de las normas emanadas de éste. Tal concepción sería de todo punto inaceptable, y su manifestación en este ámbito se traduciría en una doble representación procesal del Estado: de un lado a través del MF y de otro a través del Abogado del Estado ${ }^{1035}$, lo que resultaría contradicto-

provincias que merezca el establecimiento de criterios comunes. Asimismo, el $n^{\circ} 9$ autoriza a los Letrados Jefes a ejercitar las acciones penales y civiles derivadas de hechos calificados como falta o como delito, en este último caso exclusivamente cuando tenga lugar el ofrecimiento de acciones a tenor del art. 109 LECrim. Fuera de los supuestos de este número, sin embargo, cabe también la interposición de querella aun cuando para ello será precisa "la autorización del Centro directivo en los términos reglamentarios".

${ }^{1034}$ Cfr. ANTOLISEI, L'Offesa e il danno nel reato, Bérgamo 1930, p. 100.

${ }^{1035} \mathrm{La}$ asunción de facultades de acusación por órganos públicos diversos al MF, aun en los supuestos de daño o perjuicio para los intereses estatales, ha sido en alguna ocasión sometida a crítica, resaltando la incoherencia de admitir simultáneamente la intervención de dos acusadores públicos. Así SÁEZ JIMÉNEZ, J. y FERNÁNDEZ LÓPEZ DE GAMBOA, E., Compendio..., op. cit. p. 900, recelosos con la acusación particular y abiertamente contrarios a la ejercitada por las Administraciones públicas, alegaban que el Estado tendría una doble representación en el procedimiento criminal: la del Ministerio Público y la del Abogado del Estado, lo cual además de absurdo resultaría incongruente con el principio de igualdad procesal respecto a las partes contendientes. A tenor de su argumentación, "la entelequia de que el Ministerio Fiscal es el representante de la Ley en abstracto y el Abogado del Estado el gestor de los intereses de la personalidad privada del propio Estado podía mantenerse cuando con error se sostenía la doble y bifronte personalidad, pública y privada, del Estado". Superada tal concepción y admitida la personalidad única y la doble capacidad, no se comprende, según los autores citados, cómo a nombre del Estado, genuina representación de la Ley, se pueda postular dualmente. Y ello aunque se pretendiera sostener el viejo argumento de la separación del Estado como poder y del Estado como Administración, diciéndose que el Fiscal representa al primero y que el Abogado del Estado postula a nombre de la segunda. De tener cabida tal diferenciación, su sitio de mejor desenvolvimiento sería el contencioso administrativo, y, precisamente en éste, resultaría lo contrario, que el Abogado del Estado asume la personalidad de la Administración al tiempo que la de la 
rio en sí mismo al defenderse simultáneamente y por una doble vía el interés público ${ }^{1036}$. El concepto de perjuicio que entendemos aceptable es sólo aquel que toma en cuenta la titularidad de los bienes jurídicos atacados por el delito, por lo que habremos de concluir que, cuando el Estatuto Orgánico de la Dirección General de lo Contencioso habla de un perjuicio para el Estado, se está refiriendo a una afección patrimonial sobre los propios bienes de éste ${ }^{1037}$. Se tratará de un interés patrimonial específico, diferente al que motiva la intervención del MF en cuanto ésta, que se realiza en cumplimiento de su misión como garante de la legalidad y del interés público tutelado por la ley, puede incluso llegar a chocar en ocasiones con aquel interés civil defendido por el Abogado del Estado ${ }^{1038}$.

Las Administraciones públicas no han encontrado trabas en el reconocimiento de la legitimación activa en el proceso penal cuando se tratara de delitos que afectaban al respectivo ámbito de competencias del ente de que se tratase ${ }^{1039}$. Pero la acusación por las autoridades tributarias del Estado ${ }^{1040}$, las CCAA, las Corporaciones locales o la Seguridad

Ley.

${ }^{1036}$ En este sentido vid. CAPDEVILLA, C., "La Generalitat de Cataluña como acusación particular", Cuadernos jurídicos $\mathrm{n}^{\mathrm{o}} 17$, marzo 1994, p. 18.

${ }^{1037}$ Aun cuando el Estatuto utilice el término "acusador privado", no ha de otorgársele ninguna trascendencia, pues no es más que una consecuencia de una falta de depuración terminológica y conceptual que, como hemos visto, ha dado lugar históricamente a confusiones que siguen induciendo a errores en lo referido a la participación de los particulares en el proceso penal.

${ }^{1038}$ De ahí que criticando la innecesaria duplicidad de dos acusadores públicos en el mismo proceso penal, se haya defendido en alguna ocasión que la posición del Abogado del Estado debería ser únicamente la de actor civil. Así MUÑOZ ROJAS, T., "En torno al acusador particular”, op. cit. p. 112.

${ }^{1039}$ Así, por ejemplo, la legitimación para el ejercicio de la acusación particular por la Tesorería General de la Seguridad Social. Vid. STS de 25 de abril de 1995 (RAJ 2874), en la que el TS se refiere explícitamente al art. 447 LOPJ, autorizando la actuación de Letrados de la Administración de la Seguridad Social en defensa de intereses de las Entidades Gestoras o de la Tesorería General de la Seguridad Social. Tanto el art. 55.6 j del Reglamento Orgánico de la Dirección General del Cuerpo de Abogados del Estado como las Instrucciones de la Subsecretaría de Justicia y de la Dirección General del Servicio jurídico del Estado señalan minuciosamente respecto de los Abogados del Estado la percepción de honorarios y su inclusión en las costas cuando se trata de acusadores particulares (FD $10^{\circ}$ ). En alguna ocasión se ha llegado, incluso, a establecer la necesidad de que fuera la propia Administración quien instara la persecución de algún tipo de delitos, sin que pudieran perseguirse si no constaba su autorización. Vid. en este sentido el art. 37 L50/1977 de 14 de noviembre, que fue derogada expresamente por la LO 2/1985 de 29 de abril de reforma del CP en materia de delitos contra la Hacienda Pública, la cual establecía que los delitos fiscales sólo serían perseguibles a instancias de la Administración, sin que para ello fuera necesaria la interposición de querella.

${ }^{1040}$ En relación con sumarios por fraude fiscal es relativamente habitual la personación de la Agencia Tributaria, aun después de haber puesto el hecho presuntamente delictivo en comunicación del Fiscal o del Juez de Instrucción. Se nos ha alegado por un representante de la Administración Tributaria que lo que se persigue con ello es un seguimiento directo del caso que, a la vez que sirva al objetivo de evitar la impunidad, coadyuve en la labor del fiscal 
Social goza ahora además de la carta de naturaleza que le confiere su previsión expresa en los arts. 305.4.I, 307.3.I y 308.4.I $\mathrm{CP}^{1041}$. En tales preceptos no se utiliza genéricamente el término "Administración", sino que se habilita sólo al ejercicio de la querella por los respectivos órganos competentes en función del objeto del delito: la Administración tributaria (del Estado, las CCAA o los Entes Locales) para los delitos contra la Hacienda Pública y la Seguridad Social para los delitos cometidos contra sus intereses. Una vez más ha de constatarse que en este supuesto no estamos ante una acusación popular sino ante el posible ejercicio de una acusación particular por un ofendido cualificado, que ostentaría un claro interés legítimo en el resarcimiento que puede seguir a la persecución del delito. No cabría, por tanto, la acusación por ninguna otra persona jurídico-pública en la medida en que tal esfera de facultades se determina objetivamente por la de las competencias del respectivo órgano.

\subsubsection{Ejercicio popular de la acusación por las Administraciones públicas: perversión de su propia esencia}

Distinto a lo expuesto es lo que ocurre con respecto a una posible acusación por las Administraciones Públicas sin haber recibido perjuicio patrimonial alguno derivado del delito. El ejercicio de la acusación por los particulares es satisfacción de una competencia estatal, que recae originariamente en el ámbito de atribuciones del MF, órgano de peculiar naturaleza pero en definitiva de carácter administrativo ${ }^{1042}$. La intervención de otras

sin aparecer ante la opinión pública ofreciendo una imagen negativa. Ante un abandono de la pretensión penal por el fiscal siempre cabría asumir la iniciativa y dirigir la acusación. Tal argumentación desconoce sin embargo las funciones constitucionales del MF, que, evidentemente, no tiene por qué ser especialista en el tema pero que, al igual que el instructor, podría hacerse asesorar por quien tenga la cualificación necesaria al respecto (art. 118 CE y 17 LOPJ). Queda en este momento preguntarnos si tales razonamientos no servirán para contribuir a enquistar deficiencias orgánicas y estructurales en la fiscalía tales como la falta de especialización, el que no cuente con peritos que le puedan asesorar en las más diversas materias, la inexistencia de cauces de conexión con las Administraciones competentes o el que no se la dote material y humanamente de los medios necesarios para el desempeño de su trascendental misión para defender procesalmente el interés público.

${ }^{1041}$ En ellos se declara exentos de responsabilidad penal a quienes, aun habiendo incurrido en alguna de las conductas tipificadas en el Tít. XIV del Libro II CP ("De los delitos contra la Hacienda Pública y la Seguridad Social"), regularicen su situación tributaria antes de que la Administración tributaria le haya notificado la iniciación de actuaciones de comprobación sobre su deuda o, de no haberse producido éstas, antes de que el MF, el Abogado del Estado o el de la Administración correspondiente o el Letrado de la Seguridad Social, interponga querella o denuncia contra aquél.

${ }^{1042}$ Pese a la singular previsión del art. 2 EOMF, que lo integra “con autonomía funcional” en el Poder Judicial. 
instancias estatales para asumir el papel de acusador originaría, por tanto, una duplicidad de actividades cuya inconveniencia salta a la vista. Aun cuando no haya norma en la que expresamente se impida el ejercicio de la pretensión penal por órganos de la Administración diversos al MF, su intervención activa nunca debiera poder cifrarse en el planteamiento de acusación y mucho menos en su modalidad de ejercicio popular.

La Administración Pública no es representante de la comunidad sino que es una organización puesta a su servicio y sus actos no son caracterizables como propios de aquélla, sino de una organización dependiente, necesitada de justificarse en cada caso en el servicio de la comunidad a la que está ordenada (art. 103.1 CE) ${ }^{1043}$. La defensa objetiva e imparcial de la legalidad en el orden penal así como la tutela de los intereses generales de la colectividad, constituyen una de las funciones esenciales de ese peculiar órgano administrativo que conocemos como MF. De ahí que, para la satisfacción del interés general deba instar la aplicación de la norma penal a través del mecanismo procesal de la acusación. Teniendo en cuenta la naturaleza de la competencia a la que nos estamos refiriendo, el Estado sólo puede deducir la pretensión penal en defensa del interés público a través del órgano que constitucionalmente tiene atribuida esta función. La intervención de otras instancias estatales como acusadores carecerá de todo sentido, pues se trata de una facultad atribuible sólo a sujetos privados, individuales o colectivos, pero al fin y al cabo particulares que, eso sí, se presume actuan uti cives. Hablar del ejercicio cívico de la pretensión penal por el Estado es incurrir en una contradictio in terminis, en la medida en que decir acusación popular es hablar de una esfera de no interferencia estatal, cuyo contenido viene determinado precisamente por el ejercicio de una función estatal por sujetos privados. Lo contrario sería una inaceptable perversión del reconocimiento legal, en tanto estamos precisamente ante una habilitación de los ciudadanos considerados de forma privada, en un ámbito que podríamos denominar como el no-estado ${ }^{1044}$. La intervención como actora de la Administración en el proceso penal no puede resultar, por tanto, amparada por la previsión normativa que nos ocupa. Puede afirmarse, en definitiva, que la acusación popular nunca puede ser promovida al amparo de una potestad estatal, en la medida en que tal práctica constituiría la negación de su propia esencia.

${ }^{1043}$ GARCÍA DE ENTERRÍA, E. y FERNÁNDEZ, T-R., Curso de Derecho Administrativo, T. I, 7 a ed., pp. 30 y S.

${ }^{1044}$ Deliberadamente evitamos el término sociedad civil para no transmitir una idea errónea de lo que aquí se quiere exponer. No está de más recordar que, como se dirá infra, el concepto de sociedad civil es entendido en múltiples direcciones, alguna de las cuales incluye al propio Estado. 
Si algún mérito hubiera de incluirse con carácter principal en el haber de la acusación popular, ese es sin duda el de su potencialidad para servir de contrapeso a una actuación inadecuada del MF principalmente por mor de su dependencia más o menos directa de los intereses del Ejecutivo. Aceptar que esta modalidad de ejercicio de la acusación pudiera ser aprovechada por la Administración, genuino ámbito de la actividad de tal poder, en el que además se engloba al Gobierno, sería tanto como negar la premisa mayor que fundamenta alguna de las posibles virtudes de nuestra institución. Reconocer que se pueden controlar las deficiencias de un órgano administrativo mediante el cumplimiento de la misma actividad por otras instancias estatales supondría iniciar una peligrosa carrera hacia el absurdo, cuyas primeras repercusiones podrían concretarse no sólo en un despilfarro de fondos públicos, sino también en la distorsión de alguno de los principios básicos sobre los que se asienta el proceso penal.

La Administración no sólo puede sino que está obligada a la persecución del delito, pero no desde la posición activa de conflicto con el MF inherente a la acusación popular, sino desde la fluida colaboración con éste. Tal cooperación deberá partir de la denuncia de los delitos de que tenga conocimiento, ya sea a través de la denuncia ordinaria o del "paso de tanto de culpa" 1045 , pero tendrá que incluir también la aportación de sus medios materiales y humanos para la averiguación de las circunstancias en que aquéllos se cometieron y, fundamentalmente, el no establecimiento de trabas de ningún tipo para el acopio de los elementos necesarios encaminados a una resolución jurisdiccional que dé adecuada respuesta al conflicto en que el delito consiste. La legitimidad del ejercicio de las funciones públicas se justifica sólo desde la especialización en el desempeño de éstas, por lo que lo adecuado es que la Administración en general intervenga en los procesos penales no como acusadora, sino como denunciante, perito o testigo, encomendando el desempeño de la función de acusación al órgano cuya existencia viene preordenada a su

\footnotetext{
${ }^{1045}$ La naturaleza de ambas instituciones es esencialmente idéntica, en tanto que el "paso de tanto de culpa" es una de las formas específicas de denuncia. La única diferencia se cifra en el incremento de requisitos formales, pues ha de acompañarse el testimonio de las actuaciones a raíz de las que se ha adquirido la sospecha delictiva. Es, por tanto, sólo una denuncia cualificada por su emisor, por el modo de adquirir la noticia delictiva y por ir acompañada de testimonio. Vid. TORRES ROSELL, N., La denuncia en el proceso penal, Madrid 1991, p. 440. Ejemplos del "paso de tanto de culpa" al MF se encuentran en diversas normativas sectoriales. Así por citar algún ejemplo en el art. 94 de la L22/1988 de 28 de julio, de costas o en el 47.6 del Reglamento de 25 de marzo de 1971 de la Ley de Caza. Dentro del régimen disciplinario de los empleados públicos, el art. 23.1 del RD 33/1986 de 10 de enero que aprueba el Reglamento sobre Régimen Disciplinario de Funcionarios de la Administración del Estado establece que "en el momento en que el instructor aprecie que la presunta falta puede ser constitutiva de delito o falta penal, lo pondrá en conocimiento de la autoridad que hubiese ordenado la incoación del expediente para su oportuna comunicación al $M F^{\prime \prime}$.
} 
satisfacción: el MF. Somos conscientes de que esto llevaría consigo importantes repercusiones prácticas que exigirían como mínimo la habilitación de cauces de comunicación ordinaria entre las fiscalías y las diversas Administraciones, pero tal necesidad no puede convertirse en óbice para una adecuada configuración de la pretensión penal (art. 118 CE y 17 LOPJ). Entendemos mucho más eficaz (y más rentable económicamente) una canalización de los recursos públicos diferenciando claramente el ejercicio de las tareas públicas en función de criterios de especialización, que no deben seguir el mero interés propagandista o de cercanía al lugar donde se desenvuelve el proceso penal, sino de estricta utilidad para la satisfacción de los intereses generales.

La amplia extensión de la legitimación activa reconocida por nuestra LECrim está dando lugar en la práctica a su utilización por diversas instancias administrativas, que configuran así un tertium genus entre el ejercicio de la acusación por el MF y el de los ciudadanos ${ }^{1046}$. La acusación es oficial, en tanto es un órgano del Estado quien se sirve de ella, pero no deja de utilizar los cauces procesales previstos para los sujetos privados. En la actualidad se pueden encontrar personaciones de Corporaciones Locales en causas penales por delitos con grave incidencia en la opinión pública del correspondiente ámbito geográfico. Se trata de supuestos que, sin originar un perjuicio directo a la persona jurídico-pública, constituyen un mecanismo publicitario de primer orden para concretos políticos, quienes instrumentalizan así en beneficio propio un proceso penal que, con toda seguridad, devendrá célebre en una determinada comunidad, aportando buenos dividendos publicitarios a sus promotores y restándolos a los oponentes a esa iniciativa. Hoy no es algo totalmente extraño encontrarse casos de Ayuntamientos personados en causas por delitos de asesinato, de violación o de otras graves conductas desencadenantes de la lógica solidaridad de la población hacia los perjudicados ${ }^{1047}$. La inquietud social es capitalizada

${ }^{1046}$ De ello se da cuenta también entre los temas de actualidad e interés tratados por los fiscales en la MEMORIA FGE de 1993, pp. 720 y s. La fiscalía de Cádiz resaltaba en esta ocasión que "resultaría chocante que el propio Estado, en cualquiera de sus funciones o poderes y pese a su legitimación democrática y popular, nacida de las urnas, asumiera directamente la función de acusación pública (...) resulta igualmente chocante que la misma función se ejerza por los entes en que territorialmente se organiza el Estado y que asumen una representación a efectos administrativos más concreta y limitada no sólo en extensión, sino en contenido". A nuestro juicio, ello no es sólo chocante, sino que supone una ignorancia absoluta de la función de la acusación, desvirtuadora de los principios sobre los que se debe asentar nuestro proceso penal.

${ }^{1047}$ Un ejemplo de ejercicio simultaneo de acusación popular por 5 Corporaciones Municipales se encuentra en la STS de 12 de diciembre de 1994 (RAJ 9374), en la que sostuvieron su pretensión de condena frente a la de absolución que realizó el MF. Tanto el Ministerio Público como la defensa estimaban, como en último término confirmó el TS, que sobre el mismo delito ya existía resolución jurisdiccional firme anterior, y por tanto pesaba el efecto de cosa juzgada. No nos consta que en ningún momento de la causa fuera alegada o sometida a discusión la 
políticamente por alguno de los representantes de la voluntad popular a través de su presencia en el proceso penal, buscando de esta manera una legitimación de la acusación en un ámbito más próximo al ciudadano.

Esta intervención será necesariamente financiada con cargo a las arcas municipales o provinciales, por lo que el despilfarro de fondos públicos sería una de las consecuencias que pudiéramos deducir considerándola, con benevolencia, superflua o reiterativa. Pero el problema adquiere tintes más relevantes en la medida que la personación de dos acusadores oficiales, podría generar desigualdad en perjuicio del imputado ${ }^{1048}$. De estimar admisible esta posibilidad cabría que nos encontráramos una doble representación estatal en el proceso asumiendo el papel de acusador público, en la medida que los intereses que defenderían MF y la correspondiente Administración, sujeta también en su actuación al principio de legalidad, vendrían inevitablemente a solaparse. No parece de recibo tolerar tal posibilidad, ni siquiera como hipótesis de trabajo, por lo que la admisión de querellas interpuestas por las Administraciones ha de considerarse como una corruptela procesal que ha de erradicarse cuanto antes de la práctica de nuestros Tribunales ${ }^{1049}$.

capacidad de las personas jurídico públicas para el ejercicio de la acción popular (o particular, tal y como se designa impropiamente en la sentencia), sino que la discusión se centró en otro punto de interés: la necesidad o no de identidad entre los sujetos acusadores y entre sus respectivas calificaciones como elemento determinante de la vigencia del efecto de cosa juzgada.

${ }^{1048}$ La acusación ejercitada por las Corporaciones Locales ha sido tradicionalmente vista con recelo por el legislador, consciente de los riesgos que de ello pueden derivarse y de los perjuicios para la Administración, para la Jurisdicción penal y para los hipotéticos imputados que puede acarrear una desmedida intervención de personas jurídico públicas en el proceso. Por ejemplo, con buena lógica se dispuso por Real Orden de 25 de abril de 1901 que los Ayuntamientos no podían mostrarse parte en causas criminales incluso, en aquellas que se promovieran en defensa de sus intereses, debiendo cuando adquiriesen el convencimiento de que se había cometido un delito público que afectase los intereses que representan, denunciarlo ante el Tribunal competente para que el MF promoviese la acción de la justicia. $\mathrm{Si}$, a pesar de ello, decidían mostrarse parte en alguna causa criminal, promovían o instaban su curso, nombrando al efecto Abogado y Procurador, la norma establecía el deber de que los Alcaldes y Concejales que lo hicieran, pagaran de su particular peculio todos los gastos que se originasen. Vid. voz "Acciones penales", Enciclopedia Jurídica Española Seix, T. I, Barcelona 1910, p. 452 y AGUILERA DE PAZ, E., Comentarios, op. cit. T. III, p. 113. Los Ayuntamientos de pueblos de menos de 4.000 habitantes precisaban a tenor del art. 86 de la primitiva Ley Municipal, autorización de la Diputación Provincial y dictamen de dos letrados para formalizar instancia como querellantes en causa o pleito criminal. Consulta $\mathrm{n}^{\circ} 92$ (Memoria de la Fiscalía del Tribunal Supremo de 1899). Publicada en RODRÍGUEZ DEVESA, C. y MARTÍNEZ AZNAR, G., Ley de Enjuiciamiento Criminal. Su jurisprudencia y doctrina de la Fiscalía, Aranzadi, Pamplona 1990, p. 690. Esta obligación se derivaba de una interpretación extensiva del art. 86 de la Ley Municipal, que llevaba a incluir en el término "pleitos", también el proceso penal, justificándose esta previsión en cuanto que el ejercicio de la pretensión penal por parte de esas Corporaciones sería un asunto siempre grave y que puede afectar de modo importante al interés colectivo que aquellas representan.

${ }^{1049}$ La constitución como parte acusadora de las CCAA (en concreto, de la Generalitat de Cataluña) fue abordado por CAPDEVILLA, llegando a la conclusión de que éstas podrán actuar únicamente como acusadores particulares a 
Aceptando tal perversión de la acusación popular podría darse lugar además a indeseables resultados enmarcables dentro de lo que se viene conociendo como "politización de la justicia". La variabilidad de los gestores de la res publica hace que la actuación de la Administración esté sujeta a una mutabilidad con demasiada frecuencia dependiente de criterios de oportunidad política no siempre acordes a los verdaderos intereses de los administrados, sino motivados por una poco honrada voluntad de querella política de sus gobernantes. Constituye éste un riesgo que no puede ser pasado por alto, en tanto podría erigirse en un arma más para la batalla política, situándola desde las Corporaciones Públicas en un ámbito al que no debería tener acceso habitualmente ${ }^{1050}$. La solución para el ejercicio de la acusación por quien tenga interés en ello parece fácil en estos casos, sin que la voluntad particular de los gestores de lo público tenga que arrastrar la del ente en el que se incardinan. Nada impide que pueda deducir acusación, dentro de los requisitos normativos, cualquier persona particular, bajo su única responsabilidad y en su propio nombre, aun cuando ostente una representación de cualquier grado en la Administración ${ }^{1051}$, y ya sea ésta electiva o no. Pero nunca podrá hacerlo una Corporación o Institución Pública o alguien en el nombre de ésta, ni por tanto cabe el que tal misión sea desempeñada por los Abogados del Estado o los letrados de las CCAA (art. 447.2 LOPJ). Con la admisión de este tipo de querellas se estaría distorsionando la función de la

través de sus Consejos Ejecutivos en los casos en que resultasen patrimonialmente perjudicadas. Aun cuando la Constitución concede un margen de maniobra a las CCAA para la gestión de sus intereses, nunca podrán ejercitar la acusación pública oficial, función que por tratarse del necesario instrumento procesal dirigido a la aplicación de la norma penal, queda atribuida constitucional y estatutariamente a los órganos propios del Estado, es decir, al MF. Este representará, por tanto, también los intereses generales penales de las CCAA, por ser éstas parte del Estado. En este sentido, la autora se basa en lo previsto en el Estatuto de Autonomía de Cataluña, que reconoce que "la organización y el funcionamiento del MF corresponde integramente al Estado". Resulta congruente que, si el Estado se reserva con carácter de exclusividad la competencia a fin de determinar la legalidad penal y procesal (art. 149.1.6 $6^{\circ} \mathrm{CE}$ ), se reserve también el instrumento adecuado a fin de hacer actuar ésta. CAPDEVILLA, C., "La Generalitat de Cataluña...”, op. cit. pp. 15 y ss. Una vez más debemos destacar que, siguiendo el criterio que nosotros defendemos, no sería tampoco admisible su personación como acusador particular, sino únicamente como actor civil para hacer valer su pretensión de resarcimiento por el perjuicio patrimonial eventualmente sufrido.

${ }^{1050}$ Nos consta, por ejemplo, el caso de un Ayuntamiento personado en un proceso penal por estafa y apropiación indebida seguido contra miembros del equipo de gobierno precedente en calidad de acusador popular (no era el perjudicado por el delito). Una vez retornados de nuevo al ejercicio del poder municipal los partidarios de quienes se sentaban en el banquillo, retiraron inmediatamente la acusación mediante expresa revocación del poder del procurador y del mandato a sus antiguos abogados. La perenne querella política se sirve, en definitiva, de las herramientas del sistema, y la acusación popular es objeto una vez más de instrumentalización al servicio de espurios intereses partidistas. Si la acusación popular puede ser peligrosa cuando es hecha valer por sujetos privados, cuando tal perversión del derecho procede de una corporación pública, no podemos por menos de considerarlo intolerable.

\footnotetext{
${ }^{1051}$ Aun así, seguimos mostrando nuestro deseo de la conveniencia de no reconocer legalmente a cargos electos la facultad de acusar.
} 
acusación popular en el sistema procesal, en tanto ésta se limita únicamente a constituirse en suplente o corrector de posibles deficiencias en la actividad de un órgano público (que en este caso es el MF).

Ni siquiera consideramos conveniente reconocer la facultad de acusar en el proceso penal a organismos administrativos especializados sectorialmente, aun justificado por razones de cercanía al bien jurídico atacado por el delito, que les llevaran a asumir funciones de acusación habiendo o sin haber recibido un perjuicio patrimonial por su comisión o por la necesaria reparación de sus efectos ${ }^{1052}$. La función de estos entes administrativos pasará por su colaboración directa con el MF, quien deberá siempre ser el "brazo acusatorio" de la Administración en su función constitucional de defensa de la legalidad, los derechos de los ciudadanos y el interés público tutelado por la ley ${ }^{1053}$.

\section{Quisiéramos por último hacer una reflexión en torno a otra posible corruptela} procesal: la acusación por la Policía. La actividad de los cuerpos policiales es actividad administrativa, y el que dedujeran la pretensión penal podría ser una de las peores consecuencias de la admisibilidad del ejercicio de la acusación por órganos administrativos diferentes al MF. Dentro de nuestro sistema de acusación popular tal posibilidad ha de ser objeto de un absoluto rechazo ${ }^{1054}$. La función que corresponde a la Policía Judicial es

${ }^{1052}$ No estará de más aludir aquí a lo ocurrido con el tradicional sistema de acusación privada en Inglaterra y Gales, que, en la práctica, desembocó en los años 80 en una dualidad de mecanismos de acusación ajenos a su ejercicio por sujetos privados teóricamente admitido. Allí donde no eran cuerpos policiales los que acusaban (un $25 \%$ de los casos), tal función era desempeñada no por particulares, sino en la inmensa mayoría de los casos por órganos administrativos. Las conductas delictivas atentatorias contra un determinado ámbito sectorial eran directamente perseguidas por la Administración dentro de cuyas competencias se englobara tal materia (correos, departamentos de hacienda, transporte, medio ambiente, seguridad social, aduanas, tráfico, etc). De esta manera quedaba claro que, aunque teóricamente nos encontráramos con una actividad encomendada a particulares, la necesidad de garantizar tales persecuciones hacía que fueran órganos públicos los que se arrogaran tal función. Vid. LIDSTONE, K.W., HOGG, R.; SUTCLIFFE, F. et. al., Prosecutions by private individuals and non-police agencies, Royal Commision on Criminal Procedure. Research Study nº 10, Londres 1980, pp. 15, 31 y s., 96 y 179.

${ }^{1053}$ De aceptar el ejercicio de la pretensión penal por la Administración, podría darse fácilmente el caso de la concurrencia en ella de la obligación de asumir dos posiciones procesales contrapuestas. Esto es lo que ocurriría, por ejemplo, cuando además de acusador fuera responsable civil directo o subsidiario y pudiera, en caso de condena, verse obligada a la reparación, restitución o indemnización de los perjuicios.

${ }^{1054}$ La acusación por la propia policía ha sido una constante histórica en el sistema británico hasta 1985, que se debió a la progresiva asunción de la facultad de todo ciudadano para la persecución de los delitos. Esta competencia, de la cual prácticamente nadie hacía uso, fue así de facto conferida a cuerpos profesionalmente preparados para tal fin. La inexistencia de un órgano asimilable al MF hasta la creación del Crown Prosecution Service constituía una evidente carencia que se suplía por la intervención de especialistas incardinados orgánicamente dentro de la Policía, en cuyas manos se encomendaba la decisión de perseguir o no un determinado delito. 
la de auxilio a los Juzgados y Tribunales y al MF (art. 443 LOPJ), lo cual determina que su actividad sea de exigida utilización por la Justicia ${ }^{1055}$. La Policía Judicial se encuentra en un ámbito de dependencia en relación con los Jueces, los Tribunales y el MF en sus funciones de averiguación del delito (art. $126 \mathrm{CE}$ ), por lo que no sería ni imaginable ni lícita una actuación autónoma de las Fuerzas y Cuerpos de Seguridad que condujera a una acusación independiente de la que, en su caso, ejercitara el fiscal en el marco de sus competencias. No cabe convertir la actividad de la Policía en un filtro de actuaciones susceptibles de persecución penal ${ }^{1056}$, pero tampoco en un ámbito en el que se puedan incardinar facultades autónomas de acusación. El sostenimiento de criterios divergentes entre Fiscalía y Cuerpos y Fuerzas de Seguridad en relación a la persecución de un determinado delito podría originar la apertura de dos vías de acusación paralelas, y ello se presenta a todas luces como inaceptable.

Una vez más debemos destacar la naturaleza de la acusación como imperativo tendente al enjuiciamiento de un sujeto determinado por un hecho que se afirma punible, sin que pueda ser lugar de conflicto entre los sujetos que desempeñan funciones diversas en la averiguación y persecución del delito. La existencia de criterios divergentes entre todos ellos no debe conducir a la injustificable irrupción de otros órganos administrativos en el cumplimiento de la función de acusación, sino en la fundamentada elaboración de los

\footnotetext{
${ }^{1055}$ Cfr. PEDRAZ PENALVA, E., “Algunas reflexiones sobre Policía y Administración de Justicia”, en Constitución, Jurisdicción y Proceso, op. cit. pp. 387 y ss. De toda investigación de un delito público realizada por sus funcionarios se deberá participar a la Autoridad judicial o al representante del MF (art. 284 LECrim) en un plazo que no podrá ser, salvo fuerza mayor, superior a 24 horas (art. 295 LECrim). El atestado adquiere el carácter de concreción de una denuncia cualificada por el sujeto, sin que pueda adquirir mayor valor.

${ }^{1056}$ PEDRAZ PENALVA, E., “Algunas reflexiones sobre Policía ...”, op. cit. p. 388. Ello queda además garantizado por la posibilidad de incurrir en responsabilidad penal. A tenor del art. $408 \mathrm{CP}$ "La autoridad o funcionario que, faltando a la obligación de su cargo, dejare intencionadamente de promover la persecución de los delitos de que tenga noticia o de sus responsables, incurrirá en la pena de inhabilitación especial para empleo o cargo público por tiempo de seis meses a dos años".
} 
términos en que ésta se haga presente en el proceso. 



\section{8. ÁMBITO OBJETIVO DEL EJERCICIO POPULAR DE LA ACUSACIÓN}

\section{1. Ámbito ordinario: delitos públicos y semipúblicos}

Mediante el ejercicio popular de la acusación sólo cabe hacer valer la pretensión penal en la persecución de los delitos en los que la iniciativa en la persecución no es deferida por el Estado a los agraviados: los públicos. Cualquier ciudadano no ofendido puede así poner una premisa necesaria para el ejercicio del ius puniendi estatal respecto a todas las infracciones, delitos o faltas, para los que sea predicable la obligación legal de su persecución ${ }^{1057}$.

En el caso de los delitos semipúblicos (o semiprivados) ${ }^{1058}$, el dato clave a tener en cuenta es que el denunciante o querellante no puede disponer de la pretensión penal, por lo que una vez puesta en marcha la actividad persecutoria a través de la denuncia, no es preciso que el ofendido realice acto procesal alguno. Se exige su actividad inicial, pero una vez ha dado comienzo el procedimiento, el ejercicio de la pretensión penal deviene obligación pública. El sujeto pasivo del delito tiene así el derecho a que el proceso no se inicie contra su voluntad, originando como consecuencia la impunidad de la conducta delictiva ${ }^{1059}$. Por ello, se ha afirmado, en los delitos semipúblicos, una vez que se ha puesto de manifiesto el deseo de que se persiga, el particular ofendido pierde la disponibilidad de la pretensión, convirtiéndose ésta en pretensión penal pública ${ }^{1060} . \mathrm{La}$

${ }^{1057}$ No podría entenderse aplicable la extensión de la acusación popular a conductas enmarcadas dentro del derecho administrativo sancionador, en tanto no hay previsión legal específica de su reconocimiento al respecto.

\footnotetext{
${ }^{1058}$ Con respecto a su denominación señalaba MUÑOZ ROJAS que "con la misma falta de base podrían denominarse semiprivados". MUÑOZ ROJAS, "Notas sobre la Jurisdicción y la Acción en el ámbito del proceso penal", RDProc 1977, p. 206. Entendemos más adecuada y optamos por la denominación de "delitos semipúblicos", que remarca e incide más en el aspecto público de tales infracciones. Este tipo de conductas se encuentran más cercanas a los delitos públicos que a los privados, tendencia que se ha ido acrecentando progresivamente con el tiempo al irse limitando el perdón a los supuestos específicamente previstos en la norma.
}

${ }^{1059}$ GONZÁLEZ MONTES, F., “Acción penal y perdón del ofendido en los denominados delitos semipúblicos”, Revista Facultad de Derecho Universidad de Granada, nº 2, 1983, p. 90.

${ }^{1060}$ ROBLES GARZÓN, J.A., “El Acusador Privado”, RDProc. (Ibam), 1978 p. 549. 
denuncia en los delitos semipúblicos es entendida por ello como manifestación del principio de oportunidad en la legislación material ${ }^{1061}$. Al contrario de lo que ocurre con los delitos privados, el número de conductas encuadrables en esta categoría ha venido creciendo progresivamente, de manera que el número de supuestos en que la iniciación de la persecución penal se sujeta a la voluntad de los afectados es en el CP de 1995 considerablemente mayor a lo que sucedía en otros momentos ${ }^{1062}$. En estos supuestos cabe hablar de un derecho del ofendido a crear, a través de la denuncia, el presupuesto necesario para el ejercicio de la pretensión penal. Pero una vez establecido tal presupuesto, el delito se rige, cara a su perseguibilidad, por los mismos principios que si de delito público se tratase, con lo que el MF estará obligado a tenor del art. 105 LECrim a acusar.

El agraviado tiene en ocasiones derecho a que su perdón extinga la posibilidad del ejercicio de la pretensión penal, con lo que su régimen se aproxima al de los delitos privados, pero en tanto éste no se otorgue, el proceso no se diferenciará en nada del que se sigue por los delitos públicos ${ }^{1063}$. Problema básico en relación con este tipo de conductas

${ }^{1061}$ Así GIMENO SENDRA, V., Derecho Procesal Penal, Madrid 1996, p. 67.

${ }^{1062}$ Se conceptúan como delitos perseguibles sólo a instancia de parte las siguientes conductas: 1) reproducción asistida sin consentimiento de la mujer (art. 162.2 CP); 2) agresiones, acoso y abusos sexuales (art. 191.1 CP); 3) descubrimiento y revelación de secretos a no ser que se trate de autoridad o funcionario público o afecte a los intereses generales o a una pluralidad de personas (art. 201.1 CP); 4) calumnia e injuria contra funcionario público, autoridad o agente de la misma sobre hechos concernientes al ejercicio de sus cargos (art. 215.1 CP); 5) abandono de familia o impago de prestación económica en favor del cónyuge o hijos (art. $228 \mathrm{CP}$ ); 6) daños causados por imprudencia grave en cuantía superior a 10 millones de pts. (art. $267 \mathrm{CP}$ ); 7) delitos relativos a la protección de la propiedad intelectual, industrial, del mercado y los consumidores cuando la comisión del delito no afecte a los intereses generales o a una pluralidad de personas (art. 287 CP); 8) delitos societarios de los arts. 290 a 295 cuando la comisión del delito no afecte a los intereses generales o a una pluralidad de personas (art. 296 CP); 9) acusación y denuncia falsas tras la firmeza de la sentencia absolutoria o el auto de sobreseimiento (art. 456.2 in fine).

Son faltas perseguibles únicamente previa denuncia del ofendido: 1) amenazas leves, riña con armas, coacción, injuria o vejación injusta de carácter leve (art. $620 \mathrm{CP}$ ); 2) imprudencia grave con resultado de lesiones e imprudencia leve con resultado de muerte o de lesiones (art. 621 CP); 3) alteración de términos, linderos o cualquier clase de señales o mojones destinados a fijar los límites de propiedades o demarcaciones de predios contiguos, tanto de dominio público como privado si la utilidad no excede de 50.000 pts o no sea estimable (art. $624 \mathrm{CP}$ ).

${ }^{1063}$ En favor de la supresión del perdón del ofendido vid. IBÁÑEZ LÓPEZ-POZAS, F.L., Especialidades procesales en el enjuiciamiento de los delitos privados y semiprivados, Madrid 1993, p. 171. La razón alegada es que, si el proceso ha comenzado y por lo tanto se ha dado publicidad al caso, no existe razón para que el ofendido que ya mediante la denuncia condicionante o la querella privada había manifestado su voluntad de iniciar el proceso utilice el perdón para ponerle fin. Ello podría llevar a una instrumentación del proceso en función de intereses personales o particulares. Por otra parte, se argumenta que podría limitarse la facultad del perdón hasta el momento de dictarse la sentencia firme, con lo que se evitaría que se puedan producir presiones sobre el ofendido durante el transcurso del cumplimiento de la pena para que aquél otorgue el perdón. 
es por ello el valor que deba otorgarse al perdón del ofendido, cuestión abordada tanto por el CP como por la LECrim, con efectos de diverso alcance:

a) El art. $130.4^{\circ} \mathrm{CP}$ señala como causa de exclusión de la responsabilidad criminal el perdón del ofendido por el delito, pero sólo "cuando la Ley así lo prevea", por lo que surtirá efecto únicamente previo reconocimiento legal explícito ${ }^{1064}$. En tal norma se ha de entender incluida la extinción del deber del Estado de imponer la condena y necesariamente también la extinción de la posibilidad de deducir la pretensión penal ${ }^{1065}$. Desde este punto de vista habría de considerarse superflua por reiterativa la previsión del art. 191.2 CP que, en relación con los delitos contra la libertad sexual, establece que "el perdón del ofendido o del representante legal no extingue la acción penal...". Hubiera bastado el silencio de la ley para que en este supuesto, al igual que en los demás, el perdón del ofendido no tuviera carácter excluyente de la responsabilidad criminal.

b) El art. 106.II LECrim reconoce la extinción de la "acción penal", que no de la responsabilidad criminal, por el perdón del ofendido en los delitos o faltas que no pueden ser perseguidos sino a instancia de parte. En este caso, el perdón no extingue la pena, pero sí tiene repercusiones sobre la persecución penal, en tanto podrá quedar ésta impedida por la voluntad expresa del ofendido por el delito. De esta manera, el mandato del art. 191.2 $\mathrm{CP}$ referido cobra sentido como excepción de lo genéricamente previsto en la norma procesal, puesto que, una vez denunciado el delito por el ofendido o su representante legal, en ningún caso operará el perdón como causa excluyente de la actividad de persecución por el Estado ${ }^{1066}$.

Aun cuando no hay precepto que impida la intervención activa de acusadores no ofendidos en la persecución de los delitos semipúblicos, la doctrina ha venido sosteniendo

\footnotetext{
${ }^{1064}$ A diferencia de lo que preveía el art. 25 del antiguo CP, en el que se incluían los delitos “que sólo pueden ser perseguidos mediante denuncia o querella del agraviado".

${ }^{1065}$ Esto es lo que ocurre, por ejemplo, en los delitos contemplados en los arts. 201.3 ${ }^{\circ}$ (descubrimiento y revelación de secretos), 267 últ. párrafo (daños causados por imprudencia grave en cuantía superior a diez millones de pesetas) o 639 (faltas perseguibles a instancia de parte), todos ellos del CP.

${ }^{1066}$ Esta no es, sin embargo, una opinión compartida por toda la doctrina, puesto hay autores que afirman que el perdón en los delitos semipúblicos no sólo extingue la "acción” sino también la responsabilidad penal. No existiendo ésta quedará excluido el proceso y negada la "acción”. Cfr. GONZÁLEZ MONTES, F., “Acción penal y perdón del ofendido en los denominados delitos semipúblicos”, op. cit. p. 93. Tal concepción es argumentada entendiendo, según la originaria teoría de GÓMEZ ORBANEJA, que el auto de apertura del juicio oral es la resolución que admite o deniega la acción.
} 
diversas posturas al respecto:

a) MARTÍNEZ DEL CAMPO, GÓMEZ ORBANEJA, VALERO OLTRA, GIMENO, MONTERO y SALOM entienden que se trataría de un ámbito cerrado para los no ofendidos por el delito. Alegan estos autores que la iniciación del proceso en los delitos semipúblicos dependerá de la voluntad del ofendido, continuando luego el fiscal en el ejercicio de la pretensión penal, pero sin que pueda incoarse el proceso por querella de un no ofendido, el cual tampoco podrá luego constituirse en acusador ${ }^{1067}$. Para GÓMEZ ORBANEJA el ejercicio de la acusación derivado de estas infracciones corresponde, junto al órgano público (el MF), exclusivamente a las personas a quienes viene atribuido el derecho de denuncia, no abarcando por tanto a los no ofendidos por el delito pese a la norma general de los artículos 101 y 270.1 LECrim $^{1068}$. También VALERO OLTRA negaba que cupiera ejercicio popular de la acusación en los delitos semipúblicos, en tanto queda sometida a la disposición de la parte agraviada ${ }^{1069}$. Para GIMENO, habría que vetar que el querellante popular pueda ejercitar la pretensión en un delito semipúblico. Es sólo el ofendido quien ostenta el monopolio de la no perseguibilidad a través del ejercicio de la denuncia, y de su reverso, la remisión ${ }^{1070}$. SALOM afirma que la propia naturaleza de los bienes jurídicos protegidos lleva a la consecuencia de excluir la intervención de los acusadores populares ${ }^{1071}$. En relación con las personas jurídicas, y en opinión de MUERZA ESPARZA, resultaría discutible si pueden personarse como acusadores populares en delitos semipúblicos ${ }^{1072}$.

${ }^{1067}$ Por todos vid. MONTERO AROCA, J., Derecho Jurisdiccional, T. III, p. 62.

${ }^{1068}$ Comentarios, op. cit. T. II, vol. I, p. 226 y 458, argumento que no es reiterado en su Derecho Procesal Penal (vid. 10a edición, Madrid 1986, p. 150). Coincidía con MARTíNEZ DEL CAMPO en la denominación de éstas como "acciones mixtas", autor que igualmente las excluía del principio general del art. 101 LECrim.. Vid. MARTÍNEZ DEL CAMPO, Notas..., op. cit. p. 271.

${ }^{1069}$ VALERO OLTRA, “La acción popular...”, op. cit. p. 8.

${ }^{1070}$ GIMENO SENDRA, V., "La acción popular, el jurado y los Tribunales de Escabinos”, op. cit. p. 342. Vid. también Constitución y Proceso, p. 87. GIMENO entiende también justificada la exclusión si se piensa que el ofendido es el único que puede oponerse a un sobreseimiento injustificado ante una petición en tales términos del MF (art. 644 y 645 LECrim).

${ }^{1071}$ SALOM ESCRIVÁ, J-S., “La Querella”, JUSTICIA 96, nº 2, p. 410.

${ }^{1072}$ MUERZA ESPARZA, J., en DE LA OLIVA, A., et. al. Derecho Procesal Penal, op. cit. p. 137. Cita como ejemplo una asociación cuyo objeto fundamental fuera la protección de las mujeres que hubieran sido víctima de 
En este mismo sentido, si bien de forma tangencial, se pronuncia la STC 40/1994 de 15 de febrero (FJ 3) en la que se afirma que, a diferencia de los delitos públicos para los que subsiste la acción popular, en los delitos semipúblicos y en los privados, el ofendido o sujeto pasivo de la acción delictuosa, por razones de política criminal, goza del derecho a la no perseguibilidad del delito a través del ejercicio de la acción penal.

b) Para otro sector de la bibliografía, salvado el obstáculo impeditivo de la denuncia del ofendido, no debería existir óbice para que el MF o cualquier ciudadano pudiera mostrarse parte acusadora en el proceso. La denuncia operaría como condición de procedibilidad que, una vez satisfecha, configuraría tales supuestos como si de delitos públicos se tratara. Así se pronuncian entre otros MUÑOZ ROJAS ${ }^{1073}$, FERNÁNDEZ LÓPEZ $^{1074}$, F. GONZÁLEZ MONTES ${ }^{1075}$ y J.L. GONZÁLEZ MONTES ${ }^{1076}$. También la Memoria de la Fiscalía General del Estado de 1989 reconocía que una vez formulada la denuncia no existiría impedimento legal para dar entrada al proceso a un eventual acusador popular en cuanto que la ley afirma la publicidad de la "acción penal" (101 LECrim) $)^{1077 .}$

Esta última es la posición que consideramos más adecuada, en tanto el efecto que el ordenamiento jurídico otorga a la voluntad de los ofendidos es el de impedir el proceso allí donde la persecución del delito pueda ser más perjudicial para sus intereses que la impunidad del delito. Pero, una vez salvado tal requisito previo, y dado que el MF está

violación.

${ }^{1073}$ MUÑOZ ROJAS, T., “En torno al acusador particular en el proceso penal español”, RDProc (Ibam) 1973, p. 132.

${ }^{1074}$ FERNÁNDEZ LÓPEZ, M.A., "Nuevo panorama de los delitos perseguibles de oficio y de los delitos perseguibles sólo a instancia de parte", RJCat 1979, n² 2, p. 109.

${ }^{1075}$ GONZÁLEZ MONTES, F., “Acción penal y perdón del ofendido en los denominados delitos públicos”, Rev. Facultad de Derecho Universidad de Granada, n 2, 1983, pp. 90-91.

${ }^{1076}$ GONZÁLEZ MONTES, J.L., "Notas en torno a la acción penal y su ejercicio", en Problemas actuales de la Justicia. Homenaje al Profesor Gutiérrez-Alviz, Valencia 1988, p. 742.

${ }^{1077}$ Se advertía no obstante que puede resultar excesivo que tal ofendido por el delito tenga que verse sometido a un impulso investigador y acusatorio al margen de sus directos intereses o de los que imparcial y legalmente ostenta el Fiscal, pudiendo excederse y desorbitarse el contorno pretendido por el ofendido al decidirse a perseguir el delito. En tal apreciación es perceptible el recelo hacia la actividad de acusadores no ofendidos, pero aun así, no parece que pueda establecerse impedimento para su actividad. 
obligado a deducir la pretensión penal como en el resto de las infracciones, no habría fundamento legal para impedir la intervención de otros acusadores. Lo que en cualquier caso parece claro es que, en ausencia de denuncia o querella del ofendido ${ }^{1078}$, la querella del acusador popular no podría dar lugar a la apertura del proceso, puesto que dado que el ofendido puede con su inactividad impedirla, recae también en sus manos el evitar la actividad procesal de otros sujetos, con lo que nadie podrá subrogarse en la posición de la víctima para activar el proceso penal ${ }^{1079}$. Evidentemente, el papel del acusador popular carece de relevancia en relación con el perdón del ofendido pues excede de su ámbito de atribuciones, en tanto se integra únicamente en la voluntad de aquél.

En un sentido similar a lo dicho sobre los delitos semipúblicos habrá de entenderse configurada la posible actuación del acusador popular en los supuestos delictivos cometidos fuera del territorio nacional cuando los afirmados criminalmente responsables fueran españoles o extranjeros que hubieren adquirido la nacionalidad española con posterioridad a la comisión del hecho. En estos casos, exige el art. 23.2 b) LOPJ que el agraviado o el MF denuncien o interpongan querella ante los Tribunales españoles, pero una vez satisfecha tal condición de procedibilidad no existirá obstáculo que impida la personación de ciudadanos no ofendidos como acusadores ${ }^{1080}$.

\subsection{Exclusiones}

\subsubsection{Por la naturaleza de los delitos: los delitos "privados"}

${ }^{1078}$ Reconoce la STS de 12 febrero 1986 (RAJ 591) que la denuncia del ofendido en los delitos semipúblicos es el mínimo indispensable, pero nada impide que el requisito se tenga por cumplido mediante la interposición de querella por aquél.

\footnotetext{
${ }^{1079}$ Con la única excepción de aquéllos a quienes la ley otorga el carácter de representantes de los intereses de ésta (representante legal o MF en el caso de los menores e incapaces).

${ }^{1080}$ A tenor del art. 23.3 LOPJ, no se exige sin embargo querella para la persecución de delitos que afecten al interés nacional u otros en los que el ofendido sea difícilmente individualizable. Así ocurre con los delitos de traición y contra la paz o la independencia del Estado, contra el titular de la Corona, de rebelión o sedición, de falsificación de sellos oficiales, moneda española u otras que perjudiquen a los intereses del Estado, de atentado contra autoridades o funcionarios públicos, delitos perpetrados en el ejercicio de sus funciones por funcionarios españoles residentes en el extranjero, delitos contra la Administración pública española y delitos relativos al control de cambios.
} 
Los delitos privados son conductas con escasa incidencia social cuya persecución, por razones de política criminal, queda limitada a la actividad de quien hubiere recibido la ofensa por el delito. De esta manera se trataría de evitar en casos que no revisten grave dañosidad social el strepitus fori cuando ello no sea estrictamente necesario a juicio de quien sufra el perjuicio. El ejercicio popular de la acusación queda excluido por definición de este ámbito, en tanto se trata de supuestos en los que el Estado defiere la persecución penal exclusivamente a la voluntad del sujeto agraviado y la intervención del MF, cuanto más la de terceros ajenos a la comisión del delito, quedan descartadas ${ }^{1081}$. Ello se deduce del art. 104 LECrim, que utiliza la expresión "tampoco", referida sin duda al art. 101 en el que se reconoce la generalidad del ejercicio de la pretensión penal en conexión con los siguientes en los que se contienen las excepciones a esta atribución (arts. 102 y 103 LECrim) $)^{1082}$.

\subsubsection{Por razón del procedimiento}

La exclusión de los particulares de la facultad de acusar en determinados ámbitos ha obedecido históricamente a motivaciones diversas, relacionadas siempre con esferas de aplicación de la norma penal en que la intervención de los particulares era percibida como perniciosa. Alguno de ellos, como el procedimiento para la aplicación de las medidas de seguridad, ya no está vigente en nuestro ordenamiento ${ }^{1083}$, y en otros se han derogado las

\footnotetext{
${ }^{1081}$ STS de 16 de octubre de 1978 (RAJ 3168).
}

1082

En la actualidad es encuadrable en esta categoría la conducta descrita en el art. $215 \mathrm{CP}$ : "Nadie será penado por calumnia o injuria sino en virtud de querella de la persona ofendida o de su representante legal". No tendrá esta consideración la injuria o calumnia contra funcionario público, autoridad o agente de la misma sobre hechos concernientes al ejercicio de sus cargos, supuestos en los que bastará con la denuncia.

${ }^{1083}$ Por ejemplo en el art. 14.5 de la Ley de Vagos y Maleantes de 4 de agosto de 1933. Al respecto vid. SABATER TOMÁS, A., Gamberros, homosexuales, vagos y maleantes, Barcelona 1962. La justificación del monopolio del MF en esta materia se cifraba por este autor en que "nadie podrá ser parte porque el peligro sólo produce daño social y no engendra daño individual ninguno". No parece que tomara ni siquiera en cuenta la previsión legal de ejercicio de la acusación no siendo ofendido por el delito. También el art. 12 de la Ley 16/1970 de 4 de agosto sobre Peligrosidad y Rehabilitación Social atribuía el monopolio para la solicitud de las medidas de seguridad al MF. Tal exclusión de la acusación de los particulares fue justificada por la dificultad de la prueba y la complicación de la tarea del juzgador y por la especificidad técnica de tal proceso, que exigiría la intervención únicamente de especialistas. Vid. FAIRÉN GUILLÉN, V., "El enjuiciamiento de sujetos peligrosos no delincuentes", RDProc (Ibam) 1972 pp. 335 y ss. FAIRÉN se mostraba en contra de la intervención del querellante particular, pues su actuación en una materia tan sumamente complicada como lo es la prueba de la peligrosidad -abundantemente indiciaria- podría complicar equívocamente la labor del juez. El interés del querellante particular en 
previsiones que venían a impedir la acusación de particulares no ofendidos ${ }^{1084}$. Esa exclusión pervive hoy únicamente en la Jurisdicción Militar y en la Jurisdicción de Menores, dos de los sectores donde sus factibles efectos perniciosos y la introducción a través de ella de disfuncionalidades en el sistema saltan a la vista.

\subsubsection{La Jurisdicción Militar}

En las causas ante la Jurisdicción castrense nunca ha sido reconocida a los particulares no ofendidos la aptitud para acusar, puesto que la pretensión penal era promovida siempre en régimen de monopolio por las Fiscalías jurídico-militares. Así por ejemplo en el Código de Justicia militar aprobado por RD de 27 de septiembre de $1890^{1085}$, en el Decreto de 4 de julio de 1931 (ratificado por ley de 16 de septiembre del mismo año) ${ }^{1086}$, en el art. 452 del Código de Justicia Militar aprobado por Ley de 17 de julio de $1945^{1087}$ o en su redacción tras la reforma operada por la LO 9/1980 ${ }^{1088}$.

la persecución de la peligrosidad sería difícil de probar que fuera público con respecto a un "estado", no tan nítido como el de un "delito" en el que resultó ofendido o perjudicado y ello podría abrir mucho más que en lo penal, un interés por la "venganza". En tanto ofendidos y perjudicados, sus pretensiones deberían deferirse en los tribunales civiles correspondientes (p. 369). Su argumentación tampoco contemplaba siquiera la intervención del no ofendido por el delito. En opinión de GUTIÉRREZ DE CABIEDES la solución del monopolio de la acción preventiva por el Estado sería la correcta por razones técnicas: en el proceso de peligrosidad, los sujetos que deben intervenir con alguna función directiva, juzgadores postulantes de aplicación de la medida, etc., se requiere que sean, dada la finalidad del proceso, estrictamente profesionales, y a poder ser, especializados en derecho preventivo. GUTIÉRREZ DE CABIEDES, E., “Aspectos procesales de la Ley de Peligrosidad y Rehabilitación Social y su Reglamento”, RDProc (Ibam) 1972, nº 4 p. 835.

${ }^{1084}$ Así, por ejemplo, la Ley de Orden Público 45/1959 de 30 de julio excluyó el ejercicio popular de la acusación cuando se decretara el estado de excepción (art. 46.4). Fue derogada expresamente por la DD de la LO 4/1981 de 1 de junio de los Estados de Alarma, Excepción y Sitio.

${ }^{1085}$ Según la redacción dada por Ley de 12 de julio de 1940, preveía el art. 343: "en los juicios militares se procederá de oficio y no se admitirá la acción privada".

${ }^{1086}$ Citado por ALCALÁ-ZAMORA Y CASTILlO, N., Derecho Procesal Criminal (junto con GARCÍA VALDÉS y firmado como “un redactor de la «Revista General de Legislación y Jurisprudencia»”, 2a ed., Madrid 1944, p. 90.

1087 “Los procedimientos militares se iniciarán de oficio o en virtud de parte o denuncia, o a instancia del Fiscal jurídico-militar. En ningún caso se admitirá la acción privada".

${ }^{1088}$ En su número 2 se decía que "en ningún caso se admitirá la querella. La acción privada podrá ejercitarse en todos los procedimientos seguidos por delitos solo perseguibles a instancia de parte...". Con base en este precepto, el TC admitió la posibilidad de la intervención del actor civil en el proceso penal militar, aun cuando no se tratase de 
Esta tradición se mantiene en la actualidad, y hoy en el ámbito de la Jurisdicción militar la acusación de los no ofendidos no ha encontrado respaldo ni en la Ley Orgánica de la Competencia y Organización de la Jurisdicción Militar (LOCJM), ni en la Ley Procesal Militar (LPM). La razón de esta exclusión (u olvido) por el legislador se ha justificado doctrinalmente en que "en nada favorecería los fines del proceso, aun cuando se limitara su legitimación a la pretensión punitiva"1089. El papel garantizador que pueden desempeñar los Mandos Superiores ha sido señalado como suficiente contrapeso a tal ausencia en relación con el procedimiento ordinario de la LECrim. Se ha dicho así que ello se debe al "limitado y a la vez especializado marco en el que se desenvuelve la Jurisdicción militar" y que se encontraría justificado "en la propia entidad de los bienes jurídicos afectados por la realización delictiva militar, que podemos englobar como los valores e intereses esenciales de los Ejércitos, cuya protección y defensa está encomendada al propio estamento militar y singularmente a sus Mandos Militares Superiores, como depositarios del patrimonio de la Institución y más directamente conocedores de sus características y contenido, por el que deben velar ${ }^{\prime 1090}$.

La intervención de los particulares como acusadores ante la Jurisdicción militar se contempla únicamente en calidad de ofendidos por el delito, y siempre que acusado y acusador no se encuentren entre sí en relación de jerarquía. El art. 108 LOCOJM prevé que "si la comisión de un delito o falta de la competencia de la Jurisdicción militar lesionare bienes o derechos de los particulares, los perjudicados podrán mostrarse parte en el procedimiento... No se podrá ejercer ante la Jurisdicción militar la acusación particular ni la acción civil, cuando el perjudicado y el inculpado sean militares, si entre

delitos privados, con la intención de buscar una interpretación de tal precepto que se cohonestase bien con lo previsto en el art. 24.1 CE (vid. STC 97/1985 de 29 de julio). La publicación de esta sentencia dio lugar de inmediato a una Circular de la Fiscalía del Consejo Supremo de Justicia Militar de 30 de septiembre en la que se declaraba que el derecho de los perjudicados a personarse en el proceso penal castrense quedaba limitado "a las facultades que la LECrim confiere al actor civil en sus arts. 320, 385, 651, 735854 y sus concordantes". Vid. GARCÍA LABAJO, J.M., "La acción civil en el proceso penal militar", Revista Española de Derecho Militar n ${ }^{\circ}$ 55, enero-junio 1990, T. I, p. 164.

${ }^{1089}$ Vid. en este sentido ROJAS CARO, J., Derecho Procesal Penal Militar, Barcelona 1991, p. 245.

${ }^{1090}$ BERMÚDEZ DE LA FUENTE, J.L., "Las partes en el proceso penal militar” en SÁNCHEZ GUZMÁN, E., Comentarios a las Leyes Procesales Militares (LO 4/1987 y LO 2/1989), Ministerio de Defensa, Madrid 1995, T. I, p. 587. A juicio de ROJAS CARO "el actor popular entorpecería el proceso militar y su actuación ha sido sustituida con ventaja con la intervención de los Mandos Superiores, aunque la configuración de éstos como parte sea más, mucho más, limitada que la del actor popular". Derecho Procesal Penal Militar, op. et loc. ult. cit. 
ellos existe relación jerárquica de subordinación, sin perjuicio de ejercer la acción civil ante la Jurisdicción ordinaria" ${ }^{1091}$. El art. 127 viene a reiterar lo dicho en la LOCOJM en los siguientes términos: “...podrá mostrarse parte en el procedimiento como acusador particular o como actor civil toda persona que resulte lesionada en sus bienes o derechos por la comisión de un delito o falta de la competencia de la Jurisdicción militar, excepto cuando ofendido e inculpado sean militares y exista entre ellos relación jerárquica de subordinación...".

En tanto no se reconoce expresamente el posible ejercicio de la acusación por los no ofendidos, se ha alegado en alguna ocasión que ello incumpliría lo previsto en el art. 125 CE. Así, en el informe del CGPJ al Anteproyecto de LOCOJM, se consideraba que "no cabía excluir la acción popular conforme al art. $125 C E^{\prime 1092}$, y en la tramitación parlamentaria tales razones se hicieron valer sin éxito en una enmienda del CDS (Diputado BUIL GIRAL) ${ }^{1093}$. También la doctrina procesalista ha criticado en algún momento esta falta de previsión legal: LORCA NAVARRETE la calificaba como incomprensible, añadiendo que tal opción legislativa es sólo justificable en función de su "peculiaridad" 1094 . Entendemos infundadas tales apreciaciones por cuanto, como hemos visto con anterioridad, el art. $125 \mathrm{CE}$ no obliga al legislador a introducir acción popular en todos los ámbitos del ordenamiento.

${ }^{1091}$ Con respecto a este último inciso se ha señalado la limitación legal que supone al ejercicio de la acción penal considerada como derecho fundamental a la tutela judicial efectiva en tanto el legislador hizo una interpretación errónea de la Jurisprudencia del TC (del ATC 121/1984 de 29 de febrero). Vid. GARCÍA LABAJO, "La acción civil...", op. cit. pp. 168 y s. Tampoco cabrá el ejercicio de la acusación particular en tiempo de guerra (art. 168 LOCOJM).

${ }^{1092}$ Cit. por ROJAS CARO, J., Derecho Procesal Penal Militar, op. cit. p. 245.

${ }^{1093}$ La enmienda, argumentada por un supuesto desconocimiento del contenido del art. 24.1 CE que tales previsiones admitirían, fue rechazada por abrumadora mayoría (152 votos a 8). Independientemente de la valoración política que tales preceptos merecieran, su constitucionalidad se argumentó durante la elaboración en sede parlamentaria de la ley tomando como referencia el ATC 121/1989 de 29 de febrero y la STC 97/1985 de 29 de julio. Según la interpretación de esta jurisprudencia, el ejercicio de la acusación en el procedimiento militar podría sufrir excepciones en los supuestos en los que lo impida la naturaleza de la materia regulada o lo veden intereses también constitucionalmente protegidos de condición más relevante o preponderante. Tales limitaciones encontrarían pleno acomodo en la Jurisdicción militar. Vid. la tramitación parlamentaria de la LOCOJM en Revista Española de Derecho Militar, $\mathrm{n}^{\circ}$ 53, enero-junio 1989, en especial pp. 224 y 365.

${ }^{1094}$ LORCA NAVARRETE, A.M., Comentarios a la Ley Procesal Militar, San Sebastián 1990, p. 188. LORCA alegaba que supone una discriminación favorable en el tratamiento procesal del imputado que no se correspondería bien con la interpretación que del art. 24 CE ha realizado el TC. 
Se ha justificado el que cupiera cerrar el paso al ejercicio de la acusación por los particulares en el ámbito de la Jurisdicción militar en la jurisprudencia constitucional emanada del ATC 121/1984 de 29 de febrero y de la STC 97/1985 de 29 de julio, en las que no se aborda, sin embargo, la acusación deducida por no agraviados por el delito ${ }^{1095}$. En el mismo sentido negativo a la admisión de la acusación particular contra un superior jerárquico se han pronunciado con posterioridad a la vigencia de la LOCOJM y la LPM los AATS (Sala 5a) de 2 de enero de 1989 (RAJ 641) y de 27 de mayo de 1992 (RAJ 6750). La significación de los arts. 108 LOCOJM y 127 LPM es clara en palabras del TS "en cuanto son manifestación del interés que se desea tutelar y que no es otro que la disciplina misma como base de la convivencia de la sociedad militar". Tal valor impediría "el enfrentamiento jurisdiccional, como partes, entre quienes están en una relación de subordinación jerárquica". Salvo error u omisión por nuestra parte, nada se ha dicho por el TC o el TS en relación con el ejercicio de la acusación por particulares no ofendidos, cuya actividad siempre que no fuera ejercitada por delito presuntamente cometido por un superior jerárquico, en nada afectaría al respeto a la necesaria disciplina en el marco de las relaciones internas entre los componentes de las Fuerzas Armadas.

Dado que las normas procesales militares no excluyen de forma expresa que particulares no ofendidos estén facultados para acusar, cabría plantearse si sería de aplicación subsidiaria lo previsto en la LECrim al amparo de la DA $1^{\mathrm{a}}$ LPM $^{1096}$.

${ }^{1095}$ El TC se planteaba en estos pronunciamientos la participación privada en la acusación ante la Jurisdicción militar como el conflicto entre dos intereses constitucionalmente reconocidos que deberían ser ponderados: la necesaria organización jerárquica de las Fuerzas Armadas para la satisfacción de la función que constitucionalmente les asigna el art. 8.1 CE y el ejercicio de la pretensión en el proceso penal para la satisfacción de derechos e intereses legítimos. En el conflicto entre ambos intereses habrá de otorgarse valor prioritario al primero, y la tutela judicial efectiva quedaría plenamente garantizada denunciando los hechos que se estimen constitutivos de delito o falta grave, tanto ante el Juez Togado como ante el Fiscal Jurídico Militar, para que éstos puedan determinar sobre la posible iniciación del procedimiento judicial (ATC 121/1984 FJ 4). En la STC 97/1985 estimó el alto Tribunal que sólo sería admisible la exclusión de la acusación privada cuando se ejercite entre miembros de las Fuerzas Armadas sujetos a vinculación jerárquica, evitando disensiones y contiendas dentro de éstas. La justificación aportada es que las Fuerzas Armadas "necesitan imperiosamente, para el logro de los altos fines que el art. 8.1 CE les asigna, una especial e idónea configuración, de donde surge, entre otras singularidades, el reconocimiento constitucional de forma muy particular en lo que atañe a la imprescindible organización profundamente jerarquizada del Ejército, en la que la unidad y disciplina desempeñan un papel crucial para alcanzar aquellos fines, no resultando fácil compatibilizarlas con litigios entre quienes pertenecen a la institución militar en sus diferentes grados" (FJ 4). El ejercicio de la pretensión penal por personas no pertenecientes a las Fuerzas Armadas y asistidos de un agravio directo no representaría ningún peligro para la cohesión de éstas, al perder la prohibición la razón que le dota de sentido (FJ 5).

${ }^{1096}$ En ella se prevé que "La Ley de Enjuiciamiento criminal y sus disposiciones complementarias, serán aplicables a los procedimientos penales militares, que se regirán por dichas normas en cuanto no se regule y no se 
Manteniendo una interpretación de las leyes procesales militares generosa con el reconocimiento de la acusación popular, pudiera ser defendible su posible utilización en este ámbito tan singular de ejercicio de la Potestad Jurisdiccional ${ }^{1097}$, con la necesaria excepción de que se dedujera por un subordinado jerárquico del acusado ${ }^{1098}$. Estimamos, por el contrario, que esta no es la solución más adecuada, en tanto la habilitación para deducir la pretensión penal precisa una atribución normativa expresa. La legitimación extraordinaria para acusar no viene prevista con carácter específico en las normas procesales militares, por lo que no cabría en ningún caso extender más allá de lo estrictamente imprescindible el texto de la LECrim, que sólo es lex generalis en este aspecto. La voluntad del legislador parece clara en este sentido, atribuyendo con carácter de monopolio la facultad de acusar a un órgano público (la fiscalía jurídico militar).

Queda al descubierto así una de las contrariedades del sistema de acusación por particulares, puesto que se excluye en uno de los ámbitos en los que más útil pudiera ser para el control de los órganos públicos de acusación, sobre todo si se tiene en cuenta la especial y doble vinculación de la Fiscalía Jurídico Militar ${ }^{1099}$. Si la acusación popular

oponga a la presente Ley". Es más, el propio preámbulo de la ley establece que "El procedimiento ordinario ha tomado sus normas de la Ley de Enjuiciamiento Criminal, adaptándolas a las peculiaridades que exige la Jurisdicción Militar...".

${ }^{1097}$ La Oficina de Defensa del Soldado tiene planteado un recurso de amparo en relación con esta materia sobre la base de argumentos similares a los aquí expuestos (Vid. diario "El País" de 18 de abril de 1995), con respecto al que el TC no ha llegado a pronunciarse todavía en el momento de concluir este trabajo. Hemos sido informados directamente por los recurrentes a fecha de 28 de noviembre de 1996 de que la impugnación constitucional todavía no había recibido respuesta en sentido alguno por parte del TC.

${ }^{1098}$ Puesto que en este caso se afectaría a la rígida organización escalonada jerárquicamente del estamento militar, configurada constitucionalmente como necesaria para el mantenimiento de las funciones a las que viene las Fuerzas Armadas vienen llamadas ATC 121/1984 y STC 97/1985 citados. En este caso estaríamos ante un supuesto de excepción parangonable a las del art. 103 LECrim. Debería también asumirse la limitación a la acusación popular en otros supuestos especiales tal y como ocurre con la prohibición de ejercicio de acusación particular o acción civil en tiempo de guerra (art. 168 LOCOJM).

${ }^{1099}$ Vid. Título IV LOCOJM. De la Fiscalía Jurídico Militar es predicable una doble dependencia: por un lado por su vinculación a la Fiscalía General del Estado y por otro al Ministerio de Defensa, en tanto que sus miembros habrán de pertenecer a los Ejércitos. Este último aspecto se manifiesta claramente en el art. 92 LOCOJM en tanto el Ministro de Defensa podrá impartir órdenes e instrucciones al Fiscal Togado referentes a las actuaciones que deben adoptarse para la mejor aplicación de las leyes ante los Tribunales y Juzgados Militares, así como en defensa del interés público en el ámbito militar. El Fiscal Togado tiene la facultad de impartir a los miembros de la Fiscalía jurídico Militar órdenes concretas e instrucciones sobre la interpretación y aplicación de las leyes, con carácter general o referentes a un hecho determinado, bien a propia iniciativa, o siguiendo las instrucciones o indicaciones que al efecto le haga el Fiscal General del Estado (art. 95.1 LOCOJM). Cabe incluso la avocación de sus funciones por el Fiscal General del Estado (art. 95 último párrafo LOCOJM). 
proporcionase alguna ventaja a nuestro ordenamiento, ésta se encontraría precisamente en ámbitos en los que la discrecionalidad del órgano acusador pueda estar bajo sospecha de parcialidad dimanante de su incardinación jerárquica, motivos no descartables en absoluto en la Jurisdicción militar. El legislador, sin embargo y en atención a sus especificidades, ha considerado preponderantes para impedir la intervención de acusadores privados criterios tales como el correcto funcionamiento de las Fuerzas Armadas o la naturaleza de la materia regulada.

\subsubsection{La Jurisdicción de menores}

El $\mathrm{n}^{\mathrm{o}} 1$ in fine de la Regla $2^{\mathrm{a}}$ del art. 15 de la Ley de Tribunales Tutelares de Menores, reformada por el 2.II de la LO 4/1992 prohíbe el ejercicio de la acusación por particulares en la Jurisdicción de menores, y con ello todo posible margen a la acusación popular. La exclusión no se basa en el rechazo de la idea de una pretensión penal en el procedimiento de menores $^{1100}$, sino que se argumenta desde la garantía de la máxima primordial que debe presidir este procedimiento, que no es otra que el superior interés del menor $^{1101}$. La intervención del perjudicado por el delito, con exclusión de todos los

\footnotetext{
${ }^{1100}$ Tal y como se ha hecho históricamente en alguna ocasión. Vid. en este sentido VIVES LLAMAZARES, F., "Consecuencias de la inexistencia de la acción penal en el tratamiento de la criminalidad infantil y juvenil", Anales de la Universidad de Valencia, vol. XXVI, curso 1952-53, cuaderno III-Derecho, p. 123-129, recogiendo una comunicación sobre el tema general "Tratamiento de la criminalidad infantil y juvenil”, presentado a través del Consejo Superior de Protección de Menores al Primer Congreso Hispano Luso Americano penal y penitenciario, celebrado en Madrid en 1952. En opinión del autor, a pesar de que no hay precepto en la legislación que consagre de un modo explícito y terminante el principio de que de los delitos y faltas cometidos por menores no nace la acción penal, sería evidente que la nuestra LECrim no es de aplicación en el procedimiento de los tribunales tutelares de menores. La razón se cifraba según él en que dicha acción está íntimamente conectada con la función represiva característica de los tribunales ordinarios de lo criminal, y que ella no podría tener cabida en una jurisdicción como la juvenil. Según esta concepción, afortunadamente superada en nuestros días, no habría acusación ni defensa ya que los tribunales tienen la obligación de actuar de oficio: no son defensores ni acusadores porque no es la venganza o el castigo el móvil de su actuación, sino el "salvar aquellas almas que comienzan a pervertirse y que con las medidas de reforma que se adoptan pueden regenerarse" (p. 124). Continuando con su argumentación, ello tendría como consecuencia la inaplicabilidad de la prescripción de delitos y faltas en tanto ésta es sólo garantía para el delincuente y en el caso del menor la extinción de responsabilidades por la prescripción le privaría de una "beneficiosa función educativa". La acusación por delitos privados sería inadmisible ante los tribunales de menores dado que "no puede estar en manos del perjudicado el privar al menor de estas ventajas" (las de verse sometido a las medidas de corrección impuestas por el Tribunal de Menores). Por último, los posibles indultos y amnistías no podrán afectar a menores condenados, en cuanto con ello se les privaría de los beneficios propios de un tratamiento reformador.

${ }^{1101}$ En la Jurisdicción de menores no se trata de enjuiciar conductas para establecer la sanción proporcionada, tal y como ocurre en los procedimientos penales ordinarios, sino de valorar la personalidad del menor y sus exigencias educativas y formativas. Ya en el debate parlamentario de la LO 4/1992 se puso de manifiesto el deseo del legislador
} 
demás, encuentra su cauce ordinario a través del ejercicio de las acciones civiles ante los Tribunales de este orden jurisdiccional para la restitución de objetos, reparación de daños e indemnización de perjuicios originados por el menor a que se refiere el art. 13 LORCPJM. Se le atribuye, además, la facultad de intervención para el logro de una reparación extrajudicial que impida la aplicación de alguna de las medidas legalmente previstas, así como un trámite de audiencia para poder formular su oposición a la suspensión de la ejecución del fallo (art. 16.3 LORCPJM) ${ }^{1102}$. Pero en ningún caso se contempla un papel activo en la persecución del delito de aquellos en quienes no concurra la condición de ofendido o perjudicado, de manera que puede afirmarse que no hay posibilidades de intervención ciudadana activa en este sentido más allá de la mera puesta en conocimiento de las autoridades de la comisión del delito a través de la denuncia ${ }^{1103}$.

de que, dadas las especificidades de un procedimiento presidido por una finalidad más educativa que represiva, se excluyera la confrontación directa entre menor delincuente y víctima. Sobre este debate puede verse LORCA NAVARRETE, A., El proceso español del menor, Madrid 1993, pp. 64 y ss. Esta misma idea está también presente en otros ordenamientos en los que se reconoce algún tipo de participación activa a los perjudicados por el delito en el proceso penal. Es común la exclusión en el procedimiento de menores de toda posible intervención privada con el objeto de evitar las consecuencias poco edificantes del enfrentamiento ante el tribunal de la víctima y su agresor. Así ocurre p.ej. en Alemania, donde queda excluida tanto la acusación por delitos privados contra menores como el ejercicio de la coacusación (Nebenklage) ( $\$ 80.1$ y 3 Jugendgerichtsgesetz). Se admite, sin embargo, la presencia del lesionado por el delito en el juicio oral, pero sin que se le atribuya ninguna facultad procesal y siempre con fines educativos para el menor, con el motivo de evitar toda influencia negativa en ese sentido ( $\$ 48.2$ Jugendgerichtsgesetz en relación con la Ley de Protección a la víctima de 1987 (Opferschutzgesetz)). Vid. STOCK, "Opferschutz im Strafverfahren gegen Jugendliche", Monatschrift für Kriminalität, $\mathrm{n}^{\circ}$ 87, p. 352, BRUNNER, R., Jugendgerichtsgesetz. Kommentar. Sammlung Guttentag, $9^{a}$ ed., Berlín 1991, pp. 592 y ss. También en Austria se excluye la acusación subsidiaria en el procedimiento por delitos cometidos por menores ( $\$ 44 / 2$ Jugend Gerichts Gesetz)

${ }^{1102}$ Tanto los eventuales perjudicados, como el denunciante, en tanto en él concurre la condición de interesado, deben ser destinatarios de un acto de comunicación sobre la el acuerdo de archivo de las diligencias por el MF (art. 785 bis LECrim y 5 EOMF). Aunque la LORCPJM guarda silencio sobre este extremo, no se debe olvidar que son de aplicación subsidiaria las normas de la LECrim (DA $2^{\mathrm{a}}$ LORCPJM). En este acto se deberá expresar la resolución adoptada, con la eventual advertencia del derecho que asiste al denunciante o perjudicados de ejercitar las acciones civiles nacidas del hecho en ese orden jurisdiccional. Además, en cuanto resolución que pone fin a un procedimiento es obligado notificarlo a las personas que pueden verse afectadas en armonía con lo dispuesto en el art. 270 LOPJ. Vid. Instrucción FGE 1/1993 B. 2. c). Tal situación pudiera verse sin embargo modificada a tenor de lo contenido en el Anteproyecto de la Ley Orgánica Penal Juvenil y del Menor de 27 de abril de 1995, que en su art. 43.2 admite la posibilidad de que, junto al MF, se persone el ofendido por el delito en calidad de acusador. Sobre el papel del acusador en lo referido a la conformidad vid. AGUILERA MORALES, E., "Algunos apuntes acerca de la conformidad en el procedimiento previsto en el Anteproyecto de la Ley Orgánica Penal Juvenil y del Menor, de 27 de abril de 1995", La Ley n ${ }^{\circ} 4149,22$ de octubre de 1996, pp. 2 y ss.

${ }^{1103}$ Art. 15 , regla $1^{\text {a }}$ LORCPJM. La denuncia del particular interpuesta ante el MF se equipara con el conocimiento directo por éste de la notitia criminis adquirido por publicidad del hecho. 
A pesar de la escasez de estudios sobre el procedimiento de menores, esta carencia no ha pasado inadvertida para la doctrina, y así MARTÍN OSTOS incluía la acusación popular entre sus "Bases para un borrador de anteproyecto de ley penal y procesal del menor" (Base $\left.4^{a}\right)^{1104}$, estimando que no habría razón suficiente para justificar la exclusión de acusadores popular, particular o privado ${ }^{1105}$. En favor de esta opinión podría pensarse también que, aun cuando la persecución de una finalidad educativa en beneficio del menor imputado no puede ser exigida del actor popular, tampoco puede en abstracto ser excluida. La búsqueda de la función tuitiva debe ser el objetivo de la norma material, aun cuando no fuera exigible de aquel sujeto privado que solicita su aplicación. Si lo que pretende el acusador es -y sólo puede ser- poner las bases para la aplicación de la norma penal, sería en ella y en su ejecución donde deberíamos fijarnos para considerar la validez para la satisfacción o no de las finalidades educativas del proceso.

No podemos mostrarnos concordes con esta opinión. Además de toda la argumentación supradicha, poco favorable al mantenimiento de la acusación popular en condiciones constitucionalmente correctas, estimamos que, en atención a la especificidad de los objetivos de un procedimiento en el que se pretenden acentuar las finalidades educativas, la valoración que merece esta excepción a la potencial utilización de una herramienta procesal susceptible de convertirse en arma arrojadiza contra el sistema, debe ser aplaudida. El objetivo que se persigue con la acusación es sentar las bases para un enjuiciamiento en el que, de apreciarse la existencia de delito y la participación punible del acusado, se imponga una condena, por lo que la aparición de intereses privados en la acusación podría también desactivar las peculiaridades provenientes de las finalidades educativas del proceso. La presencia en él no sólo ya de la víctima, sino también de acusadores sin nexo directo con el bien jurídico atacado, podría ser un elemento distorsionador que viniera a introducir influencias externas perjudiciales para los fines que presiden el reproche penal en el caso de los menores. La superposición de un interés sancionatorio que puede regir la actividad de los acusadores privados, sobre los fines educativos que ha de tener la actividad estatal, vendría a dibujarnos un panorama de incompatibilidad. La búsqueda de la condena no parece compadecerse bien con el

\footnotetext{
${ }^{1104}$ MARTÍN OSTOS, J.S., Justicia 91, nº 1, p. 161.

${ }^{1105}$ MARTÍN OSTOS, J.S., "El nuevo proceso de menores. Comentarios a la LO 4/1992 de 5 de junio", La Ley 1994, T. I, p. 1146.
} 
objetivo de resocialización predicable de un procedimiento dominado no por una finalidad represiva, sino pretendidamente educativa. Incluso la confrontación entre un acusador particular no ofendido y la defensa del menor en el transcurso del juicio podría incidir también en su desarrollo formativo y contribuir a desactivar lo que de instructivo pueda tener aquel procedimiento. A través de la actividad de los particulares se introducirían así elementos extraños que pondrán el acento sobre la vindicación del hecho criminal más que sobre la corrección del individuo, lo cual irá sin duda en perjuicio del menor y podrá diluir los hipotéticos efectos beneficiosos del procedimiento.

La intervención de particulares en el uso de facultades procesales podrá conducir a efectos que han de quedar desterrados del proceso de menores, por lo que en contra de una posible presencia de acusadores no oficiales en el procedimiento de menores nos vendrían a hablar las siguientes razones:

1) El necesario margen de discrecionalidad en la aplicación de la norma sustantiva y de su ejecución, dado que la intervención de particulares podría llegar a impedir la apertura de vías consensuales de resolución de los conflictos. Así, por ejemplo, podría dificultar gravemente e incluso impedir la obtención de soluciones positivas en el marco de la desjudicialización, diversión y mediación que se propugnan como recomendables en este ámbito ${ }^{1106}$. Por su específica finalidad, el de menores tiene que ser un procedimiento abierto a la discrecionalidad en su tramitación, lo cual conlleva que se tenga que conferir un poder amplio a la actuación de funcionarios y autoridades públicas y en particular a un MF sujeto a la defensa de la legalidad ${ }^{1107}$. Cooperar para colmar lagunas en el cumplimiento de tales funciones públicas estableciendo frenos frente a posibles

${ }^{1106}$ Vid. art. 2 y ss. de la RECOMENDACIÓN 87 (20), de 17 de septiembre de 1987, del COMITÉ DE MINISTROS DEL CONSEJO DE EUROPA, sobre reacciones sociales ante la delincuencia juvenil.

\footnotetext{
${ }^{1107}$ Vid. la Regla 6 a de las "Reglas mínimas de las Naciones Unidas para la Administración de la Justicia de Menores (Reglas de Beijing)" aprobadas por Resolución 40/33 de 29 de noviembre de 1985, de la Asamblea General de las Naciones Unidas. En su número 1 se establece que "Habida cuenta de las diversas necesidades especiales de los menores, así como de la diversidad de medidas disponibles, se facultará un margen suficiente para el ejercicio de facultades discrecionales en las diferentes etapas de los juicios y en los distintos niveles de la Administración de justicia de menores, incluidos los de investigación, procesamiento, sentencia y de las medidas complementarias de las decisiones". Pero el número 3 viene a concretar esas facultades especificando que "Los que ejerzan dichas facultades deberán estar especialmente preparados o capacitados para hacerlo juiciosamente y en consonancia con sus respectivas funciones y mandatos". Vid. también la Regla 11.2, que habilita a las autoridades para la resolución de estas cuestiones sin vista oficial, con arreglo a los criterios establecidos al efecto en los respectivos sistemas jurídicos.
} 
arbitrariedades parece algo deseable, pero ello no podrá llevarse a cabo al precio de permitir la entrada de intereses privados ajenos a los del menor, por lo que la intervención de sujetos particulares, que pueden estar movidos por una finalidad vindicativa, produciría más distorsiones que ventajas.

2) El obligado favorecimiento explícito de los intereses del menor ${ }^{1108}$, que no siempre se conseguirá con la pretensión del acusador no oficial de establecer únicamente las premisas para una condena, sin estar obligado a tener en cuenta otras circunstancias.

3) La difusión de informaciones perjudiciales para el menor podría suponer una intromisión en su intimidad y reputación, que debería quedar suficientemente preserva$\mathrm{da}^{1109}$. En lo que concierne a la acusación popular, esta restricción operaría de manera impeditiva en un doble momento: con anterioridad a la formulación de una acusación, puesto que sin conocer la identidad del presunto autor, mal se podrá formular ésta y durante la celebración de la vista oral, dado que en la mayoría de las ocasiones tendrá carácter reservado y no se cohonestaría con la presencia de acusadores extraños.

4) El respeto a su educación, el fomento de su completo desarrollo, la contribución a la efectiva rehabilitación del menor delincuente o el papel activo de los padres o tutores en el procedimiento, la prevención de dilaciones procesales innecesarias ${ }^{1110} \mathrm{o}$ la exclusión dentro de lo posible de medidas de restricción o privación de la libertad, son cuestiones básicas a tener en cuenta que, al menos teóricamente, no se compadecen bien con la presencia de particulares acusadores no vinculados a la defensa de los intereses del menor.

5) La especialización exigible para todos los operadores jurídicos que intervengan en el procedimiento de menores ${ }^{1111}$ no podría ser predicable con carácter general de

${ }^{1108}$ Regla 14.2 de las de Beijing.

${ }^{1109}$ Vid. art. 14. II y III LOCPJM («El Juez podrá acordar, en interés del menor, que las sesiones no sean públicas. En ningún caso se permitirá que los medios de comunicación social obtengan o difundan imágenes del menor, ni datos que permitan su identificación»), Regla $\mathrm{n}^{\circ} 8$ de las Reglas de Beijing cit. y art. 161 y 2 de la Convención sobre los derechos del niño de 20 de noviembre de 1989 ratificada por España mediante instrumento de 30 de noviembre de 1990.

${ }^{1110}$ Regla 20 de las de Beijing.

${ }^{1111}$ Vid. art. 9 de la RECOMENDACIÓN 87 (20), de 17 de septiembre de 1987, del COMITÉ DE MINISTROS DEL CONSEJO DE EUROPA, sobre reacciones sociales ante la delincuencia juvenil. 
quienes pretendieran actuar como acusadores populares.

La decisión sobre la intervención de acusadores privados en el proceso de menores debe considerarse una cuestión de técnica procesal sin incidencia sobre más derechos que los de los propios menores, pero nunca sobre los de posible actores no ofendidos. En ella se ponderan dos intereses contrapuestos: la confianza social en la adecuada actuación del MF como órgano de acusación y los perjuicios que sobre la personalidad del menor sometido a un proceso se derivarían de la intervención de sujetos privados extraños al objeto que en él se dilucida. En esa disyuntiva nosotros nos pronunciamos sin duda en favor de minimizar esos posibles perjuicios, anteponiendo los intereses del menor a los de quienes pudieran pretender hacer uso de facultades acusatorias. Estimamos, por ello, plenamente adecuado el impedimento normativo del ejercicio de la pretensión penal por particulares no lesionados por el delito ante la Jurisdicción de menores.

\subsubsection{Juicios de faltas}

La Ley se decanta en favor de la posible presencia de acusadores privados en los juicios de faltas, pues los arts. 962 y 969 LECrim contienen referencias a la querella de particulares ${ }^{1112}$. Incluso en las normas de atribución de la legitimación para acusar contenidas en los arts. 102 y 103 LECrim se habla siempre de "los delitos y faltas...". La única peculiaridad en relación a la acusación popular por delitos se cifra en que se exige la interposición de querella con los requisitos del art. 277 LECrim, pero sin que sea precisa la intervención de Abogado y Procurador (art. 969 LECrim) ${ }^{1113}$.

El problema se suscitará en la articulación práctica de esta intervención procesal, dada la dificultad que entraña compatibilizar la presencia de acusadores no ofendidos con un proceso caracterizado por su simplicidad formal y su pretendida rapidez. De no haber dado comienzo con su querella al procedimiento, la intervención de acusadores no

${ }^{1112}$ Sobre el papel de los acusadores en el juicio de faltas vid. AYO FERNÁNDEZ, M., "Las novedades de la Ley 10/1992 de 30 de abril en los juicios de faltas. La instrucción 6/92 de la F.G.E.", Actualidad Jurídica Aranzadi, $\mathrm{n}^{\mathrm{o}} 72,15$ de octubre de 1992, apartado 5 .

${ }^{1113}$ Esta previsión deja sin sentido, en el caso de ejercitarse la acusación popular, el papel cualificado que la denuncia puede llegar a tener en ocasiones al operar como tácito escrito de acusación. 
ofendidos es ciertamente difícil de imaginar en los juicios de faltas ${ }^{1114}$.

\subsubsection{La modalidad procedimental del art. 790.1.III LECrim}

El art. 790.1.III LECrim prevé que el MF, y sólo él, pueda presentar de inmediato su escrito de acusación y solicitud de apertura del juicio oral que provoque la simultánea citación para su celebración, en atención a las circunstancias de flagrancia o evidencia de los hechos, alarma social producida, detención del imputado o el aseguramiento de su puesta a disposición judicial. La intervención de un acusador popular en este caso es poco menos que imposible, por cuanto sería menester la presencia física en el Juzgado de aquél que pudiera tener en mente el previsible ejercicio privado de la acusación, acompañado además por su abogado para la inmediata interposición de la querella. En estos supuestos, más que de una expresa exclusión normativa, deberemos por tanto hablar de seria dificultad, si no de imposibilidad material absoluta, para la acusación de los particulares.

La facultad difundida genéricamente entre toda la ciudadanía para acusar precisa de trámites procesales largos, con tiempo suficiente para ser preparados adecuadamente o para instar la práctica de diligencias, lo cual no se compadece bien con las exigencias de celeridad que dan razón de ser a esta modalidad procedimental. Por tal motivo se ha dicho con razón que "la intervención de un acusador particular en esta clase de procedimientos se acoge como elemento extraño que hace chirriar la acelerada máquina que pretende implantarse" 1115 . Si esta argumentación es cierta en el caso del ofendido por el delito, mucho más en el de quienes en principio no tienen tal conocimiento directo de su comisión.

\subsubsection{Por el fuero de los acusados}

Tradicionalmente han existido hipótesis en las que se ha excluido la acusación de

\footnotetext{
${ }^{1114}$ Podemos entender que en ello se encuentra un dato más para afirmar que el legislador de 1882 pensaba en la querella de los no ofendidos únicamente como forma de iniciación procesal.

${ }^{1115}$ BARREIRO, A. J., “Anotaciones a las medidas urgentes de reforma procesal penal”, Actualidad Jurídica Aranzadi $\mathrm{n}^{\circ} 56$ (4 de junio de 1992), p. 4.
} 


\section{los ciudadanos en razón del cargo que ocupaban los imputados ${ }^{1116}$.}

\section{En la actualidad, el art. 102.2 CE establece que para el planteamiento de acusación}

\section{a los miembros del Gobierno o a su Presidente por traición o por cualquier delito contra la}

\footnotetext{
${ }^{1116}$ Así, por ejemplo, en los delitos de competencia del Tribunal de Garantías Constitucionales de la República, la competencia para acusar se atribuía a diferentes órganos según la investidura o el cargo del presunto culpable. ALCALÁ-ZAMORA distinguía todos los supuestos posibles: cuando se tratara de los Presidentes de la República, de las Cortes o del Consejo y de los Ministros, la facultad de acusar pertenecía únicamente al Congreso mediante una Comisión constituida en su seno (arts. $5^{\circ}$ y $8^{\circ}$ de la Ley de Responsabilidad del Jefe del Estado y $77.1^{\circ}$ de la ley del Tribunal de Garantías). Cuando la acusación se dirigiera contra el Presidente y Magistrados del TS y contra el Fiscal de la República, correspondería formularla, según los casos, al Fiscal de la República, al Gobierno, por medio del Ministro de Justicia, a las regiones autónomas, por medio de sus órganos ejecutivos, o a toda persona, individual o colectiva, directa o indirectamente agraviada (art. 78 Ley del Tribunal de Garantías). Con ello, se recogía una forma de acusación popular más restringida que la que preveía el art. 757 en relación con el antejuicio para exigir responsabilidad criminal a los Jueces y Magistrados, concordando así con lo previsto por el art. 123 de la Constitución republicana acerca de las personas y organismos legitimados para acudir ante el Tribunal de Garantías. Cuando la acusación afectare a los miembros del Tribunal de Garantías podrían acusar las Cortes, por medio de su Mesa, el Gobierno por medio de su Presidente, las regiones autónomas por sus órganos legislativos o ejecutivos, y toda persona individual o colectiva directamente agraviada (art. 79). Cuando los encartados fueran el Presidente y los Consejeros del Gobierno de las regiones autónomas, la acción penal competería a las Cortes por medio de su Mesa, al Gobierno de la Nación por medio de su Presidente, o a la región por su órgano legislativo o ejecutivo (art. 80). Vid. ALCALÁ-ZAMORA Y CASTILLO, N., Derecho Procesal Criminal, op. cit. pp. 90 y s.
} 
seguridad del Estado en el ejercicio de sus funciones se requerirá la iniciativa de la cuarta parte de los miembros del Congreso y la aprobación de la mayoría absoluta del mismo ${ }^{1117}$. La iniciativa queda supeditada a la voluntad de la Cámara, sin que sin ella quepa ejercicio de acusación por nadie, ni MF, ni particulares.

Los arts. 148 y 149 del Reglamento del MF, aprobado por D. de 27 de febrero de 1969 y declarado vigente por la DF $2^{\mathrm{a}}$ EOMF en lo que no se opusiera a éste, establecían que la responsabilidad criminal de los funcionarios del MF sólo sería exigible por querella del MF previa orden expresa del Fiscal del TS (hoy FGE) o por acuerdo del Tribunal competente previa audiencia del superior jerárquico del inculpado. Pero a tenor del art. 60 EOMF debemos entender que les son de aplicación los preceptos de la LOPJ en lo referido a la exigencia de responsabilidad penal de Jueces y Magistrados, por lo que no cabría duda alguna de la posibilidad de hacer uso de la acusación popular para imputarles un delito ${ }^{1118}$.

${ }^{1117}$ No estamos ante el mismo supuesto de la necesidad de solicitar la autorización de la respectiva Cámara (el "suplicatorio") para inculpar o procesar a un Diputado o Senador (art. 71.2 in fine CE), sino ante un verdadero monopolio en la iniciativa de la acusación.

${ }^{1118}$ Establece a este respecto el art. 406 LOPJ que "el juicio de responsabilidad penal contra Jueces y Magistrados podrá incoarse por providencia del Tribunal competente o en virtud de querella del MF, o del perjudicado u ofendido, o mediante el ejercicio de la acción popular". 



\section{PERSONACIÓN E INTERVENCIÓN DEL ACUSADOR POPULAR EN EL PROCESO}

\subsection{El instrumento formal para la personación: la querella}

\subsubsection{Interposición}

\subsubsection{Momento procesal}

La querella ha sido definida como el acto procesal consistente en una declaración de voluntad dirigida al órgano jurisdiccional competente por la que el sujeto activo de la misma, además de poner en conocimiento de aquél la notitia criminis, ejercita la acción penal $^{1119}$. Es configurada así como un acto procesal de comunicación y de petición, en el que se hace una doble solicitud: la iniciación de un proceso y que se tenga por parte acusadora en la causa al sujeto que la interpone. Mediante la querella el ciudadano que pretende erigirse en acusador manifiesta su inequívoca voluntad de ejercitar él mismo la pretensión penal sobre los hechos descritos, contribuyendo a la fijación de éstos con vistas a la apertura del juicio oral y acusando al sujeto que presume autor. De su admisión, se derivará la adquisición por el querellante de la cualidad de acusador, lo cual le habilita para deducir la pretensión penal.

La querella fue diseñada por el legislador de 1882 como un mecanismo de iniciación procesal mediante el que, simultáneamente, un sujeto oficial o privado asumía el papel de acusador en el proceso. En su concepción originaria, el ejercicio de la acusación por particulares no ofendidos se reconducía a los momentos iniciales del proceso y cualquier ciudadano podía interponer querella para personarse como acusador (art. 270 LECrim), sólo como forma de iniciación del proceso. De haberse empezado a desarrollar éste, no podrían ejercitar una "acción" que ya habría sido instada: la "acción penal" de la ley, la pretensión penal. En un proceso ya en curso, la interposición de una

${ }^{1119}$ Así HERCE QUEMADA, V., Derecho Procesal Penal (con GÓMEZ ORBANEJA), $10^{\mathrm{a}}$ edición, Madrid 1986. 
querella redactada conforme a los requisitos del art. 277 LECrim constituirá un acto claramente reiterativo si se tiene en cuenta que, en la mayoría de las causas, mediante ella no puede haber más que una adhesión del querellante a lo ya realizado por otros sujetos. Será difícil considerar supuestos en que con esa actividad se aporte otro plus al proceso que no sea el de la propia incorporación al mismo de otro sujeto por lo que, en principio, bastaría con la identificación de quien pretendiese acusar y del procedimiento en que deseare hacerlo para que fuera factible su admisión en él, sin que parezca necesario el rigor formal que la querella implica.

El art. 110 LECrim establece el momento procesal hasta el que es admisible la personación en la causa del perjudicado por un delito o falta, fijando éste "antes del trámite de calificación del delito". El precepto citado, cuyo origen se sitúa en una extendida práctica forense, pero no en la Ley de 1872 ni en la Compilación General de 1879, no especifica nada del caso en el que no sea el perjudicado el que deduzca acusación. De ahí que la polémica sobre la existencia de un momento preclusivo para la personación del acusador popular se haya basado precisamente en esa omisión. En los primeros momentos de vigencia de la ley esta previsión fue interpretada en el sentido de que los ciudadanos no ofendidos sólo podrían personarse en el momento de la incoación del sumario. A juicio de MARTÍNEZ DEL CAMPO, "si todo ciudadano tiene el derecho de querellarse, poniendo en ejercicio la acción pública, no se le otorga para intervenir en procesos por otros iniciados: la ley habla de ofendido, no de quien tenga la acción". Únicamente mediante querella, como acto de iniciación del procedimiento, podría el no perjudicado por el delito deducir acusación ${ }^{1120}$.

La mayoría de la bibliografía ha venido entendiendo, sin embargo, que no habría más restricción temporal a la participación de particulares en la acusación que la derivada del art. 110 LECrim, por lo que el ejercicio de la pretensión penal sería siempre independiente de la pendencia del proceso. Esta lectura, que enlaza con el viejo debate que sobre la materia se desarrolló el siglo pasado, el cual se solventó tácitamente en el reconocimiento al acusador popular de un régimen procesal prácticamente igual al del ofendido por el delito, fue iniciada en el siglo XIX por SILVELA $^{1121}$ y ha sido

${ }^{1120}$ MARTÍNEZ DEL CAMPO, Notas... op. cit., p. 279. En el mismo sentido HERRERO MARTÍNEZ, Ley de Enjuiciamiento Criminal reformada, anotada y comentada, 1908, p. 109 (cit. por GÓMEZ ORBANEJA, E., Comentarios..., op. cit. T. II, p. 605).

${ }^{1121}$ SILVELA, F., "La acción popular”, op. cit. 
representada cualificadamente por GÓMEZ ORBANEJA. A tenor de ella, la facultad de acusar no se agotaría únicamente promoviendo el proceso, sino que abarcaría también la participación mediante una serie de actos escalonados de persecución. GÓMEZ ORBANEJA se mostraba radicalmente contrario a cercenar la atribución que realiza el art. 101 LECrim estableciendo límites temporales, precisamente porque en la visión del legislador ofendidos y no ofendidos resultarían equiparados. Por ello, a su juicio, nada se opondría a extender edictalmente a todos el ofrecimiento de acciones que se realiza al perjudicado. La Ley no tendría interés especial en facilitar el ejercicio de la acusación popular dando a conocer a todos los ciudadanos la persecución del delito, y menos en que se les recuerde a todos que la acusación en el procedimiento ya iniciado les está abierta, pero a su juicio ello no quiere decir que no lo esté ${ }^{1122}$. Para GÓMEZ ORBANEJA la acusación popular quedaría totalmente desvirtuada si se limitase a la iniciativa de la incoación, rebajándola a una petición ante el órgano jurisdiccional sobre el ejercicio de la pretensión por el $\mathrm{MF}^{1123}$. De otra suerte, la acusación popular tendría meramente carácter subsidiario o supletorio (en defecto de la iniciación de oficio o por el ofendido). Y si fuese una facultad subsidiaria de la de otros sujetos, no sólo el actor popular carecería del derecho de intervenir en las causas por otros iniciadas, como sostenía MARTÍNEZ DEL CAMPO, sino que tendría que salir de la por él mismo promovida inmediatamente que su querella fuera admitida, pues el MF estaría obligado al ejercicio de la pretensión penal

${ }^{1122}$ GÓMEZ ORBANEJA, E., Comentarios..., op. cit. T. II, p. 613. No podemos por menos que considerar demasiado aventurada esta visión del profesor GÓMEZ ORBANEJA, que se realizaba sin tener en cuenta sus posibles consecuencias. Aunque sólo fuera por las dilaciones y el encarecimiento que supondría un "ofrecimiento de acciones" a la ciudadanía en general, y teniendo en cuenta que los beneficios que de ello se dedujeran serían más bien escasos, la propuesta ha de considerarse rechazable a limine.

${ }^{1123}$ De ahí que la LECrim hubiera suprimido por innecesario el art. 466 de la Compilación General, que partía del supuesto del concurso a un sumario del fiscal y varios querellantes particulares, junto al ofendido por el delito. Nuestra acusación popular no sería equiparable al Klageerzwingungsverfahren del derecho alemán, donde siguiendo el criterio del Tribunal, el Ministerio Público tiene que sostener la acusación aun contra su voluntad. Vid. GÓMEZ ORBANEJA, E, Comentarios..., op. cit., T. II, vol. I, pp. 606 y ss.; SÁEZ JIMÉNEZ, J. y FERNÁNDEZ LÓPEZ DE GAMBOA, E., Compendio..., p. 894. Aun cuando estos autores parecen apuntar hacia la concepción expuesta por MARTÍNEZ DEL CAMPO, inmediatamente se inclinan por la contraria. En su opinión, no es descartable el riesgo de que, si no se ha interpuesto la querella criminal ejercitando la acusación popular y durante la sustanciación de la misma, el fiscal o la acusación particular solicitasen el sobreseimiento, el "derecho" de ejercitar la pretensión punitiva se vería desnaturalizado, con lo que en muchas ocasiones se convertiría en una declaración programática sin ninguna efectividad. Exigen, eso sí, primero la interposición de querella, sin que baste un mero escrito de personación como en el caso del perjudicado, y segundo el ejercicio exclusivamente de la "acción penal", sin que quepa el de la civil. 
(art. 105 LECrim) ${ }^{1124}$. La personación ulterior a la calificación no supondría en ningún caso modificación de los términos o límites de la controversia o del juicio ya que el que se muestra parte, lo hará en el estado en el que éste se halle sin que se retroceda en el curso de las actuaciones ${ }^{1125}$.

A tenor de esta postura, hoy mayoritariamente aceptada ${ }^{1126}$, el planteamiento de la acusación por particulares sería tanto como la participación en la posición acusatoria en todos y cada uno de los actos en que se manifiesta ese ejercicio, lo cual conlleva tanto la facultad de promover un proceso como la de intervenir en los ya pendientes, previa la constitución como acusador ${ }^{1127}$. De esta manera, se confiere mayor trascendencia al aspecto subjetivo, referido a la intervención en el proceso como acusadores de todos y cada uno de los ciudadanos legitimados como valedores de una facultad propia, que al aspecto objetivo relacionado con la propia persecución, independientemente del sujeto que la origine. El momento preclusivo de la personación, fijado "antes del trámite de

${ }^{1124}$ GÓMEZ ORBANEJA reconoce este carácter subsidiario de la acusación popular, pero no para la iniciativa, sino precisamente para sostener la acusación en el juicio, con arreglo al art. 69 de la Ley del Jurado de 1888. A tenor de él "Cuando las partes acusadoras, en vista del resultado de las pruebas, soliciten la absolución completa de los procesados, el Presidente preguntará en alta voz si alguno de los presentes mantiene la acusación. (...) Cuando alguna persona, con capacidad legal suficiente manifestase que hace suya la acusación, será tenido por parte como tal acusador (...)". Vid. GÓMEZ ORBANEJA, E, Comentarios..., op. cit., T. II, vol. I, pp. 461, 597, 606 y ss., donde se afirma que la acusación popular hubiera podido establecerse con carácter subsidiario respecto de la iniciación de oficio, sin que nuestra ley haya adoptado esa limitación y no haga más distinción (si no es a efectos secundarios) entre el ofendido y el que no lo sea, que las contenidas en los arts. 102 y 103 LECrim.

${ }^{1125}$ GÓMEZ ORBANEJA, E, Comentarios..., op. cit., T. II, vol. I, p. 613. El fundamento de la preclusión establecida en el art. 110 había sido situado por AGUILERA DE PAZ en la índole especial del trámite de calificaciones y en los efectos que produce, lo cual impediría la concurrencia posterior de "quienes pudieran ser parte en el procedimiento". AGUILERA DE PAZ, Comentarios..., op. cit. p. 612.

${ }^{1126}$ Ha de advertirse que, en ocasiones, la aplicación realizada por nuestros Tribunales, dirigida al propósito de evitar la articulación de maniobras politizadoras de la justicia, es la de dar curso a la estricta literalidad de los arts. 109 y 110 , excluyendo a partidos políticos de la acusación en supuestos donde no aparezcan directamente como ofendidos. Así por ejemplo en los autos de la Sala de lo Civil y Penal TSJ de la Comunidad Valenciana de 17 y 26 de abril de 1990, PTC de 5 de octubre de 1990 y ATC 5/1991 de 14 de enero confirmatorio de la anterior. El TC estimó que la exigencia de personación en forma de querella (arts. 783, 101 y 270 a 280 LECrim) no abriría la vía del recurso de amparo, pues no puede reputarse irrazonable ni obstativa para la prosecución del proceso: ante tal vicio formal nada impedía la presentación de la querella, entendida como el prius necesario para que agotada adecuadamente la vía judicial fuese accesible la tutela que proporciona el recurso de amparo. Vid. también GIMENO SENDRA, V., "La acusación popular", op. cit. p. 91.

${ }^{1127}$ Cabría señalar que admitiendo esta lectura, la personación podría ser admisible en todo momento, incluso cuando se haya decretado por el instructor el secreto sumarial siempre que se tuviera noticia del seguimiento de una determinada causa por otros medios. 
calificación del delito", se ha deducido así de la regulación del llamado "ofrecimiento de acciones", contemplado hoy para las víctimas (ofendidos o perjudicados) en los arts. 109, 110, 783.II y 789.4 LECrim y 25.2 LOTJ $^{1128}$.

Este "ofrecimiento" parte del supuesto de una instrucción ya comenzada y, por tanto, de un proceso en curso en el que es preciso que el instructor realice con carácter provisional una adelantada calificación jurídico-penal del hecho que le ocupa, determinando quién es el agraviado, todavía sólo presunto ${ }^{1129}$. La referencia al ofendido como único sujeto pasivo de tal "ofrecimiento" es perfectamente lógica, y mal podría reconocer la originaria LECrim esta posibilidad a otros, lo cual hubiera comportado en cada caso la necesidad de que se ofreciera edictalmente a todos los ciudadanos legitimados para acusar la posible personación. Puede afirmarse, por ello, que originariamente, una vez iniciado el procedimiento, el ciudadano común no ofendido por el delito, carecía de fundamento normativo que le habilitara para acusar, mientras que la víctima del delito, en virtud de su afección y de un específico interés en el desarrollo del proceso, contaba con el amparo del art. 110 LECrim, que le permitía hacerlo hasta el trámite de calificaciones.

Consideramos en este sentido bastante acomodaticia la consolidada interpretación doctrinal y jurisprudencial de tales preceptos legales, ya que unifica la condición de ofendido por el delito y la de acusador popular al objeto de establecer un momento preclusivo de personación (el inicio del trámite de acusación), pero los separa tajantemente cuando se trata del "ofrecimiento de acciones". Es evidente que, tratándose del sujeto pasivo del delito, existe alguien concreto a quien realizar tal oferta, el cual podrá además ser asistido por Abogado, designado incluso de oficio. Por el contrario es prácticamente impensable que el Juez tuviera que lanzar "a los cuatro vientos" -valga la expresión- una propuesta genérica de personación para que fuera recogida por quien lo considerase conveniente, adecuado a los intereses públicos y además tuviera conocimientos, tiempo y recursos económicos suficientes. Queda así al descubierto la incongruencia de hacer equivalente en unos casos sí (a los efectos de establecer un momento preclusivo) y en

${ }^{1128}$ De no tener presente la poca depuración de que adolece el léxico de la LECrim se podría inferir una posible antinomia en tanto "las acciones se ofrecen" al ofendido, pero el que puede mostrarse parte es el perjudicado.

${ }^{1129}$ Tal y como destaca CARNELUTTI, el concepto de parte lesionada se determina en relación con el de imputado: parte lesionada es quien, en la imputación, es indicado como ofendido por el delito. CARNELUTTI, F., Lecciones..., op. cit. p. 205. 
otros no (en la obligación de realizar el ofrecimiento de acciones) al ofendido o perjudicado con el sujeto que desea acusar. Por ello lo lógico sería o bien equipararlos siempre o bien admitir que se está amoldando la norma al deseo de habilitar por vía interpretativa un cauce para la intervención del acusador popular allí donde la Ley no lo reconoce de manera expresa. Puede afirmarse una vez más que la identificación entre las facultades procesales de ofendidos y no ofendidos se basa en una consolidada pero a nuestro juicio errónea asimilación de los cauces procesales previstos para la intervención del perjudicado por el delito con los referidos a los acusadores no oficiales en general, lo cual ha venido a producir como resultado en la práctica forense la ampliación en la actualidad de las facultades procesales de los no agraviados mucho más allá de lo expresamente querido en origen por el legislador.

La distinción entre acusadores ofendidos y no ofendidos y la percepción de la querella como acto con vocación de iniciación procesal ha vuelto a cobrar vigencia en tiempos más recientes. Así, para PORTERO, REIG y MARCHENA por ejemplo, la referencia de los arts. 110 y 783 LECrim en el sentido de que cabe la personación hasta el trámite de calificación iría referida exclusivamente al agraviado por el delito que se persone como acusador particular. A su juicio, coincidente en este punto con el contenido en la Memoria de la FGE de 1989, al no tratarse de un derecho fundamental el establecido en el art. $125 \mathrm{CE}$, sería conveniente para sucesivas reformas el establecimiento de un plazo a contar desde la producción del hecho y su conocimiento, evitando que por mero oportunismo, se introdujera la querella una vez avanzado el procedimiento o, lo que es peor, que se hiciera por la mera personación y sin circunscribir la acusación a hechos concretos ni a petición de diligencias ${ }^{1130}$.

El momento preclusivo para la personación del acusador popular se suele situar en el del trámite de calificación del delito y una vez dictado el auto de apertura del juicio oral, han de cerrarse las puertas del proceso a la entrada de nuevos sujetos acusadores, preclusión obligada para que el procesado, antes de su calificación provisional, pueda

${ }^{1130}$ Memoria FGE 1989, p. 319; PORTERO, REIG, MARCHENA, op. cit., p. 35. No se aclara en tales propuestas, sin embargo, cuándo habrá de entenderse conocida la comisión del delito. No es cuestión baladí, pues tal circunstancia podría llegar a ser relevante en tanto podríamos entrar en la personación de acusadores no oficiales en el resbaladizo terreno de la arbitrariedad: ¿cómo se podría probar el momento del conocimiento por el acusador? ¿han de haberse abierto ya diligencias?, etc. 
conocer y defenderse de todas las acusaciones ${ }^{1131}$. En la práctica, y presentes las diferencias procedimentales existentes, se plantea necesariamente el problema de la determinación de cuándo haya de entenderse cumplido un trámite al que la ley se refiere sólo genéricamente:

a) En el procedimiento ordinario se han fijado plazos diversos para la calificación de los diversos sujetos acusadores (art. 649 y ss LECrim), sin establecer expresamente ninguno para el popular. Cabría distinguir cuando menos cuatro momentos en que pudiera entenderse precluido dicho trámite: el propio auto de apertura del juicio oral, la devolución de la causa por el MF una vez calificado el delito por éste, la devolución de la causa por todos los acusadores ofendidos personados en la causa o la comunicación de la causa al procesado. Ante la ausencia de previsión específica, nosotros nos inclinamos por el primero de estos momentos procesales, que podría entenderse como el inicio del "trámite de calificaciones" según la referencia del art. 110 LECrim.

b) En el procedimiento abreviado tal trámite ha de resolverse por los acusadores en un plazo común de 5 días (art. 790.1.I LECrim) e incluso podrá hacerse de inmediato por el MF (art. 790.1.III LECrim). La preclusión podría operar aquí bien en el traslado de las actuaciones al MF y a los acusadores ya personados para la solicitud de apertura del juicio oral formulando escrito de acusación o petición de sobreseimiento, bien en la formulación de ésta, bien por el transcurso del plazo legalmente previsto o bien en el acuerdo o la notificación del auto de apertura del juicio oral. La más generalizada práctica judicial entiende que el término preclusivo es este último, es decir el momento anterior a que se dé traslado a la defensa ${ }^{1132} \mathrm{o}$, más concretamente, la providencia en la que se resuelve la comunicación al procesado para su calificación por éste (art. 652 LECrim) o para la formulación del escrito de defensa (art. 790.6.VII) ${ }^{1133}$. No compartimos sin embargo esta opinión pues entendemos que en cualquiera de esos momentos estaríamos ya dentro del trámite de calificaciones y habría de considerarse precluida en todo caso la posibilidad del

${ }^{1131}$ VERGER GRAU, J., La defensa del imputado..., op. cit., p. 91.

${ }^{1132}$ NAVAJAS LAPORTE, A., "Momento preclusivo para la comparecencia del perjudicado en el proceso penal. Una reinterpretación del art. 110 LECrim. de acuerdo con el 24.1 CE”, La Ley, n” 908, 3 de abril 1984.

${ }^{1133}$ Vid. en este sentido por ejemplo MAJADA, A., Práctica procesal penal. Procedimiento Abreviado (Disposiciones Generales. vol. I), Barcelona 1990, p. 118. 
ejercicio de la acusación ${ }^{1134}$.

El TS ha sostenido que, en todo caso, la realización extemporánea de la personación es una mera irregularidad procesal, sin trascendencia sobre el derecho de defensa del acusado, cuya denuncia deberá ser hecha por la defensa de éste ${ }^{1135}$. Pero tampoco podemos estimar adecuada tal jurisprudencia, puesto que si los acusadores particular y popular no están vinculados por las actuaciones del MF y la delimitación del objeto del proceso que éste haga, una extemporánea personación sí podría incidir en el derecho de defensa del acusado que hubiera tenido que responder, alegar o aportar elementos exculpatorios en armonía con las acusaciones. Y ello aun cuando la personación fuere anterior al momento de evacuar el escrito de defensa, por lo que para garantizar su derecho a la contradicción parecería necesaria la habilitación de un trámite en el que el acusado pudiera plantear lo que estimase oportuno.

Aunque habitualmente se afirme la similar intervención en el proceso de todos los acusadores, tal circunstancia no refleja la realidad, puesto que es indudable la existencia de una desigualdad de partida: la forma en que llega la notitia criminis a cada uno de ellos. El particular ofendido tiene un conocimiento directo de la perpetración del delito, pero es el fiscal quien estará personado, en el sentido fáctico de la palabra y no en el meramente procesal, en el procedimiento abierto a consecuencia de denuncia, de atestado policial o de querella de particular ${ }^{1136}$. Dada su presencia a lo largo de la instrucción, a diferencia de los particulares no ofendidos, ordinariamente no será la querella la forma

${ }^{1134}$ Puede señalarse una única excepción: la que se producirá cuando uno de los acusadores pida la práctica de diligencias complementarias (790.2 LECrim) y el Juez acceda, dado que, una vez practicadas, se tendrá que abrir nuevamente el plazo para la formulación de acusaciones y con ello existirá un nuevo momento procesal para acusar también por otros sujetos en los términos de la ley.

${ }^{1135}$ SSTS de 28 de mayo de 1993 (RAJ 4267) y de 3 de junio de 1995 (RAJ 4535), FD $2^{\circ}$.

${ }^{1136}$ El fiscal, que habrá de ser informado de la perpetración de todo delito (art. 308 LECrim), en ejercicio de su función inspectora, se constituye al lado del juez instructor o tiene conocimiento de lo actuado a través de los "testimonios en relación, suficientemente expresivos, que le remitirá el Juez instructor periódicamente y cuantas veces se los reclame". En este caso, podrá hacer presentes sus observaciones en "atenta comunicación y formular sus pretensiones por requerimientos igualmente atentos"(art. 306 y 781 LECrim). Sus observaciones irán dirigidas a traer al proceso todos los datos, favorables o adversos a su presunto autor (si es que ya consta). Además, deberá también el instructor remitir al fiscal testimonio especial de todas las providencias o autos apelables, así como de aquellas referidas a diligencias periciales o de reconocimiento "que le interese conocer para el ejercicio de su derecho como parte acusadora" cuando no pueda notificárselos personalmente (art. 646 LECrim). Todo ello sin olvidar el posible ejercicio de facultades de investigación que se le concede en el procedimiento abreviado (art. 785 bis LECrim). 
habitual para que se persone el $\mathrm{MF}^{1137}$. El conocimiento de la perpetración del delito por el ofendido o perjudicado tendrá generalmente carácter directo, por lo que podría personarse inmediatamente interponiendo querella, o al amparo de la regulación del procedimiento abreviado, con un mero escrito de personación aceptando el "ofrecimiento de acciones" previsto en los arts. 109 y 110 LECrim. (art. 783.II LECrim) ${ }^{1138}$. Respecto a la personación del acusador popular será totalmente irrelevante cómo haya llegado hasta él la notitia criminis, pero ello exige en todo caso una posición activa por su parte. En la mayoría de las ocasiones, la noticia le llegará bien del conocimiento público de los hechos delictivos, que puede proceder simplemente de la difusión de los hechos a través de los medios de comunicación, bien por encontrarse al corriente por cualquier otra vía del desarrollo de determinadas diligencias de investigación, judiciales o extrajudiciales, sobre unos hechos presuntamente delictivos. Serán también irrelevantes las motivaciones que lo mueven a actuar en relación con su personación y nunca podrán ser tenidas en cuenta para impedir o condicionar ésta, según hemos visto en apartados anteriores.

${ }^{1137}$ El fiscal no asumirá una inequívoca posición como acusador sino bien con el escrito de calificación provisional en el procedimiento ordinario (art. 650 LECrim), bien con el escrito de acusación del procedimiento abreviado (art. 790 LECrim). Habría de reseñarse que, como excepción, en el procedimiento para las causas ante el Tribunal del Jurado, el legislador sí ha previsto un momento para la concreción de la imputación por el MF y las demás partes personadas: la comparecencia para el traslado de la imputación a la que se refiere el art. 25 LOTJ.

${ }^{1138}$ En el caso del ofendido, la jurisprudencia del TC ha señalado en reiteradas ocasiones que el "ofrecimiento de acciones" se trataría de un trámite con trascendencia constitucional en la medida que de su incumplimiento se deriva una vulneración del derecho a la tutela judicial efectiva del perjudicado. Vid. SSTC 31/1989 de 13 de febrero, 66/1992 de 29 de abril, 37/1993 de 8 de febrero (en el procedimiento militar), 98/1993 de 22 de marzo (FJ 4), 121/1994 de 25 de abril, 278/1994 de 17 de octubre (FJ 3) o 324/1994 de 1 de diciembre. Según la doctrina emanada de estas sentencias "cuando no se pone en su conocimiento la existencia de un proceso en que tan directamente se encuentran implicados sus intereses" y no toma parte en él por simple ignorancia y no por propia decisión o como resultado de su negligencia "se cercena su derecho a la efectividad de la tutela judicial" en tanto se menoscaba el derecho de defensa en un proceso en el que se ventilan intereses concernientes al sujeto. La doctrina se ha planteado por ello si la omisión del "ofrecimiento de acciones" debería conducir a la declaración de la nulidad de actuaciones. En opinión de ORTELLS, por ejemplo, no cabría una declaración de nulidad de gran amplitud en cuanto a las fases procesales afectadas, en tanto el actor que se persona en causa lo hace en el trámite en que ésta se encuentre. Sin embargo, sí la debe producir en el caso y desde el momento en que se hubiera acordado el sobreseimiento y en el supuesto y en el momento en que se hubiera producido la preclusión de la posibilidad de personarse. En ambas hipótesis, el titular de ese derecho no podría ejercitarlo, sin que, al haberse omitido el ofrecimiento conste que obedece a una decisión voluntaria, por lo que se daría el supuesto de nulidad del art. 238.3 LOPJ. ORTELLS RAMOS, M., "Las partes no oficiales...", La Ley, n 3983, 27 de febrero de 1996, p. 3 y en El proceso penal abreviado (nueve estudios), Granada 1997, pp. 85 y s.. Se pronunciaba también por la nulidad FERNÁNDEZ ENTRALGO, J., "Principios procesales y procedimentales de la Ley Orgánica 7/1988”, en La reforma del proceso penal, Madrid 1990, pp. 21 y s. 


\subsubsection{El requisito de la escritura}

La querella ha de interponerse por escrito, siguiendo así una tradición en nuestro ordenamiento cuyo fundamento se cifra en la necesidad de dar seguridad, fijeza y fehaciencia a las declaraciones hechas en ella, de modo que las consecuencias que pudieran derivarse de su inadecuado uso puedan sin sombra de duda ser atribuidas al querellante $^{1139}$. No obstante, la previsión del art. 277. II LECrim que exige "papel de oficio" ha de entenderse derogada ${ }^{1140}$, por lo que la querella podrá redactarse en papel común. La necesidad de la escritura podrá deducirse también si se tiene en cuenta la propia complejidad de los requisitos establecidos por el art. 277 LECrim, puesto que la precisión y claridad del escrito evitará las comparecencias necesarias para documentar correctamente su contenido ${ }^{1141}$.

Puesto que la admisión de la querella habrá de ser puesta inmediatamente en conocimiento de los inculpados, que podrán tomar conocimiento de las actuaciones e intervenir en todas las diligencias del procedimiento (art. 118.II y 302.1 LECrim, salvo declaración de secreto del sumario) se presentarán tantas copias como querellados haya, más otra para el $\mathrm{MF}^{1142}$.

Por su vinculación con el derecho histórico, que podría entenderse hoy carente de justificación, se ha propuesto en ocasiones la admisión de lege ferenda de una "querella oral", al igual que se viene admitiendo en relación con el ejercicio de la "acción penal" por el $\mathrm{MF}^{1143}$. Tal razonamiento sería válido a nuestro juicio para la intervención de

\footnotetext{
${ }^{1139}$ Según señala GIMENO, La Querella, op. cit. pp. 160 y ss., su fundamento hay que encontrarlo en la histórica prevención del legislador de las Partidas frente a la acusación calumniosa y las consecuencias que ésta conllevaría, presididas singularmente por la aplicación al falso acusador de la pena de Talión (Leyes $1^{\mathrm{a}}$ y $14^{\mathrm{a}}, \mathrm{T}$. $1^{\mathrm{o}}, \mathrm{P}$. VII). Ha de recordarse aquí que las Partidas no hicieron más que reiterar las previsiones del Derecho Romano. Las consecuencias que de la querella pudieran derivar podrían ser de orden sustantivo (acusación falsa, injuria o calumnia vertidas en juicio, simulación de delito) o de naturaleza procesal (imposición de costas o las derivadas del desistimiento).

${ }^{1140}$ DA $2^{\text {a }}$ de la Ley 25/1986 de 24 de diciembre de supresión de tasas judiciales, que puede entenderse aplicable por tratarse de un "escrito de parte".

${ }^{1141}$ SALOM ESCRIVÁ, J.S., “La querella”, JUSTICIA 96, nº 2, p. 426.

${ }^{1142}$ MAJADA, Práctica Procesal Penal..., op. cit., p. 96.

${ }^{1143}$ En este sentido, GIMENO SENDRA, V., La Querella, op. cit. pp. 160 y ss. y 297, quien niega el carácter de "querella oral" a la personación del ofendido aceptando el "ofrecimiento de acciones" en tanto ello no supone
} 
acusadores ofendidos por el delito, en tanto ciertamente se ha de facilitar su personación en el proceso para la defensa de su particular interés, pero no lo estimamos de recibo para la querella del acusador popular por los riesgos e inseguridades que conllevaría ${ }^{1144}$.

\subsubsection{Representación legal y defensa}

El art. 277 LECrim establece que la querella se presentará siempre por medio de Procurador con poder bastante y suscrita por Letrado, obligación de la quedan excluidas las interpuestas para la persecución de faltas (art. 969.I LECrim). La firma de Letrado supone en el caso de acusaciones de no ofendidos por el delito un requisito necesario, y aunque el escrito en el que se solicite la personación adopte la forma de querella, sin su satisfacción habrá de entenderse constituye una mera denuncia ${ }^{1145}$. En relación con la necesaria representación del Procurador cabría señalar que a partir de la personación, todas las notificaciones, citaciones y emplazamientos serán realizadas a éste (art. 182 LECrim).

Se han suscitado problemas entre la doctrina, por un lado con la clase de poder que precisaría el Procurador para la representación procesal del querellante y, por otro, con la ratificación de la querella a la que se refiere el art. $277.7^{\circ} \mathrm{LECrim}$. El poder que debe

ejercicio de la "acción penal" sino sostenimiento o preparación de la pretensión. Las ventajas de la "querella oral” se podrían cifrar en la inmediación que conlleva, en tanto la notitia criminis transcurriría con fluidez y espontaneidad, en la economía y rapidez y en el principio de la obtención de la verdad material. El procedimiento podría ser similar al contenido en el art. 267 LECrim referido a la denuncia verbal.

${ }^{1144}$ De hecho GIMENO toma como ejemplo el ordenamiento italiano y la opinión de su doctrina, en el que la querella cumple una función que se asemejaba mucho a nuestra denuncia en los delitos semipúblicos o privados.

${ }^{1145}$ La ausencia de firma de Letrado en la querella de un ofendido por el delito fue abordada en la STC 217/1994 de 18 de julio. En este supuesto el TC reitera su propia doctrina en el sentido de que la designación de Abogado y Procurador del turno de oficio requiere la concurrencia de diversos condicionamientos procesales y materiales (contenidos en el hoy derogado art. 119 LECrim) y que se pueden resumir en la existencia de un hecho punible y de un perjuicio derivado del mismo (ATC 356/1992, FJ único). Puesto que el actor perjudicado por el delito manifestó claramente su voluntad de personación, y en aplicación de la doctrina de la STC 115/1984 (FJ $2^{\circ}$ y $3^{\circ}$ ), el TC estimó que el órgano judicial estaba obligado a iniciar el trámite legalmente previsto para el nombramiento que solicitaba el actor, dada la situación de indefensión que se le ocasionaría caso contrario (FJ $2^{\circ}$ ). Pero otorgó el amparo solicitado por el recurrente estimando la vulneración de su derecho a la tutela judicial efectiva por la omisión de toda notificación de la respuesta judicial ofrecida al escrito presentado en forma de querella y tramitado como denuncia, y sobre todo por no haber hecho explícitas el órgano judicial las razones por las que consideró que los hechos a los que se refería la denuncia no eran constitutivos de delito y por las que, en consecuencia, se rechazó la personación del actor $\left(\mathrm{FJ} \mathrm{3}^{\circ}\right)$. 
acompañarse a la querella, en expresión del art. 277 LECrim., debe ser bastante, lo cual ha sido interpretado en la práctica forense como exigencia de poder especialísimo en el que se contenga una cláusula que faculte al apoderado para presentar la querella en relación a la persecución de un hecho punible concreto ${ }^{1146}$. Ello implica que deberá conferirse siempre con posterioridad al hecho objeto de enjuiciamiento, sin que quepa la genérica previsión de que un poder general ampare la representación procesal para todos los supuestos en que un ciudadano desee acusar. GIMENO encontraba justificación para esta necesidad en razones históricas derivadas de la gravedad de las penas en que podía incurrir el querellante calumnioso o negligente ${ }^{1147}$, con lo que se intentaba evitar que la responsabilidad fuera discutida o pudiera eludirse a pretexto de la insuficiencia del poder $^{1148}$. Tal interpretación se vería ratificada por la previsión del número 7 del art. 277 , que exige la firma del querellante cuando el Procurador no ostentare poder especial. En sentido contrario, señala MAJADA, en la actualidad esta interpretación restrictiva habría quedado superada, imponiéndose la suficiencia de un poder general para pleitos ${ }^{1149}$.

En nuestra opinión bastará para interponer la querella por el no ofendido un poder general para pleitos que faculte para acusar, aun cuando en este caso, el actor deberá posteriormente firmar la querella y ratificarla a presencia judicial. La exigencia de poder especialísimo tiene $a b$ initio sentido en el acusador particular, ya que para serlo debe acreditar un vínculo con el hecho y/o acusado, pero precisamente en el acusador popular lo determinante es que no exista tal nexo ${ }^{1150}$. Un defecto en el poder, como cabe interpretar la no especificación del delito de que se trate, admite ser subsanado y su

${ }^{1146}$ Así HERCE QUEMADA, con GÓMEZ ORBANEJA, Derecho Procesal Penal, 10ª edic., Madrid 1987, p. 153.

${ }^{1147}$ GIMENO SENDRA, V., La Querella, op. cit. p. 179.

${ }^{1148}$ Vid. MAJADA, Práctica Procesal Penal..., op. cit., p. 97.

${ }^{1149}$ Tal sería en su opinión la voluntad del legislador y el criterio que como más racional ha terminado por imponerse en definitiva. MAJADA, Práctica Procesal Penal, op. et loc. cit. Vid. también la Consulta Fiscalía del TS, nº 3, 27 de febrero de 1952, Memoria FTS, 1952, p. 189.

${ }^{1150}$ La razón de exigir la ratificación subsanadora podría ser la de confirmar la calidad en que se comparece, o sea popular, y por ende, sin conexión objetiva o subjetiva alguna. Sin embargo, ello es innecesario, pues expresamente en el escrito de personación habría de determinarse la calidad en que se hace y se solicita que sea admitido. 
ratificación por el querellante sería hábil a tal efecto ${ }^{151}$.

El poder notarial tendrá que ir acompañado del "bastanteo" realizado por Letrado, a través del que se afirme ser suficiente el poder habilitante para la interposición de la querella. Este requisito no viene sin embargo exigido por el art. 277 LECrim, que se limita a decir que el poder sea "bastante", por lo que su ausencia no será causa de inadmisión si el órgano jurisdiccional estima la suficiencia del poder con independencia de la opinión del Letrado ${ }^{1152}$.

Podrá ser conferido el poder no solamente en documento público ante notario, sino que también será admisible el apoderamiento apud acta realizado ante el Secretario Judicial del Juzgado instructor que haya dado comienzo a las actuaciones (art. 281.3 LOPJ). Lógicamente este apoderamiento habrá de realizarse después de cometido el delito, y por su sencillez y gratuidad sustituye con ventaja al poder notarial. Es más, en este caso no se suscitará la cuestión de la suficiencia o insuficiencia, ya que el otorgado en esta forma constituye siempre un poder especialísimo para el asunto determinado que origina la comparecencia y para el que únicamente desplegará sus efectos ${ }^{1153}$.

Puesto que la finalidad de la representación procesal es la de determinar la identificación y voluntad del querellante en el ejercicio de la acusación en orden a la asunción de posibles responsabilidades, la falta de poder es causa de anulabilidad sanable y no puede originar la desestimación de la querella, sino la mera exigencia de subsanación de los defectos ${ }^{1154}$. Del mismo modo habrá de considerarse la falta de ratificación de la querella, cuando ésta fuera precisa ${ }^{1155}$.

\footnotetext{
${ }^{1151}$ Esta interpretación vendría avalada además por lo dispuesto en el art. 11.3 LOPJ, a tenor del que los Juzgados y Tribunales sólo podrán desestimar las pretensiones que se les formulen en virtud de motivos formales "cuando el defecto fuere insubsanable o no se subsanare por el procedimiento establecido en las Leyes". Vid. en este sentido SALOM ESCRIVÁ, J.S., "La Querella", JUSTICIA 96, nº 2, p. 415. Cabe incluso que se otorgue un poder especial como cláusula adicional del poder general, modalidad que relevaría al querellante de firmar la querella. Vid. MAJADA, Práctica Procesal Penal..., op. cit. p. 98.
}

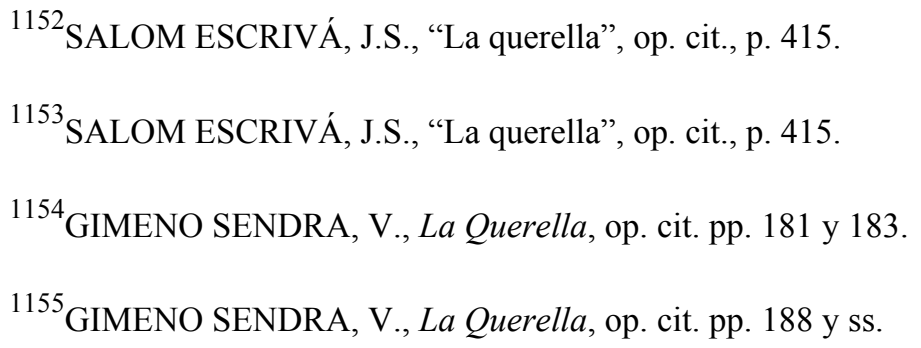




\subsubsection{Justicia gratuita y acusación popular}

De la previsión de gratuidad de la "acción popular" (art. 20.3 in fine LOPJ) no cabe derivar la concesión automática de los beneficios reconocidos por la Ley 1/1996 de Asistencia Jurídica Gratuita para las personas físicas o jurídicas incluidas en su art. 2 que reunieran los requisitos exigidos en los arts. 3 a 5. La LAJG no contiene mención expresa al ejercicio de la acusación, y además la facultad de acusar sin ser ofendido no tiene por qué quedar englobada en el derecho a obtener asistencia jurídica gratuita, en tanto su ejercicio no supone litigar en defensa de un derecho o interés propio (art. 3.4 LAJG), sino sólo defender el interés público. No se podría afirmar, pues, que de la no inclusión del ejercicio de la acusación por los no ofendidos en el ámbito objetivo de la asistencia jurídica gratuita se derivare menoscabo o deficiencia en la defensa de sus derechos. Carece además de sentido sufragar con fondos públicos el ejercicio de pretensiones penales, las cuales por otra parte, en la mayoría de los casos, se solaparán con la actividad del órgano público encargado constitucionalmente de tal misión.

Los arts. 119 y 788.4 LECrim, hoy derogados, otorgaban el "beneficio de pobreza" exclusivamente a "los perjudicados por el hecho punible o sus herederos que fueran parte en el juicio" $" 1156$. La exclusión del beneficio de justicia gratuita del acusador popular stricto sensu ha sido vista en ocasiones como una de las muestras de la discriminación a la que se le sometería en relación con el particular. Por tal motivo, la previsión legal ha merecido en ocasiones críticas doctrinales que señalaban que tal excepción conllevaría como efecto indudable el que sólo las personas que gozasen de suficientes recursos económicos para hacer frente a los cuantiosos costes del proceso podrían afrontar la carga que supone. Con carácter previo al reconocimiento constitucional de la "acción popular", SÁEZ JIMÉNEZ y LÓPEZ FERNÁNDEZ DE GAMBOA señalaban que, aun cuando la idea de negar al actor popular la designación de oficio de estos profesionales no sería desacertada, "ello plantearía un problema de tipo económico-sociológico, como el que

${ }^{1156}$ Como ya se ha visto anteriormente, y habida cuenta de la imprecisión terminológica de nuestro código procesal a este respecto, ello se ha entendido tradicionalmente referido no sólo a los perjudicados sino también a los ofendidos por el delito. A tenor de las SSTC 30/1981 y 193/1991, el derecho de defensa se ha predicado también de quienes comparecen como acusadores. Vid. también STS de 20 de septiembre de 1994 (RAJ 7073) en la que la denegación del beneficio de pobreza no se realiza porque el querellante no tenga derecho a ello, sino porque no reúne los requisitos objetivos necesarios. 
sólo podrían hacer uso de ella (de la acción popular) los que tengan bienes bastantes, con lo que se establecería ciudadanos de primera y de segunda categoría y ello va en contra de los postulados más elementales del principio de igualdad de derechos y obligaciones de los hombres ante la Ley". Se mostraban, por tanto, partidarios de su concesión cuando se cumplieran los requisitos que establece la Ley ${ }^{1157}$. En tiempos más recientes, autores como GIMENO ${ }^{1158}$ y MONTERO han señalado que la exclusión del acusador popular del beneficio de justicia gratuita debería estimarse inconstitucional cuando concurran los presupuestos del beneficio de justicia gratuita, alegando como justificación que si el art. $125 \mathrm{CE}$ reconoce un derecho a ejercitar la acción popular y el art. $119 \mathrm{CE}$ dice que la justicia será gratuita "en todo caso" para quienes acrediten insuficiencia de recursos para litigar, la conclusión no puede ser más que la de reconocer el derecho también al acusador $\operatorname{popular}^{1159}$.

No compartimos sin embargo tales afirmaciones, apegadas a la consideración del ejercicio por los ciudadanos de la acusación como ejercicio de un verdadero derecho de acción en defensa de intereses propios. En concordancia con lo sostenido a lo largo de este trabajo, acusar no es defender nada propio por lo que carecería de todo sentido incluir a quienes ejercitan la acusación en el ámbito de la LAJG. Ni siquiera tendría sentido, además, hablar de un derecho que corresponde a quienes acrediten no tener suficientes recursos económicos, puesto que por su carácter eminentemente público, la carga económica que supone la acusación ha de ser sufragada siempre con fondos públicos. Los ingresos o recursos económicos del acusador son totalmente irrelevantes en relación con su intervención en el proceso puesto que el acusador, ya fuese extremadamente pudiente o pobre de solemnidad, serviría exactamente al mismo fin, un interés que no sería ni de uno ni de otro, sino de todos a la vez. Sostener la opción contraria, aun aparentando estar entroncada con el Estado social, no es más que una forma de duplicar el gasto público

${ }^{1157}$ SÁEZ JIMÉNEZ, J. y FERNÁNDEZ LÓPEZ DE GAMBOA, E., Compendio..., p. 892.

${ }^{1158}$ GIMENO SENDRA, V., "La acción popular, el Jurado y los Tribunales de Escabinos" en COBO DEL ROSAL y BAJO FERNÁNDEZ (Directores), Comentarios a la legislación penal, T. I, Madrid 1982, p. 343.

${ }^{1159}$ MONTERO AROCA, J., Derecho Jurisdiccional, T. III, Barcelona 1994, p. 71. En la edición de 1996 de este manual (p. 73) se reafirma esta opinión, entendiendo incluida la acusación popular en el ámbito de la LAJG por cuanto comprendería a todos los que puedan ser parte en un proceso en el que la intervención de abogado y procurador sea preceptiva. Entendemos, sin embargo, y como se ha tratado de defender a lo largo de este trabajo, que no estamos ante un derecho de acceso a la Jurisdicción en defensa de derechos propios. 
para la realización de la misma actividad, o lo que es peor, facilitar el uso de la justicia para fines inconfesables extraños a la defensa del interés público. ¿Y por qué vamos a tener soportar económicamente la actividad de acusadores privados cuando ya disponemos de un profesional cuyo sostenimiento es sufragado por todos, cualificado y preparado para desempeñar tal función y vinculado por el principio de legalidad? Ello estaría incrementando los costes de la administración de la justicia al duplicar tareas, sin que pudiera afirmarse -al menos teóricamente y desde lo que debiera ser el MF- que, como consecuencia, se derivaran mejoras que no pudieran lograrse de otra forma.

\subsubsection{Pluralidad de acusadores y obligación de litigar unidos (art. 113 LECrim)}

El art. 113 LECrim establece que “...siempre que sean dos o más las personas por quienes se utilicen las acciones derivadas de un delito o falta lo verificarán (...), si fuere posible, bajo una misma dirección y representación, a juicio del Tribunal". Se faculta así al órgano jurisdiccional para determinar cuándo será necesaria la agrupación de una pluralidad de acusadores (o de actores civiles) bajo una única dirección técnica y una misma representación procesal ${ }^{1160}$. Con tal previsión se viene a impedir que cuando los intereses entre diversos acusadores sean diferentes se pueda imponer una dirección y representación conjunta, y se faculta simultáneamente al instructor a su imposición cuando el interés defendido por varios de ellos sea común. El legislador se ha inspirado aquí en razones de conveniencia, tratando dentro de lo razonable ("si fuera posible") de evitar actuaciones repetidas y gastos inútiles ${ }^{1161}$.

\footnotetext{
${ }^{1160}$ La obligación de litigar unidos a tenor del art. 113 LECrim puede considerarse una novedad en la LECrim de 1882 en relación con la provisional de 1872 y la Compilación General de 1879, pero no así con respecto al Derecho Romano ni a las Partidas. En estos sistemas el juzgador podía escoger como acusador al que considerase más fiable, bien por su cercanía al delito, bien en virtud de otra serie de circunstancias. La L. 13 ${ }^{\mathrm{a}}$, T. I, P. VII lleva por título "Como quando muchos quieren acusar a vno de algun yerro, el juez deue escoger el vno dellos, que faga la acusación". En ella se preveía que "Allegandose muchos omes en vno delante del Judgador para acusar a vn ome solo, de vn yerro que dixessen que ouiesse fecho, non deue el Judgador recebir la acusacion de todos, nin el acusado non es tenido de responder a ella. E porende deue el Juez catar, e escoger el vno dellos, el que entendiere que se muеue con mejor intencion, que faga la acusacion, e estonce, al acusamiento de aquel deue responder el acusado...". No se trataría del ejercicio agrupado de una pluralidad de pretensiones, sino del ejercicio de una única acusación por el sujeto elegido.

${ }^{1161}$ Como ya destacara GÓMEZ ORBANEJA, el ejercicio de la acusación por varios sujetos no debe traducirse para el condenado en una multiplicación injustificada de las costas procesales y para la Justicia en un alargamiento
} 
Quienes ven en el ejercicio de la acusación un derecho subjetivo de ciudadanos no ofendidos han entendido que la previsión legal del art. 113 iría dirigida a asegurar la proporcionalidad entre, por un lado, la restricción que con el objeto de evitar perjuicios en el desarrollo del proceso supone la dirección conjunta, y, por otro, el derecho de los actores de utilizar todos los medios para la defensa de su pretensión. Incluso ha sido criticado el precepto por algún sector doctrinal atendiendo a que contendría una discriminación del acusador con respecto al imputado, el cual sí podrá designar libremente al abogado de su elección, por lo que se contradiría el espíritu y la letra del art. $24 \mathrm{CE}^{1162}$.

De conformidad con la doctrina sentada por el $\mathrm{TC}^{1163}$, el derecho a la defensa y a la asistencia de letrado que el art. 24.2 CE reconoce a todos, sería predicable en el ámbito procesal penal no sólo de los acusados, sino también de quienes comparecen como acusadores. Ello comportaría que pudieran encomendar su representación y asesoramiento técnico a quien merezca su confianza y consideren más adecuado para instrumentar su propia defensa. La justificación del art. 113 LECrim se cifraría sólo en la necesidad de reforzar el derecho a un proceso sin dilaciones indebidas, por lo que el órgano jurisdiccional habrá de ponderarlo con el derecho a la defensa y asistencia de letrado. Para que pueda ordenar a las acusaciones personadas en un proceso que actúen bajo una misma dirección y representación, se requiere una suficiente convergencia de intereses e incluso de puntos de vista en la orientación de la actuación procesal que hiciera absolutamente inútil la reiteración de diligencias instadas o actos realizados por sus respectivas representaciones y asistencias letradas ${ }^{1164}$. En caso contrario se produciría una merma del

del proceso por reiteración de actuaciones conducentes a la misma finalidad. GÓMEZ ORBANEJA, E., Comentarios..., op. cit., T. II, vol. I, p. 665 y ss.

${ }^{1162}$ Vid. LORCA NAVARRETE, A. M., Derecho Procesal Penal, Madrid 1986, p. 77. LORCA especifica que en algunos casos el acusador puede ser el ofendido, por lo que debemos entender que la desigualdad a la que se refiere se podrá referir en concretas hipótesis a la existente entre un acusador no ofendido y el acusado. El argumento ha de considerarse endeble, en tanto los intereses que uno y otro ponen de manifiesto en el proceso se sitúan sobre planos tan diferentes que no admiten siquiera comparación.

${ }^{1163}$ SSTC 30/1981 de 24 de julio y 193/1991 de 14 de octubre. Vid. también en el mismo sentido la STS de 7 de diciembre de 1993 (RAJ 10182), en la que se constata una igualdad de planteamientos en el ejercicio de la pretensión por diferentes actores (FD $1^{\circ}$ ).

${ }^{1164}$ STC 30/1981 de 24 de julio y 193/1991 de 14 de octubre. En este último caso se trataba de la concurrencia en la posición acusadora entre un acusador particular víctima de un atentado terrorista y de la acusación popular representada por la "Hermandad de Victimas del Terrorismo". Vid. también STS de 7 de diciembre de 1993 (RAJ 
derecho de defensa ante los tribunales, que difícilmente se justificaría en aras de una economía procesal, puesto que la mayor o menor duración de las sesiones del juicio oral por la intervención de dos o más abogados no guardaría, en opinión del alto Tribunal, relación con el derecho a un proceso sin dilaciones indebidas.

La imposición de una dirección común no implica $a b$ initio vulneración del derecho a defender legítimos intereses, tal y como ocurrirá tratándose de una pluralidad de ofendidos por el delito que expresen su deseo de defender procesalmente su interés propio, o de la concurrencia de sujetos ofendidos y otros que no lo sean ${ }^{1165}$. En supuestos de este tipo no cabría nunca la imposición obligatoria de una dirección y representación conjunta, aun cuando no haya problema en admitirla cuando lo pidan los propios accionantes. En la medida en que pueden existir intereses contrarios entre ellos ${ }^{1166} \mathrm{o}$ discrepancia en la realización de determinados actos, la facultad del instructor de obligar a los diversos acusadores a servirse de una representación y defensa común deberá respetar siempre el derecho a hacer valer sus pretensiones.

Tratándose de una pluralidad de acusadores no ofendidos habrá de advertirse que la representación y dirección comunes son siempre técnica y legalmente posibles, aunque puedan en alguna ocasión no ser convenientes para los propios actores. La actividad de todos ellos irá dirigida siempre a la defensa del mismo interés, el único que pueden hacer valer: el interés público en la persecución de conductas que revistan la apariencia de delito. Ciertamente podrán existir discrepancias en diversos aspectos de la deducción en concreto de la acusación por diversos sujetos no ofendidos, pero el entendimiento de esta cuestión pasa necesariamente por el reconocimiento de que tales divergencias se producen en el ejercicio de la misma facultad, la cual versa además sobre el mismo objeto. El contenido de la habilitación legal a cada uno de los sujetos es exactamente el mismo: la contribución para poner los fundamentos de una declaración de voluntad estatal en la que

10182) en la que se reiteran los argumentos, existiendo en este caso igualdad de planteamientos entre las dos acusaciones.

\footnotetext{
${ }^{1165}$ Tal y como se señala en la STC 193/1991 de 14 de octubre, las posiciones de la acusación particular y de popular no son idénticas pues, mientras el acusador particular en cuanto perjudicado por el hecho delictivo puede acumular el ejercicio de las pretensiones penales y civiles, el no ofendido debe limitarse necesariamente al ejercicio sólo de la penal.

${ }^{1166}$ Advertido ya por REUS, E., Ley de Enjuiciamiento Criminal concordada y anotada extensamente por la Redacción de la Revista de Legislación y Jurisprudencia, 1883, T. I, p. 87.
} 
se imponga la pena a un sujeto si se le llega a considerar más allá de toda duda razonable responsable de la comisión de un delito. No son, por tanto, declaraciones de voluntad individuales con objetivos singulares, para la imposición de condenas independientes, sino contribuciones diversas dirigidas a la eventual materialización en un supuesto concreto el ius puniendi del Estado. Lo que defienden no es ningún derecho específico de cada uno de ellos, sino el único y común interés público, el cual quedará satisfecho con la resolución jurisdiccional que ponga fin al proceso. De ahí que la imposición de defensa y representación conjunta no repercuta en absoluto en su "derecho" a contribuir a la tutela de los intereses generales.

Un correcto desenvolvimiento del proceso, con plena utilización de los medios legalmente previstos para lograr la convicción judicial no requiere la intervención de multitud de acusadores, testigos o peritos. La reiteración de diligencias y trámites innecesarios no supondría en este sentido más que dilaciones e incremento de los costes, por lo que la prudencia del Juez ha de indicar, dentro de la Constitución y, concretamente, del debido proceso (art. 24.2 CE) dónde ha de ponerse la barrera para que éste logre su fin. Si, además, se toma en consideración que en ocasiones el "estrépito" que produzca el proceso podría impedir la clara percepción de sus fines esenciales, la limitación en la representación independiente de la acusación ha de ser entendida como totalmente deseable. De ahí que sea plenamente justificable que el instructor pueda imponer la misma representación y dirección a todos los sujetos no agraviados que acudan al proceso para defender el indivisible interés público en la persecución de los delitos, completando o supliendo de esta manera la deficiencia de la acusación pública ${ }^{167}$. A pesar de su conveniencia, esto no es lo que ordinariamente está ocurriendo en la práctica de nuestros Tribunales. Tal práctica puede acaso ser interpretada como una de las consecuencias del entendimiento doctrinal y jurisprudencial de la acusación popular como ejercicio de un derecho independiente y propio de cada uno de los ciudadanos y no como realización privada de una obligación estatal, que no varía de naturaleza en función del ejercitante y que se satisface por su ejercicio por el obligado a ello. Si en el caso de los ofendidos por el delito la asistencia técnica y la representación autónomas han de entenderse derivadas

${ }^{1167}$ Contra la decisión del instructor de obligar a litigar unidos no cabe recurso, con la natural salvedad del de reforma (art. 217 LECrim). Esta configuración pudiera acaso servir para reforzar nuestra idea de que nos hallamos ante una única posición procesal en la que se pretende la tutela de un mismo interés con independencia de los actuantes. 
del derecho de hacer valer sus intereses, en el de los acusadores populares su intervención independiente no es conceptualmente admisible para satisfacer un derecho propio.

Tampoco habría inconveniente para que la determinación inicial del instructor de obligar a litigar unidos o no a los actores pudiera verse sometida a revisión a lo largo del proceso. Cabe por ello exigir la representación y defensa común a quienes hubiesen empezado por interponer querellas independientes o se hubiesen personado separadamente desde que, según criterio del órgano jurisdiccional, resulte procedente la conducción común del proceso por defender el mismo interés. Dado este supuesto, habrá de concederse un plazo para que se pueda asumir la dirección unificada del proceso ${ }^{1168}$. A la inversa, deberá aquél autorizar o permitir que se valgan de representación distinta los que hubiesen comenzado por litigar unidos, tan pronto como aparezca la incompatibilidad de las posiciones respectivas. Ni en un caso ni en el otro, habrá de considerarse que existirá nueva personación ${ }^{1169}$.

\subsubsection{Contenido}

El contenido de la querella se determina en el art. 277 LECrim al establecer que en ella se expresarán los siguientes extremos:

$\left.1^{\circ}\right)$ El Juez o Tribunal ante quien se presente.

$2^{\circ}$ ) Los datos identificativos del acusador, de forma que pueda ser constatada $a$ limine la legitimación habilitante para el ejercicio de la acusación. Deberá hacerse constar por ello, junto con los datos identificativos, cuando menos la condición de español, la plenitud en el goce de los derechos civiles y una declaración de no hallarse incurso en causa de exclusión de la legitimación por ninguna otra causa.

$3^{\circ}$ ) Los datos identificativos del acusado o, en caso de ignorarse, designación por las señas que mejor pudieren darle a conocer. Es, como se ve, un requisito accesorio y la no individualización del sujeto contra el que se dirija la acusación no puede erigirse en

\footnotetext{
${ }^{1168}$ Habiéndose llegado ya al trámite de calificaciones se habrá de suspender hasta que ésta sea efectiva. GÓMEZ ORBANEJA, E., Comentarios..., op. cit., T. II, vol. I, p. 669.

${ }^{1169}$ GÓMEZ ORBANEJA, E., Comentarios..., op. cit., T. II, vol. I, p. 667.
} 
obstáculo para la admisión de la querella ${ }^{1170}$.

Mientras que en el proceso civil es demandado aquel sujeto contra el que se dirige la demanda, en el penal no se verá sometido al proceso el querellado, sino el inculpado objeto de la actuación judicial ${ }^{1171}$. De ahí que, aunque la querella se interponga contra un sólo sujeto, no se excluya la posibilidad de que las actuaciones procesales se dirijan también frente a otros ${ }^{1172}$. Indudablemente la querella está transmitiendo así la notitia criminis, creando la obligación de incoar las actuaciones tendentes a la investigación de los hechos individualizados y/o de los resultantes de las averiguaciones. Quizá tal amplitud, aun subjetiva, explique el que en la práctica forense se suela hacer constar en todas las querellas la coletilla de que se dirigen, aparte de los designados en ellas, "contra todos aquellos que en el curso de la tramitación de la causa hubieran tenido participación en tales hechos como autores, cómplices o encubridores" $" 1173$. Ello no es en rigor necesario para su admisibilidad, por cuanto la descripción objetiva como la delimitación subjetiva contenidas en la querella son solamente provisionales ${ }^{1174}$.

Puesto que en este momento no es imprescindible la formulación de una imputación contra un sujeto en concreto, el problema se suscitará teniendo en cuenta que de la identidad del acusado puede derivarse la ausencia de legitimación para el ejercicio de la acusación popular por parentesco (art. 103 LECrim) o, tratándose de un menor delincuente, por la imposibilidad de acusar de manera privada en la Jurisdicción de menores. Otra cuestión que dependerá en ocasiones de la identidad del inculpado es la competencia en los supuestos de aforamiento, en tanto a tenor del art. 272.II LECrim, si el querellado estuviese sometido a determinado Tribunal, será ante éste donde tenga que

${ }^{1170}$ En sentido contrario vid. SAP Bilbao de 12 de abril 1988 (publicada en La Ley 1988, T. 3, p. 702 (10673-R), en la que se afirmaba que "la querella, al contrario que la denuncia, se dirige contra persona determinada".

${ }^{1171}$ GÓMEZ ORBANEJA, E., Comentarios..., op. cit. T. II, p. 198.

${ }^{1172}$ Debiéndose atender en este caso los presupuestos del art. 118 LECrim en orden a la garantía del derecho de defensa de los sujetos sometidos a investigación criminal.

${ }^{1173}$ SALOM ESCRIVÁ, J.S., “La querella”, op. cit. p. 420.

${ }^{1174}$ No se ve alterada esta afirmación en el art. 24 LOTJ, pues no puede ni debe ser imputado en sentido estricto sólo el indicado en la querella, sino el sujeto respecto del que estime verosímil el Juez la inculpación, así como a la persona o personas determinadas para las que de cualquier actuación procesal resulte la imputación de un delito. Para el título de imputación, por tanto, ni es condición necesaria ni suficiente su determinación en la querella. 
interponerse la querella. De igual manera ocurrirá cuando fueran varios los querellados por un mismo delito o por dos o más conexos, y alguno de aquéllos estuviese sometido excepcionalmente a la competencia de un Tribunal que no fuere el llamado a conocer por regla general del delito (art. 272.III LECrim).

$\left.4^{\circ}\right)$ Relación circunstanciada del hecho en que se concreten los datos para su averiguación. No es precisa su calificación jurídica, puesto que todavía no estamos ante un escrito de acusación, sino que bastará con la mera descripción material del factum, transmitiéndose así la notitia criminis con los elementos fácticos que puedan ser necesarios para la determinación de las circunstancias del hecho criminoso. Se pone pues así en conocimiento del órgano jurisdiccional no sólo la sospecha de comisión de una conducta constitutiva de delito ${ }^{1175}$, sino la afirmación cierta del acaecimiento de unos hechos que pudieran llegar a serlo previa declaración por sentencia. De la valoración que el instructor haga de esta relación y de la existencia en ella de hechos que prima facie puedan ser considerados constitutivos de delito se derivará su fundabilidad con el objeto de iniciar la investigación ${ }^{1176}$. Este requisito acerca sustancialmente las características de la querella a las de la denuncia, en tanto ambos son mecanismos válidos para la transmisión de la notitia criminis y eventualmente hábiles para posibilitar la iniciación del procedimiento penal. Es por ello factible incluso el que una querella carente de los demás requisitos formales pueda transformarse en denuncia ${ }^{1177}$.

En la práctica, y aun cuando no sea necesario, la querella se suele acompañar de elementos que puedan contribuir a afianzar la fiabilidad de lo en ella afirmado. No obstante, es obligación del instructor hacer acopio de todos aquellos medios aconsejables para el esclarecimiento de los hechos.

$\left.5^{\circ}\right)$ Las diligencias que se deberán practicar para la averiguación del hecho. No son

${ }^{1175}$ En este sentido vid. GIMENO SENDRA, V., La Querella, op. cit. p. 237.

${ }^{1176}$ Cuando se trate de la imputación de un delito cuyo enjuiciamiento venga atribuido al Tribunal del Jurado, a la vista de la relación circunstanciada del hecho en la querella y previa valoración de su verosimilitud, podrá el Juez de Instrucción dictar resolución de incoación del procedimiento para el juicio ante el Tribunal del Jurado (art. 24.1 LOTJ).

${ }^{1177}$ GIMENO SENDRA, V., La Querella, op. cit. p. 237. Tal y como resalta TORRES ROSELL, para que esta transformación pueda ser efectiva es menester que el acto procesal respete los mínimos presupuestos y requisitos de la denuncia, ya que en otro caso habrá de entenderse que la noticia delictiva ha sido adquirida de oficio. TORRES ROSELL, N., La denuncia en el proceso penal, Madrid 1991, p. 423. 
peticiones propias de la personación, sino verdaderos actos integrados en el ejercicio de la acusación. No es imprescindible en este momento procesal la descripción de las diligencias a realizar, sino que su especificación entrará dentro de las facultades del acusador. De su ausencia o de su insuficiente configuración no puede predicarse la imposibilidad para el instructor de decretar las que estime adecuadas a los fines de la averiguación si no las hubiere realizado ya. El Juez practicará las que estime pertinentes y denegará mediante resolución motivada las que considere contrarias a las leyes, inútiles, innecesarias o perjudiciales para el objeto de la querella (art. 311 y 312 LECrim) ${ }^{1178}$.

No se habrá de instar en la querella ni el procesamiento ni la punición del presunto autor del delito, pues no es ni momento procesal para ello ${ }^{1179}$, ni entra en su propia esencia. La querella, se ha dicho, se dirigirá únicamente a contribuir en la preparación de los elementos necesarios para que, en su caso, se llegue a dictar una resolución jurisdiccional de condena, pero las peticiones en este sentido no son inherentes a ella ${ }^{1180}$. A nuestro juicio, la querella se circunscribe a afirmar que concurren los presupuestos exigibles a fin de incoar un proceso por mor de unos hechos permisivos del enjuiciamiento de un sujeto determinado o determinable.

Durante la instrucción cabe la presentación de escritos complementarios, conocidos como "escritos de ampliación de la querella", pidiendo nuevas diligencias o aportando distintos elementos fácticos. Éstos no son más que la consecuencia de la posición procesal que ha adquirido el acusador y que le permite ir perfilando mediante su actividad los términos en los que deduce la pretensión penal.

$\left.6^{\circ}\right)$ Petición de que se admita la querella, se practiquen las diligencias del número anterior y se adopten las medidas cautelares necesarias para la garantía del desarrollo del proceso $^{1181}$. En el cumplimiento de este requisito se cifra una de las principales

${ }^{1178}$ Vid. STC $351 / 1993$ de 29 de noviembre FJ. $2^{\text {o }}$ y $6^{\circ}$ y ATC 442/1985 de 3 de julio.

${ }^{1179}$ Así se pronuncia GIMENO SENDRA, V., La Querella, op. cit. pp. 244 y ss., recogiendo también la doctrina contraria.

${ }^{1180}$ GIMENO SENDRA, V., “La fianza...”, op. cit. p. 64.

${ }^{1181}$ El precepto se refiere específicamente a la detención y prisión del presunto culpable o fianza de libertad provisional y al embargo de sus bienes. Advertía GIMENO con respecto a la solicitud de tan graves medidas cautelares, y sin perjuicio del «rancio abolengo» del que gozan en la práctica forense, que no constituye requisito alguno de la querella ni puede, en la mayoría de las ocasiones, el juez acceder a ellas por su carácter prematuro y la conveniencia de practicar otras diligencias (fundamentalmente la de tomar declaración al querellado). GIMENO 
diferencias de la querella con la denuncia, ya que si en ésta hay un deseo implícito de que se inicie el proceso, en la querella tal manifestación de voluntad debe realizarse de forma explícita. Sin embargo, a nuestro juicio, esta exigencia es matizable: en la denuncia, como en la querella se estima necesaria y se pretende una actuación judicial con la diferencia de que, en la querella, además, se individualizan hecho y eventualmente sujetos querellados y la persona del querellante a efectos de la participación de éste como sujeto concreto en el proceso que en su opinión ha de abrirse.

Señala GIMENO que, pese al deseo de exhaustividad latente en la redacción de la norma, el legislador olvidó incorporar el requisito más importante, cual es la petición de que "se tenga al querellante como parte acusadora" 1182 . Tal petición ha de entenderse sin embargo realizada con la propia interposición de la querella, pues su objetivo es precisamente deducir acusación por el sujeto activo, por lo que tácitamente ha de entenderse realizada siempre.

$7^{\circ}$ ) La firma del querellante cuando el Procurador no tuviere poder especial para formular querella. En la práctica judicial se exige también la ratificación de la querella por el actor, tratando de asegurar que el querellante haga suyo en su plenitud el contenido, incluida la voluntad de personarse como "parte acusadora"1183. La exigencia de este requisito es totalmente cuestionable cuando se acompañe la querella de poder especialísimo ${ }^{184}$, aun cuando en algún caso se haya considerado requisito esencial incluso cuando tras un apoderamiento apud acta ${ }^{1185}$.

SENDRA, V., en la obra colectiva Derecho Procesal Penal, Madrid 1996, pp. 298 y ss.

${ }^{1182}$ GIMENO SENDRA, V., Derecho Procesal Penal, op. cit. p. 298; SALOM ESCRIVÁ, J.S., "La querella", op. cit. p. 424.

${ }^{1183}$ GIMENO SENDRA, V., La Querella, op. cit. p. 191. Ello se hace en concordancia con la vieja doctrina jurisprudencial que convertía la ratificación en un trámite de inexcusable observancia. Vid. las SSTS de 21 de febrero de 1966 (RAJ 1565) y de 21 de octubre de 1969 (RAJ 5121) en un caso de injurias y calumnias, en las que se sostiene que hasta la ratificación del querellante no puede decirse que su firma "sea suya sin que el propio interesado lo manifieste". No debe olvidarse, empero, que el querellante sólo ha de firmar si el poder no es especialísimo, luego la ratificación únicamente es menester con el general o especial, hipótesis en las que es comprensible la exigencia de ratificación: el escrito de querella vendrá firmado por el querellante, con lo que servirá para confirmar que verdaderamente se trata de su firma.

${ }^{1184}$ GIMENO estima con razón que en tal supuesto la ratificación sería superflua. GIMENO SENDRA, V., "La Querella”, op. cit. p. 190.

${ }^{1185}$ En este sentido SALOM ESCRIVÁ, J.S., "La querella”, op. cit. p. 430. 


\subsubsection{7. Órgano competente}

El art. 272 LECrim. establece que la querella se deducirá "ante el Juez de Instrucción competente". Será por tanto habitualmente ante el del partido en el que los hechos se hubieren cometido, pero también ante el Juez Central de Instrucción respecto a los delitos que la ley determine (art. 14.2 ${ }^{\circ}$ LECrim) ${ }^{1186}$, o incluso en los casos de aforamiento del querellado (o de alguno de ellos) ante el Tribunal competente para la instrucción (Sala 2a del TS o Sala de lo Civil y Penal de los TSJ) ${ }^{1187}$.

Una vez personado en la causa y antes de formular otras peticiones, el acusador popular podrá legítimamente promover y sostener cuestiones de competencia (art. 19.5 LECrim) $)^{1188}$.

La interposición de querella ante Juez no competente es sancionada en el art. 313 LECrim con su inadmisión ${ }^{1189}$. No obstante, si fuese dirigida a Juez no competente por razón del territorio, aunque éste no tendrá por parte acusadora al querellante, no podrá

${ }^{1186}$ El art. 273 LECrim establece ciertas excepciones, pero no en relación con la interposición de querella, sino para la realización de las primeras diligencias necesarias para hacer constar la verdad de los hechos y para detener al delincuente. Se trata de los supuestos de delitos flagrantes o de los que no dejan señales permanentes de su perpetración, o en que fuere de temer fundadamente la ocultación o fuga del presunto culpable.

${ }^{1187}$ La Sala de lo Penal del TS conocerá de la instrucción y enjuiciamiento de las causas contra el Presidente del Gobierno, Presidentes del Congreso y del Senado, Presidente del TS y del CGPJ, Presidente del TC, miembros del Gobierno, Diputados y Senadores, Vocales del CGPJ, Magistrados del TC y del TS, Presidente de la AN y de cualquiera de sus salas y de los TSJ, así como los Magistrados de éstos, Fiscal General del Estado, Fiscales de Sala del TS, Presidente y Consejeros del Tribunal de Cuentas, Presidente y Consejeros del Consejo de Estado y Defensor del Pueblo, así como de las causas que, en su caso, determinen los Estatutos de Autonomía (art. $572^{\circ}$ y $3^{\circ} \mathrm{LOPJ}$ ). La Sala de lo Civil y Penal de los TSJ de las CCAA conocerá como Sala de lo Penal de la instrucción y el fallo de las causas penales contra Jueces, Magistrados y miembros del MF por delitos y faltas cometidos en el ejercicio de su cargo en la Comunidad Autónoma, siempre que esta atribución no corresponda al TS (art. 73.3.b LOPJ).

${ }^{1188}$ En esta previsión ha visto LORCA NAVARRETE el primer precepto que, con afán de sistematización, se realiza por el legislador de la LECrim en un "intento de enumerar las distintas partes en el proceso penal". De ello deduce que el acusador particular no es una parte "inventada" por la doctrina sino reconocida por la Ley. Vid. LORCA NAVARRETE, A.M., Derecho Procesal Penal, p. 75.

${ }^{1189}$ Debe advertirse que tal norma equipara inexistencia de delito e incompetencia, cuando en verdad son distintas y diferentes las consecuencias: si el hecho no es constitutivo de delito ha de desestimarse, pero si el Juez se considera incompetente debe inadmitir, sin entrar por tanto en el fondo del tema en el segundo caso, pero sí en el primero. 
ignorar la notitia criminis contenida en la relación circunstanciada de los hechos ${ }^{1190}, \mathrm{y}$ deberá remitirla de oficio al Juez competente o realizar las actuaciones necesarias para hacer constar la verdad de los hechos y detener, en su caso, al presunto autor.

\subsubsection{Personación del acusador popular sin interposición de querella}

A tenor de lo dispuesto en el art. 270 LECrim, el ejercicio popular de la acusación habrá de realizarse en forma de querella ${ }^{1191}$. Se han suscitado dudas en relación con la regulación legal del Procedimiento Abreviado, apoyadas en la dicción del párrafo $2^{\circ}$ del art. 783 LECrim, el cual exime de interposición de querella al ofendido y perjudicado una vez cumplido el trámite de los arts. 109 y $110^{1192}$, sin que se contenga previsión expresa alguna con respecto al acusador no ofendido. De la interpretación a sensu contrario del art. 783.II LECrim se ha inferido mayoritariamente no obstante la conclusión de que, en tanto el acusador particular puede comparecer en la fase instructora sin necesidad de formular escrito de querella, ello le estaría vedado al popular, el cual necesariamente habría de deducirla a tenor de lo dispuesto en el art. 270.1 LECrim ${ }^{1193}$. Nuestro criterio es concordante a este respecto, y entendemos que la norma claramente aplicable al acusador

${ }^{1190}$ Vid. STS de 9 de diciembre de 1982 (RAJ 7389), aun cuando se trate de un delito semipúblico.

${ }^{1191}$ También el art. 2 del RDL de 13 de junio de 1927 relativo a normas para el ejercicio de las acciones penales (Derogado por Decreto de 31 de mayo de 1931 de revisión de la obra legislativa de la Dictadura) exigía que cuantos pretendieran ser admitidos como parte en un sumario, ya fueran o no ofendidos o perjudicados por el delito, no se limitarán a hacer manifestación de que desean ser parte, sino que habrían de ejercitar su acción en forma de querella con los requisitos del art. 277 LECrim.

${ }^{1192}$ En ellos no se recoge claramente esta posibilidad, pero tampoco se prohíbe de forma expresa. Por ello, en alguna ocasión con anterioridad a la introducción del art. 783.II fue defendida la tesis de que, por no tratarse de un acto de iniciación procesal, no sería imprescindible la querella para la personación en el procedimiento. Vid. GONZÁLEZ DE ALBA, P., "El derecho de acusación como función de ciudadanía”, $R G L J$ n$^{\circ} 115$ (1909), p. 49. Tal y como fue advertido por GÓMEZ ORBANEJA, E., Comentarios..., op. cit. T. II, p. 609, la ley mantiene sin embargo el término "querellante" en relación con el personado en el proceso, aun sin haber interpuesto aquella en la debida forma (p. ej. arts.642, 644 y 645). Lo que vino a hacer el art. 783 en 1988 fue sancionar lo que ya era práctica habitual en muchos juzgados que no exigían querella para que el imputado se mostrara parte en la causa.

${ }^{1193}$ Así GIMENO SENDRA, V., en MORENO CATENA, V., et. al., El nuevo Proceso Penal. Estudios sobre la LO 7/1988, Valencia, 1989, p. 106; PORTERO GARCÍA, L., REIG REIG, J. V. MARCHENA GÓMEZ, M., Comentarios a la Reforma procesal penal de la LO 7/1988 (Procedimiento Abreviado), 2a ed., Bilbao 1989, p. 35; FERNÁNDEZ ENTRALGO, J., en "Principios procesales y procedimentales”, op. cit., p. 20; ORTELLS RAMOS, M., "Las partes no oficiales en el proceso penal abreviado", op. cit., p. 2. 
no ofendido ni perjudicado es la del art. 783.I, que le obliga a acomodarse a las exigencias del libro III, capítulo $2^{\circ}$ LECrim, lo cual vendría además confirmado en el comienzo del segundo párrafo que dice "Sin perjuicio de lo que se dispone en el párrafo anterior...". Con base en la literalidad de la ley, por tanto, y dada la diferente naturaleza de acusación particular y popular, esa exención, que en el caso del ofendido cuenta hoy con el apoyo doctrinal prácticamente unánime ${ }^{1194}$, en el caso de quien sin serlo pretenda acusar, puede ser percibido por tanto como una corruptela procesal ${ }^{1195}$.

Se ha afirmado también que, en tanto con la acusación popular se estaría ejercitando una acción propia con un contenido diverso al de la iniciación del proceso (la personación en él), se precisaría necesariamente la querella aun si la fase de instrucción (sumario o diligencias previas) ya hubiera comenzado. Por la mera personación sin querella no existiría ejercicio de la acción como tal en los términos legalmente previstos y no cabría al posible acusador ejercicio de pretensión alguna ${ }^{1196}$. En una notoria y justificada declaración de desconfianza hacia el ejercicio cívico de la acusación, la FISCALÍA GENERAL DEL ESTADO advertía que podría darse fácilmente el supuesto de que, en un gesto de colaboración sobrevenido que albergase motivaciones ajenas a las de contribuir al esclarecimiento y castigo del delito, "con un mero escrito de personación al amparo del art. 101 LECrim y obviando la interposición de querella, (...) sin necesidad de conocer el asunto ni informarse debidamente cualquier ciudadano podría penetrar en el proceso y exigir que se le diese vista de lo actuado, deduciendo las peticiones que estime oportunas en abierto fraude de ley". Aun iniciado el procedimiento, la interposición de querella con todos los requisitos a ella inherentes debe ser juzgada

${ }^{1194}$ Aun cuando el apoyo no haya sido siempre explícito. GÓMEZ ORBANEJA afirmaba que la mera petición del particular de que se le tenga por parte en la causa, con arreglo al art. 110 no sería en rigor un acto de ejercicio de la acción en vista del 270, sino preparación para él en el procedimiento ya promovido ex officio o a instancias de otra persona. Comentarios..., op. cit. T. II, p. 224. GIMENO lo denomina "acción penal adhesiva" y, a su juicio tampoco sería ejercicio de la "acción penal", ya que ésta se concreta y se agota al excitar la actividad jurisdiccional. GIMENO SENDRA, V., La Querella, op. cit. p. 51. El mismo autor la encuadra dentro del modelo austriaco en "La acusación popular", $P J, \mathrm{n}^{\circ} 31$ sept. 1993, op. cit. p. 91. Vid también la STC de 18 de octubre 1990 y la STS 25 de octubre 1993, que admiten la personación de perjudicados en el proceso penal iniciado para defender sus derechos sin necesidad de ejercitar querella alguna.

\footnotetext{
${ }^{1195}$ Vid. por ejemplo MAJADA, Práctica procesal penal..., op. cit., p. 122, donde tal práctica es calificada como inadmisible.

${ }^{1196}$ MONTERO AROCA, J., Derecho Jurisdiccional, T. III, p. 62. En el mismo sentido MAJADA, Práctica procesal..., cit. p. 122 y MUERZA ESPARZA en el manual Derecho Procesal Penal con DE LA OLIVA, et al. p. 134.
} 
imprescindible para asegurar una mínima fiabilidad en el ejercicio de la pretensión ${ }^{1197}$.

No obstante lo expuesto, la obligatoriedad para los no ofendidos de deducir la pretensión penal a través de la querella ha sido en algún momento interpretada como una discriminación frente a su inexigencia a los agraviados por el delito, lo cual la haría merecedora de censura ${ }^{1198}$. Quizá por ello, la jurisprudencia ha parecido decantarse en la actualidad por su inexigibilidad para la personación no sólo del ofendido ${ }^{1199}$, sino también del acusador popular cuando el proceso esté ya pendiente. La querella se configura así únicamente como mecanismo de iniciación procesal, que carece de sentido una vez puesto en marcha el proceso, con lo que se le priva de una nota esencial propia de su naturaleza consistente en alzarse como elemento formal de garantía de fiabilidad. Se demuestra así mayor coherencia con la identificación que para otros aspectos se opera entre acusadores ofendidos y no ofendidos, entendiendo que activado el ejercicio de la pretensión penal de cualquier forma que sea, la nueva interposición de querella no tendría mayor valor que el de una mera redundancia. En este sentido se han pronunciado, por ejemplo, la STS de 12 de marzo de 1992 (RAJ 2084), a tenor de cuya doctrina un acusador popular puede incorporarse al proceso sin necesidad de querella ni fianza ${ }^{1200} \mathrm{O}$ la STS de 3 de junio de 1995 (RAJ 4535) en la que el alto Tribunal afirmaba que "una vez incoada la causa penal los requisitos exigibles de querella y presentación de fianza ceden

${ }^{1197}$ Memoria de la FGE 1989, p. 318. En idéntico sentido, pero sin mostrar esa desconfianza hacia la acusación popular, ORTELLS RAMOS, M., “Las partes...”, op. cit. p. 2.

${ }^{1198}$ Así GIMENO SENDRA, V., La Querella, op. cit. p. 91, en relación con la posibilidad de que el ofendido o perjudicado comparezca tras el "ofrecimiento de acciones" sin necesidad de querella y el no ofendido tenga que deducirla obligatoriamente. A nuestro juicio esta exigencia no puede en ningún caso considerarse discriminatoria, pues no hace más que dar respuesta desigual a dos realidades diversas.

${ }^{1199}$ SSTS 25 de octubre de 1993 (RAJ 7957).

${ }^{1200}$ En opinión de la Sala "el legislador -tratándose de delito público- no ha limitado la acción popular al derecho de pedir la incoación del proceso penal mediante querella sino que ha permitido ejercitarla en las causas ya iniciadas personándose en los términos prevenidos en el art. 110 LECrim, es decir mostrándose parte como adhesión, en nombre de la ciudadanía, a un proceso pendiente, sin dejar condicionada la eficacia de la acción penal a la formulación de la querella" (FD $1^{\circ}$ ). En este supuesto la cuestión era trascendente, dado que la condena se dictó tomando como única base la pretensión acusatoria del acusador popular, por lo que de haberse constatado la inexistencia de un vicio $a b$ origine de ésta, el pronunciamiento hubiera debido ser absolutorio. En sentido aparentemente contrario se había pronunciado entre otras la STC 157/1990 de 18 de octubre, FD. 4: “(...) la jurisprudencia de este Tribunal ha precisado que el ejercicio de la acción penal, al menos en el primer estadio procesal, ha de realizarse por medio de la correspondiente querella, pues la inicial denuncia de los hechos no supone el ejercicio de la acción penal, ni constituye en parte al que la formula (SSTC 115/1984 y 173/1987, y AATC 132/1981 y 789/1986, entre otros". 
al poderse considerar la personación como simple intervención procesal adhesiva o de coadyuvante" (el subrayado es nuestro) ${ }^{1201}$. No podemos pasar por alto que la jurisprudencia con tal práctica uniformadora de las acusaciones particular y popular está revelando con su "lenguaje intervalar" el verdadero papel a cumplir por ambas: completar o suplir a la acusación pública.

Desde otra perspectiva, todo lo expuesto no hace más que poner al descubierto una vez más la concepción del legislador originario, en la que no se veía en el ejercicio de la querella para hacer valer el interés público un derecho absoluto. La facultad de ejercitar la "acción penal para el castigo de los delitos" operaría sólo en tanto ningún otro sujeto la hubiera deducido ya. La personación del acusador popular requería como presupuesto ineludible el cumplimiento del requisito formal de la interposición de querella, en tanto éste era el instrumento para deducir la acusación. Pero además ha de reconocerse que la personación procesal y la adquisición de la condición de acusador llevan aparejadas importantes consecuencias en orden a la responsabilidad y a la intervención en todas las diligencias, por lo que el establecimiento de este requisito debe ser interpretado no sólo ya como mera formalidad para la iniciación del procedimiento, sino como un exigible aval de garantía. La acusación de los particulares no ofendidos deberá, por tanto, aparecer siempre en forma de querella, incluso en el procedimiento abreviado donde no es exigible a los ofendidos, sin que ni un mero escrito de personación manifestando la voluntad en este sentido, ni la mera denuncia puedan considerarse válidos ni suficientes ${ }^{1202}$.

\subsubsection{Admisión}

\subsubsection{El régimen de la admisión}

I.

${ }^{1201}$ En este caso se trataba de la personación del Abogado del Estado en causa seguida por delito contra el patrimonio histórico español sin el cumplimiento de los requisitos exigibles para el ejercicio popular de la acusación. El TS no entró a considerar la condición de la Administración como perjudicada o no por el delito, aunque estimaba que su interés excedía el de los simples particulares, con lo que parecía reconocerle un interés específico relacionado con el bien jurídico material atacado, por otra parte evidente.

${ }^{1202}$ La simple denuncia no es ejercicio de querella ni constituye en parte al denunciante. Vid. SSTC $115 / 84$ de 3 de diciembre, 173/87 de 3 de noviembre y AATC 132/81 de 4 de diciembre de 1981 y 789/86 de 15 de octubre. 
La vinculación que se viene realizando entre el ejercicio de la acusación por particulares y un derecho a la defensa de intereses propios, independientemente de ostentar la condición de ofendidos por el delito o no, ha originado un excesivo celo en la contemplación de las causas de inadmisión de la querella interpuestas por acusadores populares. Una reiterada, prolongada en el tiempo y, a nuestro juicio, errónea jurisprudencia ha venido declarando que los motivos contenidos en el art. 313 LECrim serían un numerus clausus de causas de inadmisión, que sólo cabría cuando los hechos objeto de la querella no fueran constitutivos de delito o cuando el órgano jurisdiccional no se considerase competente. Como ya destacara GIMENO, tal error procedería de las deficiencias técnicas de la LECrim pues, a pesar de la dicción del precepto citado, es claro que de los propios términos del cuerpo legal se deduce que la querella ha de ser repelida también en otras hipótesis ${ }^{1203}$. Eso es lo que ocurrirá, por ejemplo, cuando no se satisfagan los requisitos del art. 277 LECrim o cuando el querellante carezca de legitimación activa para acusar, bien por encontrarse en alguno de los supuestos de los arts. 102 y 103 LECrim, bien por no ser el ofendido cuando se trate de un delito privado (art. 104 LECrim).

Además, no cabe hacer una interpretación aislada del art. 313 LECrim, pues de ella se deduciría un entendimiento tergiversado de lo pretendido por el legislador. El art. 312 LECrim se refiere a que la querella sólo será admitida "si fuera procedente", habilitando el artículo siguiente al Juez a desestimar la querella en dos supuestos concretos. Parece lógico, por tanto, reconocer que para el legislador cabían otras causas de rechazo de la querella diferentes a las establecidas en este último precepto. La procedencia de la querella se erige de esta forma en requisito previo para su tramitación, el cual precisa una valoración en el plano procesal por el juzgador antes de entrar al fondo de la cuestión. El Juez habrá de examinar en primer lugar si es admisible por cumplir los requisitos esenciales establecidos por las normas procesales, para determinar, sólo posteriormente, si es idónea para cumplir su cometido por reunir en ella los elementos materiales requeridos, pronunciándose a primera vista sobre la existencia de motivo para la puesta en marcha del aparato judicial ${ }^{1204}$. La admisión de una querella frente a un sujeto produce efectos

${ }^{1203}$ GIMENO SENDRA, V., La Querella, op. cit. pp. 277 y ss.

${ }^{1204}$ Lo que ha podido inducir al error consolidado en la actualidad pudiera ser la mutilación que sufrió el art. 222 de la primitiva LECrim de 1872 al convertirse en el 312 de la de 1882. En el primero se especificaba que "cuando se 
demasiado trascendentes para que pueda venir determinada exclusivamente por la voluntad de cualquier particular, incluso sin vinculación con el hecho presuntamente delictivo. Para su admisión de la querella y su no desestimación será menester, pues, un doble análisis consistente en primer lugar en un juicio de admisibilidad y en segundo en un examen provisional sobre la fundabilidad ${ }^{1205}$.

\section{II.}

El órgano jurisdiccional instructor tendrá que realizar de oficio un análisis sobre la procedencia de la querella, valorando con carácter previo a su admisión la concurrencia de los presupuestos procesales y la inexistencia de impedimentos para ella. La decisión a adoptar implicará necesariamente un examen cuando menos sobre las siguientes cuestiones:

a) Legitimación del acusador: el instructor deberá constatar que el sujeto que pretende constituirse en acusador sin ser ofendido tiene conferida la facultad de acusar, es decir, si es español y si no se encuentra excluido por los motivos de los arts. 102, 103 y 104 LECrim.

b) Inexistencia de impedimentos procesales: el Juez habrá de examinar la no concurrencia de circunstancias que determinen la imposibilidad de proceder en un supuesto concreto. Puesto que no parece conveniente hacer resonar el strepitus fori que puede llevar consigo la admisión de una querella si sobre ésta, ya prima facie, se percibe la presencia de un impedimento que determine el que no vaya a ser posible continuar con

presentare la querella en la forma y con los requisitos prevenidos en esta ley, el Juez de Instrucción después de admitirla, si fuere procedente, mandará practicar las diligencias que en ella se propusieren...". Pero en el texto actualmente vigente el inciso subrayado ha desaparecido, induciendo a la confusión reinante en la actualidad. Quedaba clara así la necesidad de que el instructor realizara un juicio de admisibilidad antes de ordenar la práctica de diligencias. A pesar de la supresión de la coma que separaba la expresión "si fuera procedente" y de la del inciso subrayado, sigue siendo evidente que la improcedencia de la querella puede erigirse en causa de inadmisión antes de entrar a analizar si el hecho constituye o no delito o si el juez es o no competente.

${ }^{1205}$ Seguimos así la distinción realizada por FAIRÉN entre admisibilidad y fundabilidad de los actos procesales como los dos momentos que han de estar presentes en la actividad del Juez a la hora de estimar cualquier petición de las partes. Una petición será admisible cuando reúna las condiciones de que depende el examen de su contenido y estará fundada cuando por su contenido sea adecuada para producir la resolución judicial que se cita. Vid. FAIRÉN GUILLÉN, V., "Prueba documental, prueba pericial y resoluciones sobre las mismas” en Temas..., op. cit. T. II, pp. 852 y ss. 
el enjuiciamiento, habrá supuestos en que quepa inadmitir la querella como improcedente. No sólo razones de economía procesal lo aconsejan, sino también la necesidad de evitar al querellado más molestias de las estrictamente necesarias. Tales supuestos podrán ser:

1) Falta de Jurisdicción de los Tribunales españoles a tenor de lo previsto en el art. 23 LOPJ.

2) Existencia de una resolución con fuerza de cosa juzgada sobre la cuestión (sentencia o auto de sobreseimiento) que impida la apertura de nuevo del procedimiento.

3) Litispendencia de la causa en el mismo o en otro juzgado, que debería originar la inadmisión de la querella.

No podemos pasar por alto en este momento una cuestión que consideramos determinante en relación con la admisibilidad de las querellas. Puesto que la litispendencia constituye fundamento suficiente para la inadmisión, una vez abierto un proceso y deducida pretensión penal por cualquier sujeto habilitado, la intervención de otras personas como acusadores sería totalmente superflua siempre que se realizase con el objeto de defender el mismo interés público en la persecución de las conductas reputadas delictivas. Apreciar litispendencia supone reconocer que la acusación ha sido deducida por otro sujeto, por lo que una nueva querella de otro valedor de idéntico interés carece de toda razón de ser. Si el ordenamiento jurídico no concede un derecho ilimitado de acceder a la Jurisdicción en abstracto, y puesto que con la querella de un no ofendido no se defiende un interés propio sino que se hace uso de una facultad procesal para defender el interés público, ésta sólo tendrá que ser admitida cuando sirva para la función a la que viene destinada: el ejercicio de la pretensión penal. Si ésta ha sido ya deducida, podrá entenderse agotado el objeto que constituye la facultad de los ciudadanos consistente en acusar. Consecuencia de lo afirmado sería el que una vez personado uno de los sujetos autorizados por la Ley, sólo él y ningún otro podría ser acusador a lo largo de todo el proceso.

c) La satisfacción de requisitos formales en la interposición de la querella, tales como la falta de identificación del querellante, de adecuada representación procesal, de ratificación cuando ésta sea precisa, de depósito de fianza, etc. En este caso no nos encontramos antes verdaderos presupuestos de la interposición de la querella, sino sólo ante condiciones resolutorias de su admisibilidad. De no ser satisfechos plenamente, el instructor podrá conceder un plazo de tiempo para su subsanación, transcurrido el cual la 
querella habrá de entenderse inadmitida.

Estimada la improcedencia de la querella al amparo del art. 312 LECrim, ésta será inadmitida mediante auto que contendrá una motivación siquiera mínima (art. 245.1 b) y 248.2 LOPJ). Esta resolución podrá ser recurrida en reforma ante el instructor (art. 217 y 219 LECrim) y en queja ante la Audiencia (art. 218 inciso $1^{\circ}$ y 219 LECrim), con la especialidad para el procedimiento abreviado de tener que agotar el recurso de reforma previamente a la interposición del de queja $\left(787.1^{\circ} \mathrm{LECrim}\right)$.

\section{III.}

De considerar procedente la querella, mandará el instructor practicar las diligencias que estime necesarias, propuestas o no por el querellante, y entrará en el examen del contenido material de la querella para valorar a limine su fundabilidad. De esta manera tendrá que apreciar:

a) $\mathrm{Si}$ es el órgano competente. Interpuesta la querella ante un Juzgado de Instrucción, podrá éste considerarse incompetente por estimar bien que no es el del lugar de la comisión del delito o bien que su conocimiento corresponde al Juzgado central de Instrucción, a otro órgano jurisdiccional por tratarse el imputado de persona aforada, a la Jurisdicción de Menores o a la Jurisdicción militar.

b) Si los hechos contenidos en la querella se presentan como merecedores del reproche penal. El instructor examinará si, al menos en apariencia, existe el deber del Estado de perseguir las conductas socialmente dañosas para con los bienes jurídicos protegidos por la norma penal. Podrá apreciar de esta manera si existe una manifiesta falsedad en la querella ${ }^{1206}$, si se ha extinguido la responsabilidad criminal al amparo del art. $130 \mathrm{CP}$ (por muerte, indulto, perdón del ofendido en los supuestos en que surta este efecto o prescripción del delito) o si los hechos relatados no son constitutivos de delito. Se determinará así a limine la inexistencia del ius puniendi, por lo que no sólo la querella, sino también el propio proceso carecerían de objeto.

Este examen sobre las circunstancias materiales del delito ha suscitado dudas entre la doctrina y la jurisprudencia concernientes a si la admisión por el instructor de una

\footnotetext{
${ }^{1206}$ Vid. MAJADA, Práctica Procesal Penal, T. II, p. 1123, y su equiparación del régimen de la querella a lo previsto en el art. 269 LECrim para la denuncia.
} 
querella determinará una quiebra de su imparcialidad objetiva, de manera que por ese mero hecho le estuviera vedada la posibilidad de dictar la sentencia. Tal y como destaca SALOM ESCRIVÁ, la voluntad del legislador expresada en el segundo inciso del art. 313 LECrim determina que la admisión de la querella supone la realización de un propio y verdadero acto de instrucción, con todas las consecuencias que ello supone ${ }^{1207}$. Estimamos por ello que el análisis del contenido de la querella exige una serie de valoraciones que determinan la formación de un convencimiento en el instructor determinante de su “contaminación” para dictar en su momento el fallo.

Contra el auto del instructor desestimando la querella, fundado en que los hechos no son constitutivos de delito o por no considerarse competente, cabrá recurso de apelación, admisible en ambos efectos (art. 313.II LECrim). Previamente o en el mismo escrito puede interponerse el de reforma, lo cual constituye requisito necesario en el Procedimiento Ordinario ${ }^{1208}$ y tiene carácter facultativo en el Abreviado (art. 787.3 LECrim). No será requisito sine qua non para la interposición y tramitación de los citados recursos la adquisición efectiva de la condición de acusador ${ }^{1209}$.

Contra el auto definitivo de la Audiencia que determine la inadmisión de la querella no cabe recurso de casación pues, aunque pueda existir error en la apreciación in iure -la única que se realiza-, no existe fundamento legal que ampare su recurribilidad ${ }^{1210}$.

${ }^{1207}$ SALOM ESCRIVÁ, J.S., “La querella”, op. cit. pp. 442 y s. Vid. la STS de 13 de mayo de 1993 (RAJ 4218) en la que, considerando que la admisión de la querella es acto de instrucción, estima que por ella no existiría vicio en la imparcialidad objetiva del Juez aunque posteriormente fuera éste el Magistrado ponente de la causa.

${ }^{1208}$ La fiscalía del TS se llegó a ocupar en su memoria de 1899 de si era o no necesaria tal interposición previamente, resolviendo la cuestión en sentido afirmativo a tenor de la claridad del art. 222 que lo impone expresamente y a pesar de que el 313 no lo recoja. En esta línea, acogiendo las razones allí expuestas se pronuncia GIMENO SENDRA, V., La Querella, op. cit. p. 290.

${ }^{1209}$ Vid. STC 326/1994 de 12 de diciembre, supuesto en el cual no se había hecho el depósito de la fianza.

${ }^{1210}$ ORTELLS RAMOS, M., Derecho Jurisdiccional, op. cit. p. 447. Vid. ATS de 1 de diciembre de 1986 (RAJ 7773). Sobre esta cuestión la opinión ha dependido necesariamente de las sucesivas reformas del art. 848 LECrim y concordantes. En un primer momento, el número $5^{\circ}$ de este artículo recogía expresamente como susceptibles de ser recurridos en casación los autos de no admisión de querella. Sin embargo, como relata GIMENO, el TS recortó tal posibilidad relacionando este precepto con el art. 313.1 de la LECrim y reduciéndolo solamente a las desestimaciones de querellas por falta de "fundabilidad". Por Ley de 28 de junio de 1933 se reforma el precepto estableciendo sólo la recurribilidad en casación de los autos definitivos, sin especificar si el auto de inadmisión de una querella lo es o no. El TS admitió en un primer momento la viabilidad de la casación otorgándole el carácter definitivo, pero con posterioridad otras sentencias negaron tal posibilidad por ausencia de reconocimiento legal expreso, primero manteniendo su carácter definitivo y después negando éste. Tal negativa ha de entenderse correcta 


\subsubsection{Efectos de la admisión}

La admisión de la querella deberá ser puesta inmediatamente en conocimiento de los inculpados, al igual que cualquier otra actuación procesal de la que se derive una imputación para ellos (art. 118.II LECrim). Interrumpirá además la prescripción de los delitos descritos, por constituir en sí misma una actuación dirigida contra el presunto autor (art. 132.2 CP).

Será esencial para que un determinado sujeto asuma la condición de acusador, momento a partir del cual puede intervenir procesalmente en los términos que se expondrán más adelante ${ }^{1211}$. Es claro que a partir de ese momento la misma persona no podrá ocupar simultáneamente otras posiciones dentro del proceso y en particular ha de advertirse que no podrá ser:

a) acusado o responsable civil: los supuestos de autoacusación no son totalmente descabellados, y aun menos si se asumen como método de la lucha política con la voluntad de llamar la atención de la sociedad sobre una determinada norma que se considera injusta al objeto de provocar su modificación ${ }^{1212}$. Tampoco cabría la confusión en un mismo sujeto de la condición de acusador y de responsable civil, ni siquiera cuando se ostentara sólo con carácter subsidiario. Aunque no fuera un espectáculo deseable, nada podría impedir, sin embargo, que en un proceso con más de un imputado alguno de ellos dedujese acusación frente a los demás, sirviéndose así del interés público que se hace

ya que sólo ha de entenderse como definitivos los autos de sobreseimiento. Los de inadmisión de querellas no ponen fin al procedimiento, entre otras cosas porque no producirán ni siquiera litispendencia. Vid. GIMENO SENDRA, V., La Querella, op. cit. pp. 291 y s. La inadmisibilidad del recurso de casación en estos supuestos ha sido criticada por SALOM ESCRIVÁ, alegando que se trataría de autos definitivos, por lo que tendrían que ser asimilados a los de sobreseimiento del art. $848.2^{\circ}$. Lo contrario podría conducir en su opinión a "una indebida denegación del derecho de acción”. SALOM ESCRIVÁ, J.S., "La Querella”, op. cit. p. 450.

${ }^{1211}$ La LECrim usa como regla general el término querellante para comprender también al personado sin interposición de querella. Vid. arts. 642, 644 y 645 y 311, 316, 468, 471.2, 476, 529, 627, 629, etc. Vid. también GÓMEZ ORBANEJA, E, Comentarios..., op. cit., T. II, vol. I, p. 609.

${ }^{1212}$ Existen precedentes de autodenuncias masivas en relación con casos de negativa al cumplimiento del servicio militar y la prestación social sustitutoria o de interrupción voluntaria del embarazo. Al respecto vid. Instrucción de la Fiscalía $\mathrm{n}^{\circ}$ 3, de 1 de diciembre de 1986 (Memoria de la FGE 1987, pp. 423 a 425). No sería raro el intento de acudir a la acusación popular, por propia iniciativa o a través de persona interpuesta, para la autoincriminación en causas con impacto social. 
valer a través de la pretensión penal como parte de la estrategia de su defensa. La apreciación de que ello constituye un fraude procesal con vistas a su rechazo (art. 11.2 LOPJ) chocaría con la consideración actual de la jurisprudencia del TC del ejercicio de la acusación como un derecho de los ciudadanos incardinado en la tutela judicial efectiva. Pero en cualquier caso bastaría con actuar por persona interpuesta para obviar toda posibilidad de control judicial, con lo que se evidencia su factible empleo fraudulento.

b) Acusador particular: en un primer momento cabría sostener que las posiciones procesales de acusador popular y acusador particular no son identificables, atendiendo a que el primero sólo defiende el interés público, mientras que del particular cabría decir que aspira a la satisfacción de un derecho propio. Tal afirmación sería conceptualmente incorrecta y pugnaría con la esencia y finalidad del proceso penal: el acusador particular no deduce derecho alguno ni al proceso, ni a la condena, ni genéricamente al ejercicio del ius puniendi ${ }^{1213}$. El acusador particular sí tiene, no obstante, derecho a reservarse o a deducir la pretensión civil, por lo que en verdad tendría que contraerse su ubicación a lo sumo al tema patrimonial (actor civil). Es factible que acusador particular y popular se apoyen simultáneamente entre sí para su actuación, que estén representados y defendidos por los mismos profesionales ${ }^{1214}$ o incluso que obtengan provechos mutuos derivados por ejemplo de la búsqueda de "casos modelo", pero ambas posiciones procesales no podrán ser confundidas en ningún caso, puesto que su actuación obedece a la defensa procesal de intereses diversos.

c) Perito: la correcta realización de la prueba pericial exige la falta de interés directo en el perito, por lo que ha de entenderse materialmente imposible la confusión en la misma persona de esta condición con la de acusador. Una vez personado el sujeto en la causa no podrá ser citado para la realización de informe pericial alguno, puesto que se estaría en la causa de recusación del art. $468.2^{\circ}$ LECrim $^{1215}$. En el caso de los testigos no

\footnotetext{
${ }^{1213}$ Como ha señalado recientemente el TC, "la Consstitución no otorga ningún derecho a obtener condenas penales" (STC 199/1996 de 3 de diciembre, FJ 5). Sólo se abrirá el proceso que corresponda si se afirma la concurrencia de los presupuestos normativos (Cfr. arts. 642 y ss y 790.6 LECrim), la apertura no connota derecho alguno a la condena pues sólo se reconoce el "derecho al debido proceso" y la posibilidad de alegar y probar las afirmaciones conducentes a provocar en el Juez, más allá de toda duda razonable, su convicción acerca del hecho, su punibilidad y la culpabilidad del autor.
}

\footnotetext{
${ }^{1214} \mathrm{Niega}$ la posibilidad de que litiguen unidos VALERO OLTRA, R., "Consideraciones sobre la acción popular”, BIMJ n ${ }^{\circ} 1237,25$ de abril de 1981, p. 11.

${ }^{1215} \mathrm{Si}$ en su número $1^{\mathrm{o}}$ se establece como causa de recusación el parentesco con el querellante, más razón habrá
} 
existe tal impedimento legal para la concurrencia en el mismo sujeto de la condición de acusador y de testigo si ha tenido conocimiento directo de los hechos. No hay duda de que el posible interés en el logro de la condena tendría que ser tenida en cuenta por el juzgador dentro de su margen de libre valoración de la prueba.

d) Jurado: este impedimento no se deriva de su equiparación a Jueces y Magistrados (art. 3.3 y 10.7 LOTJ) a los efectos del art. 102.3 ${ }^{\circ}$ LECrim, sino de la incompatibilidad entre las funciones de acusación y fallo. Establece el art. 11 LOTJ que nadie podrá formar parte como jurado del Tribunal que conozca de una causa en la que sea acusador particular o privado, precepto que lógicamente ha de entenderse incluye también a los acusadores populares. El ejercicio cívico de la acusación constituye, por tanto, un impedimento para desempeñar la función de actuar como jurado y, simultáneamente, una vía para esquivar en un caso concreto este deber legal (art. 6 LOTJ). Desde el momento en que se haya realizado la designación de jurados para cada causa (art. 18 LOTJ) habrá de entenderse suspendida para el proceso de que se trate la facultad de acusar de los candidatos designados, circunstancia que podrá ser alegada como excusa y, en su caso, como motivo de recusación.

La litispendencia podría ser entendida también como efecto de la admisión de una querella. A pesar de los escasos estudios sobre la cuestión, no cabe negar que la litispendencia penal se halla presente en nuestro proceso, impidiendo que un mismo hecho delictivo sea enjuiciado en dos o más causas simultáneamente. En virtud del art. 300 LECrim ("Cada delito de que conozca la Autoridad Judicial será objeto de un sumario..."), la interposición de querella, una vez que haya sido admitida y dé lugar a la formación de un sumario, llevará aparejada como efecto la litispendencia penal. No se referirá ésta al propio momento de la admisión, sino que se retrotraerá al de la interposición de la querella ${ }^{1216}$. El objeto que determina la litispendencia no vendrá

para considerar que el propio querellante estará impedido para el desempeño de la función de perito en el proceso de que se trate.

${ }^{1216}$ GIMENO resalta las diferencias entre los caracteres de la litispendencia penal en relación con la que se produce en el proceso civil, llegando a la conclusión de que para la primera no es imprescindible ni la identidad subjetiva ni la identidad en la causa petendi. En razón de la "extraordinaria generosidad de la legitimación activa", para los efectos de litispendencia constituiría un requisito superfluo o indiferente el que la "acción penal" por delitos públicos sea promovida por el MF o cualquier ciudadano, sin que exista identidad en la parte actora. En cuanto a la identidad de la causa de pedir también se reputa superfluo, en tanto lo decisivo no es el título por el que se pide, sino 
constituido por una concreta calificación jurídica que el querellante otorgue a los hechos, sino por los hechos mismos y el sujeto que se reputa autor de éstos, en tanto la afirmación realizada sobre tales elementos es la que irá fijando el objeto procesal. Es, en definitiva, el mismo fundamento sobre el que se basa la concepción de la cosa juzgada en el proceso penal.

\subsection{Intervención del acusador popular en el proceso}

\subsubsection{En la instrucción}

\subsubsection{Diligencias de investigación}

El promotor de la acusación podrá tomar conocimiento de las actuaciones e intervenir en todas las diligencias del procedimiento (229 LOPJ, 302. I y 789.4 LECrim $^{1217}$ ) dentro de la extensión prevista en el 234 LOPJ, es decir, para recibir información sobre el estado de las actuaciones judiciales, conocerlas y examinarlas. Sin este conocimiento su actividad posterior quedaría indudablemente desactivada o seriamente afectada en su efectividad. Podrá intervenir activamente en las diligencias de investigación, ya sean actos de reconocimiento judicial (inspección ocular), de determinación del cuerpo del delito o de la identidad del presunto autor y sus circunstancias personales, de interrogatorio del imputado ${ }^{1218}$, declaraciones de testigos $^{1219}$ y práctica de careos entre éstos, informes de peritos ${ }^{1220}$ o pruebas

el hecho que dio origen al proceso. GIMENO SENDRA, V., La Querella, op. cit. pp. 234 y ss. De esta manera refuta el autor la opinión de CLARIÁ OLMEDO en el sentido de que "trasladada la litispendencia del proceso civil, debemos aceptarla con todas las notas que alli tiene". Tratado de Derecho Procesal Penal, IV, Buenos Aires 1964, p. 577.

1217،...Los que se personaren podrán desde entonces tomar conocimiento de lo actuado e instar lo que a su derecho convenga, acordando el Juez lo procedente en orden a la práctica de estas diligencias para abrir el juicio oral... Es de aplicación a estas diligencias lo dispuesto en los artículos 301 y 302".

${ }^{1218}$ El Juez podrá también, a instancia de los acusadores, hacer que los procesados presten cuantas declaraciones considere convenientes para la averiguación de los hechos. Pero si así lo dispone, ni el acusador privado (nueva imprecisión terminológica de la Ley), ni el actor civil podrán estar presentes en el interrogatorio (art. 385 LECrim).

${ }^{1219}$ El testigo manifestará si conoce a las partes (art. 436 LECrim) y si tiene parentesco, amistad o relaciones de cualquier otra clase. 
documentales. Podrá incluso solicitar la adopción, modificación o extinción de medidas cautelares, entre las cuales se incluye la petición al instructor de que se decrete la prisión provisional del imputado (art. 504 bis 2 LECrim) ${ }^{1221}$. Podrán también promover incidentes relativos a la competencia antes de formular su primera petición después de personado en la causa ${ }^{122}$ e incluso formular recusación (art. 53 LECrim, 218.1 ${ }^{\circ}$ LOPJ) ${ }^{1223}$.

Con el objeto de posibilitar su actuación procesal será imprescindible que los acusadores sean formalmente citados para la celebración de diligencias, independientemente de quién haya sido el sujeto que las solicitare ${ }^{1224}$. Aun cuando no nos parezca aconsejable la participación con plenas facultades procesales de acusadores sin relación con el delito en todos los actos de investigación, puesto que podría resultar perjudicial para los intereses dilucidados en el proceso penal ${ }^{1225}$, una vez personados éstos, no hay posibilidad legal de impedir su intervención en la práctica de diligencias así como de que

${ }^{1220}$ Art. 480 y 483 LECrim. Los peritos podrán ser recusados por las “partes” cuando concurran las causas del art. 468, pero sólo si el reconocimiento e informe pericial pudiere tener lugar en el juicio oral. El querellante tendrá derecho, además, a nombrar a su costa un perito que intervenga en el acto pericial (art. 471 LECrim) con la especialidad en el Procedimiento Abreviado de que si el Juez lo considera suficiente, el informe pericial sea prestado por un sólo perito (art. $7857^{\mathrm{a}} \mathrm{LECrim)}$.

${ }^{1221}$ No podrán exigirse contracautelas al acusador que solicite la adopción de medida cautelar, siempre gravosas para el imputado. La responsabilidad de su adopción recae única y exclusivamente en el órgano instructor, por lo que éste adoptará la resolución que estime procedente, sin que quepa transferir a quien la haya solicitado la carga de afianzar posibles perjuicios.

${ }^{1222}$ Art. 19.4 LECrim y, en relación con el Procedimiento Abreviado, arts. 782.1 ${ }^{\mathrm{a}}$ (el órgano superior jerárquico oirá in voce al Fiscal y a las "partes personadas") y 782.2 .II (exposición por Juez de instrucción o de lo penal a la Audiencia sobre su competencia, tras lo cual el Tribunal dará vista de la exposición al MF y a las "partes personadas"). Concuerdan en este sentido con el art. 52 LOPJ, que habla también de "partes".

${ }^{1223} \mathrm{El}$ art. 40.3.II LOTJ establece una estricta igualdad entre los acusadores y una visión unitaria de la posición procesal acusatoria en lo referido a las recusaciones sin causa de los miembros del Jurado. En este caso, si hubiere varios acusadores deberán actuar de acuerdo, que de no mediar, obligará a decidir por sorteo el orden en que se recusará.

${ }^{1224}$ Esta citación sí se preceptúa normativamente en supuestos específicos como la convocatoria a audiencia del art. 504 bis 2 o la citación para la práctica de diligencias complementarias del art. 790.II.3. También en la LOTJ, en concreto en los arts. 25.1 y $3,26,27.4,30,31$, etc.

${ }^{1225}$ Afirmaba acertadamente GIMENO que, como mínimo, parecería aconsejable evitar el sistema de cross examination y el interrogatorio directo por los querellantes a las "partes materiales" y a los testigos, debiendo formular sus preguntas a través del Juez de Instrucción. GIMENO SENDRA, V., Fundamentos de Derecho Procesal, op. cit. pp. $186-7$ y 237 , n. 475. 
tomen conocimiento de los resultados obtenidos de ellas (salvo que se declare secreto el sumario).

Con respecto a la forma y el contenido de su actividad, no se determina con carácter general en qué puede consistir ésta, por lo que habremos de remitirnos a la específica previsión normativa de cada acto. De este modo, cuando menos, han de poder asistir al acto y formular las observaciones que estime pertinentes para que se recojan en la documentación del mismo ${ }^{1226}$. Nada se especifica en la Ley del orden de actuación entre diversos sujetos acusadores, por lo que el primero en intervenir, como regla general, será aquél que proponga la diligencia de que se trate, para ceder esta posición posteriormente a los demás. Cuando no estemos ante un acto procesal realizado a instancia de ninguno de los intervinientes, la práctica forense ha articulado una prelación según la cual el que asumirá la iniciativa será el representante del MF, a continuación intervendrá el acusador particular y por último el popular ${ }^{1227}$. En todos estos casos deberá consignar su firma en la documentación de los actos en los que participen ${ }^{1228}$.

Aunque la ley habilita la intervención en el sumario de acusadores particulares, no contempla expresamente el régimen de ésta, por lo que, lo razonable es que sea dirigida según criterio del Juez de instrucción que, en último término, es el responsable de la "formación del sumario" (art. 303 LECrim). La realización de diligencias de investigación por acusadores populares tendrá que canalizarse necesariamente a través del instructor, sin que quepa (ni sea deseable) la atribución de la facultad para instarlas directamente de la Policía Judicial o de realizarlas por sí mismo. Su ámbito propio se sitúa

${ }^{1226}$ Convendría advertir que su intervención deberá ser en la mayoría de las ocasiones oral (art. 120.2 CE y 229.1 LOPJ) y que habrá de realizarse en la lengua en la que se desarrolle la actividad procesal (castellano o lengua oficial de la Comunidad Autónoma), sin que le quepa alegar indefensión ni oponerse o solicitar traducción al castellano de las actuaciones realizadas y los documentos presentados en el idioma oficial de una Comunidad Autónoma al amparo del art. 231 LOPJ. De la utilización de una lengua oficial no deseada por él no cabría nunca entender derivada una indefensión en relación con sus derechos legítimos, sobre todo si se tiene en cuenta que el acusador sólo podrá actuar por medio de procurador y abogado.

${ }^{1227}$ La transgresión de este orden, corruptela procesal que hemos podido constatar en la práctica en alguna ocasión, debe ser evitada. Ha de ser el fiscal quien marque las pautas dentro de las que ha de desarrollarse el debate procesal y la actividad del resto de los intervinientes, sin dejar que ésta pueda determinar el sentido de sus actos. Interviniendo en primer lugar la acusación popular pudiera darse a entender de que el fiscal espera lo que puedan decir los demás para escudarse en ello o bien que el Tribunal pudiere intentar "tantear" a los acusadores.

${ }^{1228}$ Arts. 332 (inspección ocular), 404 (declaraciones del imputado), 444 (testigos) o 453 (careos), todos ellos LECrim. 
en la actividad del órgano jurisdiccional, por lo que en los actos de investigación no judiciales (del MF o de la Policía Judicial) la presencia del acusador popular carece absolutamente de sentido ${ }^{1229}$. Una vez incorporadas estas diligencias al sumario ${ }^{1230}$, no habrá impedimento para que los acusadores privados tengan acceso a los resultados obtenidos y puedan fundamentar sobre ellos sus peticiones. No podemos pasar por alto que, en virtud de las facultades que se reconocen al instructor, la investigación que se realiza en el sumario no viene delimitada estrictamente por lo solicitado por acusación y defensa. El brocardo ne procedat iudex ex officio no es de plena aplicación en la fase de instrucción, en tanto el proceso puede iniciarse y desarrollarse con la mera actividad del Juez, y éste podrá en su función de averiguación aceptar o no en la mayoría de las ocasiones las diligencias propuestas en función de la utilidad o pertinencia que aprecie en ellas $^{1231}$.

No existe prohibición expresa que impida desarrollar investigaciones paralelas a las judiciales, por lo que en principio y con independencia del valor que se las pudiera otorgar, éstas no pueden ser excluidas de manera absoluta ${ }^{1232}$. Parece claro, no obstante, que la investigación de los delitos implica la disposición de medios personales y humanos que, evidentemente, no pueden estar a disposición de cualquier ciudadano. Para suplir esta imposibilidad práctica pudiera pensarse en una actividad independiente del ciudadano

${ }^{1229}$ El art. 5 EOMF faculta al MF para la recepción de denuncias y la práctica de diligencias de investigación (llevarlas a cabo u ordenarlas) en el proceso penal, otorgando a éstas presunción de autenticidad.

${ }^{1230}$ Lo cual ocurrirá en el caso de las investigaciones dirigidas por el MF tan pronto como tenga conocimiento de la existencia de un procedimiento judicial sobre los mismo hechos, puesto que en ese caso deberá remitir lo actuado al juzgado donde se haya iniciado la instrucción ( 785 bis. 3 LECrim).

${ }^{1231}$ Ha de tenerse en cuenta de nuevo que la función de los actores no era originariamente más que la de meros colaboradores del órgano jurisdiccional. Vid. PRIETO CASTRO, L. y GUTIÉRREZ DE CABIEDES, E., Derecho Procesal Penal..., cit. p. 111. Si inicialmente no podía hablarse de que en la instrucción se estuviera ante una actividad procesal regida por la contradicción y la igualdad, las sucesivas reformas legislativas han otorgado, en ocasiones inadecuadamente, un tinte acusatorio a una fase que en origen no lo era. Las diligencias previas del proceso abreviado introducidas por la LO 7/1988 de 28 de diciembre y la reforma de éstas operada por la LOTJ, han incrementado significativamente las facultades de las llamadas "partes" en detrimento de las del órgano judicial.

${ }^{1232}$ Esta circunstancia motivó incluso la queja expresada en la Circular 1/1989 de la FGE en la que, al referirse a la investigación del MF, se afirmaba que "la prohibición de una investigación subsidiaria y paralela a la judicial no se predica de las demás partes (...) lo que por el principio de igualdad de partes, tampoco puede estar vedado al fiscal". Vid. Circular FGE 1/1989 de 8 de marzo, IV, B) f) e) últ. pár. Aun demostrando una concepción poco depurada del papel de los sujetos acusadores en el proceso y del principio de igualdad de partes, la crítica toca uno de los puntos clave concerniente a la potenciación de las notas acusatorias del sumario, anhelo máximo que parece inspirar las reformas procesales de los últimos tiempos. 
acusador sirviéndose de compañías de investigación privada como solución ${ }^{1233}$. Sin embargo, el art. 19.3 de la Ley de Seguridad Privada, reproducido por el 102.1 de su Reglamento establece que los detectives privados “tampoco podrán realizar investigaciones sobre delitos perseguibles de oficio, debiendo denunciar inmediatamente ante la autoridad competente cualquier hecho de esta naturaleza que llegara a su conocimiento y poniendo a su disposición toda la información y los instrumentos que pudieren haber obtenido" ${ }^{1234}$. Esta obligación queda reiterada por el art. 103 del Reglamento, en el que se establece la obligación de facilitar datos a los órganos judiciales y policiales para el ejercicio de sus funciones.

Todo el proceso de investigación ha de ser remitido a los cauces ordinarios establecidos en la ley, lo cual es tanto como decir a través de las diligencias solicitadas y, en su caso, ordenadas por el instructor. Aunque existiera una investigación privada, los datos obtenidos a través de ella servirán únicamente para la construcción y subsiguiente fundamentación argumental de la acusación y defensa sin que, per se, tengan más valor que el que pudiere deducirse en el momento procesal oportuno-básicamente el juicio oralde su articulación como fuente de prueba a través de los medios legalmente admisibles (testimonio y, matizadamente, pericia) ${ }^{1235}$. Conviene a este tenor recordar la premisa

${ }^{1233} \mathrm{El}$ auge de las compañías privadas de investigación en los últimos años no deja de ser revelador de una cierta insuficiencia o de un déficit en la capacidad de los órganos estatales para satisfacer la necesidad pública de averiguación de las circunstancias en las que el hecho criminal aparece en la sociedad. Es altamente interesante a este respecto el estudio sobre la realidad holandesa, de ROSENTHAL, U. y HOOGEENBOOM, B., "La privatisation et la commercialisation du contrôle de la criminalité: quelques questions fondamentales, eu egard notamment à l'évolution des Pays-Bas" en CONSEJO DE EUROPA, Etudes relatives à la recherche criminologique. Vol XXVII. "Privatisation du contrôle de la criminalité. Rapports présentés à la 18 Conférence de recherches criminologiques (1988)", Estrasburgo 1990, pp. 17-44. Los autores ponen de manifiesto cómo el abandono de funciones desempeñadas antes por los poderes públicos puede significar la renuncia del Estado a responsabilidades, dejando a merced de las fuerzas económicas los órganos y empleos que dependían de ella anteriormente. De esta forma de privatización pasiva podría derivarse, en opinión de los autores citados, una negligencia estatal, en tanto el sector privado tiende a una justicia propia y la comercialización del control privado de la criminalidad conduciría a paradojas internas del sistema.

${ }^{1234} \mathrm{El}$ marco jurídico de las investigaciones realizadas por los detectives privados es en la actualidad el delimitado por los arts. 19 y 20 de la L. 23/1992 de 30 de julio (BOE 4 de agosto) de Seguridad Privada y el RD 2364/1994 de 9 de diciembre (BOE 10 de enero 1995), por el que se aprueba el Reglamento de Seguridad Privada. En Italia, p. ej., el art. 222 att CPPItal. se dedica exclusivamente a la figura de los "investigatori privati", derogando expresamente las previsiones anteriores que les prohibían realizar actuaciones sobre hechos presuntamente delictivos.

${ }^{1235}$ A diferencia de la laguna legal de nuestro sistema, en el caso italiano la Norma 38 de las de actuación y coordinación al CPPItal admite expresamente la investigación privada en favor del acusado. No cabe duda que la investigación privada puede contribuir de forma determinante para articular la estrategia defensiva del imputado y 
establecida por nuestro Supremo Tribunal que afirma no ser atendible una investigación paralela a la judicial a cargo de personas ajenas a la policía y a los Juzgados y Tribunales $^{1236}$.

\subsubsection{Los distintos acusadores en el Procedimiento Abreviado}

En la solicitud de diligencias complementarias en el Procedimiento Abreviado se observa una desigualdad en los regímenes procesales del MF y de los acusadores privados, ya que mientras que solicitadas por el primero, el juez instructor estará obligado a decretarlas, hecha la petición por uno de los acusadores no oficiales, ésta no le vinculará (art. 790.2 LECrim) ${ }^{1237}$. Tal desigualdad obedece a la imperiosa desconfianza sobre los acusadores privados y a la prevención frente a la utilización de sus facultades procesales, en este caso con el resultado de la dilatación del procedimiento en el tiempo ${ }^{1238}$. Si en el

singularmente, por lo que a la práctica se refiere, de fundamentación de las tesis del responsable civil

${ }^{1236}$ STS 13 de julio de 1992 (RAJ 6394). En relación con el proceso civil la jurisprudencia ha sido clara en el sentido de que el informe del investigador privado, operando por cuenta de la parte y al margen del proceso, no constituye prueba documental, y la denegación de su admisión no vulnera ningún derecho fundamental, sin perjuicio de que pueda presentarse como prueba testifical en la vista oral. PTC de 10 de diciembre de 1990, aludiendo a lo ya manifestado en ATC 262/1988 de 29 de febrero y 384/1989 de 7 de julio. Vid. también PÉREZ HERNÁNDEZ, E., "La constitucionalidad de las pruebas aportadas por los detectives privados", $P J \mathrm{n}^{\circ} 35$, septiembre 1994. Sobre el valor probatorio del testimonio de detectives privados, vid. p. ej. STS 12 de marzo de 1990 (RAJ 2989): únicamente tendrán el valor de una prueba testifical.

${ }^{1237}$ Se ha dicho que con ello la ley trata de subsanar con esta previsión un error que ella misma lleva en su redacción, al permitir que corresponda al juez la decisión en la que determine que ya existen elementos para formular una acusación sin haberlo inquirido previamente de los sujetos acusadores. Aunque parece claro que la decisión de que existen elementos suficientes para el ejercicio de la pretensión penal sólo puede ser adoptada por quien efectivamente la vaya a ejercer (fiscal o acusadores no oficiales), a tenor del art. 789.3 LECrim es el Juez instructor el que juzga como suficientes o no las diligencias practicadas en el atestado para fundamentar una acusación. Puesto que en este caso, se habría producido una invasión del órgano jurisdiccional respecto a las atribuciones de la acusación pública, para evitar males mayores se otorgaría la posibilidad a ésta de recuperar el terreno perdido. Vid. DÍAZ CABIALE, J.A., Principios de aportación de parte y acusatorio: la imparcialidad del juez, Granada 1996, p. 532, para quien debería reformarse el art. 789.3 en el sentido de que, en todo caso, se atribuyera al órgano jurisdiccional la facultad de inquirir al MF si le bastan los elementos con los que se dispone para ejercer la acusación, y, de ser la respuesta afirmativa, determinar la no realización de diligencias previas. Así se evitaría acudir al remedio que proporciona el art. 790.2.I. Sin embargo, en la modalidad procedimental del art. 790.1.II y III LECrim no existiría ese problema, en cuanto que producida la convicción del órgano jurisdiccional de que procede el juicio oral y existen elementos para formular la acusación, da traslado a MF y acusaciones privadas para que sean éstos quienes formulen los escritos de acusación o bien soliciten diligencias complementarias. El Juez ofrecerá el material disponible para que las acusaciones decidan lo que estimen conveniente.

${ }^{1238}$ No podemos por menos que recordar la célebre cita de COUTURE al señalar que en el procedimiento el 
caso del MF, la premisa de la legalidad deberá ser la que presida todos sus actos (124.2 CE, 2.1, 6 y 48 EOMF, 105 y 271 LECrim), en el de los segundos, tal vinculación no podrá ser constatada con certeza en ningún caso. Las razones últimas de la actuación de los acusadores privados no podrá ser en ningún momento averiguada. Ello unido al carácter complementario o sustitutorio que ha de darse a su subsistente vigencia en nuestro proceso explica los desequilibrios que en la ley existen en favor del MF en razonable y consecuente armonía con la misión a la que constitucionalmente viene éste llamado. El obligado examen judicial de las peticiones constituye un filtro orientado a ponderar su pertinencia y utilidad ${ }^{1239}$, que servirá como adecuada refutación de la credibilidad de tales pretensiones. El fiscal, entre cuyas funciones se encuentra el impulso y simplificación del procedimiento (art. 781 LECrim), adquiere una capacidad de intervención procesal de la que, con buen criterio, no se hace merecedores a los particulares $^{1240}$.

Un proceso no sería justo y equitativo si tuviera lugar en condiciones tales que pusieran al acusado en una situación de desventaja evidente frente a la acusación ${ }^{1241}$. La

tiempo es algo más que oro: es justicia. Quien dispone de él tiene en sus manos las cartas del triunfo y quien no puede esperar, de antemano ya ha sido derrotado. Si en el proceso civil tal palmaria realidad es preocupante, en el proceso penal debe ser intolerable, preservándolo de toda dilación innecesaria. Debemos llamar la atención, no obstante, acerca del cuidadoso equilibrio que ha de mantenerse entre celeridad y garantías, pues como dijo TERENTIUS, “Ius summun saepe summa est malitia” (extrema justicia es frecuentemente una extrema maldad), Ter. Haut., 796. Se ha manejado la edición P. Terenti Afri Comoediae, W.M LINDSAY; R. CAULER, Oxford University Press, Oxford Classical Texts, 1926.

${ }^{1239}$ Sobre pertinencia y utilidad de la prueba vid. PEDRAZ PENALVA, E., “Apuntes sobre la prueba pericial en el proceso penal. Particular consideración de la pericia psiquiátrica”, RDProc. (Ibam), 1994, 2, pp. 358 y ss. y bibliografía ivi cit.

${ }^{1240}$ Esta circunstancia fue advertida en la Circular FGE 1/1989 cit., para justificar la vinculación del Juez a la petición de práctica de diligencias si es hecha por el MF, pero no si lo es por los restantes acusadores. En este caso se afirmaba que "no hay aquí ruptura del principio de igualdad de partes, principio que según la doctrina del TEDH se refiere a la igualdad de armas de la acusación y la defensa pero no entre la representación pública, regida por los principios de legalidad e imparcialidad y las acusaciones particulares, movidas por un interés parcial y ajenas al interés público". Vid. Memoria de la FGE, p. 468.

${ }^{1241}$ Vid. SSTEDH Neumeister (27 de junio de 1968), Matznetter (10 de noviembre de 1969), Delcourt (17 de enero de 1970), Bönisch (6 de mayo de 1985), Brandstetter (28 de agosto de 1991) y los Informes de la Comisión Europea de Derechos Humanos en los casos Ofner y Hopfinger, párrafo 46 y Pataki y Dunshirn, párrafo 36. Su fundamento no se encontraría en nuestro Derecho en el art. $14 \mathrm{CE}$, sino que se deriva del derecho del imputado a un proceso con todas las garantías. Vid. por ejemplo ATC 553/1987 de 13 de mayo. En la SSTC 4/1982, 191/1987 de 1 de diciembre y esp. en la 114/1989 de 22 de junio (FJ 2), la igualdad de partes en el proceso se integra "en el ámbito propio de los derechos a la tutela judicial efectiva y a la defensa dentro de las actuaciones procesales". 
consideración de todos los acusadores como partes autónomas entre nuestra doctrina ha llevado en ocasiones a una inadecuada identificación o confusión entre principio de "igualdad de armas" y la igualdad entre los sujetos acusadores participantes en el proceso o de éstos con la defensa, extrapolando inapropiadamente los abundantes pronunciamientos del TEDH en relación con tal principio. Aun sin aceptar la existencia de una verdadera "igualdad de armas" entre acusación y defensa ${ }^{1242}$, se hace necesaria una clarificación que diferencie el equilibrio entre éstas de lo que sería una igualdad entre los distintos sujetos que pueden integrar la posición acusatoria. Mientras que en el primer caso nos encontramos ante un principio inherente al proceso penal con reflejo en la CE y en el $\mathrm{CEDH}$, la segunda es una cuestión accidental que no afecta por sí sola de forma trascendente a las garantías sobre las que se asienta el sistema de persecución de los delitos sino que, además, refuerza el verdadero significado de la subsistencia de las acusaciones no públicas en nuestro ordenamiento. Lo que no es más que el producto de una lógica desigualdad entre sujetos que ocupan la misma posición procesal establecida atendiendo a su correlativa posición constitucional, ha sido revestida bajo un término que oculta su verdadero contenido. La "burla de las etiquetas" se ha manifestado así en su máxima expresión, amparando bajo la misma denominación ("igualdad de partes") dos realidades absolutamente diversas. Los dos términos de comparación para determinar la exigencia de igualdad habrán de ser siempre, por un lado, la acusación, contemplada como un todo y, por otro, la defensa, de forma que ambos deberán contar con las mismas expectativas y derechos procesales. Del "principio de igualdad de armas", lógico corolario de la contradicción, se deriva la necesidad de que las partes cuenten con los mismos medios de ataque y defensa e idénticas posibilidades y cargas de alegación, prueba e impugnación ${ }^{1243}$. Este es el sentido en el que la metáfora "igualdad de armas"

${ }^{1242}$ En ningún caso se puede hablar de igualdad en la instrucción, por lo que son perfectamente admisibles las modulaciones o excepciones que puedan establecerse en esta fase por razón de la propia naturaleza de la actividad investigadora que en ella se desarrolla, encaminada a asegurar su éxito. Vid. en este sentido SSTC 13/85; 176/88; $66 / 89$ y $186 / 90$.

${ }^{1243}$ SSTC $186 / 1990$ de 15 de noviembre de 1990; 47/87; 67/86 de 26 de mayo. En esta última se dice expresamente que "este Tribunal no debe entrar a decidir en la cuestión sobre la legalidad aplicable al concepto de parte". Vid. en especial la STC 101/1989 de 5 de junio, FJ 4, que se refiere a un supuesto de ejercicio popular de la acusación. El TC configura el principio de igualdad, en su proyección específica a la igualdad de armas en el proceso integrado en el art. 24.1 CE. Tal principio significaría que "los Tribunales vienen constitucionalmente obligados a aplicar la ley procesal de manera igualitaria que garantice a todas las partes, dentro de las respectivas posiciones que ostentan en el proceso y de acuerdo con la organización que a éste haya dado la ley, el equilibrio de sus derechos de defensa sin conceder trato favorable a ninguna de ellas en las condiciones de otorgamiento y utilización de los trámites comunes, a no ser que existan circunstancias singulares determinantes de que ese equilibrio e 
transmite plásticamente lo que con ella se quiere significar. Se trata, por tanto, de una igualdad en sentido formal, que debe ser contemplada en un contexto amplio, comprensivo de toda la estructura lógica de la acusación y la defensa así como de la dialéctica entre $\operatorname{ambas}^{1244}$.

En ningún caso podrá reivindicarse una igualdad entre diversos sujetos acusadores, que no sólo iría contra la función que cada uno de ellos cumple dentro del sistema, sino incluso contra toda lógica. La igualdad entre las partes no podría suponer nunca que se reconozcan a los acusadores facultades propias que no deriven de su incardinación en esa posición procesal y que, además, sólo le vendrán atribuidas de manera instrumental. Sostener que MF y acusador popular tuvieran que contar con los mismos derechos y expectativas procesales supondría abrir un portillo privatizador a todas luces inadmisible, teniendo en cuenta los intereses que uno y otro pueden hacer valer. La prevalencia del MF no es en este sentido más que reflejo de su misión constitucional, mientras que la de las acusaciones no oficiales ha de contemplarse desde su articulación secundaria respecto de la pública, sin perjuicio de los recelos que una aprehensión realista de su mayoritario uso muestra, al hacer factible la no exclusiva defensa del interés público. La incuestionada exacerbación máxima de las notas de un sistema acusatorio en la fase de investigación, entendido como un proceso de "partes" independientes entre sí ${ }^{1245}$, ha de reputarse necesariamente incompatible con un sistema de acusación privada concurrente con la del MF en el sentido actual. Carecería de todo sentido la atribución a sujetos privados de facultades que, en alguna medida, determinan una disposición procesal, en este caso sobre la duración del procedimiento.

igualdad entre las partes sólo pueda mantenerse con un tratamiento procesal distinto que resulte razonable y sea adoptado con el fin precisamente de restablecer dichos equilibrio e igualdad". Sobre la "igualdad de armas" en el proceso penal puede verse por ejemplo MÜLLER, E., "Der Grundsatz der Waffengleichheit im Strafverfahren", NJW 1976, pp. 1063 y ss.

${ }^{1244}$ La presencia del principio acusatorio exige equilibrio entre acusadores y acusado (STC 8 de febrero de 1982), o bien, en palabras de FERNÁNDEZ ENTRALGO, "el proceso penal constituye el marco de comprensión escénica en que se enfrentan dialécticamente las pretensiones y oposiciones, contrapretensiones o resistencias de la parte acusadora y acusada, situadas en un plano de igualdad, de no discriminación arbitraria". FERNÁNDEZ ENTRALGO, J., en "Principios procesales y procedimentales...”, op. cit., p. 17.

${ }^{1245}$ Hablamos de incuestionada por cuanto se ha dogmatizado sin pararse a examinar su forzado encuadre dentro de un proceso concebido en 1882 esencialmente como delicadísima expresión conjunta entre acusatorio e inquisitivo. 


\subsubsection{3. “Publicidad para las partes” y acusación popular}

La intervención del acusador popular en el sumario constituye en la actualidad una muestra de la consagración del "principio de publicidad para las partes"1246. De ahí que, teniendo que asumir que el acusador popular pueda ser considerado "parte", se entienda habitualmente incluido dentro de la publicidad que garantiza el art. 302 LECrim. Frente a ella, y en virtud de la regla que impone (más aparente que realmente) el secreto del sumario para los terceros ajenos al proceso (art. 301 LECrim), se pretende evitar que revelaciones indebidas perjudiquen la finalidad y el objetivo de la investigación ${ }^{1247}$.

A este tenor es observable una extralimitación del poder atribuido por el legislador a los querellantes privados, que se debe sin duda a la influencia ejercida por elementos extraños al proceso penal y a los estudios sobre el proceso civil ${ }^{1248}$. El derecho a tomar conocimiento de las diligencias sumariales venía atribuida originariamente en el art. 302 LECrim sólo al procesado, mientras que el antiguo art. 316 LECrim lo hacía en favor del querellante. Contenía, sin embargo, una importante salvedad: la posibilidad en manos del Juez instructor de excluir al acusador particular del conocimiento de lo actuado, declarando de oficio o a petición del fiscal el secreto del sumario sólo para el querellante.

\footnotetext{
${ }^{1246}$ Entendido como la posibilidad de actuar en el proceso derechos e intereses afirmados legítimos a través de la defensa, que precisará un derecho de estar al corriente del desarrollo de todos los actos procesales. Como ha destacado PEDRAZ, ésta es una concepción muy restringida de la publicidad, dado que la publicidad en sentido estricto supondría una posibilidad de control social de la Justicia. Para las partes procesales, la eficacia del principio procesal-constitucional de publicidad no radicaría simplemente en tomar conocimiento de actuaciones procesales sino, teleológicamente, en crear la oportunidad de realizar actos procesales con el objeto de fundamentar su situación jurídica procesal (principio de contradicción). El TC incluye sin embargo el principio de publicidad general o publicidad en sentido estricto en la exigencia constitucional del 24.2 al referirse al "proceso público". Como destacaba el autor citado, no es de recibo que el TC mantenga tan ambigua postura, no delimitando con la mínima claridad exigible el problema. Vid. PEDRAZ PENALVA, E., "Notas sobre publicidad y proceso", en Constitución, Jurisdicción y Proceso, Madrid 1990, pp. 210 y ss., y más recientemente en "Publicidad y derecho al debido proceso. Publicidad y derecho de acceso a la información contenida en los ficheros de datos jurisdiccionales", $R G D$ n $^{\mathrm{o}} 631$, abril 1997, pp. 3889 y ss.

${ }^{1247}$ La difusión de lo sucedido, investigado o averiguado en el sumario hace presentes de alguna manera a todos, por lo que no sólo contraviene el deseo del legislador de mantener la publicidad en el sumario sólo para las partes, sino que en ocasiones podrá perjudicar los fines de la instrucción. El TC se ha pronunciado es este sentido, advirtiendo que si la colectividad se pudiera formar antes de tiempo una opinión sobre el objeto procesal, anticipando un veredicto antes de la resolución final y un pseudo-juicio sobre las pretensiones de las partes, la función de los Tribunales se podría ver fácilmente usurpada. Vid. STC 13/1985 de 31 de enero y ATC 195/1991 de 26 de junio, FJ $6^{\circ}$. Vid. al respecto también JIMENO BULNES, M.M, "El principio de publicidad en el sumario", Justicia 93, pp. 705-6.

${ }^{1248}$ De ello advertía CORTÉS DOMÍNGUEZ, V., La cosa juzgada penal, op. cit., p. 86.
} 
La igualación del régimen de intervención entre acusado y acusadores se realizó con la reforma del primer precepto y la derogación del segundo operada por la Ley 53/1978 de 4 de diciembre. La razón de esta equiparación genérica se cifró en una equivocada lectura en su aplicación al proceso penal del principio de "igualdad de armas" y del de contradicción que ya fue sometida a crítica doctrinal en su momento ${ }^{1249}$. La intervención de los particulares se fundamenta desde tal reforma legal sobre la idea de que ello es necesario para la articulación de diversas pretensiones y de que negarles el acceso a tales diligencias sería tanto como hacerles incurrir en indefensión.

El error de partida radicaría en la consideración de los particulares acusadores como auténticas partes procesales autónomas, sin tener en cuenta que más que tener expectativas procesales en tanto actores independientes cuyos intereses puedan contraponerse entre sí, las tienen sólo por su integración de una de las posiciones consustanciales a éste, la acusación. El acusador quivis ex populo no puede abogar más que por el interés público en el enjuiciamiento, y los medios procesales de los que el ordenamiento le dota no le vienen conferidos con carácter absoluto, sino sólo con carácter instrumental y subordinados a la persecución de tal fin. Una vez más ha de decirse que coadyuvar en la persecución de los delitos satisfaciendo el presupuesto en que la acusación consiste no es para los particulares defender derecho propio alguno, sino defender un interés abstracto, que se alza por encima de los intereses individuales y aun de los plurales, dirigido a la satisfacción de los fines con los que se concibe el proceso penal.

Una gran parte de la razonable desconfianza que puede generar la intervención de acusadores populares se debe precisamente a que con ello se puede favorecer la vulneración de la prohibición prescrita en el art. 301 LECrim atinente a la revelación de informaciones obtenidas en el sumario. Lo irrisorio de unas sanciones que el legislador no ha estimado conveniente retocar como contribución a la publicidad del proceso (corrección con multa de 250 a 2500 pts. al Abogado o Procurador que revelare

${ }^{1249}$ En opinión de GIMENO en lugar de realizar esta asimilación entre las facultades de uno y otros sujetos, hubiera sido mejor reformar los correspondientes preceptos de cada uno de los actos de investigación a fin de que el Juez de Instrucción pudiera, caso por caso, autorizar la entrada de las partes o, cuando pudieran frustrarse los fines de la instrucción, denegarla mediante resolución motivada susceptible de apelación en un sólo efecto. GIMENO SENDRA, V., Fundamentos de Derecho Procesal, op. cit. pp. 186-7 y 237, n. 475. 
indebidamente el secreto del sumario) ${ }^{1250}$, frente a los grandes beneficios medidos en términos de propaganda que se pueden cosechar con la difusión de informaciones acerca de lo desarrollado en determinados procesos con incidencia sobre la opinión pública, originan que el manejo de la información que el proceso genera y/o aporta pueda ser una de las principales razones que motivan la intervención en éste de ciudadanos no ofendidos. Lo importante deja de ser aquí el que se dicte una resolución jurisdiccional dirigida a la restauración de la paz social rota por el delito, para pasar a ser la propia instauración del proceso y la adquisición por éste de una trascendencia social mucho mayor. Gráfica y muy acertadamente se expuso en la Memoria de la FGE de 1989 que "resulta patente que no son siempre intereses puros de colaboración con la justicia los que animan el ejercicio de la acción popular sino criterios de oportunismo llamados a conseguir el impacto de la opinión pública" (p. 314). Hoy es una escena cotidiana la presencia de medios de comunicación a las puertas de los Juzgados y Tribunales en los que se siguen causas penales socialmente relevantes. Es también harto frecuente que tengamos puntual información de lo que ha ocurrido puertas adentro del Juzgado una vez celebrados determinados actos procesales tales como declaración del imputado, interrogatorio de testigos, careos, etc. Sin descartar que en demasiadas ocasiones sean los testigos, la defensa o incluso el propio imputado quienes transmitan el contenido de lo actuado, uno de los mecanismos habituales de propagación de tales informaciones, cuando puedan interesar a alguien y tome cuerpo como noticia, residirá en manos de los acusadores $^{1251}$.

La ilimitada difusión pública de lo actuado no es sólo una estrategia procesal dirigida a reafirmar la propia presencia en el proceso, sino sobre todo, una manera asequible de irradiar el conocimiento de los hechos criminales presuntamente cometidos por el imputado, con el objeto de incidir en la opinión de toda la colectividad. La difusión y propaganda del proceso quedan así aseguradas, siempre desde una óptica parcial que pretende la satisfacción de determinados intereses sólo coincidentes en el mejor de los

${ }^{1250}$ Teniendo en cuenta que en la originaria LECrim la sanción era de 50 a 500 pts. (¡de las de 1882 !) y que este precepto fue reformado por última vez por la ley de 14 de abril de 1955, parece llegado el momento de revisar al alza tales cuantías o la imposición de otro tipo de sanciones. El mantenimiento de una cautela de esta naturaleza ha de ser juzgado necesario.

${ }^{1251}$ El Juez o el Fiscal pueden ser sometidos a corrección disciplinaria e incluso penal en caso de difusión indebida de la información. Vid. arts. 417.12 (falta muy grave), 418.7 (falta grave) en relación con el 396, todos ellos de la LOPJ, para los Jueces y Magistrados. En el caso de los fiscales, arts. 62 y ss. en relación con el 50 EOMF. 
casos con los buscados con la iniciación y desarrollo de aquél ${ }^{1252}$. No puede pasarse por alto tampoco la corresponsabilidad de medios de comunicación ávidos por transmitir informaciones lo más reservadas posibles, que no dudan en mantener acuerdos de colaboración expresa o tácita con acusadores, cuando no son ellos los que directamente asumen esta función. De este modo, no es exagerado afirmar que la propaganda, que no publicidad, en los procesos con acusador popular alcanza cotas cualitativamente diferentes a la de la generalidad de los supuestos. Si éstos no pudieran rentabilizar de alguna manera sus esfuerzos en preocupaciones, tiempo y dinero, y la publicidad en provecho propio es seguramente una de esas contraprestaciones, es muy probable que no mantuvieran su acusación ${ }^{1253}$.

Pudiera contemplarse la potencialidad de la acusación popular como acicate para un mejor desarrollo de la función jurisdiccional, derivada del control social sobre el desenvolvimiento de la actividad procesal que contribuya a colmar alguna de sus deficiencias, por ejemplo acelerando la tramitación de los procesos sobre los que existe una férrea observación pública. Pero es indudable que ello origina mayores perjuicios que ventajas, tales como la quiebra de hecho de la presunción de inocencia, la presencia de juicios paralelos ${ }^{1254}$, la dedicación prioritaria de los órganos jurisdiccionales a estos asuntos en detrimento de otros, etc. Todo ello sin olvidar la inequívoca, inexacta, parcial e interesada información que, en no pocas ocasiones, es la que se suministra al gran

${ }^{1252} \mathrm{Al}$ fin y al cabo, el proceso no es noticia en sí, sino que la noticia viene determinada por la notoriedad social de los intervinientes, la actuación del Juez o las consecuencias que se vayan a derivar. Son siempre cuestiones extraprocesales las que determinan el interés en hacer noticiable lo que ocurra en los Tribunales. Vid. GUZMÁN FLUJA, V.C., “Algunos aspectos de la relación Justicia - medios de comunicación”, Justicia 91, III, pp. 593 y ss.

${ }^{1253}$ Es de justicia apuntar la mínima, aunque decisiva aportación a tal pervertido uso de la Justicia de algún juez ansioso de notoriedad y de algún letrado que, directa o indirectamente, encuentra así el medio para incrementar el volumen o calidad de asuntos de su despacho.

${ }^{1254} \mathrm{El}$ tema de los juicios paralelos y la garantía del debido proceso ha suscitado históricamente una justificada preocupación social, doctrinal y jurisprudencial. La existencia de juicios paralelos en los medios de comunicación (trial by press, trial by newspapers) como potencial instrumento de injerencia indirecta sobre el desarrollo de la actividad jurisdiccional puede ser favorecida por la introducción en el proceso de intereses no suficientemente controlables Sobre tal cuestión puede consultarse GUZMÁN FLUJA, V.C., "Algunos aspectos de la relación justicia-medios de comunicación”, op. cit. passim; GARZÓN VALDÉS, E., "El principio de publicidad", Doxa $\mathrm{n}^{\circ}$ 14, pp. 75-135; VERGER GRAU, J., "Los juicios paralelos y la presunción de inocencia, con especial referencia al Jurado", en La criminalidad organizada ante la Justicia, GUTIÉRREZ-ALVIZ CONRADI, F. (Coordinador), Sevilla 1996, pp. 191 y ss. Entre la doctrina alemana vid. ESER, A. / MEYER, Öffentliche Vorverurteilung und faires Strafverfahren y más recientemente WEILER, "Medienwirkung auf das Strafverfahren”, ZRP 4 de abril de 1995, p. 130. 
público. De ahí a poder sostener la presencia de algún tipo de influjo sobre el desarrollo de la actividad jurisdiccional -en especial, con jueces no profesionales-, hay un trecho que no es difícil recorrer y que deja al descubierto el verdadero riesgo, representado en este caso por la puesta en peligro de la imparcialidad del juzgador.

\subsubsection{Secreto del sumario y acusación popular}

Tratándose de delitos públicos, y a pesar de la previsión general de publicidad para las partes, la declaración de secreto del sumario prevista en el art. 302.II puede excluir temporalmente para los sujetos procesales diversos al MF la posibilidad de tomar conocimiento de las actuaciones y de intervenir en la práctica de diligencias (no así de proponerlas) ${ }^{1255}$. Con ello no se incide sobre un derecho inalienable de particulares acusadores en defensa de pretensiones propias, sino que su facultad de intervención en el proceso cede temporalmente en favor del buen destino de la investigación ${ }^{1256}$.

Esta exclusión ha de reputarse lógica y justificada, en tanto se cohonesta bien con la naturaleza de cada uno de los sujetos, su función en el proceso y la imprescindible garantía de la máxima discreción en el esclarecimiento del delito. La desigualdad que con respecto al MF supone, carece de especial relevancia que pudiera motivar su impugnación, en cuanto este trato diferente se adecua a una desigual función y a la posibilidad de que se hagan valer intereses no siempre idénticos. La presencia del MF en todas las diligencias, aun en las declaradas secretas, está motivada por su tarea dentro del sistema como defensor de la legalidad y valedor de los derechos e intereses tutelados por ésta, lo que determina su responsabilidad sobre el contenido de la pretensión penal. La intervención de un acusador popular en diligencias sumariales declaradas secretas, con el aparente objetivo de contrarrestar eventuales veleidades inquisitivas de los órganos jurisdiccionales no sólo incrementaría desmedidamente el riesgo de que la investigación

\footnotetext{
${ }^{1255}$ Esta resolución podrá ser adoptada de oficio o a instancias de los acusadores, incluido el popular, aun cuando ello no parezca coherente con su función en el proceso. Sería defendible tal posicionamiento si lo que se pretende es amparar la adopción por el Juez de medidas limitativas de los derechos fundamentales cuyo éxito dependa de su desconocimiento por el sujeto pasivo de la investigación.

${ }^{1256}$ El secreto sumarial se deberá situar dentro de unos márgenes de apreciación de su necesidad por el instructor, que habrán de considerar en todo caso la necesaria máxima de publicidad (art. 120.1 CE, 232.1 LOPJ), no tanto en lo referido a los acusadores, sino sobre todo para el imputado, a quien lo realizado al amparo de la actuación secreta puede depararle muy gravosas consecuencias para sus posibilidades de defensa.
} 
no alcanzara sus fines, sino que en rigor carecería de sentido ${ }^{1257}$. No parece de recibo que cualquier particular, por el mero hecho de interponer una querella, pudiera tener acceso a informaciones que atañen a ámbitos demasiado sensibles para los derechos de los sujetos pasivos de la investigación o para el propio destino de ésta. Es más, la presencia de un sujeto procesal no apegado a la búsqueda de la legalidad, movido por la defensa de intereses no controlables y dirigidos en todo caso sólo a fundamentar una imputación, operaría en contra de principios esenciales del proceso, en tanto ello le permitiría adquirir $a b$ origine una indudable e injustificada ventaja sobre el acusado.

De otra parte, su mero carácter accesorio y/o sustitutivo no resultaría afectado por las posibilidades que el ordenamiento le ofrece de tomar conocimiento de lo actuado al levantarse el secreto del sumario, sujeto legalmente a una limitación temporal ${ }^{1258}$. Antes de la conclusión del sumario deberá éste alzarse, posibilitando la solicitud de práctica de nuevas diligencias tras conocer lo actuado con el objeto bien de refutar, bien de rebatir las conclusiones obtenidas. El secreto sumarial no puede de esta manera constituir una vía para mantener información reservada fuera del alcance de particulares intervinientes en el proceso (identidad de los testigos, informes periciales, etc.). Allí donde esta reserva sea precisa por operar un interés superior (protección de testigos ${ }^{1259}$, reserva de determinados

${ }^{1257}$ Incluso en el supuesto de que se inicie un proceso penal a instancias de un acusador privado en contra de la voluntad del MF. En este caso, el que se decrete el secreto del sumario no podría ser nunca entendido como detrimento de las facultades de defensa de estos sujetos, que por otro lado nada suyo defienden.

${ }^{1258}$ Los límites temporales se articulan en dos direcciones: 1) el plazo en el que las diligencias hayan sido declaradas secretas no podrá durar más de un mes a lo largo de un mismo sumario (aun cuando éste se fraccione), y 2) deberá alzarse con un mínimo de 10 días de antelación a su conclusión. En cualquier caso, el TC ha reconocido que una ampliación de ese marco temporal objetiva y suficientemente justificada no vulneraría el derecho a la no indefensión (STC 176/1988 de 4 de octubre).

${ }^{1259}$ Para que sea de aplicación la LO 19/1994 de 23 de diciembre, de protección a testigos y peritos en causas criminales será necesario que el Juez “aprecie racionalmente un peligro grave para la persona, libertad o bienes de quienes pretenda ampararse en ella, su cónyuge o persona a quien se halle ligado por análoga relación de afectividad, o sus ascendientes, descendientes o hermanos" (art. 1.2). Apreciada tal circunstancia, podrá adoptar de oficio o a instancia de cualquiera de los representantes de las "partes" varias decisiones tendentes a la protección de la identidad y la integridad del testigo o perito: que en las diligencias no consten sus datos identificativos, que comparezca de forma que no pueda ser identificado visualmente y que todas las notificaciones que se le deban hacer se realicen en el juzgado (art. 2). Pero la citada ley tampoco se revela suficiente para impedir que cualquier acusador llegue a conocer la identidad de testigos o peritos. Al objeto de garantizar su posible tacha o recusación, el Juez o Tribunal que haya de entender la causa está obligado a proporcionar la identidad de testigos o peritos si "cualquiera de las partes solicitase motivadamente en su escrito de calificación provisional, acusación o defensa, el conocimiento de la identidad de los testigos o peritos propuestos, cuya declaración o informe sea declarado pertinente" (art. 4.3 LOPTP). 
datos personales de la víctima, etc.), la declaración del sumario como secreto se revela como mecanismo claramente insuficiente.

En cuanto a su alcance objetivo, la declaración de secreto del sumario, podrá ser de carácter total o parcial, abarcando según criterio del Juez todas las actuaciones o sólo una parte de ellas. Pero en ningún caso cabe su limitación en función de los sujetos procesales, puesto que el ámbito subjetivo de la previsión se extiende por igual a todos los intervinientes distintos del MF, sin establecer diferencias entre acusadores ofendidos o no ofendidos, ni de éstos con respecto al imputado. No sería de recibo la exclusión independiente del conocimiento de la actividad procesal para el acusador popular y no para el actor particular o del imputado, por lo que, o bien se declara secreto para todos, o tal declaración debe quedar excluida ${ }^{1260}$. El secreto, para que lo sea de verdad, tiene que operar frente al mayor número posible de sujetos, por lo que únicamente quien ofrece desde su institucionalizada profesionalidad garantías de actuación y sujeción a criterios de estricta legalidad y objetividad, el MF, puede hacerse acreedor de tal excepción. La declaración de secreto del sumario no puede imponerse como castigo procesal a un sujeto que pudiera actuar en fraude de ley, sino como resultado de una situación objetiva en la que se aprecia la necesidad de cerrar temporalmente la investigación del delito al conocimiento externo que pudiera llevar aparejada como consecuencia la frustración de sus resultados. Aun cuando el CP contemple duras sanciones para quienes revelen actuaciones declaradas secretas por la autoridad judicial ${ }^{1261}$, la garantía no es suficiente, dado que el hipotético perjuicio que producirían tales revelaciones indebidas ya se habría podido producir de manera irreparable ocasionando la frustración de la investigación.

${ }^{1260}$ La imposibilidad de declarar secreto el sumario solamente para alguno de los sujetos procesales fue criticada por GIMENO a raíz de la reforma de 1978 con la que se introdujo la posibilidad para las "partes acusadoras" de intervenir en todas las diligencias del proceso. En su opinión, el principio de "igualdad procesal o de armas" no sería invocable para justificar unos efectos que mecánicamente se trasladan a ambas partes. Si uno de ellos adoptara una conducta obstruccionista o pusiera en peligro el secreto instructorio, sería perfectamente lícito que el juez declarase para cada uno de ellos el secreto instructorio, pero resultaría desproporcionado que las chicanas o malas artes de una de las partes, tuvieran que perjudicar en todo caso a la otra. Vid. GIMENO SENDRA, V., Fundamentos..., op. cit. p. 237 , n. 475.

${ }^{1261}$ Art. 466 CP. En el caso de los Abogados y Procuradores, la sanción será de multa de 12 a 24 meses e inhabilitación especial para empleo o cargo público, profesión u oficio de 1 a 4 años. Si la revelación de las actuaciones declaradas secretas fuese realizada por el Juez o miembro del tribunal, representante del MF, Secretario Judicial o cualquier otro funcionario al servicio de la Justicia, la pena ascenderá para equipararse a las de violación de secretos del art. 417 en su mitad superior. 
Desde otro punto de vista, ha de destacarse que precisamente la presencia de una pluralidad de acusadores puede ocasionar efectos secundarios no pretendidos en relación con la declaración del sumario como secreto. No es descartable que en sumarios donde conste la personación de una pluralidad de acusadores se esté incentivando desproporcionadamente su declaración como secretos por el órgano jurisdiccional. MAJADA advertía cómo en ocasiones puede ocurrir que eventuales peticiones de prácticas de diligencias repetidas, contradictorias o que se superpondrían con las ya practicadas, no harían más que embarullar y dilatar la investigación, con efectos contraproducentes sobre la causa, por lo que el órgano jurisdiccional se vería de alguna manera motivado para excluir temporalmente del proceso a unos sujetos molestos ${ }^{1262}$. Aun cuando tales peticiones podrían ser rechazadas por el instructor simplemente considerándolas innecesarias o perjudiciales (art. 312 LECrim), tal argumento no carecería de razón, en tanto es indudable que la reiteración de peticiones, aun cuando se rechacen una por una, puede suponer una rémora que lastre el desarrollo de la fase sumarial.

A ello ha de añadirse, además, la desconfianza que, a la vista de lo que ocurre con cierta asiduidad, merece la discreción (o mejor, la indiscreción) de los querellantes privados. Puesto que las sanciones previstas para imponer a los representantes de las partes que vulneren el secreto sumarial vienen siendo insuficientes para lograr su respeto, bien por la dificultad de averiguar la fuente divulgadora, bien por su práctica inaplicación, acaso la mejor forma de evitar la difusión antes de tiempo de los datos que se deriven de la investigación, podría ser la de privar de su conocimiento a todos los sujetos procesales particulares. Cuantas más personas puedan ser objeto de suspicacia sobre la fiabilidad de su discreción en el mantenimiento en un ámbito reservado de lo actuado en el sumario, tanto mayor será la probabilidad de que el Juez decida conferirle el carácter de secreto, vetando de esta manera su arbitraria difusión, al menos durante el periodo de tiempo que la Ley le autoriza ${ }^{1263}$. Quien más perjudicado resultará de ello será sin duda el imputado,

${ }^{1262}$ MAJADA, Práctica Procesal Penal..., op. cit., T. II, p. 1050, quien realiza esta afirmación refiriéndose a "procesos masa".

\footnotetext{
${ }^{1263}$ Casos sonados en este sentido, merecedores de relevancia en los medios de comunicación, han sido aquellos en que mediaba la personación de Partidos Políticos en asuntos donde los imputados estaban cercanos a ámbitos de poder. La declaración del secreto sumarial en fechas coincidentes con campañas electorales no se hizo esperar en dos conocidos casos de este tipo: el asunto "Juan Guerra" (en marzo de 1991) y el asunto "Filesa" (antes de las elecciones de junio de 1993), mereciendo una generalizada crítica periodística por lo que se interpretaba como un intento de privar al debate político de elementos esenciales.
} 
que verá temporalmente mermadas sus posibilidades de defensa y, quizá, determinadas éstas para el resto del proceso. Como consecuencia cabría inferir que, al impedirse la difusión de las diligencias de investigación practicadas y de sus resultados, no se estaría operando sólo en prevención de una utilización desviada de la facultad de acusar que pudiera ir en perjuicio de los fines de la investigación, sino que tendría incidencia indirecta, pero muy real, sobre los derechos del imputado en el proceso. La declaración del sumario como secreto sólo puede ser contemplada como un mal inevitable y todo aquello que la favorezca, como es el caso de la presencia de acusadores extraños al delito, ha de merecer desaprobación en tanto no ofrezca como contrapartida alguna ventaja mayor a cambio ${ }^{1264}$.

\subsubsection{En el juicio oral}

\subsubsection{La fase intermedia y la apertura del juicio oral}

En la fase intermedia, denominada con frecuencia entre nuestra doctrina "juicio de acusación", se viene a determinar si concurren o no los presupuestos necesarios para la apertura del juicio oral, emitiendo un juicio de probabilidad o de razonabilidad sobre la afirmación contenida en la acusación. La garantía de que el proceso se desarrolle por el impulso de un sujeto diferente del órgano judicial obliga a que no se pueda pasar a la fase de juicio oral sin que haya incitación por sujeto diverso al Juez, por lo que, incluso, cabe la búsqueda de un sujeto que pueda sostener una pretensión que pudiera tener visos de ser fundamentada (arts. 642 y ss. LECrim). No por ello siempre que exista ésta tiene por qué haber necesariamente proceso y, aun constando, no tendrán que darse en todo caso por buenos los términos en los que se establece ${ }^{1265}$. La afirmación de lo contrario significaría una extralimitación del poder de la acusación, que en combinación con el acceso indiscriminado de los particulares a ella, supone un riesgo incalculable de introducción de

\footnotetext{
${ }^{1264}$ Conscientes de las singulares circunstancias atravesadas por la Justicia en los últimos años, tal vez pudiere ser necesario no olvidar el riesgo de su instrumentalización para erigirse en instrumento de "politización de la justicia" o de "judicialización de la política", según las conocidas expresiones de WEBER, W., Weimarer Verfassung und bonner Grundgesetz, Göttingen, 1949, pp. 25 y ss.

${ }^{1265}$ Vid. CORTÉS DOMÍNGUEZ, V., La cosa juzgada penal, op. cit., p. 85.
} 
elementos de privatización en sede penal, con posibles resultados nefastos ${ }^{1266}$.

En el Procedimiento Abreviado, a diferencia de lo que ocurre en el Ordinario, el órgano competente para el control de la existencia de un mínimo fundamento en las acusaciones formuladas es el instructor ${ }^{1267}$. La apertura del juicio oral no puede ser consecuencia automática de la presencia de una o más acusaciones, sino de la apreciación de la concurrencia de indicios racionales de criminalidad (art. 790. 6 LECrim). Esta fórmula, extrapolada del art. 384 LECrim, opera como delimitación negativa, en el sentido de que cuando no concurran tales indicios, el instructor deberá acordar el sobreseimiento. Ello exige un "juicio de probabilidad" por parte del instructor, análisis que ha de ser más minucioso, si cabe, ante los escritos de acusación de sujetos privados. La apertura del Juicio oral incide gravemente en el imputado, por lo que será menester tanto por él como por la economía del proceso, expurgarlo de todas aquellas pretensiones cuya carencia de un mínimo fundamento sea detectable a limine. Una vez más habrá de reiterarse que con ello no se afecta derecho alguno del acusador, que no está actuando en defensa de un interés personal, sino que se protege fundamentalmente el derecho del imputado a no seguir sufriendo de forma innecesaria la llamada "pena de banquillo"1268.

El acusador popular debe ser citado para su comparecencia en el acto del juicio

\footnotetext{
${ }^{1266}$ Tal y como ya fue oportuna y certeramente advertido por GÓMEZ ORBANEJA, la acusación popular debe ir necesariamente ligada a algún tipo de control sobre la fundamentación de sus pretensiones. De ahí que en los sistemas procesales que no conozcan un juicio sobre la acusación, es evidente que ésta tenga que estar rodeada de cautelas, pues de otro modo esa facultad en manos de los particulares se estaría equiparando a la de demandar en el proceso civil. Vid. GÓMEZ ORBANEJA, E., Comentarios..., T. II, vol. I, p. 230.

${ }^{1267}$ Se ha señalado la posible inconstitucionalidad de la atribución del conocimiento sobre el fundamento de la
cusación al mismo órgano competente para dictar el fallo, por lo que la regulación del Procedimiento abreviado
upondría una evidente mejoría. Así p. ej. VERGER GRAU, J., La defensa del imputado..., op. cit. pp. 94 y ss. A su
uicio, cabría solventar el problema mediante las normas de reparto de los asuntos, atribuyendo esta función a una
ección de la Audiencia distinta de aquella que vaya a conocer del asunto. DÍAZ CABIALE, J.A., Principios de
aportación de parte y acusatorio..., op. cit. p. 494, afirma con rotundidad la inadecuación a las exigencias
constitucionales de la regulación del proceso ordinario por delitos en lo que se refiere a la atribución de la fase
ntermedia al órgano que va a fallar. En su opinión no serían de recibo soluciones menos drásticas que la atribución
lórgano instructor, tales como entender caso por caso sobre si existió algún tipo de conocimiento sobre la bondad o
no del auto de procesamiento o que siempre cabría atribuírselo a otra sección de la Audiencia, lo cual conllevaría
además una alteración de las normas de competencia funcional (art. 622. I LECrim). Estas soluciones no serían más
que "paños calientes" y todo tipo de razones lógicas impelen a una reforma en la que el Juez de instrucción en los
procesos ordinarios conozca también de la fase intermedia.

${ }^{1268}$ No hay juicio más injusto que aquél que no debió iniciarse, tal y como reza la célebre cita tomada de los "Principios..." de CARNELUTTI (p. 97).
} 
oral y la falta de citación, sin que hubiere comparecido dándose por citado, es uno de los motivos que abren la vía casacional por quebrantamiento de forma (art. 850.2 LECrim). Satisfecho adecuadamente ese requisito y en ausencia injustificada del acusador popular, nada obstará para que el juicio dé comienzo sin su presencia si comparecen los restantes acusadores. En el balance entre evitar dilaciones procesales y abrir el proceso a la intervención de los particulares entendemos que, una vez satisfechas en forma las exigencias legales en cuanto a notificación, la primera de estas dos máximas deberá prevalecer.

En el procedimiento ordinario se prevé como trámite inicial de esta fase la comunicación de la causa a las partes, al objeto de que formulen escrito de calificación provisional (art. 649 y ss. LECrim) ${ }^{1269}$. Su escrito de calificación deberá determinar los hechos punibles que resulten del sumario, la calificación legal que realicen sobre los mismos expresando cuál es en su opinión el delito que constituyen, la participación de los procesados así como las circunstancias atenuantes o agravantes ${ }^{1270}$ y las penas que corresponderían según su calificación. Además, deberá incluir específicamente el escrito de calificación del "acusador privado" la cantidad en que se aprecien los daños y perjuicios causados por el delito o la restitución de la cosa, así como la persona a cuya responsabilidad se atribuya ${ }^{1271}$.

\subsubsection{Planteamiento de cuestiones previas}

Si bien la Ley no contiene una previsión expresa, los acusadores no oficiales están

\footnotetext{
${ }^{1269}$ No es necesario que se dé traslado de la causa o se acuerde un requerimiento por el órgano jurisdiccional para que se recoja la misma si ya es conocida plenamente por las acusaciones por haber tenido acceso a ella con anterioridad y le hubiera sido notificada la providencia en que se tenía por evacuado el trámite de calificación de la acusación particular. Vid. STC 101/1989 de 5 de junio, FJ. 3: la no calificación por la acusación popular en el plazo legal por su propia negligencia haría precluir el trámite e impediría su acceso al proceso.

${ }^{1270}$ Nunca las eximentes, puesto que ello no se compadecería con el de sentido ordinario de la intervención de un sujeto en cuyo poder de disposición está el apartamiento de la querella en cualquier momento, quedando únicamente sujeto a responsabilidad por lo actuado (art. 274.II LECrim).

${ }^{1271}$ Una vez más cabe constatar que el legislador no contemplaba la posibilidad de un acusador popular en este estadio del procedimiento, pues no cabe imaginar a un acusador popular sosteniendo pretensión civil alguna. La mención al "acusador privado" que se hizo en la ley, en la que con posterioridad se ha entendido incluido el acusador popular, estaba pensando lógicamente en un acusador ofendido por el delito.
} 
legitimados para la proposición de cuestiones previas del art. 666 LECrim $^{1272}$, y su alegación podría estimarse dirigida a la subsanación de requisitos formales determinantes de la validez y corrección de la sentencia que, en su día, pueda recaer en la causa. En la práctica, no cabe esperar del acusador popular la proposición de ninguna otra de las cuestiones previas que no sea la de declinatoria de jurisdicción o la de falta de autorización administrativa para procesar: si su intención fuera aducir alguna de las otras (cosa juzgada, prescripción, indulto), le resultaría mucho más sencillo desistir del ejercicio de la pretensión penal sin más, haciendo frente en su caso a la responsabilidad por lo actuado (art. 274.II LECrim). La alegación de estas últimas cuando se considerase necesario, conducentes en caso de estimación a un sobreseimiento libre (art. 675 LECrim), sería lo más razonable si se tratase de un sujeto que pretendiera la defensa única y exclusivamente del interés público. Mucho nos tememos, sin embargo, que, en relación con el acusador popular, tal circunstancia no pueda ser siquiera imaginada, pues la imparcialidad no tiene por qué ser una de las notas que presidan su actuación ${ }^{1273}$.

En caso de que tales cuestiones fueran alegadas por el encausado o el MF, el acusador popular deberá recibir copia del escrito en el que se propongan y de los documentos en que se fundamenten (art. 668.II LECrim). Deberá contestar en plazo de tres días, presentando a su vez los documentos en que su respuesta se base (art. 669 LECrim). Podrá participar también en la vista e informar "lo que convenga a su derecho", que en el caso de las cuestiones de los números $2^{\circ}$ a $4^{\circ}$ normalmente será su consideración como improcedentes.

\subsubsection{Intervención en el juicio oral}

El acusador popular interviene en el juicio oral sosteniendo la pretensión penal, aun cuando se celebre a puerta cerrada (art. 680 y ss. LECrim) ${ }^{1274}$. Participará por tanto

${ }^{1272}$ Cfr. MUÑOZ ROJAS, T., “Las cuestiones previas”, RDProc 1ª́poca (continuación), 1964, I-II, pp. 107 y s.

${ }^{1273} \mathrm{Si}$, además, se tiene en cuenta la aptitud del planteamiento popular de la acusación para la defensa de intereses propios del acusador, de llegar a alegarse tales cuestiones, podríamos incluso pensar en algún tipo de acuerdo con el imputado en busca de la finalización del proceso, motivado por razones extravagantes al interés público que debe presidir el ejercicio de la acusación.

${ }^{1274} \mathrm{El}$ art. 681 se refiere en este supuesto al "acusador privado", pero dada la asimilación que se viene realizando del régimen legal de todos los acusadores privados, o tomando en cuenta la imprecisión terminológica que 
en todas las actuaciones probatorias a desarrollar en el juicio oral: a) en el interrogatorio cruzado de testigos donde les podrá hacer directamente a los testigos las preguntas que consideren oportunas y fuesen pertinentes en vista de sus contestaciones (art. 708 LECrim) ${ }^{1275}$; b) en el examen de peritos, solicitando aclaraciones y planteando preguntas y repreguntas (art. 724 LECrim), e incluso pudiendo recusarlos por las causas y en las formas previstas en los arts. 468 y ss. LECrim $^{1276}$; c) en la prueba documental y el examen de documentos y piezas de convicción (art. 726 LECrim) ${ }^{1277}$; d) en la constitución junto con el Tribunal, el Secretario Judicial y los demás sujetos en el lugar del reconocimiento judicial, pudiendo hacer constar en las diligencias las observaciones que estimen pertinentes (art. 727 LECrim).

El orden en el que intervienen el MF y los diversos acusadores, cuando exista una pluralidad de ellos, no viene expresamente recogido en la Ley y la laguna legal se ha salvado mediante un uso forense que se deriva de la previsión del art. 701. IV LECrim. Puesto que a tenor de éste habrá de empezarse por las diligencias de prueba y examen de testigos que hubiere ofrecido el MF, para continuar con las propuesta por los demás actores, el orden del interrogatorio otorga el primer lugar a aquél y a continuación, habilita la intervención de éstos ${ }^{1278}$. La Ley no especifica tampoco la preferencia en el

se achaca a la LECrim, debemos entender que la referencia se entiende hecha a los acusadores diferentes al MF, por lo que no es factible la exclusión del acusador popular. No será necesario detenernos en los posibles perjuicios que ello puede llevar aparejado al proporcionar una vía para el conocimiento público de lo que, en principio y por razones justificadas, habría quedado vedado de éste.

${ }^{1275}$ El presidente no permitirá que el testigo conteste a sus preguntas o repreguntas cuando éstas sean capciosas, sugestivas o impertinentes (art. 709 LECrim).

${ }^{1276}$ El parentesco de consanguinidad o de afinidad dentro del cuarto grado con el querellante se constituye en una de las causas de recusación. Ello no puede ser visto sino como una manifestación más del carácter privado con el que la LECrim concebía en origen a los particulares acusadores. Si, en el caso del ofendido, el interés privado es determinante y la exclusión de un perito cercano a él es totalmente lógica para evitar parcialidades derivadas de su interés en la causa, en el de un acusador público, teóricamente impulsado por sanos deseos de ejercicio de una función de ciudadanía, no tendría por qué habilitarse esta causa de recusación. Igual que no existe una previsión similar en el caso de parentesco con el fiscal, no habría razón para la duda en relación con un perito ligado por vínculo familiar al querellante no ofendido, si no fuera admitiendo que el interés que defienden ambos acusadores públicos no es el mismo, sino que en el caso del particular puede estar mediatizado por su propio provecho.

${ }^{1277}$ La parca regulación de la prueba documental y del examen de documentos y piezas de convicción de la LECrim no contiene previsión expresa alguna en relación con los acusadores, por lo que su régimen debe ser deducido de las restantes previsiones en materia probatoria. Como mínimo, deberemos poder constatar la facultad para el acusador de proponerla, la posibilidad de intervención en su práctica y el conocimiento de sus resultados.

${ }^{1278}$ En el caso de que la pretensión penal fuera sostenida sólo por un acusador que lo haga en contra de las tesis 
turno de intervención entre acusadores no oficiales, cuestión que su redacción originaria no hubiera podido prever puesto que no admitía una multiplicidad de acusadores con diferente función procesal, sino sólo una hipotética pluralidad de acusadores que hicieran valer "acciones" diversas. Una vez que con el tiempo se admitió la equiparación de los regímenes legales de los diferentes acusadores, un consolidado y justificado uso forense determina que sean los acusadores que representen los intereses del ofendido los que intervengan en primer lugar, dejando el último para el o los acusadores populares. El vínculo material con el objeto del proceso determina la prioridad en el ejercicio de la defensa de sus pretensiones. La duda se suscitará en el caso de una pluralidad de acusadores populares personados, en los que no existe per se nexo con el delito. En este supuesto, que entendemos debería ser evitado con anterioridad en aplicación del art. 113 LECrim, los criterios a seguir para determinar el orden en la intervención pudieran ser bien el del momento de la personación en la causa o bien el de la calificación más grave del delito. El primero de ellos se justificaría por la preferencia que otorga la prioridad en el tiempo y la razón del segundo pudiera cifrarse en facilitar la contradicción por el imputado y la articulación de su defensa empezando por las acusaciones más graves.

Podrán los acusadores plantear también cuestiones prejudiciales no devolutivas, en tanto éstas podrían surgir de sus alegaciones o de la investigación y aparecer tan íntimamente ligadas al hecho punible que fuera imposible racionalmente su separación ${ }^{1279}$. Los problemas en relación con la acusación popular se presentarán cuando tenga que ser un órgano jurisdiccional diferente al penal quien los resuelva, por lo que cabrá distinguir:

a) Las cuestiones prejudiciales devolutivas determinantes de la culpabilidad o la inocencia del imputado o de la validez de un matrimonio o supresión de un estado civil que podrán plantearse durante el juicio oral también a instancias del acusador popular. Su

del MF, a pesar de que no se contemple en el art. 701 LECrim, razones de coherencia obligan a que se conceda a aquél el turno de intervención con anterioridad a éste. Quienes aseguran la existencia del deber estatal de imponer la pena deben exponer sus alegaciones en primer lugar, por lo que si no es esta la tesis del fiscal, deberá intervenir en último lugar tras la defensa. Se ha sostenido que en caso contrario quienes sostuvieran la acusación verían menoscabado o mediatizado su derecho a defenderla por la intervención del fiscal. Vid. ESCOBAR JIMÉNEZ en MORENO VERDEJO, J, et al., El Juicio Oral..., p. 261.

${ }^{1279}$ La resolución sobre la cuestión quedará sujeta a las normas de derecho material correspondientes (art. 7 LECrim), pero su eficacia se limitará a "sólo el efecto de la represión" (art. 3 LECrim) o a los "solos efectos prejudiciales" (art. 10.1 LOPJ). 
estimación determinará la suspensión del procedimiento hasta que sean resueltas por el Tribunal competente o bien la fijación de un plazo para que "las partes acudan al tribunal civil o contencioso-administrativo competente" (art. 4 y 5 LECrim) ${ }^{1280}$.

b) El acusador popular está también legitimado para solicitar del órgano jurisdiccional el planteamiento de cuestiones de inconstitucionalidad (arts. 35 y ss LOTC, 5.2 y 3 LOPJ). La duda se suscita en caso de admisión de ésta por el órgano jurisdiccional y su planteamiento ante el TC, ya que es cuestionable si deberá habilitarse también en el proceso constitucional un cauce para la intervención del acusador quivis ex populo al objeto de que no pudiera ser estimada su posible indefensión. En nuestra opinión ello ha de rechazarse, en tanto el acusador popular no defiende una pretensión propia, por lo cual no se ve afectado derecho de defensa alguno. Al existir un trámite de audiencia del MF (art. 37.2 LOTC) el interés público, el mismo que representa el acusador popular, quedará plenamente garantizado y defendido.

c) Las cuestiones prejudiciales comunitarias a las que se refiere el art. $177 \mathrm{TCE}^{1281}$ pueden ser instadas por los órganos jurisdiccionales, de oficio o a instancia de parte, por lo que en principio al acusador popular no le puede ser vedada la facultad de proponerlas $^{1282}$. Es más, si la cuestión se plantease en un asunto pendiente ante un órgano jurisdiccional cuyas decisiones no sean susceptibles de ulterior recurso, dicho órgano estará obligado a someter dicha cuestión al TJCE (art. 177.III TCE). De nuevo se plantea la cuestión de si deberá concederse en este caso intervención o audiencia al acusador popular en el procedimiento ante el TJCE, y de nuevo la respuesta ha de contemplar la especificidad del procedimiento de que se trate. En este caso la intervención de las partes

${ }^{1280}$ De nuevo es aquí perceptible que la LECrim no estaba pensando en ningún momento en el acusador popular como sujeto procesal más allá de la iniciación del procedimiento, por lo que nunca se le llegaría a atribuir la condición de parte. La facultad de cualquier ciudadano de acusar no le otorga ningún tipo de legitimación extraordinaria para su intervención en otro proceso, aun cuando venga directamente preordenado a la resolución de cuestiones fundamentales para el procedimiento penal en curso. Aun cuando en estos juicios sea parte el MF (art. 4.III LECrim), la intervención del acusador popular en tal calidad, saliendo del ámbito procesal penal para irrumpir en otros no habilitados ordinariamente a la intervención de terceros ajenos al objeto procesal, ha de reputarse sencillamente inadmisible.

${ }^{1281} \mathrm{Al}$ respecto vid. JIMENO BULNES, M.M, La cuestión prejudicial del artículo 177 TCE, Barcelona 1996.

${ }^{1282}$ No podemos pasar por alto que la interpretación del Derecho Comunitario ha adquirido una trascendencia básica en relación con determinados tipos penales de la llamada delincuencia económica, supuestos muy propicios para la intervención de acusadores en los que no se dé la condición de ofendido por el delito. 
del proceso a quo es ciertamente escasa, pero cabe la posibilidad de hacer llegar al Tribunal "memorias u observaciones" por escrito ${ }^{1283}$.

Siguiendo el orden lógico de todo el decurso procesal, y aun cuando tampoco haya previsión legal expresa, el acusador popular realizará su informe oral en el último lugar de entre los acusadores. La Ley se refiere en este extremo sólo al "defensor del acusador particular, si le hubiere" (art. 734 LECrim) o a "la acusación" (art 793.6 LECrim), pero en aplicación de la lectura dada a estas expresiones, dentro de ellas habría de considerarse englobado también al acusador popular. Igual que los restantes sujetos procesales, podrá hacer uso de la calificación a través de conclusiones alternativas, lo cual, a la vista de la apertura en la legitimación de nuestro sistema, permite un amplio abanico de calificaciones diversas, pudiendo originar la multiplicación de los elementos que enmarcan el debate procesal.

A diferencia de lo que ocurre con el fiscal, y a pesar de que no exista prohibición legal, en el caso de los acusadores no oficiales, no es imaginable otra posibilidad que la formulación de conclusiones definitivas en las que se ratifique la existencia de presupuestos para una resolución de condena, aun cuando éstos, a la vista de la ocurrido en la fase probatoria, pudieran quedar configurados de forma diversa a los de la calificación inicial. Tanto la incomparecencia injustificada a este trámite, como la petición de absolución por su parte, podrían equipararse al apartamiento del proceso ("apartamiento de la querella" en la terminología de la LECrim -art. 274.II-), y en ambos casos pudiera entenderse que existe un desistimiento tácito ${ }^{1284}$.

\subsubsection{Terminación del proceso}

${ }^{1283}$ Vid. JIMENO BULNES, M.M, La cuestión prejudicial..., op. cit. p. 445.

${ }^{1284} \mathrm{El}$ abandono, que puede producirse en cualquier momento, no exigiría manifestación de consentimiento de ningún tipo por parte del acusado pues en nada le podría perjudicar. Los términos del debate procesal ya estarán fijados en orden al alcance de la sentencia. De haber otro sujeto personado como acusación, el proceso continuará sin el acusador que se haya "apartado de la querella", pero de no haberlo, la sentencia que se dicte será necesariamente absolutoria. 


\subsubsection{Medios de impugnación}

La legitimación impugnativa se recoge expresamente en el art. 854 LECrim en referencia a la casación, pero se aplica analógicamente a todos los supuestos en los que haya un pronunciamiento definitivo. A tenor del citado precepto, podrán interponer recurso el MF, los que hayan sido "parte" en los juicios criminales, los que sin haberlo sido resulten condenados y los herederos de unos y otros ${ }^{1285}$. De ello parece deducirse inequívocamente la legitimación también de los acusadores populares personados en la causa $^{1286}$.

La pluralidad de sujetos acusadores tendrá sin embargo dos importantes repercusiones en el planteamiento y sustanciación de los recursos:

a) En relación con el dies a quo para el cómputo del plazo del recurso. Pese a que cada sujeto pueda interponer el correspondiente recurso una vez que le haya sido notificada la resolución, será la última notificación a los que hubieren tomado parte en el juicio la que determine el momento a partir del que empiezan a contarse los plazos correspondientes (art. 211, 212, 856 y 974 LECrim).

b) Dependiendo del recurso de que se trate, la ley incorpora mecanismos para atender a las alegaciones de las restantes "partes":

* en el recurso de reforma: se deberán presentar tantas copias del escrito interponiendo el recurso cuantas sean los sujetos personados y se les deberá hacer entrega de ellas para que realicen prácticamente de forma inmediata las contraalegaciones que estimen por conveniente, exigencia ineludible para su consideración por el Juez (art. 222

${ }^{1285}$ Un nuevo recordatorio del matiz civilista con el que la LECrim se refería a "las partes" se puede deducir de la admisión de los herederos de los actores para interponer el recurso de casación. Desde luego no creemos que el legislador de 1882 pensara en que el heredero del acusador no víctima pudiera recurrir en casación, por lo que hablar de su heredero no tendría razón de ser. Ello nos lleva a considerar una vez más que no se pensaba en absoluto en acusadores no ofendidos, sino sólo en quienes tuvieran un interés privado que, evidentemente, era transmisible a sus causahabientes.

\footnotetext{
${ }^{1286}$ No puede olvidarse que el derecho a que las resoluciones jurisdiccionales del proceso penal puedan ser sometidas a revisión es un imperativo constitucional que opera, en principio, en favor del imputado y no del acusador. El art. 14.5 del Pacto Internacional de Derechos Civiles y Políticos de Nueva York establece que "toda persona declarada culpable de un delito, tendrá derecho a que el fallo condenatorio y la pena que se le haya impuesto sean sometidos a tribunal superior, conforme a lo prescrito por la Ley" y el TC ha entendido por la vía del 10.2 CE que el derecho a los recursos en el sentido expuesto integra el derecho a la tutela judicial efectiva, aun cuando conceptualmente fuera más exacta su acogida en el debido proceso (art. 24.2 CE).
} 


\section{LECrim).}

* en la apelación: existe la carga de la personación, ya que de lo contrario pueden precluir sus facultades (art. 224 y 227 LECrim). En este caso, los personados tomarán conocimiento de los autos y cada parte, comenzando por la apelante, dispondrá de un plazo (3 días) para la instrucción debiendo devolver los autos con la manifestación de haberse instruido (art. 229 LECrim). El momento en que se ha de fundamentar el recurso es la vista oral, formulando el apelante las oportunas alegaciones y los apelados contraalegaciones en apoyo de la confirmación del auto apelado.

El acusador popular que haya intervenido en una causa penal no podrá, sin embargo, promover ni interponer el mal llamado "recurso de revisión", aun cuando le constare la concurrencia de alguna de las causas legalmente previstas ${ }^{1287}$. Sin dudar de la buena voluntad del ciudadano no ofendido que acusa en el proceso penal, y que ahora pudiera actuar alentado por motivos de justicia material, la facultad de instar la revisión no parece corresponderse con su función de sostenedor de la acusación. Tal solicitud sólo se podrá orientar hacia el reexamen en favor del reo de una sentencia condenatoria, y ello tiene poco que ver con su posición procesal.

\subsubsection{La ejecución}

La tarea del acusador popular en el proceso termina con la sentencia firme que lo pone fin, sin que haya norma que apoye la prolongación de su actividad. Su posición como acusador termina precisamente allí donde comienza la efectiva imposición del castigo al amparo de la declaración de existencia del ius puniendi estatal. El CP prevé, no obstante, un trámite de audiencia a las "partes" para dejar en suspenso el cumplimiento de las penas privativas de libertad inferiores a dos años (arts. 80.2, 81 y $87.1 \mathrm{CP}$ ) y para la sustitución de las que no excedan de un año (art. $88 \mathrm{CP}$ ). De ahí que, a tenor de esta previsión, el acusador popular que hubiere intervenido en el proceso pueda manifestar en estos casos lo que considere conveniente al interés público que debe presidir su intervención.

${ }^{1287}$ Sólo están legitimados para promover e interponer, en su caso, el recurso de revisión el MF, el penado y, fallecido éste, sus familiares (art. 955 y ss. LECrim). 
La legislación penitenciaria no contempla en ningún momento la intervención de acusadores privados respecto a las penas privativas de libertad, y ni siquiera se les reconoce legitimación para recurrir las resoluciones del Juez de Vigilancia penitenciaria sobre la situación de los internos, al igual que se hace con el MF o el propio interno ${ }^{1288}$. Algún autor ha planteado que ello carece de motivos y sería incompatible con el art. 125 $\mathrm{CE}$, y por ende incongruente con nuestro ordenamiento procesal. Tales opiniones favorables a la intervención de los acusadores populares se basan sobre la errónea incardinación de la acusación popular en el ámbito de los Derechos Fundamentales, que hablaría en favor de la existencia de un interés legítimo en la ejecución penal. Según ellas, y confundiendo radicalmente la función procesal del MF, la presencia de éste no tendría por qué impedir la de acusadores populares, por lo que se llega a sugerir que deberían poder recurrir tales resoluciones todos aquéllos que hubieran intervenido activamente en el proceso penal ${ }^{1289}$.

Tal intelección no sería sin embargo admisible, puesto que la ejecución penal tiene que ver con el resultado del proceso, pero de ninguna manera con el desarrollo de éste y la forma de satisfacción del presupuesto procesal en que la acusación consiste. Parece claro que el acusador popular deberá estar absolutamente al margen del control de la ejecución, en tanto esta función se extralimitaría absolutamente de la naturaleza y sentido de su participación en el proceso. El tratamiento penitenciario, materia altamente sensible en conexión con Derechos Fundamentales de los internos, ha de estar siempre dirigido a la reeducación y reinserción social y una intervención externa podría comprometer esos

${ }^{1288}$ DA $5{ }^{\mathrm{a}}$ LGP.

${ }^{1289}$ LÓPEZ BARJA DE QUIROGA, J., "Recursos contra las decisiones del Juez de Vigilancia Penitenciaria”, $P J, \mathrm{n}^{\circ}$ especial III, pp. 152 y s. 
objetivos $^{1290}$, lo cual contribuiría a hacerla indeseable.

${ }^{1290}$ Ello sin entrar a valorar la posible intervención de la víctima del delito durante la ejecución de la sentencia, haya tomado parte o no en el proceso. En contra de la intervención de los sujetos privados en esta materia, ni aun de los acusadores particulares y en favor de la inexistencia de una acción popular " $n i$ ante ni contra el Juez de Vigilancia Penitenciaria" se mostraba ASENCIO CANTISÁN, H., "Recursos contra las resoluciones del Juez de Vigilancia Penitenciaria en la Ley Orgánica del Poder Judicial”, $A D P C P$ enero-abril 1987, nº 1, p. 158. 


\section{MECANISMOS DE GARANTÍA FRENTE A UN INADECUADO EJERCICIO POPULAR DE LA ACUSACIÓN}

\subsection{Fianza}

\subsubsection{Justificación histórica, naturaleza y sentido en la actualidad}

La exigencia de fianzas para el ejercicio de la acusación tiene origen en el Derecho Romano $^{1291}$, pero, como ha sido expuesto por GIMENO, la que la LECrim prevé para el acusador popular es un fenómeno relativamente reciente en nuestro Derecho, que apareció como un usus fori sustitutivo de la imposición de formas de garantía personal mucho más restrictivas. La fianza que hoy conocemos es producto de la evolución de antiguas formas de sujeción física del querellante a obligaciones personales para el supuesto de que no fuera capaz de probar su acusación, momento en el que cabría la imposición de la misma pena que solicitara para su oponente (Talión). Es sólo a partir de la primitiva LECrim de 1872 cuando la previsión de fianza pecuniaria alcanza reflejo normativo en conjunción con otros elementos, tales como la severidad de las penas por falso testimonio, la desconfianza frente al juramento de calumnia de los juristas liberales de la época, o a una deficiente regulación del delito de acusación y denuncia falsa. Las deficiencias de la ley penal material motivaron de esta manera la consagración del uso forense en que la fianza consistía y, en último término, la opción del legislador por la vía procesal como remedio para solucionar tal falta de fiabilidad ${ }^{1292}$. Constituía la fianza del acusador un intento de evitar los males que en el proceso penal podría deparar su utilización calumniosa impulsada por el prejuicio consistente en presumir que el ofendido por el delito se mueve siempre en el proceso de buena fe en defensa de un interés propio, pero no así quien no lo

\footnotetext{
${ }^{1291}$ Dig. 48, 2, 7, 1 (ULPIANO): “Cauent itaque singuli, quod crimen obiciant, et praetera perseueraturus se in crimine usque at sententiam" (Presten todos caución por haber imputado un delito, y además, de que perseverarán en la acusación hasta sentencia).

${ }^{1292}$ GIMENO SENDRA, V., "La fianza del acusador particular: Notas sobre la legitimación activa y «caución juratoria» en el proceso penal”, RDProc (Ibam) 1976, pp. 55 y ss.
} 
Pese a lo que pudiera parecer a primera vista, contemplando la aparente amplitud subjetiva de la acusación, la fianza ha de ser vista hoy como un residuo histórico de una concepción acentuadamente privada y muy restrictiva del acceso de los particulares al proceso penal. Se sirve además, y muy significativamente, de uno de los criterios menos igualitarios en que cabría pensar: el de la capacidad económica. Podemos entender comprensible el ejercicio de una facultad que se predicaba inherente a la condición de ciudadano sólo previo depósito dinerario, únicamente si lo hacemos enmarcando aquélla dentro de una mentalidad decimonónica de corte radicalmente liberal ${ }^{1294}$. Dado que en el momento codificador a nadie se le escapaba que la puesta en práctica de la habilitación de acusar podría amparar excesos y perjuicios derivados de su utilización abusiva, la necesidad de afianzar los hipotéticos daños no constituía más que la lógica consecuencia del deseo de evitarlos. Pero el resultado que tal previsión produciría no puede ser más esclarecedor, ya que únicamente el sujeto que tuviera medios suficientes para acceder a la Jurisdicción podría ejercer lo que se consideraba un aspecto integrante de la esfera jurídica personal: lo que se entendía como un “derecho a acusar"1295. Parece fácil pensar a este respecto, y la escasa jurisprudencia nos habla de ello, que en el momento originario de la LECrim no era siquiera imaginable la acusación por sujetos no ofendidos que no integraran las pudientes élites burguesas.

En tiempos más recientes, pero con anterioridad a la vigencia de la Constitución de 1978, fue advertido por la doctrina que la exigencia de fianzas pudiera cohibir a potenciales acusadores y ser fuente de discriminaciones, por lo cual carecería de justificación si lo que se buscaba era que los particulares colaboraran en funciones

${ }^{1293}$ GIMENO SENDRA, V., “La fianza...”, op. cit., p. 56, que sitúa su origen en las Partidas. Este cuerpo normativo no hizo sin embargo más que recoger una previsión ancestral que, como se ha visto, encontró acomodo también en el Derecho Romano. En opinión del citado autor, además, la práctica forense suele reflejar lo contrario, es decir, que el acusador popular se mueve por intereses más límpidos que los del ofendido por el delito. Vid. también su trabajo más cercano en el tiempo con GARBERÍ LLOBREGAT, J., "La protección procesal del Medio Ambiente", PJ, n 37, p. 153.

${ }^{1294}$ Pensemos por un momento en el censitario derecho de sufragio, perfecto correlato en el ámbito electoral de lo que constituiría en el proceso penal la acusación popular.

${ }^{1295}$ En el caso del ofendido por el delito, la facultad de acusar sin fianza parece integrar el patrimonio: el art. 281.1 y 2 exime de la obligación de prestar fianza no sólo al ofendido (o sus parientes en caso de homicidio) sino también a sus herederos, con lo que en este supuesto estaríamos ante un derecho transmisible mortis causa. 
$\overline{\text { públicas }^{1296} \text {. La fianza constituiría un freno al ejercicio de la acusación que se calificaba }}$ como censurable y distanciado del contexto histórico en el que se instauró, en tanto el ejercicio de lo que se estimaba como un derecho cívico no debería estar sometido a condicionamiento económico alguno. Dado que la única razón de ser de tal exigencia sería la inercia histórica del legislador, basada en el temor al ejercicio de acusaciones calumniosas, por no responder en la actualidad a los principios de la LECrim ni a la práctica forense habría dejado de tener sentido, y por ello procedería su expulsión del ordenamiento jurídico. Tales males deberían encontrar respuesta en la reforma de la ley penal sustantiva, con la introducción de un tipo relativo al fraude procesal a imagen del ordenamiento italiano y con el reforzamiento, tendente a su mayor efectividad, del de acusación falsa ${ }^{1297}$.

Ya en vigor la Constitución se ha sostenido, en consonancia con las opiniones anteriores, que la exigencia de fianza para el ejercicio de la acusación por particulares habría de entenderse abrogada a tenor del art. 24.1 $\mathrm{CE}^{1298}$. Para evitar querellas infundadas el instrumento a utilizar no podría ser el depósito de fianzas, sino los autos de inadmisión o sobreseimiento ${ }^{1299}$. El TC ha abordado también la adecuación de la mera previsión de la exigencia de fianza al derecho a la tutela judicial efectiva, estableciendo taxativa y reiteradamente que la imposición de ésta no impide por sí misma el acceso a la jurisdicción y, por ello, no sería en sí misma contraria a su contenido esencial (SSTC 62/1983 de 11 de julio, 113/1984 de 29 de noviembre, 147/1985 de 29 de octubre y $326 / 94$ de 12 de diciembre).

El objetivo de la imposición de la fianza es el de ofrecer una garantía para responder de lo que la ley denomina "las resultas del juicio" (art. 280 in fine LECrim), sin que esté claro lo que debamos entender incluido en tal rúbrica. Dado que en la Ley no se

\footnotetext{
${ }^{1296}$ MUÑOZ ROJAS, T., "En torno al acusador particular en el proceso penal español”, RDProc (Ibam) 1973, p. 144.

${ }^{1297}$ GIMENO SENDRA, V., “La fianza...”, op. cit. pp. 83 y s. y 96.

${ }^{1298}$ GIMENO SENDRA, V., “La acción popular, el jurado y los Tribunales de escabinos”, en COBO DEL ROSAL y BAJO FERNÁNDEZ, Comentarios a la legislación penal, T. I, 1982, p. 342 en relación con el comentario al art. 24.1 CE (p. 148).

${ }^{1299}$ GIMENO SENDRA, V., "Los derechos de asociación (sic) penal al juez legal y de defensa y sus derechos instrumentales”, en COBO DEL ROSAL y BAJO FERNÁNDEZ, Comentarios a la legislación penal, op. cit. p. 148, reiterado en Constitución y Proceso, Madrid 1988, p. 78.
} 
establecen ni criterios ni preferencias para la adjudicación de la cantidad depositada en concepto de fianza, una vez determinado que no ha de ser devuelta, la cuestión permanece abierta $^{1300}$. Habremos de entender, empero, que el legislador se está refiriendo con aquella expresión de una parte a la imposición de las costas procesales y de otra a las responsabilidades derivadas del ejercicio de una acusación calumniosa:

a) Para hacer frente a las costas del juicio, cuando se aprecie por el juzgador temeridad o mala fe (art. 240.3 LECrim). En ellas se habrán de incluir los gastos de defensa y representación, los honorarios de los peritos y las indemnizaciones a testigos (art. 241 LECrim). Se debe advertir, no obstante, que los supuestos en los que se haya de perder la fianza y adjudicarse al Estado por haber procedido con temeridad o mala fe son realmente difíciles de imaginar ${ }^{1301}$.

b) Para responder de las responsabilidades dimanantes de una acusación calumniosa. En este sentido la finalidad de la fianza sería la de asegurar los posibles daños y perjuicios que pudieran derivarse de una acusación calumniosa o de una conducta procesal maliciosa y negligente por parte del acusador particular ${ }^{1302}$. Aun cuando con carácter genérico es difícil determinar cuáles pudieran ser estos perjuicios, parece que en primer lugar la garantía dineraria tendrá que ir destinada a hacer frente a las responsabilidades civiles dimanantes del delito de acusación falsa del art. $456 \mathrm{CP}$ por el que, en su día y en su caso, se condene al querellante. El monto de tales responsabilidades tendrá que venir determinado por sentencia firme y a su abono se asignará total o parcialmente la cuantía de la fianza depositada en la medida que requiera su satisfacción. Téngase en cuenta además que las responsabilidades pecuniarias que pudieran declararse en la

${ }^{1300}$ Sólo en el derogado art. 777 LECrim se contemplaba expresamente el destino de la fianza en relación con la promoción del antejuicio para exigir responsabilidad criminal a los Jueces y Magistrados. En concreto se preveía en él que "si hubiere condena en costas, no se devolverá la fianza hasta que se satisfagan; y si no se pagaren en el término que se fije para ello, se harán efectivas por cuenta de la fianza, devolviendo el resto a quien la hubiera prestado". El precepto ha sido derogado junto con el resto del Tít. II del Libro IV de la LECrim por la DA $1^{\text {a }}$ de la LOTJ y sobre él había estimado el TS que no era contradictorio con la norma del art. 20.3 LOPJ, sino corolario de la misma. Vid. Auto TS de 27 de abril de 1993 (RAJ 3286). En este caso no se trataba de un recurso de casación, sino del único supuesto de apelación de que conocía el TS al amparo del antiguo art. 763, por impugnarse la resolución de un recurso de súplica interpuesto ante TSJ contra providencia del propio Tribunal.

\footnotetext{
${ }^{1301}$ En este sentido vid. PORTERO, REIG, MARCHENA, Comentarios a la Reforma procesal penal de la LO 7/1988 (Procedimiento Abreviado), p. 35.

${ }^{1302}$ STC 326/1994 de 12 de diciembre, FJ. 3.
} 
sentencia ${ }^{1303}$ son de dos tipos y van dirigidas a dos fines completamente diferentes: por una parte formarán parte de la responsabilidad penal e integrarán la pena de multa, pero por otra integrarán también la responsabilidad civil ex delicto. En aplicación de un criterio victimológico es a esta última a la que deberá darse carácter preferente, aplicando la cantidad de la fianza restante, una vez satisfecha la indemnización por daños y perjuicios, a la obligación de abonar la multa impuesta.

La fianza constituye a juicio de la mayoría de la doctrina actual solamente una condición resolutoria de la admisibilidad de la querella, pero no una causa que determine la inadmisibilidad a limine de ésta ${ }^{1304}$. No es un presupuesto procesal, toda vez que la concurrencia de dicho requisito deviene necesaria sólo en el momento o con posterioridad a la interposición de la querella, pero nunca con anterioridad a la misma (FENECH). Constituye así un elemento formal del acto de querella sin integrar su contenido, sino que fue instaurada con el propósito de asegurar su fundamento. La función de la fianza se cifraría, por tanto, en la garantía de que al actor no lo animan fines meramente caprichosos ${ }^{1305}$. Por ser elemento formal de garantía de la fiabilidad de la propia querella no podría ni confundirse ni utilizarse para la adopción de medidas cautelares y no cabría aplicar la fianza (o una cautela específica) como garantía de daños que pudiera causar la adopción a instancia de un acusador popular de una medida cautelar, personal o real, cuando la causa terminara mediante sobreseimiento libre o absolución ${ }^{1306}$.

La omisión de prestar fianza por el acusador popular no puede impedir uno de los principales efectos de la querella, puesto que al transmitir la notitia criminis, la obligación del Juez de instruir el sumario deviene ineludible en virtud del art. 308 LECrim. La fianza operaría no como causa de desestimación a limine de la querella, sino sólo como condición resolutoria de su admisibilidad y sus efectos quedarán condicionados a que

${ }^{1303}$ Vid. PEDRAZ PENALVA, E., Las medidas cautelares reales..., op. cit. pp. 31 y ss.

${ }^{1304}$ Por todos vid. GIMENO SENDRA, V., "La fianza...”, op. cit. p. 88.

${ }^{1305}$ En este sentido vid. Memoria FGE 1988, Madrid 1989, p. 317. La fianza es, en palabras de DE LA OLIVA, condición del ejercicio de la "acción popular", pero no de su existencia, y en ese sentido el art. 20.3 LOPJ habrá de interpretarse de forma que la fianza venga a procurar una cierta garantía de comportamiento serio al ejercitar la acción, sin llegar a impedir de facto su ejercicio. DE LA OLIVA, A., et al., Derecho Procesal Penal, Madrid 1993, p. 183.

\footnotetext{
${ }^{1306}$ Semejante corruptela procesal, que nos consta está ocurriendo en la práctica en relación pretensiones penales deducidas por asociaciones de defensa del medio ambiente en delitos de esta naturaleza, viene a incurrir en un error sobre la verdadera naturaleza de la medida cautelar en el proceso penal y sobre la responsabilidad de su adopción.
} 
$\overline{\text { fuera satisfecha efectivamente. } \mathrm{Si} \text {, una vez requerido el actor para que realice su abono, }}$ desoyese el mandato, el Juez desestimará la querella por falta de admisibilidad mediante auto, extendiendo sus efectos al momento de la interposición, cuya consecuencia será la extinción de los efectos de litispendencia e interrupción de la prescripción ${ }^{1307}$. El ejercicio de la acusación se entendería renunciado por él a los solos efectos de no tenerle por acusador, sin que quede eximido de las responsabilidades que ya se hubiesen podido generar (por ejemplo si se constata que estamos ante un delito de denuncia o acusación falsa del art. $456 \mathrm{CP})^{1308}$.

\subsubsection{Régimen legal de la imposición de la fianza}

\subsubsection{Sujetos obligados}

Obligados al depósito de fianza estarán los acusadores no ofendidos, tal y como se deriva de las previsiones de la LECrim en relación con la interposición de querella (Tít. II, Libro II). Establece el art. 280 LECrim que "el particular querellante presentará fianza de la clase y en la cuantía que fijare el Juez o Tribunal para responder a las resultas del juicio". De tal imperativo se exceptúa únicamente al ofendido y sus herederos

\footnotetext{
${ }^{1307}$ GIMENO SENDRA, V., “La fianza...”, op. cit. pp. 93 y s.
}

${ }^{1308}$ Los efectos de no realizar el depósito de la fianza exigida fueron abordados por la STC 326/1994 de 12 de diciembre (FJ 3). En este caso la Unión de Consumidores de España, en adhesión al MF, pero realizando un ejercicio cívico de la acusación, intentó personarse en un proceso por delitos monetarios y de estafa. El Juzgado Central de Instrucción le requirió para que, antes de tenerle por parte, prestara una fianza de 2.000 .000 de pesetas al objeto de responder de las resultas del juicio. Los recursos de reforma y subsidiario de apelación de la entidad actora dirigidos a impugnar esta resolución no se tuvieron por interpuestos, ya que el Juzgado estimó que, al no haberse depositado la fianza exigida para tenerla como parte, todavía no habría adquirido tal condición. En el subsiguiente recurso de queja ante la Sala de lo Penal de la AN, se desestimó la pretensión de la actora por la misma razón, pero añadiendo el dato comparativo de que por no acreditarse que se trataría únicamente de una adhesión a la acusación del fiscal y por poder rebasarse ésta, nos encontraríamos ante "un plus acusatorio, una auténtica querella para cuyo ejercicio era legal y no arbitraria, además de ponderada, la fianza exigida". El TC abordó la cuestión entendiendo que el depósito de fianza para impugnar su propia cuantía sería una injustificada o arbitraria limitación del derecho a los recursos y, en esa medida, una lesión del consagrado en el art. 24.1 CE. Aun cuando efectivamente la Unión de Consumidores no pudiera ser considerada todavía parte procesal, el previo depósito de la fianza carecerá de sentido como presupuesto previo para poder cuestionar la cuantía de la misma puesto que el auto que inadmite una querella es impugnable en apelación (art. 313 LECrim). Según el tenor literal de la sentencia, la finalidad de la fianza es la de “asegurar los posibles perjuicios y consiguientes responsabilidades que pudieran derivarse de una acusación calumniosa o de una conducta procesal maliciosa o negligente por parte del acusador particular. Sin embargo, dichos perjuicios no son susceptibles de materializarse por la interposición de recursos como los inadmitidos, máxime cuando en el presente caso el proceso se había incoado a instancias del MF y se había sobreseido provisionalmente, no existiendo base suficiente para interpretarlos ni siquiera como una maniobra dilatoria" (FJ 3). 
o representantes legales y, en los delitos de asesinato y homicidio, al viudo o viuda, los ascendientes y descendientes, los colaterales hasta el segundo grado y los herederos de la víctima (art. 281 LECrim) ${ }^{1309}$. A ellos se deben añadir los extranjeros ofendidos por el delito cuando la exención de la fianza dimane de tratados internacionales o de la aplicación del principio de reciprocidad (art. 281 in fine).

La desigualdad entre los acusadores no ofendidos y los demás a efectos de imposición de fianza ha sido en ocasiones criticada por la doctrina, en tanto de ella se pudiera derivar una vulneración del derecho a la igualdad contenido en el art. 14 CE. Para VIVES ANTÓN, por ejemplo, esta distinción, que nunca habría tenido mucho sentido y sería de dudosa constitucionalidad, habría de desaparecer: ni siempre habría de exigirse fianza al actor popular, ni siempre el ofendido habría de quedar exento de ella ${ }^{1310}$. Sin embargo el TC ha tenido ocasión de pronunciarse en sentido contrario, convalidando esta diferenciación al partir de la distinta afección que el delito produce sobre las personas, por lo que habrá de otorgarse mayores facilidades para la acusación a los más cercanamente afectados por el delito, lo cual no podría en principio calificarse de irracional ${ }^{1311}$. Esta gradación en la afección, sin olvidar además el aparentemente disímil fundamento constitucional entre ambas posibilidades de acusación ${ }^{1312}$, parece que constituiría motivo suficiente para fundamentar la constitucionalidad de la previsión legal. En cualquier caso, tal desigualdad, se dice, no supone un obstáculo grave o impeditivo a lo que el TC ha considerado ejercicio de un Derecho Fundamental relacionado con el de acceder a la Jurisdicción $^{1313}$. Constituye un aspecto esencial con respecto a esta materia determinar quién puede ser considerado sujeto exento de la prestación de fianza por ostentar la cualidad de ofendido por el delito. El TC vino a dar respuesta a una cuestión no resuelta

\footnotetext{
${ }^{1309}$ A pesar del contrario pronunciamiento jurisprudencial, no puede afirmarse en sentido estricto que la exención legal alcance a cualquiera que alegue un perjuicio derivado del hecho delictivo.

${ }^{1310}$ VIVES ANTÓN, T.S., "Doctrina constitucional y reforma del proceso penal”, PJ, $\mathrm{n}^{\mathrm{o}}$ especial II, p. 111. Reitera así la argumentación de GIMENO, que considera no concordante con la práctica forense la utilización siempre bienintencionada de la acusación por el ofendido, frente a la desconfianza que genera la de un sujeto ajeno en principio al delito.

${ }^{1311}$ SSTC 62/1983 de 11 de julio, FJ. 4, 113/1984, de 29 de noviembre, FJ 2, 147/85 de 29 de octubre, FJ 3 y $326 / 94$ de 12 de diciembre, FJ. 2.

${ }^{1312}$ Tal distinción entre los fundamentos constitucionales de las acusaciones particular y popular se afirma por ejemplo en la STC 34/94 de 31 de enero, FJ 2.

${ }^{1313}$ STC $62 / 1983$ de 11 de julio, FJ 4.
} 
por la Ley, estimando que habría de entenderse como tal solamente a los titulares de derechos que hubieran resultado directamente dañados u ofendidos por el delito que da origen a la querella. No bastaría por tanto la alegación de un genérico interés como simple ciudadano en la correcta actuación de los Poderes Públicos, sino que se exige la inmediata afección de la propia esfera jurídica ${ }^{1314}$.

Llegados a este extremo y en línea con lo hasta ahora defendido, hemos de puntualizar nuestra discrepancia. No es factible entender ni admitir que el particular ofendido/perjudicado por el delito pueda pretender algo distinto de lo que prescribe la Ley en aras del interés general normativamente reconocido e institucionalmente representado por el MF, concretable en el enjuiciamiento de un sujeto y hecho determinados. Ni al actor popular, ni al particular pueden reconocérseles intereses extravagantes que fuera de la Ley provoquen un resultado distinto al que debe perseguir el MF. Sólo la falta de diligencia o la insuficiencia de medios, o bien la búsqueda explícita o implícita de objetivos espurios por el Ministerio Público justificaría un mejor "resultado" procesal por el hecho de que intervengan dos o más acusadores ${ }^{1315}$. Con esta salvedad, la experiencia demuestra que una multiplicidad de sujetos no propicia una convicción judicial más razonable "cualitativa" o, lo que sería absurdo, "cuantitativamente". Sí es cierto, en cambio, que la satisfacción de intereses personales exclusivamente patrimoniales sea alcanzable con más plenitud en el proceso penal cuando el mismo afectado se ocupa de inquirir o aportar todos los elementos para su más exacto aquilatamiento y declaración judicial. De esto se deduce, pues, lo absurdo que parece distinguir por el grado de afección si es o no conveniente la prestación de fianza.

Reduciendo al absurdo el argumento vigente, cabría llegar al criterio contrario: una mayor afección connota menor objetividad, luego aconseja para serenar apresuradas estimaciones personales que se imponga al particular ofendido o perjudicado la obligación de prestar fianza para garantizar que no va a perseguir más que los fines generales. Dicho

${ }^{1314}$ STC $147 / 85$ de 29 de octubre, FJ. 3.

${ }^{1315}$ Como si el mejor "resultado" procesal fuere la condena. Vid. en relación con ello CABEZUDO RODRÍGUEZ, N., El Ministerio Público y la justicia negociada en los Estados Unidos de Norteamérica, Granada 1996, pp. 15 y 52 y ss., acerca de la mejor valoración de fiscales de conformidad con el mayor número de condenas y con el menor número de recursos dispuestos. Aunque subyazca una verdad indiscutible: el fiscal que investiga y arguye coherentemente aportando convincentes medios de prueba logrará más condenas que el que no lo haga así, pero, para evitar fallos desestimatorios puede terminar acusándose en las hipótesis más claras, menos complejas y en las que se disponga de elementos aptos para lograr la convicción judicial. 
$\overline{\text { de otro modo, si el acusador popular tuviere un interés personal en la persecución, ello le }}$ podría aproximar a la acusación particular. Repeler el instinto de venganza objetivando el proceso y del propio ius puniendi, parece algo elemental, por lo que habría de dificultarse el acceso de cualesquiera que pudiera distorsionar a través de su subjetivación las apreciaciones fácticas introducibles en el debate procesal. Habrá de destacarse también la incoherencia de la concepción vigente desde el momento que la exigencia de fianza ha llegado a reducirse en las hipótesis en que la querella popular no constituye el punto de partida de la notitia criminis, inexigiéndose, como veremos a continuación, cuando su formulación se haga una vez incoado el proceso ${ }^{1316}$.

\subsubsection{Excepciones a su obligatoriedad introducidas jurisprudencialmente}

La fianza ha sido utilizada históricamente a modo de barrera impeditiva del paso al proceso de particulares, que se levantaba allí donde interesaba que el control quivis ex populo no se viera sujeto a limitación alguna ${ }^{1317}$. En la actualidad, los acusadores no ofendidos o perjudicados por el delito están siendo en determinados casos progresivamente eximidos por los Tribunales de la prestación de fianza, a pesar de la expresa obligación impuesta por el art. 280 y su no inclusión en el 281 LECrim. Es posible observar así la mencionada y reciente doctrina del TS, que considera injustificada la exigencia de fianza cuando el proceso ya se haya iniciado por otro sujeto procesal: puesto que constituye sólo un requisito de admisibilidad de la querella cuando ésta es medio de iniciación del procedimiento penal, sólo se justificaría para dar comienzo a éste. Pero "cuando el ejercicio de la acción popular se realiza en un proceso en curso y dictado el auto de procesamiento, la necesidad de tal requisito no parece ser razonable. (...) Su finalidad es

\footnotetext{
${ }^{1316}$ Así, por todas, lo declara la STS de 12 de marzo de 1992 (RAJ 2084) al decir que "cuando el ejercicio de la acción popular se realiza en un proceso en curso y dictado el auto de procesamiento, la necesidad de tal requisito no parece ser razonable".

${ }^{1317}$ En algunos momentos la exención de requisitos de garantía de seriedad en la persecución se derivaba del deseo de evitar a toda costa la impunidad de delitos considerados especialmente graves, la cual pudiera derivarse del temor a las resultas de la acusación y el juicio. Buen ejemplo de ello era la innecesariedad del requisito de la inscriptio para algunos delitos graves contenida en las Partidas. En otras ocasiones era el carácter de los delitos el dato esencial que convertía a todos los ciudadanos en perjudicados directos, por lo que dada esta circunstancia, no cabría exigir cautela a quien era perjudicado por el delito. Así ocurría, por ejemplo, conforme al art. 79 de la antigua Ley Electoral de 8 de agosto de 1907, en los delitos electorales para los que no se debería exigir depósito ni fianza de ninguna especie al objeto de ejercitar la acción pública.
} 
$\overline{\text { constituir freno a la acusación calumniosa y asegurar posibles responsabilidades, por lo }}$ que en un proceso no puesto en marcha por él carece de sentido" ${ }^{\text {"1318. }}$.

La obligatoriedad de la fianza vendría predeterminada, por tanto, por la litispendencia y la intervención de otros sujetos en la posición actora. Tanto la interposición de querella, como el requisito formal para la validez de ésta en que consiste la prestación de fianza, cederán al poderse considerar la personación como una simple intervención procesal adhesiva o de coadyuvante en relación con el MF u otro acusador. El TS, más recientemente ha dicho que resultaría intrascendente "una exigencia formal que mal se compadece con las exigencias del derecho al proceso justo o legalmente debido que establece el art. 24 CE, al pretender extender el ámbito formal de lo que es «puesta en marcha» del proceso a una simple corroboración, más o menos homogénea, con la activación del proceso jurisdiccional por parte de la acusación pública" ${ }^{1319}$. Nos encontramos ante la misma argumentación que la realizada por la Sala de lo Penal de la AN que condujo al pronunciamiento de la STC 326/94 de 12 de diciembre antes citada. En su resolución argumentaba aquel órgano que la fianza impuesta a la recurrente era legal y no arbitraria además de ponderada, dado que no se trataba de una "mera adhesión al MF", sino que podría rebasar aquella, implicando un "plus acusatorio" y, por tanto, una "verdadera querella". A contrario sensu pudiera afirmarse que si no existiese tal "plus acusatorio", no estaríamos en presencia de una querella, sino de una mera adhesión a las pretensiones del MF, careciendo de sentido por tanto la exigencia de fianza. Recapitulando hasta aquí, la fianza sería exigible al acusador popular sólo si, admitida, transmite la notitia criminis dando lugar a la incoación del proceso, lo que no acaecería si éste ya se hubiere abierto, pues dejaría de constituir freno a acusaciones calumniosas. Se olvida de esta manera que el MF puede también solicitar el sobreseimiento y que, con sustento en los planteamientos de la acusación popular, puede abrirse el juicio oral, a virtud del que pudiere resultar calumniosa, sin que el acusado se viera protegido por una fianza que no se ha exigido. En esta recapitulación conviene incidir también en un segundo punto: ¿se exigirá caución cuando por el contenido (¿inicial sólo? ¿y si hay posterior ampliación?) pudiere deducirse que rebasa de los límites de la del MF?. Pensemos en cuáles pudieran ser los parámetros que sirvan para estimar rebasada la acusación pública: ¿de carácter objetivo, subjetivo o de ambos?. Todo ello convierte,

\footnotetext{
${ }^{1318}$ STS de 12 de marzo de 1992 (RAJ 2084).

${ }^{1319}$ STS de 3 de junio de 1995 (RAJ 4536).
} 
nuevamente, el régimen de la acusación popular en un terreno peligrosamente resbaladizo, que puede conducir a situaciones cercanas a la arbitrariedad.

El TS ha excluido también la exigencia de fianza no sólo cuando el proceso se haya iniciado a instancias de otro sujeto activo, sino cuando la acusación fuera realizada simultánea y conjuntamente por víctimas y por no ofendidos por el delito. Se ha señalado así que "interponiéndose querella conjuntamente y bajo la misma representación que los perjudicados u ofendidos por el delito, que están exentos de prestar fianza, carecería de sentido exigir fianza a uno de los litisconsortes y a otros no cuando se trataba de un mismo acto de iniciación procesal y de una parte formalmente única" ${ }^{1320}$. No se pierda de vista que tan singular posibilidad trasluce un interés igual o la aceptación de una misma defensa de los diversos intereses.

Asistimos, como se ve, a un intento por parte de los órganos jurisdiccionales de esquivar más o menos racionalmente un requisito legal perturbador (la fianza), por considerarlo totalmente superfluo e ineficiente para servir a los fines a los que en principio vendría destinado, dejando intocada la institución a la que sirve (la acusación popular). La originaria LECrim, al introducir el requisito de la querella como mecanismo de iniciación procesal y de la fianza como elemento formal de garantía de fiabilidad de aquélla, no contempló siquiera la posibilidad de que la actividad del acusador no ofendido se solapara con la del MF. Puesto que la pretensión que podrían ejercitar ambos era exactamente la misma, esta cuestión quedaba descartada de raíz y, en consecuencia, no habría por qué darle solución alguna. Ha sido la práctica y, más concretamente, la creciente utilización de la acusación popular la que ha venido a destapar un problema larvado. Ahora, una vez constatado que la intervención de los acusadores privados no sólo se produce como mecanismo de iniciación procesal, se pone de manifiesto que la fianza puede carecer de razón de ser en algunos casos: precisamente en aquellos en los que se trate de una simple adhesión a las pretensiones de algún otro sujeto procesal activo. Llevando la misma argumentación hasta sus últimas consecuencias, y situándonos en el plano inmediato forense y doctrinal, debería admitirse que en estos casos ya no estamos ante una acusación verdaderamente autónoma, sino ante una mera intervención adhesiva a la planteada por otra persona, pero con las dificultades insalvables que conlleva entender que el actor está ejercitando un derecho propio que de manera refleja queda afectado. Así mismo, desde aquí cabría entrar a considerar si puede seguir teniendo sentido, y de qué

\footnotetext{
${ }^{1320}$ STS de 23 de octubre de 1987 (RAJ 7591).
} 
$\overline{\text { manera, el aceptar la intervención de sujetos privados cuya función se limitará a prestar }}$ apoyo y cobertura a la acusación del MF. Si el sujeto privado mantiene las mismas tesis acusatorias que el Ministerio Público, su presencia estará necesariamente de más.

Con respecto al ejercicio privado de la acusación en el ámbito de la protección de intereses difusos, y específicamente del medio ambiente, sostienen GIMENO y GARBERÍ la inaplicabilidad de la obligación de prestar fianza tanto de los extranjeros como de los no ofendidos ${ }^{1321}$. Al primero, se afirma, le serían aplicables el largo catálogo de exenciones de la caución de arraigo en el proceso civil ${ }^{1322}$. Para los acusadores populares debería tenerse en cuenta que todos los perjudicados ${ }^{1323}$ están exentos del pago de fianza, y que el carácter difuso del bien jurídico protegido (un derecho de disfrute) tiene como titular a la sociedad en su conjunto por tratarse de un delito de riesgo. Por ello habrán de estar legitimados para el ejercicio de la pretensión penal en calidad de ofendidos por el delito todos y cada uno de los miembros que integran la comunidad social y, de modo singular, las asociaciones de defensa del medio ambiente a las que, en tanto defensoras de intereses difusos, en modo alguno se les podrá constreñir al pago de la fianza del art. 280 LECrim $^{1324}$. En opinión de los citados autores, la exoneración del abono de fianza se basa en que cualquiera que ejercite una pretensión penal lo llevará a cabo en cuanto titular de un derecho subjetivo coincidente con el bien jurídico protegido.

A nuestro juicio, sin embargo, no nos encontramos ante supuestos de acusación popular stricto sensu, sino ante el ejercicio de la pretensión penal por un representante, socialmente cualificado, del bien jurídico protegido, el cual a la postre actuará con un carácter asimilado al del ofendido por el delito. De seguir considerando este supuesto

${ }^{1321}$ GIMENO SENDRA, V. y GARBERÍ LLOBREGAT, J., "La protección procesal del Medio Ambiente”, $P J$, no 37, p. 154.

${ }^{1322}$ Las derivadas del $534 \mathrm{LEC}$, de la reciprocidad convencional, legislativa o jurisprudencial y, sobre todo, de la pertenencia del extranjero a alguno de los Estados signatarios del Convenio Internacional de La Haya de 1 de marzo de 1954. A tenor del art. 22 del Convenio tendente a facilitar el acceso internacional a la justicia de 25 de octubre de 1980, ratificado por España por Instrumento de 20 de enero de 1988 (BOE 30 de marzo), éste sustituirá en las relaciones entre los Estados que lo ratifiquen a los arts. 17 a 26 del de 1954. Vid. también el acuerdo europeo relativo a la transmisión de solicitudes de asistencia jurídica gratuita, firmado en Estrasburgo el 27 de enero de 1977, ratificado por Instrumento de 14 de noviembre de 1985 (BOE 21 de diciembre).

\footnotetext{
${ }^{1323}$ Lo legalmente correcto, aunque claramente insuficiente, sería hablar de ofendidos (art. 281.1 LECrim.) y no de perjudicados.

${ }^{1324}$ GIMENO SENDRA, V. y GARBERÍ LLOBREGAT, J., “La protección procesal del Medio Ambiente”, op. cit. p. 154.
} 
como una exención de la fianza del acusador popular deberíamos admitir que el requisito formal determinante del ejercicio de la acusación por los particulares que constituye el depósito de la fianza, se estaría haciendo depender de la naturaleza del delito ante el que nos encontremos. El carácter abstracto del ejercicio de la pretensión en el proceso penal, desvinculado necesariamente del bien jurídico atacado, quedaría contradicho por la realidad práctica. Parece lógico y plenamente compartible -en la vigente situación de la acusación pública- el de que puedan acceder al proceso quienes de forma altruista defiendan intereses de pertenencia común al objeto de hacerlos valer en unas condiciones favorables, ya lo hagan de forma individual o colectivamente. Pero, por definición, tal supuesto no debería encontrar acomodo en la acusación popular, sino en la acusación particular planteada por un sujeto asimilado al ofendido.

\subsubsection{Depósito y devolución de la fianza}

A falta de un precepto expreso en la LECrim sobre las modalidades que puede adoptar la fianza de los acusadores populares, la doctrina se ha servido de la regulación establecida para la fianza como medida cautelar real del Tít. IX del Libro II LECrim (arts. 589 y ss), dirigida al aseguramiento de las responsabilidades pecuniarias que pudieran declararse procedentes ${ }^{1325}$. El art. 591 se refiere en este sentido a que "la fianza podrá ser personal, pignoraticia o hipotecaria", por lo que parece podrá constituirse en metálico $^{1326}$, en efectos públicos al precio de cotización, en valores mercantiles cuya cotización en Bolsa haya sido autorizada o bien mediante pignoración de bienes muebles que hayan sido previamente tasados. No habría problema tampoco en reconocer como válida la fianza hipotecaria (arts. 593 y ss LECrim). Mayores dudas plantearía la fianza personal en virtud del predicado carácter personalísimo de la facultad de acusar, pero entendemos que puede constituir un medio igualmente válido para servir a las funciones previstas por la Ley, por lo que debe ser admitida sin demasiados reparos. No hay

${ }^{1325}$ Ello se debe a la remisión expresa contenida en el hoy derogado art. 762 LECrim en relación con la fianza que debía depositar el no ofendido por el delito para promover el antejuicio, la cual se planteaba por escrito redactado en forma de querella (antiguo art. 764 LECrim).

\footnotetext{
${ }^{1326}$ Cabe advertir que si la fianza es depositada en dinero o cheques, deberá ingresarse en la cuenta de depósitos y consignaciones judiciales. Vid. RD 34/1988 de 21 de enero por el que se regulan los pagos, depósitos y consignaciones judiciales y Orden de 5 de junio de 1992.
} 
$\overline{\text { precepto que impida el que un sujeto, persona física o persona jurídica (en particular, }}$ entidad financiera) se haga cargo de las responsabilidades en que pudiera incurrir el acusador popular, por lo que tampoco puede ser negada tal posibilidad ${ }^{1327}$.

Una vez finalizado el proceso y constatado el carácter no temerario o abusivo de la acusación, la devolución de la fianza deberá ser decretada de oficio en la propia sentencia. Tal reintegro deberá realizarse en el momento en que la sentencia devenga firme por la entidad en la que se encuentra la cuenta de pagos, depósitos y consignaciones, previa presentación por aquél de impreso formalizado y firmado por el Secretario y el Juez o Presidente del órgano jurisdiccional competente con los requisitos del art. 7.2 RD 34/1988 (de pagos, depósitos y consignaciones judiciales). Puesto que no hay previsión expresa sobre la devolución de los intereses generados por el depósito, aun cuando el proceso pueda prolongarse años, podría ser conveniente que a la cuantía de la fianza se añadiera de oficio por el órgano jurisdiccional la suma correspondiente a la aplicación del porcentaje del interés legal del dinero vigente en el momento de la devolución.

\subsubsection{Cuantía y exigencia de proporcionalidad}

Nada se expresa en la LECrim acerca de la cuantía de la fianza a imponer, a no ser el que deba ser útil para estar a las resultas del juicio (art. 280 in fine). A ello se ha venido a añadir la exigencia de proporcionalidad a los recursos del actor, que como tendencia instaurada por las SSTC 62/1983 de 11 de julio, 113/1984 de 29 de noviembre y 147/1985 de 29 de octubre, culminó con la introducción del art. $20.3^{\circ}$ de la LOPJ: “no podrán exigirse fianzas que por su inadecuación impidan el ejercicio de la acción popular, que será siempre gratuita" ${ }^{1328}$.

La dicción de este precepto no es tan clara como cabría desear, pues el vocablo inadecuación es referible tanto a la clase de fianza cuanto a su importe. Se entiende generalmente que, desde su aprobación, vino a establecer un límite cuantitativo que el

\footnotetext{
${ }^{1327}$ Nos mostramos así de acuerdo con GIMENO, que admite el aval o "garantía bancaria" GIMENO SENDRA, V., Derecho Procesal Penal, Madrid 1996, p. 300.

${ }^{1328} \mathrm{El}$ origen de este cambio ha sido cifrado por GIMENO en determinados abusos de gran envergadura por parte de los Jueces en los inicios de la actual democracia, realizados con el objeto de "ahuyentar" a acusadores populares a través de la imposición de fianzas desorbitadas. GIMENO SENDRA, V., "La acusación popular", op. cit. p. 92. Advierte con razón el autor que "en la Dictadura del General Franco no se recuerda uso alguno de la acción popular".
} 
órgano jurisdiccional no podrá superar, por la obligación de que la fianza no resulte desorbitada en relación a la naturaleza del proceso o a las condiciones personales del acusador $^{1329}$. Esta exigencia ha servido a GIMENO para hablar del tránsito entre una fase "permisiva" y una fase "expansiva" en el ejercicio de la acusación popular, en la que se impondría su potenciación desde las mismas instancias del Poder Judicial que antes la presenciaban con recelo ${ }^{1330}$. En opinión de DE LA OLIVA, la ratio iuris del precepto contenido en el art. 20.3 es clara: no se deberán imponer fianzas que, por su cuantía, se alcen como obstáculos insalvables para el ejercicio de la acusación. A la hora de determinar la "adecuación" de la fianza, no sólo se tendrá en cuenta aquel límite negativo, sino también serán determinantes los recursos económicos líquidos del accionante ${ }^{1331}$.

El requisito de la fianza sigue constituyendo en demasiadas ocasiones una barrera infranqueable para la mayoría de la población, de modo que quienes no puedan prescindir temporalmente de una cantidad mayor o menor de dinero o no encontrasen un fiador personal verían vetado $a b$ initio el ejercicio popular de la acusación ${ }^{1332}$. Como ha sido resaltado por FAIRÉN la exigencia de fianzas elevadas que no se hallen al alcance más que de grupos o corporaciones de riqueza superior puede constituir "un medio inexorable de hacer fracasar a la «acción popular»". El proceso penal se convertiría en coto de "elementos de un grupo o casta dominantes", bien se tratara de fianzas en metálico, bien de las obtenidas por aval bancario, "mucho más fácil cuando se tiene acceso directo a los bancos, directamente o por intermedio de amigos o correligionarios" 1333 . FAIRÉN tiene que aceptar, sin embargo, el sistema de fianzas con el fin de evitar la utilización abusiva cuantitativa y cualitativamente de la acusación como medio de retorsión, de venganza o

${ }^{1329}$ En este sentido, ANDRÉS IBÁÑEZ, P. y MOVILLA ÁLVAREZ, C., El Poder Judicial, Madrid 1986, p. 315.

${ }^{1330}$ GIMENO SENDRA, V., “La acusación popular”, op. cit. p. 93.

${ }^{1331}$ DE LA OLIVA, A. et al, Derecho Procesal Penal, op. cit., p. 183.

${ }^{1332}$ Tal y como advertía CALAMANDREI, “tratar como iguales a sujetos que económica y socialmente están en desventaja, no es sino otra forma de desigualdad e injusticia. (...) la afirmación puramente jurídica de la igualdad de las partes puede ser letra muerta, si en el caso concreto la disparidad de cultura y de medios económicos coloca a una de las partes de no poder servirse de aquella igualdad jurídica”. CALAMANDREI, P., "Aspectos sociales y políticos del proceso civil”, Proceso, ideologías, sociedades, p. 67.

${ }^{1333}$ FAIRÉN GUILLÉN, V., “Acción del Fiscal y Acción Popular. El refuerzo de esta última”, Tapia, octubre 1989, p. 64. 
intimidación $^{1334}$.

La racionalidad de la cuantía de la fianza así como su trascendencia constitucional y la determinación del derecho con el que ha de ponerse en relación ha sido abordada en varias ocasiones por el TC. Nuestro más alto intérprete de la Primera Norma, sin entrar a valorar el monto cuantitativo de la fianza, ha estimado que si es desproporcionada en relación a los medios de quienes pretendan interponer querella, se estaría impidiendo u obstaculizando gravemente su ejercicio, lo cual podría conducir en la práctica a la indefensión proscrita por el art. 24.1 CE ${ }^{1335}$. La fijación de la cuantía corresponderá, no obstante, a los órganos de la Jurisdicción ordinaria, limitándose la función del TC únicamente al control de la arbitrariedad e irracionalidad de aquella decisión judicial. Para ello no basta que el sujeto afectado alegue esta supuesta vulneración de sus derechos, sino que la proporcionalidad de la fianza deberá haber constituido objeto de alguna resolución jurisdiccional, incluso en vía de recurso, en el proceso del que traiga su origen la impugnación constitucional ${ }^{1336}$. Otros criterios objetivos para fijar la cuantía y estimar o no la racionalidad de la fianza, tales como la gravedad o trascendencia social del hecho supuestamente delictivo por el que se acusa, o bien los daños patrimoniales o morales que de una acusación calumniosa o de una conducta procesal maliciosa o negligente se podrían irrogar al imputado, permanecerían ajenos a la relevancia constitucional del monto de la fianza a imponer ${ }^{1337}$.

\footnotetext{
${ }^{1334}$ Ibídem. Advierte también, con fundamento en la experiencia propia, de amigos y compañeros abogados, que "el actual sistema de fianzas (...) es el, probablemente motivado por la rareza de exigirse fianzas muy altas". Vid. también del mismo autor "El artículo 125 de la Constitución: la acción popular y su fortalezimiento", en La reforma del proceso penal. II Congreso de Derecho Procesal de Castilla y León, Ministerio de Justicia, Madrid 1989, p. 605, donde se declara partidario de no eliminar "todas especie de fianzas", no por razones de economía procesal, sino por el riesgo de que el proceso penal pueda devenir en "un arma de los delincuentes organizados, en lugar de serlo de los «hombres justos y benéficos» de que hablaba la Constitución de Cádiz". No quisiéramos pasar por alto la cita recogida por FAIRÉN en el mismo lugar atribuida a GOLDBERG, antiguo Juez del Tribunal Federal de los EEUU: "Una justicia basada en las fianzas, en el mejor de los casos es una justicia de talonario o de cheques; y en el peor... un racket (trampa, fraude, timo, chantaje) altamente comercializado".
}

${ }^{1335}$ Vid. las SSTC 62/1983, 113/1984, 147/1985 y 326/1994 citadas. Cfr. también STC 202/1987, de 17 de diciembre (FJ. 6), referida a la imposibilidad de adaptar al ámbito civil y las relaciones inter privatos las previsiones en relación con la fianza del ámbito penal.

${ }^{1336}$ STC 326/1994 FJ. 2.

${ }^{1337} \mathrm{La}$ "especial relación con las personas y hechos que dan lugar a la querella" y en esa medida el "interés" del querellante se encuentran simplemente citados como criterios de determinación de la cuantía de la fianza en la STC 147/85 de 29 de octubre (FJ 3). El Tribunal no entra, sin embargo, en su valoración por no haberse deducido pretensión a ese respecto. 
De la doctrina constitucional parece deducirse que, cuando por la desproporción entre los medios de quien interpone la querella y la cuantía de la fianza se impida el acceso a la Jurisdicción, quedaría afectado un derecho fundamental, en tanto se estaría originando indefensión al denegar el primer requisito del derecho a la tutela judicial efectiva. También el criterio de la proporcionalidad de la fianza con los recursos económicos del actor ha encontrado apoyo entre nuestra doctrina, que ha entendido que la imposición de fianzas excesivas constituye una forma de impedir el acceso de los ciudadanos a la Jurisdicción. GIMENO y GARBERÍ han abordado la cuestión, llegando a la conclusión de que, en el hipotético supuesto de exigibilidad de fianzas, al incidirse en el ejercicio de un derecho fundamental como el del 24.1 en relación con el $125 \mathrm{CE}$, ésta habrá de estar sometida a la vigencia del principio de proporcionalidad. Una de sus principales exigencias sería que se adecue al cumplimiento del fin constitucionalmente perseguido, la incoación del proceso penal, razón por la cual habría de ser también adecuada al patrimonio del acusador particular, para quien no se puede convertir nunca en un impedimento para el legítimo ejercicio de lo que califican como "derecho a la acción penal" ${ }^{1338}$. Inapropiadamente se conecta la acusación popular con el art. 24.1 en relación con la garantía de un supuesto "derecho de acusar", lo cual lleva como consecuencia resaltar los aspectos subjetivos, en detrimento de aspectos puramente objetivos como los de "estar a las resultas del juicio", que no dependen de la capacidad económica del actor, sino de la potencial dañosidad de su acción procesal.

Esa tendencia del TC, de la doctrina y del legislador, desconceptualizadora de la acusación popular, puede a primera vista parecer que supone un avance progresivo en el sentido de hacer accesible el proceso a todos los ciudadanos y no sólo a los que disponen de un alto nivel económico. Pero en atención a la finalidad de la fianza del acusador popular -responder de las resultas del juicio (art. 280 LECrim.)- carece, en nuestra opinión, de suficiente fundamentación lógica. El monto del patrimonio del actor es independiente de los daños o perjuicios que de su actuación procesal se puedan derivar. El que en la práctica sea su valoración lo que determine el importe de la fianza que se deba prestar ${ }^{1339}$ no parece garantía suficiente sobre su fiabilidad: no es descartable que un acusador movido por torcidas intenciones, por pobre que sea, pueda servirse del proceso

${ }^{1338}$ GIMENO SENDRA, V. y GARBERí LLOBREGAT, J., “La protección procesal...”, op. cit. p. 154.

${ }^{1339}$ Memoria FGE 1989, p. 317; PORTERO, REIG, MARCHENA, Comentarios a la Reforma procesal penal de la LO 7/1988..., op. cit., p. 35. 
como arma de intereses ajenos al de la defensa del interés público o bien, a la inversa, que el más rico de los ciudadanos utilice su exceso de tiempo libre para constituirse en desinteresado valedor del interés común.

No se debe olvidar tampoco la posibilidad de acusar a través de un tercero interpuesto con escasos recursos económicos, burlando la tan reiterada proporcionalidad a la búsqueda de objetivos extravagantes. El fraude procesal a que aquella contemplación de la fianza puede dar lugar es fácil de deducir y muy difícil de atacar: puesto que lo único relevante desde el punto de vista constitucional son los recursos económicos del actor, bastará con que las pretensiones penales sean deducidas siempre por sujeto insolvente, por iniciativa propia o sirviendo como persona interpuesta a los intereses de otra, para que se esquive sin mayor problema el requisito de la fianza. ¿Qué fianza se podría imponer a un hipotético actor popular insolvente cuando por reducida que ésta fuera se le produciría indefensión y, a tenor de tal doctrina jurisprudencial se vulneraría su derecho a la tutela judicial efectiva?. Aunque pudiera hipotéticamente llegar a probarse la existencia de una conducta calificable como fraude procesal en la acusación por persona interpuesta, reto realmente complejo, el establecimiento de sanciones disuasorias tampoco sería garantía suficiente para impedirlo ${ }^{1340}$.

Debemos contar, además, con una dificultad añadida: la de averiguar la cuantía real del patrimonio del querellante que sirva como punto de referencia en la fijación del monto de la fianza para que ésta no sea desproporcionada. Una investigación profunda en esta materia que no se reduzca a la mera intuición del instructor, con el riesgo de arbitrariedades que podría conllevar, requiere cuando menos la petición de información sobre los datos fiscales y otros signos de la capacidad económica de quien pretende erigirse en acusador. Ello implicaría un esfuerzo en tiempo y recursos por parte de los instructores, sobre todo si pensamos en supuestos de pluralidad de acusadores. Únicamente tratándose de acusadores que pudieran quedar incluidos en los términos de la Ley de Asistencia Jurídica Gratuita y solicitaren su aplicación, la cuestión podría solventarse fácilmente, en cuanto para el reconocimiento del derecho de asistencia jurídica gratuita la correspondiente Comisión ya habrá considerado las posibilidades económicas del actor. En el resto de los casos, tal constatación, al exigir al menos el

\footnotetext{
${ }^{1340}$ No se nos alcanza qué tipo de sanción podría llevar aparejada esta conducta una vez constatado que no es subsumible en el delito de acusación falsa: las de carácter pecuniario no serían efectivas, al menos con celeridad, puesto que estamos hablando de un sujeto insolvente, y no cabría tampoco su exclusión del proceso pues no dejaría de estar legitimado legalmente para acusar por sí mismo.
} 
requerimiento por el órgano instructor de los datos económicos o fiscales del actor, abrirá la posibilidad del control de éstos también por la defensa ${ }^{1341}$. Sólo los sujetos que no tuvieran inconveniente alguno en que su patrimonio o sus recursos económicos fueran conocidos siquiera someramente, se servirán de la facultad de acusar. La proporcionalidad adquiere así una relevancia subjetiva demasiado acentuada que, llevada a sus últimas consecuencias, hace totalmente inoperante el depósito de fianza para los fines a los que supuestamente se encamina.

Contemplando el problema desde el otro lado se podría también reprochar a esta exigencia de fianza (y de proporcionalidad al patrimonio del actor) el que imponiéndose altas fianzas puede que no se impida un ejercicio desviado de la pretensión penal. Aquella supuesta garantía deviene también en este sentido inútil y superflua. El depósito de una gran cantidad de dinero, que se devolverá casi con seguridad (siempre que no se aprecie conducta dolosa o temeraria), puede llegar a compensar en supuestos en los que, gracias a ese dinero paralizado, pueda extraerse un beneficio de la pendencia del proceso. Contemplado así el problema, supuesto que desgraciadamente ya se está produciendo en la práctica, la fianza constituye un mínimo freno a persecuciones interesadas (en el peor sentido de la palabra) o precipitadas. Se podría afirmar, en conclusión, que ni el daño que puede producir el ejercicio de la acusación tiene por qué ser proporcional al patrimonio del querellante, ni la imposición de fianza por alta que ésta sea tiene por qué ser disuasoria para acusadores acomodados a los que compensa deducir una pretensión penal a través de la que se puedan indirectamente satisfacer intereses ajenos al público derivado del enjuiciamiento penal.

A nuestro juicio, la intensa y desnaturalizada protección que se otorga con esta doctrina del TC al ejercicio popular de la acusación habrá de ser ponderada con los posibles perjuicios o molestias que su mero uso acarrea al imputado en su tiempo, en su honor e incluso en su patrimonio, ocasionados por la afección si no explícita, sí indirecta, al derecho a la presunción de inocencia. Sólo cuando nos encontremos con que la imposición de fianza incide en el ejercicio de un derecho fundamental del acusador (acceso a la Jurisdicción para la defensa de intereses propios o no individualizables cuya representación se ostente legítimamente), aquella obligatoriedad debería con toda razón ceder ${ }^{1342}$.

\footnotetext{
${ }^{1341}$ Evidentemente interesada, además del control por el Juez y el Fiscal obligados a verificar la legalidad del planteamiento de la acusación.

${ }^{1342}$ En este caso, sopesando los intereses en litigio, y tomando todas aquellas medidas necesarias para la
} 


\subsubsection{Crítica a la formulación legal de su exigencia}

La bibliografía se muestra hoy día mayoritariamente favorable a la supresión de la fianza con el fin de no convertir la acusación popular en un derecho oligopolístico en manos sólo de los ciudadanos con más alta capacidad económica ${ }^{1343}$. Se ha tildado en este sentido de inconstitucional la exigencia de prestar caución, por cuanto vendría a negar un derecho de acción a los que no dispongan de medios, sometiendo el ejercicio de un derecho cívico a condicionamientos económicos. La fianza no sólo estaría hoy distanciada del contexto histórico en que se instauró ${ }^{1344}$ sino que además en la actualidad sería inútil $^{1345}$ y sólo supondría un mínimo freno a las persecuciones precipitadas, ligeras ${ }^{1346} \mathrm{o}$

adecuada protección del derecho a la presunción de inocencia del imputado, entendemos conveniente la apertura del proceso a los ofendidos o perjudicados por el delito, entendiendo también por tales a las entidades que defienden intereses de naturaleza colectiva. En estos supuestos el perjudicado se sirve de la incoación a su instancia del proceso penal o de su presencia en él para objetivos diversos a la mera defensa de la legalidad, aspirando legítimamente a la adecuada reparación o compensación por el daño producido. Esta intervención debe gozar por tanto, dentro de ciertos límites, de protección por parte del ordenamiento jurídico. Aun cuando el interés principal que mueve la actividad del actor ofendido por el delito esté alejado del de la sociedad en su conjunto, e incluso asumiendo el riesgo de que pueda actuar maliciosamente, quien ostenta la estrecha vinculación con el hecho delictivo que supone la titularidad del bien jurídico protegido por el tipo penal, debe encontrar una vía para su activa intervención en un proceso en el que se dilucidan cuestiones referentes a su vida o su patrimonio.

${ }^{1343}$ En este sentido se han podido escuchar desde hace tiempo también voces procedentes de las asociaciones judiciales y de los partidos políticos. Entre las primeras podemos citar la declaración del $3^{\circ}$ Congreso de la ASOCIACIÓN PROFESIONAL DE LA MAGISTRATURA celebrado en febrero 1983 (Justicia 83, II, p. 497), que solicitaba su supresión en los procesos en que se ventilasen intereses generales superiores y, en especial, cuando se tratase de delitos contra la salud pública, malversación de caudales públicos, evasión de capitales, delitos económicos de gran entidad, etc.. Con posterioridad, esta petición ha sido realizada también desde la asociación JUECES PARA LA DEMOCRACIA. Cfr. JD, septiembre 1988, n 4 "Documentos de Jueces para la Democracia: «Por el control democrático de la justicia»”. J.M. BANDRÉS, Materiales del III Congreso, pp. 20 y ss. A este respecto se dice que "En el campo de la legitimación, directamente vinculado al tema del control democrático, se hace preciso insistir en la necesidad de eliminar toda clase de obstáculos al ejercicio de la acción popular, eliminando, en particular, el actual sistema de fianzas". (Ponencia de BELLOCH, J.A. e IBARRA, J.L. titulada "Control democrático de los órganos judiciales y de los órganos gubernativos del Poder Judicial"). Incluso desde algunos Partidos Políticos se ha propugnado también su eliminación como uno de los "obstáculos que injustificadamente dificultan el ejercicio de la acción popular como medio de participación en la Administración de Justicia". Así se incluía por ejemplo en el programa electoral del PSOE en las elecciones legislativas de 1982, con el que alcanzó entonces el triunfo. Vid. Justicia 83, nº 1, p. 214.

${ }^{1344}$ GIMENO SENDRA, V., “La fianza...”, op. cit. p. 83.

${ }^{1345}$ GUTIÉRREZ ALVIZ Y ARMARIO, F. y MORENO CATENA, V., Comentarios a las leyes politicas. Constitución Española, op. cit., p. 604. 
$\overline{\text { interesadas. Además sería muy difícil concebir supuestos en los que se haya de perder la }}$ fianza y adjudicarse al Estado o al acusado por haber procedido con temeridad o mala $\mathrm{fe}^{1347}$. En algún caso se ha hecho prevalecer la alusión a la gratuidad del art. 20.3 LOPJ sobre el art. 280 LECrim, entendiendo que sólo sería exigible su depósito a los extranjeros $^{1348}$. Incluso la jurisprudencia del TS, constante la del TC, se ha encargado de señalar la inutilidad de este sistema de fianzas dinerarias señalándose que "de todos es sabido que, en la práctica, esa garantía exigible es más ficticia que real en cuanto que su cuantía es siempre simbólica ante el temor de posibles indefensiones" $" 1349$.

La contradicción en la exigencia de la fianza es constatable en el propio tenor del art. 20.3 LOPJ al prohibir que se exijan fianzas "que por su inadecuación impidan el ejercicio de la acción popular". Cabría señalar en primer lugar que la adecuación de la fianza es un concepto ambiguo, evidentemente indeterminado y susceptible de valoración por el instructor, que habrá de vincularse bien al patrimonio del actor, bien al objetivo de evitar los perjuicios derivados de una acusación calumniosa. Ya hemos sostenido anteriormente que el primero de estos criterios nos parece poco consistente, peligroso e incluso inane por la posible utilización de un testaferro insolvente, por lo que, en todo caso, sólo podemos entenderlo vinculado con la finalidad a la que se dirige el ejercicio de la pretensión. La fianza será en este sentido adecuada sólo si es apropiada para cumplir su objetivo o si sirve al fin al que se preordena, es decir, a constituir un freno frente a posibles acusaciones temerarias o realizadas con mala fe. Pero en muchas ocasiones sólo en un momento muy posterior a la interposición de la querella, una vez pendiente el proceso y sobre todo una vez finalizado éste, podrá constatarse la concurrencia o no de tal circunstancia y la obligación de devolver o no la fianza depositada. Valorar la inadecuación del importe de la fianza exigiría por ende una anticipación que roza el sofisma: la cuantía dineraria a depositar con carácter previo al proceso para estar a las resultas de éste habrá de ser ponderada a priori sin saber cuáles van a ser aquéllas o siquiera si van a existir ${ }^{1350}$. Para la fijación de su cuantía se exige de los Jueces que no sea

\footnotetext{
${ }^{1346}$ Memoria FGE, Madrid 1989, p. 317.

${ }^{1347}$ Memoria FGE cit. p. 317; PORTERO, REIG, MARCHENA, op. cit. p. 35.

${ }^{1348}$ Así se pronuncia LORCA NAVARRETE, A.M., Derecho Procesal Penal, p. 77.

${ }^{1349}$ STS de 5 de junio de 1993 (RAJ 4824) FD $1^{\text {o. }}$.

${ }^{1350}$ Tal vez la única intelección coherente del calificativo "adecuado" pudiere ser no cuantitativa, sino
} 
$\overline{\text { inadecuada a algo que todavía no se puede saber qué es, por lo que ante el riesgo de }}$ impedir sin fundamento el ejercicio de la acusación la cuantía de la fianza, allí donde se imponga, sólo podrá ser simbólica. La capacidad de cálculo que se exige del Juez para fijar la fianza sobrepasa a la que de él se requiere en el art. 589 LECrim a fin de fijar la iudicatum solvi, en cuanto para ésta el instructor cuenta, al menos, con la inicial comprobación del hecho (art. 13 LECrim) ${ }^{1351}$.

El inciso del art. 20.3 LOPJ que impone que la fianza no puede en ningún caso obstaculizar la acusación popular es aun más incongruente si cabe, ya que si aquélla no es hábil para cerrar el paso siquiera a su realización calumniosa, entonces quedará patente la futilidad de esta previsión.

Imaginemos la intervención de un no ofendido que deduce la acusación en un supuesto de criminalidad económica, con imputación de un delito a los gestores de una potente y reputada sociedad mercantil. ¿Con qué criterio se fijará la fianza? Si atendiéramos sólo a circunstancias objetivas que tomaran en cuenta la entidad de los posibles daños que le supondrá a la entidad gestionada por los acusados el sometimiento de éstos a un proceso, la fianza a imponer sería tan alta que dudamos mucho que un sujeto pudiera hacerle frente motivado por puro civismo, aun cuando lo hiciera arropado por algún colectivo afín. Tal coste podría ser asumido quizá por un competidor, pero en ese caso probablemente no nos encontremos ya ante una intervención altruista. Si acudimos por el contrario al criterio subjetivo, dependiente del patrimonio del actor para su determinación, mucho nos tememos que se estará posibilitando la ilimitada intervención de acusadores que aprovechando la impunidad que les proporciona el que la imposición de una fianza les origine indefensión, se servirán de ello con fines poco claros. La conjunción de ambos criterios es prácticamente imposible: ¿en qué fianza cabe pensar para un acusador pobre que pretenda interponer querella por un delito societario con perjuicio grave para el interés general?. Cualquier respuesta lleva consigo su contradicción, por lo que parece aconsejable modificar una previsión que en la práctica viene resultando poco útil.

Es necesario constatar por último que, en demasiadas ocasiones, la finalidad

cualitativa, de modo que permitiere que pudiere repelerse si por sus características no fuese apta para su más pronta y eventual realización forzosa, cubriendo total o parcialmente las resultas del juicio.

${ }^{1351}$ PEDRAZ PENALVA, E., Las medidas cautelares..., op. cit. pp 131 y ss., estima desde el uso del art. 13 que es factible y aconsejable ya en este estadio procesal la adopción de medidas cautelares reales. 
$\overline{\text { primordial que se predica de la fianza no podrá considerarse totalmente satisfecha, puesto }}$ que determinados daños habrán adquirido una dimensión irreparable. Nos estamos refiriendo en concreto a los derivados de la llamada "pena de banquillo", al tristemente demostrable efecto estigmatizador no ya de la pena, sino del propio proceso y su trascendencia pública. La dificultad de valorar el daño moral de tal injusta pseudo-pena y de su reflejo sobre el honor y la propia imagen, siquiera temporalmente, serían en ese sentido un plus a añadir a un daño irremediablemente producido sobre el injustamente imputado.

\subsection{Delito de acusación y denuncia falsa}

El art. $456.1 \mathrm{CP}$, incluido en el Título XX de su Libro $2^{\circ}$ ("Delitos contra la Administración de Justicia"), recoge el delito de acusación y denuncia falsa en los siguientes términos: "Los que, con conocimiento de su falsedad o temerario desprecio hacia la verdad, imputaren a alguna persona hechos que, de ser ciertos, constituirían infracción penal, si esta imputación se hiciera ante funcionario judicial o administrativo que tenga el deber de proceder a su averiguación, serán sancionados: $1{ }^{\circ}$ Con la pena de prisión de seis meses a dos años y multa de doce a veinticuatro meses, si se imputara un delito grave. $2^{\circ}$ Con la pena de multa de doce a veinticuatro meses, si se imputara un delito menos grave. $3^{\circ}$ Con la pena de multa de tres a seis meses, si se imputara una falta.". Este tipo penal goza de una honda raigambre en nuestro sistema y su referencia a la acusación falsa ha constituido históricamente un contrapeso frente al amplio reconocimiento de la facultad de acusar ${ }^{1352}$. Cabría dejar constancia ya en este momento

${ }^{1352}$ Todos los estudios doctrinales sobre este tipo penal han venido a coincidir en resaltar la importancia de su evolución histórica en relación con la regulación actual, especialmente en lo referido a su ubicación sistemática y su conexión con el bien jurídico objeto de protección. Sobre el delito de acusación y denuncia falsa vid. entre otros TABOADA TUNDIDOR, C., Las denuncias y querellas delictivas. Apuntes acerca de la mentira como delito, Madrid 1930; CUERVO PITA, M., “Acusación y Denuncia falsa”, NEJ Seix 1950, vol. II, pp. 358 y ss.; TORRES AGUILAR, J., "El delito de acusación y denuncia falsas y las faltas", Pretor, 1952, n 2, pp. 28 y ss.; FERRER SAMA, "El delito de acusación o denuncia falsa" en Homenaje a Nicolás Pérez Serrano, Madrid 1959, pp. 335 a 374; MILLÁN GARRIDO, "El delito de acusación y denuncia falsas", Información jurídica, no 317, abril-junio 1973, pp. 16 y ss.; QUINTERO OLIVARES, G., "Notas sobre la acusación falsa”, RJCat. 1976, nº 4, pp. 819-847; LUZÓN PEÑA, "Consideraciones sobre la sistemática y alcance de los delitos contra la Administración de Justicia", en Estudios Penales, Libro Homenaje al prof. ANTÓN ONECA, Universidad de Salamanca 1982; MAGALDI PATERNOSTRO y GARCÍA ARÁN, "Los delitos contra la Administración de Justicia ante la Reforma Penal”, en Documentación jurídica, $\mathrm{n}^{\circ} 37$ a 40, pp. 1118 y ss.;MUERZA ESPARZA, J.J., "El delito de acusación y denuncia falsa (art. 325 CP) en la jurisprudencia del Tribunal Supremo", La Ley, 1986, IV, pp. 1041 y ss.; MAGALDI PATERNOSTRO, M‥J., “Aspectos esenciales de la acusación y denuncia falsa”, ADPCP 1987-I, pp. 37-72; RUÍZ 
de su inestable ubicación sistemática en los diversos textos positivos, pues si en los primeros Códigos Penales, como continuación de lo previsto en textos precedentes ${ }^{1353}$, se situaba entre las falsedades in genere, es a partir de 1932 cuando pasa a incluirse entre los delitos contemplados bajo la rúbrica "Delitos contra la Administración de Justicia"1354.

Uno de los puntos más controvertidos en esta materia es la del bien jurídico protegido, en tanto se discute si se trataría del ataque a un único bien jurídico o una pluralidad de ellos. La doctrina actual opta entre los conceptos de "honor personal del falsamente acusado" y "Administración de Justicia", o ambos conjuntamente, como posibles objetos de protección ${ }^{1355}$. La acusación y la denuncia falsa son vistos por la doctrina penalista mayoritaria y por la jurisprudencia del TS como delitos pluriofensivos que vulneran ambos bienes, aun cuando la tendencia actual sea la de valorar en mayor medida el primer aspecto en perjuicio del segundo ${ }^{1356}$. No obstante, para VIVES ANTÓN y RUIZ VADILLO el fundamento del delito estribaría en una lesión al honor que prevalece sobre las perturbaciones procedimentales que lleva aparejadas, por lo que tal

VADILLO, E., "Delitos de acusación y denuncia falsa" en SERRANO BUTRAGUEÑO, I., et. al. Delitos contra la Administración de Justicia, Granada 1995, pp. 77-99, DÍAZ PITA, Ma.M, El delito de acusación y denuncia falsas: problemas fundamentales, Barcelona 1996; FERNÁNDEZ-ESPINAR, G.; "La acusación y denuncia falsas en el marco de los delitos contra la Administración de Justicia", Actualidad Penal nº 28, 7-13 de julio de 1997, pp. 629641.

${ }^{1353}$ La Novísima Recopilación recogía la conducta en el Libro XII, Tít. VI, Ley VI (“De los falsos delatores y testigos falsos"); el CP de 1822 en el Tít. V, Capítulo II, arts. 429 a 431 ("De los acusadores, denunciadores y testigos falsos; de los perjuros ( $y$ demás que en juicio u oficialmente faltaren a la verdad"), distinguiendo por un lado entre "acusación falsa y calumniosa" y "acusación no probada" y por otro "el desamparo o separación de la acusación formalizada" de los simples denunciadores "de mala fe y calumniosamente"; el CP de 1848 en el Título IV, Capítulo VI, art. 241 ("acusación o denuncia que hubiere sido declarada calumniosa en sentencia ejecutoriada"); el CP de 1870 en el Tít. IV, Capítulo VI, arts. 340 y 341; el CP de 1928 también en el Tít. IV, Capítulo VI, arts. 404 a 406.

${ }^{1354}$ En concreto en el Título V, Capítulo I, art. 322. En el mismo sentido se situaba el art. 325 del CP de 1944, sobre el cual se han basado la mayoría de los trabajos doctrinales al respecto.

${ }^{1355} \mathrm{El}$ bien jurídico protegido por este delito se planteaba en la doctrina histórica como una opción entre el honor (PACHECO) y la fe pública (GROIZARD), argumento éste último respaldado por la incardinación del delito entre las falsedades. Vid. VIVES ANTÓN, T.S.; con BOIX REIG, J., ORTS BERENGUER, E., CARBONELL MATEU, J.C. y GONZÁLEZ CUSSAC, J.L., Derecho Penal. Parte Especial, $1^{\text {a }}$ ed. Valencia 1993, pp. 272 y ss. La simple constatación de la existencia de una dualidad de bienes es unánime hoy entre la literatura penalista, y las dudas se dirigen a dilucidar si el ataque se realiza sobre un bien jurídico personal (el interés del acusado), sobre uno colectivo (la "Administración de Justicia") o simultáneamente sobre ambos.

${ }^{1356}$ Así, por ejemplo, SSTS de 10 de noviembre de 1969, 22 de octubre de 1974, 23 de septiembre de 1987 o 19 de septiembre de 1990. El TS otorga prevalencia al buen funcionamiento de la Justicia, pero no establece claramente el contenido de los bienes jurídicos protegidos. 
delito no sería más que una calumnia configurada de forma específica en atención a las circunstancias que en ella concurren ${ }^{1357}$. La existencia de un único bien jurídico protegido constituido por una afección a la "Administración de Justicia" es todavía hoy posición minoritaria entre la doctrina. Quien manifiesta más claramente esta opción es MAGALDI, autora para la que el verdadero sujeto pasivo del delito de acusación falsa es el Estado encarnado en los órganos a los que legalmente se asigna la potestad jurisdiccional y que han sido indebidamente utilizados, mientras que el sujeto falsamente acusado será sólo perjudicado por el delito, lo cual le habilita para exigir el resarcimiento civil ${ }^{1358}$. Esta opinión ha encontrado reflejo últimamente en la jurisprudencia del TS, si se tiene en cuenta que el bien jurídico honor ha dejado de ser considerado como objeto de protección, y en ocasiones no es siquiera aludido ${ }^{1359}$.

La dificultad para concretar el ámbito objetivo que deba considerarse incluido en el concepto "Administración de Justicia" ha sido abordada con frecuencia por la literatura penalista, sin que se hayan alcanzado soluciones que puedan entenderse plenamente

${ }^{1357}$ Según esta concepción, en la que prevalece el honor como bien jurídico protegido, la imposición de una pena a las denuncias o acusaciones falsas sobre la base de una perturbación causada a la Justicia resultaría desproporcionada. El ejercicio de pretensiones infundadas (que perturbarían a los Tribunales tanto como las falsas) no tiene ni puede tener respuesta más enérgica que la consistente en las sanciones, a lo sumo de orden meramente pecuniario, que puede contener la ley procesal. VIVES ANTÓN, T.S., Derecho Penal, op.et loc. cit. Considera también la acusación y la denuncia falsas como manifestaciones de la calumnia y la injuria RUIZ VADILLO, E., "Delitos de acusación y denuncia falsas", op. cit. pp. 80 y ss. El honor del mendazmente acusado no es sostenido por ningún autor como bien jurídico protegido por el tipo con carácter exclusivo, sino que para la opinión mayoritaria, integraría de manera conjunta con la "Administración de Justicia” el objeto de la protección del art. 456 CP. De estos dos bienes, el honor quedaría protegido de modo indirecto o subsidiario, pues de no realizarse una imputación falsa de forma hábil para dar comienzo a un procedimiento penal, constituiría solamente una calumnia. MUÑOZ CONDE, F., Derecho Penal. Parte Especial, 10ª edición, Valencia 1995, p. 727.

${ }^{1358}$ MAGALDI PATERNOSTRO, M.J., “Aspectos esenciales de la acusación y denuncia falsa”, op. cit. pp. 42 y 46. En el mismo sentido se sitúa la doctrina alemana (SCHRÖDER, LANGER, RUDOLPHI, LENCKER) citada por DÍAZ PITA, M.M., El delito de acusación y denuncia falsa..., op. cit., pp. 40 y s. Sostiene la misma opinión también DÍAZ PITA en El delito de acusación y denuncia falsa..., op. cit., pp. 61 y ss., aun sin descartar que la afección al honor del acusado pueda haber sido ponderada por el legislador a la hora de señalar la pena asignada al delito. Las razones en que se basa son las siguientes: $1^{\circ}$ ) El bien jurídico “Administración de Justicia” no ha de entenderse como un concepto puramente formal o filosófico, sino como potestad jurisdiccional en el sentido de intervención legítima de los órganos facultados para resolver los conflictos sociales por medio de la aplicación del derecho objetivo. $2^{\circ}$ ) La última doctrina del TS. $3^{\circ}$ ) El ataque al honor es sólo un instrumento para el ataque a la Administración de Justicia, por lo que puede dar lugar a otros recursos penales o civiles para su resarcimiento.

${ }^{1359}$ Así por ejemplo las SSTS de 16 de mayo de 1990 (RAJ 4026), de 17 de noviembre de 1992 (RAJ 9350) y de 20 de enero de 1993 (RAJ 131). En todas ellas se trata de acusaciones dirigidas a paralizar procesos civiles en curso por sujetos que ven afectados negativamente sus intereses por su desarrollo. Por tal razón entiende el TS pervertido en primer lugar el fin del proceso penal, aun cuando ello lleve consigo también un perjuicio para el falazmente acusado. Vid. en especial el FD $2^{\circ}$ de la última sentencia citada. 
esclarecedoras $^{1360}$. En unos casos se defiende que lo atacado es el fin de la misma, más que su vertiente institucional orgánica ${ }^{1361}$, en otros se trataría de la propia función del proceso penal por constituir una iniciación indebida del mismo ${ }^{1362}$. MAGALDI y GARCÍA ARÁN configuran objetivamente el bien jurídico protegido como "los fines legítimos (¡sic!) del proceso penal”, diversificados en un fin inmediato de hallazgo de la "verdad objetiva de los hechos enjuiciados" y en un fin último de resolución jurídica de los conflictos sociales ${ }^{1363}$. A juicio de DÍAZ PITA, el ataque que el delito produce se dirigiría a socavar la potestad jurisdiccional, en tanto desnaturalización y utilización indebida de la misma, al provocar la iniciación del cauce legítimo (el proceso) para la resolución de un conflicto social, cuando el conflicto social no existe o, al menos, no ha sido provocado por el sujeto acusado o denunciado ${ }^{1364}$. No obstante, en lo que estimamos mejor técnica procesal, a nuestro juicio el bien jurídico consistiría en tutelar el rogado desarrollo procesal de la potestad jurisdiccional, lo cual conllevaría el respeto a las exigencias del acusatorio (nemo iudex sine actore), al imparcial desenvolvimiento de la función jurisdiccional únicamente factible por Jueces inamovibles, independientes y sometidos exclusivamente a la Ley y, finalmente, con escrupuloso respeto al debido proceso y a las normas ordinarias procesales que lo hacen posible.

El art. 456 CP prohíbe la realización de conductas de atribución falsaria de hechos constitutivos de infracciones penales públicas a personas determinables o determinadas, otorgando relevancia penal a la realización de dichas conductas cuando vayan dirigidas a

${ }^{1360}$ Sobre la controversia doctrinal al respecto vid. DÍAZ PITA, M.M., El delito de acusación y denuncia falsa..., op. cit., pp. 25 y ss.

${ }^{1361}$ Así FERRER SAMA op. cit. pp. 335 y ss.; QUINTERO OLIVARES, op.cit. p. 821.

${ }^{1362}$ QUINTANO RIPOLLÉS, Curso de Derecho Penal II, pp. 570 y ss., opinión a la que parece adherirse LUZÓN PEÑA.

${ }^{1363}$ MAGALDI PATERNOSTRO y GARCÍA ARÁN, "Los delitos contra la Administración de Justicia ante la Reforma Penal”, en Documentación jurídica, n 37 a 40, pp. 1133 y ss. MAGALDI PATERNOSTRO, M.J., “Aspectos esenciales de la acusación y denuncia falsa", op. cit. p. 45. No podemos pasar por alto afirmaciones como tan ligeramente manifestadas si se tienen en cuenta dos extremos: 1) el proceso penal, si lo es, no podría perseguir fines ilegítimos; y 2) no es de recibo entre la más moderna literatura procesal hablar del hallazgo de una verdad objetiva como fin inmediato del proceso, sino únicamente de la convicción judicial más allá de toda duda razonable.

${ }^{1364}$ DÍAZ PITA, M.M., El delito de acusación y denuncia falsa..., op. cit., pp. 40 y s. entiende que el contenido objetivo del bien jurídico "Administración de Justicia" está integrado por la potestad jurisdiccional, en el sentido de “capacidad detentada (sic) en exclusiva por los órganos integrantes del Poder Judicial para resolver conflictos sociales mediante la aplicación del derecho objetivo". 
$\overline{\text { provocar el ilegítimo nacimiento de un proceso penal contra una persona }}{ }^{1365}$. El precepto exige por tanto:

a) Imputación de hechos que, de ser ciertos, constituirían infracción penal. Puede tratarse, por tanto, de hechos constitutivos de cualquier tipo de delito o falta, ya sea público, semipúblico o privado ${ }^{1366}$. Basta además con que la imputación se realice, aunque no se active efectivamente el proceso penal, por lo que nos encontramos ante un delito de peligro en el que el legislador adelanta las barreras de la protección penal a la simple puesta en peligro del bien jurídico cuya lesión desea evitar a través de la protección. Se considerará cumplido el injusto típico con la mera realización de la conducta prohibida ${ }^{1367}$.

b) Conocimiento de la falsedad o temerario desprecio hacia la verdad. El legislador de 1995 ha optado por una concepción subjetiva de la falsedad de los hechos, entendiendo que existirá cuando haya discrepancia entre lo que el sujeto sabe (o debiera saber) y lo que manifiesta ante el funcionario ${ }^{1368}$. No se trata de que su versión no se ajuste a lo efectivamente ocurrido en la realidad, sino sólo de que no se corresponda con lo que le es conocido o de que en su manifestación se produzca un "temerario desprecio hacia la verdad'. En atención a esta última circunstancia se puede afirmar que cabría no sólo una comisión dolosa con dolo directo cuando se produzca la imputación con plena consciencia de la falsedad, sino también una comisión con dolo eventual cuando no se hayan tomado en consideración todos los elementos básicos que contribuyan a poner de manifiesto las

\footnotetext{
${ }^{1365}$ MAGALDI PATERNOSTRO, M.J., “Aspectos esenciales de la acusación y denuncia falsa”, op. cit. p. 38. No compartimos la afirmación de QUINTERO OLIVARES, que consideraba también encuadrable en el delito de acusación falsa el ejercicio de la acusación por alguno de los sujetos o en alguno de los supuestos excluidos (arts. 102 y 103 LECrim) ocultando su condición o limitación. En opinión del citado autor, mediante esa conducta se habría logrado precisamente lo que la ley pretende evitar, esto es, la puesta en funcionamiento del aparato judicial sobre un motivo falso. Vid. QUINTERO OLIVARES, G., "Notas sobre la acusación falsa", op. cit. p. 56. En nuestra opinión en este supuesto es observable una conducta de mala fe procesal, pero no puede entenderse aplicable la literalidad del art. $456 \mathrm{CP}$, por cuanto de no ser falsa la imputación, no cabría entenderla subsumible en el tipo. De otra manera se estaría realizando una desproporcionada incriminación, no acorde con los principios de legalidad penal y de intervención mínima.

${ }^{1366}$ Es así constatable una diferencia entre el art. 456 del vigente CP y el 325 del antiguo, ya que éste exigía que se tratara de delitos o faltas "de los que dan lugar a procedimiento de oficio".

${ }^{1367}$ MAGALDI PATERNOSTRO, M.J., “Aspectos esenciales de la acusación y denuncia falsa”, op. cit. p. 46.

${ }^{1368}$ Con ello puede entenderse zanjada la cuestión doctrinal "falsedad objetiva versus falsedad subjetiva". Las posiciones al respecto son recogidas y sistematizadas por DÍAZ PITA, M.M., El delito de acusación y denuncia falsa..., op. cit., pp. 67 y ss. o FERNÁNDEZ-ESPINAR, G., “La acusación y denuncia falsas...”, pp. 634 y ss.
} 
circunstancias en las que se han producido los hechos que se acusan ${ }^{1369}$.

Restaría saber si cabe también su comisión imprudente, cuestión en la que tradicionalmente se han pronunciado en sentido negativo doctrina y jurisprudencia ${ }^{1370}$. Esta modalidad de comisión ha sido sin embargo admitida recientemente en determinados supuestos por MAGALDI o DÍEZ PITA, y siempre conectada con la defensa de una concepción objetiva de la falsedad y de la Justicia como bien jurídico protegido. A tenor de ella, se estará cometiendo un delito de acusación o denuncia falsas cuando el sujeto actúe sin la suficiente información dentro de los límites de sus posibilidades como ciudadano antes de interponer denuncia o querella por unos hechos presuntamente delictivos, puesto que dicha acción conlleva el riesgo no permitido por el ordenamiento jurídico de la puesta en marcha indebida de un proceso penal, es decir, la lesión del bien jurídico "Administración de Justicia"1371. No obstante, esta construcción se ve determinada en la actualidad por el art. $12 \mathrm{CP}$ en el que se señala que "las acciones $u$ omisiones imprudentes sólo se castigarán cuando expresamente lo disponga la ley", circunstancia que no recoge específicamente el art. 456 CP. Podría llegarse a concluir por ello que, hoy por hoy, la acusación imprudente sería una conducta atípica. Del tenor literal del precepto sólo cabría considerarla incluida en el tipo cuando el "temerario desprecio hacia la verdad" se entienda referido a una forma culposa de comisión delictiva en su modalidad de temeraria, siendo ésta equivalente a olvido de las más elementales normas de prudencia y atención.

${ }^{1369}$ Admite el dolo eventual sobre la base del actual CP por ejemplo MUÑOZ CONDE, F., Derecho Penal. Parte Especial, 11 a edición (1996), p. 797, que modifica así la opinión manifestada con anterioridad en relación con el antiguo CP, a tenor de la cual sostenía la posible comisión imprudente. Vid. por ejemplo la edición de 1994 del manual citado, p. 727.

${ }^{1370}$ Vid. STS de 23 de septiembre de 1987 (RAJ 6624), en la que se afirma que "esta Sala ha declarado que se trata de un delito esencialmente intencional que excluye la forma culposa" y STS de 23 de septiembre de 1993 (RAJ 6782) en la que se señala que "exluida la forma culposa, este delito sólo puede atribuirse a título de dolo, únicamente cuando se pruebe o se infiera razonable y razonadamente que el sujeto llevó a cabo su acusación o denuncia con malicia, es decir, con conocimiento de la falsedad o con manifiesto desprecio hacia la verdad". Los criterios que conducían a tal postura eran la duplicidad de bienes jurídicos protegidos, la defensa del carácter subjetivo de la falsedad o la intención del legislador de evitar que los ciudadanos se abstuvieran de interponer denuncias por miedo a un posible procesamiento en caso de resultar falsa. El estudio de tales razones es abordado en profundidad desde una perspectiva crítica por DÍAZ PITA, M.M., El delito de acusación y denuncia falsa..., op. cit., pp. 87 y ss.

${ }^{1371}$ MAGALDI PATERNOSTRO, M.J., “Aspectos esenciales de la acusación y denuncia falsa”, op. cit. pp. 55 y ss. y DÍAZ PITA, M.M., El delito de acusación y denuncia falsa..., op. cit., pp. 109 y ss. 
La acusación con conocimiento de la falsedad o temerario desprecio hacia la verdad en relación con el contenido objetivo o subjetivo de la imputación realizada es una conducta plenamente incardinable en el tipo penal del art. $456 \mathrm{CP}$. Aun cuando éste se refiera con carácter genérico a "imputación" sin especificar en lo que haya de consistir ésta, la interposición de querella en la que se describan hechos presuntamente delictivos es una de las formas más características en las que puede verificarse la atribución de un delito. Es más, podría alegarse que dicha conducta contiene un "plus" de peligrosidad en relación con la de la mera denuncia, ya que la interposición de querella obliga a los órganos jurisdiccionales a dictar una resolución, aun cuando sea sólo de inadmisión, que deberá ser notificada al querellante, mientras que con la denuncia no siempre ocurrirá lo mismo, ya que cabe su simple archivo ${ }^{1372}$. Puesto que lo exigido por el art. $456 \mathrm{CP}$ es la realización de una conducta idónea para desencadenar la reacción punitiva del Estado, bastará con la interposición de la querella para que se cumpla la conducta típica, sin que deban realizar más actos de acusación durante el procedimiento ${ }^{1373}$.

c) Realización de la conducta ante funcionario judicial o administrativo que tenga el deber de proceder a su averiguación, requisito que distingue fundamentalmente a la acusación falsa de la calumnia. En el caso de ejercicio falsario de la acusación por los no ofendidos tal exigencia se verá satisfecha con la interposición de la querella ante el Juez de Instrucción, momento que habrá de considerarse como el consumativo del delito, independientemente del resultado que con ello se consiga.

Con base en los art. 456.II CP y 638.II y III LECrim no será preciso esperar a que el Tribunal que conoció de la causa principal inicie de oficio la persecución del delito de

${ }^{1372}$ A tenor del art. 269 LECrim, el Tribunal o funcionario receptor de la denuncia se abstendrán de todo procedimiento cuando los hechos denunciados no revistieren el carácter de delito o la denuncia fuere manifiestamente falsa. El CP no otorga ninguna valoración especial al ejercicio en falso de la acusación frente a la que hace de la denuncia falsa y no se establece una agravación de la pena fundamentada sobre un mayor cuestionamiento de la presunción de inocencia del imputado.

\footnotetext{
${ }^{1373}$ No cabría englobar esta conducta en el cohecho del art. 422 CP aunque los sujetos que pueden incurrir en este delito sean "cualesquiera personas que participen en el ejercicio de la función pública". El actor popular desempeña una función pública, pero su posición no es subsumible dentro de lo que cabría entender por "ejercicio de la función pública". Si cometiere el delito de acusación falsa a cambio de dádiva o promesa, este comportamiento sería harto difícil de integrar en el tipo penal del cohecho. GÓMEZ ORBANEJA se planteaba si bastaba con la imputación falsa mediante denuncia hecha ante autoridad administrativa o judicial o era necesaria la interposición de querella, pronunciándose en el sentido de que se cumpliría el tipo penal con la mera imputación falsa. GÓMEZ ORBANEJA, E., Comentarios..., op. cit. p. 466.
} 
acusación falsa, sino que bastará con la sentencia firme o el auto también firme de sobreseimiento ${ }^{1374}$ o de archivo ${ }^{1375}$ para que pueda ser perseguido. El Tribunal mandará proceder de oficio contra el acusador (o denunciante) siempre que de la causa principal resulten indicios bastantes de la falsedad de la imputación, sin perjuicio de que el falsamente acusado, y sólo él, pueda presentar denuncia sobre los hechos, que operará como condición para la persecución penal de la misma manera que en los delitos semipúblicos. Parece que no habría inconveniente en que la mera inadmisión de la querella reputada mendaz constituyera condición suficiente para erigirse en fundamento de una persecución falsa, pues tal rechazo mediante auto puede ser considerado como uno de los momentos en que puede producirse el archivo por parte del Instructor. Para ello habrá de realizarse una actividad de investigación, siquiera mínima, que exigiría el examen del contenido de la querella para constatar a limine su fundabilidad, apreciando bien la inexistencia del delito, bien la ausencia de elementos incriminadores por los hechos objeto de la acusación para el imputado.

La condena por el delito de acusación o denuncia falsa en dos ocasiones lleva aparejada una consecuencia provocada por la desconfianza que pesa sobre estos sujetos $^{1376}$ : la no atribución de legitimación para acusar sin ser ofendido (art. 102. II y III LECrim). Ello tendrá que ser estimado bien de oficio, bien a instancia del imputado en el

${ }^{1374}$ El sobreseimiento puede ser libre o provisional (la STC 34/1983 de 6 de mayo viene a equipararlos). En el mismo sentido SSTS 18 de junio de 1990 (RAJ 7303) y 16 de diciembre de 1991 (RAJ 9318). RUIZ VADILLO expresa, sin embargo, su opinión discrepante en relación con ello, pues mientras el sobreseimiento libre aunque adopte la forma de auto, equivale a una sentencia absolutoria, el provisional constituye una expresión de impotencia en la investigación con carácter de interinidad. RUIZ VADILLO, E., "Delitos de acusación y denuncia falsas", op. cit. pp. 89 y 91 y ss. En el mismo sentido, atendiendo a la exigencia de firmeza de la resolución jurisdiccional, cualidad que no sería predicable de un sobreseimiento provisional ya que suspende sólo temporalmente el proceso, vid. MAGALDI PATERNOSTRO, M.J., “Aspectos esenciales de la acusación y denuncia falsa”, op. cit. p. 69.

${ }^{1375}$ Vid. STS de 18 de junio de 1993 (RAJ 5204) en la que el auto de archivo se hace equivalente al de sobreseimiento.

${ }^{1376}$ En el orden material la condena por acusación falsa, aun en una sola ocasión puede tener también repercusiones civiles: si el acusado es testador del querellante, éste será considerado incapaz para suceder por causa de indignidad e incurrirá en justa causa de desheredación (art. $756.3^{\circ}$ y $852 \mathrm{CC}$ ). El primero de estos preceptos exige "que la ley señale pena no inferior a la de presidio o prisión mayor" y el segundo prevé como justas causas de desheredación “las de incapacidad por indignidad para suceder, señaladas en el art. 756 con los números $1^{\circ}, 2^{\circ}, 3^{\circ} y$ $5^{\circ}$. La acusación falsa es, además, causa justa para desheredar a los hijos y descendientes (853 CC), a los padres y ascendientes $(854 \mathrm{CC})$ y al cónyuge, aunque la reconciliación posterior de ofensor y ofendido prive a éste del derecho de desheredar, y deje sin efecto la desheredación ya hecha. Tales previsiones no encuentran plena aplicación en relación con el ejercicio de acusación popular, ya que por tratarse de acusaciones entre parientes se hallan excluidas del ámbito objetivo del derecho (art. 103 LECrim). Sí cabría pensar en el supuesto de la acusación de un cónyuge contra otro por delitos cometidos contra la persona de sus hijos y por el de bigamia (art. 103.1 LECrim). 
$\overline{\text { momento. Si el condenado una sola vez por un delito del } 456 \text { CP acusase y durante el }}$ procedimiento recayera sentencia firme condenándolo de nuevo, cesará su legitimación, puesto que la condición negativa del precepto hay que referirla no al acto de iniciación querella o personación en la causa-, sino a todos y cada uno de los actos procesales que el ejercicio de la acusación lleva consigo ${ }^{1377}$.

\subsection{Imposición de costas}

El art. 20.3 LOPJ prevé que la acción popular "será siempre gratuita", pero parece obvio pensar que ello sólo puede entenderse referido a las costas de interposición de la querella y sustanciación del proceso. No cabría sostener que el ejercicio de tal facultad no conlleve coste económico alguno, puesto que, cuando menos, el Notario cobrará el poder otorgado para interponer la querella, la actuación del Procurador generará derechos económicos y la defensa letrada devengará honorarios ${ }^{1378}$. La cuestión esencial será, por tanto, resolver quién será responsable de hacer frente a esos desembolsos, cómo hayan de ser éstos abonados y si cabrá la imposición a un acusador popular de los gastos originados por la defensa del imputado en caso de absolución.

Los criterios de imposición de costas en el caso de acusadores no ofendidos se han asimilado tradicionalmente a los mismos principios que en el de los ofendidos por el delito, en tanto del texto de la Ley no pueden derivarse diferencias claras entre ambos. La doctrina generalmente admitida por la Sala $2^{\mathrm{a}}$ del TS en relación con las costas de la acusación particular, conforme a los arts. 109, 240 y concordantes LECrim, es que ha de entenderse que rige la procedencia de su inclusión en las costas procesales, salvo cuando haya formulado peticiones no aceptadas y absolutamente heterogéneas con las del $\mathrm{MF}^{1379}$, o cuando la acusación sea notoriamente superflua, inviable, inútil o perturbadora ${ }^{1380}$. La

${ }^{1377}$ GÓMEZ ORBANEJA, E., Comentarios..., op. cit., T. II, vol. I, p. 467.

${ }^{1378}$ DE LA OLIVA, A., et al, Derecho Procesal Penal, Madrid 1993, p. 183.

${ }^{1379}$ Vid. entre otras SSTS 6 de abril de 1988 (RAJ 2739), 2 de noviembre de 1989 (RAJ 8533), 9 de marzo de 1991 (RAJ 1958), 22 de enero de 1992 (RAJ 430), 27 de noviembre de 1992 (RAJ 9547) y 8 de febrero de 1995 (RAJ 832).

${ }^{1380}$ Entre otras SSTS 27 de diciembre de 1993 (RAJ 4800), 2 de febrero de 1994 y 25 de abril de 1995 (RAJ 2874). Tampoco se podrán imponer las costas de la acusación particular cuando su actividad sea inane, meramente pasiva o de acompañamiento al MF. Vid. por todas STS de 30 de noviembre de 1996 (RAJ 9773). 
heterogeneidad excluyente de las costas supondría una radical discordancia entre la conceptuación jurídica y la tipología penal sustentadas por los acusadores, con lo que se trataría de garantizar que acusaciones intrascendentes y notoriamente innecesarias agravasen injustamente para el condenado las repercusiones patrimoniales de la causa. $\mathrm{La}$ peculiar posición procesal de los acusadores particulares origina para determinar el alcance y procedencia de reintegros económicos la ponderación de su posicionamiento, su diligencia y su actividad técnico-jurídica a lo largo del debate judicial. Con ello habrán de eliminarse en lo posible las desproporciones en relación con la trascendencia de su intervención con el fin de adecuar a términos de justa compensación los esfuerzos desplegados en defensa de sus intereses sin reducir sus lógicas expectativas, pero también sin propiciar abusivas consecuencias ${ }^{1381}$. De ahí que no sólo pueda dejarse de incluir los gastos originados por la acusación particular, sino que se podrá imponer a estos sujetos también el abono de las restantes costas cuando su intervención se produzca con temeridad o mala fe ${ }^{1382}$.

El reembolso de los gastos originados por la acusación popular no es, sin embargo, admitido con iguales criterios ${ }^{1383}$. La más reciente jurisprudencia, que entendemos plenamente acertada en este sentido, se ha mostrado reacia a la posibilidad de que tales cantidades puedan ser repercutidas sobre el imputado que resulte condenado, independientemente de la relevancia de la intervención del acusador para la consecución de tal resultado ${ }^{1384}$. La actividad de particulares no ofendidos no admite ser englobada

\footnotetext{
${ }^{1381}$ STS de 17 de mayo de 1996 (RAJ 4537) FD 6º.
}

${ }^{1382}$ La apreciación de temeridad o mala fe debe ser valorada en cada caso por el órgano jurisdiccional, aun cuando pueda adoptarse como criterio el que quien dedujera la pretensión no pudiera dejar de tener conocimiento de la injusticia y sinrazón de su acción. Cuando tal circunstancia sea palmaria, quien ejercitara la pretensión conociéndolo deberá pechar con los gastos y perjuicios derivados causados con su actuación. Vid. en este sentido SSTS de 25 de marzo de 1993 (RAJ 3152), de 15 de enero de 1997 (RAJ 182) FD $8^{\circ}$ y también de 15 de enero de 1997, (RAJ 334), FD $2^{\circ}$. En cualquier caso la terminología de la LECrim, que habla indistintamente de querellante, acusador particular o acusador privado no es óbice en ninguno de estos pronunciamientos jurisprudenciales para entender incluido en ellos la acusación del ofendido por el delito.

${ }^{1383}$ SÁEZ JIMÉNEZ, J., Enjuiciamiento Criminal, p. 960, estimaba que no se pueden imponer las costas del acusador popular "por muy relevante que sea su actuación, puesto que la ley cuida de determinar que la imposición sólo podrá comprender las costas de los acusadores particulares y de los actores civiles". En contra de esta posición vid. MONTERO AROCA, J.; "Las costas de la acusación particular en los procesos de urgencia” op. cit. p. 577. En su opinión la LECrim no distingue en ningún caso entre acusador popular y acusador particular y legitima en el art. 101 a los dos.

${ }^{1384}$ Vid. en este sentido la STS de 21 de febrero de 1995 (RAJ 1417), que declara que las costas procesales de la acusación popular no pueden repercutirse sobre los acusados en tanto "el ejercicio de la acción popular por un ente 
inadecuadamente entre las costas procesales a las que tenga que hacer frente el condenado, puesto que la presencia del MF es suficiente garantía en el ejercicio de la pretensión penal. No sería de recibo por ello hacer recaer sobre el condenado en costas esa carga, en errónea aplicación del criterio del vencimiento objetivo. La repercusión sobre aquél de los gastos de todas las acusaciones supondría una evidente desproporción entre la consecuencia jurídica prevista por el ordenamiento y la sanción efectivamente impuesta, ya que no tiene por qué asumir los gastos generados por un sujeto que, en el mejor de los casos, sólo cubre una posible deficiencia en el funcionamiento de los órganos estatales. Cierto es que la naturaleza de la condena en costas no es la de una sanción, sino sólo la de resarcimiento de los gastos procesales, pero incluyendo los producidos de forma superflua por la acusación popular, éstos se extenderían mucho más de lo imprescindible, por lo que podrían considerarse desproporcionados.

Pero tampoco tendría demasiado sentido que el acusador tuviera que asumir una carga económica -salvo en las hipótesis de acusación falsa- cuando su actividad se dirige a un interés no específicamente suyo, sino perteneciente a toda la colectividad. Admitir lo contrario nos aportaría pistas de la aparición en el proceso de intereses diversos, lo cual no parece aceptable. La acusación es una función pública, de cuyo ejercicio se derivará el bien común que el proceso persigue, independientemente del resultado condenatorio o absolutorio obtenido con ella. Aunque de la afirmación por el acusador popular de la concurrencia de presupuestos para la resolución jurisdiccional no se derivara una condena, el mero hecho de deducir la pretensión debería significar siempre obrar en interés público. Lo lógico parecería, en este sentido, que los costes de la acusación en su ejercicio por particulares no ofendidos fueran sufragados en su integridad con fondos públicos. De ahí que en ese plano teórico no cupiera vincular el reembolso de los gastos al resultado del proceso: el interés público habría quedado satisfecho tanto con la condena como con la absolución del imputado. Si en virtud de la pretensión del acusador popular se condenara al imputado, y puesto que no es admisible que el gasto sea soportado por éste, ni que pueda repercutirse sobre los condenados, sería necesario admitir que tendrá

no imbricado en la dinámica delictiva nunca puede dar origen al resarcimiento". Se trata de un supuesto de delito de prostitución, en el que es difícil apreciar cuando pudiera estar un sujeto particular acusador "imbricado en la dinámica delictiva". En el mismo sentido vid. SSTS de 2 de febrero de 1996 (RAJ 788), FD $20^{\circ}$ (acusación por delito de torturas ejercitada por una asociación); de 20 de diciembre de 1996 (RAJ 1125 de 1997), FD 4º (acusación ejercitada por un Ayuntamiento en delito de homicidio). En la STS de 13 de febrero de 1997 (RAJ 728), FD 5º, se sostiene que la acusación popular puede ser condenada en costas por temeridad o mala fe y, sin embargo, no puede incluir las suyas en el condenado. 
$\overline{\text { que venir financiado por las arcas estatales. La propia naturaleza pública de la acusación }}$ obliga a que los costes que derivan de su ejercicio, oficial o no, sean asumidos en todo caso por el Estado y los costes de la formulada por un no ofendido tendrían que ser soportados por él mismo sólo cuando fuera apreciada temeridad o mala fe en su actuación (art. $240.3^{\circ}$ LECrim $^{1385}$.

Ello no puede sin embargo ser fácilmente tolerado, en tanto con el ejercicio privado de la acusación se activan, en la práctica, intereses particulares en muchos casos ajenos al público en dar curso a un proceso donde se constate la necesidad o no de que el Estado imponga una sanción. Una vez más quedan al descubierto las contradicciones internas en nuestro sistema de acusación, por lo que puede entenderse que la intervención de particulares no sería más que un lujo caro e innecesario por superfluo, en tanto dos sujetos cuya actividad por definición se dirige a la consecución del mismo interés (MF y acusador popular), coincidirían en la actividad a desarrollar y estarían financiados por las arcas estatales.

\subsection{Fraude procesal}

El art. 11.2 LOPJ establece que "los Juzgados y Tribunales rechazarán fundadamente las peticiones, incidentes y excepciones que se formulen con manifiesto abuso de derecho o entrañen fraude de ley o procesal". Se abre así en teoría una vía útil que pudiera poner coto a posibles extralimitaciones en el ejercicio de la acusación por particulares. No cabría a su amparo privar a un sujeto de su condición de acusador si cumple los requisitos legales de atribución de legitimación, pero sí repeler sus iniciativas cuando llevaren consigo ora una finalidad diversa a aquella con la que fueron concebidas por el legislador, ora una mala fe procesal ${ }^{1386}$.

${ }^{1385}$ Un criterio para la interpretación de lo que sea "temeridad" en el ejercicio de la acusación puede encontrarse en la STS de 5 de diciembre de 1996 (RAJ 8949). En ella se descarta el comportamiento temerario de la acusación popular, a pesar de la absolución con la que concluyó el juicio, sobre la base de la naturaleza de los hechos y el origen de la iniciación del proceso penal por denuncia del MF a raíz de un expediente disciplinario administrativo contra el acusado. Vid. también STS de 13 de febrero de 1997 (RAJ 728), FD 5º en la que se señala que "la imposición de costas a la parte actora del juicio penal presenta un paralelo con el proceso civil pero no referida a la absolución como vencimiento, porque éste no existe en el ámbito de la declaración de los delitos y conminación de penas, sino referido a la temeridad o mala fe procesales de la acusación".

${ }^{1386} \mathrm{Si}$ fuera apreciada mala fe en un momento posterior a la interposición de la querella siempre cabría el 


\subsection{Sanciones pecuniarias}

Para responder a una conducta maliciosa o negligente por parte del acusador cabría pensar también en la posibilidad de imposición de sanciones pecuniarias de las previstas en el Tít. V, Libro V LOPJ para "los que intervienen en los pleitos o causas" en uso de las facultades gubernativas de los órganos jurisdiccionales (arts. 448 a 453 LOPJ). En este caso, constatado un incumplimiento de las obligaciones establecidas en las leyes procesales y siempre que el hecho no constituya delito, se podría imponer una corrección consistente en la imposición de una multa, para cuyo abono pudieran incluso detraerse alguna cantidad de la fianza depositada como cautela. Tal hipótesis ha de ser rechazada no obstante, por cuanto la responsabilidad de una actuación procesal incorrecta deberá recaer únicamente sobre el Abogado o Procurador que la cause, y no sobre su cliente o representado, que es quien habrá depositado la fianza.

sobreseimiento una vez constatada la inexistencia de elementos que puedan incriminar al sujeto acusado. Vid. GIMENO SENDRA, V., Constitución y Proceso, op. cit. p. 78. 



\section{Cuarta parte:}

\section{Razones alegadas en pro del mantenimiento de la acusación popular}





\section{CARÁCTER DEMOCRATIZADOR DE LA ACUSACIÓN POPULAR}

La conexión entre el ejercicio de la acusación por los ciudadanos y cierta concepción de la democracia es prácticamente unánime entre nuestra doctrina iuspublicista y, singularmente, entre la procesalista ${ }^{1387}$. La idea de participación, subyacente a la definición constitucional de España como Estado social y democrático de Derecho (art. 1.1 CE), se trasfiere a todos los aspectos de la vida pública, para concluir en que, a la potenciación de una mayor participación, iría indisolublemente unida una profundización democrática que alcanzaría todos los ámbitos a que se pudiera extender. En tanto ello fuera así, de la participación resultaría un incremento de los espacios democráticos en los que las relaciones sociales se desenvuelven. Constituye, además, uno de los principales fundamentos de esta visión el espaldarazo que supuso el reconocimiento constitucional de la "acción popular" (art. $125 \mathrm{CE}$ ), precepto que se suele interpretar con un carácter muy expansivo. El anhelo democrático que inspiró todo el texto de la norma fundamental tomaría cuerpo también en la generalizada extensión de las facultades acusatorias, lo cual parecería contribuir al ideal de Justicia, presente ya en el Preámbulo de la Carta Magna y en su art. 1.1, premisa irrenunciable y valor supremo sobre el que se asienta nuestro Ordenamiento Jurídico. A tenor de estas opiniones, la participación ciudadana en la acusación haría que el proceso penal pudiera ser contemplado como una lucha pro salute rei publicae en la que todos debamos sentirnos activamente implicados.

${ }^{1387}$ Entre otros muchos pueden verse a título meramente ejemplificativo MUÑOZ ROJAS, T., "En torno al acusador particular en el proceso penal español", RDProc (Ibam.) 1973, p. 107, para quien "la existencia de la acción popular hoy se justifica en la proyección democrática y abierta del Estado social de derecho"; GIMENO SENDRA, V., La Querella, op. cit. p. 101, que la configura como una forma de participación democrática en la Administración de Justicia, "ya de por si bastante distanciada del pueblo"; LOZANO-HIGUERO PINTO, M., "Notas sobre la participación procesal y su proyección en las formas alternativas de justicia", RUDProc., n 0, 1988, p. 49, para quien constituye "expresión en lo subjetivo del ideal participativo en la medida en que están afectados intereses generales"; CONDE-PUMPIDO FERREIRO, C., "El principio de legalidad y el uso de la oportunidad reglada en el proceso penal", $P J \mathrm{n}^{\mathrm{o}}$ especial VI, pp. 17-36, que ve en la acusación popular "un plus en el ejercicio democrático y constitucional de la participación de los ciudadanos españoles en el proceso penal, no obstante los riesgos o peligros que, a veces, se han querido ver en ella"; HUERTA CONTRERAS, M., "El Poder Judicial en la Constitución Española", Granada 1995, pp. 126 y ss. (acción popular como forma de participación democrática). Es significativo que ALCALÁ-ZAMORA no la incluyera entre el catálogo de instituciones que en su opinión aspiran a la democratización de la justicia, entre las que él destacó el jurado, la elección aplicada a la provisión de cargos judiciales y la libertad de defensa. Vid. ALCALÁ-ZAMORA y CASTILLO, N., "Preocupaciones y directivas fundamentales del Derecho Procesal Contemporáneo", conferencia pronunciada en 1950 y publicada en Estudios de Teoría General de historia del proceso (1945-1972), México 1974, pp. 127 y s. 
Una concepción monopolística de la acusación chocaría con una supuestamente necesaria difuminación de ésta entre todos los que debieran sentir el interés público en la persecución como un interés personal, llegando voluntariamente a soportar las molestias que se pudieran derivar de su actuación por mor de la corrección de un supuesto déficit democrático de la Justicia. Los acercamientos participativos entre la sociedad y la administración de la justicia son percibidos con frecuencia como formas de mejora de ésta última de los que se vería singularmente beneficiada. La participación constituiría así una solución a un problema de legitimación inherente a todo el sistema.

La acusación popular debe ser, no obstante, sometida a valoraciones antitéticas que nos hagan superar adhesiones incondicionales, muchas veces irreflexivas, a las que el prurito por "lo democrático" conduce en ocasiones. No todo lo participativo es siempre y necesariamente democrático, y ni siquiera sería deseable constituir peligrosos espacios ilimitados de participación en el proceso penal en aras de enraizar la democracia. La participación en la vida política, económica, cultural y social a la que hace referencia el art. 9.2 CE habrá de ser real y efectiva y situarse en los centros de poder, en los lugares de toma de las decisiones para que sea tal, pero no tiene que ser omnipresente en todos los ámbitos de la vida y en todo momento. Lo que se pretenderá en este capítulo es determinar si, y en qué condiciones, el ejercicio de la acusación por los particulares es incardinable en ese concepto de participación que conduce a la construcción y afianzamiento de un Estado democrático o, por el contrario, no constituye más que el reflejo de una "falacia de la participación" a evitar, sustitutiva de un déficit representativo propio del sistema.

Aquella vinculación entre acusación popular y democracia se ha realizado desde variadas perspectivas, en algunos casos confluyentes entre sí, cuyo examen se intentará abordar por separado a continuación. Se analizarán también, siquiera someramente, los razonamientos fundamentales en que se basa esa supuesta conexión entre acusación popular, participación y democracia, los cuales se han planteado en ocasiones más como inconsistentes proclamas de buena voluntad, que soportados sobre un aparato argumental suficientemente sólido. Con lo que se expone, se busca desvelar que ese predicado carácter democrático sería únicamente reconducible a su origen plenamente liberal decimonónico, para intentar reafirmar el deseo y la necesidad de desvincular los conceptos de democracia y de acusación por particulares. Ello se hace con el objetivo de tratar de evitar caer en el error de elegir instrumentos que pretendidamente garantizan participación en la Justicia haciendo que por ella se tenga que pagar un precio 
$\overline{\text { desproporcionado y pudiendo ocultar una insuficiente participación política. La excesiva }}$ confianza en principios que, en ocasiones, pueden llegar a resultar ilusorios, si no falsos, puede proporcionar una visión desmedidamente optimista que peque de ingenua, por lo que será necesario avanzar desde un principio nuestra opinión de que la Justicia, y en concreto la penal, no es conceptualmente, ni en la práctica debe ser, un espacio estatal necesitado de legitimación "popular". El "complejo Justicia" (jurisdicción, acción y proceso), dinámicamente interrelacionado en sus dos momentos (estático o constitucional

$\mathrm{y}$ dinámico o procesal) ${ }^{1388}$, desde la legalidad que lo objetiva fundamentalmente y delimita su desenvolvimiento procesal, no requiere ni permite legitimidad social ni, por su puesto, legitimidad política alguna. El proceso penal no debe por ello constituir tampoco un ámbito abierto a una desaforada participación, que pueda incluso hacer quebrar sus estructuras básicas.

\subsection{Justificación histórica: acusación popular como signo de democracia y de democratización de la Justicia}

A tenor de esta argumentación se suele afirmar que la acción popular del proceso penal sería "consustancial a la democracia" 1389 en tanto gozar de una honda raigambre liberal, reflejo de épocas democráticas de la historia. Se defiende así que fue instaurada o floreció en los momentos más liberales y no ha tenido vigencia cuando no soplaban aires democráticos en el sistema político. Intentaremos a continuación realizar un análisis sobre este tipo de justificaciones:

\section{1) En épocas democráticas}

Históricamente, el monopolio acusatorio del MF se ha contemplado en la ideología liberal como una inaceptable consecuencia de la estatalización de la vida social, mientras que, por el contrario, la acusación popular expresaría el vigor de la sociedad y del individuo ${ }^{1390}$. En este sentido cabría encuadrar la manifestación retórica de alguno de

\footnotetext{
${ }^{1388}$ Vid. PEDRAZ PENALVA, E., "Publicidad y derecho al debido proceso. Publicidad y derecho de acceso a la información contenida en los ficheros de datos jurisdiccionales”, $R G D, \mathrm{n}^{\circ}$ 631, abril 1997, p. 3892.

${ }^{1389}$ GIMENO SENDRA, V., “La acusación popular”, op. cit. p. 94.

${ }^{1390}$ Para una más completa comprensión de este tipo de argumentos debemos remitirnos necesariamente a lo expuesto en la parte histórica de este trabajo.
} 
nuestros autores decimonónicos de un supuesto deseo de hacer innecesaria la existencia de un órgano estatal de acusación, anhelo que el curso de la historia habría demostrado utópico $^{1391}$.

Tal intelección es sólo posible, sin embargo, si se enmarca dentro de la estructura de un Estado liberal abstencionista por naturaleza, el cual, sirviéndonos de criterios actuales, ha de reputarse insuficientemente democrático e insostenible si no es asumiendo el riesgo de cobijarnos al amparo de una trasnochada impronta ideológica. El papel de la acusación en el Estado Social actual no debe ser el de ámbito de libertad frente a actuaciones estatales, cuanto el de que, en el ejercicio de éstas, sea tomado en cuenta que se dirigen a la tutela de intereses sociales. La indiscutible raigambre liberal de la acusación popular debe ser hoy revisada para no asumir la servidumbre de permanecer dentro de unos límites de configuración del Estado y la sociedad que en ningún caso se adecuan a nuestro momento histórico. El rancio pedigrí democrático que se predica de ella pudo servir como argumento en circunstancias en las que la defensa de una esfera de libertad individual frente a la intromisión del Estado era objetivo prioritario, pero hoy ésta sería una fundamentación insuficiente y, en cierto modo, inconsistente, que además puede erigirse en fuente de anacronismos teóricos ${ }^{1392}$.

No es enteramente cierto que la querella por delitos públicos sea un logro del

${ }^{1391}$ SILVELA, F., “La acción popular”, op. cit. p. 483. Este deseo ha sido percibido por algún autor también en la voluntad del legislador procesal de 1882. Así GIMENO SENDRA, V., "La acción popular, el jurado y los tribunales de escabinos", op. cit. p. 339, Constitución y Proceso, p. 84. A nuestro juicio tal voluntad no correspondería al legislador, sino a alguno de sus primeros intérpretes. Nos referimos concretamente a SILVELA, al cual entendemos parte interesada en tales manifestaciones, puesto que con ellas pretendía defender un sistema que se asemejara al inglés de aquellos momentos. Releyendo los últimos párrafos de la brillante Exposición de Motivos de la LECrim no cabría extraer la conclusión a la que llegaba este autor, sino precisamente la contraria. Decía ALONSO MARTÍNEZ que "educados los españoles durante siglos en el procedimiento escrito, secreto e inquisitorial, lejos de haber adquirido confianza en la Justicia y de coadyuvar activamente a su recta administración, haciendo, como el ciudadano inglés inútil la institución del Ministerio Público para el descubrimiento y castigo de los delitos han formado ideas falsas...". Pero tal afirmación se hacía sólo para justificar la falta de costumbres adecuadas al sistema acusatorio y al juicio oral y público, lo cual dificultaría la aplicación y el cumplimiento de la nueva Ley por el imperante recelo hacia la Justicia. No obstante, si nos fijamos en el penúltimo párrafo, comprobaremos que contiene toda una declaración de fe no sólo en la Magistratura sino también en el MF, lo cual no puede ser en ningún caso considerado como una muestra favorable a su supresión: "Al logro de fin tan importante y trascendental coadyuvarán, sin duda, el celo e ilustración de la Magistratura y el Ministerio Fiscal, que no es posible, Señor, montar una máquina delicada y hacerla funcionar con éxito, sino contando con el asentimiento, el entusiasmo, la fe y el patriotismo de los que han de manejarla".

${ }^{1392}$ En opinión de VÉLEZ-MARICONDE, Derecho Procesal Penal, T. I, 2a ed., p. 293, la acusación popular sería "fuente de anacronismos teóricos y de inconvenientes prácticos". Vid. también su obra "El ejercicio de la acción penal", en Estudios de Derecho Procesal Penal, T. I, esp. pp. 257 y ss. 
$\overline{\text { Estado liberal, tal y como se ha afirmado en alguna ocasión }}{ }^{1393}$, sino que lo plenamente correcto sería afirmar que la ideología liberal revitalizó (o casi resucitó) en España un sistema que permanecía latente en nuestro ordenamiento jurídico y que se adaptaba singularmente bien a su pretensión de establecer garantías del ejercicio de derechos individuales frente a la intromisión estatal en un momento en que el MF, desde su vinculación al Ejecutivo, estaba asumiendo la facultad y la obligación de acusar. Así como en otros Estados ello fue considerado entonces un inaceptable paso atrás de varios siglos en la evolución de los sistemas de persecución del delito, en el nuestro fue mantenido como una singular declaración política de principios. En cualquier caso, no habría podido ser vista como un progreso ni siquiera en el momento de su implantación normativa, sino sólo como la victoria de las tendencias más conservadoras de la época ${ }^{1394}$.

\section{2) En épocas de dictadura}

\section{a) Regímenes autoritarios nacionalsocialistas o fascistas}

Como muestra de apoyo a la conexión entre acusación popular y democracia se ha argüido también la crítica al ejercicio de la acusación por sujetos privados formulada, velada o explícitamente, desde sectores afines a diversos regímenes dictatoriales, y entre nuestra doctrina durante el régimen franquista ${ }^{1395}$. Desde un punto de vista práctico, su escasa utilización en este periodo ha sido interpretada bien como lógica, a tenor de un componente autoritario que impediría la actividad individual, bien como un propósito deliberado y programado desde los detentadores del poder estatal de arrinconar la actividad ciudadana en beneficio de la autoridad estatal, representada en el proceso penal por la figura de un funcionario público titular de la facultad de deducir la pretensión

${ }^{1393}$ GIMENO SENDRA, V., Constitución y Proceso, p. 75, refiriéndose al derecho de acción y al de querella.

${ }^{1394}$ Afirmaba FERNÁNDEZ DE VELASCO que constituyendo la acción popular (administrativa) "una lucha por el derecho de forma jurídica, disciplinada, no violenta o revolucionaria", se ofrecería como una "institución conservadora, alta manifestación de solidaridad social'. FERNÁNDEZ DE VELASCO, R., La acción popular en el Derecho Administrativo, Madrid 1920, p. 73.

${ }^{1395}$ La confirmación de esta idea está presente en FENECH, M., "Nuevas orientaciones del Derecho Procesal Penal", RGLJ 1941, n 170, p. 81. Estudios posteriores no hacen más que ratificarlo. Así RIEHLE, G., Die Rechtsstaatliche Bedeutung der Staatsanwaltschaft unter besonderer Berücksichtigung ihrer Rolle in der nationalsozialistischen Zeit, Francfort 1985 o SCHUMACHER, U., Staatsanwaltschaft und Gericht im Dritten Reich, Colonia 1985. 
penal $^{1396}$.

Con el advenimiento de los regímenes totalitarios fascistas italiano, alemán o español, la concepción liberal de la acusación popular entendida como instrumento de tutela de derechos públicos perdió gran parte de su sustento ideológico e institucional. La acción popular del proceso penal no era vista sino como una inaceptable "asunción y ejercicio por un particular de competencias y funciones que son esencial y orgánicamente propias del Estado" ${ }^{1397}$, eso sí, de un Estado sujeto a una concepción totalizadora. Se reforzaba de esta manera la idea, ya presente en la ideología liberal, según la cual la asunción de funciones públicas por el ciudadano es típica de una concepción arcaica y poco evolucionada de formación del Estado, donde todavía no se habrían perfeccionado los instrumentos necesarios para realizar sus fines institucionales. Cuando, por el contrario, la organización estatal asume formas más desarrolladas, personificándose y distinguiéndose de la masa de los ciudadanos, el auxilio prestado por el individuo a la Administración Pública a través de la acusación popular no podía considerarse sino inútil y anacrónico ${ }^{1398}$. El proceso penal autoritario tendría como única función la tutela de un interés público no tanto en la solución pacífica del conflicto sino en la propia represión del delito, por lo que no sería necesaria la habilitación de espacios procesales para la salvaguardia de otros intereses ajenos a los propios del Estado. Con esta concepción se originó el arrinconamiento prácticamente total de la intervención privada en el proceso, en tanto habría perdido su caldo de cultivo.

No carecen de razón por ello quienes afirman que en una sociedad autoritaria la acusación popular es un elemento distorsionador, pero tal afirmación debe ser matizada, en tanto no refleja enteramente una realidad no tan lineal como a primera vista podría

${ }^{1396}$ GIMENO SENDRA, V., La Querella, op. cit. p. 103: “lo coherente, a simple vista, en un país con una instancia jurídicapolítica manifiestamente totalitaria sería desterrar la acusación popular como institución democrática y concentrar el "poder" de la acción penal en un órgano administrativo, tal y como se hizo en la legislación nazi”. Vid. también ALMAGRO NOSETE, J., “Acción popular”, La Reforma del Proceso Penal, II Congreso de Derecho Procesal de Castilla y León; Ministerio de Justicia, Madrid 1989, p. 226, para quien "los criterios contrarios a la acción popular pueden encontrar campo abonado en sociedades politicas, cuyos componentes autoritarios o un estatismo a ultranza, influyen creando un clima hacia los poderes del ciudadano". A pesar de su escasa utilización, FAIRÉN defiende que la acusación popular supuso un "elemento de incalculable valor en tiempos de dictadura, y que lo ha de seguir mostrando si el Ministerio Fiscal fallase". Comentarios a la LOPJ, op. cit. p. 50.

${ }^{1397}$ CRISAFULLI, Voz “Azione popolare”, Nuovo Digesto Italiano, II, Turín 1937, p. 140, esp. n. 1.

${ }^{1398}$ BORGHESI, D., Voz “Azione Popolare”, Enciclopedia Giuridica, Roma 1988, p. 4. 
$\overline{\text { parecer. En primer lugar debe constatarse también entre apologistas de los sistemas }}$ dictatoriales la presencia de defensores del ejercicio de la acusación por los ciudadanos, si bien con un objetivo muy diferente al que se sostenía desde planteamientos liberales. La clave no estaría en la participación en el proceso como instrumento de ruptura de un posible autoritarismo estatal, sino en la vigilancia de la comisión de los delitos mediante un control disperso. Se pretendería implantar así una suerte de "panoptismo social difuso" 1399 en el que cada ciudadano controlara a sus semejantes y fuera controlado por todos los demás, llevando de esta manera el poder estatal de enjuiciamiento y consecuente aplicación de las normas hasta los últimos rincones de la vida comunitaria. Este método capilarizado de control social sería apto no sólo para la prevención de delitos sino, en tanto haría predominar criterios de eficiencia, también para el gobierno político de la colectividad. El actor popular sería así una especie de longa manus del poder del Estado y su acusación un elemento integrador del control estatal.

Es buen ejemplo de ello la opinión expresada en la Alemania de 1936 por WOLF, para quien la "Volksklage" constituía un ${ }^{1400}$. WOLF, profesor de Filosofía del Derecho y Derecho Eclesiástico, p elemento esencial dirigido al cumplimiento de la norma penal en el "nuevo Estado" ropugnaba en el "nuevo Estado" una concepción diferente de la participación de los particulares, la cual se llevaría a cabo mediante la "acusación del pueblo (Volksklage ${ }^{1401}$. A su juicio, tal intervención se había basado hasta ese momento en las premisas del Estado liberal, según las cuales el ciudadano debería permanecer siempre vigilante de la actividad del Fiscal, por naturaleza dependiente del Ejecutivo. En aquel modelo no se trataría tanto de contribuir a la persecución penal del Estado, cuanto de controlar ésta, reafirmando la insuficiente protección que se proporciona al perjudicado por el delito ${ }^{1402}$. Sin embargo, según su planteamiento, la participación privada no se

${ }^{1399}$ El término lo tomamos de FERRAJOLI, L., Derecho y Razón. Teoría del Garantismo penal, que a su vez se sirve de la denominación "panoptismo carcelario" con origen en BENTHAM.

${ }^{1400}$ WOLF, E., "Die Beteiligung des Verletzten am Strafverfahren”, Deutsche Juristen-Zeitung, no 21 (1936), pp. 1257-1266.

${ }^{1401}$ Es también muestra del ambiente intelectual en el que se lanza esta propuesta la utilización del término de fuertes connotaciones germánicas "Volk-" (Pueblo) en lugar de los que se venían utilizando hasta entonces para expresar ideas semejantes: "Popular-" o "Privat-", de origen latino o "Bürgerliche-" (cívico, civil), de claras resonancias liberales.

${ }^{1402}$ WOLF, E., “Die Beteiligung...”, op. cit. p. 1059. A tenor de su concepción, afín al sistema político nacionalsocialista en el que se sitúa, y sobre la base de consideraciones históricas y dogmáticas, la acusación privada (Privatklage) y la acusación accesoria (Nebenklage) deberían desaparecer: no cabría desconfianza alguna en que la 
debiera realizar para la defensa de un derecho de carácter individual, tal y como había sido defendido desde posturas liberales, sino primordialmente en tanto los individuos integraban el Pueblo, y éste, considerado como sujeto de derechos y sometido al principio del caudillaje (Führerprinzip), se identificaba con el Estado ${ }^{1403}$. En opinión de WOLF, el Estado Nacionalsocialista precisaría también de una coparticipación de los "integrantes del Pueblo" en el proceso penal, colmando posibles errores del fiscal y contribuyendo a la eminente función pública de persecución de todos los delitos, de manera que la defensa de Pueblo y Estado quedasen absolutamente garantizadas. El mecanismo a través del que tal garantía tomaría cuerpo debería ser a través de la "idea de los antiguos pueblos germánicos de la acusación del pueblo (Volksklage)", mediante la que a cualquiera, ofendido o no por el delito, se le garantizara un derecho de acusar si, con motivo de una denuncia presentada, el fiscal rehusara hacerlo ${ }^{1404}$. Este derecho no sería conferido con carácter ilimitado, sino sólo se facultaría para su ejercicio a los varones mayores de 25 años que estuvieran en posesión de los derechos civiles. No deberían añadírsele trabas económicas de ninguna naturaleza "para no transferir los perjuicios de la plutocracia de la acusación privada a la acusación del pueblo" ${ }^{1405}$.

No son menos reveladores del servicio que puede prestar la acusación popular a regímenes totalitarios los numerosos ejemplos de acciones populares en normas promulgadas durante nuestra posguerra civil. Estas previsiones se hallan dispersas en disposiciones sancionadoras muy abiertas, con abundantes connotaciones valorativas y

actividad del fiscal se fuera a desviar de sus obligaciones, con lo que aquellas preocupaciones de los pensadores liberales carecerían de fundamento. Ello no es más que un botón de muestra de los impulsos dados por los juristas afines al régimen nacionalsocialista de eliminar todas las formas de control privado del proceso penal, de los que precisamente WOLF se distancia con su teoría de la Volksklage.

${ }^{1403}$ Para una exposición de la ideología nacional socialista aplicada a la Justicia desde un planteamiento apologético, vid. entre nuestra doctrina la singular obra de FENECH, M., La posición del juez en el nuevo Estado, Madrid 1941. En opinión de FENECH "el príncipe no representa al pueblo, sino que lo integra (...) No es semejanza como representante y representado, sino igualdad" y "el Führer y el Pueblo forman una unidad". op. cit. pp. 58 y 81.

${ }^{1404}$ En relación con la no persecución por razones de oportunidad, WOLF afirma que la mera exclusión de la acusación por el fiscal denota ya la ausencia de interés público en la persecución y, por tanto, en estos casos no sería admisible tampoco una acusación del pueblo. WOLF, E., “Die Beteiligung...”, op. cit. p. 1265.

${ }^{1405}$ La apertura del juicio oral en estos supuestos se sometería a un “juicio de acusación”, en tanto sería decidida por un Consejo formado por cuatro miembros (el presidente del Landgericht, el primer Fiscal y dos jueces legos de la circunscripción), quienes oirían al acusador del pueblo en sesión no pública, decidiendo sobre la fundamentación de sus pretensiones y admitiendo o rechazando su participación en el proceso. 
$\overline{\text { precisadas de un férreo control para su cumplimiento, en las que los límites con la simple }}$ denuncia, en ocasiones premiada con recompensa, no estaban siempre nítidamente delimitados. Podrían citarse así como ejemplos la Ley de 13 de julio de 1940 de descanso dominical (art. 12: "Será pública la acción para corregir y castigar las infracciones de esta ley"); la de 29 de marzo de 1941, Texto Refundido de la Ley de Impuestos de Derechos Reales y sobre transmisión de bienes (art. 41: "La acción para denunciar actos sujetos al impuesto es pública, y los denunciadores tendrán derecho a percibir la totalidad de la multa cuando faciliten a la Administración todos los documentos necesarios para practicar las liquidaciones...."); el Reglamento para la aplicación de la Ley de protección a las Familias numerosas de 1 de agosto de 1941 (art. 29: "La acción para denunciar los hechos señalados en el artículo anterior es pública...", (casos de resistencia de las empresas y organismos privados a la prestación de los beneficios establecidos, de ocultación de datos por parte de los beneficiarios, de falsedad, de presentación maliciosa de datos, préstamo del título a personas ajenas y en general de cualquier uso indebido o abusivo del mismo); el Decreto de 20 de febrero de 1942 sobre contrabando y defraudación (art. 4: "La acción para perseguir las infracciones es pública, pero corresponderá especialmente a las autoridades del orden fiscal..."); el Decreto de 14 de diciembre de 1942 sobre Impuesto de consumos de lujo (art. 27.1: "Es pública la acción dirigida a promover el castigo de las defraudaciones cometidas en perjuicio del impuesto"); la Orden de 15 de febrero de 1944 sobre contribución industrial, de Comercio y de Profesiones e Impuesto sobre tarjetas de identidad y personal en Ifni (art. 27: " $\mathrm{La}$ acción de denunciar las ocultaciones y defraudaciones por este impuesto es pública..."); la Orden de 23 de febrero de 1944 sobre el Impuesto sobre la radioaudición (art. 26: "Es pública la acción dirigida a promover el castigo de las infracciones y de las defraudaciones cometidas en perjuicio del impuesto"); la Ley de 30 de diciembre de 1944 sobre Capacidad civil de los indígenas en los Territorios del Golfo de Guinea (art. 8.5: "Será pública la acción para denunciar y exigir, ante las Autoridades o Tribunales que corresponda, las responsabilidades de todo orden que se deriven de los actos a que se refieren los párrafos anteriores" (contratación ilícita con indígenas...); el Reglamento de 8 de febrero de 1946 del Impuesto sobre la pólvora y mezclas explosivas (art. 28: "Es pública la acción para denunciar las infracciones que se señala en este reglamento" y art. 29: "Es pública la acción para denunciar las ocultaciones o defraudaciones que en este reglamento se señalan"); el Reglamento de 26 de julio de 1946 del Impuesto de la Radioaudición (art. 24.1: "Es pública la acción dirigida a promover el castigo de las defraudaciones cometidas en perjuicio del impuesto"); la Instrucción de la Dirección 
$\overline{\text { General de Correos y Telecomunicaciones de } 20 \text { de mayo de } 1949 \text { sobre Estaciones }}$ radioeléctricas particulares (art. 23: "Será pública la acción para denunciar las faltas cometidas contra el Reglamento por las estaciones de aficionados autorizadas por la Dirección General, así como la existencia de las clandestinas. El denunciante tendrá derecho a la mitad del importe líquido de la multa impuesta por la falta"); etc. A tenor de las previsiones citadas, su uso no era más que uno de los reflejos externos de un Estado autoritario omnicontrolador ${ }^{1406}$, tendente a una utilización máxima del derecho sancionador y, en este sentido, no sería desatinado afirmar que la acción popular no significaría una maximización del principio democrático, sino un claro déficit de éste ${ }^{1407}$.

Por otro lado, la acusación popular procedente del Derecho Romano y el Derecho Común, se consolidó en nuestro sistema durante la Restauración, no precisamente uno de los momentos de auge del liberalismo decimonónico español, se mantuvo prácticamente invariable durante la dictadura de Primo de Rivera y, a pesar de la existencia de intentos de supresión, no se movió un ápice durante el régimen franquista. Ello induce a pensar que su presencia en la Ley no era molesta a los ojos de gobiernos autoritarios y, aun cuando no se recuerden supuestos en que fuera ejercitada, su falta de virtualidad o de efectividad práctica no derivaba de una prohibición legal. El intenso control de las opiniones discrepantes y el "Principio del Caudillaje", según el cual pueblo y Estado se identifican con su líder ${ }^{1408}$, representado orgánicamente en el proceso penal a través del $\mathrm{MF}^{1409}$, aportarían razones para la ausencia de tal actividad. La falta de verdaderos

${ }^{1406}$ No deben olvidarse los fines de prevención general que aparecían como fundamento de la acusación de cualquiera ya en Las Partidas. De ellos se daba noticia también en el FEBRERO, al afirmar que “...cuando los hombres criminales ven en cada uno de los que le rodean un vigilante observador de su conducta, refrenan sus malvados impulsos...". FEBRERO O LIBRERÍA DE JUECES, ABOGADOS Y ESCRIBANOS, por GARCÍA GOYENA, F. y AGUIRRE, J. T. VIII, $3^{a}$ ed., Madrid 1845, Marginales 7513 y s. En la $4^{a}$ edición (1852), en la que intervino VICENTE Y CARAVANTES, se reiteran los mismos argumentos en el T. V, Marginales $50 \mathrm{y} \mathrm{s}$. Necesariamente nos tenemos que remitir aquí de nuevo a lo expuesto en la parte histórica de este trabajo.

${ }^{1407}$ Acaso por ello advierte GIMENO SENDRA, V., La Querella, op. cit. p. 104, que “no cabe descuidar que la acusación popular puede interesar a un Estado totalitario en tanto en cuanto constituye una vía más de "información" y de represión de los delitos que el Estado tiene especial interés en perseguir. Por ello, no ha sido nada casual, que en nuestro país, antes que en la LECrim., la acusación popular se consagrara en la legislación de imprenta".

${ }^{1408} \mathrm{Al}$ respecto vid. la extrapolación de las ideas del nacional-socialismo alemán y el fascismo italiano a nuestro país que realizaba FENECH, M., La posición del Juez en el nuevo Estado, op. cit., Passim y esp. pp. 58, 81 y 115.

${ }^{1409}$ Cabe recordar aquí que, a tenor del art. 35.I de la antigua Ley Orgánica del Estado de 1966 y el art. 1 del Reglamento del MF de 1969, el MF era un "órgano de comunicación entre el Gobierno y los Tribunales de Justicia". 
canales de expresión de las inquietudes sociales y la escasez de recursos económicos podrían ser otros argumentos. En cualquier caso, en tanto la acusación popular es una institución cuyo ejercicio va dirigido al enjuiciamiento y eventual aplicación de la norma penal, y ésta servía a los intereses de un Estado autoritario, su utilización habría sido decididamente represiva. En lugar de echarla en falta, deberíamos felicitarnos por ello del desconocimiento de su uso en esta sombría época de nuestra historia.

\section{b) Regímenes totalitarios comunistas. El ejemplo de la RDA}

En regímenes políticos autoritarios de signo contrario el intento de lograr un "control social" del proceso a través de sistemas de participación en la acusación no podría considerarse tampoco extraño ${ }^{1410}$. La idea de colectividad que regía la vida en estas sociedades era particularmente adecuada al establecimiento de mecanismos de delación de las conductas discrepantes o "antisociales". La participación de los individuos que comulgaran con la ideología oficial en la persecución de las infracciones, dentro de unas determinadas coordenadas políticas, fue considerada también un mecanismo especialmente útil para la consolidación del sistema.

En la República Democrática Alemana, por ejemplo, junto a un estricto monopolio acusatorio atribuido a la Fiscalía como órgano encargado de "velar por la seguridad de la sociedad socialista y del ordenamiento del Estado, así como de los derechos de los ciudadanos dentro de la estricta observancia de la legalidad socialista" ${ }^{1411}$, existía la llamada "acusación social" (geschellschaftliche Anklage), instaurada al servicio de la persecución de delitos considerados graves con especial trascendencia social ${ }^{1412}$. No era, sin embargo, una acusación popular stricto sensu, sino más bien una estrecha fisura en el

\footnotetext{
${ }^{1410}$ Una referencia a este respecto sobre el antiguo ordenamiento soviético puede verse en BARONE, G., Enti colletivi e proceso penale (dalla constituzione di parti civile all'accusa privata), Milán 1989 p. 33.

${ }^{1411}$ Art. 97 de la Constitución de la RDA de 6 de abril de 1968.

${ }^{1412}$ El “acusador social”, al igual que el "defensor social” no tuvieron un perfil definido hasta 1968, aun cuando se mantuvieron en la norma hasta la desaparición oficial del Estado en 1990. La propuesta para su instauración partió de BEYER y NEUMANN y del Tribunal de distrito de Gera, siguiendo el modelo de la Unión Soviética. Vid. BEYER, K.H. y NEUMANN, H., “Die Mitwirkung der Werktätigen am Strafverfahren”, 1966. En la opinión por ellos manifestada, tras una primera fase en la que, con la revolución de octubre, el pueblo tomó participación activa en la persecución del delito, debería empezar una segunda, al igual que en la URSS, cuyo objetivo final fuera la erradicación de la criminalidad a través de la construcción del comunismo, y para la cual estarían llamados los acusadores y los defensores sociales (p. 59).
} 
monopolio acusatorio de la fiscalía, por cuyo hueco sólo se dejaba entrar en el proceso a los que previa y abiertamente ostentasen la condición de defensores de la legalidad socialista. El art. 54.1 StPO de la RDA especificaba quiénes podían intervenir como acusadores o defensores sociales: los representantes populares, miembros elegidos del National Front, de los sindicatos, de los órganos colectivos de trabajadores y agricultores, etc. A éstos se atribuían facultades de intervención en el proceso tales como la capacidad para expresar su opinión sobre la existencia del delito, la personalidad y la culpabilidad del encausado, la aportación o petición de prueba, el derecho a solicitar la suspensión del proceso, la de contribuir en la interposición de recursos, etc. El Tribunal, el Fiscal y los restantes órganos de investigación (policía) estaban obligados a cooperar a fin posibilitar la intervención de estos actores que aportarían al proceso "los valores imperantes en la sociedad socialista a través de los representantes de sus colectivos"1413. Al acusador social se le encargaba la acusación cuando existía la sospecha de comisión de un delito que afectare gravemente a la legalidad socialista, a la esfera pública (Öffenlichkeit) o a los grupos a los que representan, así como cuando se considerase necesario que el colectivo informase al Tribunal de alguna circunstancia sobre el delito ${ }^{1414}$. Los acusadores estaban obligados, además, a hacer valer todas las circunstancias agravantes, atenuantes o excluyentes de la responsabilidad penal ${ }^{1415}$, por lo que su función era la misma que la del MF, pero configurada de una manera ciertamente peculiar. Tal tarea era desempeñada habitualmente por "trabajadores modelo" (Vorbildliche Werktätige) que, por razón de sus cualidades, gozaban de especial autoridad, a los que se atribuía una función de enlace entre los órganos de tutela judicial y las organizaciones encargadas de la garantía del orden, la seguridad y la legalidad en sus respectivos ámbitos de responsabilidad estatal y social $^{1416}$. Una ulterior obligación era la de mantener informados a los miembros de sus respectivas organizaciones o colectivos sobre los resultados del proceso en marcha, contribuyendo de esta forma a la difusión de éste.

Este instrumento estaba configurado normativamente como un medio más para la

\footnotetext{
${ }^{1413}$ Vid. BEYER, K.H. y NEUMANN, H., “Die Mitwirkung der Werktätigen...”, op.cit. p. 38

${ }^{1414}$ Normalmente se trataba, pues, de delitos con un alto contenido de peligrosidad social, aun cuando se excluían explícitamente los delitos políticos de los capítulos 1 y 2 de la parte especial del Código Penal. Se exigía, sin embargo, no conocer al acusado por tener convivencia inmediata con él (art. 55.2 StPO RDA).

${ }^{1415}$ Art. 56.1.1 StPO RDA.

${ }^{1416}$ BEYER, K.H., Strafverfahrensrecht. Lehrbuch, Berlín 1977, p. 133.
} 
$\overline{\text { instrucción de los ciudadanos y el ejercicio de un más intenso control social }{ }^{1417} \text {. Con ésta }}$ y otras instituciones de similar naturaleza ${ }^{1418}$, la posición del Estado en el proceso se veía reafirmada a través de su apertura a los representantes de organizaciones constituidas y autorizadas en cuanto afines al poder. Se trataría de la mera expresión de una opinión pública, dirigida y controlada desde instancias extra y preprocesales, que se dejaba oír durante el proceso y que, una vez finalizado éste, serviría de canal de distribución de información a una sociedad que se pretendía vertebrar políticamente. El círculo de expansión del poder quedaba cerrado: el Estado dirige y protege los colectivos encargados de la creación y el sustento de una opinión pública que así se ve controlada, les concede posteriormente la posibilidad de intervenir en el proceso, y por último les atribuye la función de difusores sociales del proceso como una de las formas de defensa de la legalidad que sustenta el propio Estado ${ }^{1419}$.

\subsection{Justificación política: acusación popular como derecho participativo}

El carácter político que se atribuye al ejercicio de la acusación por los ciudadanos deriva de una supuesta modificación que su reconocimiento operaría en las relaciones de aquéllos con el poder estatal, puesto que al asumir la gestión de un interés público ${ }^{1420}$, se

${ }^{1417}$ MOHRMANN, U., Die geschellschaftlice Beteiligung an der Strafrechtspflege in der DDR. Ein Beispiel für die Erziehungsfunktion eines sozialistisschen Staates, Colonia 1972. Abiertamente se expresaba la necesidad de contribución "en la extirpación de la criminalidad de la vida social en tanto importante deber del Estado Socialista $y$ de todas las fuerzas sociales para la construcción del socialismo". Con un afán de establecer diferencias con los regímenes occidentales, se definía como "una muestra más de la progresiva unidad del Estado y el Pueblo en la construcción del Socialismo frente a la inevitable separación entre el Pueblo y el régimen imperialista de Alemania Occidental”. Vid. BEYER, K.H. y NEUMANN, H., “Die Mitwirkung der Werktätigen...”, op.cit. pp. 9 y 23.

${ }^{1418}$ Así los Tribunales sociales o el defensor social.

${ }^{1419}$ A la vista de este tipo de manipulación política de la Justicia, podría afirmarse con KIRCHHEIMER que la justicia política no constituye medio de garantía de la justicia, sino uno más de los medios de reafirmación del poder político. KIRCHHEIMER, O., Political Justice. The Use of Legal Procedure for Political Ends, Princeton, New Jersey 1961.

${ }^{1420}$ "A través del ejercicio de la acción popular el ciudadano-actor asume en cierta manera una condición de gestor de los intereses públicos, de valedor del bien común encargado en la legalidad cuyo mantenimiento o restauración se postula”. ANDRÉS IBÁÑEZ, P. y MOVILLA ÁLVAREZ, C., El Poder Judicial, Madrid 1986, p. 311. 
$\overline{\text { propiciaría un acercamiento entre la Justicia y la sociedad }}{ }^{1421}$. Se sostiene, en este sentido, que la acusación popular sería un ius activae civitatis, una forma de representación popular en el proceso o un ejercicio directo de la democracia.

\section{I.}

El concepto de acusación popular, aceptado hoy mayoritariamente, como derecho subjetivo público, cívico y activo, perteneciente a la esfera del status activae civitatis descrito por JELLINEK ${ }^{1422}$, procede en nuestra doctrina de FAIRÉN ${ }^{1423}$, pero ha sido desarrollado muy singularmente por GIMENO ${ }^{1424}$. Asumieron así estos autores el encuadre de la querella en el status positivo, realizado por la doctrina italiana tomando como base su ordenamiento ${ }^{1425}$, para ir un paso más allá en atención a las peculiaridades del nuestro. Mientras que la adscripción de la querella privada sí tenía reflejo literal en la obra de JELLINEK, la extensión realizada por FAIRÉN y GIMENO supuso una concepción ciertamente novedosa ${ }^{1426}$. Según esta lectura, mediante la actividad del acusador popular, más que solicitar una prestación del Estado, lo que haría sería asumir una función pública, cual es el mantenimiento de la acusación pública. Su fundamento habría de encontrarse en la consagración del principio nemo iudex sine actore, y su finalidad sería la reintegración del orden jurídico perturbado por la comisión del delito. Excluir

\footnotetext{
${ }^{1421}$ En este sentido, XIFRÁ HERAS, J., "La Jurisdicción en la Constitución de 1978” en el volumen colectivo El Poder Judicial, vol. III, Dirección General de lo Contencioso del Estado, Madrid 1983, p. 2717, que habla de "aparato judicial" y sociedad.

${ }^{1422}$ JELLINEK, G., System der subjektiven öffentlichen Rechte, Tubinga 1905. Reimpresión de la $2^{\mathrm{a}}$ edición de 1919, Darmstadt 1963. Existe traducción al italiano de VITAGLIANO, G., Sistema dei Diritti Pubblici Subbiettivi, Milán 1912.

${ }^{1423}$ La idea se apunta en FAIRÉN GUILLÉN, V., "Ideas sobre una Teoría General del Derecho Procesal", RDProc. 1966 (enero-marzo), p. 46, pero se expresa claramente en sus artículos "Para una Teoría General del Derecho Procesal" y "El proceso como función de satisfacción jurídica", Temas del Ordenamiento Procesal, T. I, pp. 312 y 415 respectivamente.

${ }^{1424}$ Especialmente en su obra La Querella, Barcelona 1977, pero también a lo largo de todas sus posteriores publicaciones.

${ }^{1425}$ Vid. por todos BATTAGLINI, G., La Querela, $3^{\circ}$ ed., Turín 1958, pp. 203 y ss. La querella se conceptúa para otro sector bibliográfico italiano como "un poder" o "una facultad". De esta manera se intentó caracterizar una figura subjetiva diversa del verdadero y propio derecho, cuyo elemento esencial sería la falta de atribución de una obligación a otro sujeto. Vid. CANDIAN, A., La Querela, Milán 1951, pp. 20 y ss.

${ }^{1426}$ GIMENO SENDRA, V., La querella, op. cit. pp. 95 y ss.
} 
$\overline{\text { de su ejercicio a quienes no gocen de la plenitud de sus derechos civiles, o a quienes no }}$ ostenten la condición de ciudadanos sería achacable precisamente a su incardinación dentro de ese status activae civitatis.

El esfuerzo de adaptación de las categorías diseñadas por JELLINEK a la intervención de particulares en nuestro proceso penal pudo tener sentido en un momento histórico, pero hoy ha de considerarse que ha perdido gran parte de su utilidad como criterio de clarificación. Para realizar este aserto nos basamos en dos razones: a) la superación por la doctrina iuspublicista de la teoría de JELLINEK desde que fue difundida a principios de siglo, reconociéndola, eso sí, el debido tributo; y b) la inadaptabilidad de una categoría -la del status activae civitatis- que su autor elaboró para otorgar una base al derecho político de sufragio, pero en ningún caso a un supuesto derecho de acusación. De ahí que cuando se fundamenta la acusación popular con base en estos argumentos, no sólo se está errando en la infructuosa adaptación de categorías ajenas a su naturaleza, sino también en el mismo intento de servirse de aquéllas cuando ya han sido sobrepasadas por el curso de la historia y de la dogmática. El intento se realiza, por tanto, no con JELLINEK sino a pesar de él ${ }^{1427}$, y no con la única de las clasificaciones de los derechos subjetivos de entre las posibles, sino con una fundamental pero que se constituyó como servidora de un modelo liberal y censitario de Estado de Derecho, hoy felizmente superado.

a) Con respecto a la primera de las razones, la que apunta la superación de la teoría de JELLINEK y su insuficiencia para definir los derechos propios del Estado Social, deberíamos destacar que la categoría de los derechos públicos subjetivos fue elaborada por la doctrina alemana del derecho público de finales del siglo XIX y formulada destacadamente por JELLINEK en su Sistema de los Derechos Públicos Subjetivos ${ }^{1428}$. La citada teoría, producto de la ideología individualista liberal, adolecía de una estrecha vinculación a los esquemas políticos del Estado liberal de Derecho, y constituyó uno de

\footnotetext{
${ }^{1427}$ Compartimos y hacemos nuestras las opiniones manifestadas en este sentido, en relación con la adscripción que la LOTJ hace del jurado en el status activae civitatis, por VIDAL ZAPATERO, J.M. y REY MARTÍNEZ, F., "La Constitución y el Legislador del Jurado", Abogados de Valladolid, no 14, de diciembre. 1995, p. 21. El argumento es desarrollado por PEDRAZ PENALVA, E. en "Notas sobre el Jurado que viene", Revista del Ilustre Colegio de Abogados del Señorio de Vizcaya, $2^{\mathrm{a}}$ época, nº 1, enero/marzo 1996, p. 75.

${ }^{1428}$ Con ella se intentó inscribir los derechos en un sistema de relaciones jurídicas entre el Estado y los particulares, creando lo que ha sido denominado como el "paradigma de una teoría de posiciones totales abstracta". ALEXY, R., Teoría de los Derechos Fundamentales, traducción de GARZÓN VALDÉS, E., Madrid 1993, p. 247.
} 
$\overline{\text { los pilares básicos de su funcionamiento }}{ }^{1429}$. Por ello se ha intentado en ocasiones mantener su vigencia eliminando "su cabeza de absolutismo tardio" para colocarla "sobre pies democráticos" ${ }^{1430}$. Con este objeto, a la primitiva clasificación de JELLINEK entre los status subjectionis, status libertatis, status civitatis y status activae civitatis ${ }^{1431}$, han sido añadidas otras categorías tales como el status positivus socialis, que engloba los derechos sociales, ajenos a la concepción del estado liberal ${ }^{1432}$ y el status activus processualis, necesario para garantizar la participación activa de los interesados en los procesos de formación de las decisiones públicas ${ }^{1433}$. El concepto de status activo sería un

${ }^{1429}$ Por ello ha sido destacado que el mérito de la teoría de JELLINEK fue dotar a la dogmática de los Derechos Fundamentales de un soporte riguroso, fundado en el plano de la estricta positividad, pero no deja de ser un planteamiento realizado desde una concreta concepción política que se pone al servicio de ésta: la del Estado liberal de Derecho, creación doctrinal de la misma dogmática iuspublicista alemana a la que pertenecía JELLINEK. El alcance jurídico de la positivación de las libertades del individuo residía tan sólo en la abstención de determinadas conductas, de supresión de las fuerzas opresoras del Estado y limitación de su arbitrariedad, pero sin señalar aquello que sería conveniente que el Estado hiciera. Cabe recordar en este momento que, a tenor de esta concepción, los Derechos Fundamentales no serían concebidos más que como autolimitaciones del poder soberano, esferas de actividad privada contrapuestas a la actividad pública o bien como libertades limitadoras del poder. Vid. PÉREZ LUÑO,

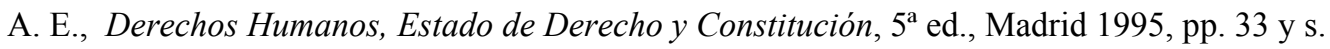

${ }^{1430}$ HÄBERLE, P., “Grundrechte im Leistungsstaat”, p. 80.

${ }^{1431}$ En opinión de JELLINEK, la pertenencia al Estado califica a cada ciudadano y se concreta en una serie de relaciones que lo colocan en diversas situaciones jurídicas, de las que surgen las pretensiones jurídicas que son los derechos públicos subjetivos. Éstos se han ido afirmando progresivamente en cuatro fases o status (System..., op. cit. pp. 94 y ss.):

a) status subiectionis (status pasivo), que no permite el nacimiento de ningún derecho subjetivo, sino solamente una situación pasiva de los destinatarios de la norma emanada del poder público. El Estado es destinatario de prestaciones de los particulares a él sometidos.

b) status libertatis (status negativo), en el que se reconoce un ámbito de autonomía, una esfera de no injerencia del poder en el ámbito de actividad de los individuos. Los fines estrictamente individuales, aquellas acciones irrelevantes para el Estado, encontrarían su satisfacción a través del acto libre del individuo.

c) status civitatis (status positivo), que permite a los ciudadanos solicitar del Estado un comportamiento activo por parte de éste. Se otorga al ciudadano el derecho a solicitar para sí pretensiones positivas del Estado.

d) status activae civitatis (status de la civilidad activa, de la aktive Zivität), en el que el ciudadano disfruta de derechos políticos, participa en la formación de la voluntad del Estado como miembro de la comunidad política. Al ciudadano se le otorgan capacidades que se encuentran fuera de su libertad natural.

${ }^{1432}$ La intervención estatal en el terreno económico y social crea unos derechos que ya no pueden considerarse como límites de la acción estatal (Staatsschranken), sino como fines de la acción estatal (Staatszwecke), configurando una significación abiertamente polémica respecto a la cómoda ideología individualista del laissez faire, y a su incapacidad para evitar o corregir las tensiones sociales fruto de desigualdades económicas. Vid. PÉREZ LUÑO, Derechos Humanos..., op. cit. p. 88.

${ }^{1433}$ Convendría hacer un breve excurso sobre éste último, definido por DENNINGER como “el reconocimiento de la facultad de cada persona para participar activamente y asumir su propia responsabilidad en los procedimientos que le afectan, así como en el seno de las estructuras organizativas más directamente vinculadas con el ejercicio de los derechos fundamentales". Cit. por PÉREZ LUÑO, A. E., "La evolución del Estado Social y la 
punto de partida, pero se precisaría establecer diferencias sirviéndose de instrumentos más refinados. Estima además ALEXY que los derechos a organización y procedimiento frente al legislador no son competencias, sino derechos a competencias, y en tanto tales pertenecerían al status positivo, aun cuando su objeto (la organización y el procedimiento) sí pertenezca al status activo. En su opinión "resumir bajo un concepto todas las competencias que el individuo posee en un sistema jurídico es una cuestión interesante pero, para ello no debería utilizarse el concepto de status activo. El sistema de JELLINEK dirigido a la relación ciudadano/Estado quedaría así destrozado. Tampoco parece funcional incluir en el status activo todas las posiciones jurídicas cuya asunción puede, de alguna manera, influir en la voluntad estatal'. Por ello se pronuncia el citado autor en favor de una concepción estricta del status activus, utilizando la denominación “derechos políticos" para un concepto más amplio ${ }^{1434}$. Debemos advertir, en cualquier caso, que con tales reflexiones ALEXY está diferenciando, por ejemplo, el derecho al voto del derecho a manifestar la propia opinión. Extrapolar esto al derecho de acusación sería peligroso, en tanto podría inducir al error de homologar entre sí supuestos totalmente heterogéneos ${ }^{1435}$.

transformación de los derechos fundamentales" en OLIVAS, E., (Editor) Problemas de legitimación en el Estado Social, pp. 99 y ss. El reconocimiento del status activus processualis con el que se trataría de evitar un nuevo y posible status subiectionis en que podría degenerar el status positivus socialis, es producto de la dimensión institucional u objetiva de los Derechos Fundamentales, que, junto a su dimensión como garantías jurídicas de la libertad individual, fue formulada principalmente por HÄBERLE (carácter dual de los derechos fundamentales). Los Derechos Fundamentales serían, además de garantías individuales, derechos de participación (Teilhaberrechte) en los procesos de decisión política, económica, social y cultural. El status activus processualis debería ser adscrito, por tanto, al status activus, el cual hasta este planteamiento había sido primariamente jurídico-material. Vid. HÄBERLE, P., Die Wesensgehaltgarantie des Art. 19 Abs. 2 GG, $2^{\text {a }}$ ed., Karlsruhe 1972, pp. 70 y ss, y Grundrechte im Leistungsstaat, Berlín 1971, pp. 81 y ss.

${ }^{1434}$ Vid. ALEXY, R., Teoría..., op. cit. pp. 464 y ss.

${ }^{1435}$ En nuestro país también han existido intentos de revisar, actualizar y complementar las categorías de JELLINEK, de entre los cuales cabe destacar el de GARCÍA DE ENTERRÍA al distinguir dos tipos de derechos públicos subjetivos: los típicos o activos y los reaccionales o impugnatorios. Mientras que los primeros incorporan pretensiones activas del administrado frente a la Administración para la consecución de prestaciones patrimoniales, para el respeto de titularidades jurídico-reales, para la exigencia de vinculación a actos procedentes de la propia Administración, o para el respeto de una esfera de libertad formalmente definida, los reaccionales surgen cuando el administrado ha sido perturbado en su esfera vital de intereses por una actuación administrativa ilegal. En este último supuesto le asistirá al particular un derecho subjetivo dirigido a la eliminación de esa actuación ilegal y al restablecimiento de la integridad de sus intereses, fiscalizando de esta manera la totalidad de la legalidad administrativa. GARCÍA DE ENTERRÍA, E., "Sobre los Derechos Públicos Subjetivos", REDA no 6, pp. 427 y ss, esp. p. 445, en el Libro Homenaje a Gómez Orbaneja, Madrid 1977, pp. 195 y ss. esp. 217 y en Curso de Derecho Administrativo con FERNÁNDEZ, T.R., Madrid 1987, p. 53. 
No obstante, como se ha destacado por la literatura especializada en relación con los Derechos Fundamentales, a pesar de los esfuerzos teóricos para adaptar la concepción clásica de los derechos públicos subjetivos a las nuevas situaciones jurídicas producto de la evolución del Estado liberal y a las condiciones materiales del desarrollo económico y social, aquéllos no serían más que "tentativas de injertar nueva savia en un tronco caduco", por lo que su aplicación a supuestos actuales no origina más que distorsión ${ }^{1436}$. En el Estado social y democrático de Derecho, meta a alcanzar con un desarrollo progresivo de cuanto postula el art. 1.1 CE, la soberanía no debe ser considerada como patrimonio estatal, sino como atributo concreto de todos los ciudadanos, y los derechos como momentos del ejercicio del poder, que no se contraponen a él, sino que le son coexistenciales. Los derechos deberán ser entendidos, por tanto, como limitaciones que la soberanía popular impone a los órganos que dependen de ella y no como autolimitación de éstos ${ }^{1437}$.

No cabría hablar tampoco de la acusación popular como elemento que origine un status, tal y como afirma GIMENO al decir que "la querella pública confiere a los particulares un status activae civitatis" ${ }^{1438}$. El status al que se refería JELLINEK es el tipo de relación del individuo con el Estado y no es, por tanto, un derecho (el tener jurídico de una persona ${ }^{1439}$, sino una situación (el ser jurídico de una persona). De un status resultan derechos subjetivos públicos, éstos se fundan en aquél, surgen de él y se vinculan con él y, puesto que éste los genera, tiene consecuentemente un carácter previo al concreto derecho. La adaptación de los derechos para incluirlos en un status sería entonces una labor realizada en la dirección inversa. De los diferentes status surgen

${ }^{1436}$ PÉREZ LUÑO, A. E., Derechos Humanos..., op. cit. p. 34. En el mismo sentido se pronuncia PECESBARBA MARTínEZ, G., Curso de Derechos Fundamentales. Teoría General, Madrid 1995, p. 28. Sobre el componente técnico-jurídico del propio concepto de "derecho subjetivo público" y su cuestionamiento por la doctrina actual, es de destacar que, en tanto circunscrito a los derechos como límites al poder, sólo serían éstos esgrimibles ante los poderes, autoridades y funcionarios, pero no en las relaciones entre particulares. Tal defecto puede ser considerado hoy como insalvable.

${ }^{1437}$ De esta forma, la categoría de los derechos públicos subjetivos, entendidos como autolimitación estatal en beneficio de determinadas esferas de interés privado, pierde su sentido al hallarse superada por la propia dinámica económico-social de nuestro tiempo, en el que el disfrute de cualquier Derecho Fundamental exige una política jurídica activa (y en la mayor parte de las ocasiones también económica) por parte de los Poderes Públicos. PÉREZ LUÑO, A.E., Derechos Humanos..., op. cit. p. 34.

${ }^{1438}$ GIMENO SENDRA, V., La Querella, op. cit. p. 294.

${ }^{1439}$ JELLINEK utiliza casi siempre el término Anspruch (pretensión) y no Recht (derecho). 
$\overline{\text { derechos, pero no son los concretos derechos los que definen el status, sino el contenido }}$ de éste lo que determina el de aquéllos. Lo único que cabría afirmar a este respecto sería que ese status define una forma de relación ciudadano-Estado con la que la acusación popular podría cohonestarse bien.

Sobre la visión de la acusación popular como parte del status activae civitatis cabría señalar, parafraseando a HÄBERLE, que no sería más que un loable intento de situarla "sobre pies democráticos", hecho desde una óptica actual pero con relación a conceptos desfasados ${ }^{1440}$. Nuestra abiertamente liberal LECrim, al igual que ocurrió en el debate sobre el sistema de acusación de otros países de nuestro entorno que no llegaron tan lejos en la apertura de la legitimación, pensaba sobre todo en un derecho subjetivo de los individuos, de cuya conjunción resultaría el bien común. El objetivo no sería tanto la búsqueda primaria del interés general, para lo cual ya se había creado un MF y se había vinculado su función a la defensa de la legalidad, cuanto la garantía de un derecho individual que se consideró inexpropiable por el Estado. Decir hoy que ese derecho contribuye a formar la voluntad del Estado es decir bien poco si consideramos que ésta, en un Estado democrático, se forma desde muy variados ámbitos que abarcarían desde la propia libertad ideológica que se traduce en el sentido del voto, hasta el reconocimiento de los deberes estatales de realizar determinadas prestaciones, que en tanto derechos del individuo, determinan también la actuación y con ello las manifestaciones de voluntad del Estado $^{1441}$.

Con respecto a la concepción de la acusación popular como derecho subjetivo cabría también alguna crítica. No sólo se trataría de constatar la inadecuación de un concepto objeto de controversia ${ }^{1442}$, sino sobre todo de que el derecho subjetivo, definido

${ }^{1440}$ El mismo intento es repetido por GIMENO en relación con el jurado. Vid. la dura crítica al respecto opuesta por PEDRAZ PENALVA, E., “El jurado como vía de participación popular”, La Ley, 1994, II, p. 1008, n. 31.

${ }^{1441}$ Es en este sentido en el que compartimos plenamente la afirmación de ALEXY de que la teoría de JELLINEK está poco depurada $\mathrm{y}$, aun constituyendo un punto de partida irrenunciable, precisaría de instrumentos más refinados para que pueda ser de utilidad. ALEXY, R., Teoría..., op. cit. pp. 254 y 467 entre otras.

1442 JELLINEK define derecho subjetivo como "el poder de la voluntad humana dirigido a un bien o un interés reconocido y protegido por el ordenamiento jurídico”. System..., op. cit. p. 44. Vid. las críticas al concepto de derecho subjetivo en relación con los Derechos Fundamentales y la teoría del status recogidas por ALEXY en su Teoría..., op. cit. pp. 264 y ss. Cabe citar entre éstas la realizada por PREUSS, quien propone una comprensión de las "libertades garantizadas por los derechos fundamentales no como derechos subjetivos sino como normas de organización de la libertad social" en las que habría radicadas autorizaciones individuales. Sería una "concepción de los Derechos Fundamentales como otorgamientos de libertad concreta en la sociedad", aun cuando su crítica no vaya encaminada tanto al propio concepto de derecho subjetivo cuanto al contenido de algunos de éstos y las teorías 
$\overline{\text { como poder de la voluntad otorgado por el ordenamiento jurídico para la satisfacción de }}$ un interés, exige la delimitación de cuál sea éste. Únicamente sobre la base de su defensa estaríamos ante un derecho subjetivo que incida en la esfera personal del individuo ${ }^{1443}$. Sólo podría articularse la acusación de los ciudadanos no ofendidos como derecho subjetivo si afirmásemos encontrarnos ante un derecho otorgado para la defensa de un concreto interés, el cual debería ser el de establecer las necesarias premisas para el enjuiciamiento penal. Puesto que ese interés está ligado a una obligación estatal, considerar la categoría de los derechos públicos subjetivos válida para interpretar la naturaleza de la acusación popular es aceptar el tránsito por un terreno resbaladizo que no consideramos conveniente tener que atravesar.

b) En relación con la segunda de las dos razones apuntadas, la inadaptabilidad de las teorías de JELLINEK a nuestra acusación popular entendida como derecho subjetivo, podríamos invocar los siguientes argumentos:

1) Es cierto que JELLINEK enmarcaba dentro del status activae civitatis los derechos políticos mediante los que el ciudadano disfrutaría de un derecho a participar en la formación de la voluntad del Estado como miembro de la comunidad política, pero lo hizo básicamente para referirse al derecho de sufragio ${ }^{1444}$. JELLINEK partía de una visión de los derechos subjetivos públicos ajena en gran medida al proceso penal, $\mathrm{y}$ cuando se refiere a algún derecho (o mejor, alguna pretensión -Anspruch-) de los particulares dentro de éste, lo hace en relación con el acusado (p. ej. el derecho al recurso) ${ }^{1445}$.

que los sustentan. Ello le lleva a afirmar que esta problemática se basaría en una “individualización y subjetivación de bienes colectivos".

${ }^{1443}$ Sin perjuicio de su oportuno planteamiento, debe advertirse que somos conscientes de los problemas que se derivarían sobre la admisibilidad de abiertas legitimaciones para la tutela de los intereses no sólo individuales, sino también los colectivos al amparo del art. 7.3 LOPJ.

${ }^{1444}$ Vid. JELLINEK, G, System..., op. cit. pp. 136 y ss, esp. p. 139. El individuo ejercitaría funciones estatales, y en tanto órgano del Estado, no tendría como tal un derecho por sí mismo, sino solamente competencias estatales. La voluntad del Estado se realizaría o bien mediante la obligación o bien mediante la autorización. Allí donde se le permite al particular el cumplimiento de funciones públicas, nos dice JELLINEK, "la satisfacción de las funciones necesarias para el bien común mediante la voluntad del individuo sólo está garantizada cuando la actividad en interés común satisface a la vez un interés individual'. Esta concepción del sufragio como función tampoco podría ser mantenida hoy a la luz del constitucionalismo de nuestros días, para el que el voto constituye un Derecho Fundamental y no una mera función atribuida a un sector de la población (art. $23 \mathrm{CE}$ ).

${ }^{1445}$ JELLINEK, G., System..., op. cit. p. 128 (“...sólo en tanto se ponen en cuestión intereses individuales, 
$\overline{\text { El concepto de acción como pretensión de tutela jurídica, es definido por él como la }}$ capacidad concedida por el derecho público de poner en movimiento normas de derecho público en interés individual ${ }^{1446}$, y lo reserva exclusivamente para el proceso civil y, en menor medida, el administrativo ${ }^{1447}$.

2) En la misma obra, en el capítulo titulado "Los derechos de los órganos estatales", sí se refiere JELLINEK, sin embargo, a una institución cercana aunque diversa a nuestra acusación popular: la potestad atribuida a cualquier ciudadano de algunos cantones suizos para que mediante una acción pública pudiera instar ante el Tribunal Federal la anulación de normas administrativas federales o cantonales adoptadas en contra de las previsiones legales. En concreto, al referirse a estas acciones populares de derecho público como vías para la representación de un interés general, especifica que el Juez, puesto a examinar la concurrencia de estos supuestos, no deberá decidir si se ha respetado una pretensión jurídica individual del actor, sino si la pretensión jurídica de la colectividad a la observancia del ordenamiento jurídico se ha respetado por el Estado, que es el llamado a realizarla ${ }^{1448}$. Es el ejercicio de una función pública, y no el de un derecho subjetivo (aunque fuera también público), el sustrato sobre el que se fundamentaría el ejercicio de aquella pretensión de tutela jurídica del interés general. A nuestro juicio, si quisiéramos hacer una adaptación de la acusación popular en su régimen legal actual a la teoría de JELLINEK, la deberíamos incluir precisamente aquí, en el ejercicio de funciones estatales. El intento de hacer de ella un derecho subjetivo fundamentado en uno de los cuatro status parece apuntar un desideratum sobre su función participativa y pretendidamente democrática, pero no se ajusta a la visión de aquel autor.

3) Al aludir al ejercicio de derechos de soberanía estatal por los particulares (“Ausübung staatlicher Hoheitsrechte durch Private") se refiere JELLINEK a acusadores "privados". Pero no lo hace al acusador popular, de cuya existencia o deseabilidad no da

conoce el proceso penal también pretensiones individuales") y p. 355, donde textualmente se reconoce que “...en la garantía de la apelación y la casación reposa ya la pretensión jurídico-individual de una decisión judicial sobre un derecho perteneciente al Estado".

${ }^{1446}$ Vid. también ORESTANO, R., Azioni, diritti soggetivi, persone giuridiche, Bolonia 1978, p. 42.

${ }^{1447}$ JELLINEK, G., System..., op. cit. pp. 124, 261 (para personas morales) y 349 y ss. La pretensión de tutela jurídica (Anspruch auf Rechtsschutz), que surge del status positivo, es de naturaleza pública y tiene por fuente la propia personalidad.

${ }^{1448}$ Vid. JELLINEK, System..., op. cit. p. 235. 
noticia alguna a pesar de su cualificada formación romanista, sino al denunciante ofendido (o a su familia) tratándose de delitos en los que tengan que ser éstos quienes activen el funcionamiento de la Justicia (Acusación privada-Privatanklage-). El Estado transferiría a éste en su calidad de persona privada la función que en abstracto le correspondería al Ministerio Público, atribuyéndole un derecho a tener un puesto propio en el proceso penal ${ }^{1449}$. El Estado, titular originario del Derecho de acusación -Strafklagerecht-, delega una de sus funciones, atribuyéndola a determinados particulares. No se está hablando, por tanto, de compartir la titularidad de una función exclusivamente estatal, sino de cederla en concretos y específicos supuestos. Así fue recibida entre la doctrina italiana la teoría de JELLINEK y de ahí deriva la incardinación doctrinal de su querella en el status civitatis.

Debemos señalar, por otra parte, que la facultad del ofendido en el procedimiento penal alemán de instar el procedimiento para compeler al ejercicio de la acción ( el " $\mathrm{Kla}$ geerzwingungsverfahren") contra la decisión del MF de rechazar una querella ${ }^{1450}$ no constituía para JELLINEK un derecho perteneciente al Estado, sino simplemente una facultad del status positivo y, más propiamente, del derecho a la tutela jurídica. En este caso el derecho subjetivo tendría por contenido una acción procesal de un órgano del Estado -Anspruch auf eine prozessuale Handlung eines Staatsorganes-, pero no desde luego el ostentar un papel activo a lo largo del proceso con el objeto de constituirse en acusador $^{1451}$. Es decir, se tratará de un derecho perteneciente al status positivo que no consiste en actuar por sí mismo, sino que tiene por contenido pedir que otro sujeto actúe.

\section{II.}

El planteamiento popular de la acusación ha sido también incardinado en el de ejercicio de la soberanía popular, atendiendo a que ésta exige para su realización unos instrumentos que garanticen y tutelen la participación efectiva del pueblo en la actividad

${ }^{1449}$ JELLINEK, System..., op. cit. pp. 252 y ss. JELLINEK equipara este supuesto al de la acusación subsidiaria del perjudicado en el ordenamiento austriaco (art. 48 ÖStPO).

${ }^{1450}$ Arts. 170-175 de la StPO de 1873, en relación con el 61 del antiguo Código Penal alemán.

${ }^{1451}$ Hemos de fijarnos en el dato de que, según la concepción de JELLINEK, la querella privada, que confiere a los sujetos un papel activo en el proceso, es ejercicio de derecho de soberanía del Estado cedido por éste a los particulares. Sin embargo, el Klageerzwingungsverfahren, que confiere una facultad de instar la actuación del Estado, es parte del status positivo. 
política $^{1452}$. Al amparo de esta concepción, la acusación popular sería una manifestación de la actividad política, y el Estado se autolegitimaría haciendo retornar parcelas de su poder a aquéllos de los que provienen sus facultades, en este caso, la de perseguir los $\operatorname{delitos}^{1453}$.

Partiendo de la premisa del pluralismo político como principio imperante en nuestra sociedad, la acusación popular ha sido también percibida como una traslación de esa aspiración al ámbito del proceso penal. El pluralismo imperante en la realidad social, entramado plural en el que se interaccionan los individuos y los distintos grupos sociales, tomaría cuerpo en la función acusatoria y de ello se derivaría un impulso democrático. Se ha afirmado así que sería una forma de ejercicio de la democracia, ya con carácter representativo, ya con carácter directo, en tanto a través de ella se asumirían funciones estatales. Es calificada en este sentido como manifestación del ejercicio de la soberanía popular y derecho de participación política ${ }^{1454}$ o como forma de participación democrática en la Justicia ${ }^{1455}$. No sólo contribuiría a democratizar el proceso, sino también la sociedad entera, de la cual el juicio penal no es sino un instrumento de salvaguardia. Aun cuando el ofendido tenga que poder participar, también deberán intervenir los demás integrantes de la sociedad en su conjunto ${ }^{1456}$. Se ha afirmado por ello

${ }^{1452}$ La vinculación entre Estado democrático y soberanía popular ha sido habitual en la tradición constitucional europea. A tenor del principio de soberanía popular formulado por ROUSSEAU en su "Contrato Social”, el titular de la soberanía es el conjunto del Pueblo en un momento determinado, poseyendo cada ciudadano una parcela de la misma. Una de las consecuencias derivadas del art. 1.2 de nuestra Carta Magna sería que el pueblo debiera participar en las instituciones del Estado en todos sus niveles, de forma directa o a través de sus representantes. Vid. ESTEBAN, J. de y GONZÁLEZ-TREVIJANO, P. J., Curso de Derecho Constitucional Español, Madrid 1992, pp. 148 y s. Sin embargo, en opinión de VARELA SUANZES, J., "Algunas reflexiones sobre la soberanía popular en la Constitución Española”, Revista Española de Derecho Constitucional, nº 36, sept.-dic. 1992, pp. 78 y ss., el art. 1.2 $\mathrm{CE}$, pese a imputar la soberanía al pueblo, debería interpretarse desde los esquemas de la soberanía nacional.

${ }^{1453}$ Vid UBERTIS, G., “Azione penale e sovranità popolare”, Riv. Ital. Dir. e proc. Penale 1975, pp. 1196 y ss. La soberanía que el art. 1 de la Constitución italiana atribuye al Pueblo ("la sovranità appartiene al popolo") no sería sólo soberanía quod titulum sino también quod exercitium. El Pueblo, como titular de la soberanía, debe tener posibilidad de impulso y de control sobre las esferas de acción en las que se distingue tradicionalmente las competencias del Estado-aparato.

${ }^{1454}$ Vid. GHIARA, A., "Partecipazione popolare all'esercizio dell'azione penale”, La Giustizia Penale 1982, Parte prima I, pp. 257 y s. La participación activa en el ejercicio de la acusación encontraría legitimación en el principio democrático (art. 1 y 3.II Constitución Italiana: participación efectiva en la organización política, económica y social del país), o en el principio de participación directa del Pueblo en la Justicia (art. 102. últ.). En el mismo sentido UBERTIS, G., “Azione penale e sovranità popolare”, op. cit., p. 1193.

\footnotetext{
${ }^{1455}$ Vid. por ejemplo GIMENO SENDRA, V., La Querella, op. cit. p. 101.

${ }^{1456}$ UBERTIS, G., “Azione penale...”, op. cit., pp. 1191 y ss.
} 
$\overline{\text { que "la acción popular, ayer, hoy y mañana, seguirá siendo una acción de ejercicio }}$ cuantitativo limitado, pero será siempre un rasgo distintivo de libertad y compromiso político de los ciudadanos" 1457 .

Cabría destacar en un primer momento lo chocantes que resultan los intentos de fundamentar un derecho de acusación de los ciudadanos desde la soberanía popular residenciada en el Pueblo español, sobre todo si consideramos que la acusación popular era precisamente la propia y característica de momentos históricos en los que este concepto de soberanía no era siquiera imaginable. Pero, además, el Pueblo español al que alude el art. 1.2 CE no es más que un sujeto unitario e ideal, puramente ficticio, determinado y unificado por el ordenamiento jurídico del Estado. La soberanía que se manifiesta a través de la Constitución entera no recae, por tanto, en cada uno de los españoles, sino en todos en su conjunto de manera indivisible, lo que ante todo quiere decir que no recae en ningún otro sujeto ni en ningún órgano ${ }^{1458}$. No puede haber, por tanto, ejercicio de soberanía en la actividad individual de un sujeto aislado, como ocurre en el caso del acusador popular.

El proceso penal no es momento ni lugar de representación de la voluntad popular si no es en tanto ineludible presupuesto para la aplicación de una norma penal democráticamente elaborada. Su fin no puede centrarse en la participación ciudadana ni en la opción democrática entre diversas posibilidades, y la atención a criterios de democracia representativa debe considerarse fuera de lugar en el caso del ejercicio de la acusación. Mediante ella no se hace más que poner las premisas esenciales para aplicar la ley, esta sí, elaborada necesariamente con las premisas constitucionales y, por ende, democráticas. El instrumento que obliga a potenciar una mayor participación popular en los poderes del Estado es el art. 9.2 CE, que atribuye a los poderes públicos la función de “... facilitar la participación de todos los ciudadanos en la vida política, económica, cultural y social" ${ }^{1459}$. Pero reconocer que la participación popular constituya una

${ }^{1457}$ ALMAGRO NOSETE, J., “Acción Popular”, en La reforma del Proceso Penal. II Congreso de Derecho Procesal de Castilla y León, Madrid 1989, p. 231.

${ }^{1458}$ Por ello se ha dicho que la declaración del art. 1.2 CE tendría así un efecto más negativo que positivo. VARELA SUANZES, J., “Algunas reflexiones...”, op. cit., pp. 78 y ss.

${ }^{1459}$ El precepto que la Constitución dedica a la participación política (art. 23.1), concreción del anterior, no sería en ningún caso aplicable a la participación ciudadana en la acusación, puesto que ésta debe ser un llamamiento a intervenir en la toma de decisiones y sólo se refiere por ende a los derechos políticos. No es de recibo la mención que se hace en la Exposición de Motivos de la LOTJ sobre la fundamentación constitucional del Tribunal del Jurado en 
$\overline{\text { necesidad que se puede satisfacer a través de la función de acusación implicaría otorgarle }}$ un carácter de órgano de representación -lógicamente política- que le es conceptualmente extraño y que debe permanecer en todo caso extramuros de la justicia penal.

Si a través de su planteamiento por particulares se hicieran presentes los intereses sociales podría afirmarse que allí donde no apareciese, lo cual ocurre en la mayoría de las ocasiones, cabría que el interés general sufriera un déficit de representación. Estableciendo una hipotética escala que "graduara" la legitimidad democrática de los sistemas de acusación, deberíamos asumir que, aceptando funciones representativas o meramente participativas en la acusación popular, los procesos en los que hubiera una pluralidad de actores ostentarían una superior legitimidad democrática ${ }^{1460}$. Carecería de sentido, pues, justificar la acusación por particulares sobre la premisa de un genérico derecho de participación, incrementador per se de las esencias democráticas de la Justicia. La intervención de un particular en el proceso penal no aportará a este tenor un innecesario fundamento o plus de democracia, y su intervención, por sí sola, no es ni más ni menos democrática que su no intervención.

A pesar de la dicción del art. 117.1 CE, no cabría afirmar que la justicia emane

el art. 23. 1 CE como reconocimiento del derecho de participación pública. Cfr. la doctrina reiterada del TC, y por todas las SSTC 51/1984 de 25 de abril (FJ. 2) y 119/1995 de 17 de julio. En el FJ 5 de esta última se recoge la doctrina de que "sólo allí donde la llamada a la participación compete finalmente, el ejercicio directo o por medio de representantes del poder político -esto es sólo allí donde se llame al pueblo como titular de ese poder-estaremos en el marco del 23.1 CE". Han sido señalados frecuentemente otros derechos de participación en los que se supone una acción positiva de sus titulares, que tiene que ser amparada y promocionada por los poderes públicos y por las instituciones. A través de la participación se contribuiría a la formación de la voluntad política y a la toma de decisiones de éstos, pero también, en uso de ellos podrán acceder los ciudadanos a la Administración para formar parte de ella como funcionarios, para intervenir en el procedimiento de elaboración de disposiciones administrativas como usuarios, en la físcalización de los servicios públicos, o para ser oídos y presentar alegaciones en los procedimientos administrativos. En muchos casos son derechos no tan directos y claros como el del art. 23, sino que precisan un desarrollo legal, como pueden ser los derivados de los arts. 105 y $51.2 \mathrm{CE}$. En este sentido se pronuncia, por ejemplo, PECES-BARBA MARTÍNEZ, G., Curso de Derechos Fundamentales..., op. cit., p. 460.

${ }^{1460}$ A todas luces tal argumento no es de recibo, en tanto un concreto proceso no debería ser más o menos “democrático" que otro, sino que, de considerarse conveniente, todos lo deberían ser por igual. En todo caso aquella caracterización sólo podría venir dada en abstracto con una formulación del tipo "este sistema de acusación es democrático en cuanto sirve a la satisfacción del interés público constitucionalmente garantizada". En el caso de admitir la necesidad de incrementar la representación en la función acusatoria, para que ésta fuera verdaderamente democrática, la lógica consecuencia debería ser la elección participativa de los acusadores, idea que hoy por hoy no nos consta que cuente con defensores en nuestro país. Aún más, siguiendo con esa hipotética escala representativa, la personación como acusador en un proceso penal, por ejemplo, de un Ayuntamiento, cuya "legitimación democrática" parece más directa que la del MF, puesto que está refrendado por las urnas, debería ser preferente a la de éste. Ello podría conducir a afirmar su carácter superfluo en hipótesis de este tipo, sin que, sin embargo, parezca deseable. 
$\overline{\text { directamente del Pueblo }}{ }^{1461}$, sino que lo que directamente emana de éste son todas los momentos de ejercicio del poder del Estado constitucionalmente previstos (art. 1.2 CE). Y el ejercicio de la acusación en el proceso penal no puede ser considerado ajeno a tal previsión. No cabe por ello buscar mayores legitimaciones democráticas en la acusación cuando es ejercitada por un sujeto privado por ser más cercana a la sociedad, sino que todo ejercicio de la acusación, en tanto ejercicio de un poder del Estado, ha de considerarse necesariamente emanación del Pueblo. La legitimación formal, uno de los pilares sobre los que descansa el Estado de Derecho, se basa en la naturaleza procedimental de la democracia, según la cual, la titularidad de una competencia se legitimará por la consecuente racionalidad de su ejercicio ${ }^{1462}$. La única legitimación sobre la que se puede indagar en la función de acusación dentro del Estado de Derecho es, por consiguiente, la racionalidad de su ejercicio y su adecuación a los fines que constitucionalmente le vienen señalados. Lo verdaderamente democrático será, pues, la dotación de los adecuados mecanismos para el efectivo cumplimiento de la legalidad penal, premisa exigible de los Poderes Públicos, tanto en el momento de elaboración de la norma como en el de su concreción práctica. Si una fiscalía sujeta al principio de legalidad, trasladase éste íntegra y eficazmente a sus funciones, se estaría satisfaciendo plenamente la verdad de la ley en garantía de los legítimos derechos de los ciudadanos. El cauce ordinario de introducción del interés público en el proceso ha de ser necesaria e inexcusablemente el MF, por cuanto ésta es precisamente una de las funciones que le vienen atribuidas constitucional y estatutariamente (art. 124.1 CE y 1 EOMF). El ciudadano no tiene por qué hacerse cargo, bajo pretextos participativos o de cualquier otro tipo, de la molestia y el coste que le originaría la asunción de una función propia de quien constitucionalmente viene obligado, sino que quienes se ocupen de ello habrán de ser sus responsables.

Entre el derecho a participar en la formación de la voluntad estatal a través del sufragio y el ejercicio de la acusación popular, supuestos participativos errónea pero frecuentemente unidos se podría observar una nítida diferencia. Mientras que en este

${ }^{1461}$ Afirma en este sentido LUCAS VERDÚ que es “inexacta” la expresión de que la Justicia emana del pueblo, porque lo que el constituyente ha querido decir es que el Poder Judicial emana del pueblo a tenor del art. 1.2 CE. La Justicia es un valor que no crea el pueblo ni sus representantes, sino que ha de ser reconocido y aplicado. LUCAS VERDÚ, P., "La Justicia emana del Pueblo y se administra en nombre del Rey”, en el volumen colectivo El Poder Judicial, T. II, pp. 1756-7.

${ }^{1462}$ PEDRAZ PENALVA, E., "Del CGPJ y de la selección de sus miembros", La Ley no 4018, 18 de abril de 1996, p. 7. Sobre la legitimación del poder, más allá de su mera validez formal vid. HABERMAS, J., Problemas de legitimación en el capitalismo tardio, Buenos Aires 1973, pp. 120 y ss. 
último caso, la intervención de los particulares es puramente contingente y viene a afianzar una función a la que el Estado está llamado en primer lugar, en el del derecho de sufragio la participación de los ciudadanos es tan esencial que sin ella no es siquiera imaginable el vigente Estado. La acusación popular puede contribuir a configurar la voluntad estatal que se realizará en la aplicación de la norma, pero su presencia no sólo no es estrictamente necesaria sino que, en ocasiones, podrá ser definitivamente perturbadora. El ciudadano acusador satisface un presupuesto para que se manifieste la voluntad de la ley, mientras que el votante contribuye a la formación genérica de aquella voluntad. A ningún sujeto mayor de edad puede serle negado en tanto integrante del Estado el derecho de ejercitar el derecho de voto para determinar su voluntad, pero no habrá reparo alguno que nos impida determinar normativamente a quién y para qué supuestos se autoriza al ejercicio de otras funciones estatales. Podremos llegar a admitir que hablando de acusación popular estemos ante una institución participativa, pero en ningún caso, podría ser conceptuada como representativa. Es enteramente cierto que puede servir como cauce para el afloramiento de inquietudes sociales o para superponerse al funcionamiento del sistema estatal de aplicación de la norma penal, corrigiendo en alguna ocasión posibles deficiencias, lo cual implica mistificar la Justicia, negar la Ley pretendidamente general y sancionar un déficit representativo de la política del Estado.

La única representación verdadera es la que se deriva del procedimiento electoral determinador de la generalidad de los intereses a satisfacer. A través de la acusación de un ciudadano cualquiera no se representa a los habitantes de un ámbito territorial específico, a los de una determinada edad, a los de una concreta adscripción ideológica y ni siquiera a los teóricamente más interesados en la persecución de un determinado tipo de delitos. De la participación en el proceso no se tendría que derivar en ningún caso un equilibrio entre intereses diferentes o entre una pluralidad de opciones de pensamiento. Y puesto que no todos podemos participar a la vez en el proceso, la acusación estará normalmente sólo al alcance del más listo, el más audaz, el mejor informado, el que tenga más dinero o mayor interés o simplemente del más rápido. Al proceso no se accede como acusador popular en cuanto representante de nadie, y a ninguno de los que asumen este papel se le podrá interrogar sobre su ideología o sobre las motivaciones que impulsan su actividad. La idea de representación política deberá estar ausente, y la adscripción ideológica de los actores deberá ser totalmente accesoria e irrelevante. Hablar de pluralismo político carecerá de sentido cuando la ideología no debe poder representar papel alguno, en tanto no tiene un 
espacio reconocido de manifestación ${ }^{1463}$. La acusación popular no nos hablaría, por tanto, de representación, sino de asamblea, es decir, no del supuesto en el que el elegido actúa por todos, sino del supuesto en el que uno cualquiera del conjunto de los ciudadanos, el que lo desee, actúa en lugar de todos los demás ${ }^{1464}$. La simple "popularización” de la Justicia no puede, por todo ello, ser afirmada ilusoria y equívocamente como inevitable “democratización” de ésta ${ }^{1465}$.

La acusación popular, según venimos reiteradamente planteando, desde su vigente papel sustitutivo de la acusación pública ha de pretender y procurar un constitucional enjuiciamiento de un sujeto por un hecho que se afirma punible. Es decir, la plena vigencia de la ley y no su sustitución o adaptación, lo cual competería al Legislativo. No cabría admitir la búsqueda de modelos de justificación de las resoluciones jurisdiccionales basados en criterios utilitaristas, instrumentalistas, consensualistas o simplemente democráticos. Lo buscado ha de ser únicamente, y de conformidad con la Constitución, que la decisión judicial exprese y razone la convicción del Juez más allá de toda duda razonable acerca de la suficiencia de los hechos alegados y objeto de prueba para desvirtuar la presunción de inocencia y, de este modo, la correspondencia lo más aproximada posible entre aquéllos y las conductas descritas normativamente ${ }^{1466}$. La exigencia de aplicación de la norma penal admite diversas interpretaciones que inevitablemente llevarán consigo un hondo calado político, pero teniendo en cuenta la insuficiencia del ejercicio de la acusación para servir de reflejo a las diversas, múltiples y mutables concepciones políticas imperantes en la sociedad, no cabrá sostenerse de ella

\footnotetext{
${ }^{1463}$ Aun más, dado que no todos los ciudadanos que quieran participar en el proceso podrán hacerlo de forma independiente (art. 113 LECrim), si admitiéramos la acusación popular como espacio hábil para la participación política, estaríamos cercenando la posibilidad de que fueran admitidas en él todas las ideologías que quisieran hacerse presentes.

${ }^{1464} \mathrm{La}$ actividad de un sujeto que por su propia voluntad interviene en el proceso no puede constituir " $\mathrm{voz}$ del pueblo" alguna. En primer lugar sería totalmente cuestionable la deseabilidad de que el proceso penal pueda constituir reflejo de un "sano sentir del pueblo", de reminiscencias rousseaunianas, y en segundo, tal sujeto nunca podría arrogarse una representatividad que nadie le podría conferir: un sólo ciudadano, no elegido por nadie y vinculado sólo a su propio interés, no puede erigirse en voz de una conciencia general o de la sensibilidad social.

${ }^{1465}$ PEDRAZ PENALVA, E., “Notas sobre publicidad y proceso”, op. cit. p. 221.

${ }^{1466}$ Para FERRAJOLI, lo que exige el plano epistemológico y político será que la legitimidad de las decisiones penales se condicione sólo a la verdad empírica de sus motivaciones. La fundamentación de los juicios se debe realizar sobre una verdad convalidable o invalidable como tal a través de controles lógicos y empíricos que la sustraigan lo más posible del error y el arbitrio. FERRAJOLI, L., Derecho y Razón. Teoría del garantismo penal, op. cit. pp. 67 y ss.
} 
virtudes representativas ${ }^{1467}$ que oculten su funcionalidad para servir junto al interés público a otros diversos ${ }^{1468}$. No sería demasiado aventurado por ello formular la hipótesis de que, precisamente cuanto más escaso sea el uso que se hiciese de la acusación popular, mayores cotas democráticas habrá alcanzado el proceso penal y no a la inversa, puesto que procesalmente se estará defendiendo única y exclusivamente el interés público y apartando otros extravagantes a éste.

\subsection{Justificación sociológica: acusación popular como factor de mejora de la percepción social de la Justicia}

\section{I.}

La defensa de la sociedad ha sido uno de los argumentos que, desde tiempos remotos y con mayor frecuencia, han servido para fundamentar la deseabilidad de la acusación popular ${ }^{1469}$. Han sido moneda común entre la bibliografía diversos razonamientos en el sentido de que, puesto que el delito es un ataque a la sociedad como un todo, el cuerpo social deberá poder defenderse a través de cualquiera de sus miembros e incluso de varios a la vez. Los ciudadanos deberán sentirse involucrados en la tarea de defender intereses comunes mediante la persecución de todos los delitos, en la

${ }^{1467}$ La laxitud que permite la verificación en el caso concreto del principio de legalidad en el proceso penal puede ser sólo admisible desde la intelección de la acusación como función estatal única, sea quien sea el sujeto que la ejercite. No podría ser admisible la idea de que las diferentes orientaciones o enfoques de la acusación sirvieran a intereses diversos coincidentes con los de los sujetos que los hacen valer. El interés que se actúa con la acusación es público (proporcionar los presupuestos necesarios para el enjuiciamiento), y no cabría hablar en abstracto de conflicto de intereses entre MF y acusadores populares, sino sólo de diferentes percepciones de ese mismo interés.

${ }^{1468}$ En caso contrario podríamos llegar por otra vía a lo que PEDRAZ ha definido, en relación con el supuesto control social que realiza el jurado sobre la aplicación de la norma, con la afirmación de que tal razón "en vez de convalidar el poder fáctico de la norma, convalidaría el poder normativo de lo fáctico, esto es, como si en lugar de que la libertad política constituyera la social fuera la social la que constituyera la política". PEDRAZ PENALVA, E., "El Jurado como vía de participación popular", La Ley, no 3509, 29 de abril de 1994, p. 3. Entendemos, además, trasladables a la acusación las palabras de este autor para refutar el que el ejercicio de la función de Jurado sea fundamento de la democracia en el sentido de que "si la democracia constitucional preceptivamente establece la igualdad politica, calificar a esta exigua y ocasional intervención popular en la Justicia de piedra angular democrática responde a un incongruente criterio representativo carente de la razón cooperativa desde la que sólo la sociedad se realiza autónomamente".

${ }^{1469}$ Afirmaba MARTÍNEZ DEL CAMPO que el sistema de acusación pública de la LECrim. "patentiza más que otro ninguno el carácter público del delito y la solidaridad de los elementos del cuerpo social”. MARTÍNEZ DEL CAMPO, E., Notas al Libro Primero de la Ley de Enjuiciamiento Criminal, T. I, Madrid 1885, p. 262. 
corresponsabilidad de los individuos integrantes de la sociedad para la defensa de ésta ${ }^{1470}$. La punición de los delitos concerniría directamente a los ciudadanos, corresponsabilizando a todos los componentes de la sociedad y sirviendo de control a la actuación del Estado. El interés no les atañe sólo como simples particulares sino como miembros de una determinada colectividad en la que se enmarcan ${ }^{1471}$. Con ello se intentaría reforzar la denominada "cultura jurídica externa" ${ }^{1472} \mathrm{y}$, dado que el propio proceso cumple un importante fin de educación cívica o social ${ }^{1473}$, la acusación popular podría ser considerada como "Escuela de ciudadanía"1474.

A tenor de este tipo de lecturas, los ciudadanos se constituirían mediante el ejercicio de la acusación en vigilantes activos que no permanecerían impasibles ante el delito, de lo cual cabría inferir la transmisión de valores de compromiso social ${ }^{1475}$. La acusación popular tendría una importante función socializadora y de integración colectiva, puesto que el ciudadano que hace uso de ella actúa uti cives y no uti singulus ${ }^{1476}$. La dualidad entre acusación oficial y acusación por particulares tomaría cuerpo en el proceso penal en el sentido de que el MF sería la posición representada por el

${ }^{1470}$ Ello se incardina también en la hegeliana idea de que el delito es lesión a la sociedad entera, puesto que el delincuente ofende en un miembro de la sociedad a todos, perturbando la conciencia jurídica (el Rechtsbewußtsein). Vid. HEGEL, Filosofia del Derecho, § 218.

${ }^{1471}$ MORENO CATENA, V., en la obra colectiva Derecho Procesal Penal T. III, Madrid 1996, p. 171.

${ }^{1472}$ En el sentido definido por FRIEDMANN, L., Introducción al Derecho, traducción de VERGER GRAU, J., Zaragoza 1988, pp. 7 y s., "cultura jurídica", como elemento del sistema jurídico, sería el conjunto de las actitudes de la gente frente al Derecho y al sistema jurídico, sus creencias, valores, ideas y expectativas. Mientras que la cultura jurídica interna sería la de los operadores jurídicos que trabajan desde dentro del sistema jurídico, la externa sería la del resto de los ciudadanos.

${ }^{1473}$ Que para ALCALÁ-ZAMORA sería el de inculcar entre los justiciables el respeto a la ley y a la justicia, y hacerles comprender los inconvenientes de la autodefensa. Proceso, autocomposición y autodefensa, op. cit. p. 220.

${ }^{1474}$ ALMAGRO NOSETE, J., “Acción popular”, op. cit. p. 227. En el mismo sentido se pronunciaba MUÑOZ ROJAS, T., "En torno al acusador particular...", op. cit. p. 142: "en los tiempos y en los países en que los ciudadanos han alcanzado un alto grado de civismo, de solidaridad, de educación social, de colaboración pública, etc. la acción popular ha de tener gran utilidad".

${ }^{1475}$ Cabría traer aquí a colación la conocida cita de MARTIN LUTHER KING en la que afirmaba "preocupémonos no porque haya hombres malos que hagan el mal, sino porque hay hombres buenos que son indiferentes a él".

${ }^{1476}$ Este papel integrativo ha sido señalado también entre la doctrina extranjera por DOMINIONI, O., Le parti nel processo penale, Milán 1985, pp. 101-103. 
$\overline{\text { Estado, mientras que la del acusador popular sería la de la sociedad a quien corresponde }}$ un derecho de acusar ${ }^{1477}$. Se alzaría como baluarte frente a una burocracia tendencialmente omnipresente, impidiendo la asfixia de las iniciativas ciudadanas que pudieran quedar ahogadas en una intervención desmedida de instancias estatales, para constituir el más genuino portavoz de la sociedad ante los Tribunales ${ }^{1478}$.

La contemplación de la acusación popular como mecanismo que constituye a los ciudadanos en vigilantes es el más antiguo y extendido entre los esgrimidos en su defensa, pero ha de desatacarse que se basa en un artificio mental teórico preñado de connotaciones individualistas, propias de una concepción ideológica enraizada en la decimonónica visión liberal del Estado. Ha de tenerse en cuenta en este sentido:

a) Que la separación y contraposición entre sociedad civil y Estado tiene mucho que ver con sentimientos fuertemente arraigados, pero merecería ser fruto de una somera revisión que nos llevará necesariamente a la conclusión de que no es sino una forma de expresión de la "quimera liberal" ${ }^{1479}$. El espacio donde se incardina el ejercicio quivis ex populo de la acusación sería la llamada "sociedad civil" ${ }^{1480}$, cuyos elementos esenciales

${ }^{1477}$ Afirmaba FERNÁNDEZ MONTES que "el derecho de acusar no puede limitarse ni restringirse a los ciudadanos. El Ministerio Fiscal representa al Estado pero la acusación corresponde a toda la sociedad". Recensión de los Coloquios de la Asociación de Antiguos Alumnos de la Escuela de Práctica Jurídica de Madrid (curso 1960-1961), en Boletín Informativo del Instituto Español de Derecho Procesal, n 93, mayo 1960, cit. por VIADA, C., Curso..., op. cit. p. 131.

${ }^{1478}$ MUÑOZ ROJAS, T., “En torno al acusador particular...”, op. cit., p. 144.

${ }^{1479}$ No debe olvidarse que en el Estado Social no debe existir fractura entre Estado y Sociedad. Como destaca OLIVAS, E., "Problemas de legitimación en el Estado Social", en el volumen colectivo del mismo título dirigido por él, p. 27, "lo social es, inmediatamente, jurídico-político -lo social no puede expresarse socialmente, y refuerza el desequilibrio entre garantía jurídica de la igualdad y desigualdad efectiva en la distribución de oportunidades de participación política activa.". Vid. también ABENDROTH, W., "Der demokratische und soziale Rechtstaat als politischer Auftrag" en Der bürgerliche Rechtstaat, vol. I, pp. 265 y ss. y en español, con FORSTHOFF, E., y DOEHRING, K., El Estado Social, Centro de Estudios Constitucionales, Madrid 1986, traducción de PUENTE EGIDO, pp. 9 y ss. Como tiene dicho Elías DÍAZ, "no resulta fácil de explicar por qué los Estados son tan malos si los individuos son tan buenos; quién vota, por ejemplo, a gobernantes tan malvados y estúpidos; por qué incluso los Estados democráticos son tan insensibles, reaccionarios y aviesos cuando la sociedad civil es tan sana, inteligente y abierta; no se explica, en fin, por qué los buenos son tan torpes y débiles para dejarse gobernar así por los malos, más fuertes o más listos, que controlan totalmente y por todas partes los Estados y sus aparatos de poder". Prólogo a su obra De la maldad estatal y la soberanía popular, Madrid 1984, p. 11. La acción mutua Estado-sociedad fue reseñada entre otras por la STC 18/1984 de 7 de febrero, FJ 3 en los siguientes términos: "la configuración del Estado como social de Derecho culmina una evolución en la que la consecución de los fines de interés general no es absorbida por el Estado, sino que se armoniza en una acción mutua Estado-sociedad".

${ }^{1480}$ Así por ejemplo UBERTIS, G., “Azione penale...”, cit. p. 1194, n. 11, analizando diversas concepciones de la denominada "sociedad civil" (Marx y Gramsci interpretados por BOBBIO). 
serían las instituciones sociales y la esfera pública en la que los agentes sociales se relacionan ${ }^{1481}$. El Estado cumpliría así sólo el papel de "guardián nocturno", en tanto no se prevé la exigencia por su parte de una conducta activa que satisfaga las expectativas sociales y no meramente contemplativa. Más coherente sería, sin embargo, dirigir con preferencia la actividad ciudadana a la exigencia a los Poderes Públicos de un recto ejercicio de las facultades en ellos delegadas, que la idea de que el Estado pueda llegar a desentenderse de una obligación que le compete plenamente en pro de su realización por los ciudadanos ${ }^{1482}$.

b) Que es cierto que el ejercicio por los particulares de la acusación tiene un valor

${ }^{1481}$ Debemos advertir que entendemos por "Sociedad Civil" solamente aquellas áreas de la vida social fuera del control directo del Estado, reconociendo que ello se hace no sin cierta dosis de mera intuición y sin entrar en las disquisiciones sobre un concepto redescubierto y rescatado en tiempos recientes y hoy muy en boga. Sobre el concepto de "sociedad civil", sus diversas acepciones y la concreción práctica en la reciente historia de nuestro país vid. PÉREZ DÍAZ, V., La primacía de la sociedad civil, Madrid, 1993, pp. 76 y ss., y del mismo autor, "La sociedad civil como posibilidad", en la revista Claves, no 50, marzo 1995, pp. 16 y ss., esp. p. 23; CORTINA, A., Ética de la Sociedad Civil. El concepto de "sociedad civil" es problemático de abordar por su excesiva ambigüedad, resultado en parte de una complicada historia intelectual. Primero fue sinónimo de sociedad política pero, hoy día, en su acepción más generalizada, se nos presenta como concepto opuesto al de Estado. PÉREZ DÍAZ la define como "entramado de instituciones socio-políticas que incluye: un gobierno (o estado) limitado, que opera bajo el imperio de la ley; un conjunto de instituciones sociales tales como mercados y asociaciones basadas en acuerdos voluntarios entre agentes autónomos, y una esfera pública, en la que estos agentes debaten entre sí, y con el Estado, acerca de asuntos de interés público, y se comprometen en actividades públicas". La sociedad es civil en tanto sus agentes son ciudadanos (y no súbditos) y son ciudadanos sólo porque son agentes autónomos frente al Estado, el cual tiene un poder limitado para entrar dentro de sus dominios. El tema de la sociedad civil es también uno de los puntos claves de la obra de HABERMAS, quien sostiene un concepto más restringido que parece identificarla con la "publicidad" o "esfera pública" (Öffentlichkeit). Vid. la obra culmen de su pensamiento jurídico, HABERMAS, J., Faktizität und Geltung. Beiträge zur Diskurstheorie des Rechts und des demokratischen Rechtsstaats, Francfort 1992, pp. 435 y ss. La sociedad civil (Zivilgeschellschaft) de hoy no puede ser la de la tradición liberal con base en Hegel (bürgerliche Geschellschaft), sino que, a diferencia de ella, su núcleo estaría constituido por conglomerados y asociaciones no estatales y no económicas, unidas sobre una base voluntaria que fijan las estructuras comunicativas de la esfera pública en el componente social del mundo de la vida (p. 443). La esfera pública-política como estructura comunicativa está enraizada en el mundo vital precisamente sobre su base de sociedad civil. A este respecto aquélla es descrita como el suelo que nos hace percibir la resonancia de problemas que deben ser tratados por el sistema político, dado que en ningún otro lugar podrán encontrar solución. En esa medida, la esfera pública es un sistema de aviso con sensores no especializados, pero sí sensibles a la sociedad en su conjunto, que funciona como "conciencia moral" del poder político. Serán las instituciones políticas las encargadas de tomar las decisiones, pero la percepción de los problemas de la sociedad y de la interpretación de éstos que se realiza en la esfera pública sólo se podrá realizar a partir de contextos comunicativos de los afectados potenciales.

${ }^{1482}$ Destacaba VÉLEZ MARICONDE que "el carácter liberal y democrático de la acción popular se afirma sobre la falsa premisa de suponer implícitamente una antítesis entre la noción de autoridad, de poder público, y la de libertad y democracia, puesto que no se comprendería cómo la intervención del ciudadano puede ser un correctivo liberal y democrático de la acción estatal, si no se supone en la función del Ministerio Público una tendencia a una actividad contraria a la libertad y a la democracia". VÉLEZ MARICONDE, A., "El ejercicio de la acción penal", en Estudios de Derecho Procesal, T. I, Córdoba 1956, p. 263. 
$\overline{\text { divulgativo de los mecanismos jurídicos, pero ni es el único ni el más conveniente de los }}$ posibles. Tratándose de la acusación popular nos encontramos con un tipo cuando menos peculiar de participación, en tanto ésta sólo puede ser indirecta al precisar la intervención mediatizadora de, por lo menos, dos profesionales cualificados técnicamente que desempeñen las tareas de abogado y procurador, conditio sine qua non para el acceso al proceso en calidad de acusador. La predicada función "educativa" queda devaluada por la necesidad no sólo de realizar una mera descripción fáctica, sino también de desarrollar una actividad jurídica para la que son precisos conocimientos técnicos que no están al alcance de cualquiera. Su carácter voluntario haría que, lógicamente, esa supuesta "educación" beneficiara a quienes manifiesten su interés en recibirla, y no a quienes más necesitan de ella. Sobre el terreno práctico cabría señalar que si el ciudadano medio obtiene poca "educación jurídica" de la observación de lo actuado por el MF, mucha menos obtendrá del ejercicio de la acusación por alguno de sus conciudadanos más audaz, más rico o más rápido. O si la obtiene, en todo caso la indeterminación de los motivos que le mueven, hará que sea una educación más sesgada por su vinculación a criterios no explícitos. Mucho más aceptables que la acusación popular serían, por ende, otras formas de participación que no intentaran tanto alcanzar derechos que por su propia naturaleza estarían siempre en poder de un reducido y cualificado número de ciudadanos, cuanto aquéllas que puedan suministrar cauces de control general sobre los encargados de satisfacer intereses socialmente relevantes ${ }^{1483}$.

Cabría señalar, por último y por el contrario, que precisamente la falta de educación ciudadana ha sido utilizada en determinados momentos históricos como argumento en contra de la acusación popular ${ }^{1484}$. La relatividad de su definición como

${ }^{1483}$ La publicidad del proceso juega en este sentido un papel trascendental, pues como señalaba BENTHAM, J., Tratado de las pruebas judiciales, compilado por DUMONT, traducción y comentarios de ANDUAGA ESPINOSA, B., Madrid 1843, pp. 102 y ss., "si la publicidad es necesaria para asegurar o garantizar la probidad del juez, no lo es menos para cimentar la confianza del público. Supongamos (...) que una justicia secreta fuese siempre bien administrada: ¿qué se ganaría con eso? casi nada...”. La mera denuncia o la intervención como testigo en una causa penal constituyen también fórmulas de contribución al reforzamiento de la "cultura jurídica", aun cuando tales formas de colaboración no alcancen los niveles de actividad que conlleva el planteamiento de la acusación. La denuncia, en muchas ocasiones, podría satisfacer gran parte de las ventajas que se atribuyen a la acusación popular en lo referido a colaboración ciudadana en la persecución del delito, con las ventajas que supone su sencillez formal, que no origine gastos al ciudadano, que no sea precisa la intervención de profesionales que mediaticen el papel del denunciante, etc.

${ }^{1484}$ En la relación que acompañaba al proyecto de Código Procesal Penal italiano de 1905 (FINOCCHIARIOAPRILE) se afirmaba que "La acción popular demanda en los ciudadanos actividad, amor, celo por la cosa pública, serenidad e imparcialidad en la acusación. Antes de acogerla, un legislador que quiera proteger la libertady la paz de los consociados debe estar seguro de que siempre será ejercitada en interés público, que el ciudadano se 


\section{"Escuela de ciudadanía" queda así patente: lo que para algún sector es elemento de educación, para otros debería ser manifestación de una educación que no existe.}

II.

Se ha sugerido también que la acusación popular se dirigiría a mejorar la percepción pública de lo que sucede en el proceso, constituyendo un medio para fortalecer la confianza de los ciudadanos en las instituciones ${ }^{1485}$. Su principal activo desde esta perspectiva sería el otorgar trascendencia pública al cumplimiento de una función estatal, haciendo que con la actividad o inactividad de particulares pudiera hablarse respectivamente de una expresa o una tácita aprobación social ${ }^{1486}$. Su función se centraría

constituirá acusador para reivindicar los derechos de la comunidad social, que no será llevado por el odio ni por la venganza, ni por cualquier otro interés que no sea el del bien público (...) La educación civil no ha llegado entre nosotros a un grado que nos permita inducir que la acción popular pueda llevar a la Administración de Justicia el auxilio que prometen sus propugnadores. El instituto, desde el punto de vista de la ciencia abstracta, tiene un carácter liberal y democrático, pero en las condiciones presentes de nuestras costumbres sería peligroso a la tranquilidad de los ciudadanos. No es posible esperar de las iniciativas cívicas en un país en que el poder público encuentra graves obstáculos cuando requiere la cooperación de los particulares a la administración de justicia, como denunciantes, testigos o jueces; no es posible que se reanimen hasta el punto de que un ciudadano, estimulado sólo por el intento del bien público, ejercite el derecho de acusación con la responsabilidad que de él deriva para cumplir un deber civil. Sería de temer, por lo contrario, que el ejercicio de la acción penal sirviese para satisfacer odios y para suscitar venganzas, o se convirtiera en medio de acusaciones temerarias o calumniosas o de sórdidas especulaciones". Nos servimos de la traducción de FAIRÉN, publicada en Comentarios... op. cit. p. 50, quien afirma que, a diferencia de lo expresado por FINOCCHIARIO-APRILE, en España los ciudadanos han venido progresivamente mostrando su madurez y se han compenetrado con la acción popular. No mostraba una visión tan optimista el mismo autor algunos años antes, cuando afirmaba que "la acción popular a la que tan fundados inconvenientes se le achacan tiene la ventaja de permitir a la comunidad subsanar directamente las omisiones en que puedan incurrir sus representantes $(M F)$ (...). El Deus ex machina del éxito del sistema que se base en la acción popular está en la finura del sentido jurídico del pueblo. Y en ocasiones cabe dudar del pueblo español en este aspecto". FAIRÉN GUILLÉN, V., Voz “Acción”, Nueva Enciclopedia Jurídica, p. 203, n. 133. VÉLEZMARICONDE tiene escrito otro párrafo significativo a este respecto en su Derecho Procesal Penal, T. I, $2^{\mathrm{a}}$ ed., Buenos Aires, p. 285: "Si la humanidad pudiese tocar el límite ideal del progreso civil (....) si la perfección intelectual y moral fuese dote y carácter ordinario de sus componentes sería fácil consentir que el fenómeno anormal del delito confiriese a cada individuo normal, es decir, a cada hombre moral o intelectualmente perfecto, la potestad de constituirse en órgano de la defensa social para promover y aun para actuar las providencias necesarias a la eliminación del fenómeno perturbador. Pero en una sociedad semejante ni siquiera existiría la organización permanente de la Jurisdicción".

${ }^{1485}$ Destacaba IBÁÑEZ que los ciudadanos creerán mejor en aquéllo en lo que participan que no en lo que reciben facturado de los órganos jurisdiccionales. IBÁÑEZ Y GARCÍA VELASCO, M., "Independencia y autonomía del Ministerio Fiscal en el Proceso Penal”, RDProc 1967, vol. II, p. 103.

${ }^{1486}$ Sirviéndonos de la plástica metáfora de BARATTA, A., "La vida y el laboratorio del Derecho. A propósito de la imputación de responsabilidad en el proceso penal”, Doxa n $^{\circ} 5$, 1988, pp. 275 y ss., diríamos que sobre el laboratorio procesal en el que se reproduce un conflicto social, se desarrolla un teatro en el que los actores 
en evitar el quebranto que podría suponer la pérdida del sentimiento de que la justicia se hace efectivamente ${ }^{1487}$, y su virtud principal será la de incrementar la confianza de los ciudadanos en la Justicia.

Una de las metas de la presencia de acusadores populares sería la de evitar la impunidad a través de un disperso control ciudadano que impidiera el que algún delito quedase sin castigo $^{1488}$. La reacción social condiciona en buena medida el volumen y la estructura de la criminalidad $^{1489}$, por lo que la intervención activa de particulares podría constituir un instrumento participativo de medida de la respuesta penal que adecuara la persecución a la "demanda social" de control del delito. La intervención de particulares acusadores sería indicativo de que la inquietud social exige la persecución de tal o cual conducta criminal así como la intensidad con la que ésta se debe producir. La prevención general positiva obligaría a la persecución de todos los delitos que fueran percibidos como tales por la sociedad ${ }^{1490}$, y no sería tan relevante la perfección técnica y los resultados del proceso, cuanto el que constituya un reflejo de las pautas de soportabilidad social del delito. De igual manera, podría contribuir a la concreción de conceptos jurídicos indeterminados presentes en las normas, aportando un factor de corrección a la

representan sus papeles. La acusación popular constituiría así uno de los mecanismos de potencial intervención del público al que tal representación se orienta, previsto para el caso de que aquella reconstrucción artificiosa no sea de su entero agrado.

${ }^{1487}$ Es conocida la doctrina sentada por el TEDH en el sentido de que la justicia no sólo debe ser administrada, sino también aparecer ante la opinión pública como efectivamente administrada. Vid. por ejemplo la STEDH Delcourt, de 17 de enero de 1970.

${ }^{1488}$ Vid. por ejemplo VALERO OLTRA, R., “Consideraciones sobre la acción popular”, BIMJ, n 1237,25 de abril de 1981, p. 11. Cabría recordar en este momento el modelo vigente en Inglaterra, en el que el carácter difuso de la atribución de la facultad de ejercitar la pretensión penal y la pervivencia de la acusación privada son vistas como instrumento idóneo para promover la justicia penal conforme a las exigencias reales de la sociedad, y no como una decisión discrecionalmente adoptada por la autoridad pública. Ello lleva a la necesidad de hacer públicos los criterios de persecución así como los resultados obtenidos por los oficiales públicos, la comunicación de los supuestos de archivo y sus causas, etc., confiriendo a los particulares, bajo ciertas premisas, la oportunidad de intervenir cuando no se muestren conformes con su actividad.

${ }^{1489}$ Hasta qué punto la eficacia de la norma depende de la opinión pública lo demuestran las altas “cifras oscuras de la criminalidad" unidas a la baja predisposición hacia la denuncia en delitos considerados irrelevantes. Para los defensores del labelling approach, el control social no se limita a detectar la criminalidad, sino que la crea o configura, realizando una función constitutiva. Vid. GARCÍA-PABLOS DE MOLINA, A., Criminología. Una introducción a sus fundamentos teóricos para juristas, Valencia 1992, pp. 67 y ss.

${ }^{1490}$ Sobre el papel de la prevención general positiva en el sistema penal puede verse por todos SCHUMANN, K.F., Positive Generalprävention. Ergebnisse un Chancen der Forschung, Heidelberg 1989, esp. pp. 1-13. 
actividad de los funcionarios públicos.

Puesto que no hay delito sin sentencia, sentencia sin proceso, ni proceso sin acusación, el control ciudadano sobre ésta significaría su integración por vía indirecta en el control de la criminalidad. El ejercicio popular de la acusación constituiría un mecanismo adecuado para evitar una "razonable inclinación hacia la autodefensa organizada", que sería mucho más peligrosa ${ }^{1491}$. Con su planteamiento no sólo se buscaría una resolución más justa, sino sobre todo una resolución que contribuyera a apaciguar de una forma socialmente asumible un conflicto presente en la comunidad ${ }^{1492}$. En ausencia de una configuración socialmente aceptable de la hipótesis acusatoria que va a ser objeto de contradicción no se estaría dando respuesta al interés general, por lo que la acusación sería un instrumento dirigido a asegurar el consensum omnium sobre la validez y legitimidad de la norma y sobre los valores contenidos en ella. No se trataría sólo de que deban ser sometidas a un proceso de verificación y refutación que las configure como válidas para destruir la presunción de inocencia, sino también de que tengan que atravesar por un proceso de justificación pública que afiance la adecuación y credibilidad de su contenido entre el público en general. Esta posibilidad de realizar privadamente la actividad del fiscal podría tener un valor psicológico, consistente en otorgar validez y coherencia lógica al sistema, aportando tranquilidad a las conciencias a través de la búsqueda de una verdad socialmente aceptable sobre los hechos con trascendencia penal. El juicio penal se configuraría en este sentido como actividad no exclusivamente cognoscitiva de los hechos presuntamente delictivos, sino también a través de la acusación, como recognoscitiva sobre la validez de las normas penales para dar una respuesta socialmente aceptable a los comportamientos típicamente antijurídicos. La acusación popular formaría parte de los cauces para el control de las funciones estatales e integraría en esa dimensión el conjunto de herramientas de que se dota el ordenamiento jurídico para reafirmar la credibilidad de (y la confianza en) la efectiva actuación de sus principios.

La crítica a este tipo de planteamientos puede formularse desde cuatro diversas perspectivas:

${ }^{1491}$ FAIRÉN GUILLÉN, V., “Acción del MF y acción popular. El refuerzo de esta última”, Tapia nº 48, p. 61.

${ }^{1492}$ CARNELUTTI resaltaba que el público es el destinatario del juicio, aquel por el cual se juzga. CARNELUTTI, "La publicidad en el proceso penal", Cuestiones..., p. 121. 
a) El propio concepto y significado de la Ley en el Estado de Derecho, en tanto los argumentos reseñados convertirían al acusador popular en actor de excepción de la potestad de determinar la verdad de la norma. La Ley no sería más que una propuesta de ordenación social o de provisional reconocimiento de intereses generales, supeditado siempre a su verificación en el proceso.

b) La innecesariedad y el carácter superfluo de tales argumentos una vez constitucionalmente garantizada la sujeción del MF al principio de legalidad y asegurada su consiguiente e imparcial actividad, dotándole de los medios precisos para ello.

c) El peligro de que la intervención de particulares fomente una privatización del proceso penal y no un incremento de la publicidad de éste. La respuesta al delito perseguible de oficio debe ser por definición uniforme y cierta, sin que la actividad de los particulares determine el contenido y la aplicabilidad o no de los preceptos penales ${ }^{1493}$. No podría cuestionarse, pues, que en los delitos públicos sea exigible una intervención estatal en el momento en que conste la notitia criminis, sin que se deba esperar a que una actividad de particulares señale los lugares donde se han podido producir quiebras en la paz social $^{1494}$. El momento procesal podría ser revelador de deficiencias en la norma material o de los cauces procesales para hacerla efectiva, pero ni ello es deseable ni ha de ser buscado, sino únicamente observado como algo inevitable con el propósito de su erradicación. Al amparo de criterios de oportunidad no cabría su entendimiento como lugar adecuado para un control social privado sobre las conductas ajenas. Si se tiene en cuenta el establecimiento por el legislador de tipos penales contenedores de preceptos de carácter vago e indeterminado o la introducción de diversas modalidades de negociación, llegaremos a la conclusión de estar otorgando una incertidumbre al ejercicio de la pretensión penal generadora de una percepción social de la Justicia que podríamos calificar, siendo benevolentes, de distorsionada. No hay duda, además, de que con ello se

\footnotetext{
${ }^{1493}$ Afirmar lo contrario sería tanto como asumir que la denuncia de los delitos, cauce ordinario para poner en comunicación de la autoridad pública la comisión del delito, es insuficiente para activar los mecanismos de persecución, ya per se, o, lo que es más grave, por la reluctancia a su utilización. Pensemos en este sentido en la comprensión de la sociedad española de hace unos años ante la defraudación fiscal. De otro lado, la resistencia a denunciar puede venir del temor en ciertos núcleos de población ante la reacción de grupos incontrolados (mafias, terrorismo, narcotráfico...).

${ }^{1494}$ A diferencia de ellos, en el caso de los delitos semipúblicos podríamos afirmar que la autorización para proceder en que la querella consiste, determina un criterio definidor de la ruptura de la paz jurídica de la comunidad, la cual sólo se entenderá producida con la conducta activa del ofendido. Si ésta falta no habrá razón para la intervención del derecho penal.
} 
acentuaría la tendencia represiva del sistema penal, al contribuir determinados particulares con su actividad acusadora únicamente a la búsqueda expresa de la sanción ${ }^{1495}$. La ampliación del ámbito de la acusación más allá de lo necesario estaría así plagada de riesgos, en la medida en que inevitablemente produce perjuicios a los sujetos frente a los que se dirija ${ }^{1496}$.

d) La irracionalidad que supone la solapada introducción a través de la acusación por particulares de lo que pretende ser un correctivo a verdaderos déficits de representación política. Los controles sobre la actividad de las autoridades públicas, necesarios en

\footnotetext{
${ }^{1495}$ Es más, en consonancia con la existencia de normas penales abiertas, la consideración del ejercicio popular de la acusación como criterio de evaluación social de las conductas que deben ser castigadas, podría originar resultados no descartables, consistentes, por ejemplo, en la reactivación de normas penales con contenido moral. Esto es lo que ha ocurrido en la práctica en Inglaterra, donde uno de los principales ámbitos de utilización de la acusación privada es precisamente el relacionado con la aplicación de tipos penales arcaicos contenedores de preceptos referidos a la moral y las costumbres. Tal experiencia no es tampoco ajena a la realidad práctica de nuestro país: vid. la STS de 5 de junio de 1993 (RAJ 3962), que declara expresamente en una causa por delitos relativos a la prostitución que la acusación popular no debe convertirse en cauce para la imposición de las reglas de moralidad del actor.

${ }^{1496}$ Ya advertía MONTESQUIEU que "la libertad política consiste en la seguridad o al menos en la convicción que se tiene de la propia seguridad. Dicha seguridad no se ve nunca tan atacada como en las acusaciones públicas y privadas. Así, pues, la libertad del ciudadano depende principalmente de que las leyes criminales sean buenas. (...) Cuando la inocencia de los ciudadanos no está asegurada tampoco lo está su libertad' Del espíritu de las leyes, lib. XII, cap. II. A ello se debe añadir el riesgo de la puesta en peligro de las libertades de los disidentes y de sus espacios legítimos de desviación, cercenados al amparo de un control social difuso de las conductas. FERRAJOLI, L., Derecho y Razón. Teoría del garantismo penal, pp. 545 y ss. realiza esta afirmación en relación con una hipotética concesión a las mayorías de lo que denomina "poder judicial de enjuiciamiento y/o acusación".
} 
un Estado de Derecho, tendrían que situarse en otros momentos tales como el de elaboración de la norma y el de la generalizada asunción por las autoridades de la correspondiente responsabilidad en el ejercicio de sus funciones para la satisfacción de intereses generales. El desempeño directo por los ciudadanos de funciones de los órganos públicos desplazaría tal responsabilidad de lugar, pudiendo originar el que se supliera veladamente un defecto en los controles sobre la responsabilidad política. 


\section{DEFENSA DE INTERESES COLECTIVOS MEDIANTE EL EJERCICIO DE LA ACUSACIÓN}

\subsection{Intereses colectivos y participación de asociaciones en el proceso penal para invocar su tutela}

I.

Los intereses a cuya defensa nos referiremos aquí, calificados de colectivos, difusos, metaindividuales, de grupo, o amparados bajo cualquier otra de las denominaciones posibles, ocupan una posición ambigua dentro del sistema de protección de los derechos ${ }^{1497}$. Sus fronteras se encuentran difuminadas entre, por una parte, los intereses públicos -entendidos como intereses generales de la colectividad, referidos a bienes no susceptibles de apropiación exclusiva, en los que el disfrute de ese bien por parte de un individuo o un grupo determinado no está limitado por el goce concurrente de otros miembros de la colectividad-, y, por otra, los intereses individuales -que tienen por objeto bienes susceptibles de apropiación exclusiva por otros sujetos- ${ }^{1498}$. Es comúnmente

${ }^{1497}$ Una primera dificultad estriba en una mera cuestión terminológica: la propia designación de los intereses a los que nos queremos referir. BUJOSA VADELL, L., La protección jurisdiccional de los intereses de grupo, Barcelona 1995, pp. 59 y ss. cita las siguientes denominaciones extraídas de la doctrina sobre el tema: intereses de grupo, colectivos, difusos, sociales, de serie, de sector, de categoría, difundidos o propagados, profesionales, fragmentarios, sin estructura, sin dueño o anónimos, supraindividuales, superindividuales, de clase y dispersos; sin que estas denominaciones sean entendidas de forma unívoca por todos los autores que se han ocupado de ellas. El autor se pronuncia en última instancia en favor de la denominación "intereses de grupo", la cual, sin carecer de ambigüedad, es algo más precisa que el resto. En otros casos se opta por denominaciones que hacen hincapié en la plurisubjetividad de los intereses o bienes jurídicos en cuestión, más que en la mera agregación de sus representantes. En este sentido se enmarcan denominaciones como la de "bienes jurídicos de titularidad supraindividual", en tanto los ciudadanos siguen siendo los últimos titulares de aquellos bienes jurídico-penales. Vid. CARBONELL MATEU, J.C., "Breves reflexiones sobre la tutela de los llamados intereses difusos", en BOIX REIG, J. (Director), Intereses Difusos y Derecho Penal, Cuadernos de Derecho Judicial, XXXVI, CGPJ, Madrid 1994, p. 17. Como señalara ALMAGRO, la categoría de los intereses colectivos no constituye un concepto acabado y categorial, sino que más bien invoca una idea-fuerza renovadora de la clásica e insuficiente tutela procesal. ALMAGRO NOSETE, J., "La protección procesal de los intereses difusos en España”, JUSTICIA 83, n I, p. 69 con fundamento en lo expuesto por CAPPELLETTI, M., "Formazioni Sociali e interessi di gruppo davanti alla giustizia civile", Riv. Dir. Proc. julio-sept. 1995, pp. 362 y ss. Hemos de referirnos también en este momento a la primera monografía sobre la cuestión: la de LOZANO-HIGUERO y PINTO, M., La protección procesal de los intereses difusos, Madrid 1983, y en especial a este respecto, su distinción entre diversas figuras afines (pp. 142 y ss.). Vid. asimismo la más reciente de SILGUERO ESTAGNAN, J., La tutela jurisdiccional de los intereses colectivos a través de la legitimación de los grupos, Madrid 1995, pp. 25 y ss.

${ }^{1498}$ BUJOSA VADELL, L.-M., La protección jurisdiccional..., op. cit. p. 211, utilizando expresiones de DENTI, 
admitido en nuestros días que, a pesar de que el derecho penal no podría abarcar todas las esferas de la vida hasta hacerse omnipresente, sólo amparando estos intereses con toda la intensidad del ordenamiento jurídico, podrá ser posible desarrollar una adecuada protección de todos los bienes con relevancia constitucional ${ }^{1499}$.

Una dificultad añadida estriba en que nos enfrentamos con una realidad pluriforme, en la que es distinguible sólo con ciertas dificultades y deficiencias una diversidad de casos. Dentro del sistema de protección penal de intereses jurídicos no estrictamente individuales podrían al menos considerarse:

1) Delitos con "sujeto pasivo masa", supuestos en los que determinados bienes jurídicos objeto de tutela individual fueran lesionados o puestos en peligro simultáneamente para una pluralidad de individuos (p.ej. estafas colectivas o delitos societarios que afectan a un conjunto grande de accionistas). Con ellos se protegen unas condiciones de garantía de bienes jurídicos individuales tales como la vida, la integridad, la salud o el patrimonio de una multitud de sujetos ${ }^{1500}$. En este caso se tratará de una suma de intereses reconducibles a las categorías tradicionales, pero con dificultades para ser defendidos por la debilidad de su posición: son intereses individuales que por su contenido cualitativamente homogéneo son susceptibles de defensa procesal colectiva.

2) Delitos cuya peculiaridad no estriba en la individualización de los daños, sino en los que la expectativa de tutela jurídica del interés o bien dañado es compartida por

V. en La Giustizia Civile, Bolonia 1989, p. 114.

${ }^{1499}$ Se ha señalado por ello que resultaría falaz enarbolar el argumento del principio de intervención mínima como barrera del avance del Derecho penal hacia la tutela de intereses de titularidad supraindividual. La incorporación de nuevos intereses al derecho penal no ha estado libre de críticas, procedentes de quienes consideran que tomarse en serio el principio de intervención mínima del derecho penal o su carácter de ultima ratio, significaría no incrementar el número de figuras delictivas y limitar el ámbito de aplicación del Código Penal. Sin embargo, parece comúnmente aceptado que la extensión del Derecho Penal no debe tener nada que ver con el carácter individual o colectivo del bien jurídico objeto de tutela. En este sentido vid. CARBONELL MATEU, J.C., "Breves reflexiones sobre la tutela de los llamados intereses difusos", op. cit. p. 11. En palabras de PORTILLA CONTRERAS, G., "Principio de intervención mínima y bienes jurídicos colectivos", $C P C$ nº 39, 1989 y en Derecho Penal y Criminología. Revista del Instituto de Ciencias penales y criminológicas de la Universidad Externado de Colombia, $\mathrm{n}^{\circ}$ 43, enero-abril 1991, pp. 33 y ss., "en ningún caso la hipertrofia penal del Estado Social se debe reducir a costa de los denominados bienes colectivos que suelen responder a los principios penales más clásicos, sino de las metáforas conceptuales, sin que se entre a decidir sobre los valores afectados por la convicción social".

${ }^{1500}$ De ahí que la doctrina penalista hable de "bienes jurídicos colectivos de referente individual". Vid. así DOVAL PAÍS, A., "Estructura de las conductas típicas con especial referencia a los fraudes alimentarios" en Interereses Difusos..., BOIX REIG, J. (Director), op. cit. p. 42. 
sujetos (individuales o colectivos) diversos al específico titular de aquél. Este es el caso, por ejemplo, de las asociaciones de víctimas del terrorismo en delitos de atentados de tal naturaleza, de los grupos de defensa contra el racismo en delitos de ataques de este tipo o de los grupos feministas en supuestos de agresiones sexuales ${ }^{1501}$.

3) Delitos que afectan bienes de titularidad colectiva, supuestos en los que no se puede cuantificar ni identificar la parte de titularidad que cada individuo tiene sobre el bien jurídico (p. ej. la organización democrática del Estado, el erario público, el medio ambiente $^{1502}$, los derechos de los consumidores, etc). Se refieren a la relación de todos y cada uno de los miembros de la colectividad con un bien no susceptible de apropiación exclusiva y cuya fruición por uno no excluye la de los demás. Nadie puede ser considerado titular exclusivo y, al mismo tiempo, todos los miembros de un grupo o de una categoría determinada son sus titulares ${ }^{1503}$. Parece claro que los legítimos intereses

${ }^{1501}$ En este caso podríamos preguntarnos por el sentido que tiene la acusación de otros sujetos cuando hay un agraviado individual y específicamente determinado. El que el legítimo interés del ofendido sea representado procesalmente por sí mismo o por una asociación cuyos fines coincidan en mayor o menor medida con éste es algo que debería permanecer dentro de su libertad personal.

${ }^{1502}$ Sobre los bienes jurídicos protegidos en los delitos medioambientales puede verse RENGIER, R., "Zur Bestimmung und Bedeutung der Rechtsgüter im Umweltstrafrecht”, NJW 1990, pp. 2506 y ss.; HOHMANN, O., Das Rechtsgut der Umweltsdelikte. Grenzen des strafrechlichen Umweltschutzes, Francfort 1991. Este último autor rechaza la idea de establecer una categorización diferenciada entre bienes jurídicos individuales y colectivos, y opta por una teoría monista sobre la naturaleza de los bienes jurídicos. En la medida que esta se deriva de una diferente concepción del Estado, garantizador ante todo de ámbitos de libertad del individuo, sólo éste, tomado individualmente y sin reparar en su pertenencia a un colectivo, podría ser considerado portador de bienes jurídicos (pp. 58 a 73). Más recientemente ha sido abordada la cuestión en nuestro país por GIMENO SENDRA y GARBERÍ LLOBREGAT en "La protección procesal del Medio Ambiente", $P J \mathrm{n}^{\circ}$ 37, p. 149, situando el bien jurídico protegido en tales delitos en el "derecho al disfrute", el cual ostentaría por definición un carácter difuso.

${ }^{1503}$ En el ámbito civil CAPPELLETTI los denomina “intereses de grupo en sentido estricto", pero en este caso entiende que nadie puede ser titular de ellos. Estos intereses serían materialmente iguales a los intereses públicos, pero no subjetivamente. CAPPELLETTI, M., "Formazioni sociali e interessi di gruppo davanti alla giustizia civile", Riv.D.Pr. 1975, p. 372. Sin embargo, tratándose de bienes jurídicos tutelados por la norma penal, no podemos caracterizar estos intereses como difusos sin un referente subjetivo sobre el que apoyarse. A nuestro juicio deben ser considerados intereses de titularidad supraindividual cuyo carácter no se separa de lo que constitucionalmente es considerado como la fuente de todos los derechos: la dignidad de la persona y el libre desarrollo de la personalidad (art. $10 \mathrm{CE}$ ). Los bienes jurídicos de titularidad supraindividual son propios de cada uno de los ciudadanos, sin que entendamos oportuno asumir a estos efectos conceptos superadores del individuo como sujeto pasivo o titular de bienes jurídicos. De este modo, no encontramos acertadas aquellas concepciones que abandonan el referente individual marginando los aspectos de relación entre bienes jurídicos y sujetos concretos para ascender a un plano de posibles "titularidades colectivizadas" de los derechos.

En el diseño de la norma penal, la existencia de asociaciones para la defensa de determinados bienes no es un dato que a priori deba ser juzgado trascendente. Incluso aceptando como referente la hipotética existencia de sujetos colectivos que pudieramos considerar víctimas de delitos, ello no debería constituirse en criterio de fijación de preceptos penales materiales. Con carácter general la norma penal debe ser independiente de la voluntad de la víctima, y específicamente tratándose de la protección de intereses colectivos, el atender al componente 
colectivos protegidos a través de tipos penales que tutelan el medio ambiente, los derechos de los consumidores, el funcionamiento de la Hacienda Pública, etc. no pueden ser considerados bienes jurídicos en el sentido tradicional. Una vez admitida por toda la doctrina y, lo que se presenta como más trascendente, por la jurisprudencia, el necesario amparo de esos intereseses supraindividuales en el proceso penal, habremos de preguntarnos ahora por las formas para su efectiva tutela judicial. Tales intereses resultan coincidentes con el objetivo de organizaciones políticas, sociales, económicas, etc., por lo que a los efectos de su defensa se ha visto en ellas un inmejorable instrumento para su invocación procesal ${ }^{1504}$.

\section{II.}

La necesidad de establecer tipos de acción colectiva que respondan a la superación de la bipartición tradicional interés público/interés privado ${ }^{1505}$ no puede, sin embargo, ser considerado algo novedoso, sino que es un aspecto que retorna periódicamente al debate científico. El planteamiento de la acusación por asociaciones ha cobrado vigorosa

victimológico (viktimologisches Ansatz) de los tipos penales puede implicar su no vigencia fáctica: la norma penal sólo se activará si encuentra una víctima despierta y dispuesta a la defensa con las armas del sistema penal. En ese sentido es en el que podemos constatar una contradicción al asistir de forma simultánea, por una parte, a la creciente protección en la legislación penal de bienes jurídicos funcionales en los que el papel de la víctima se halla debilitado $\mathrm{y}$, por otra, al incremento de la orientación victimológica de otros tipos penales, cuando es claro que ello precisa de una víctima real y palpable que se constituya en referente. Vid. a este respecto HASSEMER, W., "Rücksichten auf das Verbrechensopfer", Festschrift für Ulrich Klug zum 70. Geburtstag", T. II, p. 227. Existe traducción de CANTARERO, R., publicada en ADPCP 1990, pp. 241 y ss. En el mismo sentido vid. SEELMANN, K., "Paradoxien der Opferorientirung im Strafsachen", JZ 1989, p. 672. Entre nuestra doctrina aborda el tema de la despersonalización en los casos de víctima colectiva LANDROVE DIAZ, G., Victimología, Valencia 1992, pp. 40 y ss.

${ }^{1504}$ Los grupos que realizan de manera abierta una influencia sobre los círculos políticos, sociales, económicos o de cualquier otro tipo han dejado de ser una realidad circunscribible solamente al ámbito de los países del Common Law, y su creciente influencia en la Europa continental es hoy una realidad palpable de la que no nuestro país no constituye una excepción. Para una completa panorámica sobre el tema de la presión ejercitada por grupos de interés en diversas materias y con diversas armas procesales, especialmente en lo referido al mundo anglosajón, vid. la interesante obra de HARLOW, C. y RAWLINGS, R., Pressure through Law, Londres, Nueva York 1992. En España se ha multiplicado en los últimos años de manera espectacular tanto el número de asociaciones de todo tipo como el de sus integrantes y hoy podría afirmarse que abarcan todos los ámbitos de la vida social. Según los datos del Registro de Asociaciones del Ministerio del Interior, el número de asociaciones era en 1970 de 9.629, en 1980 de 35.589 y en 1989 de 74.884. Vid. PÉREZ DÍAZ, V., "La primacía de la Sociedad Civil”, Madrid 1993, p. 60.

${ }^{1505}$ Para abarcar la(s) dicotomía(s) público/privado, publicidad/privaticidad, Estado/sociedad son de gran interés los trabajos de BULLINGER, M., Derecho Público y Derecho Privado, Madrid 1976 y especialmente el ya citado HABERMAS, J., Strukturwandel der Öffentlichkeit. 
actualidad en los últimos tiempos, aun cuando en absoluto ha sido una cuestión ajena a los términos en los que históricamente se ha desarrollado el debate sobre la intervención de particulares en el proceso penal. Dejando de lado el paradigma que representaron las asociaciones inglesas para la persecución del delito, ya abordado en otro lugar de este trabajo, la idea de conjunción de intereses confluyentes de una pluralidad de particulares agrupados en su defensa, aparece con frecuencia como una de las mejores maneras, si no la única, para la adecuada materialización en el proceso de intereses de naturaleza supraindividual $^{1506}$.

En España, este tipo de participación de los particulares en el proceso penal se ha presentado generalmente no sólo como una manifestación de acusación popular, sino como el ámbito preferente de ésta, y en muchas ocasiones como el único en el que adquiriría verdadera trascendencia. Las afirmaciones en el sentido de que nuestra institución necesita del fenómeno asociativo "como el aire que respiramos"1507 o que "pretender que el ciudadano individual comparezca a ejercitar la acción popular, prescindiendo del correspondiente movimiento, asociativo significa condenar a la acción popular al ostracismo" ${ }^{1508}$, han sido por ello compartidas de manera prácticamente unánime. La generalidad de la doctrina de nuestro país mantiene que el mayor interés teórico y las mejores perspectivas prácticas de futuro de la acusación popular se sitúan hoy en su ejercicio colectivo, no sólo como forma de distribuir gastos o garantizar su

\footnotetext{
${ }^{1506}$ Los primeros precedentes de este tipo de proposiciones se encuentran ya a principios de nuestro siglo. Así, en Italia, el Proyecto FINOCCHIARIO-APRILE de 1911 contenía una alusión a la autorización para el ejercicio de la "acción penal" por "asociaciones legalmente constituidas por un fin de interés profesional o público, relativamente a los delitos que directamente conciernen a su institución" y por "instituciones públicas de beneficencia relativamente a los delitos cometidos en su propio daño, siguiendo asi el sistema inglés...". Recogido por VÉLEZMARICONDE, Derecho Procesal Penal, T. I, p. 287 y por AMODIO, E., "L'azione penale delle asociazioni dei consomatori per le repressione delle frodi alimentari", Riv. Ital. Dir. e Proc. Penale, 1974, p. 522. Vid. también la Memoria sobre el Congreso Internacional de Derecho Penal de Bucarest de 1929, publicada en Révue Internationale de Droit Penal, VI, 1929, pp. 474 y ss., en el que se discutió la posibilidad de atribuir a asociaciones la facultad de promover la pretensión penal en delitos con trascendencia colectiva, tales como los referidos a la pornografía, la caza furtiva o el ejercicio abusivo de las profesiones sanitarias.

${ }^{1507}$ GIMENO SENDRA, V., "La fianza del acusador particular: notas sobre la legitimación activa y «caución juratoria» en el proceso penal", RDProc (Ibam) 1976, p. 73. En opinión de GIMENO, puesto que la acusación pública era más una institución existente en la ley que en la práctica, debería necesariamente estimularse el asociacionismo que, entre otras finalidades, podría tener las de perseguir delitos que atenten contra la sociedad entera. De ello serían una buena primera muestra las, entonces recien creadas, asociaciones de defensa de la naturaleza.
}

${ }^{1508}$ GIMENO SENDRA, V., Constitución y Proceso, Madrid 1988, p. 86, quien lo afirma en relación con supuestos tales como la defensa del consumidor o del medio ambiente. 
$\overline{\text { efectividad }}{ }^{1509}$, sino sobre todo en la representación de intereses de naturaleza colectiva o difusa a través de ella ${ }^{1510}$.

Si el derecho penal ha ido abarcando progresivamente parcelas más amplias en defensa de bienes jurídicos no estrictamente individuales (delitos económicos, medioambientales, de consumo, etc), su tutela procesal ha encontrado, a falta de otra vía satisfactoria para su defensa, el cobijo necesario al abrigo de la inexigencia de requisitos de legitimación y, en la praxis, el ejercicio popular de la acusación ha hallado así en los últimos tiempos su mayor campo de aplicación y justificación. Es frecuente encontrar entre quienes han abordado la necesidad de una adecuada defensa de los intereses difusos afirmaciones fundamentadas sobre la validez de la acusación popular para constituir un baluarte de vigilancia y defensa de derechos e intereses generales que se adaptaría

${ }^{1509}$ Así FAIRÉN GUILLÉN, V., "Acción del Fiscal y Acción Popular. El refuerzo de ésta última”, Tapia, octubre 1989, p. 62 y n. 29, que apela a la "solidaridad de los ciudadanos menos favorecidos por la fortuna ante el delito".

${ }^{1510}$ Ya SILVELA afirmaba, al hilo de su discurso en defensa de la acusación popular y en referencia a las asociaciones inglesas para la persecución del delito, que en nuestro país no podríamos contar con "tales y tan eficaces iniciativas, pero porque ellas sean raras en producirse, turbias en manifestarse y endebles en mantenerse ¿Debemos cortar los caminos por donde pudieran guiarse hacia el bien y el progreso de instituciones y costumbres?". SILVELA, F., "La acción popular", RGLJ 1888, p. 485. El argumento es destacado entre otros muchos por ALMAGRO NOSETE, J., "El derecho procesal en la nueva constitución", RDProc. 1978, p. 864 y del mismo autor "La protección procesal de los intereses difusos en España", JUSTICIA 83, n I, p. 85, quien solicita un reconocimiento expreso para las asociaciones no estatales de la "acción popular", puesto que "donde más campo tiene es en el de las nuevas materias de interés social y respecto de los intereses colectivos y difusos". LOZANO-HIGUERO PINTO, M., "Notas sobre la participación procesal y su proyección en las formas alternativas de justicia", RUDProc., $\mathrm{n}^{\circ}$ 0, 1988, p. 49, establece como una de las manifestaciones del ideal participativo en lo subjetivo la tendencia al mayor número posible de participantes y con ello de la acción popular en la medida en que estén afectados intereses generales. Para BUJOSA VADELL, L.M., "Notas sobre la protección procesal penal de intereses supraindividuales a través del Ministerio Fiscal y de la acción popular", JUSTICIA 1990, nº 1, pp. 115 y ss., aun reconociéndole ciertos inconvenientes, la "acción popular" no sería un instrumento ni mucho menos desechable para la tutela de intereses supraindividuales, por lo que sería adecuada si las iniciativas privadas se coordinasen con controles públicos. Para MONTERO AROCA se trataría de atribuir realidad práctica a la acción popular. MONTERO AROCA, J., et al., Derecho Jurisdiccional, op. cit. T. III, p. 60. MUERZA ESPARZA, J., en DE LA OLIVA et al. Derecho Procesal Penal, op. cit., p. 135, afirma que la propia configuración de determinados delitos parece exigir la intervención en el proceso como acusadores populares a ciertas entidades por verse afectado su objeto: los sindicatos en delitos contra la seguridad en el trabajo, las asociaciones ecologistas en el delito ecológico, las de consumidores en materia de consumo, las de defensa de la vida humana desde la concepción en los delitos de aborto, etc. SILGUERO ESTAGNAN, J., La tutela jurisdiccional de los intereses colectivos..., op. cit. pp. 119 y ss y 370 y ss. la califica también como institución hábil para esta defensa en el ámbito penal, aun cuando sea discutible su eficacia en ámbitos procesales diferentes al penal o sancionador. No sólo desde los cultivadores de la ciencia procesal, sino también desde otros ámbitos jurídicos se ha sostenido la aptitud de la acusación popular como mecanimo de defensa procesal frente a agresiones a bienes colectivos. Vid. por ejemplo XIFRÁ HERAS, J., "La Jurisdicción en la Constitución de 1978", en el volumen colectivo El Poder Judicial, T. III, p. 2717; PÉREZ LUÑO, A.E., "La evolución del Estado Social y la tranformación de los Derechos Fundamentales", en OLIVAS, E. (Editor), Problemas de legitimación en el Estado Social, op. cit., pp. 103 y ss. 
$\overline{\text { particularmente bien a nuestros tiempos. El proceso penal habría optado por un grado de }}$ apertura tal, que haría que no se planteasen particulares problemas de legitimación activa $^{1511}$, de manera que en el se resuelve la cuestión de las barreras de legitimación que concurren en otros sectores del ordenamiento jurídico (administrativo y, sobre todo, civil) y que dificultan o directamente impiden la efectiva tutela de valiosos intereses cuando su titularidad es discutible por difundida ${ }^{1512}$. En la medida en que contamos con una "acción popular", legitimación y capacidad procesal coincidirían, sin que fuera preciso ni alegar ulteriores circunstancias ni indagar más: no tiene por qué haber un nexo inmediato entre el objeto de la pretensión y el sujeto que la ejercita, sino que se presupone siempre el interés en la tutela procesal de concretos bienes jurídicos. La requerida superación del individualismo liberal decimonónico habría concluido así en la configuración de la actividad de los entes colectivos en el proceso penal como una modalidad de acusación $\operatorname{popular}^{1513}$.

Hoy se asume de manera generalizada en España que en este tipo de delitos todo ciudadano no sólo es ofendido por los hechos, sino que puede actuar, individual o

${ }^{1511}$ Conclusiones de las Jornadas sobre el medio ambiente organizadas por el CGPJ, Ministerio de Justicia y Fiscalía General del Estado, (Segovia, 29 sept.-1 de oct. 1988), publicadas en $P J, \mathrm{n}^{\circ}$ especial I, p. 7. En la Conclusión $6^{\mathrm{a}}$ se dice (en relación con el medio ambiente) que "el reconocimiento del ejercicio de la acción popular en el seno de la Constitución como forma de participación de la ciudadanía en la Administración de Justicia debe llevar a la interpretación menos entorpecedora del acceso a los Tribunales, en solicitud de amparo judicial, tratándose de tutelar un bien cultural y fundamental para el desarrollo de la persona y cuyo ejercicio está orientado en defensa de bienes colectivos y en consecuencia siendo presumible la licitud, legitimidad y directa afección a la comunidad de las infracciones que se produzcan". Vid.entre otros también, SERRANO MORENO, J.L., "El conflicto ecológico en el momento judicial del Estado de Derecho", JD, nº 25, marzo 1996, p. 80.

${ }^{1512}$ El proceso civil sería un coto cerrado cuyo portón de entrada sólo podría franquearse mediante la concurrencia de legitimación, la cual presupone la afirmación de un nexo de unión directa o indirecta entre sujeto y derecho alegado. El proceso administrativo sería un espacio semi-abierto, en el que la mera alegación de un interés directo (no sólo ya de un derecho) se comportaría como soporte jurídico suficiente para sostener la legitimación. Vid. así GARBERÍ LLOBREGAT, J., Curso de Derecho Procesal Administrativo, con GIMENO SENDRA, MORENO CATENA y GONZÁLEZ-CUELLAR SERRANO, Valencia 1994, p. 126, "En el ámbito del Derecho Privado la titularidad sobre las relaciones jurídicas suele reconducirse casi siempre a la figura del derecho subjetivo... En la esfera del Derecho Administrativo, en cambio, no sólo la titularidad de un derecho subjetivo confiere legitimación a los sujetos para obtener una tutela judicial efectiva y de fondo, sino que también la titularidad de un "interés directo" se comporta como soporte jurídico suficiente para ostentarla... (en cambio) ...en los supuestos de acción popular la legitimación proviene del mero hecho de ser ciudadano". Cfr. también sobre el tema de la legitimación REBOLLO PUIG, M., "Interesados y denunciantes en el procedimiento administrativo sancionador", $P J \mathrm{n}^{\circ} 29$, marzo 1993, pp. 59-78.

${ }^{1513}$ La ulterior dificultad cifrada en la necesidad de cumplir determinados requisitos de capacidad, que impedía tradicionalmente la acusación de las personas jurídicas, debería hoy considerarse totalmente superada sobre la base de la constante doctrina del TC y en menor medida del TS, ya abordada con anterioridad. 
colectivamente en el proceso penal en calidad de acusador popular sujetándose a las condiciones que tal intervención conlleva (querella, fianza, no ofrecimiento de acciones, no derecho a asistencia jurídica gratuita, imposibilidad de ejercitar la acción civil). En la medida en que para defender un interés personal ha de asumirse la defensa de uno común $^{1514}$, ambos intereses legítimos, individual y general, quedarían subsumidos en el mismo objeto de tutela, y no sería posible el deslinde entre ambos. El interés procesal abstracto propio del acusador popular quedaría fundido con el interés material protegido por la norma penal que tutela bienes jurídicos de titularidad supraindividual, llegándose a identificar ambos. No se señala, sin embargo, distinción alguna frente a lo que ocurre en otras conductas delictivas con víctima identificable, con las que a primera vista puede observarse una diferencia fundamental: al proceso penal podrán concurrir tanto un ofendido directamente, haciendo valer en este caso una peculiar modalidad de legitimación cualificada (la que otorga la posición de acusador particular) y, junto a él, también cualquier otro ciudadano por el mero hecho de serlo, sirviéndose de la facultad de acusar sin tener que alegar vinculación material con el objeto procesal. Mientras el primero defenderá un interés privado, el segundo no podrá defender otro interés legítimo que no sea el público en sentar los fundamentos para una resolución en la que se aplique la norma penal.

El art. 7.3 LOPJ $^{1515}$, precepto con una gran potencialidad interpretativa pero que nada en las procelosas aguas de la indeterminación, recoge expresamente la legitimación procesal de los grupos en los siguientes términos: "Los Juzgados y Tribunales protegerán los derechos e intereses legítimos, tanto individuales como colectivos, sin que en ningún caso pueda producirse indefensión. Para la defensa de estos últimos se reconocerá la legitimación de las corporaciones, asociaciones y grupos que resulten afectados o que estén legalmente habilitados para su defensa y promoción" ${ }^{1516}$. En este genérico

${ }^{1514}$ Tal y como afirmó el TC en su célebre sentencia 62/1983 de 11 de julio (FJ 2) “cuando un miembro de la sociedad defiende un interés común sostiene simultáneamente un interés personal, o, si se quiere desde otra perspectiva, que la única forma de defender el interés personal es defender el interés común".

${ }^{1515}$ Con anterioridad ya el art. 20.1 de la Ley General para la Defensa de Consumidores y Usuarios de 1984 (L. 26/1984 de 19 de julio) contenía una norma específica que habilitaba la intervención de las asociaciones de consumidores para la defensa de intereses no sólo de sus asociados o de las propias asociaciones, sino también de los generales de los consumidores y usuarios. Este precepto es contemplado como el punto de inflexión en el reconocimiento de la legitimación procesal colectiva. Vid. BUJOSA VADELL, L., La protección jurisdiccional..., op. cit. pp. 296 y 311 y ss.

${ }^{1516}$ Para un pormenorizado estudio del iter legislativo del precepto, así como de su contenido, vid. BUJOSA VADELL, L., La protección jurisdiccional..., op. cit. pp. 297 y ss, quien se pronuncia en favor de conferir a tal 
$\overline{\text { reconocimiento es observable, por tanto, un doble carácter en la participación de }}$ asociaciones y grupos: bien por estar afectados sus integrantes, es decir, por compartir sus miembros la titularidad de un interés jurídico individual, cuya suma genera uno más amplio, bien por estar legalmente habilitados en virtud de un reconocimiento público ${ }^{1517}$. Centrándonos en el ámbito penal, creemos poder afirmar que en ninguno de los dos casos estaremos ante supuestos de acusación popular, sino ante otro tipo de legitimación más restringida: bien la que se otorga a una amplia pluralidad de afectados por el hecho delictivo que, con una finalidad utilitarista, pueden agruparse, bien la que previo reconocimiento normativo expreso corresponderá a grupos específicamente habilitados a tal efecto.

\subsection{Los ejemplos del derecho comparado}

previsión no sólo un valor meramente programático, sino también el de una norma que debe ser aplicada inmediatamente por los Jueces pese a los riesgos de discrecionalidad que ello conlleva.

${ }^{1517}$ El término "grupo afectado" carece de un significado estrictamente jurídico y no constituye un concepto referido a una corporación ya constituída, sino que va mucho más en el sentido del 9.2 CE (“...el individuo y los grupos en que se integra"), que se inspiró claramente en el art. 2 de la Constitución italiana ("i diritti inviolabili dell'uomo... nelle formazioni sociali ove si svolge la sua personalità"). Sobre su contenido en relación con esta materia vid. UBERTIS, G., “Azione penale e sovranità popolare”, Riv. Ital. Dir. proc. Pen. 1975, p. 1213. Es, por tanto, un concepto más sociológico que jurídico y más fáctico que meramente formal. La pertenencia a un grupo de los que hace referencia ese inciso del art. 7.3 LOPJ puede ser totalmente independiente de la voluntad del sujeto y, en cualquier caso, no es trascendente la exigencia de requisito formal alguno en el que se exprese esa voluntad. Así, por ejemplo, la pertenencia a una familia, a un barrio, a la colectividad de pasajeros de un autobús. Lo trascendente será el individuo, el ciudadano singular que no desaparece en la colectividad en la que se integra, sino que mantiene una presencia personalizada e independiente, integrada y coordinada con la de los demás, pero con intereses propios. En el caso de los grupos "legalmente habilitados para la defensa y promoción (de intereses generales)", las presencias individuales desaparecen diluidas en la globalidad que supone una única voluntad común: la del grupo o corporación. La asociación se articula y se presenta frente al exterior de forma monolítica y no como conjunto de personalidades dispersas encadenadas por un interés común. De ahí que el régimen que se deba conferir a una u otra sea sustancialmente diferente: mientras que las primeras podrán ser, y de hecho en la mayoría de los casos lo serán, entes sin personalidad, que no surjan a la vida en tanto el daño no sea producido, las segundas precisarán de un explícito reconocimiento: la "habilitación legal" a la que se refiere el art. 7.3 LOPJ, y que necesariamente deberá ser previa a la comisión del hecho delictivo. Si en el primer caso la norma se refiere sólo genéricamente a "grupos", en el segundo parece exigirse un plus que pasaría por la constatación de que disponen de personalidad jurídica. No obstante, tal y como resalta BUJOSA VADELL, la contraposición entre corporaciones y asociaciones por un lado y "grupos que resulten afectados" por otro no debe llevar a la conclusión de que en el caso de los grupos inorgánicos no quepa una habilitación legal. BUJOSA VADELL, L., La protección jurisdiccional..., op. cit. p. 304. El propio ordenamiento jurídico español ofrece ejemplos de habilitación legal para la defensa de intereses colectivos a entes sin personalidad jurídica tales como las comunidades de propietarios de la Ley de Propiedad Horizontal. En contra se pronuncian GUTIÉRREZ SANZ, M.R. y SAMANES ARA, C., "Comentario al art. 7.3 de la LOPJ en relación con la protección procesal de los derechos de los consumidores", La Ley 1988, T. 2, p. 1158. 
La necesidad percibida social y políticamente de representación de intereses de naturaleza colectiva y la conveniencia de que ésta se haga presente también en el proceso penal es hoy una realidad común en todos los países de nuestro entorno. Ello ha obligado en algunos casos a un replanteamiento de concepciones restrictivas del concepto de legitimación procesal activa, asentado en sede penal en una larga tradición de exclusión de los particulares. Más allá de la denuncia quivis ex populo, presente en todos los sistemas, el modelo y la tendencia común del derecho comparado acerca de la participación de los ciudadanos en facultades acusatorias ha vuelto a aparecer junto con el tema de la participación de la "gran olvidada del proceso penal": la víctima. Prácticamente postergada desde finales del siglo XIX, la intervención activa en la acusación de sujetos privados individuales o colectivos en el proceso ha sido en este sentido objeto de profuso debate en los últimos tiempos. Pero a diferencia de lo que ha ocurrido en nuestro país, donde la acusación popular se ha convertido en el ropaje con el que se reviste toda intervención privada cuando no se trata estrictamente de la de un ofendido directo por el delito, en cuantas referencias se encuentran en modelos de derecho comparado, tal intervención se orienta a través de la participación de grupos constituidos para la defensa de intereses colectivos que son equiparados normativamente al ofendido por el delito. En ningún caso se prevén intervenciones privadas con la amplitud de nuestro sistema, pero al amparo de normas que habilitan en diferente medida la participación de determinadas asociaciones en la persecución del delito, se ha dado cabida a un tipo de legitimación en el proceso penal que se puede considerar ajeno a la tradición de aquellos sistemas y que es contemplado frecuentemente como una grieta en la base del monopolio acusatorio oficial.

Seguidamente se acometerá un somero examen de alguno de los diversos modelos que reconocen algún tipo de representación de intereses colectivos en el proceso penal a través de entes colectivos, prescindiendo conscientemente del estudio de dos sistemas clave de entre los cercanos a nosotros: el alemán y el inglés. Del primero se prescinde dado que, a pesar de que en algún caso se haya defendido lo contrario ${ }^{1518}$, las facultades

\footnotetext{
${ }^{1518}$ La opinión de que ha de permitirse la participación en el proceso penal a determinadas organizaciones cuando no exista un perjudicado directo fue planteada con motivo de la discusión sobre la intervención de la víctima en el proceso penal por RÖSSNER, D. y RÜDIGER, W., Opferbezogene Strafrechtspflege. Leitgedanken und Handlungsvorschläge für Praxis und Gesetzgebung, Bonn 1984, p. 3. Más recientemente, puede reseñarse el pronunciamiento de TIEDEMANN en el sentido de reconocer a ciertas asociaciones el carácter de ofendido en relación con el ejercicio del Klageerzwingungsverfahren. Vid. TIEDEMANN, K., "Thesen zu einem modernen menschenrechtsorientierten Strafprozeß”, ZRP 1992, no 3, p. 108. En el ámbito administrativo, la apertura de la legitimación para la tutela de normas medioambientales hasta propugnar una acción popular fue defendida por
} 
$\overline{\text { directas de acusación de las asociaciones en el proceso penal son en la actualidad }}$ inexistentes $^{1519}$. Del inglés, porque por virtud de su especificidad se estudiará más detenidamente en el siguiente capítulo de este trabajo ${ }^{1520}$. Con carácter previo se pueden extraer tres características situadas como denominador común en los ordenamientos en los que existe tal reconocimiento: 1) ausencia de una legitimación totalmente abierta, que obliga necesariamente a los sujetos intervinientes a contar con una habilitación legal expresa; 2) equiparación o asimilación de la posición procesal de la asociación a la de la víctima; y 3) garantía del monopolio acusatorio del MF, dado que ningún sujeto privado adquiere la condición de parte acusadora autónoma sino, simplemente y como máximo, la de coadyuvante procesal del MF o la de actor civil.

RUPP, H. H., "Popularklage in Umweltschutzrecht?", ZRP 1972, pp. 30-35. Con reservas frente a una legitimación abierta de tal naturaleza, si bien centrado en el proceso civil, vid. LEIPOLD, D., "Die Verbandsklage zum Schutz allgemeiner und breitgestreuter Interessen in der Bundesrepublik Deutschland", en GILLES, P., (editor) Effektivität des Rechtschutzes und verfassungsmäßige Ordnung. Die deutschen Landesberichte zum VII. Internationalen Kongreß für Prozeßrecht in Würzburg 1983, pp. 57 y ss., esp. p. 91 y ss. Son más frecuentes hoy las voces que reclaman una acción colectiva cuya titularidad pudieran ostentar determinadas asociaciones reconocidas a tal efecto y que estuviera sometida a algún tipo de control. Vid. en este sentido REHBINDER, BURGBACHER, KNIEPER, Bürgerklage im Umweltschutzrecht, Berlín 1972; REHBINDER, E., "Argumente für die Verbandsklage im Umweltrecht”, ZRP, 1976, 7, pp. 157 y ss.; BIZER, J./ ORMOND, T./ RIEDEL, U., Die Verbandsklage im Naturschutzrecht, Bremen 1990. En opinión de estos autores, esta acción se derivaría del art. 19.4 GG (la garantía de la protección de los derechos individuales), del principio democrático y de las obligaciones del Estado de Derecho. Más recientes son las aportaciones de WOLF, R., "Zur Entwicklung der Verbandsklage im Umweltrecht", Zeitschrift für Umweltrecht 1/1994, pp. 1-11 y WINCKELMANN, C., "Die Verbandsklsge im Umweltrecht im internationalen Vergleich", Zeitschrift für Umweltrecht 1/1994, pp. 12-14, donde se presenta un breve pero interesante estudio de derecho comparado sobre esta materia (Suiza, Holanda, EEUU).

${ }^{1519}$ La idea de la participación de asociaciones en la acusación ha contado con pronunciamientos expresos en contra, negándose incluso la posible consideración de las asociaciones como perjudicados. En este sentido se pronuncia WEIGEND, T., Deliktsopfer und Strafverfahren, op. cit. p. 420.

${ }^{1520}$ No podemos soslayar una referencia, siquiera mínima, a otros países anglosajones. Así por ejemplo, en Canadá se propuso oficialmente a mediados de la década de los 80 la ampliación de las facultades de los acusadores privados en relación con la necesaria intervención de la víctima en el proceso, en especial en la defensa de intereses de carácter colectivo, donde los grupos sociales actuarían como “perros guardianes” (sic) en sus respectivos ámbitos. Vid. LAW REFORM COMMISION OF CANADA, Private Prosecutions/Private Poursuits, Working Paper n 52 , Ottawa 1986, pp. 20 y ss. Sobre la acción popular para la protección del Medio Ambiente en algunos estados de Norteamérica (Michigan, Minnesota y Florida), así como alguna posibilidad a nivel federal, vid. KÖTZ, H., "Public Interest Litigation: a comparative survey" en la obra colectiva dirigida por CAPPELLETTI, M., Acces to Justice and the Welfare State, Florencia 1981, p. 110. 


\subsubsection{Italia}

El tema de la participación de entes colectivos en el proceso penal italiano ha estado siempre ligado, de una parte, al monopolio del planteamiento de la acusación por el Ministerio Público garantizado por su ejercicio obligatorio, y, de otra, a la intervención como parte civil ${ }^{1521}$. Si, con relación al primero, se admite que ha sido una constante histórica del proceso penal italiano ${ }^{1522}$, sobre la constitución como parte civil cabe decir que con el tiempo se operó progresivamente una lenta transformación de un instrumento procesal esencialmente resarcitorio en un instituto considerado idóneo para garantizar la participación de las formaciones sociales en la justicia penal ${ }^{1523}$.

A estos dos elementos se fue añadiendo a lo largo de los años 80 el reconocimiento por el legislador de una específica facultad de intervención procesal a determinadas asociaciones para la represión de delitos que afectaran a intereses de la comunidad, con carácter concurrente y de manera paralela a la acusación del Ministerio Público ${ }^{1524}$. Como

${ }^{1521}$ La defensa de intereses colectivos en el proceso penal a través de la actuación de asociaciones para su defensa había sido abordado por la doctrina italiana con anterioridad al nuevo Código casi siempre desde el punto de vista del ejercicio de la acción civil resarcitoria. Vid. en este sentido AMODIO, E., "L'azione penale delle associazioni dei consumatori per la repressione delle frodi allimentari", Riv. it. dir. proc. pen., 1974, pp. 515-536; BRICOLA, F., "Partecipazione e giustizia penale. Le azioni a tutela degli interessi collettivi", Questione Criminale, 1976, 6; ALBAMONTE, A., "Gli interessi collettivi ed il processo penale nel contesto della partecipazione popolare all'amministrazione della giustizia" en Rivista Penale, 1978, pp. 435-437; MARCONI, "La tutela degli interessi collettivi in ambito penale", Riv. it. dir. proc. pen., 1979, 1052; GRASSO., "Enti esponenziale ed esercizio dell'azione civile nel processo penale", Giustizia Penale, 1987, III, p. 1 y ss.

${ }^{1522}$ Se han suscitado dudas sobre si el art. 112 de la Constitución Italiana ("Il pubblico ministero ha l'obbligo di esercitare l'azione penale") reconoce, junto con la obligatoriedad de la acusación por el Ministerio Fiscal, el monopolio por parte de éste. En sentido contrario al monopolio se pronuncian por ejemplo AMODIO, E., “Azione...”, op. cit. p. 533 y BARONE, G., Enti collettivi e processo penale, Milan 1989, p. 249.

${ }^{1523}$ BARONE, G., Enti collettivi..., op. cit., pp. 170 y ss.

${ }^{1524}$ La más significativa es la conferida por la Ley de 8 de julio de 1986, n. 349, que instituye el Ministerio de Medio Ambiente y dicta normas en materia de daños ambientales en su art. 14.4. En él se especifica que "le associazioni di cui al precedente art. 13 e i cittadini, al fine di sollecitare l'essercizio dell'azione da parte dei soggetti legittimati, possono denunciare i fatti lesivi dei beni ambientali dei quali sono a conoscenza", lo cual ha sido interpretado como instrumento de activación de la Jurisdicción penal a través de la transmisión de una notitia criminis cualificada. Cfr. BARONE, G., Enti collettivi..., op. cit. p. 190. El ordenamiento italiano admite determinados ejemplos de acciones populares en ámbitos administrativos, tales como las normas electorales, de defensa de los intereses municipales y de beneficencia pública. Al respecto puede consultarse v. gr. LUGO, A., Voz “Azione popolare (parte generale)”, en Enciclopedia del Diritto, CALASSO, F. (Director), 1957; AGRIFOLIO, S., "Riflessioni critiche sulle azioni popolari come strumento di tutela degli interessi collettivi", en Le azioni a tutela di interessi collettivi. Atti del convegno di studio (Pavia, 11-12 giugno 1974), Padua 1976, pp. 181-190; GRASSO, "Una tutela giurisdizionale per l'ambiente", Riv. dir. proc., 1987, pp. 505 y ss.; TARUFFO, "La legittimazione ad agire e le tecniche di tutela nella nuova diciplina del danno ambientale", Riv. crit. dir. priv. 1987, pp. 429 y ss.; 
culminación de este proceso puede ser entendido el Codice di Procedura Penale de 1988, en el que se ha optado por una tercera vía completamente novedosa, a tenor de la cual se han abandonado tanto la vieja idea de atribuir a las asociaciones un verdadera y autónoma facultad de ejercitar la "acción penal" como la más reciente de una participación de los sujetos colectivos como parte civil en el proceso. En el nuevo texto procesal se ha optado por una intervención de entes colectivos entendida como exteriorización de un poder de mera acusación, en el que la connotación privada de la titularidad atribuida a un sujeto distinto del Fiscal convive con la dimensión pública resultante de la finalidad de cooperación en el ejercicio de la pretensión penal ${ }^{1525}$. A las organizaciones les viene conferida ex lege una doble tarea, situada por un lado en el auxilio y soporte del Ministerio Público y, por otro más trascendente, en el control de éste mediante la concesión de un status asimilado al del ofendido en cuanto sujeto colectivo representante del interés vulnerado por el delito.

Este reconocimiento va dirigido a reafirmar no sólo la representatividad del ente de que se trate, sino también la relevancia del interés protegido en el plano social y constitucional. Tal y como ha sido advertido por la doctrina, la intervención de los entes colectivos supone desde un plano constitucional un reforzamiento de los derechos inviolables del ciudadano, por lo que debe ser exigible del legislador ordinario la delimitación con prudencia de aquellos sectores en que esta participación sea admisible, en tanto la admisión indiscriminada de la intervención social presentaría graves implicaciones de orden constitucional y procesal. De un lado la presencia permanente de organizaciones en el proceso le otorgaría un matiz "colectivista", que llevaría a la opresión de los individuos por parte de las asociaciones y, de otro, podría producirse una contaminación del sistema acusatorio mediante una lesión del principio de "igualdad de armas" entre acusación y defensa por la diferencia de los medios a disposición de

LANDI, P., La tutela processuale dell'ambiente (art. 18 della lege 8 luglio 1986, n. 349), Padua 1991; CARAVITA, B., "Il ruolo delle associazioni nella tutela ambientale: dalla tutela giurisdizionale degli interessi diffusi al riconocimento legislativo", Diritto pubblico dell'ambiente, Bolonia 1990, pp. 277-304.

${ }^{1525}$ BARONE, op. et loc. ult. cit. Entre las obras publicadas con posterioridad al CPPItal vid. también MANTINI, P. et al., Associazioni ecologiste e tutela giurisdizionale dell'ambiente. Profili amministrativi, civile e penali, Rimini 1990, esp. el capítulo a cargo de GIAMPIETRO, F., pp. 187 y ss; RIVELLO, P.P, "Riflessioni sul ruolo ricoperto in ambito processuale dalla persona offesa dal reato e dagli enti esponenziali”, Riv. ital. dir. proc. penale, 1992, pp. 608 y ss.; MORETTI, B., "Enti esponenziali: costituzione di parte civile o intervento ex art. 91 ss. nel nuovo Codice di Procedura Penale", Riv. ital. dir. proc. penale 1994, pp. 1532 y ss. 
$\operatorname{ambos}^{1526}$.

El art. 91 CPPItal establece que "Gli enti e le associazioni senza scopo di lucro ai quali, anteriormente alla commissione del fatto per cui si procede, sono state riconosciute, in forza de legge, finalità di tutela degli interessi lesi dal reato, possono esercitare, in ogni stato e grado del procedimento, $i$ diritti e le facoltà attribuita alla persona offesa dal reato". Como se ve, el legislador atribuye así a determinados entes colectivos representantes de intereses lesionados por el delito los mismo derechos y las mismas facultades conferidas al ofendido ${ }^{1527}$, los cuales se podrán ejercitar en cualquier momento procesal (art. 93.4 CPPItal). Esta atribución no se individualiza mediante una norma general, sino que habrá de ser especificada en cada ocasión concreta con arreglo a las normas del Código. Se plasma así un nuevo sistema que, al apartarse de las concepciones existentes hasta ese momento, opera una clara diferenciación entre los sujetos portadores de pretensiones no penales, cuya intervención en el proceso se produce sólo en función de los efectos que podrían derivar del juicio penal en otras sedes, y aquéllos que son portadores de una propia y verdadera pretensión penal. Pretensiones civiles y pretensiones penales están por tanto netamente separadas en el plano de los instrumentos procesales destinados a hacerlas valer ${ }^{1528}$. Entre los intereses puramente privados y los intereses sociales objeto inmediato de tutela penal, el papel procesal de los entes colectivos asume una dimensión y una connotación totalmente original, que se aparta de su consideración como ofendidos y con ello de una posible desnaturalización de ese concepto $^{1529}$. La acción civil deja de ser el único cauce para la intervención de los

${ }^{1526}$ BARONE, G., Enti collettivi..., op. cit. pp. 252-3. El riesgo de erosión de este principio es justificado excepcionalmente por el autor en relación con los bienes colectivos (salud, medio ambiente...), puesto que en tales sectores la protección penal se enfrenta normalmente a imputados potentes y organizados. Para el resto de los supuestos no lo considera sin embargo admisible. Op. cit. p. 221.

${ }^{1527}$ De ahí quese haya dicho en alguna ocasión que se trata de un tipo de acción popular. Así se pronuncian por ejemplo MAIWALD, M. e IPPOLITI, A., “Eine neue Strafprozeßordnung für Italien”, JZ, n 19/1989, p. 876.

${ }^{1528}$ BARONE, G., Enti collettivi..., op. cit. pp. 98 y 206. Gran parte de la doctrina propugna el abandono de la tradicional dicotomía privado-público de origen decimonónico, en cuanto se halla superada hoy por una realidad social bien articulada. Incluso se ha llegado a decir por la biliografía especializada italiana que se podrían distinguir tres órdenes de intereses lesionados como consecuencia del delito: uno de carácter privado, al cual se refiere la intervención del ofendido, otro público tutelado con la intervención del Ministerio Público y un tercero colectivo, que legitima la intervención de las asociaciones representativas. Vid. MORETTI, B., "Enti esponenziali...”, op. cit. p. 1541.

${ }^{1529}$ La distorsión del concepto de acción civil para adaptarse a las nuevas necesidades sociales había sido resaltada doctrinalmente con frecuencia. Vid. p. ej. DI CHIARA, G., "Interessi collettivi e diffusi e tecniche di tutela nell'orizzonte del codice del 1988", Riv. ital. dir. e proc. penale 1991, p. 435. Al amparo del nuevo texto procesal, 
$\overline{\text { particulares en el proceso, y los entes colectivos asumen una situación jurídica habilitante }}$ para la intervención en el proceso penal sobre la base de una fictio iuris consistente en la asimilación a la titularidad del interés tutelado por la norma penal violada. Ese interés no es de naturaleza estrictamente privada, ni tampoco es de carácter penal sustancial, sino que es considerado simplemente un específico interés jurídico de contornos difusos, pero que en todo caso se constituye en interés habilitante de la intervención procesal de quienes como sujeto colectivo asumen su representación.

Las facultades que se les atribuyen explícitamente son de tres tipos: de carácter acusatorio, de solicitud de prueba y de impulso procesal y, entre ellas, se pueden citar: la de designar un defensor (art. 100 CPPItal por remisión del 101.2), solicitar la comparecencia de testigos, peritos, asistentes técnicos o de las partes privadas, así como la admisión de nuevos medios de prueba útiles para la comprobación de los hechos (art. 505 CPPItal), reclamar en el juicio oral la lectura de las declaraciones verbales o de los informes periciales obrantes en autos (art. 511.6 CPPItal, en relación con los números $1 \mathrm{a}$ 5), solicitar motivadamente del Ministerio Público la interposición de recursos, con la obligación expresa de éste de comunicar al solicitante mediante resolución motivada su decisión de no interponerlo (art. 572 CPPItal), etc. Pero además les corresponden también las mismas atribuciones que al ofendido por el delito (art. 91 CPPItal. in fine), entre las que se pueden destacar, a título de ejemplo, el derecho de indicar posibles elementos de prueba en cualquier momento del procedimiento (excepto en la casación) a través de una memoria (art. 90.1 in fine), el derecho a intervenir en la práctica de pruebas por el Ministerio Público no repetibles (art. 360), el derecho de solicitar al fiscal la promoción de un incidente probatorio (art. 394) así como la asistencia a éste (art. 401), el derecho de presentar oposición si el fiscal hubiera propuesto al juez el archivo con solicitud motivada de continuación de las investigaciones (art. 410), la facultad de pedir del Procurador General la avocación de la investigación preliminar (art. 413), el derecho a ser notificado

\footnotetext{
algunos autores entienden derogadas aquellas normas en las que se concedía un derecho a intervenir como parte civil a determinadas asociaciones, dejando a esta institución en el nuevo proceso penal una finalidad exclusivamente reparatoria y privada. Con ello pretenden evitar una contaminación privatista del proceso penal, excluyendo por ejemplo una formación de la prueba penal con la participación de sujetos titulares de pretensiones no penales, que conllevaría inevitables retrasos derivados de la introducción de intereses de naturaleza no penal y con sacrificio de la exigencia de celeridad propia del nuevo tipo de proceso. BARONE, G., Enti collettivi..., op. cit., p. 207. Sin embargo, tanto un sector de la doctrina como alguna de la jurisprudencia posterior al CPP, se orientan en el sentido de admitir como parte civil a los entes representativos de intereses supraindividuales cuando defienden un interés concreto y localizado territorialmente, es decir, cuando el interés se subjetiviza. Vid. MORETTI, B., "Enti esponenziali...”, op. cit. p. 1538.
} 
del señalamiento de la audiencia preliminar (art. 419) y del auto de apertura del juicio (art. 429), etc. Se trata, como se ve, del ejercicio de derechos y facultades de control en la actividad investigadora y de planteamiento de la acusación, y es precisamente en el terreno probatorio en lo referido a la represión de delitos socialmente dañosos y de gran relevancia para la comunidad donde la actividad de las asociaciones adquiere hoy su máxima trascendencia ${ }^{1530}$.

No toda asociación por el mero hecho de estar legalmente constituida y tener como objetivo la defensa de intereses de naturaleza colectiva puede tener acceso directo al proceso, sino que se requiere un reconocimiento administrativo expreso. La atribución de este reconocimiento habilitante de las asociaciones no se realiza con carácter discrecional, sino que se otorga al amparo de una norma legal y sólo se dará a los entes que reconozcan entre sus finalidades la tutela de intereses colectivos susceptibles de ser lesionados por el delito. Dado que tal norma habilitante deberá ser una ley ${ }^{1531}$ que, lógicamente, reflejará los criterios políticos del legislador en cada momento, el peligro que tal sistema conlleva se manifiesta a primera vista en la medida en que no es descartable el riesgo de que sólo accedan a esta categoría las asociaciones cercanas a centros de poder ${ }^{1532}$. Para obtener este reconocimiento habilitante, las asociaciones deberán solicitarlo a través de una petición en la que se recojan sus datos esenciales (denominación, sede, representante social, etc.), así como los procedimientos en los que se desee intervenir, el nombre del abogado que asumirá la defensa y una exposición sumaria de las razones de tal intervención (art. 93 CPPItal). La habilitación deberá hacerse efectiva con anterioridad a la comisión del hecho, con lo que se contribuye a garantizar la seriedad de la actividad, en tanto una asociación preexistente y no meramente ocasional asegurará mejor la tutela de bienes jurídicos supraindividuales lesionados por el delito. Estos intereses encontrarán de esa manera un centro de referencia ya constituído, y no se correrá el riesgo de que sean

${ }^{1530} \mathrm{La}$ calificación como derecho o facultad no es únicamente gramatical, sino que hay una diferencia notable: mientras que en el caso de los derechos es exigible del órgano público a quien se dirigen (juez o fiscal) un deber de pronunciamiento, el cumplimiento de un acto que sea expresión de una mera facultad no generaría en aquellos una obligación correlativa. Vid. SIRACUSANO, D., et al., Diritto Processuale Penale, vol. I., Milán 1994, p. 215.

${ }^{1531}$ Deberá ser bien una Ley estatal, bien una regional dictada en ejecución de una del Estado.

${ }^{1532}$ En otro sentido se ha señalado también como riesgo el que una excesiva laxitud en la norma pudiera originar un control por los órganos jurisdiccionales, que introdujera subrepticiamente en el plano operativo y con fines selectivos un filtro más fino, originador de valoraciones discrecionales y, en esa medida, de discriminaciones. Con el objeto de evitar la percepción de que los tipos de intereses privilegiados son demasiado amplios, ha sido elaborado el concepto de "bien colectivo fundamental de relevancia constitucional", que se alza como límite insuperable repecto a la intervención de sujetos colectivos en el proceso penal. Así BARONE, G., Enti collettivi..., op. cit. pp. 220 y s. 
acaparados por defensores ocasionales sino que se conocerá con carácter previo quiénes son los sujetos que pueden asumir tal tarea ${ }^{1533}$. Por último es de señalar que entre los requisitos exigibles con carácter general para el reconocimiento de las facultades previstas en el art. 91 CPPItal, se encuentra la ausencia de cualquier interés de lucro.

Dada la accesoriedad del ejercicio de las facultades conferidas en el proceso penal a las asociaciones, el art. 92 CPPItal exige la subordinación de su actividad al consentimiento del ofendido allí donde éste pueda ser personalmente individualizado. Este asentimiento del perjudicado está sujeto a requisitos formales ciertamente rigurosos, tendentes a garantizar su veracidad (debe resultar de acto público o escritura pública autenticada) y no se puede conferir, bajo sanción de nulidad, a más de una asociación (art. 92.2 CPPItal). Es revocable en cualquier momento, pero en este caso no podrá ser conferido de nuevo (art. 92. 3 y 4 CPPItal), con lo que parece clara la intención del legislador de asegurar la fiabilidad de la prestación del consentimiento, evitando que pudiera negociarse con él. Todos estos preceptos van dirigidos, por un lado, a impedir la intervención de quienes no sean del agrado del ofendido y, por otro, a evitar la más mínima sospecha de instrumentalización y de falta de espontaneidad de tal consenso, en cuanto en él pudieran concurrir maniobras no transparentes tanto de la parte que lo presta, como de la que lo solicita ${ }^{1534}$. Tratándose de una pluralidad de afectados podría darse el riesgo de intervención de una pluralidad de asociaciones a las que se hubiera otorgado consentimiento. La interpretación de la norma del 92.2 CPPItal parece clara en el sentido de excluir rigurosamente la proliferación de tales sujetos en el proceso penal, por lo que la solución parecería ser la admisibilidad de un consentimiento acumulativo en favor de un sólo ente. Con el fin de alejar el peligro de maniobras poco claras y de una instrumentalización de la prestación del consentimiento por el ofendido, el Juez deberá verificar de oficio y caso por caso la existencia y el mantenimiento de las condiciones a las que la ley subordina la presencia de los entes representativos en el proceso ${ }^{1535}$. Debe advertirse que si no fuera identificable la persona ofendida con carácter individual, el presupuesto del consenso no opera y, por consiguiente, no se condiciona la intervención

${ }^{1533}$ Cfr. Relazione al progetto preliminare del CPP.

${ }^{1534}$ CONSO, G. y GREVI, V., Profili del nuovo Codice di Procedura Penale, Padua 1990, p. 78; SIRACUSANO, D. et. al., Diritto Processuale Penale, vol. I, Milán 1994, p. 221.

${ }^{1535}$ BARONE, G., Enti collettivi..., op. cit. p. 219. 
de entes colectivos ${ }^{1536}$. Ha sido reconocido jurisprudencialmente por ello que las asociaciones ambientalistas pueden intervenir en el procedimiento por daños ambientales sin el previo consentimiento de particular ofendido alguno, al ser imposible determinar la parte ofendida, constituida por una colectividad territorialmente localizada en un cierto lugar y en un preciso momento histórico y, por tanto, sujeta a variación ${ }^{1537}$.

El CPPItal prevé la posibilidad de oposición a la intervención en el proceso de estas agrupaciones siempre que se repute que no cumplen los requisitos legales para el ejercicio de los derechos y facultades puestos en garantía de situaciones metaindividuales. Para esta oposición estarán legitimadas las partes efectivas o potenciales, según el estadio en el que la oposición se formula, así como el ofendido, que podrá revocar el consentimiento prestado (art. 95.1 CPPItal). Incluso el propio órgano jurisdiccional podrá de oficio examinar la concurrencia de los presupuestos habilitantes de la intervención para, en caso contrario, excluir al ente o asociación (art. 95.4 CPPItal). El Juez adoptará la decisión que considere oportuna sobre la intervención tras un trámite de audiencia.

\subsubsection{Francia}

El debate sobre la acusación de particulares se ha planteado históricamente en el país vecino en dos ocasiones: con motivo de la introducción de la institución del MF y, precisamente, de forma pareja al debate sobre la bondad de la participación de asociaciones en la persecución del delito. Si la primera podemos situarla cronológicamente en el periodo post-revolucionario, la segunda, que encontró alguna manifestación a finales del siglo pasado ${ }^{1538}$, ha vuelto a aparecer en épocas muy cercanas en el tiempo a

${ }^{1536}$ BARONE, G., Enti collettivi..., op. cit. p. 222.

${ }^{1537}$ Vid. CONSO, G. y GREVI, V., Commentario Breve al Nuovo Codice di Procedura Penale, Padua 1994, comentario al art. 91 (III). En el caso de malos tratos a animales se contempla también la admisión en el proceso de una asociación para la defensa de éstos, en cuanto el bien jurídico protegido no son los animales en sí, sino el sentimiento ético-social de humanidad hacia ellos. LANDI, P., La tutela processuale dell'ambiente, op. cit. p. 121 sostiene, sin embargo, una opinión discrepante, para afirmar que es preciso el consentimiento expreso prestado por el Estado o el ente territorial que ejercite la acción de responsabilidad. Destaca con ello la discriminación que se contiene en la legislación penal con respecto a la legislación civil, en la que sí se prevé una acción colectiva de las asociaciones.

${ }^{1538}$ La cuestión sobre la atribución de un papel activo a las asociaciones en la persecución del delito apareció planteada por primera vez en Francia a finales del siglo pasado por NOURRISON, P. , De la participation des particuliers à la poursuite des crimes et délits, París $1894 \mathrm{y}$, posteriormente, del mismo autor, L'association contre le crime, París 1901. En la propuesta formulada por él, bajo una clara influencia del sistema inglés de persecución de 
$\overline{\text { nosotros. Con motivo de la reivindicación de las funciones de la víctima en el proceso y }}$ con el objetivo de dar respuesta a las nuevas necesidades de representación de intereses de naturaleza colectiva a través de organizaciones privadas, públicas o para-públicas, el tema de las formas de participación de particulares en el proceso volvió a surgir así en la doctrina francesa en la década de los $80^{1539}$.

los delitos, se incluía la posibilidad de que determinadas asociaciones filantrópicas pudieran pretender la perseción de crímenes enmarcables dentro de su ámbito de competencias. El debate se reprodujo en el seno de la "Sociedad de prisiones" en 1896 (Révue pénitentiaire, 1896, pp. 510-528, 649-689), interviniendo en él las más señeras figuras de las ciencias penales francesas. Se estimó en aquel momento que el número de delitos había aumentado rápida y peligrosamente, y que la policía y la Justicia precisaban de ayuda. Incluso se alegaba que delitos no demasiado graves en sí mismos como la mendicidad, el vagabundeo o el furtivismo se dejaban de perseguir, con lo que ello significaba de inmoralidad y de riesgo de conducir a sus autores a delincuencia más grave. Se manifestó también el deseo de reproducir los esquemas del sistema inglés de persecución privada de las conductas consideradas contrarias a la moral, entre las que destacaban la prostitución y las publicaciones pornográficas. Personajes entonces célebres como el Senador René BÉRENGUER, fundador y presidente de la "Societé contre la licence des rues", y nostálgicos del orden moral que habían asumido el papel de guardianes de las buenas costumbres, celebraban propuestas de esta naturaleza, las cuales se ajustaban perfectamente a sus aspiraciones de control difuso de todos los delitos y específicamente de los que afectasen a las "sanas costumbres". El modelo que se deseaba instaurar era el inspirado en el sistema inglés, en el que las asociaciones de protección de la infancia y de los animales habían logrado un papel fundamental en la persecución de determinados delitos. A pesar de la opinión contraria de numerosos Magistrados que se oponían a otorgar a las asociaciones facultades que fueran más allá de la mera denuncia, la Societé des Prisons adoptó un "acuerdo favorable a la extensión del derecho de citación directa a las asociaciones reconocidas de utilidad pública especialmente autorizadas a este efecto y para los asuntos que se correspondan con el objeto mismo de su institución". A raíz de esta declaración y de truculentos asuntos muy populares en que las víctimas fueron niños, en 1898 se intentó abrir la puerta a la persecución de delitos contra la infancia a asociaciones especialmente dedicadas a su protección que hubiesen sido autorizadas por el Ministerio de Justicia (en concreto el frustrado art. 7 del proyecto que, sin ese precepto, llegó a ser la Ley de 19 de abril de 1898). Pero este precepto no llegó a aprobarse, puesto que fue combatido enérgicamente desde los bancos ocupados por los senadores representantes de la izquierda republicana y radical y desde los ocupados por la derecha política. Mientras que los primeros se mostraban temerosos de abrir un portillo demasiado amplio a corrientes conservadoras y clericales, los segundos veían en ello una abdicación de las obligaciones del MF, la instauración de una indeseable competencia privada y los riesgos de chantaje por parte de asociaciones cuestionables. Así, lo que había sido producto de un acuerdo con fines humanitarios entre senadores católicos y de la izquierda moderada, fue víctima de la conjunción entre dos extremos y se convirtió en el reflejo de la perenne querella Iglesia-Estado. Vid. Revue pénitentiaire cit. p. 688 y SCHNAPPER, B., "L'Action penale, le ministere public et les associations: naissance et contestation d'un quasi-monopole (XIX-XX siecles)" en Travaux du XXIII Congrès de l'Association française de criminologie..., pp. 31 y s. Sustentaron también esta opinión el criminalista JOLY, H., "Les associations et l'Etat dans la lutte contre le crime", Revue politique et parlamentaire, septiembre 1895, pp. 430 y ss.; VIDAL, G. Course de Droit Criminel et de Science Pénitentiaire, $3^{\mathrm{a}}$ ed., París 1906, p. 740, y $9^{\mathrm{a}}$ ed. (corregida por MAGNOL, J.) París 1949, p. 919. En cualquier caso, no fue el último intento de hacer partícipes a las asociaciones en la persecución del delito. Vid. por ejemplo las conclusiones claramente favorables a este sistema propugnadas por MERLE, P., Droit de Pursuite des particuliers (en matière d'Infraction à la loi pénale), Toulouse 1906, p. 165, quien alegaba la saludable influencia que supondría la intervención de las asociaciones de ayuda a la infancia, liberando a la policía de asuntos de menor importancia y confiriendo la posibilidad de mejorar la conducta de los padres con la amenaza de una querella criminal. Para este autor, el papel de las asociaciones sería el de estimular la actividad del MF y suplir su inactividad en asuntos de menor importancia. De esta manera se adoptarían los beneficios de este tipo de persecuciones sin asumir los problemas de la acusación de los no ofendidos (tentativas de chantaje, acuerdos, etc.).

${ }^{1539}$ En este sentido se enmarcan los Travaux du XXIII Congrès de l'Association française de criminologie, 
El papel tradicional de los grupos de defensa de intereses colectivos en el proceso penal francés se ha limitado básicamente al ejercicio de los derechos correspondientes al actor civil, limitados a los procesos en los que se dilucidaran cuestiones referentes a bienes jurídicos propios de su esfera sectorial ${ }^{1540}$. Su considerable extensión en la actualidad ha originado la introducción en la acción civil francesa de mayores elementos con finalidad represiva o vindicativa, en detrimento de los meramente reparadores o de indemnización ${ }^{1541}$. La utilización de la acción civil, ha ido trasluciendo así un sentimiento de sospecha, decepción y crítica a las deficiencias de la justicia penal ${ }^{1542}$. Su presencia en el proceso no ha permanecido libre de críticas, procedentes sobre todo de quienes consideran que con ella se amenaza la acción pública firmemente asentada sobre su histórico monopolio ${ }^{1543}$, pero goza hoy de la aceptación mayoritaria, al considerar que, con su contribución, la Justicia estará menos encerrada en sí misma y más abierta a la percepción de problemas sociales que aflorarán de forma colectiva y no con un carácter meramente individual. Esta preocupación por las nuevas formas de represión del delito con intervención de instancias privadas ha llevado a algún autor a decir que "más vale la fragmentación de las persecuciones que su asfixia" ${ }^{1544}$.

La promulgación de determinadas leyes en los años 80 ha operado una reformulación de la posibilidad de constituirse en parte civil a las organizaciones de

organisé par la'Association française de criminologie et par le Centre de recherches de politique criminelle (París, 17 y 18 de octubre de 1986), publicados en Archives de Politique Criminelle n ${ }^{\circ}$ 10, 1988.

${ }^{1540}$ Sobre el sistema tradicional de ejercicio de la acción civil en los casos de colectividades vid. GARRAUD, R., Traité théorique et pratique d'Instruccion Criminelle et de Procédure Pénale, T. I, París 1907, pp. 260 y ss. Vid. también WEIGEND, T., Deliktsopfer und Strafverfahren, op. cit. p. 420, n. 148.

${ }^{1541}$ BOULAN, F., "Le double visage de l'action civile exercée devant la jurisdiction répressive" en Juris Classeur Penale 1973. I. 2563, cit. por KUHNMUNCH, O., "La defense des interets collectifs et l'eclatament des poursuites" en Archives de Politique criminelle no 10, 1988, p. 50.

${ }^{1542}$ PIERRE, C., "Rapport de Synthese de Travaux du XXIII Congrès de l'Association française de criminologie...", op. cit. p. 87. Puede verse también LARGUIER, J., Action individuelle et intérêt général (Quelques reflexions sur le juge pénal et l'action civile), París 1964.

${ }^{1543}$ Cfr. LARGUIER, J., "L'action publique menacée. A propos de l'action civile des associations devant les juridictions répressives”, Dalloz, 1958, Chron. VI, p. 29.

${ }^{1544}$ KUHNMUNCH, O., "La defense des interets collectifs...", op. cit. p. 50. Las formas de intervención de las asociaciones en la persecución del delito no se agotan en la participación en el proceso, sino que podrían abarcar desde el control indirecto a través de la prensa a la contribución en la prevención de la delincuencia. 
$\overline{\text { protección de intereses difusos }}{ }^{1545}$. El fundamento legal de este reconocimiento es variado, pero se ha ido superponiendo en sus diversas modalidades al art. 2 CPPFr, atinente al ejercicio de la acción civil por el perjudicado. Se otorgan así facultades procesales específicamente a las asociaciones contra el racismo (art. 2-1), contra la violencia sexual (art. 2-2), de lucha contra los malos tratos a la infancia (art. 2-3), que combatan los crímenes contra la humanidad (art. 2-4), que defienda los intereses de los integrantes de la Resistencia (art. 2-5) y los antiguos combatientes (art. 2-11), contra la discriminación por razón de sexo (art. 2-6), de protección de espacios naturales (art. 2-7) y de los animales (art. 2-13), de defensa de los minusválidos (art. 2-8), de tutela de las víctimas de delitos de terrorismo (art. 2-9), de lucha contra la exclusión social (art. 2-10), de lucha contra la delincuencia en el tráfico (art. 2-12), de defensa de la lengua francesa (art. 2-14), de defensa de las víctimas de accidentes de los transportes públicos o de lugares abiertos al público (art. 2-15) ${ }^{1546}$, etc.

Los poderes de iniciativa procesal atribuidos a las asociaciones francesas para la defensa de intereses colectivos se refieren al ejercicio de pretensiones civiles en el juicio criminal y, en concreto, al resarcimiento o la reparación de los daños causados, sin que en ningún caso se ponga en cuestión el monopolio del ejercicio de la acusación de que goza el $\mathrm{MF}^{1547}$.

${ }^{1545}$ Estas normas vinieron precedidas por una tendencia jurisprudencial de apertura a la admisión de su papel activo en el proceso penal, fundada sobre el reconocimiento de un daño inmaterial directo causado por el delito sobre el objeto social de la asociación. Característica esencial del sistema francés a este respecto era que, salvo expreso reconocimiento normativo, la acción civil de una asociación no sería admisible más que cuando hubiera sido lesionada directamente por el delito, con lo que a falta de una previsión legal específica, se estaba de facto imposibilitando la asunción de un papel activo en la defensa de los intereses que las asociaciones representaban. De ahí que normalmente fuera utilizada la vía interpretativa para ampliar hasta límites cercanos a la deformación el instituto de la constitución en parte civil: a nuevas necesidades -la representación de intereses colectivos-, se intentó dar respuesta acomodando mecanismos procesales ya asentados en la tradición.

\footnotetext{
${ }^{1546}$ Entre estos actores civiles que contribuyen a la incoación del proceso penal se puede citar en primer lugar, cronológicamente y por razón de su importancia, el papel de los sindicatos, a los cuales ya desde finales del s. XIX se les vino reconociendo capacidad para el ejercicio de pretensiones colectivas de reparación del daño originado por delitos del ámbito social o laboral. No podemos olvidar tampoco las asociaciones de defensa de la moralidad pública con respecto a las infracciones cometidas a través de la prensa. Sobre estas puede verse HENRY, "Rapport à la Societé general des Prisons sur l'exercice de l'action civile par les associations à but désintéressé et spécialement par les ligues de moralité", Révue pénitentiaire, 1928, pp. 88 y ss.; COLLARD DE SLOOVERE, et al. en la memoria sobre el Congreso Internacional de Derecho Penal de Bucarest, Révue internationale de droit penal, VI, 1929, pp. 474 y ss.

${ }^{1547}$ Nos debemos remitir aquí, por ello, a lo que se expondrá en el capítulo siguiente al hilo del ejercicio de la acción civil en el proceso penal francés.
} 
Es condición para la admisibilidad de este tipo de acciones la correspondencia con el objeto de la persona moral aun cuando, a veces y para determinados tipos de infracciones, se amplíe el ámbito a los delitos conexos. En otros supuestos, la ley realiza una enumeración explícita de las infracciones por las que será admisible el ejercicio de acción civil ${ }^{1548}$. Un último requisito aplicable a algunos tipos de delitos es el necesario consentimiento de la víctima cuando la persona ofendida pueda ser individualizada, exigible por ejemplo en la intervención de este tipo de asociaciones en los procesos por delitos sexuales o motivados por el odio racial. Se requiere, además, un plus de antigüedad, cifrado normalmente en cinco años de existencia previa de la asociación antes de la comisión del hecho delictivo, al objeto de asegurar la concurrencia de una sólida estructura organizativa como garantía de fiabilidad ${ }^{1549}$. En ocasiones se precisa también una ulterior autorización administrativa para el ejercicio de la pretensión civil en el proceso penal, como ocurre por ejemplo con las asociaciones de consumidores. En este caso se establecen reglamentariamente tres criterios que operan como condiciones para determinar su reconocimiento administrativo en calidad de ente representativo: el primero de ellos será el de la antigüedad de al menos de un año, pero junto a él se requiere también la demostración de una efectiva actividad en defensa de los intereses de los consumidores y un número mínimo de afiliados que contribuyan con sus cotizaciones al sostenimiento de la asociación ${ }^{1550}$.

${ }^{1548}$ Este último es el caso del ejercicio de la acción civil derivada de delitos de agresión sexual o de discriminación por razón del sexo o de la orientación sexual, muy alejado por tanto de las atribuciones a las asociaciones para la defensa de la moralidad. Cfr. KUHNMUNCH, O., "La defense des interets collectifs...", op. cit. pp. 47 y s.

${ }^{1549}$ Se excluyen de esta limitación temporal las asociaciones que se propongan la persecución de los crímenes contra la humanidad o los de guerra, así como las de defensa de la moral y el honor de la Resistencia o los deportados. Cfr. art. 36.I de la Ley n ${ }^{\circ} 83-466$ de 10 de junio de 1983. Se entiende que es suficiente espacio temporal el transcurrido desde la comisión de los supuestos delitos de guerra. Esta posibilidad fue utilizada en el famoso asunto de la persecución por crímenes de guerra a Klaus Barbie en Lyon en 1985. Vid. KUHNMUNCH, O., "La defense des interets collectifs...”, op. cit. p. 41, n. 25.

\footnotetext{
${ }^{1550}$ Ha de tenerse en cuenta la Ley n ${ }^{\circ} 88-14$, de 5 de enero de 1988 , relativa a las actuaciones en justicia de las asociaciones reconocidas de consumidores y a la información de éstos, promulgada a raíz de la restricción operada por la Sentencia de la Cour de Cassation de 16 de enero de 1985, al interpretar la expresión "action civile" como referida únicamente a la reparación de un daño causado por una infracción penal. En la citada Ley se derogó el art. 46 de la n ${ }^{\circ} 73-1193$ de 27 de diciembre de 1973, de orientación del comercio y la artesanía, conocida como Ley Royer y pionera en Europa en el establecimiento de mecanismos de tutela de los consumidores. La Ley de 1988 establece en su art. 1 que las asociaciones reglamentariamente declaradas que tengan como objeto estatutario explícito la defensa de intereses de los consumidores, pueden, si han sido habilitadas con este fin (art. 2), ejercitar los derechos de la parte civil en relación con hechos delictivos que hayan ocasionado un perjuicio directo o indirecto al interés colectivo de los consumidores. Las condiciones de habilitación de las asociaciones para el ejercicio de la
} 
Instituciones similares de participación de las asociaciones en ejercicio de acciones civiles en el proceso penal se reconocen también en el derecho belga ${ }^{1551}$ y en el luxemburgués, específicamente en materia de protección de los consumidores ${ }^{1552}$.

\subsubsection{Portugal}

La promoción del proceso penal portugués, asentado sobre una estructura acusatoria, está regida por un sólido monopolio en manos del fiscal ${ }^{1553}$. La acusación es conceptuada en ese sentido como acto de promoción de la actividad tendente a la realización del derecho penal objetivo, esto es, el "poder-deber" del Ministerio Público (y sólo de éste) de proponer al Tribunal la apreciación de un tema atinente a la realización de una pretensión punitiva del Estado ${ }^{1554}$. Sin embargo, el art. 68.1 del Código de Processo Penal aprobado por Decreto-Ley n ${ }^{\circ}$ 78/87 de 17 de febrero prevé la posible constitución de un assistente en el proceso, sujeto al que el Código atribuirá la condición de participante procesal. Assistente puede ser, en primer lugar, el ofendido, es decir el titular directo de los intereses que la ley intenta proteger con el establecimiento de un tipo penal ${ }^{1555}$, pero pueden también asumir la posición de assistentes las personas a quien se

acción civil en el proceso penal, reguladas en la actualidad por el decreto 88-586 de 6 de mayo de 1988, no sufrieron modificación en relación con el sistema anterior. Al respecto vid. MORIN, A., "La acción de interés colectivo ejercida por las organizaciones de consumidores antes y después de la ley del 5 de enero de 1988", REDC 1991, pp. 3 y ss. y entre nuestra doctrina la detallada exposición de BUJOSA VADELL, L.M., La protección jurisdiccional..., op. cit. pp. 192 y ss. y 281.

${ }^{1551}$ En Bélgica, la Ley de atribución de un derecho a deducir pretensiones en materia de protección del medio ambiente a las asociaciones de 12 de enero de 1993, exige que se trate de asociaciones sin ánimo de lucro cuyo objeto social sea la protección del medio ambiente y que estatutariamente definan el ámbito territorial de actuación. Deberán tener atribuída personalidad jurídica por lo menos tres años antes de plantear la acción, así como demostrar mediante una memoria de sus actividades que realizan efectivamente una labor en concordancia con su objeto social.

${ }^{1552}$ Vid. también el resumen en materia de derecho de los consumidores contenido en el Boletín 2/85, "El acceso de los consummidores a la justicia", pp. 25 y ss. y el Libro Verde sobre el Acceso de los Consumidores a la Justicia y solución de litigios en el mercado único, presentado el 16 de noviembre de 1993.

${ }^{1553}$ Art. 224 de la Constitución Portuguesa. Existe una salvedad en relación con los delitos semipúblicos y privados, en cuyo análisis no entraremos.

${ }^{1554}$ FIGUEIREDO DIAS, J. de, "Sobre os sujeitos processuais no novo Código de Processo Penal" en el volumen colectivo O novo Código de Processo Penal, Coimbra 1988, p. 9.

${ }^{1555}$ Se trata de un concepto restringido de ofendido, que no se identifica con el de mero lesionado. Se excluyen de este concepto, a título de ejemplo, el mero poseedor en el delito de hurto, cualquier sujeto a excepción del Estado en el delito de falso testimonio o la Sociedad de Autores en delitos contra la propiedad intelectual en tanto lo que se 
les reconozca esta posibilidad en una ley sectorial, abriéndose así una vía de representación de intereses colectivos. Tal es el caso, por ejemplo, del Decreto Ley $\mathbf{n}^{\mathbf{o}}$ 28/84 de 20 de enero de Infracciones antieconómicas y contra la salud pública, que reconoce en su art. 43 que "Cualquier persona, singular o colectiva, puede intervenir como asistente en los procesos instaurados por delitos previstos en esta norma...", y en el 44 que, "las asociaciones de consumidores (ley 29/81) y las asociaciones profesionales son admitidas a intervenir como asistentes en los procesos por delitos previstos en esta norma" ${ }^{1556}$.

El art.69.1CPPPort configura a los assistentes como colaboradores o auxiliares del Ministerio Público, a cuya actividad subordinan su intervención en el proceso, por lo que no es factible que actúe sin que el fiscal lo haya hecho ya. No son meros sujetos procesales accesorios o secundarios dependientes en todo momento de aquél, sino que les vienen asignadas facultades propias tales como las de requerir investigación en relación con hechos por los que el Ministerio Fiscal no haya deducido acusación (art. 287.1.b CPPPort.), intervenir en la investigación y en la instrucción ofreciendo pruebas e instando las diligencias que consideren necesarias, deducir acusación independiente de la del MF e, incluso, recurrir las decisiones que les afecten (art. 69.2 CPPPort). Sin embargo, estas atribuciones podrían resultar equívocas, en cuanto pudiera llegar a pensarse en una posible acusación autónoma del assistente. Ello no es sin embargo así, pues, a tenor del art. 284.1 CPPPort, la ley le confiere solamente el derecho de requerir la apertura de la instrucción en crímenes públicos en caso de abstención del Ministerio Público (art. 287.1.b. CPPPort) o, como alternativa, provocar una intervención del superior jerárquico de aquél (art. 278 CPPPort). La acusación del assistente se limitará a la mera adhesión a la del Ministerio Público y sólo podrá solicitar las pruebas que no consten en la acusación del Ministerio Público (art. 284.2.b CPPPort).

Tomando como base la figura del assistente, se puede observar también un supuesto parejo a nuestra acusación popular en el sistema portugués de persecución los delitos de corrupción y malversación de caudales públicos (art. 68.1.e CPPPort). Dada la

protege son los derechos de los consumidores. Vid. la recopilación de jurisprudencia al respecto en TOLDA PINTO, A.A., O novo processo penal. Guia prático, Lisboa s.f. pp. 128-9.

${ }^{1556}$ También el art. 41 de la Ley 34/87 de 16 de julio de responsabilidad penal de los titulares de cargos políticos reconoce la facultad de acusar del Ministerio Público y, con subordinación a él, entre otros, sólamente a aquél ciudadano o entidad que hayan sido directamente ofendidos. 
$\overline{\text { peculiaridad de los bienes jurídicos protegidos, en este supuesto cualquier persona puede }}$ ser assistente, lo cual se traduce de hecho prácticamente en un ensanchamiento absoluto del concepto de ofendido ${ }^{1557}$.

\subsection{Propuesta de lege ferenda: asimilación al ofendido por el delito de las agrupaciones para la defensa de intereses colectivos}

I.

La acusación de determinados colectivos ha sido defendida en ocasiones desde la desconfianza en el MF, afirmando que "la acción popular puede asumir un importante papel en la persecución de aquellos delitos que puedan infringir un bien perteneciente a la esfera o patrimonio social, con respecto a los cuales se ha podido observar un escaso celo por parte del MF a la hora de ejercitar la acción y sostener la acusación penal "1558. Se ha alegado también la inadecuación del MF para la defensa de intereses de naturaleza colectiva con fundamento en otras razones: su excesiva semejanza cultural y psicológica con el Juez, que haría difícil su conversión en defensor de intereses grupales; su excesiva ligazón con el Ejecutivo; su caracterización como institución jerárquica y de carrera que le resta dinamismo y supone una cierta tendencia conservadora o, por lo menos, de ausencia de la rebeldía que exige la defensa de intereses por naturaleza conflictuales; su falta de especialización, que implica ausencia de preparación específica para enfrentarse a delitos complejos y, por último, la carencia de medios materiales y personales ${ }^{1559}$. A tenor de estas opiniones, el amparo de este tipo de intereses exigiría una agresividad ideológica y una versatilidad en las iniciativas que chocaría con la esclerotización y rigidez de las

${ }^{1557}$ Sin embargo, en opinión de FIGUEIREDO DIAS, J., Direito Processual Penal, vol. I, 1974, p. 514, la justificación de la norma ha de buscarse en el deseo del legislador de encontrar colaboración en todos los particulares para la detección y encausamiento de tales graves infracciones, si bien teóricamente se podría basar en que en estos casos cualquier ciudadano es particular e inmediatamente ofendido por la infracción. Se ha designado por ello a estos supuestos como “crimes de acção popular”. Vid. MAIA GONÇALVES, M. L., Código de Processo Penal Anotado, $7^{\mathrm{a}}$ ed. Coimbra 1996, p. 165.

${ }^{1558}$ GIMENO SENDRA, V., Constitución y Proceso, p. 85.

${ }^{1559}$ BUJOSA VADELL, L.M., "Notas ...”, op. cit. p. 114. 
estructuras burocráticas sobre las que el MF se organiza $^{1560}$.

No puede afirmarse que estos argumentos se ajusten en nuestros días totalmente a la verdad, y es necesario reconocer importantes avances en los últimos tiempos en la asunción por parte del MF de un papel activo en delitos como los medioambientales ${ }^{1561}$. Parece claro que alguna de estas razones se fundamentan sobre un sustrato de decepción sobre la aptitud de los concretos integrantes del MF y, lo que es más grave, de una resignación patológica que podría llevar a aceptar deficiencias del sistema como consustanciales a éste. Aun aceptando la parcial verdad del diagnóstico sobre el MF, es constatable la existencia de una inquietud efervescente en significados sectores de la fiscalía desde los que se propugna la imperiosa urgencia de una reconceptualización del Ministerio Público ${ }^{1562}$. No parece existir, además, razón fundamental alguna para que sea más frecuente en este tipo de procesos en favor de una tutela de intereses colectivos una actuación especialmente funesta del órgano público de acusación. Si estos intereses, considerados socialmente vitales, no encontrasen un adecuado defensor en el MF, órgano al que constitucional y estatutariamente viene encomendada la tutela del interés público (arts. $124 \mathrm{CE}$ y 1 EOMF), la tarea urgente consistirá en detectar los lugares donde se enmarquen esas insuficiencias para ponerles coto.

No compartimos el optimismo con el que se dibuja la acusación popular como tabla de salvación para la defensa de intereses grupales puesto que, a nuestro juicio, darnos por satisfechos y pensar en tener cubiertas las espaldas por contar con un instrumento de garantía de carácter privado, supondría doblegarse ante la impotencia y, lo que es más grave, aceptar una inadmisible delegación de competencias estatales en la esfera privada. La acusación popular podría así llevar ínsito el peligro de servir de alibi para justificar el enquistamiento de los fallos en el sistema y el peligro de tener que

${ }^{1560}$ En el mismo sentido, pero en relación a la justicia civil y, por tanto, con una diferencia esencial, se pronunciaba CAPPELLETTI, M., "Formazioni soziali e interessi di gruppo davanti alla giustizia civile", Riv. Dir. Proc., 1975, pp. 374 y ss. y con GARTH en "The Protection of diffuse, fragmented and collective interests in civil litigation", incluida en Effektiver Rechtsschutz und Verfassungmäßige Ordnung, Giesecking, Bielefeld 1983, pp. 129 y ss.

${ }^{1561}$ Sobre la actividad del MF en la protección del medio ambiente vid. esp. la Memoria de la FGE de 1994, pp. 673-695. Publicado también en Revista de Derecho Ambiental, nº 15, pp. 121-139.

${ }^{1562}$ Han de destacarse en este sentido la preocupación por reforzar el imparcial desarrollo de su actividad reduciendo al mínimo su dependencia jerárquica del Ejecutivo, la reivindicación de un incremento de las dotaciones de material y personal, la especialización de consuno con las nuevas tareas asumibles y con las progresivas y complejas situaciones a que han de hacer frente, etc. 
aceptar la subjetividad de los distintos grupos en la selección de los objetivos. Confiar en que la actividad de particulares organizados aporte mediante la acusación un plus que venga a colmar lagunas o deficiencias del Ministerio Público en la defensa de bienes jurídicos colectivos, podría equivaler a depositar a ciegas una desmedida fe en un porvenir incierto, sin haber asegurado antes el presente.

Sin querer pasar por alto las graves contradicciones y subsiguientes disfuncionalidades del Ministerio Público, convendría preguntarnos ahora si la insuficiencia de su actividad detectada en relación con estas materias no se corresponderá en alguna medida con la ausencia de iniciativas ciudadanas mucho más sencillas y menos gravosas que la de personarse en el proceso penal, como puede ser la de la mera denuncia ${ }^{1563}$. Deberíamos cuestionarnos en esta línea por qué los ciudadanos no acuden individual o colectivamente (o no lo hacen de manera suficiente) ante las autoridades para revelar la comisión de conductas delictivas que afectan al interés general, si la colaboración de ciudadanos concienciados e informados es, sin duda, el mejor sistema para la detección y persecución de este tipo de delitos ${ }^{1564}$. Una vía de cooperación estable con la autoridad pública por parte de los grupos que por su especialización abordan temas a los que el derecho penal es sensible, les convertiría en cooperantes y haría de ellos una meritoria fuente de información en la que primarían los aspectos de concienciación y colaboración frente a los de conflicto ${ }^{1565}$. De esta manera, asumirían la tarea, si no de participantes directos en el proceso, sí por lo menos de difusores de la actividad estatal en un tema de tanta trascendencia social como es la persecución de delitos socialmente muy dañosos y de perjuicios difícilmente personalizables por aquéllos de quienes es constitucionalmente

${ }^{1563}$ Vid. así por ejemplo BRICOLA, "Participazione e giustizia penale. Le azioni a tutela degli interessi collettivi”, $Q C, 1976$, pp. 11 y s.

${ }^{1564}$ Cabe traer a colación aquí la Circular de la FGE 1/1990 de 26 de septiembre, en la que se impulsa a la asunción por parte de los miembros del MF de un planteamiento activo en tales funciones, adoptando las iniciativas y utilizando todos los medios que les otorga la legalidad vigente, entre los que ha de contarse la recepción de denuncias a través de los "grupos ecológicos" (sic). Vid. también PÉREZ DE GREGORIO, J.J., "Las asociaciones ecologistas y de defensa ambiental como colaboradoras del Poder Judicial”, en VERCHER / PERIS, La protección del medio ambiente en España, p. 209. Este autor, fiscal especializado en temas medioambientales, ha señalado también el importante papel que pueden desempeñar este tipo de asociaciones en las funciones de asesoramiento técnico y científico al MF y los Tribunales penales para la correcta iniciación del proceso y su eficaz conclusión.

${ }^{1565}$ La posible extensión del (o equiparación al) concepto de ofendido a estos entes cuando hubieran sido los denunciantes debería conllevar necesariamente la información, cuando menos y en su caso, sobre el archivo de las denuncias tal y como prevé el art. 785 bis 1 en el caso de investigaciones realizadas por la Fiscalía. 
exigible $^{1566}$

La compatibilización entre iniciativas privadas y públicas de forma que mutuamente se vigilen y controlen no deja de ser atractiva, por cuanto es hábil para acarrear resultados positivos. De lo que se trata en este momento es de negar la idoneidad de remedios vistosos, pero no siempre dotados de operatividad, frente a déficits palpables y actuales del MF: puesto que la Fiscalía carece de especialización suficiente, lo correcto sería proveer los cauces para que alguno de sus integrantes se instruyera en materias relevantes o que contara con el permanente asesoramiento de especialistas; puesto que es evidente que requiere más medios materiales y humanos, lo lógico sería reclamar un aumento de éstos; puesto que la experiencia nos dice que en demasiadas ocasiones se revela como correa de transmisión de órdenes del Ejecutivo no siempre legalmente admisibles, lo óptimo sería habilitar un sistema de amortiguación de los efectos indeseables de su dependencia exigida constitucionalmente, etc. Se dirá por el contrario que, precisamente dadas esas deficiencias y conscientes de ellas, deberemos hacer acopio de los medios necesarios para combatirlas, para lo cual la acusación popular constituiría uno de ellos. Sin negar que en alguna ocasión pueda ser así, y precisamente porque en otros muchos casos no lo será, las esperanzas que cabe cifrar en su efectividad en la práctica no pueden ser sobredimensionadas, sobre todo si se tiene en cuenta que el trasvase de atribuciones públicas a la esfera privada puede ser una forma de solapar alguna de las solubles deficiencias en el funcionamiento de los órganos públicos.

II.

La unanimidad existente entre nuestra doctrina sobre la inadecuación, insuficiencia o incapacidad de las estructuras procesales clásicas liberales para acometer la defensa de intereses colectivos, constituye un punto de partida que compartimos. Entendemos, sin embargo, que en estas hipótesis no estamos ante supuestos de acusación popular, sino ante una realidad diferente que debería ser reconocida de forma expresa por nuestras normas procesales. A nuestro juicio debería avanzarse un paso más en esta materia, hasta llegar a afirmar que la presencia de defensores de intereses no individualizables en el proceso

${ }^{1566}$ No puede pasarse por alto que la repercusión pública que alcanza la actividad procesal de este tipo de agrupaciones cuando se realiza en relación con un tema "perteneciente a la esfera o patrimonio social" convierte voluntaria o involuntariamente el proceso penal en un lugar de discusión pública sobre cuestiones socialmente trascendentes o relevantes. 
penal ha de abordarse de una forma cualitativamente distinta a la de la acusación sostenida por un no ofendido ${ }^{1567}$.

La facultad para acusar sin ser ofendido, en tanto "popular", se reconoce en abstracto y sin relación con específicos intereses materiales, por lo que su ejercitante no precisa invocar lesión de derecho subjetivo ni de interés legítimo alguno, ni cabría en absoluto indagar la motivación que le impulsa a asumir el esfuerzo que supone su actividad procesal. Ello sería totalmente irrelevante para su admisión, puesto que precisamente la existencia de un vínculo entre sujeto y objeto, con independencia del número de sujetos de los que éste sea predicable y de la evanescencia o concreción de su interés, nos aportará pistas sobre la caracterización de una pretensión como no popular. Desde el momento en que hablemos de exigencia de un interés concreto, aun cuando pongamos a éste apellidos de contornos tan difuminados entre sí tales como "legítimo", "directo" o "personal", estaremos marcando ya la línea divisoria a partir de la cual el concepto de acusación popular ha de quedar automáticamente excluído.

La legitimación colectiva en el proceso penal adquiere una dimensión intrínsecamente diversa a lo expuesto, en la medida en que habrán de ponderarse los lazos que unen a sujeto y objeto procesal. Se requiere, por ende, llegar a distinguir entre la verdadera acusación popular frente a la habilitación para la defensa colectiva de intereses de carácter material y titularidad generalizada, cuyo fundamento se encontraría en el art. 7.3 LOPJ. Si en la primera no será necesario esgrimir interés específico alguno para poder acusar, en la segunda sí deberá haber una correlación entre el ámbito de la organización de que se trate y el bien jurídico que se afirme lesionado ${ }^{1568}$. Así como, en general, el ciudadano asiste con buenos ojos al hecho de que un grupo ecologista en su tarea de defensa del equilibrio medioambiental intervenga activamente en un delito de contaminación, no ocurriría otro

\footnotetext{
${ }^{1567}$ Es necesario en este sentido superar progresivamente la configuración de la acusación popular como uno de los dos únicos baluartes de la publicidad en el sentido expuesto por PEDRAZ al afirmar que "la publicidad en su primitivo sentido liberal ha perdido gran parte de su significado salvo en los dos únicos baluartes subsistentes: la motivación de las resoluciones y la acción popular, no como instituto diseñado en el s. XIX para reforzar la liberalización de la sociedad, sino para su posible uso en defensa de los intereses legítimos colectivos (art. 7 LOPJy 24.1CE) o de intereses de grupo o difusos". PEDRAZ PENALVA, E., "Notas sobre publicidad y proceso", PJ, $\mathrm{n}^{\circ}$ especial XI, p. 129 y en Constitución, Jurisdicción y Proceso, op. cit. pp. 223 y ss.

${ }^{1568}$ Afirmaba AMODIO que el papel de las asociaciones de consumidores no es asimilable al del actor popular, ya que en este caso el ciudadano hace valer ocasionalmente el interés en la represión de un hecho criminal, pero las asociaciones promueven la tutela de un interés colectivo de acuerdo a su objeto institucional. AMODIO, E., “L’azione penale delle asociazioni dei consomatori”, op. cit. p. 529.
} 
tanto si ese mismo grupo lo hiciera, por ejemplo, en un caso de agresión sexual o de homicidio. A fin de que tales sujetos no se extralimiten en las funciones que el ordenamiento jurídico pretende otorgarles, parece necesario requerir una conexión entre el concreto interés material y los objetivos para los que se creó la entidad o los que motivan su existencia. Estar habilitado para defender el interés público procesal, conducente en su caso a la aplicación de la norma penal, sea cual sea ésta y sin reparar en su contenido, o estarlo solamente para defender un interés derivado del enjuiciamiento, que conduzca eventualmente a la aplicación de una norma que protege un bien jurídico concreto, son presupuestos de partida diversos a los que, naturalmente, debe asignarse un tratamiento jurídico diverso $^{1569}$.

El ejercicio popular de la acusación no es comprensible como vía para la tutela de singulares intereses jurídico-materiales o como representación de éstos, sino que sólo admite ser dibujada por el ordenamiento jurídico como mecanismo de cierre del sistema. Considerar al acusador popular representante de bienes jurídicos (medio ambiente, salud pública, etc) es realizar un enfoque desviado del tema, puesto que su propia naturaleza excluye la vinculación con el objeto de tutela de la norma material. Su papel no es el de defensor de interés material alguno, sino el de valedor de un único interés de carácter público, consistente en la afirmación de la concurrencia de los presupuestos para el enjuiciamiento de un sujeto por unos hechos. O dicho con otras palabras, el acusador popular no actúa supliendo la voluntad de nadie que haya sufrido un perjuicio por el delito, aun cuando esa ofensa sea tan tenue que se entienda difuminada entre todos los miembros de la sociedad, sino que obra única y exclusivamente en virtud de un mandato que la colectividad autoorganizada ha atribuido al Estado: la función de acusación. El ámbito de la acusación popular stricto sensu es -y sólo puede ser-, pues, el de la defensa del genérico interés público, pero no la de concretos intereses protegidos por la norma penal. Aun cuando los intereses hechos valer no sean de carácter individual, sino que coincidan o se solapen con los de una colectividad más o menos determinada, seguirán siendo intereses materiales, por lo que parece claro que la acusación de sujetos colectivos se realiza en estas hipótesis como representantes de ellos. El sentido dogmático de la acusación popular en nuestro sistema, desde una perspectiva teórico-jurídica, no admite conceptualmente su encaje en estas hipótesis. La doctrina sentada por el TC ha venido requiriendo, además, que la intervención activa de las personas jurídicas en el proceso

\footnotetext{
${ }^{1569}$ Sentido en el que ya se ha pronunciado reiteradamente la doctrina del TC.
} 
$\overline{\text { penal tenga alguna conexión con los fines asociativos de éstas }}{ }^{1570}$, con lo que la frontera entre acusación popular y acusación de los grupos de defensa de intereses colectivos vendrá acotada por la constatación del nexo entre sujeto actor y concreto bien jurídico protegido por la norma material.

Estamos, no obstante, ante supuestos en los que ni el concepto de derecho subjetivo ni el de interés legítimo podrían ser aplicables sin problemas, pero donde la presencia de grupos organizados y reconocidos por el ordenamiento constituye ciertamente un válido referente de atribución de facultades procesales. La necesidad social y política de que tales intereses se vean representados puede imponer la apertura del proceso al ejercicio de pretensiones penales por sujetos particulares, por lo que ha de considerarse bienvenida toda iniciativa conducente a su mejor tutela. El problema se cifrará a partir de aquí en determinar en qué supuestos y con qué condiciones será socialmente aceptable la aparición de valedores de bienes jurídicos colectivos, pero no parece aconsejable cerrar los ojos a la esencia del problema afirmando que quienes pretendan defenderlos deban hacerlo a través del ejercicio popular de la acusación. Estos sujetos activos, cuya mera existencia se revela fundamental para la profundización de las libertades democráticas inherentes al Estado Social y a la transformación de las relaciones ciudadano-Estado, no deben ser considerados como "un sujeto cualquiera más" que se interesa por la garantía de la paz social a través de la persecución de todos los delitos, sino como representantes de un peculiar interés material, jurídicamente tutelable, que se afirma vulnerado, lo cual origina que su intervención procesal sea diferente y cualificada con respecto al de otros sujetos. Aun cuando una y otra finalidad no se excluyan entre sí, sino que, en ocasiones, se complementen, ello no debe hacer confundir el objetivo a alcanzar con los medios utilizados en el empeño. La defensa a través de los grupos de intereses colectivos propios de su objeto, afortunadamente aceptada hoy con carácter general, debe por ende orientarse lege ferendae de modo que traduzca esa especificidad.

El grave riesgo de considerar el proceso criminal como lugar adecuado para el planteamiento de conflictos sociales se cifra entre otros extremos en el empleo de mecanismos inadecuados a la estructura y finalidad constitucional de la Justicia, con

${ }^{1570}$ SSTC 241/1992 de 21 de diciembre de 1992 (FJ 5º) (Mujeres de Policía Nacional en relación con delitos de apología del terrorismo), 34/1994 de 31 de enero (asociación ecologista en delito de prevaricación de un funcionario sobre el objeto de una infracción medioambiental). Afirma el TC en esta última sentencia que "...no puede negarse que existen algunas infracciones cuya persecución se conecta directamente con el objeto de ciertas entidades asociativas. Esto es lo que sucede precisamente con el de la Asociación recurrente". 
miras a la consolidación de procesos de legitimación ${ }^{1571}$ que deberían ser ajenos al lugar donde se actúa el ius puniendi. Aun cuando los intereses a defender por los entes colectivos no sean estrictamente penales, las casi omnímodas facultades del Juez para el esclarecimiento de los hechos que generan expectativas de reunión de un material apto para su eventual empleo en otros órdenes, la mayor rapidez y contundencia de los fallos penales, el que posteriormente éstos sean más fácilmente ejecutables, la mayor carga de estigmatización que el proceso penal conlleva y los menores costes que origina, hacen de la persecución penal un cauce a través del que se canaliza la satisfacción de demasiadas pretensiones que en origen serían civiles o administrativas ${ }^{1572}$. El proceso penal, en cuanto tal, comporta hoy -fruto de sucesivas aportaciones históricas- una serie de

${ }^{1571}$ Como puede verse, usamos el término "procesos de legitimación” con un sentido extra y metaprocesal propio de enfoques como el estudiado certeramente entre otros por HABERMAS, J., Problemas de legitimación en el capitalismo tardío, con indudables raices en el clásico trabajo de SCHMITT, C., Legalidad y legitimidad.

${ }^{1572}$ Un ejemplo de ello puede ser el acuerdo firmado en junio de 1994 entre, por una parte, la empresa ENDESA, titular de una central térmica presunta responsable de daños al Medio Ambiente en la comarca de Els Ports-Maestrat (Castellón), y, por otra, la Generalitat Valenciana, los Ayuntamientos cuyos términos municipales habían sufrido la contaminación de la central térmica y tres asociaciones ecologistas. En este caso, el iter judicial había comenzado por una demanda civil interpuesta contra la empresa. Ésta quedó paralizada pronto por la vis atractiva del proceso penal suscitado, en el que concurrieron en calidad de acusadores no sólo los Ayuntamientos afectados, sino también tres asociaciones ecologistas bien implantadas en la zona (Acció ecologista Agró, Colla ecologista de Castelló y Grup ecologista de Vilafranca). Al tener noticia éstas últimas del intento de llegar a un acuerdo privado, a instancias y con apoyo de la Generalitat Valenciana, entre la empresa presunta responsable de la contaminación y los Ayuntamientos afectados, manifestaron su intención de proseguir en su acusación, aun conscientes de la dificultad de conseguir una condena de los responsables (órdenes de la Fiscalía General del Estado habían cerrado el paso a la petición de procesamiento los altos cargos de la empresa). A la vista de las circunstancias, la empresa optó por reconocer a las asociaciones ecologistas la legitimidad necesaria para entrar en la negociación que ya estaba en marcha, a cambio del "desistimiento" de su querella. Su presencia posterior en el proceso de negociación contribuyó a concluir un acuerdo entre todas las partes en conflicto. Este convenio, dotado con la aportación económica de la empresa acusada y de la Administración, recogía, entre otros, el compromiso de reducción de las emisiones, la estricta vigilancia de éstas y la constitución de una fundación para la recuperación y mejora ecológica de Els PortsMaestrat con la presencia de todos los que intervinieron en aquella negociación.

Constituyó ésta, como se ve, una vía de arreglo civil de una cuestión penal, donde se dilucidaban importantes cuestiones que afectaban a derechos de naturaleza extraindividual. Y es esta la razón por la que el acuerdo no ha gozado de aceptación general entre otras asociaciones ecologistas ni entre todos los integrantes de las que lo firmaron: la función de prevención general del derecho penal, más en una materia tan sensible como ésta, impediría todo acuerdo de naturaleza negociada que impida la aplicación de la norma. Los defensores del acuerdo alegan su efecto positivo, por cuanto, aunque no hay condena, sí hay un reconocimiento implícito de la culpabilidad, un propósito de reducción del daño en el futuro y un compromiso de dotar con los necesarios fondos la restauración del daño y la mejora del Medio Ambiente de la zona. En definitiva, la intervención de defensores de intereses de naturaleza colectiva se activó a través de un proceso penal, llegándose a una solución de otra naturaleza a la que no hubieran tenido acceso posible en otras circunstancias que no fueran la de contar con un arma de presión. Este arma era la propia continuación del proceso penal abanderada por alguien que contaría con el apoyo de la opinión pública y originaría daños superiores, aun sin condena. Como epílogo ha de señalarse que el proceso no terminó ahí, puesto que algunos propietarios de terrenos afectados sitos en Cataluña (es decir, fuera del ámbito territorial del acuerdo) continuaron, con pocas perspectivas de éxito, personados en la causa. 
$\overline{\text { garantías resumibles en el debido proceso que, por estar articuladas en defensa del orden }}$ jurídico, pero con prevalente incidencia en el acusado, nos lo muestran como un instituto demasiado rígido y en sí poco idóneo para la satisfacción de cualquier pretensión extravagante, por lícita que ésta sea. Las carencias en la apertura de la capacidad para actuar válidamente en los procesos civiles y administrativos y la vis attractiva característica del penal, podrían llegar a privarle de su carácter de ultima ratio, confiriéndole una naturaleza que no le corresponde: la de constituir un mecanismo de respuesta para todos los presuntos ilícitos que no encuentren cauce representativo adecuado. No es por tanto admisible que el procedimiento penal se convierta en el lugar de representación de legítimos intereses más allá de lo que su propia esencia reclama, ni lo sería su utilización como sucedáneo justificativo de un inexistente debate político, utilizando al judicial como sustitutivo del legislador al atribuirle funciones cualitativamente diferentes a las que constitucionalmente le vienen conferidas.

\section{III.}

En el ejercicio de la acusación es menester el trazado de una clara línea divisoria entre las facultades del titular o representante del bien jurídico dañado o puesto en peligro, frente a quien no ostenta tal condición. Sobre esta premisa, se habrá de concluir necesariamente que la acusación popular de nuestro proceso penal no se corresponde con las funciones del primero, sino con las del segundo. No establecer esa distinción y permanecer afirmando su confusión en la figura del acusador popular puede acarrear dos consecuencias confrontadas pero igualmente incorrectas: 1) el establecimiento de trabas superfluas y obstativas a quienes pretendan la defensa de un interés supraindividual de naturaleza material y diferente del mero interés procesal en la garantía de la paz social en abstracto o 2) la excesiva apertura del proceso a quienes, haciendo valer un supuesto derecho propio a la instauración y participación en éste, se sirvan de él únicamente para alcanzar espurias finalidades publicitarias a costa de la credibilidad del sistema. Abrir de par en par las puertas del proceso puede dar lugar a dar entrada en él a patologías inútiles más que a los que, ideológicamente, se afirman beneficiosos aires participativos. Por contra, cerrar del todo esas puertas a representantes de intereses materiales caracterizados por su indefinición subjetiva sería tanto como establecer diferencias en función del objeto procesal. El esfuerzo en conjugar esas realidades es uno de los objetivos de las reflexiones 
que aquí se realizan $^{1573}$.

Cuando el bien jurídico que se afirma vulnerado carezca de un titular individual que pueda afirmarlo como propio, de una persona distinguida por una lesión de carácter cualitativamente distinto de la del común de los ciudadanos, la necesidad de que sus legítimos intereses se vean representados procesalmente no desaparece, sino que simplemente se hace más difícil y deberá transcurrir por caminos poco transitados que nos compelen a intentar buscar soluciones novedosas. La apertura de la legitimación procesal en estos casos ha de venir, al igual que en otros órdenes jurisdiccionales, de la mano de la ampliación en el plano material del concepto del interés legítimo, dejando paso a su defensa procesal por los sujetos colectivos que lo representen. Si la flexibilización de las instituciones procesales clásicas, sobre la que ya se está avanzando en los procesos civil o administrativo, no se ha percibido necesaria en el penal, ello ha sido precisamente por el amparo que ha ofrecido tradicionalmente en nuestro sistema la acusación popular. Empero, al objeto de hacer valer concretos intereses en relación con el bien jurídico dañado o puesto en peligro, el cauce no puede seguir siendo éste, sino que en el futuro podría articularse a través de otro que, si bien nació a la par y como especialidad de la propia acusación popular, encuentra hoy diferente fundamento: la "acusación particular", eso sí, ejercitada no por la víctima sino por alguien que pretende la tutela de similares intereses $^{1574}$.

${ }^{1573}$ La Recomendación N ${ }^{\circ} \mathrm{R}(83) 7$ del Comité de Ministros del Consejo de Europa sobre "la participación del público en la política criminal" instaba a los Estados miembros a reconocer en sus respectivos ordenamientos la habilitación de formas adecuadas de participación de los ciudadanos en la lucha contra la criminalidad. Sin embargo, ningún Estado, ni siquiera los que mantenían sistemas de acusación privada, ha llegado tan lejos en la apertura de teóricos ámbitos participativos superadores de lo que en el ordenamiento español representa la acusación popular. A la consecución de esos anhelos de representación de intereses colectivos, hasta no hace mucho ausentes de las normas procesales, se dirigen en todos los Estados de nuestro entorno las formas de equiparación con los ofendidos por el delito de las asociaciones para su defensa. El texto de la Recomendación citada puede verse en MORENILLA RODRIGUEZ (Coordinador), "La Justicia Penal y la política criminal en el Consejo de Europa", Documentación Jurídica $\mathrm{n}^{\circ}$ 56, Tomo XIV, oct-dic 1987, p. 329.

${ }^{1574}$ La equiparación de la posición procesal de las asociaciones para la defensa de intereses colectivos con la del ofendido por el delito no es novedosa en nuestra doctrina y, en alguna ocasión, ha sido ya reseñada la conveniencia de realizar algún tipo de equivalencia entre el acusador popular y el ofendido cuando se tratase de delitos que afecten a intereses generales. Así, por ejemplo, la exclusión de la necesidad de querella en estos casos ha sido defendida, entre otros, por JORI TOLOSA, J.L., "Problemática procesal de la protección de intereses difusos", en BOIX REIG, J., Intereses difusos..., op. cit. p. 102. En esa dirección apuntan también alguna de las propuestas de GIMENO SENDRA, V. y GARBERÍ LLOBREGAT, J., "La protección procesal...”, op. cit. pp. 157-8, realizadas con la vista puesta en los delitos medioambientales y presentadas como desiderata para una futura "ley de defensa del Medio ambiente". A tenor de su opinión, debiera otorgarse un mandato ex lege a las asociaciones no gubernamentales y sin espíritu de lucro legalmente inscritas, a fin de que pudieran ejercer, en nombre de los perjudicados, las acciones 
La presencia de un acusador popular stricto sensu en estas hipótesis no daría adecuada respuesta a los intereses que se reputa deben estar representados en el proceso, por lo que la asimilación de ciertas agrupaciones al carácter de ofendido por el delito situaría la discusión en su lugar correcto. Este reconocimiento supondría la demostración de que el sistema de persecución penal, para acoger nuevas expectativas presentes en la comunidad, ostenta una flexibilidad apta para llegar a asumir la existencia de intereses merecedores de tutela y el papel activo que puede ejercer a este respecto la sociedad vertebrada a través de cuerpos intermedios. La superación del garantismo ${ }^{1575}$ procesal individualista no debe conducir, por tanto, a salvaguardar derechos de grupos para acusar, sino a establecer vías para el afloramiento de concretos intereses de los individuos que, por razones de operatividad, no podrían ser atendidos de manera efectiva si se reclamaran aisladamente. El pragmatismo nos lleva así a afirmar que la diligencia de quien voluntariamente asume su defensa debe suplir la carencia de una persona que sienta el daño como propio e individualizado de manera cualificadamente diferente a los demás integrantes del cuerpo social.

Donde se necesita ejercer una labor de vigilancia incisiva que supera las capacidades de un individuo aislado o donde se hayan de aunar esfuerzos para canalizar una respuesta frente a ataques a bienes jurídicos colectivos procedentes de poderosos contrarios, precisar con exactitud la persona a la que hayamos de considerar víctima deviene una tarea compleja y a menudo infructuosa. Dada tal dificultad o imposibilidad, el ordenamiento jurídico consciente de la trascendencia de que tales intereses materiales se vean representados en el proceso, podría habilitar a determinados sujetos, preferentemente agrupados, para ello. En la medida que este tipo de sujetos activos no serían portadores de intereses individuales, sino de otros de carácter colectivo o de clase, la fórmula más adecuada para referirnos a este tipo de intervenciones en el proceso penal será la de la representación ideológica (ideological plaintif) a la que ya se refería CAPPELLETTI en otros ámbitos ${ }^{1576}$. Su pretensión en el proceso no irá referida a un

civiles y penales que estimaran convenientes bajo un régimen similar al que en la actualidad ostenta el Ministerio Púbico. Esta intervención sería de carácter subsidiario a la actividad de los particulares.

${ }^{1575}$ Expresión acuñada por la literatura italiana que se ha trasladado en demasiadas ocasiones acríticamente por un sector de la nuestra.

${ }^{1576}$ CAPPELLETTI, M., “Appunti sulla tutela giurisdizionale di interessi collettivi o diffusi” en el volumen colectivo Le azione a tutela di interessi collettivi, Atti del Convegno di Studio (Pavia, 11-12 de giugno 1974), Padua 1976, p. 51. 
$\overline{\text { derecho o interés propio, sino que adquiriría sentido sólo en cuanto realizada por el }}$ protagonista de una genérica y objetiva representación de intereses, la cual debería habérsele conferido con carácter previo y tras la comprobación del cumplimiento de los requisitos legalmente establecidos. No estamos ante una representación de carácter subjetivo, en la que la voluntad de un sujeto sea sustituida por la de otro, sino ante una de carácter objetivo, de intereses no divisibles que el legislador debiera estimar conveniente atribuir a un sujeto colectivo. El ejercicio colectivo de la acusación sería así representación no de persona ninguna, sino de intereseses jurídicamente tutelables y de difícil atribución subjetiva. Con ello no haríamos más que buscar una voz que represente unos concretos intereses materiales, un sujeto asimilado al ofendido allí donde con carácter genérico la ley no puede distinguir a nadie a quien pueda asignarse tal condición con exclusión de todos los demás ${ }^{1577}$. No se trataría de la atribución de una facultad generalizada de acusar, sino de la satisfacción en el momento procesal de lagunas derivadas de la obligada falta de concreción de la norma sustantiva en determinados tipos delictivos.

Si razones de efectividad y operatividad práctica llevan al individuo a reforzar vínculos de solidaridad con quienes comparte inquietudes, razones de pragmatismo nos deben llevar a admitir la asimilación de estos colectivos a la figura del ofendido. Sería necesario distinguir así entre la acusación popular stricto sensu y lo que pudiéramos denominar "acusación particular colectiva", en tanto pretensión formulada por agrupaciones organizadas para la defensa de bienes jurídicos difícilmente individualizables al objeto de su tutela jurisdiccional. Aun cuando la primera pudiera plantearse también por sujetos colectivos no cabría obviar sus diferencias cualitativas. Puesto que ambas responden a necesidades diferentes, no pueden ser tratadas de forma idéntica, por

\footnotetext{
${ }^{1577}$ Hacia un objetivo equiparable al aquí expuesto se dirige lo expresado en foros como el del XV Congreso Internacional de Derecho Penal celebrado en Río de Janeiro en 1994. En relación con la necesidad de reconocer al ofendido por el delito la posibilidad de intervención en el proceso, se adujo entonces que "un papel similar de colaboración debería ser conferido a las asociaciones legalmente reconocidas como promotoras en defensa de un interés general o colectivo para determinadas clases de delitos". Vid. Revue Internationale de Droit Penal, vol. 66, $1^{\circ}$ y $2^{\circ}$ trimestres de 1995, p. $93, n^{\circ} 28$. Con respecto al ofendido se dice textualmente en el $\mathrm{n}^{\mathrm{o}} 27$ que "la persona que se considere afectada por una infracción debería tener la posibilidad de constituirse, en su caso gratuitamente, como parte "acusadora" ("parte civil" o "acusador particular"), de solicitar al Tribunal la reparación materialy moral y de hacer controlar por un tribunal u otro órgano independiente la negativa de los órganos estatales de perseguir o de instruir un proceso contra el autor del correspondiente delito. Asimismo la parte ofendida debería tener derecho a influir en el desarrollo del proceso penal en caso de acción pública, sobre todo mediante el reconocimiento de su derecho a proponer medios de prueba y de su derecho de recurso. En esta misma hipótesis, debería tener el derecho de solicitar al tribunal una decisión sobre los daños y perjuicios".
} 
lo que establecer requisitos idénticos en unos y otros casos originaría claras disfucionalidades. Si la rigidez en el establecimiento de requisitos formales para la acusación particular ejercitada por un colectivo impediría o dificultaría seriamente su operatividad o su función práctica (imposición de fianzas, imposibilidad de ejercitar la acción civil, etc.), en la acusación popular stricto sensu la posible flexibilización en la imposición de tales requisitos podría generar alguna suerte de manipulación.

Consecuencia de todo ello es que muchas de las soluciones aportadas por la doctrina nos parecen claramente insuficientes, ya que alteran principios sustanciales del proceso penal. Ello hace que, de lege ferenda, consideremos conveniente incluir en la LECrim, sobre el fundamento del art. 7.3 LOPJ, el reconocimiento expreso dentro de ciertos límites de la asimilación a la condición de ofendido de los grupos de afectados y de las asociaciones legalmente habilitadas para la defensa de intereses de naturaleza colectiva. El objetivo de esta propuesta se cifra en conferir una lógica interna al sistema que sitúe la línea divisoria entre quienes ostentan o representan un legítimo interés material, frente a los que hacen valer únicamente un abstracto interés en la garantía de la paz social a través del enjuiciamiento de las conductas afirmadas delito. La generalidad del precepto de la LOPJ citado debería encontrar su concreción en el proceso penal sin servirse de la cobertura que le proporciona el reconocimiento de la acusación popular, en la medida en que ésta no da respuesta adecuada a los problemas que se tratan de solucionar. Cuestiones tales como la representación de los actores, el depósito de fianzas y la cuantía de éstas, el ofrecimiento de acciones, la publicidad del proceso, la asistencia jurídica gratuita, la imposición de las costas, etc. no deberían encontrarse sujetas a la indeterminación actual, sino que deberían contar con un adecuado fundamento legal. La utilización creativa de los moldes procesales tradicionales no dejará de producir disfuncionalidades, por lo que, ya que el sistema se muestra insuficiente en sí mismo, habrá de abordarse la modificación de la norma en el sentido de acercarla a las verdaderas exigencias reclamadas por la evolución de la sociedad.

Nuestra concepción de la acusación promovida en el ámbito propio de su objeto social por agrupaciones para la defensa de intereses colectivos, como una de las especies de acusación del ofendido por el delito conllevaría:

1) Realizar un "ofrecimiento de acciones" de forma que algún sujeto pudiera comparecer en el proceso penal como sostenedor o representante de los bienes jurídicos lesionados o puestos en peligro por el delito (art. 109, 110 y 783.II LECrim). 
2) No imponer fianza alguna para acusar, en tanto su equiparación con los ofendidos haría reconducible su posición procesal a lo previsto en el art. $281.1^{\circ} \mathrm{LECrim}$.

3) Tomar en cuenta esa asimilación al fijar los criterios de imposición de costas, por lo que no habría inconveniente en que, en aplicación del principio del vencimiento objetivo, una condena en costas recogiera en su tasación los gastos generados por la actuación procesal de las asociaciones en los mismos términos en que se hiciera para el ofendido. El reconocimiento de la facultad de defender intereses colectivos a través de la acusación por los grupos debería ir acompañado de medidas que contribuyeran a fomentarla, para que pasase de ser algo más que un candoroso deseo de incrementar la vertebración de nuestra sociedad en torno a grupos cuidadores de intereses relevantes para toda la comunidad. En este sentido, la compensación económica por los gastos efectiva y necesariamente desembolsados, sería un primer paso imprescindible para que no se erija en una mera entelequia o una facultad puramente teórica.

4) En tanto representantes de un interés ofendido, no habría tampoco óbice para que pudieran plantear la acción civil derivada del delito ${ }^{1578}$.

\section{IV.}

La regulación actual obliga a interpretaciones forzadas entre lo que se quiere reconocer -la trascendencia del papel de los entes colectivos para la defensa de bienes jurídicos de esta naturaleza- y el cauce procesal escogido -la acusación popular-. Lo conveniente podría ser, por tanto, realizar un cambio normativo en el sentido expuesto que viniera a determinar expresamente los requisitos que hayan de cumplir las asociaciones a las que se confiriera esta trascendente función. Reconociendo a estos sujetos colectivos su asimilación a la condición de ofendido, se les atribuiría una importante faceta de intervención en la vida pública. Por ello se precisa la articulación con carácter previo de sistemas de filtro, garantizadores de la fiabilidad de los propios entes colectivos y del contenido de las pretensiones que en un futuro pudieran ejercitar, tendentes a evitar posibles abusos a los que pudiera dar lugar una utilización fraudulenta del arma sensible en que consiste el proceso penal. Con ello se buscará el objetivo de no

\footnotetext{
${ }^{1578}$ En este sentido se ha pronunciado ya el TS, reconociendo que cuando se trate de un bien en el que la colectividad humana se halla interesada, la responsabilidad civil es perfectamente postulable por cualquiera de los ejercitantes de la pretensión penal. Vid. SSTS de 1 de abril de 1993 y de 24 de enero de 1995 (RAJ 141), en relación con la muerte por un cazador de una especie protegida.
} 
tener que hacer frente a un precio demasiado alto en la credibilidad del sistema a fin de garantizar la tutela de los intereses a los que nos referimos ${ }^{1579}$.

Con vistas a este nuevo marco normativo que se propone, parece necesario que la atribución de legitimación a grupos y asociaciones se realice bien con un carácter amplio, mediante la apertura del proceso a todos los que defiendan intereses colectivos, que se concretaría con lo previsto en normas materiales sectoriales (consumo, medio ambiente, patrimonio histórico artístico, etc.), bien con un carácter más restringido, a través del reconocimiento específico sólo a determinadas asociaciones (sindicatos, grupos ecologistas, asociaciones declaradas de utilidad pública ${ }^{1580}$, etc.) ${ }^{1581}$. La norma en la que se atribuya legitimación para acusar con este carácter diverso al de los acusadores populares debería establecer, cuando menos, exigencias tales como:

1) La agrupación deberá ser persona jurídica, carácter que se tendría que mantener a lo largo de todo el proceso, por lo que su disolución conllevaría el decaimiento de la pretensión $^{1582}$. Tendrán que ser colectivos motivados únicamente por un interés altruista, en tanto no defienden intereses de sus propios miembros, sino los de toda la comunidad o cuando menos, los de una pluralidad no identificable de sujetos ${ }^{1583}$.

${ }^{1579}$ Ha sido advertido también que es preciso el establecimiento de diversos controles para evitar una indiscriminada atribución de poder procesal a un círculo ilimitado de sujetos. Haciéndose eco de una abundante doctrina italiana, señala BUJOSA VADELL que cuando no se produce esa ampliación puede concurrir el peligro de que los intereses difusos terminen teniendo como interlocutor a la magistratura: el Magistrado se convierte en representante de intereses colectivos, con lo que pierde credibilidad el instrumento procesal. Vid. en especial AMODIO, "L'azione penale delle asociazioni dei consumatori per la represione delle frodi alimentari", Riv. Dir. Proc. Pen. 1974, pp. 545 y CONSO, G., "Formazioni sociali e giustizia penale”, Riv. Dir. Proc. 1976, p. 12, que se refiere a una posible desnaturalización de la sentencia que la haría convertirse en "vendetta social" y singularmente BUJOSA VADELL, L.M., "Notas...”, op. cit. p. 109.

${ }^{1580}$ Vid. art. 4 Ley 191/1964 de 24 de diciembre, a tenor de la nueva redacción introducida por la DA $13^{\text {a }}$ de la Ley 30/1994 de Fundaciones y de incentivos fiscales a la participación privada en actividades de interés general (RAL 3273).

${ }^{1581} \mathrm{Si}$ se reconociera la posibilidad del ejercicio de la acusación por todos los grupos y en todo tipo de delitos estaríamos ante una acusación popular conferida expresamente no sólo a los individuos, sino también a personas jurídicas, con lo que la diferencia no sería apreciable con respecto al sistema actual.

${ }^{1582}$ Los entes sin personalidad, aun cuando pudieran ser ofendidos por determinados delitos (en especial los de naturaleza patrimonial) y en esa medida constituirse como acusadores particulares, no tendrían posibilidad de acusar en defensa de intereses colectivos. Vid. MONTERO AROCA, J., en la obra colectiva Derecho Jurisdiccional, T. III, Barcelona 1996, p. 68 y MUERZA ESPARZA, J., en DE LA OLIVA et al. Derecho Procesal Penal, Madrid 1993, p. 135 .

${ }^{1583}$ La distinción entre grupos "egoístas" y grupos "altruistas" es frecuente, por ejemplo, entre la bibliografía 
2) $\mathrm{Su}$ finalidad estatutaria u objeto social tendría que incluir la defensa o promoción de los intereseses que trata de representar, de forma que la delimitación del ámbito de su actividad servirá como referente para la constatación de que el concreto objeto procesal posee un nexo con el sujeto activo.

3) Se requeriría también que la agrupación existiese con carácter previo a la comisión del hecho que se afirma delictivo, así como que hubiese desarrollado una actividad anterior real y no sólo formal. De esta manera se excluiría la intervención de asociaciones creadas "ad hoc" para un caso concreto ${ }^{1584}$ o de "entes fantasma", pues no sería aceptable que pudieran llegar a constituirse en acusadores especializados y profesionalizados, superando su genuino papel como defensores de unos intereses concretos, que, en alguna ocasión extrema, pueden servirse del proceso penal.

4) Su ámbito territorial de actuación deberá incluir el lugar de comisión del delito o el de la producción del resultado lesivo o peligroso ${ }^{1585}$.

Los riesgos de un sistema de estas características se cifran, por un lado, en que la fijación de requisitos demasiado estrictos que obligaran a un control intenso de las asociaciones podría llegar a conferirlas de hecho un status cuasi-gubernamental, de insider dentro de un sistema frente al que en ocasiones tendrían que tomar partido ${ }^{1586}$.

alemana.

${ }^{1584}$ La creación de entes ad hoc para la persecución de un concreto delito deberá encontrar su cauce de expresión a través de los "grupos de afectados", suma de todos aquellos que hayan sufrido un perjucio individualizable.

${ }^{1585}$ Se han destacado entre la doctrina anglosajona los factores internos y externos que pueden ser usados para predecir el éxito de la efectividad de la utilización de la Justicia para la defensa de intereses colectivos a través de asociaciones. Entre estos han de señalarse los siguientes: 1) la longevidad del grupo; 2) la presencia de "liberados" o de juristas y otros especialistas voluntarios comprometidos con la causa; 3) la atención sobre temas concretos y candentes; 4) el contar con recursos financieros, incluyendo el apoyo de asociaciones benéficas; 5) la capacidad para hacer acopio y manejar datos técnicos (especialmente en materia de consumo y medio ambiente); 6) la capacidad para generar y difundir publicidad no sólo entre la opinión pública en abstracto, sino también a través de revistas especializadas y entre la judicatura; 7) la coordinación entre la dirección y los afiliados; 8) la coordinación y cooperación con otros grupos; 9) la capacidad para hacer que las autoridades competentes apoyen las tesis del grupo; 10) el control sobre el cumplimiento de sus funciones. HARLOW, C. y RAWLINGS, R., Pressure..., op. cit. p. 303, asumiendo criterios elaborados en los EEUU.

${ }^{1586}$ Habrá de tenerse en cuenta que tales colectivos serán grupos de los denominados "proactivos", es decir, constituidos explícitamente o que actúan con el fin de potenciar la instauración y el cumplimiento de unas determinadas normas, frente a los grupos "reactivos" cuyo objetivo se sitúa en la crítica o directamente en la desobediencia de la norma (p. ej. sufragistas en su momento, insumisos en nuestros días) con el objetivo final de su modificación. Debe ser observado que, con carácter general, los grupos de tendencia conservadora podrán jugar por ello con ventaja en este terreno, en la medida que la inercia para el mantenimiento de la ley suele ser superior a las fuerzas que propugnan su modificación. Sobre esta distinción vid. HARLOW, C. y RAWLINGS, R., Pressure..., op. 
$\overline{\text { Podría penalizarse de esta manera la participación de grupos menos organizados o menos }}$ potentes ${ }^{1587} \mathrm{y}$, lo que es más importante en esta conflictual materia, que determinadas agrupaciones que mantuvieran posturas de oposición radical pudieran quedar al margen ${ }^{1588}$. Es patente en este sentido la diversa consideración entre los grupos que podríamos denominar "formalistas" frente a aquellos otros que podríamos caracterizar como "activistas". Entre los primeros se incluye a organizaciones que gozan de una respetabilidad social unánime o muy mayoritaria (Cruz Roja, Hermandades de Donantes de Sangre, Unicef, Asociaciones de Víctimas del Terrorismo, etc.). Los segundos serían expresión de las opiniones o voluntades de una minoría, más o menos amplia y más o menos cargada de razones, que por ello mismo chocarán frente a las de otros sectores políticos, sociales, económicos o de la Administración (colectivos ecologistas, asociaciones contra la tortura, etc.). El acceso al proceso y, una vez dentro de él, las probabilidades de obtener una resolución que responda a sus aspiraciones son, a priori, muy diferentes en función de que nos encontremos ante uno u otro grupo. Aun cuando en muchos casos los grupos "activistas" se dediquen prioritariamente a recordar las obligaciones de las Administraciones públicas, serán vistos en ocasiones con hostilidad por éstas y se mostrarán recelosos ante la actuación de la Justicia, con la que en ocasiones se habrán tenido que enfrentar abiertamente ${ }^{1589}$.

Asegurar la fiabilidad de los sujetos intervinientes que asumen una posición en condiciones ventajosas en el fino mecanismo del proceso penal no puede ser visto como

cit, p. 8, que se refieren también a las diferencias entre los que se han denominado entre la doctrina anglosajona "one shot players" ("operadores de un disparo") y los "repeat players" ("operadores de repetición"). Mientras que los primeros sólo raramente inician pleitos, los segundos (compañías de seguros, Departamentos de la Administración, grupos muy potentes, etc...) serían sujetos que, bien litigan frecuentemente, bien son demandados frecuentemente, por lo que se benefician de su experiencia y de secciones de su organización o personas especializadas para el cumplimiento de esas funciones.

${ }^{1587}$ A la interposición de filtros consistentes en una decisión previa no jurisdiccional sobre los grupos se refería GÓMEZ DE LIAÑO GONZALEZ, F., "La legitimación colectiva y el art. 7 LOPJ", Justicia 86 nº 3, p. 571. En su opinión, deberían ser los Tribunales los que se pronunciasen sobre esa admisión, ya que de otra manera podría existir una desviación del mandato constitucional.

${ }^{1588}$ Parece claro que la búsqueda de la respetabilidad y de la garantía de las fuentes de financiación pública, elementos básicos aunque no suficientes para alcanzar resultados favorables, podrían originar cambios de actitud que incidan sobre su neutralidad y sobre los criterios que rigen su actuación.

${ }^{1589}$ Tales argumentos en relación con las asociaciones ecologistas han sido destacados por PÉREZ DE GREGORIO, J.J., "Las asociaciones ecologistas y de defensa ambiental como colaboradoras del Poder Judicial", op. cit. , pp. 207 y ss. 
restricción de un derecho de hipotéticos actores, sino como la constitución de un aval frente a intromisiones perniciosas. Aun conscientes de que la existencia de requisitos previos puede cercenar iniciativas espontáneas que pudieran resultar en ocasiones positivas, no debería haber inconveniente alguno en admitir éstos si lo que se propugna es simplemente la realización de un examen formal por el Tribunal, basado en datos objetivos. No deberá tratarse en ningún caso de un control de la propia asociación, sino de una verificación externa de ciertos requisitos formales que no impida el que puedan seguir constituyendo espacios autónomos, no generados ni sustentados por el sistema político $^{1590}$.

En otro sentido, ha de ser reputado conveniente establecer todo tipo de impedimentos a la manipulación de intervenciones privadas en el proceso penal que pudieran derivarse de una escasa representatividad ${ }^{1591}$ o una deficiente preparación de los valedores de intereses colectivos, de la celebración de pactos colusorios expresos o tácitos entre acusadores y acusados o del abandono del proceso por causas calificables como irregulares.

Una cuestión ulterior a resolver se sitúa en la amplitud objetiva de este reconocimiento, la especificación de los ámbitos en los que en concreto puede operar tal representación de intereses y la forma en que ello se llevará a cabo. Será por tanto necesario establecer normativamente:

1) Cuáles son los procesos penales en los que se considera necesaria o conveniente la representación colectiva de intereses materiales.

2) En qué condiciones y con qué límites pueden asumir los grupos esta función representativa. A este tenor, habrán de regularse al menos cuestiones tales como la publicidad de la iniciación de estos procesos de manera que se posibilite efectivamente el concurso de los grupos, las formas de representación por personas físicas, el destino de las indemnizaciones logradas, etc.

\footnotetext{
${ }^{1590}$ En cualquier caso, el resto de las agrupaciones siempre tendrían abierta la posibilidad de interponer denuncias o incluso de ejercitar la acusación popular en sus términos legales en razón de su carácter de no ofendidos por el delito.

${ }^{1591}$ En muchos casos, este tipo de grupos se crean en torno a una persona hiperactiva o a un incidente aislado, por lo que su representatividad puede ser cuestionada por tratarse más de un colectivo con concretos intereses personalizables que de un grupo con genuinas reivindicaciones.
} 
3) A quién haya de atribuirse la preferencia en caso de concurrir varios grupos a acusar, lo cual podría determinarse, por ejemplo, en función del momento de su personación, de la capacidad para sostener la pretensión hasta el final del proceso, etc. 


\section{ACUSACIÓN POPULAR COMO INSTRUMENTO DE CONTROL DEL MF}

\subsection{Acusación popular y principio de oportunidad}

\subsubsection{Tomas de posición doctrinales}

El principio de oportunidad ha sido fragmentadamente ${ }^{1592}$ definido entre nuestra doctrina como la "facultad que al titular de la acción penal asiste, para disponer, bajo determinadas condiciones, de su ejercicio con independencia de que se haya acreditado la existencia de un hecho punible contra un autor determinado" 1593 . Su introducción se ha justificado históricamente, de un lado, partiendo de un enfoque que favorece las facultades de dirección de la Justicia penal por parte del Ejecutivo, sobre quien recae la responsabilidad de regir la política criminal, a través de la institución del $\mathrm{MF}^{1594} \mathrm{y}$, de

${ }^{1592}$ Para PEDRAZ PENALVA, E., "Principio de proporcionalidad y principio de oportunidad", en Constitución, Jurisdicción y Proceso, op. cit. pp. 348 y ss. y esp. p. 350, sería ésta una visión parcial o fragmentada en cuanto sólo se considera el MF y la disposición del ejercicio de la "acción penal".

${ }^{1593}$ La definición corresponde a GIMENO SENDRA, V., "Los procedimientos penales simplificados (principio de «oportunidad» y proceso penal monitorio)", PJ, $\mathrm{n}^{\circ}$ especial II, (Justicia Penal) p. 34. Como señala DE DIEGO DÍEZ, L.A., La conformidad del acusado, Valencia 1992, p. 210, n. 64, la mención al "titular de la acción penal" puede llevar a confusión en un sistema de legitimación abierta para acusar como es el nuestro.

${ }^{1594}$ Que el MF sea en la actualidad un órgano dependiente jerárquicamente del Ejecutivo es una innegable realidad enraizada constitucionalmente: el Gobierno es quien propone el nombramiento del Fiscal General del Estado (arts. 124.4 CE y 29.1 EOMF), puede interesar de él que promueva ante los Tribunales las actuaciones pertinentes en orden a la defensa del interés público (art. 8.1 EOMF) y resolverá sobre la viabilidad de las peticiones oída la Junta de Fiscales de Sala (art. 8.2.II EOMF), que a su vez está compuesta de Fiscales de $1^{\text {a }}$ Categoría (art. 34 EOMF), cuyo destino es provisto por el Gobierno (art. 36 EOMF). Además, los Fiscales Jefes de las respectivas Audiencias podrán ser también removidos por el Gobierno (art. 41 EOMF). Si ello se suma a los principios de unidad de actuación y dependencia (arts. 124.2 CE y 2 EOMF), habrá de concluirse necesariamente en que las hipotéticas influencias del Ejecutivo pueden llegar a todos los integrantes de la carrera Fiscal. En virtud de la competencia predicable del Gobierno para definir lo que haya de entenderse como "interés público", podrá poner en conocimiento del MF, por conducto del Fiscal General, la concurrencia de tal interés en un determinado supuesto. Destaca ALAMILLO CANILLAS, F., El Ministerio Fiscal español (su organización y funcionamiento), Madrid 1990, pp. 19 y s., con base en la Memoria FGE de 1984 (pp. 440-441) que "todo ordenamiento jurídico complejo contiene zonas de índole opcional, tanto en el terreno de los intereses privados como en el de los públicos, y, en lo que concierne a éstos el gobierno es el legitimado para realizar las opciones que hayan de hacerse valer ante la Justicia con carácter prioritario". En cualquier caso, la utilidad de la acusación popular no aflora cuando el Gobierno "interese" del FGE el ejercicio de determinadas pretensiones penales, sino precisamente cuando "interese" su no iniciación o su 
otro, por el interés en la garantía de la justicia material y en la eficaz y rápida administración de ésta, en contraste con un formalismo legal que la pudiese atenazar ${ }^{1595}$. Este último argumento es el que hace que, en la actualidad, la conformidad sea percibida como una forma de alivio de la sobrecargada Justicia ${ }^{1596}$, como un cauce de introducción de criterios de utilidad pública o interés social ${ }^{1597}$, como una taumatúrgica coincidencia de intereses en evitar el juicio oral ${ }^{1598}$ o como consecuencia de la superación de la teoría retributiva de la pena ${ }^{1599}$.

La acusación popular se ha ligado históricamente a la garantía del principio de

tergiversada formulación.

${ }^{1595}$ Básicamente en estos términos fue situada la cuestión por GOLDSCHMIDT, J., Problemas jurídicos y políticos del proceso penal, op. cit. p. 124. Según su concepción, “al dominio del principio de oportunidad en el primer sentido se opuso la tendencia del Estado de Derecho de la segunda mitad del s. XIX, mientras que hoy día (1935) el principio de la legalidad tiene que ceder a un principio de la oportunidad en el segundo sentido, es decir, en favor de la justicia material".

${ }^{1596}$ En opinión de ZARZALEJOS NIETO la conformidad en el proceso penal abreviado es una "herramienta contundente para desescombrar los sobrecargados juzgados españoles", ZARZALEJOS NIETO, J., "El nuevo proceso abreviado para delitos menos graves (LO 7/1988)" en VVAA, Nuevos Tribunales y nuevo proceso penal. Estudios sobre la Ley 39/88 y LO 7/1988. Demarcación y planta. Juzgados de lo penal y proceso penal abreviado", $2^{\mathrm{a}}$ ed. Madrid 1989, pp. 159 y ss.; MALLO MALLO sitúa su justificación en "obvias razones de economía procesal", MALLO MALLO, L.A., "Algunas consideraciones sobre la conformidad en el Procedimiento Abreviado" en El Procedimiento Abreviado, Cuadernos de Derecho Judicial n ${ }^{\circ}$ IX, CGPJ, Madrid 1992, pp. 397 y ss. RUIZ VADILLO reconoce que el principio de oportunidad no perfecciona humana o técnicamente la justicia penal, pero sí sirve para aligerar el número de causas que llegan hasta los tribunales, RUIZ VADILLO, E., "El principio de oportunidad reglada", en La reforma del proceso penal, II Congreso de Derecho Procesal de Castilla y León, Madrid 1989, p. 391. Vid. también en el mismo sentido PUENTE SEGURA, L., La conformidad en el proceso penal español, Colex, Madrid 1994, p. 31.

${ }^{1597}$ Estas razones de utilidad social son cifradas con base en el derecho comparado por GIMENO en: a) la escasa lesión social producida mediante el delito y la falta de interés social en la persecución penal; b) el estímulo a la pronta reparación a la víctima; c) evitar los efectos criminógenos de las penas cortas privativas de libertad; d) la obtención de la rehabilitación del delincuente mediante su sometimiento voluntario a un procedimiento de readaptación; e) obtener la "reinserción social" de presuntos terroristas y una mejor información de las bandas armadas. GIMENO SENDRA, V., MORENO CATENA, V. y CORTÉS DOMÍNGUEZ, V., Derecho Procesal Penal, Madrid 1996, pp. 14 y ss. Vid. también DE DIEGO DÍEZ, L.A., La conformidad..., op. cit. p. 214; RODRÍGUEZ GARCÍA, N., El consenso en el proceso penal español, Barcelona 1997, pp. 115 y ss.

${ }^{1598}$ Recoge así RODRÍGUEZ GARCÍA (El consenso..., op. cit. p. 115) el argumento manifestado por FERNÁNDEZ ENTRALGO, J. en "Los principios procesales y procedimientos de la LO 7/1988", en la obra colectiva La reforma del proceso penal, Tecnos, Madrid 1990, p. 38.

${ }^{1599}$ Vid., por ejemplo, VIVES ANTÓN, T.S., Comentarios a la Ley de Medidas Urgentes de Reforma Procesal. T. II, La reforma del proceso penal, Valencia 1992, pp. 283 y ss., que se refería a una "mentalidad retributiva"; MORENO CATENA, V., en el prólogo de la obra La conformidad del acusado, de DE DIEGO DÍEZ, Valencia 1997, p. 5. 
legalidad en el ejercicio de la persecución penal, puesto que, sin necesidad de realizar un detallado análisis, parece claro que el juego del principio de oportunidad tiene importantes repercusiones sobre el papel que en el proceso desempeñen particulares acusadores. El reconocimiento constitucional y legal de la acción popular ha constituido a este tenor uno de los puntos esenciales en los que se ha fijado la literatura procesalista en el debate sobre el principio de oportunidad. Curiosamente, la facultad para el ejercicio de la pretensión penal que nuestro ordenamiento concede a particulares no ofendidos ha servido tanto para defender la implantación de manifestaciones de oportunidad, que en ella encontrarían un contrapeso garantizador, como para intentar cerrarles el paso por cuanto implicarían una restricción en la libertad de acusar.

Los argumentos barajados a este respecto pueden cifrarse en los siguientes aspectos:

a) La mayoría de nuestros autores sostienen que la acusación popular supone un relevante elemento de garantía para el correcto ejercicio de la pretensión penal ${ }^{1600}$, en tanto puede indirectamente controlar al Ministerio Público y transmitir implícitamente a éste y al resto de la ciudadanía el mensaje de que la búsqueda de soluciones al conflicto que supone el delito previas a la resolución judicial no podrá realizarse de una forma arbitraria. Si al órgano oficial se le admite "disponer" de la acusación sólo bajo la atenta mirada de quienes quieran acceder al proceso, su espacio de arbitrio quedará aparentemente reducido. La acusación por los ciudadanos sería así un factor favorable a la incorporación normativa de la oportunidad al ordenamiento jurídico español, puesto que la actividad de cualquier sujeto legitimado permitiría, al menos teóricamente, completar y suplir faltas injustificadas e injustificables de acusación por el $\mathrm{MF}^{1601}$. Confiando en que

\footnotetext{
${ }^{1600}$ En este sentido se manifiestan entre otros VIVES ANTÓN, T.S., "Doctrina constitucional y reforma del proceso penal”, PJ, nº especial II, pp 100 y 108: “la acción popular está para impedir que el gobierno pueda dejar de perseguir este o aquel delito por razones de conveniencia"; FAIRÉN GUILLÉN, V., "El Ministerio Fiscal en la reforma de 1988", Tapia, marzo-abril 1989, p. 69; ARMENTA DEU, T., Criminalidad de bagatela y principio de oportunidad: Alemania y España, Barcelona 1991, pp. 201 y s. y 238 y s.; DE DIEGO DÍEZ, L.A., La conformidad del acusado, op. cit. pp. 242 y ss.

${ }^{1601}$ Así se manifestaba PEDRAZ PENALVA, E., "Principio de proporcionalidad y principio de oportunidad" en Constitución, Jurisdicción y Proceso, Madrid 1990, p. 364. Este autor se mostraba, no obstante, pesimista en cuanto a su efectividad práctica (a excepción de la defensa de intereses colectivos): "Aconsejable sería no absolutizar este instrumento en que la acción popular consiste. Al igual que el jurado, la acción popular es un instituto hoy quizás de dudosa o ambigua eficacia -salvo en la protección de intereses colectivos-, entre otras razones por el defecto de la generalidad ciudadana que como elemento del juicio de culpabilidad se pretende actualizadamente hacer presente; también por el frecuente abuso -en verdad, desproporción- en la fijación de los importes de las fianzas a prestar; por el miedo a las consecuencias dimanantes del ejercicio individual de la acción popular en determinados tipos de
} 
su mera existencia legal pueda llegar a provocar intervenciones reparadoras, toda la ciudadanía se constituiría en vigilante, supliendo carencias o deficiencias, voluntarias o inducidas, de quien constitucionalmente viene obligado al planteamiento de la pretensión penal. Con ello se estaría otorgando a la acusación popular un papel Deus ex machina ${ }^{1602}$ en el multiforme instituto de la conformidad de nuestro ordenamiento jurídico.

En palabras de ALMAGRO, la acusación popular se revelaría así como un “control social más de la democracia, incluso en los supuestos en que primordialmente está obligado el Ministerio Fiscal y otros órganos especializados al ejercicio del derecho a la Jurisdicción y esta obligación venga impuesta con sujeción al principio de legalidad, pues en todo caso impide que este principio de legalidad (formal), se pueda, en algunos casos, transformarse materialmente en un principio de oportunidad"1603. También CONDE-PUMPIDO, uno de los más ardorosos defensores de la oportunidad, señala que abriría "una amplia panoplia de controles sociales, que se unen al posible control judicial y que hacen que nuestro sistema pueda ser uno de los más seguros en orden a corregir eventuales desviaciones en el ejercicio de la oportunidad reglada" ${ }^{1604}$.

Incluso el legislador de la LOTJ ha dado por bueno un papel subsidiario de la acusación popular frente a reparos derivados de posibles actitudes de inhibición del MF, asumiendo su potencial de control de factibles manifestaciones del principio de oportunidad. Ya la propia Exposición de Motivos de la LO 5/1995, para rechazar la crítica de que la decisión que remite al juicio oral deje sin mecanismo de efectividad el principio de obligatoriedad de la acusación, afirma que “(...) tal reproche olvida que para iniciarse este procedimiento tiene que haber precedido denuncia o querella de alguien que, de no ser el Ministerio Fiscal, bien puede, dada la afortunada previsión constitucional de la

criminalidad, etc.”, op. cit. n. 214.

${ }^{1602}$ La acertada expresión, que se refiere a aquel remedio que aparece en el teatro de forma milagrosa para salvar a "los buenos", se ha tomado de MASCAREÑAS, C.E., Voz "Acción Penal", Nueva Enciclopedia Jurídica, Barcelona 1950, p. 199. La recoge también FAIRÉN GUILLÉN, V., Voz “Acción”, op. cit. p. 203, n. 133.

${ }^{1603}$ ALMAGRO NOSETE, J., "Poder Judicial y Tribunal de Garantías en la nueva Constitución española” en VVAA Lecturas sobre la Constitución, Facultad de Derecho UNED, Madrid 1978, p. 308 y “Acción Popular”, op. cit. p. 227.

${ }^{1604}$ CONDE-PUMPIDO FERREIRO, C., "El principio de legalidad y el uso de la oportunidad reglada en el proceso penal", $P J, \mathrm{n}^{\circ}$ especial VI, p. 34. 
acción popular, suplir la falta de instancia del acusador público" ${ }^{1605}$. A tenor de esta concepción y, dado el caso, cualquier persona podría suplir carencias en la actuación del acusador público solicitando la apertura de la instancia.

b) La facultad de acusar los sujetos privados ha servido otras veces para fundamentar la oposición a cualquier ámbito de discrecionalidad en la persecución de los delitos. Se afirma en este sentido que tal discrecionalidad vendría de facto a limitar o, incluso, a impedir aquella intervención privada y, puesto que no sería posible su supresión por tratarse de un derecho constitucionalmente garantizado ${ }^{1606}$, se alteraría una de las bases sobre las que se asienta nuestro proceso penal, restringiendo derechos de los ciudadanos ${ }^{1607}$. La oportunidad sería admisible en otros sistemas (como el alemán), en los que no se atribuye legitimación para acusar a particulares, pero nunca en el nuestro ${ }^{1608}$.

\subsubsection{Intervención activa del acusador popular en relación con la conformidad del acusado}

La regulación legal de la conformidad, en cuya falta de precisión se han visto en ocasiones propósitos deliberados del legislador ${ }^{1609}$, es oscura también en lo referido al papel de los acusadores no oficiales, pero el análisis de las capacidades de la acusación popular no podría desligarse de las concretas manifestaciones que adopta en nuestro sistema. Para abordar la cuestión, y dejando de lado otras esclarecedoras clasificaciones de elaboración doctrinal, hemos considerado conveniente servirnos a tal efecto de un criterio teleológico. Atendiendo a la finalidad que sigue la actuación del acusador popular

\footnotetext{
${ }^{1605}$ Exposición de Motivos de la LO 5/1995 del Tribunal del Jurado, III, 2, a) $4^{\text {o }}$ párrafo.

${ }^{1606}$ BARONA VILAR, S., "Algunas reflexiones en torno al instituto de la conformidad en el proceso penal”, $L a$ Ley $\mathrm{n}^{\circ} 3621,4$ de octubre de 1994.

${ }^{1607}$ ARMENTA DEU, T., Criminalidad de bagatela y principio de oportunidad: Alemania y España, Barcelona 1991, pp. 201 y s.

${ }^{1608}$ MONTERO AROCA, J., Derecho Jurisdiccional, con ORTELLS RAMOS, GÓMEZ COLOMER y MONTÓN REDONDO, T. III, 1994, pp. 22 y 24.

${ }^{1609}$ Así, por ejemplo, CALVO SÁNCHEZ, M.C., "Procedimiento Abreviado: lagunas y dificultades interpretativas", en Recopilación de ponencias y comunicaciones. Planes provinciales y territoriales de formación, CGPJ, 1992, p. 1442.
} 
en el principio de oportunidad distinguiremos así entre dos tipos de participación:

\section{A) Para el logro de un consenso con el acusado:}

El art. 791.3 LECrim establece para el Procedimiento Abreviado que "en su escrito, firmado también por el acusado, la defensa podrá manifestar su conformidad con el escrito de acusación que contenga pena de mayor gravedad. Tal conformidad podrá formalizarse conjuntamente con el escrito de acusación del Ministerio Fiscal" ${ }^{1610}$. El tenor literal de la ley parece excluir de esta manera la formalización conjunta de la conformidad con un escrito de acusación diferente del elaborado por el MF, lo cual trasluce un razonable principio de desconfianza en la adopción de soluciones consensuadas con acusadores no oficiales.

Se ha propugnado, no obstante, que el acusador popular podría cumplir no solamente un papel de espectador a la espera de una deficiente actuación del Fiscal, sino que también sería dable, en el marco de lo legalmente previsto para el MF, la posibilidad de atribuirle facultades activas de negociación al objeto de articular la pretensión penal. En opinión de FAIRÉN, por ejemplo, si el único que pudiera negociar fuera el MF, se estaría realizando una restricción indebida en el desarrollo de la “acción popular". Nada autorizaría a que el Fiscal usurpase (sic) para sí facultades de la acusación popular que, a su juicio, estaría prevista con un superior rango al ser de naturaleza constitucional ${ }^{1611}$. ARMENTA DEU ve también en la acusación popular "la gran preterida" en la regulación del Procedimiento Abreviado, principal esfera de juego del principio de oportunidad. Afirma así que "parece evidente que en el supuesto en que dicha acción se hubiera ejercitado el acusador particular deberá tomar parte en la negociación con un parecer vinculante. Esto que puede suponer un «perjuicio» (caso de oponerse) a la finalidad aceleradora de la institución constituye, sin embargo, una garantía básica

\footnotetext{
${ }^{1610}$ Estamos, pues, ante dos modalidades para la realización de la conformidad: 1) en la calificación provisional de la defensa, que no supone necesariamente la existencia de negociaciones extraprocesales, aunque sí puedan haber existido o 2) junto con el escrito de acusación del Ministerio Fiscal, supuesto supeditado a la existencia de esos contactos previos que lleven a una actuación coordinada de ambas partes A estos contactos se refirió expresamente la Circular 1/89 afirmando que ello "obliga a facilitar los contactos con la defensa en la fase de calificación, para poder llegar a un acuerdo de conformidad en tal momento". Vid. Memoria FGE 1989, p. 417.

${ }^{1611}$ FAIRÉN GUILLÉN, V., "Las conformidades del sujeto pasivo en el procedimiento de la Ley de 28 de diciembre de 1988”, Justicia 89, pp. 18 y s. y 29.
} 
$\overline{\text { aunque no suficiente del quehacer del fiscal" }{ }^{\prime 612} \text {. Todo ello conduce a la citada autora a }}$ no ser partidaria de una posición preeminente del fiscal respecto del que denomina "acusador público" (que no es otro que el popular). No habría nada que justificase relegar la posición de este último en el proceso so pretexto, declarado o no, del efecto dilatador, ya que, además de la función garantista, constituye parte esencial de los derechos procesales de los ciudadanos en el juicio penal ${ }^{1613}$.

DE DIEGO DÍEZ resalta también tanto el olvido del legislador en lo atinente a la intervención de la acusación popular en la conformidad como lo que califica como "predominio y superioridad, difícilmente explicables, de las facultades negociadoras del Ministerio Fiscal". La razón alegada por este autor es que no parece haberse tenido en cuenta que el posible acuerdo del MF con la defensa del acusado se tornará estéril si cualquier acusador no oficial solicitase pena de mayor gravedad (arts. 791.3 y 793.3.I LECrim). Por ello, en su opinión, “lo más adecuado sería que las fórmulas consensuales se negociasen con la intervención de todas las partes personadas, admitiéndose, por analogía, la conformidad del acusado formalizada conjuntamente con la acusación no oficial de mayor gravedad", sin que su posible efecto dilatorio pueda constituirse en óbice puesto que la acusación popular "forma parte esencial de los derechos fundamentales de los ciudadanos en el procedimiento penal" ${ }^{\prime 614}$. VARELA CASTRO se fijaba en la laguna que se deriva de la regulación legal en el supuesto de la concurrencia de otros acusadores personados en la causa y, a su parecer, nada debería impedir la presentación de la conformidad junto al escrito de acusación de cualquiera de las otras partes cuando fueran más graves que la del Ministerio Público ${ }^{1615}$.

${ }^{1612}$ ARMENTA DEU, T., Criminalidad de bagatela..., op. cit., p. 238. Por ello resalta la autora que la acción popular supone una ventaja indudable respecto de otros ordenamientos como el alemán a la hora de controlar el uso de la oportunidad. Relata en nota que fue testigo en un Seminario en relación con el principio de legalidad, celebrado en la Universidad de Munich, de una propuesta de importar la acción popular al ordenamiento alemán. Pese a haberlas buscado con detenimiento, no hemos podido encontrar referencias en la literatura procesal penal alemana reciente en la que se realice públicamente tal defensa.

${ }^{1613}$ Ibídem. Puede verse en el mismo sentido también ARMENTA DEU, T., "El proceso penal: nuevas tendencias, nuevos problemas", $P J, 41-42$ pp. 76 y s., más reciente en el tiempo pero menos específico.

${ }^{1614}$ DIEGO DÍEZ, L. A. de, La conformidad del acusado, op. cit., pp. 291 y ss.

${ }^{1615}$ VARELA CASTRO, L., "Para una reflexión sobre el régimen de conformidad en el procedimiento abreviado" en Cuadernos de Derecho Judicial, IX, 1992, CGPJ. En el mismo sentido se manifiesta MORENO VERDEJO, J., "La conformidad...", op. cit., p. 45. 
En sentido opuesto, la posibilidad de que acusadores no oficiales tuvieran alguna disponibilidad sobre el principio de oportunidad ha sido rechazada rotundamente por GIMENO. Alega este autor que "siendo motivos de «interés público»los únicos que pueden justificar un sobreseimiento por razones de oportunidad y correspondiendo al MF "promover la acción de la justicia en defensa del interés público tutelado por la Ley», tan sólo está legitimado para solicitar del órgano jurisdiccional dicho sobreseimiento el MF y no las demás partes privadas, que actúan por otros móviles y ostentan otros intereses en la esfera del proceso" ${ }^{1616}$. Tal rechazo ha sido también sostenido por BAÑÓ Y ARACIL, para quien el MF no está "vinculado a la ofensa", sino al principio de legalidad y al de imparcialidad, puesto que en él se delega el interés público y no tiene interés personal alguno ${ }^{1617}$. PUENTE SEGURA se muestra contrario a la presentación conjunta de un escrito de acusación particular y defensa que recoja un acuerdo, basándose por un lado en el tenor literal de la Ley, que se refiere exclusivamente al MF, y por otro en que ello impediría separar adecuadamente la responsabilidad penal de la civil ${ }^{1618}$.

Estas últimas son las opiniones que entendemos se adecuan menos mal a la residual función de los acusadores populares en nuestro proceso penal, dado que las contrarias se basan en una supuesta igualdad entre sujetos acusadores aplicada de forma inapropiada y en sí misma injustificable. La posición que MF y acusadores no ofendidos por el delito ocupan dentro del sistema procesal sólo podría ser equiparable en un plano estrictamente formal, en los objetivos que vienen a satisfacer con su actuación (la tantas veces señalada afirmación de los presupuestos para el enjuiciamiento de una conducta afirmada como delito), pero están separados radicalmente por la sujeción del primero únicamente a la defensa del interés público. Los acusadores privados pueden constituir un filtro corrector del ejercicio de la actividad del acusador oficial, pero no sería admisible la búsqueda autónoma por ellos de acuerdo alguno con el acusado, por cuanto de esa manera

${ }^{1616}$ GIMENO SENDRA, V., “Los procedimientos penales simplificados...”, op. cit., p. 373.

${ }^{1617}$ BAÑÓ Y ARACIL, J., “El MF en la instrucción de los delitos”, RGD, marzo 1994, nº 594, p. 1768.

${ }^{1618}$ PUENTE SEGURA, L., La conformidad en el proceso penal español, Madrid 1994, pp. 58 y s. El autor se refiere al riesgo de negociaciones entre los acusadores particulares y el imputado para obtener una rebaja en la pretensión penal a cambio de importantes compensaciones en cuanto a la reparación civil. Concluye por ello afirmando que, de aceptarse esta posibilidad, sólo cabría este tipo de conformidad cuando la pena interesada por el Ministerio Público fuera la más grave. Entendemos sin embargo que en relación con la función del acusador popular esta argumentación carece de sentido, en tanto su calificación nunca llevará aparejada solicitud de pena menor a la interesada por el MF. 
se estaría elevando su ámbito de competencias mucho más de lo proporcionado a su naturaleza y función procesal, amen de introduciendo veleidades subjetivas disconformes con lo que es y debe ser la Justicia penal ${ }^{1619}$.

En ningún caso podrá situarse en un plano de estricta igualdad a acusadores populares y MF, por lo que cualquier "negociación" entre particular e imputado a los fines de incidir en la pretensión penal ha de reputarse rechazable per se. Allí donde cupiera legalmente un "consenso", debe ser únicamente factible entre acusado y acusador público, pudiéndose reservar a particulares, en todo caso residualmente, la misión de control sobre la actividad del órgano público de acusación. De admitir la posibilidad contraria se estaría abriendo un portillo privatizador, con el consiguiente margen para el manejo de la persecución penal por sujetos privados sin vinculación al interés público, que hace de ella algo inaceptable incluso como posibilidad teórica. Ni el objetivo a lograr con la oportunidad lo recomienda, ni parecería admisible rolar así el proceso, lo que pudiera ser utilizado, aun ocasionalmente, para fines desconocidos hábiles no sólo para llegar a ser bastardos, sino contrarios a los imperativos jurídico-fundamentales.

La cuestión admite también ser contemplada desde la igualdad entre acusación y defensa como principio inherente al debido proceso. Si consideramos que el fundamento del principio del consenso en el proceso penal ha de buscarse no en la confesión del imputado sino en su derecho de defensa, éste no se encontraría precisamente en la mejor situación para negociar enfrentándose a peticiones independientes de una pluralidad de acusadores. El acusador popular no tendría absolutamente nada que perder y mucho que ganar sobredimensionando los términos de su acusación siempre que no incurriera con su imputación en falsedad ${ }^{1620}$. Difícilmente entrará en una dinámica negociadora, a no ser para la segura obtención de una condena, y aun así, por razón de la indeterminación de sus móviles, no sería descartable la presencia de un interés en la continuación del proceso o en la finalización de éste a cambio de alguna compensación pecuniaria o de otra naturaleza. La estrategia procesal del imputado debería conformarse a su presencia en el procedimiento y, en cualquier caso, sería seguramente diferente y más perjudicial para sus intereses que la que utilizaría de no concurrir una acusación de naturaleza privada. Si se

\footnotetext{
${ }^{1619}$ Es necesario recordar el riesgo de jugar con la acusación popular para obtener compensaciones económicas del acusado.

${ }^{1620}$ Lo cual, en cualquier caso, no es todavía constatable. El delito de acusación falsa serviría aquí sólo como prevención a posteriori. La figura del fraude procesal tampoco podría operar con carácter preventivo.
} 
otorgara capacidad negociadora a acusadores populares, por mínima que ésta fuera, se estaría admitiendo que un sujeto privado estuviera en condiciones de inducir al imputado a declararse culpable al objeto de obtener con ello una sustanciosa rebaja de la hipotética condena que, cual espada de Damocles, pende sobre su cabeza en desaforada medida. Si la conformidad integra la autonomía de la voluntad del imputado, cuando ésta pudiera quedar configurada de forma viciada no debería ser admisible.

Es evidente que al negarse facultades negociadoras al acusador popular, los posibles acuerdos entre MF y acusado podrán quedar desvirtuados en presencia de una solicitud de pena mayor por otro acusador, con lo que sus efectos quedarían desbaratados. Pero ello no es más que una lógica consecuencia de la unidad de la pretensión penal, velada en nuestro sistema por la plural legitimación para su planteamiento. Este carácter único se manifiesta claramente en la "justicia negociada", en la medida que la conformidad deberá referirse siempre a una configuración singular de la pretensión penal que englobará dentro de sí la realizada por los demás sujetos habilitados.

\section{B) Para poner trabas a posibles acuerdos con otros acusadores:}

Se ha resaltado que el que no se deba reconocer legitimación a los particulares para solicitar el sobreseimiento por razones de oportunidad no significaría que éstos carecieran de interés para oponerse al mismo ${ }^{1621}$. Tratándose de acusadores populares, este interés se podrá dirigir a desvincular al Tribunal de la obligación de dictar una sentencia de estricta conformidad, al abrirle un abanico de hipótesis acusatorias entre las que se cuente alguna no concordada con el acusado. La conformidad ha de producirse con carácter absoluto sobre la calificación más grave de las de los acusadores (arts. 655 y 689 LECrim) o sobre la acusación que “contenga pena de mayor gravedad” (arts. 791.3 y 793.3 LECrim) ${ }^{1622}$, lo cual obligará al acusado a tener que asumir plenamente la configuración de los hechos,

${ }^{1621}$ Por ello sostenía que las facultades que confiere nuestro ordenamiento al ofendido por el delito en orden al sostenimiento de la acusación ante la petición de sobreseimiento del MF (arts. 642, 644 y 645) o la de recurrir en apelación un auto de sobreseimiento debieran ser mantenidas, con mayor razón, si llegase a instaurarse un sobreseimiento por razones de oportunidad. GIMENO SENDRA, V., "Los procedimientos penales simplificados...", op. cit. p. 373.

${ }^{1622}$ En la LECrim originaria el objeto de conformidad no era una concreta petición de pena, sino una calificación jurídica de los hechos que se traducía en la petición de pena. Sin embargo, actualmente, el ámbito de la conformidad se determina por las penas solicitadas en concreto (no por las señaladas en abstracto en el Código Penal), por lo que la declaración de conformidad se refiere formalmente a la calificación jurídica y la correspondiente petición de pena, pero no al propio delito. Vid. en este sentido MONTERO AROCA, J., Derecho Jurisdiccional, (1996) T. III, p. 25. 
la calificación jurídica y la solicitud de imposición de pena realizada por quien afirme que concurren unos presupuestos para la resolución jurisdiccional que supongan una mayor gravedad de la infracción criminal ${ }^{1623}$. En caso de pluralidad de acusadores, la declaración de conformidad deberá darse normalmente con la solicitud de pena realizada por alguno de los no oficiales, cuya intervención procesal se orientará habitualmente a la búsqueda explícita de una condena, con lo que no será el acusador público, sino uno privado, particular o popular, quien determine el límite de los cargos imputados ${ }^{1624}$. No puede obviarse, por ende, que ello dificultará el acuerdo con el acusado al verse incrementada la gravedad de la pena a conformar ${ }^{1625}$.

Distinguiremos aquí las posibilidades de juego de la acusación popular en función de los diversos momentos procesales en los que cabe la conformidad en nuestro sistema:

\section{1) En la instrucción: el reconocimiento de hechos del art. $789.5 .5^{\circ}$ LECrim:}

En estas hipótesis, que apenas se dan en la praxis, la fase de instrucción se acortará

${ }^{1623}$ La determinación de cuál sea la pena más grave cuando las solicitadas tengan la misma naturaleza habrá de fijarse en función del quantum contenido en cada una de ellas. Más dificultades se presentan en caso de heterogeneidad, hipótesis en las que podría ser de aplicación la escala del art. 33 CP que califica las penas en graves, menos graves y leves. En este sentido vid. DE DIEGO DÍEZ, L.A., La conformidad del acusado, op. cit. pp. 250 y ss. La determinación de si es más gravosa para el imputado una u otra pena puede ser ciertamente problemática, compleja y sujeta a interpretaciones, puesto que dependerá de múltiples circunstancias no siempre determinables en abstracto en el momento de la calificación por los acusadores. Así, por ejemplo, la privación temporal del derecho a conducir vehículos a motor durante un plazo de un año, pena leve (art. 33.4.a) CP), puede suponer una mayor gravosidad para muchos sujetos que la imposición de una multa de dos meses y un día, pena menos grave (art. 33.3.g) CP), cuyo cumplimiento se solventa con un desembolso económico.

${ }^{1624}$ Con respecto a la petición de responsabilidad civil, a juicio de algún autor con firme base en la literalidad de la norma, la gravedad se referiría únicamente a la pena. Con ello, la conformidad se habrá de prestar a la calificación que contenga pena más grave, aunque contenga petición de responsabilidad civil inferior a otra calificación con pena más leve. En este sentido vid. VARELA CASTRO, L., "Reflexiones sobre...”, op. cit. p. 205. Esta interpretación ha sido sin embargo refutada por MORENO VERDEJO, J., "La conformidad...”, op. cit. pp. 46 y s., para el que llevaría a soluciones inadmisibles tales como que se privara a una parte del enjuiciamiento sobre su petición de responsabilidad civil por la existencia de una conformidad sobre un quantum de indemnización inferior, pero establecido por quien solicitaba pena más grave y obtuvo en el escrito de calificación provisional la conformidad del acusado. En su lugar, opta por una interpretación conjunta con el art. 689 LECrim., en el sentido de que la conformidad habrá de prestarse sobre las peticiones penal y civil más graves respectivamente, aun cuando procedan de diferente parte acusadora. Ello obligaría a consignar la conformidad en dos escritos de acusación o a especificar en el escrito de defensa su acuerdo con la pretensión penal de una acusación y con la civil de otra. Señala asimismo este autor, aplicando supletoriamente los arts. 695 y 697 LECrim que, si la conformidad se produce sólo sobre la responsabilidad penal pero no alcanzase a la civil, el juicio tendría que seguir con respecto a ésta.

${ }^{1625}$ Es factible pensar incluso que si el acusador popular sobrepasara los límites objetivos de aplicación de las diversas manifestaciones del principio de oportunidad se podrá de hecho impedir su aplicación. 
$\overline{\text { evitando o simplificando la intermedia }}{ }^{1626}$. Se trata de un reconocimiento de hechos que puedan fundamentar una calificación, pero no de ésta, que no se habrá podido hacer todavía, ni de la pena. Su límite objetivo, a diferencia de otros supuestos, viene determinado por la petición de pena más grave fijada por la que en abstracto lleve aparejado el delito ${ }^{1627}$. El art. 789.5.5 habilita esta posibilidad únicamente "a instancia del Ministerio Fiscal y del imputado", con lo que parece claro que el acusador popular no podría instar la remisión al Juez de lo Penal, pero no se impide que sea escuchado para que pueda alegar lo que estime oportuno ${ }^{1628}$. No obstante, esta abreviación del procedimiento encuentra su razón de ser únicamente en los momentos iniciales, cuando el detenido declare ante el Juez de guardia, por lo que es difícilmente conjugable con la presencia de acusadores populares, y sus posibilidades de actuación quedan prácticamente enervadas $^{1629}$.

El encartado, asumiendo y reconociendo ante el Juez ${ }^{1630}$ los hechos que se le presentan, puede tener interés en que se dé por concluida la fase de instrucción en ese estadio, impidiendo que una más profunda investigación le suponga perjuicios mayores de los que aquel reconocimiento le podría deparar. No cabría una intervención activa

${ }^{1626}$ Según se afirma en la Circular FGE 1/89, esta modalidad no es una conformidad stricto sensu, sino que “constituye una manifestación del consenso (...) El juicio no se evita, sólo se anticipa y facilita”.

${ }^{1627}$ Dado que el ámbito competencial viene determinado por la referencia a los Juzgados de lo Penal, expresamente se descarta aquellos delitos cuyo enjuiciamiento sea competencia de las Audiencias (art. 14.3 y 779 LECrim y $33 \mathrm{CP}$ ). Deberá existir por tanto una operación mental de calificación de los hechos que, caso de rebasar la competencia del Juez de lo Penal, evidenciaría la ausencia de competencia de éste. Al respecto vid. MORENO VERDEJO, J., "La conformidad...”, op. cit. p. 33.

${ }^{1628}$ Del texto de la Ley puede inferirse la existencia de una convocatoria inmediata a juicio oral a las partes personadas, quienes formularán en el mismo acto sus pretensiones, dictándose a continuación sentencia in voce (art. 794.2 LECrim).

${ }^{1629} \mathrm{Si}$ la personación del ofendido es poco menos que imposible (es difícil pensar que se le haya realizado ya el “ofrecimiento de acciones" del art. 110 LECrim.), prácticamente impensable en ese momento procesal será la existencia de una personación en forma por parte de un acusador no ofendido. Afirma MORENO VERDEJO, J., "La conformidad ...”, op. cit. p. 35, que, puesto que el reconocimiento de hechos se haría en ausencia del ofendido, sólo podrá darse con los efectos aquí predicados cuando se trate de hechos en los que no existan perjudicados posibles o bien en los que habiéndose efectuado el ofrecimiento de acciones por la Policía judicial o por el Juzgado a través de telegrama u otro medio de similar rapidez (789.4. inciso 3) no se hubieran personado aquéllos antes del inicio del juicio o renunciaren a las acciones. PORTERO, REIG y MARCHENA, op. cit. p. 67, señalan que, existiendo un acusador diverso al MF que solicitase pena superior, sería difícil llegar al entendimiento que a este acto preconiza.

${ }^{1630}$ Y no ante la policía o el MF, conforme a la consolidada doctrina del TC (SSTC 135/89, 186/90, 128/93 y 129/93). 
$\overline{\text { decisiva por parte del acusador popular en otro sentido que no fuera el de obstaculizar }}$ mediante su querella el rápido término de la instrucción y subsiguiente remisión de las actuaciones a juicio. Una vez reconocidos los hechos no sería tampoco descartable su personación, cuyo escrito de conclusiones provisionales deberá basarse en este caso en los hechos que el imputado haya reconocido ${ }^{1631}$.

2) En el momento de evacuar los escritos de calificación provisional (art. $655 \mathrm{y}$ 791.3 LECrim):

Una vez sostenida supra la inadmisibilidad de que acusador popular y acusado formulen conjuntamente una calificación provisional, debemos tener en cuenta que en este momento procesal cabe que en su escrito de defensa el acusado asuma la acusación más grave. Ello nos obliga a considerar que tal manifestación se hará habitualmente en referencia a alguno de los escritos de acusación formulados por los acusadores privados, con lo que serán éstos quienes en la práctica determinen el límite de los cargos a conformar. El acusador popular estará así en disposición de interferir en la voluntad del acusado realizando una calificación inasumible o más gravosa para éste, puesto que el único beneficio al conformarse con la pena sería la obtención de una rebaja en el quantum de ésta que supusiera una mejora en relación con sus expectativas.

3) En el inicio del juicio oral (arts. 688 a 700 y 793.3.I LECrim):

En el Procedimiento Ordinario, si la causa versare sobre delito para cuyo castigo se pida la imposición de pena "correccional", preguntará el Presidente a cada uno de los acusados si se confiesa reo del delito imputado (art. 688 LECrim) ${ }^{1632}$, estableciéndose que "si en la causa hubiere, además de la calificación fiscal, otra del querellante particular o diversas calificaciones de querellantes de esta clase, se preguntará al procesado si se confiesa reo del delito, según la calificación más grave, y civilmente responsable por la cantidad mayor que se hubiese fijado" (art. 689 LECrim) ${ }^{1633}$. El primer inciso del art.

${ }^{1631}$ En la práctica, el acuerdo con reconocimiento de los hechos habrá sido precedido de alguna negociación con el MF, lo cual hará que las pretensiones de las demás acusaciones, una vez cerrada la somera instrucción, y contando con la dificultad para proponer nuevas pruebas a celebrar en un juicio oral que se celebrará inmediatamente, no podrán diferenciarse demasiado entre sí.

${ }^{1632}$ La manifestación de conformidad deberá hacerse por el acusado y ratificada por su defensor (art. 694 LECrim). Tendrá que referirse en este caso no a la pena pedida, sino al delito mismo según la calificación articulada por los acusadores.

${ }^{1633}$ Dado que el ámbito de aplicación del procedimiento ordinario se reduce a los delitos castigados con pena privativa de libertad superior a nueve años, excluyendo todos los demás supuestos (art. 779 LECrim., según la 
793.3.I LECrim prevé que "antes de iniciarse la práctica de la prueba, la acusación y la defensa con la conformidad del acusado presente, podrán pedir al Juez o Tribunal que proceda a dictar sentencia de conformidad con el escrito de acusación que contenga pena de mayor gravedad" 1634 . En su último inciso se dice que "si la pena no excediera de tres años ${ }^{1635}$, el Juez o Tribunal dictará sentencia de estricta conformidad con la aceptada por las partes" 1636 .

El papel que puede jugar el acusador popular en esta modalidad, que aporta pocas ventajas para la economía procesal, pero que es la más frecuente en la práctica, es precisamente el brindar al órgano jurisdiccional la posibilidad de no dictar sentencia de "estricta conformidad"1637, realizando calificaciones en su escrito de acusación superiores

redacción dada por la DF. $1^{\text {a }}$ de la LO 10/1995, de 23 de noviembre, del CP), será poco frecuente, aunque no imposible, que se produzcan conformidades en el marco del Procedimiento Ordinario. Sin embargo, según ha señalado la doctrina de forma prácticamente unánime, la importancia de esta regulación es su carácter supletorio en relación con la del Abreviado o la del Procedimiento ante el Tribunal del Jurado. En este sentido se pronuncian entre otros GIMENO SENDRA, V., Derecho Procesal. T. II. El proceso penal, Valencia 1992, p. 430; ASENCIO MELLADO, J.M., Principio acusatorio y derecho de defensa..., op. cit. p. 53; ARMENTA DEU, T., Criminalidad de bagatela y principio de oportunidad..., op. cit., p. 242 y MORENO VERDEJO, J., "La conformidad en el procedimiento abreviado", op. cit., p. 28.

${ }^{1634}$ La conformidad cabe aquí a instancia de cualquiera de los acusadores, pero se tendrá que realizar siempre con referencia a la acusación más grave. Expresa el citado precepto que la conformidad podrá prestarse también al escrito "que se presentará en ese acto, que no podrá referirse a hecho distinto, ni contener calificación más grave que la del escrito de acusación", con lo que se nos habla ya de una especialidad: la posible presentación en el inicio del juicio de un nuevo escrito de acusación. Esta mención ha sido considerada incongruente y desprovista de motivación, puesto que no se refiere a que al acusador que no hubiera presentado escrito de acusación (por haber solicitado el sobreseimiento) lo haga ahora, sino que es una posibilidad de presentar un escrito de acusación provisional que sustituye y da nueva redacción al anterior. Ello favorece sólo la rebaja en la petición de pena (la calificación habrá de ser más leve) con el fin de hacer más fácil la conformidad y presupone la existencia de contactos previos entre defensa y acusación al objeto de obtenerla. MORENO VERDEJO, J., "La conformidad...", op. cit. p. 57, basado en el análisis del iter legislativo de este precepto que realiza DEL MORAL, A., "El derecho a ser informado de la acusación en el procedimiento abreviado para determinados delitos", Actualidad Penal, 13, 27 marzo-2 abril 1989, p. 659. Atendiendo al proceso de elaboración del precepto, se observa que este escrito era el que podría presentar el acusador que hubiera solicitado el sobreseimiento, por lo que es lógico que no pueda contener calificación más grave al objeto de que el imputado no se encuentre con una acusación sorpresiva una vez elaborado el escrito de defensa. En concordancia con la negativa que hemos defendido a la existencia de esos contactos entre acusador popular y defensa, deberá negarse también cualquier intervención de aquél a este respecto.

${ }^{1635}$ La mención de "seis años" ha de entenderse derogada por el límite de penas menos graves y delitos menos graves establecido en el nuevo CP de 1995.

${ }^{1636}$ Aun cuando la doctrina no sea concorde a este respecto, se ha señalado que el límite de tal posibilidad no es sino el del propio Procedimiento Abreviado (pena de nueve años de privación de libertad). El matiz diferencial introducido por la Ley se cifraría en la vinculación a la que se ve sometido el órgano jurisdiccional. Vid. GÓMEZ COLOMER, J.L., en MONTERO AROCA, J. et al, Derecho Jurisdiccional, T. III, 1996, p. 258.

${ }^{1637}$ Por estricta conformidad entiende el TS una vinculación del Juez al contenido de los hechos y no a las penas, 
a las que el acusado podría mostrarse dispuesto a aceptar.

En el procedimiento ante el Tribunal del Jurado ${ }^{1638}$, si la pena solicitada por las acusaciones se encontrara dentro de los límites operacionales de la conformidad, la defensa podría también manifestar su conformidad absoluta con la más grave de ellas, pudiendo el Juez imponer la pena correspondiente sin necesidad de celebración de la vista ante el Tribunal del Jurado. El acusador popular estará así en disposición de impedir la no celebración de vistas ante el Tribunal del Jurado calificando la conducta muy por encima de los límites que el acusado esté dispuesto a admitir ${ }^{1639}$.

4) Con el fin de impedir la disolución del jurado "por la conformidad de las partes" (art. 50 LOTJ):

El art. 50 LOTJ permite la disolución del jurado "si las partes interesaren que se dicte sentencia de conformidad con el escrito de calificación que solicite pena de mayor gravedad, o con el que se presentare en el acto, suscrito por todas, sin inclusión de otros hechos que los objeto de juicio, ni calificación más grave que la incluida en las

interpretación que tiene la ventaja de asimilar esta conformidad a las otras de la Ley aun cuando no parece adaptarse al tenor literal del precepto. Vid. p. ej. STS de 17 de junio de 1991 (RAJ 4728). En este caso parece existir un deficiente entendimiento por el legislador de la esencia del principio acusatorio.

${ }^{1638}$ La posible incardinación del instituto de la conformidad de la defensa a la acusación en el Procedimiento ante el Tribunal del Jurado no procede de su expresa previsión en la LOTJ sino de la aplicación supletoria de la LECrim (art. 24.2 LOTJ). Las dudas se han suscitado sobre a cuál de los dos conjuntos normativos que disciplinan la conformidad habría de entenderse hecha tal remisión, al del Procedimiento Ordinario o al del Abreviado. GIMENO se inclina en favor de la primera de las dos opciones, puesto que, a pesar de la posterioridad del segundo, la ausencia de una remisión específica a este régimen impide sostener otra interpretación: a tenor de los arts. 780.1 LECrim y 24.2 LOTJ el procedimiento común es el ordinario. De esta manera, a su juicio, los arts. 655 y 688 y ss. LECrim, que en la actualidad se encuentran prácticamente abrogados, gracias a la Ley del Jurado recobrarían toda su vigencia. GIMENO SENDRA, V., Ley Orgánica del Tribunal del Jurado, Colex, $1^{a}$ edición, Madrid 1996, pp. 191 y s. En el mismo sentido vid. Derecho Procesal Penal, op. cit. pp. 327 y s. y 754. Una opinión contraria es sostenida por MARCHENA GÓMEZ, M., "El Fiscal y la Ley del Jurado", en VARELA CASTRO, L. (director), El Tribunal del Jurado, CGPJ, Madrid 1996, p. 318, puesto que aun sin existir razones materiales que impongan un régimen diferenciado y excluyente en materia de conformidad respecto del ya previgente en los restantes procedimientos ordinarios, el legislador lo ha abordado como una lex specialis y, por tanto, de aplicación prevalente respecto a la regulación general.

${ }^{1639}$ Cabe señalar también que el art. 51 LOTJ prevé la disolución del jurado y la absolución del imputado cuando “el MF y las demás partes acusadoras, en sus conclusiones definitivas, o en cualquier momento anterior del juicio, manifiesten que desisten de la petición de condena del acusado". El desistimiento de la pretensión origina en virtud del principio nemo iudex sine actore la terminación del proceso mediante absolución. Es detectable también aquí un espacio de intervención del acusador popular, en tanto podría impedir la disolución del jurado y la sentencia absolutoria manteniendo su acusación aun cuando los demás acusadores, oficial o privados, manifiesten su intención de desistir. 
conclusiones provisionales". Atendiendo al tenor literal del precepto y a su ordenación sistemática, esta conformidad podrá prestarse únicamente en el acto de las conclusiones definitivas, pero no al inicio de las sesiones del juicio oral aun cuando parezca claro que con ella no se reporten excesivos beneficios a la economía procesal o a la posible estigmatización del acusado ${ }^{1640}$. En la práctica, esta previsión podrá malograr conformidades en un momento anterior, puesto que la defensa contará con este último recurso para el supuesto de que la prueba en el juicio oral le resulte desfavorable ${ }^{1641}$. Podría decirse con MARCHENA que el legislador ha abordado en este procedimiento el instituto de la conformidad desde una supuesta especificidad que, lejos de enriquecer el sistema, ha enturbiado su entendimiento ${ }^{1642}$.

A la acusación popular le asiste la posibilidad de dificultar, e incluso impedir, factibles acuerdos, en tanto a éstos se ha de llegar sobre la base de la calificación provisional que solicite pena de mayor gravedad, con lo que le bastaría con realizar una que fuera difícilmente asumible por el acusado. Su negativa sería además suficiente para impedir la realización de una calificación definitiva común, en tanto la Ley exige que de realizarse una nueva, ésta venga suscrita por el acusado y todos los acusadores.

\subsubsection{Juicio crítico}

Creemos conveniente llamar la atención sobre los siguientes aspectos:

1) La acusación popular no es obstáculo suficiente para impedir la entrada en nuestro sistema de manifestaciones del principio de oportunidad, en cuanto no existe

\footnotetext{
${ }^{1640}$ GIMENO SENDRA, V., Ley Orgánica del Tribunal del Jurado, op. cit. p. 273 y PUENTE SEGURA, L., La conformidad..., op. cit. p. 152, n. 2 en relación con el proyecto de LOTJ. DE DIEGO DÍEZ, L.A., La conformidad..., op. cit. pp. 549 y ss. sostiene una opinión contraria sobre la base de la escasa utilidad que tendría una conformidad prestada en el último trance del juicio, lo cual le conduce a afirmar que podrá realizarse en cualquier momento procesal entre la constitución y la cesación de funciones del jurado. De otra manera sólo se estaría evitando el veredicto del Jurado, pero tendría muy escasa utilidad para el acusado por lo que no sería "sugerente, ni para la acusación ni para la defensa, llegar a una conformidad en las postrimerías del juicio” (p. 551).

${ }^{1641}$ El legislador ha olvidado además que tal conformidad se realizará en un acto oral ante el Jurado (la formulación de las conclusiones definitivas), con lo que se estará originando un pequeño incidente entre la acusación y la defensa a fin de que pueda culminarse este "plea bargaining" en el pertinente escrito de transacción procesal efectuado bajo la forma de conclusiones definitivas. GIMENO SENDRA, V., Derecho Procesal Penal op. cit. p. 328, Ley Orgánica del Tribunal del Jurado, op. cit. p. 274.

${ }^{1642}$ MARCHENA GÓMEZ, M., “El Fiscal y la Ley del Jurado”, op. cit. p. 318.
} 
$\varlimsup$ limitación constitucional a la modulación legislativa del diseño orgánico en el que los particulares estén habilitados para plantear la pretensión penal. La oportunidad puede por ende ser considerada parte de la libertad configuradora del marco normativo de la acusación, que no admite ser extraído del ámbito competencial del legislador ordinario. Nos mostramos así en desacuerdo con las posiciones de quienes rebaten la introducción del principio de oportunidad basándose en la vigencia de la acusación popular.

2) La acusación no pública ha constituido una de las causas que han servido históricamente para consolidar los fundamentos teóricos del principio de oportunidad en la persecución penal, en cuanto éste constituiría una de las inevitables consecuencias inherentes a la difundida legitimación para acusar, y no sólo una garantía frente a su abuso $^{1643}$. Se ha afirmado por algún autor extranjero que, mientras en los sistemas donde rige el monopolio acusatorio del MF, su sujeción a la legalidad debe ser por necesidad obligatoria, allí donde otros sujetos tuvieran atribuida la competencia para deducir la pretensión penal, la oportunidad tiene que ser consecuencia lógica ${ }^{1644}$. Este razonamiento, referido originariamente al sistema británico, se podría formular en los siguientes términos: dado que cualquier ciudadano puede determinar y seleccionar cuáles son los delitos que quiere o no perseguir de entre aquéllos de los que tiene noticia, no tendría por qué regir un principio que obligue a los oficiales públicos a perseguir automáticamente todos aquellos que conozca ${ }^{1645}$. La asignación de la facultad de acusar a ciudadanos no ofendidos constituiría a la vista de estos razonamientos un argumento favorecedor de la introducción del principio de oportunidad.

3) Habrá de contemplarse a mayor abundamiento que si del llamado "principio del

${ }^{1643}$ En la parte histórica de este trabajo ha sido ya expuesto cómo la defensa de la acusación popular subsidiaria fue utilizada como uno de los argumentos sobre los que se apoyaban las tesis de los partidarios de la introducción de manifestaciones del llamado principio de oportunidad. Vid. por ejemplo GNEIST, R. v., Vier Fragen.., op. cit.; MANNHEIM, "Die Durchbrechung des Legalitätsgrundsatzes”, Juristische Wochenschrift, LIII, 1924. ARMENTA DEU ha resaltado por el contrario que "una de las cuestiones básicas para la eficacia y viabilidad de la oportunidad es -como ya apreció el legislador penal alemán del siglo pasado- el monopolio de la acción en la persona del fiscal. Asi sucede en los EE.UU.". ARMENTA DEU, T., Criminalidad de bagatela y principio de oportunidad...", op. cit., p. 238, n. 767.

${ }^{1644}$ Asíen opinión de LEONE sólo podría ser admitida la no obligatoriedad de la acción penal si ello se contrapesara con el reconocimiento de la acusación privada, aunque fuera subsidiaria. LEONE, G., Voz “Azione penale", Enciclopedia del Diritto, 1959, p. 856.

${ }^{1645}$ Vid. en este sentido WILLIAMS, “Discretion in Prosecuting”, Crim. L. R. (1956), p. 223; LIEBENHETZE, A., Opportunitätsprinzip und Legalitätsprinzip in England, Dissertation, Marburg 1971, pp. 96 y ss. 
consenso" se pudieran seguir ocasionales ventajas, la intervención de acusadores populares podría contribuir en alguna medida a desarbolarlas, con lo que se privaría a la oportunidad de parte de los efectos beneficiosos que sobre él se vienen predicando (celeridad, evitar el carácter infamante del proceso en delitos de bagatela, alcanzar soluciones de compensación extravagantes al proceso, etc. ${ }^{1646}$. Como fundamento de esta afirmación podrían apuntarse las siguientes razones:

a) La acusación popular no es útil en procedimientos o modalidades procedimentales presididas por la celeridad, puesto que la introducción de trámites que permitieran la actividad de particulares en ejercicio de la pretensión penal conllevaría establecer trabas que operarían en detrimento de ese objetivo ${ }^{1647}$. La rapidez de los procedimientos exige disposición de los sujetos procesales para la inmediata realización de diligencias, lo cual no parece corresponderse bien con la función del acusador no ofendido. Esta circunstancia hace que la potencialidad de la acusación popular en uno de los campos de mayor aplicación del principio de oportunidad, la persecución de delitos de bagatela, esté necesariamente reducida desde la propia configuración legal. El control que supuestamente realizaría la ciudadanía no sería posible en causas por delitos poco graves, o por lo menos en aquéllas para las que se contemplara normativamente alguna modalidad procedimental acelerada, que precisara de la disposición constante y permanente de acusadores ante el Juzgado.

b) La acusación popular es, y conviene que siga siendo, escasa en su aparición. El ejercicio de la acusación por los no ofendidos tiene además que sujetarse al cumplimiento de unos requisitos formales necesarios que, por venir a establecer una serie de exigencias que precisan un esfuerzo en tiempo y dinero, no hacen de ella un instrumento atractivo para su generalizada utilización. Los posibles ejercitantes voluntarios de la pretensión penal estarán obligados a seleccionar las causas en que intervienen, por lo que su planteamiento popular nunca será suficientemente efectivo para

${ }^{1646}$ La Circular de la FGE 1/1989 recomendaba en relación con el llamado "principio del consenso" que en los escritos de acusación del MF, en concordancia con su función constitucional, se tuviera en cuenta como fin no sólo la actuación del ius puniendi estatal, sino también otros tales como la pronta reparación a las víctimas de los delitos o la resocialización del imputado. Estas motivaciones no podrán ser nunca exigibles de un acusador popular, al cual en principio, no le vincula la defensa del interés público.

${ }^{1647}$ Incluso firmes valedores del principio de oportunidad reconocen que la acusación de los particulares puede suponer un obstáculo a la finalidad aceleradora del instituto, aun procurando quitarle importancia a esta circunstancia al reseñar sus virtudes como mecanismo de control. En este sentido por ejemplo ARMENTA DEU, T., Criminalidad de bagatela y principio de oportunidad..., op. cit., p. 238; DE DIEGO DÍEZ La Conformidad..., op. cit. p. 244. 
garantizar un extendido control.

Los panoramas idílicos en los que sujetos altruistas se personan en el proceso penal para la defensa del bien común son ciertamente escasos en la práctica, puesto que lo normal es que los particulares acusen con el objeto de obtener de su acción provecho para un interés particular. Puesto que uno de los principales intereses que motiva la acusación de particulares no ofendidos se cifra en la adquisición de notoriedad, estos sujetos acusarán normalmente en asuntos que alcancen la trascendencia social, política o de otra naturaleza, suficiente para poder rentabilizar sus desembolsos, pero no así en la pequeña criminalidad ordinaria donde el principio de oportunidad se podría mostrar operativo. En casos de grave criminalidad la propia difusión pública de lo que sucede en el proceso podría erigirse ${ }^{1648}$ ya en elemento de control apto para evitar posibles arbitrariedades del MF, sin que por ello sea imprescindible la presencia de más valedores del interés público que él.

c) La acusación popular no presenta utilidad alguna para la rápida reparación del daño, otra de las predicadas ventajas del principio de oportunidad. Es claro que tras muchos archivos yace un desistimiento de la pretensión penal que, aun cuando en estricta aplicación de la legalidad debería haberse ejercitado, se obvia sobre la base de razones de justicia material y de concurrencia de intereses entre ofensor y perjudicado una vez que se ha alcanzado algún tipo de acuerdo resarcitorio (imprudencias indemnizadas, cheques sin fondos reintegrados, pequeñas defraudaciones repuestas, etc.). En estas hipótesis la intervención de un acusador popular en la función de control que se le atribuye podría dificultar y llegar incluso a impedir posibles acuerdos tendentes a la rápida obtención de la correspondiente reparación por la víctima. Mediante el ejercicio de la única facultad para la que están legitimados, la acusación, podrían sin duda dificultar o impedir la obtención de acuerdos sobre la restitución, el resarcimiento o la indemnización de los perjuicios. Con ella se abre camino a la intromision de terceros no vinculados a la defensa del interés público en los cauces de satisfacción de un legítimo y privado interés ajeno.

d) Los sujetos no ligados a la defensa del interés público, sino movidos por razones sobre las que no cabe indagar y que no podrán tenerse en cuenta como criterio

\footnotetext{
${ }^{1648} \mathrm{Cfr}$. el problema añadido que se plantea por la discutible fiabilidad, exactitud y corrección de la información mediática en los citados trabajos de PEDRAZ PENALVA, E., "Notas sobre publicidad y proceso" y "Publicidad y derecho al debido proceso. Publicidad y derecho de acceso a la información contenida en los ficheros judiciales".
} 
$\overline{\text { excluyente de su ejercicio de la pretensión penal, pueden introducir elementos de }}$ distorsión en un ámbito ya de por sí muy sensible. La siempre parcial actividad del acusador popular irá dirigida a la consecución de los presupuestos de una condena, habitualmente más gravosa de la eventualmente instada por el fiscal, por lo que intereses como la satisfacción del interés del ofendido en la pronta y efectiva reparación o el evitar los efectos estigmatizadores sobre el imputado del proceso o la pena, no tienen por qué preordenar su actividad. Si, con la vista puesta en innegables necesidades de justicia material, la negociación sobre los cargos puede ser admitida aun a regañadientes, la intervención de un particular acusador ajeno al delito debe ser observada con recelo. No sería de recibo en este sentido confundir la discrecionalidad dentro de un marco normativamente establecido para el planteamiento de la pretensión por un órgano oficial, con la apertura de una puerta a su ejercicio arbitrario, sobre la premisa de que éste pudiera ser corregido con nuevas arbitrariedades, procedentes de la actividad de acusadores privados. La aceptación de la idea de "justicia negociada" debería por ello ir indisolublemente unida a la iniciativa únicamente de acusadores vinculados a la defensa de criterios determinados y suficientemente conocidos, afectos en definitiva a la tutela exclusiva del interés público.

5) El lugar en el que la función procesal del acusador popular cobra sentido es en la factible imposición de un control privado sobre la actividad del MF, que supliera residualmente sus deficiencias en un ejercicio inadecuado de la pretensión penal. No obstante, un verdadero control sobre las hipótesis de aplicación de criterios de oportunidad habría de venir a través del efectivo examen por el órgano jurisdiccional de la concurrencia de los requisitos formales y materiales que condicionan este medio anormal de finalización del procedimiento penal. Tal verificación, dirigida a evitar una actitud pasiva del Juez que lo convirtiera en mero autómata en la aplicación de lo acordado por otros sujetos, debería partir de una clarificación legal de los criterios a los que el Tribunal tuviera que atender para determinar la finalización o la continuación del juicio ${ }^{1649}$.

6) De la acusación popular son predicables deficiencias intrínsecas que imposibilitan el depositar en ella una plena confianza para constituir un instrumento de

${ }^{1649}$ Tal y como sostiene ORTELLS RAMOS en relación con la no vinculación judicial a la conformidad, sorprende en un tema tan trascendental que se omita mencionar algún criterio al que el Tribunal deba atender para determinar si dicta inmediatamente sentencia u ordena la continuación del juicio. ORTELLS RAMOS, M., "El nuevo procedimiento penal abreviado: aspectos fundamentales", Justicia 89, $\mathrm{N}^{\circ} \mathrm{III}$, p. 559 , incluido en su recopilación $E l$ proceso penal abreviado (nueve estudios), Granada 1997, p. 15. 
$\overline{\text { garantía en relación con el principio de oportunidad. Puesto que sólo en una coyuntura }}$ difícil de producirse podrá llegar a ser hoy de efectiva utilidad práctica, el control que se pretende que asuma sería demasiado poroso, constituyendo un filtro ineficaz. En tanto mecanismo deficiente e insuficiente a tal efecto, no sería de recibo contemplarla como salvaguardia frente a la generalización de manifestaciones consensuales en nuestro proceso penal. El debate sobre la deseabilidad y conveniencia o no del principio de oportunidad habrá de contar con un dato esencial: la acusación popular no constituye en la práctica un baluarte inexpugnable contra la arbitrariedad o discrecionalidad de las actuaciones públicas, y su simple invocación, sin tener en cuenta su efectividad práctica, puede convertirse en paraguas protector para la justificación de las manifestaciones de oportunidad en nuestro sistema, sin que la garantía que pueda proporcionar no sea en demasiadas ocasiones más que un mero espejismo.

\subsection{Acusación popular y facultades de investigación del MF}

\subsubsection{En la actualidad}

\subsubsection{Procedimiento Abreviado}

En el ámbito de aplicación del Procedimiento Ordinario por delitos el instructor por excelencia es un órgano jurisdiccional (arts. 87.1.a) LOPJ y 14.2 LECrim) y el MF no tiene facultades de dirección de la investigación ${ }^{1650}$. En el Procedimiento Abreviado, en cambio, sí se le inviste expresamente de estas facultades ${ }^{1651}$, aun cuando se trate de una

${ }^{1650}$ Aunque tampoco se excluya la realización de averiguaciones previas al sumario, las cuales en ningún caso se integrarán en el procedimiento, aunque sí sirvan para solicitar del Juez Instructor la práctica de diligencias. Podrán llevarse a cabo en todos los procedimientos penales (Ordinario, Abreviado, del Tribunal del Jurado y de Faltas) al amparo del art. 5 de la L. 50/1981 (EOMF), de los arts. 269, 287 y concordantes de la LECrim y para su realización los funcionarios del MF podrán recabar el auxilio de la Policía Judicial.

${ }^{1651}$ Sobre la investigación del MF en el procedimiento abreviado vid. Circular FGE 1/1989, Memoria FGE 1989, pp. 431 y ss. y el capítulo "Las partes acusadoras", redactado por GIMENO SENDRA en el volumen colectivo $E l$ nuevo Proceso Penal. Estudios sobre la LO 7/1988, Valencia 1989, esp. pp. 93 y ss. En la práctica es constatable que la previsión legal no se ha desarrollado tan ampliamente como parecía desear el legislador de la LO 7/1988. Las causas de esta deficiencia en la aplicación de la previsión legal, sin entrar en su adecuación, se han cifrado fundamentalmente por la doctrina y por la propia fiscalía en la carencia de medios materiales y personales de ésta. En este sentido se pronuncia p. ej. SANCHÍS CRESPO, C., El Ministerio Fiscal y su actuación en el procedimiento 
dirección "secundaria", puesto que la competencia con carácter prevalente sigue recayendo en el Juez instructor (art. 785 bis.3 LECrim) ${ }^{1652}$. Si bien el MF no es hoy por hoy órgano director de la investigación penal, sí posee algunas facultades investigadoras que permiten afirmar su razonable preeminencia en este aspecto frente a los acusadores privados. A diferencia de éstos, al MF le viene reconocido expresamente un papel activo en la investigación (art. 785 bis 1 LECrim) ${ }^{1653}$, para el que goza de las facultades de dirección sobre la Policía Judicial que, tratándose de actuaciones previas a la apertura de actuaciones judiciales, le otorga el art. 20 del R.D. 769/1987 sobre regulación de la Policía Judicial $^{1654}$. A tenor de lo que se expone en la Circular de la FGE 1/1989, el fiscal podrá acordar cualquier clase de diligencia, documental, personal, pericial o real, que estime útil a los fines de la investigación ${ }^{1655}$. El art. 785 bis LECrim le concede, además, potestad para hacer comparecer ante sí a cualquier persona a fin de recibirle declaración sujetándose a las mismas exigencias de la citación judicial, pudiendo recibir las declaraciones tanto de posibles imputados como de testigos. La exclusión de los acusadores populares de las tareas investigadoras ha de entenderse en este sentido totalmente adecuada a su posición procesal, en tanto se trata de una actividad que debe ser

abreviado. Especial referencia al procedimiento preliminar fiscal, Granada 1995, p. 193.

${ }^{1652}$ A pesar de ello, el MF podrá tomar la iniciativa instando del Juez aquello que considere pertinente a los fines de la investigación (art. 3.1, 3.5, 4.1 EOMF y 781 LECrim).

${ }^{1653}$ También se atribuyen estas facultades en el art. 18. bis.1 d) EOMF para ciertas investigaciones económicas de la Fiscalía Especial para la Prevención y Represión del Tráfico Ilegal de Drogas tales como las referidas a situación económica y patrimonial, operaciones financieras y mercantiles, etc., pudiendo requerir de las Administraciones Públicas, Entidades, Sociedades y particulares las informaciones que estime precisas. De igual manera, el art. 18 ter EOMF, en relación con el 5 de la misma ley, confiere facultades de investigación a la Fiscalía Especial para la Represión de los Delitos Económicos relacionados con la corrupción. La referencia al art. 5 exige que se haya recibido denuncia (o bien atestado, que se considera denuncias a tenor del art. 297.I LECrim), a diferencia de lo que prevé el 785 bis LECrim para el Procedimiento Abreviado, que se extiende también a la adquisición de la notitia criminis por otros medios y a la iniciación de oficio.

${ }^{1654} \mathrm{El}$ art. 20 del R.D. 769/1987 de 19 de junio sobre regulación de la Policía Judicial establece que "cuando los funcionarios integrantes de las Unidades Orgánicas de la Policía Judicial realicen diligencias de investigación criminal formalmente concretadas a un supuesto presuntamente delictivo, pero con carácter previo a la apertura de la correspondiente actuación judicial, actuarán bajo la dependencia del Ministerio Fiscal. A tal efecto, darán cuenta de sus investigaciones a la Fiscalía correspondiente que, en cualquier momento, podrá hacerse cargo de la dirección de aquéllas, en cuyo caso los miembros de la Policia Judicial actuarán bajo su dependencia directa y practicarán sin demora las diligencias que el Fiscal les encomiende para la averiguación del delito y el descubrimiento y aseguramiento del delincuente".

${ }^{1655}$ No ocurre lo mismo con respecto a aquellas diligencias o medidas que supongan restricción de derechos (con la excepción de la detención). Vid. art. 5.II EOMF. 
desarrollada sólo desde ámbitos oficiales.

Al tener conocimiento el fiscal de un procedimiento judicial sobre los mismos hechos, deberá cesar en sus diligencias de investigación (785 bis 3 LECrim), circunstancia que deviene relevante ante la ausencia de un monopolio acusatorio del MF en nuestro sistema $^{1656}$. La Circular de la FGE citada expuso a este respecto una primera queja en relación con la desigualdad que supondría frente a los demás acusadores el que se vedara al Fiscal de esta manera la realización de diligencias de investigación. La prohibición de una investigación subsidiaria y paralela no se predicaba de los demás, por lo que podrían realizar investigaciones propias al no existir prohibición legal y en defensa de una manifestación de un mal entendido principio de "igualdad entre las partes", se afirmaba que tales facultades serían también aplicables al Fiscal ${ }^{1657}$.

La crítica más trascendente desde nuestra perspectiva es, sin embargo, la que se refiere a la posible interferencia de acusadores no públicos en el desarrollo de las investigaciones de los delitos, que voluntaria o involuntariamente pueden ocasionar distorsiones que incidirán no siempre de forma positiva en las fases iniciales de la persecución. Teniendo noticia de una investigación por la fiscalía y mediante la interposición de una querella, cualquier sujeto estará en situación de hacer cesar al MF en el conocimiento de un asunto, ya sea con fines altruistas, ya con fines dilatorios o de mero fraude procesal. La previsión legal origina que, una vez interpuesta querella, el conocimiento del asunto se le deberá encomendar al órgano jurisdiccional competente, que ya habrá tenido noticia de él ${ }^{1658}$.

${ }^{1656}$ Esta obligación había sido sometida a crítica incluso con anterioridad a la aprobación de la LO 7/1988, en concreto con motivo del Anteproyecto de Ley de Procedimiento Penal Abreviado, que confería facultades instructoras simultáneamente al MF y a los Jueces instructores. En aquel momento no pasó por alto el hecho de que esta doble vía pudiera utilizarse para, en función de los intereses de los participantes, acudir bien al Juez bien al Fiscal. Vid. la exposición de GIMENO SENDRA en el capítulo "Las partes acusadoras", del volumen colectivo $E l$ nuevo Proceso Penal. Estudios sobre la LO 7/1988, p. 97.

${ }^{1657}$ Memoria cit. p. 448. Una vez más vemos como se incurre en el error de identificar la igualdad entre los diversos sujetos acusadores con un principio de igualdad entre acusación y defensa que conduce a afirmaciones quizá poco meditadas. Si a partir de ese momento procesal el Fiscal no tiene facultades de investigación, con mayor motivo carecerán de ellas los acusadores no oficiales, a los que no se faculta en ningún momento para su realización o cuando menos para instar su admisión como elementos relevantes en la causa.

${ }^{1658}$ Advertía de esa posibilidad real de abuso, que ya se habría podido constatar en la práctica, MAJADA, A., Práctica Procesal Penal. Procedimiento Abreviado, Vol. II, Barcelona 1990, p. 819. En ocasiones tal previsión ha servido también para evitar la sospecha de manipulación política en el desarrollo de la actividad investigadora del MF. Así cabe conceptuar por ejemplo el ejercicio de la acusación popular por dos partidos políticos (IU y Partido 
Esta factible utilización fraudulenta, o por lo menos interesada, de la acusación popular ha sido puesta de manifiesto acertadamente por la Secretaría Técnica de la Fiscalía del Tribunal Superior de Justicia de Madrid en su Memoria de $1994{ }^{1659}$. En ella se expuso la conveniencia de modificar el $\mathrm{n}^{\mathrm{o}} 3$ del art. 785 bis LECrim, en tanto resulta anómalo "que permanezca fuera del control del Fiscal la correcta conclusión de su investigación, quedando además al arbitrio de un tercero, que puede ser incluso ajeno al investigado -acusación popular-, y puede determinar, cuando menos, una momentánea suspensión del procedimiento investigador del Fiscal'. Las posibles perturbaciones o dilaciones en la investigación originadas por diferencias de criterios o simplemente por lo que el Juez pueda tardar en reaccionar, podrían malograr determinados resultados de la investigación. Tales razones llevarían a la necesidad de suprimir esa cesación inmediata, señalando en su lugar un plazo para la conclusión o articular alguna otra fórmula que, sin alargar innecesariamente la pendencia de la investigación fiscal sobre el posible imputado, evitase dejar al arbitrio de terceros, perjudicar o frenar el resultado de las diligencias de investigación del $\mathrm{MF}^{1660}$.

\subsubsection{Procedimiento del Tribunal del Jurado}

El procedimiento del Tribunal del Jurado ha sido configurado por el legislador con

Andalucista) que originó el que en mayo de 1990 la investigación iniciada por la fiscalía en torno al célebre "caso Juan Guerra" pasase a manos de un órgano jurisdiccional para su instrucción.

${ }^{1659}$ Memoria de la Fiscalía del Tribunal Superior de Justicia de la Comunidad de Madrid. Año 1994, pp. 21 y ss. Su Secretaría Técnica estaba dirigida por D. Alfredo RAMOS SÁNCHEZ, a quien se debe atribuir la responsabilidad de su redacción.

${ }^{1660}$ La justificación de esta propuesta se encuentra precisamente en el desproporcionado y perturbador papel que conlleva la actuación de los particulares acusadores, por lo que la Memoria de la Fiscalía de Madrid citada recoge la queja de que "asistimos con harta frecuencia a la interrupción de investigaciones del Ministerio Fiscal, en aplicación del precepto citado, tras la apertura de un procedimiento judicial a instancias de un accionante popular, no perjudicado por el delito, verdaderos habituales de la querella, sin otra meta que la inmediata satisfacción de intereses personales, tan ajenos a la Administración de Justicia como el cultivo de la imagen pública que tan buenos dividendos rinde a algunos profesionales, políticos o empresarios". Concluye la exposición de los fiscales madrileños con la esperanzada afirmación de que la experiencia vivida en nuestro país en relación con la acusación popular aconseja un desarrollo del art. $125 \mathrm{CE}$ armonizado con las facultades investigadoras del Fiscal que evite la espuria utilización de "uno de los medios más preciados y útiles para lograr la transparencia en la Administración de Justicia Penal". No obstante esta declaración de buenas intenciones, no se aporta en concreto ninguna solución capaz de dar respuesta a la difícil cuestión de armonizar la vigencia de la acusación popular con las facultades investigadoras del MF. Vid. Memoria Fiscalía Madrid 1994 cit. p. 23. 
$\overline{\text { el ánimo de que constituyera expresión plena de los principios de oralidad, publicidad, }}$ inmediación y prueba formada con fundamento en la libre convicción. La LOTJ dice decantarse por un sistema de instrucción en el que, desde el momento en que el hecho justiciable y la persona sean determinados y se inicie este procedimiento, alguien ajeno al Juez tenga que formular una imputación antes de iniciar la investigación, la cual será valorada por el órgano judicial ${ }^{1661}$. Esta imputación habrá de basarse lógicamente en indicios suficientes que puedan servir de fundamento racional a una acusación, por lo que con carácter previo, y aun cuando la Ley no lo reconozca expresamente, será menester una mínima labor de indagación. Dadas las características de esta peculiar fase de instrucción, la práctica de tales averiguaciones debería ser asumida teóricamente por los acusadores, y no por el Juez Instructor al que parece que pretende apartar de cualquier valoración de la actividad encaminada a realizar un fundamento de los elementos probatorios. Esta opinión queda sin embargo desvanecida por la redacción del art. 27 LOTJ, en especial en sus números 1, 3 y 4, como también señaladamente por lo que está ocurriendo en la realidad.

En el caso del MF, este proceso preliminar de investigación puede realizarse a través de sus facultades de dirección sobre la Policía Judicial señaladas en el art. 20 R.D. 769/1987 citado. Esta facultad es ajena a las atribuciones conferidas a acusadores particulares y populares, los cuáles sólo podrán fundar mínimamente una acusación en el caso de que hubieren obtenido suficientes indicios o elementos de cargo a través de procedimientos que, en cualquier caso, serán extrajudiciales. De ello cabe inferir que sólo cuando haya un conocimiento extraprocesal de los hechos y el inculpado, podrán llegar a tener los acusadores alguna posibilidad de asumir un verdadero papel activo. Aun cuando en el marco de la comparecencia prevista en el art. 25 LOTJ las "partes" puedan solicitar del Juez Instructor las diligencias de investigación que estimen oportunas $\left(\mathrm{n}^{\circ} 3\right)$, el art. 24 LO 5/1995 exige que la imputación del delito se haya realizado contra persona o personas determinadas. Ya en presencia judicial, el acusador popular podrá asumir facultades activas en la proposición de nuevas diligencias para la comprobación del hecho justiciable, pero en la mayoría de los casos habrá sido necesaria la realización de unas mínimas diligencias de averiguación al objeto de concretar el sujeto contra el que se dirija el procedimiento. Su intervención activa está, por tanto, íntimamente ligada a las facultades revisoras de la acusación por el instructor: constatada la insuficiencia de los

${ }^{1661}$ Vid. Exposición de motivos LOTJ. 
$\overline{\text { elementos incriminadores o la conveniencia de afianzarlos, éste podrá acordar la }}$ continuación del procedimiento. La relevancia de la acusación popular se ceñirá únicamente a instar del Juez las diligencias que contribuyan al acopio de elementos para fundamentar la imputación. No obstante, puesto que el art. 27.3 LOTJ prevé que el Juez pueda ordenar las diligencias que él estime necesarias como complemento a las solicitadas por las "partes" 1662 , la presencia de acusadores privados no es determinante para su realización.

\subsubsection{Procedimiento de Menores}

El Procedimiento de Menores es el ámbito donde por primera vez, y a título cuasi experimental, se ha atribuido de manera exclusiva al MF, junto con la iniciativa procesal, la competencia para la investigación de los delitos en aras de salvaguardar la imparcialidad del juzgador (en este caso el Juez de Menores) ${ }^{1663}$. La novedad operada por la LO 4/1992 de 5 de junio sobre la denominada a partir de ese momento "Ley reguladora de la competencia y el procedimiento de los Juzgados de menores" (LORCPJM) ${ }^{1664}$, ha supuesto la introducción en nuestro sistema procesal de un verdadero banco de pruebas sobre la viabilidad de la atribución de la competencia para instruir el sumario al $\mathrm{MF}^{1665}$.

${ }^{1662}$ Siempre limitadas a la comprobación del hecho justiciable y respecto de las personas objeto de imputación por los acusadores. El papel del Juez no es, por tanto, enteramente pasivo o de mero espectador, sino que puede asumir facultades activas en la investigación, eso sí, sólo sobre el hecho y el sujeto objeto de la imputación.

${ }^{1663}$ Así se reconoce expresamente en la Exposición de motivos de la LO 4/1992, promulgada a raíz de la STC 36/1992 en la que se declaró la inconstitucionalidad sobrevenida de la legislación de menores entonces vigente (Ley y Reglamento de Tribunales Tutelares de Menores, aprobados por Decreto de 11 de junio de 1948). En acertada doctrina el TC ha señalado que el derecho a un Juez imparcial excluye la posibilidad de que el Juez mismo asuma la acusación (FJ 6).

${ }^{1664}$ El art. 15 de la Ley de Tribunales Tutelares de Menores, reformado por el 2.II. de la LO 4/1992, establece en la regla $2^{\mathrm{a}}$ de su $\mathrm{n}^{\circ} 1^{\mathrm{o}}$ que "Corresponde al MF la defensa de los derechos, la observancia de sus garantías, el cuidado de la integridad física y moral del menor, por lo que dirigirá la investigación de los hechos, ordenando que la Policía Judicial practique las actuaciones que estime pertinentes para su comprobación y la de la participación del menor en los mismos, impulsar el procedimiento, así como solicitar del Juzgado de Menores la práctica de las diligencias que no pueda efectuar por sí mismo...". Con ello el legislador lleva a su extremo la obligación de separación entre las funciones de investigación y fallo (STEDH Nortier c. Países Bajos de 24 de agosto de 1993 y STC 60/1995 de 17 de marzo). Esta misma regla in fine es la que excluye el ejercicio de pretensión penal por particulares y, con ello, la acusación popular.

${ }^{1665}$ Debido a la escasez de la regulación operada en dicha norma fue la Instrucción de la FGE 1/1993 de 16 de marzo la que vino a establecer las líneas generales de actuación del MF en este procedimiento acogiéndose a lo previsto en los arts. 5 EOMF y 785 bis LECrim. 
La actividad del MF en la instrucción está sometida, no obstante, a los límites previstos en el EOMF (adopción de medidas cautelares o limitativas de derechos) y, para ello, la regla $2^{\mathrm{a}}$ del art. 15.1 LORCPJM establece que el Fiscal habrá de solicitar del Juzgado de Menores la práctica de diligencias que no puede realizar por sí mismo ${ }^{1666}$.

Este ámbito es significativamente uno de los escasos supuestos donde se impide el ejercicio de acusación por particulares ${ }^{1667}$, con lo que queda salvada la dificultad que supondría la armonización de la actividad de tales acusadores y la de un MF configurado como dominus litis en la fase inicial del procedimiento. La no convivencia dentro del mismo procedimiento del ejercicio cívico de la acusación y de la dirección de la investigación por el MF hace que no podamos aventurar ningún resultado práctico con vistas a una futura generalización de ésta a todo el sistema procesal penal, aun cuando parezca aparentemente clara la incompatibilidad entre ambas en un plano meramente teórico. Tan importante novedad en nuestro sistema procesal penal no ha sido hasta el momento, salvo error u omisión por nuestra parte, objeto de un estudio con la profundidad que la cuestión merece ${ }^{1668}$.

\subsubsection{Acusación popular e instrucción por el MF}

\subsubsection{Problemas y soluciones doctrinales}

\footnotetext{
${ }^{1666}$ Dado que éste es el órgano encargado del fallo, podría entenderse que su intervención en la fase de instrucción podría en algún caso originar la quiebra de su imparcialidad objetiva, y así una vulneración del derecho al Juez imparcial. En este sentido, la STC 60/1995 se ocupó de la concreción de los actos que dentro de la instrucción pudieran considerarse como actos jurisdiccionales, frente a aquellos otros cuya realización podrá recaer en el ámbito de competencias del MF. La doctrina sentada por el TC en esta materia, vino a decir que tanto las diligencias que el MF no puede realizar por sí mismo, como la adopción de medidas cautelares y de modo especial el depósito o internamiento provisional del menor no constituyen en puridad actos de investigación o instructorios, sino actos puramente jurisdiccionales. El Juez de Menores no se configura por tanto como Juez Instructor, sino como "Juez de la Libertad" o garante del libre ejercicio de los Derechos Fundamentales.

${ }^{1667}$ Tal exclusión, como se abordó en el tema 8 , ha sido argumentada desde la garantía de la máxima primordial que debe presidir el procedimiento, que no es otra que el superior interés del menor.

${ }^{1668}$ Vid. p. ej. el apartado C.1.c) de la Instrucción de la FGE de 16 de marzo sobre líneas generales de actuación del MF en el Procedimiento de la LO 4/1992 de 5 de junio. Vid. asimismo MARTÍN OSTOS, J., "El nuevo proceso de menores. Comentarios a la LO 4/1992 de 5 de junio", La Ley 1994, T. 1, pp. 1142-1153 y DOLZ LAGO, M.J., "El Fiscal y la reforma de menores. Balance de experiencias tras la LO 4/1992", Revista Vasca de Derecho Procesal y Arbitraje 1995, III, pp. 480 y ss.
} 
La atribución al MF de la competencia para la investigación de los delitos en el marco de la ampliación de sus facultades procesales que se viene operando, es hoy día una de las cuestiones de mayor trascendencia para el futuro de nuestro sistema de persecución penal ${ }^{1669}$. Sin adentrarnos en una polémica trascendental, pero que excede con creces los límites de este trabajo, nos limitaremos a reseñar la incidencia que a este respecto podría adquirir su convivencia con la acusación popular en el ordenamiento jurídico. Y ello puesto que no cabe duda que un modelo en el que el MF fuera el encargado de la investigación de los delitos afianzaría un inequívoco desequilibrio en abstracto entre sujetos acusadores, conllevaría importantes restricciones e incluso podría llevar aparejada la exclusión del ejercicio de la acusación por particulares.

La modificación que se viene proponiendo ${ }^{1670}$ se propugna principalmente desde el anhelo de evitar una posible parcialidad objetiva ${ }^{1671}$ en que supuestamente podría incurrir un Juez que simultáneamente tuviera que hacer acopio de elementos incriminadores ${ }^{1672}$.

${ }^{1669}$ Se muestran favorables a esta atribución entre otros RUIZ VADILLO, E., "La actuación del MF en el proceso penal", $P J \mathrm{n}^{\circ}$ especial II, pp. 53-89; GIMENO SENDRA, V., “Algunas sugerencias sobre la atribución al MF de la investigación oficial", JUSTICIA 88, $\mathrm{n}^{\circ} 4$, p. 834; VIVES ANTÓN, T.S., Comentarios a la Ley de Reforma Procesal, vol. II, La Reforma del Proceso Penal, Valencia 1992; BAÑÓ y ARACIL, J., "El MF en la instrucción de los delitos" $R G D$ marzo 1994, $\mathrm{n}^{\circ}$ 594, pp. 1743-1774. De la misma manera se han pronunciado las Memorias anuales de la FGE de los últimos años (1987, p. 15; 1988, pp. 20 y 21; 1989, p. 17; 1990, pp. 18 a 20; 1991, p. 17; 1992, pp. 25 a 27; 1993, pp. 19 y 20; 1994, p. 32). Aunque con significativas matizaciones sobre qué fiscal y su juego con el Juez, se mostraría favorable a esta atribución PEDRAZ PENALVA, E., "Sobre el «Poder Judicial» y la LOPJ" en Constitución, Jurisdicción y Proceso, op. cit. p. 202, y "Principio de proporcionalidad y principio de oportunidad" en Constitución, Jurisdicción y Proceso, op. cit. p. 348, n. 137.

${ }^{1670}$ Ésta se realiza con respaldo en las reformas operadas en derecho comparado siguiendo los modelos del derecho anglosajón (Alemania desde la década de los 70, Portugal e Italia en los 80). Para un repaso sobre la instrucción del Fiscal en estos tres sistemas vid. GÓMEZ COLOMER, J-L., "El Fiscal Instructor", Justicia 96, II, pp. 261 y ss.

${ }^{1671}$ Tal y como fue destacado por la fiscalía del TC en los antecedentes de la STC 60/1995, la doctrina del TEDH ha distinguido dos clases de imparcialidad: la subjetiva (ausencia de prejuicios o parcialidades de un juez concreto en un caso concreto)(Casos De Cubber y Piersack), la cual se presume siempre salvo prueba en contrario (informe de la $\mathrm{CEDH}$, caso Hauschildt), y la objetiva o funcional, que hace relación a las garantías que el órgano judicial ofrece para excluir cualquier duda razonable sobre su imparcialidad por consideraciones de carácter funcional u orgánico. Esta última se puede considerar comprometida cuando el Juez encargado de la decisión realiza o ha realizado una investigación directa de los hechos y ha intervenido directamente en la instrucción, esto es, cuando se confunden en una misma persona las funciones de instructor y juzgador, o cuando el Juez que ha de decidir ha tenido una intervención indirecta en la instrucción, la ha supervisado o intervenido como Fiscal en ella (caso Piersack). En el FJ $4^{\circ}$ de la STC 60/1995 se establece que la imparcialidad del Juez excede el ámbito meramente subjetivo de las relaciones del Juzgador con las partes, para erigirse en una auténtica garantía en la que se puede poner en juego nada menos que la auctoritas o prestigio de los Tribunales que, en una sociedad democrática, descansa en la confianza que la sociedad deposita en la imparcialidad de la Justicia.

${ }^{1672}$ Uno de los argumentos barajados con mayor frecuencia en favor de que sea el MF quien instruya es el de que 
$\overline{\text { A juicio de sus defensores, esta opinión se vería apuntalada con razones prácticas, ya que }}$ la instrucción por el MF permitiría una agilización de la Justicia impidiendo duplicidad en las actuaciones ${ }^{1673}$. Las objeciones frente a ella son de diversa naturaleza ${ }^{1674}$, y han sido sistematizadas por GÓMEZ COLOMER bajo los siguientes $\operatorname{argumentos}^{1675}$ : 1) la instrucción es oficio de Juez y no de parte, por lo que encomendársela al Fiscal sería un contrasentido y una incoherencia; 2) la fase de investigación no sólo entraña actos de investigación, sino también enjuiciamientos jurídicos (inadmisión de la querella, imposición de medidas cautelares...); 3) la dependencia de los fiscales respecto del Poder Ejecutivo, que haría peligrar la investigación objetiva e imparcial de los delitos, cosa que no ocurriría con los órganos jurisdiccionales; 4) los fiscales no tienen atribuida la potestad jurisdiccional, que se ejerce exclusiva y excluyentemente por Jueces y Magistrados (art. $117 \mathrm{CE})$; 5) razones de índole práctica imposibilitarían que los fiscales asumieran tal función: un juez instructor seguiría siendo necesario, la plantilla es escasa, existen deficiencias funcionales, la Policía Judicial sería quien de facto asumiera la investigación,

instruir no es juzgar, hacer ejecutar lo juzgado, ni proteger derechos de las personas, supuestos en los que, de producirse en el sumario, en todo caso debiera intervenir un órgano jurisdiccional. La actual asignación de la competencia de investigar los delitos a los Jueces de instrucción podría, en opinión de algún sector doctrinal, determinar de tal manera la quiebra de la imparcialidad objetiva de estos órganos jurisdiccionales que incluso se ha llegado a considerar en alguna ocasión como inconstitucional. El Juez adoptaría de oficio resoluciones que le contaminan objetivamente y es el MF quien ejerce el control de la legalidad de un modo indirecto a través de los recursos, por lo que se estaría operando un inadmisible cambio de papeles. En este sentido se ha pronunciado RODRÍGUEZ RAMOS, L., “¿El juez de instrucción es inconstitucional?”, en AJA 19 de septiembre de 1996, pp. 1 y ss. Vid. también su artículo “¡Muerte al Juez inquisitivo!. Comentario a la STC 186/1990 de 15 de noviembre y algo más”. La Ley 1991, T. I, pp. 1089 y ss. No se trataría sólo de criticar una hipotética parcialidad subjetiva en relación con los sujetos intervinientes en el proceso sino de la parcialidad objetiva a la que ha aludido el TC en diversas ocasiones y, en especial, con motivo de la conocida STC 145/88 de 12 de julio en la que se declaró inconstitucional el fallo por parte del Juez de instrucción en aquellos casos en los que hubiera instruido. RODRÍGUEZ RAMOS se refiere a una auténtica "orgía inquisitiva" en la que el juez comanda un "equipo instructor" compuesto por el Fiscal y los peritos, en la que las posibilidades de defensa del imputado se ven cercenadas hasta extremos que las hacen inoperantes.

${ }^{1673}$ En este sentido vid. las Memorias de la FGE citadas.

${ }^{1674}$ En contra se destacan DE LA OLIVA SANTOS, A. Jueces imparciales, fiscales «investigadores» y nueva reforma para la vieja crisis de la justicia penal, Barcelona 1988, passim y esp. pp. 70 y s., para quien "son muy pocos los autores de prestigio que defienden que esa fase preparatoria del juicio oral, reconocida con su verdadero e incontestable contenido, se encomiende al Ministerio Fiscal" o FAIRÉN GUILLÉN, V., "El Ministerio Fiscal en la reforma procesal de 1988 (y II)", Tapia n $^{\circ}$ 45, p. 65, sirviéndose del argumento de la dependencia del Fiscal con respecto al Ejecutivo. También tomando como base razones organizativas, estructurales y prácticas, pero no dogmáticas se muestra contrario GÓMEZ COLOMER, J-L., "El Fiscal Instructor”, en JUSTICIA 96, n² 2, pp. 271 y ss.

${ }^{1675}$ GÓMEZ COLOMER, J-L., “El Fiscal Instructor”, op. cit, pp. 276 y ss. 
habría menos garantías para el imputado, etc.

El régimen legal actual de la acusación popular toma por base la existencia de un Juez de Instrucción encargado de la admisión de las querellas y de la ordenación de las diligencias que estime pertinentes de entre las solicitadas. Ello podría chocar con la atribución de la investigación al MF, puesto que a primera vista parece claro que, si éste pudiera por sí sólo configurar íntegramente la actividad instructoria, habida cuenta de la imposibilidad de asumir una investigación privada paralela, el papel de los acusadores no oficiales debería quedar sometido a lo resultante de la que aquél realizara. Esta limitación de las facultades acusatorias de los particulares ha sido considerada en alguna ocasión razón suficiente como para negar la conveniencia y la adecuación constitucional de la investigación por el MF, en tanto ello podría no ser coherente con nuestro sistema de acusación popular ${ }^{1676}$.

Entre los sectores doctrinales favorables a la instrucción del MF se ha afirmado su compatibilidad con la acusación popular, y se ha asignado a ésta última una función correctora que operaría en apoyo del cambio legal ${ }^{1677}$. En relación con el posible influjo del Ejecutivo se ha hecho notar que la presencia de acusadores particulares o populares podría contribuir a minimizar los riesgos que pudieran derivarse para la Justicia penal ${ }^{1678}$. Se destaca, por ello, que la actividad de particulares recurriendo ante el necesario "Juez de Garantías" las actuaciones del MF que consideren no satisfacen adecuadamente los requisitos de su actividad podría neutralizar posibles injerencias en asuntos con

\footnotetext{
${ }^{1676}$ Menos aún lo sería con la inclusión del ejercicio de la pretensión penal por el ofendido en el Derecho a la tutela judicial efectiva del 24.1 CE, afirmada reiteradamente por el TC. Vid. ORTELLS RAMOS, M., "El nuevo procedimiento penal abreviado: aspectos fundamentales", Justicia 89, p. 551. Resalta también el hecho de que supone una restricción a un derecho constitucional BARONA VILAR, S., "Algunas reflexiones en torno al instituto de la conformidad en el proceso penal", La Ley no 3621, 4 de octubre de 1994.

${ }^{1677}$ Se ha defendido en este sentido que la previsión constitucional constituiría una garantía necesaria de la pervivencia teórica de la acusación popular. Vid. por ejemplo VIVES ANTÓN, T.S., "Doctrina constitucional y reforma del proceso penal", PJ, $\mathrm{n}^{\mathrm{o}}$ especial II, Jornadas sobre la Justicia Penal en España, Madrid 1987, p. 107 y GIMENO SENDRA, V., “Algunas sugerencias sobre la atribución al M.F. de la investigación oficial”, Justicia 88, p. 834.

${ }^{1678}$ Afirmaba DE LA OLIVA que atribuir la investigación al Fiscal sería tanto como "dejar el honor, la libertad y el patrimonio de las personas en manos de servidores públicos que se han de comportar con arreglo al "principio" de "dependencia jerárquica", es decir a las órdenes de sus superiores, hasta el FGE", Jueces imparciales..., op. cit. p. 80. Incluso quienes propugnan la atribución de la instrucción al MF hacen corresponder esta aspiración con una mayor garantía de independencia con respecto al Ejecutivo.
} 
trascendencia política $^{1679}$. Dado el papel de control que el acusador popular puede y debe jugar respecto de la actuación del MF en un sistema en el que se confiera a éste la posición de órgano instructor, la solución no sería la supresión de la acusación popular ni su mero mantenimiento formal, sino que incluso debiera ser potenciada como elemento de garantía $^{1680}$.

El engarce entre la atribución de la facultad de dirigir la investigación al fiscal, sometido a los principios de legalidad e imparcialidad, y el mantenimiento de las competencias acusatorias de los particulares exige modular las funciones de estos últimos con respecto al primero, las cuales pasan necesariamente por una desigualdad entre ambos. En este sentido, se han propuesto una serie de garantías tendentes a que la regulación de la acusación popular no supeditase su ejercicio o lo subordinase al control por el MF. De lo contrario, afirmaba ALMAGRO, se harían naufragar sus posibilidades distorsionando su propia naturaleza, que, a su juicio, sería la de constituir una posición principal y no subordinada a ninguna otra ${ }^{1681}$. Las diferencias entre acusaciones, necesarias en tanto el acusador popular estaría instrumentalizado para que actúe con sujeción a la ley, pero no ligado por un estricto deber de ser imparcial, servirían para introducir matices en la vinculación de la resolución judicial a la petición del fiscal, pero no a la petición del acusador particular, siempre supeditada al filtro de la ponderación judicial. En cualquier caso, y en opinión de ALMAGRO, estas diferencias necesarias en la fase de investigación, deberían reducirse al mínimo o eliminarse prácticamente durante la fase de juicio oral. Asimismo, la "intensidad de la acusación del querellante popular" tendría que ser, como mínimo, equivalente a la de la del MF y, a diferencia de éste, nunca se le podría permitir mantener una propuesta absolutoria, formular peticiones equivalentes como el sobreseimiento libre y otras tendentes a resultados favorables para los acusados tal como pudiera ser el producir pruebas de descargo, puesto que en este caso siempre

\footnotetext{
${ }^{1679}$ Vid. RODRÍGUEZ RAMOS, L., “¿El juez de instrucción...”, op. cit. p. 5.

${ }^{1680}$ CALVO SÁNCHEZ, M.C., “Algunas sugerencias en torno a la futura reforma del proceso penal”, Justicia 90, pp. 69 y ss. para quien "la solución no puede hallarse en la supresión de acción popular, como se ha intentado en otras épocas, amparándose en los intereses espúreos que solían guiar su ejercicio y en la, al parecer probada, inutilidad de la misma".

${ }^{1681}$ En palabras de ALMAGRO, “...o sobra la acción popular (que es lo que desgraciadamente piensan algunos). O no sobra. Pero en este segundo caso, no se puede dar gato por liebre”. ALMAGRO NOSETE, J., “Acción Popular", en La Reforma del Proceso Penal. II Congreso de Derecho Procesal de Castilla y León, Madrid 1989 , p. 228. Este autor habla de un "litisconsorcio activo facultativo" que componen la fiscalía y la acusación popular, en tanto se considera a ambas posiciones como principales y no subordinadas una a la otra.
} 
tendría a su disposición el desistimiento $^{1682}$.

Otro posible fraude procesal frente al que normativamente debiera establecerse algún tipo de prevención sería el supuesto en el que el acusador popular solicitase, antes de lo adecuado, la apertura del juicio oral, originando una incorrecta terminación de la fase sumarial que pudiera conllevar la absolución en el juicio oral. Con este motivo VIVES ANTÓN ha planteado la necesidad de que el MF pudiera disponer de un margen suficiente entre el ejercicio de la acusación popular y la apertura del proceso, al objeto de reunir elementos de prueba suficientes para afrontar el juicio. De esta forma se evitaría, en su opinión, que a instancias de un acusador particular pudiera dar comienzo el plenario antes de lo debido ${ }^{1683}$.

Doctrinalmente se han tratado de articular soluciones prácticas que intentan salvar los escollos derivados de la ventaja de la que gozaría el MF en la fundamentación de sus pretensiones o en las trabas que los demás acusadores pudieran llegar a encontrar para hacer lo propio, por ejemplo cuando se impidiera la práctica de determinadas diligencias fundamentales al objeto de llevar a término sus aspiraciones. Estas soluciones, sustentadas necesariamente en la intervención de un órgano jurisdiccional, son básicamente dos:

a) Atribución de facultades de investigación directamente al acusador popular: esta posición ha sido defendida por ALMAGRO, para quien el actor popular podría desempeñar funciones de dirección de la investigación con el pertinente permiso judicial, prestado por el Juez de Instrucción que conozca de la querella. Los actos de investigación autorizados se encomendarían a la Policía Judicial. Con ello, afirma, se diversificarían y potenciarían como garantías diferenciadas las posibilidades legales de persecución del hecho delictivo. En un caso la investigación oficial acordada libremente por el MF, y en otro la investigación oficial, autorizada por el Juez de Instrucción, al ciudadano español en $_{\text {general }}{ }^{1684}$.

b) Posibilidad de que el acusador popular interese del MF la práctica de diligencias cuya práctica vendría asegurada por un control judicial: para quienes propugnan esta solución, a pesar de que el MF asumiera la carga de la investigación de los delitos, no por

\footnotetext{
${ }^{1682}$ ALMAGRO NOSETE, J., “La acción popular”, op. cit. p. 230.

${ }^{1683}$ VIVES ANTÓN, T.S., “Doctrina constitucional...”, op. cit. p. 107.

${ }^{1684}$ ALMAGRO NOSETE, J., “Acción Popular”, op. cit., pp. 229 y ss.
} 
ello se excluirían las facultades de los particulares para instar a través de la querella ante la autoridad Judicial la incoación de un procedimiento penal. El Juez asumiría una posición de órgano garante, al que los diversos sujetos podrían dirigirse a efectos de ordenar la práctica de diligencias complementarias a las del MF, ejerciendo en último término una función de control sobre la adecuación a la legalidad de la persecución penal ${ }^{1685}$. La intervención de acusadores no vinculados por el principio de imparcialidad exige como requisito sine qua non un control garantizador, que pasa necesariamente por la intervención de un órgano jurisdiccional ${ }^{1686}$. Parece evidente además que, en la mayoría de los supuestos, el MF no aceptará la práctica de las diligencias interesadas por acusadores privados, puesto que, si las hubiera estimado adecuadas, las habría realizado él mismo. Tal negativa constituiría el requisito habilitante para reclamar la tutela del "Juez de Garantías", quien asumiría así no sólo facultades de control sobre la imposición de medidas limitativas de los Derechos Fundamentales, sino que en el caso de intervención de los particulares en la acusación, seguiría realizando una verdadera actividad instructora sometida a la iniciativa de un sujeto privado.

\subsubsection{Juicio crítico}

A tenor de lo expuesto hasta aquí, nos corresponde en este momento llamar la atención sobre varios aspectos:

1) La obligatoriedad para el fiscal de remitir al Juez de Instrucción lo actuado como investigador en el momento en que tenga noticia de la existencia de un procedimiento judicial (art. 785 bis.3 LECrim) puede dar lugar en el Procedimiento Abreviado a manejos fraudulentos como los que se han señalado supra. Las precauciones frente a ellos tendrían que pasar por evitar que la interposición de querella privase inmediatamente del conocimiento de la instrucción al Fiscal, lo cual se podría realizar bien estableciendo un

${ }^{1685}$ Vid. GIMENO SENDRA, V., “Algunas sugerencias...”, op. cit. p. 834 En este sentido se dirigía también el primer Anteproyecto de Ley de Procedimiento Penal Abreviado, elaborado en el mandato del ministro MÚGICA HERZOG. Vid. GIMENO SENDRA, V., "Las partes acusadoras”, capítulo del volumen colectivo El nuevo proceso penal..., op. cit. p. 97.

\footnotetext{
${ }^{1686}$ Este órgano no podría ser el mismo competente para el fallo en tanto, como ha sido sostenido por el TC, la decisión sobre la admisión de la querella o la ordenación de las diligencias solicitadas en ella pondrán en tela de juicio la imparcialidad del órgano jurisdiccional que las dicte STC 145/1988 de 12 de julio, FJ. 7, aludiendo al deber del Juez establecido en el art. 3.3 de la derogada LO 10/1980 de resolver con arreglo a la LECrim en caso de interposición de querella o denuncia.
} 
plazo desde la interposición de una querella para concluir la investigación, bien habilitando la posibilidad de realizar una investigación judicial simultanea a la del fiscal. La primera de estas soluciones transferiría a un momento posterior el problema que suscita la factible intervención interesada de un particular acusador, pero no sería suficiente para impedir posibles manipulaciones del curso de la instrucción. La otra opción, es decir, admitir que MF y Juez Instructor pudieran desarrollar investigaciones paralelas, instauraría un régimen de "doble vía" con el que en nada se favorecería el sistema de persecución de los delitos. Los riesgos que se ocultan tras un sistema como éste serían, por un lado, las posibles faltas de coordinación que originarían duplicidad de actuaciones y, por otro, la instauración de una "doble ventanilla" para la instrucción de los delitos, habilitando una duplicidad de cauces y competencias no bien delimitados para el mismo objetivo. La iniciativa de uno u otro órgano podría verse sometida a utilización por quienes, en función de sus propios intereses, eligieran uno u otro cauce ${ }^{1687}$, denunciando o constituyéndose como acusadores tras interponer querella. Si en el primer caso el órgano encargado de la instrucción sería el MF, en el segundo, y por vía indirecta, se tendrían que conferir competencias instructoras a un órgano jurisdiccional ${ }^{1688}$.

2) La vigencia de la acusación popular no puede erigirse en freno limitativo de la asignación normativa al MF de la competencia para instruir las causas por delito. Con base en ella no cabe entender que el legislador se halle limitado como para impedirle modificar el régimen de persecución de los delitos. A nuestro juicio, la oposición a esta atribución no podrá tomar en cuenta la vigencia de la acusación popular, en tanto ésta no admite ser considerada como elemento determinante.

3) Con vistas a un hipotético desempeño de la instrucción por el MF es de señalar que en ningún caso sería admisible asignar a particulares acusadores facultades propias en la investigación de delitos, ya se realizaran a través de la Policía Judicial, ya mediante compañías privadas. La actividad investigadora de particulares consagraría la existencia de instructores necesariamente parciales, en tanto en ellos concurrirán ineludiblemente intereses privados que se podrían superponer a los propios de la persecución penal. Cuesta

${ }^{1687}$ Vid. el informe del CGPJ de 13 de octubre de 1988.

${ }^{1688}$ En contra puede verse ALMAGRO NOSETE, J., “Acción popular”, op. cit. pp. 229 y s. en cuya opinión la expresión "doble ventanilla" no podría convertirse en un "fetiche" que frustrase "la espléndida realidad jurídica de un posible sistema procesal penal, que diversifique las posibilidades legales de persecución del hecho delictivo. En un caso, la investigación oficial acordada libremente por el Ministerio Fiscal, en otro, la investigación oficial, autorizada por el Juez de Instrucción, al ciudadano español'. 
imaginarse la escena de funcionarios de la Policía Judicial impulsados y dirigidos por sujetos privados realizando acopio de pruebas para servir a unos intereses cuyos últimos fines nos son desconocidos, aun cuando pudieran venir a contribuir al afianzamiento del principio de legalidad. Sería inadmisible que esta posibilidad llegara a tomar cuerpo en nuestro sistema y se confirieran facultades de investigación a acusadores populares, puesto que el reconocimiento de la capacidad para instar la actuación de la Policía Judicial excedería con mucho de sus funciones.

4) La compatibilidad entre instrucción del MF y acusación popular pasa necesariamente por la implantación de controles de la actividad propuesta o realizada por los particulares acusadores, al objeto de que quede garantizada la máxima sujeción de éstos a la defensa del interés público. Puesto que no sería admisible que tal filtro se atribuyera al MF, quien al fin y al cabo sería quien $a b$ origine estaría encargado de la instrucción, los controles habrán de ser necesariamente judiciales. Ello tendría que articularse prácticamente a) de manera simultanea a la realización de diligencias por el MF o b) en una verificación judicial sobre el fundamento de la acusación realizada una vez que el MF diera por concluida la instrucción.

a) En el primero de estos supuestos estaríamos de nuevo ante una duplicidad de actuaciones sobre el mismo objeto, realizadas unas por el MF y otras por el "Juez de Garantías”, quien a través de la aprobación o denegación de las diligencias solicitadas por acusadores privados personados, estaría de facto asumiendo funciones instructoras.

b) En el otro caso podríamos pensar en una intervención en la investigación de particulares acusadores que se realizara con carácter subsidiario a la llevada a cabo por el MF. Su fundamento tendría que ser una verificación judicial de la insuficiencia de elementos incriminadores para la apertura del juicio oral ${ }^{1689}$ que podría permitir el que sujetos privados (ofendidos o no por el delito) solicitaran la realización de nuevas diligencias. De esta manera, el "Juez de Garantías" asumiría también la responsabilidad sobre el desarrollo de la instrucción.

5) La compatibilización entre la instrucción por el MF y el ejercicio popular de la acusación exige, a nuestro juicio, el mantenimiento de facultades instructoras por un

${ }^{1689}$ Se ha alegado en ocasiones, sin embargo, que nadie mejor que quien ha de mantener la acusación puede opinar sobre la conveniencia o no de procesar, concluir el sumario y solicitar la apertura del juicio oral. En este sentido vid. por ejemplo BAÑÓ y ARACIL, J., "El Ministerio Fiscal en la investigación de los delitos", $R G D$ n $^{\circ} 594$, marzo 1994, p. 1755. 
órgano jurisdiccional $^{1690}$. El deseo de privar absolutamente a éstos de la competencia para la investigación de los delitos, con la salvedad de la adopción de medidas limitativas de Derechos Fundamentales, debería llevar aparejada ineludiblemente la exclusión del ejercicio de la acusación por sujetos particulares.

\subsection{Modalidades de control de la acusación por particulares en el derecho comparado: reafirmación del monopolio acusatorio oficial}

La historia y el derecho comparado ofrecen múltiples y variadas soluciones a los inconvenientes surgidos de la falta de controles en un sistema dominado por un monopolio acusatorio. Todos los ordenamientos se han dotado de mecanismos de verificación de las decisiones que adopta el MF, ya sean de carácter interno (sujeción in abstracto a la legalidad, sometimiento a unos criterios más o menos detallados, más o menos rígidos, más o menos explícitos), ya de carácter externo a través de la intervención de particulares con facultades más o menos amplias ${ }^{1691}$, o bien, simultáneamente, de ambos. Puesto que nuestra acusación popular, se incardina en el segundo de estos grupos, esta incursión en el derecho comparado se centrará en éstos.

La pervivencia de un constante y extendido intento de establecer garantías de la correcta utilización del poder estatal de acusación a través de cauces de control externo, ha sido frecuentemente ligada a su consideración como válvulas de seguridad para casos de abuso en el ejercicio de aquél. Ha de advertirse, sin embargo, que fuera de la ardorosa defensa que en nuestro país se ha practicado de la acusación popular, han sido muy escasas las voces que han llegado tan lejos como para sostener la conveniencia de una participación generalizada de ciudadanos en la iniciación y sostenimiento del proceso penal. La acusación popular española es, si se quiere, el más aperturista y el de mayor

${ }^{1690}$ La explicación más clara de esta cuestión puede deducirse si se tiene en cuenta que, desde su origen, la acusación popular cumple exactamente la misma función que el MF. Atribuir a éste la investigación supondría en consecuencia tener que atribuírsela de manera similar a los acusadores privados, idea que en ningún caso podría considerarse admisible.

${ }^{1691}$ Otros sistemas de control externo que no pasan por el reconocimiento de facultades acusatorias a los particulares, tales como el control parlamentario de la responsabilidad política del Ministro en cuyo ámbito de competencias se encuentre el MF o la estrecha vigilancia realizada por los medios de comunicación, se perfilan como las soluciones preferidas por algunos ordenamientos diferentes al nuestro. Vid. JOUTSEN, en WILLIAMS, J.E., The role of the prosecutor, Londres 1987, pp. 82 y ss. 
$\overline{\text { solera de los controles externos de la acusación, pero ni es el único freno a la arbitrariedad }}$ del fiscal ni puede asegurarse que sea el que más garantías ofrece. En este apartado trataremos de hacer una somera panorámica de derecho comparado que sirva de referente al anhelo de conferir canales de participación a particulares para el control más o menos estrecho de la acusación. Se intentará presentar aquí alguna de las posibilidades exploradas por otros sistemas, teniendo que aceptar para ello el no desdeñable riesgo de descontextualizarlas del momento histórico en el que surgieron, del sistema en el que se incardinan o de las razones de fondo que han motivado su proposición o mantenimiento. Veamos, pues, cuáles son esos contrapesos, mecanismos de equilibrio o válvulas de seguridad propios de otros sistemas.

\subsubsection{El sistema acusatorio inglés}

La peculiaridad de un sistema de acusación exclusivamente privada se cifraría en la inexistencia de un órgano público para el ejercicio de la pretensión penal, por lo que aun cuando ésta fuera deducida por un órgano de la Administración, su actuación se considerará teóricamente exactamente igual que la de un particular. Este sistema, vigente en Inglaterra hasta hace poco más de una década, es rechazado hoy generalizadamente, tanto por razones teóricas como prácticas. Entre las primeras podría incluirse la común aceptación de que la persecución penal debe ser una indeclinable función estatal de naturaleza pública, mientras que entre las segundas habrían de citarse las difícilmente atajables colusiones entre acusador y acusado o la indeseada y posible impunidad de ciertos delitos en caso de que por cualquier razón (presiones, chantajes, dejadez, escasez de medios, etc.) no concurriera acusador alguno.

Juzgamos conveniente abordar un estudio del sistema inglés de acusación en tanto, junto con la peculiaridad que la acusación popular confiere al nuestro, es el único dentro de los europeos en el que el MF (o un órgano equivalente) no es titular exclusivo de la facultad de deducir la pretensión penal ${ }^{1692}$. Sin embargo, y a pesar de que el vínculo de

${ }^{1692}$ Esta circunstancia ha sido puesta de relieve entre la doctrina internacional p. ej. por HUBER, B., "The office of the State Prosecutor. Its legal status, function and control”, Revue Internationale de Droit Penal, vol. 63, n 3-4 1992 (bis), pp. 1197 y 1211. Para una extensa panorámica sobre los diversos sistemas de persecución penal en 23 países de Europa vid. HELSINKI INSTITUTE FOR CRIME PREVENTION AND CONTROL AFFILIATED WITH THE UNITED NATIONS, Non-Prosecution in Europe. Report of the European Seminar held in Helsinki, Finland, 22-24 March 1986, Helsinki 1986. 
influencia en la justificación de nuestra acusación popular es incuestionable desde una perspectiva histórica, la no vigencia de un monopolio acusatorio en Inglaterra y en España no son equiparables si no es salvando importantes diferencias cualitativas. La acusación quivis ex populo sigue siendo teóricamente el sistema en vigor en aquel ordenamiento, pero en la práctica no es más que un deseo retórico con muy poca virtualidad práctica en la defensa de intereses públicos. Nuestra intención a este respecto es presentar el sistema instaurado por la Prosecution of Offences Act de 1985 (en adelante POA) sin olvidar la tradición histórica sobre la que se asienta, para ir desgranando las dificultades prácticas con las que se enfrenta la radical y no enteramente correcta afirmación de que en el Reino Unido cualquier persona puede acusar.

\subsubsection{La acusación oficial}

El sistema inglés se enmarca dentro de los modelos plenamente acusatorios del adversary system y ha gozado siempre de importantes peculiaridades en relación con los legitimados para formular la pretensión penal. La Prosecution of Offences Act de 1985 $(P O A)$ supuso una reestructuración orgánica de la persecución de los delitos que puso fin en Inglaterra a una de las singularidades históricas de un sistema que, extendido por muchos de los Estados que integran la Commonwealth, únicamente se mantenía allí donde había nacido ${ }^{1693}$. El denominado Crown Prosecution Service (CPS), en funcionamiento desde abril de 1986, y básicamente equiparable en sus funciones al MF de

\footnotetext{
${ }^{1693}$ Por lo que respecta a Canadá, el tema de las acusaciones privadas y en especial las ejercitadas por asociaciones y grupos de defensa de intereses colectivos fue objeto de estudio y de interés a mediados de los años 80 . En concreto la "Comisión de Reforma legislativa" propugnaba no sólo el mantenimiento sino también la ampliación de los derechos de la acusación privada, igualándolos a los del acusador público. En su opinión, la sociedad como un todo es la beneficiaria en el momento en que de la interacción ciudadana positiva con el sistema de acusación pública resulta un control adicional sobre la discrecionalidad oficial. El sentimiento que percibe el ciudadano excluirá la sensación de la rutina en la administración de justicia y se afianzarán valores democráticos básicos en tanto se promueve la imagen general de un sistema de Justicia eficiente. En Nueva Zelanda y Australia se mantienen también las acusaciones privadas con cierta extensión, si bien en éste último caso los procedimientos ante los Tribunales superiores son asumidos por los Crown Prosecutors. Vid. LAW REFORM COMMISION OF CANADA, Working Paper 52. Private Prosecutions, 1986. En el marco de un sistema sobre el papel apegado al inglés, subsisten determinadas formas de acusación privada también en Nigeria como forma de salvaguarda frente a inactividad, negligencia o corrupción del acusador público. Al respecto vid. OKAGBUE, I., Private prosecution in Nigeria: recent developments and some proposals, Lagos 1991. En opinión de la autora, la acusación privada afianza el interés de la sociedad en el incremento de la aplicación de la ley, salvaguarda los derechos civiles y satisface desde dentro del sistema el interés del individuo por la venganza personal de las ofensas (p. 29 y s.).
} 
cualquier otro país ${ }^{1694}$, se encarga de llevar ante los Tribunales las acusaciones por delitos investigados por la policía, por lo cual ha sido considerado como "el brazo forense" de ésta.

Aun cuando quepa la posibilidad de que el CPS asuma también la responsabilidad de acusar por delitos no investigados por la policía, dicha tarea permanece en estas hipótesis generalmente en manos de los órganos administrativos en cuyo ámbito sectorial se sitúen las conductas delictivas. En este caso se trata de Departamentos de la Administración que disponen de una serie de posibles sanciones alternativas (amonestación, multas, decomiso de bienes, suspensión de licencias, etc.) junto con la facultad de instar la acusación en el proceso penal, la cual utilizan como último resorte para el cumplimiento de las normas de la materia propia de su competencia ${ }^{1695}$. En la actualidad, esta función viene atribuida principalmente al Serious Fraud Office, creado específicamente por la Criminal Justice Act de 1987 para la represión de los grandes fraudes y que no sólo incluye a juristas sino también a personal cualificado en labores de auditoría, contabilidad, etc. Este organismo cuenta con facultades directivas de la investigación previa, de decisión sobre los imputados y sobre los cargos, de selección del material, preparación del juicio, etc. Junto con el CPS es el único Departamento que existe principalmente para la acusación de los delitos. Ostentan un papel relevante en el mismo sentido, sin que en estos casos la función de acusación sea exclusiva, otras instancias gubernamentales como el Inland Revenue (delitos fiscales o de tráfico de drogas), la Seguridad Social (fraudes en esta materia), o diversos Departamentos de comercio e industria, salud, medio ambiente, correos, etc., siempre dentro del ámbito de sus respectivas competencias ${ }^{1696}$.

\footnotetext{
${ }^{1694}$ Se ha dicho que hablar de un sistema de acusación independiente y parejo a nuestro MF en Inglaterra es difícilmente conciliable con su tradición legal. Así por ejemplo VERCHER NOGUERA, A., “¿Hacia un Ministerio Fiscal inglés?", La Ley, 1987, T. 2, pp. 923-927. Aporta una perspectiva comparada entre el acusador británico y nuestro MF también MARCHENA GÓMEZ, M., El Ministerio Fiscal: su pasado y su futuro, Madrid 1992.

${ }^{1695}$ Representan así una excepción al principio del sistema inglés de separación entre las funciones de investigación y acusación del delito basada en las particularidad de los delitos de que se trate. Con motivo de la revisión del sistema de acusación en Inglaterra y Gales, las recomendaciones de la ROYAL COMMISSION ON CRIMINAL PROCEDURE se manifestaron en favor de mantener la acusación de agencias gubernamentales justificada por motivos de especialidad y de conocimientos en los diferentes ámbitos. Tal observación fue respetada, por lo que no cabe hablar hoy en Inglaterra de un monopolio de las acusaciones oficiales, en tanto el CPS no es el único órgano oficial encargado de llevar a cabo en nombre de la Corona la persecución de todos los delitos.

${ }^{1696}$ EMMINS, C.J., A practical approach to Criminal Procedure, 4 a ed., Londres, 1990, p. 10, Blackstone's on Criminal Procedure, 1993, p. 937. El art. 145.1 de la Customs and Excise Management Act de 1979 prevé también
} 


\subsubsection{La acusación privada y su funcionalidad}

\section{I.}

El ejercicio privado de la acusación es percibido en Inglaterra como un Derecho Fundamental de naturaleza constitucional, que actúa como cortapisa al monopolio acusatorio del Estado frente a la posible inercia, inactividad, arbitrariedad, incompetencia, parcialidad o corrupción de la autoridad pública ${ }^{1697}$. A pesar de sus enormes costes y de las grandes dificultades que lleva consigo, las acusaciones privadas se han convertido en un remedio para personas que se sienten frustradas y molestas con las decisiones que resuelven en sentido negativo el planteamiento de la acusación ${ }^{1698}$. Sin contar con cifras exactas del número de acusaciones privadas, todo apunta a que el muy escaso número de las deducidas por particulares o personas jurídicas (empresas o asociaciones) ha crecido en los últimos tiempos ${ }^{1699}$.

que las infracciones contra ella sólo puedan ser perseguidas por los oficiales encargados de ello.

${ }^{1697}$ La ROYAL COMMISION ON CRIMINAL PROCEDURE llegó a recomendar la abolición de la acusación privada considerando las siguientes razones: 1) se utilizaba muy pocas veces; 2 ) las acusaciones rutinarias deberían ser responsabilidad del $C P S ; 3$ ) eran inconsistentes; 4) las agresiones leves, ámbito principal de la acusación popular, son un híbrido con el derecho civil que deben desaparecer de las normas penales; 5) el abono de las costas suponen una dificultad añadida; 6) personas con intenciones maliciosas podrían iniciar una acusación y no continuar con ella; 7) no hay posibilidad de obtener justicia gratuita para los acusadores; 8) el derecho es inadecuado y en la práctica no se usa; 9) no hay demanda pública de incrementar la oportunidad o facilidad de uso de tal derecho. Posteriormente la Comisión legislativa se pronunció por mantener las acusaciones privadas, pero con un mero papel subsidiario. Sólo se podría instar un procedimiento penal por particulares tras el rechazo por el órgano público acusatorio de sus razonamientos y, en opinión de los integrantes de la Comisión, una vez que se aceptara la acusación por los Magistrados, los costes deberían ser asumidos por el Estado. Sin embargo, el Gobierno no vio suficiente justificación para imponer tal restricción a lo que se consideró como un importante derecho, y tampoco encontró apropiado este incremento de gastos, por lo que el resultado fue el mantenimiento de la acusación privada sin necesidad de desembolsos procedentes del erario público. Vid. ROYAL COMMISION ON CRIMINAL PROCEDURE, op. cit. marg. 7.46 a 7.51 y HOME OFFICE LAW OFFICE'S DEPARTMENT; An independent Prosecution Service for England and Wales. Presented to Parliament by the Secretary of State for the Home Department and the AG, Londres 1983, p. 9. Un amplio resumen se puede consultar en SAMUELS, A.,"Non-Crown Prosecutions: Prosecutions by Non-Police Agencies and by Private Individuals", Crim. L. R. enero 1986, pp. 33 y ss.

${ }^{1698}$ Con frecuencia pertenecen a este grupo los afectados por graves accidentes con pluralidad de víctimas, en los que el Servicio Público de Acusación ha declinado perseguir en varias ocasiones. Se trasluce así un cierto grado de subsidiariedad en la consideración del papel de las acusaciones privadas ejercitadas en estos supuestos. Si la presión sobre la opinión pública a través de los medios de comunicación no es suficiente como para conseguir incidir de forma favorable sobre la actividad del CPS, siempre quedará abierto el subsidiario cauce de la acusación privada. HUBER, B., op. et loc. cit.. y HARLOW, C. y RAWLINGS, R., Pressure trough Law, p. 228.

${ }^{1699}$ Puesto que ni las estadísticas criminales ni las judiciales recogen el dato de las acusaciones dirigidas por los 
Hoy por hoy, sin embargo, el principal campo de utilización en la práctica de la acusación privada en Inglaterra no es el que se pudiera equiparar a nuestra acusación popular, sino que se orienta mucho más en el sentido de cumplir el papel que en casi todos los sistemas continentales ostenta la querella privada. Tratándose de un ámbito fronterizo entre lo que social y legalmente se consideran delitos leves o simples injustos civiles, sólo susceptibles de ser sometidos a consideración de un tribunal penal por razones de conveniencia, la "private prosecution" inglesa cumple una función supletoria de la del órgano público allí donde éste no ve interés público en acusar ${ }^{1700}$, de manera similar a como opera la acusación por delitos privados en otros sistemas ${ }^{1701}$.

\section{II.}

Para el ejercicio de la acusación por personas físicas privadas no se establecen limitaciones que nos obliguen a detenernos en el examen de los sujetos legitimados, y únicamente cabe reseñar que se admite la representación procesal y que en la Crown

particulares, esta apreciación la realizamos tomando como base referencias secundarias (los memoranda en relación con el CPS, conversaciones privadas, prensa, etc.). En este sentido se pronuncia también HUBER, B., "The office of the State Prosecutor...”, op. cit. p. 1212, quien añade que el número de las acusaciones privadas es ínfimo en contraste con las iniciadas por los órganos acusatorios oficialmente encargados de esta misión. Es necesario reseñar que las acusaciones privadas en el Reino Unido no son para la inmensa mayoría de los operadores jurídicos un punto de interés relevante.

${ }^{1700}$ Un interesante trabajo al respecto, realizado con anterioridad a la existencia de un órgano de acusación público, es el realizado por LIDSTONE, K. W. / HOGG, R. / SUTCLIFFE, F. in collaboration with A.E. Bottoms and Monica A. Walker, Prosecutions by private individuals and non-police agencies, Londres 1980. El estudio demuestra la vinculación entre los criterios de persecución públicos y la utilización de la acusación privada. Así, por ejemplo, es significativo que todas las acusaciones privadas por robo en Londres se produjeran en los Tribunales sitos en la zona de competencia de la Metropolitan Police, cuya política se orientaba en el sentido de que fueran los dueños de las tiendas los que se ocuparan de la acusación de los robos de éstas (p. 99). El incremento en la utilización de la acusación privada es, por tanto, directamente proporcional a la dejación de funciones que hagan los órganos públicos a los que se confiere la persecución penal. El resto de los casos son de acusaciones por delitos de agresiones comunes y los autores del estudio reconocían no haber encontrado ningún caso en que la acusación privada hubiera sido usada como necesaria salvaguarda para los ciudadanos contra la inactividad por parte de los funcionarios públicos (p. 110).

${ }^{1701}$ En 1981, con motivo del estudio desarrollado al respecto por la llamada “Comisión Philips", se percibió que muchas de las acusaciones privadas eran ejercitadas no por individuos, sino por establecimientos comerciales que empleaban sus propios detectives. También era relativamente frecuente la acusación realizada por organizaciones altruistas tales como las Sociedades de protección de la infancia o de los animales. Vid. THE ROYAL COMMISION ON CRIMINAL PROCEDURE (Presidida por PHILIPS, C.), The Investigation and Prosecution of Criminal Offences in England and Wales: the Law and the Procedure, Londres 1981, pp. 15 y ss. y 60 y ss. En 1977, según estimaciones, sólo el 27\% de las acusaciones no fueron realizadas por la Policía. De ellas, el 24\% (es decir el 0'7 \% del total) por particulares. El resto fueron deducidas por las Administraciones de correos, transportes y protección del Medio Ambiente. 
Court se deberá acudir asistido por Abogado ${ }^{1702}$.

Con respecto a las personas jurídicas, se han suscitado dudas sobre la capacidad para acusar de las asociaciones, resolviéndose de manera afirmativa incluso cuando se trata de meras agrupaciones sin personalidad jurídica ${ }^{1703}$. El ámbito con mayor presencia de acusaciones privadas planteadas por colectivos ${ }^{1704}$ es el referido al mundo animal, en el que las tensiones entre cazadores y saboteadores de la caza y entre investigadores y militantes pro "liberación animal" han llegado frecuentemente ante los Tribunales penales ${ }^{1705}$. No es sin embargo el único, puesto que los grupos usan también la acusación privada en otras materias relativas a la protección del medio ambiente (ruido, polución), la propiedad intelectual ${ }^{1706}$, la salud o la vivienda ${ }^{1707}$. En la actualidad goza de gran difusión la actividad de asociaciones especializadas en la persecución de delitos de tráfico

${ }^{1702}$ Vid. R. v. George Maxwell (Developments) Ltd. (1980) 71 Cr. App. R. (Criminal Appeal Reports) 83.

${ }^{1703}$ MURPHY, P. (Editor), Blackstone's Criminal Practice 1983, p. 929.

${ }^{1704}$ Aun cuando nos limitemos a reseñar la actividad de personas jurídicas de naturaleza privada y no de corporaciones públicas, en algunos casos es difícil una neta diferenciación por cuanto a algunas se les confiere una naturaleza jurídica mixta, intermedia entre lo privado y lo público. Entre éstas se cuentas todas las "Royal Society for...", como la Reales Sociedades para la Protección de la Infancia, de las Aves o contra la crueldad hacia los animales.

${ }^{1705}$ SAMUELS, A., "Non-Crown Prosecutions: Prosecutions by Non-Police Agencies and by Private Individuals", Crim. L. R. enero 1986, p. 36 y esp. HARLOW, C. y RAWLINGS, R., Pressure..., op. cit. pp. 207 y ss. Los autores aportan cifras estadísticas de la actividad acusatoria de la Royal Society for prevention of cruelty to animals (RSPCA), cuya política consiste en perseguir allí donde hay suficientes pruebas para acudir a los Tribunales. Otras asociaciones como la Royal Society for the protection of Birds (RSPB) optan por una política dirigida primordialmente a la denuncia.

${ }^{1706}$ La FACT (Federation against Copyright Theft), trabajando en cooperación con la policía consiguió que se detuviera a unos acusados a requerimiento suyo, aun cuando no consiguió que se les condenara, puesto que la actividad de la Policía sólo puede ser canalizada en el proceso a través del Crown Prosecution Service. Vid. Ealing Justices, ex parte Dixon (1990) 2 QB 91, relatado en Blackstone's, op. cit. p. 929.

${ }^{1707}$ En muchos de estos casos, la acusación privada se erige en un publicitario “balón de oxígeno" o simplemente como forma de presión sobre las autoridades administrativas para obligar a éstas a adoptar medidas contundentes respaldadas por una opinión pública concienciada. No es desdeñable la actividad de las asociaciones en materias circundantes a la acusación aun cuando no suponga un ejercicio directo de ésta. Presionar directamente a las Autoridades Públicas para que se acuse o incidir en la opinión pública, creando un estado de opinión favorable a la acusación, son formas más baratas y ocasionalmente más efectivas de hacer cumplir las normas objeto de su actividad y que incluso pueden llegar a servir de base a un endurecimiento de éstas en el sentido de sus pretensiones. Los grupos, en la mayoría de las ocasiones, intentan persuadir a los diferentes Departamentos de la Administración de la necesidad de actuar, de forma que consiguen sus objetivos de forma indirecta. Ello no está reñido con el ejercicio de la acusación en su caso, y así HARLOW, C. y RAWLINGS, R., Pressure..., op. cit. pp. 212 y ss. relatan asuntos como el de una asociación de pescadores de caña acusando por razón de la contaminación de las aguas o la de Greenpeace por contaminación generada por una industria química. 
$\overline{\text { relacionados con la conducción bajo influencia de bebidas alcohólicas, que proporcionan }}$ apoyo y asistencia a las familias de víctimas fallecidas o heridas por conductores irresponsables o bebidos ${ }^{1708}$.

\section{III.}

La acusación privada no es un derecho objetivamente ilimitado de los particulares, sino que está sujeta a una serie de limitaciones que menoscaban seriamente sus teóricas potencialidades. A este respecto debemos distinguir entre las trabas que se presentan con carácter previo a su formulación y las que concurren en su ejercicio:

\section{A) Con carácter previo a su formulación}

En este caso, las limitaciones de la acusación privada tienen relación directa con las conductas a perseguir, puesto que existen algunas exclusiones objetivas de carácter absoluto (por ejemplo, delitos donde puedan estar implicados intereses nacionales) ${ }^{1709} \mathrm{y}$ supuestos en los cuales es precisa la previa autorización del Attorney-General o del Director of Public Prosecutions ${ }^{1710}$. En estas hipótesis, la acusación privada puede ser

${ }^{1708}$ La Campaign Against Drinking and Driving (CADD), formada en 1985 basa su actividad en la petición de prohibición total del alcohol en la conducción, la condena por homicidio para los conductores bebidos que ocasionen muertes, y el derecho de recurso para las víctimas y sus familiares en caso de sentencias demasiado benévolas. Además tiene una publicación: Advice and Information on the Criminal and Civil Law. En la actualidad goza de un status cuasi-oficial y su capacidad de presión en el trato directo con los Fiscales es bastante elevado. Vid. HARLOW, C. y RAWLINGS, R., Pressure..., op. cit. pp. 231 y ss. A esta asociación y a su boletín se refiere también FAIRÉN GUILLEN, V., “Acción, proceso y ayuda a las víctimas del delito”, La Ley 1991, T. 3 , p. 863 y Ensayo sobre procesos complejos, p. 149, n. 24.

${ }^{1709}$ La ROYAL COMMISION ON CRIMINAL PROCEDURE encargada del diseño del sistema de acusación vio esta necesidad de una exclusión absoluta, pero advertía que ello debería entenderse con un carácter restrictivo. Recogido por EDWARDS, J. Ll. J, The Attorney-General, Politics and the Public Interest, Londres 1984 p. 26 , n. 25.

${ }^{1710}$ El Attorney-General es el principal agente de la ley (Law Officer) de la Corona y normalmente es un miembro del Parlamento perteneciente al partido mayoritario que goza de la confianza del Primer Ministro. Aunque no es parte del Gabinete, ostenta un cargo ministerial y, por tanto, forma parte del Gobierno, es el encargado de la asistencia jurídica a éste y responde ante la Cámara de los Comunes de las cuestiones relativas a asuntos legales. Es también responsable de la supervisión de las tareas del Director of Public Prosecutions, políticamente responsable del Crown Prosecution Service y preside la "English Bar". El Solicitor General es el segundo "Law Officer of the Crown" y está subordinado inmediatamente al Attorney General. Normalmente se trata de un parlamentario también perteneciente al partido mayoritario. Actúa como representante del $A G$ y puede ejercitar cualquier potestad que éste tenga reconocida si el cargo de $A G$ está vacante, no puede éste actuar por enfermedad o si se le ha autorizado para ello. Vid. Law Officers Act 1944, sección 1. El Director of Public Prosecutions, a través precisamente del Crown Prosecution Service es el responsable de la dirección de todas las persecuciones penales instituidas por la Policía. 
$\overline{\text { impedida con carácter previo por los oficiales encargados de la persecución y permanece }}$ para ellos abierta la facultad de intervenir en cualquier proceso penal cuando lo estimen necesario ${ }^{1711}$. El consentimiento de estos Law Officers of the Crown es necesario para poner en marcha un gran número de acusaciones, que en origen se referían a crímenes contra el Estado, el orden público o de corrupción, pero que abarcan hoy un amplio abanico $^{1712}$. De entre ellos podemos citar delitos tan variopintos como los referidos a estupro, suicidio, conspiración, genocidio, delitos con explosivos, fotografía pornográfica de niños, libelo, libelo sedicioso, publicaciones obscenas, secretos oficiales, motín, delitos de orden público, de odio racial, disturbios, robo entre cónyuges, etc ${ }^{1713}$.

Uno de los argumentos más extendidos para justificar esta intervención es que se dirige a impedir intromisiones en circunstancias donde la acusación no es apropiada. En asuntos concernientes a materias con trascendencia política o con alto grado de sensibilidad social, se atraería la atención pública, permitiendo al acusado aparecer como defensor de importantes principios y libertades, lo cual no representaría un factor positivo ${ }^{1714}$. De esta manera, el control por los oficiales públicos hace que las

${ }^{1711}$ Vid. las monografías sobre el tema de EDWARDS, J. L1.J, The Law Officers of the Crown, Londres $1964 \mathrm{y}$ The Attorney-General, Politics and the Public Interest, Londres 1984. Para una referencia general, vid. MARTIN, E. A. (Editor), A concise Dictionary of Law, Oxford Reference, 2a edición, Oxford-Nueva York 1992.

${ }^{1712}$ La necesidad de un consentimiento por parte del Attorney-General para entablar pretensiones penales tiene su origen inmediato en su competencia exclusiva para la persecución de los delitos contra la Corona (sedición o traición) en el siglo XVIII. Durante el siglo XIX y principios del XX algunas normas sectoriales fueron estableciendo cláusulas limitativas a las acusaciones privadas en materias en las que estaban implicados intereses de naturaleza supraindividual: aguas territoriales (1878), libelo (1881), sustancias explosivas (1883) o secretos oficiales (1911), pero es fundamentalmente a partir de la Segunda Guerra Mundial cuando este requerimiento se empezó a extender entre las normas penales británicas. La necesidad de que un funcionario público diera su autorización a la acusación privada y, con ello, quedara en gran medida ésta sometida a su voluntad, se ha explicado tanto por la convicción de que la legislación referida a determinadas materias sería puesta en práctica mejor si de esa tarea se encargaran oficiales públicos responsables públicamente de su cumplimiento, como por las tendencias racionalizadoras de los gobiernos modernos. En unos primeros momentos, una situación de guerra total hacía lógica una intervención del Estado fuera de lo común, pero posteriormente esta necesidad se justificó en el argumento de que la creación y consolidación del Estado del Bienestar exigía que la puesta en práctica de la legislación en la que éste se fundamenta debiera ser controlada por oficiales públicos. Vid. HAY, D., "Controlling the English...", op. cit. p. 180.

${ }^{1713}$ Una completa clasificación de los delitos que precisan de este consentimiento para su persecución se encuentra en ARCHBOLD, Criminal Pleading, Evidence \& Practice, 1994, Tables and Index volume, pp. 275 y ss.

${ }^{1714}$ DICKENS, B.M., “The Attorney-General's Consent to Prosecution”, Modern Law Review, nº 35, 1972, pp. 347 y ss. Esta misma fue la opinión del William Committee on Obscenity and Film Censorship, que recomendaba que este tipo de cuestiones (obscenidad y censura) no se persiguieran de forma privada. Su argumento era que "hay un número de individuos que son mucho más susceptibles a ser ofendidos que la generalidad. Dudamos que sea de interés público el conceder a estas personas la posibilidad de defender sus puntos de vista no representativos ante 
$\overline{\text { posibilidades de acusación privada hayan quedado relegadas a un ámbito objetivo }}$ bastante restringido del que se excluyen materias en las que la acusación privada pudiera afectar a importantes intereses políticos o sociales y originar conflictos más graves que los que viene a resolver.

El debate sobre la capacidad del Parlamento de introducir limitaciones legales al derecho de acusación privada tuvo uno de sus puntos álgidos en 1959, con motivo de la discusión de la “Obscene Publications Bill”, una materia en la que se ponía de manifiesto la contraposición de intereses individuales (especialmente los de ciudadanos con una sensibilidad hiperdesarrollada en estas cuestiones) con otros que afectan a la colectividad en general, tal y como podrían entenderse las libertades de expresión o de creación artística. Los argumentos con base en los cuales un consentimiento del Director of Public Prosecutions o del Attorney-General se veía justificado hacían referencia a las siguientes necesidades: 1) asegurar la consistencia en el desempeño de las funciones acusatorias en materias donde la ley está abierta a multitud de interpretaciones ${ }^{1715}$;2) prevenir abusos en la persecución evitando acusaciones vejatorias ${ }^{1716}$; 3) aplicar uniformemente la ley en materias que difícilmente podían definirse de manera estricta en ella, introduciendo factores mitigantes de esas posibles diferencias; 4) proporcionar un control centralizado sobre el uso de la ley penal cuando ésta afectara a áreas particularmente sensibles o controvertidas tales como las relaciones raciales o la censura; 5) asegurar que las decisiones de perseguir un delito tomaran en cuenta importantes consideraciones de carácter político o de trascendencia internacional, tales como las referidas a secretos oficiales o a

los tribunales, particularmente cuando el delito no les afecta directamente. Sólo tendrán un status autoconcedido de iniciar los procedimientos". Vid. también LIDSTONE, K.W., et al., op. cit. p. 198.

${ }^{1715}$ Frente a ello se alegó que ésta no debía ser razón para limitar las acusaciones privadas, puesto que precisamente su presencia garantiza la interpretación correcta de normas equívocas sometiéndolas al control ejercido por diferentes personas con diferentes puntos de vista. La uniformidad en la aplicación de la ley es competencia exclusiva de los Tribunales y no se puede conseguir interponiendo la intervención del Ejecutivo entre éstos y la ley que deben aplicar. Memorandum del Attorney-General Manningham-Buller presentado al Select Committee on the Obscene Publications Bill recogido por HETHERINGTON, T., Prosecution and the Public Interest, Londres 1989 , p. 154 y por EDWARDS, J. Ll. J, The Attorney-General, Politics and the Public Interest, Londres 1984, p. 27, quien destaca el peligro que este razonamiento lleva consigo de diferencia en la actividad práctica de la acusación por las diferentes secciones policiales.

${ }^{1716}$ En supuestos donde entran en juego subjetivas normas de moralidad u opiniones religiosas o políticas, tales como los delitos de los que aquí se trataba, se dice que la acusación privada es utilizada para satisfacer los caprichos del acusador más que para reivindicar sus derechos o ayudar en la administración de la justicia penal. Vid. EDWARDS, J. L1. J, The Attorney-General..., op. cit., Londres 1984 p. 28. 
$\overline{\text { piratería aérea }{ }^{1717} \text {. Más recientemente, con motivo de la discusión sobre la Prosecution of }}$ Offences Act de 1985 se pusieron sobre la mesa los mismos argumentos, y el AG en ese momento, Lord ELWYN-JONES, defendió la necesidad de retener el control de la acusación en ciertos "casos sensibles, tales como secretos oficiales, publicaciones obscenas, delitos electorales, corrupción pública y varios delitos sexuales".

Prevenciones de este tipo se han ido incorporando progresivamente a la legislación penal, y muy especialmente en áreas políticamente sensibles, transmitiendo una idea de cierta selectividad en las conductas que merecen ser perseguidas ${ }^{1718}$. Hay quien vio en la introducción de continuas limitaciones legales al ejercicio de la acusación por los particulares el claro mensaje de que este antiguo derecho, a la vista de la actitud del legislador, no sería en la actualidad más que un anacronismo ${ }^{1719}$. Este control sobre las decisiones de acusar, incardinado entre las potestades de los Law Officers of the Crown, sólo estará sujeto a un control de naturaleza política en su responsabilidad ante el Parlamento, pero en ningún caso se podrá ver sometido a una revisión judicial posterior. Adquiere así unos niveles limitados prácticamente por la admisibilidad en el terreno político de las decisiones adoptadas. La primitiva garantía de la acusación privada como contrapeso a la inactividad o mala voluntad de las autoridades públicas queda de esta forma en entredicho precisamente en áreas abiertamente expuestas a la intervención política del Ejecutivo ${ }^{1720}$.

${ }^{1717}$ Vid. EDWARDS, J. L1. J, The Attorney-General,..., op. cit. Londres 1984, p. 26, n. 25, que recoge así los argumentos del HOME OFFICE (Ministerio del Interior). Se proponía la competencia exclusiva para la intervención por el Attorney-General en materias de trascendencia política o carácter internacional y compartida con el Director of Public Prosecutions en el control de áreas especialmente sensibles, dejando para éste último la facultad de intervención en los demás casos en que ello se viera necesario.

${ }^{1718}$ Por ejemplo en lo concerniente a delitos de disturbios o incitación a ellos y los derivados de odio racial. En los dos primeros casos se requiere el consentimiento del $D P P$ para la acusación y en el último, el consentimiento del $A G$. Art. 7.1 y 27.1 de la Public Order Act de 1986. vid. SMITH, A.T.H., Offences against public order (including the Public Order Act 1986), Londres 1987, pp. 38 y s.

${ }^{1719}$ Concretamente Lord HUTCHINSON. Vid HETHERINGTON, T, Prosecution and the Public Interest, op. cit., Londres 1989, pp. 86 y s.

${ }^{1720}$ HAY, D., "Controlling the English...", op. cit. p. 180, se permite presentar este hecho como muestra de la insensibilidad de los Parlamentarios actuales para contemplar las persecuciones privadas como garantía constitucional de las libertades, en contraposición a la actitud demostrada históricamente por sus predecesores, quienes celosos frente a todo aquello que aparentara ser una muestra de tiranía, así la habían visto. Un listado de más de 100 normas que contienen esta restricción a las acusaciones privadas lo proporcionaron LIDSTONE, K.W. et al., Prosecution..., op. cit. apéndice F, p. 217. Es interesante a este respecto destacar la clasificación de las razones para este tipo de restricción, abierta en muchos casos a la arbitrariedad, que realizó el Ministerio del Interior (Home 


\section{B) En el ejercicio de la acusación}

1) Asunción del ejercicio de la pretensión penal por los órganos públicos de acusación: el primero de los límites, y quizá el que ponga en entredicho más claramente la virtualidad de la acusación privada en el sistema inglés, es la posibilidad del Attorney General o del Director of Public Prosecutions bajo su dirección, de asumir cualquier acusación iniciada por un particular (art. 6.2 POA). Tal facultad puede ser ejercitada en cualquier momento del procedimiento y se dirige a retomar (take over) una acusación privada, bien para continuar con ella, bien expresamente para hacerla decaer ${ }^{1721}$. Una vez asumida, el acusador oficial dispone de ésta con absoluta libertad dentro de los márgenes de lo razonable y no representa la posición del acusador privado o sus intereses, ni asume la responsabilidad de lo realizado por él hasta entonces ${ }^{1722}$.

La facultad de hacer decaer la acusación simplemente no presentando pruebas de cargo contra el acusado (art. $23 P O A$ ) es un amplio poder ${ }^{1723}$ que ha llevado siempre tras

Office). Según su informe, la acusación privada podrá ser limitada 1) para afianzar la consistencia de las acusaciones o evitar abusos, 2) para posibilitar un factor de mitigación difícilmente previsible en abstracto por la ley, 3) para proveer un control central sobre el uso del derecho penal en áreas sensibles tales como las relaciones raciales o la censura, y 4) para asegurar que la decisión sobre la acusación toma en cuenta importantes cuestiones de política pública o de carácter político o internacional. Vid. LIDSTONE, K.W. et al., Prosecution..., op. cit. p. 198 y EDWARDS, J., The Attorney General, politics and the public interest, Londres 1984, p. 26, n. 25.

1721 “Where criminal proceedings are institued in circumstances in which the Director is not under a duty to take over their conduct, he may nevertheless do so at any stage". La potestad del DPP de asumir cualquier acusación tiene su origen en la ley de 1908 ya que la de 1879 se especificaba que "nada interferirá el derecho de cualquier persona a iniciar, emprender o conducir procedimientos penales". Incluso en algún voluntarioso proyecto de Constitución escrita para el Reino Unido se le ha conferido carácter constitucional, admitiendo tácitamente la presencia de acusadores privados. Vid. por ejemplo el proyecto del INSTITUTE FOR PUBLIC POLICY RESEARCH, A written Constitution for the United Kingdom, Londres 1993, art. 48.4.3.

${ }^{1722}$ Es posible retomar la acusación incluso en la segunda instancia, en cuyo caso no es necesario para el $D P P$ tener en cuenta cuál hubiera sido la posición del particular acusador. En su informe anual sobre la actividad del $C P S$ en 1987/88, el DPP GREEN afirma que ello haría vulnerable al CPS frente a presiones inadecuadas, posiblemente en perjuicio del acusado.

${ }^{1723}$ Se puede hacer uso de tal facultad incluso en supuestos en que hubiera habido previa inactividad por parte del CPS. Vid. R. v Bow Stipendiary Magistrate, exp. South Coast Shipping Co. Ltd. and Another (1993) 1 All. E. R. p. 219, Journal of Criminal Law (1993) n $n^{\circ} 57$, pp. 214 y ss . El caso se refiere a un grave accidente de navegación en el Támesis en el que fallecieron 51 personas como consecuencia del hundimiento de un barco de recreo que chocó contra una draga. Una vez que se supo que el patrón de ésta estaría libre de cargos, se intentó una acusación privada por el marido de una de las víctimas contra los propietarios y ciertos miembros de su tripulación. La defensa alegó que esta acusación constituía un abuso del proceso por cuanto su único objetivo consistía en originar un posicionamiento de la opinión pública en su favor, retardar el proceso e introducir en él elementos de confusión, todo lo cual iría en contra del derecho a un juicio justo. Estos argumentos fueron rechazados por considerar que la actividad del particular a la búsqueda de publicidad no afectaría a la "limpieza" del proceso, por lo que no 
de sí una comprensible polémica ${ }^{1724}$. Su efecto es necesariamente una sentencia absolutoria, lo cual la diferencia de la retirada de cargos (con autorización del Juez ${ }^{1725}$ ) o de la interposición de un "nolle prosequi", hipótesis en las que el proceso podrá ser reabierto con posterioridad, dejándolo en la práctica pospuesto sine die ${ }^{1726}$. No obstante, ha sido ratificado jurisprudencialmente en varias ocasiones, destacándose siempre las razones de interés público que motivan en cada caso la decisión y la necesidad de que la acusación deba ser dirigida correctamente ${ }^{1727}$. Esta facultad no ha sido utilizada con demasiada frecuencia y de la práctica parece deducirse que se asumen las acusaciones de los particulares sólo en casos de especial trascendencia política (por ejemplo, espionaje) o social (v.gr., cuando ha habido multitud de afectados) ${ }^{1728}$.

constituiría un abuso de éste.

En defensa del mantenimiento de esta potestad ha sido alegado que, en la práctica, hay supuestos en los que el $D P P$ no ha interferido en absoluto la acusación emprendida por un particular, aun cuando ésta se haya emprendido tras una decisión de funcionarios de su Departamento o del CPS basada en la no existencia de pruebas suficientes que sustentasen los cargos. Aún más, se ha señalado también que, en ocasiones, ha sido el propio acusador el que ha solicitado del DPP su intervención para que éste se hiciera cargo de la acusación. HETHERINGTON, Prosecution and the Public Interest, op. cit. p. 160.

${ }^{1724}$ El único control que resta para contrarrestar esta amplia facultad es el derivado de la posible petición de responsabilidad política ante el Parlamento que pudiera recaer en el $A G$, de la cual se deriva también la del $D P P$ como encargado del CPS.

\footnotetext{
${ }^{1725}$ Necesaria tanto para las acusaciones particulares como para las ejercitadas por funcionarios públicos. Vid. $R$. v. Comptroller General of Patents, ex p. Tomlison (1899) 1 Q.B. 909 citada por EDWARDS, J. Ll. J, The AttorneyGeneral..., op. cit., p. 452.
}

${ }^{1726}$ EDWARDS, J. L1. J, The Attorney-General..., op. cit., p. 451.

${ }^{1727}$ Un caso que ha adquirido relevancia es el Turner v. Director of Public Prosecutions (1978) 68 Cr. App. R. 70. Turner, que había sido condenado por robo a siete años de prisión, acusó de robo a uno de sus cómplices en la comisión del delito, Saggs, contra el cual no se había procedido como recompensa a su colaboración para la resolución del caso y la condena de Turner y de otros. El $D P P$ se hizo cargo de la acusación con vistas a no presentar pruebas de cargo. Turner respondió iniciando una acción contra el $D P P$, alegando que su intervención no se ajustaba a la legalidad y estaba realizando un abuso del proceso. En la sentencia del Tribunal de Apelación se reafirmó el derecho del $D P P$ de realizar este tipo de intervenciones, estimando que no son ilegales y haciendo notar los efectos negativos que lo contrario podría tener sobre futuras investigaciones en materia criminal. Vid. la narración del caso realizada por la propia persona que ocupaba el cargo de Director of Public Prosecutions en aquellos momentos: HETHERINGTON, T, Prosecution and the Public Interest, op. cit., Londres 1989, p. 45 y esp. 159 y s. En el caso Attorney General v Raymond (1982) QB 839, en el que uno de los acusados acusaba a su vez de falso testimonio a uno de los testigos de cargo, el $D P P$ asumió también la acusación para hacerla decaer por falta de pruebas alegando que lo único que se pretendía era poner trabas al proceso originario. El Tribunal convalidó esta actuación entendiendo que entraba dentro de sus facultades discrecionales.

${ }^{1728}$ Podemos citar únicamente la cifra de que entre los años 1987 y 1989 el $C P S$ asumió 28 casos de acusación privada, de entre los cuales en 10 no procedió y en el resto continuó la tarea iniciada por el acusador privado. Vid. 
2) Facultad de poner fin al proceso (nolle prosequi): una ulterior limitación a las acusaciones privadas viene determinada por la facultad discrecional que se atribuye al Attorney-General para poner fin a cualquier proceso penal mediante el denominado "nolle prosequi", cuya interposición termina automáticamente en la fase intermedia ${ }^{1729}$ un procedimiento de indictment ${ }^{1730}$. En la actualidad, se suele emplear únicamente por motivos humanitarios en caso de incapacidad física o mental del acusado sobrevenida en el transcurso del proceso que le impida estar en condiciones para continuarlo y no se pueda interrumpir éste de otra manera. Pero no hay nada que impida al $A G$ hacerlo por otros motivos entre los que podría citarse, por ejemplo, el que la persecución no sea de interés público, privando con ello a los ciudadanos de su derecho constitucional a mantener bajo su dirección y a su propio cargo una acusación privada. Tradicionalmente ha sido sostenido por la generalidad de la doctrina la doble función del "nolle prosequi": en un sentido para disponer sobre persecuciones oficiales técnicamente imperfectas y en otro de evitar persecuciones privadas inatacables desde el punto de vista procedimental, pero que resultaran "opresivas" 1731 . Entre estas últimas habría de incluirse el supuesto de que, bajo la promesa de no persecución a uno de los imputados, aportara éste datos esenciales para la condena de los demás ${ }^{1732} \mathrm{o}$ las acusaciones inviables y gravosas económicamente ${ }^{1733}$.

La decisión del AG es absolutamente discrecional, no puede delegarse y no está sometida a control alguno por los Tribunales ${ }^{1734}$. Una vez más, el único control posible

The Times, 8 de agosto de 1991, cit. por HUBER, B., "The office of the state prosecutor...”, op. cit. 1212.

${ }^{1729}$ Vid. la referencia a ello de VERGER GRAU, J. en La defensa del imputado y el principio acusatorio, Barcelona 1994, p. 85.

${ }^{1730}$ Es decir, los más graves y de los cuales conoce un jurado en la Crown Court. Los procedimientos Sumarios (Summary Trial) se celebran en la Magistrates' Court sin jurado.

${ }^{1731}$ EDWARDS, J. Ll. J, The Attorney-General,..., op. cit., p. 445. EDWARDS reconoce, sin embargo, que la utilización interesada de la persecución penal no es patrimonio exclusivo de las persecuciones privadas realizadas por ciudadanos a título particular, sino que también puede serlo de la Policía y de otras agencias con competencias acusadoras.

${ }^{1732}$ SAMUELS, A., “Non-crown prosecutions...”, op. cit. p. 41.

${ }^{1733}$ Por ejemplo la que inició en un asunto de libelo tras una absolución por el mismo caso y unos costes, abonados por el erario público, de más de 50.000 libras. Vid. ROZENBER, J., The case for the Crown. The inside story of the Director of Public Prosecutions, Wellingborough 1987, p. 172.

${ }^{1734}$ Vid SAMUELS, A., "Non-Crown Prosecutions: Prosecutions by Non-Police Agencies and by Private Individuals", The Criminal Law Review 1986, p. 41 n. 38. En sentido contrario se manifiesta SAMUELS, que, con base en el caso Council of Civil Service Unions (1985) A.C. (Law Reports, Appeal Cases) 374, afirma que probable- 
sobre esta potestad es el político, traducible a través de su responsabilidad ante la House of Commons. Una garantía más viene determinada por cuanto si bien un nolle prosequi impide la continuación del proceso, no impide reabrirlo con posterioridad. No se trata, en definitiva, más que de una suspensión sine die, en relación a la cual existe el convencimiento de que no se debe utilizar de forma abusiva privando al acusado de una sentencia que podría ser también absolutoria ${ }^{1735}$.

3) Limitaciones en la investigación. Prohibición de acceso a las pruebas: aunque los individuos tengan reconocido el derecho a instar una acusación privada, no se les confiere una facultad implícita de acceso a documentos tales como atestados policiales, informes y fotografías que estén en manos del CPS $^{1736}$. La imposibilidad de acceder a las pruebas y de recabarlas por sí mismos opera así como una limitación clave para que la acusación privada cumpla la función que teóricamente tiene encomendada.

4) Los costes del procedimiento: el gasto ocasionado por la persecución es reconocido por la generalidad de la doctrina como la mayor limitación al ejercicio de la acusación por particulares y la principal causa de que en la actualidad ésta se encuentre prácticamente fuera de lugar ${ }^{1737}$. Puesto que no es posible obtener el beneficio de ayuda legal (legal aid), los gastos de la investigación, preparación y representación de la acusación deben ser sufragados en principio del propio bolsillo del acusador. Sólo a posteriori, en los procedimientos por indictable offences (delitos graves) y en los de summary offences (delitos leves) ante la Divisional Court o la Cámara de los Lores, el Tribunal podrá conceder el reintegro de los gastos que considere razonables para compensar suficientemente al acusador privado que haya vencido en juicio. El art. 17.1 POA (1985) prevé el abono de las cantidades que el Tribunal considere razonables para cubrir los gastos en que haya incurrido en el procedimiento, previsión que no opera cuando el acusador sea funcionario público ${ }^{1738}$. Este reembolso, que habrá de ser

mente ahora sí esta sometido a revisión judicial, a no ser que haya actuado "por razón de Estado".

${ }^{1735}$ SAMUELS, A., “Non-Crown Prosecutions...”, op. cit. p. 41.

${ }^{1736}$ R. v. Director of Public Prosecutions, ex p. Hallas (1987) 87 Cr. App. R. 340.

${ }^{1737}$ EDWARDS, J. L1. J, The Attorney-General,..., op. cit., Londres 1984, p. 451 se refiere a los costes como una dificultad mayor para detener una acusación privada vejatoria u opresiva utilizada por las Autoridades que la misma potestad del nolle prosequi.

${ }^{1738}$ Con ello se puede ver una vez más que para el legislador inglés la acusación ejercitada por un oficial público o por un particular es exactamente lo mismo. 
solicitado expresamente, abarca los gastos del procedimiento, comprendidos por ejemplo los derivados de la intervención de testigos propuestos a su instancia, pero no se extiende a los producidos con motivo de la investigación ${ }^{1739}$.

Como contrapartida, el acusador privado asume el riesgo que implica compensar los gastos de la otra parte si su acusación no tiene éxito.

5) Limitación de las acusaciones maliciosas o vejatorias: el art. $24 P O A$ contiene una disposición encaminada a frenar el uso impropio de la acusación privada, a tenor de la que la High Court podrá dictar una resolución restringiendo a un individuo su derecho a iniciar una acusación privada si no cuenta con su permiso ${ }^{1740}$. Ésta no lo autorizará "a no ser que esté convencida de que el inicio de la persecución no constituye un abuso del proceso penal y de que hay fundamento razonable para la institución del procedimiento por el solicitante".

La institución del abuso del derecho, y su concreta manifestación como abuso del proceso, ha sido también utilizada para limitar en cierta medida las facultades del acusador privado. La jurisprudencia ha señalado que constituiría un abuso del proceso permitir a un acusador privado perseguir por un cargo que el $C P S$ ya había retirado con anterioridad tras un acuerdo con el acusado ${ }^{1741}$, o plantear una acusación como ardid para desbaratar unas negociaciones ${ }^{1742}$. Todo ello nos habla de una muy diferente consideración de la acusación privada en Inglaterra en relación con la idea que se sostiene de la acusación popular en nuestro país.

IV.

${ }^{1739}$ Las mismas prescripciones para el abono de los gastos se prevén también para la instancia de apelación ante la Court of Appeal. Vid. A guide to Proceedings in the Court of Appeal Criminal Division, $\mathrm{n}^{\mathrm{o}} 20.1$.

${ }^{1740}$ Con ello se amplía una posibilidad ya prevista en la Supreme Court Act de 1981 en materia civil. Se trata de una posibilidad más teórica que real, diseñada en abstracto como mecanismo de garantía. HETHERINGTON la juzgaba, sin embargo, útil para casos excepcionales, reconociendo que no conocía de la iniciación de ningún procedimiento de este tipo. HETHERINGTON, T., Prosecution and the Public Interest, op. cit., p. 158.

\footnotetext{
${ }^{1741}$ R. v. Grays Justices, ex p. Low (1990) Q.B. 54, 88 Cr. App. R. 291.

${ }^{1742}$ R. v. Horseferry Road Magistrates' Court, ex p. Stephenson (1989) C.O.D. (Crown Office Digest) 470.
} 


\section{El "Code for Crown Prosecutors"1743 contiene dos criterios (tests) sucesivos que}

habrán de cumplirse para discernir la conveniencia de acusar en un supuesto concreto: el de la prueba y el de la concurrencia de interés público en la persecución ${ }^{1744}$. Con base en el primero deberá decidirse la suficiencia de la prueba para fundamentar de forma realista una acusación, y consistiría en el análisis de la concurrencia de una alta probabilidad de condena $^{1745}$. Acto seguido se deberá usar el denominado “criterio del interés público" el cual es mutable en cada caso ${ }^{1746}$ y determinará también la opción entre iniciar o no la persecución $^{1747}$.

El que la decisión básica sobre el planteamiento de la acusación no pueda ser sometida a revisión judicial hace relevante el valor de su ejercicio privado como salvaguardia frente a hipotéticos errores del oficial. A partir de que se opte por no acusar, se abrirá la posibilidad de deducir privadamente la pretensión, aun cuando ello suponga

${ }^{1743}$ Aprobado en 1986 y modificado en 1988, constituye la declaración de principios manifestada públicamente, bajo la que el Director of Public Prosecutions ejercita sus funciones, que aporta una base de actuación uniforme y fundamenta la responsabilidad de los acusadores públicos.

${ }^{1744}$ Es muy significativa a este respecto la frase pronunciada por el Attorney-General Lord SHAWCROSS: "No ha habido en este país nunca una regla -y espero que no la haya nunca-por la que todos los delitos que se presuman cometidos deban ser perseguidos". Vid. House of Commons Debates, vol. 483, columna 681 (29 de enero de 1951). Vid. también la sentencia R. v DPP, ex $p$. C., The Times, 7 de marzo 1994, DC.

${ }^{1745}$ Así se pronunciaba HETHERINGTON, quien llegó a ser calificado por la prensa como "el Señor 51\%”, haciendo referencia a su constante defensa de la necesidad de perseguir cuando la probabilidad de condena fuera superior al $50 \%$.

${ }^{1746}$ Se consideran relevantes para la concurrencia de interés público en la persecución otras circunstancias tales como la premeditación, la comisión del delito en grupo, la utilización de armas, la reincidencia, el que la víctima desarrollara un servicio público, el que el acusado se sirviera de una posición de autoridad, la concurrencia de cualquier forma de discriminación en el motivo del delito, la marcada diferencia de edad entre delincuente y víctima e incluso la extensión de determinados delitos, aun cuando no sean especialmente graves. CROWN PROSECUTION SERVICE, The Code for Crown Prosecutors, $\mathrm{n}^{\mathrm{0}} 6.4$.

${ }^{1747}$ Con respecto a este último HETHERINGTON fija su contenido en las siguientes notas: 1) el interés por el sostenimiento del Derecho penal en tanto la sociedad decide qué es lo que trata como delito; 2) no será necesario para el interés público reaccionar a los requerimientos emotivos de una parte de la sociedad en la formulación de la política acusatoria. El acusador debe considerar si una campaña, quizá inspirada por los medios de comunicación es verdadero reflejo de la opinión pública; 3 ) el interés del acusado, que a veces requiere la no acusación; 4) Acusar es caro y el presupuesto debe ser administrado adecuadamente. HETHERINGTON, T., Prosecution and the Public Interest, op. cit. p. 149. Aun cuando los vínculos de dependencia del AG y su posición dentro del Gobierno no implique necesariamente que haya de estar influenciado por las fuerzas políticas de cuya confianza goza, el hecho de que la decisión de perseguir o no un delito no se fundamente en estrictas razones de legalidad, abre un incuestionable amplio margen de discrecionalidad. A este respecto, sólo la posible exigencia de responsabilidades políticas y el control ejercido por la opinión pública bien informada a través de los medios de comunicación pueden servir de freno a la arbitrariedad. Vid. HUBER, B., “The office of the State Prosecutor...”, op. cit. p. 1197. 
$\overline{\text { siempre un desembolso }}{ }^{1748}$. Al derecho de acusar se le reconoce así una misión de control sobre los órganos estatales, y de hecho, casi todas las acusaciones privadas se inician tras estimar el CPS la insuficiencia de la prueba de que se dispone o la inexistencia de interés público en la acusación ${ }^{1749}$. En estos casos, la acusación privada estaría llamada a cubrir el hueco que deja la labor del acusador oficial, haciendo realidad su teórico papel como "valiosa salvaguardia constitucional". La posición del acusador no deja de ser única, individual y singular y, por tanto, la idea de intercambiabilidad entre acusación pública y privada o de subsidiariedad entre ambas está presente, pero nunca la compatibilidad de las dos al mismo tiempo: no cabe que acusador oficial y acusador privado compartan simultáneamente la misma posición, sino sólo que la ocupe uno u otro ${ }^{1750}$.

No puede olvidarse tampoco que la acusación privada es un freno de capacidad ciertamente limitada frente a discrecionalidades de la acusación oficial, en tanto, como se ha visto, podrá operar sólo cuando no se oponga a la voluntad del legislador en supuestos políticamente sensibles o cuando el órgano oficial acusador permita la intervención de particulares en la acusación ${ }^{1751}$. Pero además, contra la decisión del CPS de no proceder en un supuesto concreto o de no continuar la persecución de un delito ya iniciada no hay posibilidad de queja para los particulares, ofendidos o no por el delito, ni facultades de control por el Tribunal ${ }^{1752}$.

${ }^{1748}$ Vid. ASHWORTH, A., “The «Public Interest» element in prosecutions”, Crim. L. R., sept. 1987, pp. 597607, esp. 605.

${ }^{1749}$ Fourth Report of the Home Affairs Committee 1989-1990, Crown Prosecution Service. HMSO Londres 1990, par. 48.

${ }^{1750}$ Sólo sería posible una presencia de la víctima del delito en el proceso solicitando la denominada "compensation", aun cuando en este caso apenas se le atribuyan facultades.

${ }^{1751}$ En este sentido vid. LIDSTONE, K.W. et. al., Prosecution..., op. cit. p. 197.

${ }^{1752}$ Las razones que se ocultan tras estas decisiones no suelen trascender públicamente, dado que en ocasiones se toman en cuenta datos en poder del acusador que se estima no deben trascender públicamente. tales como los referentes a testigos, informes médicos del acusado, etc. Es también un criterio de actuación presente en la actividad del $C P S$ el no dejar que la posición de la víctima influya: donde a su juicio no existan perspectivas realistas de condena, no debe afectarle la posibilidad de que la víctima inicie con posterioridad una acusación privada. Puesto que el acusador público puede equivocarse, el mantenimiento de la acusación privada encuentra su razón de ser, pero no por ello la actitud o los deseos de la víctima o su familia deben afectar en cuestiones esenciales la posición del acusador público. Ello está sin embargo muy presente en la actividad diaria del acusador oficial. Alcanzó amplia difusión pública el caso de unos padres que acusaron de homicidio a la persona que proporcionó droga a su hijo drogadicto a la vista de que la Policía no lo hacía. Se dice que éste ha sido el primer caso del siglo de persecución privada por homicidio, si bien en último término el $D P P$ se hizo cargo de la acusación. R. v Austin, The Times, 21 de 


\subsubsection{Balance}

El derecho tradicional a la acusación privada parece haber sido rodeado en Inglaterra de lo que se ha calificado como un "aura casi sagrada" 1753 , pero su pervivencia normativa responde más a un deseo encuadrable en el mantenimiento de un derecho histórico útil para la defensa de intereses privados, que en su efectividad práctica para la tutela del interés general. El ejercicio privado de la acusación está ineludiblemente determinado por intereses individuales, por lo que no es visto hoy como un arma particularmente útil en la práctica para la protección del interés público o para asegurar que el acusador público desempeñe su tarea justa y eficientemente por mandato de la comunidad.

Un cúmulo de prevenciones legales, prácticas forenses y, sobre todo, la necesidad de desembolso económico, hacen que sea imposible hablar de la acusación privada inglesa como una verdadera actio popularis. En unos casos sólo teóricamente es viable su utilización, mientras que en otros falla en las posibilidades para el acopio de pruebas o por razones financieras ${ }^{1754}$. La intervención de oficiales públicos de la Corona puede, además, desactivar la virtualidad teórica de la acusación privada con demasiada facilidad ${ }^{1755}$. En delitos con trascendencia pública, cualquier salida que diera operatividad a la acusación privada como mecanismo de control sobre las autoridades está así prácticamente cegada.

La acusación privada se utiliza en escasas ocasiones y opera sobre todo como freno

feb. 1986. Vid. HETHERINGTON, T., Prosecution and the Public Interest, op. cit., p. 200, SAMUELS, A., "NonCrown Prosecutions...”, op. cit. p. 33, n. 3 y EMMINS, C.J., A practical approach... op. cit. p. 11.

${ }^{1753}$ En palabras del Profesor COLE citadas por HETHERINGTON, p. 154.

${ }^{1754}$ Cfr. HARLOW, C. y RAWLINGS, R., Pressure..., cit. p. 236.

${ }^{1755}$ La doctrina sentada por Lord DILHORNE en Gouriet v. Union of Post Office Workers no deja ninguna duda en este sentido de los amplísimos poderes que el Attorney General puede ejercitar de forma discrecional haciendo disposición de la acusación en cualquier momento procesal: “(El $A G)$...podría detener cualquier acusación por indictment instando un nolle prosequi. Sólo tendría que firmar una orden diciendo que no desean que la persecución continúe sin que necesiten aportar ninguna razón. Puede dirigir el ejercicio de una acusación o pedir del Director of Public Prosecutions que asuma la dirección de cualquier procedimiento penal y decirle que no presente prueba alguna. En el ejercicio de estos poderes no está sujeto a dirección de sus colegas de Ministerio o al control de los Tribunales". 
$\overline{\text { a la discrecionalidad en delitos de bagatela }}{ }^{1756}$, en los que el interés preponderante es el puramente privado. En la práctica funciona sólo como "válvula de seguridad" allí donde la policía considera que no hay interés público en perseguir, aunque el delito haya existido, hipótesis en las que incluso sus oponentes le reconocen algún mérito ${ }^{1757}$. La garantía que proporciona es la de transformar al ciudadano en último resorte que habilita y legitima el que se le den facultades discrecionales a la policía, posibilitando que sea quien sienta la ofensa el que persiga el delito ${ }^{1758}$. En este sentido, y considerando la realidad práctica, podría compararse en nuestro sistema con los delitos perseguibles a instancia del ofendido, con la particularidad de que la iniciativa se atribuye quivis ex populo, aun cuando evidentemente sea la víctima del delito la más interesada normalmente en su persecución ${ }^{1759}$.

Se ha sugerido que el interés público se podría lograr mucho mejor continuando el proceso educativo de la sociedad acerca del papel que juega el acusador, sus métodos de trabajo y los principios que aplica de forma que la sociedad esté en posición de observar $\mathrm{y}$, donde corresponda, criticar tras contar con la información ${ }^{1760}$. Habría además otros

${ }^{1756}$ Vid. WILLIAMS, G., “The Power to Prosecute”, Crim. L. R. 1955, p. 602: “Una acusación privada en caso de asesinato ahora nos chocaría, incluso en Inglaterra, como una grotesca perversión del procedimiento legal; no podríamos tolerar que una persona privada quisiera acabar con la vida de otra mediante el procedimiento penal aunque eso fuera en tiempos lo normal".

${ }^{1757}$ No por ello se ha dejado de destacar que ha servido ocasionalmente como justificación o excusa para la inactividad de la Policía o de órganos públicos de acusación.

${ }^{1758}$ Se ha utilizado en cuestiones en las que un sujeto en particular se ha considerado agraviado aun sin ser el afectado directamente. Así por ejemplo por injurias vertidas en un libro (Gleaves v. Deakin and others (1979) 2 All. E.R. 497 o Goldsmith v. Pressdram Ltd. All. E.R. 557 (1977) ), o por libelo (R. v. Gay News Ltd. (1979) A.C. 617). En estos casos lo significativo fue que hubo protestas en la prensa por los costes que suponía para el Estado asumir una acusación particular y que ello podría alentar otras menos justificadas. La legislación sobre libelo no exigía consentimiento oficial para la instauración de una persecución en esta materia.

${ }^{1759}$ La distinción entre ofendido y no ofendido por el delito en relación con el proceso penal es relativamente reciente en el Reino Unido y sólo es perceptible en las nuevas tendencias doctrinales que recogen las inquietudes victimológicas.

${ }^{1760}$ En este sentido HETHERINGTON, T., Prosecution and the Public Interest, op. cit. p. 162. Conscientes de la relevancia de la imagen que sobre la sociedad se proyecte del servicio que presta, la institución del CPS realiza en este sentido considerables esfuerzos para dar a conocer los "tests" en los que se basa su actuación en cada caso concreto. No podemos pasar por alto una necesaria referencia al esfuerzo de divulgación entre los ciudadanos (y no sólo entre el lector especializado) de los criterios guía de persecución de los que se sirven los acusadores públicos y que se aprueban anualmente (art. $10 P O A$ ). La oficina de divulgación del CPS distribuye con profusión el cuadernillo con los criterios de persecución, ideado con sencillez y destinado a un público medio no experto en derecho. Una atractiva y cuidada presentación que presta atención al diseño gráfico son también características del denominado 
mecanismos que podrían hacer evaporarse la necesidad de preservar un derecho privado a la acusación: 1) Responsabilizar claramente al acusador público frente a la sociedad y frente al Parlamento; 2) Dar a conocer a la sociedad las razones de la acción del acusador, en especial cuando la decisión sea la de no perseguir; 3) Conferir al Parlamento un control sobre la adecuación de las normas por las que se decide las acusaciones, los fondos que se ponen a su disposición, la forma en que se organizan y dirigen y las políticas que se $\operatorname{aplican}^{1761}$.

Cabría extraer como conclusión que el sistema inglés manifiesta claramente que la existencia y el mantenimiento de un derecho de acusación en manos de particulares depende en gran medida de las convicciones sociales que al respecto existan entre los ciudadanos. El que añada un plus al proceso penal tiene más que ver con la percepción que el público al que va dirigido reciba de él, que con un efectivo papel para la defensa del interés público, la cual probablemente se pueda conseguir por otros cauces más adecuados a la estructura básica del proceso. Se trata de un derecho poco más que simbólico, sin demasiada trascendencia práctica, pero fuertemente arraigado en la conciencia constitucional del país y defendido a capa y espada en cada ocasión que ha sido cuestionado.

\subsubsection{Control privado de la acusación pública}

\subsubsection{Acusación subsidiaria: el modelo austriaco}

La defensa de la acusación privada subsidiaria encontró respaldo entre algunos sectores de la doctrina continental europea del siglo XIX y principios del XX, y fue conectada a menudo con la vigencia del principio de oportunidad. El razonamiento de los partidarios de opciones de este tipo radicaba, con unos u otros matices, en que existiendo una acusación estatal parecería superflua, redundante y perturbadora una acusación de otra naturaleza. Sólo cuando aquélla fallara por alguna razón, voluntaria o involuntariamente, por acción u omisión del órgano oficial encargado, habría de abrirse una vía para

“Annual Report”, en el que se da noticia pública y general de la actividad del CPS durante un periodo de actividad, hábil también como instrumento de difusión de su actividad. Su obligada presentación ante el Parlamento se deduce del art. 9 de la $P O A$.

${ }^{1761}$ HetherINGTON, T., Prosecution and the Public Interest, op. cit. p. 204. 
que los particulares asumieran una función que el órgano público habría hecho decaer ${ }^{1762}$. La acusación subsidiaria de particulares adquirió vigencia ya desde el siglo pasado en Austria, donde fue instaurada como contrapeso al monopolio del MF en la acusación de los delitos públicos. Se daba cuerpo así a un correctivo para el caso de que éste vulnerara el principio de legalidad o se sirviera inadecuadamente del de oportunidad, sin por ello atribuir a estas conductas el carácter de delitos privados. No obstante, la debilitada posición procesal del sujeto privado que asume la acusación pública no permite afirmar en la actualidad que sirva efectivamente al cumplimiento de tal función ${ }^{1763}$.

El art. 48 de la actual ÖStPO prevé para quienes tengan reconocida la condición de "Interviniente Privado" ("Privatbeteiligte") ${ }^{1764}$ la posibilidad de deducir subsidiariamente acusación en los siguientes supuestos: 1) En el archivo de la denuncia o de las diligencias previas de averiguación (art. 90 ÖStPO); 2) Cuando se archive la investigación preliminar

\footnotetext{
${ }^{1762}$ Entre los representantes de esta opción podríamos citar entre la doctrina italiana a ALIMENA, BERTSCHI, VACCA, GUARNIERI, LEONE o MARGHIERI, entre la germánica a GNEIST, STUMM, OPPENHEIM, JANKA (Austria), EICHENBERG (Suiza), GEYER, HOLTZENDORF, LISZT, LOBE, NAGLER, OETKER, PFENNINGER, ROSENBERG o SCHWEIZER. Entre la de nuestro país, a MARTÍNEZ DEL CAMPO, ZAFRA y el Anteproyecto de Bases para la Reforma del Procedimiento Penal de la Comisión Reorganizadora de la Administración de Justicia de 1929, en cuya base $3^{\mathrm{a}}$ se establecía la acusación popular subsidiaria con respecto a la del MF o de la del perjudicado u ofendido. Nos debemos remitir aquí necesariamente a la parte histórica de este trabajo, pero ha de hacerse referencia también desde una perspectiva más actual a MASSA, C., Voz "Azione Popolare (Diritto Penale)", en Enciclopedia del Diritto dirigida por CALASO, F., 1957, p. 874. Es preciso, además, distinguir claramente entre los partidarios de atribuir esta facultad exclusivamente al ofendido o perjudicado por el delito de aquellos otros que se muestran a favor de que cualquier ciudadano pueda sostener la acusación cuando ésta no haya sido iniciada o haya sido hecha decaer por el MF.
}

${ }^{1763}$ Vid. por ejemplo PLATZGUMMER, W., Grundzüge des österreichischen Strafverfahrens, $7^{\mathrm{a}}$ ed., Viena 1996, pp. 56 y ss; KAUER, “Zur Rechtsstellung des Subsidiaranklägers”, Juristische Blätter 1952, pp. 456. En relación con su papel en la fase de investigación solamente vid. WEDRACK, P.E., Das Vorverfahren in der StPO, Viena 1996, pp. 71 y ss. Sobre las facultades atribuidas al acusador subsidiario en la actualidad DRIENDL, J. en JESCHECK, H.H. (Editor.), Funktion und Tätigkeit der Anklagebehörde im ausländischen Recht, Baden-Baden 1979, pp. 228 y s.; KAUER, R., "Zur Rechtsstellung des Subsidiaranklägers”, Juristische Blätter 74 (1952), pp. 456 y s. Hoy día la acusación subsidiaria está sometida a críticas que inciden sobre todo en su escasa trascendencia práctica. Vid. en este sentido la discusión en Verhandlungen des 9. Österreichischen Juristentages (Abteilung Strafrecht), Viena 1985, singularmente las opiniones de FELZMANN, que proponía la ampliación del círculo de las personas autorizadas para acusar subsidiariamente (p. 12); MOOS, para quien la función práctica de la acusación subsidiaria más que controlar la acusación, es la garantía de que el perjudicado buscará una satisfacción al daño que se le ha inferido aun cuando el Fiscal renuncise a la persecución (Grundstrukturen einer neuen Strafprozeßordnung, p. 103 y ss.) o JESIONEK que se declara partidario de un Klageerzwingungsverfahren según el modelo alemán. Para su configuración como método de control del principio de legalidad es de interés SEILER, R., Legalitätsprinzip und Weisungsrecht im Strafproze $\beta, 1968$, pp. 36 y ss.

${ }^{1764}$ Es decir, el que habiendo sido perjudicado en sus derechos por un delito perseguible de oficio, se persona antes de la vista oral para hacerlos valer (vid. art. 47 ÖStPO). 
(art. 109 ÖStPO); 3) En la retirada de la acusación "firme" (rechtskräftige) antes de la vista oral y 4) En los de retirada de la acusación en el curso de la vista oral.

El ejercicio subsidiario de la acusación pública por particulares antes de la calificación definitiva está sujeto a un control judicial que determinará si es adecuado el archivo o procede la intervención de los legitimados. En las hipótesis de archivo, el MF estará obligado a notificarlo al perjudicado, el cual podrá solicitar ante la Ratskammer la incoación de diligencias de investigación si ha adquirido la condición de "Interviniente Privado". Si se retirare la acusación durante la instrucción, pero antes de la calificación definitiva, el Juez Instructor notificará al interviniente privado esta circunstancia, para que pueda asumir el ejercicio de la acusación pública. Una vez que la calificación sea definitiva, el "Interviniente privado" tendrá que ser informado de la retirada de la acusación, pero no existirá control judicial para su asunción por aquél. Si no ha dado comienzo la vista oral, se abrirá un plazo de 14 días para que manifieste su intención de hacerse cargo de la pretensión penal, y si ha dado ya comienzo deberá el "interviniente privado" que esté presente asumir esta función, puesto que en caso contrario precluirá su derecho de poder hacerlo.

A diferencia del MF, el acusador subsidiario no está obligado a la búsqueda de todos los elementos, tanto positivos como negativos sobre el acusado, por lo que no tiene por qué hacer valer los de descargo en favor del presunto reo. Ha de destacarse, además, que en los supuestos en los que un particular asuma subsidiariamente el ejercicio de la acusación, se reserva al MF la autorización en cualquier momento procesal para informarse de la marcha del procedimiento, para inspeccionar los autos y, lo que es más importante, para retomar la acusación de nuevo cuando lo estime oportuno (art. 49.1 ÖStPO).

\subsubsection{Control judicial sobre la acusación a instancia de particulares: el Klageerzwingungs-verfahren}

I.

Ejemplos de controles judiciales a iniciativa de los particulares sobre la actividad acusatoria oficial existen en los sistemas italiano ${ }^{1765}$ y portugués ${ }^{1766}$, pero por su larga

${ }^{1765}$ Vid. la "Opposizione alla richiesta di archivazione" del art. 410 CPPItal., a través de la que el ofendido 
vigencia y por la influencia que ha ejercido sobre aquellos otros, hemos centrado nuestra atención en el "Procedimiento para compeler al ejercicio de la acción penal" alemán (Klageerzwingungsverfahren) previsto en los arts 172 a $177 \mathrm{StPO}^{1767}$. Se trata éste de un instrumento de control de la legalidad de la actuación del MF que puede ser instado con carácter previo a la fase intermedia del procedimiento. Con él se configura una facultad de control judicial sobre las decisiones del fiscal denegatorias de la acusación, por lo que no es una modalidad de ejercicio directo de la pretensión penal que venga a quebrar el monopolio del fiscal, sino un procedimiento abierto a particulares agraviados para instar de un órgano jurisdiccional que compela al MF a que, pese a su opinión en contra, despliegue sus facultades de persecución. Dado que el Klageerzwingungsverfahren no es propiamente acusación, el solicitante no puede realizar una calificación del delito, sino que su facultad le permite únicamente poder instar del órgano judicial que obligue a la persecución, pero no los términos en que ésta se deba realizar.

El monopolio acusatorio del MF ha sido estrechamente vinculado en Alemania a la obligatoriedad de la acusación y a la sujeción al principio de legalidad en su ejercicio ${ }^{1768}$. Este procedimiento ha sido visto por la doctrina como una compensación al ofendido por esta atribución exclusiva de la competencia para instar el procedimiento penal ${ }^{1769}$. Dos son, pues, las razones sobre las que se ha justificado su necesidad, ligadas a una doble finalidad y situadas en una perspectiva concreta y otra general. Mientras que en el determinado proceso de que se trate, se dirigiría sólo a la defensa de los intereses del perjudicado por el delito ${ }^{1770}$, en su contemplación sobre un plano abstracto que atendiera

puede oponerse al archivo solicitando la realización de diligencias supletorias de investigación.

${ }^{1766} \mathrm{El}$ "Requerimiento para abertura de instruçao" del art. 287 CPPort permite solicitar la apertura de la instrucción de los delitos públicos por el assistente cuando el MF no deduzca acusación.

${ }^{1767}$ Sobre este procedimiento puede consultarse en castellano la obra de GÓMEZ COLOMER, J.L., El proceso penal alemán. Introducción y normas básicas, Barcelona 1985, pp. 154 y ss.

${ }^{1768}$ Mientras hoy la obligación de persecución penal de la fiscalía se deduce de la obligación estatal de garantía de la Justicia, gran parte de la antigua doctrina la derivaba de las propias normas del derecho penal material. SCHMIDT, E. , Lehrkommentar I, marg. 385.

${ }^{1769}$ En este sentido se pronuncian SCHÄFER, Strafprozeßrecht, Introducción al capítulo 13, marg. 25 y JANS, S., Die Aushöhlung des Klageerzwingungsverfahren, Francfort 1990, p. 9. Su fundamentación constitucional derivaría del art. 19 IV GG (derecho de acceso a la justicia frente a lesiones inferidas por los poderes públicos) y del 103.1 GG (derecho a la audiencia judicial en tanto sujeto del proceso). Vid. MAUNZ-DÜRIG, Grundgesetzkommentar, T. IV, p. 22a.

${ }^{1770}$ En opinión de algún sector doctrinal, se orientaría a la protección de un derecho subjetivo público derivado 
al sistema en su globalidad, aquella justificación se debería cifrar en la garantía del principio de legalidad. Dados los reparos con respecto a la vulnerabilidad frente a influencias políticas o de cualquier otro tipo que afectarían a la concreta actividad de cada uno de los miembros de la fiscalía ${ }^{1771}$, la función del Klageerzwingungsverfahren se situaría desde un punto de vista global precisamente en la garantía del aseguramiento y la materialización del principio de legalidad que podría hacer peligrar el monopolio ${ }^{1772}$. En tanto el interés individual de satisfacción del ofendido por el delito se erigiría en motivación para el control de la Justicia, el Klageerzwingungsverfahren vendría teóricamente a reforzar la unificación de criterios y la igualdad entre todas las persecuciones $^{1773}$.

\section{II.}

La legitimación activa para instar este procedimiento viene conferida únicamente al denunciante en el que concurra la calidad de ofendido por el delito (art. $172 \mathrm{StPO}$ ), concepto éste objeto de una controversia entre la doctrina que no puede darse por zanjada. La dificultad básica se sitúa en la inexistencia en la StPO y en el StGB de un concepto legal de ofendido, por lo que en la mayoría de las ocasiones su definición habrá de hacerse sólo de forma casuística. Ofendido será la persona afectada de forma inmediata por el hecho afirmado en uno de los bienes jurídicos reconocidos por el precepto

del principio de legalidad y del monopolio acusatorio del MF: a la monopolización de la persecución penal por el Estado se correspondería la obligación estatal frente a la comunidad de hacer efectiva aquélla, y en ese sentido, sería generadora de un derecho subjetivo sólo de los ofendidos por el delito a la persecución penal. ROXIN, C., Strafverfahrensrecht, $22^{\mathrm{a}}$ ed., Munich 1991, p. 261, citando a KALSBACH, Die gerichtliche Nachprüfung von Maßnahmen der Staatsanwaltschaft im Strafverfahren, 1967 pp. 92 y ss.; PETERS, Strafprozeßrecht, $4^{\mathrm{a}}$ ed. p. 536; SCHULZ, J., Beiträge zur Nebenklage, Berlín 1982, p. 174. El perjudicado no sólo tendría un derecho genérico a que se inicie un proceso, sino un interés personal jurídicamente fundado en la persecución penal derivado de la función del derecho penal como sistema protector de derechos individuales. En tanto bastaría para la satisfacción de tal interés la obligación de garantía jurídica estatal, el Klageerzwingungsverfahren proporcionaría una vía para el aseguramiento de tal interés.

${ }^{1771}$ No debe olvidarse que la organización de la fiscalía alemana también tiene una estructura jerárquica, en cuya cúspide se sitúan el Ministro Federal de Justicia y los Ministros de Justicia de los Estados Federados. Vid. p. ej. MAIWALD, M., “Die Beteiligung des Verletzten am Strafverfahren”, Goltdammer's Archiv für Strafrecht, 1970, pp. 33 y ss. y 51 o JANS, S., Die Aushölung..., op. cit. p. 10.

${ }^{1772}$ PETERS, K., Strafprozeßrecht, 4 a ed. p. 536; MEYER-GOßNER, en LÖWE-ROSENBERG, Kommentar zur StPO, $23^{\mathrm{a}}$ ed. art. 172, marg. 1, MÜLLER, R., en Karlsruher Kommentar zur StPO, art. 172, marg. 1.

${ }^{1773}$ Vid. WEIGEND, T., Deliktsopfer und Strafverfahren, op. cit., pp. 498 y ss. 
penal $^{1774}$, por lo que no actuará en calidad de representante de la comunidad, sino, precisamente, sobre la base del daño que le distingue de los demás ${ }^{1775}$. En otros casos el criterio de legitimación se ha sostenido que sería el "interés autorizado para la retribución o la satisfacción", definiendo al ofendido como "el que ha sido perjudicado en sus intereses por la acción punible afirmada de tal manera que su petición de persecución penal se fundamenta en una necesidad de satisfacción que debe ser reconocida" ${ }^{1776}$. En lo que sí parece haber pleno acuerdo es en la exclusión de una iniciativa totalmente abierta, cercana a lo que pudiera ser una acción popular para la iniciación de este procedimiento ${ }^{1777}$. Es exigible, por tanto, una afección directa a bienes jurídicos de la propia esfera personal, con la lógica salvedad de los delitos contra la vida, donde tal interés legitimador derivará del parentesco próximo ${ }^{1778}$.

El problema se plantea abiertamente en delitos de naturaleza colectiva o con

${ }^{1774}$ Vid. por todos KLEINKNECHT/MEYER, Strafprozeßordnung. 38 a ed., art. 172, marg. 9, si bien la misma definición con alguna variante se puede encontrar en los restantes comentaristas a la StPO.

${ }^{1775}$ El reflejo en la jurisprudencia ha sido muy diverso, puesto que la última decisión al respecto la tienen los Oberlandesgerichte sin que pueda llegar a pronunciarse el Bundesgerichthof. AMEHUNXEN, C., Der Nebenkläger im Strafverfahren, Lübeck 1980, p. 27 reseña, tomando como referencia la jurisprudencia, quiénes son perjudicados en determinados delitos y quiénes no pueden considerarse como tales. Entre estos últimos destaca singularmente en relación con nuestro tema la exclusión por ejemplo de las asociaciones protectoras de animales en delitos de malos tratos a éstos o de cualquier sujeto no afectado directamente en delitos contra el Medio Ambiente, contra la seguridad del estado o de distribución ilegal de material pornográfico. No es considerado perjudicado por el delito de incitación al odio racial un miembro de una comunidad religiosa o de un sector de población (en este caso el presidente de la comunidad cultural israelí de Munich), puesto que no es portador del bien jurídico de la paz pública, posición que sólo podrá asumir la comunidad estatal. Auto OLG München de 25 de marzo de 85, NJW 1985, p. 2430. En favor de su reconocimiento como ofendido ROXIN, C., Strafverfahrensrecht op. cit. p. 253. Puede consultarse una amplia referencia jurisprudencial en KIRSTGEN, J. R., Das Klageerzwingungsverfahren, Dissertation, Bonn 1986, pp. 84 y ss.

${ }^{1776}$ Así SCHMIDT, E., Lehrkommentar zur StPO, 2a parte, art. 171 marg. 12. En similares términos, MAIWALD, M., "Die Beteiligung des Verletzten am Strafverfahren”, Goltdammer's Archiv für Strafrecht, 1970, pp. 33 y ss.

${ }^{1777}$ Lo cual ha sido designado como "Popularklageerzwingungsverfahren". Cfr. WACHE/ SCHMIDT en PFEIFFER, G., Karslruher Kommentar zur StPO, Munich 1993, p. 894.

${ }^{1778}$ OSTENDORF, H., “Das öffentliche Klageerzwingungsverfahren: ein notwendiges Institut zur Kontrolle der Staatsanwaltschaft", Recht und Politik 1980, pp. 201 y s. En opinión de KIRSTGEN, J. R., Das Klageerzwingungsverfahren, op. cit., pp. 90 y 102: "la acción popular, ajena a nuestro ordenamiento jurídico debe ser excluida con la cualidad de perjudicado", aun reconociendo que el incremento de la aceptación se realiza mediante una ampliación lo más grande posible del concepto de ofendido. Sin embargo, ello operaría en perjuicio de la protección del imputado (p. 93). 
trasfondo político donde hablar de víctima individualizada no es fácil ${ }^{1779}$. Este procedimiento carece de virtualidad en delitos tan llamativos como los que afecten a la seguridad del Estado o las infracciones a la ley de extranjería, para los cuales no existe nadie que pueda considerarse perjudicado ${ }^{1780}$.

\section{III.}

El Klageerzwingungsverfahren adolece de un importante límite, en cuanto no podrá ser instado cuando la decisión del MF haya sido adoptada dentro del margen de apreciación que le reconoce la apertura al principio de oportunidad presente en el procedimiento penal alemán ${ }^{1781}$. Dado que esto supone la exclusión de control jurisdiccional de más de un tercio de las peticiones de archivo por la fiscalía, tal cuestión ha dado pie a las críticas procedentes de quienes se muestran recelosos frente al constante avance de las amenazas al principio de legalidad. La necesidad de aprobación judicial en estos casos no supone suficiente garantía, en tanto que ésta apenas es negada. Por ello, la existencia de este procedimiento ha sido percibida, tal y como ocurre en ocasiones con nuestra acusación popular, como una adecuada garantía frente al abuso de los márgenes de apreciación de la fiscalía ${ }^{1782}$. Sobre esa base se ha defendido su expansión a los

${ }^{1779}$ El concepto de ofendido no es objeto de discusión en los supuestos en que el daño a la colectividad se solapa a un perjuicio individual, ya que para esos supuestos, tal consideración es asumida por el titular de los bienes jurídicos dañados. Esto es lo que ocurriría en los delitos de denuncia falsa o de conducción temeraria con resultado de lesiones o muerte o en otros tipos penales en los que el perjuicio recae sobre un bien jurídico de la comunidad pero se reflejan sobre bienes jurídicos individualizables (falso testimonio, falsedad documental, falsificación de moneda, etc.). KIRSTGEN, op. cit. p. 100. En consonancia con alguna jurisprudencia, se ha defendido la condición de ofendido por el delito de cada uno de los accionistas en delitos societarios cometidos en perjuicio de la sociedad anónima y que por ello repercuten en su patrimonio, sus expectativas o su derecho a la información. ZIELINSKI, D., "Zur Verletzteneigenschaft des einzelnen Aktionärs im Klageerzwingungsverfahren bei Straftaten zum Nachteil der Aktiengeschellschaft", Wistra 1993, I, pp. 6 y ss.

${ }^{1780}$ ROXIN, C, Strafverfahrensrecht, op. cit. p. 261.

${ }^{1781}$ Art. 172.2 StPO en relación con los arts. $153.1,153$ a) 1 incisos 1 y 6,153 b. 1, 153 c, 154.1, 154 b y 154 c. No incluye por tanto esta exclusión la de la no persecución por motivos políticos del art. $153 \mathrm{~d}$.

${ }^{1782}$ ROXIN, C., Strafverfahrensrecht, op. cit. p. 253. Un pormenorizado estudio sobre esta materia es el realizado por WERNER, K., Der Einfluß der Verletzten auf Verfahreneinstellungen der Staatsanwaltschaft, Munich 1986. Vid. también la reseña sobre esta obra en ZStW 103 (1991), 1, pp. 211-216. Su conclusión no es sin embargo favorable a la intervención de los particulares en todos los supuestos legales de ejercicio facultativo de la acusación por el MF. Esa intervención debería producirse sólo en los casos de los arts. 153 y 153a StPO y debería cifrarse solamente en un examen de adecuación a la norma de la petición de sobreseimiento, sin entrar en su valoración. En cualquier caso, tal control judicial sólo tendría sentido cuando fallaran los propios controles internos de la fiscalía. En el resto de los supuestos (153c, 153d, y 154d StPO), el examen judicial carece de sentido. 
sobreseimientos a petición de la fiscalía, siempre que éstos se encuentren ligados a criterios normativos cuya interpretación pueda ser constatable ${ }^{1783}$.

Existe también una limitación temporal en perjuicio de los legitimados, que opera como garantía de seguridad jurídica y de no afectación de los intereses del imputado. En concreto la queja debe interponerse dentro de las dos semanas a contar desde el conocimiento de la decisión del fiscal de no acusar (art. 172.1 StPO) y la solicitud de resolución judicial en el plazo de un mes (art. 172.2 StPO).

Sin entrar en el análisis minucioso del procedimiento, debe destacarse que éste consta de una fase ante la propia fiscalía que, ante el rechazo de la solicitud del legitimado, abre la vía jurisdiccional. La petición ante el Tribunal competente (los Oberlandesgerichte) deberá acompañarse de los motivos que se aleguen y los medios de prueba que se estimen oportunos, de manera que las solicitudes que se consideren inadmisibles o una muestra de querulancia podrán ser rechazadas de plano. Es preceptiva la firma de abogado, pero no es pacífica la opinión de que pueda nombrarse de oficio para deducir tal pretensión. El Tribunal deberá examinar los autos o realizar sus propias averiguaciones, pero, en todo caso, deberá dar traslado de la solicitud al imputado y habilitar un trámite de audiencia si se propone estimarla, ya que en caso contrario se vulneraría su derecho a la audiencia judicial (art. 173.II StPO y 103.I GG). Si la solicitud es admitida, el Tribunal resuelve mediante auto ordenando que se deduzca acusación cuando ya se haya realizado la investigación sumarial por la fiscalía (art. 175.1) o su realización si ésta fue rechazada $a b$ initio $^{1784}$. El auto obliga a la fiscalía a formular escrito de acusación, con lo que formalmente se garantiza el principio acusatorio, aun cuando materialmente esté limitado por la necesaria vinculación a la resolución jurisdiccional en que se imponga acusar ${ }^{1785}$. A partir de ese momento procesal, la actuación de la fiscalía es en principio libre, y podrá incluso solicitar la absolución del

${ }^{1783}$ Vid. WEIGEND, T., Deliktsopfer und Strafverfahren, op. cit. pp. 520 y 547.

${ }^{1784}$ El auto por el que se deniega la solicitud del Klageerzwingungsverfahren adquiere fuerza de cosa juzgada material e impide tanto el que se inste de nuevo el procedimiento, como que se ejercite nuevamente la pretensión penal a no ser por hechos no analizados por el Tribunal (art. 174.II StPO).

${ }^{1785} \mathrm{Si}$ en su origen el Klageerzwingungsverfahren se hizo acreedor de cuantiosos reparos doctrinales, en tanto la intervención de los órganos jurisdiccionales en el ejercicio de la pretensión penal suponía un paso atrás hacia el proceso inquisitivo, hoy, visto su reducido uso y su valor como garantía, tal examen sobre el fundamento de la acusación no recibe censuras en ese sentido. Vid. JANS, S., Die Aushölung..., p. 13. Fueron sonadas las críticas vertidas por GNEIST, quien puede ser calificado sin duda como el principal y más ardiente defensor de la acusación popular en la Alemania del siglo XIX. 
acusado o aprobar el sobreseimiento judicial al amparo del art. 153.II StPO. En compensación a la desconfianza que esto puede originar para el solicitante exitoso, la StPO autoriza al ofendido por el delito su intervención en el proceso como Nebenkläger (art. 395.I.3).

\section{IV.}

Su utilización práctica es ciertamente escasa, debido a las también escasas perspectivas de éxito, bien porque los Tribunales rechazan la mayoría de las solicitudes, bien porque en los pocos supuestos restantes no se satisface la pretensión del actor ${ }^{1786}$. Su trascendencia no se ha cifrado, sin embargo, en el número de ocasiones en que es efectivamente puesto en funcionamiento, sino en una función pasiva de autocontrol de la fiscalía. Tal y como se ha señalado en alguna ocasión, su objetivo es más preventivo que curativo $^{1787}$. Su activo principal se sitúa en lo que JANS denomina "efectos psicológicos": la mera existencia de un procedimiento con el fin de someter a control judicial la actividad del fiscal propicia en gran medida su correcta actuación, especialmente en lo referido a las decisiones de archivo de las causas ${ }^{1788}$. Estos efectos son juzgados altamente positivos para la Justicia penal, por cuanto originarían una percepción más positiva de ésta por parte de la población y una mejor aceptación de sus actuaciones ${ }^{1789}$. Tales ventajas alcanzarían a la Fiscalía como institución, a sus propios integrantes, a las víctimas de los delitos y a los ciudadanos en general, quienes percibirán una mejor imagen de la Justicia penal. De ahí que su rara utilización no sea vista como un argumento que opere en contra de su mantenimiento, sino por el contrario como la consecuencia del buen funcionamiento de la institución del MF a lo que contribuye su

\footnotetext{
${ }^{1786}$ BISCHOFF, G., Das Klageerzwingungsverfahren. Eine empirische Analyse mit Vorschlägen zur Reform, Dissertation, Gelsenkirchen 1987 realizó un estudio estadístico al respecto, obteniendo resultados que dejan a las claras las muy escasas posibilidades de conseguir una sentencia condenatoria por esta vía. Así, con cifras referidas a 1982, de las 1792 demandas de incoación de un proceso de esta naturaleza, sólo 8 terminaron en un mandato dirigido al ejercicio de la acusación, y de ellas solamente una concluyó con una condena. PETERS, Strafprozeßrecht, p. 537 , aun reconociendo lo escaso de su utilización habla de un número creciente de solicitudes de incoación.

${ }^{1787}$ WEIGEND, T., Deliktsopfer und Strafverfahren, op. cit., p. 492.

${ }^{1788}$ Cfr. JANS, S., Die Aushölung..., op. cit. p. 16 y RIE $\beta$, P., en LÖWE-ROSENBERG, Kommentar..., op. cit. art. 172, marg. 3, n. 11.

${ }^{1789}$ KIRSTGEN, J. R., Das Klageerzwingungsverfahren, op. cit. p. 84.
} 
$\overline{\text { mera existencia }}{ }^{1790}$. Por ello se ha llegado a decir que constituye "un seguro barómetro del clima político dominante en cada momento" ${ }^{1791}$.

Con ocasión del constante y recurrente debate sobre la conveniencia de buscar alternativas a este procedimiento que garanticen simultáneamente la efectiva aplicación del principio de legalidad, en ocasiones ha sido citada (más que considerada realmente) la posibilidad del establecimiento de alguna modalidad de acusación popular o privada, bien con carácter principal, bien subsidiario ${ }^{1792}$. Esta idea se ha rechazado en todas las ocasiones en que se planteó, utilizando argumentos tales como que sería “absolutamente incompatible con los principios fundamentadores del proceso penal" 1793 o que sería necesario evitar manipulaciones de la Justicia provinientes de acusaciones impulsadas por querulantes abusivos ${ }^{1794}$. Se alega también, por otro lado, que pudiera ser que provocara el efecto inverso, en tanto el fiscal, consciente de que la persecución podría ser iniciada también por otras personas, adoptara una actitud pasiva y careciera de la suficiente motivación para la adecuada realización de la función que le viene encomendada ${ }^{1795}$.

Existen importantes propuestas de reforma que destacan la conveniencia lege ferendae de ampliar su ámbito para reforzar su función de control. Allí donde no hay un

${ }^{1790}$ En este sentido vid. p. ej. WEHNERT, A., Rechtliche und rechtstatsächliche Aspekte des Klageerzwingungsverfahren, Francfort a. M. 1988, p. 174.

${ }^{1791}$ Aun cuando numéricamente su utilización sea exigua, es importante señalar que la mayor parte de todos los Klageerzwingungsverfahren incoados se dirigían a forzar la acusación contra funcionarios públicos, lo cual da ya una idea de su valor como garantía frente a hipotéticas deficiencias en la actividad estatal. JANS, S., Die Aushölung..., p. 22.

${ }^{1792}$ Las propuestas de abolición o reforma se pueden encontrar sistematizadas en WEHNERT, A., Rechtliche und rechtstatsächliche Aspekte..., op. cit. pp. 93 y ss.

${ }^{1793}$ JANS, S., Die Aushölung..., op. cit. pp. 18 y ss., esp. n. 109.

${ }^{1794}$ OSTENDORF, H., “Das öffentliche...”, pp. 200 y ss., para cuyo remedio el autor propone que el papel de actor en el procedimiento pueda ser asumido por parlamentarios federales o de los Estados Federados, legítimos representantes de la voluntad popular y que de esta manera extenderían sus funciones también al proceso. WEHNERT, A., Rechtliche und rechtstatsächliche Aspekte..., op. cit. p. 102 rechaza esta posibilidad por el riesgo de politización del proceso penal.

${ }^{1795}$ Vid. DIETZ, Die Anklageerhebung, pp. 72 y ss; JANS, S., Die Aushölung..., op. cit. pp. 18 y ss. Otros argumentos que se señalan en contra de cualquier tipo de acusación con connotaciones privadas son la conveniencia de que la persecución sea realizada por autoridades especiales y la pasividad del comportamiento de los ciudadanos frente al Estado. Así OSTLER, F., Das Klageerzwingungsverfahren, Strafrechtliche Abhandlungen, 287, Breslau 1931, p. 6. 
$\overline{\text { perjudicado determinado claramente por tratarse de tipos penales que protegen bienes }}$ jurídicos colectivos, el procedimiento pierde efectividad y el necesario control del MF dejaría de existir, asumiendo éste un papel casi omnipotente ${ }^{1796}$. Esta laguna en la utilidad práctica del "Procedimiento para compeler al ejercicio de la acusación", ya había sido destacada con anterioridad en conexión con los delitos políticos o los dirigidos contra la seguridad del Estado ${ }^{1797}$, pero en el presente ha sido planteada con mayor vigor por cuanto los tipos penales tendentes a la protección de bienes jurídicos no atribuibles a un sujeto singular se han incrementado de manera significativa. No podemos pasar por alto en este sentido la propuesta de TIEDEMANN quien, buen conocedor de la acusación popular española y de su utilización en la práctica, se muestra partidario de optar a este respecto por inspirarse en lo que él denomina como "el modelo español". Para ello incluye entre sus "Tesis para un proceso penal moderno orientado a los derechos humanos" la idea de que, para una efectiva protección de la víctima, sería necesario que hubiera una posibilidad quivis ex populo de controlar la no iniciación de un proceso penal en casos de interés general, tales como los de delitos contra el medio ambiente, económicos o de corrupción ${ }^{1798}$.

${ }^{1796}$ OSTENDORF, H., “Das öffentliche...”, p. 203; WEHNERT, A., Rechtliche..., op. cit, p. 175. Sin embargo KIRSTGEN, op. cit., p. 102 muestra su discrepancia argumentando la inutilidad de esa ampliación. Puesto que en su opinión la utilidad del Klageerzwingungsverfahren se fundamenta en la aceptación social de la actividad del fiscal, allí donde no haya un perjudicado directo ésta no quedaría afectada. Este autor sostiene que el daño a la comunidad se compone de la suma de una pluralidad de daños individualizables, por lo que donde no hay perjuicio sobre bienes jurídicos individualizables este procedimiento perdería su razón de ser. De ahí que niegue rotundamente una ampliación del ámbito de las personas autorizadas para la solicitud de ejercicio de la acción y excluya expresamente a las organizaciones y asociaciones aun afectándose bienes jurídicos de su ámbito de actuación (p. 116).

${ }^{1797}$ DIETZ, H., Die Anklageerhebung. Strafrechtliche Abhandlungen, 235, Breslau-Neukirch 1933, Reimpresión Francfort/Tokio 1977, pp. 68 y ss. Aun reconociendo su valor político, destaca las limitaciones inherentes al Klageerzwingungsverfahren por cuanto se podrían producir repercusiones muy negativas para las minorías políticas. Este tipo de inconvenientes fueron los que le hicieron manifestarse preferentemente por una acusación popular subsidiaria (p. 73). Con carácter más genérico destacan esta limitación también KOHLHAAS, M., "Das Klageerzwingungverfahren in seiner neuen form", GA 1954, p. 129; SCHMIDT, E., "Rechtsauffasung der Staatsanwaltschaft und Legalitätsprinzip", Monatschrift für Deutsches Recht 1961, p. 272 y en Strafprozeß und Rechtstaat. Strafprozeßrechtliche Aufsätze und Vorträge, Gotinga 1970, p. 102.

${ }^{1798}$ TIEDEMANN, K., “Thesen zu einem modernen menschenrechtsorientierten Strafprozeß”, ZRP 1992, nº 3, $\mathrm{p}$. 108. Procediendo de un experto en Derecho Penal económico como es el Prof. TIEDEMANN, tal propuesta no puede entenderse como un mero brindis al sol. 


\subsubsection{Coacusación, acusación accesoria, conjunta o adhesiva: la Nebenklage alemana}

Aunque también en nuestro país haya sido propugnado en algún momento un modelo de este tipo con participación como coadyuvante del ofendido por el delito junto con el $\mathrm{MF}^{1799}$, el ejemplo más claro de coacusación en la actualidad es el que nos proporciona la Nebenklage del derecho alemán ${ }^{1800}$ (arts. 395 a $\left.402 \mathrm{StPO}\right)^{1801}$. A pesar de su larga tradición, ha sido la Ley de Protección de la Víctima aprobada en diciembre de 1986 la que proporcionó un papel procesal más relevante al coacusador, confiriéndole una posición similar a la del acusador privado (Privatkläger) (art. 397.1 StPO). En ejercicio de la Nebenklage determinados particulares ofendidos por el delito pueden intervenir junto al fiscal en el juicio oral con derechos procesales propios, con lo que se dota a los agraviados por determinados delitos en los que hay una afección a bienes jurídicos estrictamente personales ${ }^{1802}$ de una vía procesal de acceso dirigida tanto a su propia satisfacción como al control de la fiscalía ${ }^{1803}$.

${ }^{1799}$ En este sentido se manifestaban p. ej. SÁEZ JIMÉNEZ, J. y LÓPEZ FERNÁNDEZ DE GAMBOA, E., Compendio de Derecho Procesal Civil y penal, T. 4, vol. I, Madrid 1966, pp. 881 y ss. En su opinión, eliminada de nuestro sistema como debería ser la acusación popular, el ofendido o perjudicado que pretendiese ejercitar la pretensión penal, deberá actuar como simple coadyuvante del MF, no existiendo por tanto más que una sola acusación. Si el MF se negase a deducir acusación, o en el curso de la causa solicitase el sobreseimiento, o en el acto del juicio oral retirase la acusación, es entonces cuando el coadyuvante, podría convertirse en acusador subsidiario, ejercitando o sosteniendo la pretensión penal.

${ }^{1800}$ No olvidamos el assistente del proceso penal portugués, al cual ya se ha hecho referencia en el capítulo anterior.

${ }^{1801}$ En castellano puede consultarse la citada obra de GÓMEZ COLOMER, J.L., El proceso penal alemán. Introducción y normas básicas, op. cit., pp. 210 y ss., si bien su edición es anterior a la reforma operada por la Ley de protección de la víctima (Opferschutzgesetz) de 18 de diciembre de 1986, que modificó sustancialmente la participación del coacusador.

${ }^{1802}$ Se trata en la mayoría de los casos de víctimas de delitos graves en los que se afecta a bienes jurídicos con un alto componente personal tales como la vida, la integridad física, la libertad sexual o la libertad personal. La coacusación es utilizada en un tercio de las ocasiones en que es admisible, lo cual significa un $10 \%$ de todos los procesos penales. Gran parte de estos supuestos son delitos relacionados con el tráfico y en especial lesiones culposas.

${ }^{1803}$ La discusión sobre la naturaleza de la Nebenklage se cifra precisamente en la preponderancia de uno u otro objetivo. Tal cuestión puede ser constatada no sólo teórica sino también empíricamente. En este sentido vid. DIETHILD, H., Die Rechtswircklichkeit der Nebenklage. Eine rechtstatsächliche Untersuchung an 569 nebenklagefähigen Strafverfahren, Gotinga 1983, p. 189. En caso de muerte, se admite la coacusación de los parientes del fallecido. También podrá constituirse como coacusador el denunciante al que se hubiera concedido razón en un Klageerzwingungsverfahren, con lo cual se pretende garantizar la fiabilidad de la acusación interpuesta 
Al acusador adhesivo se le atribuye en especial un derecho autónomo para personarse en el proceso, formular preguntas e instar la realización de pruebas. Puede también interponer recursos independientemente del MF, pero éste siempre intervendrá en la siguiente instancia, aun cuando sea para oponerse a su admisión. En la práctica se hace muy escaso uso de estas posibilidades, por lo que no puede deducirse que su intervención suponga un retraso en el procedimiento, sino únicamente un considerable incremento en los costes derivados de la intervención de abogado. Con respecto al procedimiento para su tramitación, habría de señalarse que no se trata de un procedimiento independiente y que el coacusador no satisface un interés público, sino que defiende únicamente la satisfacción de su interés personal. Por ello no está obligado como el Fiscal a la objetividad, sino que contribuye al control de la actividad de éste desde un ámbito estrictamente privado en tanto la ley lo configura como "coparticipante junto a la autoridad de acusación".

Quien quiera constituirse en coacusador debe ostentar plena capacidad procesal para poder intervenir y realizar válidamente actos procesales. Aun cuando puede solicitar su personación mediante escrito al efecto en cualquier fase del procedimiento, su intervención se desarrolla sólo en la fase del juicio oral, en la cual, por otra parte, puede actuar simultáneamente como testigo de cargo. No asume la iniciativa de la persecución, sino que con su actuación contribuirá teóricamente al esclarecimiento del hecho objeto de enjuiciamiento. Puede ser representado por abogado y el ejercicio de la coacusación habilita para la solicitud de asistencia jurídica gratuita (art. 397 a) StPO). Con respecto a las costas, con carácter general, los gastos originados por la actuación del Nebenkläger en todas las instancias deben ser soportados por el acusado cuando haya sido condenado o el proceso se haya sobreseído a tenor del art. 153.2 StPO. En caso de absolución, el propio coacusador deberá hacer frente a las costas generadas a su instancia, pero no a las del imputado absuelto, que serán asumidas de oficio.

La coacusación no tiene hoy por función solamente la acusación, sino que se dirige fundamentalmente a la preparación de un proceso civil de reparación del daño y, en todo caso, a dar curso a una necesidad de retribución reconocida por el ordenamiento

contra la voluntad del MF. Hemos de señalar también la posible utilización de la Nebenklage en supuestos de acusación por delitos privados, cuestión que no se aborda, por cuanto el ámbito de este estudio pretende ceñirse a su utilización en los delitos públicos. Precisamente hasta la "Ley de Protección de la Víctima", éste era casi exclusivamente el único ámbito de utilización de la Coacusación. Vid. ROXIN, C., Strafverfahrensrecht, op. cit. p. 404. 
jurídico ${ }^{1804}$. Por ello, y dado que no se corresponden con la idea de resocialización ni la idea de retribución ni el incremento de los gastos de la acusación, que correrán siempre a cargo del imputado cuando sea condenado, en opinión de un nutrido sector de la bibliografía se ha propuesto de lege ferenda su transformación en un proceso de restitución que sitúe el interés por la reparación del daño del perjudicado en primer plano ${ }^{1805}$. Se ha alegado también desde una perspectiva constitucional que pudiera tener una repercusión negativa sobre los principios de igualdad y de proporcionalidad. Con respecto al primero, podrían percibirse desigualdades bien entre los ofendidos por diversos delitos ${ }^{1806}$, bien entre diferentes acusados en función del delito objeto de persecución. En relación con el segundo la duda se suscita sobre si puede considerarse suficientemente justificada la posible intervención en el proceso de los ofendidos por el delito, con la finalidad de controlar la actividad del MF o de proteger sus intereses, en tanto que con ello se podría producir una carga desproporcionada sobre los condenados, en especial en materia de costas, sin aportar al proceso nada más ${ }^{1807}$. Otras razones alegadas han sido que, puesto que su intervención se produce ya en la fase del juicio oral, no puede ser útil para el esclarecimiento de los hechos; que constituye una sinecura de los Abogados o que deteriora considerablemente la atmósfera procesal por el enfrentamiento directo entre víctima y acusado ${ }^{1808}$. Parece claro, además, que su intervención vendrá siempre a fortalecer la posición procesal del acusador frente a la del imputado ${ }^{1809}$.

La discusión sobre el mantenimiento de la Nebenklage sigue abierta hoy día. Pese

${ }^{1804}$ Vid. HÖLZEL, U., Das Institut der Nebenklage, Nüremberg 1980, p. 197.

${ }^{1805}$ PRINZ, H-J., "Die Nebenklage- ein überholtes Rechtsinstitut", ZRP, 1971, p. 128; ROXIN, C., Strafverfahrensrecht, $22^{\mathrm{a}}$ ed., Munich 1991, p. 416.

${ }^{1806}$ WEIGEND habla en relación con la "Ley de Protección de la Víctima" de 1987 de un "principio de dos clases" en cuanto a la participación del ofendido. Mientras a los habilitados como Nebenkläger se les confieren toda una panoplia de posibilidades de intervención, las demás víctimas no encuentran ningún cauce para hacer ésta efectiva. WEIGEND, T., Deliktsopfer und Strafverfahren, op. cit. p. 508.

${ }^{1807}$ WEIGEND, T., Deliktsopfer und Strafverfahren, op. cit., p. 473. Al respecto vid. también DIETHILD, H., Die Rechtswircklichkeit der Nebenklage... op. cit. pp. 184 y ss. El autor reconoce sin embargo que el Bundesverfassungsgericht se ha pronunciado sin embargo en favor de la constitucionalidad de la institución.

${ }^{1808}$ WEIGEND, T., Deliktsopfer und Strafverfahren, op. cit., p. 435.

${ }^{1809}$ SCHÜNEMANN, “Zur Stellung des Opfers im System der Strafrechtspflege”, NstZ 1986, p. 198. 
a lo sostenido en épocas pasadas ${ }^{1810}$, y ante la evidencia de que el acusador adhesivo no hace valer un interés público sino un mero interés privado, en opinión de la doctrina mayoritaria actual tal instituto jurídico produce más disfuncionalidades en el sistema de persecución penal que provechos ${ }^{1811}$. De ahí que sea frecuentemente propugnado que el legítimo interés en la reparación, merecedor de protección por el ordenamiento jurídico, se vea satisfecho de otras maneras que no incluyan en ningún caso el ejercicio de funciones acusatorias por particulares ofendidos.

\subsubsection{Acción civil con contenido penal}

La acción civil del perjudicado en el proceso penal es una característica institución del ordenamiento francés que, en su ejercicio individual o colectivo, ha ido adquirido un creciente papel para controlar desde el interior del proceso la actividad del acusador en régimen de monopolio, el $\mathrm{MF}^{1812}$. La acción civil por delitos, cuyo objeto esencial es la reparación del perjuicio sufrido por motivo del delito ${ }^{1813}$, se puede plantear ante los Tribunales civiles o los penales, sin que una vez elegida una vía pueda optarse por la

${ }^{1810}$ Vid. en especial las consideraciones políticas formuladas desde la desconfianza típicamente liberal en el fiscal por OPPENHEIM, L., Die Nebenklage des deutschen Strafprozesses, Breslau 1889, pp. 77 y ss. La generalización a todos los delitos de la acusación adhesiva serviría en su opinión de válido sustitutivo a una acusación popular subsidiaria, cuyos inconvenientes vendría a evitar. Dado que la principal virtud de la Nebenklage no se centra en su verdadera utilización, sino en los efectos de su mera existencia sobre la actividad de los funcionarios del MF, apunta incluso la posibilidad de que cualquier ofendido por el delito o incluso cualquier otra persona, pueda en el futuro intervenir como acusador adhesivo (p. 87). Esta configuración de una acusación popular adhesiva se hizo acreedora inmediatamente de críticas que vieron en ella exactamente los mismos peligros de privatización que en la acusación popular a secas, en la medida que atribuía un derecho de deducir acusación a particulares y no simplemente una facultad de intervención en el proceso. Vid. STENGLEIN, "Die Nebenklage", Der Gerichtsaal 42 (1889), pp. 161 y ss.

${ }^{1811}$ KERNER, H. J., "Die Wiedereinsetztung des Opfers als Subjekt des (Straf-) Rechts", en JANSEN, H. y KERNER, H.J. (Editores), Verbrechensopfer, Sozialarbeit und Justiz, Bonn 1985, p. 499. La Nebenklage no sería más que un cuerpo extraño en el sistema, que no sirve ni a los intereses de éste ni a los de la víctima. Vid. p. ej. RÖSSNER, D. y WULF, R., Opferbezogene Strafrechtspflege, p. 130. Cfr. también ESER, A., “Zur Renaissance des Opfers im Strafverfahren”, en DORNSEIFER et. al. (Editores), Gedächtnisschrift für Armin Kaufmann, Colonia 1989, p. 729.

${ }^{1812}$ El art. 1 CPPFr. establece "L'action publique pour l'application des peines est mise en mouvement et exercée par les magistrats ou par les fonctionnaires auxquels elle est confiée par la loi" y en el art. 31 se especifica que "Le ministère public exerce l'action publique et requiert l'application de la loi".

${ }^{1813}$ RASSAT, M.-L., Procédure pénale, $2^{\mathrm{a}}$ ed. París 1995, pp. 489 y ss. 
otra $^{1814}$. En su ejercicio ante la Jurisdicción criminal cabe deducirla antes de la puesta en marcha de la acusación pública (action) o bien después de ésta (intervention), y, en la práctica, puede llegar a convertirse en una suerte de acusación paralela a la del MF, perdiendo su naturaleza civil para adquirir las características de una acusación adhesiva que contribuye a sostener de manera conjunta la pretensión penal desde una óptica diferente $^{1815}$. Ello queda de manifiesto palmariamente en circunstancias donde la indemnización solicitada es meramente simbólica, consistente por ejemplo en un franco $^{1816}$.

Los sujetos que hayan sufrido directamente la lesión por causa del delito están legitimados para el ejercicio de la acción civil (art. 2 CPPFr), y toda persona que se pretenda agraviada podrá constituirse en parte civil en cualquier momento del procedimiento mediante solicitud ante Juez de Instrucción competente (arts. 85 y ss. CPPFr). Para ello deberá realizar, bajo amenaza de inadmisión de la acción, una consignación pecuniaria, que el instructor fijará en proporción a los recursos del actor, para responder de las posibles responsabilidades civiles derivadas de un abuso en el ejercicio de la acción civil. Esta obligatoriedad puede ceder por decisión judicial o por tener reconocido el derecho a percibir asistencia jurídica gratuita (art. 88 y 88-1 CPPFr).

Si al momento de ejercitarse la acción civil, el procedimiento no se hubiere iniciado todavía, uno de los efectos de la solicitud será precisamente la "puesta en movimiento de la acusación" (mise en mouvement de l'action publique) ${ }^{1817}$, lo cual, en la práctica, servirá para provocar la actuación del acusador oficial si éste hubiera mostrado

${ }^{1814}$ El ejercicio de la acción civil ante los Tribunales penales presenta ventajas tales como la de obtener una reparación más rápidamente, con menor coste y de manera más efectiva por la mayor coerción e intimidación que supone el proceso penal. Supone, además, la forma más efectiva de obtener una indemnización cuando el autor de la infracción sea en principio desconocido (sólo cuando ya se haya iniciado la persecución penal) o cuando sean varios los que sean declarados responsables solidarios. Como desventajas, la doctrina se ha fijado en las mayores dificultades en relación con la prueba y en el riesgo de condena civil o incluso penal por denuncia calumniosa. Vid. LARGUIER, J., Procédure pénale, 12ª ed., Paris 1989, pp. 60 y ss.

${ }^{1815}$ Cfr. MOLINARI, F., Pubblico Ministero e accusa penale (Problemi e prospettive di riforma), (a cura di Giovanni CONSO), Bolonia 1979, p. 213.

${ }^{1816}$ De ahí que se ha llegado en ocasiones a cuestionar si la iniciativa procesal constituye un derecho autónomo. POULPIQUET, J., "Le droit de mettre en mouvement l'action publique: conséquence de l'action civile, ou droit autonome", Revue de science criminelle et de droit pénale comparé, 1975, p. 37.

${ }^{1817}$ Vid. art. 1.II CPPFr.: “Cette action (la pública) peut aussi être mise en mouvement par la partie lésée, dans les conditions déterminées par le présent code". 
hasta ese momento una actitud pasiva. No entra en las facultades del actor civil la acusación stricto sensu, sino sólo la demanda de una pretensión indemnizatoria para la que la declaración de culpabilidad constituirá conditio sine qua non. Se confiere a esta institución así, por vía indirecta, una capacidad potencial para someter al Ministerio Público a un control derivado de la actividad de particulares, si bien con carácter general, sólo de los agraviados por el delito ${ }^{1818}$.

${ }^{1818}$ Una excepción a ello es, como se ha visto en el capítulo anterior, la habilitación que se ha conferido, primero por vía interpretativa y luego normativamente, a las asociaciones para la defensa de intereses colectivos para el ejercicio de la acción civil en sus respectivos ámbitos competenciales. 


\section{CONCLUSIONES}

1. La acusación quivis ex populo trae su origen del Derecho romano clásico, en el que constituyó uno de los ejemplos de actio popularis. En ausencia de un oficial público encargado de acusar, la legitimación a tal efecto se confería a todos los ciudadanos, siempre que no viniere expresamente excluida por razón de las personas o los delitos. El redescubrimiento de las acciones populares romanas realizado por la doctrina alemana e italiana del siglo XIX trajo consigo un intenso debate sobre la calidad en la que el actor ejercitaba su acción: como representante del populus o como valedor uti cives de un derecho propio.

2. La acusación popular fue recibida en el ordenamiento jurídico castellano fundamentalmente a través de las Partidas, donde quedó configurada en términos prácticamente idénticos a los del Derecho romano, y muy similares a los aún vigentes. Del momento codificador cabe reseñar que, tanto en los proyectos normativos como en las opiniones doctrinales y de los operadores jurídicos, existió una constante oscilación entre el deseo de salvaguardar el sistema tradicional de acusación y el de cerrar el paso a posibles manejos fraudulentos mediante ésta. Una vez superado el proceso inquisitivo y al amparo de la ideología liberal, la función acusar quedó en nuestros textos procesales configurada simultaneamente como derecho de los ciudadanos y como obligación estatal, otorgando prioridad a la primera de estas dos perspectivas. No obstante, la pervivencia legal de la acusación quivis ex populo pudo ser en su momento interpretada como una declaración retórica de principios, en tanto la única facultad procesal que se atribuía a ciudadanos no ofendidos era la de instar la iniciación del procedimiento.

Puede ser contemplada, pues, como un residuo histórico, reflejo de una insuficiente consolidación del MF en calidad de defensor del interés público.

3. A lo largo del siglo XIX se desarrolló en varios Estados europeos un intenso debate doctrinal sobre la conveniencia de articular sistemas de acusación privada, sustitutivos o contrapesos frente a la actividad de unos órganos públicos cuyo sometimiento en mayor o menor grado al Ejecutivo los hacía merecedores de una profunda desconfianza. Tal polémica concluyó con la introducción en sus normas procesales de muy reducidas facultades de intervención activa de sujetos privados, todas ellas 
únicamente predicables de la víctima del delito. El ejercicio popular de la acusación fue reputado como un instituto que el curso de los tiempos había dejado atrás y que, además, llevaba inherentes serios peligros de utilización fraudulenta.

Al margen del sistema español, la acusación por ciudadanos no ofendidos sólo se mantuvo en Inglaterra, justificada en lo que se percibía como un derecho firmemente enraizado en su mentalidad jurídica que, a su vez, impedía la creación de un órgano público acusador. Las asociaciones inglesas para la persecución de los delitos jugaron en el siglo XIX un papel relevante a este respecto, supliendo aquella carencia con la agrupación de iniciativas privadas.

4. La previsión del primer inciso del art. $125 \mathrm{CE}$ no establece límites estrictos para que el legislador pueda entrar a modular el ámbito, la extensión e incluso la propia existencia de "acciones populares". La acción popular puede entenderse articulada constitucionalmente como una competencia ínsita en la organización de la Justicia, diseñada para demandar la tutela judicial de intereses generales mediante la actividad procesal de una pluralidad indefinida e indeterminada de particulares. En este precepto han de quedar comprendidas las varias manifestaciones de acción popular presentes en nuestro ordenamiento (en sede penal, administrativa o contable), pero no es admisible la ampliación de éstas con apoyo en una genérica constitucionalización de la "acción popular".

5. La "acción penal" de la LECrim (arts. 100 y ss.) no constituye derecho alguno, sino un conjunto objetivo de actividades que no cambian de naturaleza en función del sujeto, público o privado, que las realice. La acusación popular no admite su inclusión, ni siquiera de manera indirecta, en el art. 24.1 CE, en tanto con su ejercicio no se pretende la defensa de un legítimo interés propio, sino sólo la tutela a iniciativa privada del interés público procesal. Nos apartamos así de la opinión expresada por la doctrina mayoritaria y de la sentada por el TC, que han visto en ella un ius ut procedatur o una manifestación del derecho de acción.

6. El ejercicio de la pretensión penal sólo puede constituir una función pública, comprensible en el marco del Estado Social y de Derecho, prevista en el marco del debido proceso penal para la satisfacción de un presupuesto ineludible de la tutela procesal del 
interés público: nemo iudex sine actore, ne procedat iudex ex officio. Mediante su planteamiento se afirma la concurrencia de los presupuestos objetivos y subjetivos necesarios para un enjuiciamiento comprensivo de la aplicación normativa al caso. La legitimación para formularla corresponde conceptualmente al órgano estatal creado para la imparcial satisfacción de esta tarea, el MF. Sólo residualmente es aceptable la asunción de esta competencia por particulares, en tanto su actividad pueda ser necesaria para la plena consecución de intereses públicos que, transitoriamente, y por negligencia o ineficacia, se permite que el MF no quiera o no pueda defender. La subsistencia de la acusación popular resulta en cualquier caso deslegitimada siempre que sirva para actuar intereses de otra naturaleza, en cuanto tales, extraños al proceso penal. Resalta su equívoca configuración al cotejarla con la de la acusación particular, en la que, a nuestro juicio también anómalamente, se prevé la persecución de un interés material puramente privado.

7. Para el planteamiento de la acusación sin ser agraviados por el delito están legitimados los ciudadanos españoles no excluidos de tal facultad: los que no gocen de la plenitud de sus derechos civiles, los condenados dos veces por acusación falsa y los Jueces y Magistrados (art. 102 LECrim). Aun así, la acusación entre parientes queda excluida legalmente (art. 103 LECrim). Con tales excepciones se afirma el no desconocimiento de ninguno de sus derechos inalienables, realizándose simplemente un diseño orgánico en el que se posibilita la acusación popular. La práctica forense propicia el planteamiento de la acusación por personas jurídicas privadas, aun cuando en puridad carezca de sentido. No sería nunca admisible su ejercicio por Administraciones Públicas, en tanto de esa manera se estaría pervirtiendo la propia esencia de la acusación popular.

8. El ámbito objetivo del ejercicio cívico de la acusación son las causas por delitos públicos y semipúblicos, sin que tenga razón de ser en los llamados “delitos privados". El veto de la acusación popular en la Jurisdicción Militar, ámbito donde la desconfiguración orgánica de la fiscalía la hace merecedora de una doble desconfianza, no puede ser objeto de reproche constitucional. En el caso de la Jurisdicción de menores, la acusación popular podría distorsionar la específica naturaleza de un proceso que no está orientado sólo a la represión, sino al que se pretende dotar de finalidades educativas. En modalidades procedimentales presididas por la celeridad el ejercicio de la acusación por no agraviados tiene, de facto, un muy escaso margen de operatividad. 
9. El ejercicio popular de la acusación debe realizarse siempre a través del instrumento formal de la querella, interpuesta antes del trámite de calificaciones por escrito signado por abogado y procurador. Para ello no cabrá invocar el derecho a la asistencia jurídica gratuita. La imposición por el instructor de una dirección y representación conjunta a todos los ejercitantes de la acusación popular es siempre posible al amparo del art. 113 LECrim. Una vez la querella sea estimada procedente y mínimamente fundada por el instructor, el acusador popular podrá tomar parte en el procedimiento para el ejercicio de la pretensión penal. En atención a su función procesal complementaria, no lo hará en idéntica posición que el MF. Será a partir de ese momento titular de las cargas, expectativas y derechos procesales dimanantes de tal configuración en el procedimiento penal.

10. El vigente régimen normativo de la fianza y su entendimiento jurisprudencial y doctrinal no admite contemplarla como contrapeso suficiente frente a un uso desvirtuador de la acusación popular: la exigencia de proporcionalidad con los recursos del actor (art. 20.3 LOPJ) puede perfectamente no ser compatible con su utilidad para responder de "las resultas del juicio" (art. 280 LECrim). El delito de acusación falsa (art. $456 \mathrm{CP}$ ) se entenderá consumado con la mera interposición de la querella realizada con conocimiento de la falsedad de la imputación o con "temerario desprecio hacia la verdad". Las costas provocadas por la intervención del acusador popular en ningún caso han de recaer en el condenado, sino que lo coherente con su desempeño de una función pública sería que fueran sufragadas con fondos públicos, a no ser que judicialmente se apreciara su utilización fraudulenta, aun cuando ello no parezca deseable.

11. La acusación popular no puede propiciar una democratización de la Justicia, por otro lado innecesaria por inexistente, y no hay razones históricas, políticas o sociológicas que puedan llegar a ser convincentes en ese sentido. El peor riesgo de este tipo de fundamentaciones se cifra en que sirvan para encubrir el déficit representativo allí donde es imprescindible en un Estado de Derecho: en lo político.

12. La acusación entablada por agrupaciones para la defensa de intereses colectivos ha de ser entendida lege ferendae como una modalidad de participación procesal de un representante del interés ofendido. Siguiendo modelos ya presentes en el 
$\overline{\text { derecho comparado, cabría a lo sumo equipararlas a la víctima del delito en causas }}$ seguidas por infracciones donde se afecten bienes jurídicos supraindividuales. Para ello se requeriría el establecimiento de ciertas condiciones garantizadoras de la fiabilidad de tales sujetos.

13. La acusación popular suple la (in)actividad del MF, por lo que pudiera, aquí y ahora, ser útil en algún caso para corregir sus carencias. Como elemento de control en el juego del principio de oportunidad, ámbito donde se le han atribuido poderes taumatúrgicos, adolece de importantes deficiencias que hacen de ella un filtro demasiado poroso que, incluso, sería apto para quebrar alguna de sus posibles virtudes. La acusación popular precisa ineludiblemente de controles judiciales, por lo que, sin constituir un óbice capaz de impedir la instrucción por el MF, parece difícilmente compatible con ella.

El análisis de derecho comparado sobre las facultades de control de la acusación por los particulares muestra la extendida y firme consolidación del monopolio acusatorio oficial. La salvedad que a este respecto pudiera suponer el sistema inglés es mucho más teórica que estrictamente real.

14. El mantenimiento del vigente régimen de acusación popular es comprensible única y exclusivamente en atención a presentes taras orgánicas y funcionales del órgano constitucionalmente obligado a la tutela del interés público. Solventados tales fallos en la fiscalía, ciertamente salvables, no sólo no habría inconveniente en no reconocer el planteamiento popular de la acusación, sino que sería la opción que mejor se adecuaría a los imperativos del Estado Social y de Derecho. 


\section{BIBLIOGRAFÍA}

ABELLA, Joaquín

Ley de Enjuiciamiento Criminal comentada, $4^{\text {a }}$ ed., Madrid 1894

ABENDROTH, Wolfgang

"Der demokratische und soziale Rechtstaat als politischer Auftrag" en Der bürgerliche Rechtstaat, vol. I, pp. 265 y ss; "El Estado de Derecho democrático y social como proyecto político", en El Estado social, con FORSTHOFF, Ernst y DOEHRING, Karl; traducción de PUENTE EGIDO, José, Centro de Estudios Constitucionales, Madrid 1986, pp. 9-42

ABENDROTH, Wolfgang; LENK, Kurt (Editores)

Introducción a la ciencia política, Munich 1964, Barcelona 1971

AGRIFOLIO, Sergio

"Riflessioni critiche sulle azioni popolari como strumento di tutela degli interessi collettivi”, en Le azioni a tutela di Interessi Collettivi, Padua 1976

AGUILERA DE PAZ, Enrique

Comentarios a la LECrim, 6 tomos, $1^{\text {a }}$ ed., Madrid 1916; $2^{\text {a }}$ ed., Madrid 1923

ALAMILLO CANILLAS, Fernando

El MF español (su organización y funcionamiento), Colex, Madrid 1990

ALBAMONTE, Adalberto

"Gli interessi collettivi ed il processo penale nel contesto della partecipazione popolare all'amministrazione della giustizia", Rivista Penale 1978, pp. 435-437

ALCALÁ-ZAMORA, Niceto

- "Lo que debe ser el Ministerio Público", RGLJ 1929, LXXVIII, T. 155, nº 5, pp. 519-531 y en Estudios de Derecho Procesal, Editorial Góngora, Madrid 1934

- "Enseñanzas y sugerencias de algunos procesalistas sudamericanos acerca de la acción”, en Estudios de Teoría General e Historia del Proceso (1945-1972), pp. 317-373 y originariamente en los Estudios de Derecho Procesal en honor de Hugo Alsina, Buenos Aires, 1946, pp. 761-820

- Proceso, autocomposición y autodefensa, UNAM, $2^{\mathrm{a}}$ ed., México 1970

-"Examen de la estructura y contenido de la LECrim de 1882 en el momento de su promulgación", RDProc (Ibam) n 2-3, 1982, pp. 259-289

-"Puntualizaciones relativas al concepto de parte", RDProc (Ibam) no 1, 1983, pp. 103-134

ALCALÁ-ZAMORA Y CASTILLO, Niceto y LEVENE, Ricardo (hijo)

Derecho Procesal Penal, Buenos Aires, s.f.

ALCUBILLA

Diccionario de la Administración Española, Madrid 1914 
ALEXY, Robert

-Teoría de la Argumentación Jurídica, traducción de ATIENZA, M. y ESPEJO, I. Centro de Estudios Constitucionales, Madrid 1989

-Teoría de los Derechos Fundamentales, traducción de GARZÓN VALDÉS, Centro de Estudios Constitucionales, Madrid 1993

ALIMENA, Bernardino

"L'azione penale popolare", en Studi di Procedura Penale, Fratelli Bocca, Turín 1906, pp. 201-220

ALLORIO, Enrico

-“L'Ordinamento giuridico nel prisma dell'accertamento giudiziale”, Rivista di Diritto Civile 1955, incluido en Problemi di Diritto, vol. I, Milán 1957, pp. 3 y ss. Traducción de SENTÍS MELENDO, El Ordenamiento Jurídico en el prisma de la declaración judicial, Buenos Aires 1958

-"Legittimazione e «interese» ad agire" en Problemi di diritto, vol. I, pp. 193-251, Milán 1957; traducción de SENTÍS MELENDO, S., Problemas de Derecho Procesal, T. II, Buenos Aires 1963, pp. 249 y ss.

ALMAGRO NOSETE, José

-"Poder Judicial y Tribunal de Garantías en la nueva Constitución española”, en VVAA, Lecturas sobre la Constitución, Facultad de Derecho UNED, Madrid 1978 -“El derecho procesal en la nueva constitución”, RDProc. 1978, 4, pp. 857-901

-"La acción popular ante el Tribunal de Garantías Constitucionales.Valoración crítica", Revista de Derecho Político, UNED. no 12, invierno 1981/82 pp. 66-83 -“La protección procesal de los intereses difusos en España”, Justicia 83, I, pp. 69 y ss.

- Constitución y Proceso, Bosch, Barcelona 1984

-“Acción Popular" en La Reforma del Proceso Penal, II congreso de Derecho Procesal de Castilla y León, Secretaría General Técnica de Publicaciones del Ministerio de Justicia, Madrid 1989, pp. 225-231

ALONSO GARCÍA, Enrique

"El art. 24.1 de la CE en la Jurisprudencia del TC: problemas generales", en Estudios sobre la Constitución Española. Homenaje al profesor Eduardo García de Enterría, MARTIN-RETORTILLO, S. (Coordinador), T. II, pp. 1008 y ss.

ALONSO ROMERO, $\mathrm{M}^{\mathrm{a}} \mathrm{Paz}$

El Proceso Penal en Castilla (siglos XIII-XVIII), Ediciones Universidad de Salamanca, 1982

ÁLVAREZ GENDÍN, Sabino

"Acción popular y recursos administrativos contra los actos de Administración Local" $R A P \mathrm{n}^{\mathrm{o}} 11$ (1953), pp. 221-267

ÁLVAREZ POSADILLA, Juan

Práctica Criminal por principios o modo y forma de instruir los procesos criminales, Madrid 1815

ÁLVAREZ SUÁREZ, Ursicinio

Curso de Derecho Romano, T. I., Madrid 1955

AMEHUNXEN, Clemens

Der Nebenkläger im Strafverfahren, Lübeck 1980 
AMODIO, Ennio

"L'azione penale delle asociazioni dei consumatori per la repressione delle frodi alimentari”, Riv. ital. Dir. e Proc. Pen. 1974, pp. 515-536

ANDRÉS IBÁÑEZ, Perfecto y MOVILLA ÁLVAREZ, Claudio

El Poder Judicial, Tecnos, Madrid 1986

ANDREWS, J. A.

"Public Interest and Criminal Proceedings", Law Quarterly Review 104, 1988, pp. 410-421

ANDRIOLI

"Significato attuale dell'azione nel processo penale", RDProc. 1973, pp. 355 y ss.

ANTOLISEI, Francesco

L'offesa e il danno nel reato, Bergamo 1930

ANÓNIMOS

-“Das Prinzip der Strafverfolgung”, Deutsche Viertelsjahreschrift, nº 87 (1859),

III, $1^{\text {a }}$ parte, pp. 71-149

-"Private prosecution: a remedy for district attorney's unwarranted inaction", The Yale Law Journal, vol. 65, diciembre 1955, $\mathrm{n}^{\mathrm{o}} 2$

ARAGONESES MARTÍNEZ, Sara

"Introducción al régimen procesal de la víctima del delito. Deberes y medidas de protección", RDProc (Ibam), nº 2, 1995, pp. 409-440

ARANGÜENA FANEGO, Coral

Teoría general de las medidas cautelares reales en el proceso penal español, Barcelona 1991

$A R C H B O L D$

Criminal Pleading, Evidence and Practice, Sweet \& Maxwell, Londres 1995

ARMENTA DEU, Teresa

-Criminalidad de bagatela y principio de oportunidad, PPU, Barcelona 1991

-Principio acusatorio y derecho penal, Bosch, Barcelona 1995

-“El proceso penal: nuevas tendencias, nuevos problemas", $P J, \mathrm{n}^{\circ} 41-42$, pp. 53-86 ARRAZOLA

Enciclopedia española de Derecho y Administración, Madrid 1848

ASENCIO CANTISÁN, Heriberto

"Recursos contra las resoluciones del Juez de Vigilancia Penitenciaria en la LOPJ", $A D P C P$ enero-abril 1987, nº 1, pp. 153-164

ASENCIO MELLADO, José María

Principio acusatorio y derecho de defensa en el proceso penal, Estudios Trivium, Madrid 1991

ASHWORTH, Andrew

"The «Public Interest» element in prosecutions", Crim. Law Rev., septiembre 1987, pp. 597-607

ASHWORTH, Andrew y FIONDA, J.

"The new Code for Crown Prosecutors: prosecution, accountability and the Public Interest", Crim. Law Rev. 1994, pp. 894-903

ASOCIACIÓN PROFESIONAL DE LA MAGISTRATURA (APM)

Conclusiones del $3^{\circ}$ congreso (10-13 de febrero de 1983), Justicia 83, II, p. 497 
ASSINI, N. y MANTINI, P. (Editores)

Associazioni ecologiste e tutela giurisdizionale dell'ambiente, Rimini 1990

AYO FERNÁNDEZ, Manuel

"Las novedades de la Ley 10/1992 de 30 de abril en los juicios de faltas. La instrucción 6/92 de la F.G.E.", Actualidad Jurídica Aranzadi, n 72, 15 de octubre de 1992

BAILEY, V. (Editor)

Policing and Punishment in 19th-Century Britain, Londres 1989

BANDRÉS SÁNCHEZ-CRUZAT, J.M.

El Derecho Fundamental al proceso debido y el Tribunal Constitucional, Aranzadi, Pamplona 1992

BANZHAF, Tomás A.

Polémica sobre la “actio”, Ediciones Jurídicas Europa y América, Buenos Aires 1974

BAÑó y ARACIL, Jorge

“El Ministerio Fiscal en la instrucción de los delitos”, $R G D, \mathrm{n}^{\circ}$ 594, marzo 1994, pp. 1743-1774

BAÑO LEÓN, J.M.

"La distinción entre derecho fundamental y garantía institucional en la Constitución Española", REDC n ${ }^{\circ}$ 24, sept.-dic. 1988

BARATTA, A.

"La vida y el laboratorio del Derecho. A propósito de la imputación de responsabilidad en el proceso penal", Doxa $\mathrm{n}^{\circ} 5$, pp. 275 y ss.

BARBOSA MOREIRA, José Carlos

-“A açao popular do diritto brasileiro como instrumento de tutela jurisdiccional dos chamados interesses difusos" en Studi in onore di Enrico Tullio Liebmann, vol. IV, pp. 2674 y ss. Milán 1979 y en Temas de Direito Processual, Sao Paulo 1977

-"La iniciativa en la defensa judicial de los intereses difusos y colectivos (un aspecto de la experiencia brasileña)", RDProc $\mathrm{n}^{\mathrm{o}} 3$, 1992, pp. 527-532

BARCELLONA, Pietro

Postmodernidad y comunidad. El regreso de la vinculación social, Madrid 1992

BARREIRO, A.J.

"Anotaciones a las medidas urgentes de reforma procesal penal", Actualidad Jurídica Aranzadi no 56, 4 de junio de 1992, p. 4

BARONA VILAR, Silvia

"Algunas reflexiones en torno al instituto de la conformidad en el proceso penal",

La Ley, no 3621, 4 octubre 1994

BARONE, Giuseppe

Enti Colletivi e proceso penale. Dalla constituzione di parti civile all'accusa privata, Giuffré, Milán 1989

BARREIRO, Alberto Jorge

"Anotaciones a las medidas urgentes de reforma procesal penal", Actualidad Jurídica Aranzadi n ${ }^{\mathrm{o}}$ 56, 4 de junio de 1992, p. 4

BARTOLONI FERRO, Abraham 
"La querella en los procesos por delitos de acción pública", RDProc (Arg.) 1945 I, pp. 337-351

BATTAGLINI, Giulio

La Querela, $3^{\mathrm{a}}$ ed., Turín 1958

BECCARIA, Cesare

De los delitos y de las pena, Traducción de TOMÁS Y VALIENTE, Francisco, Aguilar, Madrid 1969

BECHER, Johannes

Die querulatorische Justizdienstaufsichtsbeschwerde, Europäische Hochschulschriften. Peter Lang, Francfort; Berna; Nueva York 1986

BELING, Ernst

Deutsches Reichstrafprozeßrecht, Berlín y Leipzig 1928. Traducción de FENECH, M., Derecho Procesal Penal, Labor, Barcelona 1943

BELLÓN GÓMEZ, I.

Apuntes de procedimientos judiciales y práctica forense, T. III, Procedimientos Penales, Madrid 1941.

BENDER, Erich

Das Klageerzwingungsverfahren Gesichte und Reformbestrebungen, Düsseldorf 1937

BENEVOLO

"Della partecipazione dei privati all'esercizio dell'azione penale", Rivista penale 1890, II, pp. 109 y ss.

BENNET, T.

Evaluating Neighbourhood Watch, Cambridge Studies in Criminology, $\mathrm{n}^{\mathrm{o}}$ 61, Cambrige 1990

BENNION, Francis

"The new Prosecution Arrangements (1). The Crown Prosecution Service", Crim. Law Rev., enero1986, pp. 3-15

BENTHAM, Jeremy

-Organisation of the Judicial Establishment, 1790

-Tratado de las pruebas judiciales, compilado por DUMONT, traducción y comentarios de ANDUAGA ESPINOSA, B., Madrid 1843

BERENINI

Azione ed istruzione penale, organi e funcione, Parma 1888

BERMÚDEZ DE LA FUENTE, J.L.

"Las partes en el proceso penal militar" en Comentarios a las Leyes Procesales Militares (LO 4/1987 y LO 2/1989), SÁNCHEZ GUZMÁN, E. (Editor), Ministerio de Defensa, Madrid 1995, T. I, pp. 587 y ss.

BETTIOL, G. y BETTIOL, R.

Istituzioni di diritto e procedura penale, $4^{\mathrm{a}} \mathrm{ed}$. Padua 1989

BETTIOL, G.

Instituciones de Derecho Penal y Procesal, traducción de GUTIÉRREZ-ALVIZ Y

CONRADI, F., Barcelona 1977

BEVAN, Vaughan; LIDSTONE, Ken

The investigation of Crime. A guide to Police Powers, Butterwords, Londres, 


\footnotetext{
Dublín, Edimburgo 1991

BEYER, K.H. y NEUMANN, H.

Die Mitwirkung der Werktätigen am Strafverfahren, Berlín (este), 1966

BINDING, Karl

-Drei Grundfragen der Organisation des Strafgerichts, Abhandlungen T. 2 pp. 12 , 1876

-“Der Entwurf einer StPO”, Gerichtssaal 74 (1909), pp. 43

BISCARDI, A.
}

"Inquisitio ed accusatio nel processo criminale «extra ordinem»", en Seminarios Complutenses de Derecho Romano. I. Cuestiones de Jurisprudencia y Proceso, abril-junio 1989, pp. 234 y ss.

BISCHOFF, G.

Das Klageerzwingungsverfahren. Eine empirische Analyse mit Vorschlägen zur Reform, Dissertation, Gelsenkirchen 1987

BIZER, J.; ORMOND, T y RIEDEL, U.

Die Verbandsklage im Naturschutzrecht, Bremen 1990

BLANCH NOUGUÉS, José María

La intransmisibilidad de las acciones penales en el Derecho Romano, UA ediciones, Dykinson, Madrid 1997

BLANKENBURG, Erhard; SESSAR, Klaus; STEFFEN, Wiebke

Die Staatsanwaltschaft im Prozeß strafrechtlicher Sozialkontrolle, Duncker\&Humblot, Berlín 1978

BÖCKENFÖRDE, Ernst-Wolfgang

Escritos sobre Derechos Fundamentales, traducción de REQUEJO PAGÉS y VILLAVERDE MENÉNDEZ, Nomos Verlaggesellschaft, Baden-Baden 1993

BOIX REIG, Javier (Director)

Intereses Difusos y Derecho Penal, Cuadernos de Derecho Judicial, $\mathrm{n}^{\mathrm{o}}$ XXXVI, CGPJ, Madrid 1994

BONET NAVARRO, Ángel

Escritos sobre la Jurisdicción y su actividad, Zaragoza 1981

BORGHESI, Domenico

Voz “Azione Popolare”, en Enciclopedia Giuridica. Instituto de la Enciclopedia Italiana, Roma 1988

BRICOLA, Franco

"Partecipazione e giustizia penale. La azioni a tutela degli interessi collettivi", en La Questione Criminale, abril 1976, pp. 16 y 32 y en VVAA, Le azione a tutela di interesse colletivi, Padua 1976

BRINGEWAT, Peter

"Die Nebenklage, ein wirksames Verfahren zur "privaten Kontrolle" staatsanwaltschaftlicher Strafverfolgung”, GA 1972, pp. 289 y ss

BRUNO, Tommaso

Voz "Azione Popolare", en Il Digesto Italiano, vol. IV parte 2, Roma, Nápoles 1893-1899, pp. 951 y ss.

BRUNS, C.G.

“Die römische Popularklagen”, Zeitschrift für Rechtsgeschichte, T. III, 1864, pp. 
341-415. Incluida en Kleinere Schriften, T. I, Weimar 1882, pp. 313 y ss.

BUJOSA VADELL, Lorenzo

-"Notas sobre la protección procesal penal de intereses supraindividuales a través del Ministerio Fiscal y la acción popular", Justicia 90, I, pp. 101-120

-La protección jurisdiccional de los intereses de grupo, Bosch, Barcelona 1995

BULLINGER, Martin

Derecho Público y Derecho Privado, Madrid 1976

CABEZUDO RODRÍGUEZ, Nicolás

El Ministerio Público y la justicia negociada en los Estados Unidos de Norteamérica, Comares, Granada 1996

CAFFERATA NORES, José I.

Temas de Derecho Procesal Penal, Depalma, Buenos Aires 1988

CALAMANDREI, Piero

-Istituzioni di Diritto Processuale Civile secondo il nuovo Codice, $1^{\mathrm{a}}$ y $2^{\mathrm{a}}$ partes, Padua 1943, 1944. Traducción de SENTÍS MELENDO, Buenos Aires, 1962

-“La relatività del concetto d'azione", Riv. Dir. Proc. Civ. 1939, I, pp. 22-46 y en Opere Giuridiche I, Nápoles 1965, pp. 431 y ss. Traducción de SENTIS MELENDO en CALAMANDREI, Estudios sobre el proceso civil, Buenos Aires 1945

CALDERANO, Biagio

Contributo allo studio del Diritto di Querela, CEDAM, Padua 1978

CALVO SÁNCHEZ, Ma del Carmen

-"Incidencia de la participación popular en la Administración de Justicia sobre la duración del juicio oral", RUDProc, nº 0, 1988, pp. 97-106

-“Algunas sugerencias en torno a la futura reforma del proceso penal”, Justicia 90, I, pp. 49-76

-"Procedimiento Abreviado: lagunas y dificultades interpretativas", en Recopilación de ponencias y comunicaciones. Planes provinciales y territoriales de formación, CGPJ 1992, pp. 1427-1451

CANDIAN, Alberto

La Querela, Giuffre, Milán 1951

CAPDEVILLA, Carmen

“La Generalitat de Cataluña como acusación particular", Cuadernos Jurídicos no 17, marzo 1994, pp. 15-20

CAPPELLETTI, Mauro

-"Formazioni sociali e interessi di gruppo davanti alla giustizia civile", Riv. Dir. Proc. julio-septiembre 1975, pp. 361-402

-"Appunti sulla tutela giurisdizionale di interessi collettivi o diffusi”, en el volumen colectivo Le azione a tutela di interessi collettivi, Atti del Convegno di Studio (Pavia, 11-12 junio de 1974), Padua 1976

CAPPELLETTI, Mauro y GARTH, Brian

"The Protection of diffuse, fragmented and collective interests in civil litigation", en Effektiver Rechtsschutz und Verfassungsmäßige Ordnung, Gieseking, Bielefeld 1983, pp. 117-159

CARAVITA, Beniano 
Diritto Pubblico dell'ambiente, Il Mulino, Bolonia 1990 (esp. Capítulo 14: "Il ruolo delle asoziacione", pp. 282 y ss.)

CARBONELL MATEU, Juan Carlos

"Breves reflexiones sobre la tutela de los llamados intereses difusos", en BOIX REIG, J. (Director), Intereses Difusos y Derecho Penal, Cuadernos de Derecho Judicial, no XXXVI, CGPJ, Madrid 1994

CARNELUTTI, Francesco

-Sistema di diritto processuale civile I, Padua 1936

-Il danno e il reato, Padua 1926

-Lezione sul processo penale I, Roma 1946, Traducción de SENTÍS, Buenos Aires 1950

-Las miserias del Proceso Penal, Buenos Aires 1959

-"Saggio di una teoria integrale dell'azione", Riv. di Dir. Proc. 1946, pp. 7 y ss.

Traducción de SENTÍS MELENDO en Cuestiones sobre el Proceso Penal, Buenos Aires 1961

-"Poner en su puesto al Ministerio Público", en Cuestiones sobre el Proceso Penal, Buenos Aires 1961

CARRARA, Francesco

-“Azione Penale", Rivista Penale III

-Programma del corso di Diritto Criminale. Parte generale (vol. I) y Parte especiale (vol. II), B. Canovetti, Lucca 1879. Traducción publicada por Temis, Bogotá 1973

CARSTEN, Ernst

Die Geschichte der Staatsanwaltschaft in Deutschland, Scientia Verlag, Reimpresión de la edición de Breslau 1932, Aalen 1971

CASADO GIMÉNEZ, César

"El litisconsorcio necesario y el derecho de acusación en el proceso penal (pugna entre el párrafo $6^{\circ}$ del art. 384 y el 113 de la LECr", La Ley 1981, I, pp. 947-955

CASABÓ RUIZ, José Ramón

-“Los orígenes de la Codificación penal en España: el plan de Código Criminal de 1787”, ADP, № XIII (1969), pp. 313-342

-Estudio preliminar y edición del Proyecto de Código Criminal de 1830 y Proyecto de Código Criminal de 1834, Murcia 1978.

CASAVOLA, Franco

Sudi sulle azioni popolari romane. Le “actiones populares”, Jovene, Nápoles 1958

CASTILLO SOBERANES, Miguel Ángel

"El Monopolio del ejercicio de la acción penal del Ministerio Público en México", Universidad Nacional Autónoma de México, México 1992

CERDÁ RUIZ DE FUNES, Joaquín

"En torno a la pesquisa y procedimiento inquisitivo en el derecho castellano-leonés de la Edad Media", Anuario de Historia del Derecho Español, T. XXXII (1962)

CHIARA, G. di

"Interessi collettivi e diffussi e tecniche di tutela nell'orizonte del Codice del 1988", Riv. dir. proc. penale, 1991, pp. 426 y ss. 
CHIAVARIO, Mario (Coordinador)

Commento al nuovo Codice di Procedura Penale, vol. I, UTET, Turín 1989

CHIOVENDA, Giuseppe

-“L'azione nel sistema dei diritti”, en Saggi di diritto Processuale, $1^{\circ}$ vol., Bolonia 1903

-Principii di diritto processuale civile, Reimpresión, Nápoles 1965

CLARIÁ OLMEDO

Tratado de Derecho Procesal Penal, IV, Buenos Aires 1964

COBO DEL ROSAL, Manuel

"Problemas penales y procesales de la denuncia", en Primeras Jornadas sobre problemas actuales de la Justicia Penal, GONZÁLEZ MONTES, José Luis (Editor), Universidad de Granada 1994, pp. 39-50

CODACI-PISANELLI

-Azione Popolare, Nápoles 1887

-Le azioni popolari, Relazioni al terzo Congresso giuridico nazionale, p. 10, Florencia 1891

COENDERS, Albert

"Ueber den Strafantrag und die Privatklage des Nichtverletzten", GS 1915, Bd. 83

COLAÇO ANTUNES, L.F.,

"Los intereses difusos: ubicación constitucional, tutela jurisdiccional y «acción popular de masas» (En torno a la revisión de la Constitución Portuguesa de 8 de julio de 1989)", RAP 124, enero.-abril 1991, pp. 417-435

COLLARD DE SLOOVERE, VAN PARYS, HENRY, ALTAVILLA, GLASER (Stephanie) y TEODORESCO

Memoria sobre el Congreso internacional de derecho penal de Bucarest, Révue Internationale de Droit Penal, VI, 1929, pp. 474 y ss

COMISIÓN GENERAL DE CODIFICACIÓN

Memoria Histórica de los Trabajos. RGLJ, T. XXXVIII, Madrid 1871, pp. 19 y ss y pp. 189 y ss.

CONDE-PUMPIDO FERREIRO, Cándido

"El principio de legalidad y el uso de la oportunidad reglada en el proceso penal", $P J \mathrm{n}^{\mathrm{o}}$ especial VI, pp. 17-36

CONDE-PUMPIDO FERREIRO, Cándido; et al.

"Posición instructora del Ministerio Fiscal. Principio de persecución del delito: actividad reglada y criterios de oportunidad", en El Poder Judicial en Europa. Conferenia en Madrid de los Presidentes y Fiscales Generales de los Tribunales Supremos de los Estados Miembros de las Comunidades Europeas. Tema 6, vol. II

CONSO, Giovanni

-Accusa e sistema accusatorio, Milán 1961

-"Formazioni sociali e giustizia penale", Riv. di Dir. Proc. 1976, pp. 1-17

CONSO, Giovanni y GREVI, Vittorio

-Profili del nuovo Codice di Procedura Penale, CEDAM, Padua 1990

-Commento Breve al Nuovo CPP, Padua 1994

CORDERO, Franco

-Procedura Penale, Giuffrè, $3^{a}$ ed., Milán 1995 
-"Linee di un processo accusatorio", en Ideologie del Processo Penale, Giuffrè, 1966

-Procedura Penale, $2^{\mathrm{a}}$ ed. Giuffrè, Milán 1993

CORDÓN MORENO, Faustino

La legitimación en el proceso contencioso-administrativo, Pamplona 1979

CORTÉS DOMINGUEZ, Valentín

La cosa juzgada penal, Publicaciones del Real Colegio de España, Bolonia 1975

CORTINA, Adela

Ética de la Sociedad Civil, Madrid 1994

COSCULLUELA MONTANER, Luis

"Acción pública en materia urbanística", $R A P 71$ (1973), pp. 9 y ss.

COSTA, E.

"Nota a proposito di alcuni recenti studi sulle azioni popolare romane", Riv. ital. di

CRISAFULLI scienze giuridiche, 11, (1891), pp. 360 y ss.

Voz “Azione popolare”, en Nuovo Digesto Italiano, II, Turín 1937, pp. 140 y ss.

CROWN PROSECUTION SERVICE

Annual Report for the period.... From the Director of Public Prosecution to the Attorney General (1986-1994)

CRUZ VILLALÓN, Pedro

"Dos cuestiones de titularidad de derechos: los extranjeros y las personas jurídicas", REDC no 35 (1992), pp. 81 y ss.

CUBILLO RODRIGUEZ, Carlos

"La acción popular en el orden jurisdiccional contable", RDProc. 1992, n 2, pp. 253-284

CUERVO PITA, $\mathrm{M}$.

Voz “Acusación y denuncia falsas”, Nueva Enciclopedia Jurídica Seix, vol. II, pp. 358 y ss.

D'ALBORA, Francisco J.

"Intervención del querellante conjunto en el nuevo Código Procesal Penal", Revista Jurídica Argentina "La Ley", T. 1991-E, p. 1405

DAHM, Georg

"Die Grenzen des Parteiprozesses", ZStW T. 52 (1932) pp.587-611

DANILOVIC, J.

"Observations sur le «actiones popolares»", Studi in onore di G. Grosso 6, Turín 1974, pp. 13-43

DÁVILA MILLÁN, Ma Encarnación

Litisconsorcio necesario. Concepto y tratamiento procesal, $2^{\mathrm{a}}$ ed., Bosch, Barcelona 1992

DAVIS, Jennifer S.

"Prosecutions and their context: The use of the Criminal Law in Later Nineteenth-Century London" en HAY, Douglas y SNYDER, Francis (editores), Policing and Prosecution in Britain 1750-1850, Clarendon Press, pp. 343-396, Oxford 1989

DELMAS-MARTY, Mireille 
"Ni victimes ni procureurs, qui sont-ils?", en Travaux du XXIII Congrès de l'Association française de criminologie, organisé par la'Association française de criminologie et par le Centre de recherches de politique criminelle (París, 17 y 18 de octubre de 1986). En Archives de Politique criminelle no 10, 1988. pp. 11-18 DELPON, J.A.

Essai sur l'histoire de l'action publique et du Ministére Public, París 1830

DENTI, Vittorio

Voz “Interessi Diffusi”, en Novissimo Digesto Italiano, Apéndice IV, Turín 1982, pp. 306 y ss.

DEVIS ECHANDIA, Hernando

Compendio de Derecho Procesal. T. I., Teoría General del Proceso. 10ª ed., ABC, Bogotá 1985

DEVLIN, Patrick

The Criminal Prosecution in England, Oxford University Press, Londres 1960

DÍAZ, Elías

De la maldad estatal y la soberanía popular, Madrid 1984

DÍAZ, Silvia A.

Visión del nuevo Código Procesal Penal de la Nación, Depalma, Buenos Aires 1991

DÍAZ CABIALE, José Antonio

-La admisión y práctica de la prueba en el proceso penal. Premio «Poder Judicial» 1992, Cuadernos del CGPJ, 20, 1992

-Principios de aportación de parte y acusatorio: la imparcialidad del juez, Comares, Granada 1996

DÍAZ PITA, María del Mar

El delito de acusación y denuncia falsas: problemas fundamentales, PPU, Barcelona 1996

DIEGO DÍEZ, Luis Alfredo de

La conformidad del acusado, Tirant lo Blanch, Valencia 1997

DIETRICHT, Heinz

DIETZ, Hans

Querulanten, Ferdinand Enke Verlag, Stuttgart 1973

-“Einschränkung des Legalitätsprinzip in Strafverfahren”, Verhandlungen des 29.

DJT. 3. Band Gutachten, Berlín 1908

-Die Anklageerzwingung, Strafrechtliche Abhandlungen 235, Breslau-Neukirch 1933. Reimpresión Francfort-Tokio 1977

DÍEZ-PICAZO, Luis

-"Notas sobre el Derecho a la Tutela Judicial Efectiva" $P J \mathrm{n}^{\circ}$ 5, marzo 1987, pp. 41-49

-Régimen Constitucional del Poder Judicial, Civitas, Madrid 1991

DOMINIONI, Oreste

-Voz "Parte (Dir. Proc. Penale)", Enciclopedia del Diritto, T. XXXI, 1981

-Le parti nel processo penal, Giuffré, Milán 1985

-Voz "Azione Penale" en Digesto delle Discipline penalistiche, Turín 1987, pp. 398 y ss. 
DÖRING, W.

Der Anklage- und Inquisitionsprozeß bei Carpzow, Emsdetten 1935

DOU y BASSOLS, Ramón Lázaro

Instituciones de Derecho Público General de España con noticia del particular de Cataluña, T. VIII, Madrid 1803.

DOVAL PAÍS, Antonio

"Estructura de las conductas típicas con especial referencia a los fraudes alimentarios", en BOIX REIG, J., Intereses Difusos y Derecho Penal, Cuadernos de Derecho Judicial, nº XXXVI, CGPJ, Madrid 1994

EDWARDS, John

The Attorney General, Politics and the Public Interest, Sweet \& Maxwell, Londres 1984

EGUIZÁBAL, José Eugenio

Apuntes para una historia de la legislación española sobre imprenta, Madrid 1879

EIMERIC, Nicolau

El Manual de los Inquisidores, (Traducción del Directorium Inquisitorium publicado originariamente en 1375 y comentado en 1578 por Francisco PEÑA) Muchnik editores, Barcelona 1996

ELIZONDO Y ÁLVAREZ, Francisco Antonio de

Práctica Universal Forense de los Tribunales de España y de las Indias, T. I, Madrid 1779; T. IV, Madrid 1784

EMMINS, C.J.

A practical approach to Criminal Procedure, $4^{\mathrm{a}}$ ed. Londres 1990

ESCRICHE

Diccionario Razonado de Legislación y Jurisprudencia, Madrid 1874

ESER, Albin

"Funktionswandel strafrechtlicher Prozeßmaximen: Auf dem Weg zur «Reprivatisierung» des Strafverfahrens?" en Recht und Verfahren. Symposion der rechtswissenschaftlichen Fakultäten der Albert-Ludwigs-Universität Freiburg und der Städtischen Universität Osaka, KROESCHELL, Karl (Editor), Heidelberg 1993

ESMEIN, A.

Histoire de la procédure criminelle en France et specialement de la procédure inquisitoire depuis le XIIle. siècle jusqu'à nos jours, París 1882, (Reedición, Francfort 1969, Editorial Sauer \& Auvermann)

ESTEBAN DRAKE, A.

El Derecho Público Subjetivo como instrumentación técnica de las libertades públicas y el problema de la legitimación procesal, Civitas, Madrid 1981

FABRE, Emile

De l'acusation publique chez les anciens peuples, París 1875

FADDA, Carlo

-L'azione popolare, Turín 1894

-“Le qualità morali dell'attore popolare", en Raccolta di scriti offerti al prof.

Pessina nel cinquentesimo anno d'insegnamento, FILANGIERI (editor)

FAIRÉN GUILLÉN, Víctor 
-La acción, Derecho Procesal y Derecho Político, En Estudios de Derecho Procesal, Madrid 1955, pp. 64 y ss. Originariamente en RDProc (Arg.) 1950, I, pp. 40-83, en RDProc 1951, 3, pp. 395-430, y en italiano en Jus, 1951, II.

-Voz “acción”, Nueva Enciclopedia Jurídica Seix, Barcelona 1975, pp. 190-207. -"Procesamiento, sobreseimiento, acusación”, ADP 1967, III, pp. 630 y ss.

-Presente y futuro del Proceso Penal español (El "Anteproyecto de Bases para el Código Procesal Penal" de 1967, la Ley de 8 de abril de 1967), Secretariado de publicaciones, intercambio científico y extensión universitaria. Universidad de Valencia, 1967

-"Para una teoría general del Derecho Procesal", en Temas del Ordenamiento Procesal I, pp. 272-351

-"El proceso como función de satisfacción jurídica" en Temas del Ordenamiento Procesal I, pp. 353-433

- "El enjuiciamiento de sujetos peligrosos no delincuentes", RDProc (Ibam) 1972 pp. 335 y ss.

-"La situación actual del Ministerio Fiscal", RDProc (Ibam) 1970, IV, pp. 759-812 -Problemas del proceso por peligrosidad sin delito, Tecnos, Madrid 1972

-“Independencia judicial en España en la actualidad", Ponencia nacional para el VII Congreso Internacional de Derecho Procesal (Würzburg 12-17 septiembre 1983), incluida en Estudios de Derecho procesal civil, penal y constitucional, T. I, Madrid 1983, pp. 49-103

-“De nuevo sobre el concepto de acción y pretensión”, RDProc. n n 1, 1988, pp. 731

-"El art. 125 de la Constitución: la acción popular y su fortalecimiento", Comunicación al II Congreso de Derecho Procesal de Castilla y León, Zamora 1989, en La Reforma del Proceso Penal. II Congreso de Derecho Procesal de Castilla y León, Madrid 1989, pp. 599-608

-“Acción del Fiscal y acción popular. El refuerzo de esta última”, TAPIA n ${ }^{\circ} 48$, octubre 1989

-Ensayo sobre procesos complejos, Tecnos, Madrid 1991

-“Acción, proceso y ayuda a las víctimas del delito”, La Ley 1991, T. III, pp. 862881

-“Acción del Ministerio Fiscal y acción popular. Su titularidad y extensión”. En Estudios de Derecho procesal civil, penal y constitucional vol. III, La reforma del Proceso penal (1988-1992), Edersa, Madrid 1992

FENECH, Miguel

-“Nuevas orientaciones del Derecho Procesal Penal", $R G L J 1941, \mathrm{n}^{\circ} 170, \mathrm{pp} .81$ y ss.

-La posición del Juez en el nuevo Estado, Madrid 1941

-Derecho Procesal Penal, $3^{\mathrm{a}}$ ed., Barcelona 1960; El Proceso Penal, 4ª ed., Madrid 1992

FERNANDES DE OLIVEIRA, Regis

"Medidas para hacer efectivo el acceso a la Justicia", $P J \mathrm{n}^{\circ} 33$, Marzo 1994, pp. 243-248

FERNÁNDEZ DE AYALA 
Práctica y Formularios de la Chancillería de Valladolid, Editorial Francisco Revilla, Zaragoza 1773

FERNÁNDEZ ENTRALGO, Jesús

"Los principios procesales y procedimentales de la Ley Orgánica 7/1988", en La reforma del proceso penal, con ANDRÉS IBÁÑ̃EZ, Perfecto; CONDEPUMPIDO TOURÓN, Cándido; PÉREZ MARIÑO, Ventura; VARELA CASTRO, Luciano, Tecnos, Madrid 1990, pp. 15-69

FERNÁNDEZ DE HERRERA VILLARROEL, Gerónimo

Practica Criminal. Instruccion (nueva util) de substanciar las causas..., Imprenta Real, Madrid 1672

FERNÁNDEZ LÓPEZ, Miguel Ángel

"Nuevo panorama de los delitos perseguibles de oficio y de los delitos perseguibles sólo a instancia de parte”, RJCat 1979, nº 2, pp. 109 y ss.

FERNÁNDEZ MARTÍN-GRANIZO, Mariano

El Ministerio Fiscal en España (notas para una construcción de dicha figura y estudio de su posición en el Derecho Procesal español), Madrid 1977

FERNÁNDEZ MONTES

Recensión de los Coloquios de la Asociación de Antiguos alumnos de la Escuela de Práctica Jurídica de Madrid (curso 1960-1961) en Boletín Informativo del Instituto Español de Derecho Procesal no 93, Mayo 1960

FERNÁNDEZ RODRIGUEZ, Tomás Ramón

"La acción popular en el Proyecto de LOPJ", en Estudios sobre el proyecto de $L O P J$, recopilación de las conferencias del ciclo de estudios sobre el proyecto de LOPJ convocado por la Escola d'Administració pública de Catalunya, Generalitat de Catalunya, Barcelona 1985

FERNÁNDEZ TORRES, Juan Ramón

"La legitimación corporativa en la jurisprudencia contencioso-administrativa y el derecho a la tutela judicial efectiva", en Estudios en homenaje al profesor Jesús González Pérez II, Madrid 1993, pp. 1379 y ss.

FERNÁNDEZ DE VELASCO, Recaredo

La acción popular en el Derecho Administrativo, Reus, Biblioteca de la RGLJ, vol. XX, Madrid 1920

FERRER SAMA

"El delito de acusación y denuncia falsa" en Homenaje a D. Nicolás Pérez Serrano, Madrid 1959, pp. 335-374

FERRAJOLI, Luigi

Derecho y Razón. Teoría del Garantismo Penal, Editorial Trotta, Madrid 1995

FIGUEIREDO DIAS, Jorge

-Direito Processual Penal, 1974

-"Sobre os sujeitos processuais no novo CPP" en el volúmen colectivo $O$ novo Processo Penal, Coimbra 1988

FILANGIERI, Carlo

Ciencia de la Legislación, Traducción de J. de Ribera, Madrid 1821. Existe una edición de 1836, comentada por CONSTANT, B.

FLORIAN, Eugenio 
-"Degli organe per l'esercizio dell'azione penale", Riv. Dir. e Proc. Pen. 1912, III, pp. 398 y ss; 449 y ss.

-Elementos de Derecho procesal Penal, (Traducción de Prieto-Castro), Bosch, Barcelona 1934

-Il Proceso Penal e il nuovo Codice, Casa Editrice Dottor Francesco Vallardi, Milán 1914

FLORIAN, Eugenio / BERNAU

Commento al Codice di Procedura Penale. P. I, Lavori Preparatorii, II. I progetti ministeriali del 1905 e del 1911, Turín 1913

FONT SERRA, Eduardo

La acción civil en el proceso penal. Su tratamiento procesal, Madrid 1991

FORTUNA, Ennio

Azione Penale e azione resarcitoria, Giuffré, Milán 1980

FOSCHINI, Gaetano

Sistema del Diritto Processuale Penale, T. I, 2a ed., Giuffré, Milán 1965

FRANZHEIM, Horst

“Zur Behandlung querulatorischer Strafanzeigen”, GA 1978, pp. 142-146

FRIEDMANN, L.

FRISCH

Introducción al Derecho, traducción de VERGER GRAU, J., Zaragoza 1988

"Der Begriff des "Verletzten" im Klageerzwingungsverfahren", JZ 1974, 7

GALLEGO ANABITARTE, Alfredo

Derechos Fundamentales y Garantías Institucionales: análisis doctrinal y jurisprudencial (Derecho a la educación; autonomía local; opinión pública), Civitas, Madrid 1994

GARCÍA, Eduardo Augusto

"La supresión del querellante y del actor popular", RDProc (Arg.) 1943, II, pp. 281 y ss.

GARCÍA DE CECA LÓPEZ, Carlos y GUERRERO SANCHEZ DE PUERTA, Ignacio "La igualdad procesal de las partes en la fase intermedia del procedimiento abreviado. Comentario a la STC 186/1990 de 15 de noviembre", La Ley 1991, T. 1, pp. 90-91

GARCÍA GONZÁLEZ, J.,

"El juramento de Manquadra", Anuario de Historia del Derecho Español, XXV, pp. 211-255

GARCÍA DE ENTERRÍA, Eduardo

-“Sobre los Derechos Públicos Subjetivos", REA no 6, pp. 427 y ss.; Homenaje a Gómez-Orbaneja, Editorial Moneda y Crédito, Madrid 1977, pp. 195 y ss.

-Curso de Derecho Administrativo, con T. R. FERNÁNDEZ, T. II, $4^{\mathrm{a}}$ ed., Madrid 1993

GARCÍA GOYENA, F. y AGUIRRE, J.

Febrero o Librería de Jueces, Abogados y Escribanos, Tomo VIII, Madrid 1845

GARCÍA LABAJO, Juan M.

"La acción civil en el proceso penal militar", REDEM n ${ }^{\circ} 55$, T. I, enero-junio 1990, pp. 161-173 
GARCÍA VALDÉS, Carlos

"La Cooperación de los sectores público y privado en la lucha contra la delincuencia en España", en CANCINO MORENO, A.J. (Recopilador) Pensamiento Penal Moderno. Edición Homenaje al Descubrimiento de América, pp. 271-276, Universidad Externado de Colombia, 1991

GARCÍA-PABLOS DE MOLINA, A.

Criminología. Una introducción a sus fundamentos teóricos para juristas. Valencia 1992

GARCÍA-TREVIJANO GARNICA, E.

"Consideraciones sobre la acción pública y el Medio Ambiente", Revista de derecho Urbanístico y Medio Ambiente, octubre-diciembre 1995, n 145, pp. 141164

GARRAUD, R.

Traité theorique et pratique d'instruction criminelle et de Procédure Pénale, París 1907

GEIßER, Hans

"Das Anklagemonopol der Staatsanwaltschaft und die Gewährperson als Aufklärungsmittel im Ermittlungs- und als Beweismittel im Strafverfahren”, GA 1983, pp. 385 y ss.

GEYER, August

Lehrbuch des gemeinen deutschen Strafproceßrechts, Leipzig 1880

GHIARA, A.

"Partecipazione popolare all'esercizio dell'azione penale", Giustizia Penale 1982, I, pp. 258 y ss.

GIARDA, Angelo

La persona offesa dal reato nel processo penale, Dott. A. Giuffrè Editore, Milán 1971

GIL-ROBLES GIL-DELGADO, Jaime

"La acción judicial popular y la audiencia de los ciudadanos en el área del derecho ambiental", Ponencia presentada en las Jornadas sobre Medio Ambiente (Segovia 29 de septiembre - 1 de octubre de 1988), publicada en $P J, \mathrm{n}^{\mathrm{o}}$ especial IV, Madrid 1989

GIMENO SENDRA, Vicente

-"La fianza del acusador particular: Notas sobre legitimación activa y caución juratoria en el proceso penal", RDProc (Ibam) 1976, pp. 55-97

-La Querella, Bosch, Barcelona 1977

-"Los derechos de asociación (sic) penal, al juez legal y de defensa y sus derechos instrumentales" y "La acción popular, el Jurado y los Tribunales de Escabinos", en Comentarios a la legislación penal, Tomo I, "Derecho Penal y Constitucional", dirigidos por COBO DEL ROSAL y BAJO FERNÁNDEZ, pp. 141-190 y 337343 respectivamente.

-"La participación popular en la administración de Justicia", en el volumen colectivo El Poder Judicial, vol. II, pp. 1405-1445, DIRECCION GENERAL DE LO CONTENCIOSO DEL ESTADO, Madrid 1983

-"Los procedimientos penales simplificados (principio de oportunidad y proceso 
penal monitorio)", PJ 1986, $\mathrm{n}^{\circ}$ especial II, (Justicia Penal), pp. 31-49

-Constitución y Proceso, Tecnos, Madrid 1988

-Capítulo "Las partes acusadoras" en el volumen colectivo El nuevo proceso penal. Estudios sobre la LO 7/1988, Tirant lo Blanch, Valencia 1989, pp. 65-112

-“La acusación popular", PJ, n $\mathrm{n}^{\mathrm{0}} 31$, septiembre 1993, pp. 87-94; publicado en francés ( "L'accusation publique en Espagne") en Revue de Science Criminelle et de Droit Pénal Comparé, nº 4, octubre-diciembre 1994 pp. 739-746

-“Los delitos económicos en el nuevo Código Penal”, Actualidad Jurídica Aranzadi, 6 de junio de 1996, pp. 1, 5 y 6.

-Ley Orgánica del Tribunal del Jurado (Comentada), Colex, Madrid 1996

GIMENO SENDRA, Vicente; MORENO CATENA, Víctor; CORTÉS DOMÍNGUEZ, Valentín

Derecho Procesal Penal, Colex, Madrid 1996

GIMENO SENDRA, Vicente; MORENO CATENA, Víctor; GARBERÍ LLOBREGAT, José; GONZÁLEZ-CUÉLLAR, Nicolás

Curso de Derecho Procesal Administrativo, $2^{\mathrm{a}}$ ed., Tirant lo Blanch, Valencia 1994

GIMENO SENDRA, Vicente; GARBERÍ LLOBREGAT, José

"La protección procesal del Medio Ambiente", $P J, \mathrm{n}^{\mathrm{o}} 37$, pp. 141-158

GISBERT GISBERT

"Sobre el fiscal de vigilancia penitenciaria", $R G D$ 526-527, julio-agosto 1988

GITTLER, J.

"Expanding the Role of the Victim in a Criminal Action", Pepperdine Law Review

GIUFFRE, V.

11 (1984), pp. 117 y ss.

Il diritto penale nell 'esperienza romana, 1989

GLASER, Joshua

-“Das Prinzip der Strafverfolgung”, en Gesamelte kleine Schriften 1860, I, pp. 520 y ss.

-Handbuch des Strafprozesses, Leipzig, 1883 (T. I) y 1885 (T. II)

GLEISPACH, W.

"Der deutsche Entwurf eines gesetzes über der Rechtsgang in Strafsachen", Schweizerische Zeitschrift für Strafrecht, T. 33, 1920, pp. 269 y ss

GNEIST, Rudolf

"Die Staatsanwaltschaft und die Privatklage", en Vier Fragen zur deutschen Strafprozeßordnung, Berlín 1874, pp. 16-57

GOLDSCHMIDT, James

-Der Prozess als Rechtslage. Eine Kritik des prozessualen Denkens, reimpresión de la edición publicada en Berlín, 1925, Scientia Verlag, Aalen, 1962

-"Derecho Justicial Material (pretensión de tutela jurídica y derecho penal)" RDProc (Arg), 1946, T. I, pp. 18 y ss. Traducción de GROSSMANN, C. del trabajo Materialles Justizrecht, aparecido en 1905 en el homenaje a B. HÜBLER -Problemas Jurídicos y Políticos del Proceso Penal, Bosch, Barcelona 1935; publicado también como Principios Generales del Proceso, vol. II, Buenos Aires 1961 
GÓMEZ COLOMER, Juan Luis

-El Proceso Penal alemán. Introducción y normas básicas, Bosch, Barcelona 1985

-“Acción particular, acción popular y sobrecarga de la Administración de Justicia penal", $P J \mathrm{n}^{\circ} 8$, dic 1987 pp. 27 y ss.

-“El Fiscal Instructor”, Justicia 96, II, pp. 259-286

GÓMEZ DE LIAÑO GONZÁLEZ, Fernando

"La legitimación colectiva y el art. 7 LOPJ", Justicia 86, III, pp. 549-576

GÓMEZ Y NEGRO, L.

Elementos de Práctica Forense, Valladolid 1830

GÓMEZ ORBANEJA, Emilio

-“La acción penal como derecho al proceso", Revista de Derecho Privado, no 371 ,

Febrero 1948, pp. 72-97

-"Reforma de la querella particular", Actas del I Congreso Nacional de Derecho Procesal, Madrid 1950

-Comentarios a la LECrim. T.II, Vol. I, Bosch, Barcelona 1951

GÓMEZ ORBANEJA, Emilio y HERCE QUEMADA, Vicente

Derecho Procesal Penal, 10ª ed., Madrid 1986

GÓMEZ DE LA SERNA, P. y MONTALBÁN, J.M.

Tratado Académico-Forense de los Procedimientos Judiciales, T. III, Madrid 1861 GONIN, Daniel

"Agir et punir, au nom de...", Travaux du XXIII Congrès de l'Association française de criminologie, organisé par la'Association française de criminologie et par le Centre de recherches de politique criminelle (París, 17 y 18 de octubre de 1986).

Publicado en Archives de Politique criminelle no 10, 1988; pp. 51-57

GONZÁLEZ DE ALBA, Primitivo

"El Derecho a la acusación como función de ciudadanía", RGLJ no 115 (1909), pp. $29-50$

GONZÁLEZ MONTES, Fernando

"Acción penal y perdón del ofendido en los denominados delitos semipúblicos", RFDU Granada n², 1983, pp. 83-93

GONZÁLEZ MONTES, José Luis

"Notas en torno a la acción penal y su ejercicio", en MORENO CATENA, V. (Coordinador), Problemas actuales de la Justicia. Homenaje al Profesor Gutiérrez-Alviz, Valencia 1988, pp. 737-746

GONZÁLEZ NANDÍN, Sebastián

Reflexiones sobre la legislación penal, el jurado y las costumbres judiciales de Inglaterra, Imprenta de la RGLJ, Madrid 1877

GONZÁLEZ PÉREZ, Jesús

-El derecho a la tutela jurisdiccional, Cuadernos Civitas, Madrid 1984

-Comentarios a la Ley del Suelo, $5^{\text {a }}$ ed., Madrid 1988

GORDILLO, Manuel

"La incapacidad procesal por demencia del querellante", RDProc (Ibam) 1947, pp. 7-26

GRASSO, Eduardo

-“Gli interessi della Collettivitá e l'azione collettiva”, Riv.Dir. Proc. 1983, pp. 24- 
56

-“Enti esponenziale ed esercizio dell'azione civile nel processo penale”, Giustizia Penale, 1987, III, pp. 1 y ss.

GROß (von)

"Das Princip der Strafverfolgung", Deutsche Vierteljahresschrift 1860, 2, pp. 250 y ss.

GUARNIERI, Giuseppe

La parti nel processo penale, Milán 1949. Traducción publicada en Puebla (México), 1952

GUASP DELGADO, Jaime

"La pretensión procesal", Anuario de Derecho Civil 1952, fasc. 1, T. V. Reedición

Civitas, Madrid 1981

GUERRERO, Walter

La acción penal, Loja (Ecuador) 1989

GUTIÉRREZ, Josef Marcos

Práctica Criminal de España, Madrid 1819, 1824 y $1826\left(2^{\mathrm{a}}, 3^{\mathrm{a}}\right.$ y $4^{\mathrm{a}}$ ediciones $)$

GUTIÉRREZ DE CABIEDES, Eduardo

-"Aspectos procesales de la Ley de Peligrosidad y Rehabilitación social y su reglamento", RDProc (Ibam) 1972, n 4 pp. 817-850 y en Estudios de Derecho procesal, Pamplona 1974, pp. 539-582

-"La correlación entre acusación y sentencia", Revista de la Facultad de Derecho de Madrid, XIV, no 37 (1970), pp. 73 y ss. y en Estudios de Derecho procesal, Pamplona 1974, pp. 509-535

GUTIÉRREZ-ALVIZ y ARMARIO, Faustino; MORENO CATENA, Víctor

Comentario al art. $125 \mathrm{CE}$ "La participación popular en la Administración de Justicia”, en ALZAGA, O. (Director), Comentarios a las Leyes politicas. Constitución Española de 1978, Editorial Revista de Derecho Privado, Tomo IX, art. 113-127, pp. 597-605,

GUTIÉRREZ-ALVIZ Y CONRADI, Faustino

“Doctrina procesal española sobre la acción: 1830-1930", RDProc. (Ibam) nº1, 1979, pp. 21-43

GUTIÉRREZ SANZ, M.R. y SAMANES ARA, C.

"Comentario al art. 7.3 de la LOPJ en relación con la protección procesal de los derechos de los consumidores", La Ley 1988, T. II, pp. 1157-1160

GUZMÁN FLUJA, Vicente Carlos

"Algunos aspectos de la relación justicia-medios de comunicación”, Justicia 91, III, pp. 593 y ss.

HÄBERLE, Peter

"Grundrechte im Leistungsstaat", Die Wesensgehaltgarantie des Art. 19, Abs. 2 $G G$, C.F. Müller, Heidelberg, $3^{\text {a }}$ ed., 1983

HABERMAS, Jürgen

-Strukturwandel der Öffentlichkeit, $5^{\text {a }}$ ed., Neuwied-Berlín 1971

-Faktizität und Geltung. Beiträge zur Diskurstheorie des Rechts und des demokratischen Rechtsstaats, $4^{\mathrm{a}}$ ed., Francfort 1994

HAHN, Karl (Editor) 
Die gesammten Materialien zur StPO und dem Einführungsgesetz zu derselben vom 1.2.1877, 2. ed. von STEGEMANN, E. (editor), Berlín 1885

HAMPTON, Celia

Criminal Procedure. $3^{\mathrm{a}}$ ed. Sweet \& Maxwell, Londres 1982

HARLOW, Carol y RAWLINGS, Richard

Pressure Through Law, Routledge, Londres-Nueva York 1992

HASSEMER, Winfried

-“Legalität und Opportunität im Strafverfahren. Eine Skizze”, en Strafverfolgung und Strafverzicht. Festschrift zum 125jährigen Bestehen der Staatsanwaltschaft Schleswig-Holstein, OSTENDORF, Heribert (Editor), Kassel 1992, pp. 529-540 -"Rücksichten auf das Verbrechensopfer", en Festschrift für Ulrich Klug zum 70. Geburtstag, KOHLMANN, Günter (Editor), T. II. Colonia 1983. Traducción de CANTARERO, Rocío, ADPCP, 1990, pp. 241 y ss.

HAWSER, Lewis; WIGDDER, Basil

"The prosecution process in England and Wales", Report by JUSTICE, Londres 1970

HAY, Douglas

-“Controlling the English Prosecutor”, Osgoode Hall Law Journal, vol. 21, 1983, pp. 165-185

-"Prosecution and Power: Malicious Prosecution in the English Courts, 1750-1850" en HAY, Douglas y SNYDER, Francis (editores), Policing and Prosecution in Britain 1750-1850 Clarendon Press, Oxford 1989

HAY, Douglas y SNYDER, Francis

"Using the Criminal Law, 1750-1850: Policing, Private Prosecution, and the State", en HAY, Douglas y SNYDER, Francis (editores), Policing and Prosecution in Britain 1750-1850, Clarendon Press, Oxford 1989

HEFENDEHL, Roland

"Die Popularklage als Alternative zum Strafrecht bei Delikte gegen die Gemeinschaft", GA 3, marzo 1997, pp. 119-134

HELSINKI INSTITUTE FOR CRIME PREVENTION AND CONTROL

Non prosecution in Europe. Report of the European Seminar held in Helsinki, Finland 22-24 March 1986, Publication Series nr. 9, Helsinki 1986

HENKEL, H.

HENRY

Strafverfahrensrecht. Ein Lehrbuch, Stuttgart 1968

"Rapport à la Societé general des Prisons sur l'exercice de l'action civile par les associations à but désinteressé et specialment par les ligues de moralité", Révue Penitentiaire 1928, pp. 88 y ss.

HERNÁNDEZ HENRÍQUEZ, Esteban Emilio

-“Garantías del justiciable e inadecuada iniciación en el proceso penal por delitos públicos y semipúblicos", RDProc 1975, n 2-3, pp. 451-472

-"El ofrecimiento de acciones en el proceso penal. Especial atención a los arts. 110 y 118 de la LECrim.”, RDProc 1976, nº 4, pp. 881-904

HERRERO MARTÍNEZ

Ley de Enjuiciamiento Criminal reformada, anotada y comentada, 1908 
HERRMANN, Joachim

"Beweisaufnahme durch die Parteien und Kreuzverhör im anglo-amerikanischen Strafverfahren”, ZStW, T. 80, 1968 pp. 775 y ss.

HERZOG, Felix

"Límites del Derecho Penal para controlar los riesgos sociales (una perpectiva crítica ante el Derecho Penal de Peligro)", PJ diciembre 1993, pp. 79-88

HETHERINGTON, Thomas

Prosecution and the Public Interest, Waterlow, Londres 1989

HEVIA BOLAÑO, Juan de

HIPPEL

Curia Philipica, Madrid 1797

Deutsches Strafrecht, T. I, Berlín 1925

HOHMANN, Olaf

Das Rechtsgut der Umweltsdelikte. Grenzen des strafrechtlichen Umweltschutzes, Francfort 1991

HOLTZENDORF

-Gutachten über die Frage: Kann die Privatklage... eingeführt werden? Verhandlungen des 12. deutsche Juristentages, T. I, Berlín 1874

-Die Umgestaltung der Staatsanwaltschaft von Standpunkt unabhängiger Strafjustiz, Berlín 1865

HOUSE OF COMMONS

Crown Prosecution Service. Fourth Report, vol I y II, 1990

HUBER, Barbara

-"La posizioni degli organi di accusa en Gran Bretagna" en Publico Ministero e accusa penale (problemi e prospettivi di riforma), CONSO, G. (editor), Zanichelli, Bolonia 1979

-"The office of the State Prosecutor. It's legal status, function, and control", Révue Internationale de droit penal/International Review of Penal Law 63, $3^{\circ} \mathrm{y}^{\circ}$ trimestre 1992 bis, pp. 1189-1216

HUBER, Ernst Rudolf (Editor)

Dokumente zur deutschen Verfassungsgesichte, T. I, (1803-1850), Stuttgart 1978

HÖLZEL, Ursula

Das Institut der Nebenklage. Eine Betrachtung unter rechtshistorischen, rechtsdogmatischen und rechtspolitischen Geschichtspunkten, Dissertation, HÖPLER Erlangen 1980

Reform des Strafverfahrens. 35. Deutsche Juristentag. 1928/29, (zweite Sitzung der Dritten Abteilung) p. 632, Berlín, Leipzig 1928

HUERTA CONTRERAS, M.

"El Poder Judicial en la Constitución Española", Granada 1995

HÜSSING, Diethild

Die Rechtswircklichkeit der Nebenklage. Eine rechtstatsächliche Untersuchung an 569 nebenklagefáhigen Strafverfahren, Dissertation, Gotinga 1982

IBÁÑEZ Y GARCÍA VELASCO, Miguel

"Independencia y autonomía del Ministerio Fiscal en el Proceso Penal", RDProc 
1967, vol II, pp. 103-152 y vol. III, pp. 63-108

IBÁÑEZ LÓPEZ-POZAS, Fernando L.

Especialidades procesales en el enjuiciamiento de delitos privados y semiprivados, Dykinson, Madrid 1993

ICHINO, Giovanna

"Costituzione di parte civile di associazioni e sindacati nel processi penale", Rivista Giuridica del Lavoro, III, 1977, pp. 639-690

IHERING, Rudolf von

Der Kampf um's Recht 18 ed., Viena 1913. Traducción española de POSADA, Adolfo, con prólogo de Leopoldo Alas (Clarín), La lucha por el derecho, Madrid 1921, Reedición en cuadernos Civitas, Madrid 1985

IRIBAS, J.

"El Ministerio Fiscal no es parte", RDProc 1952, II, pp. 187 y ss.

JACKSON, R.M.

The Machinery of Justice in England, Cambridge University Press, Cambridge 1972

JACOBY, J.E.

The american Prosecutor: a search for identity. Massachusets, Toronto 1980

JANKA, Karl

Staatliches Klagemonopol oder subsidiäres Strafklagerecht, Erlangen 1879

JANS, Sigrid

Die Aushöhlung des Klageerzwingungsverfahren, Lang, Francfort 1990

JELLINEK, G.

System der subjektiven öffentlichen Rechte, Scientia, Tubinga 1905, Reimpresión de la $2^{\text {a }}$ ed. (1919), Darmstad 1963. Existe traducción al italiano de VITAGLIANO, G., Sistema dei Diritti Pubblici Subbiettivi, Milán 1912

JESCHECK, Hans-Heinrich / LEIBINGER, Rudolf (Editores)

Funktion und Tätigkeit der Anklagebehörde im ausländisches Recht, Nomos, Baden-Baden 1979

JIMÉNEZ ASENJO, Enrique

-“Orientaciones para la reforma de la LECrim.”, RDProc (Ibam) 1952, pp. 67-116

-Derecho Procesal Penal, Vol. I., Edersa, Madrid, s. f.

JIMÉNEZ BLANCO

"Garantías Institucionales y derechos fundamentales en la Constitución", en Homenaje a García de Enterría, 1991, T. II, pp. 635 y ss.

JIMÉNEZ HERNÁNDEZ, José Ignacio

"Algunos problemas en torno al desarrollo del art. 125 de la Constitución", en el volúmen colectivo El Poder Judicial, Dirección General de lo Contencioso del Estado, T. II, pp. 1585-1619

JIMENO BULNES, María del Mar

-"El principio de publicidad en el sumario", Justicia 93, pp. 705 y ss.

-La cuestión prejudicial del artículo 177 TCE, Bosch, Barcelona 1996 $\mathrm{JOHN}$

Beiträge zur Beteilung des Entwurfs einer deutschen Strafprozeßordnung (Monopol der Staatsanwaltschaft, Privatklage, Antragsverbrechen), en Allgemeine 
deutsche Strafrechtszeitung, 1873, pp. 193 y ss., 228 y ss.

JOLY, $\mathrm{H}$.

"Les associations et l'Etat dans la lutte contre le crime", Révue politique et parlamentaire, septiembre 1895, pp. 430 y ss.

JORI TOLOSA, José Luis

"Problemática procesal de los Intereses Difusos", en BOIX REIG, Javier (Director), Intereses Difusos y Derecho Penal, Cuadernos de Derecho Judicial, $\mathrm{n}^{\circ}$ XXXVI, CGPJ, Madrid 1994

JOUTSEN, Matti

The role of the victim of Crime in European Criminal Justice Systems, Helsinki 1987

JUECES PARA LA DEMOCRACIA

"Defensa de los intereses difusos", Separata de $J D \mathrm{n}^{0} 12, \mathrm{I} / 1991$, Materiales del VI Congreso de Jueces para la Democracia, Logroño 20-22 junio 1991, pp. XXIII y ss.

JUSTICE

A public defender, Londres 1987

KAISER, Michael

Die Stellung des Verletzten im Strafverfahren, Friburgo de Brisgovia 1992

KALSBACH

Die gerichtliche Nachprüfung von Maßnahmen der Staatsanwaltschaft im Strafverfahren, 1967

KAUER, R.

"Zur Rechtsstellung des Subsidiaranklägers", Juristische Blätter (Austria) 74 (1952), pp. 456 y ss.

KAUFMANN, Arthur y HASSEMER, Winfried

El pensamiento jurídico contemporáneo. Edición española a cargo de ROBLES MORCHÓN, Gregorio. Traducción de la $5^{\text {a }}$ ed., Debate, Octubre 1992

KAUFMANN, Hilde

Strafanspruch, Strafklagerecht, Gotinga 1968

KENT, Jorge

"El querellante: su exclusión del proceso penal como ineluctable sinónimo del apogeo de la impunidad" Revista Jurídica Argentina La Ley, 1991-D, pp. 936 y ss.

KERNER, Hans Jürgen

"Die Wiedereinsetztung des Opfers als Subjekt des (Straf-) Rechts", en JANSEN, H. y KERNER, H.J. (Editores), Verbrechensopfer, Sozialarbeit und Justiz, Bonn 1985

KING, P.J.R.

"Prosecution Associations and their Impact in Eighteen-Century Essex", en HAY, Douglas y SNYDER, Francis (editores), Policing and Prosecution in Britain 1750-1850, pp. 171-207, Clarendon Press, Oxford 1989

KIRCHHEIMER, Otto

Political Justice. The Use of Legal Procedure for Political Ends. Princeton University Press. Princeton, New Jersey 1961

KIRSTGEN, Johennes Rudolf 
Das Klageerzwingungsverfahren, Bonn 1986

KLEINHEYER, G.

"Tradition und Reform in der Constitutio Criminalis Carolina", en LANDAU, P.; SCHROEDER, F.C., Strafrecht, Strafprozeß und Rezeption, Francfort 1984

KLEINKNECHT / MEYER

Strafprozeßordnung, $38^{\mathrm{a}}$ ed.

KLEINSCHRODT, Gallus Alons

"Ueber den Werth des Anklage und Untersuchungsprozesses gegen einander, nebst Vorschlägen zur Verbesserung des peinliches prozesses im Allgemeinem”, Archiv des Kriminalrechts, (1800) T. II, 4, pp. 7 y ss.

$\mathrm{KOCH}$, Harald

Prozeßführung im öffentlichen Interesse. Rechtsvergleichende Entwicklungsbedingungen und Alternativen objektiver Rechtsdurchsetzung, Alfred Metzner, Francfort 1983

KOHLHAAS, Max

"Das Klageerzwingungverfahren in seiner neuen form", GA 1954, pp. 129 y ss.

KOROSEC, V.

"Le Code de Hammurabi et les droits antérieurs", Revue Internationale des droits de l'Antiquité, T. VIII (1961)

KUHNMUNCH, Olivier

"La defense des interets collectifs et l'eclatament des poursuites", Travaux $d u$ XXIII Congrès de l'Association française de criminologie, organisé par la'Association française de criminologie et par le Centre de recherches de politique criminelle (París, 17 y 18 de octubre de 1986). Publicado en Archives de Politique criminelle $\mathrm{n}^{\mathrm{o}}$ 10, 1988, pp. 35-50

KURLAND, Philip y WATERS, D.W.M.

"Public Prosecutions in England 1854-79: an Essay in English Legislative History", Duke Law Journal 1959, pp. 493-562

KÜHNE, Hans-Heiner

"Die tatsächliche Bedeutung von Opferrechten in der Deutschen Strafprozeßordnung", Monatschrift für Kriminologie und Strafrechtsreform, 1986, pp. 98 y ss.

LALLA, Paolo de

Il Concetto legislativo di azione penale, Jovene, Nápoles 1966

LANDI, Pasquale

La tutela processuale dell'ambiente (art. 18 dela llege 8 luglio 1986, n. 349), Padua 1991

LANDROVE DÍAZ, Gerardo

Victimología, Tirant lo Blanch, Valencia 1992

LARGUIER, J.

-“L'action publique menaceé. A propos de l'action civile des associations devant les jurisdictions reppresives", Dalloz 1958, Chron. VI, p. 29

-Action individuelle et interêt général (Quelques réflexions sur le juge pénal et l'action civile), París 1964

LASSO GAITE, Juan Francisco 
Crónica de la Codificación española. 3. Procedimiento Penal, Ministerio de Justicia; Comisión General de Codificación, Madrid 1975

LATTE, K.

"Beiträge zum griechischen Strafrecht, I: Die Entstehung der Popularklagen", en Zur griechischen Rechtsgeschichte, BERNEKER, E. (Director), Darmstadt 1968, pp. 263-282

LAW REFORM COMMISION OF CANADA

"Private Prosecutions / Private Poursuits", Law Reform Commision of Canada. Working Paper 52, Ottawa 1986

LEIPOLD, D.

"Die Verbandsklagen zum Schutz allgemeiner und breitgestreuter Interessen in der Bundesrepublik Deutschland", en Effektivität des Rechtschutzes und verfassungsmäßige Ordnung. Die deutschen Landesberichte zum VII. Internationalen Kongreß für Prozeßrecht in Würzburg 1983, GILLES, P. (Editor), pp. 57 y ss.

LEMO, Elio

L'accusa suppletiva nel dibattimento penale, Giuffrè, Milán 1972

LEONE, Giovanni

-"Linee generali di una reforma del proceso penale", Riv. Dir. Proc. 1948, pp. 219 y ss.

-Voz “Azione penale”, Enciclopedia del Diritto, pp. 851-860

LEY, Auguste

"La vengeance", Revue de Droit Pénal et de Criminologie, 1937

LEZÓN, M.

"El art. 103 de la LECrim", Revista de los Tribunales y de la Legislación Universal, $1896, \mathrm{n}^{\circ} 7$, pp. 99 y ss

LIDSTONE, Ken W. / HOGG, Rusell / SUTCLIFFE, Frank

Prosecutions by private individuals and non-police agencies. Royal Commision on Criminal Procedure. Research Study $n^{\circ}$ 10, Londres 1980

LIEBENHETZE, August

"Opportunitätsprinzip und Legalitätsprinzip in England”, Dissertation, Marburg 1971

LIESA, I.

"Sobre el concepto de ofendido por el delito", $R G L J \mathrm{n}^{\circ} 181$ (1947), pp. 809 y ss.

LISZT, Franz von

-“Die Privatklage in Österreich", Gerichtssaal, no 29 (1877), pp. 187 y ss.

-"Das Prinzip der Strafverfolgung nach dem österreichische Strafgesetzentwurfe", Strafrechtliche Aufsätze und Vorträge, T. I, Berlín 1905, pp. 35 y ss.

-"Mitteilungen der internationalen Kriminalistische Vereinigung", T. 16, Berlín 1909

LOBE, von

-Reform des Strafverfahrens. Zweite Sitzung der Dritten Abteilung. 35. Deutsche Juristentag 1928/29, Berlín, Leipzig 1928

-“Zur Reform des Strafprozesses", Gerichtssaal 1928

LÓPEZ BARJA DE QUIROGA, Jacobo 
"Recursos contra las decisiones del Juez de Vigilancia Penitenciaria", PJ n ${ }^{\mathbf{0}}$ especial III, pp. 149-163

LÓPEZ-FRAGOSO ALVAREZ, Tomás

"El Derecho de acción como a derecho a la tutela judicial efectiva", Anales de la

Facultad de Derecho (Universidad de la Laguna), no 11, 1991, pp. 49-64

LÓPEZ-MORENO, S.

Principios Fundamentales del Procedimiento Civil y Criminal, T. II, Madrid 1901

LORÁN GIMENO

“Acción pública y acción popular”, Seminarios 1984 de la Asociación de Censores

Letrados y Contables del Tribunal de Cuentas y Servicio de estudios del mismo, Madrid 1985

LORCA NAVARRETE, Antonio María

-Comentarios a la Ley Procesal Militar, Instituto Vasco de Derecho Procesal, San Sebastián 1990

-El Proceso español del menor, Dikynson, Madrid 1993

LOZANO Y CORBI, Enrique

La legitimación popular en el proceso romano clásico, Barcelona 1982

LOZANO-HIGUERO PINTO, Manuel

-La protección procesal de los intereses difusos, UNED, Madrid, 1983

-"Notas sobre la participación procesal y su proyección en las formas alternativas de justicia", RUDProc, $\mathrm{n}^{\mathrm{o}}$ 0, 1988, pp. 37-56

-“Cambio social, socialización y privatización de la Justicia”, Justicia 88, III, pp. $565-580$

-"De nuevo sobre la tutela de los intereses difusos (en especial del patrimonio histórico-artístico"), Justicia 96, II, pp. 287-318

LUCAS VERDÚ, P.

"La Justicia emana del Pueblo y se administra en nombre del Rey", en el volumen colectivo El Poder Judicial, Dirección General de lo Contencioso del Estado, T. II, pp. 1756 y ss.

LUCCHINI, Luigi

"Azione penale (Appunti di reforma legislativa)", Rivista Penale di dottrina, Legislazione e Giurisprudenza, vol. XLIX, 1899

LUÉ, G.B.

Voz "Azione Popolare", Enciclopedia Giuridica Italiana, vol. I parte V, Milán 1904, pp. 1390-1467

LUGO, Andrea

Voz "Azioni popolare (in generale)", Enciclopedia del Diritto (Giuffrè), T. IV, 1959

LÖWE, E. / ROSENBERG, W / RIEß, P. (Editores)

Die Strafprozeßordnung und das Gerichtsverfassungsgesetz Großkommentar, 24 ${ }^{\text {a }}$ ed., Berlín-Nueva York 1989

MAGALDI PATERNOSTRO, M ${ }^{\mathrm{a}}$ José

"Aspectos esenciales de la acusación y denuncia falsas", ADPCP 1987, I, pp. $37-$ 72

MAGALDI PATERNOSTRO, Ma José; GARCÍA ARÁN, M. 
"Los delitos contra la Administración de Justicia ante la reforma penal", Documentación Jurídica, no 37-40, pp. 1118 y ss.

MAGALHÃES, J.

“Ambiente de perdição, Acções de Salvação: A Acção Popular Ecológica e o Direito às Compensações por Prejuízio Ambiental no Horizonte Português de 1992", Revista de Direito Público, no 8, 1990, pp. 9 y ss.

MAITLAND, F.W.

Justice and Police, MacMillan, Londres 1885

MAIWALD, Manfred

"Die Beteiligung des Verletzten am Strafverfahren”, GA, 1970, pp. 33 y ss.

MAIWALD, Manfred; IPPOLITI, A.

"Eine neue StPO für Italien", $J Z$, n $^{\circ} 19,1989$, pp. 876 y ss.

MAJADA, Arturo

Práctica procesal penal. Procedimiento Abreviado, Bosch, Barcelona 1990

MANDUCA, F.

La procedure penale e la sua evoluzione scientifica, Nápoles 1988. Se ha manejado la traducción de PINTOS y PINTOS, Ángel, El procedimiento penaly su desarrollo científico, La España Moderna, Madrid s.f.

MANNHEIM

"Die Durchbrechung des Legalitätsgrundsatzes", Juristische Wochenschrift, LIII, 1924

MANSFIELD, Graham; PEAY, Jill

The Director of Public Prosecution. Principles and practices for the Crown Prosecutor, Tavistock, Londres 1987

MANTINI, Pierluigi; D'ELLANNO, Paolo; VERARDI, Carlo; GIAMPIETRO, Franco Associazioni ecologiste e tutela giurisdizionale dell'ambiente. Profili amministrativi, civili e penali, Rímini 1990

MANTOVANI, D.

Il Problema d'origine dell'accusa popolare, Padua 1989

MANZINI, Vincenzo

Diritto Processuale Penale Italiano, Turín 1952. Traducción de SENTÍS MELENDO, Santiago y AYERRA REDÍN, Marino, Tratado de Derecho Procesal Penal, Buenos Aires 1951

MARCHENA GÓMEZ, Manuel

-El Ministerio Fiscal: su pasado y su futuro, Marcial Pons, Madrid 1992

-“El Fiscal y la Ley del Jurado", en El Tribunal del Jurado, VARELA CASTRO, L. (Director), CGPJ, Madrid 1996.

MARCONI, G.

"La tutela degli interessi collettivi in ambito penale", Riv. ital. dir. proc. penale 1979, III, pp. 1052 y ss.

\section{MARGHIERI}

"Le azioni popolari. Se, in quali limiti e con quale cautela possa, in relazione ad alcune categorie di reati, ammetersi sussidiariamente l'azione penale civica, ossia popolare". Relazione al terzo Congresso giuridico nazionale. Archivio Giuridico, XXXIII, 317, Florencia 1891 
MARQUARDT, Hanno

Die Entwicklung des Legalitätsprinzip. Ein historisch-empirischer Beitragung zur Gesetzgebung, Mannheim 1982

MARTIN, Elizabeth A. (Editor)

A concise Dictionary of Law, Oxford Reference, 2a ed., Oxford New York 1992 MARTÍN BERNAL, José Manuel

"La acción penal y la tutela de los grupos", Actualidad Penal n' 16, 24 abril 1988, pp. 809-820, ref. 296

MARTÍN OSTOS, José de los Santos

-"Bases para un borrador de anteproyecto de ley penal y procesal del menor", Justicia 91, I, pp. 159-166

-"El nuevo proceso de menores. Comentarios a la LO 4/1992 de 5 de junio", La Ley 1994, T. 1, pp. 1142-1153

MARTÍNEZ, Manuel Sylvestre

Libreria de Jueces, utilisima y universal..., T. I, 4a impresión, Madrid 1769

MARTÍNEZ ARRIETA, Andrés

"La víctima en el proceso penal", Actualidad Penal 1990, IV, V, marg. 41 y 49

MARTÍNEZ DEL CAMPO, Eduardo

Notas al Libro $1^{\circ}$ de la Ley de Enjuiciamiento Criminal, Madrid 1885

MARTÍNEZ PEREDA, José Manuel

El proceso por delito privado, Bosch, Barcelona 1976

MARTÍNEZ VAL

Montero Ríos y su época, Madrid 1980

MASCAREÑAS, Carlos E.

Voz "Acción Penal”, Nueva Enciclopedia Jurídica. T. II, Barcelona 1950

MASCHKE

"Zur Theorie und Geschichte der Popularklagen", Zeitschrift der Savigny-Stiftung,

Romanistische Abteilung, 6 (1885), pp. 226-259

MASSA, Carlo

Voz "Azione popolare (diritto penale)", Enciclopedia del Diritto, T. IV,

CALASSO, F. (Director), Giuffrè, 1959

MASUCCI

Voz "Azione penale", Enciclopedia del Diritto Penale Italiano, PESSINA (Editor), Milán 1906

MEDINA, Justo G.

"Eliminación del querellante particular en los delitos de acción pública", RDProc (Arg.) 1949, I, pp. 196-199

MERLE, Pierre

Droit de Pursuite des particuliers (en matière d'Infraction à la loi pénale), Toulouse 1906

MEYER, Jürgen

Dialektik im Strafprozeß, Tubinga 1965

MEYER, Maria-Katharina

Zur Rechtsnatur und Funktion des Strafantrages, Decker\&Müller, Heidelberg 1984 
MEYER / GOß NER

Comentarios al art. 172 StPO en LÖWE-ROSENBERG, Kommentar zur StPO, $23^{\mathrm{a}}$ ed.

MIELE, Carmine

La polizia privata. Le guardie particolari giurate e gli istituti di vigilanza e di investigazione privata. L'investigatore privato nel nuovo processo penale, Turín 1990

MILLÁN GARRIDO

"El delito de acusación y denuncia falsas", Información Jurídica, 317, abril-junio 1973 , pp. 16 y ss.

MIRALLES, Melchor; ARQUÉS, Ricardo

Amedo. El Estado contra ETA, Plaza\&Janés / Cambio 16, Barcelona 1989

MITTERMAIER, Carl Joseph Anton

Das deutsche Strafverfahren, Heidelberg 1839 (T. I), 1840 (T. II)

MITTERMAIER

"Legalitätsprinzip und Ausdehnung der Privatklage", en Reform des Strafprozesses. Kritische Bemerkungen der von der Kommission für die Reform des Strafprozeßes gemachtenVorschläge, ASCHROTT, P.F. (Editor), Berlín 1906

MOHRMANN, U.

Die geschellschaftliche Beteiligung an der Strafrechtspflege in der DDR. Ein Beispiel für die Erziehungsfunktion eines sozialistischen Staates, Colonia 1972

MOLINARI, F.

"Pubblico ministerio e azione penale nell'ordinamento francese", en Pubblico Ministero e accusa penale, CONSO, G. (Director), Bolonia 1979, pp. 213 y ss.

MOMMSEN, Theodor

-Römisches Strafrecht, 1899. Traducción española de DORADO, P., Madrid, s.f. -“Die Popularklagen”, publicado en Gesammelte Schriften, Juristische Schriften I, T. 3, Berlín 1907. Reimpresión Berlín-Dublín-Zürich 1965

MONER, Joaquín Manuel

"Diferencias y semejanzas entre la acción de querella, la de denuncia y la de los actores civiles establecidas por la Ley de Enjuiciamiento Criminal", RGLJ T. 48 (1876), pp. 56 y ss.

MONTERO AROCA, Juan

-"Las costas de la acusación particular en los procesos de urgencia", Revista de Derecho Judicial 1973, no 54, pp. 15-46 y en Estudios de Derecho Procesal, Barcelona 1981, pp. 571-599

-“El principio acusatorio. Un intento de aclaración conceptual”, Justicia 92, IV, pp. $775-788$

-La Legitimación en el Proceso Civil (Intento de aclarar un concepto que resulta más confuso cuanto más se escribe sobre él), Civitas, Madrid 1994

-“La garantía procesal penal y el principio acusatorio", La Ley 1994, I, pp. 973984

-“Los privilegios en el proceso penal”, $P J \mathrm{n}^{\circ} 39$, pp. 253-286

MONTERO AROCA, Juan; GÓMEZ COLOMER, Juan Luis; ORTELLS RAMOS, Manuel; MONTÓN REDONDO, Alberto 


\section{Derecho Jurisdiccional. Proceso Penal (T. III), Bosch, Barcelona 1996 \\ MONTESQUIEU \\ Del espíritu de las leyes, Libro VI, cap. VIII, Res Publica. Clásicos del pensamiento político y social. Tecnos, Madrid 1972 \\ MONZÓN Y ARAGÓN, Eduardo \\ Cincuenta años de Doctrina de la Fiscalía del Tribunal Supremo. Memorias 1926-1975}

MOOS, S. R. y TOMBS, J.

Prosecution in the public interest, Edimburgo 1982

MORENILLA RODRIGUEZ, José María (Coordinador)

"La Justicia Penal y la política criminal en el Consejo de Europa", Documentación Jurídica $\mathrm{n}^{\circ}$ 56, T. XIV, octubre-diciembre 1987

MORENO CATENA, Víctor

-“La justicia penal y su reforma”, Justicia 88, I, pp. 313-318

-Tema 9 ("Las partes procesales") en Derecho Procesal Penal, Colex, Madrid, 1996 (con GIMENO SENDRA, Vicente y CORTÉS DOMÍNGUEZ, Valentín), pp. 157-203

MORENO VERDEJO, Jaime

"La conformidad en el procedimiento abreviado" en El Juicio Oral en el Proceso Penal (con especial referencia al Procedimiento Abreviado, MORENO VERDEJO, Jaime; MARCHENA GÓMEZ, Manuel; ESCOBAR JIMÉNEZ, Rafael; DÍAZ CABIALE, José Antonio; MORAL GARCÍA, Antonio del; SERRANO BUTRAGUEÑO, Ignacio; ANDRÉS IBÁÑEZ, Perfecto, Comares, Granada 1995

MORETTI, Barbara

"Enti esponenziali: costituzione di parte civile o intervento ex art. 91 ss nel nuovo CPP”, Riv. Ital. dir. proc. penale 1994, pp. 1532 y ss.

MUERZA ESPARZA, Julio

"El delito de acusación y denuncia falsa (art. 325 CP) en la jurisprudencia del TS", La Ley, 31 de octubre de 1986, vol. IV (1986), pp. 1041 y ss.

MÜLLER, E.

“Der Grundsatz der Waffengleichheit im Strafverfahren”, NJW 1976, pp. 1063 y SS.

MÜLLER/SAX/PAULUS

Kommentar zur StPO, Francfort 1988

MUÑOZ ROJAS, Tomás

-"Las cuestiones previas en el proceso penal", RDProc $1^{a}$ época (continuación), 1964, I-II, pp. 95-134

-“En torno al acusador particular en el proceso penal español”, RDProc (Ibam) 1973, pp. 105-157

MUÑOZ SABATÉ, Luis

"La ineficacia de las reclamaciones de cantidad en España", RJCat. 1972, n 1

MURGA, José Luis

-Derecho Romano Clásico. T. II (el proceso), Zaragoza 1980

-"Las acciones populares en la «Lex Coloniae Genetivae Iuliae»", Seminarios 


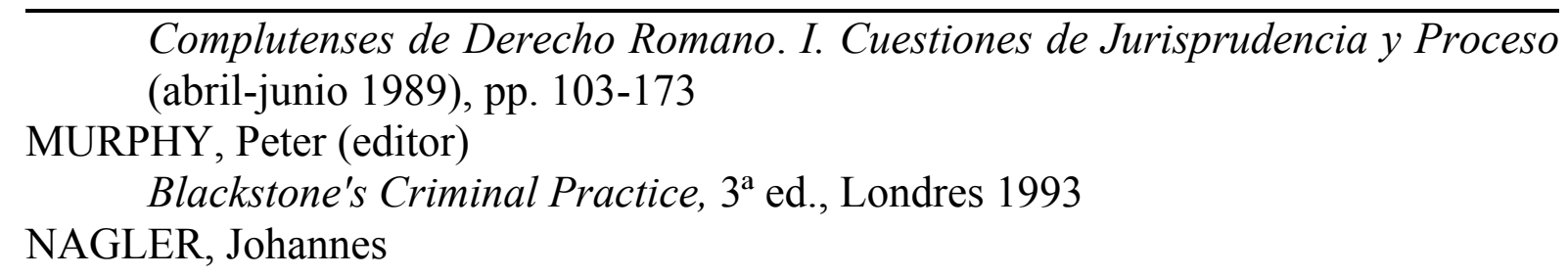

"Die Protokolle der Strafprozeßkommision unter Berücksichtigung ihres Einflusses auf den Entwurf zur StPO und die geplante Novelle zum GVG', Der Gerichtssaal 73 (1909)

NAVAJAS LAPORTE, A.

"Momento preclusivo para la comparacencia del perjudicado en el proceso penal. Una reinterpretación del art. 110 LECrim. de acuerdo con el 24.1 CE", La Ley, no 908, 3 de abril 1984

NAVARRO, Guillermo Rafael

La Querella, Pensamiento Jurídico Editora, Buenos Aires 1981

NEUMANN, Ulfrid

"Die Stellung des Opfers im Strafrecht", en Strafrechtspolitik. Bedingungen der Strafrechtsreform, HASSEMER, Winfried (Editor), Francfort, Berna, Nueva York 1987

NIETO, Alejandro

-'La discutible supervivencia del interés directo", $R E D A 12$, pp. 39 y ss.

-Derecho Administrativo Sancionador, $2^{\mathrm{a}}$ ed., Madrid 1994

NIETO MARTÍN, Adán

Fraudes comunitarios. Derecho Penal Económico Europeo. Barcelona 1996

NOSENGO, Serafino

Comentario a los arts. 91 y ss. del CPPItal. en CHIAVARIO, M., Commento al nuovo Codice di Procedura Penale, vol. I, UTET, Turín 1989

NOURRISON, P.

-De la participation des particuliers à la poursuite des crimes et délits, París 1894, y "Sur la poursuite criminelle par les associations", en Bulletin de la Societé de législation comparée, XXXIV

-L'association contra le crimen, París 1901

ODERIGO, Mario A.

Derecho Procesal Penal. Tomos I y II, 2a ed., Depalma, Buenos Aires 1980

OETKER (von)

-“Nebenklage und Adhäsionsprozess", Gerichtssaal 105 (1935)

-“Legalitäts, Opportunitäts, Klageerzwingungsverfahren”, Gerichtssaal 105 (1935), pp. 374 y ss

OETTINGER, $\mathrm{H}$.

Anklagetätigkeit des Privaten im Strafprozeß unter besonderer Berücksichtigung der Regelung im Basler Recht, Berna 1914

OKAGBUE, Isabella

Private Prosecution in Nigeria: recent developments and some proposals, Lagos 1991

OLIVA SANTOS, Andrés de la

-Sobre el Derecho a la Tutela Jurisdiccional. La persona ante la Administración 
de Justicia: derechos básicos, Bosch, Barcelona 1980

-Jueces imparciales, fiscales "investigadores" y nueva reforma para la vieja crisis de la Justicia Penal, PPU, Barcelona 1988

-"Disponibilidad del objeto, conformidad del imputado y vinculación del Tribunal a las pretensiones de las partes", $R G D$ octubre-noviembre 1992, pp. 9853-9903

OLIVA SANTOS, Andrés de la; ARAGONESES MARTÍNEZ, Sara; HINOJOSA

SEGOVIA, Rafael; MUERZA ESPARZA, Julio; TOMÉ GARCÍA, José Antonio

Derecho Procesal Penal, Editorial Centro de Estudios Ramón Areces, Madrid 1993

OLIVAS, Enrique

Problemas de legitimación en el Estado Social, Editorial Trotta, Madrid 1991

OLIVERA I.

"Problemas del procedimiento de urgencia: las costas del querellante particular o

OPPENHEIM, L. actor civil", RJCat. 1961, pp. 817 y ss.

OPPET, O.

Die Nebenklage des deutschen Strafprozesses, Breslau 1889

"Die Popularklage der Berner Handfeste. Ein Beitrag zur Geschichte der Popularstrafklage im deutschen Recht", Zeitschcrift für Schweizer Recht, T. VII, (1894)

ORESTANO, R.,

-Voz “Azione (in generale)”, Enciclopedia del Diritto, Milán 1959, pp. 853 y ss.

-Azione, diritti soggettivi, persone giuridiche, Bolonia 1978

ORTELLS RAMOS, Manuel

-"El nuevo proceso penal abreviado: aspectos fundamentales", Justicia 89, III, pp.

545-568. También en El proceso penal abreviado (nueve estudios), Granada 1997, pp. $1-24$

-"Las partes no oficiales en el proceso penal abreviado", La Ley, $\mathrm{n}^{\circ} 3983,27$ de febrero de 1996, pp. 1-7. También en El proceso penal abreviado (nueve estudios), pp. 79-102

ORTIZ DE ZÚÑIGA, Manuel

Práctica General Forense, Madrid 1874

OSTENDORF, Heribert

"Das öffentliche Klageerzwingungsverfahren: ein notwendiges Institut zur Kontrolle der Staatsanwaltschaft", Recht und Politik 1980, pp. 200 y ss

OSTLER, Friedrich

Das Klageerzwingungsverfahren, Strafrechtliche Abhandlungen 287, Breslau 1931

PAALZOW

Zur Lehre von der römischen Popularklagen, Berlín 1889

PACHECO, J.F.

Estudios de derecho penal, Madrid 1887

PASTOR LÓPEZ, Miguel

-El proceso penal inglés (estudio comparativo de sus directrices fundamentales), RDProc. 1967 vol. I pp.67-126 y vol. II pp. 43 y ss.

-El proceso de persecución (análisis del concepto, naturaleza y específicas 
funciones de la instrucción criminal). Secretariado de Publicaciones. Universidad de Valencia, Valencia 1979

PECES-BARBA MARTÍNEZ, Gregorio Curso de Derechos Fundamentales. Teoría General, Madrid 1995

PEDRAZ PENALVA, Ernesto

-Las medidas cautelares reales en el proceso penal ordinario español, Trivium, Madrid 1985

-"De la Jurisdicción en la Teoría de la división de poderes de Monstesquieu", en Constitución, Jurisdicción y Proceso, Akal, Madrid 1990, pp. 9-42

-"Sobre el «poder» judicial y la ley orgánica del poder judicial”, en Constitución, Jurisdicción y Proceso, op. cit. pp. 141-202

-"Notas sobre publicidad y proceso", en Constitución, Jurisdicción y Proceso, op. cit. pp. 203-226

-"Principio de proporcionalidad y principio de oportunidad", en Constitución, Jurisdicción y Proceso, op. cit. pp. 313-376

-Los privilegios de las Administraciones públicas en el proceso civil, Civitas, Madrid 1993

-“El jurado como vía de participación popular", La Ley 1994, T. II, pp. 1006-1014 y en Política criminal y nuevo Derecho Penal. Libro Homenaje a Claus Roxin, SILVA SÁNCHEZ, José María (Editor), Bosch, Barcelona 1997, pp. 425-438

-"Reflexiones sobre la prueba pericial en los procesos penal y civil. Particular consideración de la pericia psiquiátrica", en Salud mental y Justicia. Problemática civil y penal. Internamientos en Derecho civil y penal. La peligrosidad, PÉREZ GÓMEZ, Santiago (Director), Cuadernos de Derecho Judicial, CGPJ, Madrid 1994, pp. 389-514

-"Notas sobre el Jurado que viene", Revista del Ilustre Colegio de Abogados del Señorío de Vizcaya, $2^{\mathrm{a}}$ época, ${ }^{\mathrm{o}}$ 1, enero-marzo 1996

-"Del Consejo General del Poder Judicial y de la selección de sus miembros", $L a$ Ley $\mathrm{n}^{\circ}$ 4018, 18 de abril de 1996, pp. 1-12

-"Del Consejo General del Poder Judicial y de la selección de sus miembros", Proemio a El Gobierno de la Justicia. El Consejo General del Poder Judicial, PEDRAZ PENALVA, E., (Coordinador), Valladolid 1996

-“El objeto del proceso civil", en El objeto del proceso civil, MARÍN CASTÁN, Francisco (Director), Cuadernos de Derecho Judicial, Escuela Judicial / CGPJ, Madrid 1996, pp. 13-48

-"Publicidad y derecho al debido proceso. Publicidad y derecho de acceso a la información contenida en los ficheros judiciales", RGD n 631, abril 1997, pp. 3889-3927. Contenido también en La criminalidad organizada ante la justicia, GUTIÉRREZ ALVIZ CONRADI, Faustino (Director), Sevilla 1996, pp. 157-190 PÉREZ GORDO, Alfonso

-La suspensión del juicio ejecutivo, Barcelona 1971

-Prejudicialidad penal y constitucional en el proceso civil, Barcelona 1982

PÉREZ DE GREGORIO, J.J.

"Las asociaciones ecologistas y de defensa ambiental como colaboradoras del Poder Judicial" en La protección del Medio Ambiente en España, VERCHER, A. 
y PERIS, pp. 209 y ss.

PÉREZ HERNÁNDEZ, E.

"La constitucionalidad de las pruebas aportadas por los detectives privados", $P J \mathrm{n}^{\circ}$ 35, septiembre 1994

PÉREZ LUÑO, Antonio Enrique

Derechos Humanos, Estado de Derecho y Constitución, Tecnos, $5^{\mathrm{a}}$ ed., Madrid 1995

PÉREZ MORENO, Alfonso

"La acción popular en materia de urbanismo", Revista de Derecho Urbanístico, $\mathrm{n}^{\circ}$ 15, pp. 84-85

PERIS SIERRA, J.M.

"Situación jurídico procesal y economía de la víctima en España", Revista Jurídica de Castilla-La Mancha $\mathrm{n}^{\mathrm{o}}$ 13, diciembre 1991, pp. 45 y ss.

PETERS, Karl

-“Sozialadäquanz und Legalitätsprinzip”, Festschrift für Hans Welzel zum 70. Geburtstag, 1974, pp. 415 y ss.

-Strafprozeß. Ein Lehrbuch, $4^{\mathrm{a}}$ ed., Heidelberg 1985

PFEIFFER, Gerd (editor)

Karlsruher Kommentar zur StPO und GVG, C.H. Beck'sche, $3^{\text {a }}$ ed. Munich 1993 PFENNINGER, Hans Felix

-"Die Staatsbürgerliche Anklage”, Schweizerische Juristenzeitung T. 13, 1916 / 1917 pp. 291 y ss.

-“Der öffentliche Ankläger im schweizerischen Strafverfahren”, Schweizerische Juristenzeitung 162, pp. 96 y ss.; 113 y ss.

-“Die Popularstrafanklage”, Schweizerische Zeitschrift für Strafrecht 29 (1926), pp. 259 y ss.

PHILIPS, David

"Good Men to Associate and Bad Men to Conspire: Associations for the Prosecution of Felons in England, 1760-1860", en HAY, Douglas y SNYDER, Francis (editores), Policing and Prosecution in Britain 1750-1850, Clarendon Press, Oxford 1989, pp. 113-170

PIERRE, Christian

"Rapport de Synthese de Travaux du XXIII Congrès de l'Association française de criminologie, organisé par la'Association française de criminologie et par le Centre de recherches de politique criminelle" (París, 17 y 18 de octubre de 1986). Archives de Politique Criminelle no 10, 1988, pp. 19-34.

PIQUÉ VIDAL, Juan; RIFÁ SOLER, José Ma; SAURA LLUVIA, Luis; VALLS GOMBAU, José F.

El Proceso Penal práctico. Comentarios, Jurisprudencia, Formularios, La Ley, $3^{\text {a }}$ ed. Madrid 1997

PLATZGUMMER, W.

Grundzüge des österreichischen Strafverfahrens, $6^{\mathrm{a}}$ ed., Viena 1996

PORTERO GARCIA, Luis; REIG REIG, José Vicente; MARCHENA GOMEZ, Manuel Comentarios a la Reforma procesal penal de la LO 7/1988 (Procedimiento Abreviado), 2a ed., La casa del Abogado, Bilbao 1989 
PORTILLA CONTRERAS, G.

"Principio de intervención mínima y bienes jurídicos colectivos", $C P C$ n ${ }^{\circ} 39,1989$ y en Derecho Penal y Criminología. Revista del Instituto de Ciencias Penales y Criminológicas de la Universidad Externado de Colombia, $\mathrm{n}^{\mathrm{o}} 43$, enero-abril 1991, pp. 33 y ss.

POSTIGLIONI, Amadeo

"L'azione civile in difesa dell'ambiente", Rivista trimestrale di diritto publico, 1987 pp. 303 y ss.

POULPIQUET, $\mathrm{J}$.

"Le droit de mettre en mouvement l'action publique: conséquence de l'action civile, ou droit autonome", Revue de Science Criminelle et de Droit Pénale Comparé, 1975 , pp. 37 y ss.

PRIETO-CASTRO FERRÁNDIZ, Leonardo

"La acción penal y la querella", Actas del I Congreso Nacional de Derecho

Procesal, Madrid 1950. Incluido en Trabajos y orientaciones de Derecho Procesal, pp. 608-612, Madrid 1964

PRIETO-CASTRO FERRÁNDIZ, Leonardo y GUTIÉRREZ DE CABIEDES, Eduardo Derecho Procesal Penal, $3^{\mathrm{a}}$ ed., Tecnos, Madrid 1987

PRINZ, H.-J.

"Die Nebenklage -ein überholtes Rechtsnstitut", ZRP 1971, pp. 128 y ss.

PUENTE SEGURA, Leopoldo

La conformidad en el proceso penal español, Colex, Madrid 1994

QUINTANO RIPOLLÉS, Antonio

"Naturaleza sustantiva y procesal de la querella privada", RDProc 1952, pp. 117 y sS.

QUINTERO OLIVARES, Gonzalo

"Notas sobre la acusación falsa", RJCat. 1976, pp. 819-847

RADZINOWICZ, Leon

A history of English Criminal Law and its Administration from 1750, Stevens \& Son, Londres 1968 (vol. 4)

RANIERI, S.

L'azione penale. Contributo alla teoria dell'azione nel diritto processuale penale, Milán 1928

RASSAT, Michèle-Laure

Procédure pénale, $2^{\mathrm{a}}$ ed., París 1995

REBOLLO PUIG, Manuel

"Interesados y denunciantes en el procedimiento administrativo sancionador", $P J$

REDENTI, E. $n^{\circ} 29$, marzo 1993, pp. 59-78

Diritto Processule Civile, T. I, Milán 1949

REHBINDER, E.

“Argumente für die Verbandsklage im Umweltrecht", ZRP 1976, 7, pp. 157 y ss.

REICHS-JUSTIZAMTE (Editor)

Protokolle der Kommission für die Reform des Strafprozesses, T. I, Berlín 1905 RENTON / BRONN 
Criminal Procedure according to the law of Scotland, 1994

RESINA, Pedro

La legitimación activa de la mujer en el proceso criminal romano, Ediciones clásicas, Madrid 1996

REUS, E.

Ley de Enjuiciamiento Criminal concordada y anotada extensamente por la redacción de la Revista de Legislación y Jurisprudencia, Madrid 1883

RIEHLE, Gerhard

Die Rechtsstaatliche Bedeutung der Staatsanwaltschaft unter besonderer Berücksichtigung ihrer Rolle in der nationalsozialistischen Zeit, Francfort 1985

RIEß, Peter

-“Die Zukunft des Legalitätsprinzip”, NStZ 1981, pp. 2-10

-"Die Rechtsstellung der Verletzten im Strafverfahren. Gutachten C zum 55.

Deutschen Juristentag", Verhandlungen des 55. DJT, T. I. Munich 1984

RIVELLO, Pier Paolo

-"Sulla legitimazione delle organizzazioni sindacali a costituirse parte civile in procedimenti di omicidio o lesioi colpose con violazione di norme poste a tutela della salute dei lavoratori", Rivista italiana di diritto e procedura penale 1981, 4, pp. 1558-1571

"Riflessioni sul ruolo ricoperto in ambito processuale dalla persona offesa dal reato e dagli enti esponenziali", Riv. Ital. dir. e proc. penale, 1992, pp. 608 y ss.

ROBERT, Philippe

"L'Action des Groupements, des estraegies evolutives", Travaux du XXIII Congrès de l'Association française de criminologie, organisé par la'Association française de criminologie et par le Centre de recherches de politique criminelle (París, 17 y 18 de octubre de 1986), Archives de Politique criminelle nº 10, 1988. pp. 59-76.

ROBLES GARZÓN, Juan A.

"El acusador privado", RDProc 1978 pp. 533-571

ROCK, M. Paul

"La opinión pública y la legislación penal" en La Justicia Penal y la política criminal en el Consejo de Europa, MORENILLA RODRIGUEZ (Coord.) Documentación Jurídica n ${ }^{\circ}$ 56, T. XIV, oct-dic 1987

RODRÍGUEZ DEVESA, Carlos y MARTÍNEZ AZNAR, Germán

Ley de Enjuiciamiento Criminal: su Jurisprudencia y Doctrina de la Fiscalía, Aranzadi, Pamplona 1990

RODRÍGUEZ GARCÍA, Nicolás

El consenso en el proceso penal español, Bosch, Barcelona 1997

RODRÍGUEZ MARTÍN, Ciriaco

"Consideraciones sobre el capítulo primero, título preliminar de la Ley Provisional de Enjuiciamiento Criminal de 22 de diciembre de 1872”, RGLJ, T. 44 (1874), pp. 297 y ss.

RODRÍGUEZ RAMOS, L.

-“¡Muerte al Juez inquisitivo! Comentario a la STC 186/1990 de 15 de noviembre y algo más", La Ley 1991, T. I, pp. 1089 y ss. 
“¿El Juez de instrucción es inconstitucional?, Actualidad Jurídica Aranzadi, 19 de septiembre de 1996, pp. 1 y ss.

ROJAS CARO, José

Derecho Procesal Penal Militar, Bosch, Barcelona 1991

RÖNNAU, Thomas

Die Absprache im Strafprozess. Eine Untersuchung von Absprachen nach geltendem Strafprozessrecht, Baden-Baden 1990

ROSENBERG, Leo

Tratado de Derecho Procesal Civil, Traducción de ROMERA VEGA, Ángela, Buenos Aires 1955

ROSENBERG, W.

Mitteilungen des Internationalen Kriminalistischen Vereinigung, vol. 16, Berlín 1919

ROSENTHAL, Uriel y HOOGEENBOOM, Bob

"La privatisation et la commercialisation du contrôle de la criminalité: quelques questions fondamentales, eu egard notamment à l'évolution des Pays-Bas", en CONSEJO DE EUROPA, Privatisation du contrôle de la criminalité. Rapports présentés à la 18 Conférence de recherches criminologiques (1988). Etudes relatives à la recherche criminologique. Vol XXVII. pp. 17-44, Estrasburgo 1990 RÖSSNER, Dieter y RÜDIGER, Wulf

Opferbezogene Strafrechtspflege. Leitgedanken und Handlungsvorschläge für Praxis und Gesetzgebung, Bonn 1984

ROXIN, Claus

Strafverfahrensrecht, 22 $2^{\mathrm{a}}$ ed., Munich 1991

ROYAL COMMISSION ON CRIMINAL PROCEDURE

The Investigation and Prosecution of Criminal Offences in England and Wales: the Law and the Procedure, PHILIPS, Cyril (Director), Her Majesty's Stationers Office, Londres 1981

ROZENBERG, Joshua

The Case for the Crown. The Inside Story of the Director of Public Prosecutions, Wellingborough 1987

RUBIANES, Carlos J.

-La querella de acción pública, Ediciones Depalma, Buenos Aires 1964

-Manual de Derecho Procesal Penal. Tomo II. El Proceso penal, Depalma, Buenos Aires 1977

RUIZ VADILLO, Enrique

-"La actuación del Ministerio Fiscal en el proceso penal", $P J, \mathrm{n}^{\circ}$ especial II, Justicia penal, pp. 53-91

-"Delitos de acusación y denuncia falsa" en SERRANO BUTRAGUEÑO, Ignacio, et al., Delitos contra la Administración de Justicia, Granada 1995

RÜPING, Hinrich

"Die Geburt der Staatsanwaltschaft in Deutschland", GA 1992, 4, pp. 147-158

RUPP, Hans Heinrich

"Popularklage in Umweltschutzrecht?", ZRP 1972, pp. 30-35

SABATER TOMÁS, Antonio 
Gamberros, homosexuales, vagos y maleantes, Barcelona 1962

SABATINI, Giuseppe

"Vecchio e nuovo nella teoria dell'azione penale", Archivo penale 1962, pp. 145 y SS.

SÁEZ JIMÉNEZ, Jesús

Enjuiciamiento criminal. Comentarios prácticos a la LECrim referidos a la Ley de urgencia, Santillana, Madrid 1962

SÁEZ JIMÉNEZ, Jesús y LÓPEZ FERNÁNDEZ DE GAMBOA, Epifanio

Compendio de Derecho Procesal civil y penal, tomo 4, vol. I, Santillana, Madrid 1966

SAGARRA I TRÍAS, E.

Los Derechos Fundamentales y Libertades Públicas de los extranjeros en España, Bosch, Barcelona 1991

SALA, Juan

Ilustración del Derecho Real de España, T. II, $3^{\mathrm{a}}$ ed., Madrid 1832

SALOM ESCRIVÁ, J-S.

"La Querella", Justicia 96, II, pp. 387-454

SAMUELS, Alec

"Non-Crown Prosecutions: Prosecutions by Non-Police Agencies and by Private Individuals", Crim. Law Rev. 1986, pp. 33 y ss.

SAN SEGUNDO ARRIBAS, Magín

“Jurisdicción y acción popular", Seminarios 1984 de la Asociación de Censores Letrados y Contables del Tribunal de Cuentas y Servicio de estudios del mismo, pp. 241 y ss., Madrid 1985

SANCHÍS CRESPO, C.

El Ministerio Fiscal y su actuación en el Procedimiento Abreviado. Especial referencia al procedimiento preliminar fiscal, Granada 1995

SANDERMANN, Almut

"Waffengleichheit" im Strafprozeß. Zu den rechtlichen Grundlagen dieses Rechtsinstituts, Colonia 1975

SANTAMARÍA PASTOR, J.A.

Fundamentos de Derecho Administrativo, I, Madrid 1988

SANTOS HIDALGO

Manual de Práctica Forense, $2^{\mathrm{a}}$ ed., Madrid 1853

SAPOSHINIKOW, I.

"Die Beteiligung der geschellschaftlicen Ankläger in den Gerichtsprozessen", en VVAA, Die Öffentlichkeit im Kampf gegen die Kriminalität, pp. 158-164, DDR Verlag, Berlín (Este) 1961

SATTA, S.

-"Ultima tendenze della teoria dell'azione", Rivista Internazionale di filosofia del diritto, 1940

-Voz "Giurisdizione (nozioni generale)" en Enciclopedia del Diritto, XIX, Milán 1970, pp. 218 y ss.

SATTA, S. / PUNZI, C.

Diritto Processuale Civile, Padua 1993 
SAVALL Y DRONDA, P.

"Ejercicio de acciones por el declarado rebelde", RGLJ T. 43 (1873), pp. 56 y ss.

SCHACKY, Susanne von

Das Privatklageverfahren und seine Berechtigung Heute, Dissertation, Munich 1975

SCHÄFER, Karl

Strafprozeßrecht. Eine Einführung, de Gruyter, Berlín, Nueva York 1976

SCHMIDT, Eberhard

-Einführung in die Geschichte der deutschen Strafrechtspflege, $3^{\mathrm{a}}$ ed, Gotinga 1965

-Lehrkommentar zur StPO und zum GVG, T. I, Gotinga 1964, pp. 35 y ss.

SCHMIDT-ERNSTHAUSEN

"Legalitätsprinzip und Ausdehnung der Privatklage", en ASCHROTT, P.F., Reform des Strafprozesses. Kritische Bemerkungen der von der Kommission für die Reform des Strafprozeßes gemachten Vorschläge, Berlín 1906

SCHNAPPER, Bernard

"L'Action penale, le ministere public et les associations: naissance et contestation d'un quasi-monopole (XIX-XX siecles)", Travaux du XXIII Congrès de l'Association française de criminologie, organisé par la'Association française de criminologie et par le Centre de recherches de politique criminelle (París, 17 y 18 de octubre de 1986), Archives de Politique Criminelle no 10, 1988, pp. 19-34

SCHNEIDER, Hans Joachim

La posición jurídica de la víctima del delito en el derecho y en el proceso penal, en Criminología y Derecho Penal al servicio de la persona. Libro homenaje al profesor Antonio Beristain, DE LA CUESTA ARZAMENDI et. al. (Coordinadores), San Sebastián 1989, pp. 379 y ss.

SCHUBERT, A.

"Privat Initiative in Law Enforcement: Associations for the Prosecution of Felons,

1744-1856" en Policing and Punishment in 19th-Century Britain, BAILEY, V. (Editor), Londres 1989, pp. 37 y ss.

SCHULZ, Jan

Beiträge zur Nebenklage, Duncker \& Humboldt, Berlín 1982

SCHUMACHER, U.

Staasanwaltschaft und Gericht im Dritten Reich, Colonia 1995

SCHUMANN, K.F.

Positive Generalprävention. Ergebnisse und Chancen der Forschung, Heidelberg 1989

SCHÜNEMANN, Bern

"Zur Stellung des Opfers im System der Strafrechtspflege", NZStR 1986, pp. 193 y SS.

SCHÜTZE, Theodor Reinhold

Das staatsbürgerliche Anklagerecht in Strafsachen, Graz 1896

SCHWARZE, F.O.

"Die Reform der Staatsanwaltschaft", Der Gerichtsaal 16 (1864), pp. 401 y ss.

SCHWEIZER, Margit 
Die Mitwirkug Privater bei der Strafverfolgung, Dissertation, Zürich 1940

SCIALOJA, V.

Prefazione a Le azioni popolari romane di Bruns, en Studi Giuridiche, I, 1, Roma

1933, pp. 108 y ss. Publicada originariamente en Archivio Giuridico 1882

SECRETARY OF STATE FOR THE HOME DEPARTMENT AND THE ATTORNEY GENERAL

Crown Prosecution Service. The Government reply to the fourth report from the Home Affairs Committee session 1989-1990 HC 118, 1990

SEELMANN, K.

"Paradoxien der Opferorientirung im Strafsachen", JZ 1989, pp. 672 y ss.

SERRA DOMÍNGUEZ, Manuel

-“Evolución histórica y orientaciones modernas del concepto de acción”, RDProc. 1968, III, julio - septiembre 1968, pp. 35-92 y en Estudios de Derecho Procesal, Barcelona 1969, pp. 118-158

-“Intervención de las compañías aseguradoras en el proceso penal”, Justicia 82, IV, pp. 41-68

-"Precisiones en torno a los conceptos de parte, capacidad procesal, representación y legitimación”, Justicia 87, pp. 289-313

SERRANO, León José

“Organización del Ministerio Fiscal y Tribunales", RGLJ, T. 47 (1875), pp. 322 y SS.

SERRANO ALBERCA, José Manuel

Comentarios al art. $125 \mathrm{CE}$, en GARRIDO FALLA (Director), Comentarios a la Constitución, Civitas, Madrid 1985, pp. 1847 y ss.

SERRANO BUTRAGUEÑO, Ignacio (Editor)

Delitos contra la Administración de Justicia, Granada 1995

SERRANO MORENO, José Luis

"El conflicto ecológico en el momento judicial del Estado de Derecho", $J D$ n ${ }^{\circ} 25$, marzo 1996, pp. 78-85

SGUBBI, F.

-“Tutela penale di "interessi diffusi"”, Questione Criminale 1975, pp. 439-481

-“L'interesse diffuso come oggetto della tutela penale", en VVAA, La tutela degli interessi diffusi nel diritto comparato, Milán 1976, pp. 549-594

SHEEMAN, A.V.

Criminal Procedure. Scotland and France, Edimburgo 1990

SIGLER, J.A.

"Public Prosecution in England and Wales", Crim. Law Rev. 1974, pp. 643 y ss.

SILGUERO ESTAGNAN, Joaquín

La tutela jurisdiccional de los intereses colectivos a través de la legitimación de los grupos, Dykinson, Madrid 1995

SILVA MELERO, Valentín

"La estructura del proceso penal en relación con el concepto de parte", RDProc 1946, pp. 247-272

SILVELA, Francisco

“La acción popular", $R G L J \mathrm{n}^{\mathrm{o}} 73$, (1888), pp. 457-487 
SIRACUSANO, D.; GALATI, A.; TRANCHINA, G.; ZAPPALÀ, E.

Diritto Processuale Penale, vol. I, Milán 1994

SOLA, Mariano

"La acción pública en la Ley de funcionamiento del Tribunal de Cuentas", en Seminarios 1984 de la Asociación de Censores Letrados y Contables del Tribunal de Cuentas y Servicio de estudios del mismo, Madrid 1985

SOLOZÁBAL ECHAVARRÍA, Juan José

"La libertad de expresión desde la teoría de los derechos fundamentales", REDC, mayo-agosto 1991, n 32, pp. 73-112

SOTO NIETO, Francisco

Correlación entre acusación y sentencia,Montecorvo, Madrid 1979

STAFFORD, Richard J.

Private Prosecutions. Practice \& Procedure in the Criminal Court, Shaw \& Sons, Londres 1989

STAUB, K.

Über den Geschädigten nach zürischem Strafprozessrechte, Zürich 1905

STEPHEN, James Fitzgerald

-"The Criminal Law and the Detection of Crime", 2 Cornhill Magazine 1860, pp.

697 y ss.

-A History of the Criminal Law of England, Londres 1883

STOPPATO

"L'esercizio dell'azione penale", Riv. Penale XXXVII, pp. 5 y ss.

STUMM, Hans Richard

Der Antrag auf gerichtliche Entscheidung nach par. 172 StPO, Leipzig 1927

SUESS, E.

Die Stellung der Parteien im modernen Strafprocesse, Viena 1898

SUNDELIN

Die Staatsanwaltschaft in Deutschland, Anclam 1960

SZLECHTER, 亡̀.

"La procédure accusatoire en droit suméro-babylonien", Révue Internationale des droits de l'Antiquité, T. XVI (1969), pp. 99 y ss.

TABOADA TUNDIDOR, Carlos

La denuncia y la querella delictivas. Apuntes acerca de la mentira como delito, Reus, Madrid 1930

TAK, P.J.P.

The legal scope of non-prosecution in Europe, HEUNI (Helsinki Institute for Crime Prevention and control. Affiliated with the United Nations), Publication Series n⿳0 8, 1986.

TAORMINA, Carlo

“"Vecchio e nuovo nella teoria dell'azione penale» alle soglio del nuovo Codice di Procedura", Giustizia Penale 1988, III, pp. 129-162

THIERSCH

"Legalitätsprinzip und Ausdehnung der Privatklage", en ASCHROTT, P.F., Reform des Strafprozesses. Kritische Bemerkungen der von der Kommission für die Reform des Strafprozeßes gemachten Vorschläge, Berlín 1906 
TIEDEMANN, Klaus

“Thesen zu einem modernen menschenrechtsorientierten Strafprozeß”, ZRP 1992, 3 , pp. 107 y ss.

TIPPELSKIRCH (von)

"Über das Verhältniß der öffentlichen zur Privatanklage; mit besonderer Beziehung auf die neuren Strafgesetzgebungen Deutschlands", Gerichtssaal 11 (1859) pp. 183, 241

TOLDA PINTO, A.A.

O novo processo penal. Guía prático, Lisboa s.f.

TOLOMEI, Alberto Domenico

I Principi fondamentali del processo penale, Padua 1931

TOMÁS Y VALIENTE, Francisco

-El Derecho Penal de la Monarquía Absoluta (Siglos XVI-XVIII), Tecnos, Madrid 1969

-Manual de Historia del Derecho Español, Tecnos, Madrid 1990

TONNINI

"Le organizzazioni dei consomatori nel processo penale", Riv. ital. dir. proc. penale 1979 , pp. 151 y ss.

TORRES, Rafael

La mirada en la nuca, Ediciones Libertarias. Madre Tierra, Madrid 1991

TORRES AGUILAR, J.

"El delito de acusación y denuncia falsa y las faltas", Pretor, 1952, n 2, pp. 28 y SS.

TORRES ROSELL, Nuria

La denuncia en el proceso penal, Montecorvo, Madrid 1991

TRENZADO RUIZ, M.

"Proyección de D. Eugenio Montero Ríos sobre la Administración de Justicia española", RDProc (Ibam) 1972, nº 1, pp. 121-163

UBERTIS, G.

“Azione Popolare e sovranità popolare", Riv. ital. dir. proc. pen. 1975, pp. 1191 y ss.

ULLMANN, Emanuel

-“Beschränkung des Legalitätsprinzip im Strafverfahren”, Verhandlungen des 29. deutschen Juristentages, T. I, Berlín 1908

-Lehrbuch des deutschen Strafprozessrechts, Munich 1893

VACCA, G.

-Voz “Atto d'accusa”, Digesto Italiano V, 2, 1893

-Commento al CPP, Turín 1913

VALENTINI REUTER, Cristina

Le forme di controllo sull'esercizio dell'azione penale, Cedam, Padua 1994

VALERIOLA, Tomás

Idea General de la Policía o Tratado de Policía, Valencia 1798-1805, Reedición publicada en la colección "Clásicos de la Administración”, Madrid 1977

VALERO OLTRA, Rafael

"Consideraciones sobre la acción popular", $B I M J \mathrm{n}^{\circ}$ 1237, 25 de abril 1981, pp. 


\section{$5-12$}

VALLADARES, Luis Paciano de

"Ley Provisional de Enjuiciamiento Criminal de 22 de diciembre de 1872", RGLJ, T. 42 (1873), pp. 140 y ss.

VARELA CASTRO, Luciano

"Fundamentos político-constitucionales y procesales" en el volumen coordinado por el mismo autor El Tribunal del Jurado, Cuadernos de Derecho Judicial, CGPJ, octubre 1995

VARGAS, Alvaro

"El régimen de la acción penal (a la luz del estatuto vigente y del proyecto de Código", Revista Nuevo Foro Penal no 34, oct-nov-dic 1986, pp. 439-445

VÁZQUEZ SOTELO, José Luis

"El principio acusatorio y su reflejo en el proceso penal español. Homenaje a la

Ley de Enjuiciamiento Criminal tras sus cien años de vigencia", RJCat 1984, 2 , pp. 373-415

VELÁSQUEZ GÓMEZ, Iván

"La acción en el proceso penal", Tribuna Penal. Revista del Colegio de Abogados de Antioquia (Colombia) 1987

VÉLEZ MARICONDE, Alfredo

Derecho Procesal Penal, T. I, $2^{\mathrm{a}}$ ed.

VERGER GRAU, Joan

-La defensa del imputado y el principio acusatorio, Bosch, Barcelona 1994

-"Los juicios paralelos y la presunción de inocencia, con especial referencia al Jurado", en La criminalidad organizada ante la Justicia, GUTIÉRREZ-ALVIZ CONRADI, F. (Coordinador), Sevilla 1996, pp. 191 y ss.

VIADA LÓPEZ-PUIGCERVER, Carlos

-"Notas sobre la necesidad de reforma de la LECrim", RGLJ 1950, nº 187, pp. 337 y ss.

-“Capacidad, representación, legitimación y postulación en el proceso penal", Pretor 1954

-“Correlación entre la acusación y la sentencia”, RDProc (Ibam) 1959, pp. 419444

-“La legitimación activa en los delitos semipúblicos”, $A D P$ 1962, n 15, pp. 618 y SS.

-“Orientaciones y líneas generales de la Reforma y del Proceso Penal en España”, Conferencia ante el Ilustre Colegio de Abogados de La Coruña (6 de sept. de 1960)

-Curso de Derecho Procesal Penal I, Madrid 1962

VIADA LÓPEZ-PUIGCERVER, Carlos y ARAGONESES ALONSO, Pedro

Curso de Derecho Procesal Penal I, $4^{\text {a }}$ ed. Madrid 1974

VIDAL, G.

Course de Droit Criminel et de Sciencie Penitentiaire, 3ª ed., París 1906

VICENTE Y CARAVANTES

Febrero o Librería de Jueces, Abogados y Escribanos, Tomo V , Madrid 1852

VILLADIEGO VASCUÑANA Y MONTOYA, Alonso de 
Instruccion Politica, y Practica Iudicial conforme al estilo de los Consejos, Audiencias, y Tribunales de Corte, y otros ordinarios del Reyno, Madrid 1617

VIVES ANTÓN, Tomás Salvador

-“Doctrina constitucional y reforma del proceso penal", $P J \mathrm{n}^{\circ}$ especial II, pp. $93 \mathrm{y}$ SS.

-La Reforma del Proceso Penal II (Comentarios a la LMURP), Tirant lo Blanch, Valencia 1992

VIVES ANTÓN, T.S.; BOIX REIG, J., ORTS BERENGUER, E., CARBONELL MATEU, J.C. y GONZÁLEZ CUSSAC, J.L.

Derecho Penal. Parte Especial, $1^{\text {a }}$ ed., Tirant lo Blanch, Valencia 1993

VIVES LLAMAZARES, Francisco

"Consecuencias de la inexistencia de la acción penal en el tratamiento de la criminalidad infantil y juvenil", Anales de la Universidad de Valencia, vol. XXVI,

V.H.Ch curso 1952-53, cuaderno III-Derecho, pp. 123-129

De la Organización, Atribuciones y Deberes del Ministerio Fiscal, Madrid 1853 VOLK, Klaus

Prozeßvoraussetzungen im Strafrecht. Zum Verhältnis von materiellem Recht und Prozeßrecht, Rolf Gremer, Ebelsbach, 1978

WACH, Adolf

"Struktur des Strafprozesses", en Festgabe der Leipziger Juristenfakultät für Karl Binding zum 7. August 1913, Dunckler\&Humboldt, Munich, Leipzig 1914

WEHNERT, Anne

Rechtliche und rechtstatsächliche Aspekte des Klageerzwingungsverfahren, Lang, Francfort 1988

WEIGEND, Thomas

-Anklagepflicht und Ermessen. Die Stellung des Staatsanwalts zwischen Legalitäts- und Oportunitätsprinzip nach deutschem und amerikanischem Recht, Nomos, Baden-Baden 1978

-Deliktsopfer und Strafverfahren, Dunckler \& Humboldt, Berlín 1989

-"Die Reform des Strafverfahrens. Europäische und deutsche Tendenzen und WEILER Probleme”, ZStW 104 (1992), pp. 586-512

"Medienwirkung auf das Strafverfahren", ZRP 4 de abril de 1995, pp. 130 y ss.

WERNER, Karin

Der Einfluß der Verletzten auf Verfahrenseinstellungen der Staatsanwaltschaft, Munich 1996

WILCOX, A.F.

The Decision to Prosecute, Londres 1972

WILLE, Heinrich

"Das externe Weisungsrecht", en "Strafverfolgung und Strafverzicht. Festschrift zum 125jährigen Bestehen der Staatsanwaltschaft Schleswig-Holstein", OSTENDORF, Heribert (Editor), pp. 317-327, Carl Heymans, Kassel 1992

WILLIAMS, John Eryl Hall (Editor)

The Role of the Prosecutor, Report of the International Criminal Justice Seminar 
held at the London School of Economics and Political Science in January 1987. Avebury, Londres 1988

WILLIAMS, Glanville

-“The Power to Prosecute”, Crim. Law Rev. 1955, pp. 596 y ss.

-"Discretion in Prosecuting", Crim. Law Rev. 1956, pp. 222 y ss.

WINCKELMANN, Christian

"Die Verbandsklsge im Umweltrecht im internationalen Vergleich", Zeitschrift für Umweltrecht 1/ 1994, enero 1994, pp. 12-14

WINKEL. L.C.

"Quelques remarques sur l'accusation publique en droit grec et romain", Revue Internationale des Droits de l'Antiquité T. XXIX, 1982, pp. 292 y ss.

WOHLERS, Wolfgang

Entstehung und Funktion der Staatsanwaltschaft. Ein Beitrag zu den rechtshistorischen und strukturellen Grundlagen des reformierten Strafverfahrens. Duncker\&Humboldt, Berlín 1994

WOLF, Erik

"Die Beteiligung des Verletzten am Strafverfahren", Deutsche Juristen-Zeitung, 21, 1936, pp. 1257-1266

WOLF, Rainer

"Zur Entwicklung del Verbandsklage im Umweltrecht", Zeitschrift für Umweltrecht 1/1994, enero 1994, pp. 1-11

XIFRÁ HERAS, Jordi

"La Jurisdicción en la Constitución de 1978", en El Poder Judicial, vol. III, pp. 2717 y ss., Dirección General de lo Contencioso del Estado, Madrid 1983

XIOL RÍOS, Juan Antonio

"Consideración de algunos aspectos del proceso contencioso administrativo como respuesta a los fenómenos de masificación social: la legitimación, la limitación de las instancias, el tratamiento en serie de los recursos y los efectos de la sentencia", Cuadernos de Derecho Judicial, $\mathrm{n}^{\circ} \mathrm{XV}$, Jurisdicción Contencioso-Administrativa: aspectos procesales, Madrid 1992, pp. 131-205

ZACHARIAE, Albert

Handbuch des deutschen Strafprocesses, Gotinga 1861 (T. I); 1868 (T. II)

ZAFRA, J.

"Posición del Ministerio Fiscal en el futuro proceso penal", RDProc. 1961, n 4, pp. 753-843

ZARZALEJOS NIETO, J.

"El nuevo proceso abreviado para delitos menos graves (LO 7/1988) en el volumen colectivo Nuevos Tribunales y nuevo proceso penal. Estudios sobre la Ley 39/88 y LO 7/1988. Demarcación y Planta. Juzgados de lo Penal y proceso penal abreviado, $2^{\mathrm{a}}$ ed., Madrid 1989, pp. 159 y ss.

ZÄTZSCH, Jörg

"Die Betiligungsrechte des Verletzten im Strafverfahren (status activus) - Eine

Kritische Betrachtung”, ZRP 1992, 5, pp. 167-170

ZELLER, H.

"Die Popularstrafklage”, Schweizerische Juristenzeitung 1916/1917, pp. 158 y ss. 
ZIELINSKI, Diethar

"Zur Verletzteneigenschaft des einzelnen Aktionärs im KEV bei Straftaten zum Nachteil der Aktiengeschellschaft", Wistra 1993, 1, pp. 6-9

ZIMMERMANN, Holger P.

Freiheit und Gebundenheit der Staatsanwaltschaft bei der Anklageerhebung. Zugleich ein Beitrag zu den historischen und Rechtsphilosophischen Grunlagen des reformierten Strafprozesses. VVF, Munich 1988

ZIPF, Heinz

-“Strafantrag, Privatklage und staatlicher Strafanspruch”, GA 1969, pp. 234 y ss. -Kriminalpolitik, C.F. Müller, Heidelberg, Karlsruhe 1980 


\section{ÍNDICE}

ABREVIATURAS

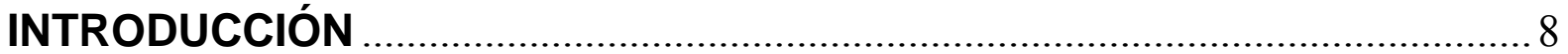

1 DERECHO ROMANO: ACUSACIÓN Y ACTIONES POPULARES ..........................15

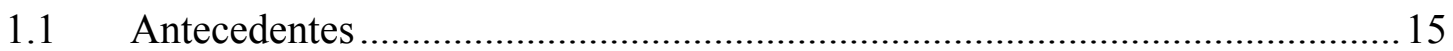

1.2 La actio popularis romana y el derecho de acusar ........................................... 18

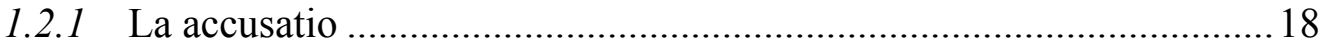

1.2.1.1 Regla general: acusación quivis ex populo ………………….... 18

1.2.1.2 Exclusiones ............................................................................. 21

1.2.1.3 Concurrencia de varios acusadores...........................................2. 24

1.2.1.4 Garantías de fiabilidad de la acusación...................................22

1.2.2 Las actiones populares romanas ………………………………….....26

1.2.3 Redescubrimiento de las acciones populares romanas

en el siglo XIX: el actor popular como valedor de un

derecho propio o como "procurator populi"........................................30

2 LA ACUSACIÓN POPULAR EN NUESTRO DERECHO

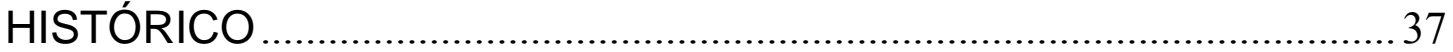

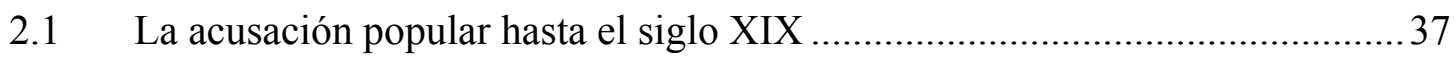

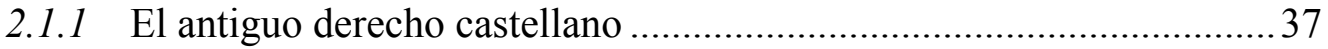

2.1.2 El proceso canónico y las Decretales..................................................38

2.1.3 La legislación alfonsina ………………………………………….....40

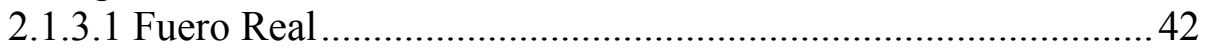

2.1.3.2 Las Partidas ............................................................................. 42

Legitimados para acusar ………………………………….... 43

Pluralidad de acusadores...........................................................4 46

Garantías en el ejercicio de la acusación ....................................47

2.1.3.3 Decadencia de las acusaciones particulares..............................52

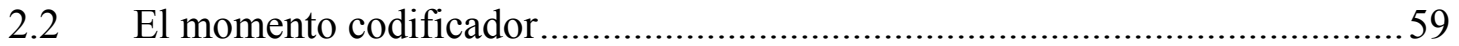

2.2.1 Periodo anterior a las leyes de Enjuiciamiento Criminal......................59

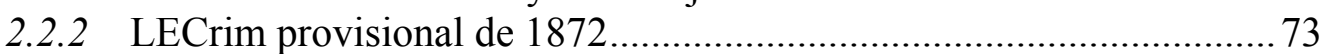

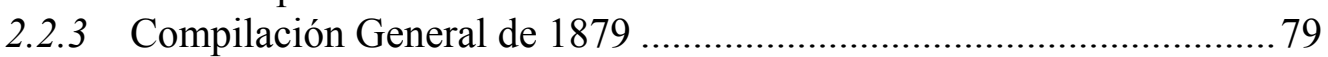

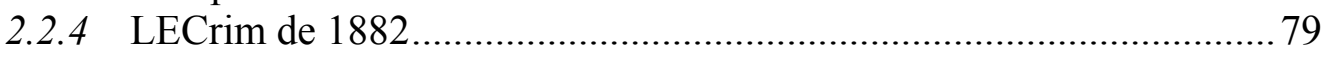


2.2.6 Intentos posteriores de reforma................................................... 102

3.1 Modelos precedentes de referencia.............................................................. 110

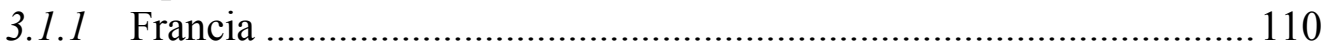

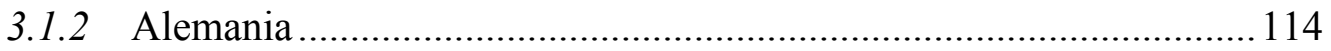

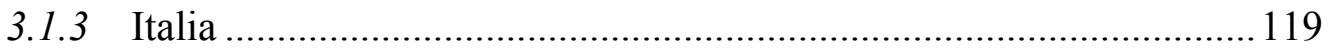

3.2 Resistencia a la instauración de un órgano público acusador y

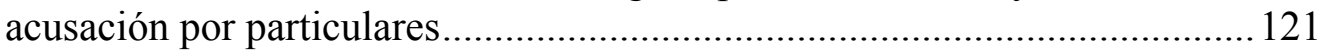

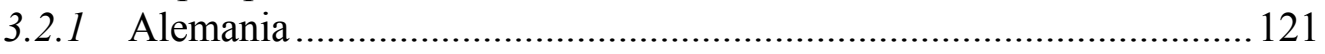

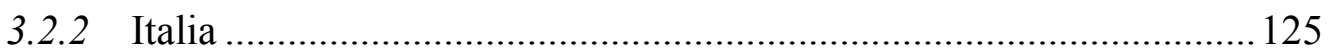

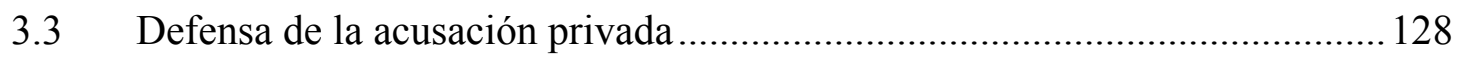

3.3.1 Tendencias ultraliberales: acusación exclusivamente privada .......... 128

3.3.2 Diferentes modalidades de acusación privada como fórmula complementaria al monopolio del MF .............................. 132

3.3.2.1 Las diversas propuestas ...................................................... 132

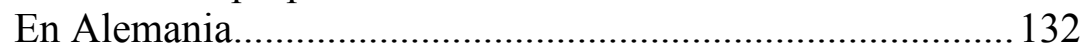

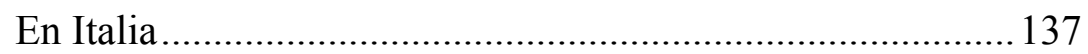

Modelos equiparables al español ........................................ 147

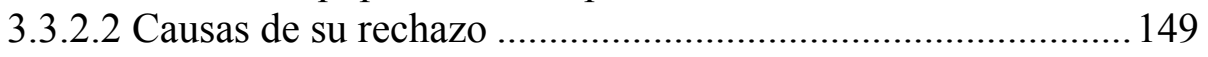

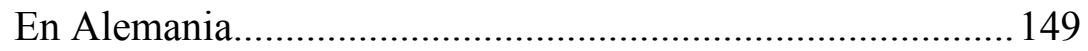

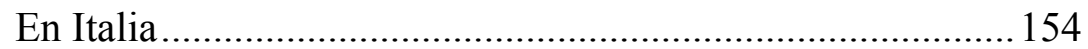

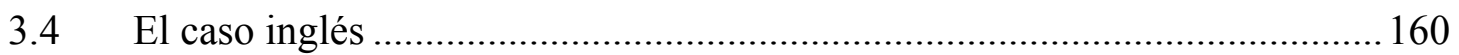

3.4.1 Apuesta por un sistema teóricamente privado de persecución de los delitos .................................................................................. 160

3.4.2 Las asociaciones inglesas para la persecución de los delitos ............ 171

4 LA PREVISIÓN CONSTITUCIONAL DE LA ACCIÓN POPULAR

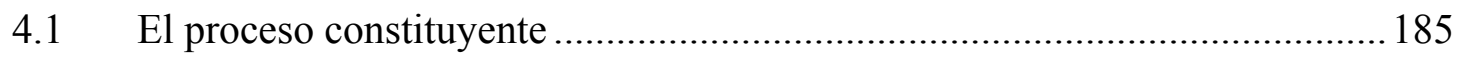

4.1.1 Plasmación en el texto constitucional ............................................... 185

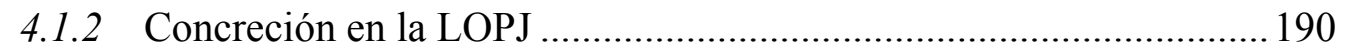

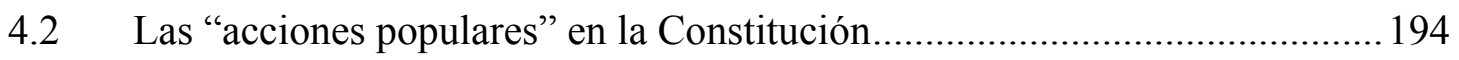

4.2.1 Datos predicables de las "acciones populares".................................. 194

4.2.2 Manifestaciones de "acción popular" contenidas en la previsión constitucional 
5.1 La acusación popular como derecho abstracto a la actividad jurisdiccional: el denominado «ius ut procedatur» ......................................207

5.1.1 La opinión de la doctrina anterior a la Constitución...........................208

5.1.1.1 La concepción de BELING................................................... 208

5.1.1.2 La adaptación realizada por GÓMEZ

ORBANEJA...................................................... 210

5.1.1.3 FAIRÉN: máxima abstracción de la acción.............................2214

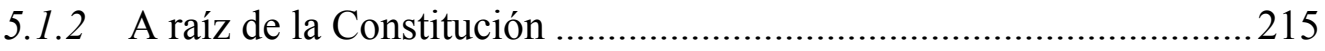

5.1.2.1 Las diversas opiniones doctrinales ....................................216

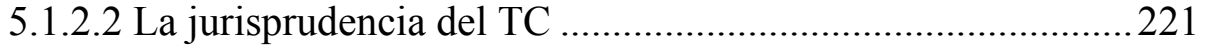

5.1.2.3 La jurisprudencia del TS ..................................................223

5.1.2.4 No es un derecho a la tutela jurisdiccional

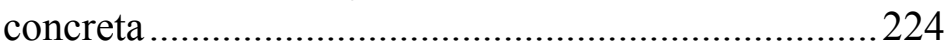

5.2 El ejercicio de la acusación popular no integra el derecho de acción ...........227

5.2.1 Derecho de acción y acción penal................................................222

5.2.1.1 Relatividad del concepto de acción ......................................227

5.2.1.2 Acción y “acción penal” ......................................................2230

5.2.1.3 La pluralidad de significados del término “acción penal” en la LECrim .....................................2236

5.2.1.4 Balance.

5.2.2 El derecho constitucional de acción no es invocable para el ejercicio de la acusación.

5.2.3 La acusación popular ni es ni integra el derecho fundamental a la tutela jurisdiccional.

6 ACUSACIÓN POPULAR COMO MODALIDAD DEL EJERCICIO DE LA COMPETENCIA ESTATAL DE ACUSAR.

6.1 Las diversas denominaciones de la acusación ..............................................263

6.1.1 “Acción pública” y “acción popular” .................................................2263

6.1.1.1 Publicidad de la acción ..........................................................263

6.1.1.2 Acción popular y acción pública:

términos originariamente sinónimos.........................2265

6.1.1.3 Inadecuación del término "acción pública"

para designar la acusación de los particulares

no ofendidos.

6.1.2 La denominación de los diversos sujetos acusadores .......................2274

6.1.3 Acusación popular, acusación particular y acusación privada ..........2277

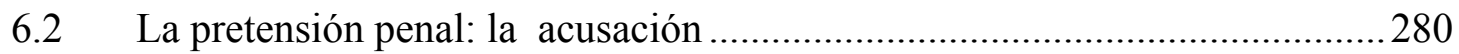

6.2.1 Adaptación del concepto de pretensión al ámbito penal....................280

6.2.2 La acusación: afirmación de la concurrencia de presupuestos objetivos y subjetivos para el enjuiciamiento.............................284 


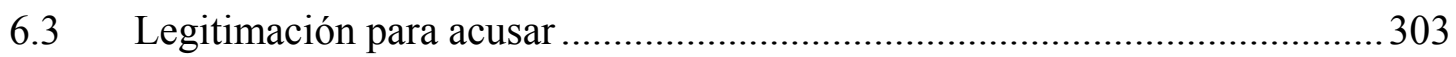

6.3.1 Principio de oficialidad de la acusación por delitos públicos..............303

6.3.1.1 Deber estatal de garantizar la resolución

de los conflictos a través del debido proceso...............303

6.3.1.2 Derecho de los ciudadanos al proceso penal y derecho a que se acuse …………………...................304

6.3.1.3 Legitimación ordinaria para acusar: el MF.............................312

6.3.2 Acusación quivis ex populo .............................................................315

6.3.3 La "acusación particular".....................................................................319

6.4 Ejercicio por particulares de la acción civil en el proceso penal......................337

7 SUJETOS LEGITIMADOS PARA EL EJERCICIO POPULAR DE LA ACUSACIÓN.

7.1 Personas físicas: condiciones para la atribución de legitimación para acusar sin ser ofendido por el delito ……………………...................347

7.1.1 El criterio de la nacionalidad ...........................................................347

7.1.2 No estar incurso en causa de exclusión ................................................362

7.1.2.1 Gozar de la plenitud de los derechos civiles

(art. 102.1 LECrim) 363

7.1.2.2 No haber sido condenado dos veces por delito de acusación y denuncia falsas

(art. 102.2 LECrim) (...……………………………......366

7.1.2.3 No ser Juez o Magistrado (art. 102.3 LECrim)........................370

7.1.2.4 Excepciones a la exclusión ....................................................... 377

7.1.3 El parentesco con el acusado como causa de exclusión de la legitimación (art. 103 LECrim) ....................................................... 381

7.1.3.1 Prohibición de acusarse los cónyuges entre sí (art. 103.1 $1^{\circ}$ LECrim) 383

7.1.3.2 Prohibición de acusarse ascendientes, descendientes o hermanos entre sí (art. 103.2 $2^{\circ}$ LECrim)..............386

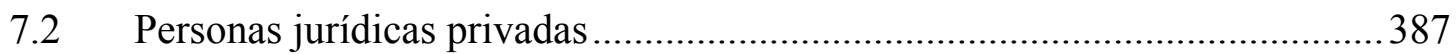

7.2.1 Negativa histórica a su reconocimiento ..............................................387

7.2.2 Plena aceptación en la actualidad ......................................................395

7.2.3 Dos supuestos específicos de ejercicio de la acusación por asociaciones.

7.2.3.1 Ejercicio profesional privado de la acusación.

El caso "Indagatoria Popular"

7.2.3.2 Partidos Políticos 400

7.3 Las Administraciones Públicas como acusadores ..........................................413

7.3.1 Ejercicio de la acusación en caso de perjuicio para el Estado .............413 
7.3.2 Ejercicio popular de la acusación por las

Administraciones públicas: perversión de su propia esencia

8.1 Ámbito ordinario: delitos públicos y semipúblicos .................................. 413

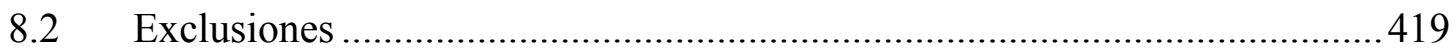

8.2.1 Por la naturaleza de los delitos: los delitos "privados".....................4 419

8.2.2 Por razón del procedimiento ............................................................ 419

8.2.2.1 La Jurisdicción Militar........................................................420

8.2.2.2 La Jurisdicción de menores.................................................... 425

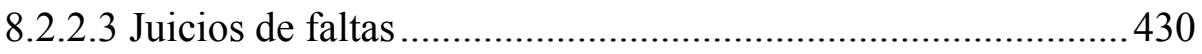

8.2.2.4 La modalidad procedimental del art. 790.1.III ...................... 431

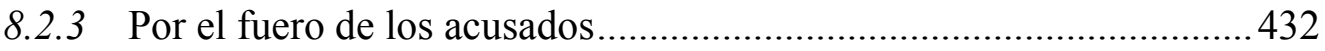

9 PERSONACIÓN E INTERVENCIÓN DEL ACUSADOR POPULAR

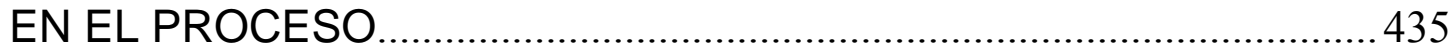

9.1 El instrumento formal para la personación del acusador popular:

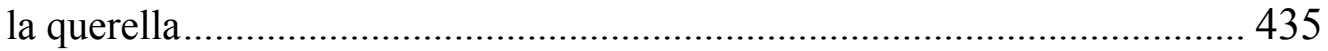

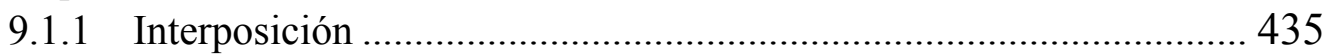

9.1.1.1 Momento procesal........................................................... 435

9.1.1.2 El requisito de la escritura .....................................................44 44

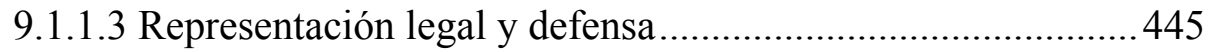

9.1.1.4 Justicia gratuita y acusación popular ..................................... 448

9.1.1.5 Pluralidad de acusadores y obligación de litigar unidos (art. 113 LECrim) ..............................450

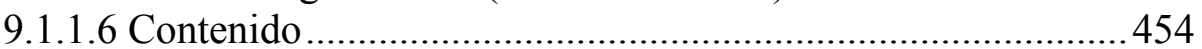

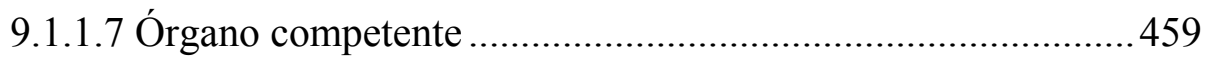

9.1.1.8 Personación del acusador popular sin interposición de querella......................................... 460

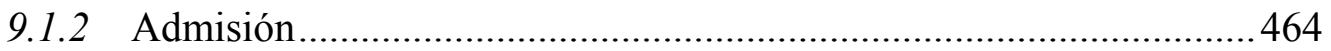

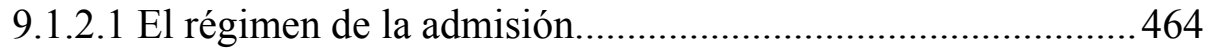

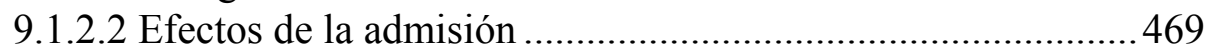

9.2 Intervención del acusador popular en el proceso........................................472

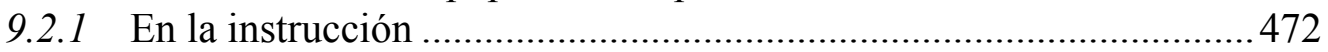

9.2.1.1 Diligencias de investigación .............................................. 472

9.2.1.2 Los distintos acusadores en el Procedimiento

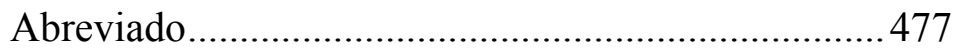

9.2.1.3 "Publicidad para las partes" y acusación popular .................. 481

9.2.1.4 Secreto del sumario y acusación popular.................................4 485

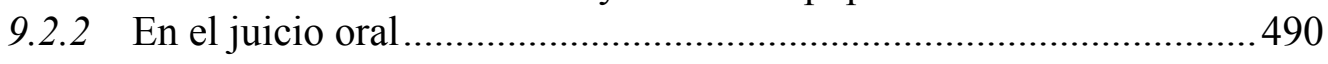


9.2.2.2 Planteamiento de cuestiones previas..................................... 492

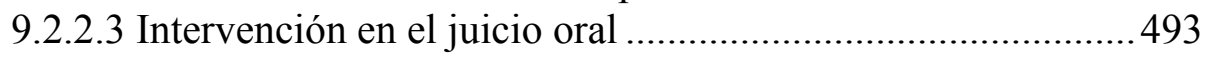

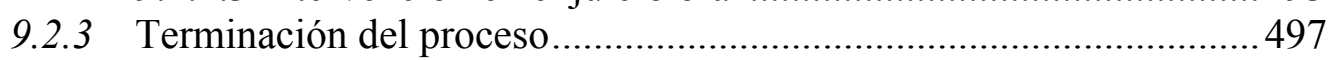

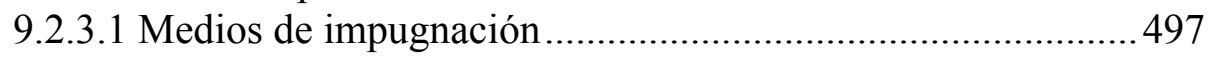

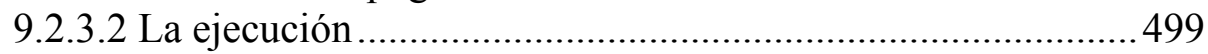

10 MECANISMOS DE GARANTÍA FRENTE A UN INADECUADO

EJERCICIO POPULAR DE LA ACUSACIÓN ........................................501

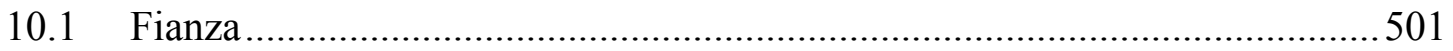

10.1.1 Justificación histórica, naturaleza y sentido en la actualidad ............501

10.1.2 Régimen legal de la imposición de la fianza ...................................506

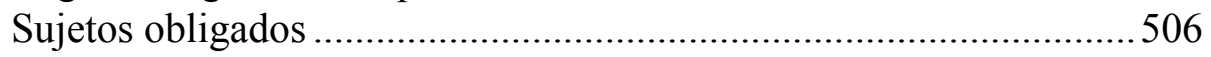

10.1.2.1 Excepciones a su obligatoriedad introducidas jurisprudencialmente............................................509

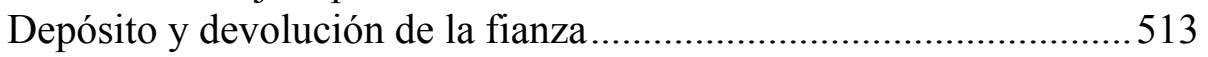

Cuantía y exigencia de proporcionalidad.......................................514

10.1.3 Crítica a la formulación legal de su exigencia................................5520

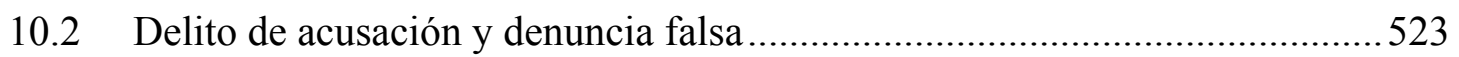

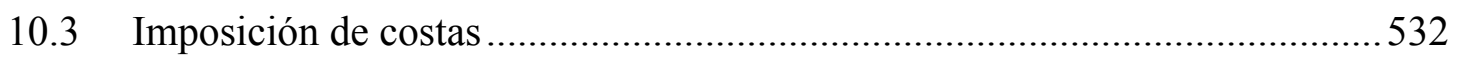

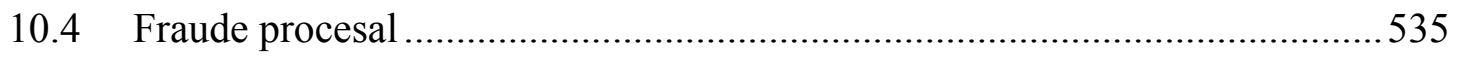

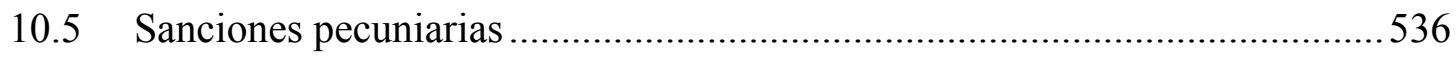

11 CARÁCTER DEMOCRATIZADOR DE LA ACUSACIÓN POPULAR

11.1 Justificación histórica: acusación popular como signo de democracia y de democratización de la Justicia.

11.2 Justificación política: acusación popular como derecho participativo ...........552

11.3 Justificación sociológica: la acusación popular como factor de mejora de la percepción social de la justicia.

12 DEFENSA DE INTERESES COLECTIVOS MEDIANTE EL EJERCICIO DE LA ACUSACIÓN

12.1 Intereses colectivos y participación de asociaciones en el proceso penal para invocar su tutela 


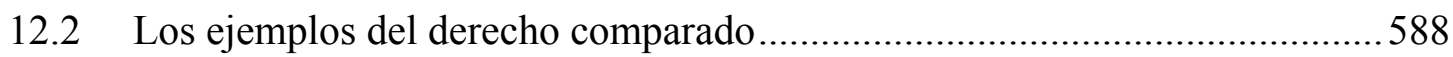

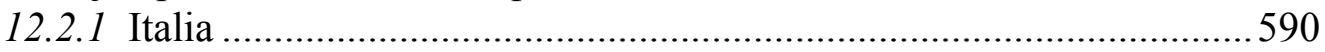

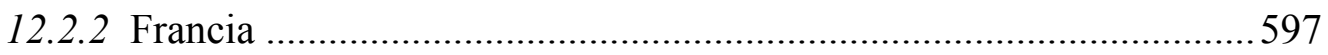

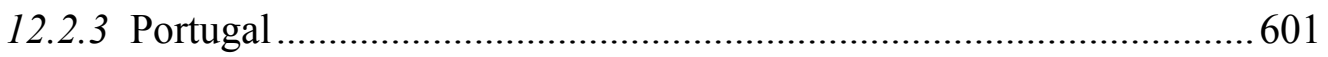

12.3 Propuesta de lege ferenda: asimilación al ofendido por el delito de las agrupaciones para la defensa de intereses colectivos

13 LA ACUSACIÓN POPULAR COMO INSTRUMENTO DE CONTROL

DEL MF.

13.1 Acusación popular y principio de oportunidad ..............................................623

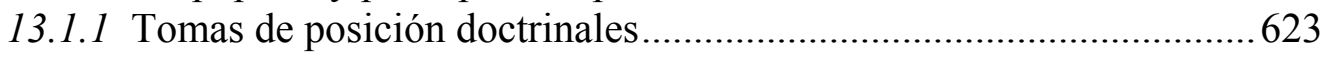

13.1.2 Intervención activa del acusador popular en relación

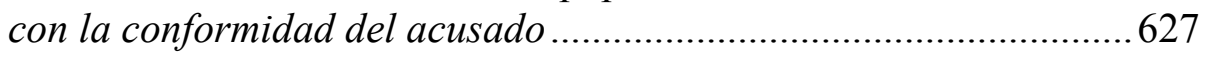

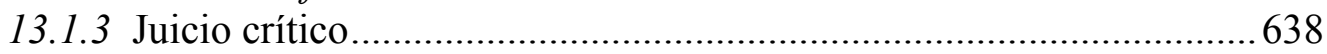

13.2 Acusación popular y facultades de investigación del MF ............................643

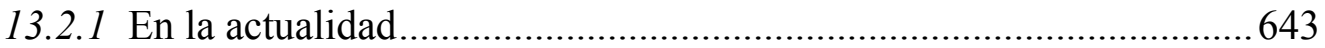

Procedimiento Abreviado ................................................................643

Procedimiento del Tribunal del Jurado ................................................64 647

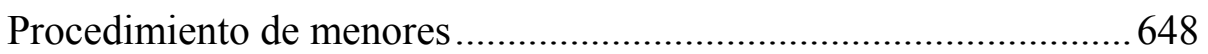

13.2.2 Acusación popular e instrucción por el MF .....................................650

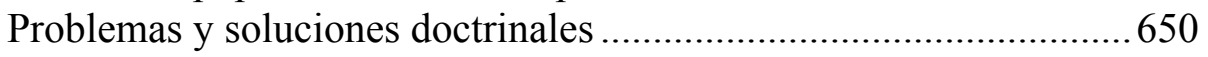

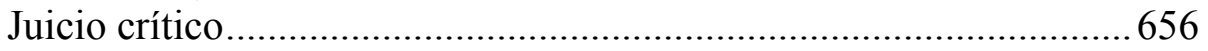

13.3 Modalidades de control de la acusación por particulares en el derecho comparado: reafirmación del monopolio acusatorio oficial.............658

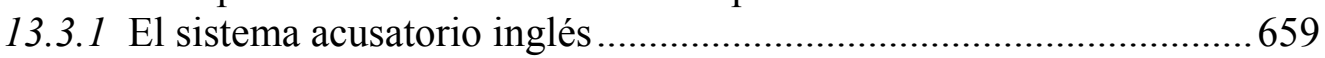

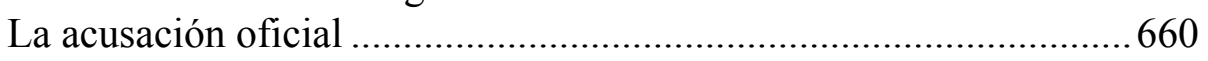

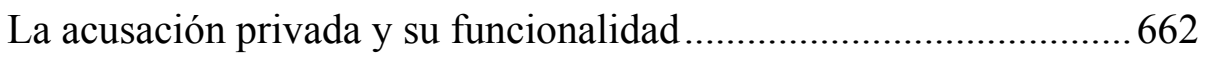

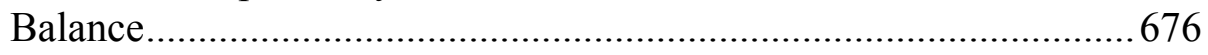

13.3.2 Control privado de la acusación pública...........................................679

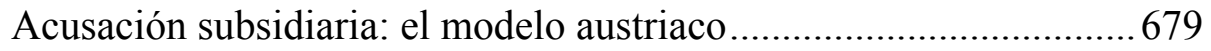

13.3.2.1 Control judicial sobre la acusación a instancia de particulares: el Klageerzwingungsverfahren......... 681

13.3.2.2 Coacusación, acusación accesoria, conjunta o adhesiva: la Nebenklage alemana .............................690 690

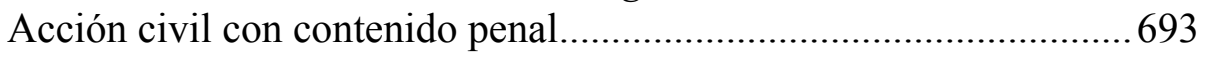


$15 \quad$ BIBLIOGRAFÍA …................................................................................. 702

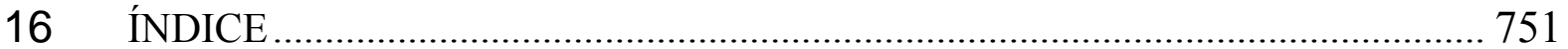

